\title{
Montana's Comprehensive Fish and Wildlife Conservation Strategy
}

33 The mission of Montana Fish, Wildlife \& Parks is to provide for the stewardship of the fish, wildlife, parks and recreational resources of Montana, while contributing to the quality of life for present and future generations. To carry out its mission, FWP strives to provide and support fiscally responsible programs that conserve, enhance and protect Montana's 1) aquatic ecotypes, habitats, and species, 2) terrestrial ecotypes, habitats, and species, and 3) important cultural and recreational resources.

\section{Montana Fish, Wildlife \& Parks} 2005 


\section{DRAFT WORKING DOCUMENT DO NOT DUPLICATE}

45 Table Of Contents

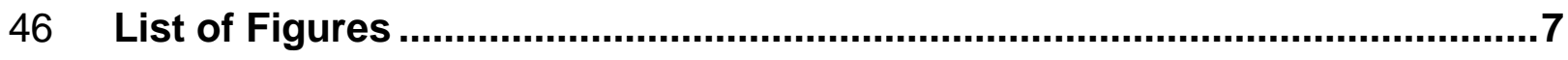

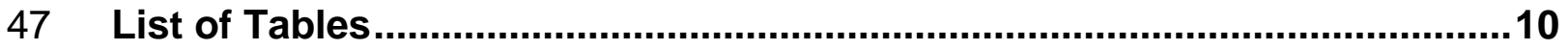

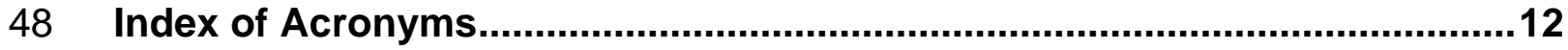

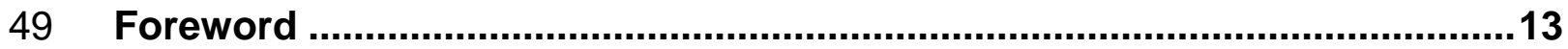

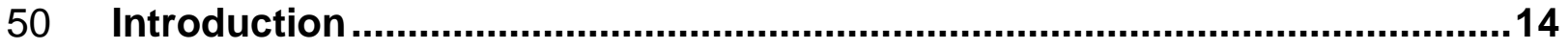

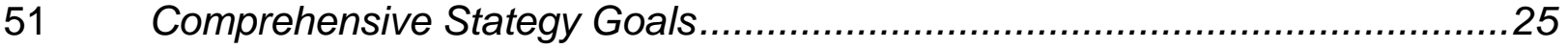

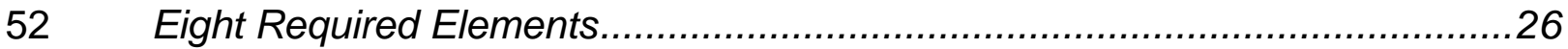

53 International Association of Fish and Wildlife Agencies Guidelines................22

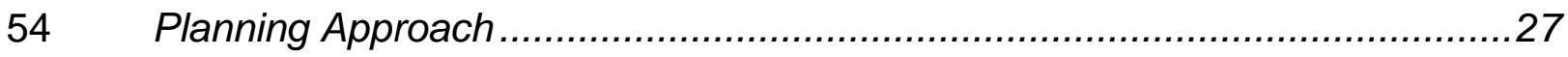

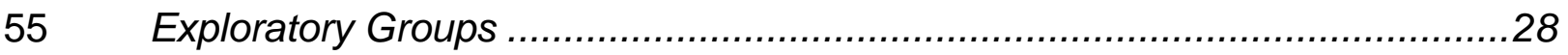

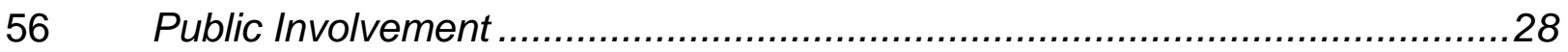

$57 \quad$ The Four Components of Montana's Strategy ............................................... 31

$58 \quad$ Categorizing the Levels of Conservation Need …......................................32

$59 \quad$ How Montana's Comprehensive Strategy Will Work ..................................... 32

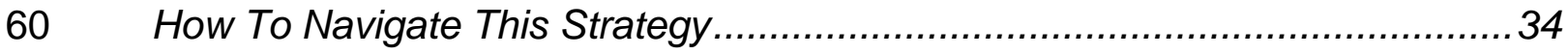

61 Component I: Ecotype Focus Areas of Greatest Conservation Need ..........35

62 Intermountain/Foothill Grassland Ecotype ...............................................3

63 Terrestrial Conservation Focus Areas in Greatest Need (Tier I) ..................43

$64 \quad$ Bitterroot/Frenchtown Valleys (406,859 acres) .................................43

$65 \quad$ Central Montana Broad Valleys (2,604,058 acres) ..............................46

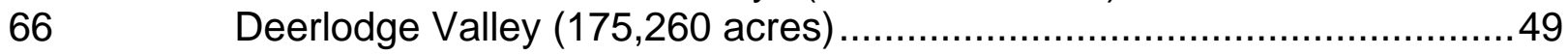

$67 \quad$ Flathead River Valley $(1,586,787$ acres) …...................................... 52

$68 \quad$ Little Belt Foothills $(839,541$ acres) …….......................................55

$69 \quad$ North Tobacco Root Mountains and Foothills (224,989 acres) ................58

$70 \quad$ Rocky Mountain Front Foothills (2,018789 acres) ..............................6.

$71 \quad$ South Elkhorn Mountains (171,059 acres) .......................................6. 64

72 Southwest Montana Intermontane Basins and Valleys (2,077,477 acres)67

$73 \quad$ Upper Yellowstone Valley $(178,039$ acres) …................................... 70

$74 \quad$ Aquatic Conservation Focus Areas in Greatest Need (Tier I) ......................73

$75 \quad$ Big Hole River (153 River Miles) ....................................................... 73

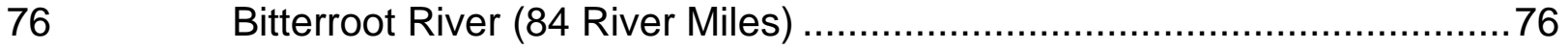

$77 \quad$ Blackfoot River (127 River Miles) …............................................. 78

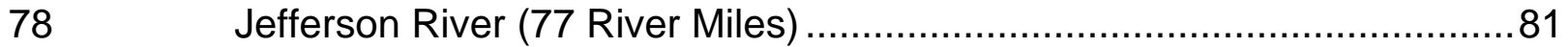

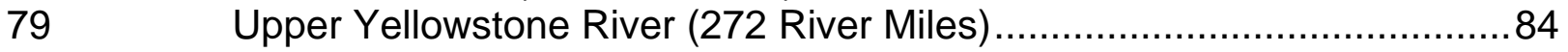

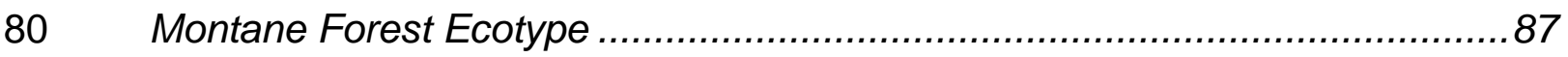




\section{DRAFT WORKING DOCUMENT DO NOT DUPLICATE}

81

82

83

84

85

86

87

88

89

90

91

92

93

94

95

96

97

98

99

100

101

102

103

104

105

106

107

108

109

110

111

112

113

114

115

116

117

118

119

Terrestrial Conservation Focus Areas in Greatest Need (Tier I) .................94

Mission/Swan Valley and Mountains (679,663 acres) ............................94

Aquatic Conservation Focus Areas in Greatest Need (Tier I) ....................97

Lower Clark Fork (149 River Miles) ...................................................97

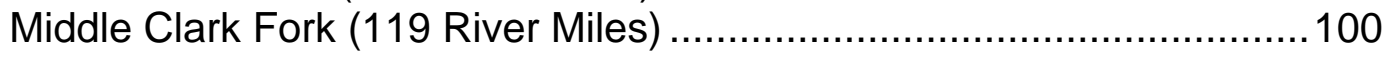

Plains Grasslands and Plains Forest Ecotype ..........................................103

Terrestrial Conservation Focus Areas in Greatest Need (Tier I) ...............112

Missouri Coteau $(5,278,913$ acres) ............................................... 112

Montana Sedimentary Plains $(13,828,142$ acres) ...............................115

Aquatic Conservation Focus Areas in Greatest Need (Tier I) ....................118

Lower Missouri River (175 River Miles) .............................................118

Lower Yellowstone River (278 River Miles) ..................................... 120

Powder River (220 River Miles) ...................................................... 122

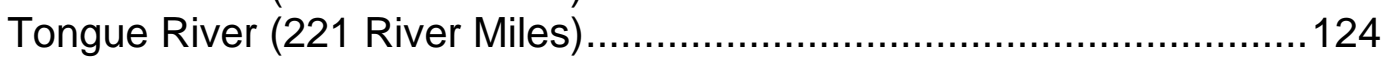

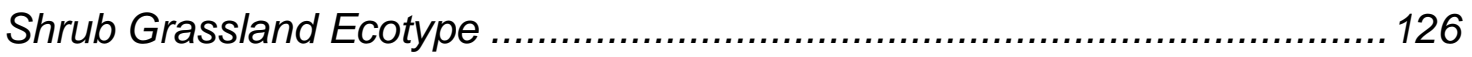

Terrestrial Conservation Focus Areas in Greatest Need (Tier I) ................130

Bighorn Intermontane Basin $(290,287$ acres) .................................. 130

Montana Glaciated Plains $(17,806,106$ acres) ................................... 133

Montana Shale Plains $(2,403,965$ acres $)$........................................ 136

Powder River Basin/Breaks/Scoria Hills (2,095,021 acres).................. 139

Shale Scablands $(417,176$ acres) …........................................... 142

Aquatic Conservation Focus Areas in Greatest Need (Tier I) ...................145

Middle Missouri River (540 River Miles) ............................................ 145

Component II: Community Types of Greatest Conservation Need ...........148

Grassland Complexes (31,551,627 acres or 33.53\% of Montana).............. 149

Mixed Broadleaf Forests (883,498 acres or $0.94 \%$ of Montana) .................. 153

Mixed Shrub/Grass Associations (4,159,693 acres or 5.34\% of Montana) ... 156

Wetland \& Riparian $(3,724,224$ acres or 3.94\% of Montana) ...................... 159

Sagebrush and Salt Flats (5,625,886 acres or 5.97\% of Montana).............. 165

Mountains Streams (59,364 Stream Miles in Montana)..............................167

Prairie Streams (91,189 Stream Miles in Montana)................................. 170

Component III: Species of Greatest Conservation Need .............................173

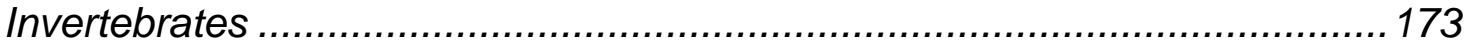

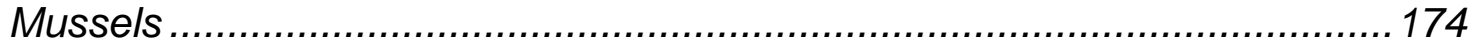

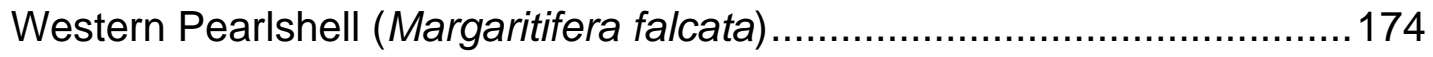

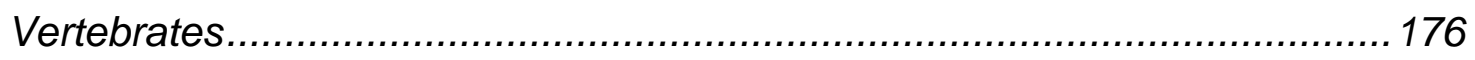

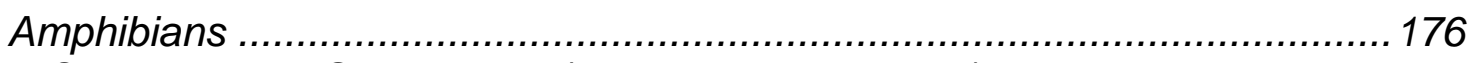

Coeur d'Alene Salamander (Plethodon idahoensis) ...............................176

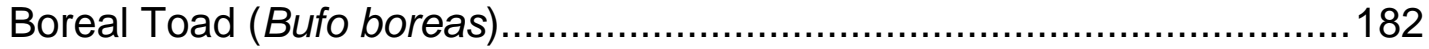




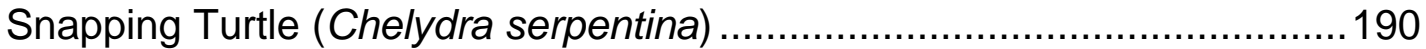

Harlequin Duck (Histrionicus histrionicus) .........................................215

Yellow Rail (Coturnicops noveboracensis)

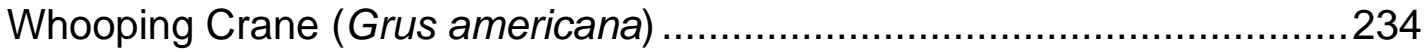

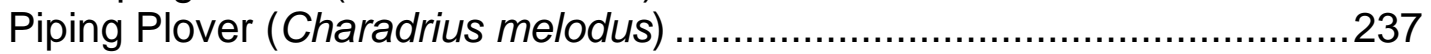

Mountain Plover (Charadrius montanus) .............................................242

Long-billed Curlew (Numenius americanus) .........................................246

Interior Least Tern (Sterna antillarum athalassos) .................................249

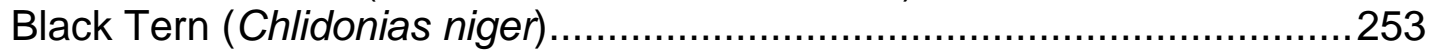

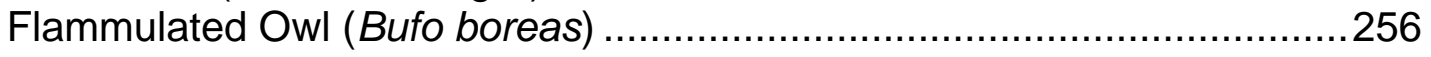

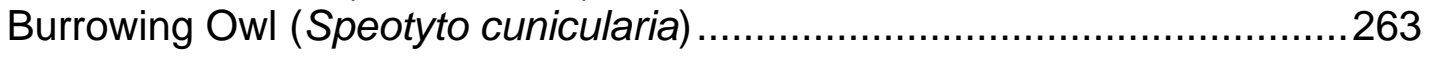

Black-backed Woodpecker (Picoides arcticus) .......................................266

Olive-Sided Flycatcher (Contopus cooperi) ……..................................271

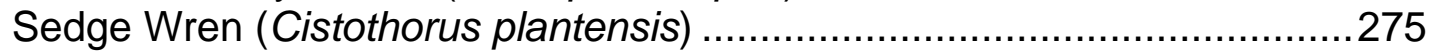

Nelson's Sharp-tailed Sparrow (Ammodramus nesloni) ............................277

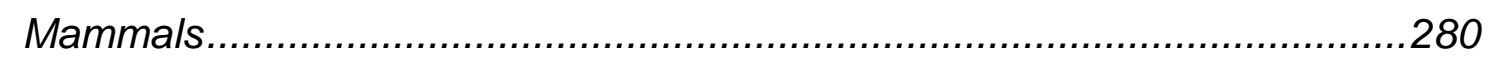

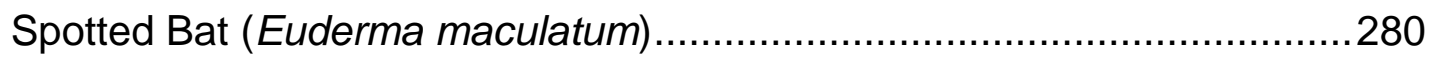

Townsend's Big-eared Bat (Corynorhinus townsendii) .............................285

Pallid Bat (Antrozous pallidus) .......................................................290

Pygmy Rabbit (Brachylagus idahoensis) .............................................294

Hoary Marmot (Marmota caligata) .......................................................29

Black-tailed Prairie Dog (Cynomys ludovicianus) ..................................299

White-tailed prairie Dog (Cynomys leucurus).........................................302

Great Basin Pocket Mouse (Perognathus parvus) ....................................304

Northern Bog Lemming (Synaptomys borealis) ......................................307

Meadow Jumping Mouse (Zapus hudsonius) .......................................... 311

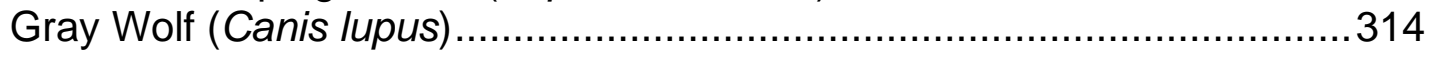

Grizzly Bear (Ursus arctos horribilis) ...................................................

Black-footed Ferret (Mustela nigripes) .................................................320

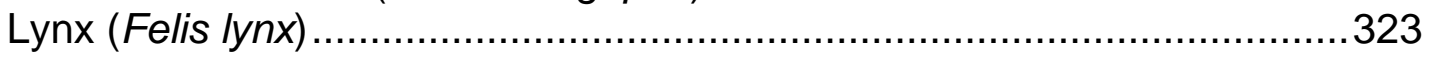

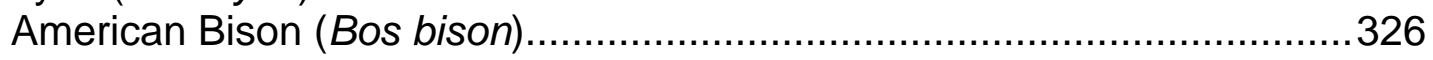

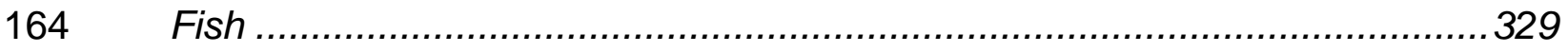


White Sturgeon (Kootenai River Population) (Acipenser transmontanus) . 329 Pallid Sturgeon (Scaphirhynchus albus) ..................................................333

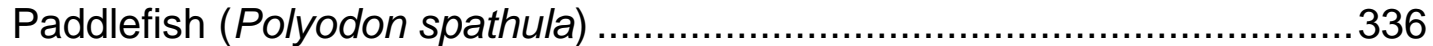
Shortnose Gar (Lepisosteus platostomus) ............................................342 Yellowstone Cutthroat Trout (Oncorhynchus clarki bouvieri) .......................344 Westslope Cutthroat Trout (Oncorhynchus clarki lewisi) ...........................349 Columbia Basin Redband Trout (Oncorhynchus mykiss gairdneri).............353

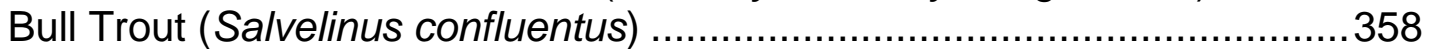
Lake Trout (native lakes) (Salvelinus namaycush) ..................................365

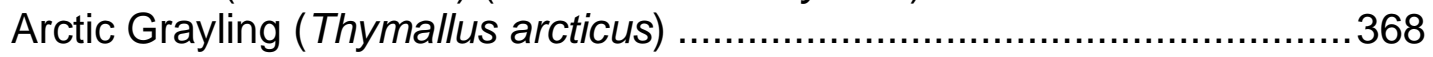

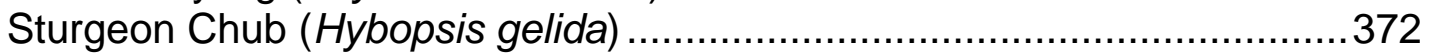

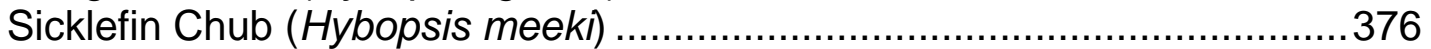

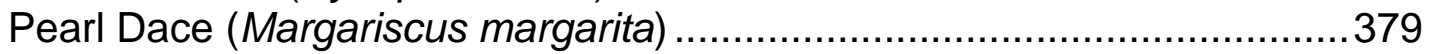

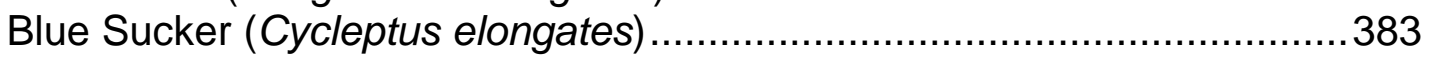
Trout-perch (Percopsis omiscomaycus) …...........................................385

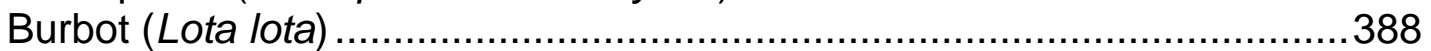

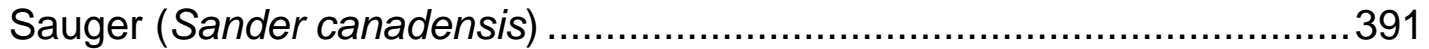

Component IV: Greatest Inventory Needs ................................................396

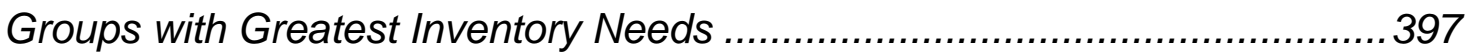

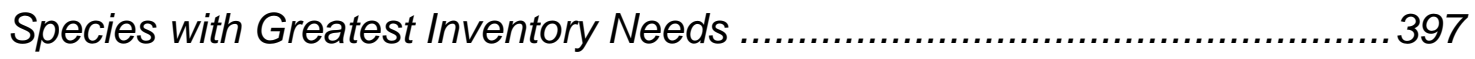

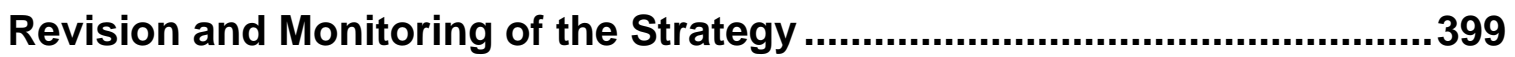

Law Enforcement, Con/Ed, and State Parks............................................403

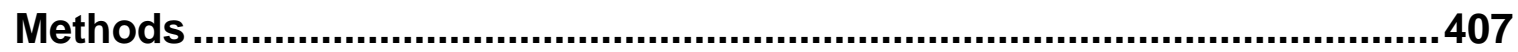

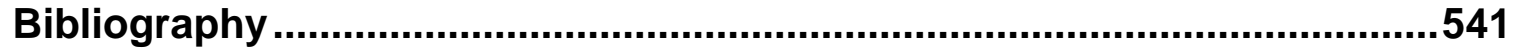

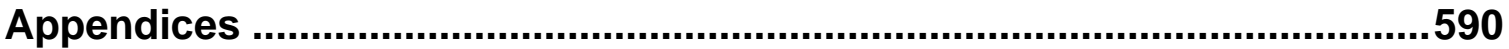

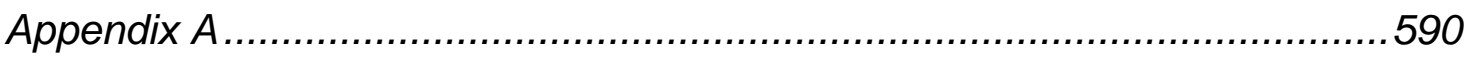

Guiding Principles for States to Consider in Developing Comprehensive Wildlife Conservation Plans and Wildlife Conservation Strategies (PlansStrategies) for the State Wildlife Grant and Wildlife Conservation and

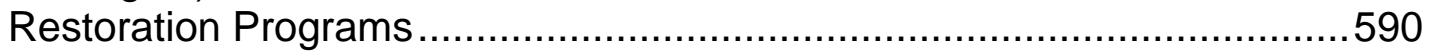

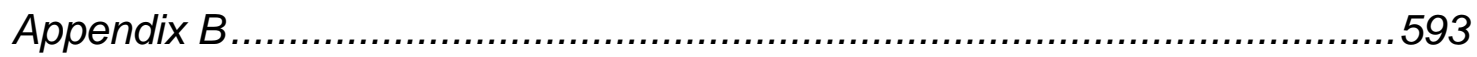

Process for Allocating Annual State Wildlife Grant Funds ........................593

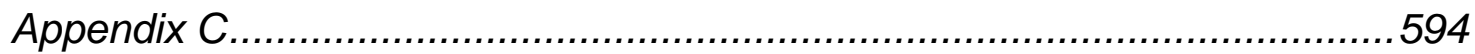

Fish, Wildlife \& Parks State Wildlife Grant Program ...............................594

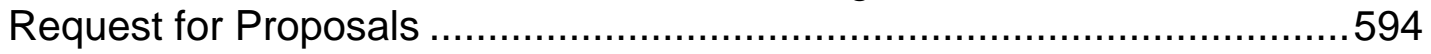

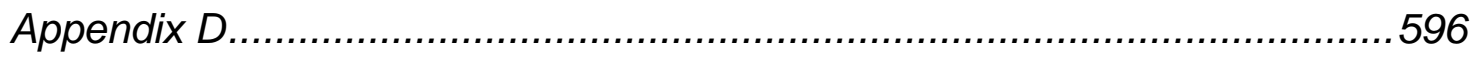

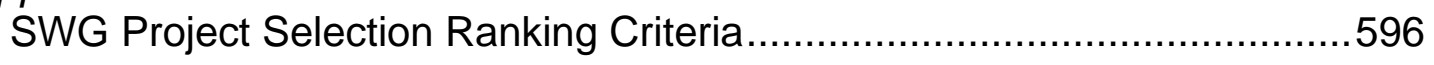

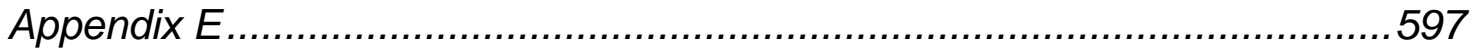




\section{DRAFT WORKING DOCUMENT DO NOT DUPLICATE}

203 Montana Fish, Wildlife \& Parks Staff Exploratory Group............................597

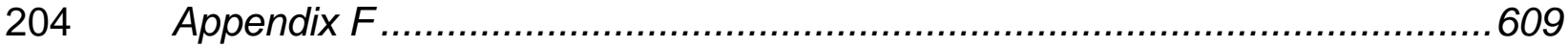

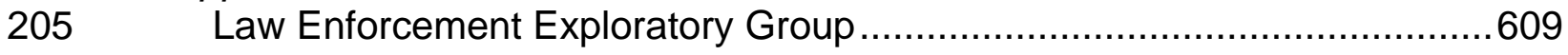

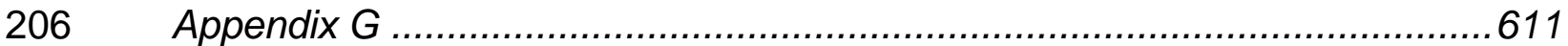

$207 \quad$ Invitees to Advisory Group Meeting October 1, 2003 ............................611

208 Questions and Input of Participants of October 1, 2003 Advisory Group613

$209 \quad$ Appendix H: Terrestrial Focus Area Priorities ......................................622

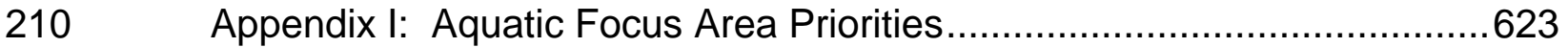

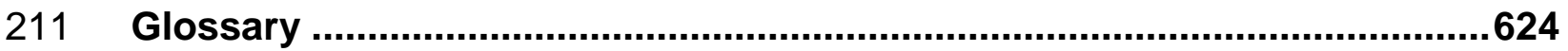

212

213 


\section{DRAFT WORKING DOCUMENT DO NOT DUPLICATE}

\section{List of Figures}

214

215

216

217

218

219

220

221

222

223

224

225

226

227

228

229

230

231

232

233

234

235

236

237

238

239

240

241

242

243

244

245

246

247

248

249

250

251

252

253

254

255

256

257

258

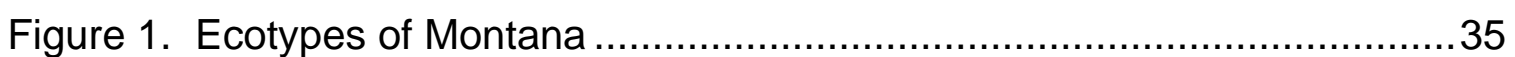

Figure 2. Intermountain/Foothill Grassland Ecotype ....................................37

Figure 3. Bitterroot/Frenchtown Valleys Focus Area..................................... 43

Figure 4. Central Montana Broad Valleys Focus Area ....................................46

Figure 5. Deerlodge Valley Focus Area ...................................................49

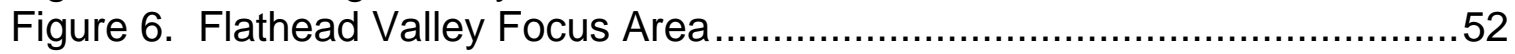

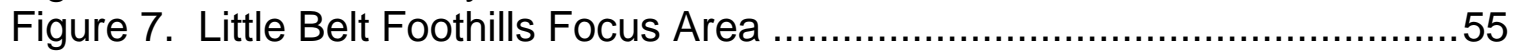

Figure 8. Tobacco Root Mountains Focus Area ..........................................58

Figure 9. Rocky Mountain Front Foothills Focus Area ...................................61

Figure 10. South Elkhorn Mountains Focus Area.........................................64

Figure 11. Southwest Montana Intermontane Basins and Valleys Focus Area..67

Figure 12. Upper Yellowstone Valley Focus Area.........................................70

Figure 13. Big Hole River Focus Area..................................................... 73

Figure 14. Bitterroot River Focus Area................................................... 76

Figure 15. Blackfoot River Focus Area .................................................. 78

Figure 16. Jefferson River Focus Area .................................................. 81

Figure 17. Upper Yellowstone River Focus Area ..........................................84

Figure 18. Montane Forest Ecotype ....................................................... 87

Figure 19. Mission/Swan Valley and Mountains Focus Area .......................... 94

Figure 20. Lower Clark Fork River Focus Area ............................................ 97

Figure 21. Middle Clark Fork Focus Area ……....................................... 100

Figure 22. Plains Grassland and Plains Forest Ecotype ................................103

Figure 23. Missouri Coteau Focus Area.................................................. 112

Figure 24. Montana Sedimentary Plains Focus Area...................................115

Figure 25. Lower Missouri River Focus Area ............................................ 118

Figure 26. Lower Yellowstone River Focus Area ......................................120

Figure 27. Powder River Focus Area ................................................... 122

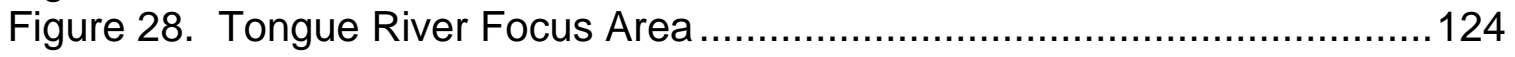

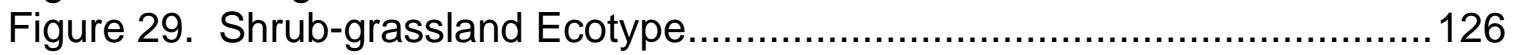

Figure 30. Bighorn Intermontane Basin Focus Area ..................................130

Figure 31. Montana Glaciated Plains Focus Area....................................... 133

Figure 32. Montana Shale Plains Focus Area..........................................136

Figure 33. Powder River Basin/Breaks/Scoria Hills Focus Area .....................139

Figure 34. Shale Scablands Focus Area.................................................. 142

Figure 35. Middle Missouri River and Tributaries Focus Area .......................145

Figure 37. Distribution of Grassland Community Types................................149

Figure 37. Distribution of Mixed Broadleaf Forest Community Types .............. 153

Figure 38. Distribution of Mixed Shrub/Grass Associations Community Types 156

Figure 39. Distribution of Wetland and Riparian Community Types.................159

Figure 40. Distribution of Sagebrush and Salt Flats Community Types ...........165

Figure 41. Distribution of Mountain Stream Community Types.......................167

Figure 42. Distribution of Prairie Stream Community Types ...........................170

Figure 43. Distribution of the Western Pearlshell Mussel...............................174

Figure 44. Distribution of the Coeur d'Alene Salamander .............................176 


\section{DRAFT WORKING DOCUMENT DO NOT DUPLICATE}

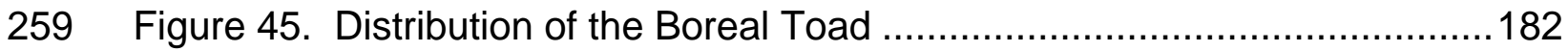

260 Figure 46. Distribution of the Northern Leopard Frog.................................. 186

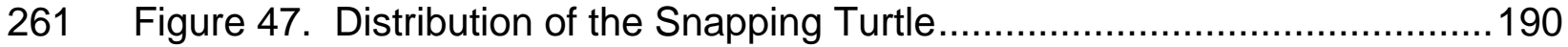

262 Figure 48. Distribution of the Spiny Softshell Turtle .................................... 194

263 Figure 49. Distribution of the Western Hognose Snake ................................ 197

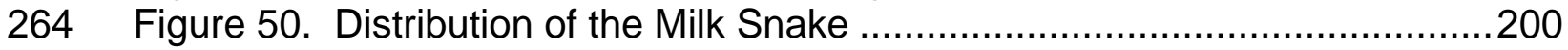

265 Figure 51. Distribution of the Smooth Green Snake...................................202

266 Figure 52. Distribution of the Common Loon ..............................................204

267 Figure 53. Distribution of the Trumpeter Swan .........................................211

268 Figure 54. Distribution of the Harlequin Duck .........................................215

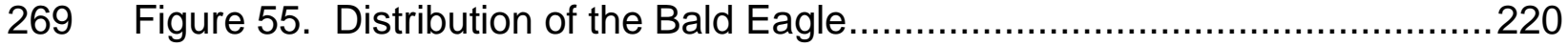

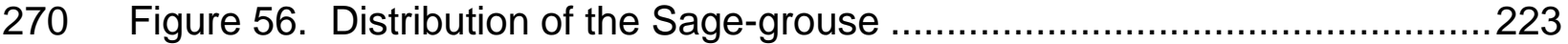

271 Figure 57. Distribution of the Columbian Sharp-tail Grouse ..........................22

272 Figure 58. Distribution of the Yellow Rail ..................................................232

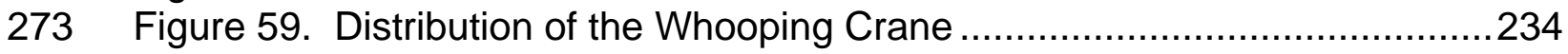

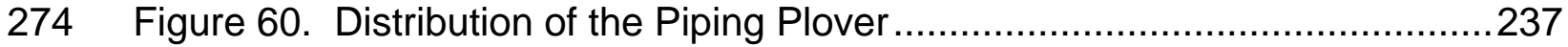

275 Figure 61. Distribution of the Mountain Plover ........................................242

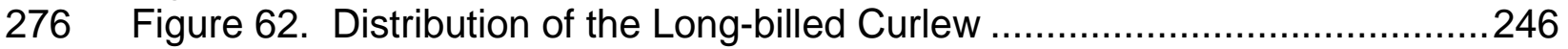

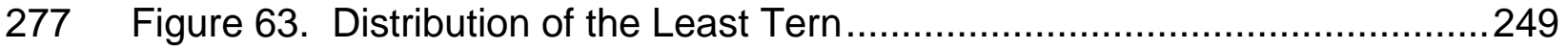

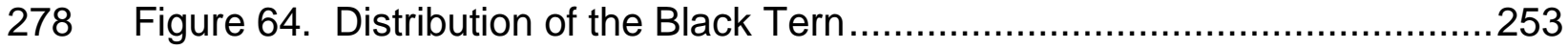

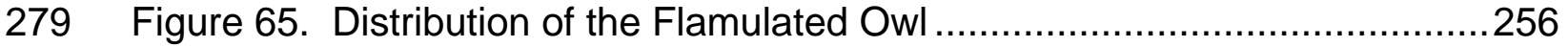

280 Figure 66. Distribution of the Burrowing Owl..........................................263

281 Figure 67. Distribution of the Black-backed Woodpecker ..............................266

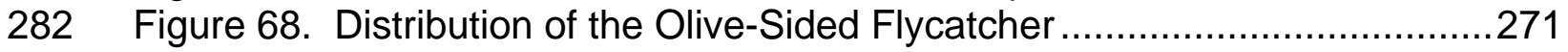

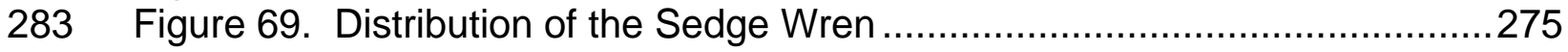

284 Figure 70. Distribution of the Nelson's Sharp-tailed Sparrow.........................277

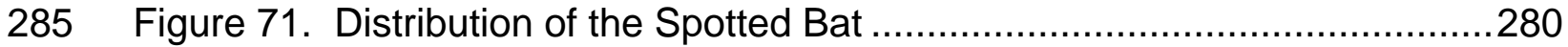

286 Figure 72. Distribution of the Townsend's Big-eared Bat ..............................285

287 Figure 73. Distribution of the Pallid Bat.................................................290

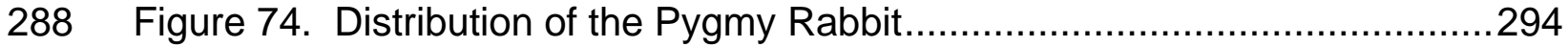

289 Figure 75. Distribution of the Hoary Marmot ..............................................297

290 Figure 76. Distribution of the Black-tailed Prairie Dog...................................299

291 Figure 77. Distribution of the White-tailed Prairie Dog ..................................302

292 Figure 78. Distribution of the Great Basin Pocket Mouse ..............................304

293 Figure 79. Distribution of the Northern Bog Lemming …...............................307

294 Figure 80. Distribution of the Meadow Jumping Mouse .................................311

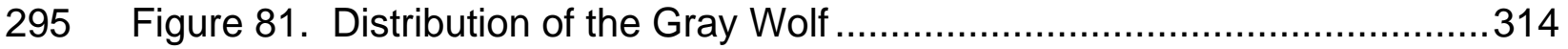

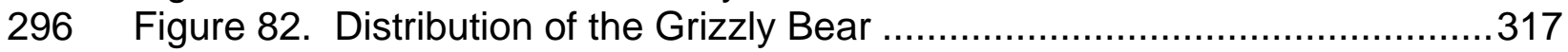

297 Figure 83. Distribution of the Black-footed Ferret .......................................320

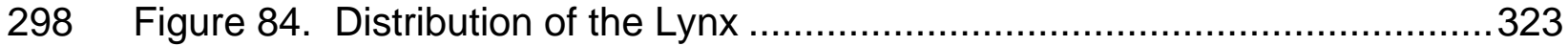

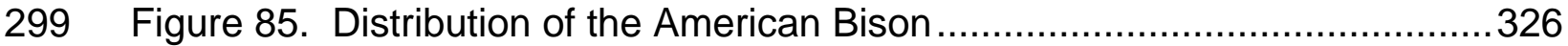

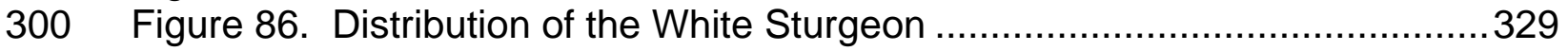

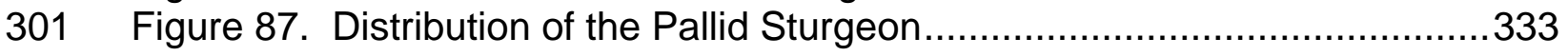

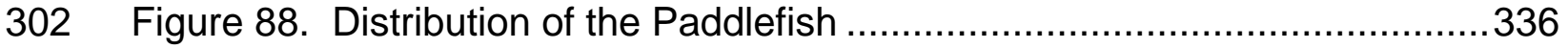

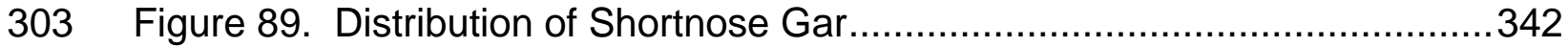

304 Figure 90. Distribution of the Yellowstone Cutthroat Trout.............................344 
305 Figure 91. Distribution of the Westslope Cutthroat Trout …...........................349

306 Figure 92. Distribution of the Columbia Basin Redband Trout .........................353

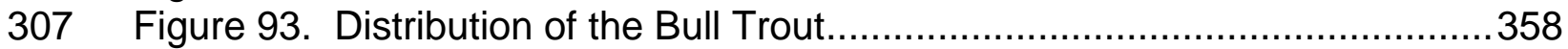

308 Figure 94. Distribution of Native Populations of lake Trout .............................365

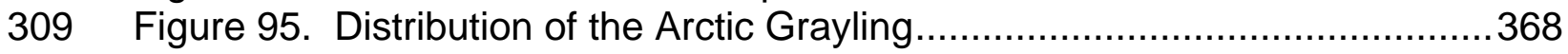

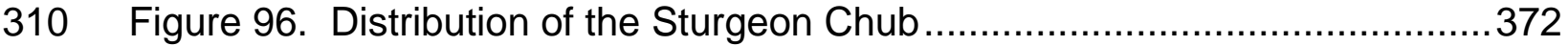

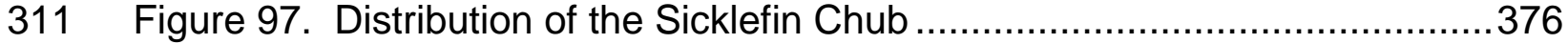

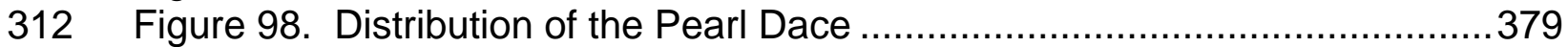

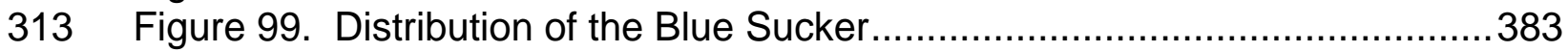

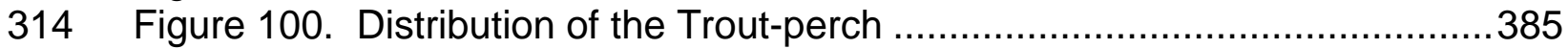

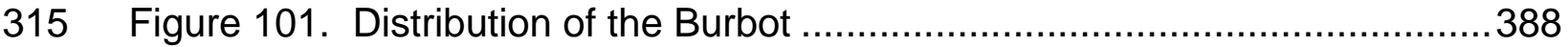

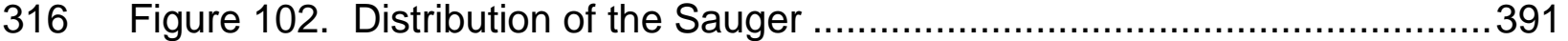

317

318 


\section{DRAFT WORKING DOCUMENT DO NOT DUPLICATE}

\section{List of Tables}

319

320

321

322

323

324

325

326

327

328

329

330

331

332

333

334

335

336

337

338

339

340

341

342

343

344

345

346

347

348

349

350

351

352

353

354

355

356

357

358

359

360

361

362

363
Table 1. Conservation \& Management Plans of Montana.................................411

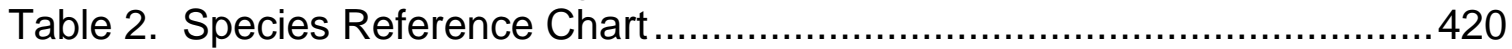

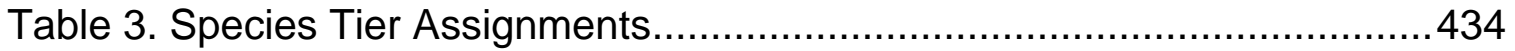

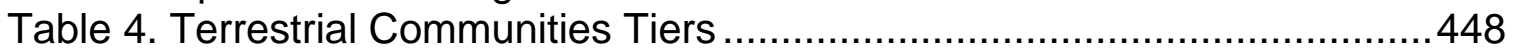

Table 5. Aquatic Community Tiers ...............................................................449

Table 6. Terrestrial Focus Area Rankings based on USFS Subsections ..........449

Table 7. Aquatic Focus Area Rankings based on Fourth Code HUC's .............451

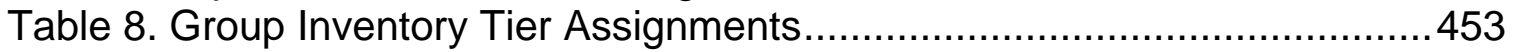

Table 9. Species Inventory Tier Assignments ..............................................454

Table 10. Bitterroot/Frenchtown Valleys Focus Area-Species Associations ..... 471

Table 11. Central Montana Broad Valleys Focus Area-Species Associations .. 474

Table 12. Deerlodge Valley Focus Area-Species Associations .......................477

Table 13. Flathead River Valley Focus Area-Species Associations..................479

Table 14. Little Belt Foothills Focus Area-Species Associations.......................482

Table 15. North Tobacco Root Mountains and Foothills Focus Area-Species

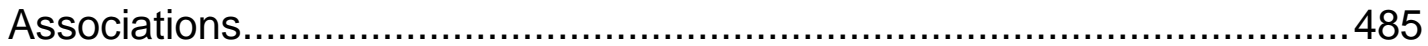

Table 16. Rocky Mountain Front Foothills Focus Area-Species Associations .. 487

Table 17. South Elkhorn Mountains Focus Area-Species Associations............490

Table 18. Southwest Montana Intermontane Basins \& Valleys Focus Area-

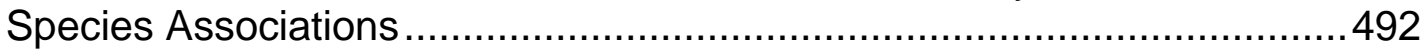

Table 19. Upper Yellowstone Valley Focus Area-Species Associations ........... 495

Table 20. Big Hole River Focus Area-Species Associations ........................... 497

Table 21. Bitterroot River Focus Area-Species Associations .......................... 498

Table 22. Blackfoot River Focus Area-Species Associations...........................499

Table 23. Jefferson River Focus Area-Species Associations...........................500

Table 24. Upper Yellowstone River Focus Area-Species Associations .............501

Table 25. Mission/Swan Valley and Mountains Focus Area-Species Associations

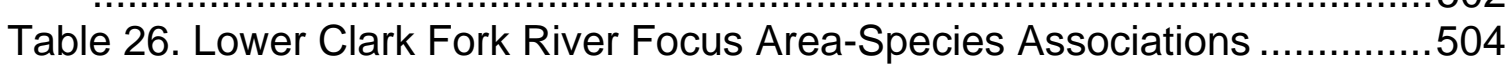

Table 27. Middle Clark Fork River Focus Area-Species Associations ...............505

Table 28. Missouri Coteau Focus Area-Species Associations .........................506

Table 29. Montana Sedimentary Plains Focus Area-Species Associations ......509

Table 30. Lower Missouri River Focus Area-Species Associations .................. 512

Table 31. Lower Yellowstone River Focus Area-Species Associations .............513

Table 32. Powder River Focus Area-Species Associations .............................514

Table 33. Tongue River Focus Area-Species Associations .............................515

Table 34. Bighorn Intermontane Basin Focus Area-Species Associations .......516

Table 35. Montana Glaciated Plains Focus Area-Species Associations ............518

Table 36. Montana Shale Plains Focus Area-Species Associations .................521

Table 37. Powder River Basin/Breaks/Scoria Hills Focus Area-Species

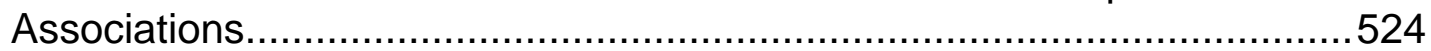

Table 38. Shale Scablands Focus Area-Species Associations .........................527

Table 39. Middle Missouri River Focus Area-Species Associations...................529

Table 40. Grassland Complexes Communities-Species Associations ...............530 
364 Table 41. Mixed Broadleaf Forest Communities-Species Associations 533

365 Table 42. Mixed Shrub/Grass Associations Communities-Species Associations

366

367 Table 43. Riparian \& Wetland Communities-Species Associations ......................535 534

368 Table 44. Sagebrush \& Salt Flat Communities Species-Associations ...............538

369 Table 45. Mountain Stream Communities-Species Associations ......................539

370 Table 46. Prairie Stream Communities-Species Associations ….....................540

371

372 


\author{
372 Index of Acronyms \\ 373 \\ 374 \\ 375 \\ AFA \\ Application for Federal Assistance \\ 376 \\ BLM \\ Bureau of Land Management \\ 377 \\ BOR \\ Bureau of Outdoor Recreation \\ CARA \\ Conservation and Reinvestment Act \\ 378 CFWCS \\ 379 CRP \\ 380 CPUE \\ 381 D-J \\ 382 DEQ \\ 383 \\ 384 \\ DNRC \\ 385 \\ ESA \\ Comprehensive Fish and Wildlife Conservation Strategy \\ Conservation Reserve Program \\ Catch Per Unit Effort \\ Dingell Johnson \\ Department of Environmental Quality \\ Department of Natural Resources \\ Endangered Species Act of 1973 \\ 386 GAP 50 \\ 387 GYE \\ (Montana) Fish, Wildlife \& Parks \\ 388 HUC \\ 389 IAFWA \\ 390 LWCF \\ 391 LIP \\ 392 MDOT \\ 393 MFWP \\ 394 NHP \\ 395 NPS \\ 396 NRCS \\ 397 \\ 398 \\ NWR \\ 399 PILT \\ 400 POD \\ 401 P-R \\ Geospacial Analysis Program (50 scale) \\ Greater Yellowstone Ecotype \\ Hydrologic Unit Code \\ International Association of Fish and Wildlife Agencies \\ Land and Water Conservation Fund \\ Land Incentives Program \\ Montana Department of Transportation \\ Montana Fish, Wildlife \& Parks \\ Natural Heritage Program \\ National Parks Service \\ Natural Resource Conservation Service \\ National Wildlife Refuge \\ Partners in Flight \\ Payment in Lieu of Taxes \\ Point Observation Databse \\ Pittman-Roberts \\ 402 RNA \\ 403 SOC \\ 404 SWG \\ Research Natural Area \\ Species of Concern \\ 405 TNC \\ 406 TWS \\ State Wildlife Grants \\ The Nature Conservancy \\ The Wildlife Society \\ United State Department of Agriculture \\ Inited States Forest Service \\ 408 USFS \\ 409 USFWS \\ 410 USGS \\ 411 WCRP \\ United States Fish and Wildlife Service \\ United States Geological Survey \\ Wildlife Conservation and Restoration Program
}




\section{DRAFT WORKING DOCUMENT DO NOT DUPLICATE}

\section{Foreword}

413

414

415

416

417

418

419

420

421

422

423

424

425

426

427

428

429

430

431

432

433

434

435

436

437

438

439

440

441

442

443

444

445

446
Montana, like other states, is rich in fish and wildlife species but unfortunately not in the funds needed to address them all successfully. Responding to the need for funding, Congress established the State Wildlife Grants (SWG) program in 2001. The funds support conservation projects for species historically overlooked because money has been short. To ensure that funds are used efficiently and effectively, Congress charged each state to develop a comprehensive assessment of its fish, wildlife, and their associated habitats. Montana Fish, Wildlife \& Parks (FWP) committed to developing such an assessment and, after two years of development, created a document that FWP regards as an important evolution in wildlife management.

It might be easiest to view Montana's comprehensive assessment as a statewide fish and wildlife census and as an analysis of the places our fish and wildlife inhabit. The assessment reads almost like a field guide and is a great source of information for anybody interested in Montana's fish and wildlife. This strategy has the potential to bring together people of diverse backgrounds and skills to achieve conservation on a grand scale. It is an opportunity to integrate existing conservation efforts, develop additional programs, and leverage the limited resources available to benefit the most species.

\section{Montana's Comprehensive Fish and Wildlife Conservation Strategy is this} generation's opportunity to be part of something as significant as the efforts to pass the Pittman-Robertson and Dingell-Johnson acts, which saw hunters and anglers agreeing to fund conservation efforts through taxes on hunting and fishing equipment. FWP hopes this comprehensive assessment will enable Montana to build on past successes and broaden the agency's ability to fulfill its mission to conserve all species.

\section{Jeff Hagener}

Director

Montana Fish, Wildlife \& Parks 


\section{DRAFT WORKING DOCUMENT DO NOT DUPLICATE}

446

447

448

449

450

451

452

453

454

455

456

457

458

459

460

461

462

463

464

465

466

467

468

469

470

471

472

473

474

475

476

477

478

479

480

481

482

483

484

485

486

487

488

489

490

\section{Acknowledgements}

This Strategy was developed through collaboration and hard work of many FWP employees alongside numerous agencies, organizations and public throughout Montana. A special thanks is extended to the Montana Senators, the Honorable Conrad Burns and the Honorable Max Baucus and member of House of Representatives, the Honorable Denny Rehburg who continue to support State Wildlife Grant funding. Although all the individual contributors are too numerous to recognize, we would like to especially acknowledge the critical support provided by Montana Natural Heritage Program, The Nature Conservancy, The National Wildlife Federation, the Montana Wildlife Federation, Montana Audubon, The Defenders of Wildlife, The Rocky Mountain Elk Foundation, The Blackfoot Challenge, the Tribes of Montana, The University of Montana, Montana State University, U.S. Forest Service-Northern Region, and Bureau of Land Management.

\section{Introduction}

\section{By Mike Aderhold}

For centuries Native Americans observed and hunted Montana's wildlife. Their stories sketched on rocks and passed on by oral tradition constitute Montana's earliest wildlife record.

Montana's scientific wildlife record starts just 200 years ago with the observations of six members of the Lewis \& Clark expedition (Lewis, Clark, Ordway, Floyd, Gass and Whitehouse). They followed a western tradition of writing notes on paper. These pioneering naturalists documented the rich variety of wild animals that existed in Montana at the dawn of European settlement.

Heading home in 1806, the Lewis \& Clark expedition passed trappers traveling west. These mountain men were soon followed by traders. They were followed by explorers, surveyors, wealthy tourists... pioneering women, prospectors and cowboys... miners, ranchers, missionaries...merchants, railroaders, tradesmen... speculators, entrepreneurs... wolfers, tuskers, and homesteaders. Their tradition was to live off the land as much as possible. The impacts on fish and wildlife were devastating.

In 1912, William Hornaday, then director of the New York Zoological Park, wrote to several Montanans asking about wildlife that had become extinct or was threatened with extinction. In his 1913 book, Our Vanishing Wildlife it was noted in the Montana section that many birds were on the verge of extinction. But the only animals that had vanished from the wild were free roaming bison, passenger pigeons and whooping cranes. Threatened animals included blue grouse, trumpeter swans, most waterfowl species, long-billed curlews, white-tailed 


\section{DRAFT WORKING DOCUMENT DO NOT DUPLICATE}

491 ptarmigans, plovers, grizzly bear and moose. Montana had fewer than 3,000 elk,

492

493

494

495

496

497

498

499

500

501

502

503

504

505

506

507

508

509

510

511

512

513

514

515

516

517

518

519

520

521

522

523

524

525

526

527

528

529

530

531

532

533

534

535

536

less than 3,000 antelope and very few deer east of the Rockies.

\section{REACTION}

The initial reaction of residents of the Montana Territory to their disappearing wildlife heritage included passage of protective legislation, creation of a wildlife agency, instituting revenue generating licenses, organization of an enforcement effort, and the start of a wildlife restoration program.

\section{EARLY LEGISLATION (1864-1893)}

The first Montana Territorial Legislature (1864-65) passed a bill requiring “...a rod or pole line and hook...to catch trout in the Territory". In 1876 a law was passed prohibiting fishing with explosives. In 1881 a law was passed prohibiting the dumping of sawdust and mill waste into a stream. Starting in 1883 the popular pastime of collecting bird eggs was prohibited. In 1893 moose and elk hunting seasons were closed statewide.

\section{CREATION OF A MONTANA WILDLIFE AGENCY (1901)}

When Montana became the 41st State of the Union on November 8, 1889, county commissioners were empowered to hire one game warden for each county. There was either no money or little concern because no wardens were immediately appointed. By 1900 only four of the then 24 counties hired game wardens. The first board of Fish and Game Commissioners was appointed by Governor Robert A. Smith on March 4, 1895. A State Game Warden, R.A. Wagner, was appointed in July 1898.

The 1901 Legislature, acting on a recommendation of the Fish and Game Commissioners, organized the Montana Fish and Game Department (April 1, 1901). The charter created fish and game districts and authorized the appointment of up to eight "deputies"- one for each district. The new Department received over 1,000 applications for positions that paid \$100 per month including travel expenses.

\section{ENFORCEMENT (1886-1916)}

It is impossible to regulate effectively without some degree of enforcement. This was discovered in Yellowstone National Park where despite federal and state laws, market hunting, souvenir collecting and livestock trespass were rampant. Early Park Superintendents and visiting naturalists documented the problem and finally appealed to War Department Secretary W.W. Belknap.

On August 20, 1886, Captain Moses Harris, led M Troop, First United States Cavalry, into Mammoth Hot Springs, Wyoming. He took over the duties of the 


\section{DRAFT WORKING DOCUMENT DO NOT DUPLICATE}

537 civilian superintendent and his soldiers assumed the role of park police. Captain

538 Harris was under orders from General Phil Sheridan to control the poachers, stop

539 the vandalism and protect the buffalo and elk.

540

541 Eight years later Congress would pass the Yellowstone Park Protection Act of

5421894 giving the Army some authority to arrest violators and confiscate their

543 equipment. The Army would stay in Yellowstone Park for 32 years and become

544 the model for National Park Service rangers and western State Game Wardens.

545

546

547

Initially all of Montana's Fish and Game employees were commissioned law

548

549

550

551

552

553

554

555

556

557

558

559

560

561

562

563

564

565

566

567

568

569

570

571

572

573

574

575

576

577

578

579

580

581

582 enforcement officers. The Director was initially called the "State Game Warden" and the district employees were called "Deputy Game Wardens". One of the first assignments of new deputies was to go throughout their districts posting the game laws.

FIRST LICENSES (1901-1905)

The 1901 legislature required nonresidents to purchase a $\$ 25$ big game license and a \$15 license was required to hunt game birds. The first resident hunting and fishing license was created in 1905 . The cost of the license was \$1, at a time when a laborer's wage was $\$ 2$ a day. Only one license was required per family. There were 30,220 licenses sold in 1905 . Receipts for the year were $\$ 30,593.50$ and expenses incurred by the Fish and Game were $\$ 16,788.40$. In 1906, receipts totaled $\$ 24,491.13$ and expenses were $\$ 17,410.95$.

This new system required a support staff. The first year 300 Justices of the Peace were supported to some degree by the license sales and fines for wildlife violations.

\section{LAND PROTECTION AND RESTORATION (1872-1936)}

In 1872 Congress set aside 3,300 square miles of land around the headwaters of the Yellowstone River. "...to provide against the wanton destruction of fish and game... and against their capture or the destruction for the purpose of merchandise...". Yellowstone National Park and the enactment of its Protection Act in 1894, were the first field efforts to conserve wildlife habitat in the West.

President Benjamin Harrison started the first government "preserve" in 1892 when he set aside Afognak Island off the coast of Alaska for the protection of terrestrial wildlife, salmon and sea mammals. President Theodore Roosevelt started the national "Refuge" movement in 1903 with Pelican Island NWR off the east coast of Florida. Before leaving office in 1909, Roosevelt created 52 more wildlife refuges on federal land - all by "executive order". In 1908 Congress followed by authorizing federal funds to purchase 12,800 acres from the Flathead Indians for the first part of the National Bison Range. 


\section{DRAFT WORKING DOCUMENT DO NOT DUPLICATE}

583

584

585

586

587

588

589

590

591

592

593

594

595

596

597

598

599

600

601

602

603

604

605

606

607

608

609

610

611

612

613

614

615

616

617

618

619

620

621

622

623

624

625

626

627

628

Between 1911 and 1936 the State of Montana established 46 "Preserves" starting with the Snow Creek, Pryor Mountain, and Gallatin Preserves in 1911 and the Sun River Preserve in 1913. Between 1913 and 1925 state refuges and preserves were established in 24 states.

The original "preserve" concept was to protect relic wildlife populations from hunting and human harassment. As these protected populations increased they naturally spread to adjacent areas and some resident animals were trapped and relocated to suitable habitat. In 1910, 25 elk from the Northern Yellowstone Park winter range were relocated to Fleecer Mountain. This was the first Fish and Game relocation of a big game species. Butte and Anaconda hunters and anglers paid \$5/elk to cover the transportation.

In 1907 the Montana Legislature created a \$1 resident fishing license. Some of this money was used the next year to open the first state fish hatchery in Anaconda. This hatchery was initially used to raise cutthroat trout to enhance populations throughout their Montana range.

Wardens and Forest Service personnel started surveying elk along the Rocky Mountain Front in 1903.

\section{PITTMAN-ROBERTSON ACT (1937)}

In 1936, the first North American Wildlife Conference brought together leaders of the most prominent conservation organizations and representatives from more than 20 agencies concerned about the nation's wildlife resources. The "proceedings" of this meeting, now a collector's item, brought together more information on the status of North American wildlife and the problems facing wildlife conservation, than had ever been published in one volume. Out of this meeting came a commitment to develop a "national wildlife program".

In 1937, a Senate Special Committee on the Conservation of Wildlife Resources and a similar committee in the House introduced a bill earmarking Depression Era excise taxes on sporting arms and ammunition to state wildlife agencies for conservation easements, development, and research. The Federal Aid in Wildlife Restoration Act, or Pittman/Robertson Act (named for the two committee chairmen, Rep. A. Willis Robertson, Virginia, and Sen. Key Pittman, Nevada), became law September 2, 1937.

This law created a special fund that continues to earn revenue from an $11 \%$ federal excise tax on firearms, ammunition, and archery equipment, and a 10\% tax on handguns. This fund is administered by the U.S. Fish and Wildlife Service. Most of the revenue is apportioned among the states by a formula based $50 \%$, on the state's area and $50 \%$ on the number of hunting license holders. No state receives less than one-half of $1 \%$, or more than $5 \%$, of the amount annually available. These federal allocations must be matched by state funds, with states 


\section{DRAFT WORKING DOCUMENT DO NOT DUPLICATE}

629 providing at least 25\% (for every dollar of federal money, the states must match

630 with 33.33 cents). One of the most farsighted features of the act was a 29 word

631 requirement that each state must prohibit diversion of hunting license revenue to

632 other uses. All 50 states have enacted such laws. The goal was to ensure that

633 every state could sustain a long-term wildlife restoration and management

634 program.

635

636

637

638

639

640

641

642

643

644

645

646

647

648

649

650

651

652

653

654

655

656

657

658

659 With this new funding the Fish \& Game Department (later Fish, Wildlife \& Parks)

660

661

662

663

664

665

666

667

This foundation allowed Montana to buy land for wildlife (1938) and to employ its first wildlife biologists (1940). Since its passage, Montana has received $\$ 125,230,898$ dollars in apportionments (through FY04). Most of Montana's 84 Wildlife Management Areas were purchased with these matching funds.

In 1970 amendments to the P-R Act gave Montana an option. Instead of submitting individual projects, it could submit a "comprehensive fish and wildlife resource management plan" covering at least five years. Once approved, projects encompassed by this plan, would be routinely funded.

\section{DINGELL-JOHNSON ACT (1950)}

During World War II Congress enacted excise taxes on fishing equipment. After the War, Rep. John Dingell, Michigan and Sen. Edwin Johnson, Colorado, put together a bill modeled closely after the P-R program using revenues originally derived from the 10 percent federal excise tax on fishing rods, creels, reels, artificial lures, baits and flies. Forty percent of this allocation is based on the state's geographic area and 60 percent on the number of the state's fishing license holders. This law also had a requirement that the state must prohibit the diversion of fishing-license revenues and there was also a requirement for a 1:3, state:federal match. The statute was officially called the Federal Aid in Sport Fish Restoration Act and Montana through FY04 has received \$103,378,741 dollars. hired regional fisheries biologists and started a number of management projects including native fish management in rivers, the impact of logging on streams, fish problems at irrigation diversions, a study of the habits and habitat of native grayling and, in 1955, the long remembered exotic fish removal above the site of Tiber Dam.

It was also during the 1950s that the seven administrative regions were established, with regional offices set up in Kalispell, Missoula, Bozeman, Great

668 Falls, Billings, Glasgow and Miles City.

669

670

671

672 LAND AND WATER CONSERVATION FUND (1965)

673 In 1963, in response to increasing demands for outdoor recreation, Congress 674 created the Bureau of Outdoor Recreation (BOR) in the Department of Interior. Two years later, in 1965, Congress established the Land and Water 


\section{DRAFT WORKING DOCUMENT DO NOT DUPLICATE}

675 Conservation Fund using monies from the disposal of federal surplus property,

676 certain user fees and some of the federal royalties from offshore (outer

677 continental shelf) oil and gas production. Money from this fund is appropriated by

678 Congress and the amount varies. It has been as high as $\$ 900$ million a year

679 nationwide.

680

681

682

683

684

685

686

687

688

689

690

691

692

693

694

695

696

697

698

699

700

701

702

703

704

705

706

707

708

709

710

711

712

713

714

715

716

717

718

719

The broad purpose of LWCF is to "...provide a diversity of outdoor recreation resources which would allow individual active participation in a variety of outdoor pastimes...".

Up to $60 \%$ of the appropriation may be used to cost-share, on a 50:50 matching bases, certain activities carried out by the states, including “...planning, acquisition and development of needed land and water areas...". Responsibility for the program was transferred to the National Park Service in 1981.

Over the years this funding has been erratic. In 1965 the funding was $\$ 300$ million; \$600 million in 1978; \$900 million from 1980 through 1989. During the 1980s dozens of Montana communities funded swimming pools and tennis courts and FWP's Parks Division purchased Wildhorse Island and parts of Giant Springs Heritage State Park.

During the 1990s the appropriations were greatly reduced and the state/local part of the LWCF dropped to zero between 1995 and 1999. The Bureau of Land Management (BLM), U.S. Forest Service (USFS) and U.S. Fish \& Wildlife Service (USFWS) all receive LWCF money which has been used to purchase inholdings, wetlands and some easements.

\section{ENDANGERED SPECIES ACTS $(1966,1969,1973)$}

During the 1960s concern grew about the status and conservation of our rarest plants and animals. There was prolonged debate about the role of government for species threatened by human activities. The first result was the Endangered Species Preservation Act of 1966. That law directed the heads of all federal agencies in the Departments of Interior, Agriculture and Defense to protect native wildlife declared "endangered". It also provided funds to acquire habitat for these animals. It required the Secretary of the Interior to identify species in jeopardy.

In 1969, Congress passed the Endangered Species Conservation Act. It expanded the definition of "fish and wildlife" to include reptiles, amphibians, mollusks and crustaceans. It expanded the listing to include animals classified as "threatened with extinction" and it made commercial traffic of "endangered" and "threatened" species illegal.

A few years later Congress enhanced the 1969 Act still more to create the Endangered Species Act of 1973 (ESA). With a few changes this is the statute

720 we use today. This law formalized the listing procedure and required the 


\section{DRAFT WORKING DOCUMENT DO NOT DUPLICATE}

721

722

723

724

725

726

727

728

729

730

731

732

733

734

735

736

737

738

739

740

741

742

743

744

745

746

747

748

749

750

751

752

753

754

755

756

757

758

759

760

761

762

763

764

765

766 development of "recovery plans". It increased criminal penalties, added funds for habitat acquisition and put state "threatened" and "endangered" species under the clear authority and legal jurisdiction of the federal government.

There was also movement at the state level. In 1972, the International Association of Fish and Wildlife Agencies (IAFWA) and The Wildlife Society (TWS) developed a model state nongame and endangered species law. The 1973 Montana Legislature adopted this law on July 1, 1973. It granted Fish, Wildlife \& Parks the authority to conserve resident "endangered" and "threatened" wildlife and to conduct nongame and endangered species research, acquire habitat for their use and to develop management programs for these species.

Presently, Montana has 14 species listed as either federally "Threatened" or "Endangered" - 4 birds, 4 mammals, 3 fish and 3 plants. "Threatened" (9 species) include Bald Eagle, Piping Plover, Grizzly Bear, Gray Wolf, Canada Lynx, Bull Trout, Water Howellia, Spalding Catchfly, Ute Ladies'- tresses. Endangered (5 species) include Whooping Crane, Least Tern, Black-footed Ferret, Pallid Sturgeon, White Sturgeon. Nationally there are now 276 Threatened species (147 plants) and 987 Endangered species (599 plants).

\section{FORSYTHE-CHAFEE ACT (1980)}

In 1980 Congress passed the Fish and Wildlife Conservation Act that is also referred to as the Nongame Act or Forsythe-Chafee Act (John Chafee, Rhode Island and Edwin Forsythe, New Jersey). This was meant to to promote the conservation of nongame fish and wildlife that receive relatively little $(12-13 \%$, 1985, FWS est.) assistance under the Pittman-Robertson and Dingell Johnson statutes. The Forsythe-Chafee Act authorizes federal technical and financial assistance to the states, generally on a $75 \%-25 \%$ state basis, for the development of plans, programs and projects benefiting nongame animals. "Nongame" is defined as those species "not ordinarily taken for sport" and which are not listed as "endangered" or "threatened" under the Endangered Species Act.

The Forsythe-Chafee Act was to be financed by general revenue appropriated annually by Congress. The statute authorized appropriations up to $\$ 5$ million for fiscal years 1982-1985 but neither the Reagan Administration nor Congress ever appropriated any money.

The U.S. Fish \& Wildlife Service studied 25 potential funding methods including general appropriations, various fees and different excise taxes. In 1986 Congress held a hearing on nongame legislation and the financing study, but because of the deficits during the Reagan and the first Bush Administrations, this nongame proposal stalled. 


\section{DRAFT WORKING DOCUMENT DO NOT DUPLICATE}

780

781

782

783

784

785

786

787

788

789

790

791

792

793

794

795

796

797

798

799

800

801

802

803

804

805

806

807

808

809

810

811

812

MITCHELL ADMENDMENT (1988)

Some dramatic declines in shore birds and neotropical migrants were documented during the 1980s. Several bird, conservation organizations made this concern a cause and Congress responded by adjusting the U.S. Fish \& Wildlife Service's budget expressly for bird monitoring. The new Senate Majority Leader George Mitchell pointed out that the USFWS, under the Migratory Bird Act of 1918 and the Fish \& Wildlife Conservation Act of 1980, had responsibility to monitor all migrating birds not just waterfowl and raptors. The USFWS needed to identify management actions before any particular species becomes listed as Federally threatened or endangered.

This was a strong message from Congress that it was time for the USFWS and other wildlife agencies to reexamine their programs and establish new priorities for all wildlife species. The National The Audubon Society dedicated 31 intermountain/foothill grassland to this specific issue in its 1989/1990 Wildlife Report.

\section{PARTNERS IN FLIGHT (1990)}

Partners In Flight (PIF) is a cooperative effort involving federal, state and local government agencies, philanthropic foundations, professional organizations, conservation groups and the academic community. It was launched in 1990 to promote the conservation of birds not covered by existing conservation activities. Its initial focus was on neotropical migrants - species breeding in North America and wintering in Central and South America.

The goal of Partners In Flight is to focus resources on improving monitoring, inventory, research, management and education programs involving birds and their habitats. This group and the North American Bird Conservation Initiative, Bird Conservation International, the National The Audubon Society Society, and others kept the pressure on for nongame funding.

TEAMING WITH WILDLIFE INITIATIVE (1995)

The Internation Association of Fish and Wildlife Agencies (IAFWA) was founded in 1902 and today it includes the leaders of wildlife agencies throughout the U.S., Canada and several Central American countries. In 1995 this group took on the challenge of finding money for a comprehensive wildlife management program. Traditionally western state wildlife programs have been almost exclusively supported by hunters and anglers.

IAFWA recruited a "team" that included the American Fisheries Society, the Izaak Walton League, the National Wildlife Federation, the National The Audubon Society Society, The Nature Conservancy, The Wildlife Society, the Wildlife Management Institute and others. They developed an idea to establish a federal 


\section{DRAFT WORKING DOCUMENT DO NOT DUPLICATE}

813 tax on a variety of outdoor supplies including backpacks, sleeping bags, tents,

814 canoes, binoculars, spotting scopes, photographic equipment, bird seed, feeders,

815 etc. The money would be allocated to states to fund programs benefiting

816 nongame wildlife.

817

818

819

820

821

822

823

824

825

826

827

828

829

830

831

832

833

834

835

836

837

838

839

840

841

842

843

844

845

846

847

848

849

850

This movement eventually attracted over 3,000 supporting groups and in 1998 the team introduced the initial version of CARA (Conservation and Reinvestment Act).

\section{MAGNUSON-STEVENS (1996)}

During the 1980s and early 1990s some coastal fish stocks diminished to the point where their survival was questioned. Senators Warren Magnuson

(Washington) and Ted Stevens (Alaska) led the discussion about coastal species and the impact on the economy of coastal cities and towns. In the hearing for the Fishery Conservation and Management Act much was said about the continuing loss of marine, estuarine and other aquatic habitats. The law highlighted the need for a national program to address conservation and management of the fishery resources throughout the United States. This, along with mounting concern about bird species, added more impetus to the push for a broad-based fish and wildlife conservation program.

\section{CONSERVATION AND REINVESTMENT ACT (1997)(CARA) FIRST ITERATION}

The CARA concept came from two places. The first was the Teaming With Wildlife coalition which initially settled on the "tried \& successful" excise tax idea by which hunters and anglers supported the P-R and D-J programs. The challenge was how to get the millions of recreationists who do not hunt or fish to pony up a share of the money needed to research, monitor and manage the majority of wildlife species not classified as "game".

The "teaming" concept was a creative partnership of recreation groups, equipment manufacturers, retailers, state and local politicians, land management agencies, wildlife agencies and others. The number of team members eventually surpassed 3,500. Each group wanted consideration for their special interest. The bill grew weekly and eventually had 8 Titles or Sections dealing with a.) coastal conservation; b.) land and water funding - city parks and recreation

851

852

853

854

855

856

857 areas; c.) nongame funding; d.) state park programs; e.) historic preservation initiatives; f.) federal lands and Indian lands; g.) conservation easement and species recovery programs and $h$.) federal payments in lieu of taxes (PILT payments).

This huge bill got a trial run in 1997. No one was prepared to embrace the whole thing. Unlike the gun manufacturers in 1937, many recreation equipment

858 manufacturers and dealers were reluctant to advocate higher taxes for their 


\section{DRAFT WORKING DOCUMENT DO NOT DUPLICATE}

859

860

861

862

863

864

865

866

867

868

869

870

871

872

873

874

875

876

877

878

879

880

881

882

883

884

885

886

887

888

889

890

891

892

893

894

895

896

897

898

899

900

901

902

903

904 customers and higher cost for their products. Some consumers broke ranks with their interest groups and expressed opposition. No Senator or Representative was willing to sponsor a bill with so many new taxes and so much new spending.

\section{CONSERVATION AND REINVESTMENT ACT (1998) (CARA) SECOND ITERATION}

Rather than collect money from people who buy outdoor products some suggested using the federal royalties and taxes from offshore oil and gas leasing and production. That idea had been around since the Land and Water Conservation Fund was created in 1965 . The revenue, which is over $\$ 4$ billion a year, generally goes directly to the Treasury. A slice of it had been pared out for LWCF but the bulk of this money had been used to balance the budget since the Carter Administration (1977-1981). The Clinton Administration was enjoying prosperity and there was a budget surplus so, in a bipartisan move, the proposed funding source for CARA funding source was switched to off shore oil and gas royalties. CARA would guarantee $\$ 3$ billion annually from the offshore drilling account for a 15 year period for all the programs in the original bill.

Scores of lawmakers came on board at the prospect of guaranteed funding for their states. Hundreds of grass root and national conservation groups continued to push the CARA idea in hope of winning earmarked money for their pet projects. President Clinton swore to make passage of CARA a priority in his final 2000 budget negotiations. All 50 governors supported CARA.

This idea started, not with the Teaming with Wildlife crew, but with a comparatively limited four-year-old proposal to use royalties from offshore oil and gas drilling to mitigate the damages caused by those activities. The initial draft plan would have created a revenue-sharing and coastal conservation fund for coastal states and the conservation of coastal areas.

The Conservation and Reinvestment Act flew high the summer of 2000. It passed the House with a 315 to 102 vote and had 66 sponsors in the Senate. The Senate Energy and Natural Resources Subcommittee voted 13-7 to report the historic legislation to the full Senate.

As the Clinton administration moved to a close, CARA encountered resistance. Some viewed the guaranteed, mandatory $\$ 45$ billion, 15-year stream of funding as an "entitlement" that circumvented the appropriations process. Western legislators did not like the LWCF Title and the potential to shift more land from the private to the public sector. Some Senators balked at the magnitude of the spending and brought up concerns about Social Security and Medicare. Still others brought up concerns about the primary maintenance backlog in National Parks and National Wildlife Refuges and suggested dealing with those problems first before acquiring new land. Finally some were angry at the administration's move to create a number of new National Monuments. 


\section{DRAFT WORKING DOCUMENT DO NOT DUPLICATE}

905

906

907

908

909

910

911

912

913

914

915

916

917

918

919

920

921

922

923

924

925

926

927

928

929

930

931

932

933

934

935

936

937

938

939

940

941

942

943
In the fall, just before the November 2000 presidential election the White House backed off the CARA proposal and worked out a compromise with the House Interior Appropriations Committee. The $\$ 3$ billion a year, 15-year, guaranteed $\$ 45$ billion package was reduced to a 6 year, $\$ 12$ billion total discretionary fund. This was called CARA Lite. President Clinton signed this bill (HR 4578) on October 11, 2000.

STATE WILDLIFE GRANTS (2001)

In 2001, during the first year of the George W. Bush administration, Congress created the State Wildlife Grant program (SWG). The State Wildlife Grant funding was aimed at providing help to the states to develop a broad-based, comprehensive wildlife program that addressed all vertebrate wildlife species. The hope was that implementation of such a program could avoid the expense and problems that come with recovering threatened and endangered species.

State Wildlife Grant monies are appropriated annually. So far Montana has received almost \$4.5 million: (\$1.3 million, 2002; \$1.0 million, 2003; \$1.08 million, 2004; and $\$ 1.09$ million, 2005) plus $\$ 852,710$ from a one-time 2001 transition program called the Wildlife Conservation and Restoration Program (WCRP).

In Montana, some of the State Wildlife Grant funds have been used to survey prairie fish, restore native Arctic grayling and westslope cutthroat trout, study sauger genetics and sauger movements in the Yellowstone River, investigate the status of native burbot, support management of the grizzly bear and the gray wolf, conserve black-tailed prairie dogs, and to conduct a statewide inventory of small mammals.

To receive future funding every state must develop a Comprehensive Fish and Wildlife Conservation Strategy by October 1, 2005. These strategies will help define a more integrated approach to the stewardship of all wildlife species with additional emphasis on species of concern and habitats at risk. It could shift the focus from single species management and highly specialized individual efforts to a more geographically based, landscape-oriented fish and wildlife conservation effort. 


\section{DRAFT WORKING DOCUMENT DO NOT DUPLICATE}

\section{Comprehensive Stategy Goals}

944

945

946

947

948

949

950

951

952

953

954

955

956

957

958

959

960

961

962

963

964

965

966

967

968

969

970

971

972

973

974

975

976

977

978

979

980

981

982

983

984

985

986

987

988
This Comprehensive Strategy embraces all vertebrate species known to exist in Montana including both game and nongame species as well as some invertebrate species (freshwater mussels and crayfish). In the early years of fish and wildlife management, the focus was clearly placed on game animals and their related habits. This was, and continues to be, a result of almost all of the agency's funding being provided by hunters and anglers. Although FWP has no intention of reducing the attention focused on important game species, it is apparent that effective conservation actions directed to particular community types will benefit a variety of game and nongame species. As a result, FWP believes that with this new funding mechanism and conservation strategy in place, managing fish and wildlife more comprehensively is a natural progression in the effective conservation of the remarkable fish and wildlife resources of Montana.

Although game species are included in the Strategy, its priority is to describe those species and their related habitats in greatest conservation need. We interpreted "in greatest conservation need" to mean focus areas, community types and species that are significantly degraded or declining, federally listed, or where important distribution and occurrence information to assess the status of individuals and/or groups of species is lacking. Because management of game species has been largely successful over the last 100 years, most have populations that are stable or increasing and fewer were identified as in greatest conservation need (49 nongame, 11 game).

The methods and databases developed as part of this planning process are powerful tools that could be used in the future to help integrate other fish and wildlife management priorities as they are established. For this particular iteration of the Strategy, the following goals were developed.

- Identify all of Montana's fish and wildlife and related habitats in greatest need of conservation

- Develop and prioritize management strategies to conserve fish and wildlife and related habitats in greatest need

- Work independently and in partnership to conserve, enhance and protect Montana's diverse fish and wildlife resources, and address each species equitably regardless of classification as game or nongame, rare or "at risk"

- Improve FWP's ability to address present and future funding challenges and opportunities

- Integrate monitoring and management of game and nongame fish and wildlife species 


\section{DRAFT WORKING DOCUMENT DO NOT DUPLICATE}

989

990

991

992

993

994

995

996

997

998

999

1000

1001

1002

1003

1004

1005

1006

1007

1008

1009

1010

1011

1012

1013

1014

1015

1016

1017

1018

1019

1020

1021

1022

1023

1024

1025

1026

1027

1028

1029

1030

1031

1032

1033

1034

- Meet all 8 requirements of WCRP and SWG

\section{Eight Required Elements}

Congress identified the required elements of this Strategy in the WCRP legislation and the USFWS adopted those same elements as a condition of receiving WCRP and SWG funds.

1. Information on the distribution and abundance of species of wildlife, including low and declining populations, as the state management agency deems appropriate, that are indicative of the diversity and health of the State's wildlife.

2. Descriptions of locations and relative condition of key habitats and community types essential to conservation of species identified in (1).

3. Descriptions of problems that may adversely affect species or their habitats identified in (1), and priority research and survey efforts needed to identify factors that may assist in restoration and improved conservation of these species and habitats.

4. Descriptions of conservation actions determined to be necessary to conserve the identified species and habitats and priorities for implementing such actions.

5. Proposed plans for monitoring species identified in (1) and their habitats, for monitoring the effectiveness of the conservation actions proposed in (4), and for adapting these conservation actions to respond appropriately to new information or changing conditions.

6. Descriptions of procedures to review the Comprehensive Strategy at intervals not to exceed ten years.

7. Plans for coordinating, to the extent feasible, the development, implementation, review, and revision of the Strategy with Federal, State, and local agencies and Indian Tribes that manage significant land and water areas within the state or administer programs that significantly affect the conservation of identified species and habitats.

8. Congress has affirmed through WCRP and SWG, and other guidance to us and our partners, that broad public participation is an essential element of developing and implementing these Strategies, the projects that are carried out while these Strategies are developed, and the Species in Greatest Need of Conservation that Congress has indicated such programs and projects are intended to emphasize. 


\section{International Association of Fish and Wildlife Agencies 1035 Guidelines}

1036

1037 1038

1039

1040

1041

1042

1043

1044

1045

1046

1047

1048

1049

1050

1051

1052

1053

1054

1055

1056

1057

1058

1059

1060

1061

1062

1063

1064

1065

1066

1067

1068

1069

1070

1071

1072

1073

1074

1075

1076

1077

1078

1079
In addition to the 8 Congressional requirements, the International Association of Fish and Wildlife Agencies (IAFWA) and the U. S. Fish and Wildlife Service (USFWS) established supplemental guidelines to assist with Strategy development (Appendix A). These guidelines provided recommendations within four areas: 1) planning process and partnerships, 2) focus and scope, 3) format and content, and 4) completion, outcomes, and availability. The FWP CFWCS planning team used all of these guidelines in the creation of this document.

\section{Planning Approach}

\section{Technical and Steering Committees}

Development of the Strategy was guided by a steering committee and a technical committee. The Technical Committee served in an advisory capacity to the Steering Committee. Steering Committee members guided the planning processes including approach to public and outside agency involvement, allocation of funds (Appendices B, C, and D), approval of methods and results for identifying habitat, species and survey and inventory priorities and internal preparation for implementation of the Strategy.

\section{Steering Committee}

Chris Smith

Larry Peterman

Ron Aashiem

Mike Aderhold

Don Childress

Chris Hunter

Chief of Staff

Chief of Field Operations

Administrator of Conservation and Education

Regional Supervisor

Administrator of Wildlife Division

Administrator of Fisheries Division

- Roles and Responsibilities: Provide policy-level direction and oversight to development of FWP's Comprehensive Fish and Wildlife Conservation Strategy and use of the SWG funds; approve projects to be funded with SWG; allocate SWG funds and FWP matching funds to support projects.

\section{Technical Committee}

Janet Hess-Herbert

Information Management Unit Leader

T.O. Smith

Adam Brooks

Rebecca Cooper

Ken McDonald

Tom Palmer

Jen Pelej
Federal Assistance Coordinator

Federal Assistance Specialist

Fisheries Management Bureau Chief

Information Bureau Chief
Information Specialist 


\section{DRAFT WORKING DOCUMENT DO NOT DUPLICATE}

$\begin{array}{lll}1080 & \text { Brad Schmitz } & \text { Regional Fisheries Manager } \\ 1081 & \text { Jim Williams } & \text { Regional Wildlife Manager } \\ 1082 & \text { Heidi Youmans } & \text { Nongame Bureau Chief } \\ 1083 & \text { Graham Taylor } & \text { Regional Wildlife Manager } \\ 1084 & & \\ 1085 & \text { - Roles and Responsibilities: Assist in the development of FWP's } \\ 1086 & \text { Comprehensive Fish and Wildlife Conservation Strategy; identify, evaluate } \\ 1087 & \text { and prioritize potential SWG projects; recommend allocation of SWG } \\ 1088 & \text { funds to Steering Committee; develop Applications for Federal Assistance } \\ 1089 & \text { (AFA, a document required to receive SWG funds) and other required } \\ 1090 & \text { project documentation, including interim and final reports; monitor } \\ 1091 & \text { implementation of projects, including tracking budgets and expenditures. }\end{array}$

\section{Exploratory Groups}

\section{FWP Staff Exploratory Group}

A group of FWP staff was assembled early in the planning process at the request of the Technical and Steering Committees to develop ideas about the most effective way to develop Montana's Strategy that would meet all 8 Congressional requirements (Appendix E).

\section{FWP Law Enforcement Exploratory Group}

Enforcement officers were brought together as an exploratory group and they identified the ways that Law Enforcement could help implement the priorities identified by the Montana's Strategy if Congress allowed some of future allocated SWG funding to be used for enforcement activities (Appendix F).

\section{Agency and Non-Governmental Organization Exploratory Group}

Before planning began, agencies and organizations that manage significant land and water areas or have significant control over these areas were invited to participate in an advisory group meeting led by Jeff Hagener, FWP Director. The goal of this meeting was to identify what level of involvement each of these groups wanted to have during the development of the Strategy. All of the participants indicated that their respective agencies and organizations were interested in the Strategy and would also like to be informed of progress on the Strategy and would be willing to provide support as needed. Most participants indicated that they would like to have the opportunity to review the Strategy prior to its submission to the USFWS (Appendix G).

\section{Public Involvement}

Public involvement is critical to development of a strategy for Montana and will become even more important as FWP moves toward implementation. The first 


\section{DRAFT WORKING DOCUMENT DO NOT DUPLICATE}

1126 steps toward gaining public involvement in development of the Strategy were to

1127

1128

1129

1130

1131

1132

1133

1134

1135

1136

1137

1138

1139

1140

1141

1142

1143

1144

1145

1146

1147

1148

1149

1150

1151

1152

1153

1154

1155

1156

1157

1158

1159

1160

1161

1162

1163

1164

1165

1166

1167

1168

1169

1170 hold an Advisory Group meeting and conduct a mail back survey. The purpose of the Advisory Group meeting, held in October 2004, was to identify what level of involvement stakeholder organizations wanted to have during the Strategy development process. The survey, on the other hand, was administered by mail to randomly selected Montana residents. The goal was to learn their opinions on the types of comprehensive management that SWG funds promote (results included below). The information obtained was used to aid development of the comprehensive strategy and will help direct its implementation.

In addition to the Advisory Group and survey, other public involvement tools have been used or will be used to involve partner groups, fish and wildlife enthusiasts, landowners, and more. As part of the strategy review process, FWP will hold seven public meetings this summer, one per region, where attendees can learn more about the strategy and provide comments. Print publications, including an executive summary and visual aids will be available at the public meetings. In addition, online news pages have been developed on the FWP website at http://fwp.state.mt.us, under "Wild Things." Background information and the draft strategy will be posted in a user-friendly format to facilitate review and comment. Press releases were/will be issued regarding developments in SWG funding, the release of the draft Strategy for review, and its submittal for publication. All press releases are posted online as well.

After publication of the Strategy, extensive statewide outreach will occur. Outreach plans include print publications, educational materials and programs, press releases, online announcements, posters, magazine and television features, video, face-to-face communications, and more. The audiences will include elected officials, landowners, conservation groups, agricultural and industry interests, other government agencies, community leaders, Tribes, educational institutions, fish and wildlife enthusiasts, hunters and anglers, media, etc. Montana's public involvement efforts will also be linked to a national information campaign, led by the International Association of Fish and Wildlife Agencies.

The comprehensive strategy is designed to be collaborative with local communities and partner groups. Efforts will be made to distribute as much information as possible, solicit and incorporate feedback, and develop support and involvement in the implementation of recommended actions.

\section{SWG Survey}

FWP conducted a mail survey of Montana residents during late summer, 2004 to learn their opinions about the types of comprehensive management SWG promotes. The goals of the survey were to: 


\section{DRAFT WORKING DOCUMENT DO NOT DUPLICATE}

1171

1172

1173

1174

1175

1176

1177

1178

1179

1180

1181

1182

1183

1184

1185

1186

1187

1188

1189

1190

1191

1192

1193

1194

1195

1196

1197

1198

1199

1200

1201

1202

1203

1204

1205

1206

1207

1208

1209

1210

1211

1212

1213

1214

1215

1216

- Better understand what Montanans think about FWP conserving all fish and wildlife species in Montana.

- Provide information that will aid development and future implementation of Montana's Comprehensive Fish and Wildlife Conservation Strategy.

Mail back surveys were administered to 10,500 randomly selected households across Montana, and nearly a 30 percent response rate to the survey was achieved.

\section{Survey Discussion}

Overall, the survey results suggest that most Montanans are supportive of FWP taking a broader role when it comes to managing the state's diverse fish and wildlife. A majority of the survey respondents (62\%) reported it is important or very important to them that FWP ensure there are healthy populations of nongame animals.

Implementing the Strategy will be the biggest challenge and at this point in time, providing the appropriate level of nonfederal match is the biggest concern. This survey asked two key questions related to funding: (1) Are Montanans supportive of FWP using some monies obtained from hunters and anglers to help match federal SWG funding? and, (2) Are Montanans willing to help pay for the conservation of nongame animals in ways other than by purchasing hunting and/or fishing licenses and equipment?

Results from this survey revealed that most Montanans are supportive (56\%) of FWP using some monies obtained from hunters and anglers to help match federal SWG funding. However, there were a significant number (32\%) of respondents who reported this to be unacceptable to them. Furthermore, only about half of the hunter and anglers identified in the survey found this be acceptable to them. These findings suggest that while it is acceptable for FWP to use some hunter and angler license dollars for this purpose, the agency needs to act prudently in doing so and should keep hunters and anglers informed of how their license dollars are being used.

Another question posed by the survey was, what about other potential sources of funding to help match federal SWG funding? A majority of the survey respondents (61\%) said they would not be willing to help pay for the conservation of nongame animals in ways other than by purchasing hunting and/or fishing licenses and equipment. From this survey it appears that most Montanans are supportive of FWP taking a broader role when it comes to managing the state's fish and wildlife. Yet, most are unwilling to help directly pay for this in ways other than by purchasing hunting and fishing licenses. The results of this survey have confirmed that securing alternate funding will be a major challenge for implementation of Montana's Comprehensive Fish and Wildlife Conservation 


\section{DRAFT WORKING DOCUMENT DO NOT DUPLICATE}

1217 Strategy in the future. Additional research on this topic is recommended if FWP 1218 is to successfully take the steps necessary to fully meet the needs of a broader 1219 constituency.

1220

\section{The Four Components of Montana's Strategy}

Montana's Comprehensive Fish and Wildlife Conservation Strategy is organized into four components. At the broad scale, focus areas in component 1 help guide attention to certain geographical areas of Montana where the fish and wildlife community types (component 2) that are in greatest need of conservation occur. Often, fish and wildlife within a community type face similar conservation concerns. Addressing these concerns using community level conservation allows many species to comprehensively benefit from conservation strategies. However, some species populations have declined so far, or are so specialized that conservation strategies at the broad scale might not be effective. Therefore, the 60 fish and wildlife species in greatest need of conservation have been included in component 3 . The conservation strategies of these species should be addressed specifically whether through broad or fine scale actions. Finally, there are many species and groups of species that we do not have available adequate occurrence data for in order to determine their status. Component 4 provides a list of these species and groups of species that are in greatest need of inventory.

Component One: Geographic Focus Areas in the landscape that contain significant fish and wildlife communities (species and their associated habitats) that are identified as being in greatest need of conservation.

This is a strategy to focus resources and efforts toward geographical areas where they can benefit the largest number of species and communities in need of conservation

Component Two: Fish and Wildlife Community Types that are in the greatest need of conservation (7 identified).

This is a high leverage strategy to address the conservation concerns of whole ecological communities or species groupings. Implementing conservation strategies at this level will comprehensively benefit many fish and wildlife species.

Component Three: Fish and Wildlife Species that are in the greatest need of conservation (60 identified).

Species whose needs must be specifically addressed, whether through focus areas, community types or directly or indirectly

Component Four: Species and groups of species to be targeted for inventory. 


\section{DRAFT WORKING DOCUMENT DO NOT DUPLICATE}

1263

1264

1265

1266

1267

1268

1269

1270

1271

1272

1273

1274

1275

1276

1277

1278

1279

1280

1281

1282

1283

1284

1285

1286

1287

1288

1289

1290

1291

1292

1293

1294

1295

1296

1297

1298

1299

1300

1301

1302

1303

1304

1305

1306

1307

1308

Over time, this strategy will allow us to collect data 1) for species or species groups we do not have sufficient information to determine their level of conservation need, or 2) for species that are important or indicator species for health of certain communities, or 3) for species used as measures of success in a comprehensive approach to fish and wildlife management.

\section{Categorizing the Levels of Conservation Need}

Within each component, focus areas, community types, and species were prioritized into three Tiers, based on their level of conservation need. Likewise, all species were prioritized for Inventory needs using similar definitions.

Tier I: Greatest conservation need. Montana Fish, Wildlife \& Parks has a clear obligation to use its resources to implement conservation actions that provide direct benefit to these species, communities and focus areas.

Tier II: Moderate conservation need. Montana Fish, Wildlife \& Parks could use its resources to implement conservation actions that provide direct benefit to these species, communities and focus areas.

Tier III: Lowest conservation need. Although important to Montana's wildlife diversity, these communities, species and focus areas are either abundant/widespread or are believed to have adequate conservation already in place.

Tier IV: Species that are non-native, incidental or on the periphery of their range and are either expanding or very common in adjacent states.

\section{How Montana's Comprehensive Strategy Will Work}

Montana's strategy is intended to be dynamic and is based on the concept that fine-scale information for any of Montana's species will be used to continually refine and adjust the classification for that species when appropriate. This will be accomplished using the inventory component of the strategy. In turn, modifications to the list of species in greatest need of conservation should help re-direct priorities in terms of the most at risk community types. This information will then be used to direct our attention to new geographical areas of Montana and help focus the delivery of the appropriate conservation efforts that help address the most critical, where possible. We have made every effort to use existing management plans to describe the conservation concerns and needs for focus areas, community types and species. In this way the Strategy attempts to tie together many different plans at different levels in order to facilitate collaboration. A full list of conservation and management plans can be found in Table 1. 


\section{DRAFT WORKING DOCUMENT DO NOT DUPLICATE}

1309

1310 
1310

1311

1312

1313

1314

1315

1316

1317

1318

1319

1320

1321

1322

1323

1324

1325

1326

1327

1328

1329

1330

1331

1332

1333

1334

1335

1336

1337

1338

1339

1340

1341

1342

1343

1344

1345

1346

1347

1348

\section{How To Navigate This Strategy}

Most users will be interested in particular components of the Strategy. Readers should decide if they are interested in landscape level conservation, a particular community type or a specific species.

\section{If you are Interested in Landscape or Community Scale Conservation}

Refer to the Table of Contents and directly reference the Ecotype (Component I) or the Community Type (Component II) that you are interested in. For example, if you are interested in Montane Forests of western Montana, use the table of contents to locate Montane Forest and there you will find listed all focus areas individually under that Ecotype. On the other hand if you are interested in Riparian and Wetland Community Types, refer to the table of contents under Component II and proceed to the appropriate page. Within the focus areas and community types you will find descriptions and a map of the area or type, fish and wildlife and habitats associated with them, conservation concerns and needs as well as a reference to selected management plans.

\section{If you are Interested in Species Scale Conservation}

If you are interested in a particular fish or wildlife species, you can use the table of contents and look under Component III to locate the page number for any Tier I species you are interested in. You can also use the Species Reference Guide (Table 2 not yet complete for draft review) and locate the page numbers where you can find any species in the Strategy, regardless of Tier. Tables for the focus areas, community types and inventory needs associated with a species can also provide additional information such as lists of other species that are associated comprehensively with similar areas or community types.

\section{If you are Interested in Inventory}

Proceed directly to the fourth component of the Strategy. Species groups and individual species that are in greatest need of inventory are listed taxonomically and then alphabetically. Once you have found the species or group of interest, coded symbols are provided to the right of that species or group that indicate some of the reasons why they are in greatest need. A legend is provided for these codes at the beginning of the section for that Component. 


\section{Component I: Ecotype Focus Areas of Greatest Conservation Need}

1350

1351

1352

1353

1354

1355

1356

"This is a strategy to focus resources and efforts toward geographical areas where they can benefit the largest number of species and communities in need of conservation."

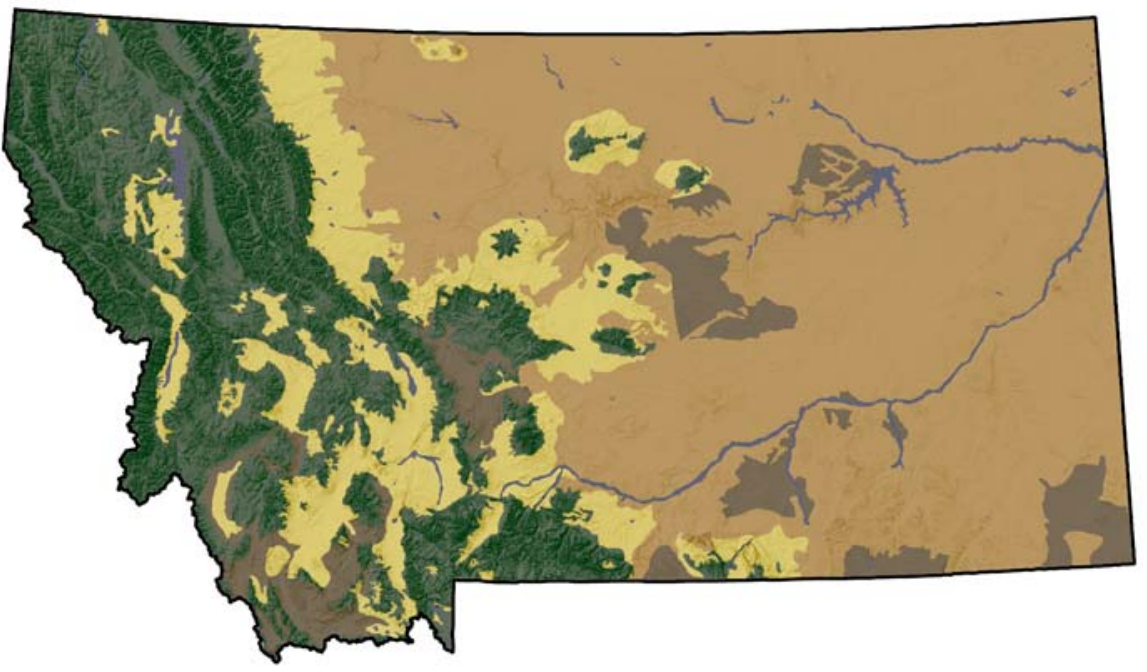

Figure 1. Ecotypes of Montana

Montana Fish, Wildlife \& Parks habitat programs currently use five ecotypes to describe the broad areas of Montana's landscape that have similar characteristics; Intermountain/foothill grassland, Montane Forest, Plains Grassland, Plains Forest, Shrub Grassland, and Riparian (Montana Fish, Wildlife \& Parks 1991). For the Strategy, we combined the Plains Grassland and Plains Forest into one ecotype. We also defined Riparian as a community type instead of an ecotype since it occurs throughout all of the other ecotypes.

Within each of the ecotypes, Tier I (greatest need of conservation) geographic focus areas have been identified for all terrestrial and aquatic areas of the state (Apendices $\mathrm{H}$ and $\mathrm{I}$ ). Aquatic and terrestrial areas were identified separately to facilitate implementation of conservation strategies, with the understanding that overlap does exist. Only the areas in greatest need of conservation are described in the body of the Strategy. These areas guide our attention to locations that offer some of the best opportunity to conserve Montana's community types and fish and wildlife species in greatest need of conservation. 


\section{DRAFT WORKING DOCUMENT DO NOT DUPLICATE}

1380 The habitats and species of greatest conservation need are listed for each area along with strategic conservation concerns and needs. Montana Fish, Wildlife \& Parks should leverage existing programs to conserve these areas alongside other state and federal agencies, private organiztions and the public. Specific agencies, organizations or individuals will be effective at implementing many of the conservation strategies. However, landowner based and collaborative projects should be encouraged. Conservation efforts that are under way by various groups that address the conservation strategies should be supported. In some cases working groups might need to be initiated in order to begin addressing the conservation concerns. A good model for how working groups could operate is the Blackfoot Challenge. The Blackfoot Challenge is a Montana group that coordinates management of the Blackfoot River, its tributaries, and adjacent lands. It is organized locally and known nationally as a model for preserving the rural character and natural beauty of a watershed and surrounding areas. Although its charter dates to 1993, Blackfoot landowners have played an instrumental stewardship role since the late 1970s_bringing conservation easement legislation, walk-in hunting areas and recreation corridor management to Montana. The Blackfoot Challenge can be contacted at Blackfoot Challenge 


\section{Intermountain/Foothill Grassland Ecotype}

1418

1419

1420

1421

1422

1423

1424

1425

1426

1427

1428

1429

1430

1431

1432

1433

1434

1435

1436

1437

1438

1439

1440

1441

1442

1443

1444

1445

1446

1447

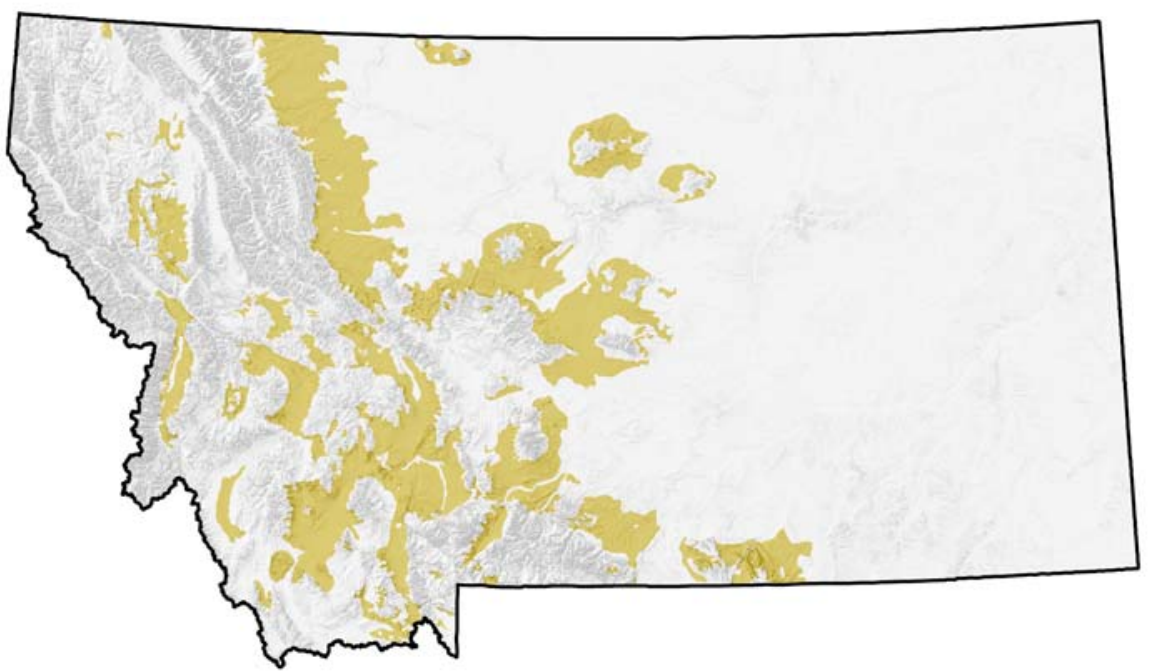

Figure 2. Intermountain/Foothill Grassland Ecotype

Intermountain/foothill grassland is a mosaic of private and public lands that extends from the glaciated Flathead River Valley to the north, south to the Centennial Valley, and east to Rocky Mountain Front, where there remains some of Montana's most diverse fish and wildlife habitats. This western Montana ecotype harbors more wildlife communities than any other in Montana. It also harbors Montana's greatest concentrations of human population in and near the towns of Kalispell, Missoula, Helena, and Bozeman. The attraction for wildlife and for people is western Montana's broad, lush and sweeping valleys cradled by the peaks of the Rocky Mountains. The intermountain/foothill grasslands are cut and formed by meandering rivers that create core riparian zones and wetland areas that often include glacial lakes and potholes that attract nesting waterbirds. Addressing the challenges that accompany the interface between human settlement and fish and wildlife and their habitats will be critical to the conservation of these areas.

\section{Landscape Characteristics}

The Intermountain/Foothill Grassland ecotype includes 13,414,271 acres and represents $14.3 \%$ of Montana's land area. The intermountain/foothill ecotype generally lies on level to moderate topography at valley bottoms or lower slopes of mountains with the Flathead, Clark Fork, Bitterroot, Missouri, Big Hole, Beaverhead, Jefferson, Gallatin, Madison, Yellowstone and Blackfoot rivers cutting through the ecotype. Elevations are lowest in some of the northwestern valley locations, in some cases below 3,000 feet. Elevations between 3,000 and 4,000 feet occur broadly in the Flathead/Mission and Tobacco valleys. The upper Townsend, Gallatin, and Blackfoot valleys are mostly between 4,000 and 5,000 feet as well as much of the foothill region to the east of the mountains. 


\section{DRAFT WORKING DOCUMENT DO NOT DUPLICATE}

1448 The Jefferson, Madison, Shields/Smith, Paradise, and Deerlodge valleys range from 4,500 to 5,500 feet. Due to glaciation, the northern part of the Flathead Basin contains hundreds of potholes, many of which retain water throughout the average summer.

\section{Soils}

Floors of the intermountain valleys of southwestern Montana are mostly composed of thousands of feet of tertiary valley fill deposited at the end of the first stage of mountain building. During the ice ages, the cordilleran ice sheet covered the northern part of the Flathead Basin at various times. Glacial Lake Missoula, formed from melt water from this ice sheet, reached south into the Bitterroot Valley and west into what is now Washington. Sediments from this lake, plus outwash materials from the ice sheet cover most of the valley bottoms of the southern part of the Flathead Basin (i.e., south Mission Valley, Hot Springs Valley). Lake sediments farther south (Missoula and Bitterroot Valleys) apparently have been eroded away, exposing tertiary fill. The northern parts of the Flathead Basin as well as the Tobacco Valley are underlain by glacial till.

In some places, the foothill areas are underlain by outwash from the adjacent mountains, however, more commonly the substrate is some form of sedimentary bedrock. The foothills along the east front (Bowman's Corner to the Canadian border), the area north and east of Livingston, and some of the area surrounding the Bearpaw and Little Rocky mountains is underlain by moderately hard sandstones and soft shales of the Cretaceous (beginning about 100 million years ago) Eagle to Willow Creek formations. Part of the foothill areas of these mountains also comprises Cretaceous soft black marine shales (Colorado Group, Montana Group, Pierre Shale), Cretaceous soft sandstones, siltstones, and claystones (Fox Hills Sandstone, Kootenai Formation). Some of these sedimentary strata may be gently to steep uplift as a result of nearby mountain building.

Most of the soils in this ecotype $\left(82 \%, 20,500 \mathrm{mi}^{2}\right)$ are described as well developed with dark topsoil horizons, clay 'B' horizons, having cool temperature regime and occurring under semiarid to subhumid moisture conditions.

\section{Climate}

The climate of the intermountain/foothills grassland ecotype varies considerably from one end to another; generally there is more resemblance to the climate of the plains grassland than to adjacent mountains. The northwestern valleys are influenced more by pacific storms in winter and have a more maritime climate than the more southerly valleys. Temperatures there tend to be milder during the winter and there is a greater proportion of precipitation received during the winter. Arctic climate outbreaks affect the entire ecotype but to a lesser extent the northern foothills. 


\section{DRAFT WORKING DOCUMENT DO NOT DUPLICATE}

1494

1495

1496

1497

1498

1499

1500

1501

1502

1503

1504

1505

1506

1507

1508

1509

1510

1511

1512

1513

1514

1515

1516

1517

1518

1519

1520

1521

1522

1523

1524

1525

1526

1527

1528

1529

1530

1531

1532

1533

1534

1535

1536

1537

1538
Annual temperatures average $44^{\circ} \mathrm{F}$. throughout much of the Gallatin, Townsend, Helena, northern Jefferson, Bitterroot and Flathead/Mission valleys. In these valleys some areas may have annual temperatures of $45^{\circ} \mathrm{F}$. The Blackfoot, Madison, Paradise, and Jefferson/Beaverhead valleys are about a degree colder because of elevation and/or topography that favor the formation of extreme temperature inversions even in summer. Foothill areas in central and southern Montana experience about the same annual average temperatures as the colder intermountain valleys. The coldest part of the ecotype is the northern foothills along the eastern front. Some parts of this area sustain average temperatures of $39^{\circ}$ to $40^{\circ} \mathrm{F}$.

Although maximum daily temperatures in the northwest valleys are similar to those in the Gallatin/Townsend/Helena valleys, nighttime temperatures average about 5 degrees warmer in the former areas. This generates mean January daily temperatures ranging from $22^{\circ}$ to $25^{\circ} \mathrm{F}$. in the northwest and $20^{\circ}$ to $23^{\circ}$ in the lower southwest valleys. Temperatures in the colder valleys of the southwest and west central areas range from $19^{\circ}$ to $21^{\circ} \mathrm{F}$. in January. In foothill locations, January temperatures range from $15^{\circ}$ to $22^{\circ} \mathrm{F}$.

Mean daily temperatures in July are highest in the Gallatin, Townsend, Helena, northern Jefferson, Bitterroot, and Mission valleys. In the warmest parts of these valleys, daily maximums range from $85^{\circ}$ to $86^{\circ} \mathrm{F}$. In the Madison, Jefferson/Beaverhead, Paradise and Flathead valleys, and most of the foothill areas, maximum daily temperatures are about a degree lower. The coldest valleys in the extreme southwest and west central areas attain maximums from 80 to 82 degrees. Highest July nighttime temperatures in the ecotype occur in the Helena and Townsend valleys where they range from $49^{\circ}$ to $50^{\circ} \mathrm{F}$. The Gallatin valley is about a degree cooler. A degree cooler than that is nighttime temperatures in the lower Jefferson, Bitterroot, and Flathead/Mission valleys and most of the foothill region. Nighttime temperatures of $43^{\circ}$ to $46^{\circ} \mathrm{F}$. are experienced in the west central and extreme southwestern valleys.

The protection afforded the intermountain valleys by the mountains is reflected by the generally much higher annual extreme minimum temperatures contrasted with most of the area to the east. The Mission and Bitterroot valleys are the only parts of Montana with significant areas in plant hardiness zone 5 (mean annual minimums in the minus teens). The rest of these valleys along with the Jefferson/Beaverhead, Gallatin, Madison, Townsend, Helena, Deerlodge, Blackfoot, Missoula and Tobacco valleys, are in hardiness zone 4B (mean annual minimums in the $-21^{0}$ to $-25^{\circ} \mathrm{F}$. range). The central and southern foothill area is mostly in zone $4 \mathrm{~A}$ (mean annual minimums in the $-26^{\circ}$ to $-30^{\circ} \mathrm{F}$. range). The northern foothill region is partially in Zone 3(mean annual minimums from $31^{0}$ to $-40^{\circ} \mathrm{F}$.). 


\section{DRAFT WORKING DOCUMENT DO NOT DUPLICATE}

1539 The highest annual extreme maximum temperatures occur in the Mission valley where much of this area reaches $98^{\circ}$ to $99^{\circ} \mathrm{F}$. on average each year. The

1541 Flathead, Missoula, part of the Deerlodge, the lower Jefferson, Gallatin, and 1542 Townsend and Helena valleys normally reach $95^{\circ}$ to $97^{\circ} \mathrm{F}$. This is also the case

1543 for the southern and central foothill region.

1544

1545

1546

1547

1548

1549

1550

1551

1552

1553

1554

1555

1556

1557

1558

1559

1560

1561

1562

1563

1564

1565

1566

1567

1568

1569

1570

1571

1572

1573

1574

1575

1576

1577

1578

1579

1580

1581

1582

1583

1584

The longest frost-free season exists in the lower Helena valley, and the central and southern foothill sections. Here the season ranges from 120 to 130 days. Lower portions of the Gallatin valley, the Townsend valley, and the Flathead/Mission valley have frost free season ranging from 100 to 125 days. Seasons in the Jefferson, Madison, Paradise, Bitterroot and Missoula valleys last from 90 to 110 days. Other valleys and the northern foothill areas have seasons ranging from 70 to 100 days.

The intermountain valleys and foothills are basically semi-arid, but considerably wetter than the plains grasslands. Mean annual precipitation overall is 15.4 inches. The foothill portion of the ecotype generally is wetter than the intermountain valley portion. Much larger expanses of area receiving more than 16 inches annually occur in the former than the latter area. Broad areas receiving between 10 and 12 inches are found in the Jefferson/Beaverhead valleys, while parts of the Jefferson/Beaverhead/Centennial and Helena valleys get less than 10 inches annually. The Blackfoot valley and eastern portions of the Flathead/Mission valley receive between 12 and 16 inches while western parts of the Flathead/Mission Valley tend to be drier.

Reflecting the stronger maritime influence in the northwest, those valleys tend to receive a smaller proportion of their precipitation in the growing season than do the southwestern valleys and most of the foothill regions. The percentage of moisture falling in the growing season for the Flathead/Mission, Missoula, and Bitterroot valleys ranges from 37 to 45 percent, with a portion of the Mission valley slightly higher than that. The extreme southwestern valleys (Jefferson/Beaverhead, Madison) and the northern and central foothill region collect 52 to 60 percent of the water during the growing season. Most other areas are in the range of 45 to 55 percent.

\section{Anthropogenic}

The Intermountain/Foothills Grassland Ecotype is diverse both in land management and its uses by humans. Primary recreational activities include hiking, mountaineering, hunting, biking, snowmobiling, wildlife watching, and skiing. The primary industries in this ecotype are building/construction, farming, ranching, mining and tourism. The breakdown of landowner stewardship for intermountain/foothills grassland ecotype is as follows:

U.S. Federal Agencies: 1,007,758 acres, which include BLM: 494,520 acres 


\section{DRAFT WORKING DOCUMENT DO NOT DUPLICATE}

1585

1586

1587

1588

1589

1590

1591

1592

1593

1594

1595

1596

1597

1598

1599

1600

1601

1602

1603

1604

1605

1606

1607

1608

1609

1610

1611

1612

1613

1614

1615

1616

1617

1618

1619

1620

1621

1622

1623

1624

1625

1626

1627

1628

1629

1630
USFS: 408,403 acres

USFWS: 64,556 acres

NPS: 18,286 acres

State Agencies: 892,545 acres

Tribal Lands: 1,091,650 acres

Private: $10,187,909$ acres

City \& County: 6,487 acres

\section{Vegetation}

Plant community composition is influenced primarily by the total annual precipitation ranging from 8 to more than 20 inches, yearly precipitation distribution, and soil characteristics. The yearly precipitation distribution and to a certain extent the total precipitation are related to general geographic location. Northern valleys and foothills tend to receive more total precipitation than more southern areas, while northwestern valleys have a more maritime (winter/spring wet) precipitation. This has an impact on the distribution of major grass species. Most of the potential natural grassland communities within this ecotype can be perceived as different combinations of six or seven major grass species accompanied by a number of subordinate grass and forb species.

Rough fescue (Festuca scabrella) extends southward into Montana from Canada, its center of distribution (Moss and Campbell 1947, Coupland and Brayshaw 1953, Tisdale 1947, Stickney 1960). Rough fescue is most abundant and widespread in Northwestern Montana on both sides of the Divide, declining southward and penetrating below $46^{\circ}$ only in the Gravelly and Madison ranges. The east most occurrences are near Lewistown at the foot of the Judith Mountains.

Idaho fescue (Festuca idahoensis) occurs throughout the intermountain/foothill ecotype wherever moisture conditions are favorable, becoming at least a subordinate species at 15 inches of annual precipitation (Ross and Hunter 1976). As well as being a component of most rough fescue communities, Idaho fescue forms habitat types with bluebunch wheatgrass (Agropyron spicatum) in most of the medium elevations of southwestern Montana and with western thickspike wheatgrass (Agropyron dasystachyum) in foothill areas just east of the mountains where there is enough moisture (Mueggler et al. 1980). Idaho fescue rarely occurs as the sole dominant grass. The two Idaho fescue habitat types usually contain prairie junegrass (Koeleria cristata) as a subordinate grass. Forbs commonly associated with Idaho fescue include silky lupine (Lupinus sericeus), arrowleaf balsamroot (Balsamorhiza sagitatta), sticky geranium (Geranium viscosissimum), phlox (Phlox kelseyi), blanketflower (Gaillardia aristata), and pussytoes (Antennaria microphylla).

Bluebunch wheatgrass is the most widely spread major forage grass in Montana, occurring at least as co-dominant on some sites statewide. In the 


\section{DRAFT WORKING DOCUMENT DO NOT DUPLICATE}

1631 intermountain/foothills grassland ecotype it is a dominant grass on all upland 1632 sites within the 10 to 14 inches precipitation zone (Ross et al. 1976). On fine 1633 textured soils bluebunch grass forms plant communities where western 1634

1635 wheatgrass and thickspike wheatgrass are co-dominants. Prairie junegrass is usually present and fairly abundant. Other common species include big sagebrush (Artemisia tridentate ssp. wyomingensis), milkvetches (Astragalus spp.), biscuitroot (Lomatium spp.), sandberg bluegrass (Poa sandbergii), hairy goldenaster (Chrysopsis villosa), and green needlegrass (Stipa viridula). Sites with medium textured, well-drained, shallow soils support little western wheatgrass compared to the finer textured soils but more species like needleand-thread (Stipa comata), sandberg bluegrass and sometimes blue grama (Bouteloua gracilis) as co-dominants. Such sites occupy about $9 \%\left(2,325\right.$ miles $\left.^{2}\right)$ of the ecotype. These communities may contain a variety of shrub species, but those in which shrubs are dominants are included in the Shrub/grassland ecotype. On sandy sites, bluebunch wheatgrass is a major vegetation constituent along with needle-and-thread, Indian ricegrass (Oryzopsis hymenoides), and sometimes prairie sandreed (Calamovilfa longifolia). Other species that may be found are aromatic sumac (Rhus aromatica), threadleaf sedge (Carex filifolia) and yucca (Yucca glauca). Within the 15 to 19 inch precipitation zone, bluebunch wheatgrass shares dominance with rough fescue in the northwest and Idaho fescue in the southwest and south central areas of Montana.

Needle-and-thread grass occurs as a community type in some valleys of the extreme southwest (Mueggler et al. 1980). This type is found on well-drained, shallow soils that might be limy. Other species include western and thickspike wheatgrass, prairie junegrass, threadleaf sedge, and fringed sedge (carex crinita).

Other sites within the intermountain/foothill grassland ecotype include saline lowlands that support major grasses such as basin wildrye (Elymus cinereus), Nuttall alkaligrass (Puccinellia nuttalliana), alkali cordgrass (Spartina gracilis), saltgrass (Distichlis stricata), alkali bluegrass (Poa juncifolia), kelsey phlox (Phlox kelseyi), and occasionally greasewood (Sarcobatus vermiculatus). Also found are subirrigated areas and wetlands that are often dominated by various species of willow (Salix spp.) and a variety of hydromorphic grasses, sedges and rushes. These might include Canada reedgrass (Calamagrostis Canadensis), cattails (Typha latifolia), Baltic rush (Juncus balticus), and basin wildrye (Leymus cinereus). 
1681

1682

1683

1684

1685

1686

1687

1688

1689

1690

1691

1692

1693

1694

1695

1696

1697

1698

1699

1700

1701

1702

1703

1704

1705

1706

1707

1708

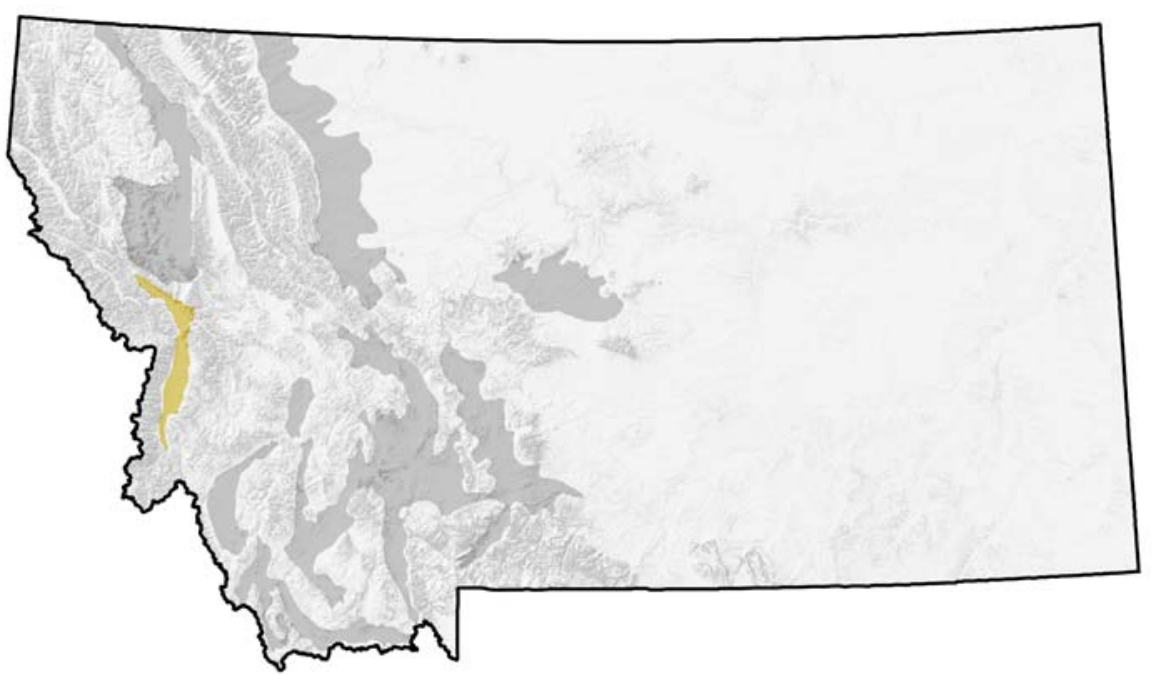

Figure 3. Bitterroot/Frenchtown Valleys Focus Area

The Bitterroot/Frenchtown Valley is dominated by views of the jagged peaks of the Bitterroot Range to the west and the lower Sapphire Mountains. The Bitterroot River bisects the valley floor from Idaho north to Missoula. The valleys are arid, flat or gently rolling landscapes two to 15 miles wide. While valley supports many habitats--from grassland and riparian to forests and sagebrush-most of the area is now in agricultural production. The rolling mountain foothills at the valley edges are important elk, white-tailed deer, and mule deer winter range. In the valley bottoms, the cottonwood riparian habitats are some of the most productive wildlife habitats in the state and are home to a wide variety of birds, mammals, reptiles and amphibians.

\section{Landscape Characteristics}

This subsection contains intermountain valleys that formed in alluvium, outwash, and lacustrine sediments. Elevations range from 3,000 to 4,400 feet. Drainage density is slight. Wetlands occur along both the Clark Fork and Bitterroot rivers. Mean annual precipitation ranges from 11 to 25 inches, about 40 to 60 percent falling as snow. The soil temperature and moisture regimes are frigid and typic ustic. The primary natural disturbances are flooding and fire. Land use is predominantly extensive urban/suburban development and agricultural activities. The breakdown for land stewardship in the Bitterroot/Frenchtown Valleys is as follows:

U.S. Federal Agencies: USFS:
42,935 acres, which include 40,155 acres 
1709

1710

1711

1712

1713

1714

\section{Associated Habitats}

2,780 acres

State Agencies:

14,147 acres

348,727 acres

\begin{tabular}{ccc}
\hline Habitat & Habitat Tier & Percentage of Area \\
\hline Mixed Xeric Forest & III & 3.57 \\
Wetland \& Riparian & I & 3.72 \\
Urban & III & 3.73 \\
Douglas Fir & II & 4.48 \\
Sagebrush & I & 4.57 \\
Agricultural Lands - Dry & III & 5.73 \\
Mixed Mesic Forest & II & 6.05 \\
Ponderosa Pine & II & 6.65 \\
Mixed Mesic Shrubs & II & 8.52 \\
Altered Herbaceous & II & 10.17 \\
Agricultural Lands - Irrigated & III & 11.19 \\
Low/ Moderate Cover Grasslands & I & 25.11 \\
\hline
\end{tabular}

1715

1716

1717

1718

1719

1720

1721

1722

1723

1724

1725

1726

1727

1728

1729

1730

1731

1732

1733

1734

1735

1736

1737

1738

1739

1740

1741

Note: A total of $93.50 \%$ of the Bitterroot/Frenchtown Valleys area is represented. $6.50 \%$ is made up of a combination of other habitat types.

\section{Associated Species of Greatest Conservation Need}

There are a total of 342 terrestrial vertebrate species that are found within the Bitterroot/Frenchtown Valleys Focus Area. All associations can be found within Table 10.

Amphibians: Coeur D'Alene Salamander, Boreal Toad, and Northern Leopard Frog

Birds: Common Loon, Trumpeter Swan, Harlequin Duck, Bald Eagle, Long-billed Curlew, Black Tern, Flammulated Owl, Black-backed Woodpecker, and Olivesided Flycatcher

Mammals: Townsend's Big-eared Bat, Northern Bog Lemming, Gray Wolf, and Grizzly Bear

\section{Conservation Concerns}

- Habitat loss, degredation and fragmentation especially as a result of human population growth

- Invasive and exotic plant and animal species

- Development of transportation infrastructure

- Unsustainable domestic livestock grazing and timber harvest practices 


\section{DRAFT WORKING DOCUMENT DO NOT DUPLICATE}

1742

1743

1744

1745

1746

1747

1748

1749

1750

1751

1752

1753

1754

1755

1756

1757

1758

1759

\section{Conservation Strategies}

- Support strategic conservation easements by conservation organizations or public agencies

- Promote sustainable land management practices on public lands

- Support state/federal tax incentives which discourage habitat fragmentation

- Participate in partnerships to develop and implement weed control strategies

- Improve grazing and timber management to enhance biological diversity on existing managed/protected areas

- Promote further development of county ordinances that help to guide future residential and commercial development

\section{References}




\section{Central Montana Broad Valleys (2,604,058 acres)}

1761

1762

1763

1764

1765

1766

1767

1768

1769

1770

1771

1772

1773

1774

1775

1776

1777

1778

1779

1780

1781

1782

1783

1784

1785

1786

1787

1788

1789

1790

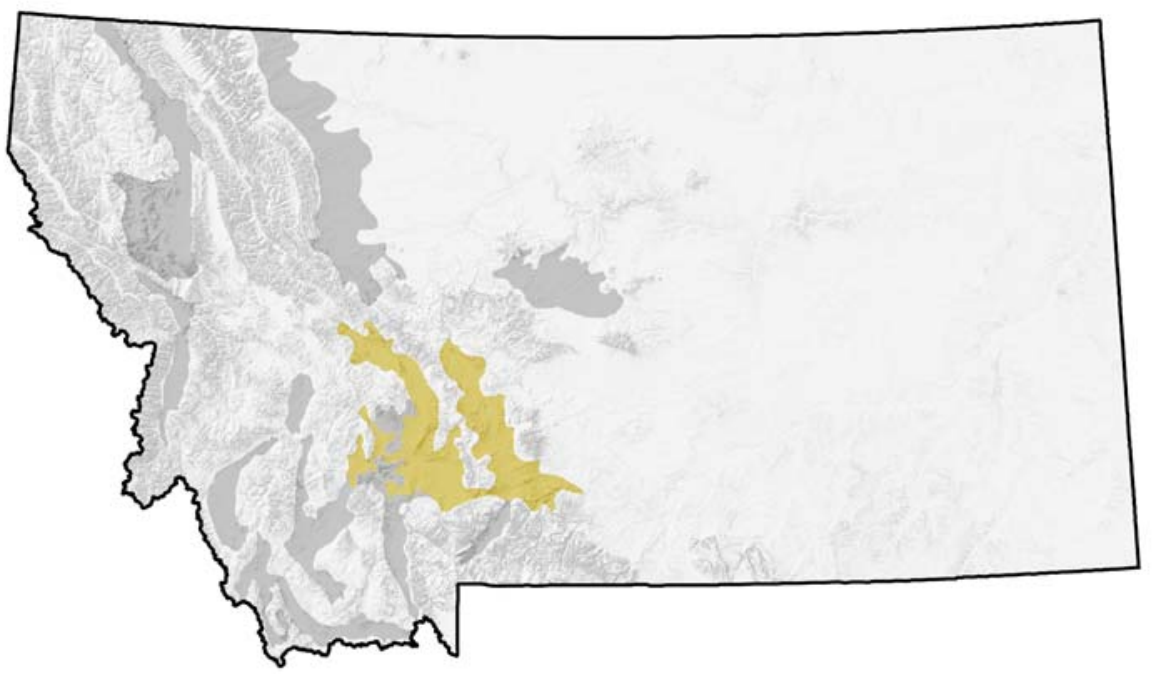

Figure 4. Central Montana Broad Valleys Focus Area

These central valleys include the areas from Three Forks, where the Missouri River begins, north through the Helena Valley and White Sulfur Springs, generally east of the Belt Mountains. The valleys are situated among the foothills of the Rocky Mountains where precipitation is reduced by the rain shadow effect.

Low and moderate cover grasslands dominate the valley floors and the dry environment highlights the importance of the riparian areas along the Missouri, Smith and other rivers and streams. Higher elevations capture enough precipitation to support fir, spruce and pine forests.

\section{Landscape Characteristics}

This subsection has broad intermontane valleys that formed in Tertiary sediments and Quaternary alluvial deposits derived from volcanic rocks, shale, and sandstone. Elevations range from 3,750 to 6,800 feet. Drainage density is low. Mean annual precipitation ranges from 10 to 25 inches, about 30 percent falling as snow. The soil temperature and moisture regimes are frigid and aridic ustic. The primary natural disturbances are fire and flooding. Land use is predominantly livestock grazing, crop production, and urban/suburban development. The breakdown for land stewardship in the Central Montana Broad Valley is as follows:
U.S. Federal Agencies:
101,375 acres, which include
BLM:
67,460 acres
USFS:
USFWS:
State Agencies:
21,313 acres
556 acres
Private:
162,163 acres
2,331,192 acres 
Associated Habitats

\begin{tabular}{ccc}
\hline Habitat & Habitat Tier & Percentage of Area \\
\hline Moderate/ High Cover Grasslands & I & 2.19 \\
Rock & III & 3.83 \\
Wetland \& Riparian & I & 5.24 \\
Sagebrush & I & 8.16 \\
Very Low Cover Grasslands & I & 8.45 \\
Agricultural Lands - Irrigated & III & 9.45 \\
Agricultural Lands - Dry & III & 11.08 \\
Low/ Moderate Cover Grasslands & I & 38.26 \\
\hline
\end{tabular}

Note: A total of $86.65 \%$ of the Central Montana Broad Valleys area is represented. $13.35 \%$ is made up of a combination of other habitat types.

1796

1797

1798

1799

1800

1801

1802

1803

1804

1805

1806

1807

1808

1809

1810

1811

1812

1813

1814

1815

1816

1817

1818

1819

1820

1821

1822

1823

1824

1825

1826

1827

\section{Associated Species of Greatest Conservation Need}

There are a total of 317 terrestrial vertebrate species that are found within the Central Montana Broad Valleys Focus Area. All associations can be found within Table 11.

Amphibians: Boreal Toad and Northern Leopard Frog

Birds: Common Loon, Bald Eagle, Sage-grouse, Mountain Plover, Long-billed Curlew, Black Tern, and Burrowing Owl

Mammals: Townsend's Big-eared Bat, Pallid Bat, Black-tailed Prairie Dog, Grizzly Bear, and Lynx

\section{Conservation Concerns}

- Habitat loss, degredation and fragmentation especially as a result of human population growth

- Invasive and exotic plant and animal species

- Unsustainable domestic livestock grazing and timber harvest practices

\section{Conservation Strategies}

- Support strategic conservation easements by conservation organizations or public agencies

- Promote sustainable land management practices on public lands

- Support state/federal tax incentives which discourage habitat fragmentation

- Participate in partnerships to develop and implement weed control strategies 


\section{DRAFT WORKING DOCUMENT DO NOT DUPLICATE}

1828

1829

1830

1831

1832

1833

1834

1835

1836

1837

1838

1839

- Improve grazing and timber management to enhance biological diversity on existing managed/protected areas

- Promote further development of county ordinances that help to guide future residential and commercial development

\section{References}

The Nature Conservancy. 2000. Middle Rockies-Blue Mountains Ecoregional Conservation Plan. Prepared by the Middle Rockies - Blue Mountains Planning Team. 58 pgs + appendices. 


\section{Deerlodge Valley (175,260 acres)}

1841

1842

1843

1844

1845

1846

1847

1848

1849

1850

1851

1852

1853

1854

1855

1856

1857

1858

1859

1860

1861

1862

1863

1864

1865

1866

1867

1868

1869

1870

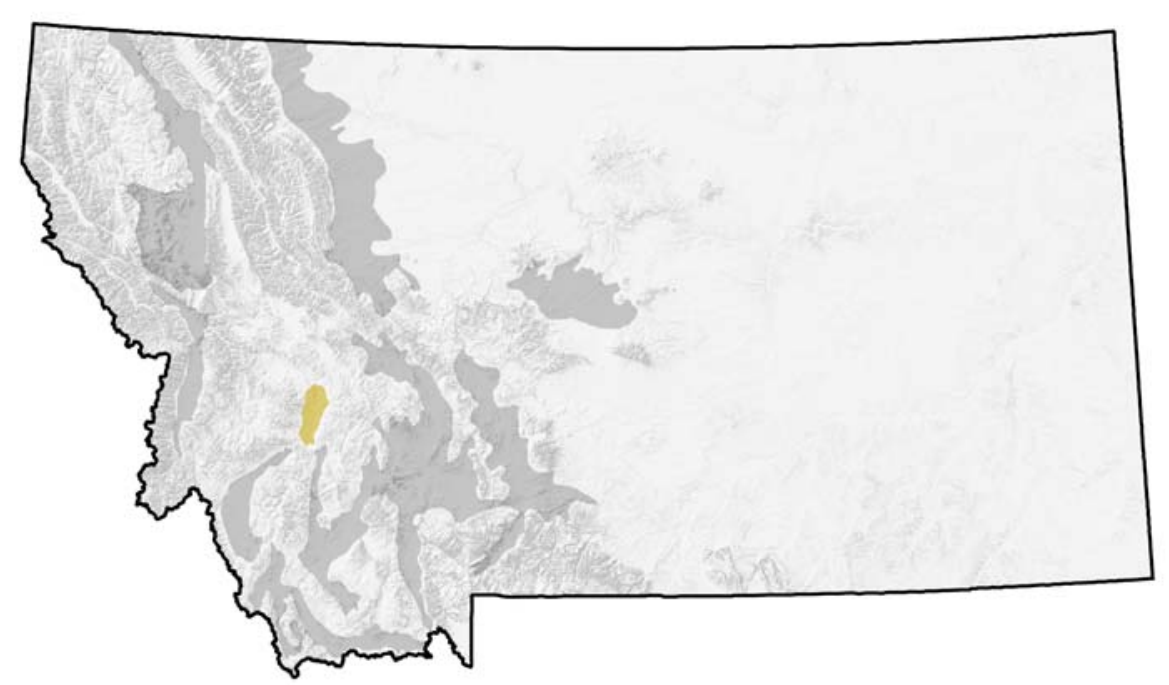

Figure 5. Deerlodge Valley Focus Area

One of several broad, intermountain valleys located in southwestern Montana, the north-flowing Clark Fork River bisects the Deerlodge Valley along an eastwest axis. Cattle ranching and hay production are the chief agricultural activities. Native bunchgrasses occur on the valley foothills, which provide important elk and deer winter range and supports other diverse nongame wildlife.

\section{Landscape Characteristics}

This subsection is comprised of an intermontane valley that formed in Tertiary sedimentary rocks and recent stream deposits. Elevations range from 4,400 to 6,000 feet. Drainage density is moderate. Mean annual precipitation ranges from 11 to 16 inches, about 20 percent falling as snow. The soil temperature and moisture regimes are frigid and aridic ustic. The primary natural disturbances are flooding and mass wasting. Land use is predominantly agriculture, livestock grazing, and urban/suburban development. The breakdown for land stewardship in the Deerlodge Valley is as follows:
U.S. Federal Agencies:
1,792 acres, which include
BLM:
62 acres
NPS:
1,730 acres
State Agencies:
14,023 acres
Private:
159,445 acres 
1873

1874

1875

1876

1877

1878

1879

1880

1881

1882

1883

1884

1885

1886

1887

1888

1889

1890

1891

1892

1893

1894

1895

1896

1897

1898

1899

1900

1901

1902

1903

1904

\begin{tabular}{ccc}
\hline Habitat & Habitat Tier & Percentage of Area \\
\hline Very Low Cover Grasslands & I & 2.00 \\
Mixed Barren Sites & III & 2.14 \\
Altered Herbaceous & II & 3.22 \\
Mixed Xeric Shrubs & I & 4.70 \\
Sagebrush & I & 4.96 \\
Moderate/ High Cover Grasslands & I & 5.37 \\
Wetland \& Riparian & I & 6.14 \\
Agricultural Lands - Irrigated & III & 6.99 \\
Mixed Mesic Shrubs & II & 7.18 \\
Low/ Moderate Cover Grasslands & I & 51.73 \\
\hline
\end{tabular}

Note: A total of $94.42 \%$ of the Deerlodge Valley area is represented. $5.58 \%$ is made up of a combination of other habitat types.

\section{Associated Species of Greatest Conservation Need}

There are a total of 260 terrestrial vertebrate species that are found within the Deerlodge Valley Focus Area. All associations can be found within Table 12.

Amphibians: Boreal Toad and Northern Leopard Frog

Birds: Common Loon, Trumpeter Swan, Harlequin Duck, Bald Eagle, Long-billed Curlew, and Black Tern

Mammals: Townsend's Big-eared Bat, and Lynx

\section{Conservation Concerns}

- Habitat loss, degredation and fragmentation especially as a result of human population growth

- Invasive and exotic plant and animal species

- Unsustainable domestic livestock grazing and timber harvest practices

\section{Conservation Strategies}

- Support conservation easements by conservation organizations or public agencies

- Promote sustainable land management practices on public lands

- Support state/federal tax incentives which discourage habitat fragmentation

- Participate in partnerships to develop and implement weed control strategies 


\section{DRAFT WORKING DOCUMENT DO NOT DUPLICATE}

1905

1906

1907

1908

1909

1910

1911

1912

1913

1914

1915

1916
- Improve grazing and timber management to enhance biological diversity on existing managed/protected areas

- Promote further develop of county ordinances that help to plan for and manage development

\section{References}

The Nature Conservancy. 2000. Middle Rockies-Blue Mountains Ecoregional

Conservation Plan. Prepared by the Middle Rockies - Blue Mountains Planning Team. 58 pgs + appendices. 
1918

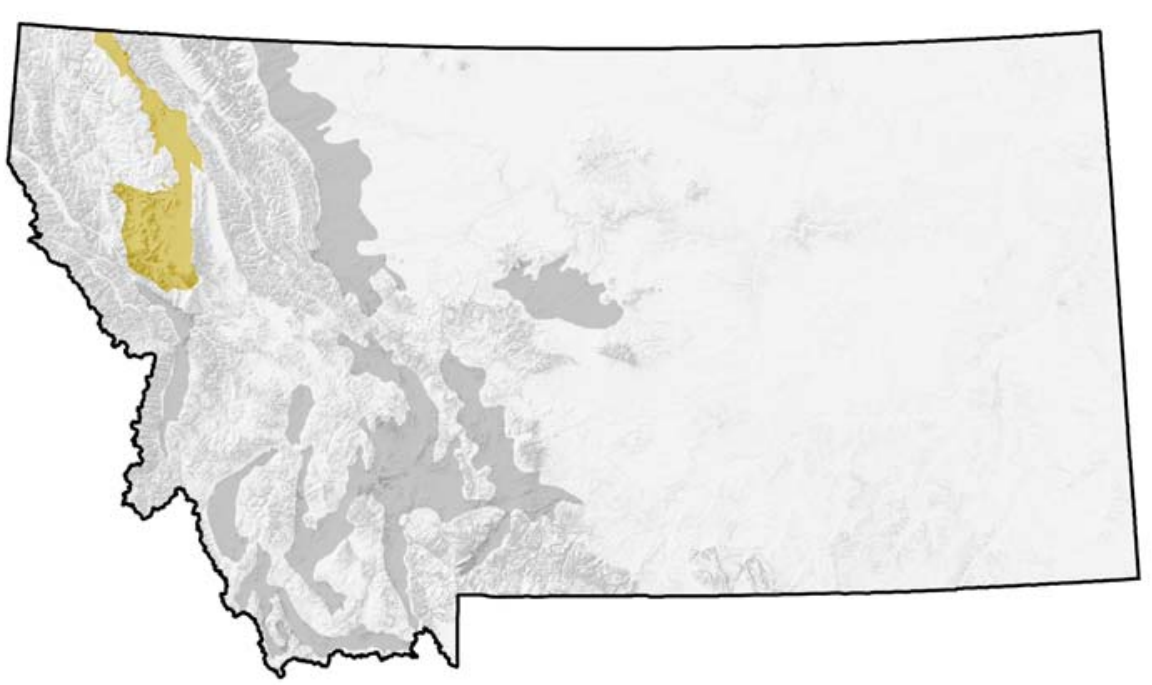

\section{Figure 6. Flathead Valley Focus Area}

The glaciated Flathead Valley of northwestern Montana lies among majestic mountain ranges and cradles the Flathead River. The primary stem of the Flathead, the Stillwater and Tobacco rivers are among the major headwater rivers of the Columbia basin. The valley supports diverse wetland and aquatic communities including glacial lakes, ponds, spring creeks, riparian swamps, cottonwood forests, oxbow lakes, and Flathead Lake, the nation's largest natural freshwater lake west of the Mississippi. The northern and southern reaches of the valley still support intact palouse prairie habitats interspersed with wetlands and forest. This region historically has provided habitat for nesting, migrating, and wintering waterfowl, and a range of habitats for upland game birds, raptors, shorebirds, colonial waterbirds and other resident and migratory species. It also contains important seasonal habitat for black bears, grizzly bears, mountain lions, elk, mule deer, and white-tailed deer. The rich resources of the valley floor, the riparian/wetlands, grasslands, and foothills--are primarily in private ownership, and are under extreme development pressure.

\section{Landscape Characteristics}

This subsection is composed of an intermontane basin that formed alluvium, glacial outwash, and lacustine sediments underlain by argillite, siltite, and dolomite. Elevations range from 2,300 to 4,500 feet. Drainage density is low to moderate. Mean annual precipitation ranges from 14 to 25 inches, about 50 percent falling as snow. The soil temperature and moisture regimes are frigid and typic xeric. The primary natural disturbances are fire and flooding. Land use is predominantly agriculture and timber harvest on public and to a greater degree private lands, as well as rural/suburban development. The breakdown for land stewardship in the Flathead River Valley is as follows: 
U.S. Federal Agencies: USFS: USFWS:

State Agencies:

Tribal Lands:

Private:

1955

\section{Associated Habitats}

\begin{tabular}{ccc}
\hline Habitat & Habitat Tier & Percentage of Area \\
\hline Lodgepole Pine & III & 2.54 \\
Wetland \& Riparian & I & 2.85 \\
Mixed Mesic Shrubs & II & 2.85 \\
Ponderosa Pine & II & 2.92 \\
Mixed Xeric Forest & III & 3.06 \\
Agricultural Lands - Dry & III & 3.40 \\
Altered Herbaceous & II & 4.22 \\
Sagebrush & I & 6.63 \\
Douglas Fir & II & 7.26 \\
Water & III & 9.29 \\
Agricultural Lands - Irrigated & III & 9.88 \\
Low/ Moderate Cover Grasslands & I & 15.56 \\
Mixed Mesic Forest & II & 17.71 \\
\hline
\end{tabular}

Note: A total of $88.16 \%$ of the Flathead River Valley area is represented. $11.84 \%$ is made up of a combination of other habitat types.

1961

\section{Associated Species of Greatest Conservation Need}

There are a total of 344 terrestrial vertebrate species that are found within the Flathead River Valley Focus Area. All associations can be found within Table 13.

Amphibians: Boreal Toad and Northern Leopard Frog

Birds: Common Loon, Trumpeter Swan, Bald Eagle, Columbia Sharp-tailed Grouse, Long-billed Curlew, Black Tern, Flammulated Owl, Black-backed Woodpecker, and Olive-sided Flycatcher

Mammals: Townsend's Big-eared Bat, Northern Bog Lemming, Grizzly Bear, Gray Wolf, and Lynx

\section{Conservation Concerns}

- Habitat fragmentation as a result of human population growth/development 


\section{DRAFT WORKING DOCUMENT DO NOT DUPLICATE}

1980

1981

1982

1983

1984

1985

1986

1987

1988

1989

1990

1991

1992

1993

1994

1995

1996

1997

1998

1999

2000

2001

2002

2003

2004

2005

2006

2007

2008

2009

2010

2011

2012

2013

2014

2015

2016

2017

2018

2019

2020

- Wetland and riparian habitat degradation

- Water quality degradation

- Invasive or exotic plant and animal species

- Unsustainable domestic livestock grazing and timber harvest practices

- Altered fire regimes

\section{Conservation Strategies}

- Support conservation easements and other methods that help protect critical habiatat on private lands

- Support watershed, riparian \& grassland restoration opportunities with Confederated Salish and Kootenai Tribes, Montana Department of Environmental Quality, US Natural Resource Conservation, \& Partners for Wildlife Program

- Work with Department of Transportation and Federal Highway Commission to effectively mitigate impacts of highway construction

- Support management of grazing to maintain riparian vegetation, streambank and channel stability in excellent condition

- Support efforts to eradicate exotic or invasive plant species when appropriate

\section{References}

Confederated Salish and Kootenai Tribes and Montana Fish, Wildlife \& Parks. 2003. Flathead Subbasin Plan Assessment: Executive Summary. NWPCC.

Portland, OR.

Kootenai Tribe of Idaho and Montana Fish, Wildlife \& Parks. 2004. Public Review Draft Kootenai Subbasin Plan. Executive Summary. Report prepared for the Northwest Power and Conservation Council. Portland, OR.

The Nature Conservancy. 2004. Canadian Rocky Mountains Ecoregional Assessment. Four volumes, including Report, Appendices, Conservation Area Descriptions \& Maps.

United States Fish \& Wildlife Service. 2004. Conservation Focus Areas of the Great Divide: A vast region encompassing the Upper Missouri, Yellowstone and Upper Columbia watersheds. Publisher: USFWS, Benton Lake Wildlife Refuge, Great Falls, MT. 77pgs. 
2022

2023

2024

2025

2026

2027

2028

2029

2030

2031

2032

2033

2034

2035

2036

2037

2038

2039

2040

2041

2042

2043

2044

2045

2046

2047

2048

2049

2050

2051

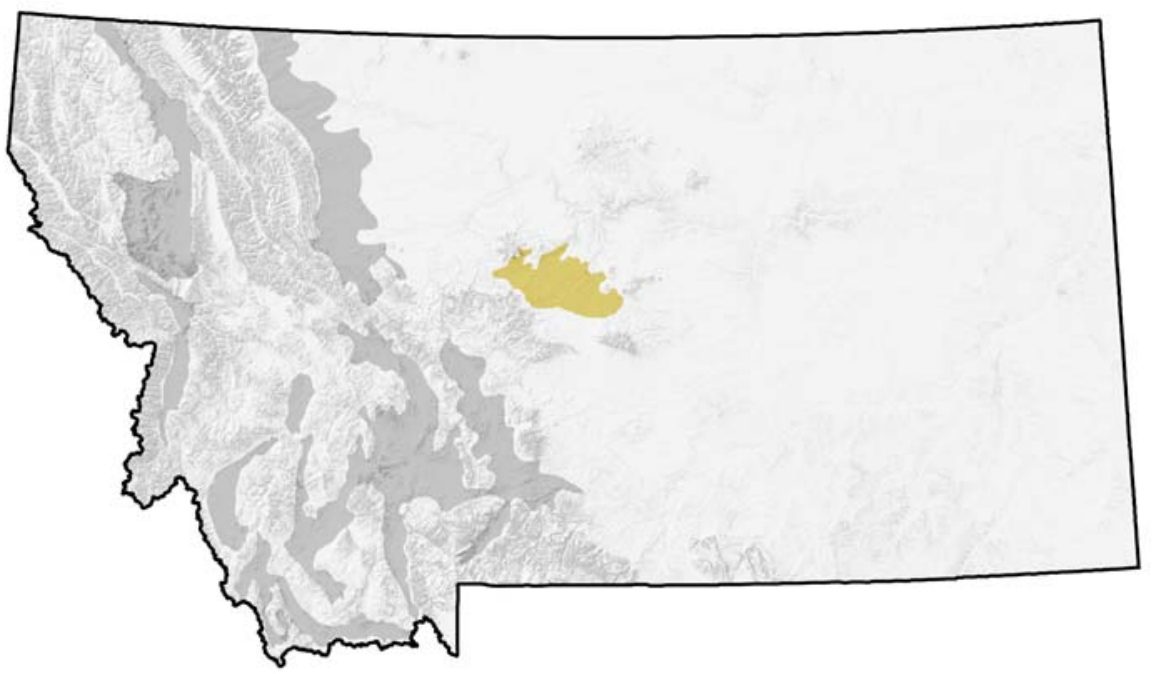

Figure 7. Little Belt Foothills Focus Area

The Little Belt Foothills cover the Judith Basin, a large mountain foothill grassland community rimmed by the Little Belt, Highwood, Moccasin and Big Snowy mountains. The Judith River, tributary to the Missouri River, is the basin's primary drainage. Large, flat grassland benches define the high foothills. The lower elevations are comprised of rangeland interspersed with croplands and sprawling terraces dominate the lower elevations. While about 30 percent of the landscape in the Judith Basin is farmed, the remaining areas support bunchgrass and sagebrush grasslands.

\section{Landscape Characteristics}

This subsection is composed of foothills, terraces, and fans that formed in shale, siltstone, and terrace deposits. Elevations range from 3,500 to 5,000 feet.

Drainage density is moderate. Mean annual precipitation ranges from 15 to 19 inches, having approximately 40 to 50 percent falling as snow. The soil temperature and moisture regimes are frigid and ustic. The primary natural disturbance is drought. Land use is predominantly livestock grazing at higher elevations, with a combination of cropping and livestock grazing at lower elevations. The breakdown for land stewardship in the Little Belt Foothills is as follows:
U.S. Federal Agencies:
16,309 acres
BLM:
15,197 acres
USFS:
1,112 acres
State Agencies:
77,159 acres
Private:
746,073 acres 
DRAFT WORKING DOCUMENT DO NOT DUPLICATE

2052

2053

2054

2055

2056

2057

2058

2059

2060

2061

2062

2063

2064

2065

2066

2067

2068

2069

2070

2071

2072

2073

2074

2075

2076

2077

2078

2079

2080

2081

2082

2083

2084

2085

2086

2087

2088

2089

Associated Habitats

\begin{tabular}{ccc}
\hline Habitat & Habitat Tier & Percentage of Area \\
\hline Mixed Mesic Shrubs & II & 2.04 \\
Very Low Cover Grasslands & I & 2.36 \\
Wetland \& Riparian & I & 7.34 \\
Moderate/ High Cover Grasslands & I & 11.69 \\
Agricultural Lands - Irrigated & III & 18.99 \\
Agricultural Lands - Dry & III & 22.88 \\
Low/ Moderate Cover Grasslands & I & 29.12 \\
\hline
\end{tabular}

Note: A total of $94.42 \%$ of the Little Belt Foothills area is represented. $5.58 \%$ is made up of a combination of other habitat types.

\section{Associated Species of Greatest Conservation Need}

There are a total of 293 terrestrial vertebrate species that are found within the Little Belt Foothills Focus Area. All associations can be found within Table 14.

Amphibians: Boreal Toad and Northern Leopard Frog

Birds: Bald Eagle, Sage-grouse, Mountain Plover, Long-billed Curlew, Black Tern, and Burrowing Owl

Mammals: Townsend's Big-eared Bat, Black-tailed Prairie Dog, and Black-footed Ferret

Reptiles: Western Hognose Snake and Milk Snake

\section{Conservation Concerns}

- Unsustainable domestic livestock grazing and timber harvest practices

- Altered natural fire regime

- Invasive or exotic plant species

- Fragmentation and loss of native habitat as a result of conversion to cropland and human population growth/development

\section{Conservation Strategies}

- Government and private conservation programs/activities that encourage and support private land stewardship

- Encourage the conservation of natural rangeland communities

- Increased efforts to maintain ecological features (i.e. black-tailed prairie dog colonies) or processes (i.e. fire) on public lands

- Cooperative efforts to reduce the abundance of invasive or exotic species 


\section{DRAFT WORKING DOCUMENT DO NOT DUPLICATE}

\section{References}

2091

2092 The Nature Conservancy. 1999. Ecoregional Conservation in the Northern Great 2093 Plains Steppe. Northern Great Plains Steppe Ecoregional Planning Team. 76 2094 pgs.

2095

2096 
2098

2099

2100

2101

2102

2103

2104

2105

2106

2107

2108

2109

2110

2111

2112

2113

2114

2115

2116

2117

2118

2119

2120

2121

2122

2123

2124

2125

2126

2127

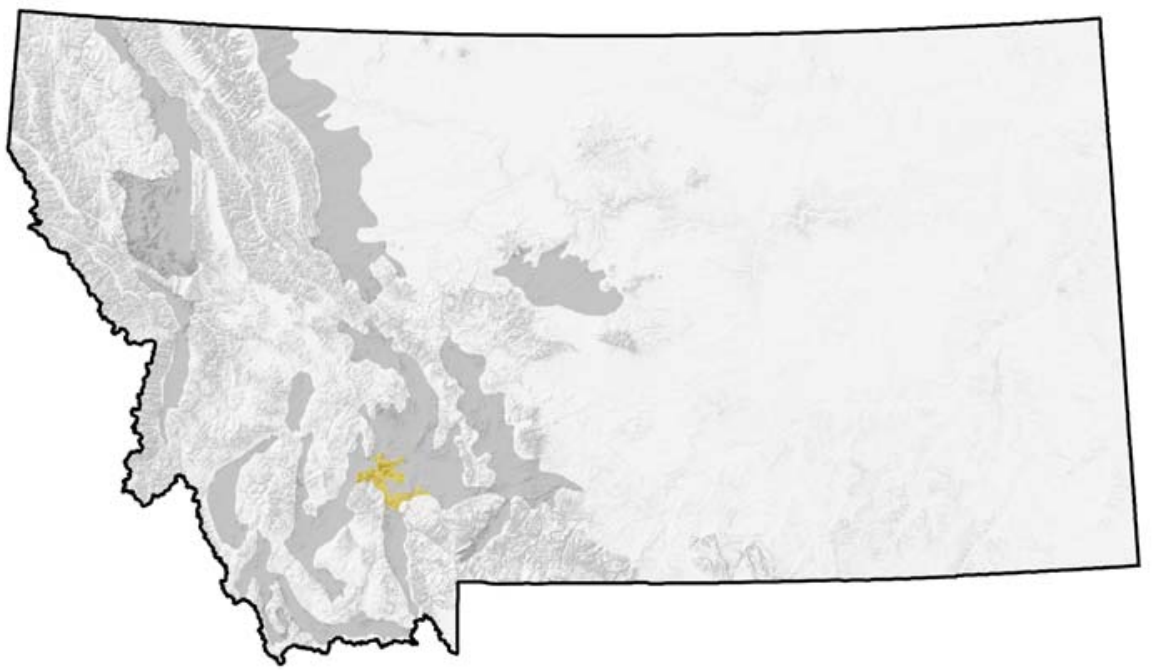

Figure 8. Tobacco Root Mountains Focus Area

The rugged peaks of the Tobacco Root Mountains overlook this area with their abundant high mountain lakes providing excellent fishing opportunities. These mountains have seen extensive historical mining activity resulting in numerous roads. The foothills provide important elk and mule deer winter range and are dominated by sagebrush/grassland that has seen conversion from spraying and burning of sagebrush. Along the Jefferson River there are productive cottonwood riparian habitats supporting an abundance of wildlife species including whitetail deer and recently introduced Merriam's turkeys. This valley bottom is home to extensive agricultural production of cattle and alfalfa with little or no grain production.

\section{Landscape Characteristics}

This subsection is composed of complex faulted mountains and foothills that formed in gneiss, volcanic, and a variety of sedimentary bedrock. Elevations range from 4,200 to 8,000 feet. Drainage density is high. Mean annual precipitation ranges from 10 to 25 inches, about 35 percent falling as snow. The soil temperature and moisture regimes are frigid (cryic at higher elevations) and aridic ustic. The primary natural disturbance is fire. Land use is predominantly livestock grazing and timber harvest. The breakdown for land stewardship in the North Tobacco Root Mountains and Foothills is as follows:

U.S. Federal Agencies: $\quad 32,309$ acres

BLM:

17,544 acres USFS:

State Agencies:

14,765 acres

Private:

171,985 acres 
Associated Habitats

\begin{tabular}{ccc}
\hline Habitat & Habitat Tier & Percentage of Area \\
\hline Wetland \& Riparian & I & 2.11 \\
Agricultural Lands - Dry & III & 3.29 \\
Limber Pine & III & 3.36 \\
Agricultural Lands - Irrigated & III & 3.83 \\
Douglas Fir & II & 5.01 \\
Mixed Xeric Forest & III & 7.42 \\
Very Low Cover Grasslands & I & 8.24 \\
Sagebrush & I & 11.88 \\
Low/ Moderate Cover Grasslands & I & 50.44 \\
\hline
\end{tabular}

2131

2132

Note: A total of $95.59 \%$ of the North Tobacco Root Mountains and Foothills area is represented. $4.41 \%$ is made up of a combination of other habitat types.

\section{Associated Species of Greatest Conservation Need}

There are a total of 244 terrestrial vertebrate species that are North Tobacco Root Mountains and Foothills Focus Area. All associations can be found within Table 15.

\section{Amphibians: Boreal Toad}

Birds: Flammulated Owl and Bald Eagle

Mammals: Townsend's Big-eared Bat, Grizzly Bear, and Lynx

\section{Conservation Concerns}

- Habitat loss, degredation and fragmentation especially as a result of population growth/development

- Invasive or exotic plant and animal species

- Unsustainable domestic livestock grazing and timber practices

\section{Conservation Strategies}

- Support strategic conservation easements/protection by conservation organizations or public agencies by providing advice and technical assistance

- Promote sustainable land management practices on public lands

- Support state/federal tax incentives which discourage habitat fragmentation

- Participate in partnerships to develop and implement weed control strategies 


\section{DRAFT WORKING DOCUMENT DO NOT DUPLICATE}

2164

2165

2166

2167

2168

2169

2170

2171

2172

2173

2174

2175
- Improve grazing and timber management to enhance biological diversity on existing managed/protected areas

- Promote and further develop county ordinances that help to manage and plan for development

\section{References}

The Nature Conservancy. 2000. Middle Rockies-Blue Mountains Ecoregional

Conservation Plan. Prepared by the Middle Rockies - Blue Mountains Planning

Team. 58 pgs + appendices 
2175 Rocky Mountain Front Foothills (2,018789 acres)

2176

2177

2178

2179

2180

2181

2182

2183

2184

2185

2186

2187

2188

2189

2190

2191

2192

2193

2194

2195

2196

2197

2198

2199

2200

2201

2202

2203

2204

2205

2206

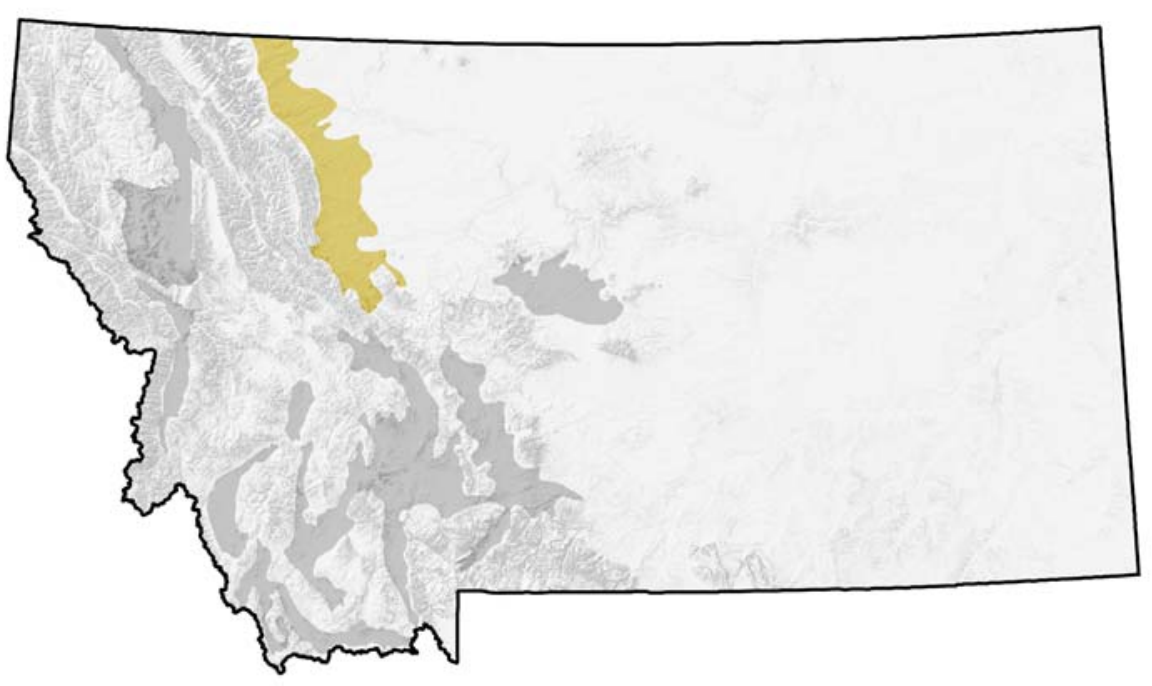

Figure 9. Rocky Mountain Front Foothills Focus Area

The Rocky Mountain Front, from Alberta, Canada south through Montana, marks the easternmost edge of the Bob Marshall Wilderness where thrust-faulted mountains give way to rolling foothills and Great Plains grasslands. This variable landscape still offers glimpses of grizzly bears moving from high-mountain fir and spruce forests to native prairie grasslands dotted with pothole marshes where migrating birds stage season after season. With the exception of bison, all of the native mammals that inhabited this land when Lewis and Clark passed through survive here.

\section{Landscape Characteristics}

This subsection is composed of mountain front foothills, moraines, fans, and terraces that formed in calcareous shales overlain by till, outwash, alluvium, and terrace deposits. The landscape has been modified by glaciation. Elevations range from 3,400 to 8,500 feet. Drainage density is low to moderate. Mean annual precipitation ranges from 12 to 20 inches, about half falling as snow. The soil temperature and moisture regimes are frigid and typic ustic. Chinook winds are frequent. The primary natural disturbance is fire. Land use is predominantly livestock grazing. The breakdown for land stewardship in the Rocky Mountain Front Foothills is as follows:

U.S. Federal Agencies:

33,421 acres

BLM:

9,019 acres

USFS:

4,819 acres

USFWS:

State Agencies:

1,421 acres

Tribal Lands:

172,603 acres

482,906 acres

Private: 
Associated Habitats

\begin{tabular}{ccc}
\hline Habitat & Habitat Tier & Percent of Area \\
\hline Limber Pine & III & 2.02 \\
Mixed Broadleaf Forest & I & 2.13 \\
Altered Herbaceous & II & 3.77 \\
Agricultural Lands - Dry & III & 4.41 \\
Agricultural Lands - Irrigated & III & 5.96 \\
Mixed Mesic Shrubs & II & 6.13 \\
Wetland \& Riparian & I & 6.47 \\
Moderate/ High Cover Grasslands & I & 10.46 \\
Low/ Moderate Cover Grasslands & I & 49.69 \\
\hline
\end{tabular}

Note: A total of $91.03 \%$ of the Rocky Mountain Front Foothills area is represented. $8.97 \%$ is made up of a combination of other habitat types.

\section{Associated Species of Greatest Conservation Need}

2215

2216

There are a total of 361 terrestrial vertebrate species that are found within the Rocky Mountain Front Foothills Focus Area. All associations can be found within Table 16.

Amphibians: Boreal Toad and Northern Leopard Frog

Birds: Common Loon, Trumpeter Swan, Harlequin Duck, Bald Eagle, Piping Plover, Mountain Plover, Long-billed Curlew, Black Tern, Flammulated Owl, and Burrowing Owl

Mammals: Townsend's Big-eared Bat, Black-tailed Prairie Dog, Northern Bog Lemming, Grizzly Bear, and Lynx

Reptiles: Western Hognose Snake

\section{Conservation Concerns}

- Habitat fragmentation from development as a result of conversion of natural lands to agriculture and human population growth/development

- Energy exploration and development activities

- Invasive or exotic plant or animal species

\section{Conservation Strategies}

- Government and private conservation programs/activities that encourage and support private land stewardship

- Policy-based approaches that encourage the conservation of natural communities, rather than support their conversion 
2244

2245

2246

2247

2248

2249

2250

2251

2252

2253

2254

2255

2256

2257

2258

2259

2260

2261

2262
- Increased efforts to maintain ecological features (i.e. black-tailed prairie dog colonies) or processes (i.e. fire) on public lands as they disappear from private lands.

- Cooperative efforts to reduce the abundance of invasive or exotic species

\section{References}

The Nature Conservancy. 2005. Unpublished Report.

The Nature Conservancy. 1999. Ecoregional Conservation in the Northern Great Plains Steppe. Northern Great Plains Steppe Ecoregional Planning Team. 76 pgs.

United States Fish \& Wildlife Service. 2004. Conservation Focus Areas of the Great Divide: A vast region encompassing the Upper Missouri, Yellowstone and Upper Columbia watersheds. Publisher: USFWS, Benton Lake Wildlife Refuge, Great Falls, MT. 77pgs. 


\section{South Elkhorn Mountains (171,059 acres)}

2264

2265

2266

2267

2268

2269

2270

2271

2272

2273

2274

2275

2276

2277

2278

2279

2280

2281

2282

2283

2284

2285

2286

2287

2288

2289

2290

2291

2292

2293

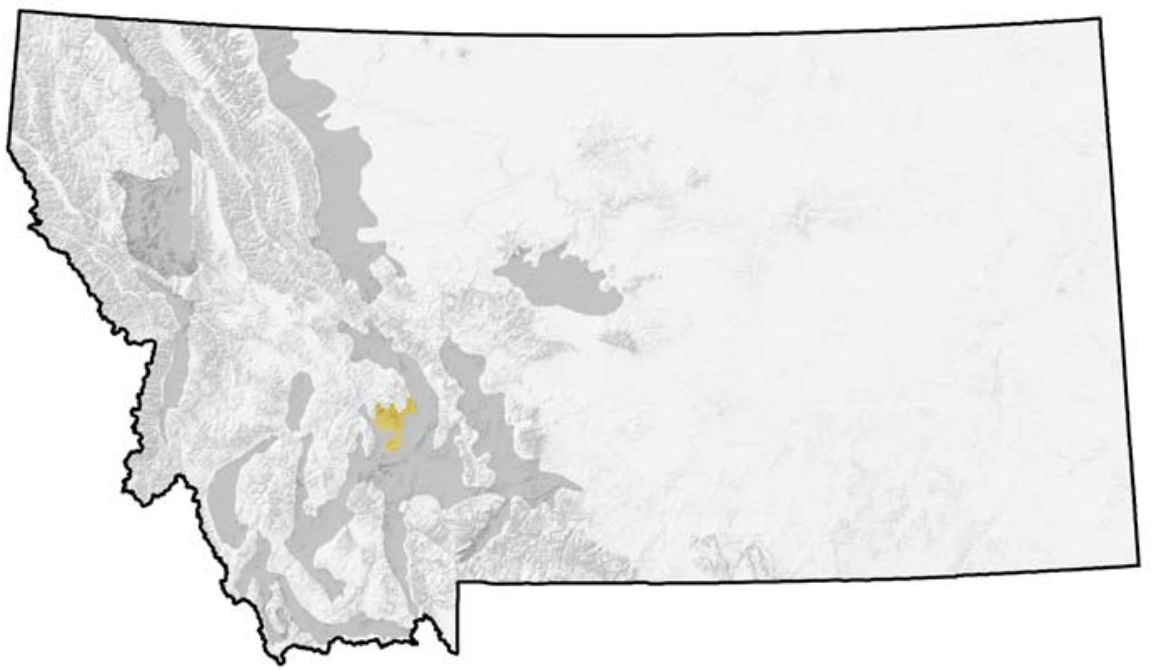

Figure 10. South Elkhorn Mountains Focus Area

The South Elkhorn Mountains are a diverse landscape with vegetation and topography more typical of Central Montana than the Intermountain Western portion of Montana. Sagebrush Grasslands and broken and rough terrain are found through much of this area although much of the southern portion has been converted to dryland grain and CRP grasslands. Mule deer and antelope are common throughout much of the South Elkhorn Mountains and Sage-grouse were rumored to have been common prior to loss of much of their primary sagebrush habitat. In the northern portion of this area as the mountainous portion of the Elkhorn Mountains are approached, the common geologic formations are limestone ridges and outcrops. These ridges provide the environment for abundant stands of mountain mahogany, which among other things makes this area very attractive mule deer winter range.

\section{Landscape Characteristics}

This subsection is composed of mountains and foothills that formed in limestone, dolomite, argillite, andesite, sandstone, and quartzite. Elevations range from 4,500 to 7,500 feet. Drainage density is low. Mean annual precipitation ranges from 12 to 22 inches, about 30 percent falling as snow. The soil temperature and moisture regimes are frigid (cryic at higher elevations) and aridic ustic. The primary natural disturbance is fire. Land use is predominantly livestock grazing and timber harvest. The breakdown for land stewardship in the South Elkhorn Mountains is as follows:
U.S. Federal Agencies:
71,105 acres, which include
BLM:
USFS:
8,494 acres
22,610 acres 
DRAFT WORKING DOCUMENT DO NOT DUPLICATE

2294 State Agencies:

2295 Private:

2296

2297

2298

2299

2300

2301

2302

2303

2304

2305

2306

2307

2308

2309

2310

2311

2312

2313

2314

2315

2316

2317

2318

2319

2320

2321

2322

2323

2324

2325

2326

2327

2328

2329 habitat types. 17. assistance
6,425 acres

93,529 acres

Associated Habitats

\begin{tabular}{ccc}
\hline Habitat & Habitat Tier & Percentage of Area \\
\hline Lodgepole Pine & III & 2.12 \\
Montane Parklands \& Subalpine Meadows & III & 3.42 \\
Rocky Mountain Juniper & III & 7.41 \\
Mixed Xeric Forest & III & 7.54 \\
Douglas Fir & II & 8.17 \\
Very Low Cover Grasslands & I & 13.66 \\
Sagebrush & I & 22.13 \\
Low/ Moderate Cover Grasslands & I & 28.70 \\
\hline
\end{tabular}

Note: A total of $93.14 \%$ of the South Elkhorn Mountains area is represented. $6.86 \%$ is made up of a combination of other

\section{Associated Species of Greatest Conservation Need}

There are a total of 242 terrestrial vertebrate species that are found within the South Elkhorn Mountains Focus Area. All associations can be found within Table

Amphibians: Northern Leopard Frog

Birds: Bald Eagle and Black-backed Woodpecker

Mammals: Townsend's Big-eared Bat, Pallid Bat, Gray Wolf, and Lynx

\section{Conservation Concerns}

- Habitat loss, degredation and fragmentation especially as a result of human population growth

- Invasive or exotic plant or animal species

- Unsustainable domestic livestock grazing and timber harvest practices

\section{Conservation Strategies}

- Support strategic conservation easements/protection by conservation organizations or public agencies by providing advice and technical

- Promote sustainable land management practices on public lands

- Support state/federal tax incentives which discourage habitat fragmentation 
2330

2331

2332

2333

2334

2335

2336

2337

2338

2339

2340

2341

2342

2343
- Participate in partnerships to develop and implement weed control strategies

- Improve grazing and timber management to enhance biological diversity on existing managed/protected areas

- Promote and further develop county ordinances that help to plan for and manage development

\section{References}

The Nature Conservancy. 2000. Middle Rockies-Blue Mountains Ecoregional

Conservation Plan. Prepared by the Middle Rockies - Blue Mountains Planning Team. 58 pgs + appendices. 
2345

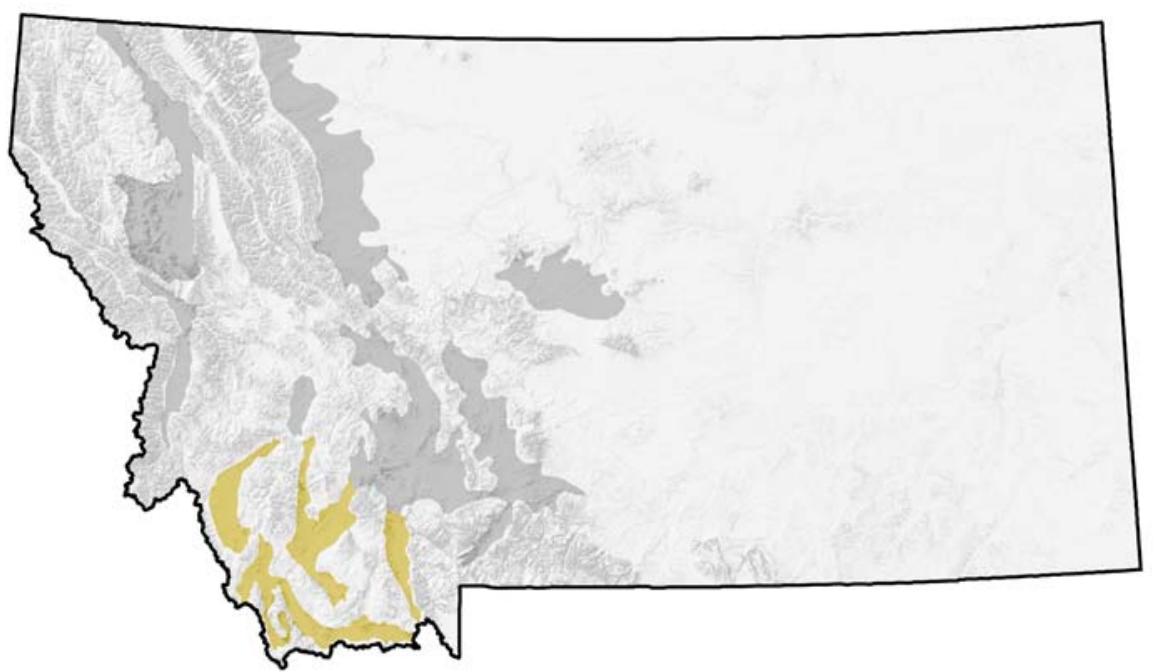

Figure 11. Southwest Montana Intermontane Basins and Valleys Focus Area

The area consists of valleys located between mountain ranges, and typically follows major stream courses. Many small tributary mountain streams flow down the hillsides of these valleys and support wetlands and rivers such as the Red Rock, Madison, Jefferson and Big Hole rivers, and Red Rock Lakes. The vegetation is a mix of sagebrush grassland on the valley floor and, in the wet valley bottoms, riparian species like sedges and willow are common. Coniferous forest and aspen stands in the wetter microsites dominate the higher elevations. The coniferous forest and adjacent sagebrush communities provide winter habitats for mule deer and elk, while the riparian bottoms provide yearlong habitat for white-tailed deer. These intermountain basins and valleys are highly valued for residential development, and are under the imminent threat of habitat fragmentation.

\section{Landscape Characteristics}

This subsection consists of intermontane basins and broad valleys that formed in alluvium, glacial deposits, and Tertiary volcanic materials. Elevations range from 4,700 to 7,600 feet. Drainage density is low. Mean annual precipitation ranges from 9 to 20 inches, about 10 percent falling as snow. The soil temperature and moisture regimes are frigid and aridic ustic. Parts of the Red Rock Basin and Big Hole Valley have cryic temperature regimes. The primary natural disturbances are flooding and fire. Land use is predominantly livestock grazing, agriculture, and urban/suburban development. The breakdown for land stewardship in the Southwest Montana Intermontane Basins and Valleys is as follows:
U.S. Federal Agencies:
479,632 acres, which include BLM: 344,156 acres 


$\begin{array}{lll}2375 & \text { USFS: } & 96,180 \text { acres } \\ 2376 & \text { USFWS: } & 38,610 \text { acres } \\ 2377 & \text { NPS: } & 680 \text { acres } \\ 2378 & \text { State Agencies: } & 275,028 \text { acres } \\ 2379 & \text { Private: } & 1,318,307 \text { acres }\end{array}$

Associated Habitats

\begin{tabular}{ccc}
\hline Habitat & Habitat Tier & Percentage of Area \\
\hline Very Low Cover Grasslands & $\mathrm{I}$ & 5.19 \\
Wetland \& Riparian & $\mathrm{I}$ & 6.94 \\
Agricultural Lands - Irrigated & $\mathrm{III}$ & 9.04 \\
Sagebrush & $\mathrm{I}$ & 30.19 \\
Low/ Moderate Cover Grasslands & $\mathrm{I}$ & 31.81 \\
\hline
\end{tabular}

Note: A total of $83.17 \%$ of the Southwest Montana Intermontane Basins and Valleys area is represented. $16.83 \%$ is made up of a combination of other habitat types.

\section{Associated Species of Greatest Conservation Need}

There are a total of 296 terrestrial vertebrate species that are found within the Southwest Montana Intermontane Basins and Valleys Focus Area. All associations can be found within Table 18.

\section{Amphibians: Boreal Toad}

Birds: Common Loon, Trumpeter Swan, Bald Eagle, Sage-grouse, Long-billed Curlew, and Flammulated Owl

Mammals: Townsend's Big-eared Bat, Pygmy Rabbit, Great Basin Pocket Mouse, Gray Wolf, Grizzly Bear, and Lynx

\section{Conservation Concerns}

- Habitat fragmentation as a result of population growth/development

- Invasive or exotic plant species

- Dewatering as a result of water diversion

- Disruption of natural disturbance processes or hydrologic regimes

- Unsustainable domestic livestock grazing and timber harvest practices

- Altered fire regime

\section{Conservation Strategies}

- Support strategic conservation easements/protection by conservation organizations or public agencies by providing advice and technical assistance 


\section{DRAFT WORKING DOCUMENT DO NOT DUPLICATE}

2415

2416

2417

2418

2419

2420

2421

2422

2423

2424

2425

2426

2427

2428

2429

2430

2431

2432

2433

2434

2435

2436

2437

2438

2439

2440

2441

2442

2443

2444

2445

2446

2447

2448

2449
- Promote sustainable land management practices on public lands

- Support state/federal tax incentives which discourage habitat fragmentation

- Participate in partnerships to develop and implement weed control strategies, especially strategies which promote plant diversity

- Improve grazing and timber management to enhance biological diversity on existing managed/protected areas, especially discourage practices that degrade riparian areas

- Promote and further develop county ordinances that help to plan for and manage development

- Support conservation easement program and incentives to land owners that protect habitat

- Manage for sustainable use of recreational vehicles on public lands

\section{References}

Fargione, Joseph, Brown, Cynthia S., Tilman, David. 2003. Community assembly and invasion: An experimental test of neutral versus niche processes. PNAS. Vol. 100 (15): 8916-8920.

Montana Partners for Fish \& Wildlife. 2000. Centennial Valley. 4 pgs. More information at http://www.r6.fws/gpv/pfw/montana/mt3c.htm

The Nature Conservancy. 2005. Unpublished Report.

The Nature Conservancy. 2000. Middle Rockies-Blue Mountains Ecoregional Conservation Plan. Prepared by the Middle Rockies - Blue Mountains Planning Team. 58 pgs + appendices

United States Fish \& Wildlife Service. 2004. Conservation Focus Areas of the Great Divide: A vast region encompassing the Upper Missouri, Yellowstone and Upper Columbia watersheds. Publisher: USFWS, Benton Lake Wildlife Refuge, Great Falls, MT. 77pgs. 
2451

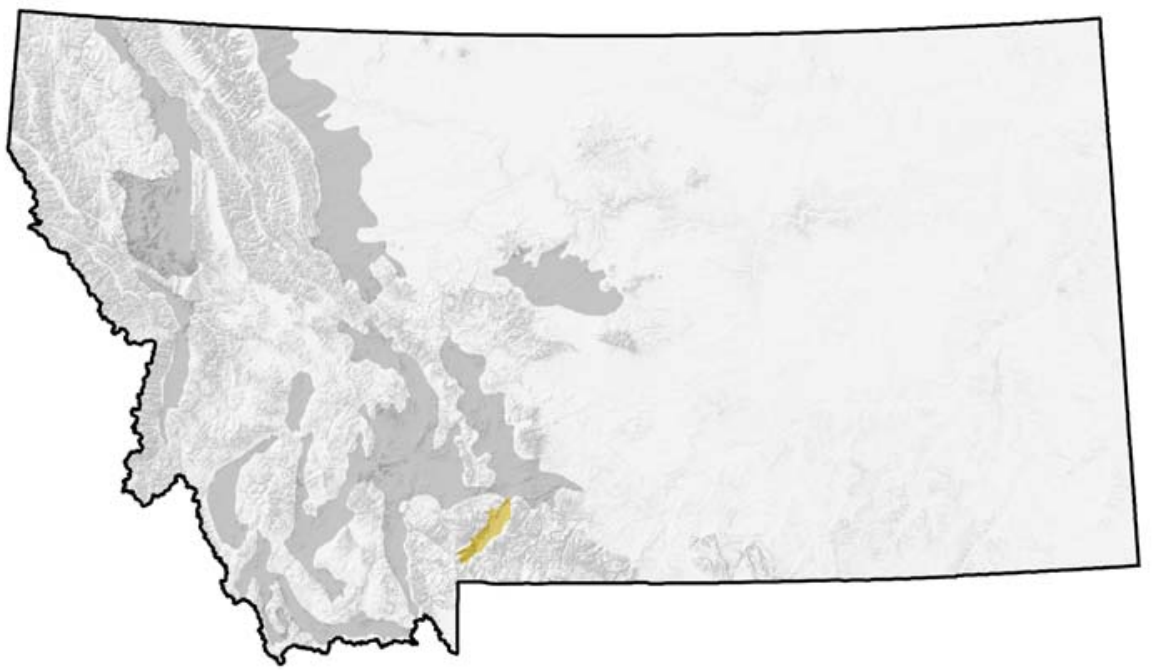

Figure 12. Upper Yellowstone Valley Focus Area

The Upper Yellowstone Valley, south of Livingston, is better known to many as Paradise Valley. Bracketed by the Absaroka-Beartooth Wilderness on the east and the Gallatin Range on the west, the valley's grassland habitats are bisected by the Yellowstone River and its riparian areas and cottonwood stands. Several streams in the area harbor genetically pure populations of Yellowstone cutthroat trout. Much of the valley lies in the rain shadow of the mountains and is a wintering area for elk, bighorn sheep, and mule deer. The area supports grizzly bears, and there is increasing wolf presence. Cradled within the Gallatin and Absaroka ranges are low-elevation meadows, limited juniper stands mixed with grasslands and sagebrush. Higher up are forests of aspen, pine, spruce, subalpine fir, and whitebark pine.

\section{Landscape Characteristics}

This valley is composed of valley floor, terraces, toeslopes, and foothills that formed in alluvium and Tertiary sedimentary and volcanic rocks. Elevations range from 4,500 to 7,500 feet. Drainage density is moderate and wetlands are fairly common. Mean annual precipitation ranges from 15 to 40 inches, about 55 percent falling as snow. The soil temperature and moisture regimes are frigid and aridic ustic. The primary natural disturbance is flooding. Land use is predominantly recreational development, with some agriculture and livestock grazing. The breakdown for land stewardship in the Upper Yellowstone Valley is as follows:
U.S. Federal Agencies:
18,656 acres, which include
BLM:
USFS:
1,668 acres
16,988 acres 
2481 State Agencies:

2482

2483

2484

2485

2486

2487

2488

2489

2490

2491

2492

2493

2494

2495

2496

2497

2498

2499

2500

2501

2502

2503

2504

2505

2506

2507

2508

2509

2510

2511

2512 other habitat types. Table 19. Woodpecker
12,293 acres

146,101 acres

\section{Associated Habitats}

\begin{tabular}{ccc}
\hline Habitat & Habitat Tier & Percentage of Area \\
\hline Mixed Broadleaf Forest & I & 2.14 \\
Mixed Xeric Forest & II & 2.28 \\
Moderate/ High Cover Grasslands & I & 2.28 \\
Mixed Subalpine Forest & III & 3.95 \\
Agricultural Lands - Dry & III & 3.98 \\
Wetland \& Riparian & I & 4.57 \\
Montane Parklands \& Subalpine Meadows & III & 5.00 \\
Douglas Fir & II & 5.17 \\
Sagebrush & I & 5.49 \\
Agricultural Lands - Irrigated & III & 7.15 \\
Rock & III & 7.87 \\
Very Low Cover Grasslands & I & 11.16 \\
Low/ Moderate Cover Grasslands & I & 28.56 \\
\hline
\end{tabular}

Note: A total of $89.61 \%$ of the Upper Yellowstone Valley area is represented. $10.39 \%$ is made up of a combination of

\section{Associated Species of Greatest Conservation Need}

There are a total of 265 terrestrial vertebrate species that are found within the Upper Yellowstone Valley Focus Area. All associations can be found within

Amphibians: Boreal Toad and Northern Leopard Frog

Birds: Trumpeter Swan, Bald Eagle, Long-billed Curlew, and Black-backed

Mammals: Gray Wolf, Grizzly Bear, and Lynx

\section{Conservation Concerns}

- Recreational infrastructure development especially road network development

- Sedimentation in streams

- Habitat loss and fragmentation especially as a result of human population growth/development

- Unsustainable timber harvest practices

- Unsustainable irrigation practices 


\section{DRAFT WORKING DOCUMENT DO NOT DUPLICATE}

\section{Conservation Strategies}

2514

2515

2516

2517

2518

2519

2520

2521

2522

2523

2524

2525

2526

2527

2528

2529

2530

2531

2532

2533
- Support strategic conservation easements/protection by conservation organizations or public agencies by providing advice and technical assistance

- Promote sustainable land management practices on public lands

- Support state/federal tax incentives which discourage habitat fragmentation

- Improve grazing and timber management to enhance biological diversity on existing managed/protected areas

- Promote and further develop county ordinances that help to plan for and manage development

\section{References}

A Biological Conservation Assessment for the Utah-Wyoming Rocky Mountain Ecoregion: Report to the Nature Conservancy. 2001. R. Noss, G. Wuerthner, K. Vance-Borland, and C. Carroll. Conservation Science, Inc. 125 pp. + Executive Summary and Appendix D. 


\section{Aquatic Conservation Focus Areas in Greatest Need (Tier I)}

2537

2538

2539

2540

2541

2542

2543

2544

2545

2546

2547

2548

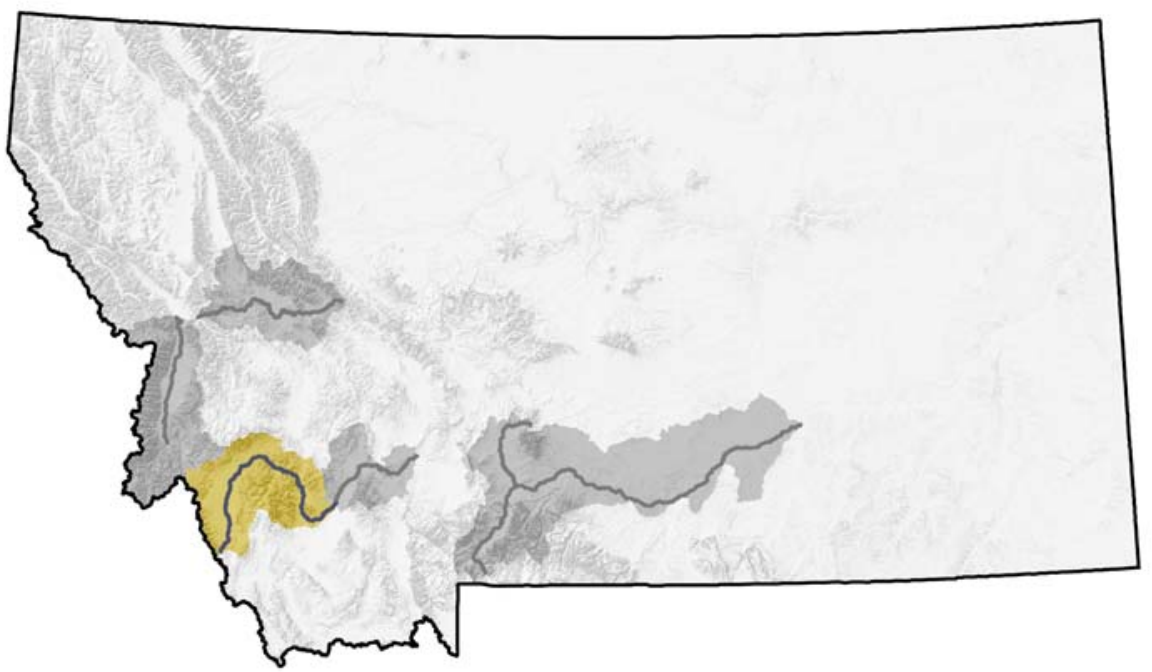

Figure 13. Big Hole River Focus Area

Originally named the Wisdom River by Meriwether Lewis, the Big Hole River and its tributaries start along the boarder of Montana and Idaho. Surrounded by hay meadows, the upper Big Hole separates the Bitterroot Range on the west from the Pioneer Mountains to the east. The middle section of the river runs through a length of gorge and then glides out through hay meadows, once again, where it teams up with the Beaverhead River to create the Jefferson.

\section{Associated Habitats}

\begin{tabular}{cccc}
\hline Habitat Type & Habitat Tier & Acres & Miles \\
\hline Intermountain Valley Rivers & II & & 153 \\
Intermountain Valley Streams & II & & 967 \\
Lowland Lakes & III & 297 & \\
Lowland Reservoirs & III & 64 & \\
Mountain Lakes & III & 2886 & \\
Mountain Reservoirs & III & 12 & \\
Mountain Streams & II & & 2929 \\
\hline
\end{tabular}

2549

2550

2551

2552

2553

2554

\section{Associated Species of Greatest Conservation Need}

There are a total of 20 aquatic species that are found within the Big Hole River Focus Area. All associations can be found within Table 20. 


\section{DRAFT WORKING DOCUMENT DO NOT DUPLICATE}

2555

2556

2557

2558

2559

2560

2561

2562

2563

2564

2565

2566

2567

2568

2569

2570

2571

2572

2573

2574

2575

2576

2577

2578

2579

2580

2581

2582

2583

2584

2585

2586

2587

2588

2589

2590

2591

2592

2593

2594

2595

2596

2597

2598

2599

Invertebrates: Western Pearlshell

Fish: Westslope Cutthroat Trout, Lake Trout (native lakes), Arctic Grayling, and Burbot

\section{Conservation Concerns}

- Diversion of water for irrigation ditches and livestock watering

- Valley fragmentation for subdivisions

- Noxious weeds

- Removal of woody riparian vegetation

- Culverts, dams, irrigation diversions or other instream barriers that fully or partially impede fish movement and reduce connectivity of habitat

- Modification and degradation of stream channels caused by various construction or land management practices

- Degradation of riparian vegetation caused by various land management practices Such activities de-stabilize streambanks, increase sediment inputs, and reduce shading

- Entrainment of juvenile and adult fishes by irrigation diversion or other water intakes

- Alterations of the quantity or timing of streamflows causing dewatering or unnatural flow fluctuations that diminish the quantity or quality of essential habitats

- Water quality: warm, turbid water (caused by shallow in-stream ponds/reservoirs, removal of overhanging vegetation, exposure of erodable soils due to unsustainable land management practices, irrigation returns, etc.) is a problem for cool/cold water riverine systems and species

- Water chemistry problems can arise due to municipal discharge, irrigation return water, and other sources

\section{Conservation Strategies}

- Increased installation of stockwater wells in place of irrigation ditches

- Support management of grazing to maintain habitat in excellent condition

- Pursue conservation easements within the valley

- Removal or modification of barriers in a manner that restores fish passage

- Restoration of stream channels, stream banks and riparian areas to a condition that simulates their natural form and function

- Screening or modification of irrigation diversions or other water intakes in a manner that prevents entrainment of fishes

- Implementation of various water conservation or flow management practices that restore essential habitats and simulate the natural hydrograph 


\section{DRAFT WORKING DOCUMENT DO NOT DUPLICATE}

\section{References}

2601

2602 Montana Partners for Fish \& Wildlife. 2000. Big Hole River Watershed. 4 pgs.

2603 More information at http://www.r6.fws/gpv/pfw/montana/mt3c.htm

2604

2605 


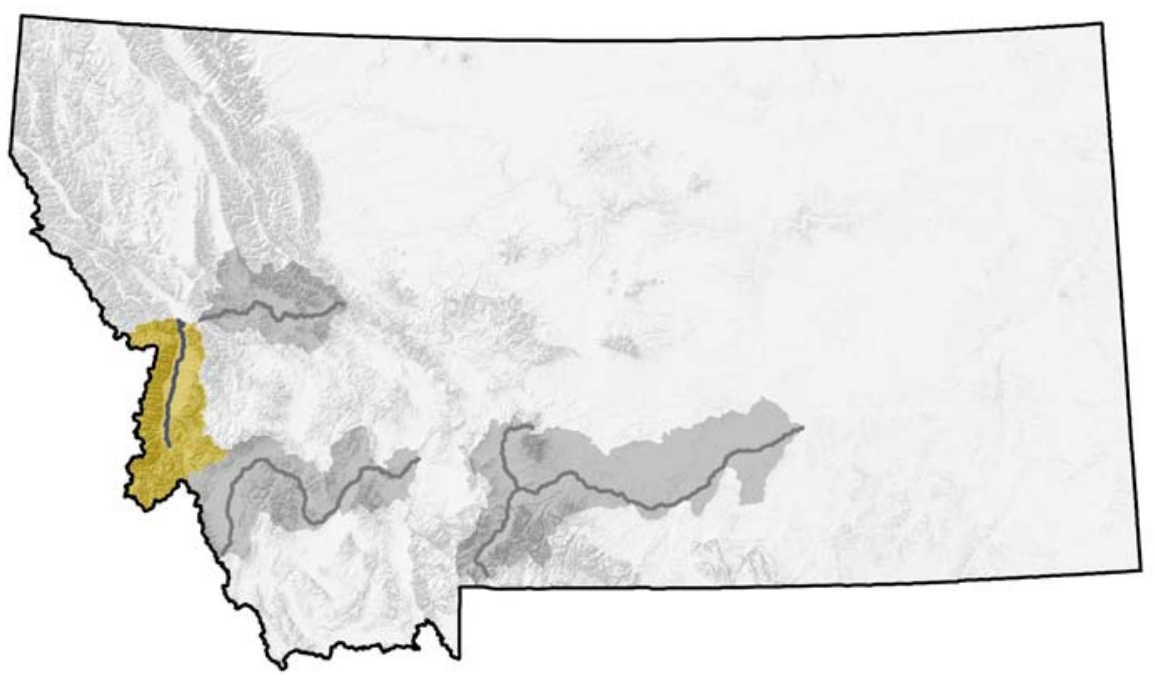

\section{Figure 14. Bitterroot River Focus Area}

This river originates in the Anaconda-Pintler Wilderness and the Bitterroot Mountains in Montana. As the primary tributaries flow together near Conner, Montana it continues north along Highway 93 for 85 miles where it empties into the Clark Fork River near Missoula. To the west, is the glacial Bitterroot Range, and to the east rises the smoother and drier Sapphire Mountains. Just west of the Bitterroot Range lies the Selway Bitterroot Wilderness that encompasses more than 2.15 million acres. The river is characterized by constantly shifting stream channels among extensive cottonwood and Ponderosa Pine bottomland.

\section{Associated Habitats}

\begin{tabular}{cccc}
\hline Habitat Type & Habitat Tier & Acres & Miles \\
\hline Intermountain Valley Rivers & II & & 84 \\
Intermountain Valley Streams & II & & 325 \\
Lowland Lakes & III & 1260 & \\
Mountain Lakes & III & 2946 & \\
Mountain Reservoirs & III & 27 & \\
Mountain Streams & II & & 3304 \\
\hline
\end{tabular}

\section{Associated Species of Greatest Conservation Need}

There are a total of 22 aquatic species that are found within the Bitterroot River Focus Area. All associations can be found within Table 21.

Invertebrates: Western Pearlshell 


\section{DRAFT WORKING DOCUMENT DO NOT DUPLICATE}

2628

2629

2630

2631

2632

2633

2634

2635

2636

2637

2638

2639

2640

2641

2642

2643

2644

2645

2646

2647

2648

2649

2650

2651

2652

2653

2654

2655

2656

2657

2658

2659

2660

2661

2662

2663

2664

2665
Fish: Westslope Cutthroat Trout, and Bull Trout

\section{Conservation Concerns}

- Valley fragmentation as a result of human population growth

- Presence of non-native aquatic species

- Water quality problems due to municipal discharge, irrigation return water, and other sources

- Culverts, dams, irrigation diversions or other instream barriers that fully or partially impede fish movement and reduce connectivity of habitat

- Modification and degradation of stream channels caused by various construction or land management practices

- Degradation of riparian vegetation caused by various land management practices. Such activities de-stabilize streambanks, increase sediment inputs, and reduce shading

- Entrainment of juvenile and adult fishes by irrigation diversion or other water intakes

- Alterations of the quantity or timing of streamflows causing dewatering or unnatural flow fluctuations that diminish the quantity or quality of essential habitats

\section{Conservation Strategies}

- Pursue conservation easements within the valley

- Removal or modification of barriers in a manner that restores beneficial fish passage

- Restoration of stream channels or stream banks to a condition that simulates their natural form and function

- Modification of riparian management practices such that riparian vegetation is allowed to recover

- Screening or modification of irrigation diversions or other water intakes in a manner that prevents entrainment of fishes

- Implementation of various water conservation or flow management practices that restore essential habitats and simulate the natural hydrograph 


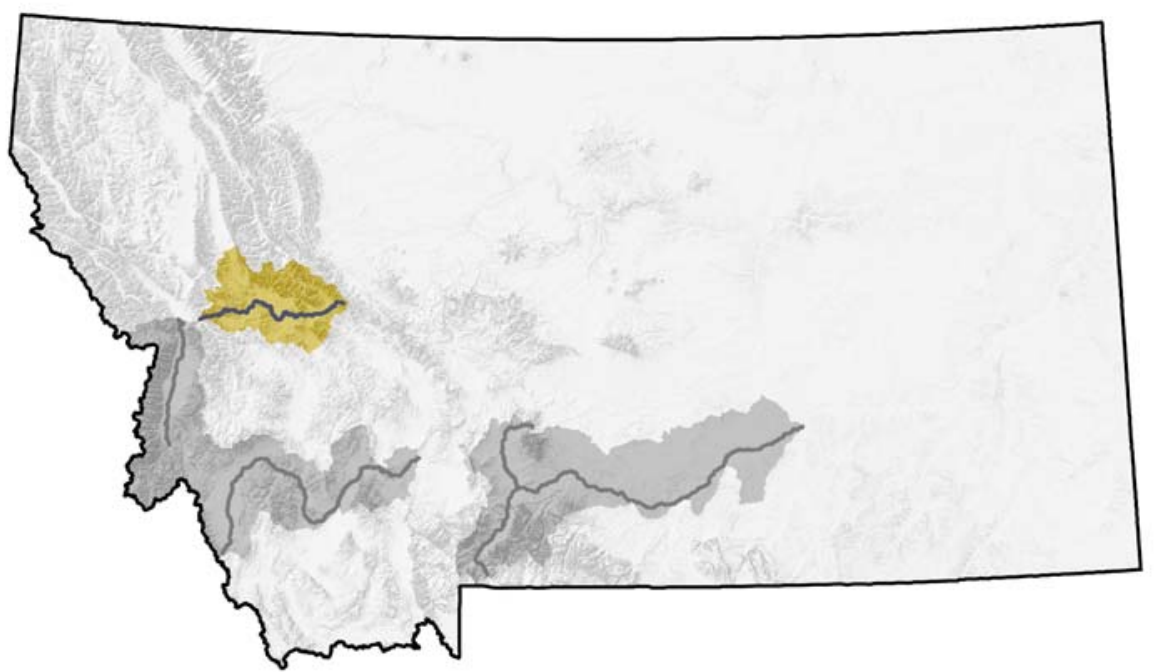

\section{Figure 15. Blackfoot River Focus Area}

The Blackfoot River begins at the junction of Beartrap and Anaconda creeks near the Continental Divide and flows west 132 miles to its mouth at Bonner, Montana. Near its headwaters, the Blackfoot River drops through glaciated high-alpine meadows and runs between steep, forested slopes. Above Lincoln, the river almost annually goes underground, then re-appears below Lincoln and meanders through conifer forests and wetlands until it intersects with the North Fork of the Blackfoot River. For its remaining 52 miles, the Blackfoot levels out, and moves through open ranch and timbered areas, until it meets the Clark Fork River near Bonner. A free flowing river, the Blackfoot is affected by soon to be removed Milltown Dam, which has blocked fish passage on the Clark Fork River since 1907.

\section{Associated Habitats}

\begin{tabular}{cccc}
\hline Habitat Type & Habitat Tier & Acres & Miles \\
\hline Intermountain Valley Rivers & II & & 127 \\
Intermountain Valley Streams & II & & 316 \\
Lowland Lakes & III & 6525 & \\
Lowland Reservoirs & III & 390 & \\
Mountain Lakes & III & 2604 & \\
Mountain Reservoirs & III & 5 & \\
Mountain Streams & II & & 3207 \\
\hline
\end{tabular}




\section{DRAFT WORKING DOCUMENT DO NOT DUPLICATE}

2687 There are a total of 25 aquatic species that are found within the Blackfoot River

2688 Focus Area. All associations can be found within Table 22.

2689

2690

2691

2692

2693

2694

2695

2696

2697

2698

2699

2700

2701

2702

2703

2704

2705

2706

2707

2708

2709

2710

2711

2712

2713

2714

2715

2716

2717

2718

2719

2720

2721

2722

2723

2724

2725

2726

2727

2728

2729

2730

Invertebrates: Western Pearlshell

Fish: Westslope Cutthroat Trout and Bull Trout

\section{Conservation Concerns}

- Culverts, dams, irrigation diversions or other instream barriers that fully or partially impede fish movement and reduce connectivity of habitat

- Modification and degradation of stream channels caused by various construction or land management practices

- Degradation of riparian vegetation caused by various land management practices. Such activities de-stabilize streambanks, increase sediment inputs, and reduce shading

- Entrainment of juvenile and adult fishes by irrigation diversion or other water intakes

- Alterations of the quantity or timing of streamflows causing dewatering or unnatural flow fluctuations that diminish the quantity or quality of essential habitats

- Unnatural hydrograph and water temperatures associated with presence and operations of large dams, as well as blockage of migratory corridors

- Water quality: warm, turbid water (caused by shallow in-stream ponds/reservoirs, removal of overhanging vegetation, exposure of erodable soils due to unsustainable land management practices, irrigation returns, etc.) is a problem for cool/cold water riverine systems and species

- Water chemistry problems that arise due to contamination by hard rock mines in headwaters, irrigation return water, and other sources

\section{Conservation Strategies}

- Removal or modification of barriers in a manner that restores fish passage for fluvial native fish

- Implementation of a comprehensive mine cleanup in the headwaters of the Blackfoot River upstream of Lincoln, Montana

- Restoration of stream channels or stream banks to a condition that simulates their natural form and function

- Modification of riparian management practices such that riparian vegetation is allowed to recover

- Screening or modification of irrigation diversions or other water intakes in a manner that prevents entrainment of fishes

- Implementation of various water conservation or flow management practices that restore essential habitats and simulate the natural hydrograph 


\section{DRAFT WORKING DOCUMENT DO NOT DUPLICATE}

2732

2733

2734

2735

2736

2737

2738
- Work to the extent feasible, to operate dams to mimic a more natural hydrograph in the primarystem rivers, and ensure more natural thermal regime. Provide passage over dams to ensure full migratory movement

\section{References}


2740

2741

2742

2743

2744

2745

2746

2747

2748

2749

2750

2751

2752

2753

2754

2755

2756

2757

2758

2759

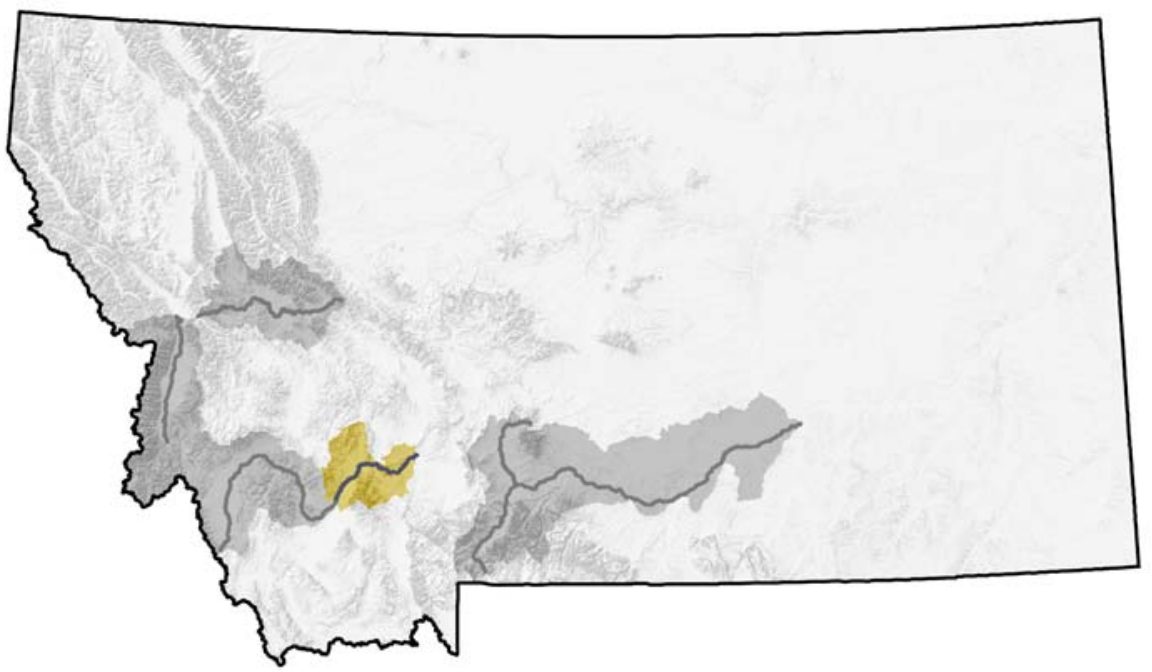

Figure 16. Jefferson River Focus Area

Lewis and Clark named this river after President Thomas Jefferson because it carried the greatest volume of water at that time compared to the near by Madison and Gallatin rivers. The Jefferson River begins where the Big Hole and Beaverhead intersect and flows north through cattle country, limestone cliffs, and into the cottonwood bottoms nears Three Forks, where it meets the Madison and Gallatin rivers to form the Missouri River.

\section{Associated Habitats}

\begin{tabular}{cccc}
\hline Habitat Type & Habitat Tier Acres & Miles \\
\hline Intermountain Valley Rivers & II & & 77 \\
Intermountain Valley Streams & II & & 1377 \\
Lowland Lakes & III & 214 & \\
Lowland Reservoirs & III & 715 & \\
Mountain Lakes & III & 627 & \\
Mountain Reservoirs & III & 609 & \\
Mountain Streams & II & & 1091 \\
\hline
\end{tabular}

\section{Associated Species of Greatest Conservation Need}

There are a total of 22 aquatic species that are found within the Jefferson River Focus Area. All associations can be found within Table 23.

Invertebrates: Western Pearshell 


\section{DRAFT WORKING DOCUMENT DO NOT DUPLICATE}

2760

2761

2762

2763

2764

2765

2766

2767

2768

2769

2770

2771

2772

2773

2774

2775

2776

2777

2778

2779

2780

2781

2782

2783

2784

2785

2786

2787

2788

2789

2790

2791

2792

2793

2794

2795

2796

2797

2798

2799

2800

2801

2802

2803

2804

2805

Fish: Westslope Cutthroat Trout, Arctic Grayling, and Burbot

\section{Conservation Concerns}

- Culverts, dams, irrigation diversions or other instream barriers that fully or partially impede fish movement an reduce habitat connectivity

- Modification and degradation of stream channels caused by various construction or land management practices

- Degradation of riparian vegetation caused by various land management practices. Such activities de-stabilize streambanks, increase sediment inputs, and reduce shading

- Entrainment of juvenile and adult fishes by irrigation diversion or other water intakes

- Alterations of the quantity or timing of streamflows causing dewatering or unnatural flow fluctuations that diminish the quantity or quality of essential habitats

- Warm, turbid water (caused by shallow in-stream ponds/reservoirs, removal of overhanging vegetation, exposure of erodable soils due to poor land management practices, irrigation returns, etc.) are a problem for cool/cold water riverine systems and species

- Water chemistry problems can arise due to municipal discharge, irrigation return water, and other sources

\section{Conservation Strategies}

- Removal or modification of barriers in a manner that restores fish passage

- Restoration of stream channels or stream banks to a condition that simulates their natural form and function

- Modification of riparian management practices such that riparian vegetation is allowed to recover

- Screening or modification of irrigation diversions or other water intakes in a manner that prevents entrainment of fishes

- Implementation of various water conservation or flow management practices that restore essential habitats and simulate the natural hydrograph

\section{References}

DNRC 2005. Canal Seepage Monitoring in the Upper Jefferson River Basin.

Land and Water Consulting, Inc. 2003. Jefferson River Water Quality

Restoration Planning Areas. Watershed Characterization Report.

Land and Water Consulting, Inc. 2003. Jefferson River Water Quality

Restoration Planning Areas. Water Quality Status Report. 
2806 Land and Water Consulting, Inc. 2004. Aerial Photo Review and Field Source 2807 Assessment -2004.

2808

2809 McGuire, Daniel 2004. Jefferson River Aquatic Macroinvertebrate Survey.

2810

2811 Montana Fish, Wildlife \& Parks. 2004. Jefferson River Fisheries Information 2812 (1979-2004).

2813

2814

2815

2816

USDA 1975. Hydrology of the Jefferson River Drainage. 


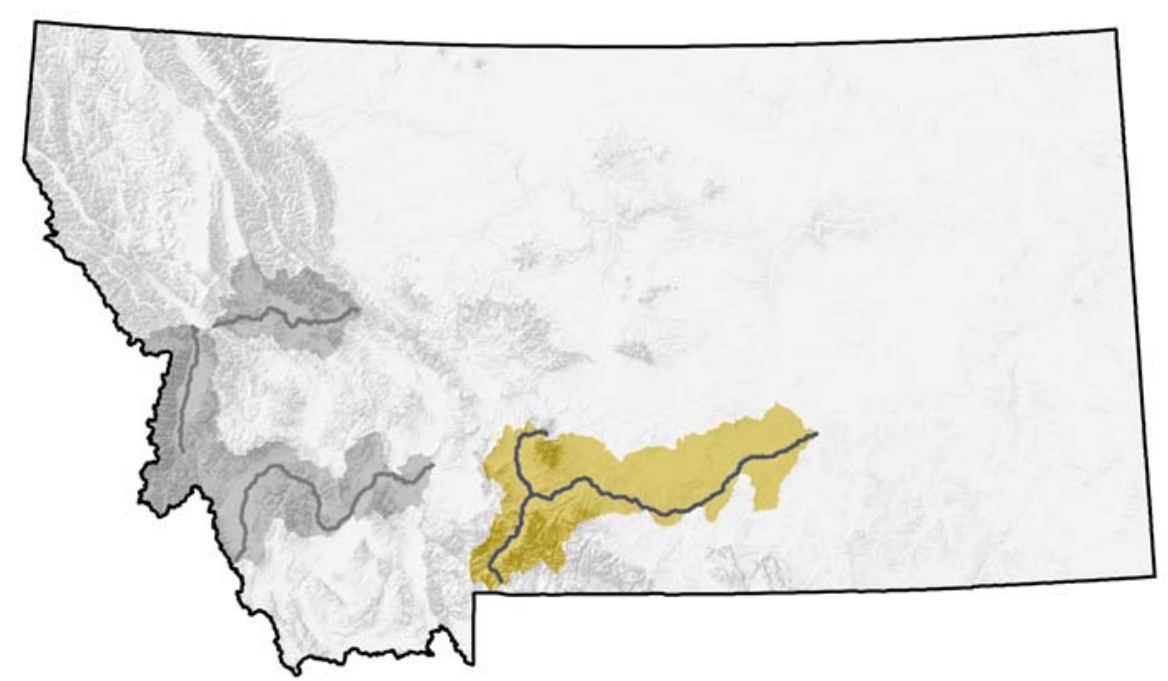

2818

Figure 17. Upper Yellowstone River Focus Area

The Yellowstone River originates in Wyoming and flows through Yellowstone National Park before entering Montana near Gardiner. From the park boundary to Livingston, the river flows north through the Gardiner Basin and eventually enters Paradise Valley, flanked by the Absarokee Mountains on the east and the Gallatin Range on the west. The river continues in a northeasterly direction from Livingston and meets up with the Missouri River just across the North Dakota border. The river has survived as one of the last, large, free flowing rivers in the continental United States. Lack of impoundments allows spring peak flows and fall and winter low flows to influence a unique and dynamic community. The Upper Yellowstone River supports clear, coldwater cutthroat trout fisheries in Yellowstone National Park to the warm-water habitats on the plains. The adjacent environments include cottonwood-willow bottomlands and broad low cover grasslands.

\section{Associated Habitats}

\begin{tabular}{cccc}
\hline Habitat Type & Habitat Tier & Acres & Miles \\
\hline Lowland Lakes & III & 10838 & \\
Lowland Reservoirs & III & 580 & \\
Mixed Source Rivers & & & \\
(Intermountain and Prairie Flow) & II & & 259 \\
Prairie Streams & I & & 5378 \\
Intermountain Valley Rivers & II & & 131 \\
Intermountain Valley Streams & II & & 1068 \\
Mountain Reservoirs & III & 1 & \\
\hline
\end{tabular}




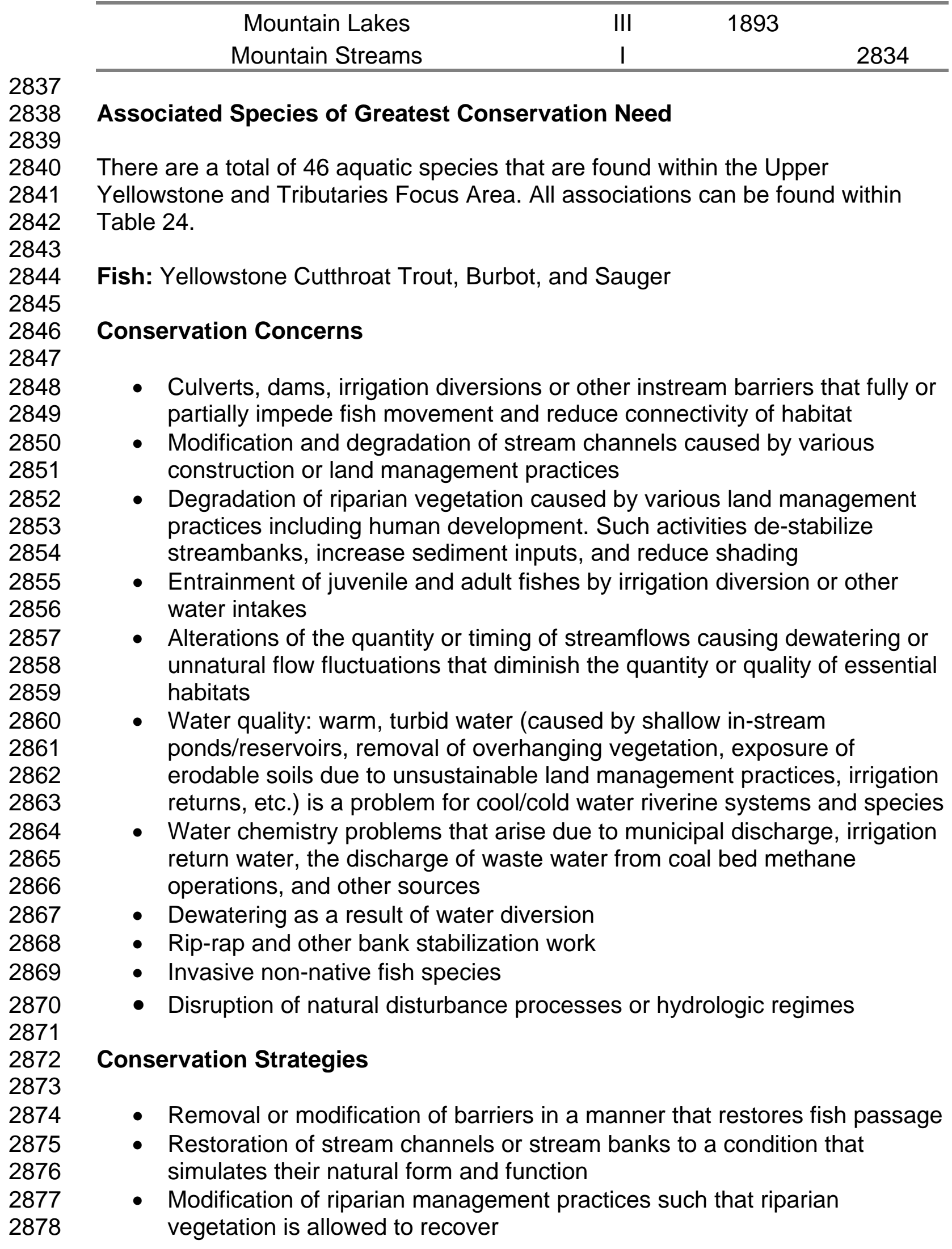


2879

2880

2881

2882

2883

2884

2885

2886

2887

2888

2889

2890

2891

2892

2893

2894

2895

2896

2897

- Screening or modification of irrigation diversions or other water intakes in a manner that prevents entrainment of fishes

- Implementation of various water conservation or flow management practices that restore essential habitats and simulate the natural hydrograph

- Restore and maintain flood dynamics and natural hydrolic regimes

\section{References}

Hansen, A., Rotella, J., Klass, L., Gyskiewicz, D. 2003. Riparian habitat

Dynamics and wildlife along the Upper Yellowstone River. Technical Report \#1. Landscape Biodiversity Lab, Montana State University, Bozeman, MT. In cooperation with The Governor's Upper Yellowstone River Task Force.

United States Fish \& Wildlife Service. 2004. Conservation Focus Areas of the Great Divide: A vast region encompassing the Upper Missouri, Yellowstone and Upper Columbia watersheds. Publisher: USFWS, Benton Lake Wildlife Refuge, Great Falls, MT. 77pgs. 


\section{Montane Forest Ecotype}

2898

2899

2900

2901

2902

2903

2904

2905

2906

2907

2908

2909

2910

2911

2912

2913

2914

2915

2916

2917

2918

2919

2920

2921

2922

2923

2924

2925

2926

2927

2928

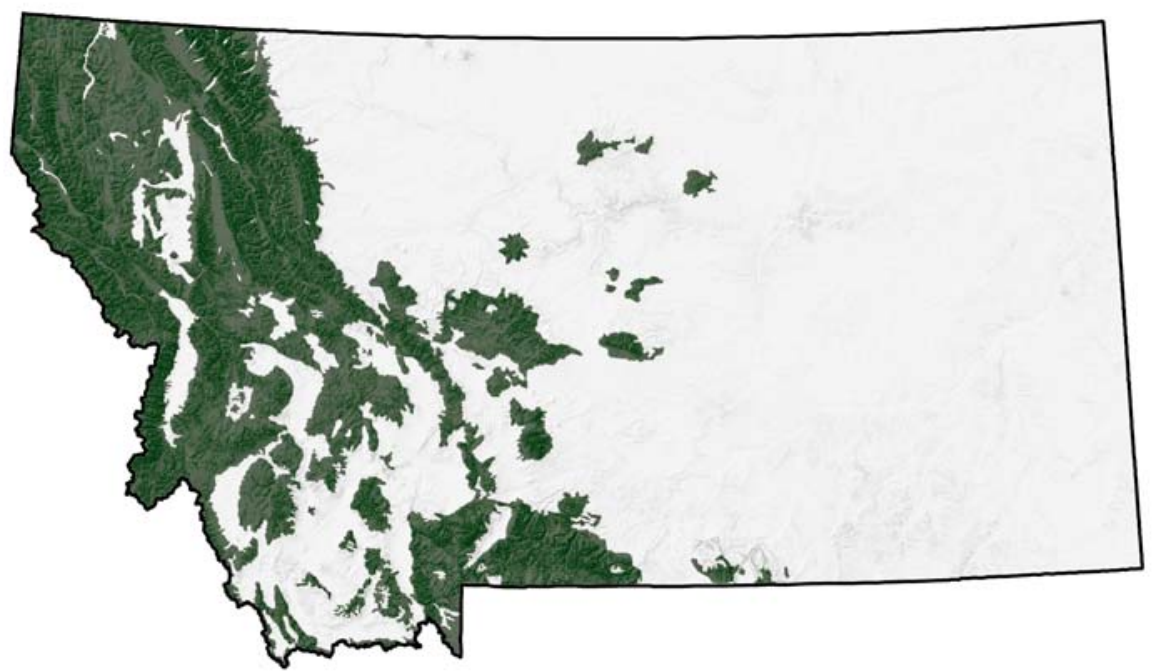

Figure 18. Montane Forest Ecotype

Montana's montane forests occur along the western third of the state from the rugged peaks of the Purcell Mountains in northwestern Montana to the Beartooth Range near Yellowstone National Park. From the foothills to their summits, vast coniferous forests of larch, fir, hemlock, pine, and spruce trees characterize these areas. Such mountain forests also serve to protect the headwaters of Montana's rivers. Most of this ecotype is in public ownership through the U.S. Forest Service. Collaboration with the USFS will be critical to the conservation of these areas.

\section{Landscape Characteristics}

The montane forest ecotype includes $24,498,117$ acres and represents $26 \%$ of the Montana. This ecotype is mostly situated on mountain slopes although a small portion is located in valleys of extreme northwest Montana. Slopes are generally moderate to steep, often exceeding $45^{\circ}$. All mountain ranges in Montana have at least some montane forest as well as the following major valley locations: lower Clark Fork, upper Flathead, Seeley/Swan, Kootenai, Bull River/Lake Creek, and the Stillwater north of Whitefish. These are all included in this ecotype.

The elevation range is the same as for the entire state (the highest and lowest elevation points in Montana are in this ecotype). The lowest elevation, 1,800 feet, occurs where the Kootenai River flows into Idaho. The highest elevation is 12,799 feet atop Granite Peak in the Beartooth Mountains. Both base elevations and mountaintop elevations are lowest in the northwest section of the ecotype, increasing toward the south. Base elevations of near 2,000 feet in the Libby, Troy, and Thompson Falls area increase to about 3,000 feet in the 


\section{DRAFT WORKING DOCUMENT DO NOT DUPLICATE}

2929

2930

2931

2932

2933

2934

2935

2936

2937

2938

2939

2940

2941

2942

2943

2944

2945

2946

2947

2948

2949

2950

2951

2952

2953

2954

2955

2956

2957

2958

2959

2960

2961

2962

2963

2964

2965

2966

2967

2968

2969

2970

2971

2972

2973
Flathead/Mission valleys and increase further to over 3,000 feet in the Missoula/Bitterroot valleys. The highest base elevations west of the divide are generally about 4,500 feet along the east front and south as far as the upper Jefferson valley. As the divide is approached from here, base elevations exceed 6,000 feet in the Big Hole and Centennial valleys. Generally, base elevations inside and outside of the mountain front as well as around the Little Belt, Big Snowy, Judith, and Crazy Mountains are around 4,000 to 4,500 feet. Base elevations around the Highwood, Bear Paw, and Little Rocky mountains are about 3,000 to 3,500 feet.

Although summit elevations of mountains in the north are lower than those in the south (i.e., major mountain ranges in the north topping out at 9,000 to 10,000 feet versus 10,500 to 12,800 feet in the south), base to summit relief is similar. High mountain ranges in all areas are 6,000 to 7,000 feet from base to summit and moderate mountain ranges 4,000 to 5,000 feet. Distances between mountain ranges are shorter in the north, particularly, and west of the divide generally, than those in the southwest.

Since the end of the Precambrian age (600 million years ago), there have been two episodes in the region now occupied by the northern Rockies. The first was a compression stage, resulting in folding and overthrusting of rock strata. Following this has been a tension stage, where the region is pulled apart, causing rock segments to pull apart and tip at various angles. This stage is currently active. During the Precambrian age, sediments were deposited over a wide area in a sea extending from the Three Forks area north into Canada. These sediments form the belt series rocks found in the mountains of most of northwestern Montana. Most of the mountains in the southwest comprise combinations of metamorphic, igneous and Paleozoic/Mesozoic (deposited after 600 million years ago) rocks. Individual mountain ranges often have a core or central area of metamorphic or intrusive igneous rock partially surrounded by uplifted layers of sedimentary rocks. Some mountain areas such as the Gallatin Range, mountains around Wolf Creek, and the Bearpaw mountains consist of extrusive igneous (lava flows). Two very large areas of intrusive igneous rock (granite) occur between Helena and Twin Bridges and the other south from Hamilton toward Anaconda. The topography of most of the higher mountain ranges has been influenced by glaciation. Mountain glaciers have created features including glacial troughs (U-shaped valleys), cirques, tarns (lakes in cirques), and sharp horns and walls. The mountains in the northwest corner were overridden by the Cordilleran Ice Sheet that tended to smooth off their tops. The northern end of the Mission Range is an example of this, whereas the southern end of this range is a prime example of mountain glaciation. Except for the Crazies and the Little Belts, the isolated mountain groups of central Montana did not experience mountain glaciation but may have partially overridden by the Laurentide Ice Sheet. Most of the mountain region has had anywhere from 10 to 45 centimeters of volcanic ash deposited on it. The heaviest deposits were in the 


\section{DRAFT WORKING DOCUMENT DO NOT DUPLICATE}

2974 extreme northwest. These deposits occurred during the time of the formation of 2975 the Cascade Mountains.

2976

2977

2978

2979

2980

2981

2982

2983

2984

2985

2986

2987

2988

2989

2990

2991

2992

2993

2994

2995

2996

2997

2998

2999

3000

3001

3002

3003

3004

3005

3006

3007

\section{Soils}

Most of the montane forest ecotype is overlain by soils that are classified as cool or cold $\left(32^{0}\right.$ to $\left.47^{0} \mathrm{~F}\right)$, cool rather than cold in the summer, and moist most of the time (termed udic). Such soils generally form under forest cover and have an organic duff layer (partially decomposed leaves, etc.) underlain by either a white leached layer or a brown clay layer. If the parent material is limestone, a calcareous layer may be present. Except for the limestone-derived soils, they are usually acid.

\section{Climate}

Most of the climate discussion is based on information in Caprio and Nielsen 1992. The climate of the montane forest ecotype is ruled by first macroclimatic influences and then by elevation influences. The general climate of the northwest mountain areas is maritime while that of the mountains farther east and south is more continental although mountain areas in general tend to be more maritime than their adjacent lowlands. Elevation affects both temperature and precipitation. A general rule of thumb is that temperature decreases about $6^{0} \mathrm{~F}$ for every 1,000 feet rise in elevation. This is a general rule and might not hold true in specific areas. Because of orographic affects, precipitation increases with increasing elevation, so that in any specific area the higher elevations are wetter. However, due to macroclimatic differences, a given elevation in one part of the state will not receive the same amount of precipitation as another. The pattern of yearly distribution will also be different.

Mean yearly temperatures range from $39^{\circ}$ to $40^{\circ} \mathrm{F}$. at lower elevations in most of the mountains to about $30^{\circ} \mathrm{F}$. at the highest elevations. The Beartooth

Mountains and plateau constitute a large and very high landmass with annual average temperatures as low as $20^{\circ} \mathrm{F}$. Throughout most of the mountain mass, January maximum daily temperatures are in the $22^{\circ}$ to $25^{\circ} \mathrm{F}$. range, however at

3008

3009 high elevations of mountains in southwestern and central Montana and Glacier

3010

3011

3012

3013 Park these temperatures range from $8^{0}$ to $19^{\circ} \mathrm{F}$. Some of the areas of northwestern Montana are warmer, with January maximum daily temperatures from $28^{\circ}$ to $30^{\circ} \mathrm{F}$. A similar pattern holds true for mean January nighttime minimums except the relative greater warmth of the northwestern mountains is more extreme. The mountains of almost the entire northwest corner exhibit January minimum temperatures in the $10^{\circ}$ to $11^{\circ} \mathrm{F}$. range no matter what elevation. The mountains of the rest of Montana have January mean minimum temperatures ranging from $4^{0}$ to $6^{0} \mathrm{~F}$. at lower elevations and $0^{0}$ to $-11^{0} \mathrm{~F}$. at highest elevations. The mean July daily temperatures at low elevations generally range from $58^{\circ}$ to $60^{\circ} \mathrm{F}$. while at high elevations they range from $51^{0}$ to $54^{\circ} \mathrm{F}$. 


\section{DRAFT WORKING DOCUMENT DO NOT DUPLICATE}

3020

3021

3022

3023

3024

3025

3026

3027

3028

3029

3030

3031

3032

3033

3034

3035

3036

3037

3038

3039

3040

3041

3042

3043

3044

3045

3046

3047

3048

3049

3050

3051

3052

3053

3054

3055

3056

3057

3058

3059

3060

3061

3062

3063

3064

3065
Those mountains bordering or surrounded by the plains have the lowest mean annual extreme minimum temperatures. The two coldest mountain ranges in this regard, the Beartooths and Crazys, experience annual minimum temperatures in the $-41^{0}$ to $-45^{\circ} \mathrm{F}$. range. At the other extreme, the mountains of the northwest corner do not generally get colder than $-27^{\circ} \mathrm{F}$. at any elevation. Annual maximums range from $85^{\circ}$ to $92^{\circ} \mathrm{F}$. throughout most of the mountains. The frost-free season at most of the higher elevations ranges from 10 to 50 days annually. Obviously frost can occur at any date. Lower elevations have seasons ranging from 50 to 90 days annually.

The montane forest ecotype is the wettest in the state. Closed canopy forests generally do not occur at less than 20 inches annual precipitation in western Montana. Within the ecotype the northwest is the wettest. A given precipitation level is reached at a much lower elevation in the northwest than in the south and east, in other words, it takes a lot more elevation to produce the same amount of precipitation in the southwest, southcentral and central mountains than it does in the northwest. In the southwest, only a few very small and scattered areas receive more than 60 inches annually. These occur at elevations greater than 11,000 feet in the Beartooth, Crazy, and Madison mountains. In the northwest, such areas are relatively large and occur in most mountain areas higher than 7,000 feet. Higher parts of Glacier Park, Cabinet Mountains, the Mission Range, and the Swan Range are estimated to receive over 120 inches annually.

Average annual precipitation for the ecotype as a whole is estimated to be around 37 inches. Some relatively small areas of the ecotype are in the 12 to 16 inch zone. $52 \%$ of the area in the ecotype receives 20 to 40 inches while the remainder receives 40 to 60 inches (20\%), 16 to 20 inches (15\%), 60 to 100 inches (9\%), 12 to 16 inches (3\%), and 100 or more inches (1\%). Yearly precipitation in the mountain areas is more maritime (more precipitation in winter than summer) than adjacent low lands. What actually might be the case is that precipitation is much higher in the mountains than other areas during winter, whereas in summer there is relatively little difference, suggesting that a major reason for the relative dryness of the low elevation areas is lack of moisture in the winter. This effect is most extreme in the northwest corner, where the relatively higher winter precipitation extends even into low elevations. The lowest percentage of growing season precipitation in the state, 22 to 27 percent, occurs in a wide area around the Cabinet Mountains and in small areas in Glacier Park and the Mission Range. Summer precipitation in the high southwestern mountains generally ranges from 32 to $35 \%$ of the total annual precipitation.

Snowfall ranges from 81 to 300 inches annually in most mountain areas depending on elevation although parts of the Mission Range, the Swan Range and Glacier Park may get 1,000 inches in an average year. In most mountain areas, the ground will be covered with at least 1 inch of snow from 120 to 260 days in an average year. A large part of the Glacier Park may have snow on the ground for over 300 days. 


\section{DRAFT WORKING DOCUMENT DO NOT DUPLICATE}

3066

3067

3068

3069

3070

3071

3072

3073

3074

3075

3076

3077

3078

3079

3080

3081

3082

3083

3084

3085

3086

3087

3088

3089

3090

3091

3092

3093

3094

3095

3096

3097

3098

3099

3100

3101

3102

3103

3104

3105

3106

3107

3108

3109

3110

3111

\section{Anthropogenic}

The montane forest ecotype is diverse both in land management and its uses by humans. Whether it is for natural resources or recreational activities, these areas have multiple opportunities for explorers and entrepreneurs. Primary activities include hiking, mountaineering, hunting, biking, snowmobiling, animal watching, and skiing. The primary industries in this ecotype are construction and the timber industry. The breakdown of landowner stewardship for montane forest ecotype is as follows:
U.S. Federal Agencies: BLM: USFS: USFWS: NPS:
State Agencies:
$17,405,054$ acres, which include 648,466 acres $15,586,235$ acres
19,707 acres
$1,125,565$ acres
765,594 acres
Tribal Lands:
825,579 acres
Private:
City \& County:
$5,231,777$ acres
6,795 acres

\section{Vegetation}

Vegetation community composition in the forested mountain areas of Montana is not affected by soil conditions except under a few conditions (Pfister et al. 1977). Forest vegetation patterns are influenced primarily by climate, topography, and species migrations patterns. The factors mentioned above result in a great variation in forest species composition across the ecotype. Because of this, the vegetation of this ecotype will be described in general areas based on climate characteristics. The northwest area north of Missoula and west of the Continental Divide has the greatest variety of tree species. The macroclimate of the northwest forest is more maritime, generally resulting in an area less subject to cold arctic outbreaks in the winter, receiving more total precipitation, and a higher proportion of precipitation in the winter. The climatic conditions create an area where potentially $100 \%$ of the land could be forested. Most valleys are forested, and except for the non-forested Flathead Basin, these are included in the Montane forest ecotype. Climate, plus a greater proximity to the Pacific, results in a greater abundance of Pacific and Intermountain flora, and a greater variety of plant species than the remainder of Montana. Grand fir (Abies grandis), western hemlock (Tsuga heterophylla), arborvitae or western red cedar (Thuja plicata), mountain hemlock (Tsuga mertensiana) and western white pine (Pinus monticola) are trees essentially confined to the northwest forested area. Western hemlock and white pine are limited primaryly due to the extreme northwest corner. Alpine larch (Larix lyallii) extends a very short distance into the northern most part of the east-of-divide area and western larch penetrates much of the westcentral region (Arno 1979). As in other parts of Montana, individual 


\section{DRAFT WORKING DOCUMENT DO NOT DUPLICATE}

3112 tree species are adapted to certain elevation zones. The order of adaptation

3113 from lowest to highest elevation, for trees in the northwest area has been

3114 determined by (Pfister et al. 1977). In those areas warm and dry enough such

3115 that there is a lower timberline adjacent to grassland, ponderosa pine (Pinus

3116

3117

3118

3119

3120

3121

3122

3123

3124

3125

3126

3127

3128

3129

3130

3131

3132

3133

3134

3135

3136

3137

3138

3139

3140

3141

3142

3143

3144

3145

3146

3147

3148

3149

3150 ponderosa) dominates at the lowest forest elevations. The upper timberline at about 8,000 feet is formed by alpine larch, whitebark pine, and subalpine fir. Grand fir, arborvitae or western red cedar, both hemlocks, and alpine larch have very narrow zones of distribution. The other conifer species may occupy elevation zones thousands of feet wide and therefore occur together with numerous other species. Generally the tree species are considered climax dominants only in the lower part of their range and are seral in upper parts, however in the northwest area, western larch, lodgepole pine, and spruce are considered seral wherever they occur (Pfister et al. 1977).

Some of the understory species common in the northwest area of the montane forest ecotype are either absent or rare in other parts of the ecotype. These include devil's club (Oplopanax horridum), queencup beadlily (Disporum hookeri), trefoil foamflower (Tiarella trifoliate), and wild sarsaparilla (Aralia nudicaulis). Heartleaf arnica (Arnica cordifolia), common juniper (Juniperus communis), and elk sedge (Carex geyeri) are rare in the northwest area but are widespread in other areas of the ecotype (Arno 1979). Understory species ubiquitous and relatively common in the northwest and throughout the montane forest ecotype include: bluebunch wheatgrass, Idaho fescue, rough fescue, snowberry (Symphoricarpus albus), spirea (Spirea betulifolia), pinegrass (Calamagrostis rubescens), ninebark (Physocarpus malvaceus), twinflower (Linnaea borealis), huckleberry (Vaccinium spp.), and kinnikinik (Arctostaphylos uva-ursi).

In the westcentral area of the montane forest ecotype the climate is drier, colder, and less maritime than the northwest, but is less continental than parts of the ecotype to the east and south. Western larch is common (although not necessarily widespread) in westcentral and northwest areas but not throughout the ecotype. Arborvitae or western red cedar, grand fir, and alpine larch penetrate slightly into this area. The elevation ordering of tree species is similar to the northwest area except that grand fir, arborvitae or western red cedar, white pine, and hemlock are missing in most areas. Understory species shared with the northwest area but uncommon or missing to the east and south include: smooth woodrush (Luzula hitchcockii), menziesia (Mentziesia ferruginia), and beargrass (Xerophyllum tenax).

3151 In areas east of the continental divide, the ecotype is reduced to relatively 3152 isolated mountain islands surrounded by grassland or shrub/grassland.

3153 Compared to the northwest and west central areas, the overall climate in the east 3154 3155 is colder, drier, and windier. This results in conditions unsuitable for several of the tree species found to the north and west. Although ponderosa pine is 3157 present in the plains forests to the east (Plains forest ecotype), it is generally absent throughout all but a small portion of this area of the montane forest 
3158 ecotype. Apparently, the growing seasons coupled with high elevations limit the 3159 distribution of ponderosa pine. The most extensive areas of ponderosa pine just 3160 east of the divide are around Helena (Arno 1979). Douglas fir, lodgepole pine, 3161 and subalpine fir dominate forests throughout this area. Lodgepole pine is an 3162 extremely common seral species dominating much of the upper Douglas fir zone 3163 and the spruce fir zone. Only a very restricted area close to Yellowstone Park is 3164 apparently climax lodgepole pine. Areas near the timberline commonly support 3165 subalpine fir and whitebark pine except on limestone substrates where whitebark 3166 pine is generally missing and is often replaced by limber pine (Pinus flexilis).

3167 Alpine larch penetrates a small distance into the northern most reaches of this 3168 area where adjacent to the northwest area. Extensive amounts of the 3169 southcentral area of the ecotype support spruce dominated forests. 
3171

3172

3173

3174

3175

3176

3177

3178

3179

3180

3181

3182

3183

3184

3185

3186

3187

3188

3189

3190

3191

3192

3193

3194

3195

3196

3197

3198

3199

3200

3201

3202

\section{Terrestrial Conservation Focus Areas in Greatest Need (Tier I)}

Mission/Swan Valley and Mountains (679,663 acres)

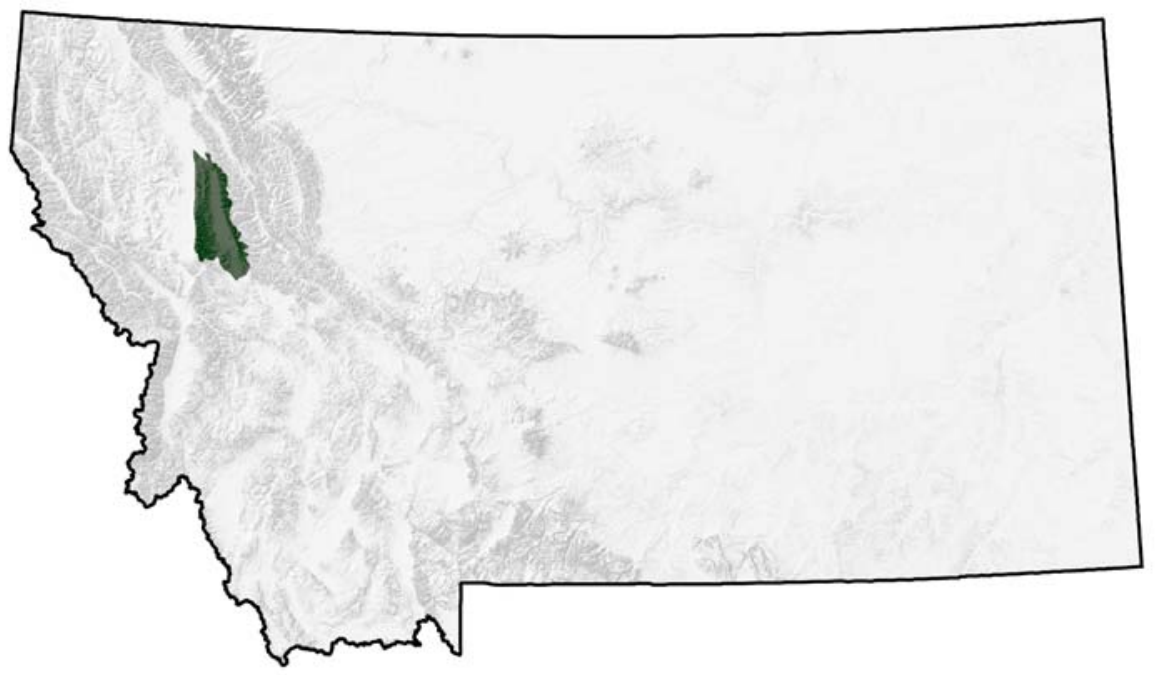

Figure 19. Mission/Swan Valley and Mountains Focus Area

This area is geologically similar to Glacier National Park, with the Swan Valley sandwiched in between the heavily glaciated ranges of the Mission and Swan Mountains. The mountain ranges and a strong Pacific storm track produce an inland maritime climate over a topography ranging from alpine ridges, cirque headwalls, and cirque basins down to moraines, terraces, and creek and river bottoms. The area is heavily forested with relatively fertile soils with most having a 6-12 inch thick layer of volcanic ash immediately below the organic matter, a souvenir from eruptions in the Cascade Range. The valley bottom, in addition to the riparian areas along streams and rivers, is comprised of a wide array of wetlands such as fens/peatlands, marshes, vernal pools, ponds, and lakes with the valley bottom area being comprised of $>15 \%$ wetlands (compared to the Montana average of $<2 \%$ wetland area). The area currently provides critical habitat for wildlife such as grizzly bear, lynx, bull trout, bald and golden eagle, peregrine falcon, common loon, northern goshawk, and wolverine. More common wildlife species include whitetail and mule deer, elk, mountain goat, moose, black bear, mountain lion, bobcat, beaver, along with a host of other mammals, fish, waterfowl, raptors, and songbirds. The valley contains one of the highest concentrations of rare plant populations in the region with most of them being associated with the wetland habitats such as water howellia.

\section{Landscape Characteristics}

This area is a large intermontane valley with adjacent block faulted mountains that formed in valley fill, till and metasedimentary rock. Volcanic ash influences most soils. Alpine glaciation has strongly shaped the landscape. Elevations 


\section{DRAFT WORKING DOCUMENT DO NOT DUPLICATE}

3203 range from 2,900 to 9,300 feet. Drainage density is moderate. Wetlands and

3204

3205

3206

3207

3208

3209

3210

3211

3212

3213

3214

3215

3216

3217

3218

3219

3220

3221

3222

3223

3224

3225

3226

3227

3228

3229

3230

3231

3232

3233

3234

3235

3236

3237 lakes occur frequently in this subsection. Mean annual precipitation ranges from 20 to 110 inches, about 80 percent falling as snow in the mountains. The soil temperature and moisture regimes are cryic and udic. The primary natural disturbances are fire, insects, and windthrow. Land use is predominantly for resource management and outdoor recreation with rural and suburban development in the valleys. The breakdown for land stewardship in the Mission/Swan Valley and Mountains is as follows:

U.S. Federal Agencies: USFS: USFWS:

State Agencies:

Tribal Lands:

Private:

Associated Habitats

\begin{tabular}{ccc}
\hline Habitat & Habitat Tier & Percentage of Area \\
\hline Snowfields Or Ice & II & 2.09 \\
Douglas-fir/ Lodgepole Pine & III & 2.36 \\
Western Larch & III & 2.55 \\
Montane Parklands \& Subalpine Meadows & III & 4.16 \\
Rock & III & 4.38 \\
Mixed Mesic Shrubs & II & 5.21 \\
Douglas Fir & II & 10.12 \\
Lodgepole Pine & III & 10.61 \\
Mixed Subalpine Forest & III & 14.57 \\
Mixed Mesic Forest & II & 31.64 \\
\hline
\end{tabular}

Note: A total of $87.68 \%$ of the Mission/Swan Valley and Mountains area is represented. $12.32 \%$ is made up of a combination of other habitat types.

\section{Associated Species of Greatest Conservation Needs}

There are a total of 246 terrestrial vertebrate species that are found within the Mission/Swan Valley and Mountains Focus Area. All associations can be found within Table 25.

\section{Amphibians: Boreal Toad}

Birds: Common Loon, Trumpeter Swan, Harlequin Duck, Bald Eagle, Flammulated Owl, Black-backed Woodpecker, and Olive-sided Flycatcher

Mammals: Townsend's Big-eared Bat, Hoary Marmot, Northern Bog Lemming, Gray Wolf, Grizzly Bear, and Lynx 


\section{DRAFT WORKING DOCUMENT DO NOT DUPLICATE}

3238

3239

3240

3241

3242

3243

3244

3245

3246

3247

3248

3249

3250

3251

3252

3253

3254

3255

3256

3257

3258

3259

3260

3261

3262

3263

3264

3265

\section{Conservation Concerns}

- Habitat fragmentation especially as a result of human population growth/development

- Wetland and riparian habitat degradation

- Invasive or exotic plant species

- Water quality degradation

- Altered fire regimes

\section{Conservation Strategies}

- Collaborate with existing conservation efforts in the area

- Conservation of private lands in the valley, including corporate timber lands

\section{References}

The Nature Conservancy. 2004. Canadian Rocky Mountains Ecoregional Assessment. Four volumes, including Report, Appendices, Conservation Area Descriptions \& Maps.

United States Fish \& Wildlife Service. 2004. Conservation Focus Areas of the Great Divide: A vast region encompassing the Upper Missouri, Yellowstone and Upper Columbia watersheds. Publisher: USFWS, Benton Lake Wildlife Refuge, Great Falls, MT. 77pgs. 


\section{Aquatic Conservation Focus Areas in Greatest Need (Tier I)}

\section{Lower Clark Fork (149 River Miles)}

3269

3270

3271

3272

3273

3274

3275

3276

3277

3278

3279

3280

3281

3282

3283

3284

3285

3286

3287

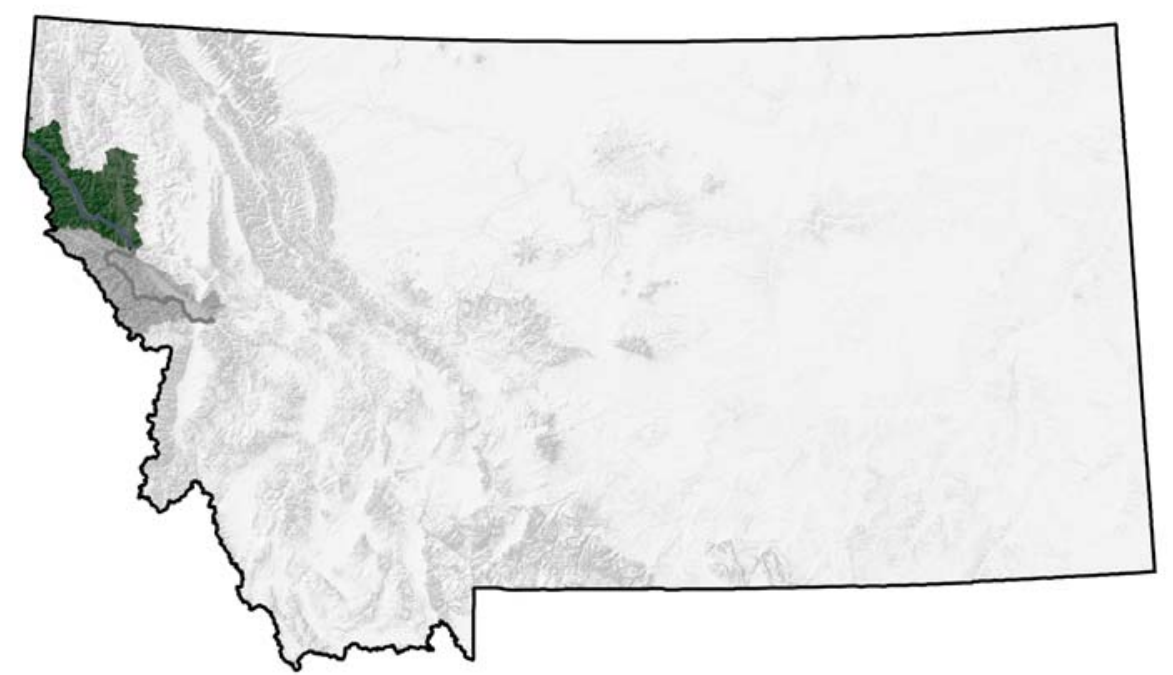

Figure 20. Lower Clark Fork River Focus Area

The lower Clark Fork River originates at the confluence of the Clark Fork River and the Flathead River near the town of Paradise and continues to the Idaho Border. The lower Clark Fork River is bordered on the south by the Bitterroot Mountains and on the north by the Cabinet Mountains. Where the Lower Clark Fork River leaves Montana, it is the largest river in Montana based on mean annual discharge. Average annual precipitation in the Lower Clark Fork drainage is quite high in comparison to other portions of Montana due to a significant maritime influence. Relatively wet and warm winter conditions commonly lead to rain-on-snow events that significantly affect the hydrology of tributaries to the lower Clark Fork River by increasing the frequency of high flow. The primarystem Clark Fork River has been substantially altered by the construction of the Thompson Falls, Noxon Rapids, and Cabinet Gorge hydroelectric projects. These dams currently impound approximately 63 miles of river within Montana.

\section{Associated Habitats}

\begin{tabular}{cccc}
\hline Habitat Type & Habitat Tier & Acres & Miles \\
\hline Intermountain Valley Rivers & II & & 149 \\
Lowland Lakes & III & 812 & \\
Lowland Reservoirs & III & 11637 & \\
Mountain Lakes & III & 3607 & \\
Mountain Streams & I & & 2053 \\
\hline
\end{tabular}




\section{DRAFT WORKING DOCUMENT DO NOT DUPLICATE}

3289

3290

3291

3292

3293

3294

3295

3296

3297

3298

3299

3300

3301

3302

3303

3304

3305

3306

3307

3308

3309

3310

3311

3312

3313

3314

3315

3316

3317

3318

3319

3320

3321

3322

3323

3324

3325

3326

3327

3328

3329

3330

3331

\section{Associated Species of Greatest Conservation Need}

There are a total of 30 aquatic species that are found within the Lower Clark Fork Focus Area. All associations can be found within Table 26.

Fish: Westslope Cutthroat Trout, and Bull Trout

\section{Conservation Concerns}

- Culverts, dams, irrigation diversions or other instream barriers that fully or partially impede fish movement and reduce connectivity of habitat

- Modification and degradation of stream channels caused by various construction or land management practices

- Degradation of riparian vegetation caused by various land management practices. Such activities de-stabilize streambanks, increase sediment inputs, and reduce shading

- Entrainment of juvenile and adult fishes by irrigation diversion or other water intakes

- Alterations of the quantity or timing of streamflows causing dewatering or unnatural flow fluctuations that diminish the quantity or quality of essential habitats

- Unnatural hydrograph and water temperatures associated with presence and operations of large dams, as well as blockage of migratory corridors

- Water quality: warm, turbid water (caused by shallow in-stream ponds/reservoirs, removal of overhanging vegetation, exposure of erodable soils due to unsustainable land management practices, irrigation returns, etc.) is a problem for cool/cold water riverine systems and species

- Water chemistry problems can arise due to municipal discharge, irrigation return water, and other sources

- Improper timber harvesting techniques

- Altered fire regimes

- Non-native fish species

- Mis-identification of fish species by anglers

\section{Conservation Strategies}

- Removal or modification of barriers in a manner that restores fish passage

- Restoration of stream channels or stream banks to a condition that simulates their natural form and function

- Modification of riparian management practices such that riparian vegetation is allowed to recover

- Screening or modification of irrigation diversions or other water intakes in a manner that prevents entrainment of fishes 
3332

3333

3334

3335

3336

3337

3338

3339

3340

3341

3342

3343

3344

3345
- Implementation of various water conservation or flow management practices that restore essential habitats and simulate the natural hydrograph

- Provide passage over dams to ensure full migratory movement

- Conservation easements

- Angler education on fish species identification

\section{References}

The Nature Conservancy. 2004. Canadian Rocky Mountains Ecoregional Assessment. Four volumes including Report, Appendices, Conservation Area Descriptions \& Maps. 
3347

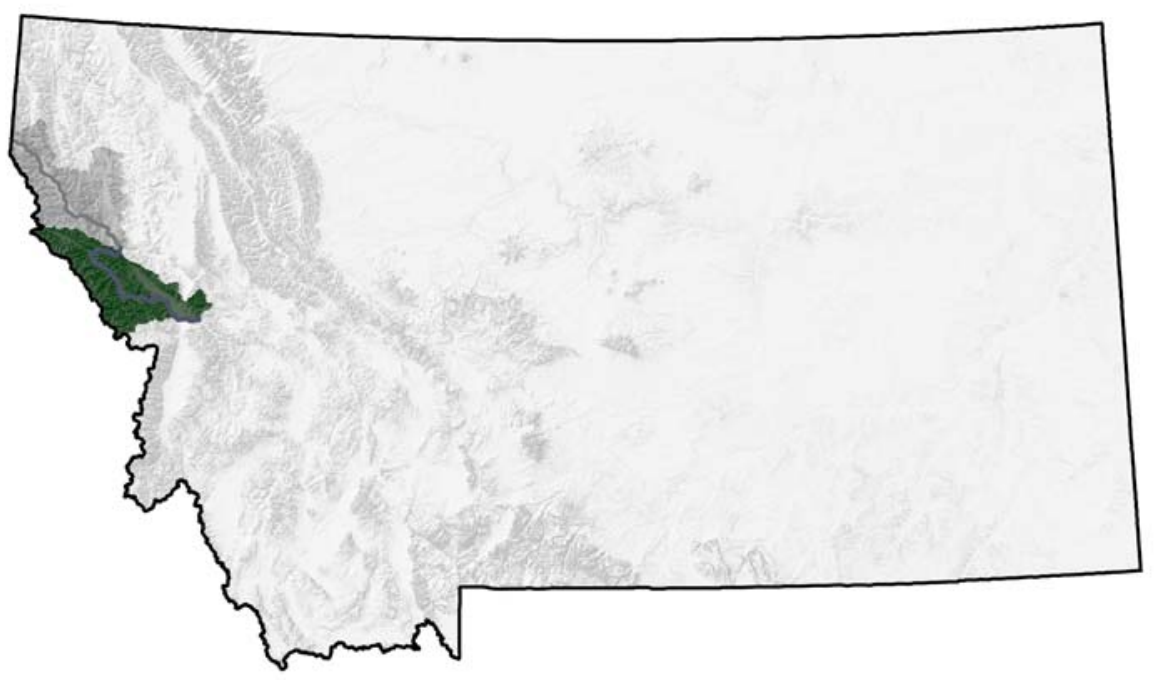

\section{Figure 21. Middle Clark Fork Focus Area}

The Middle Clark Fork River extends about 115 river miles from Milltown Dam in Bonner, Montana to its confluence with the Flathead River and is entirely free flowing. The milltown dam is scheduled to be removed in the near future. Its drainage is mountainous and covered with the large forested tracts of the Lolo National Forest and private timberlands, broken by grazing and cropland areas in the lower valleys down to the Thompson Falls Dam. Through the broad Missoula Valley, the middle Clark Fork is a sinuous river with frequent side channels, wide floodplains and cottonwood-willow bottoms. The river then transitions into the Alberton Gorge whitewater area and becomes an entrenched single channel as it proceeds toward Thompson Falls. Major tributary systems such as Rattlesnake Creek and Fish Creek drain premier roadless wildlands including the Rattlesnake Wilderness and proposed Great Burn Wilderness along the Montana-Idaho divide. This river supports an excellent coldwater trout fishery including fluvial populations of native westslope cutthroat trout and bull trout. Because the middle Clark Fork receives the waters of the Blackfoot, Bitterroot and upper Clark Fork basins, it is known as a steady and productive system that supports a consistent fishery.

\section{Associated Habitats}

\begin{tabular}{cccc}
\hline Habitat Type & Habitat Tier & Acres & Miles \\
\hline Intermountain Valley Rivers & II & & 119 \\
Intermountain Valley Streams & II & & 113 \\
Lowland Lakes & III & 546 & \\
Lowland Reservoirs & III & 9 & \\
\hline
\end{tabular}


DRAFT WORKING DOCUMENT DO NOT DUPLICATE

\begin{tabular}{cccc}
\hline Mountain Lakes & III & 1168 & \\
Mountain Streams & I & & 2080 \\
\hline
\end{tabular}

3370

3371

3372

3373

3374

3375

3376

3377

3378

3379

3380

3381

3382

3383

3384

3385

3386

3387

3388

3389

3390

3391

3392

3393

3394

3395

3396

3397

3398

3399

3400

3401

3402

3403

3404

3405

3406

3407

3408

3409

3410

3411

\section{Associated Species of Greatest Conservation Need}

There are a total of 22 aquatic species that are found within the Middle Clark Fork Focus Area. All associations can be found within Table 27.

Fish: Westslope Cutthroat Trout, and Bull Trout

\section{Conservation Concerns}

- Residential development impacts that destabalize riparian areas

- Rip-rap and other bank stabilization work

- Invasive non-native fish species

- Whirling disease

- Disruption of natural disturbance processes or hydrologic regimes

- Culverts, dams, irrigation diversions or other instream barriers that fully or partially impede fish movement and reduce connectivity of habitat

- Modification and degradation of stream channels caused by various construction or land management practices

- Degradation of riparian vegetation caused by various land management practices. Such activities de-stabilize streambanks, increase sediment inputs, and reduce shading

- Entrainment of juvenile and adult fishes by irrigation diversion or other water intakes

- Alterations of the quantity or timing of streamflows causing dewatering or unnatural flow fluctuations that diminish the quantity or quality of essential habitats

- Unnatural hydrograph and water temperatures associated with presence and operations of large dams, as well as blockage of migratory corridors

- Water chemistry problems that arise due to municipal discharge, irrigation return water, and other sources

- Altered fire regime

- Unsustainable domestic livestock grazine and timber harvest practices

- Degradation of habitat by unmanaged recreation use

\section{Conservation Strategies}

- Removal or modification of barriers in a manner that restores fish passage

- Restoration of stream channels or stream banks to a condition that simulates their natural form and function

- Modification of riparian management practices such that riparian vegetation is allowed to recover 


\section{DRAFT WORKING DOCUMENT DO NOT DUPLICATE}

3412

3413

3414

3415

3416

3417

3418

3419

3420

3421

3422

3423

3424

3425

3426

3427

3428

3429

3430

3431

3432

3433

3434

- Screening or modification of irrigation diversions or other water intakes in a manner that prevents entrainment of fishes

- Implementation of various water conservation or flow management practices that restore essential habitats and simulate the natural hydrograph

- To the extent feasible, operate dams to mimic a more natural hydrograph in the primarystem rivers, and ensure more natural thermal regime. Provide passage over dams to ensure full migratory movement

- Work with USFWS Critical Carnivore Linkage Project

- Conservation easements and cooperative efforts to address human population growth and related impacts

\section{References}

The Nature Conservancy. 2004. Canadian Rocky Mountains Ecoregional Assessment. Four volumes including Report, Appendices, Conservation Area Descriptions \& Maps.

United States Fish \& Wildlife Service. 2004. Conservation Focus Areas of the Great Divide: A vast region encompassing the Upper Missouri, Yellowstone and Upper Columbia watersheds. Publisher: USFWS, Benton Lake Wildlife Refuge, Great Falls, MT. 77pgs. 
Plains Grasslands and Plains Forest Ecotype

3436

3437

3438

3439

3440

3441

3442

3443

3444

3445

3446

3447

3448

3449

3450

3451

3452

3453

3454

3455

3456

3457

3458

3459

3460

3461

3462

3463

3464

3465

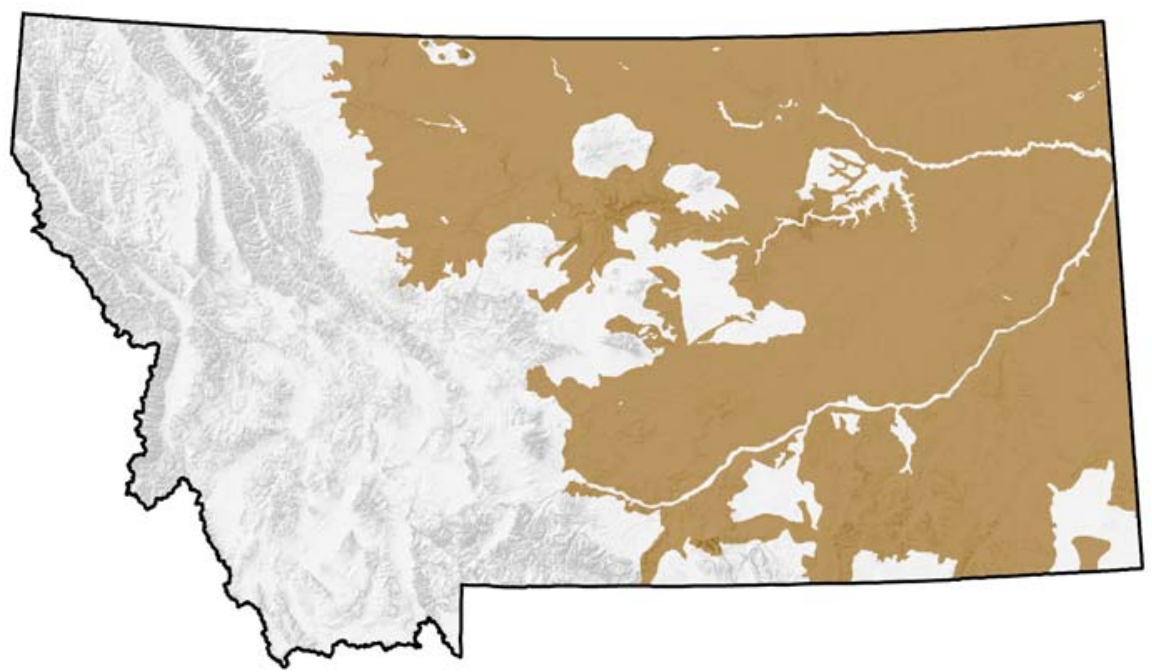

Figure 22. Plains Grassland and Plains Forest Ecotype

Montana's high eastern plains, part of America's Great Plains, are generally found on high, rolling land and on some scattered hills and wide river valleys. Some of those rivers, particularly the warm-water sections of the Yellowstone and Missouri in eastern Montana, harbor the most diverse communities of fish in the state. Its a rather harsh environment, with short, hot summers and long, cold winters that bring fewer than 15 inches of precipitation a year. In this environment, the protection offered by woody draws and the unique badlands or "breaks" provide important pockets of habitat and protection for wildlife.

In addition, Montana's unique prairie forests found in the blistered "island" mountain ranges east of the Rocky Mountains, provide a higher elevation relief where precipitation is sufficient enough to create closed-canopy forest of Great Plains ponderosa pine and various hardwoods. Although these forests are not islands in the true sense, they are a unique part of the plains landscape.

\section{Grassland}

\section{Landscape Characteristics}

The plains grassland ecotype includes 43,918,691 acres and represents $46.7 \%$ of Montana. Elevations at the western and southern edges of the plains grassland ecotype range between 3500 and 4000 feet. Elevations decrease gradually toward the northeast where the lowest point, 1900 feet, as the Missouri exits Montana, is reached. Broad areas less than 2500 feet lie near the lower Missouri and Yellowstone. For the most part the land is flat or rolling. Steeper dissected topography is found in various badland areas of the east and southeast and in river breaks areas near the Missouri and Yellowstone and some major 


\section{DRAFT WORKING DOCUMENT DO NOT DUPLICATE}

3466

3467

3468

3469

3470

3471

3472

3473

3474

3475

3476

3477

3478

3479

3480

3481

3482

3483

3484

3485

3486

3487

3488

3489

3490

3491

3492

3493

3494

3495

3496

3497

3498

3499

3500

3501

3502

3503

3504

3505

3506

3507

3508

3509

3510

3511 tributaries. Two major rivers, the Missouri and the Yellowstone, cross the entire ecotype. Flowing into these rivers are various large tributaries including the Milk, Marias, Powder, Tongue, Bighorn, and Musselshell rivers, all crossing many miles of the plains grassland. Most of the area north of the Missouri, and a little of it to the south, was overridden by the continental glaciers, creating topography that is somewhat smoother and flatter than the plains to the south. Exceptions to this are areas near some of the major rivers where erosion following glaciation has dissected the land. Glaciated plains tend to have a relatively large number of small, poorly drained depressions, some of which form potholes or small lakes.

\section{Soils}

All soils in the plains grassland ecotype are classified as cool (annual average temperatures ranging between $32^{\circ}$ and $47^{\circ} \mathrm{F}$.). Much of the soil in the glaciated plains (approximately north of the Missouri River) part of the ecotype contains large amounts of salt and may also be alkaline. Such soils may be medium textured with distinct topsoil horizons or they may be heavily clay soils without horizons. The second largest category of soils in the ecotype comprises those that have light colored topsoil layers and are not particularly saline or alkaline. These soils may or not have lime layers. Places with somewhat higher effective precipitation (due to greater precipitation and or/ lower evaporation) have dark, well-developed topsoil horizons with a distinct clay layer just beneath that. These tend to be the most fertile and most easily tilled soils in the ecotype.

\section{Climate}

The climate of the plains grassland ecotype can be generally characterized as semi-arid, cold in winter, warm in summer, and highly variable compared to the remainder of Montana. During much of the winter, Canadian high pressure pushes cold air south over the region. This type of weather pattern produces extremely low temperatures that may persist for days or weeks at a time, as well as low precipitation since moisture producing weather systems are subsequently routed south. During the summer, low pressure caused by high temperatures may draw moisture in from the Gulf of Mexico. The area is mostly outside of the primary track of the Pacific moisture-producing storm except for a period during late spring to early summer.

Mean annual temperatures range from $38^{\circ} \mathrm{F}$. in some areas in the extreme northeast to $48^{\circ} \mathrm{F}$. at some places south of the Yellowstone River. The mean for the ecotype is somewhere around $43^{\circ}$ to $44^{\circ} \mathrm{F}$. Mean January temperatures vary from $2^{0} \mathrm{~F}$. in the northeast to $21^{\circ} \mathrm{F}$. in the south. Mean July temperatures range from $63^{\circ}$ to $72^{\circ} \mathrm{F}$. The highest temperatures are along the Yellowstone River whereas the lowest are in the northwest where the ecotype abuts the intermountain /foothill ecotype. Minimum yearly temperatures upon which plant hardiness zones are based, range from $-38^{\circ} \mathrm{F}$. in the northeast to $-24^{0} \mathrm{~F}$. in the south. The boundary between hardiness zones 3 and 4 (mean minimum yearly 


\section{DRAFT WORKING DOCUMENT DO NOT DUPLICATE}

3512 temperatures in the -30s and -20s respectively) follows a line going 3513 approximately from the southeastern corner of Montana to the Sweetgrass Hills. 3514 There is no zone 5 in this ecotype. Mean annual maximum temperatures range 3515 from $104^{\circ} \mathrm{F}$. along the lower Yellowstone River to $95^{\circ} \mathrm{F}$. at the highest elevations 3516 of the ecotype in the northwest.

3517

3518 Average annual precipitation in the ecotype ranges from 10 inches in a wide 3519 band along most of the highline and a southcentral area to 16 inches in some 3520 3521 scattered eastern and southern areas. The average for the ecotype is from 12 to 14 inches. Except for some widely scattered isolated areas, the eastern portion of the ecotype tends to receive a greater proportion of its precipitation in the April 1 to July 31 (growing season) period than the west. Except for an area in the northwest, western areas near the mountains receive less than 55 percent of the precipitation in the April to August period, while most areas in the east receive over 60 percent.

Snowfall ranges from 21 to 40 inches throughout most of the area. The higher snowfalls occur in the parts of the ecotype closest to the mountains. A few isolated areas in the extreme east get less than 20 inches of snow per year. The mean number of days per year when there is at least 1 inch of snow on the ground increases from the western and southern edges of the ecotype to the northeast. The areas with the least number of days snow cover are in the Chinook zone where extremely strong and persistent winds during the winter either sublimate or melt the snow. Mean wind speeds vary from 11 to 13 miles/hour over most of the ecotype. Days with snow cover range from less than 60 to over 120 across the ecotype.

\section{Anthropogenic}

The plains grassland ecotype encompasses the largest area in Montana.

Recreational activities include hunting, fishing, and snowmobiling. Major industry includes ranching and farming, which encompass some of the largest wheat and cattle yields in the country. The breakdown of landowner stewardship for plains grassland ecotype is as follows:
U.S. Federal Agencies:
$6,081,573$ acres, which include
BLM:
$5,083,576$ acres
USFS:
142,889 acres
USFWS:
716,050 acres
NPS:
556 acres
State Agencies:
$2,886,994$ acres
Tribal Lands:
2,532,892 acres
Private:
$32,190,791$ acres
City \& County:
3,027 acres 


\section{DRAFT WORKING DOCUMENT DO NOT DUPLICATE}

3558

3559

3560

3561

3562

3563

3564

3565

3566

3567

3568

3569

3570

3571

3572

3573

3574

3575

3576

3577

3578

3579

3580

3581

3582

3583

3584

3585

3586

3587

3588

3589

3590

3591

3592

3593

3594

3595

3596

3597

3598

3599

3600

3601

3602

3603

\section{Vegetation}

On the semi-arid plains grasslands, vegetation communities and soil characteristics are strongly associated. The rather uniform climatic conditions across the area dictate that differences in plant community composition are primaryly due to the variations in available water holding capacity of the soils. Soils are organized into categories that reflect annual precipitation as well as water holding capacity. These categories, called ecological sites, are grouped on the basis of parameters such as texture, slope topographic position, and chemical characteristics. Most of the ecotype is within the 10 to 14 inch precipitation zone and therefore, textural/topographic/chemical characteristics are the primary regulators of plant community composition.

Within the ecotype there is a relatively small number of grass species that occur as dominants throughout the area. Some of these are found in various amounts in nearly all the communities, others are more specialized and occur only under certain conditions. Other major changes in the grassland communities occur with human management because of differing responses of species to management treatments. Other than dry land farming, that totally removes native vegetation, unsustainable livestock grazing impacts the native species.

Throughout the ecotype can be found western wheatgrass (Agropyron smithii), needle-and-thread (Stipa comata), bluebunch wheatgrass (Agropyron spicatum), Blue grama (Bouteloua gracilis), prairie junegrass (Koeleria macrantha), green needlegrass (Stipa viridula), thickspike wheatgrass (Agropyron dasystachyum), fringed sage (Artemisia frigida), and dense clubmoss (Selaginella densa). Other widespread species common in certain conditions include little bluestem (Andropogon scoparius), prairie sandreed (Calamovilfa longifolia), silver sage (Artemisia cana), sun-sedge (Carex stenophylla), and threadleaf sedge (Carex filifolia). Most other grasses and grass like plants are only minor community components or are dominants in very restricted areas (Ross and hunter 1976).

In terms of biomass, forbs in plains grassland communities tend to be highly subordinate in most conditions. Certain subshrubs, including fringed sage, broom snakeweed (Gutierrezia sarothrae), and prickly pear (Opuntia polyacantha) may become dominant members of some communities following overgrazing. Varying amounts of shrubs occur throughout the plains grasslands, however, the areas where shrubs contribute a large and consistent proportion of the biomass have been included in the shrub/grassland ecotype.

Patterns of species dispersal, or chorology, and precipitation distribution influence the distribution of some species throughout the ecotype. The bluestems (warm season grasses) originated farther east in the plains region of the U.S. and generally do not penetrate much beyond the eastern third of Montana with its more continental pattern of precipitation distribution. Bluebunch wheatgrass originated in the Intermountain region of the U.S. (Barker and 


\section{DRAFT WORKING DOCUMENT DO NOT DUPLICATE}

3604 Whitman 1988) where spring and winter are wet and summer dry. Although it is

3605

3606

3607

3608

3609

3610

3611

3612

3613

3614

3615

3616

3617

3618

3619

3620

3621

3622

3623

3624

3625

3626

3627

3628

3629

3630

3631

3632

3633

3634

3635

3636

3637

3638

3639

3640

3641

3642

3643

3644

3645

3646

3647

3648 abundant on most sites in the western part of the ecotype, it becomes

progressively less abundant and more restricted toward the east. Western

wheatgrass, another important plains species, decreases toward the west. The plains grassland ecotype is a zone where mixed prairie species meet some of the Pacific/intermountain bunchgrasses, although the area is primarily dominated by the former (Wright and Wright 1948).

Coarse textured sandy soils ( $2 \%$ of the ecotype) have not had time to form soil cover. Widespread species favored by coarse-textured soils include needle-andthread, little bluestem, silver sage, and threadleaf sedge (Ross and Hunter 1976) (Hansen et al. 1988). Some other species whose distribution in Montana is mostly restricted to, rather than just favored by sandy soils, include sand and big bluestems (Andropogon hallii, A. gerardi), prairie sandreed, Indian ricegrass (Oryzopsis hymenoides), sideoats grama (Bouteloua curtipendula), and Yucca glauca.

Medium textured soils, described as silty, occupy the greatest (over 70\%) range within the ecotype. Silty soils have a good combination of relatively high water holding capacity as well as high permeability and infiltration rates. Potential natural communities in medium textured soils in the 10 to 14 inch precipitation zone are dominated by western wheatgrass and needle-and-thread. However, blue grama can become relatively abundant enough during drought periods to become dominant on many sites. This suggests that plant communities in the northern Great Plains with their extreme and variable climate are not static but vary greatly over time. Culwell et al. (1986) sampled grassland in extreme eastern Montana dominated by western wheatgrass, blue grama and threadleaf sedge. Western wheatgrass and green needlegrass constitute most coverage with run-in moisture such as swales and footslopes. Bluebunch wheatgrass is a dominant in western areas with western wheatgrass and needle-and-thread becoming much less abundant. Subdominant grasses include prairie junegrass, blue grama, sun sedge, and sometimes thickspike wheatgrass. Plains reedgrass (Calamagrostis montanensis) and plains muhly (Muhlenbergia cuspidate) may be locally dominant in some western areas. Little bluestem is locally dominant in some areas mostly in the east. The most important forb genera include Lomatium and Astragalus. In addition to the common species of the rest of the plains grassland, the areas receiving between 15 and 19 inches of annual precipitation allows the establishment of some species for which the surrounding areas are too dry. These include big bluestem (Andropogon gerardii) and Idaho fescue (Festuca idahoensis). Some plant communities on medium textured soils have been altered by cultivation or long periods of heavy grazing. Heavy grazing increases blue grama, fringed sage, clubmoss, prairie junegrass, and cheatgrass (Bromus tectorum) at the expense of wheatgrass and sometimes needle-andthread. 


\section{DRAFT WORKING DOCUMENT DO NOT DUPLICATE}

3649 Fine textured soil constitutes a little over $18 \%$ of the ecotype and is less

3650

3651

3652

3653

3654

3655

3656

3657

3658

3659

3660

3661

3662

3663

3664

3665

3666

3667

3668

3669

3670

3671

3672

3673

3674

3675

3676

3677

3678

3679

3680

3681

3682

3683

3684

3685

3686

3687

3688

3689

3690

3691

3692

3693 favorable to species like needle-and-thread, prairie junegrass, and blue grama, although they will likely persist if adequate topsoil exists and is maintained. The finest textured soils with little or no topsoil support mostly western wheatgrass, green needlegrass, thickspike wheatgrass, and bluebunch wheatgrass in central and western parts of the ecotype (Ross and Hunter 1976). The heaviest clay soils are also usually saline and possible alkaline. Species not adapted to such conditions are prevented from establishing and are replaced by facultative or obligate halophytes such as western wheatgrass, saltgrass (Distichlis stricta), green needlegrass, Nuttall saltbush (Atriplex nuttallii) and greasewood (Sacrobatus vermiculatus). In low-lying areas, species favored by periodic flooding occur. These include Nuttall alkaligrass (Puccinnellia nuttalliana) and alkali cordgrass (Spartina gracilis). Areas of fine textured soils in the plains that receive greater (15 to 19 inches) precipitation than the rest of the area share many of the dominant species as the adjacent foothill regions as well as those of the rest of the plains ecotype. These foothill species include bluebunch wheatgrass and Idaho fescue. Big bluestem occurs in the easternmost areas.

Topographically complex areas in the plains grassland ecotype include the river breaks and badlands areas and are difficult to categorize vegetationally. Bluebunch wheatgrass and western wheatgrass tend to be dominant grasses in most areas. Little bluestem, prairie sand reed, needle-and-thread and green needle grass may be locally abundant. Shrubs and conifers may be locally important, especially in the breaks. Common shrubs include big sagebrush (Artemisia tridentate ssp. wyomingensis), rubber rabbitbrush (Chrysothamnus nauseosus), aromatic (skunkbush) sumac (Rhus aromatica), snowberry (Symphoricarpus occidentalis), and Nuttalll saltbush. Draws in the extreme eastern part of the ecotype provide habitat for certain woody species not normally found elsewhere except in the Midwest. The tree most commonly encountered is green ash (Fraxinus pennsylvanica). Quaking aspen (Populus tremuloides) is occasionally found and bur oak (Quercus macrocarpa) occurs in drainages of the extreme southeast (Hansen et al. 1988). Chokecherry and snowberry are shrubs commonly found in these situations. Relatively small timber stands are found scattered throughout most of the breaks area. Both ponderosa pine (Pinus ponderosa) and Douglas-fir (Pseudotsuga menziessii) occur in these stands as far east as $108.5^{\circ}$ longitude; east of this point Douglasfir drops out. The occurrence of these conifer species in the breaks is due to topoedaphic conditions since the area does not receive any more precipitation than the surrounding plains. A typical timber stand in the breaks forms a closed canopy consisting of ponderosa pine and Douglas-fir. The understory shrub component is comprised of some or all of the following; snowberry, aromatic sumac, chockecherry (Prunus virginiana), rose (Rosa nutkana), and Rocky Mountain juniper (Juniperus scopulorum). Frequent stand replacement fires in the area result in communities comprising these shrub species but minus tree overstory. Forbs and grasses include western yarrow (Achillea millefolium), aster 


\section{DRAFT WORKING DOCUMENT DO NOT DUPLICATE}

3694 (Aster falcatus), rose pussytoes (Antennaria microphylla), bluebunch wheatgrass,

3695

3696

3697

3698

3699

3700

3701

3702

3703

3704

3705

3706

3707

3708

3709

3710

3711

3712

3713

3714

3715

3716

3717

3718

3719

3720

3721

3722

3723

3724

3725

3726

3727

3728

3729

3730

3731

3732

3733

3734

3735

3736

3737

3738

3739

and plains muhly (Muhlenbergia cuspidate).

\section{Forest}

\section{Landscape Characteristics}

The plains forest ecotype includes 3,266,564 acres and represents $3.5 \%$ of Montana. Forested areas in the plains generally occupy higher areas that represent erosional remnants of resistant rock layers, particularly the Arikaree Formation near Ekalaka. These rock layers are younger than the layers supporting the surrounding grasslands (Ross et. al. 1955). The stands of Plains Forest are located on hilly regions, mostly in the southern half of the plains part of Montana. These hilly regions may be enough higher than surrounding grasslands, such that there is increased annual precipitation capable of supporting forests. Such hilly topography may also create topoedaphic conditions suitable for the establishment of tree cover. The difference in elevation between the forested hills and the adjacent grasslands is not great, generally in the neighborhood of a few hundred to at most two thousand feet. Elevation differences much greater than this would generally result in a montane forest site. The forests of the Chalk Buttes, Longpines, and area near Hammond result from hills and/or buttes rising several hundred feet above base elevations of about 3200 to 3500 feet. The large forested area just east of Ashland occupies hills rising from low elevations of about 3000 feet near the Tongue River to approximately 4400 feet. The extensive forested region extending from near Custer, through Lame Deer to Birney ranges in elevation from 4000 to 5000 feet. The lowest elevation of the Bull Mountains forested area is roughly 3000 feet at points along the Musselshell River. Highest elevations are somewhat over 4000 feet. Most of the other scattered plains forest stands are due to elevation rise of a few to several hundred feet (i.e., east of Miles City, south of Rosebud, north of Rapeljie), topoedaphic effects (i.e., along the Yellowstone River near Columbus), or proximity to mountain areas (i.e., Longpines, Chalk Buttes).

\section{Soils}

The largest single category (80\%) of soils occurring within the plains forest ecotype is described as having a relatively light-colored, thin topsoil horizon. Lime layers may be present if the parent material is calcareous. Great Groups represented include camborthids and haplargids (Montagne et al. 1982). Soils in areas with more humid regimes (14\%) have thicker, darker, topsoil and Clay 'B' horizons. Major great groups are argiborolls, argixerolls, haploborolls, and haplargids. On the wettest sites (2.5\%), soil characteristics of montane forests are found. These tend to be acid with a duff layer (partially decomposed leaves, etc.) on top and a redish-brown clay layer beneath that. The remaining major category of soils is the one where shale is the parent material. These clay soils 


\section{DRAFT WORKING DOCUMENT DO NOT DUPLICATE}

3740 great groups include torriorthents, camborthids, ustorthents, natrargids, and

3741 paleargids.

3742

3743

3744

3745

3746

3747

3748

3749

3750

3751

3752

\section{Climate}

The overall climate of the plains forest ecotype is determined by the same factors as the plains grassland, except that elevations of this ecotype are higher. These higher elevations have the effect of lowering temperatures and increasing yearly precipitation, allowing the establishment of forest.

3753

Mean annual temperatures in the areas of plains forests generally are about $1^{0}$ to $2^{0} \mathrm{~F}$. lower than the adjacent grasslands. In most cases this means temperatures from $43^{\circ}$ to $44^{\circ} \mathrm{F}$. Since most of these are in the southern or western parts of the state, their annual temperatures are several degrees higher

3754

3755

3756

3757

3758

3759

3760 than at lower elevations in the northeast. January temperatures generally are $1^{0}$ to $2^{0}$ lower than the surrounding grasslands, while July temperatures may be $3^{0}$ to $4^{0}$ lower. This suggests that the slight differences in elevation have more effect on summer temperatures than winter temperatures.

3761

3762

3763

3764

3765

3766

3767

3768

Total annual precipitation over the entire ecotype averages approximately 14.5 inches. Some of the wettest areas receive over 20 inches annually precipitation. There does not appear to be any difference in the proportion of precipitation received during the growing season as compared to the adjacent lower elevation grasslands. Depending on exact location, May or June is the wettest month of the year and February is the driest.

3769

3770

3771

The average frost-free season is typically shorter than the adjacent grasslands due to higher elevations and the reduction of overall temperatures. The frost free seasons range from 90 to 115 days.

\section{Anthropogenic}

3773

3774

3775

3776

3777

3778

3779

3780

3781

3782

3783

3784

The plains forest ecotype is the smallest in land mass of the five major ecotype types. Recreational opportunities abound in these large pockets of forest. Activities include hiking, biking, snowmobiling, hunting, cross-country skiing, wildlife watching. The primary industries in the area are livestock grazing, mining and some timber extraction. The breakdown of landowner stewardship for plains forest ecotype is as follows:
U.S. Federal Agencies:
547,647 acres, which include
BLM:
156,850 acres
USFS:
390,797 acres
State Agencies:
155,059 acres
Tribal Lands:
285,716 acres
Private:
$2,222,219$ acres

3785 


\section{DRAFT WORKING DOCUMENT DO NOT DUPLICATE}

3786

3787

3788

3789

3790

3791

3792

3793

3794

3795

3796

3797

3798

3799

3800

3801

3802

3803

3804

3805

3806

3807

3808

3809

3810

3811

3812

3813

3814

3815

3816

\section{Vegetation}

The Plains Forest Ecotype occupies 4610 square miles. It was intended to include only areas with relatively large contiguous tracts of potential forestland in this ecotype. The Missouri breaks woodlands were included with the plains grassland ecotype described earlier in this document. Because the plains forest areas are somewhat higher in elevation than the surrounding plains grassland, precipitation conditions (a combination of higher total amounts plus a favorable growing season wet moisture distribution) favor the establishment of a closed canopy forest.

Great Plains ponderosa pine (Pinus ponderosa var. scopulorum) is the sole conifer forming the plains forests, although various hardwood tree species (i.e., American elm, Ulmus americana; green ash, Fraxinus pennsylvanica, American plum, Prunus americana, and bur oak, Quercus macrocarpa) occur along some of the draws and ravines. In contrast to the ponderosa pine west of the Divide, this variety tends to be shorter. Maximum tree heights range from 35 to 60 feet in dry situations and as much as 95 feet where there is more moisture (Arno 1979). Microclimatic conditions may be favorable in some places for Douglas-fir, Pseudotsuga menziessii, to establish, but apparently seed sources are too distant. The drier forests tend to be relatively open and support mostly grass understories. Grasses commonly found in these situations include: little bluestem (Andropogon scoparius), big bluestem (Andropogon gerardii), bluebunch wheatgrass (Agropyron spicatum), blue grama (Bouteloua gracilis), and threadleaf sedge (Carex filifolia). Moist forests contain understory species common to montane forests to the west. Species include: Canada buffaloberry (Shepherdia canadensis), kinnikinnik (Arctostaphylos uvaursi), Oregon grape (Mahonia repens), twinflower (Linnaea borealis), heartleaf arnica (Arnica cordifolia), fairy bells (Disporum trachycarpum), wintergreen (Pyrola secunda) and false Solomon's seal (Smilacina stellata). 
3820

3821

3822

3823

3824

3825

3826

3827

3828

3829

3830

3831

3832

3833

3834

3835

3836

3837

3838

3839

3840

3841

3842

3843

3844

3845

3846

3847

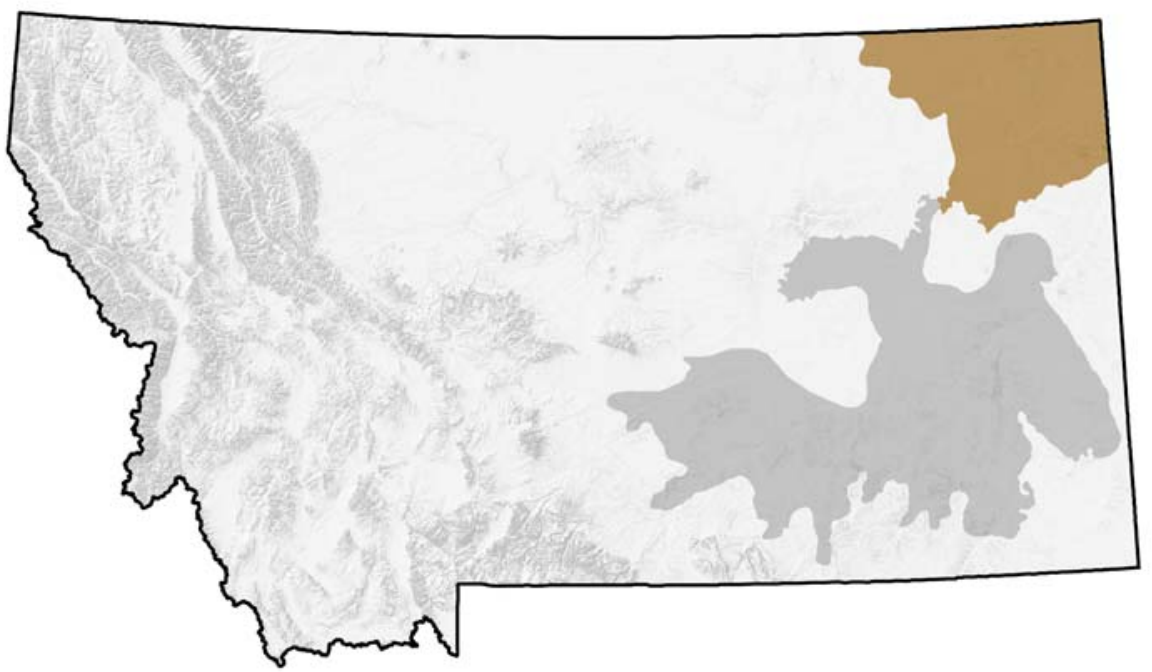

Figure 23. Missouri Coteau Focus Area

This area represents part of the large continental prairie grassland and pothole habitat that occurs in eastern Montana. This portion of Montana's prairie pothole country contains the highest density of natural wetlands. In most years, springtime finds this area dotted with small wetlands. These shallow wetlands shine amongst the small glacial hilltops that are covered with short- to mid-grass prairie species. Several wildlife and vegetative species in this area are unique, as this is the main portion of Montana that is considered to be part of this North American duck factory, the other being areas north of Chinook.

\section{Landscape Characteristics}

This area represents hummocky plains, outwash and stream terraces, fans, and floodplains that formed in thin glacial till and river sediments that lie over shale, siltstone, and sandstone. Moraines, kames, kettles, and small lakes also occur. Elevations range from 1,650 to 3,050 feet. Drainage density is moderate. Mean annual precipitation ranges from 12 to 15 inches, about 20 percent falling as snow. The soil temperature and moisture regimes are frigid and udic. Primary natural disturbances include elongated droughts, insects, and severe storms. Land use is predominantly wheat farming and range and pasture lands. The breakdown for land stewardship in the Missouri Coteau is as follows:
U.S. Federal Agencies:
147,337 acres, which include:
BLM:
117,375 acres
USFWS:
29,900 acres
NPS:
62 acres 
3848 State Agencies:

3849 Tribal Lands:

3850 Private:

3851 County \& City:

3852

3853

3854

Associated Habitats

386,782 acres

691,154 acres

$4,040,173$ acres

62 acres

\begin{tabular}{ccc}
\hline Habitat & Habitat Tier & Percentage of Area \\
\hline Moderate/ High Cover Grasslands & I & 3.57 \\
Agricultural Lands - Irrigated & III & 5.39 \\
Wetland \& Riparian & I & 6.13 \\
Altered Herbaceous & II & 12.69 \\
Low/ Moderate Cover Grasslands & I & 27.71 \\
Agricultural Lands - Dry & III & 36.19 \\
\hline
\end{tabular}

3855

3856

3857

3858

3859

3860

3861

3862

3863

3864

3865

3866

3867

3868

3869

3870

3871

3872

3873

3874

3875

3876

3877

3878

3879

3880

3881

3882

3883

3884

3885

3886

Note: A total of $91.69 \%$ of the Missouri Coteau area is represented. $8.31 \%$ is made up of a combination of other habitat types.

\section{Associated Species of Greatest Conservation Need}

There are a total of 325 terrestrial vertebrate species that are found within the Missouri Coteau Focus Area. All associations can be found within Table 28.

Amphibians: Northern Leopard Frog

Birds: Common Loon, Trumpeter Swan, Bald Eagle, Yellow Rail, Whooping Crane, Piping Plover, Long-billed Curlew, Least Tern, Black Tern, Owl

Burrowing, Sedge Wren, and Nelson's Sharp-tailed Sparrow

Mammals: Townsend's Big-eared Bat, and Meadow Jumping Mouse

Reptiles: Snapping Turtle, Spiny Softshell, Western Hognose Snake, Milk Snake, and Smooth Green Snake

\section{Conservation Concerns}

- Loss of habitat due to conversion of native prairie to small grain crops

- Wetland drainage

- Invasive or exotic plant species

- Disruption of natural disturbance processes or hydrologic regimes

- Oil drilling and exploration activities

\section{Conservation Strategies}

- Government and private conservation programs/activities that encourage and support private land stewardship 
- Policy-based approaches that encourage the conservation of natural communities, rather than support their conversion

- Increased cooperative efforts to maintain ecological features or processes on public lands, private and tribal

- Cooperative efforts to reduce the abundance of exotic species

\section{References}

The Nature Conservancy. 2005. Unpublished Report.

The Nature Conservancy. 1999. Ecoregional Conservation in the Northern Great Plains Steppe. Northern Great Plains Steppe Ecoregional Planning Team. 76 pgs.

United States Fish \& Wildlife Service. 2004. Conservation Focus Areas of the Great Divide: A vast region encompassing the Upper Missouri, Yellowstone and Upper Columbia watersheds. Publisher: USFWS, Benton Lake Wildlife Refuge, Great Falls, MT. 77pgs. 
3908

3911 3912 3913 3914 3915 3916 3917 3918 3919 3920 3921 3922 3923 3924 3925 3926 3927 3928

3929

3930 3931 3932 3933 3934 3935 3936 3937

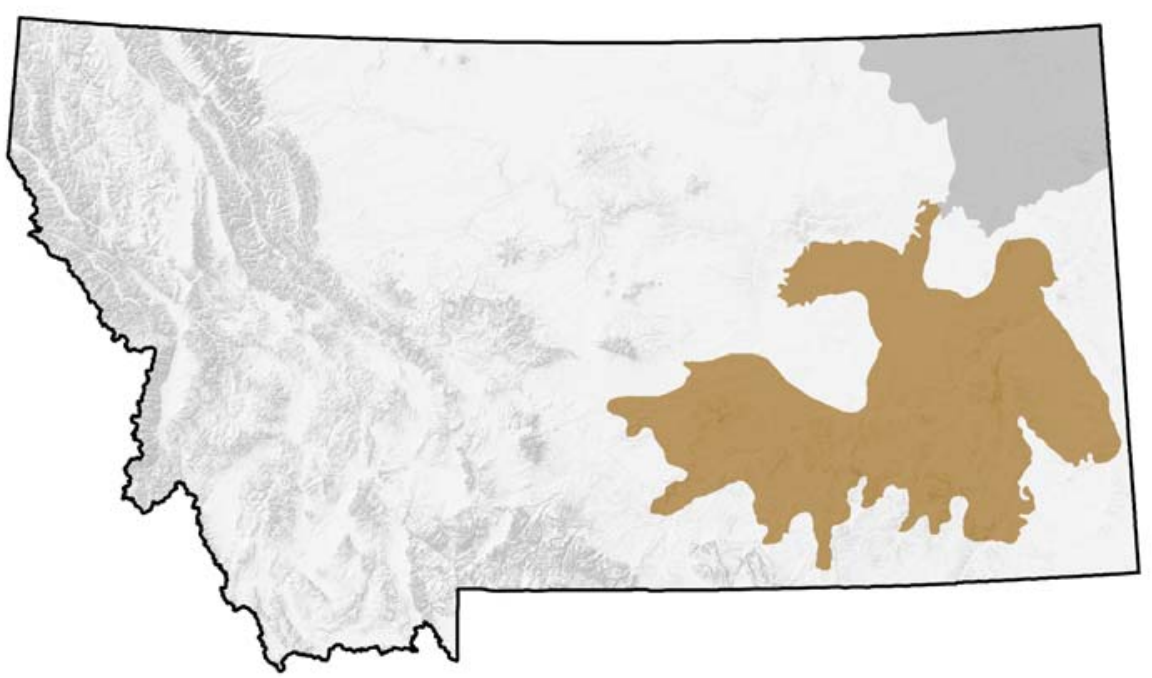

Figure 24. Montana Sedimentary Plains Focus Area

This gently sloping to rolling area contains scattered buttes and Bad Lands. It sits on heavy clay soils and consists of mostly dry shrub lands and mixed grass prairies. It receives very little precipitation and is interspersed with woody draws that contain ponderosa pine, cedar and snowberry. Agricultural practices can be found throughout the area that also supports many dry land native wildlife species such as antelope, mule deer and sage-grouse.

\section{Landscape Characteristics}

This area includes plains and hills formed in residuum and alluvium from shale and sandstone. Some lacustrine sediments also occur. Elevations range from 2,100 to 4,150 feet. Drainage density is moderate. Mean annual precipitation ranges from 10 to 14 inches, about 30 percent falling as snow. Soil temperature and moisture regimes are frigid and ardic ustic. The primary natural disturbance is fire and drought. Land use is predominantly livestock grazing with a small amount of dryland farming. The breakdown for land stewardship in the Montana Sedimentary Plains is as follows:

$\begin{array}{cl}\text { U.S. Federal Agencies: } & 1,617,799 \text { acres, which include: } \\ \text { BLM: } & 1,414,184 \text { acres } \\ \text { USFS: } & 134,240 \text { acres } \\ \text { USFWS: } & 10,934 \text { acres } \\ \text { NPS: } & 680 \text { acres } \\ \text { State Agencies: } & 792,405 \text { acres } \\ \text { Tribal Lands: } & 566,427 \text { acres } \\ \text { Private: } & 10,822,908 \text { acres } \\ \text { County \& City: } & 1,050 \text { acres }\end{array}$

$1,617,799$ acres, which include:

134,240 acres

10,934 acres

680 acres

792,405 acres

566,427 acres

1,050 acres 


\begin{tabular}{ccc}
\hline Habitat & Habitat Tier & Percentage of Area \\
\hline Xeric Shrub-grassland Associations & I & 2.31 \\
Moderate/ High Cover Grasslands & I & 2.42 \\
Very Low Cover Grasslands & I & 2.71 \\
Agricultural Lands - Irrigated & III & 2.86 \\
Ponderosa Pine & II & 4.52 \\
Wetland \& Riparian & I & 4.64 \\
Badlands & II & 4.66 \\
Sagebrush & I & 6.77 \\
Agricultural Lands - Dry & III & 9.06 \\
Mixed Xeric Shrubs & I & 10.47 \\
Low/ Moderate Cover Grasslands & I & 41.13 \\
\hline
\end{tabular}

Note: A total of $91.54 \%$ of the Montana Sedimentary Plains area is represented. $8.46 \%$ is made up of a combination of other habitat types.

\section{Associated Species of Greatest Conservation Need}

There are a total of 347 terrestrial vertebrate species that are found within the Montana Sedimentary Plains Focus Area. All associations can be found within Table 29.

\section{Amphibians: Northern Leopard Frog}

Birds: Common Loon, Trumpeter Swan, Bald Eagle, Sage-grouse, Whooping Crane, Mountain Plover, Long-billed Curlew, Least Tern, Black Tern, and Burrowing Owl,

Mammals: Spotted Bat, Townsend's Big-eared Bat, Black-tailed Prairie Dog, Meadow Jumping Mouse, Black-footed Ferret, Lynx, and American Bison

Reptiles: Snapping Turtle, Spiny Softshell, Western Hognose Snake, and Milk Snake

\section{Conservation Concerns}

- Loss of habitat as a result of conversion of native prairie to agriculture

- Invasive or exotic plant species

- Disruption of natural disturbance processes or hydrologic regimes

- Residential development along the river that degrades riparian areas

- Rip-rap and other bank stabilization work

3971

- Unsustainable domestic livestock grazing practices 


\section{Conservation Strategies}

3973

3974

3975

3976

3977

3978

3979

3980

3981

3982

3983

3984

3985

3986

3987

3988

3989

3990

3991

3992

3993

3994

3995

3996
- Government and private conservation programs/activities that encourage and support private land stewardship

- Policy-based approaches that encourage the conservation of natural communities, rather than support their conversion

- Increased efforts to maintain ecological features (i.e. black-tailed prairie dog colonies) or processes (i.e. fire) on public lands as they disappear from private lands.

- Cooperative efforts to reduce the abundance of exotic species

- Work with other agencies to focus on critical fire condition class areas

\section{References}

The Nature Conservancy. 2005. Unpublished Report.

The Nature Conservancy. 1999. Ecoregional Conservation in the Northern Great Plains Steppe. Northern Great Plains Steppe Ecoregional Planning Team.76 pgs.

United States Fish \& Wildlife Service. 2004. Conservation Focus Areas of the Great Divide: A vast region encompassing the Upper Missouri, Yellowstone and Upper Columbia watersheds. Publisher: USFWS, Benton Lake Wildlife Refuge, Great Falls, MT. 77pgs. 


\section{Aquatic Conservation Focus Areas in Greatest Need (Tier I)}

3997

3998

3999

\section{Lower Missouri River (175 River Miles)}

4000

4001

4002

4003

4004

4005

4006

4007

4008

4009

4010

4011

4012

4013

4014

4015

4016

4017

4018

4019

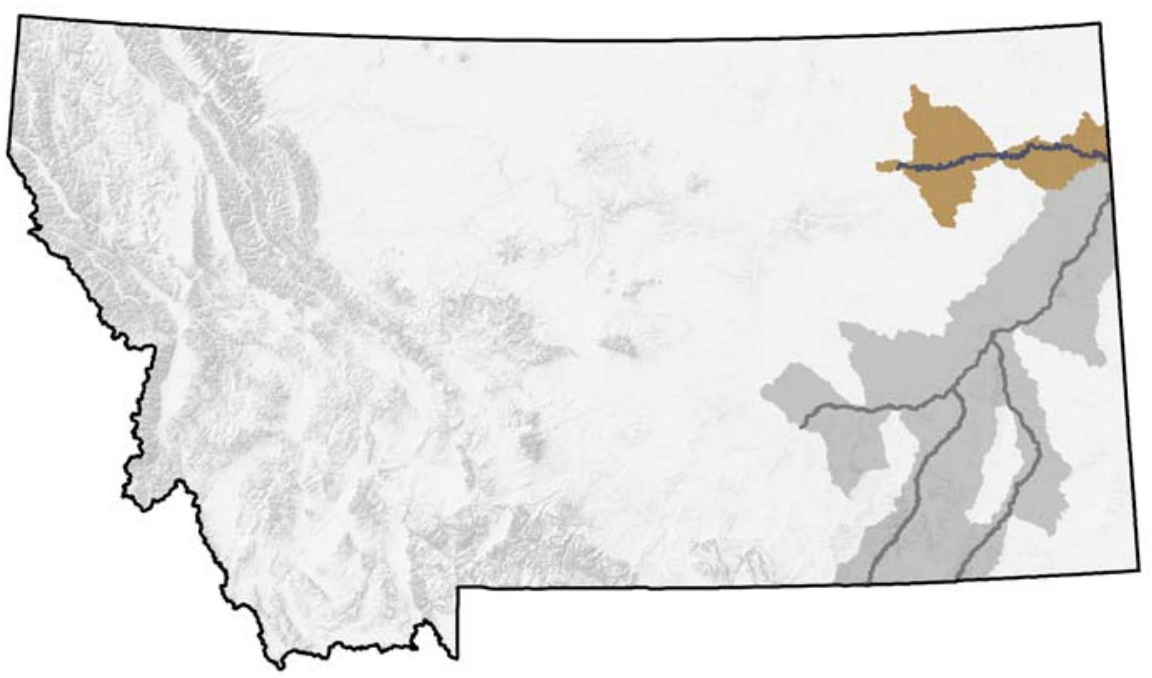

Figure 25. Lower Missouri River Focus Area

The lower Missouri River is a land of badlands, breaks, coulees and gently rolling hills. The river runs approximately 180 river miles from Fort Peck Dam to the North Dakota border. The section of river from the Dam to the town of Wolf Point is uncharacteristically cool and clear, as water discharged from bottom of reservoir is devoid of sediment and cold. Along with many native fish species, this area is occupied by nonnative trout species. Even with flows from the Milk River, this section does not return to warm water habitat until it reaches the town of Wolf Point, approximately 70 river miles downstream. From here to the North Dakota border the Missouri remains warm, with warm water tributaries like the Poplar River, Red Water River and Big Muddy Creek. The adjacent land along the lower Missouri is primarily cottonwood-willow bottomlands and irrigated cropland. As with the area immediately below Fort Peck Dam, this area supports paddlefish, pallid sturgeon, shovelnose sturgeon, sauger, goldeye, blue sucker, river carp sucker, along with many other native fish species.

\section{Associated Habitats}

\begin{tabular}{cccc}
\hline Habitat Type & Habitat Tier & Acres & Miles \\
\hline Lowland Lakes & III & 3021 & \\
Lowland Reservoirs & III & 374 & \\
Mixed Source Rivers & & & \\
(Intermountain and Prairie Flow) & II & & 175 \\
Prairie Streams & I & & 3228 \\
\hline
\end{tabular}




\section{DRAFT WORKING DOCUMENT DO NOT DUPLICATE}

4021

4022

4023

4024

4025

4026

4027

4028

4029

4030

4031

4032

4033

4034

4035

4036

4037

4038

4039

4040

4041

4042

4043

4044

4045

4046

4047

4048

4049

4050

4051

4052

4053

4054

4055

4056

4057

4058

4059

4060

4061

4062

4063

4064

4065

4066

\section{Associated Species of Greatest Conservation Need}

There are a total of 55 aquatic species that are found within the Lower Missouri

River Focus Area. All associations can be found within Table 30.

Fish: Pallid Sturgeon, Paddlefish, Shortnose Gar, Sturgeon Chub, Sicklefin Chub, Pearl Dace, Blue Sucker, Burbot, and Sauger

\section{Conservation Concerns}

- Culverts, dams, irrigation diversions or other instream barriers that fully or partially impede fish movement and reduce connectivity of habitat

- Modification and degradation of stream channels caused by various construction or land management practices

- Degradation of riparian vegetation caused by various land management practices. Such activities de-stabilize streambanks, increase sediment inputs, and reduce shading

- Entrainment of juvenile and adult fishes by irrigation diversion or other water intakes

- Alterations of the quantity or timing of streamflows causing dewatering or unnatural flow fluctuations that diminish the quantity or quality of essential habitats

- Unnatural hydrograph and water temperatures associated with presence and operations of large dams, as well as blockage of migratory corridors

- Unnatural cool, clear water such as occurs below primarystem dams can adversely impact native fish populations

- Water chemistry problems can arise due to municipal discharge, irrigation return water, the discharge of waste water from coal bed methane operations, and other sources

\section{Conservation Strategies}

- Removal or modification of barriers in a manner that restores fish passage

- Restoration of stream channels or stream banks to a condition that simulates their natural form and function

- Modification of riparian management practices such that riparian vegetation is allowed to recover

- Screening or modification of irrigation diversions or other water intakes in a manner that prevents entrainment of fishes

- Implementation of various water conservation or flow management practices that restore essential habitats and simulate the natural hydrograph

- To the extent feasible, operate dams to mimic a more natural hydrograph in the primarystem rivers, and ensure more natural thermal regime. Provide passage over dams to ensure full migratory movement 
4068

4069

4070

4071 4072 4073 4074 4075 4076 4077 4078 4079 4080 4081

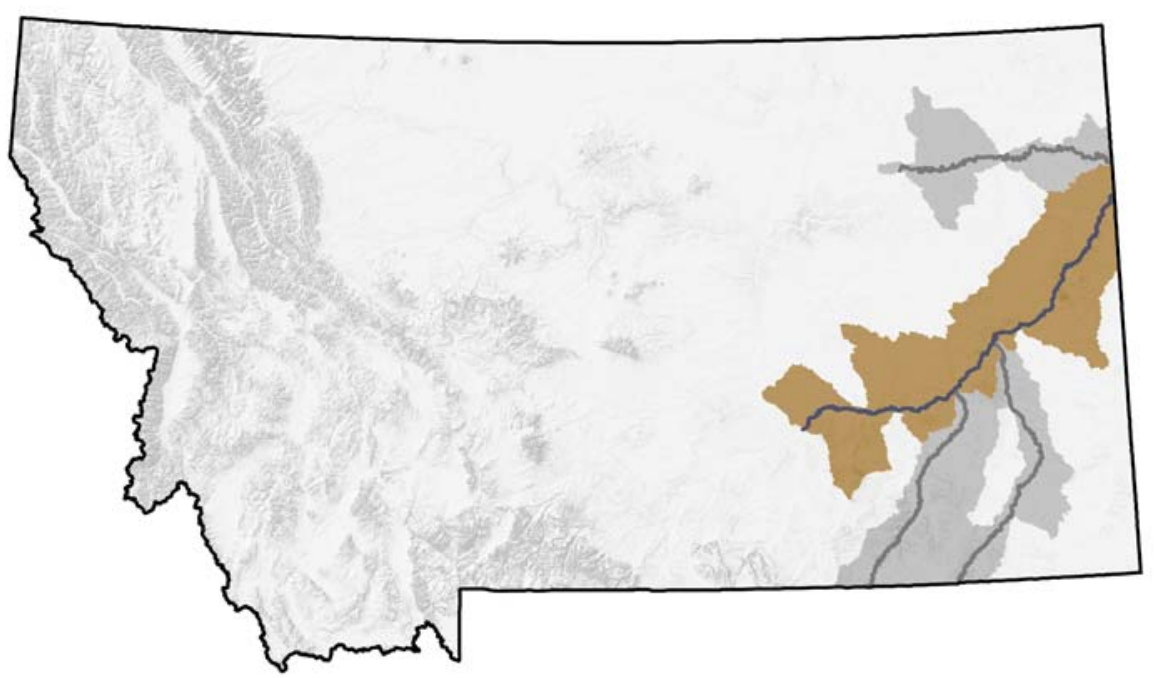

\section{Figure 26. Lower Yellowstone River Focus Area}

The French called it "Roche Jaune", meaning yellow rock, to describe the lower section of the Yellowstone that is lined with trees and meanders through yellow bluffs and rimrocks on its journey toward North Dakota. This reach of the river cuts through a country of plateaus and wind carved sandstone. By the time the Yellowstone has reached the mouth of the Bighorn River it has turned from a crystal, cold mountain stream into a warm plains river. As is it flows north and east it picks up strength from the Powder and Tongue rivers. In the lower Yellowstone you can find species like sauger, burbot and paddlefish.

\section{Associated Habitats}

\begin{tabular}{cccc}
\hline Habitat Type & Habitat Tier & Acres & Miles \\
\hline Intermountain Valley Rivers & II & & 1 \\
Lowland Lakes & III & 6577 & \\
Lowland Reservoirs & III & 1119 & \\
Mixed Source Rivers & & & \\
(Intermountain and Prairie Flow) & II & & 278 \\
Mountain Lakes & III & 251 & \\
Mountain Reservoirs & III & 177 & \\
Prairie Rivers & II & & 1 \\
Prairie Streams & I & & 11326 \\
\hline
\end{tabular}




\section{DRAFT WORKING DOCUMENT DO NOT DUPLICATE}

4086 There are a total of 65 aquatic species that are found within the Lower

4087

4088

4089

4090

4091

4092

4093

4094

4095

4096

4097

4098

4099

4100

4101

4102

4103

4104

4105

4106

4107

4108

4109

4110

4111

4112

4113

4114

4115

4116

4117

4118

4119

4120

4121

4122

4123

4124

4125
Yellowstone River Focus Area. All associations can be found within Table 31.

Fish: Pallid Sturgeon, Paddlefish, Shortnose Gar, Sturgeon Chub, Sicklefin

Chub, Pearl Dace, Blue Sucker, Burbot, and Sauger

\section{Conservation Concerns}

- Culverts, dams, irrigation diversions or other instream barriers that fully or partially impede fish movement and reduce connectivity of habitat

- Entrainment of juvenile and adult fishes by irrigation diversion or other water intakes

- Alterations of the quantity or timing of streamflows causing dewatering or unnatural flow fluctuations that diminish the quantity or quality of essential habitats

- Unnatural cool, clear water such as occurs below primarystem dams can adversely affect native fish populations

- Water chemistry problems can arise due to municipal discharge, irrigation return water, the discharge of waste water from coal bed methane operations, and other sources

- Modification and degradation of stream channels caused by various construction or land management practices

- Degradation of riparian vegetation caused by various land management practices. Such activities de-stabilize streambanks, increase sediment inputs, and reduce shading

\section{Conservation Strategies}

- Removal or modification of barriers in a manner that restores fish passage

- Restoration of stream channels or stream banks to a condition that simulates their natural form and function

- Modification of riparian management practices such that riparian vegetation is allowed to recover

- Screening or modification of irrigation diversions or other water intakes in a manner that prevents entrainment of fishes

- Implementation of various water conservation or flow management practices that restore essential habitats and simulate the natural hydrograph 
4127

4128

4129

4130

4131

4132

4133

4134

4135

4136

4137

4138

4139

4140

4141

4142

4143

4144

4145

4146

4147

4148

4149

4150

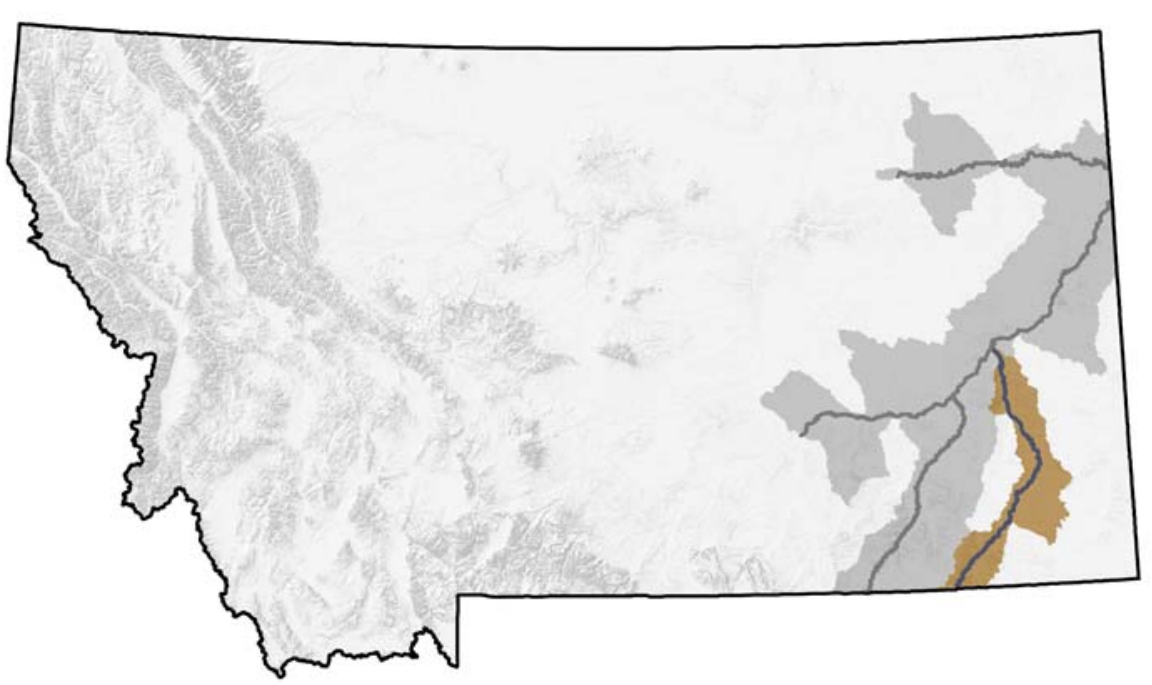

Figure 27. Powder River Focus Area

This warm prairie river originates along the eastern slopes of the Bighorn Mountains in Wyoming. Flowing 220 miles to reach the Yellowstone River, the Powder is aptly named as it is rich in sediment load. A major spawning tributary for native fishes found in the Yellowstone system, the Powder River provides spawning and nursery habitat for sauger, shovelnose sturgeon, channel catfish and many cyprinid minnow species. The flow regime of this flashy river system can fluctuate from over 2000 cfs during the March spring snowmelt period to less than $5 \mathrm{cfs}$ during the hot summer days of August. Fish in this prairie river system have evolved to utilize the Powder during periods of high flow. Sauger tagged in the primary-stem Yellowstone River have been re-captured in Clear Creek, a headwater tributary to the Powder, equating to over 220 miles of travel.

\section{Associated Habitats}

\begin{tabular}{cccc}
\hline Habitat Type & Habitat Tier & Acres & Miles \\
\hline Lowland Lakes & III & 926 & \\
Lowland Reservoirs & III & 80 & \\
Prairie Rivers & II & & 220 \\
Prairie Streams & I & & 3703 \\
\hline
\end{tabular}

\section{Associated Species of Greatest Conservation Need}

There are a total of 38 aquatic species that are found within the Powder River Focus Area. All associations can be found within Table 32.

Fish: Sturgeon Chub, Burbot, and Sauger 


\section{DRAFT WORKING DOCUMENT DO NOT DUPLICATE}

4151

4152

4153

4154

4155

4156

4157

4158

4159

4160

4161

4162

4163

4164

4165

4166

4167

4168

4169

4170

4171

4172

4173

4174

4175

4176

4177

4178

4179

4180

4181

4182

4183

4184

4185

\section{Conservation Concerns}

- Culverts, dams, irrigation diversions or other instream barriers that fully or partially impede fish movement and reduce connectivity of habitat

- Modification and degradation of stream channels caused by various construction or land management practices

- Degradation of riparian vegetation caused by various land management practices. Such activities de-stabilize streambanks, increase sediment inputs, and reduce shading

- Entrainment of juvenile and adult fishes by irrigation diversion or other water intakes

- Alterations of the quantity or timing of streamflows causing dewatering or unnatural flow fluctuations that diminish the quantity or quality of essential habitats

- Water chemistry problems that arise due to municipal discharge, irrigation return water, the discharge of waste-water from coal bed methane operations, and other sources

\section{Conservation Strategies}

- Removal or modification of barriers in a manner that restores fish passage

- Restoration of stream channels or stream banks to a condition that simulates their natural form and function

- Modification of riparian management practices such that riparian vegetation is allowed to recover

- Screening or modification of irrigation diversions or other water intakes in a manner that prevents entrainment of fishes

- Implementation of various water conservation or flow management practices that restore essential habitats and simulate the natural hydrograph

\section{References}




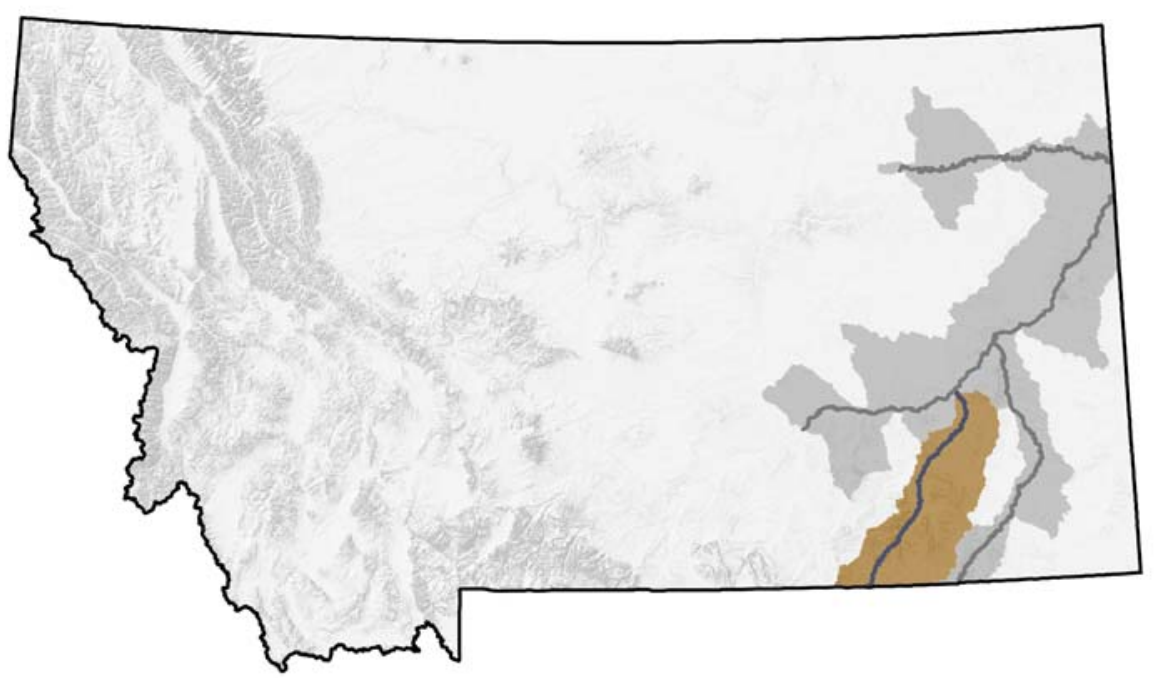

4187

4188

4189

4190

4191

4192

4193

4194

4195

4196

4197

4198

4199

4200

4201

4202

4203

4204

4205

4206

4207

Figure 28. Tongue River Focus Area

The headwaters of the Tongue River rise in the Bighorn Mountains of Wyoming.

From these sources the river flows northeast to its confluence with the

Yellowstone River at Miles City. A major spawning tributary for native fishes found in the Yellowstone system, the Tongue River provides spawning and nursery habitat for sauger, shovelnose sturgeon, channel catfish and many cyprinid minnow species. The 3,500-acre Tongue River Dam controls the river's flow in Montana. Above the reservoir, the river meanders through a broad open valley. Here its main features are turbid water, slow velocity gravel and mud bottoms, and warm water temperatures. Downstream from the dam, the river flows for 10 miles through a narrow, restrictive canyon with increasing gradient and accompanying cooler water temperatures and gravel bottoms. The Tongue River again becomes a slow, meandering valley stream for its last 179 miles.

\section{Associated Habitats}

\begin{tabular}{cccc}
\hline Habitat Type & Habitat Tier & Acres & Miles \\
\hline Lowland Lakes & III & 665 & \\
Lowland Reservoirs & III & 2176 & \\
Mountain Lakes & III & 54 & \\
Mountain Reservoirs & III & 1 & \\
Prairie Rivers & II & & 221 \\
Prairie Streams & I & & 4843 \\
\hline
\end{tabular}

\section{Associated Species of Greatest Conservation Need}




\section{DRAFT WORKING DOCUMENT DO NOT DUPLICATE}

4208 There are a total of 49 aquatic species that are found within the Tongue River

4209 Focus Area. All associations can be found within Table 33.

4210

4211

4212

4213

4214

4215

4216

4217

4218

4219

4220

4221

4222

4223

4224

4225

4226

4227

4228

4229

4230

4231

4232

4233

4234

4235

4236

4237

4238

4239

4240

4241

4242

4243

4244

4245

4246

4247

4248

4249

Fish: Paddlefish, Sturgeon Chub, Blue Sucker, Burbot, and Sauger

\section{Conservation Concerns}

- Culverts, dams, irrigation diversions or other instream barriers that fully or partially impede fish movement

- Modification and degradation of stream channels caused by various construction or land management practices

- Degradation of riparian vegetation caused by various land management practices. Such activities de-stabilize streambanks, increase sediment inputs, and reduce shading

- Entrainment of juvenile and adult fishes by irrigation diversion or other water intakes

- Alterations of the quantity or timing of streamflows causing dewatering or unnatural flow fluctuations that diminish the quantity or quality of essential habitats

- Unnatural cool, clear water such as occurs below primarystem dams can adversely affect native fish populations

- Water chemistry problems that arise due to municipal discharge, irrigation return water, the discharge of waste water from coal bed methane operations, and other sources

- Loss of species (mountain whitefish and mountain sucker) below Tongue River Dam due to water management and drought

\section{Conservation Strategies}

- Removal or modification of barriers in a manner that restores fish passage

- Restoration of stream channels or stream banks to a condition that simulates their natural form and function

- Modification of riparian management practices such that riparian vegetation is allowed to recover

- Screening or modification of irrigation diversions or other water intakes in a manner that prevents entrainment of fishes

- Implementation of various water conservation or flow management practices that restore essential habitats and simulate the natural hydrograph

\section{References}

4250 


\section{Shrub Grassland Ecotype}

4251

4252

4253

4254

4255

4256

4257

4258

4259

4260

4261

4262

4263

4264

4265

4266

4267

4268

4269

4270

4271

4272

4273

4274

4275

4276

4277

4278

4279

4280

4281

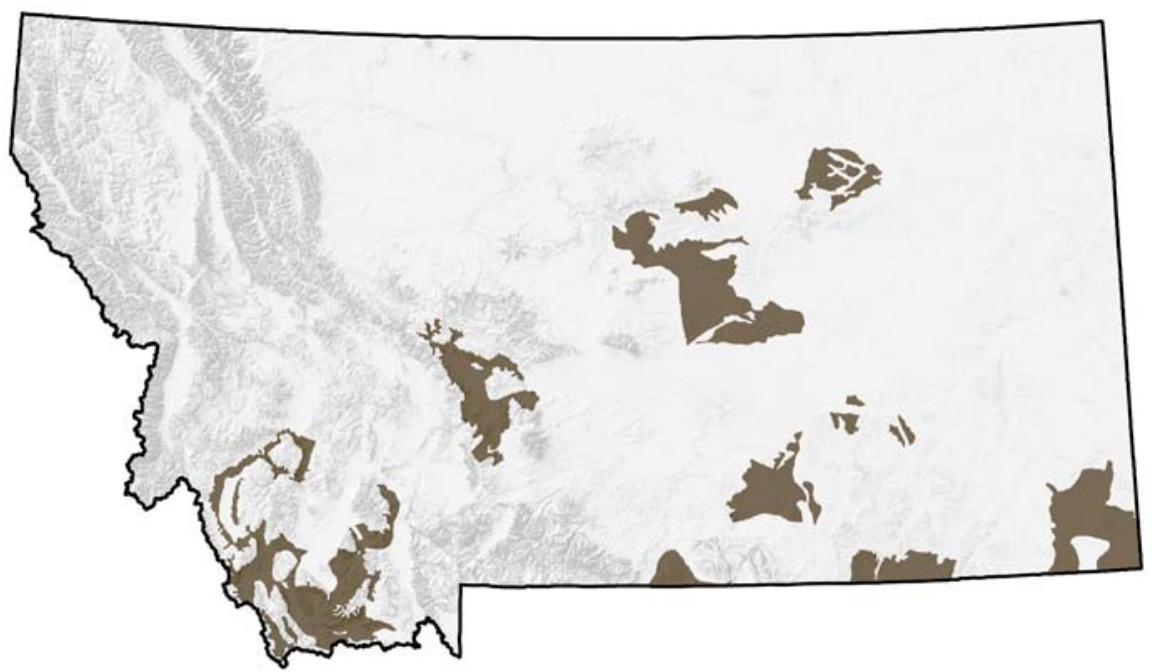

Figure 29. Shrub-grassland Ecotype

Montana's important, yet sporadic, shrub grasslands are found across the southern half Montana in high elevation valleys and along grassy slopes. The junipers and sagebrushes that characterize these generally dry slopes occupy only eight percent of Montana. Typically interspersed with low-cover grasslands, shrub grassland offers a unique transition that supports many of Montana's species of greatest conservation need. More than half of Montana's shrub grasslands are privately owned. Increasingly, the high and flat benches that traditionally provide grazing lands for wildlife and livestock are prized for residential development for their easy access with 100-mile views. In the coming years, long-term partnerships with landowners will be a crucial component of shrub grassland conservation.

\section{Landscape Characteristics}

The shrub grassland ecotype includes $7,240,566$ acres and represents $7.7 \%$ of Montana. The southwestern segment of the shrub grassland ecotype is situated in high mountain valleys and on non-forested mountain slopes at elevations from 5,500 feet to 8,000 feet. Slopes vary from nearly level in valleys to sometimes more than $45^{\circ}$ on some mountainsides. Mountain valleys and drainages associated with this segment include the Centennial, Big Hole, upper Beaverhead, and the valley between the Butte Highlands and Fleecer Mountain. Shrub grasslands are found on slopes of the Centennial, Snowcrest, Beaverhead, Pintlar, Highland, Ruby, south Bitterroot, Tendoy and Tobacco Root mountains. A segment of shrub grassland occupies the valleys of the upper Shields and Smith rivers at elevations from 4,500 to 6,500 feet. These slopes are predominantly near level or gentle. Other areas of shrub grassland are found in the northcentral and southern plains region on mostly level or gentle slopes, 


\section{DRAFT WORKING DOCUMENT DO NOT DUPLICATE}

4282 although where this ecotype occupies dissected river breaks, slopes can be

4283

4284

4285

4286

4287

4288

4289

4290

4291

4292

4293

4294

4295

4296

4297

4298

4299

4300

4301

4302

4303

4304

4305

4306

4307

4308

4309

4310

4311

4312

4313

4314

4315

4316

4317

4318

4319

4320

4321

4322

4323

4324

4325

4326 locally steep. Major drainages where these shrub grasslands are located include the Clark Fork of the Yellowstone, upper Tongue and Powder rivers, Bighorn, Musselshell, Milk, central Missouri and Missouri abouve Fort Peck Dam, and Dry Creek. Most are located in elevations ranging from 2,000 to 3,500 feet.

\section{Soils}

Land occupied by this ecotype in the southwest is geologically the same as the adjacent grasslands or forest. Shrub grasslands in the plains dominated by Wyoming big sagebrush most commonly occur on Cretaceous shales (Colorado Shale, Montane Group, and Pierre Shale in the sedimentary plains area. Other shrub grasslands occupy a variety of geological substrates. Very little shrub grassland is found in the glaciated plains.

As well as being highly variable in terms of vegetation composition, geographic location, and geology, the shrub/grassland ecotype is variable in terms of soil characteristics. Most of the major soil categories found in Montana, except for those of alpine and subalpine situations, are represented in this ecotype (Montagne et. Al 1978).

\section{Climate}

Mean annual temperature in the intermountain/foothill segment of the ecotype varies from $36^{\circ}$ to $40^{\circ} \mathrm{F}$. In the plains shrub grasslands, mean annual temperatures range from $43^{0}$ to $45^{\circ} \mathrm{F}$.

Because this ecotype occurs as widely separated segments across most of the southern half of the state, temperatures at a given time of year vary broadly. Due to the relatively high elevations where shrub grassland is found in the intermountain region, January daily temperatures are comparatively cold for that part of the state $\left(12^{0}\right.$ to $19^{\circ} \mathrm{F}$.). January temperatures in the plains segments are typical for whichever area of the state they are in and range from $10^{\circ}$ to $20^{\circ} \mathrm{F}$. July daily temperatures in the southwest segment range from $57^{\circ}$ to $63^{\circ} \mathrm{F}$. and on the plains they vary from $64^{\circ}$ to $66^{\circ} \mathrm{F}$. Mean annual extreme minimum temperatures across the ecotype vary from $-24^{0}$ to $-31^{0} \mathrm{~F}$. putting most of it into the cold side of plant hardiness zone 4 . Mean annual maximum temperatures may be anywhere from less than $85^{\circ} \mathrm{F}$. in the southwest to over $102^{\circ} \mathrm{F}$. in the southeast.

Average length of time without frost is shortest in the southwest and may only be 30 days in some places. The frost free period is the greatest in those segments near the lower Yellowstone and Missouri rivers where it may range from 115 to 130 days. 


\section{DRAFT WORKING DOCUMENT DO NOT DUPLICATE}

4327

4328

4329

4330

4331

4332

4333

4334

4335

4336

4337

4338

4339

4340

4341

4342

4343

4344

4345

4346

4347

4348

4349

4350

4351

4352

4353

4354

4355

4356

4357

4358

4359

4360

4361

4362

4363

4364

4365

4366

4367

4368

4369

4370

4371

4372

The percentage of precipitation received during the growing season is highly variable within the southwest segment, ranging from 35 to 60 percent depending on the area. The shrub and grassland around White Sulfur Springs receives 40 to 45 percent of its moisture in the growing season. In other segments of shrub grassland, 50 to 62 percent of moisture falls during the growing season.

Snowfall for the shrub/grassland areas in or near the mountains, except for the segment south of the Pryor Mountains, generally ranges from 31 to 90 inches each year. Mean number of days with snowcover in these areas varies from 90 to 160 days. An area of shrub/grassland south of the Pryor Mountains averages less than 30 inches of mean annual snowfall and generally has snow on the ground less than 60 days. The other areas generally average between 20 and 50 inches of snowfall with 60 to 100 days of snowcover.

\section{Anthropogenic}

The shrub grassland ecotype is some of the most undeveloped habitat in the state. Recreationalists and agriculturalists enjoy and appreciate it. The breakdown of landowner stewardship for shrub grassland ecotype is as follows:
U.S. Federal Agencies:
$1,851,561$ acres, which include
BLM:
$1,574,556$ acres
USFS:
228,634 acres
USFWS:
42,008 acres
NPS:
1,977 acres
State Agencies:
668,049 acres
Tribal Lands:
260,264 acres
Private:
$4,431,526$ acres
City \& County:
0 acres

\section{Vegetation}

In areas of the shrub grassland ecotype that has fine textured soils and receives 10 to 14 inches of annual precipitation, the predominant species of vegetation is the big sagebrush (Artemisia tridentate ssp). Big sagebrush dominated communities in this area normally are found on fine textured to very fine textured soils. Such areas are estimated to cover $65 \%$ of the ecotype. Where there is more available moisture due to run in or high water table, silver sagebrush (Artemisia cana) or greasewood (Sarcobatus vermiculatus) may be abundant. Silver sagebrush is favored by medium textured non-saline soils; greasewood is usually found on dense clay saline and/or alkaline soils. Silver sagebrush bottomlands in Theodore Roosevelt National Park described by Hansen et al. 1988 are probably similar to such communities in eastern Montana. Dominant species in these areas are silver sagebrush, western wheatgrass (Agropyron smithii), and green needlegrass (Stipa viridula). The dominant understory species under big sagebrush in eastern areas are western wheatgrass, prairie 


\section{DRAFT WORKING DOCUMENT DO NOT DUPLICATE}

4373 junegrass (Koeleria macrantha), and green needlegrass. Other common species

4374 include nuttall saltbush (Atriplex nuttallii), bluebunch wheatgrass (Agropyron

4375 spicatum), and various milkvetches (Astragulus spp.). In the west, dominant

4376

4377

4378

4379

4380

4381

4382

4383

4384

4385

4386

4387

4388

4389

4390

4391

4392

4393

4394

4395

4396

4397

4398

4399

4400

4401

4402 grasses are bluebunch wheatgrass, western wheatgrass, and prairie junegrass. Common forbes are milkvetches, American vetch (Vicia Americana), and biscuitroot (Lomatium spp.).

Where big sagebrush is the dominant species on silty soils in the 10 to 14 inch precipitation zone, the most abundant grasses are needle and thread (Stipa comata) and western wheatgrass in the east and bluebunch wheatgrass in the west (Ross et al. 1976) (Mueuggler et al. 1980). On limy, shallow and very shallow soils bluebunch wheatgrass is typically dominant. Communities containing both low sagebrush (Artemisia arbuscula) and big sagebrush are found in some areas of extreme southwest Montana east of the continental divide. These sites are often on limestone. Subdominant grasses include prairie junegrass and sandberg bluegrass (Poa secunda). Common forbs are hood's plox (Phlox hoodii) and blue flax (Linum perenne). Curlleaf mountain mahogany (Cercocarpus ledifolius) is another shrub restricted to the extreme southwestern part of the state. A bitterbrush (Purshia tridentate)/bluebunch wheatgrass habitat type is recognized west of the divide and an aromatic sumac (Rhus aromatica) /bluebunch wheatgrass type occurs in southcentral Montana. Other shrubs such as big sagebrush, rubber rabbitbrush (Chrysothamnus nauseosus), and Rocky Mountain juniper (Juniperus scopulorum) may be important in these types. Finally, on saline lowlands, a greasewood/western wheatgrass habitat is recognized and on uplands a greasewood/basin wildrye (Elymus cinereus) type.

4403

4404

4405

4406

4407

The areas of the shrub grassland ecotype where annual precipitation is from 15 to 19 inches are usually higher in elevation than those with annual precipitation between 10 to 14 inches. The most abundant shrub species is generally mountain big sagebrush (Artemisia tridentate ssp. vaseyana), although there may be some Wyoming big sagebrush, rubber rabbit brush, and bitterbrush. Where these shrub/grasslands occur in southwestern Montana, bluebunch wheatgrass is still an important grass species as in the 10 to 14 inch precipitation areas, but Idaho fescue is considered to be dominant. North of $46^{\circ}$ Idaho fescue is replaced by rough fescue (Festuca scabrella) as the dominant grass. These

4408

4409

4410

4411

4412

4413

4414

4415

4416 sites generally have more abundant and diverse forbs than the drier areas. In the higher precipitation areas that are well drained, typically with steep slopes, coarse textured shallow soils and often southerly exposures, the most abundant species is generally bitterbrush. West of the divide and north of $47^{0}$, rough fescue is the most productive grass. South of $47^{\circ}$ Idaho fescue or Idaho fescue and bluebunch wheatgrass are the most productive. On some sites mountain big sagebrush may be as abundant as bitterbrush. Arrowleaf balsamroot (Balsamorhiza sagitatta) and silky lupine (Lupinus sericeus) are very common both north and south. 
4417

4418

4419

4420

4421

4422

4423

4424

4425

4426

4427

4428

4429

4430

4431

4432

4433

4434

4435

4436

4437

4438

4439

4440

4441

4442

4443

4444

4445

4446

4447

\section{Terrestrial Conservation Focus Areas in Greatest Need (Tier I)}

\section{Bighorn Intermontane Basin (290,287 acres)}

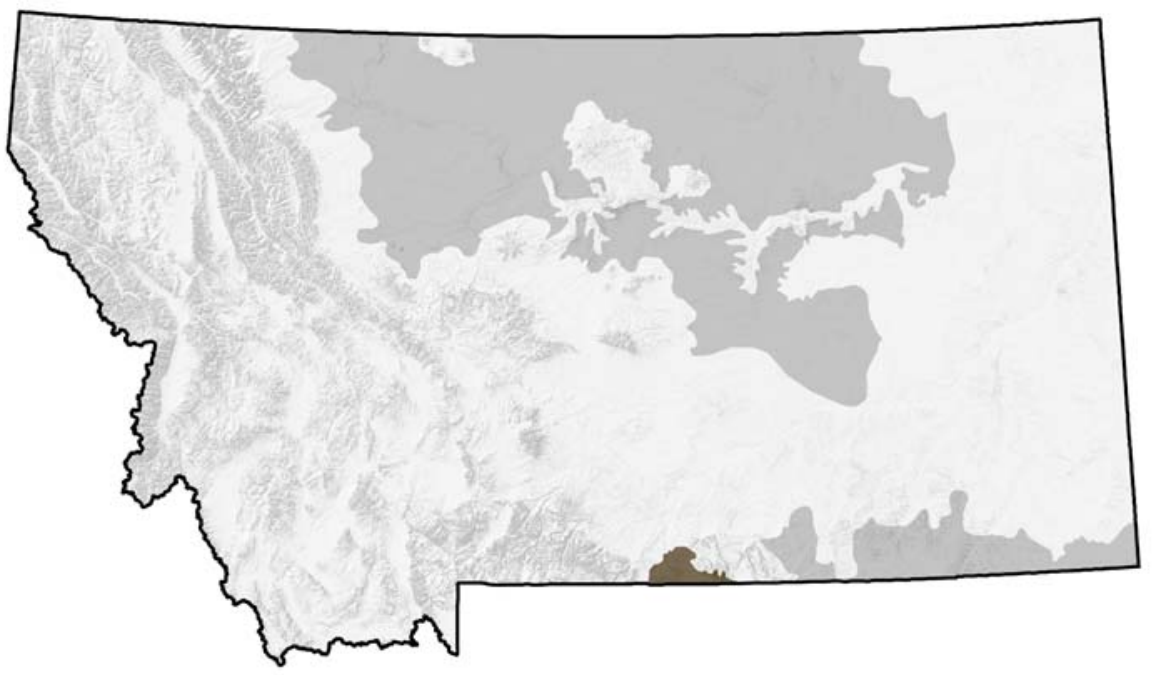

Figure 30. Bighorn Intermontane Basin Focus Area

The basin protrudes across Montana's border from Wyoming and sits in the rain shadow of the Beartooth Range. The area is home to a very diverse wildlife community and represents a limited geographic area at the end of its range that resembles communities more typical of the Great Basin and Colorado Plateau than Montana. Riparian areas are limited minor drainages and it is the driest area in Montana typically receiving only 6 inches of precipitation annually. Snow seldom lasts long due to the predominate and seemingly ever present southwest winds. Native vegetation is generally dominated by shrubs primarily black sagebrush, Wyoming big sagebrush and greasewood. Understory grasses are generally sparse with invading annuals such as cheatgrass often dominating. This is the home of the prairie rattlesnake as well as the sagebrush and horned lizards. Sage-grouse are abundant as are gray partridges. This is the only habitat in Montana that supports the chukar partridge. However, given the desert nature of the habitat mule deer and pronghorn antelope can exist only in low densities.

\section{Landscape Characteristics}

This subsection is composed of dissected plains, hills, terraces, and fans that formed in shale, siltstone, and sandstone overlain by some alluvium and lacustrine sediment. Elevations range from 3,700 to 4,700 feet. Drainage density is moderate. Mean annual precipitation ranges from 5 to 12 inches. The soil temperature and moisture regimes are mesic and ustic aridic. Winters are very dry. The primary natural disturbance is drought. Land use is predominantly 
4448 livestock grazing and irrigated cropland. The breakdown for land stewardship in 4449 the Bighorn intermontane basin is as follows:

4450

4451

4452

4453

4454

4455

4456

4457

4458

4459

4460

U.S. Federal Agencies:

BLM:

USFS:

NPS:

State Agencies:

Tribal Lands:

Private:
163,275 acres, which include:

157,097 acres

3,707 acres

2,471 acres

14,517 acres

4,819 acres

107,676 acres

\section{Associated Habitats}

\begin{tabular}{ccc}
\hline Habitat & Habitat Tier & Percentage of Area \\
\hline Agricultural Lands - Irrigated & III & 2.46 \\
Low/ Moderate Cover Grasslands & I & 3.44 \\
Utah Juniper & III & 3.73 \\
Xeric Shrub-grassland Associations & I & 5.67 \\
Badlands & II & 17.19 \\
Very Low Cover Grasslands & I & 28.28 \\
Sagebrush & I & 33.78 \\
\hline
\end{tabular}

4461

4462

4463

4464

4465

4466

4467

4468

4469

4470

4471

4472

4473

4474

4475

4476

4477

4478

4479

4480

4481

4482

4483

4484

4485

Note: A total of $94.55 \%$ of the Bighorn Intermontane Basin area is represented. $5.45 \%$ is made up of a combination of other habitat types.

\section{Associated Species of Greatest Conservation Need}

There are a total of 174 terrestrial vertebrate species that are found within the Bighorn Intermontane Basin Focus Area. All associations can be found within Table 34.

Amphibians: Northern Leopard Frog

Birds: Bald Eagle, Sage-grouse, Mountain Plover, Long-billed Curlew, and Burrowing Owl

Mammals: Spotted Bat, Pallid Bat, Black-tailed Prairie Dog, White-tailed Prairie Dog, Gray Wolf, and Black-footed Ferret

Reptiles: Western Hognose Snake and Milk Snake

\section{Conservation Concerns}

- Energy exploration and development impacts

- Invasive or exotic plant or animal species

- Disruption of natural fire disturbance processes 
4486 - Unsustainable domestic livestock grazing practices

4487

4488

4489

4490

4491

4492

4493

4494

4495

4496

4497

4498

4499

4500

\section{Conservation Strategies}

- None have been identified

\section{References}

A Biological Conservation Assessment for the Utah-Wyoming Rocky Mountain Ecoregion: Report to the Nature Conservancy. 2001. R. Noss, G. Wuerthner, K. Vance-Borland, and C. Carroll. Conservation Science, Inc. 125 pp. + Executive Summary and Appendix D.

United States Fish \& Wildlife Service. 2004. Conservation Focus Areas of the Great Divide: A vast region encompassing the Upper Missouri, Yellowstone and 4501 Upper Columbia watersheds. Publisher: USFWS, Benton Lake Wildlife Refuge, 4502 Great Falls, MT. 77pgs.

4503

4504 
4506

4507

4508

4509

4510

4511

4512

4513

4514

4515

4516

4517

4518

4519

4520

4521

4522

4523

4524

4525

4526

4527

4528

4529

4530

4531

4532

4533

4534

4535

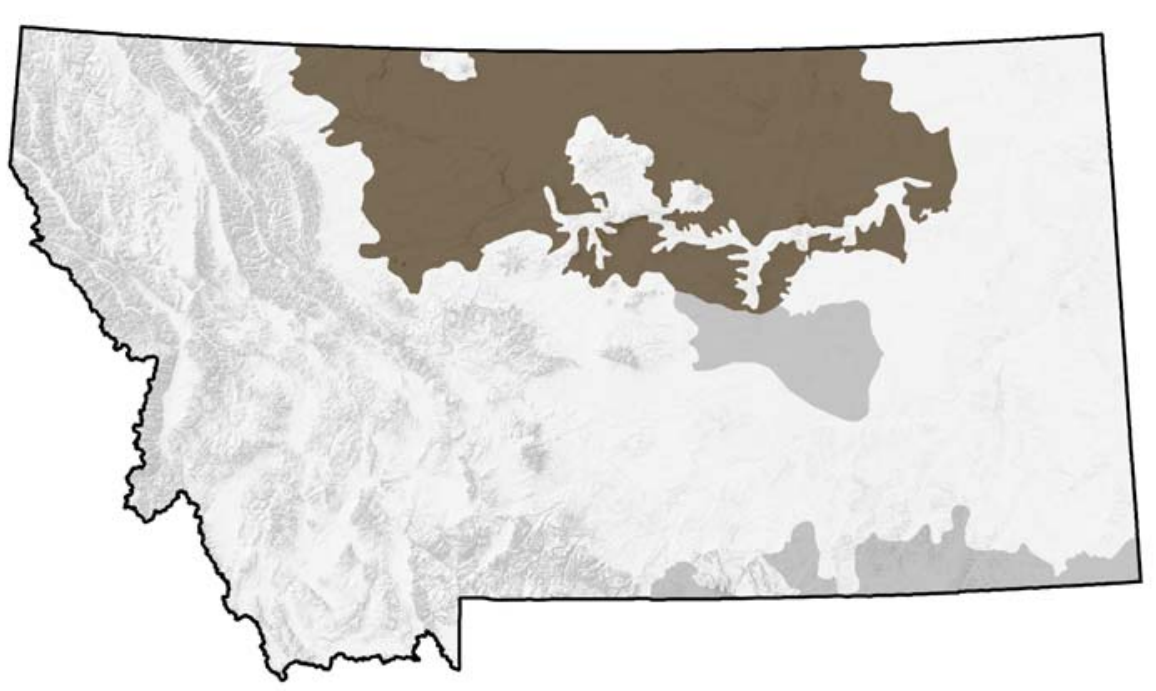

Figure 31. Montana Glaciated Plains Focus Area

Montana Glaciated Plains are dominated by level to rolling till plains covered by sagebrush grasslands and mixed short-grass prairie and croplands. This area also encompasses two island mountain ranges: the Bearpaw and Highwood Mountains. The major river drainages of the area include the Milk, Missouri, Marias, and Musselshell Rivers. In the east, this focus area is characterized by prairie that is dissected by badland of the major tributaries to the Milk, Missouri, Marias and Musselshell drainages. From the bluffs dotted with ancient teepee rings, one can observe the numerous prairie wildlife species. To the west, the area is characterized by the numerous rugged breaks that support diverse assemblages of ponderosa pine and cottonwoods depending on the availability of moisture. This area is also considered very fertile wheat growing country, most notable found in the Golden Triangle to the west.

\section{Landscape Characteristics}

This area has plains, terraces, fans and floodplains that formed in glacial till, gravel deposits, and alluvium over clay shale, sandstone, and siltstone. Elevations range from 1,800 to 7,500 feet in the Highwoods and Bearpaws. Drainage density is moderate and glacial potholes are common, especially in the northern part of subsection. Mean annual precipitation ranges from 10 to 15 inches, about 20 to 30 percent falling as snow. The soil temperature and moisture regimes are frigid and aridic ustic. The primary natural disturbance is drought. Land use is predominantly livestock grazing as well as dryland farming. The breakdown for land stewardship in the Montana glaciated plains is as follows:

U.S. Federal Agencies: $\quad 3,394,302$ acres, which include: 


\section{DRAFT WORKING DOCUMENT DO NOT DUPLICATE}

4536

4537

4538

4539

4540

4541

4542

4543

4544

4545

4546

4547

4548

4549

4550

4551

4552

4553

4554

4555

4556

4557

4558

4559

4560

4561

4562

4563

4564

4565

4566

4567

4568

4569

4570

4571

4572
$3,003,010$ acres

62 acres

283,492 acres

247 acres

$1,253,566$ acres

$1,141,133$ acres

$11,995,485$ acres

494 acres

\section{Associated Habitats}

\begin{tabular}{ccc}
\hline Habitat & Habitat Tier & Percentage of Area \\
\hline Wetland \& Riparian & $\mathrm{I}$ & 3.22 \\
Moderate/ High Cover Grasslands & $\mathrm{I}$ & 3.38 \\
Altered Herbaceous & $\mathrm{II}$ & 4.33 \\
Sagebrush & $\mathrm{I}$ & 4.67 \\
Very Low Cover Grasslands & $\mathrm{I}$ & 4.79 \\
Agricultural Lands - Irrigated & $\mathrm{III}$ & 13.87 \\
Agricultural Lands - Dry & $\mathrm{III}$ & 20.19 \\
Low/ Moderate Cover Grasslands & $\mathrm{I}$ & 33.66 \\
\hline
\end{tabular}

Note: A total of $88.11 \%$ of the Montana Glaciated Plains area is represented. $11.89 \%$ is made up of a combination of other habitat types.

\section{Associated Species of Greatest Conservation Need}

There are a total of 368 terrestrial vertebrate species that are found within the Montana Glaciated Plains Focus Area. All associations can be found within Table 35.

Amphibians: Northern Leopard Frog

Bird: Common Loon, Bald Eagle, Sage-grouse, Yellow Rail, Whooping Crane, Piping Plover, Mountain Plover, Long-billed Curlew, Least Tern, Black Tern, Burrowing Owl, Sedge Wren, and Nelson's Sharp-tailed Sparrow

Mammals: Spotted Bat, Townsend's Big-eared Bat, Black-tailed Prairie Dog, Black-footed Ferret, Lynx, and American Bison (not currently present)

Reptiles: Snapping Turtle, Spiny Softshell, Western Hognose Snake, and Milk Snake

\section{Conservation Concerns}

- Conversion of native prairie to small grain production

- Petrolium exploration and development impacts 
4573

4574

4575

4576

4577

4578

4579

4580

4581

4582

4583

4584

4585

4586

4587

4588

4589

4590

4591

4592

4593

4594

4595

4596

4597

4598

4599

4600

4601

4602

4603

4604

4605

4606

4607

4608

4609

4610

4611

4612

4613
- Invasive or exotic plant species

- Disruption of natural fire disturbance processes and hydrologic regimes

- Unsustainable domestic livestock grazing practices

- Rip-rap and other bank stabilization work

\section{Conservation Strategies}

- Government and private conservation programs/activities that encourage and support private land stewardship

- Policy-based approaches that encourage the conservation of natural rangeland communities, rather than support their conversion

- Increased efforts to maintain ecological features (i.e. black-tailed prairie dog colonies) or processes (i.e. fire) on public lands as they disappear from private lands

- Cooperative efforts to reduce the abundance of exotic species

- Implement practices (economic \& ecological) that sustain ranching profitability and promote free public access

- Maintain existing structure and functional uses of wetlands on private and federally managed lands

- Evaluate ecological implications of road development as well as reservoir and pit retention construction with the purpose of informing BLM managers, with specific implications on declining species and spread of invasive species

\section{References}

The Nature Conservancy. 2005. Unpublished Report.

The Nature Conservancy. 1999. Ecoregional Conservation in the Northern Great Plains Steppe. Northern Great Plains Steppe Ecoregional Planning Team. 76 pgs.

United States Fish \& Wildlife Service. 2004. Conservation Focus Areas of the Great Divide: A vast region encompassing the Upper Missouri, Yellowstone and Upper Columbia watersheds. Publisher: USFWS, Benton Lake Wildlife Refuge, Great Falls, MT. 77pgs.

Whitewater Wetlands Conservation Area Plan. 2004. B. Martin \& J. Stutzman, 16 $\mathrm{pp}+$ appendices. 
4615

4616

4617

4618

4619

4620

4621

4622

4623

4624

4625

4626

4627

4628

4629

4630

4631

4632

4633

4634

4635

4636

4637

4638

4639

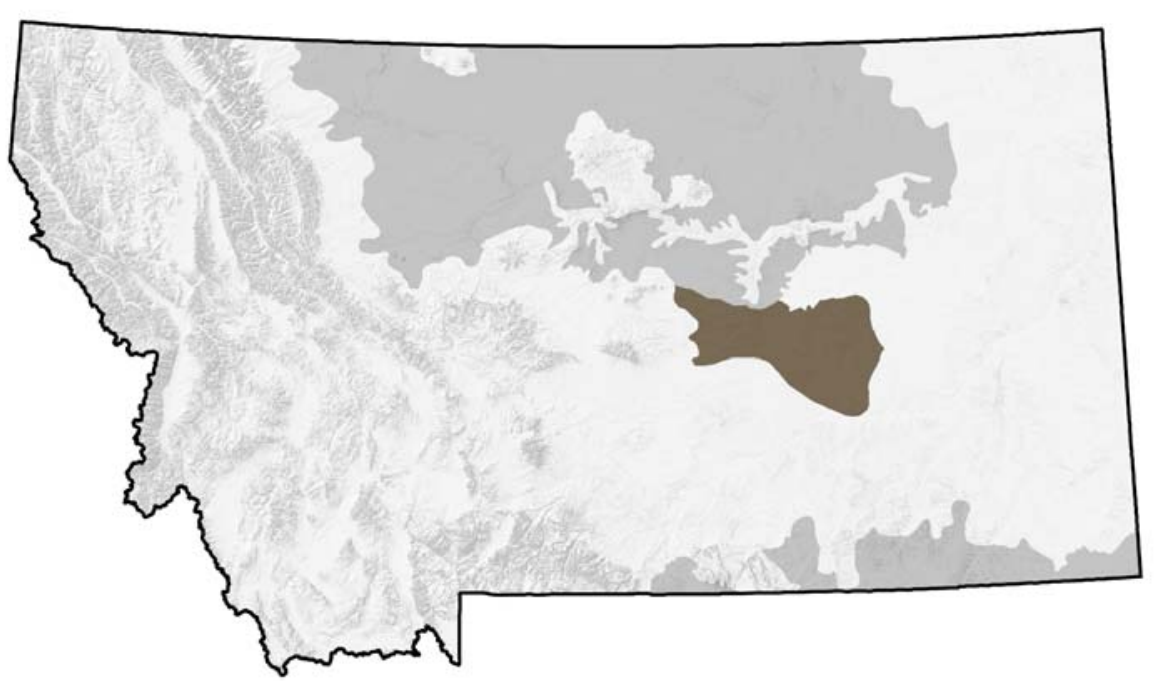

\section{Figure 32. Montana Shale Plains Focus Area}

Much of this area can be considered mountain foothill terrain that contains many woody draws with ponderosa pine and cedar stands throughout.

\section{Landscape Characteristics}

This section has dissected plains, hills, terraces, fans, and floodplains that formed in shale, siltstone, and sandstone. Elevations range from 1,500 to 3,500 feet. Drainage density is moderate to high. Mean annual precipitation ranges from 10 to 14 inches, about 30 percent falling as snow. The soil temperature and moisture regimes are frigid and aridic ustic. Summers are dry. The primary natural disturbance is drought and erosion. Land use is predominantly livestock grazing with some dryland farming. The breakdown for land stewardship in the Montana shale plains is as follows:
U.S. Federal Agencies:
278,550 acres, which include:
BLM:
275,461 acres
USFWS:
3,089 acres
State Agencies:
158,889 acres
Private:
$1,965,538$ acres

\section{Associated Habitats}

\begin{tabular}{ccc}
\hline Habitat & Habitat Tier & Percentage of Area \\
\hline Wetland \& Riparian & I & 2.46 \\
Agricultural Lands - Dry & III & 4.66 \\
Xeric Shrub-grassland Associations & I & 4.68 \\
\hline
\end{tabular}


DRAFT WORKING DOCUMENT DO NOT DUPLICATE

\begin{tabular}{ccc}
\hline Moderate/ High Cover Grasslands & I & 5.04 \\
Very Low Cover Grasslands & $\mathrm{I}$ & 6.45 \\
Badlands & $\mathrm{I}$ & 8.04 \\
Sagebrush & $\mathrm{I}$ & 8.48 \\
Mixed Xeric Shrubs & $\mathrm{I}$ & 16.51 \\
Low/ Moderate Cover Grasslands & $\mathrm{I}$ & 36.35 \\
\hline
\end{tabular}

Note: A total of $92.67 \%$ of the Montana Shale Plains area is represented. $7.33 \%$ is made up of a combination of other habitat types.

\section{Associated Species of Greatest Conservation Need}

There are a total of 307 terrestrial vertebrate species that are found within the Montana Shale Plains Focus Area. All associations can be found within Table 36.

\section{Amphibians: Northern Leopard Frog}

Birds: Common Loon, Bald Eagle, Sage-grouse, Whooping Crane, Mountain Plover, Long-billed Curlew, Black Tern, and Burrowing Owl,

Mammals: Townsend's Big-eared Bat, Black-tailed Prairie Dog, Meadow Jumping Mouse, Black-footed Ferret, Lynx, and American Bison

Reptiles: Spiny Softshell, Western Hognose Snake, and Milk Snake

\section{Conservation Concerns}

- Dewatering as a result of water diversions

- Invasive or exotic plant species

- Disruption of natural disturbance processes or hydrologic regimes

\section{Conservation Strategies}

- Government and private conservation programs/activities that encourage and support private land stewardship

- Policy-based approaches that encourage the conservation of natural communities, rather than support their conversion

- Increased efforts to maintain ecological features (i.e. black-tailed prairie dog colonies) or processes (i.e. fire) on public lands as they disappear from private lands.

- Cooperative efforts to reduce the abundance of invasive or exotic species

\section{References}




\section{DRAFT WORKING DOCUMENT DO NOT DUPLICATE}

4678 The Nature Conservancy. 1999. Ecoregional Conservation in the Northern Great 4679 Plains Steppe. Northern Great Plains Steppe Ecoregional Planning Team. 76 4680 pgs.

4681

4682 United States Fish \& Wildlife Service. 2004. Conservation Focus Areas of the 4683 Great Divide: A vast region encompassing the Upper Missouri, Yellowstone and 4684 Upper Columbia watersheds. Publisher: USFWS, Benton Lake Wildlife Refuge, 4685 Great Falls, MT. 77pgs.

4686

4687 
4689

4690

4691

4692

4693

4694

4695

4696

4697

4698

4699

4700

4701

4702

4703

4704

4705

4706

4707

4708

4709

4710

4711

4712

4713

4714

4715

4716

4717

4718

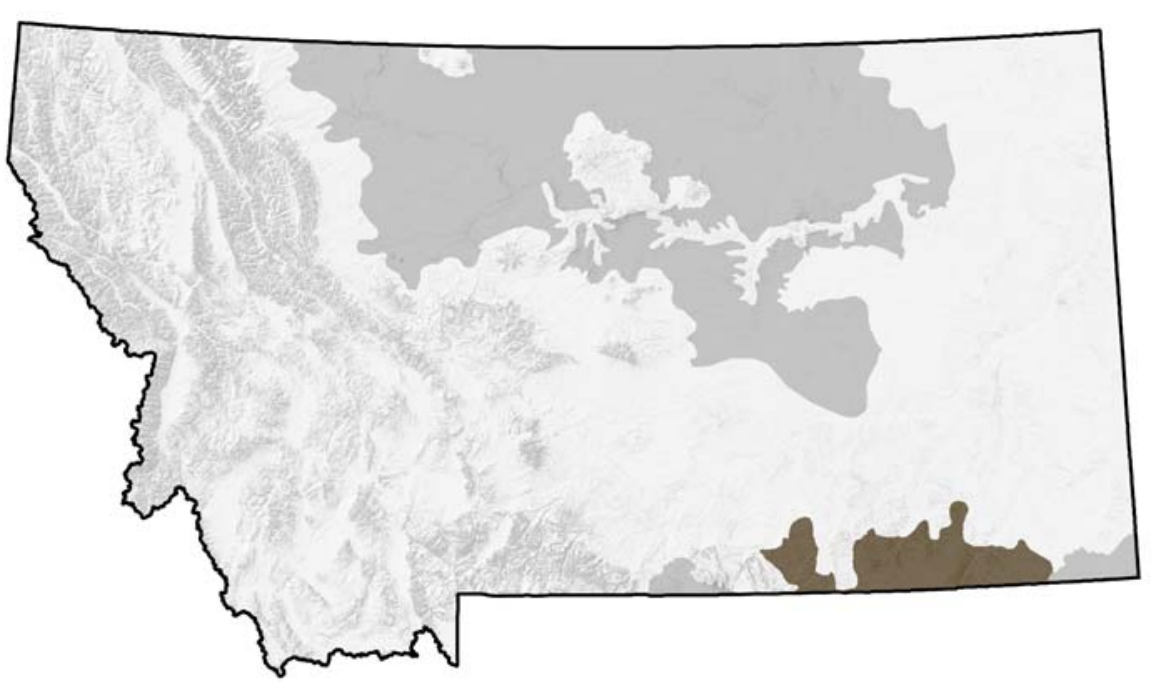

Figure 33. Powder River Basin/Breaks/Scoria Hills Focus Area

Much of this unglaciated area extends across Montana's border into Wyoming. The flat to rolling mixed grass prairie contains considerable areas of sagebrush grassland as well as ponderosa pine and juniper woodlands that are broken by occasional rugged breaks. The Powder River that cuts through the area provides significant riparian habitat for many species. This area supports irrigated and dryland crops.

\section{Landscape Characteristics}

This section has dissected plains and hills, terraces, and fans with some river breaks and badlands that formed in alluvium and colluvium from sandstone, shale, and siltstone. Elevations range from 2,100 to 4,980 feet. Drainage density is moderate to high. Mean annual precipitation ranges from 10 to 14 inches, about 20 percent falling as snow. The soil temperature and moisture regimes are frigid and aridic ustic. Summers are dry. The primary natural disturbance is drought and erosion. Land use is predominantly livestock grazing, irrigated and dryland crops. The breakdown for land stewardship in the Powder River Basin/Breaks/Scoria Hills is as follows:
U.S. Federal Agencies:
503,292 acres, which include:
BLM:
USFS:
NPS:
197,993 acres
304,928 acres
371 acres
State Agencies:
90,873 acres
Tribal Lands:
313,824 acres
Private:
$1,186,909$ acres 
DRAFT WORKING DOCUMENT DO NOT DUPLICATE

4719

4720

\section{Associated Habitats}

\begin{tabular}{ccc}
\hline Habitat & Habitat Tier & Percentage of Area \\
\hline Very Low Cover Grasslands & I & 2.70 \\
Mixed Mesic Shrubs & II & 3.31 \\
Sagebrush & $\mathrm{I}$ & 5.30 \\
Wetland \& Riparian & $\mathrm{I}$ & 6.21 \\
Mesic Shrub-grassland Associations & $\mathrm{I}$ & 7.42 \\
Low Density Xeric Forest & $\mathrm{II}$ & 8.15 \\
Mixed Xeric Shrubs & $\mathrm{I}$ & 10.04 \\
Ponderosa Pine & $\mathrm{I}$ & 11.60 \\
Low/ Moderate Cover Grasslands & $\mathrm{I}$ & 31.86
\end{tabular}

4721

4722

4723

4724

4725

4726

4727

4728

4729

4730

4731

4732

4733

4734

4735

4736

4737

4738

4739

4740

4741

4742

4743

4744

4745

4746

4747

4748

4749

4750

4751

4752

4753

4754

Note: A total of $86.59 \%$ of the Powder River Basin/Breaks/Scoria Hills area is represented. $13.41 \%$ is made up of a combination of other habitat types.

\section{Associated Species of Greatest Conservation Need}

There are a total of 299 terrestrial vertebrate species that are found within the Powder River Basin/Breaks/Scoria Hills Focus Area. All associations can be found within Table 37.

\section{Amphibians: Northern Leopard Frog}

Birds: Common Loon, Trumpeter Swan, Bald Eagle, Sage-grouse, Whooping Crane, Long-billed Curlew, Black Tern, and Burrowing Owl,

Mammals: Spotted Bat, Townsend's Big-eared Bat, Black-tailed Prairie Dog, Meadow Jumping Mouse, Black-footed Ferret, and American Bison

Reptiles: Snapping Turtle, Spiny Softshell, Western Hognose Snake, and Milk Snake

\section{Conservation Concerns}

- Energy exploration and development impacts

- Invasive or exotic species

- Disruption of natural disturbance processes or hydrologic regimes

- Loss or habitat due to conversion of native prairie to agriculture

\section{Conservation Strategies}

- Government and private conservation programs/activities that encourage and support private land stewardship

- Policy-based approaches that encourage the conservation of natural communities, rather than support their conversion 
4755

4756

4757

4758

4759

4760

4761

4762

4763

4764

4765

4766

4767

4768

4769

4770

4771

4772

4773
- Increased efforts to maintain ecological features (i.e. black-tailed prairie dog colonies) or processes (i.e. fire) on public lands as they disappear from private lands.

- Cooperative efforts to reduce the abundance of exotic species

- Cooperative efforts to achieve sustainable grazing practices on public and private lands

\section{References}

The Nature Conservancy. 1999. Ecoregional Conservation in the Northern Great Plains Steppe. Northern Great Plains Steppe Ecoregional Planning Team. 76 pgs.

United States Fish \& Wildlife Service. 2004. Conservation Focus Areas of the Great Divide: A vast region encompassing the Upper Missouri, Yellowstone and Upper Columbia watersheds. Publisher: USFWS, Benton Lake Wildlife Refuge, Great Falls, MT. 77pgs. 
4775

4776

4777

4778

4779

4780

4781

4782

4783

4784

4785

4786

4787

4788

4789

4790

4791

4792

4793

4794

4795

4796

4797

4798

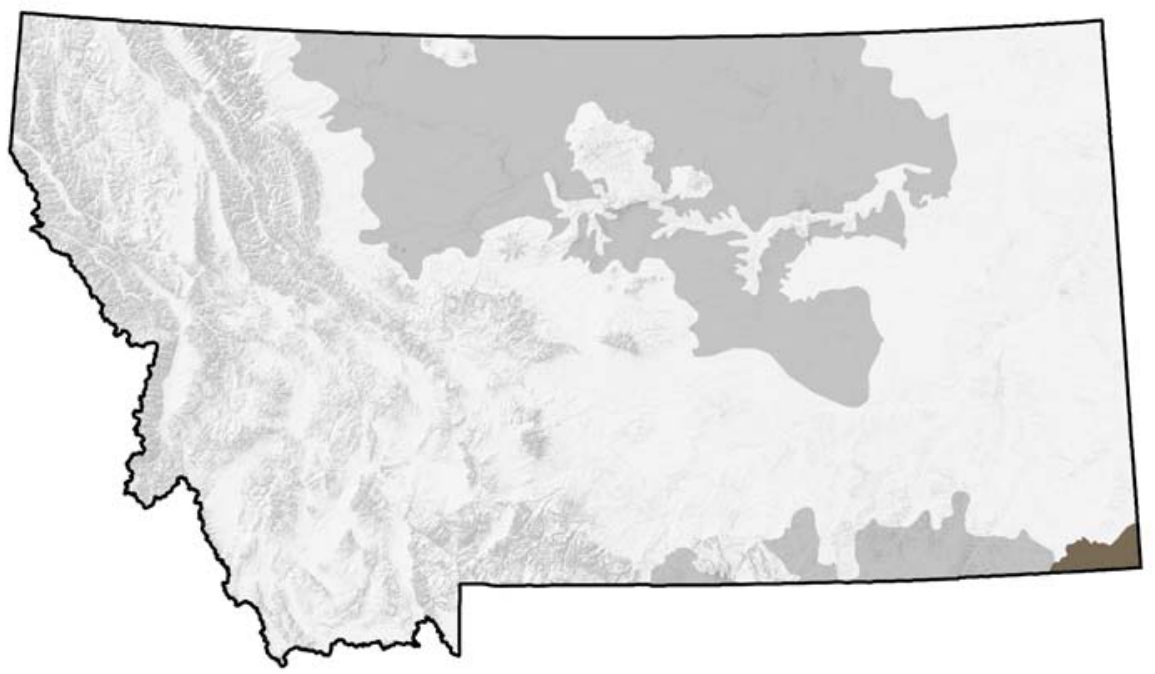

Figure 34. Shale Scablands Focus Area

This very dry area is covered mostly by sagebrush grassland that is intersected with woody draws. The species that make up the woody draws are mostly green ash, buffaloberry, chockcherry and some juniper.

\section{Landscape Characteristics}

This section is dissected shale plains formed in calcareous shale, claystone, and sandstone. Elevations range from 2,650 to 4,100 feet. Drainage density is high. Mean annual precipitation ranges from 11 to 15 inches, about 20 percent falling as snow. The soil temperature and moisture regimes are frigid and aridic ustic. The primary natural disturbance is drought. Land use is predominantly livestock grazing. The breakdown for land stewardship in the shale scablands is as follows:

U.S. Federal Agencies: $\quad 126,889$ acres, which include:

BLM:

126,889 acres

State Agencies:

21,992 acres

Private:

268,295 acres

\section{Associated Habitats}

\begin{tabular}{ccc}
\hline Habitat & Habitat Tier & Percentage of Area \\
\hline Mixed Broadleaf Forest & $\mathrm{I}$ & 2.22 \\
Mesic Shrub-grassland Associations & $\mathrm{I}$ & 3.01 \\
Low Density Xeric Forest & $\mathrm{II}$ & 3.17 \\
Moderate/ High Cover Grasslands & $\mathrm{I}$ & 3.47 \\
\hline
\end{tabular}


DRAFT WORKING DOCUMENT DO NOT DUPLICATE

\begin{tabular}{ccc}
\hline Rock & III & 4.40 \\
Mixed Mesic Shrubs & II & 4.60 \\
Mixed Xeric Shrubs & I & 5.42 \\
Very Low Cover Grasslands & I & 5.49 \\
Badlands & II & 7.60 \\
Wetland \& Riparian & I & 8.50 \\
Salt-desert Shrub/ Dry Salt Flats & I & 8.56 \\
Low/ Moderate Cover Grasslands & I & 13.01 \\
Sagebrush & I & 25.05 \\
\hline
\end{tabular}

4799

4800

4801

4802

4803

4804

4805

4806

4807

4808

4809

4810

4811

4812

4813

4814

4815

4816

4817

4818

4819

4820

4821

4822

4823

4824

4825

4826

4827

4828

4829

4830

4831

4832

4833

4834

4835

Note: A total of $94.52 \%$ of the Shale Scablands area is represented. $5.48 \%$ is made up of a combination of other habitat types.

\section{Associated Species of Greatest Conservation Need}

There are a total of 246 terrestrial vertebrate species that are found within the Shale Scablands Focus Area. All associations can be found within Table 38.

Amphibians: Northern Leopard Frog

Birds: Common Loon, Bald Eagle, Sage-grouse, Whooping Crane, Mountain Plover, Long-billed Curlew, Black Tern, and Burrowing Owl,

Mammals: Townsend's Big-eared Bat, Black-tailed Prairie Dog, Hispid Pocket Mouse, Meadow Jumping Mouse, and Black-footed Ferret

Reptiles: Snapping Turtle, Spiny Softshell, Western Hognose Snake, and Milk Snake

\section{Conservation Concerns}

- Unsustainable domestic livestock grazing practices

- Loss of natural fire regime

- Invasive or exotic species

- Loss of habitat as a result of conversion to agriculture

\section{Conservation Strategies}

- Government and private conservation programs/activities that encourage and support private land stewardship

- Policy-based approaches that encourage the conservation of natural communities, rather than support their conversion

- Increased efforts to maintain ecological features (i.e. black-tailed prairie dog colonies) or processes (i.e. fire) on public lands as they disappear from private lands.

- Cooperative efforts to reduce the abundance of exotic species 


\section{DRAFT WORKING DOCUMENT DO NOT DUPLICATE}

4836

4837 References

4838

4839 The Nature Conservancy. 1999. Ecoregional Conservation in the Northern Great

4840 Plains Steppe. Northern Great Plains Steppe Ecoregional Planning Team. 76

4841 pgs.

4842

4843 
4843

4844

4845

4846

4847 4848 4849 4850 4851 4852 4853 4854 4855 4856 4857 4858 4859 4860

\section{Aquatic Conservation Focus Areas in Greatest Need (Tier I)}

Middle Missouri River (540 River Miles)

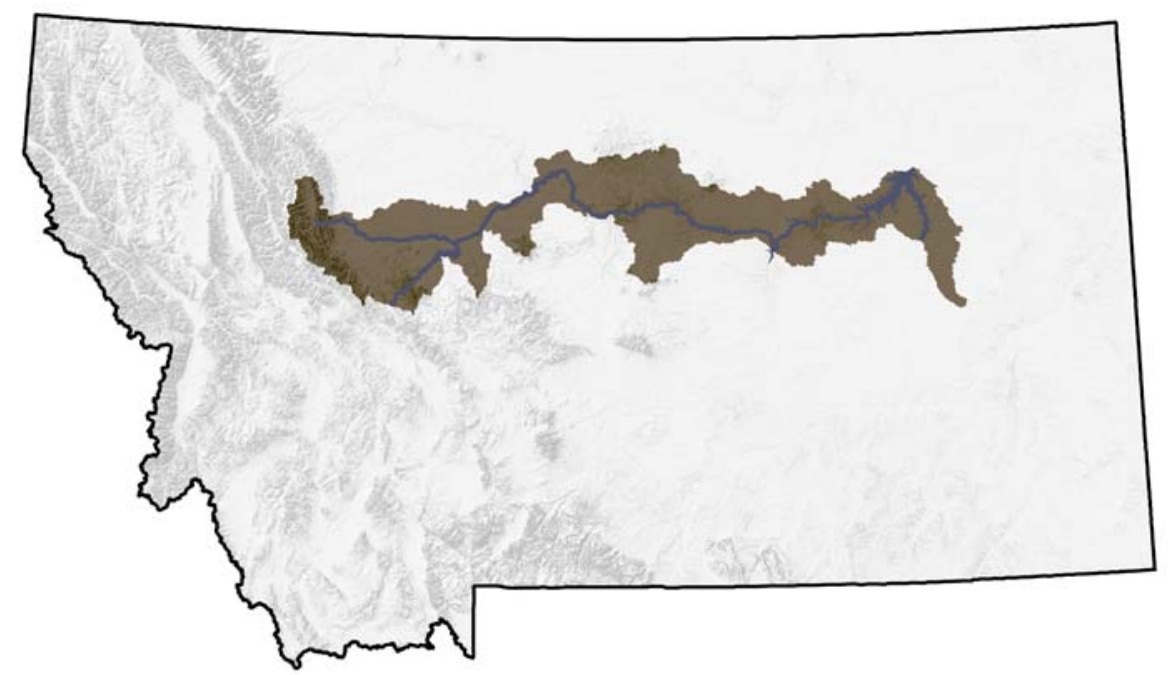

Figure 35. Middle Missouri River and Tributaries Focus Area

Once the Missouri River reaches the confluence with Hardy Creek, it becomes wide and slow for the next 60 miles and then turns into whitewater as it flows over the falls at Great Falls. Although dams have effectively covered the falls, the original cascade posed a tremendous obstacle for Lewis and Clark. From here down stream for more than two hundred miles to Fort Peck Reservoir is the longest free flowing section of the entire Missouri River. One hundred and fifty miles of this has been designated as Wild and Scenic and flows through cottonwood forests and canyons.

\section{Associated Habitats}

\begin{tabular}{cccc}
\hline Habitat Type & Habitat Tier & Acres & Miles \\
\hline Intermountain Valley Streams & II & & 2170 \\
Lowland Lakes & III & 281756 & \\
Lowland Reservoirs & III & 4505 & \\
Mixed Source Rivers & & & \\
(Intermountain and Prairie Flow) & II & & 438 \\
Mountain Lakes & III & 1139 & \\
Mountain Reservoirs & III & 1445 & \\
Mountain Streams & I & & 2289 \\
Prairie Rivers & II & & 148 \\
Prairie Streams & I & & 8909 \\
\hline
\end{tabular}




\section{DRAFT WORKING DOCUMENT DO NOT DUPLICATE}

4862

4863

4864

4865

4866

4867

4868

4869

4870

4871

4872

4873

4874

4875

4876

4877

4878

4879

4880

4881

4882

4883

4884

4885

4886

4887

4888

4889

4890

4891

4892

4893

4894

4895

4896

4897

4898

4899

4900

4901

4902

4903

4904

4905

\section{Associated Species of Greatest Conservation Need}

There are a total of 67 aquatic species that are found within the Middle Missouri

River and Tributaries Focus Area. All associations can be found within Table 39.

Fish: Pallid Sturgeon, Paddlefish, Shortnose Gar, Sturgeon Chub, Sicklefin Chub, Blue Sucker, Burbot, and Sauger

\section{Conservation Concerns}

- Culverts, dams, irrigation diversions or other instream barriers that fully or partially impede fish movement and reduce connectivity of habitat

- Modification and degradation of stream channels caused by various construction or land management practices

- Degradation of riparian vegetation caused by various land management practices. Such activities de-stabilize streambanks, increase sediment inputs, and reduce shading

- Entrainment of juvenile and adult fishes by irrigation diversion or other water intakes

- Alterations of the quantity or timing of streamflows causing dewatering or unnatural flow fluctuations that diminish the quantity or quality of essential habitats

- Unnatural hydrograph and water temperatures associated with presence and operations of large dams, as well as blockage of migratory corridors

- Unnatural cool, clear water such as occurs below primarystem dams can adversely affect native fish populations

- Water chemistry problems can arise due to municipal discharge, irrigation return water, the discharge of waste water from coal bed methane operations, and other sources

\section{Conservation Strategies}

- Removal or modification of barriers in a manner that restores fish passage

- Augment in-stream flows through leases and water conservation measures

- Restoration of stream channels or stream banks to a condition that simulates their natural form and function

- Modification of riparian management practices such that riparian vegetation is allowed to recover

- Screening or modification of irrigation diversions or other water intakes in a manner that prevents entrainment of fishes

- Implementation of various water conservation or flow management practices that restore essential habitats and simulate the natural hydrograph 


\section{DRAFT WORKING DOCUMENT DO NOT DUPLICATE}

4906

4907

4908

- To the extent feasible, operate dams to mimic a more natural hydrograph

4909

4910 References

4911

4912 


\section{Component II: Community Types of Greatest} 4913 Conservation Need

4914

4915

4916

4917

4918

4919

4920

4921

4922

4923

4924

4925

4926

4927

4928

4929

4930

4931

4932

4933

4934

4935

4936

4937

4938

4939

4940
"This is a high leverage strategy to address the conservation concerns of whole ecological communities or species groupings. Implementing conservation strategies at this level will comprehensively benefit many fish and wildlife species."

Fish and wildlife communities have not been formally defined for Montana's complex biological systems. For this Strategy, landscape characteristics, vegetative cover type, and associated fish and wildlife species were linked in order to begin describing community types. Future efforts to provide complete classifications of Montana's fish and wildlife communities will be critical for implementing this Strategy and monitoring conservation success.

Conservation at the community level provides potential to leverage conservation resources to benefit large numbers of species. Community types also provide a way to associate numerous species through common habitat requirements. These communities of plants and animals often face similar conservation concerns that can be addressed simultaneously. In the focus area component of this Strategy, geographic areas were identified that offer some of the greatest potential to conserve the community types and species in greatest need of conservation. The following community types have been identified as Tier I (in greatest need of conservation) and efforts to conserve them should not be limited to the focus areas identified in Component I. Efforts should be made to address the conservation Strategies identified for these community types across the state regardless of where they occur. 
4940 Grassland Complexes (31,551,627 acres or $33.53 \%$ of Montana)

4941

4942

4943

4944

4945

4946

4947

4948

4949

4950

4951

4952

4953

4954

4955

4956

4957

4958

4959

4960

4961

4962

4963

4964

4965

4966

4967

4968

4969

4970

4971

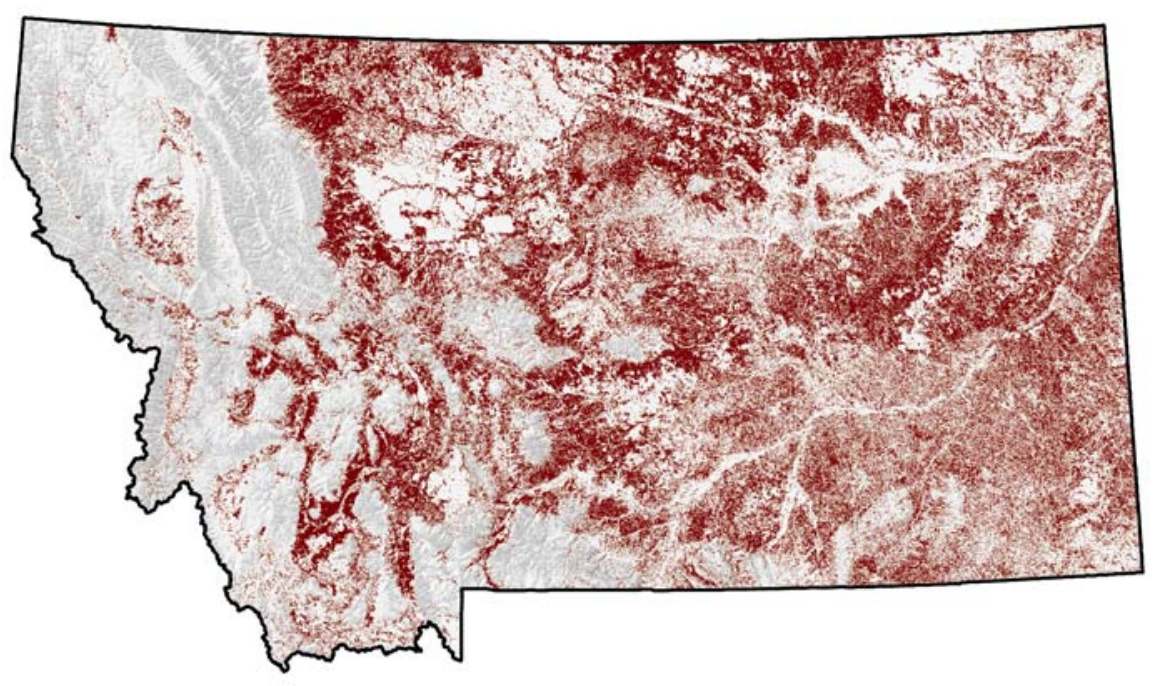

Figure 37. Distribution of Grassland Community Types

Grassland communities occur in broad western mountain valleys, high mountain meadows, and on the plains of eastern Montana. Very low to high cover grasses are characteristic of these areas and this array of grass types are found in open lands and often interspersed among shrubs. This community type is essentially associated with more terrestrial species in greatest need of conservation than any other community type in Montana.

Grassland habitats are difficult to meaningfully differentiate using only remotely sensed data like the GAP mapping. Types based on the relative cover of grass are not ecologically based or directly related to habitat conditions. Descriptions of GAP grassland types are very broad and include some species that are not common in Montana or do not occur together. A classification and mapping system that incorporates ecological data and is associated with a recognized vegetation classification like the National Vegetation Classification System will have greater management applicability in the future and should be supported.

Very low cover grasslands occur primarily in central and eastern Montana valleys. Semi-desert grasslands with total grass cover from 10-30\% cover. Dominated by short grasses and forbs. Typically has a high amount of bare soil (20-60\% cover). Grasslands with production ranges of 50-300 lb/ac. usually associated with alkaline soils and/or disturbed sites. Low/Moderate cover grasslands occur across the state in valleys and foothills. Occurs on middle to high elevation mountain slopes on south aspects. Low to moderate cover grasslands with total grass cover from 20-70\%. Dominated by short to medium height grasses and forbs. Grasslands with production ranges from 300-1800 $\mathrm{lb} / \mathrm{ac}$. Includes rangelands and non-irrigated pastures. Moderate to high cover grasslands include total grass cover from $50-100 \%$. Dominated by medium to tall 
4972 grasses in prairie areas. Grasslands with production ranges from 1000-7000

4973 Ib/ac. Moderate/High cover grasslands are associated with wet sites.

4974

4975

4976

4977

Essential Associated Plant Community

4978

Arrowleaf Balsamroot (Balsamorhiza sagittata)

4979

4980

4981

4982

4983

Big Bluestem (Andropogon gerardii)

Bluebunch Wheatgrass (Agropyron spictatum)

Blue grama (Bouteloua gracilis)

Bluestem (Andropogon spp.)

Carex species (Carex spp.)

4984

4985

4986

Clubmoss (Selaginella densa)

Elk Sedge (Carex gereyi)

Green Needlegrass (Stipa viridula)

4987

Hood's Phlox (Phylox hoodii)

4988

Idaho Fescue (Festuca idahoensis)

4989

4990

Indian grass (Sorghum nutans)

Little Bluestem (Andropogon scoparium)

Lupine (Lupinus spp.)

4991

4992

Missouri Goldenrod (Solidago missouriense)

4993 Prairie June grass (Koeleria spp.)

4994 Prairie Sandreed (Calamovilfa longifolia)

4995 Rough Fescue (Festuca scabrella)

4996

4997

Sandberg's bluegrass (Poa sandbergii)

4998

4999

Sun Sedge (Carex heliophila)

Switchgrass (Panicum virgatum)

5000

Threadleaf Sedge (Carex filifolia)

5001

Timothy (Phleum pratensis)

5002

5003

5004

5005

Western Wheatgrass (Agropyron smithii)

5006

5007

\section{Associated Species of Greatest Conservation Need}

5008

5009

5010

5011

5012

There are a total of 364 terrestrial vertebrate species that are found within the Grassland Complexes Community Type, with 202 of these species being essentially associated. These species will be bolded to denote essentially associated. All associations can be found within Table 40 .

\section{Amphibians: Boreal Toad and Northern Leopard Frog}

5013

5014

5015

5016

Birds: Trumpeter Swan, Sage-grouse, Columbia Sharp-tailed Grouse, Yellow Rail, Whooping Crane, Piping Plover, Mountain Plover, Long-billed Curlew, Black Tern, Flammulated Owl, Burrowing Owl, Sedge Wren, and Nelson's Sharp-tailed Sparrow 
5017 Mammals: Spotted Bat, Townsend's Big-eared Bat, Pallid Bat, Pygmy

5018 Rabbit, Black-tailed Prairie Dog, White-tailed Prairie Dog, Great Basin Pocket

5019 Mouse, Meadow Jumping Mouse, Grizzly Bear, Black-footed Ferret, Lynx, 5020 and American Bison

5021

5022

5023

5024

5025

5026

5027

5028

5029

5030

5031

5032

5033

5034

5035

5036

5037

5038

5039

5040

5041

5042

5043

5044

5045

5046

5047

5048

5049

5050

5051

5052

5053

5054

5055

5056

5057

Reptiles: Snapping Turtle, Spiny Softshell, Western Hognose Snake, Milk Snake, and Smooth Green Snake

\section{Conservation Concerns}

- Spread of noxious weeds and nonnative plants, especially knapweed and leafy spurge

- Oil, gas, geothermal and coal extraction and development

- Impacts from recreational use

- Fragmentation and loss due to agricultural and subdivision development

- Unsustainable grazing, \& residual effects from herbicide spraying

\section{Conservation Strategies}

- Incentives and education for private landowners to protect natural habitat

- Prevent the introduction and spread of noxious weeds on existing tracts of palouse prairie

- Reestablish fire regime

- Conservation easements or other protection of natural habitat to provide large blocks of short grass types in a diverse mosaic of habitats

- Maintain the appropriate species composition, vertical and horizontal structure on existing tracts by developing appropriate grazing strategies

- Restore areas infested with the highly flammable, invasive cheatgrass, returning them to native grasses and forbs

- Monitor leasing and development decisions and regulations applying to geophysical exploration

- Work with the poublic to establish sustainable recreation management practices, including designations of lands open, limited, or closed to offroad vehicle use

\section{References}

Casey, D. 2000. Partners in Flight Bird Conservation Plan Montana Version 1.0. Montana Partners in Flight. Kalispell, Montana.

5058

5059

Conservation Management of America's Public Lands: An Assessment and 5060 Recommendations for Progress 25 Years after FLPMA. 2001. National Wildlife Federation and the Natural Resources Defense Council. 


\section{DRAFT WORKING DOCUMENT DO NOT DUPLICATE}

5061 Ostlie, W.R, R. E. Schneider, J. M. Aldrich, T. M. Faust, R. L. B. McKim and S. J. 5062 Chaplin. 1997. The status of biodiversity in the Great Plains. The Nature 5063 Conservancy, Arlington, VA, USA. 326 pp + XII.

5064

5065 Statewide Habitat Plan. 1994. Implementation of Fish, Wildlife \& Parks

5066 Commission. Habitat Montana Policy.

5067

5068 


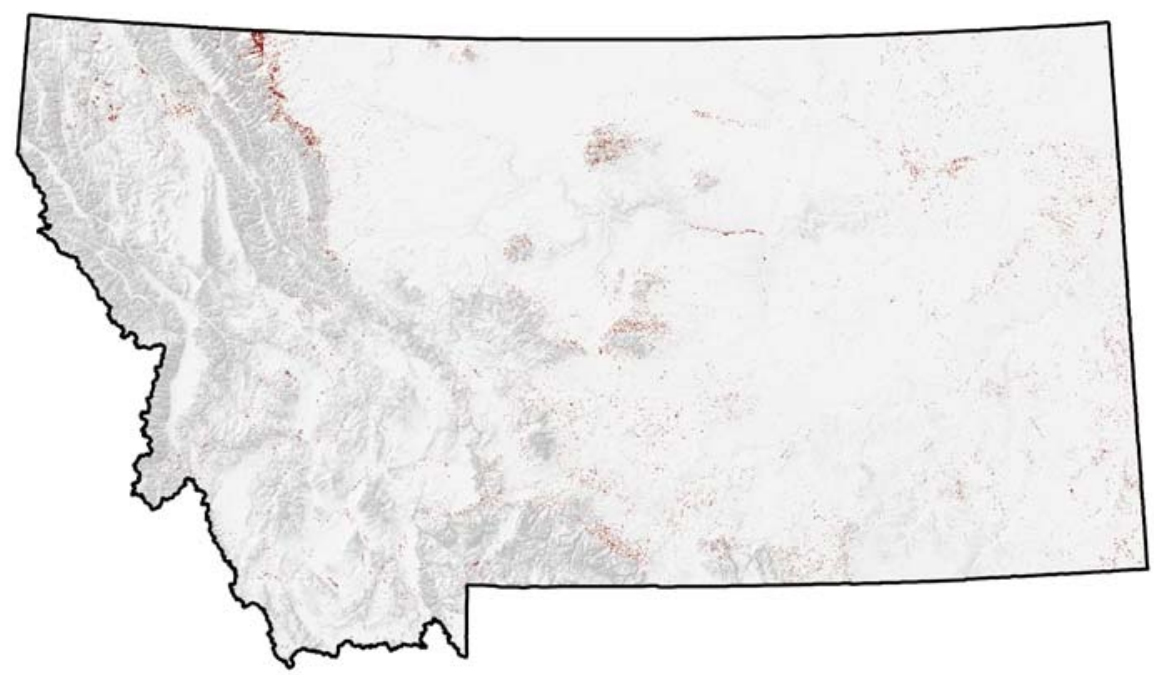

5070

5071

5072

5073

5074

5075

5076

5077

5078

5079

5080

5081

5082

5083

5084

5085

5086

5087

5088

5089

5090

5091

5092

5093

5094

5095

5096

5097

5098

5099

Figure 37. Distribution of Mixed Broadleaf Forest Community Types

\section{Aspen Galleries}

Galleries often occur within grassland openings or along the border between grasslands openings and coniferous forests. When mature, these galleries often support native tall-grass or mixed-grass prairie plants. When occurring in lowland areas, they are often home to wet meadow species or may contain small wetlands. Sunlight passes easily through the canopy of healthy, mature aspen galleries, promoting understory growth of a rich variety of grasses, wildflowers and sometimes shrubs. In combination, this complex of trees, grasses and shrubs provide unique foods (including seeds, berries or nuts) for an equally diverse array of wildlife.

\section{Woody Draws}

Draws are prominent features across eastern Montana. A much drier, upland environment often surrounds these more diverse dry streambed type areas. Water is not present long enough each year in order to classify them as a wetlands but they are characterized by a greater diversity and density of vegetation that serves a similar function. Woody draws provide essential cover, food and water for many wildlife species in Eastern Montana that otherwise would not exist. The woody draws are ribbons of life throughout eastern Montana that support some of the highest concentrations of wildlife in the area. Information exists that indicates woody draws are declining throughout the Northern Great Plains (Lesica 2005). Conserving these draws will depend on the success of green ash, the dominant plant species in most stands.

\section{Essential Associated Plant Community}




\section{DRAFT WORKING DOCUMENT DO NOT DUPLICATE}

5100

5101

5102

5103

5104

5105

5106

5107

5108

5109

5110

5111

5112

5113

5114

5115

5116

5117

5118

5119

5120

5121

5122

5123

5124

5125

5126

5127

5128

5129

5130

5131

5132

5133

5134

5135

5136

5137

5138

5139

5140

5141

5142

5143

5144

5145

Aspen (Populus tremuloides)

Basswood (Tilia americana)

Birch (Betula spp.)

Bur Oak (Quercus macrocarpa)

Green Ash (Fraxinus pennsylvanica)

Plains Cottonwood (Populus deltoides)

There are a total of 26 terrestrial vertebrate species that are found within the Mixed Broadleaf Forests Community Type, with 5 of these species being essentially associated. All associations can be found within Table 41.

\section{Conservation Concerns}

- Unsustainable grazing practices, clearing for agricultural use, and loss of habitat due to human population growth

- Altered natural fire regime

- Flood control and channelization through rip-rapping and other means

- Culverts, dams, irrigation diversions or other instream barriers that fully or partially impede movement of species and reduce connectivity of habitat

- Unsustainable harvest of older cottonwoods for lumber or pulp

- Encroachment by conifers and herbivory from wild and domestic herbivores on aspen galleries

- Unsustainable grazing by wild and domestic herbivores in woody draws

\section{Conservation Strategies}

- Re-establish fire regime in aspen galleries

- Woody draws should be managed to preserve mature trees and snags

- Work with agency or private land conservation efforts to place easements on, or implement for the most integral aspens found in forested and riparian habitats

- Work with landowners to improve grazing practices

- Maintain and recruit old growth trees for snags used by cavity nesting species

- Support initiatives to re-establish or maintain green ash in woody draws

\section{References}

Bartos, Dale L. and Campbell, Robert B. February, 1998. Decline of Quaking Aspen in the Interior West-Examples from Utah. Rangelands. Vol. 20, No. 1

Casey, D. 2000. Partners in Flight Bird Conservation Plan Montana Version 1.0. Montana Partners in Flight. Kalispell, Montana.

Elis, Janet H., Richard, Jim. A planning guide for protecting Montana's wetlands 


\section{DRAFT WORKING DOCUMENT DO NOT DUPLICATE}

5146 riparian areas. Montana Watercourse, Montana Department of Environmental

5147 Quality and Montana The Audubon Society.

5148

5149 Kootenai Tribe of Idaho and Montana Fish, Wildlife \& Parks. 2004. Public Review

5150 Draft Kootenai Subbasin Plan. Executive Summary. Report prepared for the

5151 Northwest Power and Conservation Council. Portland, OR.

5152

5153 Hansen, A., Rotella, J., Klass, L., Gyskiewicz, D. 2003. Riparian habitat

5154 Dynamics and wildlife along the Upper Yellowstone River. Technical Report \#1.

5155 Landscape Biodiversity Lab, Montana State University, Bozeman, MT. In

5156 cooperation with The Governor's Upper Yellowstone River Task Force.

5157

5158

5159

5160

5161

5162

5163

Lesica. 2005. Restoring Green Ash Regeneration from seed in declining hardwood draws. Unpublished.

5164

Statewide Habitat Plan. 1994. Implementation of Fish, Wildlife \& Parks

Commission. Habitat Montana Policy. 


\section{Mixed Shrub/Grass Associations (4,159,693 acres or 5.34\% of 5165 Montana)}

5167

5170

5171

5172

5173

5174

5175

5176

5177

5178

5179

5180

5181

5182

5183

5184

5185

5186

5187

5188

5189

5190

5191

5192

5193

5194

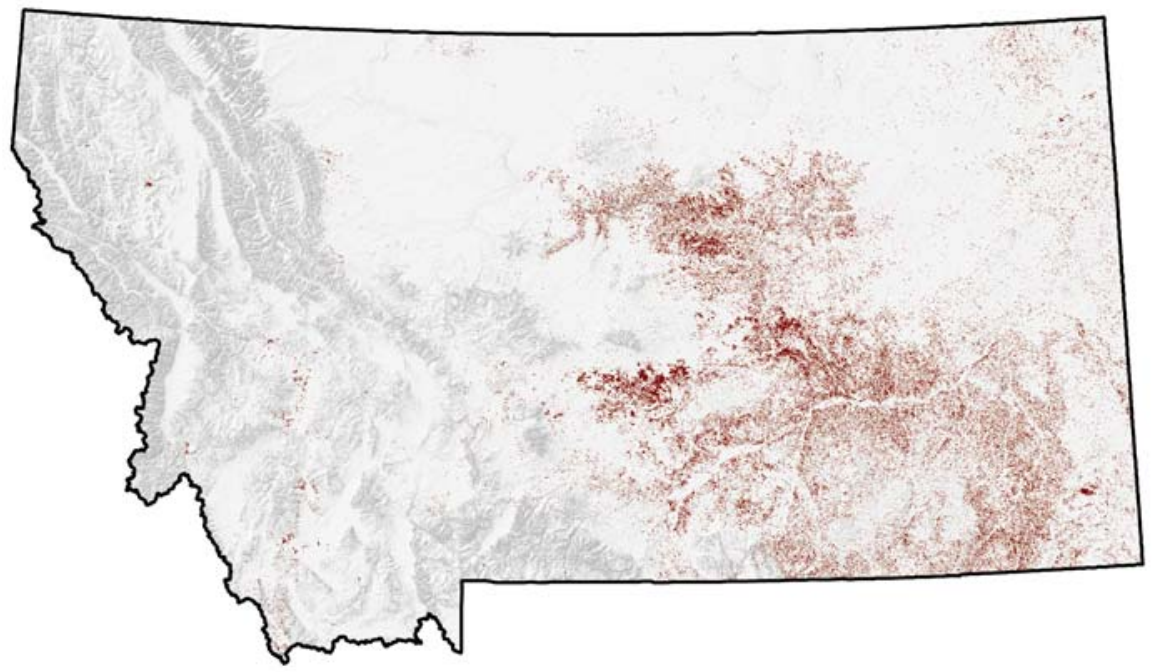

Figure 38. Distribution of Mixed Shrub/Grass Associations Community Types

The mixed shrub/grass associations community types include the shrubdominated areas that also support grass. These types can be either moist (mesic) or dry (xeric) but usually occur at low elevation and often along lower slopes. These communities are the transition between pure shrub and grass communities and support a very unique assembly of associated species.

\section{Mesic}

Occurs primarily in central and eastern Montana valleys and along some low mountain slopes. Mesic shrub-grassland associations occur with codominance between the shrub and grass species. Shrub and grass cover ranges from 10$50 \%$. It is found on moist sites usually between pure grass or shrub-dominated regions.

\section{Essential Associated Plant Community}

\section{Grass}

Bluebunch Wheatgrass (Agropyron spictatum)

Bluestem (Andropogon spp.)

Fescue (Festuca spp.)

Needle \& Thread grass (Stipa comata)

Threadleaf Sedge (Carex filifolia)

Western Wheatgrass (Agropyron smithii) 


\section{Shrubs}

5196

5197 Buffalo Berry (Shepherdia argentea)

5198 Choke Cherry (Prunus virginiana)

5199 Silver Sage (Artemisia cana)

5200 Snowberry (Symphoricarpos spp.)

5201 Sumac (Rhus spp.)

5202

5203

Xeric

5204

5205

Occurs primarily in central and eastern Montana valleys and along some low

5206 mountain slopes. Xeric shrub-grassland associations occur with codominance between the shrub and grass species. Shrub and grass cover ranges from 10$50 \%$. Found on dry sites in valleys and is usually between grass dominated and shrub dominated regions.

5210

5211

5212

5213

5214

5215

5216

5217

5218

5219

5220

5221

5222

5223

5224

5225

5226

5227

5228

5229

5230

5231

5232

5233

5234

5235

5236

5237

5238

5239

5240

\section{Essential Associated Plant Community}

\section{Grass}

Blue grama (Bouteloua gracilis)

Bluebunch Wheatgrass (Agropyron spictatum)

Bluestem (Andropogon spp.)

Fescue (Festuca spp.)

Needle \& Thread grass (Stipa comata)

Western Wheatgrass (Agropyron smithii)

\section{Shrubs}

Rabbitbrush (chrysothamnus spp.)

Sagebrush (Artemisia spp.)

\section{Associated Species of Greatest Conservation Need}

There are a total of 39 terrestrial vertebrate species that are found within the Mixed Shrub/Grass Associations Community Type, with 10 of these species being essentially associated. These species will be bolded to denote essentially associated. All associations can be found within Table 42 .

Birds: Sage-grouse, Mountain Plover, and Burrowing Owl

Mammals: Spotted Bat and Black-tailed Prairie Dog

Reptiles: Western Hognose Snake and Milk Snake

\section{Conservation Concerns}


5241

5242

5243

5244

5245

5246

5247

5248

5249

5250

5251

5252

5253

5254

5255

5256

5257

5258

5259

5260

5261

5262

5263

5264

5265

5266

5267

5268

5269

5270

5271

5272

5273

5274
- Loss of habitat due to conversion of native habitat to agriculture or as a result of human population growth/development

- Invasive species and potential for spreading

- Unsustainable grazing practices \& residual effects of herbicide spraying

- Oil, gas, coal, coalbed methane and geothermal development

\section{Conservation Strategies}

- Work with off-road vehicle users to help reduce spread of invasive weeds

- Promote grazing plans that encourage a mosaic of sagebrush, native grasses and forbs

- Create a stable native seed source for sage grasslands restoration after fires

- Support private land easements that protect natural habitat to provide large blocks of a diverse mosaic of habitats

- Incentives and education for private landowners to protect natural habitat

- Monitor leasing and development decisions and regulations applying to geophysical exploration

\section{References}

Casey, D. 2000. Partners in Flight Bird Conservation Plan Montana Version 1.0. Montana Partners in Flight. Kalispell, Montana.

Conservation Management of America's Public Lands: An Assessment and Recommendations for Progress 25 Years after FLPMA. 2001. National Wildlife Federation and the Natural Resources Defense Council.

Ostlie, W.R, R. E. Schneider, J. M. Aldrich, T. M. Faust, R. L. B. McKim and S. J. Chaplin. 1997. The status of biodiversity in the Great Plains. The Nature Conservancy, Arlington, VA, USA. 326 pp + XII. 
5276

5277

5278

5279

5280

5281

5282

5283

5284

5285

5286

5287

5288

5289

5290

5291

5292

5293

5294

5295

5296

5297

5298

5299

5300

5301

5302

5303

5304

5305

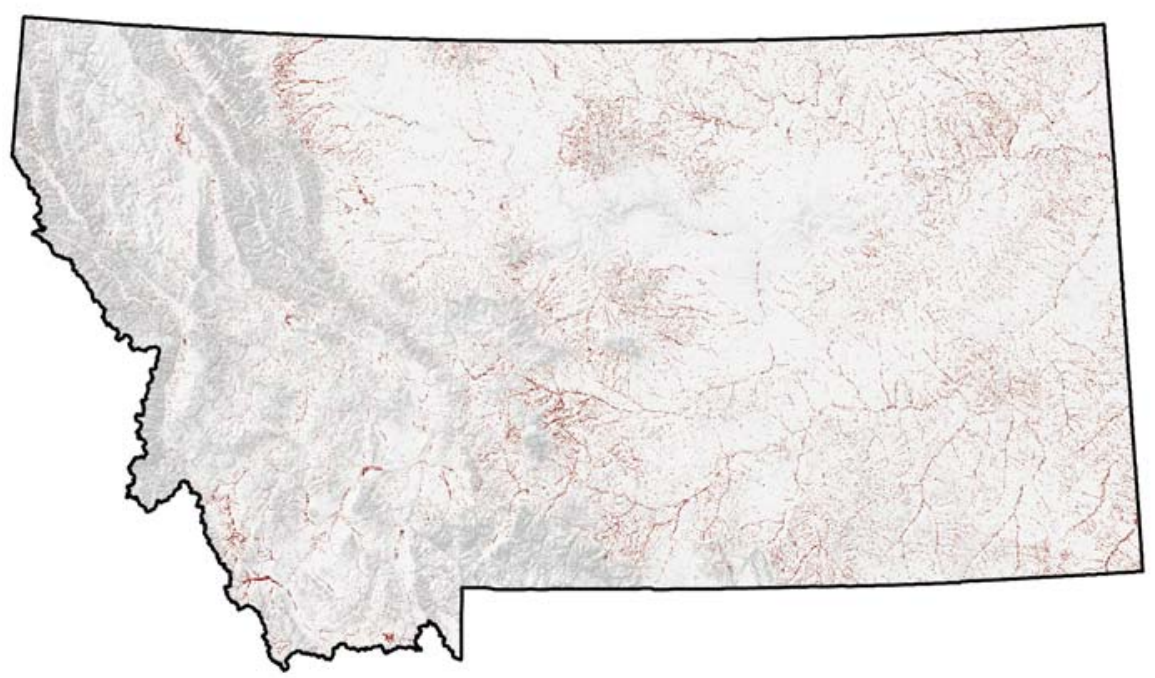

Figure 39. Distribution of Wetland and Riparian Community Types

Montana's riparian and wetland communities vary widely depending on the area of the state and elevation where they are located, but generally they represent the green zones along, rivers, streams, lakes and reservoirs and include potholes, wet meadows, marshes and bogs. This community type also includes the cottonwood forests that occur throughout Montana. Cottonwood stands develop in river and stream corridors on alluvial bars created by dynamic flows of spring run-off and mature into forests that eventually alter the direction of water flow. These stands, including Great Plains or Black cottonwoods, help stabilize banks, keep waters cool in summer, and their associated plants support diverse wildlife species. As a result of the adjacent water and diverse vegetation, these communities support the greatest concentration of plants and animals in Montana and serve as a unique transition zone between the aquatic and the terrestrial environments.

Riparian and wetland communities often occur as narrow linear bands or small depressions that are not recognized at the scale of the GAP mapping used in this analysis. More accurate and inclusive knowledge of riparian/wetland locations and types will be available if National Wetlands Inventory mapping or a similar product is completed for Montana. These types of efforts should be supported in order to improve future revisions of this Strategy.

\section{Conifer Riparian}

Occurs in riparian areas in western and south-central Montana. Riparian areas dominated by conifer forest, with total tree cover from 20-100\%. Associated shrub species: alder (Alnus spp), red-osier dogwood (cornus stolonifera), bunchberry (Cornus canadensis), willows (Salix spp.), thimbleberry (Rubus 


\section{DRAFT WORKING DOCUMENT DO NOT DUPLICATE}

5306 parviflorum), twin flower (Linnaea borealis). Associated grass and forb species:

5307 queens cup beadlily (Clintonia uniflora).

5308

5309

5310

5311

5312

5313

5314

5315

5316

5317

5318

5319

5320

5321

5322

5323

5324

5325

5326

5327

5328

5329

5330

5331

5332

5333

5334

5335

5336

5337

5338

5339

5340

5341

5342

5343

5344

5345

5346

5347

5348

5349

5350

Essential Associated Plant Community

Douglas-fir (Pseudotsuga menziesii)

Engelmann Spruce (Picea engelmannii)

Grand Fir (Abies grandis)

Red-osier Dogwood (Cornus stolonifera)

Subalpine Fir (Abies lasiocarpa)

Western Hemlock (Tsuga heterophylla)

Western Red Cedar (Thuja plicata)

\section{Broadleaf Riparian}

Occurs in riparian areas across Montana. Riparian areas dominated by broadleaf (cottonwood) forest, with total tree cover from 20-100\%. Associated shrub species: alder (Alnus spp), bunchberry (Cornus canadensis), serviceberry (Amelanchier alnifolia), thimbleberry (Rubus parviflorum), common chokecherry (Prunus virginiana), and willow (Salix spp). Associated grass and forb species: queens cup beadlily (Clintonia uniflora), carex (Carex spp). Mixed

\section{Essential Associated Plant Community}

Aspen (Populus tremuloides)

Basswood (Tilia americana)

Birch (Betula spp.)

Black Cottonwood (Populus trichocarpa)

Bur Oak (Quercus macrocarpa)

Green Ash (Fraxinus pennsylvanica)

Plains Cottonwood (Populus deltoides)

\section{Broadleaf \& Conifer Riparian}

Occurs in riparian areas in western and south-central Montana. Riparian areas dominated by mixed broadleaf (cottonwood) and conifer forest, with total tree cover from 20-100\%. Associated shrub species: alder (Alnus spp), bunchberry (Cornus canadensis), serviceberry (Amelanchier alnifolia), thimbleberry (Rubus parviflorum) and willow (Salix spp). Associated grass and forb species: queens cup beadlily (Clintonia uniflora), carex (Carex spp).

\section{Essential Associated Plant Community}

Aspen (Populus tremuloides)

5351 Black Cottonwood (Populus trichocarpa) 
5352 Grand Fir (Abies grandis)

5353 Douglas-fir (Pseudotsuga menziesii)

5354 Engelmann Spruce (Picea engelmannii)

5355 Subalpine Fir (Abies lasiocarpa)

5356 Western Larch (Larix occidentalis)

5357 Western Hemlock (Tsuga heterophylla)

5358 Western Red Cedar (Thuja plicata)

5359

5360

5361

5362

5363

5364

5365

5366

5367

5368

5369

5370

5371

5372

5373

5374

5375

5376

5377

5378

5379

Graminoid \& Forb Riparian

Occurs in riparian areas across the state. Riparian areas dominated by herbaceous species, with total herbaceous cover 30-100\%. Riparian areas with tree and shrub cover less than $15 \%$. Standing water may be present in the riparian area (cattail marshes).

5380

5381

5382

5383

5384

5385

Essential Associated Plant Community

Baltic Rush (Juncus balticus)

Bluejoint Reedgrass (Calamagrostis canadensis)

Bog Sedge (Carex rostrata)

Cinquefoil (Potentilla spp)

Cattails (Typha spp)

Lake Sedge (Carex lacustris)

Maritime Sedge (Carex incurviformis)

Northern Reedgrass (Calamagrostis inexpensa)

Rushes (Juncus spp)

Saxifrage (Saxifraga spp)

Sedges (Carex spp)

Tufted Hairgrass (Deschampsia cespitosa)

5386

5387

5388

5389

5390

5391

5392

5393

5394

5395

\section{Shrub Riparian}

Occurs in riparian areas across the state. Riparian areas dominated by shrubs, with total shrub cover from $20-100 \%$. Tree cover is less than $15 \%$ and shrubs dominate over the herbaceous species. Standing water may be present in the riparian area (willow marshes).

\section{Essential Associated Plant Community}

5396 Red-osier Dogwood (Corus stolonifera)

5397 Rose (Rosa spp) 
5398 Shrubby Cinquefoil (Potentilla fruticosa)

5399 Silver Sage (Artemisia cana)

5400 Snowberry (Symphorcarpos spp)

5401 Thimbleberry (Rubus parviflorum)

5402 Twin-berry (Lonicera involucrata)

5403 Utah Honeysuckle (Lonicera spp)

5404 Water Birch (Betula occidentalis)

5405 Willows (Salix spp)

5406

5407

5408

5409

5410

5411

5412

5413

5414

5415

5416

5417

5418

5419

5420

5421

5422

5423

5424

5425

5426

5427

5428

5429

5430

5431

5432

5433

5434

5435

5436

5437

5438

5439

5440

5441

5442

5443

5444

\section{Mixed Riparian}

Occurs in riparian areas across the state. Riparian areas dominated by a mix of shrub and herbaceous species, with codominance of shrub and grass species present. Tree cover is less than $15 \%$.

\section{Essential Associated Plant Community}

Grass species (see Graminoid \& Forb Riparian species)

Shrub species (see Shrub Riparian species)

\section{Associated Species of Greatest Conservation Need}

There are a total of 265 terrestrial vertebrate species that are found within the Riparian \& Wetlands Community Type, with 193 of these species being essentially associated. These species will be bolded to denote essentially associated. All associations can be found within Table 43.

\section{Amphibians: Coeur D'Alene Salamander, Boreal Toad and Northern Leopard Frog}

Birds: Common Loon, Trumpeter Swan, Harlequin Duck, Bald Eagle, Yellow Rail, Piping Plover, Least Tern, Black Tern, Sedge Wren, and Nelson's Sharp-tailed Sparrow

Mammals: Townsend's Big-eared Bat, Pygmy Rabbit, Northern Bog Lemming, and Meadow Jumping Mouse

Reptiles: Snapping Turtle, Spiny Softshell, and Western Hognose Snake

\section{Conservation Concerns}

- Draining and conversion of wetlands to agricultural cropland or subdivisions

- Degradation of uplands due to unsustainable grazing or industrial use

- Contaminated runoff from agriculture in wetlands \& riparian areas

- Invasion by exotic plants

- Unmanaged heavy recreational use of wetlands and rivers 


\section{DRAFT WORKING DOCUMENT DO NOT DUPLICATE}

5445

5446

5447

5448

5449

5450

5451

5452

5453

5454

5455

5456

5457

5458

5459

5460

5461

5462

5463

5464

5465

5466

5467

5468

5469

5470

5471

5472

5473

5474

5475

5476

5477

5478

5479

5480

5481

5482

5483

5484

5485

5486

5487

5488
- Dams, channelization, and rip-rapping for flood and erosion control disrupt natural stream dynamics, affecting successional patterns

- Loss of shrub layers and lack of overstory recruitment due to persistent wild and domestic grazing pressures in woody draws

- Loss of streambank stability

- Habitat loss due to human population growth

\section{Conservation Strategies}

- Work with other groups to identify wetlands that are critically important to wildlife diversity and work towards protection and enhancement

- Work with local governments and organizations to address loss of riparian and wetland areas associated with residential development through setbacks and other means

- Work with landowners or reservoir operators to provide water levels compatible with natural regimes

- Identify opportunities to provide the high flows needed for channel diversity, gravel bar development, and cottonwood regeneration along each of the major river drainages in the state

- Manage grazing and recreational uses along riparian areas and promote streambank stability

- Protect snags and mature trees in riparian systems wherever possible

- Increased management for sustainable recreational

\section{References}

A Landowner's Guide to Montana Wetlands. Montana Watercourse.

Casey, D. 2000. Partners in Flight Bird Conservation Plan Montana Version 1.0. Montana Partners in Flight. Kalispell, Montana.

Elis, Janet H., Richard, Jim. A planning guide for protecting Montana's wetlands riparian areas. Montana Watercourse, Montana Department of Environmental Quality and Montana The Audubon Society.

Kootenai Tribe of Idaho and Montana Fish, Wildlife \& Parks. 2004. Public Review Draft Kootenai Subbasin Plan. Executive Summary. Report prepared for the Northwest Power and Conservation Council. Portland, OR.

Hansen, A., Rotella, J., Klass, L., Gyskiewicz, D. 2003. Riparian habitat Dynamics and wildlife along the Upper Yellowstone River. Technical Report \#1. Landscape Biodiversity Lab, Montana State University, Bozeman, MT. In cooperation with The Governor's Upper Yellowstone River Task Force. 


\section{DRAFT WORKING DOCUMENT DO NOT DUPLICATE}

5489 Ostlie, W.R, R. E. Schneider, J. M. Aldrich, T. M. Faust, R. L. B. McKim and S. J. 5490 Chaplin. 1997. The status of biodiversity in the Great Plains. The Nature 5491 Conservancy, Arlington, VA, USA. 326 pp + XII.

5492

5493 Statewide Habitat Plan. 1994. Implementation of Fish, Wildlife \& Parks

5494 Commission. Habitat Montana Policy.

5495

5496 
5498

5499

5500

5501

5502

5503

5504

5505

5506

5507

5508

5509

5510

5511

5512

5513

5514

5515

5516

5517

5518

5519

5520

5521

5522

5523

5524

5525

5526

5527

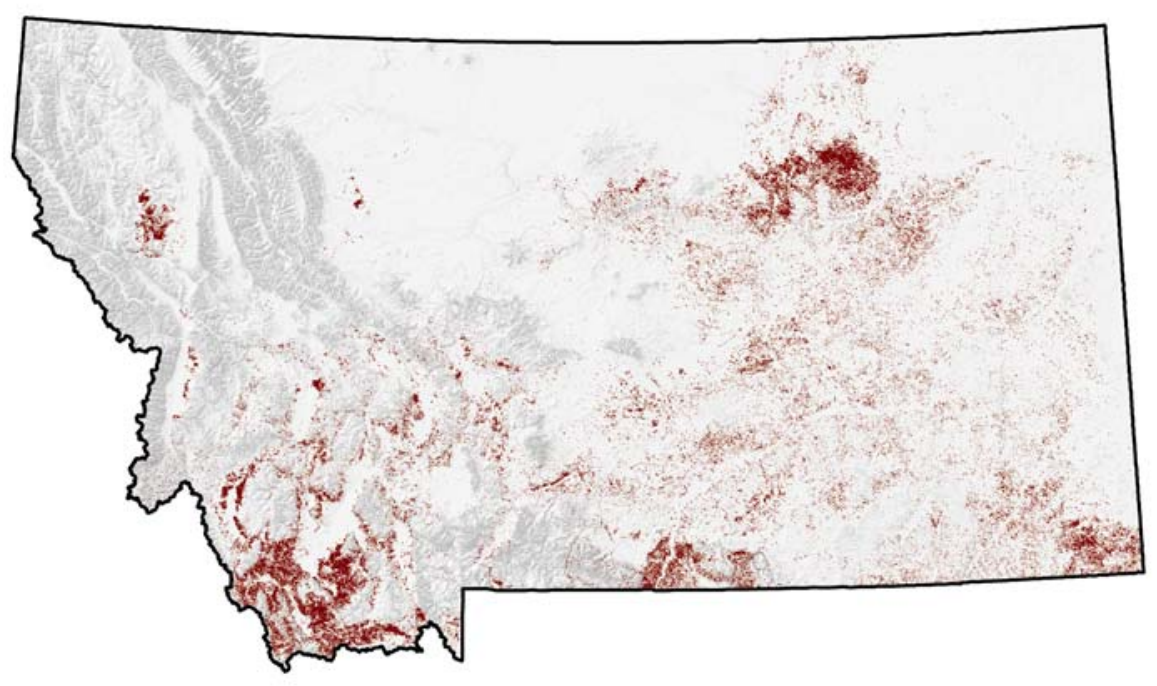

Figure 40. Distribution of Sagebrush and Salt Flats Community Types

The sagebrush community includes all sagebrush and their associated grass and shrubs although specific attention should be focused on the "shrub steppe" that is a transitional zone between arid shrubland and semiarid grassland and saltsage that occurs primarily in eastern and southeastern Montana alkalia flats. The community can be visualized as a mosaic of sagebrush communities that occur in discontinuous pockets throughout Montana but mostly in the eastern two thirds.

These communities occur across the state, primarily in valleys. Occasionally occur on low-mid elevation mountain slopes. Shrublands are dominated by sagebrush (Artemisia spp.) with $20-80 \%$ cover.

\section{Essential Associated Plant Community}

Basin Big Sagebrush (Artemisia tridentate tridentata)

Black Sagebrush Steppe (Artemisia nova)

Mountain Big Sage (Artemisia tridentate vaseyana)

Wyoming Big Sage (Artemisia tridentate wyomingensis)

Saltsage (Atriplex nuttallii)

\section{Associated Species of Greatest Conservation Need}

There are a total of 81 terrestrial vertebrate species that are found within the Sagebrush and Salt Flats Community Type, with 23 of these species being essentially associated. These species will be bolded to denote essentially associated. All associations can be found within Table 44. 
5528 Birds: Sage-grouse, Mountain Plover, Long-billed Curlew, and Burrowing Owl

5529

5530

5531

5532

5533

5534

5535

5536

5537

5538

5539

5540

5541

5542

5543

5544

5545

5546

5547

5548

5549

5550

5551

5552

5553

5554

5555

5556

5557

5558

5559

5560

5561

5562

5563

5564

5565

5566

5567

5568

5569

5570

5571

5572

\section{Mammals: Spotted Bat, Pallid Bat, Pygmy Rabbit, Great Basin Pocket}

Mouse, Black-tailed prairie dog, and White-tailed Prairie Dog

Reptiles: Snapping Turtle, Western Hognose Snake, and Milk Snake

\section{Conservation Concerns}

- Unsustainable grazing practices, conversion to agriculture, have altered the distribution and condition of Montana's sagebrush shrublands

- Invasion of weeds, woody and nonnative species

- Loss of sagebrush as result of human population growth/development

- Oil, gas, and geothermal exploration and development

- Unsustainable grazing practices

\section{Conservation Strategies}

- Protect large blocks of healthy big sagebrush

- Work with off-road vehicles users to help reduce spread of invasive weeds

- Work with private landowners through land owner incentives and conservation easements to protect critical habitats

- Promote grazing plans that encourage a mosaic of sagebrush, native grasses and forbs

- Create a stable native seed source for sage grasslands restoration after fires

- Monitor leasing and development decisions and regulations applying to geophysical exploration

\section{References}

Casey, D. 2000. Partners in Flight Bird Conservation Plan Montana Version 1.0. Montana Partners in Flight. Kalispell, Montana.

Conservation Management of America's Public Lands: An Assessment and Recommendations for Progress 25 Years after FLPMA. 2001. National Wildlife Federation and the Natural Resources Defense Council.

Frisina, Michael R., McCarthy, John, J. 2001. Montana Sagebrush Bibliography. Montana Fish, Wildlife \& Parks. 69 pp.

Ostlie, W.R, R. E. Schneider, J. M. Aldrich, T. M. Faust, R. L. B. McKim and S. J. Chaplin. 1997. The status of biodiversity in the Great Plains. The Nature Conservancy, Arlington, VA, USA. $326 \mathrm{pp}+$ XII. 


\section{Mountains Streams (59,364 Stream Miles in Montana)}

5574

5575

5576

5577

5578

5579

5580

5581

5582

5583

5584

5585

5586

5587

5588

5589

5590

5591

5592

5593

5594

5595

5596

5597

5598

5599

5600

5601

5602

5603

5604

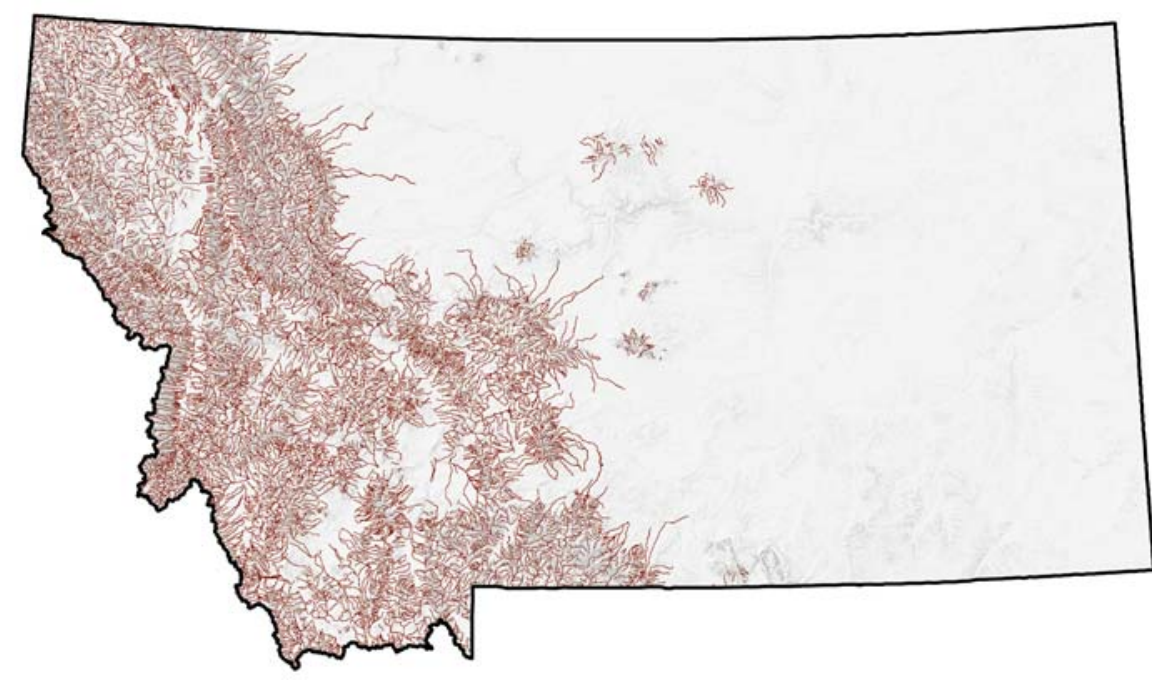

Figure 41. Distribution of Mountain Stream Community Types

Mountain streams of western Montana are typically cold and clear serving as the headwaters for all major river systems in Montana. Mountain streams often flow through montane conifer forests beginning at the highest elevations, and can be as diverse as high-alpine, steep gradient reaches to low-gradient, meadow stream types (Stagliano 2005). These streams are home to abundant native fish species and are the targets of trout fisherman from around the country. Many of these native fish are declining due to habitat degredation, dams, hybridization, overfishing, and being outcompeted by introduced salmonids. These streams support the remaining genetically pure stocks of Montana's Yellowstone and Westslope cutthroat and Bull trout.

\section{Essential Associated Plant Community}

This information has not been defined for the mountain stream community type.

\section{Associated Species of Greatest Conservation Need}

There are a total of 18 fish, mussel and crayfish species that are found within the Mountain Streams Community Type, with 17 of these species being essentially associated. These species will be bolded to denote essentially associated. All associations can be found within Table 45 .

Invertebrates: Western Pearlshell

Fish: Yellowstone Cutthroat Trout, Westslope Cutthroat Trout, Columbia Basin Redband Trout, Bull Trout, and Arctic Grayling

\section{Conservation Concerns}




\section{DRAFT WORKING DOCUMENT DO NOT DUPLICATE}

5605

5606

5607

5608

5609

5610

5611

5612

5613

5614

5615

5616

5617

5618

5619

5620

5621

5622

5623

5624

5625

5626

5627

5628

5629

5630

5631

5632

5633

5634

5635

5636

5637

5638

5639

5640

5641

5642

5643

5644

5645

5646

5647

5648

5649

5650

- Riparian degradation from roads, housing development, mining and unsustainable domestic livestock grazing practices that degrade the adjacent riparian habitat and stream channel

- Stream dewatering

- Entrainment of fish in irrigation diversions

- Stream channel alteration

- Introductions of non-native fishes

\section{Conservation Strategies}

- Support grazing techniques that improve riparian vegetation

- Increasing In-stream flows through water leasing and water conservation measures

- Placing fish screens across diversions

- Protection of native species through habitat protection and enhancement , controlling and in some cases removing non-native species, restoring or introducing native fishes into suitable waters

\section{References}

Fuller, P. L., G. Nico, and J. D. Williams. 1999. Nonindigenous fishes introduced into inland waters of the United States. American Fisheries Society, Bethesda, MD.

Marcuson, P.E. 1977. Overgrazed streambanks depress fishery production in Rock Creek, Montana. p. 143-156. In: Proc. of the workshop on livestock and wildlife-fisheries relationships in the Great Basin. Univ. California, Agric. Station, Sci. Spec. Publ. 3301, Berkeley, CA.

Platts, W.S. 1991. Livestock grazing. p. 389-424. In: W.R. Meehan (ed.), Influences of forest and rangeland management on salmonid fishes and their habitats. Amer. Fisheries Soc. Sp. Publ 19:389-423.

Platts, W.S. 1989. Compatibility of livestock grazing strategies with fisheries. p. 103-110. In: R.E. Gresswell, B.A. Barton, J.L. Kershner (eds.), Practical approaches to riparian resource management. U.S. Bureau of Land Management, P.O. Box 36800, Billings, Montana.

Platts, W.S. 1981b. Influence of forest and rangeland management on anadromous fish habitat in western North America: 7 . Effects of livestock grazing. USDA Forest Serv. Gen. Tech. Rep. PNW-124.

Rahel, F. J. 2002. Homogenization of freshwater faunas. Annual Review of Ecology and Systematics 33:291-315. 
5651 Rahel, F. J. 2000. Homogenization of fish faunas across the United States.

5652 Science 288:854-856.

5653

5654 Rahel, F. J. 1990. The hierarchical nature of community persistence: a problem

5655 of scale. American Naturalist 136:328-334.

5656

5657 Schulz, T.T., and W.C. Leininger. 1990. Differences in riparian vegetation

5658 structure between grazed areas and exclosures. J. Range Manage. 43:295-299.

5659

5660 Stagliano, D.M. 2005. Aquatic Ecotype Diversity in Montana's Missouri River

5661 Drainages: A Community Classification Project. Montana Natural Heritage

5662 Program: A report to the BLM and The Nature Conservancy. 98pp.

5663

5664 Tennant, Donald. Instream Flow Regimes for Fish, Wildlife, Recreation, and

5665 Related Environmental Resources (Billings, Mont.: U.S. Fish and Wildlife

5666 Service, 1975).

5667

5668 
Prairie Streams (91,189 Stream Miles in Montana)

5669

5670

5671

5672

5673

5674

5675

5676

5677

5678

5679

5680

5681

5682

5683

5684

5685

5686

5687

5688

5689

5690

5691

5692

5693

5694

5695

5696

5697

5698

5699

5700

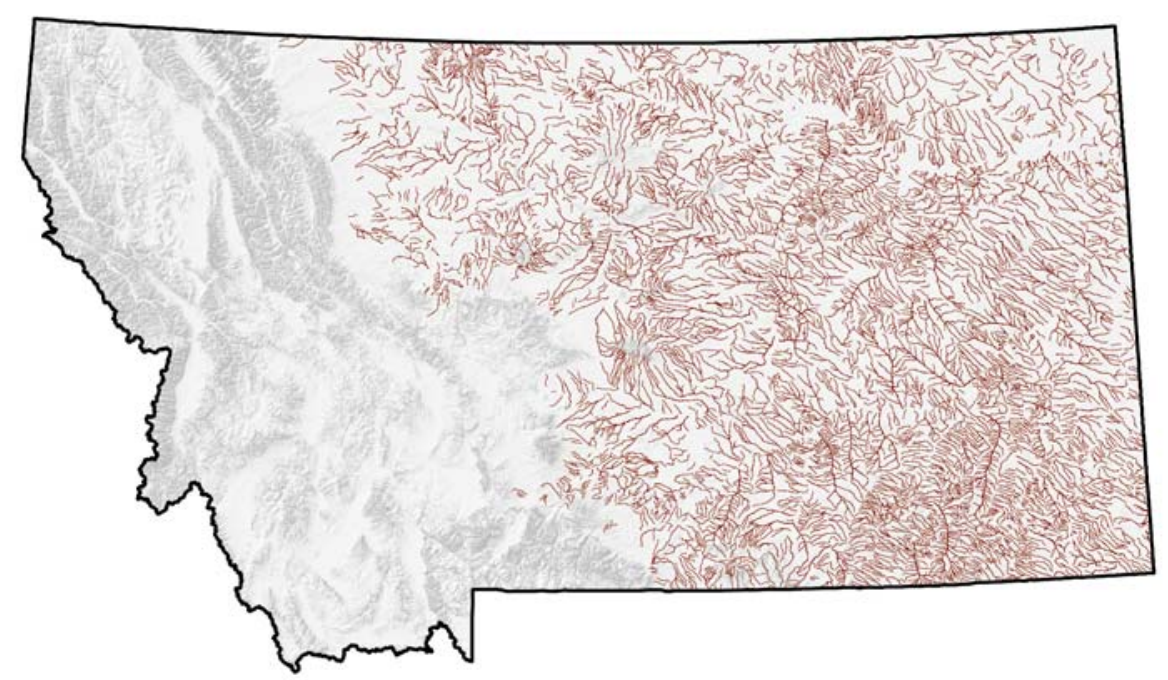

Figure 42. Distribution of Prairie Stream Community Types

There are at least 18,000 miles of prairie streams in Montana that have water either intermittently or permanently flowing through them in an otherwise dry region. Eight specific types of prairie streams were scientifically delineated for Montana (Stagliano 2005). These low elevation streams east of the Rocky Mountains are warmer than their counterparts in western Montana and support a richer and quite different variety of fish. Stagliano (2005) also documented 9 fish species group assemblages (SPA's) or community associations for the prairie stream systems. Many of these streams are slow moving, sometimes turbid and weedy, while those in the Northern Glaciated Plains can be just as clear as a mountain stream. They offer good rearing habitat for associated fish species and support many amphibians and reptiles and are crucial for populations of terrestrial wildlife.

\section{Essential Associated Plant Community}

This information has not been defined for prairie the stream community type.

\section{Associated Species of Greatest Conservation Need}

There are a total of 32 aquatic species that are found within the Prairie Streams Community Type, with 25 of these species being essentially associated. These species will be bolded to denote essentially associated. All associations can be found within Table 46.

\section{Fish: Pearl Dace}

\section{Conservation Concerns}




\section{DRAFT WORKING DOCUMENT DO NOT DUPLICATE}

5701

5702

5703

5704

5705

5706

5707

5708

5709

5710

5711

5712

5713

5714

5715

5716

5717

5718

5719

5720

5721

5722

5723

5724

5725

5726

5727

5728

5729

5730

5731

5732

5733

5734

5735

5736

5737

5738

5739

5740

5741

5742

5743

5744

5745

5746

- Degredation of riparian habitat from unsustainable domestic livestock practices

- Stream diversions and dewatering

- Poorly understood impacts of petroleum exploration and extraction

- Introductions of non-native fishes

\section{Conservation Strategies}

- Support management of grazing that maintains riparian vegetation and streambank and channel stability in excellent condition

- Place fish screens across diversions

- In-stream flow augmentation

- Increase exploration and scientific studies on impacts of Coal-bed methane on aquatic environments

- Non-native removal in selective and appropriate locations

\section{References}

Flores, R., Stricker, G., Meyer, J., Doll, T., Norton, P., Livingston, R., Jennings, M. 2001. A Field Conference on Impacts of Coal Bed Methane Development in the Powder River Basin, Wyoming, USGS Open-File Report 01-126.

Fuller, P. L., G. Nico, and J. D. Williams. 1999. Nonindigenous fishes introduced into inland waters of the United States. American Fisheries Society, Bethesda, MD.

Marcuson, P.E. 1977. Overgrazed streambanks depress fishery production in Rock Creek, Montana. p. 143-156. In: Proc. of the workshop on livestock and wildlife-fisheries relationships in the Great Basin. Univ. California, Agric. Station, Sci. Spec. Publ. 3301, Berkeley, CA.

Platts, W.S. 1991. Livestock grazing. p. 389-424. In: W.R. Meehan (ed.), Influences of forest and rangeland management on salmonid fishes and their habitats. Amer. Fisheries Soc. Sp. Publ 19:389-423.

Platts, W.S. 1989. Compatibility of livestock grazing strategies with fisheries. p. 103-110. In: R.E. Gresswell, B.A. Barton, J.L. Kershner (eds.), Practical approaches to riparian resource management. U.S. Bureau of Land Management, P.O. Box 36800, Billings, Montana.

Platts, W.S. 1981b. Influence of forest and rangeland management on anadromous fish habitat in western North America: 7. Effects of livestock grazing. USDA Forest Serv. Gen. Tech. Rep. PNW-124.

Rahel, F. J. 2002. Homogenization of freshwater faunas. Annual Review of Ecology and Systematics 33:291-315. 


\section{DRAFT WORKING DOCUMENT DO NOT DUPLICATE}

5747 Rahel, F. J. 2000. Homogenization of fish faunas across the United States.

5748 Science 288:854-856.

5749

5750 Rahel, F. J. 1990. The hierarchical nature of community persistence: a problem

5751 of scale. American Naturalist 136:328-334.

5752

5753 Schulz, T.T., and W.C. Leininger. 1990. Differences in riparian vegetation

5754 structure between grazed areas and exclosures. J. Range Manage. 43:295-299.

5755

5756

5757

Stagliano, D.M. 2005. Aquatic Ecotype Diversity in Montana's Missouri River

5758

5759

5760

5761

5762

5763

5764

5765

5766

5767

5768

5769

5770

5771

5772

5773

5774

5775

5776

5777

Drainages: A Community Classification Project. Montana Natural Heritage

Program: A report to the BLM and The Nature Conservancy. 98pp.

Tennant, Donald. Instream Flow Regimes for Fish, Wildlife, Recreation, and

Related Environmental Resources (Billings, Mont.: U.S. Fish and Wildlife

Service, 1975).

United States Geological Survey. Nov 2001. Fact Sheet FS-110-01, online:

http://pubs.usgs.gov/fs/fs-0110-01/.

United States Geological Survey. 1988. Cumulative Potential Hydrologic Impacts of Surface Coal Mining in the Eastern Powder River Structural Basin, Northeastern Wyoming. USGS Water-Resources Investigations Report 88-4046. Prepared by L.J. Martin, D.L. Naftz, H.W. Lowham, and J.G. Rankl in Cooperation with the Wyoming Department of Environmental Quality and the U. S. Office of Surface Mining, Cheyenne, WY.

5778

Wheaton, J., Metesh, J.J., 2002, Potential ground-water drawdown and recovery for coal bed methane development in the Powder River Basin, Montana, Montana Bureau of Mines and Geology Open File Report 458, 59 page(s). 
5778 Component III: Species of Greatest Conservation Need

5779

5780

5781

5782

5783

5784

5785

5786

5787

5788

5789

5790

5791

5792

5793

5794

5795

5796

5797

5798

5799

5800

5801

5802

5803

5804

5805
"These are species whose needs must be specifically addressed, whether through focus areas, community types or individually"

Conservation efforts at the landscape and community scales offer great potential to leverage resources in order to benefit multiple species. However, some species are too specialized for broad-scale conservation efforts to do much good, or populations have declined to the point where it requires individually focused conservation. For these reasons the conservation concerns and needs range from survey and monitoring or reintroduction to landscape level habitat restoration or protection. Fish, Wildlife \& Parks has a clear obligation to use its resources and work with partners to conserve Tier I species, regardless of the scale of conservation strategies identified.

All verterbrate species as well as mussels and crayfish were assessd for conservation need. Invertebrates were not included in the assessment due to lack of data. The need for data about invertebrates has been addressed in the Inventory Component of this Strategy. A complete list of species Tier assighnments can be found in Table 3.

\section{Invertebrates}

During the initial planning stages, the FWP Technical and Steering Committees determined that the Strategy would not include Montana's invertebrate species. With nearly 1,000 species of aquatic invertebrates in the state, and at least twice that number of terrestrial invertebrates, it is impossible at this time to develop a Strategy to comprehensively address invertebrate conservation in Montana. It was decided to include mussels and crayfish. 
5805

5806

5807

5808

5809

5810

5811

5812

5813

5814

5815

5816

5817

5818

5819

5820

5821

5822

5823

5824

5825

5826

5827

5828

5829

5830

5831

5832

5833

5834

5835

5836

\section{Mussels}

Western Pearlshell (Margaritifera falcata)

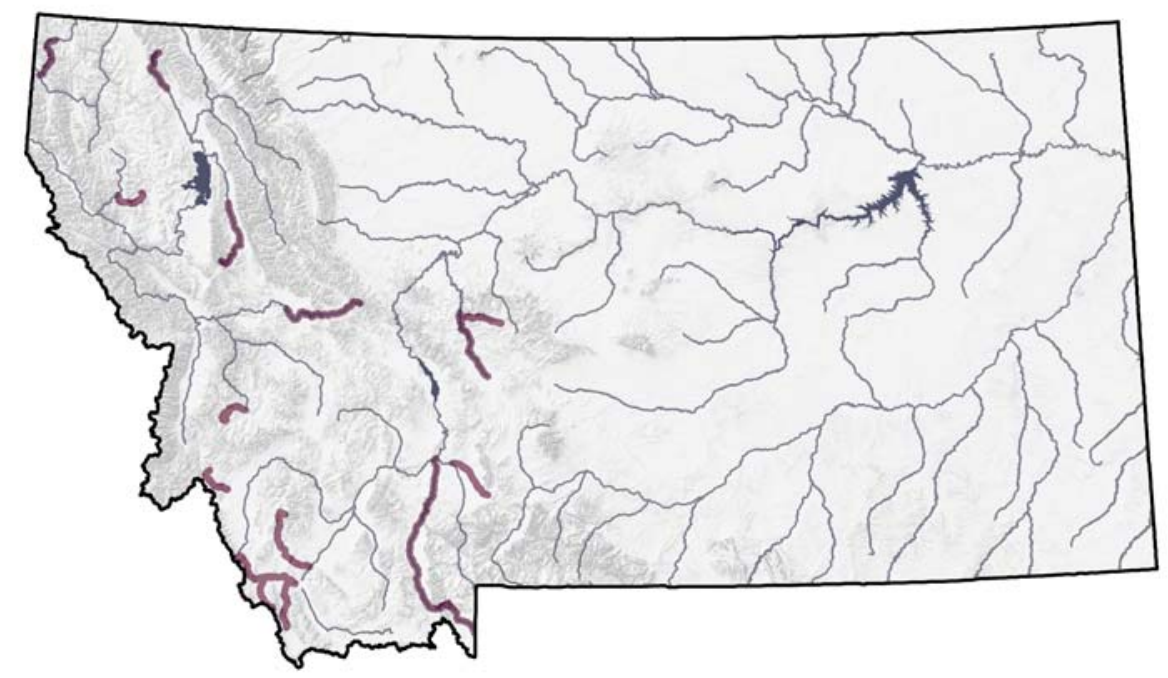

Figure 43. Distribution of the Western Pearlshell Mussel

\section{Range}

This is a headwater species occurring very near the Continental Divide in trout streams and rivers west of the Divide and in Missouri River headwaters. This species occurs in sand, gravel and even between cobble and boulders. Outside of Montana this species is reported from the Pacific drainage from southern Alaska to central California. It does not seem to occur anywhere in the central part of the continent.

\section{Habitat}

The normal fish hosts in our area are probably Oncorhynchus species, but Salmo and Salvelinus and even Rhinicthys and Catostomus are reported to be suitable. They likely crossed the divide with the west-slope cutthroat trout, which is the native salmonid of the upper Missouri River drainage. This species occurs in sand, gravel and even between cobble and boulders.

\section{Management}

Mussells are a regulated species but a better understanding of mussel distribution throughout the state is needed.

\section{Conservation Concerns}

- Habitat degradation and fragmentation (e.g., dams, stream channelization, diversions, dredging and dewatering) 


\section{DRAFT WORKING DOCUMENT DO NOT DUPLICATE}

5837

5838

5839

5840

5841

5842

5843

5844

5845

5846

5847

5848

5849

5850

5851

5852

5853

5854

5855

5856

5857

5858

5859

5860

5861

5862

5863

5864

5865

5866

5867

5868

5869

5870

5871

5872

5873

5874

5875

5876

5877

5878

5879

5880

5881

5882

- Point and nonpoint source pollution

- Stream deterioration because of high sediment loads, chiefly from agricultural runoff

- Threats to host fish also jeopardize mussel survival

- Reduced dissolved oxygen content in water

\section{Conservation Strategies}

- Consider preparing a management plan for Western Pearlshell or its inclusion into other comprehensive taxonomic management plan

- Enforcement of regulations that address the dumping of pollutants into waterways

- Restore connectivity of habitat, and managefor healthy populations native fish including cutthroat trout and bull trout

\section{Management Plan}

None

\section{Citations}

Gustafson, D.L. 1996. http://www.esg.montana.edu/dlg/aim/mollusca/marfal.html

Kovalak, W.P., S.D. Dennis and J.M. Bates. 1986. Sampling effort required

finding rare species of freshwater mussels. Intermountain/foothill grassland 34-45 in B.G. Isom, ed. Rationale for sampling and interpretation of ecological data in the assessment of freshwater ecotypes. American Society for Testing and Material, Special Technical Publication No. 894.

Payne, B.S., A.C. Miller and R. Whiting. 1997. Designing a riverine mussel survey. Intermountain/foothill grassland 150-156 in K.S. Cummings, A.C. Buchanan, C.A. Mayer and T.J. Naimo, eds. Conservation and management of freshwater mussels II: initiatives for the future. Proceedings of a UMRCC symposium, 16-18 October 1995, St. Louis, Missouri. Upper Mississippi River Conservation Committee, Rock Island, Illinois.

Stagliano, D. 2004. Systematic Survey Plan for the Freshwater Mussels in Montana. Montana Natural Heritage Program, Helena MT. 10 pgs.

Vaughn, C.C., C.M. Taylor and K.J. Eberhard. 1996. A Comparison of the Effectiveness of Timed Searches vs. Quadrate Sampling in Mussel Surveys. In K.S. Cummins, A.C. Buchanan, and L.M. Koch (eds.). The conservation and management of freshwater mussels II: initiatives for the future. Upper Mississippi River Conservation Committee, Rock Island Illinois. 
5882

5883

5884

5885

5886

5887

5888

5889

5890

5891

5892
5893

5894

5895

5896

5897

5898

5899

5900

5901

5902

5903

5904

5905

5906

5907

5908

5909

5910

5911

5912

\section{Vertebrates}

There are 636 vertebrate species that have been documented in Montana. Sixty of these were determined to be Tier I (greatest need of conservation), 143 Tier II (moderate conservation need), 281 Tier III (lower conservation need), and 152 species that were classified as Tier IV (non-native, peripheral).

\section{Amphibians}

\section{Coeur d'Alene Salamander (Plethodon idahoensis)}

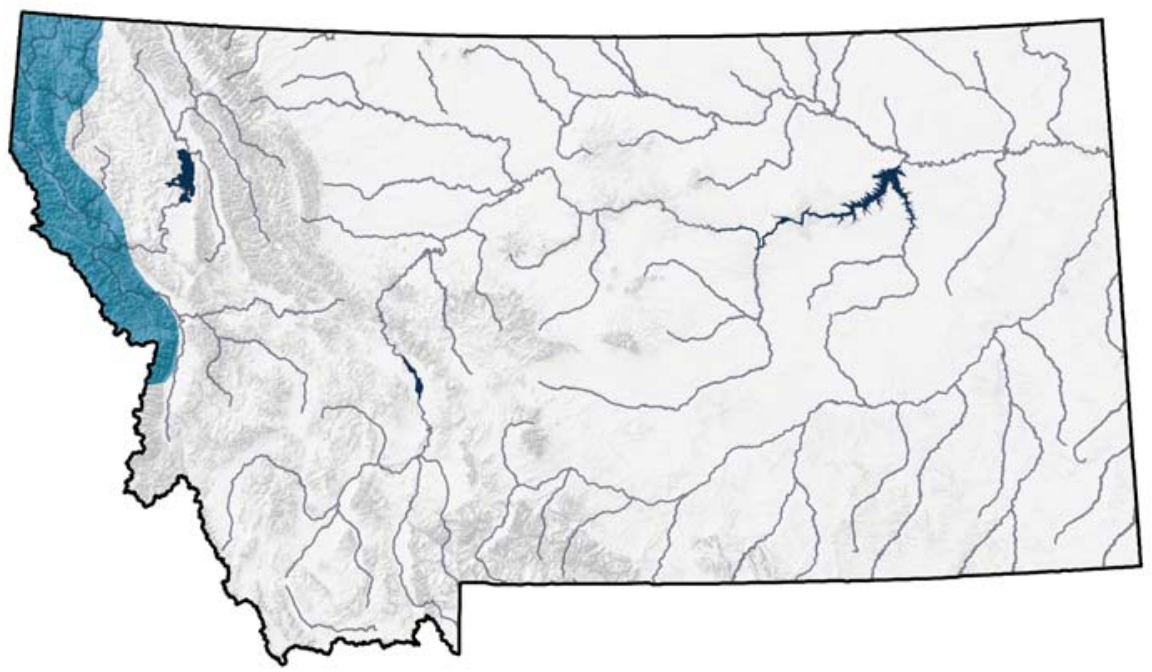

Figure 44. Distribution of the Coeur d'Alene Salamander

\section{Range}

This salamander is a regional endemic for which Montana is the eastern limit in distribution. In Montana, the Coeur d'Alene salamander is known from about 45 locations in five northwestern counties: Lincoln, Sanders, Mineral, Missoula, and Ravalli. The southern limit of known distribution is Lake Como Falls in the Bitterroot River drainage (Maxell 2002) and the northernmost population is along the South Fork of the Yaak River (Wilson and Simon 1987, Maxell et al. 2003). Maximum known elevation is 5000 feet (1524 meters).

The Coeur d'Alene salamander has been the subject of taxonomic controversy nearly since its initial discovery. First classified as a new species (Slater and Slipp 1940) it was later reclassified (Lowe 1950) as a subspecies of the Van dyke salamander (Plethodon vandykei idahoensis) found in western Washington. Evidence to support its designation as a species it is still being debated in the taxonomy world. Whether considered a species or a subspecies, the Coeur d'Alene salamander represents a unique genetic resource in Idaho, Montana, 


\section{DRAFT WORKING DOCUMENT DO NOT DUPLICATE}

5913 and British Columbia and should be managed as such (Howard 1993). The

5914 Coeur d'Alene salamander has a small range in northern Idaho, western

5915 Montana, and southeastern British Columbia. It is found in close association with

5916 water in springs or seeps, spray zones of waterfalls, and edges of streams, and

5917 feeds on aquatic insects. Coeur d'Alene salamanders tend to have small home

5918 ranges, are strongly philopatric, and show no tendency to disperse away from

5919 home ranges when disturbed (Petranka et al. 1993).

5920

5921

5922

5923

5924

5925

5926

5927

5928

5929

5930

5931

5932

5933

5934

5935

5936

5937

The Coeur d'Alene salamander is rare and local, distributed in suitable habitat (Werner and Reichel 1994) and in Montana is reported in Lincoln, Sanders, Mineral, Missoula, and Ravalli Counties. The core of distribution and area of greatest density of known locations is in the northern Idaho drainages of the St. Joe, North Fork Clearwater, and Coeur d'Alene Rivers in Idaho (Groves 1989), but the species distribution does extend northward along the Moyie River drainage into British Columbia, Canada (Wilson et al. 1989). Known from Benewah, Bonner, Boundary, Clearwater, Idaho, Kootenai, Latah, and Shoshone counties in Idaho (Groves and Petersen 1992).

\section{Habitat}

The habitat for Coeur d'Alene salamanders includes the three major habitat categories: springs and seeps, waterfall spray zones, and stream edges (Wilson and Larsen 1988, Werner and Reichel 1994, Boundy 2001, Maxell 2002). Specific primary habitats are seeintermountain/foothill grassland and streamside talus, but they also inhabit talus far from free water (deep talus mixed with moist

5938

5939

5940

5941

5942

5943

5944

5945

5946 soil on well-shaded north-facing slopes). Coeur d'Alene salamander occurrences are generally located in coniferous forests, but are not restricted to a particular overstory species or aspect. In wet weather, they also occur in leaf litter and under bark and logs in coniferous forests.

5947

5948

5949

5950

All plethodontid salamanders respire through their skin; terrestrial species lose water to the environment through evaporation and are therefore restricted to cool, damp environments. Coeur d'Alene salamanders are closely tied to water and are considered among the most aquatic plethodontids (Brodie and Storm 1970). Because they may live in the harshest climate of any northwestern plethodontid (Nussbaum et al. 1983), they are highly dependent on the thermal and hydrologic stability provided by wet habitats in otherwise inhospitable surroundings.

5951

5952

5953 5954 5955 5956 5957 Sites occupied by Coeur d'Alene salamanders in Montana have fractured rock formation present and nearby habitat are typically forested (Reichel and Flath 1995). Foraging areas include seepage areas and splash zones with high humidity, high substrate moisture, and relatively high temperatures (Wilson and Larsen 1988). Shelter is provided by deep bedrock fractures or in talus habitat 5958 populations, underground (Wilson and Larsen 1988). Montana populations are found primaryly in talus areas along splash zones of creeks, or with seeps 


\section{DRAFT WORKING DOCUMENT DO NOT DUPLICATE}

5959 running through (Teberg 1963, 1965; Wilson and Larsen 1988). Idaho and 5960 Montana populations breed in both spring and fall, although most eggs usually 5961 are laid in the spring. Eggs are laid in moist, concealed places on land (Stebbins 5962 5963 5964 5965 5966 5967 5968 5969

5970

5971

5972

5973

5974

5975

5976

5977

5978

5979

5980

5981

5982

5983

5984

5985

5986

5987

5988

5989

5990

5991

5992

5993

5994

5995

5996

5997

5998

5999

6000 1985) far down in the rocks (Werner and Reichel 1994). Generally found in moist talus, seeps and splash zones. These may be situated in open forests, meadows, or riparian areas (Groves et al. 1996).

\section{Management}

Potential threats for the species across its global range apply also to Montana populations, but population declines or extinctions have not yet been documented here. Some populations continue to be vulnerable to highway construction activity, and most occur at elevations and in forest types where timber harvest is a common activity. Routine monitoring (Groves et al. 1996) of known populations should be conducted to identify threats to each, as well as to determine their continued viability.

\section{Conservation Concerns}

- Disturbances, such as timber harvest, fire, road and trail construction, and water diversion projects

- Pollution

- Introduction of exotic species

- Restricted mobility coupled with increasing habitat fragmentation make it susceptible to local extirpation

- Disease and parasites

- Global change (climatic and atmospheric changes such as increased UV$\mathrm{B}$ radiation, pollution, acid rain, and disease)

\section{Conservation Strategies}

- Surveys of potential habitats for the Coeur d'Alene salamander

- Monitoring of known locales

- Habitat protection and conservation through regulation of development, logging, and chemical applications

- Avoid road construction within 300 feet

- Fence known salamander sites to exclude livestock

- To prevent spread of chytrid fungus, personnel working in either lentic or lotic systems should thoroughly rinse and decontaminate all equipment as described in Maxell et al (2004)

- Regulate chemical application (herbicides, pesticides, fertilizers etc.) within $\mathbf{3 0 0}$ feet of water bodies or wetlands

6001

6002

6003

\section{Management Plan}




\section{DRAFT WORKING DOCUMENT DO NOT DUPLICATE}

6004 Maxell, Bryce A., 2000, Management of Montana's amphibians: A Review of 6005 factors that may present a risk to population viability and accounts on the 6006 identification, distribution, taxonomy, habitat use, natural history and the status 6007 6008 6009

6010

6011

6012

6013

6014

6015

6016

6017

6018 and conservation of individual species. Contract No. 43-0343-0-0224. September $20,2000$.

6019

6020

6021

6022

6023

6024

6025

6026

6027

6028

6029

6030

6031

6032

6033

6034

6035

6036

6037

6038

6039

\section{Citations}

Brodie, E. D., Jr. and R. M. Storm. 1970. PLETHODON VANDYKEI. Cat. Am. Amph. Rep. 91.1-91.2.

Cassirer, E. F., C. R. Groves, and D. L. Genter. 1993. Sensitive species management guide for the Coeur d'Alene salamander. Idaho Department of Fish and Game, Boise, Idaho and the Montana Natural Heritage Program, Helena, Montana, U.S.A.

Cassirer, E. F., C. R. Groves, and D. L. Genter. 1994. Coeur d'Alene salamander conservation assessment. U.S.D.A. Forest Service, Region 1, Missoula, MT. 55 pp.

Genter, D. L., Wilson, A. G. and E. M. Simon. 1988. Supplementary report on the status of the Coeur d'Alene salamander (Plethodon vandykei idahoensis) in Montana. Unpublished report to USDA Forest Service. Montana Natural Heritage Program, Helena, Montana, U.S.A. including maps.

Groves, C. 1988, 1989. Status and distribution of the Coeur d'Alene salamander (Plethodon vandykei idahoensis) in Idaho - part II. Unpublished report. Idaho Department of Fish and Game, Boise, Idaho, U.S.A.

Groves, C. R., E. F. Cassirer, D. L. Genter, and J. D. Reichel. 1996. Coeur d'Alene Salamander (PLETHODON IDAHOENSIS). Natural Areas Journal 16(3): 238-247.

Groves, C. R. and C. Peterson. 1992. Distribution and population trends of Idaho amphibians as determined by mail questionnaire. Conservation Data center, 6040 6041 6042 6043 Idaho Department of Fish and Game, Boise, Idaho, U.S.A.

Howard, J. 1993. Genetic variation and population diverg4ence in the Plethodon Vandykei species group. Herpetologica 49: 238-247.

Lowe, C. H. Jr. 1950. The systematic status of the salamander Plethodon hardii with a discussion of problems in Aneides. Copeia 1950: 92-99.

Maxell, B. 2002. [Database file of herp. observations from 2001.] 


\section{DRAFT WORKING DOCUMENT DO NOT DUPLICATE}

6049 Maxell, B., Werner K.J., Hendricks, and P., Flath, D., 2003. Herpetology in

6050 Montana. Society for Northwestern Vertebrate Biology

6051

6052

6053

Maxell, B. A., G. Hokit, J. Miller, and K. Werner. 2004 (unpublished). Detection of

6054

6055

6056

6057

6058

6059

6060

6061

6062

6063

6064

6065

6066

6067

6068 Batrachochytrium dendrobatidis, the Chytrid fungus associated with global amphibian declines, in Montana amphibians. Unpublished mimeo. University of Montana, Missoula, Montana, U.S.A.

Montana Natural Heritage Program. 1987. Status report on the Coeur d'Alene salamander (Plethodon idahoensis) in Montana. Unpublished mimeo. USDA Forest Service Kootenai National Forest and Lolo Forest, Libby, Montana, U.S.A.

Montana Natural Heritage Program. (Accessed April 26, 2004:

$<$ http://nhp.nris.state.mt.us/animalguide>).

6069

6070

6071

6072

6073

6074

NatureServe. 2004. NatureServe explorer. An online encyclopedia of life. Version 3.0. NatureServe, Arlington, Virginia. (Accessed April 22, 2004:

http://www.natureserve.org/explorer)

Nussbaum, R. A., E. D. Brodie, Jr. and R. M. Storm. 1983. Amphibians and reptiles of the Pacific Northwest. Univ. Press of Idaho. 332 pp.

Partners in Amphibian and Reptile Conservation. 1999. Conference, Conserving Amphibians and Reptiles in the New Millennium, 2-4 June 1999; Atlanta, Georgia. (Accessed May 20, 2004; <http://www.parcplace.org>).

6075

6076

6077

6078

6079

6080

Petranka, J. W., Eldridge, M. E. and K. E. Haley. 1993. Effects of timber

harvesting on southern Appalachian salamanders. Conservation Biology 7: 363370.

6081

6082

6083

Reichel, J. D. and D. Flath. 1995. Identification of Montana's amphibians and reptiles. Mont. Outdoors 26: 15-34.

Slater, J. R. and J. W. Slipp. 1940. A new species of Plethodon from northern Idaho. Occasional Papers of

6084

6085

6086

6087

Biology. College of the Puget Sound 8: 38-43.

6088

6089

6090

6091

6092

Stebbins, R. C. 1985. Peterson Field Guides: Western Reptiles and Amphibians. Houghton Mifflin Company, Boston, Massachusetts, U.S.A.

6093

Teberg, E. K. 1963. An extension into Montana of the known range of the salamander Plethodon vandykei idahoensis. Herpetologica 19:287.

Teberg, E. K. 1965. Range extensions of the salamander Plethedon vandykei idahoensis. Copeia 1965:244.

6094 
6095 Werner, J. K. and J. D. Reichel. 1994. Amphibian and reptile survey of the 6096 Kootenai National Forest: 1994. Montana Natural Heritage Program. 105 pp.

6097

6098 Werner, J. Kirwin and J. D. Reichel. 1996. Amphibian and reptile

6099 monitoring/survey of the Kootenai National Forest: 1995. Montana Natural

6100 Heritage Program, Helena, Montana, U.S.A.

6101

6102 Wilson, A. G., E. Simon, and J. H. Larsen, Jr. 1989. Range extension for the 6103 Coeur d'Alene salamander, PLETHODON VANDYKEI IDAHOENSIS, to the 6104 Canada-United States border. Canadian Field-Nat. 103:93-94.

6105

6106 


\section{DRAFT WORKING DOCUMENT DO NOT DUPLICATE}

6106

6107
6108

6109

6110

6111

6112

6113

6114

6115

6116

6117

6118

6119

6120

6121

6122

6123

6124

6125

6126

6127

6128

6129

6130

6131

6132

6133

6134

6135

6136

6137

\section{Boreal Toad (Bufo boreas)}

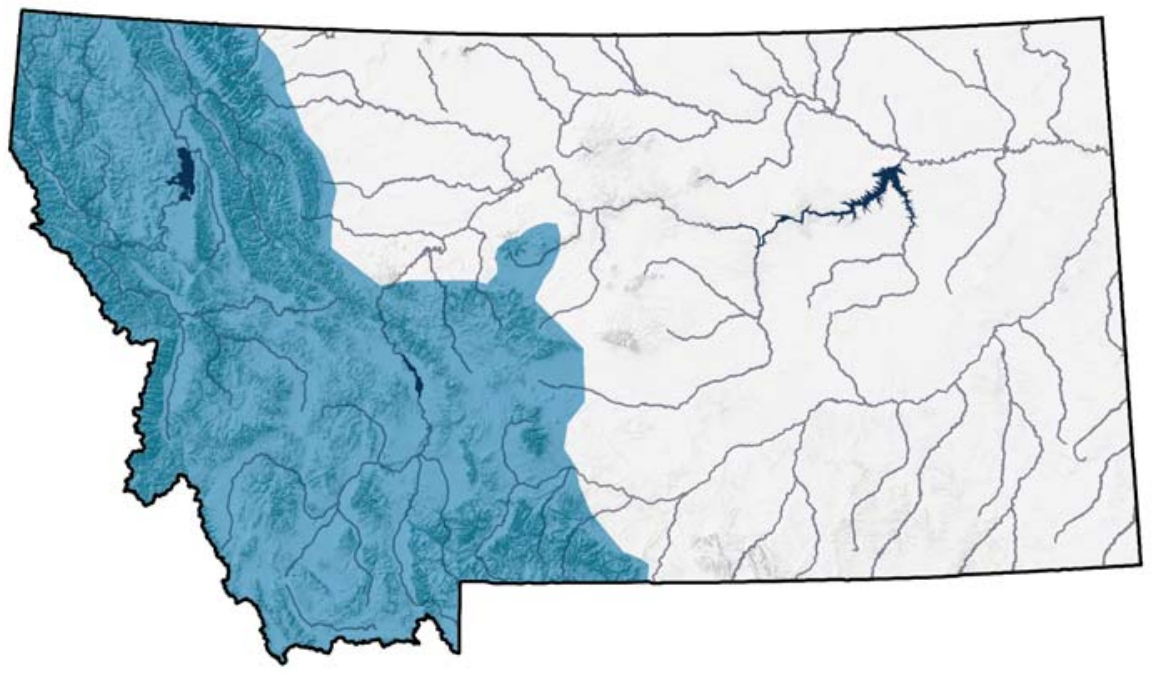

Figure 45. Distribution of the Boreal Toad

\section{Range}

The boreal toad is found throughout the mountains and intermountain valleys of the western third of the state on both sides of the Continental Divide (Maxell et al. 2003). Specimens have been collected in 22 western counties and sighted in five more, at elevations up to 9220 feet (2810 meters).

\section{Habitat}

Habitats used by boreal toads in Montana are similar to those reported for other regions, and include low elevation beaver ponds, reservoirs, streams, marshes, lake shores, potholes, wet meadows, and marshes, to high elevation ponds, fens, and tarns at or near tree line (Rodgers and Jellison 1942, Brunson and Demaree 1951, Miller 1978, Marnell 1997, Werner et al. 1998, Boundy 2001). Forest cover in or near encounter sites is often unreported, but toads have been noted in open-canopy ponderosa pine woodlands and closed-canopy dry conifer forest in Sanders County (Boundy 2001), willow wetland thickets and aspen stands bordering Engelmann spruce stands in Beaverhead County (Jean et al. 2002), and mixed ponderosa pine/cottonwood/willow sites or Douglas-

fir/ponderosa pine forest in Ravalli and Missoula counties (P. Hendricks personal observation).

Elsewhere the boreal toad is known to utilize a wide variety of habitats, including desert springs and streams, meadows and woodlands, mountain wetlands, beaver ponds, marshes, ditches, and backwater channels of rivers where they prefer shallow areas with mud bottoms (Nussbaum et al. 1983, Baxter and Stone 1985, Russell and Bauer 1993, Koch and Peterson 1995, Hammerson 1999). 


\section{DRAFT WORKING DOCUMENT DO NOT DUPLICATE}

6138 Forest cover around occupied montane wetlands may include aspen, Douglas fir, 6139 lodgepole pine, Engelmann spruce, and subalpine fir; in local situations it may

6140 also be found in ponderosa pine forest. They also occur in urban settings,

6141

6142

6143 sometimes congregating under streetlights at night to feed on insects (Hammerson 1999, P. Hendricks personal observation). Normally they remainre fairly close to ponds, lakes, reservoirs, and slow-moving rivers and streams during the day, but may range widely at night. Eggs and larvae develop in still, shallow areas of ponds, lakes, or reservoirs or in pools of slow-moving streams, often where there is sparse emergent vegetation. Adult and juvenile boreal toads dig burrows in loose soil or use burrows of small mammals, or occupy shallow shelters under logs or rocks. At least some toads hibernate in terrestrial burrows or cavities, apparently where conditions prevent freezing (Nussbaum et al. 1983, Koch and Peterson 1995, Hammerson 1999).

\section{Management}

6158

6159

6160

6161

The boreal toad was considered the most abundant amphibian of the western third of the state in previous decades (Rodgers and Jellison 1942, Brunson 1952, Maxell 2003), and is still encountered widely and frequently though by no means commonly, and is no longer ranked as the most abundant amphibian. Numerous surveys since the early 1990s indicate that this species has experienced regional population declines in the state. Boreal toads were documented to breed at only 2 to $5 \%$ of more than 2000 standing water bodies surveyed since 1997, and where breeding was documented, fewer than 10 breeding females contributed in a given year (Maxell 2000, Maxell et al. 2003). Range wide declines in this

6163

6164

6165

6166

6167

6168

6169

6170

6171

6172

6173

6174

6175 species have been indicated in Montana, as well as other western states.

\section{Conservation Concerns}

- Breeding site destruction

- Diseases such as red-leg disease and chytrid fungus

- Use of chemicals and fertilizers

- Increased predation by species attracted to human disturbance

\section{Conservation Strategies}

- Protect certain wetlands occupied by boreal toads from introduced species

6176

6177

6178

6179

6180

6181

6182

6183 and human disturbance

- Survey wetlands suitable for boreal toads

- Reduce access by livestock to known breeding sites within grazing allotments which will prevent undue trampling mortality (Bartelt 1998).

- Avoid stocking of predatory game fish at sites lacking them

- Avoid use of pesticides, fertilizers and herbicides near known breeding areas

\section{Management Plan}




\section{DRAFT WORKING DOCUMENT DO NOT DUPLICATE}

6184

6185

6186

6187

6188

6189

6190

6191

6192

6193

6194

6195

6196

6197

6198

6199

6200

6201

6202

6203

6204

6205

6206

6207

6208

6209

6210

6211

6212

6213

6214

6215

6216

6217

6218

6219

6220

6221

6222

6223

6224

6225

6226

6227

6228

6229
Maxell, Bryce A., 2000, Management of Montana's amphibians: A Review of factors that may present a risk to population viability and accounts on the identification, distribution, taxonomy, habitat use, natural history and the status and conservation of individual species. Contract No. 43-0343-0-0224. September $20,2000$.

\section{Citations}

Bartelt, P. E. 1998. Bufo boreas (Western Toad). Mortality. Herpetological Review 29:96.

Baxter, G. T. and M. D. Stone. 1985. Amphibians and reptiles of Wyoming. Second edition. Wyoming Game and Fish Department, Cheyenne.

Boundy, J. 2001. Herpetofaunal surveys in the Clark Fork Valley region, Montana. Herpetological Natural History 8:15-26.

Brunson, R. B. 1952. Recent collections of BUFO BOREAS from western Montana. Proc. Montana Acad. Sci. 11:17-19.

Brunson, R. B. and H. A. Demaree. 1951. The herpetology of the Mission Mountains, Montana. Copeia 1951:306-308.

Hammerson, G. A. 1999. Amphibians and reptiles in Colorado. Second edition. University Press of Colorado, Boulder, Colorado. xxvi + 484 pp.

Jean, C., P. Hendricks, M. Jones, S. Cooper, and J. Carlson. 2002. Ecological communities on the Red Rock Lakes National Wildlife Refuge: inventory and review of aspen and wetland systems. Report to the Red Rock Lakes National Wildlife Refuge. Montana

Jones, M. S., J. P. Goettl, and L. J. Livo. 1999. Bufo boreas (Boreal Toad). Predation. Herpetological Review 30:91

Koch, E. D., and C. R. Peterson. 1995. Amphibians \& reptiles of Yellowstone and Grand Teton national parks. University of Utah Press, Salt Lake City. xviii +188 pp.

Marnell, L.F. 1997. Herpetofauna of Glacier National Park. Northwest Naturalist, 78:17-33.

Maxell, B. A., J. K. Werner, P. Hendricks, and D. L. Flath. 2003. Herpetology in Montana: a history, status summary, checklists, dichotomous keys, accounts for native, potentially native, and exotic species, and indexed bibliography.

Northwest Fauna 


\section{DRAFT WORKING DOCUMENT DO NOT DUPLICATE}

6230

6231

6232

6233

6234

6235

6236

6237

6238

6239

6240

6241

6242

6243

6244

6245

6246

6247

6248

6249

6250

6251

6252

6253

6254

6255
Maxell, B. A., K. J. Nelson, and S. Browder. 2002. Record clutch size and observations on breeding and development of the Western Toad (Bufo boreas) in Montana. Northwestern Naturalist 83:27-30.

Maxell, B., Werner K.J., Hendricks, and P., Flath, D., 2003. Herpetology in Montana. Society for Northwestern Vertebrate Biology

Miller, J. D. 1978. Observations on the diet of RANA PRETIOSA, RANA PIPIENS, and BUFO BOREAS from western Montana. Northwestern Sci. 52:243-249.

Nussbaum, R. A., E. D. Brodie, Jr., and R. M. Storm. 1983. Amphibians and Reptiles of the Pacific Northwest. University Press of Idaho. 332 pp.

Rodgers, T. L., and W. L. Jellison. 1942. A collection of amphibians and reptiles from western Montana. Copeia 1942:10-13.

Russell, A. P., and A. M. Bauer. 1993. The amphibians and reptiles of Alberta. University of Calgary Press, Calgary, Alberta, and University of Alberta Press, Edmonton, Alberta. 264 pp.

Werner, J. K., T. Plummer, and J. Weaselhead. 1998. Amphibians and reptiles of the Flathead Indian Reservation. Intermountain Journal of Science 4:33-49. 


\section{DRAFT WORKING DOCUMENT DO NOT DUPLICATE}

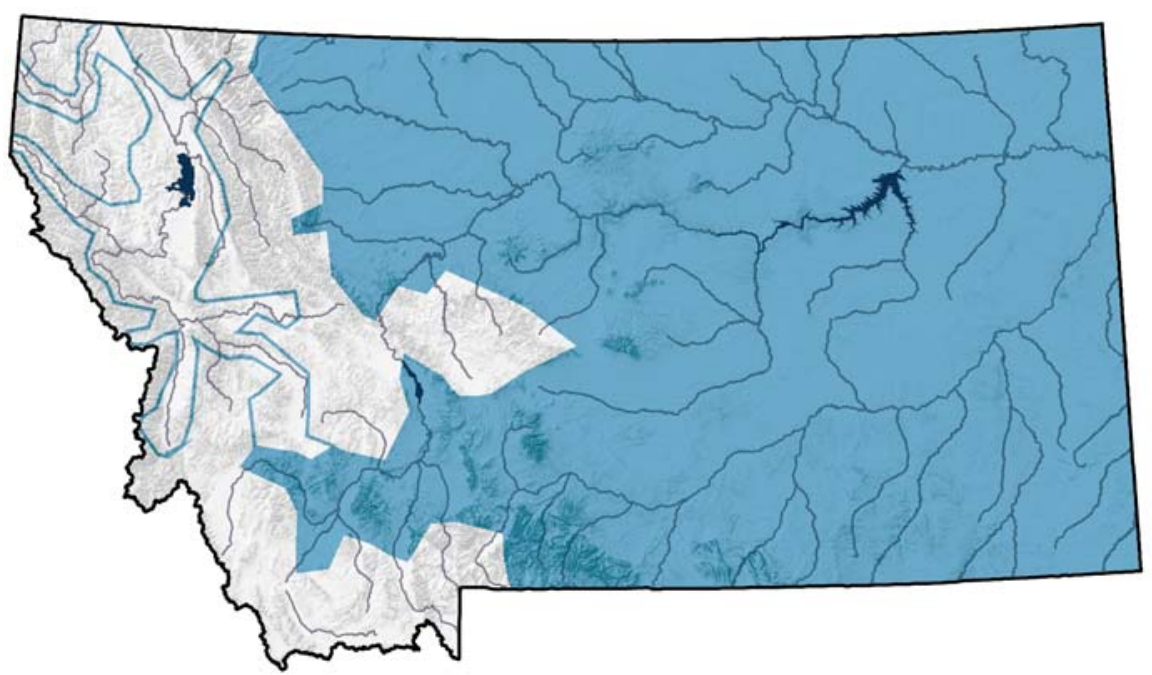

6257

6258

6259

6260

6261

6262

6263

6264

6265

6266

6267

6268

6269

6270

6271

6272

6273

6274

6275

6276

6277

6278

6279

6280

6281

6282

6283

6284

6285

6286

Figure 46. Distribution of the Northern Leopard Frog

\section{Range}

The northern leopard frog is found across the prairie regions of the eastern twothirds of Montana east of the Continental Divide (Maxell et al. 2003). It was formerly present in intermountain valleys west of the Continental Divide, especially in the Flathead and lower Clark Fork river drainages, but in recent years has been documented at only two western sites (Werner 2003): near Kalispell (Flathead County) and near Eureka (Lincoln County). This frog has been documented in all but seven Montana counties (six of which are west of the Continental Divide), at elevations up to 6700 feet (2042 meters).

The northern leopard frog historic distribution is irregular but includes western Montana except in the Big Hole area, as well as the tip of Idaho Panhandle and southeast and parts of southwest Idaho (Stebbins 1985). Recent extirpations are reported in all of western Montana and across much of the neighboring states (Werner and Reichel 1994, Reichel and Flath 1995). Known from Ada, Adam, Bear Lake, Bingham, Blaine, Boise, Bonner, Bonneville, Canyon, Caribou, Cassia, Clearwater, Custer, Elmore, Franklin, Fremont, Gem, Gooding, Jefferson, Jerome, Latah, Lincoln, Madison, Minidoka, Owyhee, Power, Teton, Twin Falls, Valley, and Washington counties in Idaho (Groves and Peterson, 1992).

\section{Habitat}

Habitats used by northern leopard frog in Montana include low elevation and valley bottom ponds, spillway ponds, beaver ponds, stock reservoirs, lakes, creeks, pools in intermittent streams, warm water springs, potholes, and marshes 


\section{DRAFT WORKING DOCUMENT DO NOT DUPLICATE}

6287 (Brunson and Demaree 1951, Mosimann and Rabb 1952, Black 1969, Miller

6288 1978, Dood 1980, Reichel 1995, Hendricks and Reichel 1996, Hendricks 1999).

6289 Northern leopard frogs require a mosaic of habitats to meet annual requirements

6290

6291 of all life stages. They occupy a variety of wetland habitats of relatively fresh

6292 water with moderate salinity, including springs, slow streams, marshes, bogs,

6293 ponds, canals, flood plains, beaver ponds, reservoirs, and lakes, usually in

6294

6295 permanent water with rooted aquatic vegetation. Adults and juveniles commonly

6296 feed in open or semi-open wet meadows and fields with shorter vegetation, usually near the margins of water bodies where there is permanent water and growth of cattails or other aquatic vegetation, yet may forage far from water in

6298 damp meadows (Stebbins 1985). They seek cover underwater and denser

6299

6300 vegetation seems to be avoided.

6301

Northern Leopard Frogs have a large range throughout much of the U.S. and

6302 southern Canada (NatureServe 2004) and are still common in many areas and in

6303 a wide array of pristine and disturbed habitats (NatureServe 2004). NatureServe 6304

6305 (2004) lists northern leopard frog in 35 states in the U.S. and 12 Canadian provinces. Populations have declined in some areas due to habitat loss and degradation, overexploitation, interactions with non-native species, and unknown

6306 causes, but the overall status remains essentially undiminished (NatureServe 2004). In Montana the northern leopard frog is found primarily in riparian habitat but is not as restricted to water as other Rana species (Black 1969, Miller 1978). This species is abundant on plains near permanent water (Black 1969, Mosimann and Rabb 1952), tends to avoid tall, dense grass areas (Miller 1978)

6312

6313

6314

6315

6316

6317 and prefers densely vegetated areas such as wet sedge meadows or cattail marshes (Reichel and Flath 1995, Werner and Reichel 1994).

6318

6319

6320

6321

6322

6323

6324

6325

6326

6327

6328

6329

6330

\section{Management}

No special management needs are currently recognized for populations in eastern Montana. However, at permanent and semi-permanent water bodies (reservoirs and stock ponds) where breeding has been observed, portions of shorelines where emergent vegetation is present or might develop could be fenced to exclude access by livestock and thereby protect breeding adults, eggs and tadpoles from trampling and the removal of emergent cover. Another option would be the creation of ponds designed for use by prairie amphibians as breeding sites, with the perimeter surrounded by fencing to prevent access by livestock. Game fish should not be introduced to any of these ponds, nor should chemical fertilizers, pesticides and herbicides be used within 100 meters of the shoreline. All breeding sites west of the Continental Divide should be protected from livestock, and organic and chemical (pesticide and herbicide) contamination. Game fish and bullfrogs should not be introduced to these sites. Care should be taken to avoid introducing parasites and fungal, bacterial, and viral pathogens when monitoring these sites (see suggestions in Maxell 2000, 6331 Maxell et al. 2003). Any populations discovered in the western region should be 6332 reported to the Native Species Biologist of the Montana 


\section{DRAFT WORKING DOCUMENT DO NOT DUPLICATE}

6333 Department of Fish, Wildlife \& Parks or the Program Zoologist of the Montana

6334 Natural Heritage Program.

6335

6336

6337

6338

6339

6340

6341

6342

6343

6344

6345

6346

6347

6348

6349

6350

6351

6352

6353

6354

6355

6356

6357

6358

6359

6360

6361

6362

6363

6364

6365

6366

6367

\section{Conservation Concerns}

- Loss of wetlands and hydrological regimes, drought

- Introduction of game fish, mosquitofish and bullfrogs

- Contamination by pesticides and herbicides

- Pathogens, including chytrid fugus (Batrachochytrium dendrobatidis)

- Global change (climatic and atmospheric changes such as increased UV$\mathrm{B}$ radiation, pollution, acid rain, and disease).

- Unsustainable use and illegal collecting

\section{Conservation Strategies}

- Protect the two remaining breeding populations west of the continental divide in Montana

- Monitor historic breeding sites and populations

- Increase understanding of demographic vital rates, including the effects of the concerns listed above

- Habitat conservation and improvement projects

- Protect breeding sites from organic and chemical (pesticide and herbicide) contamination

- Protect breeding sites from livestock impacts

- To prevent spread of chytrid fungus, personnel working in either lentic or lotic systems should thoroughly rinse and decontaminate all equipment as described in Maxell et al 2004 (unpublished)

- Allow no introduction of game fish or bullfrogs into waters with known breeding

\section{Management Plan}

Maxell, Bryce A., 2000, Management of Montana's amphibians: A Review of factors that may present a risk to population viability and accounts on the identification, distribution, taxonomy, habitat use, natural history and the status

6368

6369

6370

6371

6372

6373 and conservation of individual species. Contract No. 43-0343-0-0224. September 20, 2000.

\section{Citations}

Black, J. H. 1969. The frog genus RANA in Montana. Northwest Sci. 43:191-195. Brunson, R. B. and H. A. Demaree. 1951. The herpetology of the Mission Mountains, Montana. Copeia 1951:306-308.

6376 


\section{DRAFT WORKING DOCUMENT DO NOT DUPLICATE}

6377 Dood, A. R. 1980. Terry Badlands nongame survey and inventory: final report.

6378 [BLM Contract \#YA-512-CT8-217]. Montana Dept. of Fish, Wildlife, and Parks. 70 6379 pp.

6380

6381

6382

6383

6384

6385

6386

6387

6388

Hendricks, Paul. 1999, Amphibian and reptile surveys on Montana refuges: 1998-1999. December 1999.

6389

6390

6391

6392

6393

6394

6395

6396

6397

Maxell, B., Werner K.J., Hendricks, and P., Flath, D., 2003. Herpetology in

Montana. Society for Northwestern Vertebrate Biology

Maxell, B.A., G. Hokit, J. Miller, and K. Werner 2004 (unpublished). Detection of Batrachochytrium dendrobatidis, the Chytrid fungus associated with global amphibian declines, in Montana amphibians. Unpublished memo. University of Montana, Missoula, Montana, U.S.A.

6398

6399

6400

Miller, J. D. 1978. Observations on the diet of RANA PRETIOSA, RANA

PIPIENS, and BUFO BOREAS from western Montana. Northwestern Sci.

52:243-249.

Montana Natural Heritage Program. Montana field guide. Northern leopard frog. Online database. (Accessed November 19, 2003;

$<$ http://fwp.state.mt.us/fieldguide>).

6401

6402

6403

6404

6405

6406

6407

6408

6409

6410

6411

6412

Mosimann, J. E. and G. B. Rabb. 1952. The herpetology of Tiber Reservoir Area, Montana. Copeia 1952: 23-27.

NatureServe. 2004. NatureServe explorer. An online encyclopedia of life. Version 3.0. natureserve, Arlington,

Virginia. (Accessed April 22, 2004; <http://www.natureserve.org/explorer>).

6413

6414

6415

6416

6417

6418

6419

Partners in Amphibian and Reptile Conservation. 1999. Conference,

Conserving Amphibians and Reptiles in the New Millennium, 2-4 June 1999;

Atlanta, Georgia. (Accessed May 20, 2004; <http//www.parcplace.org>).

6420

Reichel, James D., 1995, Preliminary amphibian and reptile survey of the Lewis and Clark National Forest: 1994. March 1995.

Stebbins, R.C. 1985. Peterson Field Guides: Western Reptiles and Amphibians. Houghton Mifflin, Boston, Massachusetts, U.S. A.

6421

Werner, J. K. and J. D. Reichel. 1994. Amphibian and reptile monitoring/survey of the Kootenai National Forest: 1995. Montana Natural Heritage Program, Helena, Montana, U.S.A. 


\section{DRAFT WORKING DOCUMENT DO NOT DUPLICATE}

\section{Reptiles}

6422

6423

6424

\section{Snapping Turtle (Chelydra serpentina)}

6425

6426

6427

6428

6429

6430

6431

6432

6433

6434

6435

6436

6437

6438

6439

6440

6441

6442

6443

6444

6445

6446

6447

6448

6449

6450

6451

6452

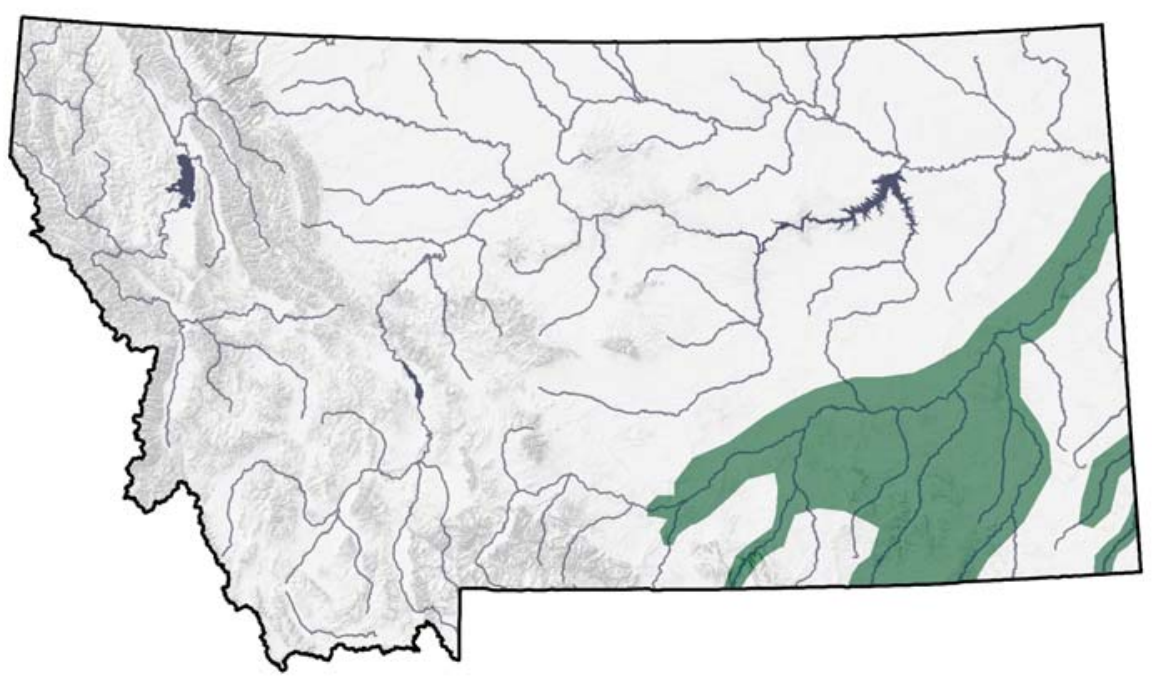

Figure 47. Distribution of the Snapping Turtle

\section{Range}

Voucher specimens have been collected in three eastern counties (Carter, Powder River, and Rosebud), with visual observations in seven additional counties (Big Horn, Custer, Dawson, Wibaux, Richland, Roosevelt and Yellowstone) at elevations up to 3800 feet (1158 meters); currently there are no reliable Montana records from the Missouri River or its tributaries. Snapping turtles have probably been introduced in several localities (there are unconfirmed reports from Gallatin, Ravalli, and Sanders counties); confirmed records from Flathead and Lake counties represent introductions.

\section{Habitat}

Habitat use by snapping turtles in Montana is probably similar to elsewhere in the range, but studies are lacking and there is little qualitative information available. They have been captured or observed in backwaters along major rivers, at smaller reservoirs, and in smaller streams and creeks with permanent flowing water and sandy or muddy bottoms (Reichel 1995, Hendricks and Reichel 1996, P. Hendricks personal observation). Nesting habitat and nest sites have not been described.

Elsewhere, snapping turtles occur in all types of shallow freshwater habitats, such as streams, rivers, reservoirs, and ponds, especially those with a soft mud bottom and abundant aquatic vegetation or submerged brush and logs (Hammerson 1999), and in brackish water in some areas. Although found most 


\section{DRAFT WORKING DOCUMENT DO NOT DUPLICATE}

6453 often in shallower water, they have been reported on the bottom of lakes in water 6454 up to 10 meters deep. Temporary ponds may also be occupied. Hatchlings and 6455 juveniles tend to occupy shallower sites than mature individuals in the same 6456 water bodies. They are mostly bottom dwellers, where they spend much of their

6457

6458

6459

6460

6461

6462

6463

6464

6465

6466

6467

6468

6469

6470

6471

6472

6473

6474

6475

6476

6477

6478

6479

6480

6481

6482

6483

6484

6485

6486

6487

6488

6489

6490

6491

6492

6493

6494

6495

6496

6497

6498

time. Although highly aquatic, they may make long movements overland if their pond or marsh dries (Baxter and Stone 1985, Ernest et al. 1994, Hammerson 1999). They hibernate singly or in groups in streams, lakes, ponds, or marshes; in bottom mud, in or under submerged logs or debris, under an overhanging bank, or in muskrat tunnels; often in shallow water; sometimes in anoxic sites (Brown and Brooks 1994). Sometimes they bask out of water, especially younger individuals and in the northern extremes of the global range.

Nests are built in soft sand, loam, vegetation debris, or even sawdust piles, most often in open areas and often a hundred meters or more from water (Congdon et al. 1987, Ernst et al. 1994, Hammerson 1999); they also nest in beaver and muskrat lodges.

\section{Management}

Montana populations of the snapping turtle are poorly understood, making management of them more difficult. It is likely that dams and large reservoirs on rivers (e.g. Fort Peck Dam and Reservoir) are detrimental to population continuity to some degree, (Maxell et al. 2003), although this species can travel overland and may be able to bypass some dams. Impacts of other habitat disturbances are not clear, but this species occupies man-made water bodies throughout its range that provide necessary resources and habitat characteristics. Construction of irrigation ditches and canals may have allowed this species to occupy manmade water bodies. Studies of nesting success, population structure, dispersal, and population size need to be conducted throughout the range of the snapping turtle in Montana.

Routine surveys for snapping turtles in appropriate habitats could be made a standard part of the field duties of agency fishery biologists. Records should be maintained of the incidental "take" by anglers, who should be encouraged to report any captured individuals; killed animals should be examined by agency fishery or wildlife biologists if possible so that data on sex, size, and food habits can be gathered and a base of information developed on the biology of this species in Montana. It is possible that even moderate harvest of adults by anglers in most localities will result in population declines, similar to Colorado (Hammerson 1999), because the life history of this species indicates recruitment of juveniles into breeding populations is low, and population densities in western states is probably low. Identified nesting sites should be monitored and protected from disturbance by humans.

\section{Conservation Concerns}


6499

6500

6501

6502

6503

6504

6505

6506

6507

6508

6509

6510

6511

6512

6513

6514

6515

6516

6517

6518

6519

6520

6521

6522

6523

6524

6525

6526

6527

6528

6529

6530

6531

6532

6533

6534

6535

6536

6537

6538

6539

6540

6541

6542

6543

6544
- Habitat loss

- Nest destruction and predation

- Human harvest of long-lived adults

\section{Conservation Strategies}

- Consider preparing management plan for Snapping Turtle or inclusion into other comprehensive taxonomic plan

- Meticulous tracking of observations

- Conservation of nest areas

- Surveys of suitable habitat that are designed to detect the species need to be carried out

- Consideration of restriction on harvests

\section{Management Plan}

None

\section{Citations}

Baxter, G. T. and M. D. Stone. 1985. Amphibians and reptiles of Wyoming.

Second edition. Wyoming Game and Fish Department, Cheyenne.

Brown, G. P., and R. J. Brooks. 1994. Characteristics of and fidelity to hibernacula in a northern population of snapping turtles, CHELYDRA SERPENTINA. Copeia 1994:222-226.

Congdon, J. D., et al. 1987. Reproduction and nesting ecology of snapping turtles (CHELYDRA SERPENTINA) in southeastern Michigan. Herpetologica 43:39-54.

Ernst, C. H., J. E. Lovich, and R. W. Barbour. 1994. Turtles of the United States and Canada. Smithsonian Institution Press, Washington, D.C. 578 pp.

Hammerson, G. A. 1999. Amphibians and reptiles in Colorado. Second edition. University Press of Colorado, Boulder, Colorado. xxvi +484 pp.

Hendricks, P. and J. D. Reichel. 1996. Preliminary amphibian and reptile survey of the Ashland District, Custer National Forest: 1995. Montana Natural Heritage Program. Helena, MT. 79 pp.

Maxell, B. A., J. K. Werner, P. Hendricks, and D. L. Flath. 2003. Herpetology in Montana: a history, status summary, checklists, dichotomous keys, accounts for native, potentially native, and exotic species, and indexed bibliography.

Northwest Fauna. 


\section{DRAFT WORKING DOCUMENT DO NOT DUPLICATE}

6545 Reichel, J. D. 1995. Montana Species of Special Concern. Montana Natural

6546 Heritage Program, Helena, Montana. 10 pp.

6547

6548 


\section{DRAFT WORKING DOCUMENT DO NOT DUPLICATE}

6548

6549

6550

6551

6552

6553

6554

6555

6556

6557

6558

6559

6560

6561

6562

6563

6564

6565

6566

6567

6568

6569

6570

6571

6572

6573

6574

6575

6576

6577

6578

6579

\section{Spiny Softshell (Apalone spinifera)}

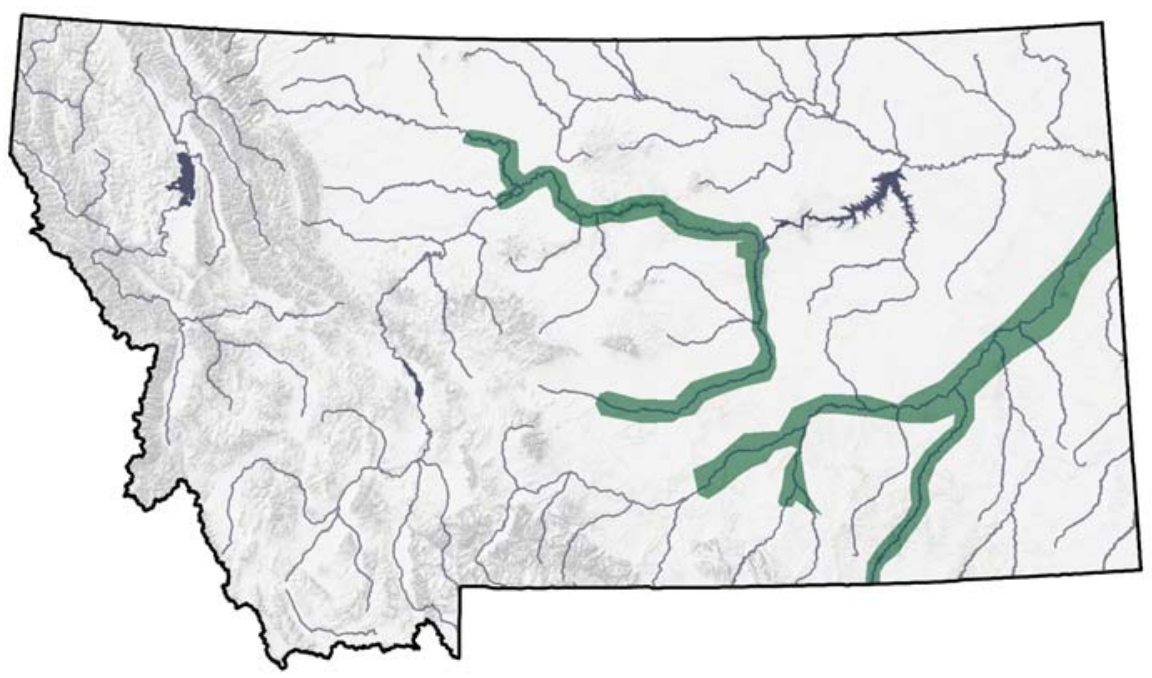

Figure 48. Distribution of the Spiny Softshell Turtle

\section{Range}

In Montana, native populations of the spiny softshell are present east of the Continental Divide in the Missouri River and Yellowstone River drainages, and some principle tributaries (Maxell et al. 2003). Large gaps remain in the species' range within Montana, especially in the Missouri River below the mouth of the Musselshell River. Spiny softshells in Montana are thought to be isolated from the remainder of the global population, and it appears the population in the Missouri River is isolated from the population in the Yellowstone River. Voucher specimens have been collected in five counties (Big Horn, Chouteau, Prairie, Rosebud, Wheatland), with visual observations in eight additional counties, at elevations up to 3600 feet (1097 meters); a questionable voucher record exists from Roosevelt County.

\section{Habitat}

Habitat use by spiny softshell in Montana is probably similar to elsewhere in the range, but studies are lacking and there is little qualitative information available. They occupy larger rivers and tributaries. Both sexes have been observed basking together on partially submerged logs in backwater sites of slow-moving water, and on sandy or muddy riverbanks (P. Hendricks personal observation).

Generally, the spiny softshell is primarily a riverine species, occupying large rivers and river impoundments, but also occurs in lakes, ponds along rivers, pools along intermittent streams, bayous, irrigation canals, and oxbows. It usually is found in areas with open sandy or mud banks, a soft bottom, and submerged brush and other debris. Spiny softshells bask on shores or on partially 


\section{DRAFT WORKING DOCUMENT DO NOT DUPLICATE}

6580 submerged logs. They burrow into the bottoms of permanent water bodies, either 6581 shallow or relatively deep (0.5 to 7.0 meters), where they spend winter. Eggs are 6582 laid in nests dug in open areas in sand, gravel, or soft soil near water (Baxter and 6583 6584

6585

6586

6587

6588

6589

6590

6591

6592

6593

6594

6595

6596

6597

6598

6599 Stone 1985, Ernst et al. 1994, Hammerson 1999, Stebbins 2003).

\section{Management}

Montana populations of the spiny softshell are poorly understood, making management of them more difficult. It is apparent that the construction of dams and large reservoirs on rivers (e.g. Fort Peck Dam and Reservoir) is detrimental to population continuity, effectively creating smaller isolated populations. Impacts of other habitat disturbances are not clear. Studies of nesting success, population structure, dispersal, and population size need to be conducted throughout the range of both Montana sub-populations (Missouri River and Yellowstone River). Routine surveys for softshells in appropriate habitats could be made a standard part of the field duties of agency fishery biologists. Records should be maintained of the incidental "take" by anglers, who should be encouraged to report any captured spiny softshell; killed animals should be examined by agency fishery or wildlife biologists if possible so that data on sex, size, and food habits can be gathered and a base of information on the biology of

6600 this species developed. Nesting sites need to be identified and protected from

6601

6602

6603

6604

6605

6606

6607

6608

6609

6610

6611

6612

6613

6614

6615

6616

6617

6618

6619

6620

6621

6622 disturbance by human activities.

\section{Conservation Concerns}

- Barriers that hamper movement of Spiny Softshell

- Habitat loss

- Nest disturbance

- Incidental take from anglers

\section{Conservation Strategies}

- Consider preparing management plan for Spiny Softshell or inclusion into other comprehensive taxonomic plan

- Conservation of major rivers in Montana

- Protect nest site from human disturbance

- Record keeping of observations

\section{Management Plan}

None

\section{Citations}

6623

6624

6625

Baxter, G. T. and M. D. Stone. 1985. Amphibians and reptiles of Wyoming.

Second edition. Wyoming Game and Fish Department, Cheyenne. 


\section{DRAFT WORKING DOCUMENT DO NOT DUPLICATE}

6626

6627 Ernst, C. H., J. E. Lovich, and R. W. Barbour. 1994. Turtles of the United States

6628

6629

6630

6631

6632

6633

6634

6635

6636

6637

6638

6639

6640

6641

and Canada. Smithsonian Institution Press, Washington, D.C. 578 pp.

Hammerson, G. A. 1999. Amphibians and reptiles in Colorado. Second edition. University Press of Colorado, Boulder, Colorado. xxvi + 484 pp.

Maxell, B. A., J. K. Werner, P. Hendricks, and D. L. Flath. 2003. Herpetology in Montana: a history, status summary, checklists, dichotomous keys, accounts for native, potentially native, and exotic species, and indexed bibliography. Northwest Fauna.

Stebbins, R. C. 2003. A Field guide to western reptiles and amphibians. Third edition. Houghton Mifflin Company, Boston, Massachusetts. 533 pp. 
6641 Western Hognose Snake (Heterodon nasicus)

6642

6643

6644

6645

6646

6647

6648

6649

6650

6651

6652

6653

6654

6655

6656

6657

6658

6659

6660

6661

6662

6663

6664

6665

6666

6667

6668

6669

6670

6671

6672

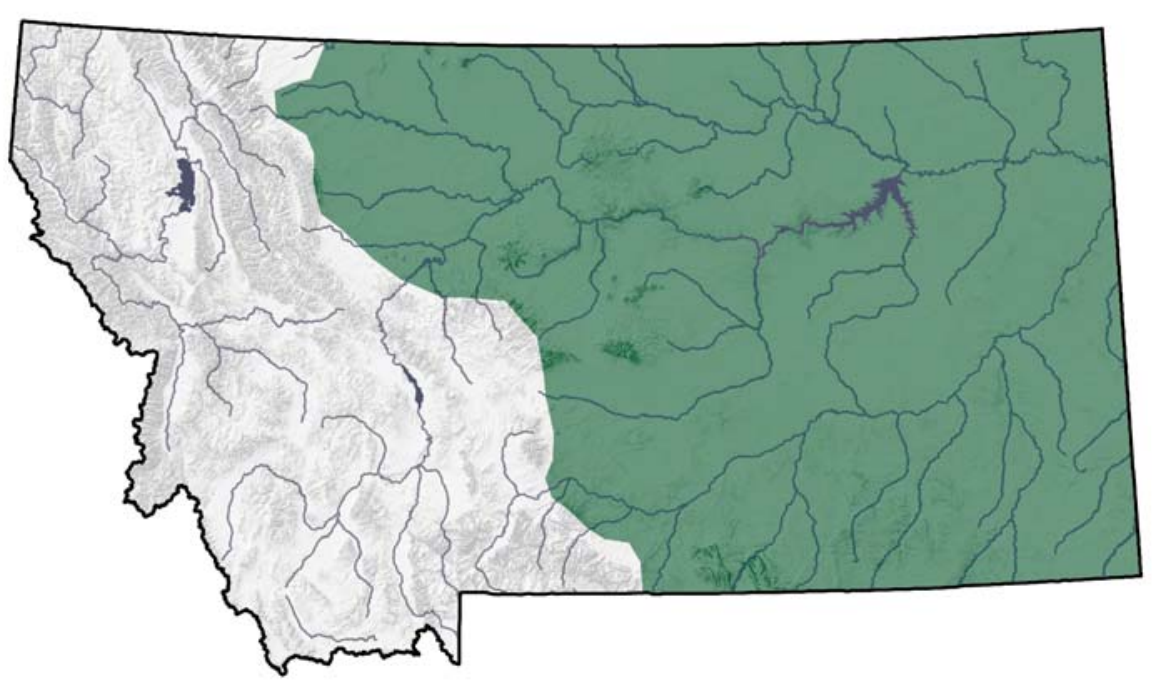

Figure 49. Distribution of the Western Hognose Snake

\section{Range}

In Montana, the western hognose snake is found east of the Continental Divide throughout the prairies, although significant gaps in the known distribution remain in the central region between the "island" mountain ranges, and there are few reports statewide in the last ten years (Maxell et al. 2003). Voucher specimens exist for 17 eastern counties, and there are observation records from seven additional counties, at elevations up to 4060 feet (1237 meters).

\section{Habitat}

Little specific information for the state is available. They have been reported in areas of sagebrush-grassland habitat (Dood 1980) and near pine savannah in grassland underlain by sandy soil (Reichel 1995, Hendricks 1999). Distribution of soil and vegetation and proximity to water could be limiting factors for distribution.

In other locations, their apparent preference for arid areas, farmlands, and floodplains, particularly those with gravelly or sandy soil, has been noted. They occupy burrows or dig into soil, and can be found under rocks or debris, during periods of inactivity (Baxter and Stone 1985, Hammerson 1999, Stebbins 2003).

\section{Management}

Apparently the western hognose snake was relatively abundant in Montana during the late 19th Century. In 1876 it was the third most common reptile (after the western rattlesnake and short-horned lizard) along the Missouri River 


\section{DRAFT WORKING DOCUMENT DO NOT DUPLICATE}

6673 between Fort Benton and the mouth of the Judith River (Cope 1879). This is no

6674 longer the case (Maxell et al. 2003); the few recent records suggest that the

6675 species is uncommon throughout Montana, although its status is largely

6676 unknown. The apparent decline in abundabce of hognose snakes may be

6677 related to extensive habitat loss associated with conversion of prairie to

6678 agricultural landscapes. As in other regions, an unknown percentage of local

6679 populations experience road mortality, as many specimen and observation

6680 records are of road-killed individuals. Draining of prairie wetlands may have

6681 negative impacts on their preferred prey (toads and frogs particularly, and

6682 perhaps turtle eggs).

6683

6684 Management of hognose snakes in Montana is hampered by a lack of basic

6685

6686

6687

information on abundance, food habits, and habitat associations. Currently, protecting grassland habitat and, where possible, preventing the destruction of

6688 rattlesnake dens where they might overwinter are the recommended

6689

6690 conservation measures.

6691

6692

6693

6694

6695

6696

6697

6698

6699

6700

6701

6702

6703

6704

\section{Conservation Concerns}

- Distribution, status and habitat uses are poorly understood

- Some evidence for declines potentially associated with habitat loss

- Pet trade industry

- Specialist diet (amphibians)

- Declines in prey (amphibians)

\section{Conservation Strategies}

- Develop a comprehensive taxanomic management plan (e.g. for reptiles) that includes the Western Hognose Snake that addresses the above listed concerns

- Record all observations of this species to continue establishing its range in Montana

6705

6706

6707

6708

6709

6710

6711

6712

6713

6714

6715

6716

6717

- Increase education and information on reptile biology and awareness of the importance of den and nest sites

- Targeted surveys (specific to hognose snakes) in suitable habitat to continue determining their range in Montana

\section{Management Plan}

None

\section{Citations}

Baxter, G. T. and M. D. Stone. 1985. Amphibians and reptiles of Wyoming.

6718

Second edition. Wyoming Game and Fish Department, Cheyenne. 


\section{DRAFT WORKING DOCUMENT DO NOT DUPLICATE}

6719 Cope, E. D. 1879. A contribution to and zoology of Montana. American Naturalist 6720 13(7): 432-441.

6721

6722

6723

6724

6725

6726

6727

6728

6729

6730

Dood, A. R. 1980. Terry Badlands nongame survey and inventory: final report.

[BLM Contract \#YA-512-CT8-217]. Montana Dept. of Fish, Wildlife, and Parks. 70 pp.

6731

6732

6733

6734

6735

6736

6737

6738

6739

6740

6741

6742

6743

6744

6745

Hammerson, G. A. 1999. Amphibians and reptiles in Colorado. Second edition. University Press of Colorado, Boulder, Colorado. xxvi + 484 pp.

Hendricks, P. 1999. Amphibian and reptile survey of the Bureau of Land Management Miles City District, Montana. Montana Natural Heritage Program, Helena, Montana. 80 pp.

Maxell, B. A., J. K. Werner, P. Hendricks, and D. L. Flath. 2003. Herpetology in Montana: a history, status summary, checklists, dichotomous keys, accounts for native, potentially native, and exotic species, and indexed bibliography. Northwest Fauna.

Reichel, J. D. 1995. Preliminary amphibian and reptile survey of the Sioux District of the Custer National Forest: 1994. Montana Natural Heritage Program. Helena, Montana. $75 \mathrm{pp}$.

Stebbins, R. C. 2003. A Field guide to western reptiles and amphibians. Third edition. Houghton Mifflin Company, Boston, Massachusetts. 533 pp.

6746

Werner et al. 2004. Amphibians and Reptiles of Montana. 


\section{DRAFT WORKING DOCUMENT DO NOT DUPLICATE}

6746

6747

6748

6749

6750

6751

6752

6753

6754

6755

6756

6757

6758

6759

6760

6761

6762

6763

6764

6765

6766

6767

6768

6769

6770

6771

6772

6773

6774

6775

6776

6777

\section{Milk Snake (Lampropeltis triangulum)}

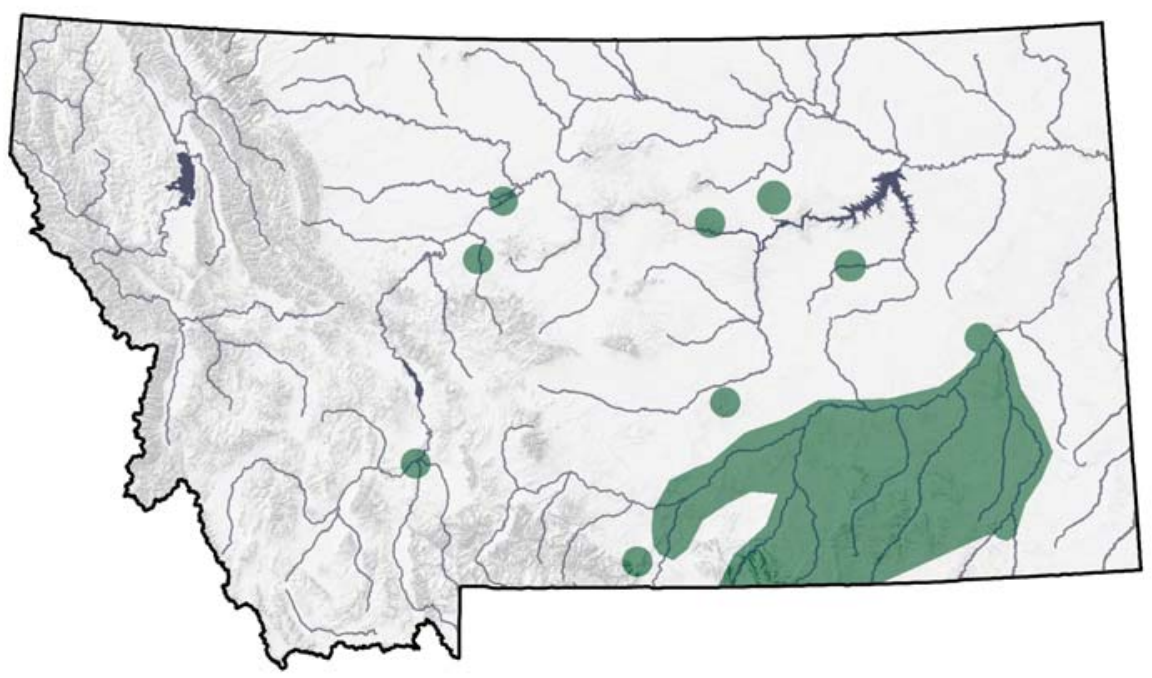

Figure 50. Distribution of the Milk Snake

\section{Range}

In Montana, the milk snake is found east of the Continental Divide throughout much of the prairie regions, although mostly south of the Missouri River (Maxell et al. 2003); significant gaps are present in the known distribution, probably due in part to a combination of restricted habitat preferences, extensive use of cover (i.e. rocks), and nocturnal habits. Voucher specimens exist for seven counties (Carbon, Chouteau, Custer, Garfield, Phillips, Powder River, Yellowstone), and there are observation records for four additional counties (Big Horn, Musselshell, Prairie, Rosebud), at elevations up to 3960 feet (1207 meters). Questionable records exist for Cascade County near Belt, and the boundary of Broadwater, Gallatin, and Jefferson counties near Three Forks.

\section{Habitat}

Little specific information is available. Milk snakes have been reported in areas of open sagebrush-grassland habitat (Dood 1980) and ponderosa pine savannah with sandy soils (Hendricks 1999, B. Maxell personal communication, L. Vitt personal communication), most often in or near areas of rocky outcrops and hillsides or badland scarps, sometimes within city limits.

\section{Management}

So few recent milk snake records exist for Montana (Maxell et al. 2003) that it is difficult to determine if management activity is needed. Nevertheless, the widely scattered recent records indicate that milk snakes continue to occupy a large part of the known range in the state, and some sites near a large urban center have 


\section{DRAFT WORKING DOCUMENT DO NOT DUPLICATE}

6778 remained occupied for the last 40 to 45 years (L. Vitt personal communication).

6779 Management for this species is hampered by a lack of basic information on

6780 abundance, food habits, and habitat associations. No specific management

6781 activities are suggested at this time, other than to protect known occupied habitat

6782 and monitoring their use in the pet trade.

6783

6784

6785

6786

6787

6788

6789

6790

\section{Conservation Concerns}

- Distribution, status, and biology are poorly understood

- Pet trade industry

\section{Conservation Strategies}

6791

6792

6793

6794

6795

6796

6797

6798

6799

6800

6801

6802

6803

- Develop a comprehensive taxanomic management plan (e.g. for reptiles) that includes the milk snake and that addresses the above conservation concerns

- Record all observations of this species to continue establishing its range in Montana

- Increase education and information on reptile biology and awareness of the importance of den and nest sites

- Targeted surveys (specific to the Milk Snake) in suitable habitat to continue determining its range in Montana

\section{Management Plan}

None

6804

6805

6806

6807

6808

6809

6810

6811

6812

6813

6814

6815

6816

6817

6818

6819

6820

\section{Citations}

Dood, A. R. 1980. Terry Badlands nongame survey and inventory: final report.

[BLM Contract \#YA-512-CT8-217]. Montana Dept. of Fish, Wildlife, and Parks. 70 pp.

Hendricks, P. 1999. Amphibian and reptile survey of the Bureau of Land Management Miles City District, Montana. Montana Natural Heritage Program, Helena, Montana. 80 pp.

Maxell, B. A., J. K. Werner, P. Hendricks, and D. L. Flath. 2003. Herpetology in Montana: a history, status summary, checklists, dichotomous keys, accounts for native, potentially native, and exotic species, and indexed bibliography.

Northwest Fauna.

6821

Werner et al. 2004. Amphibians and Reptiles of Montana. 
6823

6824

6825

6826

6827

6828

6829

6830

6831

6832

6833

6834

6835

6836

6837

6838

6839

6840

6841

6842

6843

6844

6845

6846

6847

6848

6849

6850

6851

6852

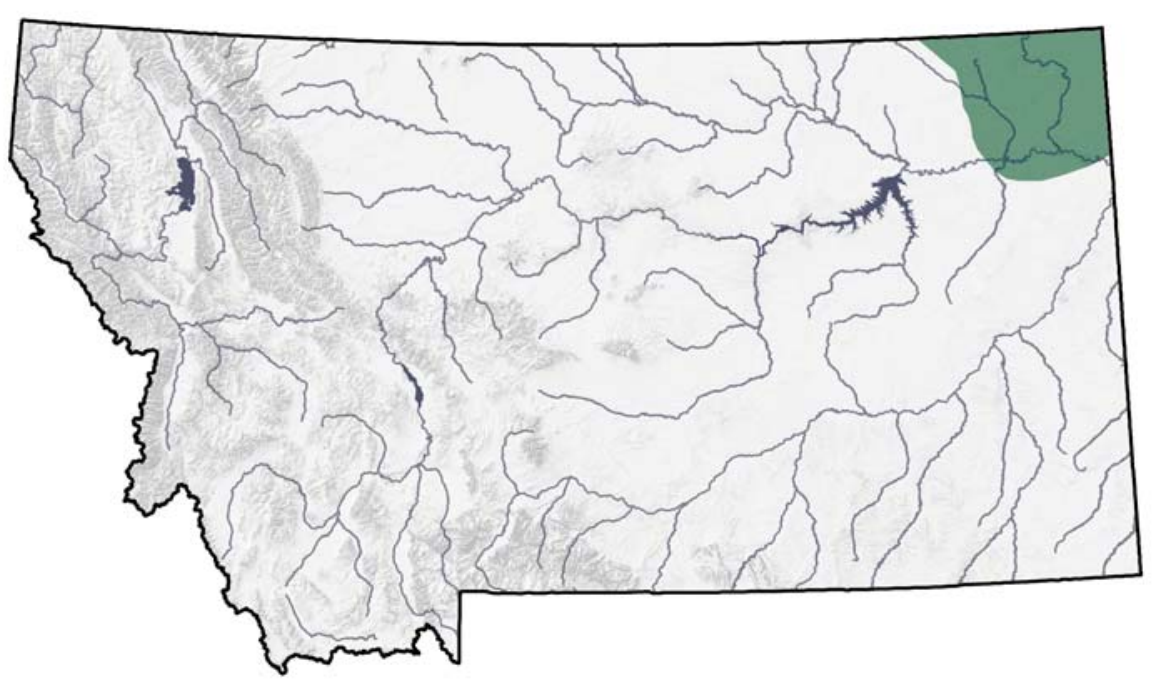

Figure 51. Distribution of the Smooth Green Snake

\section{Range}

Montana is at the edge of the global range. The smooth green snake is restricted to extreme northeastern Montana north of the Missouri River, at elevations below 2150 feet (655 meters). There are reliable records from Sheridan County (Maxell et al. 2003) and recently found in Valley County, as well as undoubtedly occurs in Roosevelt County. This snake may eventually be documented south of the Missouri River near the boundry with North Dakota.

\section{Habitat}

Little information is available for the species in Montana, though it has been reported from residential lawns, city parks, along ditches in the Prairie Pothole Region, and around wetland complexes. Based upon observations outside Montana, the smooth green snake is known to occupy meadows, grassy marshes, moist grassy fields at forest edge, mountain shrublands, stream borders, bogs, open moist woodland, abandoned farmland, and vacant lots. Periods of inactivity are spent underground, beneath woody debris and rocks, or in rotting wood. They have been found hibernating in abandoned ant mounds. Most activity is restricted to the ground, but they may climb into low vegetation, and sometimes enter water (Hammerson 1999).

\section{Management}

No special management activity is defined at this time. Habitat within areas that are known to be occupied by smooth green snakes should be protected. 


\section{DRAFT WORKING DOCUMENT DO NOT DUPLICATE}

6853

6854

6855

6856

6857

6858

6859

6860

6861

6862

6863

6864

6865

6866

6867

6868

6869

6870

6871

6872

6873

6874

6875

6876

6877

6878

6879

6880

6881

6882

6883

6884

\section{Conservation Concerns}

- Distribution, status, and biology in Montana are poorly understood

\section{Conservation Strategies}

- Develop a comprehensive taxanomic management plan (e.g. for reptiles) that includes the Smooth Green Snake and that addresses the above conservation concerns

- Record all observations of this species to continue establishing its range in Montana

- Increase education and information on reptile biology

- Targeted surveys (specific to the Smooth Green Snake) in suitable habitat to continue determining its range in Montana

\section{Management Plan}

None

\section{Citations}

Hammerson, G. A. 1999. Amphibians and reptiles in Colorado. Second edition.

University Press of Colorado, Boulder, Colorado. xxvi + 484 pp.

Maxell, B. A., J. K. Werner, P. Hendricks, and D. L. Flath. 2003. Herpetology in Montana: a history, status summary, checklists, dichotomous keys, accounts for native, potentially native, and exotic species, and indexed bibliography.

Northwest Fauna.

Werner et al. 2004. Amphibians and Reptiles of Montana. 


\section{DRAFT WORKING DOCUMENT DO NOT DUPLICATE}

6884

6885

6886

6887

6888

6889

6890

6891

6892

6893

6894

6895

6896

6897

6898

6899

6900

6901

6902

6903

6904

6905

6906

6907

6908

6909

6910

6911

6912

6913

6914

6915

\section{Birds}

\section{Common Loon (Gavia immer)}

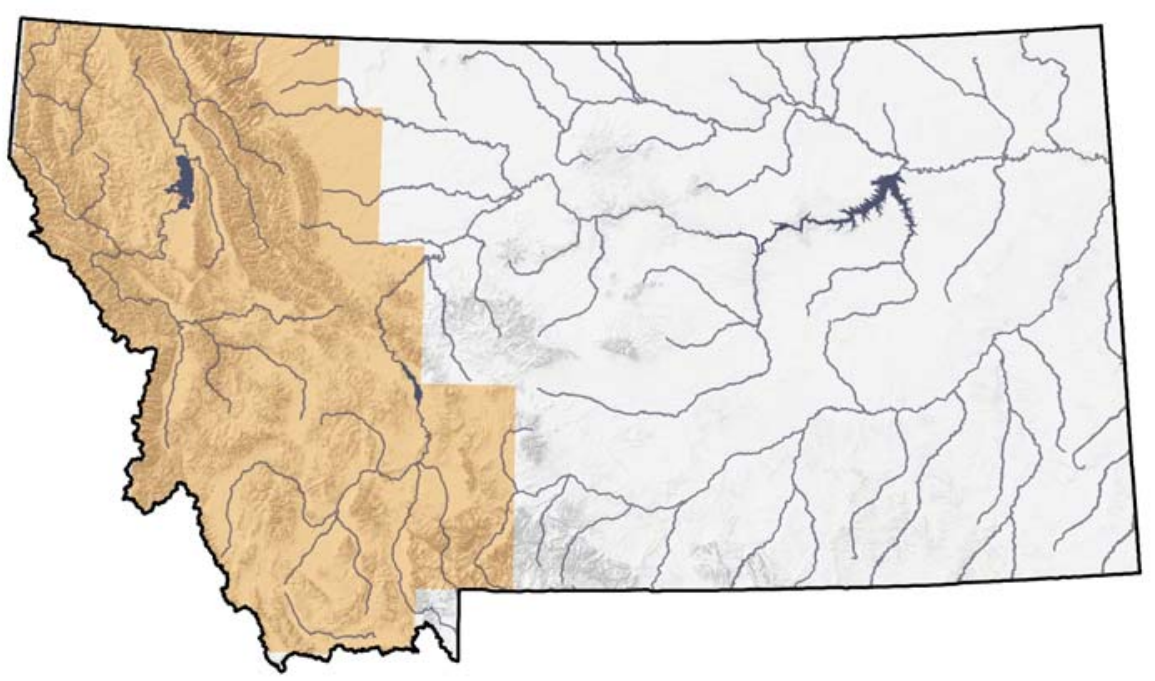

Figure 52. Distribution of the Common Loon

\section{Range}

The global population of Common Loons is considered "secure" (IUCN G5 Ranking); however, many local populations are small, isolated and are vulnerable to extinction primarily due to habitat loss and human encroachment into key habitat (Kelly 1992, Evers 2004). Loons are considered imperiled (MT ranking S2) by the Montana Natural Heritage Program and are already listed as a "sensitive species" by the U. S. Forest Service (R-1) and a Species of Management Concern by the USFWS Region 6 (U.S. Fish and Wildlife Service 1995).

In Montana, the current breeding range for Common Loons is primarily restricted to lower elevation forested glacial lakes in the northwest corner of the state. Historically, Common Loons were believed to have nested throughout the western half of the state where suitable habitat was found. The primary nesting habitat currently used is restricted to lakes in the Blackfoot, Flathead, and Kootenai River drainages with some breeding occurring on the east side of Glacier National Park and on the Blackfeet Indian Reservation, loons also currently nest in Yellowstone National Park; historic records include lakes in southwest Montana. Common Loons breeding in Canada migrate through the entire state during spring and fall. Rafts of over 60 birds have been frequently observed on major lakes and reservoirs throughout the state. Nonbreeding common loons are occasionally observed during the summer in Montana also on larger lakes or reservoirs. A pair of Common Loons once nested in central Montana, at Nelson Reservoir near Malta (F. Prellwitz, pers. com. in Dolan 1994). Common Loons have been recorded as breeding in 11 Montana counties: 


\section{DRAFT WORKING DOCUMENT DO NOT DUPLICATE}

6916 Lincoln, Flathead, Glacier, Sanders, Lake, Missoula, Powell, Lewis and Clark, 6917 Teton, Beaverhead, and Madison counties (Montana Bird Distribution 2003, 6918 MTNHP 2002) (Montana Animal Field Guide 2004). The northwestern portion of 6919

6920 Montana supports the highest density of nesting Common Loons in the lower 48 states west of the Mississippi River. Based on coordinated total counts of

6921

6922

6923

6924

6925

6926

6927

6928

6929

6930 common loons in mid-July over the last six years, Montana supports an average of 62 (+/-5) breeding pairs who successfully raise an average of 43 (+/- 8) chicks each year. In addition, surveyors count an average of 48 single or nonbreeding adult loons. Total mid-summer loon counts since 1999 range have averaged 217 (range 201-230). Based on these data, the population appears to be stabe (Bissell 2005).

6931

6932

6933

6934

6935

6936

6937

6938

6939

Based on recoveries or reobservations of adult and juvenile banded Common Loons first captured on nesting lakes in northwest Montana, our loons appear to winter along the west coast from Washington to the mid-California coast (Bissell 2005). Occasional over wintering also occurs in Montana. Common Loons have been observed over wintering (December 15 - February 15) in Lincoln, Flathead and Lake counties (Montana Bird Distribution 2003).

\section{Habitat}

In Montana, Common Loons will generally not nest on lakes less than about 13 acres in size or over 5000 feet in elevation (Skaar 1990). If nesting on a small lake, they may use an adjacent lake for supplementary foraging (Montana Animal Field Guide 2004). Successful nesting requires both nesting sites and nursery areas sheltered from winds and disturbances. Small islands, coves, and bays are preferred general areas for nesting. Loons must nest adjacent to water and they frequently nest on herbaceous shoreline areas but also logs, stumps, muskrat houses, floating vegetative mats, and gravel shorelines if that is all that is available. Nests usually consist of aquatic vegetation shaped into a shallow bowl located within a few inches of the water's edge. Nursery areas are very often sheltered, shallow coves with abundant small fish and insects (Skaar 1990). Most Montana lakes inhabited by Common Loons are relatively oligotrophic and have not experienced significant siltation or other hydrological changes.

6950

6951

6952

6953

6954

6955

6956

6957

6958

6959

Nesting loons are very sensitive to disturbances from humans. Based on studies by Don Skarr and Lynn Kelly in the 1980s and 1990s, human disturbances from boaters and anglers were causing a significant number of nest failures. During the 1980's, campgrounds and cabin development occurred on many loon nesting lakes. In some areas such as on Seeley Lake and along the Thompson Chain of Lakes where recreation was increasing, loons spent significantly more time away from their nests compared to nesting loons on lakes with little human use boats. Over time, several pairs of loons on the busier lakes were unsuccessful and have 6960 since abandoned their territories on Seeley, Salmon, and two lakes in the Thompson Chain of Lakes (Kelly 1992). 


\section{DRAFT WORKING DOCUMENT DO NOT DUPLICATE}

6961

6962

6963

6964

6965

6966

6967

6968

6969

6970

6971

6972

6973

6974

6975

6976

6977

6978

6979

6980

6981

6982

6983

6984

6985

6986

6987

6988

6989

6990

6991

6992

6993

6994

6995

6996

6997

6998

6999

7000

7001

7002

7003

7004

7005

7006
The quantity and quality of nesting habitat may limit the loon population of northwest Montana. Skaar (1990) estimated the state's "carrying capacity" at 185 potential nesting territories, based on the size and number of lakes within the species' breeding distribution. He assumed 100 ha of surface area per pair. Kelly (1992) documented a density of 72.2 surface ha of water per adult loon for the Tobacco, Stillwater, Clearwater, and Swan River drainages.

Loons are a long-lived slowly reproducing species that raise a maximum of only 1-2 young per year. It takes 3 years for loons to acquire adult plumage and an average of 7 years before adults successfully occupy a territory and raise young (Evers 2004). Adults may live to 20 years or more. Juvenile birds spend 3 winters in coastal waters before returning inland in adult plumage. Scientists studying common loons in other parts of their range estimate juvenile recruitment rates to the adult state ( 3 years) to be about $40 \%$ (Evers 2004). Loons are also poor colonizers with the young returning to within $5-20 \mathrm{~km}$ or their natal area. This slow reproductive rate combined with limited dispersal distance and extreme territoriality presents some unique challenges to wildlife managers. Common Loon habitat is relatively restricted in nature. Given their fierce territorial behavior to maintain successful occupation of a lake or portion of a lake, the occupation of all available habitats will inevitably lead to greater territorial conflicts. In recent years, Montana loon observers have picked up at least 2 dead loons thought to have died from chest impact wounds from defending adults. Observers have also reported chicks snatched by bald eagles or floating away during territorial squabbles (Bissell, pers. comm. 2005). Repeated nest failures at Upper Thompson Lake in both 2004 and 2005 appear to be related to fighting, territorial switching, and general competition between 2 adjoining nesting pairs of loons and other territorial pairs in the drainage.

In Common Loon populations of the northeast U.S. and Canada, the accumulation of methyl mercury is a threat to Common Loon survival (Evers 2004). In addition, ingestion of lead sinkers has been a source of mortality (Evers 2004). In Montana, methyl mercury levels in most Common Loon blood or egg samples are low to moderate indicating that current levels of mercury contamination are not a threat to population health.

\section{Management}

Since 1999, management of Common Loons and their habitat in Montana is coordinated through the Common Loon Working Group (CLWG), an ad hoc advisory group consisting of representatives from state and federal agencies, tribes, non-profit organizations such as the Montana Loon Society, and industry. This group coordinates surveys, research, and management programs and meets at least twice a year. The CLWG has helped solicit and fund the Loon Ranger Program as well as the recently started Loon Ecology Project using a State Wildlife Grant. 


\section{DRAFT WORKING DOCUMENT DO NOT DUPLICATE}

7007

7008

7009

7010

7011

7012

7013

7014

7015

7016

7017

7018

7019

7020

7021

7022

7023

7024

7025

7026

7027

7028

7029

7030

7031

7032

7033

7034

7035

7036

7037

7038

7039

7040

7041

7042

7043

7044

7045

7046

7047

7048

7049

7050

The current management program entails many activities focused on loon conservation including two coordinated annual population surveys: one in midMay on accessible breeding lakes to determine territorial pair presence and possibly nesting; and a second survey in mid-July to count both adults and chicks of the year. The data are collected by the CLWG and housed in a centralized database maintained by the Montana Natural Heritage Program

The management program also consists of implementing an annual outreach and education program using "Loon Rangers" at most breeding lakes that have high levels of recreation use. Through FWP's summer internship program, 3-4 college students are hired each year to help with educational signs, floating buoys, surveys, and education programs at the busiest nesting lakes. The Loon Ranger program was initiated in 2000 . Funding is provided by both agencies and private donations. For many lakes, management includes the setting out of floating buoys around nest sites where conflicts with boaters has occurred; the use of artificial loon platforms or nesting islands on lakes where nesting habitat has been reduced or lakes levels affected. Until recently, Glacier National Park participated only in annual surveys. This year, Glacier is initiating a citizen science program to more closely monitor nesting loons within the Park. FWP has summarized the various CLWG activities over the last 5 years through periodic annual reports available through the Wildlife Division or Region One headquarters. Preliminary evaluation of the education program indicates nesting success has been maintained or increased in the areas served by the program.

Other management options that have been occasionally implemented by lakeshore landowners such as FWP, DNRC, and the Forest Service include managing access to lakes through seasonal closures of trails or campsites, rerouting of roads or trails, strategic placement of educational signs, changing the design or upgrades of boat ramps, implementing no-wake rules, and providing input on proposed development projects. The members of the CLWG also work with homeowner associations to identify areas in need of conservation.

The new research efforts are focused on determining habitat factors associated with nesting success at various habitat scales; monitoring levels of methyl mercury and other contaminants in loon eggs and blood; estimating Montana's potential habitat capacity and the relationship between Montana's breeding population and adjoining populations to the west (Washington), north (Canada) or south (Wyoming); determining adult and juvenile survival and recruitment rates, and estimating overall population trend. The results will be used to update Montana's Common Loon Conservation Plan in 2008.

\section{Conservation Concerns}




\section{DRAFT WORKING DOCUMENT DO NOT DUPLICATE}

7051

7052

7053

7054

7055

7056

7057

7058

7059

7060

7061

7062

7063

7064

7065

7066

7067

7068

7069

7070

7071

7072

7073

7074

7075

7076

7077

7078

7079

7080

7081

7082

7083

7084

7085

7086

7087

7088

7089

7090

7091

7092

7093

7094

7095

- Disturbances to loon nesting and foraging lakes and shorelines caused by human activities such as boating, angling, camping, or other activities during the nesting season

- Loss of nesting habitat including alternative nesting areas and nursery areas due to development, water level alterations, and recreation

- Loss of connectivity within Montana's populations as well as between Montana's population and other western populations

- Accumulation of contaminants over life of individual birds, including lead poisioning

\section{Conservation Strategies}

- Need for population demographic and trend information for Montana as well as increased knowledge of migratory routes and other factors affecting over winter survival

- Need to estimate total amount of available habitat and percent occupancy of that habitat based on historic and current habitat conditions

- Need to implement a territorial ranking system to help identify priority nesting lakes or areas

- Need to identify areas of population sinks and sources

- Need to continue to investigate known causes of mortality including the effect of human sources including methyl mercurty and lead on breeding loons

- Need to maintain the suitability of currently used nesting territories and create site-specific management plans that use a variety of tools to maintain loon nesting sites and nursery areas

- Need to identify risks and potential threats outside Montana to Montana's breeding population and the consequences of those risks

- Need to keep current data base up to date and available for interagency use

- Complete ongoing research efforts to revise loon conservation plan

- Provide for continued cooperative funding for education and other aspects of ongoing loon management plan

\section{Management Plans}

Casey, D. 2000. Partners in Flight Bird Conservation Plan Montana Version 1.0. Montana Partners in Flight. Kalispell, Montana.

Evers, David C. 2004. Status Assessment and Conservation Plan for the Common Loon (Gavia Immer) in North America, David C. Evers, BioDiversity Research Institute, April 12, 2004) available at http://alaska.fws.gov/mbsp/mbm/loons/pdf/Common_Loon_Status_Assessment.p df 


\section{DRAFT WORKING DOCUMENT DO NOT DUPLICATE}

7096

7097

7098

7099

7100

7101

7102

7103

7104

7105

7106

7107

7108

7109

7110

7111

7112

7113

7114

7115

7116

7117

7118

7119

7120

7121

7122

7123

7124

7125

7126

7127

7128

7129

7130

7131

7132

7133

7134

7135

7136

7137

7138

7139

7140

James A. Kushlan, Melanie J. Steinkamp, Katherine C. Parsons, Jack Capp, Martin Acosta Cruz, Malcolm Coulter, Ian Davidson, Loney Dickson, Naomi Edelson, Richard Elliot, R. Michael Erwin, Scott Hatch, Stephen Kress, Robert Milko, Steve Miller, Kyra Mills, Richard Paul, Roberto Phillips, Jorge E. Saliva, Bill Sydeman, John Trapp, Jennifer Wheeler, and Kent Wohl. 2002. Waterbird Conservation for the Americas: The North American Waterbird Conservation Plan, Version 1. Waterbird Conservation for the Americas, Washington, D.C. U.S.A., 78 pp.

Skaar, D. 1990. Montana common loon management plan. Unpublished report prepared for U.S. Forest Service, Region 1. $61 \mathrm{pp}$.

\section{Citations}

Bissell, Gael N. 2005. Third Annual Common Loon Report (Draft). Unpublished report. March 2005. Region One, Montana Fish, Wildlife \& Parks, $490 \mathrm{~N}$.

Meridian Rd, Kalispell, MT 59901.

Bissell, Gael N. 2005. Personal communication.

Digital Atlas of Idaho. (Accessed June 5, 2004;<http://imnh.isu.edu/digitalatlas >).

Dolan, P. M. 1994. The Common loon (GAVIA IMMER) in the northern region: biology and management recommendations. Unpublished report. U.S.D.A. Forest Service Region 1. 76 pp.

Kelly, L. M. 1992. The effects of human disturbance on common loon productivity in northwestern Montana. M.S. Thesis, University of Montana, Missoula. 65 p.

McIntyre, J.W., and J. F. Barr. 1997. Common Loon (Gavia immer). In The Birds of North America. No. 313. A. Poole, and F. Gills, editors. The Academy of Natural Sciences, Philadelphia, PA, and the American Ornithologists' Union, Washington, DC, U.S.A.

Montana Bird Distribution: An Online Database [web application]. 2002. Helena, Montana USA: Montana The Audubon Society Society. Available at http://nhp.nris.state.mt.us/mbd/. (Accessed October 7, 2002)

Montana Natural Heritage Program (MTNHP): Biological and Conservation Database. 2002. Helena, MT (Accessed: October 7, 2002)

NatureServe Explorer. (Accessed June 5, 2004;

http://www.natureserve.org/explorer/>). Montana Animal Field Guide. (Accessed June 5, 2004,<http://nhp.nris.state.mt.us/animalguide/>). 


\section{DRAFT WORKING DOCUMENT DO NOT DUPLICATE}

7141 U.S. Fish and Wildlife Service, Office of Migratory Bird Management. 1995.

7142 Migratory nongame birds of management concern in the United States: the 1995

7143 list. U.S. Government Printing Office:1996-404-911/44014. 22 pp.

7144

7145 


\section{DRAFT WORKING DOCUMENT DO NOT DUPLICATE}

7145 7146

7147

7148

7149

7150

7151

7152

7153

7154

7155

7156

7157

7158

7159

7160

7161

7162

7163

7164

7165

7166

7167

7168

7169

7170

7171

7172

7173

7174

7175

7176

\section{Trumpeter Swan (Cygnus buccinator)}

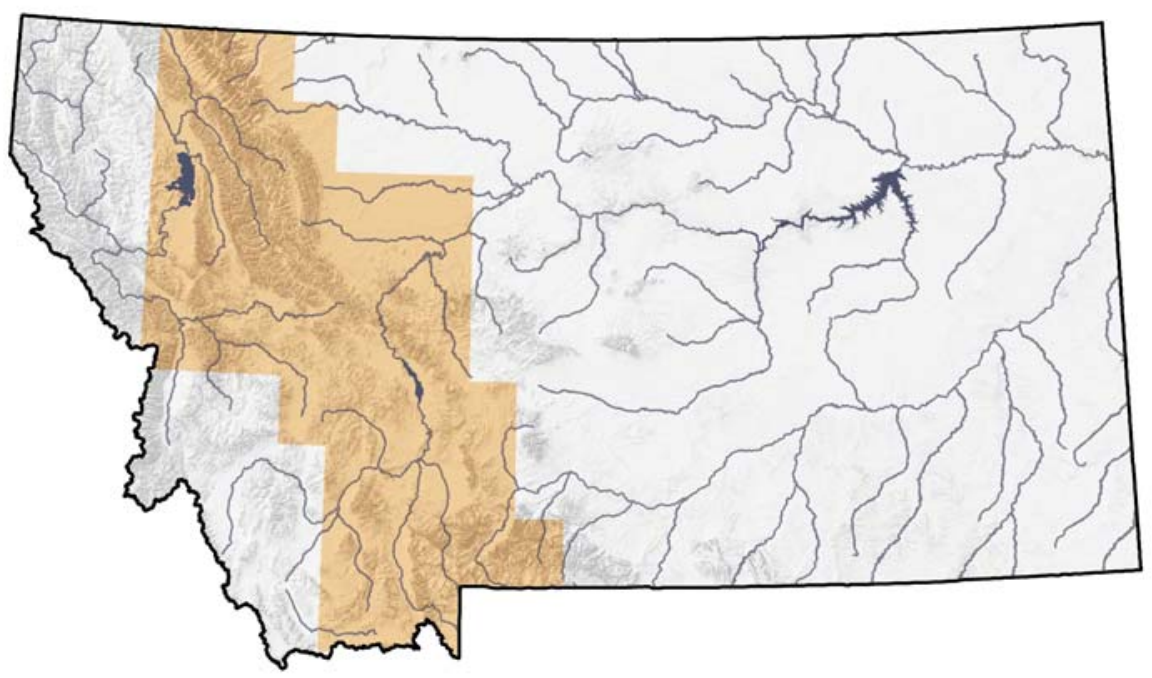

Figure 53. Distribution of the Trumpeter Swan

\section{Range}

Trumpeter Swans breeding in Montana are all part of the Rocky Mountain Population, which occurs all along the Rocky Mountain Range. The breeding range of these Trumpeter Swans in Montana is restricted to the extreme southwest corner of the state (Beaverhead County) and along the Rocky Mountain Front (Lewis and Clark County) (Montana Natural Heritage Program 2003). In Beaverhead County, Trumpeter Swans breed in Red Rock Lakes National Wildlife Refuge in the Centennial Valley, specifically the Lima Reservoir and the Upper and Lower Red Rock Lakes. In Lewis and Clark County they inhabit several small pothole lakes along the Front Range of the Rocky Mountains, most of which are west and southwest of Augusta. This is a very small subpopulation of the larger population breeding in the Centennial Valley (MTNHP 2003). Reintroductions are currently ongoing on the Flathead Indian Reservation in northwestern Montana as well.

The non-breeding range of Trumpeter Swans is also limited to several areas in the southwestern part of the state (Beaverhead, Gallatin, and Madison counties). Virtually all of the birds breeding in southwestern Montana also winter there. Birds summering in Canada that migrate to the area to winter join them. In Beaverhead County, the Red Rock Lakes area in the Centennial Valley is a major wintering ground for the species. In Madison County, they winter at Ennis Lake and the Madison River up to approximately 15 miles upstream. In Gallatin County, Trumpeter Swans winter on the south fork arms of Hebgen Reservoir, as well as the river below Hebgen Dam and several other smaller lakes in the area (MTNHP 2003). 


\section{DRAFT WORKING DOCUMENT DO NOT DUPLICATE}

7177 Trumpeter Swans breeding in Montana are non-migrants. They spend both the

7178 breeding season and the winter in southern Montana's lakes, ponds, and streams

7179 of the Red Rock Lakes National Wildlife Refuge. The Canadian subpopulation

7180 breeding in parts of British Columbia, Alberta, the Yukon, and the Northwest

7181 Territories will move south in late October to early November (Mitchell 1994).

7182

7183

7184

7185

7186

7187

7188

7189

7190

7191

7192

7193

7194

7195

7196

7197

7198

7199

7200

Fall migration dates for the Bozeman area are November 15 to December 15 (Skaar 1969). They usually follow the Rocky Mountain Front moving further south as water freezes or food diminishes. They eventually arrive in southern Montana and winter along with the resident population. Canadian swans leave their wintering grounds in early March to early April, moving up the Rocky Mountain Front toward their breeding habitat further north (Mitchell 1994). Migration dates for Bozeman are February 25 to April 15 (Skaar 1969).

\section{Habitat}

The breeding habitat for Trumpeter Swans in the Red Rock Lakes/ Centennial Valley of Montana includes lakes and ponds and adjacent marshes containing sufficient vegetation and nesting locations. Along the Rocky Mountain Front the breeding habitat is small pothole lakes, generally with sufficient water to maintain emergent vegetation through the breeding season (MTNHP 2003). However, due to recent drought conditions, this small breeding population has been severely impacted. In 2003, there was an attempt by swans to nest in the Upper Blackfoot drainage, and this area is targeted for future population augmentation or reintroduction for trumpeter swans. Habitat requirements for breeding include room to take off ( $\sim 100 \mathrm{~m})$, shallow, unpolluted water with sufficient emergent

7202

7203

7204

7205

7206

7207

7208

7209

7210

7211

7212

7213

7214

7215

7216

7217

7218

7219

7220

7221 vegetation and invertebrates, appropriate nest sites (i.e. muskrat lodges), and areas with little human disturbance (Mitchell 1994).

Their nonbreeding habitat in Montana is the many large and small lakes and ponds in extreme southern Montana, including the breeding area of the Red Rock Lakes/Centennial Valley. Swans also winter in the Ennis Lake and Madison River complex, as well as Hebgen Lake and the surrounding area. During winter appropriate habitat is areas where water does not freeze and food is plentiful and accessible. Swans will move out of one lake or pond to another if conditions become too severe.

\section{Management}

Management for Trumpeter Swans began in Montana in the early 1930s with the designation of Red Rock Lakes National Wildlife Refuge (RRLNWR). This refuge was specifically created for continued Trumpeter Swan presence and for active management practices. These early management practices consisted of protection from shooting, winter-feeding stations, and relocation to other breeding locations (Mitchell 1994). Some of these management activities are still in

7222 practice today, along with others including habitat restoration, human recreation 


\section{DRAFT WORKING DOCUMENT DO NOT DUPLICATE}

7223

7224

7225

7226

7227

7228

7229

7230

7231

7232

7233

7234

7235

7236

7237

7238

7239

7240

7241

7242

7243

7244

7245

7246

7247

7248

7249

7250

7251

7252

7253

7254

7255

7256

7257

7258

7259

7260

7261

7262

7263

7264

7265

7266

7267

7268

management, breeding, wintering habitat management, and winter translocation work (Mitchell 1994). Since 1988, Trumpeter Swans have been relocated from Red Rock Lakes NWR in southern Montana to locations in Idaho, Oregon, Wyoming and Utah to promote exploration of new wintering and habitats and to remedy the increasing problem of overpopulation in the refuge during winter. The goal is to have less than $10 \%$ winter at any one site and no swans wintering at Red Rock Lakes NWR (Baskin 1993). In 1993, winter feeding stations were terminated in the Red Rock Lakes NWR. It was believed these stations were reducing the winter range expansion work, as birds would not actively explore new wintering locations if food were made readily available in the refuge. Since then, Trumpeter Swans have indeed dispersed to new areas in the west and the remaining population in RRLNWR has stabilized. Other management techniques include the biannual Trumpeter Swan surveys conducted in the state, the management of Mute Swan populations, and the implementation of land-use guidelines on state, federal and provincial lands. All these practices are described and supported by The North American Management Plan for Trumpeter Swans (1984). As noted in the distribution comments, the Confederated Salish and Kootenai Tribes in northwestern Montana are also reintroducing Trumpeter Swans on the Flathead Indian Reservation. Trumpeter Swans are a Species of Management Concern in Region 6 (U.S. Fish and Wildlife Service 1995).

\section{Conservation Concerns}

- Isolation of breeding populations

- Wetland degradation and destruction

- Lack of information of breeding success

- Vulnerable to power line collisions

\section{Conservation Strategies}

- Relocate power lines underground in areas adjacent to nesting and brood rearing locations

- Wetland restoration programs

- Continue survey and monitoring of populations

- Protect known nesting habitat and manage nesting habitat in a manner compatible with increasing swan production

\section{Management Plans}

Casey, D. 2000. Partners in Flight Bird Conservation Plan Montana Version 1.0. Montana Partners in Flight. Kalispell, Montana.

North American Waterfowl Management Plan. 1998. Expanding the VisionUpdate. 32 pp. 


\section{DRAFT WORKING DOCUMENT DO NOT DUPLICATE}

7269 Pacific Flyway Council and USFWS. 2003. Pacific Flyway Implementation Plan 7270 for the Rocky Mountain Population of Trumpeter Swans 2003 Annual Report. 29 7271 pp.

7272

7273

7274

7275

7276

7277

7278

7279

7280

7281

7282

7283

7284

7285

7286

7287

7288

7289

7290

7291

7292

7293

7294

7295

7296

7297

Subcommittee on the Interior Population of Trumpeter Swans. 1997. Mississippi and Central flyway management plan for the Interior population of Trumpeter Swan. Mississippi and Central Flyway Councils. [C/o USFWS, Migratory Bird Coordinator] Twin Cities, MN

The North American Management Plan for Trumpeter Swans. 1984.

\section{Citations}

Baskins, Y. 1993. Trumpeter swans relearn migration. BioSci. 43(2): 76-79.

Mitchell, C.D. 1994. Trumpeter Swan (Cygnus buccinator). In The Birds of North America, No. 105 (A. Poole and F. Gill, Eds.). Philadelphia: The Academy of Natural Sciences; Washington, D.C.: The American Ornithologist Union.

Montana Bird Distribution Online Database. 2001. Helena, Montana, USA. AprilSeptember 2003. http://nhp.nris.state.mt.us/mbd/.

Skaar, P. D. 1969. Birds of the Bozeman lat-long. P. D. Skaar, Pub., Bozeman, MT. 132 pp.

U.S. Fish and Wildlife Service, Office of Migratory Bird Management. 1995.

Migratory nongame birds of management concern in the United States: the 1995 list. U.S. Government Printing Office:1996-404-911/44014. 22 pp. 


\section{DRAFT WORKING DOCUMENT DO NOT DUPLICATE}

7298 7299

7300

7301

7302

7303

7304

7305

7306

7307

7308

7309

7310

7311

7312

7313

7314

7315

7316

7317

7318

7319

7320

7321

7322

7323

7324

7325

7326

7327

7328

7329

\section{Harlequin Duck (Histrionicus histrionicus)}

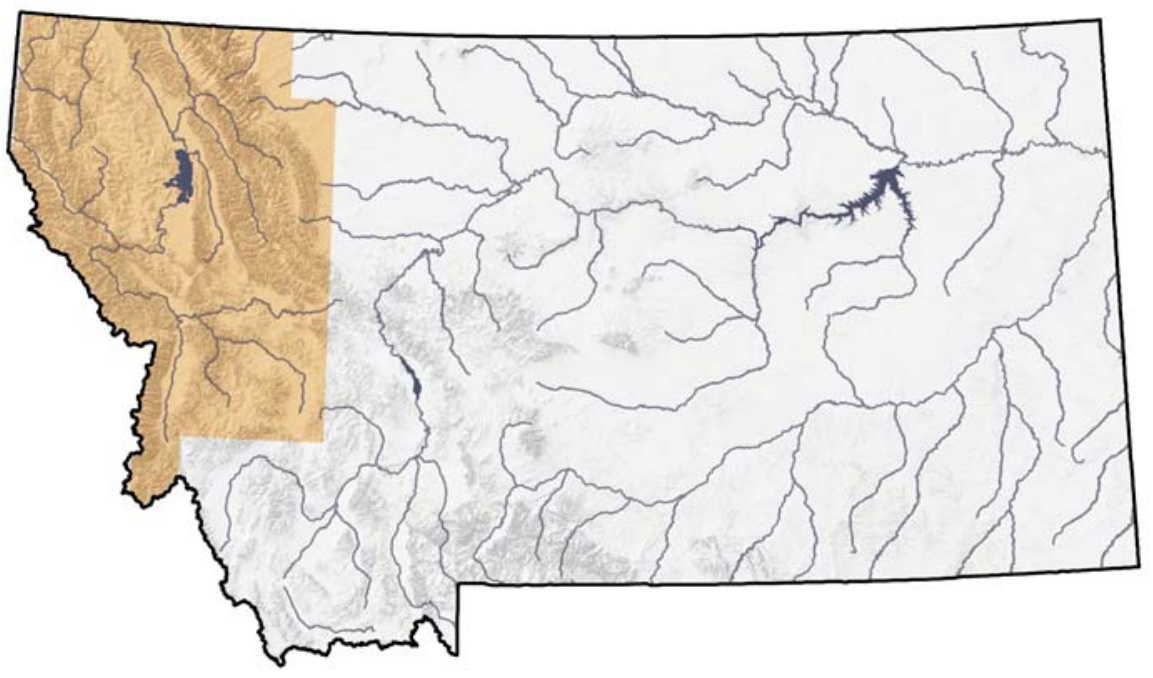

Figure 54. Distribution of the Harlequin Duck

\section{Range}

The Harlequin Duck range is small and fragmented. Found primaryly in Northwestern Montana and parts of Greater Yellowstone Ecotype.

Harlequin ducks breed from Alaska and western Canada, south to eastern Oregon, east-central California, Idaho and Wyoming; also breeds in eastern Canada. Winters from Aleutian and Pribilof Islands, south to central California; also winters from Maritime Provinces south to Maryland (Karl 2000). In North America harlequin ducks winter along the North Pacific coast, then migrate inland to nest along swiftly flowing mountain streams (Bellrose 1980). Although still globally widespread, the Atlantic population may be reaching critically low levels and the Pacific population has experienced substantial declines (NatureServe 2004).

\section{Habitat}

In Montana, most Harlequin Ducks inhabit fast moving, low gradient, clear mountain streams. Overstory in Montana does not appear to affect habitat use: 1) in Glacier National Park, birds used primarily old-growth or mature forest (90\%); and 2) most birds in streams on the Rocky Mountain Front were seen in pole-sized timber (Diamond and Finnegan 1993). Banks are most often covered with a mosaic of trees and shrubs, but the only significant positive correlation is with overhanging vegetation (Diamond and Finnegan 1993, Ashley 1994).

The strongest stream section factor in Montana appears to be for stream reaches with 2+ loafing sites per 10 m (Kuchel 1977, Diamond and Finnegan 1993, 


\section{DRAFT WORKING DOCUMENT DO NOT DUPLICATE}

7330

7331

7332

7333

7334

7335

7336

7337

7338

7339

7340

7341

7342

7343

7344

7345

7346

7347

7348

7349

7350

7351

7352

7353

7354

7355

7356

7357

7358

7359

7360

7361

7362

7363

7364

7365

7366

7367

7368

7369

7370

7371

7372

7373

7374

7375
Ashley 1994). Broods may preferentially use backwater areas, especially shortly after hatching (Kuchel 1977), though this is not apparent in data from other studies (Ashley 1994). Stream width ranges from $3 \mathrm{~m}$ to $35 \mathrm{~m}$ in Montana. On stream gradients of $7 \%$, occupied stream reaches ranged from $1.8 \%$ to $2.8 \%$ (Fairman and Miller 1990), while velocity at 42 Harlequin observation points ranged from 0.8-4.1 m per second (Diamond and Finnegan 1993). Harlequins in Glacier National Park used straight, curved, meandering, and braided stream reaches in proportion to their availability, as was the case for bottom types (Ashley 1994).

No nest sites have been reported from Montana; in the Pacific northwest, nests have been reported on rocks (3); on the ground (2); in a cliff face (1); (Bent 1925, Campbell et al. 1990); in piles of woody debris (2) (Jewett 1931, Thompson 1985); in tree cavities (2); and in a cavity on a cliff (1) (Cassirer et al. 1993).

Four habitat characteristics were noted at more than $50 \%$ of harlequin duck observations in the Tetons (Wallen 1987): 1) streamside perennial shrub vegetation; 2) meandering (braided) channel types; 3) more than 3 loafing sites/10 m; and 4) areas unused by humans. Wallen (1987) postulated that human activities might have a greater influence on breeding success than available habitat. Feeds primarily on crustaceans, mollusks, insects, and a few small fishes (Karl 2000). The Harlequin Duck Working Group (1993) has identified inventory needs for both the Atlantic and Pacific populations for wintering and breeding habitats.

In 1990 the harlequin duck was identified as potentially imperiled in western Montana. By 1991, it was considered as a candidate for listying on the Federal threatened or endangered species list. Considered a sensitive or indicator species, it is among the first species to reflect damage to the type of pristine environments where they remain (Street 1999).

Harlequin ducks breed locally on mountain streams in the western part of the state (Reichel and Genter 1995), including the Kootenai, Flathead, Clark Fork, and Blackfoot River drainages. Scattered breeding also occurs along the Rocky Mountain Front and the north edge of Yellowstone National Park (Montana Partners in Flight 2004). Harlequin ducks are known to occur in Bonner, Boundary, Clearwater, and Shoshone counties in Idaho. Harlequin ducks in Glacier National Park confine almost all activities to swiftly running waters (90\% of area used), but also used cut-off side channels and other backwaters during periods of high water and as brood rearing habitat (Kuckel 1977). Females with broods avoided all areas frequented by humans. Occupied streams in north Idaho were usually in mature/old growth western red cedar/western hemlock or Engelmann spruce/subalpine fir stands. Cassirer and Groves (1991) suggested that the presence of mature/old growth forest in north Idaho might indicate streams with high quality, low sediment loads, intact riparian areas, and relative inaccessibility to humans. Stream sections most suitable for harlequin breeding 


\section{DRAFT WORKING DOCUMENT DO NOT DUPLICATE}

7376

7377

7378

7379

7380

7381

7382

7383

7384

7385

7386

7387

7388

7389

7390

7391

7392

7393

7394

7395

7396

7397

7398

7399

7400

7401

7402

7403

7404

7405

7406

7407

7408

7409

7410

7411

7412

7413

7414

7415

7416

7417

7418

7419

7420

had gradients less than 10 degree and banks lined with dense perennial shrubs; breeding and brood rearing occurred on streams with a mean gradient less than 30 degrees. In Idaho hens nest in cliff cavities, tree cavities, and on the ground.

\section{Management}

No specific management for harlequins in Montana however continued survey and monitoring efforts by MTNHP have identified migration areas used by harlequin ducks.

\section{Conservation Concerns}

- Loss and/or degradation of habitat from mining, logging, unsustainable grazing

- Human disturbance by padlers (especially in breeding season)

- Water pollution on headwater streams utilized for nesting, brood-rearing and prey base

- Hunting on wintering grounds

- Destruction of watershed stability and stream flow regimes. High water during nesting and brood rearing can reduce or eliminate productivity. Low water will render feeding and brood rearing habitats unavailable

- Impoundments and diversions on breeding streams

\section{Conservation Strategies}

- Continue survey efforts to find occupied streams throughout its range in the state, to develop and track a statewide population estimate

- Reduce streambank or channel alteration along breeding habitat

- Decrease human disturbance such as boating, hiking and camping during breeding season

- Avoid increasing peak flows during nesting season

- Avoid increasing sedimentation

- Manage grazing to maintain riparian vegetation and streambank stability in excellent condition

\section{Management Plans}

Casey, D. 2000. Partners in Flight Bird Conservation Plan Montana Version 1.0. Montana Partners in Flight. Kalispell, Montana.

Cassirer, E. F., J. D. Reichel, R. L. Wallen, and E. C. Atkinson. 1996. Harlequin Duck (Histrionicus histrionicus) conservation assessment and strategy for the U.S. Rocky Mountains. Unpublished Technical Report, Idaho Department of Fish and Game, Lewiston, Idaho, U.S.A. 


\section{DRAFT WORKING DOCUMENT DO NOT DUPLICATE}

7421 North American Waterfowl Management Plan. 1998. Expanding the Vision-

$7422 \quad$ Update. 32 pp.

7423

7424

7425

7426

7427

7428

7429

7430

7431

7432

7433

7434

7435

7436

7437

7438

7439

7440

7441

7442

7443

7444

7445

7446

7447

7448

7449

7450

7451

7452

7453

7454

7455

7456

7457

7458

7459

7460

Will, G. C., January 1986, Waterfowl, Sandhill Crane and Snipe Management

Plan.

\section{Citations}

Ashley, J. 1994. Progress report: harlequin duck inventory and monitoring in Glacier National Park, Montana. Unpublished report. Division of Research Management, Glacier Natl. Park, Montana. 14 pp.

Bent, A. C. 1925. Life histories of North American wild fowl. Order: Anseres (Part II). U.S. Natl. Mus. Bull. 130. Washington, D.C. 316 pp.

Campbell, R. W., N. K. Dawe, I. McTaggart-Cowan, J. M. Cooper, G. W. Kaiser and M. C. McNall. 1990. The birds of British Columbia, Vols. 1 and 2: Nonpasserines. Royal British Columbia Museum, Victoria, B. C. 518 and 636 pp.

Cassirer, E. F., G. Schirato, F. Sharpe, C. R. Groves, and R. N. Anderson. 1993. Cavity nesting by harlequin ducks in the Pacific Northwest. Wilson Bull. 105:691694.

Cassirer, E. F, A. Breault, P. Clarkson, D. L. Genter, R. I. Goudie, B. Hunt, S. C. Latta, G. H. Mittelhauser, M. M. Schirato, R. L. Wallen. 1993. Status of harlequin ducks in North America. Report on harlequin duck working group.

Cassirer, E.F. and C.R. Groves. 1991. Harlequin duck ecology in Idaho. 19871990. Idaho Fish and Game and US Fish and Wildlife Service.

Diamond, S. and P. Finnegan. 1993. Harlequin duck ecology on Montana's Rocky Mountain Front. [Unpublished report]. Rocky Mountain District, Lewis and Clark National Forest, Choteau, MT. 45 pp.

Fairman, L. M. and V. E. Miller. 1990. Results of 1990 surveys for harlequin ducks on the Kootenai and Lolo National Forests, Montana. Unpublished report. Montana Natural Heritage Program, Helena.

Genter, D.L. 1993. Harlequin duck status report 1992: Montana. Intermountain/foothill grassland 31-34 in Cassirer, E.F., A. Breault, P. Clarkson, D. L. Genter, R. I. Goudie, B. Hunt, S. C. Latta, G. H. Mittelhauser, M. M. Schirato, and R. L. Wallen, editors. Harlequin ducks in North America. Harlequin Duck Working Group.

7464

7465

Harlequin duck working group. 1993. Status of harlequin ducks (Histrionicus

7466

histrionicus) in North America. Report of the Harlequin Duck Working Group. 


\section{DRAFT WORKING DOCUMENT DO NOT DUPLICATE}

7467

7468

7469

7470

7471

7472

7473

7474

7475

7476

7477

7478

7479

7480

7481

7482

7483

7484

7485

7486

7487

7488

7489

7490

7491

7492

7493

7494

7495

7496

7497

7498

7499

7500

7501

7502

7503

7504

7505

7506

7507

7508
Jewett, S. G. 1931. Nesting of the Pacific harlequin duck in Oregon. Condor $33: 255$.

Kuchel, C. R. 1977. Some aspects of the behavior and ecology of harlequin ducks breeding in Glacier National Park, Montana. M.S. thesis. Univ. of Montana, Missoula. $160 \mathrm{pp}$.

Montana Natural Heritage Program Online database. (Accessed April 26, 2004;

<http://nhp.nris.state.mt.us/animalguide>).

Montana Partners in Flight Online Database. (Accessed April 26, 2004;

<http://biology.dbs.umt.edu/landbird/mbcp/mtpif>).

NatureServe. 2004. NatureServe explorer. An online encyclopedia of life. Version 3.0. NatureServe, Arlington, Virginia. (Accessed: April 22, 2004;

$<$ http://www.natureserve.org/explorer>).

Reichel, J. D. and D. L. Genter. 1995. Harlequin duck surveys in western Montana: 1994. Montana Natural Heritage Program, Helena, Montana, U.S.A.

Spahr, R., L. Armstrong, D. Atwood, and M. Rath. 1991. Threatened, endangered, and sensitive species of the Intermountain Region. U.S. Forest Service, Ogden, Utah, U.S.A.

Street, R. 1999. Histrionicus histrionicus. Animal Diversity Web. (Accessed May 13, 2004;

$<$ http://animaldiversity.ummz.umich.edu/accounts/information/Histrionicus histrionicus.html>).

Thompson, L. 1985. A harlequin romance. Montana Outdoors 16:21-25.

Wallen, R.L. 1987. Habitat utilization by harlequin ducks in Grand Teton National Park. Unpublished MS Thesis. Montana State University, Bozeman, Montana, U.S.A.

Wallen, R.L. and C.R. Groves, 1989. Distribution, breeding biology and nesting habitat of harlequin ducks (Histrionicus histrionicus) in Northern Idaho. Natural Heritage Section. Nongame wildlife/Endangered Species Program, Bureau of wildlife. 


\section{DRAFT WORKING DOCUMENT DO NOT DUPLICATE}

7508

7509

7510

7511

7512

7513

7514

7515

7516

7517

7518

7519

7520

7521

7522

7523

7524

7525

7526

7527

7528

7529

7530

7531

7532

7533

7534

7535

7536

7537

7538

\section{Bald Eagle (Haliaeetus leucocephalus)}

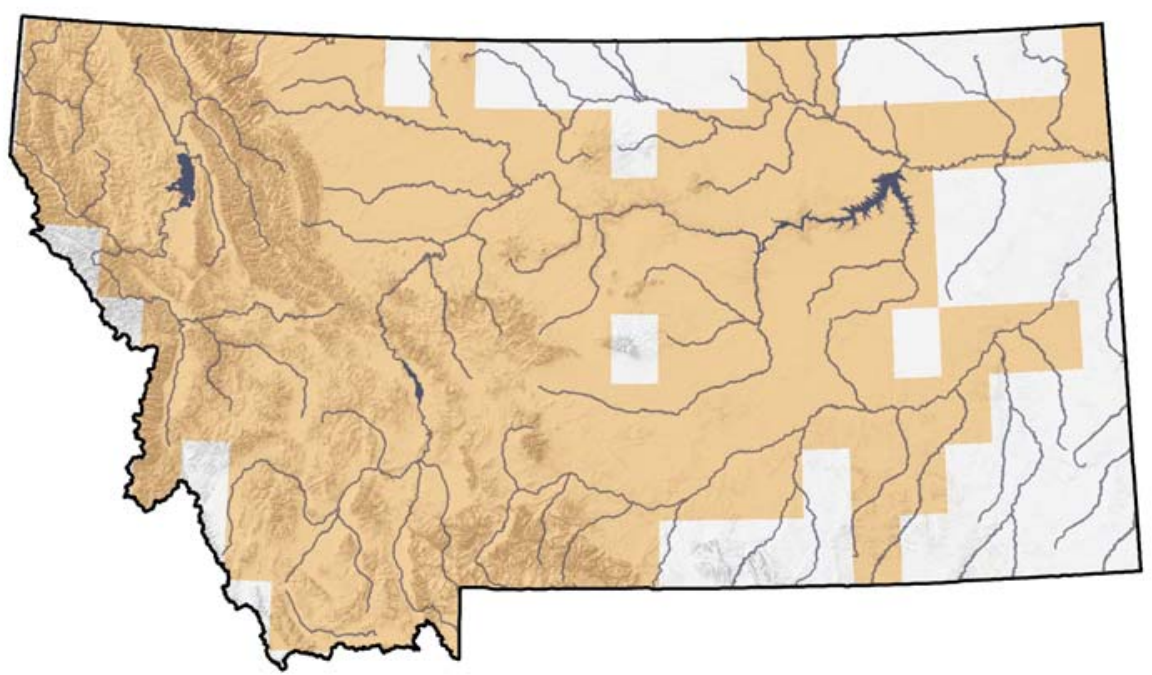

Figure 55. Distribution of the Bald Eagle

\section{Range}

The majority of birds nesting in Montana are found in the western third of the state; although breeding pairs may be found along many of the major rivers and lakes in the central portion of the state and along the Yellowstone and Missouri Rivers to the eastern prairie lands (Montana Bald Eagle Working Group 1994, MBD 2003). East of the Continental Divide, the presence of Bald Eagles may be somewhat more seasonally dependent than in the western part of the state, for migrants from more northerly climes travel through Montana to reach their wintering grounds further south.

In recent years, one of the largest fall (mid-October to mid-December) migration concentrations (200 to 300 birds at any one time, close to a thousand individuals throughout the season), to take advantage of spawning salmon, occurred at Canyon Ferry Reservoir on the Missouri River, near Helena. Formerly, migrating Bald Eagles were known to gather in large numbers in Glacier National Park where spawning Kokanee salmon were abundant. No evidence exists, however, that the eagles on the Missouri River were those that formerly congregated in Glacier National Park (Montana Bald Eagle Working Group 1994). Subsequent shifting of fall congregations is expected as salmon populations peak and wane throughout the eagle's migration corridor. See the Montana Bald Eagle Management Plan for further details and descriptions of recovery zones (Montana Bald Eagle Working Group 1994).

\section{Habitat}




\section{DRAFT WORKING DOCUMENT DO NOT DUPLICATE}

7539 In Montana, as elsewhere, the Bald Eagle is primarily a species of riparian and 7540 lacustrine habitats (forested areas along rivers and lakes), especially during the 7541 breeding season. Important year-round habitat includes wetlands, major water

7542 bodies, spring spawning streams, ungulate winter ranges and open water areas

7543 (Bureau of Land Management 1986). Wintering habitat may include upland sites.

$7544 \quad$ Nesting sites are generally located within larger forested areas near large lakes

7545 and rivers where nests are usually built in the tallest, oldest, large diameter trees.

7546 Nesting site selection is dependent upon maximum local food availability and

7547

7548

7549

7550

7551

7552

7553

7554

7555

7556

7557

7558

7559 minimum disturbance from human activity (Montana Bald Eagle Working Group 1994). See the Montana Bald Eagle Management Plan (1994) for further details including home range sizes and habitat requirements of fledgling birds.

\section{Management}

General objectives of habitat management for Bald Eagles in Montana include: maintaining prey bases; maintaining forest stands currently used or suitable for nesting, roosting, and foraging; planning for future potential nesting, roosting, and foraging habitat; and minimizing disturbances from human activities in nest territories, at communal roosts, and at important feeding sites, including water (MBEWG 1991). The Montana Bald Eagle Management Plan (MBEWG 1994) directs management of this species in the state. Specific objectives identified in

7560 the plan include: a minimum of 800 nesting pairs in the 7-state Recovery Area,

7561

7562

7563 99 of these in Montana; nesting success rate of $65 \%$ in occupied sites over a 5year period with annual average production of 1.0 fledged young per pair; population goals were realized in at least $80 \%$ of management zones with

7564

7565

7566

7567

7568

7569 nesting potential; and continued population increases for 5 consecutive years. See the Habitat Management Guide for Bald Eagles in Northwestern Montana (MBEWG 1991) and the Montana Bald Eagle Management Plan (MBEWG 1994) for further details on management guidelines and recovery objectives.

7570

7571

7572

7573

7574

7575

7576

7577

7578

7579

\section{Conservation Concerns}

- Maintaining forest stands currently used or suitable for nesting, roosting and foraging

- Sensitive to human disturbance particularly if activity occurs after nest initiation and prior to fledging

- Water turbidity caused by human activity, rendering water unsuitable for foraging

- Contaminants (lead, residual pesticides)

\section{Conservation Strategies}

7580

7581

7582

7583

7584

- Continue periodic monitoring and surveying for breeding pairs and locations of nests

- Minimize disturbance within and near nesting territories during the nesting season 
7585

7586

7587

7588

7589

7590

7591

7592

7593

7594

7595

7596

7597

7598

7599

7600

7601

7602

7603

7604

7605

7606

7607

7608

7609

7610

7611

7612

7613

7614

7615

7616

7617

- Follow MBEWG guidelines of no more than $10 \%$ of shoreline be developed on lakes within occupied nesting territories

- Development of and updated living with Bald Eagles brochure

\section{Management Plans}

Casey, D. 2000. Partners in Flight Bird Conservation Plan Montana Version 1.0. Montana Partners in Flight. Kalispell, Montana.

Montana Bald Eagle Working Group. 1994. Montana Bald Eagle management plan. 2nd edition. Bureau of Reclamation. 104 pp.

Rich, T.D., C.J. Beardmore, H. Berlanga, P.J. Blancher, M. S. W. Bradstreet, G. S. Butcher, D.W. Demarest, E. H. Dunn, W. C. Hunter, E. E. Inigo-Elias, J. A. Kennedy, A. M. Martell, A. O. Panjabi, D. N. Pashley, K. V. Rosenberg, C. M. Rustay, J. S. Wendt, T. C. Will. 2004. Partners in Flight North American Landbird Conservation Plan. Cornell Lab of Ornithology. Ithaca, NY.

\section{Citations}

Hawk Watch International. 2003. An online search for migration watch results, 1999-2002 data. http://www.hawkwatch.org/. Accessed 11 September 2003.

Montana Bald Eagle Working Group. 1991. Habitat management guide for bald eagles in northwestern Montana. 29pp.

Montana Bird Distribution Online Database. 2001. Helena, Montana, USA. AprilSeptember 2003. http://nhp.nris.state.mt.us/mbd/

Skaar, P. D. 1969. Birds of the Bozeman lat-long. P. D. Skaar, Pub., Bozeman, MT. 132 pp. 


\section{DRAFT WORKING DOCUMENT DO NOT DUPLICATE}

7617 7618
7619

7620

7621

7622

7623

7624

7625

7626

7627

7628

7629

7630

7631

7632

7633

7634

7635

7636

7637

7638

7639

7640

7641

7642

7643

7644

7645

7646

7647

7648

\section{Greater Sage-grouse (Centrocercus urophasianus)}

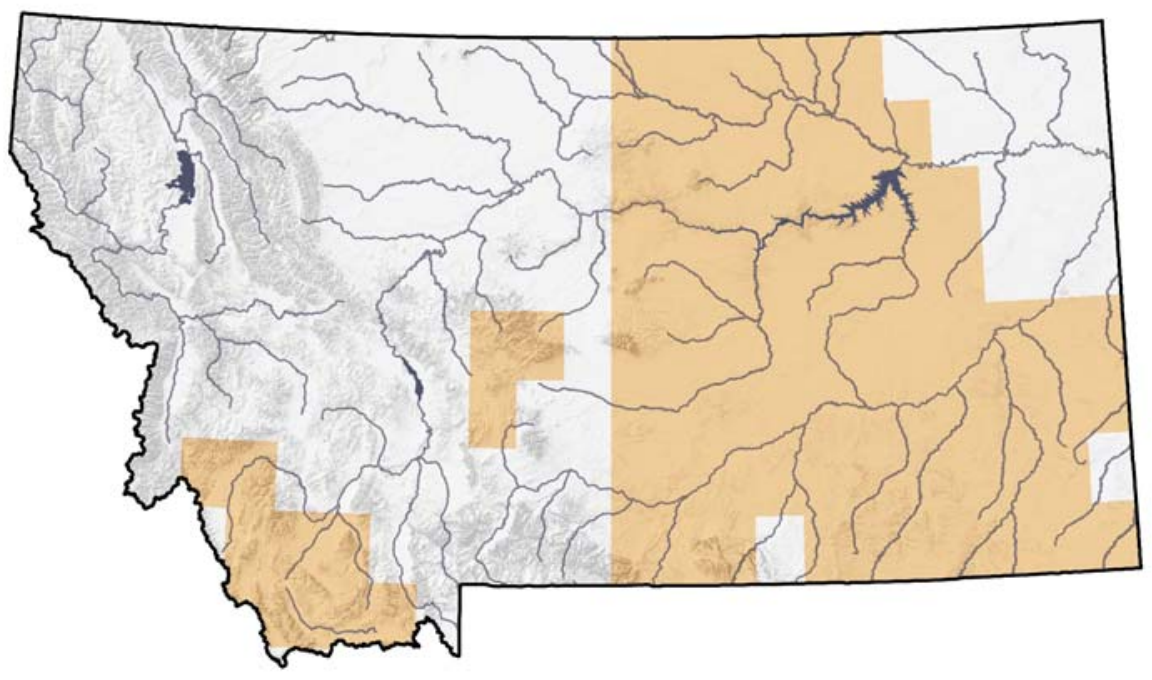

Figure 56. Distribution of the Sage-grouse

\section{Range}

Sage-grouse are native to the sagebrush steppe of western North America, and their distribution closely follows that of sagebrush, primarily big sagebrush $(A$. tridentata). Distribution of sage-grouse in Montana includes the eastern one-half and southwest corner of the state-roughly 27 million acres (11 million ha) of sagebrush-grassland in 39 counties. In eastern Montana, where close interspersion of wintering, nesting, and brood-rearing habitat rarely require large seasonal movements, sage-grouse are essentially nonmigratory. Some sagegrouse in southwestern Montana are migratory, moving between separate summer and winter areas

Historically, sage-grouse occupied the Bitterroot Valley in western Montana, southwestern Montana, most of eastern Montana, and far western North Dakota and South Dakota (Schroeder et al. 2004). One specimen was collected near Missoula Montana as late as 1900. Today, sage-grouse distribution is more restricted in Montana, South Dakota and North Dakota and is found on two National Forests i.e., Custer NF and Beaverhead-Deerlodge NF.

\section{Habitat}

Healthy, properly functioning sagebrush communities support sage-grouse and a variety of other native wildlife. Sagebrush communities in each of the sagebrush ecotypes are influenced by a variety of environmental variables. Among these variables are soil texture, moisture regime, past fire, past herbicide spraying, topography, grazing history, grazing accessibility, and recent weather pattern. The characteristics of vegetation at any particular site are the result of 


\section{DRAFT WORKING DOCUMENT DO NOT DUPLICATE}

7649

7650

7651

7652

7653

7654

7655

7656

7657

7658

7659

7660

7661

7662

7663

7664

7665

7666

7667

7668

7669

7670

7671

7672

7673

7674

7675

7676

7677

7678

7679

7680

7681

7682

7683

7684

7685

7686

7687

7688

7689

7690

7691

7692

7693

7694 superimposed environmental variables. Close examination of a functional sagebrush community reveals these factors at work in the form of a patchwork of shrubs, grasses, and forbs of varying heights, canopy coverage, and species. Individual patches within the landscape can be measured at a microsite level, such as a nest site, or can be extended to include a broader scale that might be used to describe sage-grouse wintering areas. Sage-grouse have adapted to and require this naturally occurring patchwork to meet yearlong survival and reproduction needs (Connelly et al. 2000b).

Sage-grouse select specific habitat characteristics in response to season and life stage. During the spring breeding season, males congregate on display areas to attract females. Leks are revisited annually and usually comprise clearings surrounded by sagebrush. About two-thirds of sage-grouse nests are located within 2 miles of a lek. Hens generally nest under stands of sagebrush 12-20" or more in height, seeking taller shrubs in a stand for nesting. Grasses and forbs provide additional nest concealment from predators. After eggs hatch, sagegrouse hens seek relatively open sagebrush stands with $>15 \%$ grass and forb canopy cover. Insects and succulent forbs provide critical food for young broods. As summer progresses and upland forbs desiccate, hens will move broods to moist sites along drainages, ditches, or irrigated meadows/hay crops. In general, moist areas with standing herbaceous cover, for concealing broods from predators, interspersed with sagebrush grasslands provide high quality brood habitat. Improvements in native grass and forb height and density generally translate into better nest success and brood survival. During late fall and winter, sage-grouse feed almost exclusively on sagebrush. Deep snow conditions force sage-grouse to move to areas of exposed sagebrush both for food and cover. Wintering sage-grouse prefer extensive stands of sagebrush with at least 20 percent canopy cover.

Contiguous large blocks of healthy sagebrush-grassland are best suited for meeting yearlong needs of sage-grouse. Limited seasonal habitats (e.g., nesting cover, brood rearing habitat, winter habitat, etc.) may restrict the abundance, productivity, or occurrence of sage-grouse in a particular area.

\section{Management}

Sage-grouse are managed under state authority including the statutory authority to regulate harvest. Legislative mandate designates sgae-grouse as an upland game bird (87-2-101,MCA).

FWP, in conjunction with federal land management agencies and conservation groups, monitors prairie grouse populations during spring through census of displaying males on leks. The post-harvest telephone survey provides an estimate of harvest for all upland bird species, trend in hunter numbers, and number of birds by species taken by hunters. FWP uses wings from harvested sage-grouse to estimate composition of the harvest by sex and age. 


\section{DRAFT WORKING DOCUMENT DO NOT DUPLICATE}

7695

7696

7697

7698

7699

7700

7701

7702

7703

7704

7705

7706

7707

7708

7709

7710

7711

7712

7713

7714

7715

7716

7717

7718

7719

7720

7721

7722

7723

7724

7725

7726

7727

7728

7729

7730

7731

7732

7733

7734

7735

7736

7737

7738

7739

7740

State-funded cooperative habitat projects have the potential to benefit sagegrouse. In 1987, the Montana Legislature created a process and funding source for FWP to purchase conservation interests in important wildlife habitats through conservation easements and fee title acquisitions. The program generates funding from an earmarked portion of license revenue and provides an innovative tool to protect habitat at the state level. The Upland Game Bird Habitat Enhancement Program was developed through a series of Montana legislative sessions from 1987 to 2001 . This program funds habitat enhancements on private and public lands such as vegetation plantings, grazing management systems, and leases. The program has recently helped fund (in combination with the USFWS Landowner Incentive Program) the Montana Sagebrush Initiative, which is a 30 year private land lease program designed to conserve high priority sagebrush grasslands from prescribed fire, herbicide applications, plowing, and other practices intended to reduce or eliminate sagebrush and forbs.

\section{Conservation Concerns}

- Conversion of native sagebrush grassland to cropland or nonnative pasture

- Rangeland treatments, i.e. prescribed fire and spraying

- Fragmentation of sagebrush grasslands (e.g., structural developments, roads, urban sprawl)

- Unsustainable domestic livestock grazing practices and associated habitat degredation

- Human disturbance

- Noxious weeds

\section{Conservation Strategies}

- Promote conservation of intact sagebrush grassland landscapes.

- Support livestock grazing management that maintains or improves native rangeland integrity and provides standing herbaceous cover, important for nesting and brood rearing.

- Avoid use of rangeland herbicides and prescribed fire.

- Quantify impacts of energy development and determine ways to reduce, eliminate, or mitigate negative effects.

- Continue to inventory sage-grouse leks and wintering areas.

- Develop and implement a lek monitoring strategy that will accurately measure trends in sage-grouse abundance and distribution across their range.

- Develop and implement a habitat monitoring system to determine landscape-level trends in sagebrush-grasslands.

- On a smaller scale, monitor trends in habitat condition (e.g., native rangeland integrity, habitat function, invasive weeds).

- As needed, determine local sage-grouse habitat use and movements. 


\section{DRAFT WORKING DOCUMENT DO NOT DUPLICATE}

7741

7742

7743

7744

7745

7746

7747

7748

7749

7750

7751

7752

7753

7754

7755

7756

7757

7758

7759

7760

7761

7762

7763

7764

7765

7766

7767

7768

7769

7770

7771

7772

7773

7774

7775

7776

7777

7778

7779

7780
- Guided by the Montana sage-grouse conservation plan, utilize local working groups, organizations, and agency partnerships to promote and expand sage-grouse conservation.

\section{Management Plans}

Braun, C.E. 1999b. Conservation plans. Presentation given to the Western Sagegrouse Status Conference, Jan. 14-15, 1999, Boise, ID. Online. Available:

http://www.rangenet.org/projects/grouse.html

Casey, D. 2000. Partners in Flight Bird Conservation Plan Montana Version 1.0. Montana Partners in Flight. Kalispell, Montana.

Montana Sage-grouse Work Group. 2004. Management plan and conservation strategies for sage-grouse in Montana.

Rich, T.D., C.J. Beardmore, H. Berlanga, P.J. Blancher, M. S. W. Bradstreet, G. S. Butcher, D.W. Demarest, E. H. Dunn, W. C. Hunter, E. E. Inigo-Elias, J. A. Kennedy, A. M. Martell, A. O. Panjabi, D. N. Pashley, K. V. Rosenberg, C. M. Rustay, J. S. Wendt, T. C. Will. 2004. Partners in Flight North American Landbird Conservation Plan. Cornell Lab of Ornithology. Ithaca, NY.

\section{Citations}

Connelly, J.W., M. A. Schroeder, A. R. Sands, and C. E. Braun. 2000b. Guidelines to manage Sage-grouse populations and their habitats. Wildlife Society Bulletin 28:967-985.

Connelly, J. 2001. Field Assessment. Sage-grouse Habitats and PopulationsBig Sheep Creek Basin, Montana. Unpublished report on file, BeaverheadDeerlodge National Forest, Dillon, Montana, USA.

Michael A. Schroeder, Cameron L. Aldridge, Anthony D. Apa, Joseph R. Bohne, Clait E. Braun, S. Dwight Bunnell, John W. Connelly, Pat A. Deibert, Scott C. Gardner, Mark A. Hilliard, Gerald D. Kobriger, Susan M. McAdam, Clinton W. McCarthy, John J. McCarthy, Dean L. Mitchell, Eric V. Rickerson, and San J. Stiver. 2004. Distribution of Sage-grouse in North America. Condor 106: 363376. 


\section{DRAFT WORKING DOCUMENT DO NOT DUPLICATE}

7780 7781

\section{Columbian Sharp-tailed Grouse (Tympanuchus phasianellus columbianus)}

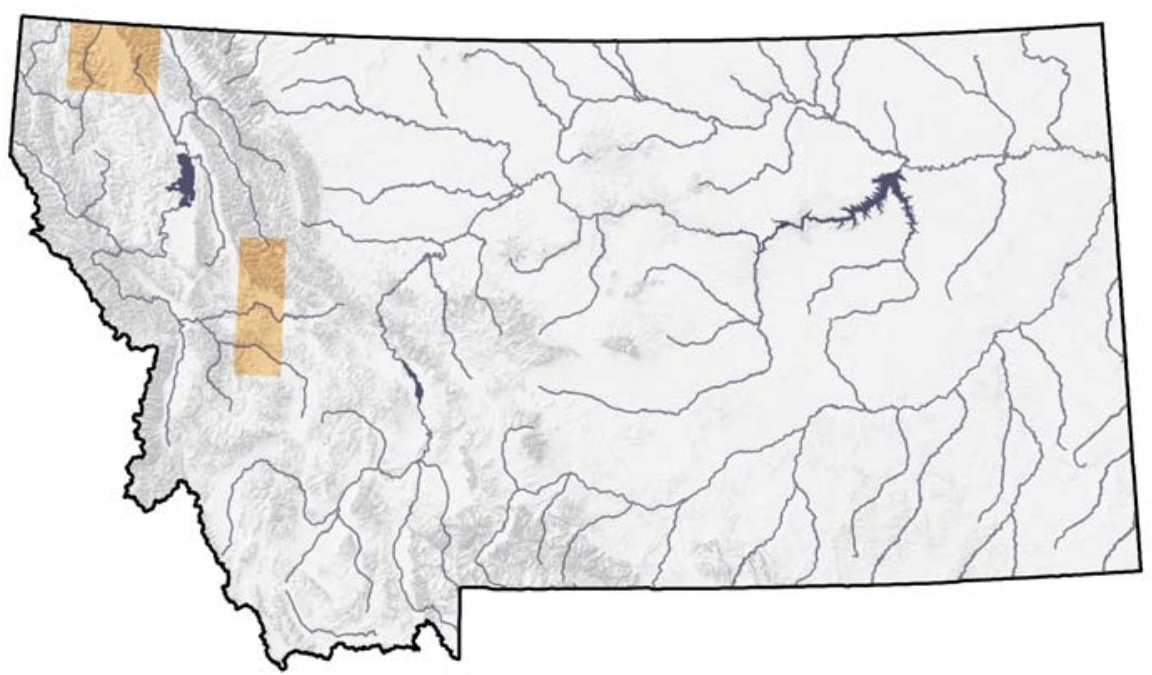

7782

7783

7784

7785

7786

7787

7788

7789

7790

7791

7792

7793

7794

7795

7796

7797

7798

7799

7800

7801

7802

7803

7804

7805

7806

7807

7808

7809

7810

7811
Figure 57. Distribution of the Columbian Sharp-tail Grouse

\section{Range}

The Columbian sharp-tailed grouse is one of six recognized subspecies of sharptailed grouse that occur in North America (AOU 1957). Historically, the Columbian subspecies ranged in suitable habitats from British Columbia south through eastern Oregon and Washington, Idaho, western Montana, Wyoming and Colorado, and northern Utah, Nevada, and California (Ulliman et al. 1998). There have been significant regional and local declines and extirpations; its geographic distribution has contracted by an estimated 90\% (Aldrich 1963, Miller and Graul 1980). Currently, there are three meta-populations of Columbian sharp-tailed grouse: one in Colorado/Wyoming; one in Idaho/Utah; and one in central British Columbia. Smaller population centers are found in south central Idaho/northeast Nevada, north central Washington, and northeast Oregon (USFWS 1999).

Montana recently supported a very small population of Columbian sharp-tailed grouse in the Tobacco Valley near Eureka. Only one dancing ground or lek is known to exist in this area, which is located on land held by the Nature Conservancy. There has been no known use of the lek during the past 3 years (T. Their, pers. comm.). Counts of males on the lek varied from a high of 33 in 1971 to the recent low. This population was supplemented with birds from British Columbia on two occasions.

Flocks of sharp-tailed grouse also occur in the Helmville area of Powel County. These have traditionally been considered Columbian subspecies. Given their geographic nearness to the plains subspecies, however, there may be genetic interchange with plains birds. Although a genetics study has shown similarities 


\section{DRAFT WORKING DOCUMENT DO NOT DUPLICATE}

7812 between a very small sample of Helmville birds and sharp-tailed grouse from

7813 Washington (Warheit and Schroeder 2001), there does not appear to be

7814

7815

7816

7817

7818

7819

7820

7821

7822

7823

7824

7825

7826

7827

7828

7829

7830

7831

7832

7833

7834

7835

7836

7837

7838

7839

7840

7841

7842

7843

7844

7845

7846

7847

7848

7849

7850

7851

7852

7853

7854

7855

7856

7857

\section{Habitat}

Columbian sharp-tailed grouse are associated with intermountain shrub grassland habitats including sagebrush grasslands and deciduous riparian and foothill shrub habitats. Brood sites are similar to nest sites, but they are usually close to broad-leaved brush patches or shrubby riparian zones. Sharp-tailed grouse need habitat with moderate vegetative cover, high plant diversity, and high structural diversity (Montana Partners in Flight 2004). Tall broad-leaved mountain shrub and riparian cover types are critical components of winter habitat for sharp-tailed grouse (Saab and Marks 1992). They often move to higher elevations to get into moister sites that support greater amounts of these types of shrubs (Ulliman et al. 1998). Suitable winter sites need to be no more than 4 miles from leks to be useful to sharp-tails (Ulliman et al. 1998).

Counting individuals at leks is the easiest way to monitor population trends. Wildlife agencies monitor leks because their size and densities provide an index to populations and indirectly reflect changes in habitat quality (Cannon and Knopf 1981, Giesen and Connelly 1993).

In Montana, Columbian sharp-tailed grouse persist only on native bunchgrassshrub stands (Mussehl et al. 1971, Montana Natural Heritage Program 2004). In some areas, conversion of native habitats to cropland, unsustainable grazing management, and/or herbicide use has resulted in loss of native grasses, forbs, and woody vegetation, habitat components necessary for providing shelter from winter weather, protection from predators, nesting cover, and food (Mussehl et al. 1971, Montana Natural Heritage Program 2004). Over the past 15 years, much of the historic Columbian sharp-tailed grouse habitat in western Montana has been subject to considerable urban development, resulting in further habitat fragmentation, likely increases in nest-predator abundance, and reduced habitat function. Self-sustaining populations of sharp-tailed grouse require thousands of acres of intact habitat; large blocks of cropland or urban developed habitat are not conducive for supporting sustainable populations (Ulliman et al. 1998). Sharp-tailed grouse habitats associated with the Helmville and Eureka areas are not considered sufficient to support viable populations over the long-term (Montana Partners in Flight 2004).

\section{Management}

As there is only one small population of Columbian Sharp-tailed Grouse in Montana, critical efforts must be maintained to encourage individuals to seek and use lek areas. Careful population counts must be made, as well as nesting sites and success. 


\section{DRAFT WORKING DOCUMENT DO NOT DUPLICATE}

7858

7859

7860

7861

7862

7863

7864

7865

7866

7867

7868

7869

7870

7871

7872

7873

7874

7875

7876

7877

7878

7879

7880

7881

7882

7883

7884

7885

7886

7887

7888

7889

7890

7891

7892

7893

7894

7895

7896

7897

7898

7899

7900

7901

7902

\section{Conservation Concerns}

- Isolated and extremely small population

- Human disturbance to leks

- Conversion of native grassland and shrub/grass communities to agriculture and other unsuitable land uses

- Encroachment of conifers onto grassland habitat

- Unsustainable domestic livestock practices

- Invasion of non-native annual vegetation

- Predation on nests by ravens and other predators

\section{Conservation Strategies}

- Protect known lek areas and the surrounding habitats within $2 \mathrm{~km}$. Search for new leks in areas with appropriate physiographic and vegetative characteristics

- Increase abundance and distribution by reintroduction program into Northwest Montana including the development of a captive rearing facility

- Solicit cooperation and communication between land managers and land owners in managing habitat

- Coordinate with British Columbia to manage suitable habitat in the Tobacco Plains area

- Protect, maintain, and enhance winter, breeding, and nesting habitats near known populations

- Monitor existing populations to determine if management actions are adequate

- Avoid pesticide use on Columbian sharp-tailed habitats

- Identify validity of Blackfoot population as Columbian sub-species

- Develop livestock management plans, which favor primarytenance or enhancement of bunchgrass communities, forbs species diversity, and upland shrubs

- Develop appropriate grazing regimes in areas of known populations

- Fence areas of deciduous trees and shrubs (especially in riparian areas) to manage livestock

- Avoid manipulation or alteration of vegetation within the breeding complex (lek and nesting areas) during the nesting period (mid-April - June)

- Prohibit physical, mechanical, and audible disturbances within the breeding complex during the breeding season (March-June), IF they might impact courtship activities and breeding during the daily display period (within 3 hours of sunrise and sunset)

- Use prescribed fire to stimulate growth and vigor of deciduous shrubs in wintering areas, as long as a minimum of $10 \%$ of habitat will provide shrub cover during the recovery period of the burned area 


\section{DRAFT WORKING DOCUMENT DO NOT DUPLICATE}

7903

7904

7905

7906

7907

7908

7909

7910

7911

7912

7913

7914

7915

7916

7917

7918

7919

7920

7921

7922

7923

7924

7925

7926

7927

7928

7929

7930

7931

7932

7933

7934

7935

7936

7937

7938

7939

7940

7941

7942

7943

7944

7945

7946

7947

7948

\section{Management Plans}

Casey, D. 2000. Partners in Flight Bird Conservation Plan Montana Version 1.0. Montana Partners in Flight. Kalispell, Montana.

Wood, M. 1991. Management Plan for Columbian Sharp-tailed grouse in Western Montana.

Young, Lewis. 1995 (unpublished). Range Permit Re-issuance: Columbian Sharp-tailed grouse. Kootenai National Forest, Eureka, Montana, U.S.A.

\section{Citations}

AOU. 1957. American Ornithological Union Check-list of North American Birds. The Lord Baltimore Press, Inc., Baltimore, Maryland. Pp 137-139.

Aldrich, J. W. 1963. Geographic orientation of American Tetraonidae. Journal of Wildlife Management 27: 529-545.

Baydack, R. K. and D. A. Hein. 1987. Tolerance of sharp-tailed grouse to lek disturbance. Wildlife Society Bulletin 15: 535-539.

Cannon, R. W., and F. L. Knopf. 1981. Lek numbers as a trend index to prairie grouse populations. Journal of Wildlife Management 45: 776-778.

Deeble, B.D. 1996. Conservation of Columbian sharp-tailed grouse, with special emphasis on the upper Blackfoot Valley, Montana. Unpublished MS Thesis, University of Montana, Missoula, Montana. U.S.A..

Dickerman, R.W. and J. P. Hubbard. 1994. An extinct subspecies of sharp-tailed grouse from New Mexico. Western Birds 25: 128-136.

Giesen, K. M. and J. W. Connelly. 1993. Guidelines for management of sharptailed grouse habitats. Wildlife Society Bulletin 21: 325-333.

Karl, J. 2000. Columbian sharp-tailed grouse (Tympanuchus phasianellus columbianus). Digital atlas of Idaho. (Accessed May 25, 2004;

$<$ http://imnh.isu.edu/digitalatlas >).

Kessler, W.B. and R.P. Bosch. 1982. Sharp-tailed grouse and range management practices in western rangelands. 1982. Intermountain/foothill grassland 133-136 in Proceedings of wildlife-livestock relationships symposium. J.M. Peek and P. Dallce, editors. University of Idaho, Moscow, Idaho, USA.

Montana Natural Heritage Program. (Accessed April 26, 2004; <http://nhp.nris.state.mt.us/animalguide>). 
7950 Montana Partners in Flight. (Accessed April 26, 2004;

$7951<$ <ttp://biology.dbs.umt.edu/landbird/mbpc>).

7952

7953

Mussehl, T., P. Schladweiler, and R. Weckwerth. 1971. Forest grouse.

7954 Intermountain/foothill grassland 143-151 in T. W. Mussehl and F. W. Howell, eds.

7955 Game management in Montana. Montana Fish and Game Dept., Game Manage.

7956 Div., Helena, MT.

7957

7958

NatureServe. 2004. NatureServe explorer. An online encyclopedia of life. Version

7959

7960 3.0. NatureServe, Arlington, Virginia. (Accessed April 22, 2004;

7961

7962

7963

7964

7965

7966

7967

7968

7969

7970 $<$ http://www.natureserve.org/explorer>).

Saab, V.A. and J.S. Marks. 1992. Summer habitat use by Columbian sharp-tailed grouse in western Idaho. Great Basin Naturalist. 52: 166-173.

Ulliman, M.J., A. Sands , and T. Hemker. 1998. Conservation Plan for Columbian Sharp-tailed Grouse and its Habitat in Idaho - Draft. Draft document on file at the Forest Supervisors Office, Idaho Falls, Idaho, U.S.A.

7971

7972

U.S. Fish and Wildlife Service (USFWS). 1999. Endangered and threatened wildlife and plants: 90 day finding on a petition to list the Columbian sharp-tailed grouse as threatened. Federal Register: October 26, 1999. V.64. No. 206. pp

7973 57620-57623. 


\section{DRAFT WORKING DOCUMENT DO NOT DUPLICATE}

7973

7974

7975

7976

7977

7978

7979

7980

7981

7982

7983

7984

7985

7986

7987

7988

7989

7990

7991

7992

7993

7994

7995

7996

7997

7998

7999

8000

8001

8002

8003

8004

\section{Yellow Rail (Coturnicops noveboracensis)}

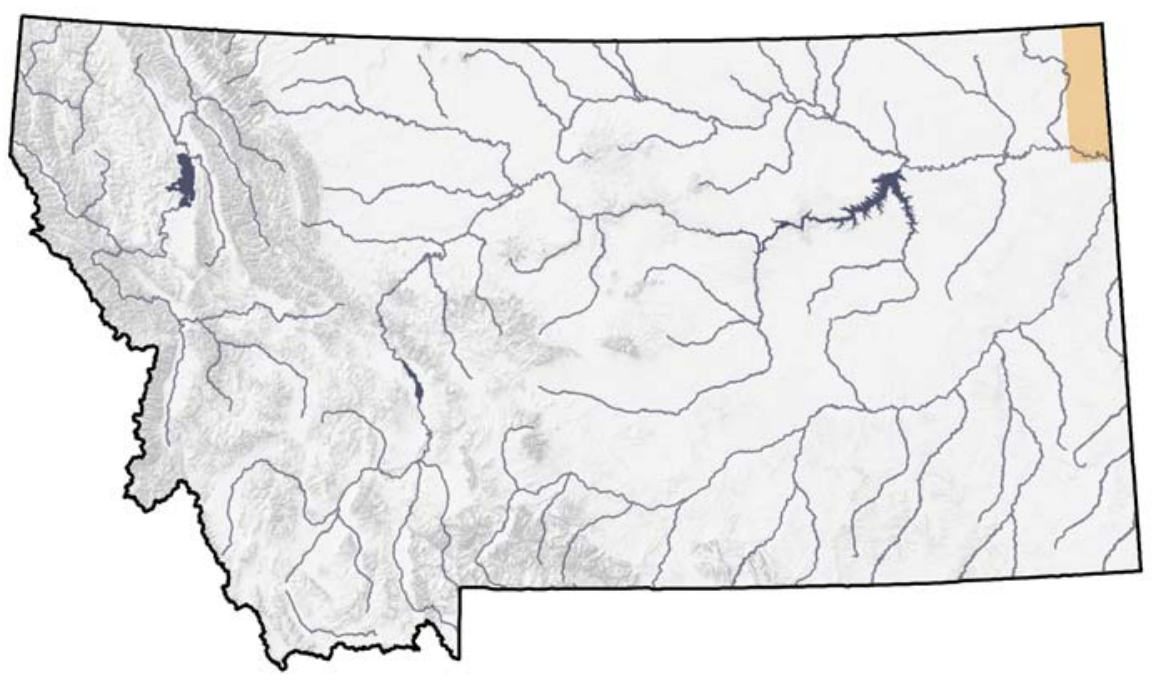

Figure 58. Distribution of the Yellow Rail

\section{Range}

With fewer than 20 known observations in the state, this species is considered rare. Wright (1997) indicates that the Yellow Rail is known to occur regularly in the northeastern corner of the state and is rare elsewhere. The first recorded observation in the state was reported in Medicine Lake in 1943. Other sightings of the species have occurred across the state with reports from East Bay of Flathead Lake (the furthest west the species has been reported in the state), Red Rock Lakes, Huntley (Yellowstone County), Bowdoin National Wildlife Refuge, and Westby (Montana Bird Distribution 2003).

\section{Habitat}

Breeding habitat selection is similar to that of other locations, and consists of wet sedge (Carex spp.) meadows and other wetlands containing grasses, rushes (Juncus spp.) and bulrushes (Scirpus spp) (Northern Prairie Wildlife Research Center 2003). Presence of the Yellow Rail is most commonly dictated by water depth, specifically one that fluctuates throughout the breeding season, i.e. wet in the early part of the breeding season and relatively dry (no standing water) by July or September (Northern Prairie Wildlife Research Center 2003).

\section{Management}

Although no management activities are in place specifically addressing the Yellow Rail in Montana, water level manipulation for other nesting species occurs at most locations where rails are found. Conscious management of water levels for waterfowl could assist in maintaining or enhancing nesting habitat for the 


\section{DRAFT WORKING DOCUMENT DO NOT DUPLICATE}

8005 Yellow Rail. Outside of the national wildlife refuges, no activities are known that 8006 consider conservation of Yellow Rails. Yellow Rails are a Species of

8007 Management Concern in USFWS Region 6 (U.S. Fish and Wildlife Service 8008 1995).

8009

8010

8011

8012

8013

8014

8015

8016

8017

8018

8019

8020

8021

8022

8023

8024

8025

8026

8027

8028

8029

8030

8031

8032

8033

8034

8035

8036

8037

8038

8039

8040

8041

8042

8043

8044

8045

8046

8047

8048

8049

\section{Conservation Concerns}

- Little known information in the state

- Human disturbance of wetland habitats

- Water level manipulation at nesting locations

\section{Conservation Strategies}

- Increased survey and monitoring projects

- Conservation practices of wetlands

- Manage reservoirs and dammed rivers in a manner that mimics more natural seasonal fluctuations

\section{Management Plans}

Casey, D. 2000. Partners in Flight Bird Conservation Plan Montana Version 1.0. Montana Partners in Flight. Kalispell, Montana.

James A. Kushlan, Melanie J. Steinkamp, Katherine C. Parsons, Jack Capp, Martin Acosta Cruz, Malcolm Coulter, Ian Davidson, Loney Dickson, Naomi Edelson, Richard Elliot, R. Michael Erwin, Scott Hatch, Stephen Kress, Robert Milko, Steve Miller, Kyra Mills, Richard Paul, Roberto Phillips, Jorge E. Saliva, Bill Sydeman, John Trapp, Jennifer Wheeler, and Kent Wohl. 2002. Waterbird Conservation for the Americas: The North American Waterbird Conservation Plan, Version 1. Waterbird Conservation for the Americas, Washington, D.C. U.S.A., 78 pp.

\section{Citations}

Montana Bird Distribution Online Database. 2001. Helena, Montana, USA. AprilSeptember 2003. http://nhp.nris.state.mt.us/mbd/.

Northern Prairie Wildlife Research Center: Biological Resources - Eastern Bluebird. United States Geological Survey: http://www.npwrc.usgs.gov. (Last updated February 21, 2003).

U.S. Fish and Wildlife Service, Office of Migratory Bird Management. 1995. Migratory nongame birds of management concern in the United States: the 1995 list. U.S. Government Printing Office: 1996-404-911/44014. 22 pp. 


\section{DRAFT WORKING DOCUMENT DO NOT DUPLICATE}

8050

8051

8052

8053

8054

8055

8056

8057

8058

8059

8060

8061

8062

8063

8064

8065

8066

8067

8068

8069

8070

8071

8072

8073

8074

8075

8076

8077

8078

8079

8080

8081

Wright, P.L. 1997. Status of Rare Birds in Montana, With Comments on Known Hybrids. Northwestern Naturalist 77:57-85.

\section{Whooping Crane (Grus americana)}

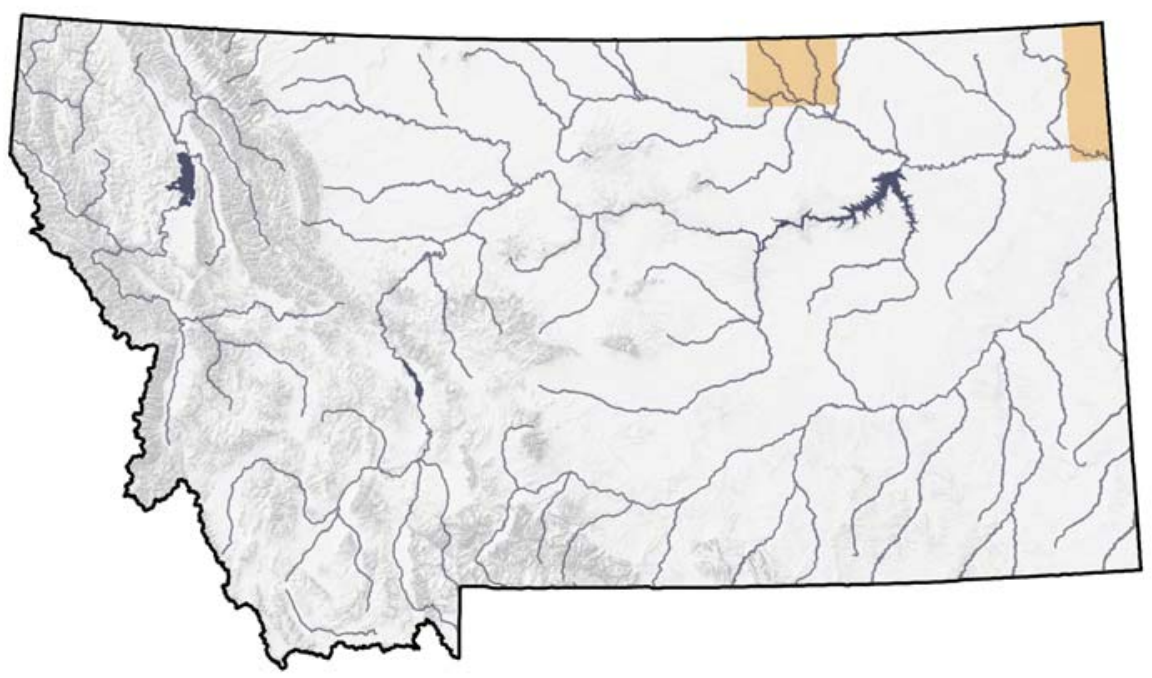

Figure 59. Distribution of the Whooping Crane

\section{Range}

Lewis and Clark reported a Whooping Crane in April of 1805 in proximity of what would become Montana and for a long time the sighting was attributed to this state. The observation is now believed, however, to have occurred in North Dakota. The earliest report of a Whooping Crane in the state is thus credited to Maximilian, Prince of Weid, for the observation of a flock of a few individuals above the mouth of the Musselshell River in September 1833 (Skaar, unpublished notes). Skaar (unpublished notes) also indicates that reports of this species for the next ninety years were scarce: singular reports exist for Big Sandy (1903), Terry (1904), and Billings (1918).

Individual, transient Whooping Cranes have been reported throughout the eastern portions of the state, with most of those records for Sheridan (Medicine Lake National Wildlife Refuge) and Roosevelt counties (MBD 2003). Historic observations of the species in the west-central portion of the state are also recorded; those reported the furthest west include observations in Gallatin County (west of Bozeman) in 1967 and Broadwater County (northwest of Townsend) in 1979 (Skaar, unpublished notes). For the past 20 years, observations have been restricted to the northeast corner of the state, with limited sightings of individuals at Red Rock Lakes National Wildlife Refuge. Reports of the birds from Red Rock Lakes are the result of the reintroduction effort to establish a population at Grays Lake, Idaho, which was a nonreproducing flock. The last bird observed at Red Rocks was seen in 2002, and it 


\section{DRAFT WORKING DOCUMENT DO NOT DUPLICATE}

8082 is presumed that since the Grays Lake flock is no longer extant, Whooping 8083 Cranes will most likely not be seen at Red Rock Lakes until another regional 8084 population is established. The birds observed in the eastern corner of Montana 8085 8086 8087

8088 8089 8090 8091 8092 8093 8094 8095 8096 8097 8098 8099 8100 8101 8102 8103 8104 8105 8106 8107 8108 8109

8110

8111

8112

8113

8114

8115

8116

8117

8118

8119

8120

8121

8122

8123

8124

8125

8126

8127 are occasional migrants traveling through from the Aransas population on journey to the breeding grounds in Alberta and the Northwest Territories.

\section{Habitat}

The Whooping Crane has been observed and breed at or within the marsh habitat present at Medicine Lake National Wildlife Refuge and Red Rock Lakes National Wildlife Refuge. Observations of individual birds in other areas of the state include grain and stubble fields as well as wet meadows, wet prairie habitat, and freshwater marshes that are usually shallow and broad with safe roosting sites and nearby foraging opportunities (MBD 2003).

\section{Management}

Efforts continue to protect and restore wetlands in the northeastern corner of Montana, in the area where whooping cranes have migrated in the past. There are also continued efforts to educate crane and waterfowl hunters on the identification of whooping cranes in an effort to avoid accidental harvest.

\section{Conservation Concerns}

- Habitat degradation and fragmentation to native prairies

- Human disturbance to nesting locations

- Potential petroleum spills in the wintering areas of Port Aransas

- Human misidentification as sandhill cranes during hunting season

\section{Conservation Strategies}

- Habitat conservation in Northeast Montana (outside Medicine Lake NWR)

- Prohibition of public access to breeding locations, including aircrafts

- Hunter education

- Periodic census to evaluate productivity

\section{Management Plans}

James A. Kushlan, Melanie J. Steinkamp, Katherine C. Parsons, Jack Capp, Martin Acosta Cruz, Malcolm Coulter, Ian Davidson, Loney Dickson, Naomi Edelson, Richard Elliot, R. Michael Erwin, Scott Hatch, Stephen Kress, Robert Milko, Steve Miller, Kyra Mills, Richard Paul, Roberto Phillips, Jorge E. Saliva, Bill Sydeman, John Trapp, Jennifer Wheeler, and Kent Wohl. 2002. Waterbird Conservation for the Americas: The North American Waterbird Conservation Plan, Version 1. Waterbird Conservation for the Americas, Washington, D.C. U.S.A., 78 pp. 


\section{DRAFT WORKING DOCUMENT DO NOT DUPLICATE}

8128

8129 Olsen, David L. 1980. Whooping Crane Recovery Plan. Whooping Crane

8130 Recovery Team (USFWS, Nebraska Game and Parks Commission, Texas Parks

8131 \& Wildlife Department, National The Audubon Society Society). 206 pp.

8132

8133

8134

8135

8136

8137

8138

8139

8140

8141

8142

\section{Citations}

Johnsgard, P. A. 1986. Birds of the Rocky Mountains with particular reference to national parks in the Northern Rocky Mountain region. Colorado Associated University Press, Boulder. xi +504 pp.

Montana Bird Distribution Online Database. 2001. Helena, Montana, USA. AprilSeptember 2003. http://nhp.nris.state.mt.us/mbd/. 


\section{DRAFT WORKING DOCUMENT DO NOT DUPLICATE}

8142

8143

8144

8145

8146

8147

8148

8149

8150

8151

8152

8153

8154

8155

8156

8157

8158

8159

8160

8161

8162

8163

8164

8165

8166

8167

8168

8169

8170

8171

8172

\section{Piping Plover (Charadrius melodus)}

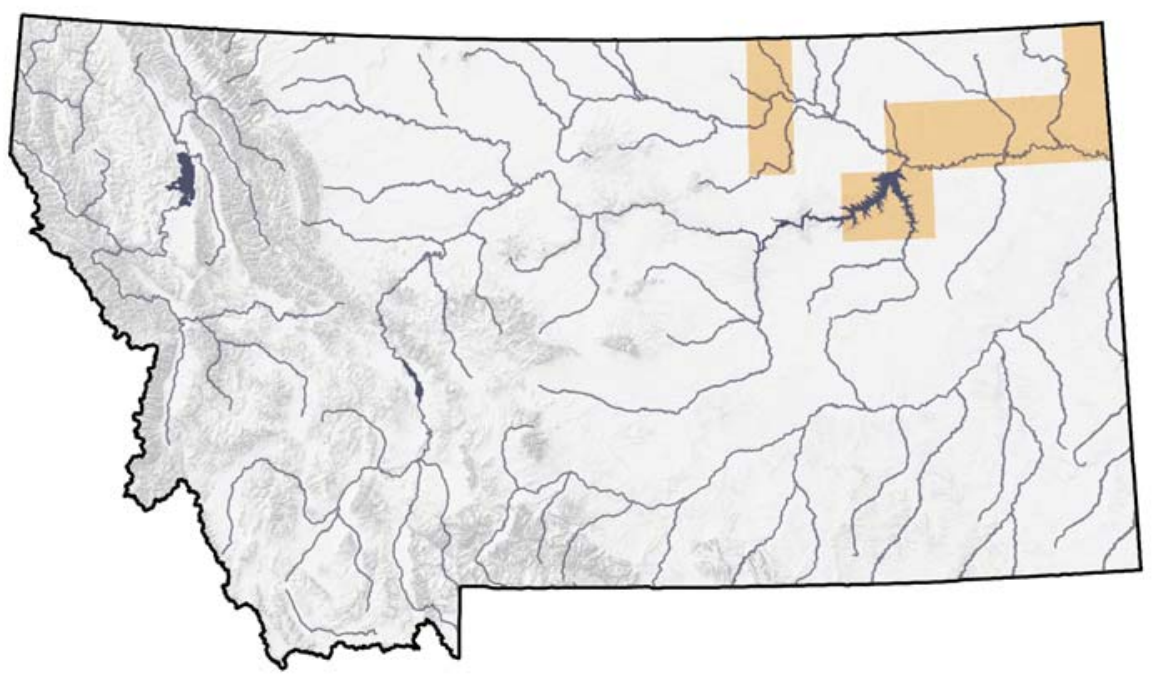

Figure 60. Distribution of the Piping Plover

\section{Range}

Piping Plovers are limited to the open shorelines of freshwater or alkaline lakes, reservoirs, rivers, or wetlands. The Piping Plover is generally a species of northern and northeastern Montana. This species is known to breed in Medicine Lake National Wildlife Refuge, Sheridan County, the Missouri River below Fort Peck Dam, Fort Peck Reservoir, Nelson Reservoir, Bowdoin National Wildlife Refuge (occasionally), and Alkali Lake (MPPRC 1994, Montana Bird Distribution 2003).

Observations of non-breeding individuals have been recorded at Freezeout Lake Wildlife Management Area, the south end of Canyon Ferry Reservoir, and Park County (MPPRC 1994, Montana Bird Distribution 2003), though it is presumed the species uses other appropriate habitat in the state during migration.

The Piping Plover usually arrives in Montana in early May and leaves the state by late August. The earliest reported observation dates for the species are for April (28 April 1993, Fort Peck Reservoir [MPPRC 1994], 2001; Upper Goose Lake, Sheridan County; [Montana Bird Distribution 2003]). Most of the observations reported in the state are for breeding individuals, or for activity that suggests breeding.

Reports of Piping Plovers during migration are not common, but do occur just east of the Rocky Mountains (Montana Bird Distribution Committee 1996).

Although they were known to breed at Bowdoin National Wildlife Refuge and at Fort Peck Reservoir, little attention was paid to the species prior to its listing in 


\section{DRAFT WORKING DOCUMENT DO NOT DUPLICATE}

8173 1985. As a result, few observations prior to 1985 are recorded (Montana Bird

8174 Distribution 2003).

8175

8176

8177

8178

8179

\section{Habitat}

Piping Plovers primarily select unvegetated sand or pebble beaches on shorelines or islands in freshwater and saline wetlands. Vegetation, if present at

8180

8181

8182 all, consists of sparse, scattered clumps (Casey 2000). Open shorelines and sandbars of rivers and large reservoirs in the eastern and north-central portions of the state provide prime breeding habitat (MFWP 2003). In Montana, and throughout the species' range, nesting may occur on a variety of habitat types. If

8184 conditions are right, alkali wetlands, lakes, reservoirs, and rivers can all provide

8185

8186

8187 the essential features required for nesting. The alkali wetlands and lakes found in the northeastern corner of the state generally contain wide, unvegetated, gravelly, salt-encrusted beaches. Rivers that flood adequately can supply open sandbars or gravelly beaches, as can large reservoirs, with their shoreline beaches, peninsulas, and islands of gravel or sand (USFWS 2003).

Sites with gravel substrate provide the most suitable sites for nesting (MPPRC 1994). One of the most limiting factors to nesting site selection is vegetation encroachment; Piping Plovers avoid areas where vegetation provides cover for potential predators. Fine-textured soils are easier to treat mechanically than rocky or gravelly soils when vegetation is determined as a limiting factor in an area's ability to provide suitable nesting habitat, but fine soils are not typically a preferred nesting substrate (MPPRC 1994). Another, and more important limiting factor in nest site selection is the location of nesting sites in relation to surrounding water levels. Nests are often inundated because water levels are kept unnaturally high throughout the breeding season (and high winds can cause nests to be flooded), or nesting sites are not available, either because of encroaching vegetation or because water levels are so high that beaches are under water during the early part of, and possibly throughout, the nesting season (MPPRC 1994). Nests are simple scrapes dug into the nest substrate, which may or may not be lined with pebbles (MPPRC 1994, 1995, Haig 1992).

\section{Management}

Four specific geographic areas recognized as providing critically important habitat and identified as essential for the conservation of the species, have been designated as "Critical Habitat Units" in Montana. The designation of critical habitat may require federal agencies to develop special management actions affecting these sites. The four units include prairie alkali wetlands and surrounding shoreline; river channels and associated sandbars and islands; and reservoirs and inland lakes with associated shorelines, peninsulas, and islands (USFWS 2003). Piping Plovers rely on these places for courtship, nesting, foraging, and brood rearing. The first, Unit 1, contains alkali lake and wetland habitat found in Sheridan County. Unit 2 is identified as riverine habitat and 


\section{DRAFT WORKING DOCUMENT DO NOT DUPLICATE}

8219 includes the Missouri River just south of Wolf Point to the state line,

8220 encompassing habitat provided by the sparsely vegetated sandbars, and sandy

8221 or gravelly beaches along this stretch of the river. Reservoirs, which include

8222 similar sandbars and sandy or gravelly beach habitat, define both Units 3 and 4.

8223 Unit 3 includes Fort Peck Reservoir, from south of the dam to and including

8224 approximately 26 miles (north to south distance) of the length of Dry Arm.

8225 Portions of Bowdoin National Wildlife Refuge, the majority of Lake Bowdoin and

8226 the western portion of the Dry Lake, were designated as Unit 4. Piping Plovers

8227 nest at Nelson Reservoir north of Bowdoin National Wildlife Refuge, but are not

8228 contained within any of the Critical Habitat Units in the state. This reservoir was

8229 excluded from the critical habitat designation because of a Memorandum of

8230 Understanding between the Bureau of Reclamation, the U.S. Fish and Wildlife

8231 Service, and the local irrigation districts. The memorandum, in combination with a

8232 biological opinion from the USFWS, guides management actions at this location

8233 (USFWS 2003). Management activities include moving nests upslope from areas

8234 where flooding of nests is imminent; using nest cages over nest bowls to prevent

8235 trampling and predation by avian predators; signing beaches to indicate nesting;

8236 beach enhancement (grading or burning unwanted encroaching vegetation);

8237 raising island elevation to make room to move nests in years with rising water

8238 during the nesting season; the release of captive-reared plovers (Erickson and

8239 Prellwitz 1999); and timing spring flow releases from Fort Peck Dam to more

8240 closely mimic the natural seasonal flows of the river (MFWP 2003). Other

8241 management activities to enhance habitat or affect better protection for this

8242 plover include building structures (weirs) to contain water in reservoirs for longer

8243 periods during the breeding season, placing gravel on otherwise muddy beaches

8244 to create appropriate substrate (Hanebury, personal communication 2003), and

8245 reducing human, dog, and vehicular disturbance during nesting (MFWP 2003).

8246 The greatest threat to nesting plovers is the loss of nesting sites by high water

8247 levels at any time of the year, but especially during the nesting season for it can

8248 result in inundation of existing nests (MPPRC 1994). Rising water levels later in

8249 the nesting season result in decreasing overall island size, and may assist avian

8250 predators to locate nests more easily (Erickson and Prellwitz 1999). These

8251 conditions enforce the need to manage reservoirs and dammed rivers in a

8252 manner that mimics more natural seasonal fluctuations.

8253

8254

8255

8256

8257

8258

8259

8260

8261

8262

8263

8264

\section{Conservation Concerns}

- Destruction and degradation of summer and winter habitat

- Shoreline erosion

- Human disturbances of nesting and foraging birds

- Predation

\section{Conservation Strategies}

- Protection of as much existing native prairie as feasible, primarily by conservation easement 


\section{DRAFT WORKING DOCUMENT DO NOT DUPLICATE}

8265

8266

8267

8268

8269

8270

8271

8272

8273

8274

8275

8276

8277

8278

8279

8280

8281

8282

8283

8284

8285

8286

8287

8288

8289

8290

8291

8292

8293

8294

8295

8296

8297

8298

8299

8300

8301

8302

8303

8304

8305

8306

8307

8308

8309

- Restoration of drained wetlands

- Increase nesting substrate when it appears to be a limiting factor affecting use of wetlands

- Avoid oil and gas development near wetlands

- Direct predator management

\section{Management Plans}

Brown, S., C. Hickey, B. Harrington, and R. Gill, eds. 2001. The U.S. Shorebird Conservation Plan, $2^{\text {nd }}$ ed. Manomet Center for Conservation Sciences, Manomet, MA.

Casey, D. 2000. Partners in Flight Bird Conservation Plan Montana Version 1.0. Montana Partners in Flight. Kalispell, Montana.

Haig, S., et al. 1988. Recovery plan for piping plovers CHARADRIUS MELODUS of the Great Lakes and northern great plains. U.S. Fish \& Wildlife Service, 160pp.

Haig, S., et al. 1994. Revised recovery plan for piping plovers CHARADRIUS MELODUS breeding on the Great Lakes and Northern Great Plains.

[Technical/Agency review draft]. Great Lakes/Northern Great Plains Piping Plover Recovery Team. 121 pp.

Montana Piping Plover Working Group. 2003. Montana Piping Plover Management Plan. Unpublished Report. 35 pp.

\section{Citations}

Erickson, K. And Prellwitz, D.M. 1999. Piping plover surveys for Nelson Reservoir, Bowdoin NWR and Hewitt Lake NWR.

Haig, S. M. 1992. Distribution and status of piping plovers in winter. Abstract, 6th Annual Meeting of the Society for Conservation Biology, p. 69.

Montana Bird Distribution Committee. 1996. Skaar's Montana Bird Distribution, Fifth Edition. Special Publication No. 3. Montana Natural Heritage Program, Helena. $130 \mathrm{pp}$.

Montana Bird Distribution Online Database. 2001. Helena, Montana, USA. AprilSeptember 2003. http://nhp.nris.state.mt.us/mbd/.

Montana Department of Fish, Wildlife, and Parks. 2003. Online informational search on Piping Plovers in Montana.

http://www.fwp.state.mt.us/wildthings/t\&e/threatened.asp. 
8310 Montana Piping Plover Recovery Committee. 1994. 1993 Surveys for Piping 8311 Plover (CHARADRIUS MELODUS) and Least Tern (STERNA ANTILLARUM) in 8312 Montana. Unpublished report. 116 pp. plus appendices.

8313

8314 Montana Piping Plover Recovery Committee. 1995. 1994 Surveys for Piping

8315 Plover (CHARADRIUS MELODUS) and Least Tern (STERNA ANTILLARUM) in 8316 Montana. 117 pp. plus appendices.

8317

8318

8319

U.S. Fish and Wildlife Service. 2003. Online informational search on Piping

8320

8321

Plover in Montana. http://mountain-

8322

prairie.fws.gov/pipingplover/Piping_Plover_Q\&A_Sept5.htm. 


\section{DRAFT WORKING DOCUMENT DO NOT DUPLICATE}

8322

8323

8324

8325

8326

8327

8328

8329

8330

8331

8332

8333

8334

8335

8336

8337

8338

8339

8340

8341

8342

8343

8344

8345

8346

8347

8348

8349

8350

8351

8352

8353

\section{Mountain Plover (Charadrius montanus)}

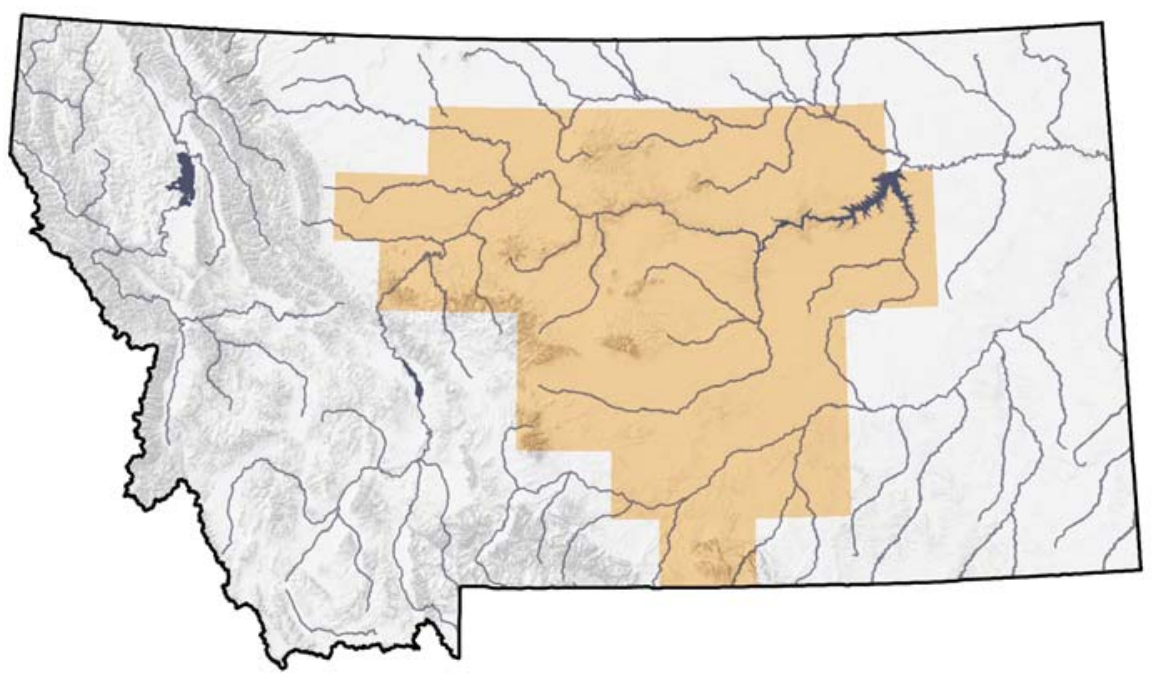

Figure 61. Distribution of the Mountain Plover

\section{Range}

Primary breeding habitat of the Mountain Plover is found in the north-central portion of the state in Phillips, Blaine, and northern Fergus and Petroleum counties (FaunaWest 1995). This area contains the largest population of Mountain Plovers in Montana, with additional breeding areas in the state in Valley County (Little Beaver Creek) in the northeastern portion of the state; in Wheatland, Golden and Musselshell counties near the Little Belt, Big Snowy, and Little Snowy Mountains in central Montana; and, in the southwestern portion of the state in Jefferson, Madison and Broadwater counties (FaunaWest 1995). Additionally, surveys in 2003 revealed Mountain Plovers in Big Horn, Carbon, Fergus, Hill, Petroleum, Rosebud, and Treasure counties (Fed. Reg. 68).

Mountain Plovers arrive in April and may remain in the state until September (Johngard 1986). The species is a rare migrant west of the Continental Divide, but is a breeding resident of the prairie lands to the east.

\section{Habitat}

Habitat use in Montana appears similar to other areas within the species global breeding range; use of prairie dog colonies and other shortgrass prairie sites are confirmed as preferred breeding habitat. Records indicate the species utilizes towns of both white-tailed (Cynomys leucurus) and black-tailed prairie dogs (Cynomys ludoviscianus) (MBD 2003). Prairie dog towns provide greater horizontal visibility, a higher percentage of bare ground, more burrows for refuge, and higher diversity of forbs than adjacent areas (Olsen 1985). Mountain Plovers will use towns as small as 3 ha (Knowles et al. 1982), but the average on one 


\section{DRAFT WORKING DOCUMENT DO NOT DUPLICATE}

8354 study was 57.5 ha (Knowles and Knowles 1984) and ranged from 6 to 50 ha in

8355

8356

8357

8358

8359

8360

8361

8362

8363

8364

8365

8366

8367

8368

8369

8370

8371

8372

8373

8374

8375

8376

8377

8378

8379

8380

8381

8382

8383

8384

8385

8386

8387

8388

8389

8390

8391

8392

8393

8394

8395

8396

8397

8398

8399 another (Olson-Edge and Edge 1987).

Primary habitat use in Montana during the breeding season includes heavily grazed, shortgrass prairie sites. Habitat in Phillips and Blaine counties, the area containing the largest known populations of Mountain Plover in the state, is dominated by the native plant species Bouteloua gracilis and Koeleria cristata.

This area also contains Stipa comata, Agropyron smithii, Carex spp., Artemisia frigida, Opuntia polyacantha, and Gutierrezia sarothrae (FaunaWest 1991). Knowles (1993) determined in the northeastern portion of the state, Mountain Plover also selected sites associated with habitat dominated by Atriplex gardneri and Eriogonum multiceps, while use in the central and southwestern areas of the state was associated with Bouteloua gracilis and Stipa comata. Strong preference was also given to sites with slopes less than 5\% and grass height of less than $6 \mathrm{~cm}$ (3 inches) (Knowles, Maj, and Hinckley 1995). Knowles (1993) indicates that sites selected within these habitat types were restricted to areas intensively grazed by prairie dogs, sheep, and/or cattle, especially those of the Stipa comata and Bouteloua gracilis habitat type (Knowles and Knowles 1997).

\section{Management}

No coordinated management activities in Montana specific to Mountain Plover were identified. However, the unifying habitat features desirable to Mountain Plovers are extremely short vegetation, a high percentage of bare soil, and an extensive area ( 0.5 to $1 \mathrm{~km}$ diameter) of nearly level terrain (Knowles and Knowles 1997). Management practices should emulate these parameters ensure that these populations persist. Several studies have suggested specific conservation actions that could be taken to benefit Mountain Plover habitat (Wershler 1989; FaunaWest Wildlife Consultants 1991; Knopf 1991; Carter and Barker 1993; U.S. Fish and Wildlife Service 1995).

\section{Conservation Concerns}

- Loss of livestock grazing (increase in vegetation height above 4 inches or $30 \%$ cover)

- Invasive non-native plant species

- Habitat loss of shortgrass prairies due to conversion to cropland

\section{Conservation Strategies}

- Cooperate with resources users in order to support sustainable domestic livestock pratices that promote Mountain Plover habitat

- Shrub and noxious weed encroachment should be controlled at known and potential breeding sites

- Existing native grassland should be protected from conversion to cropland 


\section{DRAFT WORKING DOCUMENT DO NOT DUPLICATE}

8400

8401

8402

8403

8404

8405

8406

8407

8408

8409

8410

8411

8412

8413

8414

8415

8416

8417

8418

8419

8420

8421

8422

8423

8424

8425

8426

8427

8428

8429

8430

8431

8432

8433

8434

8435

8436

8437

8438

8439

8440

8441

8442

8443

8444

\section{Management Plans}

Brown, S., C. Hickey, B. Harrington, and R. Gill, eds. 2001. The U.S. Shorebird Conservation Plan, $2^{\text {nd }}$ ed. Manomet Center for Conservation Sciences, Manomet, MA.

Casey, D. 2000. Partners in Flight Bird Conservation Plan Montana Version 1.0. Montana Partners in Flight. Kalispell, Montana.

\section{Citations}

Carter, M. F., and K. Barker. 1993. An interactive database for setting conservation priorities for western neotropical migrants. U.S. Forest Service General Technical Report RM-229: 120-144.

FaunaWest Wildlife Consultants. 2004. Mountain Plover Population Trends for Three Montana Sites. Report to Montana Fish, Wildlife and Parks. FaunaWest Wildlife Consultants, Boulder, MT, 8pp.

FaunaWest Wildlife Consultants. 1991. Status and breeding distribution of the mountain plover in Montana. Report to USDI Bureau of Land Management.

FaunaWest Wildlife Consultants, Boulder, MT, 44pp.

FaunaWest Wildlife Consultants. 1995. Mountain plover numbers, reproduction, and habitat use in three areas of Montana. [Unpublished report]. 26 pp. Bureau of Land Management, Billings, Montana.

Johnsgard, P. A. 1986. Birds of the Rocky Mountains with particular reference to national parks in the Northern Rocky Mountain region. Colorado Associated University Press, Boulder. xi +504 pp.

Knopf, F. L. 1991. Status and conservation of mountain plovers: the evolving regional effort. Report of research activities, USFWS National Ecology Research Center, Ft. Collins, CO, 9pp.

Knowles, C. J. and P. R. Knowles. 1984. Additional records of mountain plovers using prairie dog towns in Montana. Prairie Nat. 16:183-186.

Knowles, C. J. and P. R. Knowles. 1993. Mountain plover numbers, reproduction, and habitat use in three areas of Montana. Unpublished report for the Bureau of Land Management, Billings. 50pp.

Knowles, C. and P. Knowles. 1997. Mountain Plover Numbers, Reproduction, and Habitat Use in Montana: A Summary of Six Survey Years. FaunaWest Wildlife Consultants. Prepared for the Montana Department of Fish, Wildlife, \& 


\section{DRAFT WORKING DOCUMENT DO NOT DUPLICATE}

8445 Parks, Great Falls, Montana, and the Bureau of Land Management, Billings, 8446 Montana. 22 April 1997.

8447

8448

8449

Knowles, C., P. Knowles, M. Maj, and D. Hinckley. 1995. Mountain Plover

8450

8451 Numbers, Reproduction, and Habitat Use in three areas of Montana. Prepared by

8452

8453

8454

8455

8456 FaunaWest Wildlife Consultants for Bureau of Land Management, Billings, Montana.

8457

8458

8459

8460

8461

8462

8463

8464

8465

8466

Knowles, C. J., C. J. Stoner and S. P. Gieb. 1982. Selective use of black-tailed prairie dog towns by mountain plovers. Condor 84:71-74.

Montana Bird Distribution Online Database. 2001. Helena, Montana, USA. AprilSeptember 2003. http://nhp.nris.state.mt.us/mbd/.

Olson, S. L. 1985. Mountain plover food items on and adjacent to a prairie dog town. Prairie Naturalist 17(2):83-90.

Olson, S. L. and D. Edge. 1985. Nest site selection by mountain plovers in northcentral Montana. Journal of Range Management 38(3):280-282.

8467

8468

8469

8470

Olson-Edge, S. L. and W. D. Edge. 1987. Density and distribution of the mountain plover on the Charles M. Russell National Wildlife Refuge. The Prairie Naturalist. 19(4):233-238.

8471

8472

8473

8474

8475

U.S. Fish and Wildlife Service, Office of Migratory Bird Management. 1995.

Migratory nongame birds of management concern in the United States: the 1995 list. U.S. Government Printing Office:1996-404-911/44014. 22 pp.

Wershler, C. R. 1989. A management strategy for mountain plovers in Alberta. Proc. Prairie Cons. Endangered Sp. Workshop, Sask. Nat. Hist. Soc. and Can.

8476

8477 Plains Res. Center. 5 pp. 


\section{DRAFT WORKING DOCUMENT DO NOT DUPLICATE}

8477

8478
8479

8480

8481

8482

8483

8484

8485

8486

8487

8488

8489

8490

8491

8492

8493

8494

8495

8496

8497

8498

8499

8500

8501

8502

8503

8504

8505

8506

8507

8508

\section{Long-billed Curlew (Numenius americanus)}

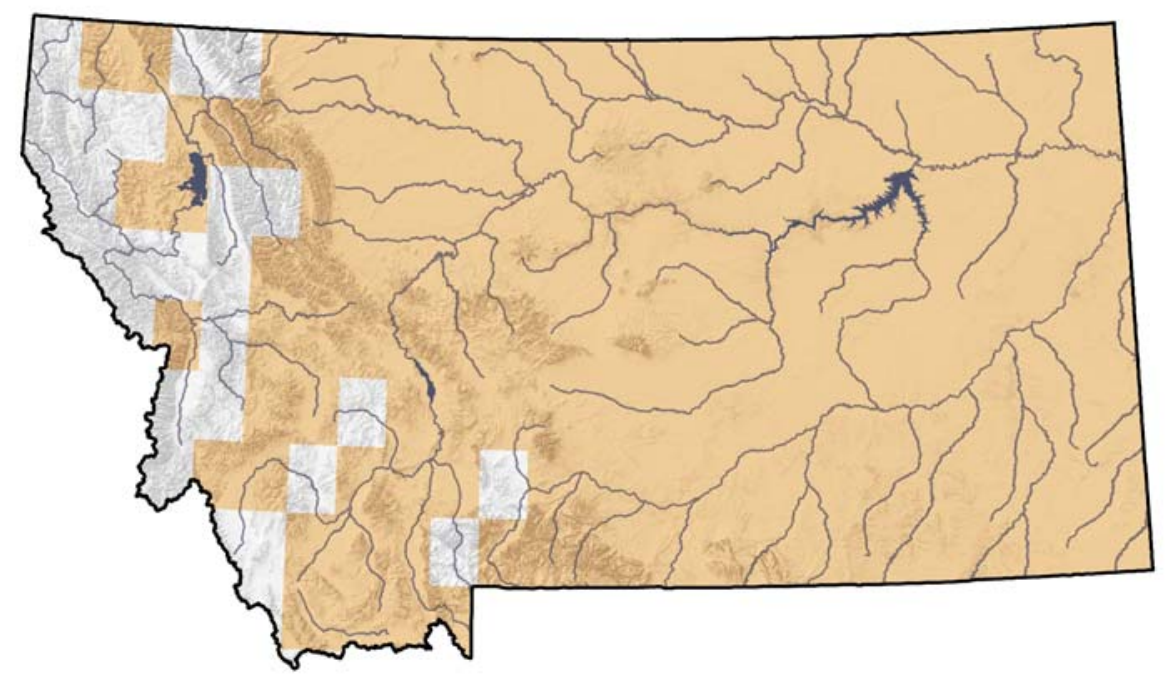

Figure 62. Distribution of the Long-billed Curlew

\section{Range}

The Long-billed Curlew breeds widely throughout the state, although it is more common east of the Rocky Mountains. Long-billed Curlews do not overwinter in the state.

\section{Habitat}

Long-billed curlews have four essential nesting habitat requirements in the northwestern United States: short grass (less than $30 \mathrm{~cm}, 11.8$ in tall), bare ground components, shade, and abundant invertebrate prey. Long-billed curlews prefer native prairies but also occupy grazed mixed-grass communities and scrub prairies. Long-billed curlews probably select sites because of shortness of vegetation and also the spacing of grass clumps. Because they rely on camouflage for protection of their eggs and themselves during incubation, the short grass presumably allows for better visibility of approaching danger, and the irregular pattern of grass clumps complements their cryptic coloration. They typically prefer areas with well drained, gravelly soils, and low, rolling terrain. Proximity to water may be another important factor in breeding habitat.

\section{Management}

Long-billed curlews are closely associated with grassland and shrub grassland habitats. Management should therefore be directed at protection and enhancement of those habitats. Of primary importance is the prevention of the conversion of upland prairie to cropland and the protection of known breeding habitat of curlews from detrimental human activities such as vehicular use, 


\section{DRAFT WORKING DOCUMENT DO NOT DUPLICATE}

8509 researcher disturbance, and shooting. Habitat areas need to be $>3$ times as large

8510 as a long-billed curlew territory, which averages about 14 ha (34.6 acres), in

8511 order for curlews to use them. Removing tall, dense residual vegetation before

8512 the pre-laying period will improve breeding habitat in overgrown areas. Removal

8513 of residual vegetation is especially important after years of above-normal

8514 precipitation. Haying and grazing can be used to provide the short vegetation and

8515 reduced vertical plant density preferred by nesting curlews but should be timed

8516 so that short vegetation is available early in the season. In southwestern Idaho,

8517 curlews avoided areas that had not been grazed within the past year. Prescribed

8518 burns can improve habitat by reducing shrub coverage and increasing habitat

8519 openness. During the breeding season following a fall range fire in western

8520 Idaho, the estimated curlew breeding density increased 30\%. Grazing should be

8521 avoided during the incubation period as trampling can reduce hatching success.

8522 In known breeding areas, pastures and hay fields should not be dragged to break

8523 up cowpies as long-billed curlews often nest near cowpies. Dragging may be

8524 acceptable if it occurs after the breeding season when eggs or chicks are no

8525 longer vulnerable.

8526

8527

8528

8529

8530

8531

8532

8533

8534

8535

8536

8537

8538

8539

8540

8541

8542

8543

8544

8545

8546

8547

8548

8549

8550

8551

8552

8553 Casey, D. 2000. Partners in Flight Bird Conservation Plan Montana Version 1.0.

8554 Montana Partners in Flight. Kalispell, Montana. 


\section{DRAFT WORKING DOCUMENT DO NOT DUPLICATE}

8555

8556

8557

8558

8559

8560

8561

8562

8563

8564

8565

8566

8567

8568

8569

8570

8571

8572

8573

8574

\section{Citations}

Dechant, J. A., M. L. Sondreal, D. H. Johnson, L. D. Igl, C. M. Goldade, P. A. Rabie, and B. R. Euliss. 2000. Effects of management practices on grassland birds: Long-billed Curlew. Northern Prairie Wildlife Research Center, Jamestown, ND. Jamestown, ND: Northern Prairie Wildlife Research Center Home Page. http://www.npwrc.usgs.gov/resource/literatr/grasbird/fplbcu/fplbcu.htm (Version 29FEB2000).

Hart, M. M., W. A. Williams, P. C. Thornton, K. P. McLaughlin, C. M. Tobalske, B. A. Maxell, D. P. Hendricks, C. R. Peterson, and R. L. Redmond. 1998. Longbilled curlew (Numernius americanus) in Montana atlas of terrestrial vertebrates. Unpublished report. Montana Cooperative Wildlife Research Unit, The University of Montana, Missoula. Pp. 269-271.

Redmond, R. L., and D. A. Jenni. 1986. Population ecology of the long-billed curlew (Numernius americanus) in western Idaho. Auk 103: 755-767. 


\section{DRAFT WORKING DOCUMENT DO NOT DUPLICATE}

8574

8575

8576

8577

8578

8579

8580

8581

8582

8583

8584

8585

8586

8587

8588

8589

8590

8591

8592

8593

8594

8595

8596

8597

8598

8599

8600

8601

8602

8603

8604

8605

\section{Interior Least Tern (Sterna antillarum athalassos)}

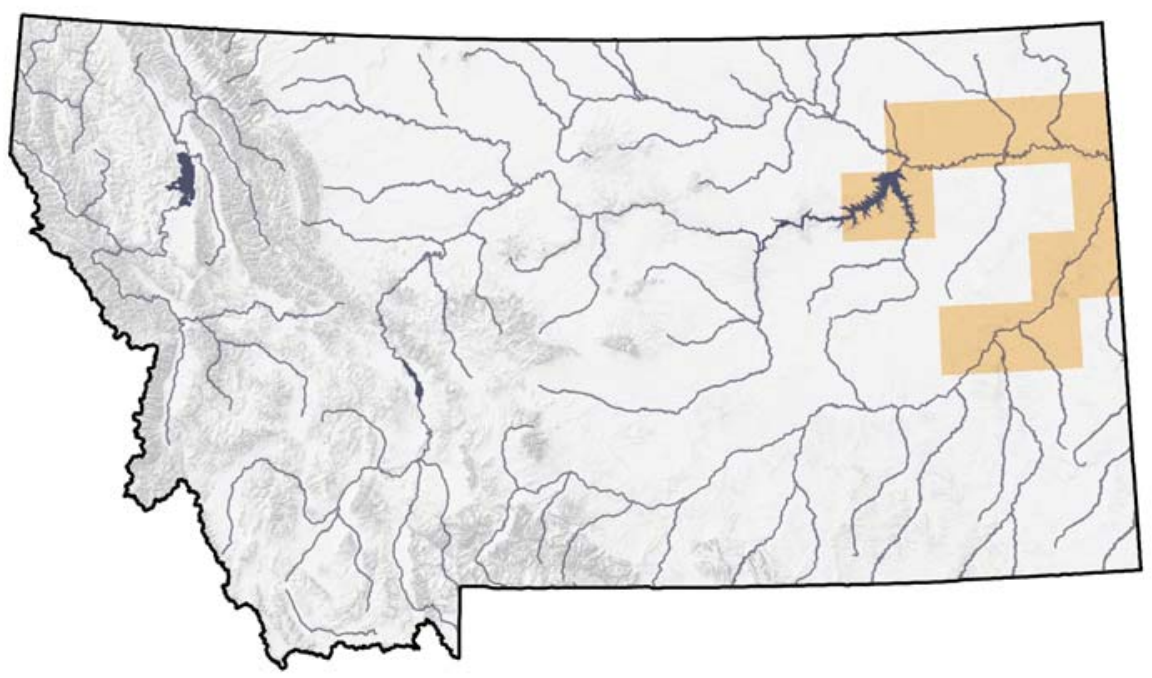

Figure 63. Distribution of the Least Tern

\section{Range}

Montana defines the western portion of the Interior Least Tern's range. The species breeds along the lower portions of the Missouri River below Fort Peck Dam, on the beaches of Fort Peck Reservoir, and on the Yellowstone River below Glendive. Records of transient individuals are few and are limited primarily to these same areas (Montana Bird Distribution 2003).

\section{Habitat}

Interior Least Terns nest on unvegetated sand-pebble beaches and islands of large reservoirs and rivers in northeastern and southeastern Montana, specifically the Yellowstone and Missouri river systems (Christopherson et al. 1992). These wide-open river channels, and lake and pothole shorelines provide the preferred characteristics for nesting terns. Sites with gravel substrate provide the most suitable sites for nesting (MPPRC 1994). One of the most limiting factors to nesting site selection is vegetation encroachment; terns avoid areas where relatively thick vegetation provides cover for potential predators. Finetextured soils are easier to treat mechanically than rocky or gravelly soils when vegetation is determined as a limiting factor in an area's ability to provide suitable nesting habitat, but fine soils are not typically a preferred nesting substrate (MPPRC 1994).

In Montana, as in other areas, another and more important limiting factor in nest site selection is the location of nesting sites in relation to surrounding water levels. Nests are often inundated because water levels are kept unnaturally high throughout the breeding season (and high winds can cause nests to be flooded) 


\section{DRAFT WORKING DOCUMENT DO NOT DUPLICATE}

8606 or nesting sites are not available (either because of encroaching vegetation or

8607

8608

8609

8610

8611

8612

8613

8614

8615

8616

8617

8618

8619

8620

8621

8622

8623

8624

8625

8626

8627

8628

8629

8630

8631

8632

8633

8634

8635

8636

8637

8638

8639

8640

8641

8642

8643

8644

8645

8646

8647

8648

8649

8650

8651

because water levels are so high that beaches are under water during the early part of, and possibly throughout, the nesting season) (MPPRC 1994).

\section{Management}

As identified in the Recovery Plan for the Interior Least Tern, delisting can be considered when four censuses confirm that the interior population has reached 7,000 and remains stable for at least 10 years. The goal for the Missouri River system is 2,100 birds (census numbers in 2003 revealed 735 birds for the Missouri River in total; Pavelka, Pers. Comm. 2003). Appropriate water management, that which includes natural seasonal flows, is identified as the major consideration for Interior Least Tern conservation in Montana, for the greatest threat to breeding pairs, in some years, is the loss of existing nesting sites from inundation by high water during the breeding season (MPPRC 1994). Rising water levels late in the nesting season can also reduce overall island size, and may result in assisting local avian predators to locate tern nests (containing eggs or nestlings) more easily (Erickson and Prellwitz 1999). These conditions reinforce the need to manage reservoirs and dammed rivers in a manner that mimics more natural seasonal fluctuations for the protection of Interior Least Tern populations. Other management activities beneficial to the species include:

instituting grazing management practices more appropriate to the conservation of the Interior Least Tern; controlling access to key nesting locations; moving nests upslope from areas where flooding of nests is imminent; relocating eggs to nests of other terns for foster incubation; signing of beaches to indicate nesting by Interior Least Terns (though in areas where there is hostility toward the species, or toward listed species in general, this is not recommended); beach enhancement (grading or burning to remove unwanted encroaching vegetation); raising island elevation to make room to move nests in years with rising water during the nesting season (MPPRC 1994); and timing spring flow releases from Fort Peck Dam to more closely mimic the natural seasonal flows of the river (MFWP 2003). Other management activities to enhance habitat or affect better protection for this species includes reducing human, dog, and vehicular disturbance during nesting (MFWP 2003).

\section{Conservation Concerns}

- Human use and predation on adults, eggs, and young by birds (e.g., kestrels, night-herons, crows, northern harrier, gulls) and mammals (foxes, skunks, weasels, opossum, rats, feral hogs, and domestic cats and dogs)

- Chemical spills and pesticide or heavy metal pollution

- Human modification of river flow (e.g., reduction of spring floods by dams) and bank stabilization and channelization, resulting in reduced availability of bare island/sandbar nesting habitat

- Loss of aquatic habitat diversity and resulting changes in fish species composition and abundance 
8652

8653

8654

8655

8656

8657

8658

8659

8660

8661

8662

8663

8664

8665

8666

8667

8668

8669

8670

8671

8672

8673

8674

8675

8676

8677

8678

8679

8680

8681

8682

8683

8684

8685

8686

8687

8688

8689

8690

8691

8692

8693

8694

8695

8696

8697

- Unsustainable irrigation may be a threat by lowering water levels/flows and reducing river areas when terns are breeding

\section{Conservation Strategies}

- Decrease human modifications of flows on larger rivers

- Decrease point and non-point inputs of pesticides and heavy metals into rivers and floodplains

- Conservation of riparian areas in Northeast Montana, decreasing human impacts

\section{Management Plans}

Casey, D. 2000. Partners in Flight Bird Conservation Plan Montana Version 1.0. Montana Partners in Flight. Kalispell, Montana.

James A. Kushlan, Melanie J. Steinkamp, Katherine C. Parsons, Jack Capp, Martin Acosta Cruz, Malcolm Coulter, Ian Davidson, Loney Dickson, Naomi Edelson, Richard Elliot, R. Michael Erwin, Scott Hatch, Stephen Kress, Robert Milko, Steve Miller, Kyra Mills, Richard Paul, Roberto Phillips, Jorge E. Saliva, Bill Sydeman, John Trapp, Jennifer Wheeler, and Kent Wohl. 2002. Waterbird Conservation for the Americas: The North American Waterbird Conservation Plan, Version 1. Waterbird Conservation for the Americas, Washington, D.C. U.S.A., $78 \mathrm{pp}$.

U.S. Fish and Wildlife Service. 1990. Recovery plan for the interior population of the least tern (Sterna Antillarum). Twin Cities, Minnesota. 90 pp.

\section{Citations}

Burger, J. and M. Gochfeld. 1990. Nest site selection in least terns (Sterna Antillarum) in New Jersey and New York. Colonial Waterbirds 13:31-40.

Christopherson, D.M., Prellwitz, D. M., and M.J. Rabenberg. 1992. Status of Piping Plovers and Least Tern in Montana.

Erickson, K. and Prellwitz, D.M. 1999. Piping Plover surveys for Nelson Reservoir, Bowdoin NWR and Hewitt Lake NWR.

Figg, D. E. 1993. Missouri Department of Conservation wildlife diversity report, July 1992-June 1993. $75 \mathrm{pp}$.

Grover, P. B. and F. L. Knopf. 1982. Habitat requirements and breeding success of charadriiform birds nesting at Salt Plains National Wildlife Refuge, Oklahoma. J. Field Ornithol. 53:139-148. 


\section{DRAFT WORKING DOCUMENT DO NOT DUPLICATE}

8698 Montana Bird Distribution Committee. 1996. Skaar's Montana Bird Distribution, 8699 Fifth Edition. Special Publication No. 3. Montana Natural Heritage Program, 8700 Helena. 130 pp.

8701

8702

Montana Bird Distribution Online Database. 2003. Helena, Montana, USA. April-

8703 September 2003. http://nhp.nris.state.mt.us/mbd/.

8704

8705

8706

8707

8708

8709

8710

8711

8712

8713

8714

8715

8716

8717

8718

8719

Montana Department of Fish, Wildlife \& Parks. 2003. Online information search on Least Tern in Montana.

http//www.fwp.state.mt.us/wildthings/t\&e/threatened.asp (Accessed: May 19, 2003)

8720

8721

8722

8723

Montana Piping Plover Recovery Committee. 1994. 1993 Surveys for Piping

Plover (CHARADRIUS MELODUS) and Least Tern (STERNA ANTILLARUM) in Montana. Unpublished report. 116 pp. plus appendices.

8724

Pavelka, Greg. 2003. Threatened and Endangered Species Specialist. U.S. Army Corps of Engineers, Operations Division, Omaha District, Gavings Pt.

Project Office. Personal communication regarding recent river censuses of Least Terns in Montana. 12 August 2003.

8725

Schulenberg, J. and M. Ptacek. 1984. Status of the interior least tern in Kansas.

Am. Birds 38:975-981.

Zickefoose, J. 1985. Least tern/piping plover recovery program. Final report to The Nature Conservancy, Connecticut Chapter. 22 pp. 


\section{DRAFT WORKING DOCUMENT DO NOT DUPLICATE}

8725

8726

8727

8728

8729

8730

8731

8732

8733

8734

8735

8736

8737

8738

8739

8740

8741

8742

8743

8744

8745

8746

8747

8748

8749

8750

8751

8752

8753

8754

8755

\section{Black Tern (Chlidonias niger)}

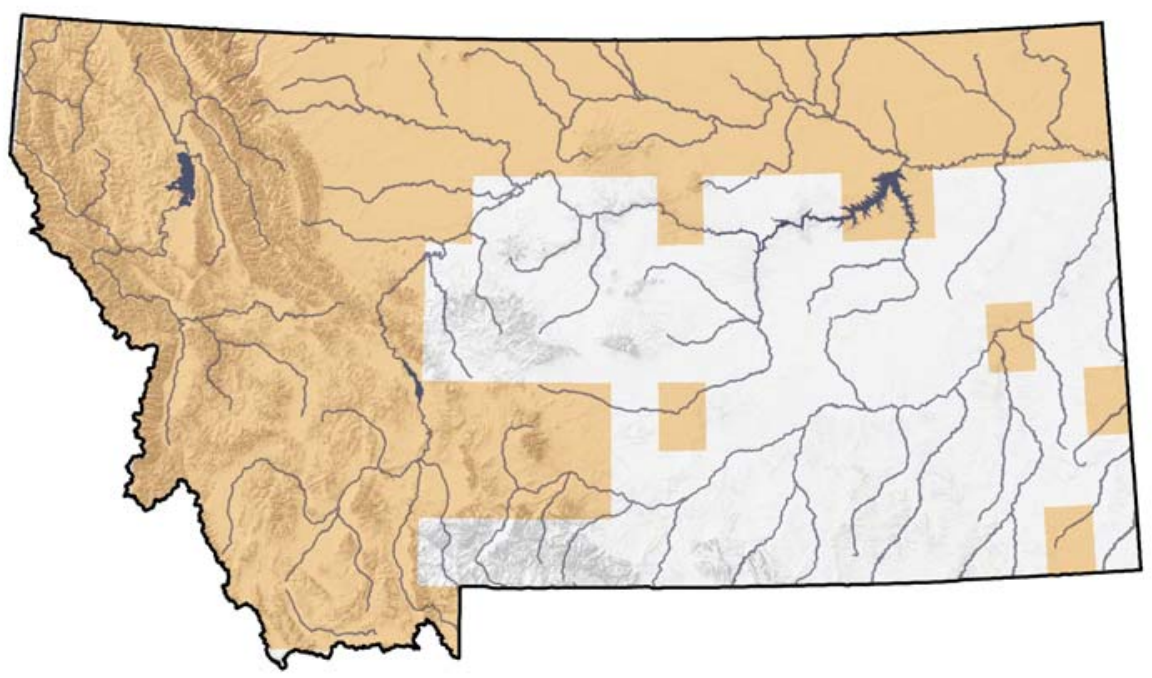

Figure 64. Distribution of the Black Tern

\section{Range}

Black Terns have been documented breeding in 12 Montana counties; most located in the northern half of the state. From east to west they include Sheridan, Phillips, Blaine, Cascade, Teton, Ponderosa, Glacier, Powell, Flathead, and Lake counties. Breeding records also exist for Beaverhead County in southwest Montana and Carter County in the southeast corner of the state.

\section{Unconfirmed breeding has also been recorded in at least five more counties} (Montana Bird Distribution 2003, MTNHP 2003). Even though breeding Black Tern colonies are located throughout many areas of Montana, this apparent wide-ranging distribution is misleading. Black Terns are limited to breeding locations with appropriate habitat, size and vegetative composition. These limitations likely account for their widely scattered distribution. Black Terns can nest wherever appropriate habitat exists, but appropriate habitat in Montana is patchy at best.

Little information is known about Black Tern migratory patterns in Montana. They are more likely to move north from wintering locations through the interior of the U.S. (Dunn and Argo 1995), so early sightings should occur in southern portions of the state. Migrating Black Terns have been observed just north of Dillon as early as April. However, the majority of spring migration observations have been in May and June. Black Terns have been observed in transit in July and August albeit fewer observations, probably due to peak breeding. The latest recorded observation was in September near Medicine Lake National Wildlife Refuge in Sheridan County (Montana Bird Distribution 2003). Migration in fall is less 


\section{DRAFT WORKING DOCUMENT DO NOT DUPLICATE}

8756

8757

8758

8759

8760

8761

8762

8763

8764

8765

8766

8767

8768

8769

8770

8771

8772

8773

8774

8775

8776

8777

8778

8779

8780

8781

8782

8783

8784

8785

8786

8787

8788

8789

8790

8791

8792

8793

8794

8795

8796

8797

8798

8799

8800

8801

concentrated through the interior of the country as birds also move to coastal areas (Dunn and Argo 1995).

\section{Habitat}

Black Tern breeding habitat in Montana is mostly wetlands, marshes, prairie potholes, and small ponds. However, several locations are on man-made islands or islands in man-made reservoirs. Across all Montana sites where Black Terns are present, approximately $30 \%-50 \%$ of the wetland complex is emergent vegetation. Vegetation within known breeding colonies includes alkali bulrushes, canary reed-grass, cattail spp., sedge spp., rush spp., reed spp., grass spp., Polygonum spp., Juncus spp. and Potamogeton spp., indicating a wide variety of potential habitats are usable by Black Terns. Water levels in known breeding localities range from about $0.5 \mathrm{~m}$ to greater than $2.0 \mathrm{~m}$ with most having depths between $0.5 \mathrm{~m}$ and $1.0 \mathrm{~m}$ (MTNHP 2003).

\section{Management}

Active management for Black Terns in Montana is currently limited to continued population monitoring and water level fluctuation control. Several Black Tern colonies are under federal or state control and monitoring of the population at those locations is completed annually. This monitoring can range from basic observation counts to nest location surveys. At some sites, federal or state agencies also monitor and regulate water levels during the breeding season for Black Terns, as well as other wetland species and waterfowl. Both population monitoring at perennial breeding locations and water level regulation should be continued on an annual basis and be expanded to other locations where Black Terns breed in the state.

\section{Conservation Concerns}

- Loss or degradation of wetlands for breeding and migration

- Pesticide reduction of favored insect foods

- Human disturbance in nesting colonies

- Lack of information

\section{Conservation Strategies}

- Implement a public education and sighting program, similar to the program for Common Loon nesting sites

- Undertake continued management actions at waterfowl management areas to reduce salinity and selenium concentrations

- Reduce nutrient loading from runoff at known Black Tern nesting sites

- Incorporate Black Tern habitats (known and potential) into any wetland restoration programs

- Continue monitoring at breeding locations 
8802

8803

8804

8805

8806

8807

8808 James A. Kushlan, Melanie J. Steinkamp, Katherine C. Parsons, Jack Capp,

8809

8810

8811

8812

8813

8814

8815

8816

8817

8818

8819

8820

8821

8822

8823

8824

8825

8826

8827

8828

8829

\section{Management Plans}

Casey, D. 2000. Partners in Flight Bird Conservation Plan Montana Version 1.0. Montana Partners in Flight. Kalispell, Montana. Edelson, Richard Elliot, R. Michael Erwin, Scott Hatch, Stephen Kress, Robert Milko, Steve Miller, Kyra Mills, Richard Paul, Roberto Phillips, Jorge E. Saliva, Bill Sydeman, John Trapp, Jennifer Wheeler, and Kent Wohl. 2002. Waterbird Conservation for the Americas: The North American Waterbird Conservation Plan, Version 1. Waterbird Conservation for the Americas, Washington, D.C. U.S.A., 78 pp.

\section{Citations}

Dunn, E. H. and D. J. Agro. 1995. Black Tern (CHLIDONIAS NIGER). In: A. Poole and F. Gill, (eds.), The Birds of North America, No. 147. Philadelphia: The Academy of Natural Sciences; Washington D.C.: The American Ornithologists Union. 24 pp.

Montana Bird Distribution Online Database. 2001. Helena, Montana, USA. AprilSeptember 2003. http://nhp.nris.state.mt.us/mbd/.

Montana Natural Heritage Program (MTNHP): Biological and Conservation Database. 2003. Helena, MT. (Accessed: March 20, 2003) 


\section{DRAFT WORKING DOCUMENT DO NOT DUPLICATE}

8829

8830

\section{Flammulated Owl (Bufo boreas)}

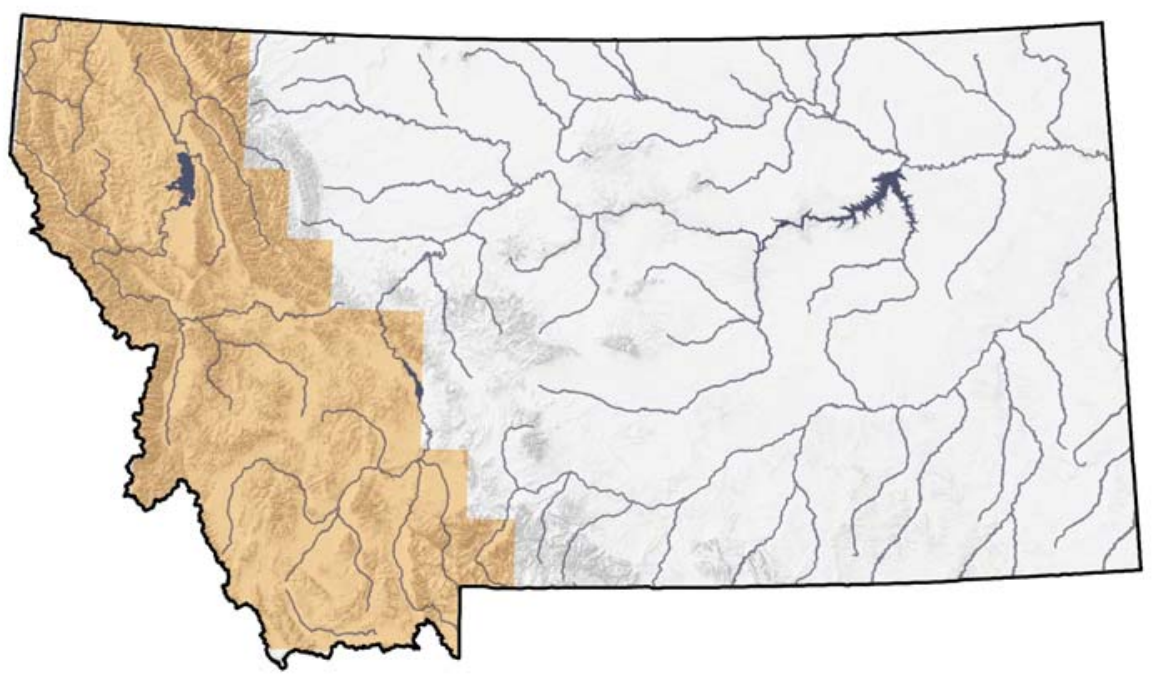

8831

8832

8833

8834

8835

8836

8837

8838

8839

8840

8841

8842

8843

8844

8845

8846

8847

8848

8849

8850

8851

8852

8853

8854

8855

8856

8857

8858

8859

8860
Figure 65. Distribution of the Flamulated Owl

\section{Range}

The range of Flammulated Owls in Montana is restricted to the western portion of the state, which includes areas east of the continental divide. Montana Bird Distribution notes eight observation records since 1996, with confirmed breeding in the Bitterroot Valley (Lenard et al. 2003). Additional breeding occurrences are confirmed in the Helena, Missoula, and Bozeman areas (Montana Bird Distribution online database 2001). Other areas of suspected breeding occur throughout western Montana. Low elevation, old growth ponderosa pine are especially important for flamulated owls.

\section{Habitat}

Information on breeding habitat in Montana is limited to one study in the Bitterroot Valley (Wright 2000). In Montana, Flammulated Owls are associated with mature and old-growth xeric ponderosa pine/Douglas-fir stands (Holt and Hillis 1987, Wright et al. 1997) and in landscapes with higher proportions of suitable forest and forest with low to moderate canopy closure (Wright et al. 1997). They are absent from warm and humid pine forests and mesic ponderosa pine/Douglas-fir (McCallum 1994a, Wright et al. 1997). Information gathered from other studies throughout their range suggest the breeding habitat of Flammulated Owls is montane forest; usually open conifer forests containing pine, with some brush or saplings (typical of the physiognomy of pre-European settlement ponderosa pine forests). The species shows a strong preference for ponderosa pine (Pinus ponderosa) and Jeffrey pine ( $P$. jeffreyi) throughout its range (McCallum 1994b). They prefer mature growth with open canopy avoiding dense young stands. Flammulated Owls are found in a cooler, semi-arid climate, with a 


\section{DRAFT WORKING DOCUMENT DO NOT DUPLICATE}

8861 high abundance of nocturnal arthropod prey and some dense foliage for roosting 8862 (McCallum 1994a). Most often they are found on ridges and upper slopes (Bull et 8863 al. 1990, Groves et al. 1997).

8864

8865

8866

In British Columbia, Flammulated Owls use dry interior Douglas-fir (Pseudotsuga

8867

8868

8869

8870 menziesii) where ponderosa pine may be a co-dominant, but pure ponderosa pine is avoided. Also sometimes they are in pure aspen and, locally, in spruce (Picea sp.)/Douglas-fir and lodgepole pine (Pinus contorta)/Douglas-fir. They prefer forests dominated by trees more than 100 years old. The highest densities are found in 140 year-old to more than 200 year-old forests; owls were restricted

8871 to forests with multi-layered canopies with an abundance of large, well-spaced

8872 trees interspersed with grassy openings up to 2 hectares in size, and where cavity-bearing snags were "moderately common" (Howie and Ritcey 1987, van

8874

8875 Woudenberg 1999). A study in the Kamloops area testing a habitat model in

8876 Douglas-fir/ponderosa pine found three variables to be significant predictors for

8877 occupied habitat: elevation (between 850 and 1,150 meters), age class (older

8878

8879

8880 stands), and canopy closure (40 to 50 percent) (Christie and van Woudenberg 1997).

8881

8882

In Idaho, they are found mostly in mature stands of ponderosa pine, Douglas-fir, or mixtures of the two with relatively open canopies (Atkinson and Atkinson

8883

8884 1990), occasionally in stands of pure Douglas-fir or aspen where ponderosa pine is absent. Sixty-five percent of detections were on upper slopes or ridges. Tree densities were approximately 500 per hectare and the mean DBH (diameter at

8885 breast height) for all trees was 32 centimeters (Groves et al. 1997). One nest

8886 cavity, excavated by a Northern Flicker, was in a 6.5 meter tall, $34 \mathrm{~cm} \mathrm{dbh}$, Douglas-fir snag (Atkinson and Atkinson 1990). In northeast Oregon, nest trees were located in stands of old-growth ponderosa pine or mixed conifers near small 8889 8890 clearings (Bull and Anderson 1978). In Colorado, they show strong preference for

8891 8892 8893 8894 old-growth ponderosa pine and Douglas-fir, using older trees for foraging and singing (Reynolds and Linkhart 1992, Linkhart and Reynolds 1997).

8895

8896 8897 8898 8899 Territories consistently occupied by breeding pairs were those containing the largest portion (more than 75 percent) of old-growth (200 to 400 years), whereas territories occupied by unpaired males and rarely by breeding pairs contained 27 to 68 percent old-growth (Linkhart and Reynolds 1997). Aspen (Populus tremuloides) is often a component of nesting habitat in Colorado and Nevada (Reynolds and Linkhart 1987b, McCallum 1994b). In northern Utah, the species 8900 8901 8902 8903 8904 8905 has successfully nested in nest boxes in montane deciduous forests dominated by aspen with some scattered firs (Marti 1997).

8906

Flammulated Owls prefer to forage in yellow pine and/or Douglas-fir, and these forest types apparently support a particular abundance of favored lepidopteron prey (McCallum 1994b). In Oregon, they forage in ponderosa pine and Douglasfir types with low to medium stem density, but show particular preference for forest/grassland ecotones (Goggans 1986, cited in McCallum 1994b). In 


\section{DRAFT WORKING DOCUMENT DO NOT DUPLICATE}

8907 Colorado, they preferred to forage in old-growth (more than 200 years), which

8908 was related both to an abundance of lepidopteron prey and to the open crowns 8909 and park-like spacing of trees which allowed greater room to maneuver for the 8910

8911 owls (Reynolds et al. 1989). The species may focus foraging in a few "intensive foraging areas" within the home range, averaging 1 hectare per range (Linkhart 1984, cited in McCallum 1994b).

8914

8915

8916

Flammulated Owls roost in dense vegetation and thickets that provide shade and protection from predators. They often roost close to trunks in fir or pine trees, or

8917 in cavities (McCallum 1994b, USDA Forest Service 1994). In Oregon, they use

8918 mixed coniferous forest rather than pure ponderosa pine (Goggans 1986, cited in

8919

8920

8921 McCallum 1994a). In Colorado, large Douglas-firs or pines with a spreading form are used (Linkhart 1984, cited in McCallum 1994a). They roost close to nests (20 to 25 meters) during the nestling stage and just before fledging, and farther away

8922

8923

8924

8925

8926 before and after (McCallum 1994a). In British Columbia, Flammulated Owls roosted in regenerating thickets of Douglas-fir (Howie and Ritcey 1987).

Migration habitat is in wooded and open areas in lowlands and mountains, including riparian areas and breeding habitat (McCallum 1994a).

8927

McCallum (1994a) and Hayward and Verner (1994) provide substantive reviews of flammulated owl habitat, behavior, and general ecology. Breeding habitat is

8928

8929

8930 primarily ponderosa pine or forest with similar characteristics, e.g., dry montane coniferous forest or aspen forests, with brushy understory or open grasslands nearby. The preferred breeding habitat hosts a high diversity or abundance of

8931

8932

8933

8934

8935

8936

8937 nocturnal arthropods (primaryly insects). Prey availability appears to be the primary factor for migration and patterns in migration and winter habitat requirements are poorly known.

Atkinson and Atkinson (1990) report territorial owls preferred relatively open, multistoried Douglas-fir, ponderosa and mixed conifer stands with some mature trees present. Territories often were near relatively open areas, natural openings, clearcuts, old burns, or grassy hillsides. Wright (1996) in the Bitterroot and Sapphire Mountains in west central Montana found flammulated owls in the

8941

8942

8943

8944

8945

8946

8947

8948

8949 breeding season related to the presence of snags and large trees near a nest area, openings at the territory scale, and the presence of low or moderate canopy closure in stands of ponderosa pine or Douglas-fir with a mosaic of grass/shrubs and forest edge.

\section{Management}

No specific management activities for Flammulated Owls are currently occurring in Montana, however, management for old-growth ponderosa pine habitats is ongoing by a number of land management agencies. Management for the 8950 8951 primarytenance of this habitat type will be beneficial for Flammulated Owls in Montana.

8952 


\section{DRAFT WORKING DOCUMENT DO NOT DUPLICATE}

8953

8954

8955

8956

8957

8958

8959

8960

8961

8962

8963

8964

8965

8966

8967

8968

8969

8970

8971

8972

8973

8974

8975

8976

8977

8978

8979

8980

8981

8982

8983

8984

8985

8986

8987

8988

8989

8990

8991

8992

8993

8994

8995

8996

8997

8998

\section{Conservation Concerns}

- Loss of old-growth forests

- Inadequate monitoring efforts

- Found in cluster distributions so that one catastrophic event could lead to loss of population

- Fire suppression

- Use of herbicides or insecticides near nests

\section{Conservation Strategies}

- Conservation of old-growth forests

- Continue monitoring efforts

- Habitat management geared toward the restoration of pre-European settlement habitat structure

- Evaluate the quality and quantity of suitable but unoccupied habitat or habitat that would be suitable with restoration

- Do not use insecticides near nest sites

- Consider use of prescribed fire near mature forest stands to reduce understory stocking and enhance the shrub component

\section{Management Plans}

Casey, D. 2000. Partners in Flight Bird Conservation Plan Montana Version 1.0. Montana Partners in Flight. Kalispell, Montana.

Rich, T.D., C.J. Beardmore, H. Berlanga, P.J. Blancher, M. S. W. Bradstreet, G. S. Butcher, D.W. Demarest, E. H. Dunn, W. C. Hunter, E. E. Inigo-Elias, J. A. Kennedy, A. M. Martell, A. O. Panjabi, D. N. Pashley, K. V. Rosenberg, C. M. Rustay, J. S. Wendt, T. C. Will. 2004. Partners in Flight North American Landbird Conservation Plan. Cornell Lab of Ornithology. Ithaca, NY.

\section{Citations}

Atkinson, E. C. and M. L. Atkinson. 1990. Distribution and status of Flammulated Owls (OTUS FLAMMEOLUS) on the Salmon National Forest. Idaho Nat. Heritage Prog., Idaho Dept. Fish Game, Salmon Natl. Forest Unpublished report. 25 pp. plus appendices.

Bull, E. L. and R. G. Anderson. 1978. Notes on flammulated owls in northeastern Oregon. Murrelet 59:26-28.

Bull, E. L., A. L. Wright and M. G. Henjum. 1990. Nesting habitat of flammulated owls in Oregon. J. Raptor Res. 24:52-55. 


\section{DRAFT WORKING DOCUMENT DO NOT DUPLICATE}

8999 Christie, D. A. and A. M. van Woudenberg. 1997. Modeling critical habitat for

9000

9001

9002

9003

9004

9005

9006

9007

9008

9009

9010

9011

9012

9013

9014

9015

9016

9017

9018

9019

9020

9021

9022

9023

9024

9025

9026

9027

9028

9029

9030

9031

9032

9033

9034

9035

9036

9037

9038

9039

9040

9041

9042

9043

9044 flammulated owls (OTUS FLAMMEOLUS). Intermountain/foothill grassland 97106 in J. R Duncan, D. H. Johnson, and T. H. Nicholls, editors. Biology and conservation of owls in the Northern Hemisphere. USDA Forest Service.

Goggans, R. 1986. Habitat use by flammulated owls in northeastern Oregon. Masters thesis, Oregon State University, Corvallis, OR.

Groves, C., T. Frederick, G. Frederick, E. Atkinson, M. Atkinson, J. Shepard and G. Servheen. 1997. Density, distribution, and habitat of flammulated owls in Oregon. Great Basin Naturalist 57:116-123.

Hayward, G. D., and J. Verner. 1994. Flammulated, boreal, and great gray owls in the United States. General Technical Report RM-253, USDA Forest Service, Rocky Mountain Research Station, Fort Collins, Colorado, USA.

Holt, D. W. and J. M. Hillis. 1987. Current status and habitat associations of forest owls in western Montana. Pp 281-288 in: Biology and conservation of northern forest owls: symposium proceedings, Feb. 3-7, Winnipeg, Manitoba. Gen. Tech. Rep. RM-142. Fo

Howie, R.R. and R. Ritcey. 1987. Distribution, habitat selection, and densities of flammulated owls in British Columbia. Intermountain/foothill grassland 249-254 in: B87NER01.

Lenard, S., J. Carlson, J. Ellis, C. Jones, and C. Tilly. 2003. P. D. Skaar's Montana Bird Distribution, 6th Edition. Montana The Audubon Society, Helena, Montana. vi + $144 \mathrm{pp}$.

Linkhart, B. D. 1984. Range, activity, and habitat use by nesting flammulated owls in a Colorado ponderosa pine forest. Masters thesis, Colorado State University, Fort Collins, CO.

Linkhart, B. D. and R. T. Reynolds. 1997. Territories of flammulated owls (OTUS FLAMMEOLUS): is occupancy a measure of habitat quality? Intermountain/foothill grassland 150-154 in J.R. Duncan, D.H. Johnson, and T.H. Nicholls, editors. Biology and conservation of owls in the Northern.

Marti, C. 1997. Flammulated owls (OTUS FLAMMEOLUS) breeding in deciduous forests. Intermountain/foothill grassland 262-266 in J.R. Duncan, D.H. Johnson, and T.H. Nicholls, editors. Biology and conservation of owls in the Northern Hemisphere. USDA Forest Service General Technical Report.

McCallum, D. A. 1994a. Flammulated Owl (Otus flammeolus). In The Birds of North America, No. 93, (A. Poole and F. Gill, eds.). Philadelphia: The Academy of Natural Sciences; Washington D.C.: The American Ornithologists' Union. 24 p. 


\section{DRAFT WORKING DOCUMENT DO NOT DUPLICATE}

9045

9046

9047

9048

9049

9050

9051

9052

9053

9054

9055

9056

9057

9058

9059

9060

9061

9062

9063

9064

9065

9066

9067

9068

9069

9070

9071

9072

9073

9074

9075

9076

9077

9078

9079

9080

9081

9082

9083

9084

9085

9086

9087

9088

9089

9090
McCallum, D. A. 1994b. Review of technical knowledge: flammulated owls. Intermountain/foothill grassland 14-46 in G. D. Hayward and J. Verner, editors. Flammulated, boreal and great gray owls in the United States: a technical conservation assessment. USFS General Technical Report,

Montana Bird Distribution Online Database. 2001. Helena, Montana, USA. AprilSeptember 2003. http://nhp.nris.state.mt.us/mbd/.

Redmond, R. L., M. M. Hart, J. C. Winne, W. A. Williams, P. C. Thornton, Z. Ma, C. M. Tobalske, M. M. Thornton, K. P. McLaughlin, T. P. Tady, F. B. Fisher, and S. W. Running. 1998. The Montana Gap Analysis Project: Final Report.

Unpublished report. Montana Cooperative Wildlife Research Unit, University of Montana, Missoula, Montana, USA.

Reynolds, R. T. and B. D. Linkhart. 1987. The nesting biology of flammulated owls in Colorado. Pp. 239-248 in: Nero, R.W., et al., (eds). Biology and conservation of northern forest owls. USDA For. Serv., Gen. Tech. Rep. RM-142.

Reynolds, R. T. and B. D. Linkhart. 1992. Flammulated owls in Ponderosa pine: evidence of preference for old growth. IN: Kaufmann, M. R., W. H. Moir, and R. L. Bassett (tech. coord.), Old-growth forests in the Southwest and Rocky Mountain regions. USDA For. Serv. Gen. Tech. Rep. RM-213. 201 pp.

Reynolds, R. T., R. A. Ryder, and B. D. Linkhart. 1989. Small forest owls. Intermountain/foothill grassland 131-143 in National Wildlife Federation. Proceedings of the western raptor management symposium and workshop. National Wildlife Federation Scientific and Technical Series No.

USDA Forest Service (USFS). 1994. Neotropical Migratory Bird Reference Book. USDA Forest Service, Pacific Southwest Region. 832 pp.

USDA Forest Service. 2004. Draft Multiple Species Inventory and Monitoring Technical Guide. Ecotype Management Coordination. USDA Forest Service, Washington DC, USA.

Van Woudenberg, A. M. 1999. Status of the Flammulated Owl (OTUS FLAMMEOLUS) in British Columbia. Working Report No. 96, British Columbia Ministry of Environment, Lands, and Parks, Victoria, B.C. 45pp.

Wright, V. 1996. Multi-scale analysis of flammulated owl habitat use: owl distribution, habitat management, and conservation. Unpublished M. S. Thesis, University of Montana, Missoula, USA.

Wright, V., S. Hejl, and R.L. Hutto. 1997. Conservation implications of a multiscale study of flammulated owl (OTUS FLAMMEOLUS) habitat use in the 
9091 northern Rocky Mountains, USA. Intermountain/foothill grassland 506-516 in J. 9092 R. Duncan, D. H. Johnson, and T. H. Nicholls, editors. B

9093

9094 Wright, V. 2000. The Aldo Leopold Wilderness Research Institute: A National 9095 Wilderness Research Program in Support of Wilderness Management. In: 9096 McCool, Stephen F.; Cole, David N.; Borrie, William T.; O'Loughlin, Jennifer, 9097 comps. Wilderness Science in a Time of Change Conference Vol 3: Wilderness 9098 as a place for scientific inquiry; 1999 May 23-27; Missoula, MT. Proc. RMRS-P9099 15-VOL-3. Ogden, UT: Department of Agriculture, Forest Service, Rocky 9100 Mountain Research Station: 260-268.

9101

9102 


\section{DRAFT WORKING DOCUMENT DO NOT DUPLICATE}

\section{Burrowing Owl (Speotyto cunicularia)}

9104

9105

9106

9107

9108

9109

9110

9111

9112

9113

9114

9115

9116

9117

9118

9119

9120

9121

9122

9123

9124

9125

9126

9127

9128

9129

9130

9131

9132

9133

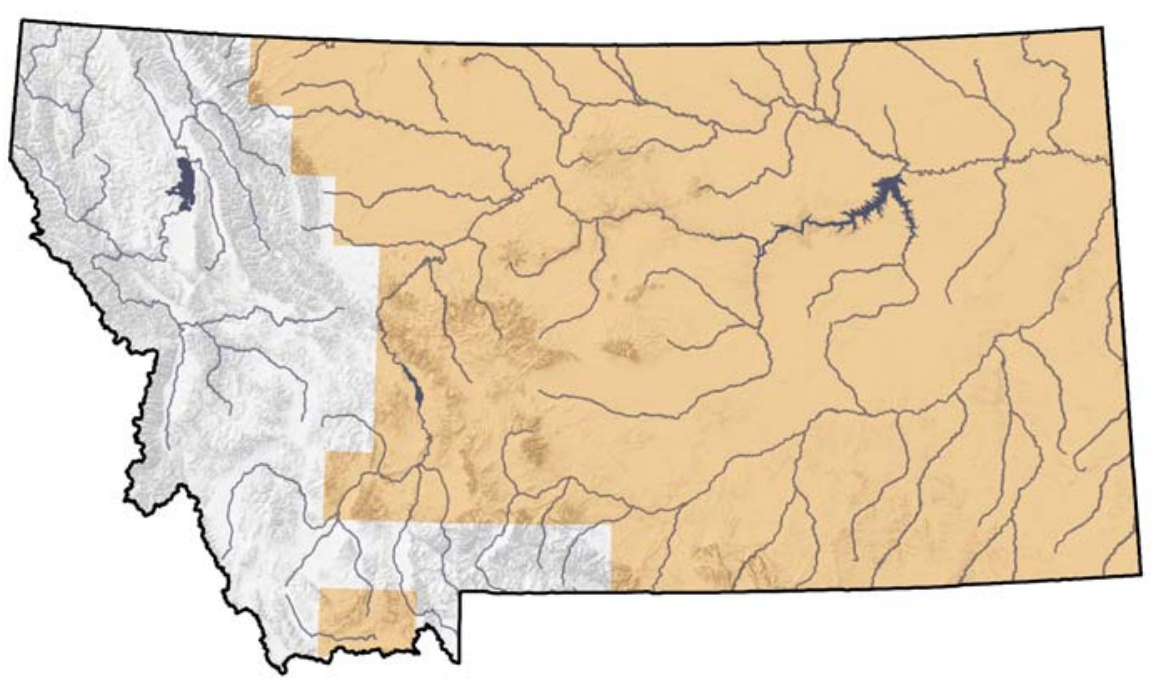

Figure 66. Distribution of the Burrowing Owl

\section{Range}

Burrowing Owls continue to be widely distributed in appropriate habitat east of the Continental Divide (Lenard et al. 2002).

\section{Habitat}

The Burrowing Owl breeds in open grasslands (Orth and Kennedy 2001) to savanna and in some areas of human habituation (e.g. airports, golf courses, road rights-of-way) (Jones and Bock 2002). Areas used for breeding are often associated with burrows created by small mammals (e.g., prairie dogs, badgers, yellow-bellied marmots, and others) (Haug et al. 1993).

Presence of burrows is a critical habitat requirement and are often found in in open grasslands, abandoned by mammals. In Montana, Black-tailed prairie dog (Cynomys ludoviscianus) and Richardson's ground squirrel (Spermophilus richardsonii) colonies provide the primary and secondary habitat for Burrowing Owls (Klute et al. 2003). The burrows may be enlarged or modified, making them more suitable. Burrowing Owls spend much time on the ground or on low perches such as fence posts or dirt mounds.

\section{Management}

Managers outside of Montana have tried conservation actions such as creating artificial burrows and perches for Burrowing Owls and regulation/protection of burrowing mammals. Successful approaches should be considered. 


\section{DRAFT WORKING DOCUMENT DO NOT DUPLICATE}

9134

9135

9136

9137

9138

9139

9140

9141

9142

9143

9144

9145

9146

9147

9148

9149

9150

9151

9152

9153

9154

9155

9156

9157

9158

9159

9160

9161

9162

9163

9164

9165

9166

9167

9168

9169

9170

9171

9172

9173

9174

9175

9176

9177

\section{Conservation Concerns}

- Elimination of burrowing mammals that provide critical habitat

- Habitat loss and fragmentation due to agricultural and urban development

- Petroleum exploration and development

- Residual effects of pesticide use

- Nest site disturbance

\section{Conservation Strategies}

- Conservation easements and other conservation practices that recover or protect native prairie grassland areas

- Continued monitoring and surveying of burrowing mammals

- Increased education and information to increase awareness of importance of nesting sites and reducing disturbance

\section{Management Plans}

Casey, D. 2000. Partners in Flight Bird Conservation Plan Montana Version 1.0. Montana Partners in Flight. Kalispell, Montana.

Klute, D. S., L.W. Ayers, M.T. Green, W.H. Howe, S.L. Jones, J.A. Shaffer, S.R. Sheffield, and T.S. Zimmerman. 2003. Status Assessment and Conservation Plan for the Western Burrowing Owl in the United States. U.S. Department of the Interior; Fish and Wildlife Service, Biological Technical Publication FWS/BTPR6001-2003, Washington, D.C.

\section{Citations}

Gervais, J. A., and R. G. Anthony. 2003. Chronic organochlorine contaminants, environmental variability, and demographics of a burrowing owl population.

Ecological Applications 13: 1250-1262.

Haug, E. A., B. A. Millsap, and M. S. Martell. 1993. In Birds of North America, No. 61, A. Poole and F. Gill, editors. Academy of Natural Science, Philadelphia, The American Ornithologist's Union, Washington, DC, USA.

Jones, Z. F., and C. E. Bock. 2002. Conservation of grassland birds in an urbanizing landscape: a historical perspective. Condor 104: 643-651.

Lenard, S., J. Carlson, J. Ellis, C. Jones, and C. Tilly. 2003. P. D. Skaar's Montana Bird Distribution, 6th Edition. Montana The Audubon Society, Helena, Montana. vi + $144 \mathrm{pp}$. 


\section{DRAFT WORKING DOCUMENT DO NOT DUPLICATE}

9178 Orth, P. B., and P. L. Kennedy. 2001. Do land-use patterns influence nest-site 9179 selection by burrowing owls (Athene cuncularia hypugaea) in northeastern 9180 Colorado. Canadian Journal of Zoology 79:1038-1045.

9181

9182 Todd, L. D., R. G. Poulin, T. I. Wellicome, and R. M. Brigham 2003. Post 9183 fledging survival of burrowing owls in Saskatchewan. Journal of Wildlife 9184 Management 67: 512-519.

9185

9186 


\section{DRAFT WORKING DOCUMENT DO NOT DUPLICATE}

9186

9187

9188

9189

9190

9191

9192

9193

9194

9195

9196

9197

9198

9199

9200

9201

9202

9203

9204

9205

9206

9207

9208

9209

9210

9211

9212

9213

9214

9215

9216

9217

\section{Black-backed Woodpecker (Picoides arcticus)}

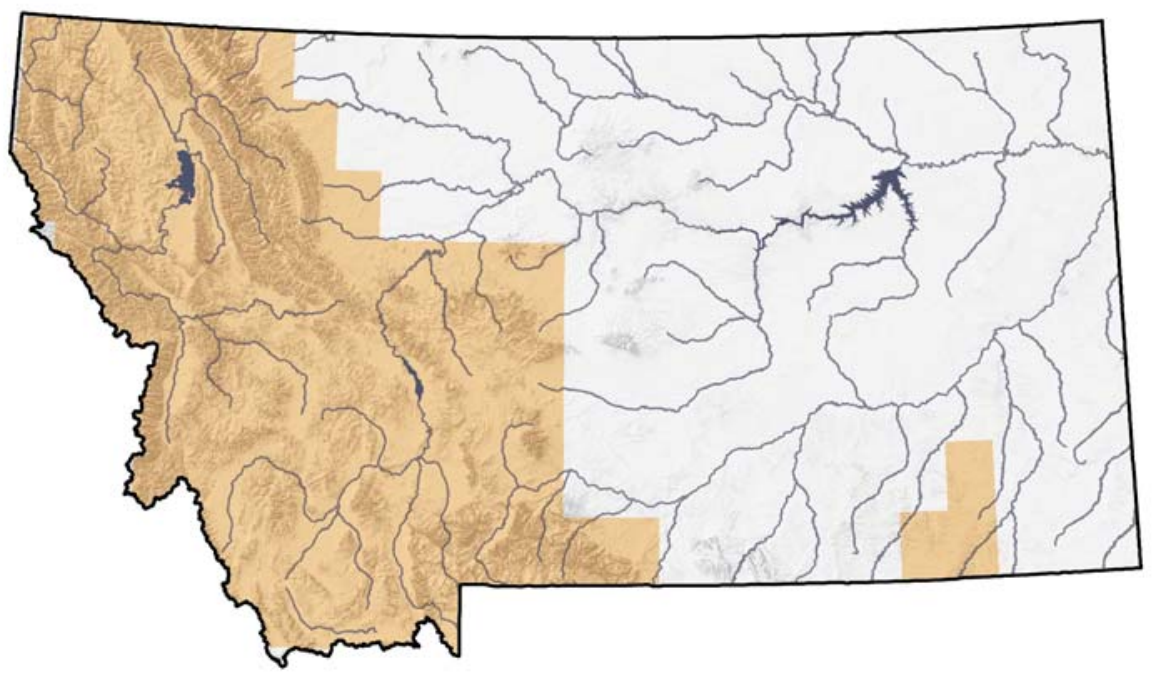

Figure 67. Distribution of the Black-backed Woodpecker

\section{Range}

The range of the Black-backed Woodpecker in Montana is primarily confined to the northwest portion of the state. The Montana Bird Distribution (2003) and The Montana Natural Heritage Program (2003) have approximately 16 confirmed breeding records for the species. Except for a single record from the southcentral area of the state (southern Park County), all the breeding records are located in northwestern counties (Lincoln, Sanders, Flathead, Missoula, Lewis and Clark, and Powell) (MBD 2003). Unconfirmed, but potential, breeding records also exist for Black-backed Woodpecker and would expand their range to most counties in the western part of the state, including areas in southwestern Montana, the Big and Little Belt Mountains area, and the Bridger Range (MBD 2003). Several unconfirmed breeding records also exist for a small area in southeast (Custer National Forest) Montana (MBD 2003).

The black-backed woodpecker (hereafter referred to as black-backed) breeds from central Alaska and northern Canada south to the mountainous regions of California, Wyoming, Black Hills, Upper Great Lakes and New England states, and into Newfoundland. Like most woodpeckers, they feed on insects living in dead or diseased trees, and hunt for wood boring insects by peeling patches of dead bark.

\section{Habitat}

The habitat of Black-backed Woodpeckers in Montana is early successional, burned forest of mixed conifer, lodgepole pine, Douglas-fir, and spruce-fir (Hutto 1995a, 1995b), although they are more numerous in lower elevation Douglas-fir 


\section{DRAFT WORKING DOCUMENT DO NOT DUPLICATE}

9218

9219

9220

9221

9222

9223

9224

9225

9226

9227

9228

9229

9230

9231

9232

9233

9234

9235

9236

9237

9238

9239

9240

9241

9242

9243

9244

9245

9246

9247

9248

9249

9250

9251

9252

9253

9254

9255

9256

9257

9258

9259

9260

9261

9262

9263 and pine forest habitats than in higher elevation subalpine spruce forest habitats (Bock and Bock 1974). This is supported by Harris (1982) who found Blackbacked Woodpeckers in two recently burned forests comprised of $73 \%$ and $77 \%$ Douglas-fir, respectively. They appear to concentrate in recently burned forests and remain for several years ( 3 to 5 ) before leaving due to prey source decline (Harris 1982). In northwestern Montana, Black-backed Woodpeckers nested in areas of western larch (Larix occidentalis) /Douglas-fir forest with a major component of old-growth (McClelland et al. 1979). Harris (1982) found Blackbacked Woodpeckers nesting within western larch even though the stand was predominately Douglas-fir. McClelland et al. (1979) determined the decay of heartwood while maintaining a hard outer shell of western larch creates an ideal nesting site for Black-backed Woodpeckers to excavate.

The black-back is thought to be sedentary, but irruptions in winter are known and associated with urban areas overcome with Dutch elm disease (Yunick 1985). Black-backed nests have been monitored in Idaho (burned ponderosa pine forests), Wyoming (burned lodgepole pine forests), Oregon (unburned mixed pine forest with bark-beetle outbreaks), and in Montana (patchily burned mixed conifer forests) (Dixon and Saab 2000). Bent (1939) found more than $75 \%$ of the black-back's diet was composed of cerambycids (flatheaded wood borers) and buprestids (round headed woodborers). It is believed the black-backed is able to more effectively extract wood-boring insect larva than other woodpeckers (Kirby 1980).

More detailed information of black-back nest sites, foraging and general behavior and ecology in the breeding season is found in recent published reviews (Dixon and Saab 2000) and in recent peer reviewed literature (Mclver and Starr 2001, Hoyt and Hannon 2002).

The value in long-term observations is evident in understanding wildlife habitat relationships (Sergio and Newton 2003). Information in the Montana Heritage Program (through May 2003), Idaho Data Conservation Center (through January 2003) show most black-back nests $(n=14)$ in Idaho are near (within $1000 \mathrm{~m}$ ) or within insect outbreaks. In Montana, nest site information is lacking but most observations are in or near insect outbreaks or recently burned areas $(n=$ being complied).

\section{Management}

No known active management is ongoing for Black-backed Woodpeckers in the state. However, studies from the western United States on the logging of post-fire trees indicated the negative impacts of this activity on Black-backed Woodpeckers (Kotliar et al. 2002). The conclusion reached was that this species rarely used even partially logged post-fire forests. Therefore, when salvage logging is planned, a delay of work for at least five years after the disturbance event is very important (Hutto 1995, Dixon and Saab 2000). This time delay is 


\section{DRAFT WORKING DOCUMENT DO NOT DUPLICATE}

9264 essential to provide habitat as the woodpecker's primary prey items (wood-boring 9265 beetles) become less abundant after this period (Caton 1996). Salvage

9266 operations should retain more than 104 to 123 snags per hectare (more than 42 9267 to 50 snags per acre) that are more than $23 \mathrm{~cm}$ diameter at breast height (dbh), 9268 more than 9 inches dbh (Dixon and Saab 2000, Wisdom et al. 2000).

\section{Conservation Concerns}

- Timber harvest

- Fire suppression

- Removal of fire-killed or insect-infested trees

- Conversion of mature and old-growth forests to young stands with few decayed trees

- Human disturbance near nest sites

\section{Conservation Strategies}

- Decrease fire suppression to allow natural occurrences in isolated areas

- Manage "salvage" logging techniques in order to promote sufficient snags

- Insure that fire, insects and wind are allowed to regularly disturb habitat throughout space and time

- Avoid human-related factors that may impact behavior

\section{Management Plan}

Casey, D. 2000. Partners in Flight Bird Conservation Plan Montana Version 1.0. Montana Partners in Flight. Kalispell, Montana.

\section{Citations}

Bent, A. C. 1939. Life histories of North American Woodpeckers. U. S. National Museum Bulletin 174, Washington DC, USA.

Bock, C. E. and J. H. Bock. 1974. On the geographical ecology and evolution of the three-toed woodpeckers, Picoides tridactylus and P. arcticus. Amer. Midl. Nat., 92(2): 397-405.

Caton, E. M. 1996. Cavity nesting birds in a post-fire habitat in northwestern Montana. Ph.D. dissertation, University of Montana, Missoula, MT.

Dixon, R. D., and V. A. Saab. 2000. Black-backed woodpecker (Picoides arcticus). In Birds of North America, No. 509. A. Poole, and F. Gill, editors. The Academy of Natural Sciences, Philadelphia, Pennsylvania, and The American Ornithologists' Union, Washington, DC. A. Poole and F. Gill, editors. The birds of North America Inc., Philadelphia, PA. 


\section{DRAFT WORKING DOCUMENT DO NOT DUPLICATE}

9310 Environment Canada. 1997. Sustaining Canada's Forests: Timber Harvesting.

9311

9312

9313

9314

9315

9316

9317

9318

9319

9320

9321

9322

9323

9324

9325

9326

9327

9328

9329

9330

9331

9332

9333

9334

9335

9336

9337

9338

9339

9340

9341

9342

9343

9344

9345

9346

9347

9348

9349

9350

9351

9352

9353

9354

9355
National Environmental Indicator Series, SOE Bulletin No. 95-4. Online.

Available: http://199.212.18.79/ind/English/Forest/Bulletin.

Goggans, R. 1989. Black-backed woodpecker. Pp. 88-89 in Clark, T. W., A. H. Harvey, R. D. Dorn, D. L. Genter, and C. Groves, editors. Rare, Sensitive and threatened species of the Greater Yellowstone Ecotype. Northern Rockies Conservation Cooperative.

Gurevitch, J., P. S. Curtis, and M. H. Jones. 2001. Meta-analysis in Ecology. Advances in Ecological Research 32: 200-241.

Harris, M. A. 1982. Habitat use among woodpeckers in forest burns. M.S. thesis. University of Montana, Missoula. 62 pp.

Hoffman, N.J. 1997. Distribution of Picoides woodpeckers in relation to habitat disturbance within the Yellowstone area. M.S. Thesis. Montana State University. Bozeman, MT. 74 pg.

Hoyt, J. S, and S. J. Hannon. 2002. Habitat associations of black-backed and three toed woodpeckers in the boreal forest of Alberta. Canadian Journal of Forest Research. 32: 1881-1888.

Hutto, R.L. 1995a. USFS Northern Region Songbird Monitoring Program: Distribution and habitat relationships. USDA Forest Service Northern Region internal report, Missoula, MT.

Hutto, R.L. 1995b. Composition of bird communities following stand-replacement fires in northern Rocky Mountain (U.S.A.) conifer forests. Conservation Biology 9:1041-1058.

Kirby, V. C. 1980. An adaptive modification in the ribs of woodpeckers and piculets (Picidae). Auk 97: 521-532.

Kotliar, N. B., S. Heil, R. L. Hutto, V. A. Saab, C. P. Melcher, M. E. McFadzen. 2002. Effects of fire and post-fire salvage logging on avian communities in conifer-dominated forests of the western United States. Studies in Avian Biology 25:49-64.

McClelland, B. R., S. S. Frissell, W. C. Fischer, and C. H. Halvorson. 1979. Habitat management for hole-nesting birds in forests of western larch and Douglas-fir. Journal of Forestry 77:480-483.

Mclver, J. D, and L. Starr, L. 2001. A literature review on the environmental effects of post fire. Western Journal of Applied Forestry 16: 159-168. 


\section{DRAFT WORKING DOCUMENT DO NOT DUPLICATE}

9356 Montana Bird Distribution Online Database. 2001. Helena, Montana, USA. April-

9357

9358

9359

9360

9361

9362

9363

9364

9365

9366

9367

9368

9369

9370

9371

9372

9373

9374

9375

9376

9377

9378

9379

9380

9381

9382

9383

9384

9385

9386

9387

9388

9389

9390
September 2003. http://nhp.nris.state.mt.us/mbd/.

Reed, J. M. 1995. Relative vulnerability to extirpation of montane breeding birds in the Great Basin. Great Basin Naturalist 55:342-351.

Sergio, I., and I. Newton 2003. Occupancy as a measure of territory quality. Journal of Animal Ecology 72: 857-865.

Stohlgren, T. J. 1998. Rocky Mountains. Pp. 473-504 in M. J. Mac, P. A. Opler, C. E. Puckett Haecker, and P. D. Doran. Status and Trends of the Nation's Biological Resources. USDI U.S. Geological Survey, Washington, D.C.

Taylor, A. R., and R. L. Knight. 2003. Wildlife responses to recreation and associated visitor perceptions. Ecological Applications 13: 951-963.

Thompson, I. D., H. A. Hogan, and W. A. Montevecchi. 1999. Avian communities of mature balsam forests in Newfoundland: age-dependence and implications for timber harvest. Condor 99: 311-323.

USDA Forest Service. 2004. Draft Multiple Species Inventory and Monitoring Technical Guide. Ecotype Management Coordination. USDA Forest Service, Washington DC, USA.

Wisdom, M. J., R. S. Holthausen, B. C. Wales, C. D. Hargis, V. A. Saab, D. C. Lee, W. J. Hann, T. D. Rich, M. M. Rowland, W. J. Murphy and M. R. Eames.

2000. Source habitats for terrestrial vertebrates of focus in the Interior Columbia Basin: broad-scale trends and management implications. Vols. 1-3. General Technical Report PNW-GTR-485. USDA Forest Service Pacific Northwest Research Station, Portland Oregon, USA.

Yunick, R. P. 1985. A review of recent irruptions of the black-backed woodpecker and three-toed woodpecker in eastern North America. Journal of Field Ornithology 56: 138-152. 
9392

9393

9394

9395

9396

9397

9398

9399

9400

9401

9402

9403

9404

9405

9406

9407

9408

9409

9410

9411

9412

9413

9414

9415

9416

9417

9418

9419

9420

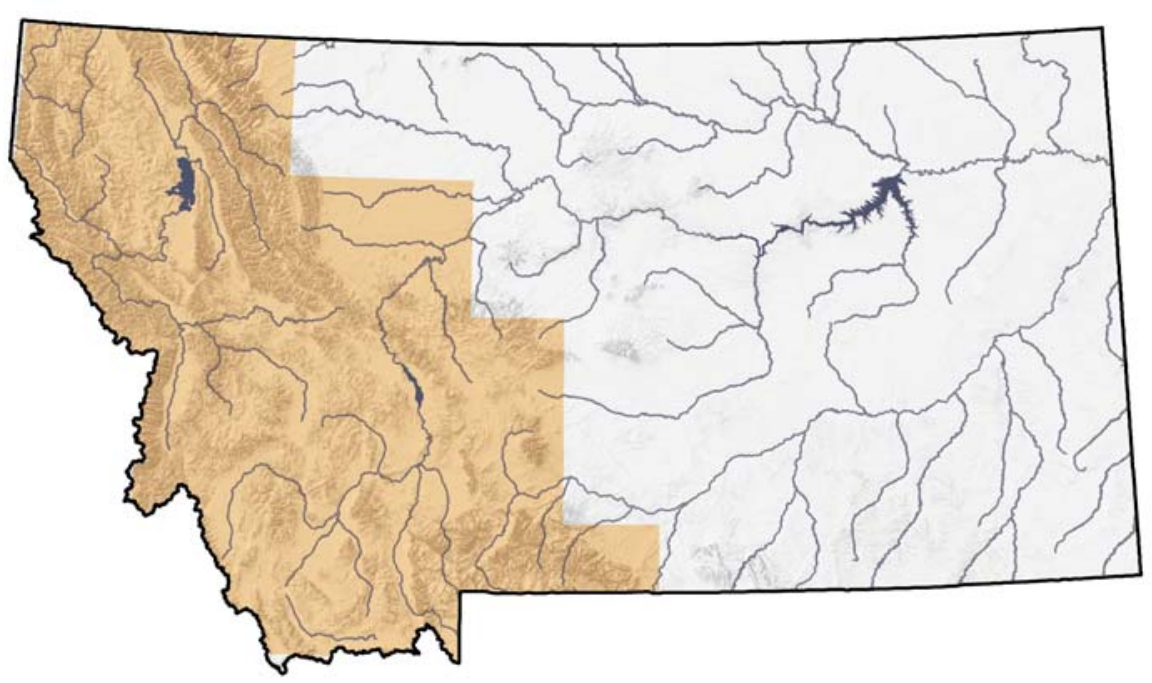

Figure 68. Distribution of the Olive-Sided Flycatcher

\section{Range}

The Olive-sided Flycatcher breeds throughout mountainous areas of the western portion of the state with unconfirmed reports of breeding in the central region of Montana (Casey 2000, Montana Bird Distribution 2003). The species' propensity for higher elevations, usually from 920 to 2130 meters, explains the transient nature of individuals reported at locations north and east of Billings (Montana Bird Distribution 2003).

\section{Habitat}

A species that generally breeds in the montane and boreal forests in the mountains of western North America, Olive-sided Flycatchers are highly adapted to the dynamics of a landscape frequently altered by fire. They are more often associated with post-fire habitat than any other major habitat type, but may also be found in other forest openings (clear cuts and other disturbed forested habitat), open forests with a low percentage of canopy cover, and forest edges near natural meadows, wetlands, or canyons (Hutto and Young 1999, Altman and Sallabanks 2000). Their affinity for forested edges near water may be a product of a higher presence of flying insects in these areas (Altman and Sallabanks 2000). They are a species common in spruce and aspen (Populus tremuloides), but are uncommon in mixed-conifer, ponderosa pine (Pinus ponderosa), pine-oak (Pinus-Quercus), and cedar-hemlock (CupressaceaeTsuga) forests, and rarely present in lodgepole pine (Pinus contorta) or pinyonjuniper (Hejl et. al. 1995 as cited in Casey 2000). 


\section{DRAFT WORKING DOCUMENT DO NOT DUPLICATE}

9421 Olive-sided flycatcher is a contrast species using a mosaic of coniferous old 9422 forests for nesting and either openings or gaps in old forests for foraging (Altman 9423 and Sallabanks 2000). Current habitat conditions are likely inferior in quantity

9424

9425

9426

9427

9428

9429

9430

9431

9432

9433

9434

9435

9436

9437

9438

9439

9440

9441

9442

9443

9444

9445

9446

9447

9448

9449

9450

9451

9452

9453

9454

9455

9456

9457

9458

9459

9460

9461

9462

9463 and quality to historic conditions because of changes in historic fire regimes, but the magnitude of the change is unknown (Wisdom et al. 2000). In unburned forests open-canopy over-story old forest conditions with high contrast early-seral edge habitat within and/or adjacent, and large snags provide for nesting and foraging needs. The species is the only common species detected more often at forest edges than in forest interiors.

The species forages on flying insects aerially from high, exposed perches atop tall trees or snags. Logging practices such as partial harvests, that retain these habitat structures while opening the forest canopy, creating more edge effects and retaining a mosaic of early to late seral habitat conditions appear to benefit the species (Altman and Sallabanks 2000, Casey 2000). Species use declines with the reestablishment of closed canopy forests. The use of fire as a management tool benefits this species, as frequent low intensity burns decrease canopy density. Population densities have been found to increase in habitats that have been opened up by fires. The retention of snags and large trees benefit the species by retaining important foraging and singing perches.

Concerns do exist that the dichotomy of increased habitat use of harvested forests and declining populations may indicate that harvested forest types may represent an "ecological" trap for the species.

\section{Management}

Management actions in Montana are currently limited by lack of conclusive information about the specific relationship between species' habitat use and reproductive success. It is unclear if stand replacing fire regimes or fires of less magnitude provide more appropriate habitat for successful reproduction (Casey 2000). In areas where fire suppression has reduced the heterogeneity of the forest, fire management techniques that promote a more historic pattern of disturbance would benefit the species (Casey 2000). Several other management techniques to benefit the species include retaining forested habitat around riparian and wetland habitats and retaining snags and large trees post-fire. Select logging practices that retain medium to large trees with a relatively open canopy closure may also provide appropriate habitat (Casey 2000). The Olive-sided Flycatcher is a Species of Management Concern in Region 6 (U.S. Fish and Wildlife Service 1995).

\section{Conservation Concerns}

- Fire suppression management

9464

9465

- Decreased of snags and large trees post fire

9466

- Conversion of forest to urban and residential areas 


\section{DRAFT WORKING DOCUMENT DO NOT DUPLICATE}

9467

9468

9469

9470

9471

9472

9473

9474

9475

9476

9477

9478

9479

9480

9481

9482

9483

9484

9485

9486

9487

9488

9489

9490

9491

9492

9493

9494

9495

9496

9497

9498

9499

9500

9501

9502

9503

9504

9505

9506

9507

9508

9509

9510

9511

9512

\section{Conservation Strategies}

- Selective logging practices

- Retain, maintain and/or restore stands of open-canopy mature and older ponderosa pine and cottonwood, and actively manage to promote their long-term sustainability

- Retention of forested edge habitat around riparian and wetland features

- Use prescribed fire, timber harvest and thinning to change forest composition and structure to restore old open forest conditions

- Identify occupied habitat and evaluate the quality and quantity of unoccupied habitat or habitat that would be suitable with restoration with fire or other action

\section{Management Plans}

Casey, D. 2000. Partners in Flight Bird Conservation Plan Montana Version 1.0. Montana Partners in Flight. Kalispell, Montana.

Rich, T.D., C.J. Beardmore, H. Berlanga, P.J. Blancher, M. S. W. Bradstreet, G. S. Butcher, D.W. Demarest, E. H. Dunn, W. C. Hunter, E. E. Inigo-Elias, J. A. Kennedy, A. M. Martell, A. O. Panjabi, D. N. Pashley, K. V. Rosenberg, C. M. Rustay, J. S. Wendt, T. C. Will. 2004. Partners in Flight North American Landbird Conservation Plan. Cornell Lab of Ornithology. Ithaca, NY.

\section{Citations}

Altman, B., and R. Sallabanks. 2000. Olive-sided Flycatcher (CONTOPUS COOPERI). No. 502 IN A. Poole and F. Gill (eds.), The birds of North America. The Birds of North America, Inc., Philadelphia, PA. 28pp.

Hejl, S.J., R.L. Hutto, C.R. Preston, and D.M. Finch. 1995. Effects of silvicultural treatments in the Rocky Mountains. Intermountain/foothill grassland 220-244 in T.E. Martin and D.M. Finch, editors. Ecology and management of neotropical migratory birds. Oxford University Press.

Hutto, R. L., and J. S. Young. 1999. Habitat relationships of land birds in the Northern Region, USDA Forest Service. General Technical Report RMRS-GTR32. USDA Forest Service, Rocky Mountain Research Station, Ogden, UT.

Montana Bird Distribution Online Database. 2001. Helena, Montana, USA. AprilSeptember 2003. http://nhp.nris.state.mt.us/mbd/.

Montana Online Animal Field Guide. 2004. (Accessed May 27, 2004; $<$ http://www.fwp.state.mt.us/fieldguide/help.aspx\#overview>). Montana Heritage Program and Montana Department of Fish, Wildlife \& Parks. Helena, Montana. 


\section{DRAFT WORKING DOCUMENT DO NOT DUPLICATE}

9513 USDA Forest Service. 2004. Draft Multiple Species Inventory and Monitoring 9514 (MSIM) Technical Guide. Ecotype Management Coordination, USDA Forest 9515 Service, Washington DC, USA.

9516 9517

U.S. Fish and Wildlife Service, Office of Migratory Bird Management. 1995. Migratory nongame birds of management concern in the United States: the 1995 list. U.S. Government Printing Office: 1996-404-911/44014. 22 pp.

Wisdom, M. J., R. S. Holthausen, B. C. Wales, C. D. Hargis, V. A. Saab, D. C. Lee, W. J. Hann, T. D. Rich, M. M. Rowland, W. J. Murphy and M. R. Eames. 2000. Source habitats for terrestrial vertebrates of focus in the Interior Columbia Basin: broad-scale trends and management implications. Vols. 1-3. General Technical Report PNW-GTR-485. USDA Forest Service Pacific Northwest Research Station, Portland Oregon, USA. 
9530

9531

9532

9533

9534

9535

9536

9537

9538

9539

9540

9541

9542

9543

9544

9545

9546

9547

9548

9549

9550

9551

9552

9553

9554

9555

9556

9557

9558

9559

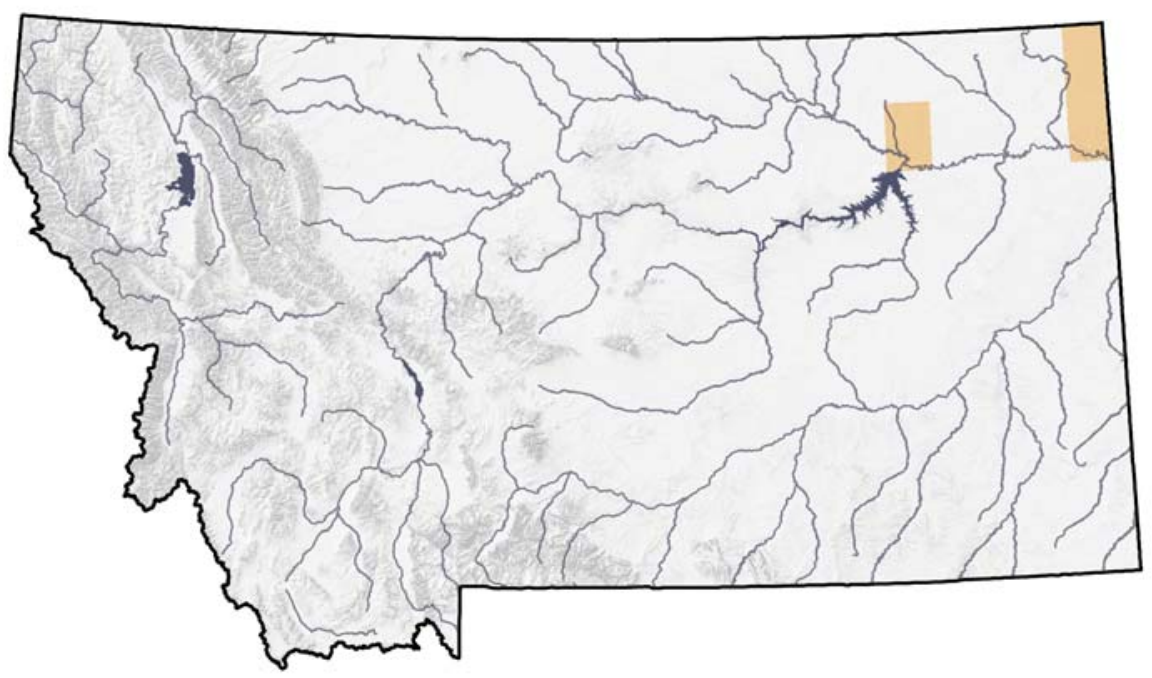

Figure 69. Distribution of the Sedge Wren

\section{Range}

The migratory pattern of this species in Montana is poorly known, and few records exist for the state. The earliest recorded date for Sedge Wren in Montana occurred in April 1909 in Gallatin County. Two recent records for Westby and Fort Peck indicate the presence of individuals in May (Montana Bird Distribution 2003).

\section{Habitat}

No specific information exists, but appropriate wetland habitat is present in the areas of the state in which the species has been recorded.

\section{Management}

No known active management is ongoing for Sedge Wren in the state. Sedge Wrens are a Species of Management Concern in USFWS Region 6 (U.S. Fish and Wildlife Service 1995).

\section{Conservation Concerns}

- Lack of information

- Human-directed disturbance to wetland habitats (i.e. disturbance can/does include impacts of cattle grazing, draining, vegetation manipulation, invasion of non-native plant and animal species, etc.)

\section{Conservation Strategies}


- Determine breeding status and identify breeding locations

- Increased survey, inventory, and monitoring projects

- Conservation/apply appropriate management of wetland habitats of known use by Sedge wrens

\section{Management Plan}

Casey, D. 2000. Partners in Flight Bird Conservation Plan Montana Version 1.0. Montana Partners in Flight. Kalispell, Montana.

9577

\section{Citations}

Montana Bird Distribution Online Database. 2001. Helena, Montana, USA. AprilSeptember 2003. http://nhp.nris.state.mt.us/mbd/

U.S. Fish and Wildlife Service, Office of Migratory Bird Management. 1995.

Migratory nongame birds of management concern in the United States: the 1995

9580 


\section{DRAFT WORKING DOCUMENT DO NOT DUPLICATE}

9580

9581

9582

9583

9584

9585

9586

9587

9588

9589

9590

9591

9592

9593

9594

9595

9596

9597

9598

9599

9600

9601

9602

9603

9604

9605

9606

9607

9608

9609

9610

\section{Nelson's Sharp-tailed Sparrow (Ammodramus nesloni)}

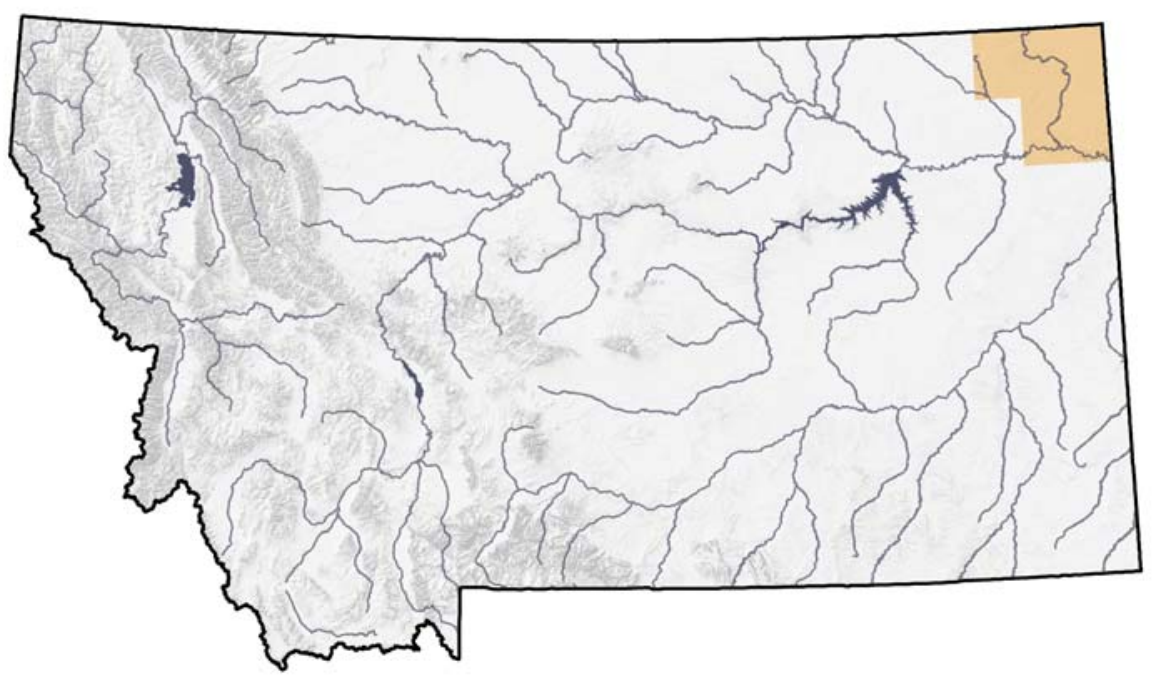

Figure 70. Distribution of the Nelson's Sharp-tailed Sparrow

\section{Range}

Nelson's Sharp-tailed Sparrow has an extremely limited range in Montana. The species has only been observed in eastern Sheridan and northeastern Roosevelt counties. About a dozen observations for this species have been made, and only a single breeding occurrence has been documented (Montana Bird Distribution 2003, MTNHP 2003).

\section{Habitat}

There is very little information about the habitat for this species in Montana, however it is assumed that the habitat is similar to that used in other portions of the species' range. This species prefers freshwater wetlands with dense, emergent vegetation or damp areas with dense grasses (Bownan 1904, Murray 1969, Stewart 1975, Krapu and Green 1978, Knapton 1979, Williams and Zimmer 1992, Berkey et al. 1993). In North Dakota, Nelson's Sharp-tailed Sparrows were common in prairie cordgrass (Spartina pectinata) stands, occurred at the edges of common reed (Phragmites australis) stands, and nested in sprangletop (Murray 1969). In northeastern North Dakota, they nested in thin, sparse grass on a wet alkali flat (Rolfe 1899, Hill 1968).

Nests usually are built in stands of grasses with litter that is persistent from year to year (Greenlaw 1993). Nests are built on or slightly above the ground in damp areas among emergent vegetation (Murray 1969, Stewart 1975). In North Dakota, Nelson's Sharp-tailed Sparrows are more abundant in dry years than in wet years (Stewart 1975). In dry years, they nest in the shallow-marsh and deep- 


\section{DRAFT WORKING DOCUMENT DO NOT DUPLICATE}

9611 marsh zones of wetlands. In wet years, they nest in cordgrass (Spartina spp.)

9612 within wet-meadow zones.

9613

9614

9615

9616

9617

\section{Management}

No known active management is ongoing for Nelson's Sharp-tailed Sparrows in the state. Conservation Reserve Program practices may provide large blocks of 9618 9619

9620

9621

9622

9623

9624

9625

9626

9627

9628

9629

9630

9631

9632

9633

9634

9635

9636

9637

9638

9639 suitable habitat for this species in northeastern Montana.

\section{Conservation Concerns}

- Not adequately monitored or understood

- Due to small occupied area, risk of extripation from state is high

- Wetland destruction

- Parisitism by Brown-headed Cowbird

\section{Conservation Strategies}

- Increased monitoring and survey efforts, especially breeding sites

- Protection of area where species is found

- Wetland restoration and protection

- Increased management of grazing regimes that promote healthy habitat

\section{Management Plans}

Casey, D. 2000. Partners in Flight Bird Conservation Plan Montana Version 1.0. Montana Partners in Flight. Kalispell, Montana.

Rich, T.D., C.J. Beardmore, H. Berlanga, P.J. Blancher, M. S. W. Bradstreet, G. 9640 S. Butcher, D.W. Demarest, E. H. Dunn, W. C. Hunter, E. E. Inigo-Elias, J. A. Kennedy, A. M. Martell, A. O. Panjabi, D. N. Pashley, K. V. Rosenberg, C. M. Rustay, J. S. Wendt, T. C. Will. 2004. Partners in Flight North American Landbird Conservation Plan. Cornell Lab of Ornithology. Ithaca, NY.

9651

9652

9653

\section{Citations}

Berkey, G., R. Crawford, S. Galipeau, D. Johnson, D. Lambeth, and R. Kreil. 1993. A review of wildlife management practices in North Dakota: effects on nongame bird populations and habitats. Report submitted to Region 6 . U. S. Fish and Wildlife Service, Denver. $51 \mathrm{p}$.

9654

Bownan, C.W. 1904. Nelson's Sharp-tailed Sparrow in North Dakota. Auk 21:385-386. 


\section{DRAFT WORKING DOCUMENT DO NOT DUPLICATE}

9655 Greenlaw, J. S. 1993. Behavioral and morphological diversification in sharp-tailed 9656 sparrows (AMMODRAMUS CAUDACUTUS) of the Atlantic coast. Auk 110:2869657303.

9658

9659

Hill, N.P. 1968. Nelson's Sharp-tailed Sparrow. Intermountain/foothill grassland 9660 815-819 in O.L. Austin, Jr., editor. Life histories of North American cardinals,

9661

9662 grosbeaks, buntings, towhees, finches, sparrows, and allies. Dover Publications

9663

9664

9665

9666

9667

9668

9669

9670 Inc., New York, NY.

9671

9672

9673

9674

9675

9676

Knapton, R.W. 1979. Birds of the Gainsborough-Lyleton region. Saskatchewan Natural History Society Special Publication 10. 72 pp.

Krapu, G.L., and R.K. Green. 1978. Breeding bird populations of selected semipermanent wetlands in south-central North Dakota. American Birds 32:110-112.

Montana Bird Distribution Online Database. 2001. Helena, Montana, USA. AprilSeptember 2003. http://nhp.nris.state.mt.us/mbd/.

Montana Natural Heritage Program (MTNHP): Biological and Conservation Database. 2003. Helena, MT. (Accessed: March 20, 2003)

9677

9678

9679

9680

9681

9682

9683

9684

9685

9686

9687

Murray, B.G., Jr. 1969. A comparative study of Le Conte's and Sharp-tailed sparrows. Auk 86:199-231.

Rolfe, E.S. 1899. Nesting of Nelson's Sparrow (AMMODRAMUS NELSONI) in North Dakota. Auk 16:356-357.

Stewart, R. E. 1975. Breeding birds of North Dakota. Tri-College Cent. for Env. Stud., Fargo. 295 pp.

9688

Williams, J.D., and M. Zimmer. 1992. First Sharp-tailed Sparrow South Dakota nesting record. South Dakota Bird Notes 44:84-85. 


\section{DRAFT WORKING DOCUMENT DO NOT DUPLICATE}

9688

9689

9690

9691

9692

9693

9694

9695

9696

9697

9698

9699

9700

9701

9702

9703

9704

9705

9706

9707

9708

9709

9710

9711

9712

9713

9714

9715

9716

9717

9718

9719

\section{Mammals}

\section{Spotted Bat (Euderma maculatum)}

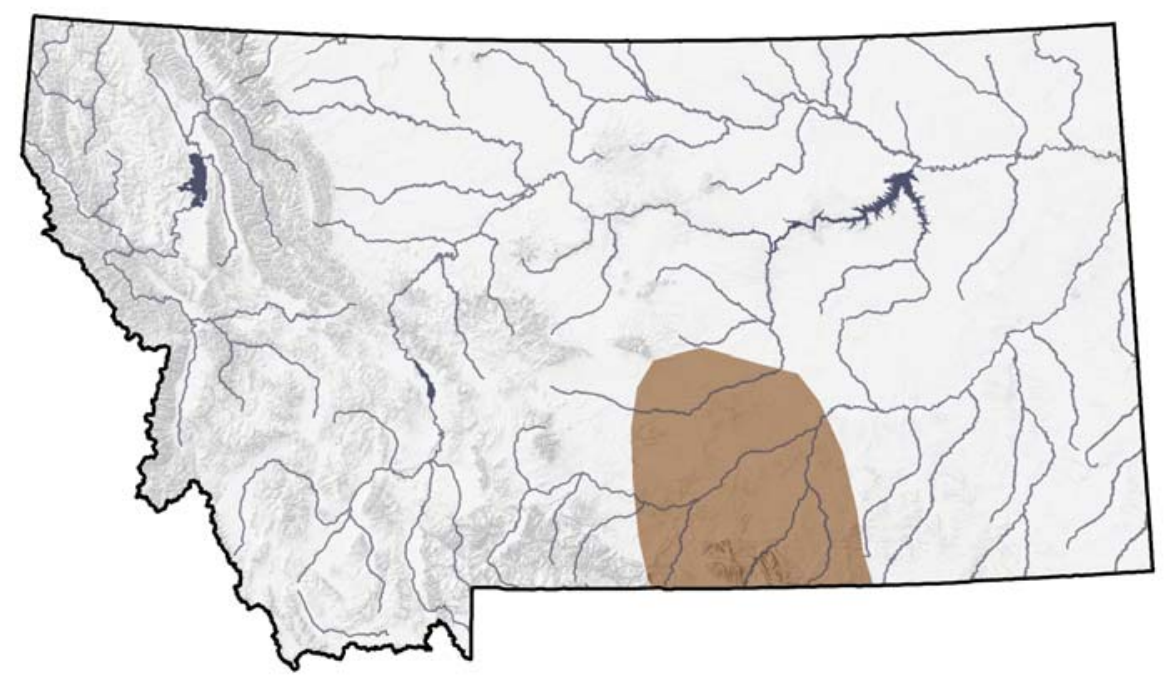

Figure 71. Distribution of the Spotted Bat

\section{Range}

The full extent of the range in Montana is unknown, due to limited survey effort and less than two-dozen reported encounters, and these mostly from Carbon County. Spotted bats appear to be restricted to areas east of the Continental Divide in south-central Montana. Voucher specimens exist for Carbon and Yellowstone counties, and there are reports from Big Horn and Powder River counties, all dating from 1949 to 1990 (Nicholson 1950, Fenton et al. 1987, Worthington 1991a, 1991b, Foresman 2001); there are recent observations from additional localities in Carbon County (Hendricks and Carlson 2001). Spotted bats in Montana have been encountered at elevations ranging from 3124 to 7800 feet (952-2377 meters).

\section{Habitat}

Spotted bats have been encountered or detected often in open arid habitats in close proximity to tall cliffs. Outside Montana these areas are sometimes dominated by Utah juniper (Juniperus osteosperma) and sagebrush (Artemisia tridentata and $A$. nova), sometimes intermixed with limber pine or Douglas-fir, or in grassy meadows in ponderosa pine savannah (Fenton et al. 1987, Worthington 1991b, Hendricks and Carlson 2001). In Montana, these areas are sometimes dominated by Rocky Mountain juniper (juniperus scopulorum). Cliffs, rocky outcrops, and water are other attributes of sites where spotted bats have been found (Foresman 2001), typical for the global range. Spotted bat has been captured foraging over an isolated pond within a few kilometers of huge 


\section{DRAFT WORKING DOCUMENT DO NOT DUPLICATE}

9720 limestone escarpments in the Big Horn Canyon National Recreation Area,

9721 Carbon County (Worthington 1991a, 1991b), and the first record for the state was

9722 of an individual that flew in an open window at a private residence in Billings,

9723 Yellowstone County (Nicholson 1950). They have been heard along the Missouri

9724 River at several locations in the Wild and Scenic section (DuBois 2005 per.com.).

9725 Spotted bats are now know to be fairly widespread, but quite sparse in

9726 population, adding to the difficulty of detection (DuBois 2005 per. com.). Factors

9727 that limit their distribution are not understood and roost habitats and sites have

9728 not been documented in Montana.

9729

9730

9731

In other areas, spotted bats have been detected at water sources and in meadow

9732

9733

9734

9735

9736

9737

9738

9739

9740

9741

9742

9743

9744

9745

9746

9747

9748

9749

9750

9751

9752

9753

9754

9755

9756

9757

9758

9759 openings, often with large cliffs nearby (Leonard and Fenton 1983, Storz 1995,

Perry et al. 1997, Rabe et al. 1998, Gitzen et al. 2001).

Spotted bats roost in caves, and in cracks and crevices in cliffs and canyons, with which this species is consistently associated; it can crawl with ease on both horizontal and vertical surfaces (Snow 1974, Van Zyll de Jong 1985). In British Columbia, individuals used the same roost each night during May through July, but not after early August (Wai-Ping and Fenton 1989). Winter habitat is poorly documented. A possible explanation for the early paucity of collections in natural situations is the bat's narrow habitat tolerance (Handley 1959, Snow 1974).

\section{Management}

Spotted bats have persisted for over 50 years in the general area of the state where they were first discovered (Nicholson 1950, Hendricks and Carlson 2001). This is encouraging, given that essentially nothing is known of abundance, reproductive biology, habitat requirements, movements, and roost site selection in Montana, nor have the potential threats to this bat been identified. The lack of information on this species makes development and implementation of any effective management activity tenuous. Fortunately, the roosting habitat most favored by this bat (cliffs) provides it protection from many kinds of disturbance. Nevertheless, any roosts that are discovered should be protected and monitored. Studies to fill the gaps in our knowledge about this bat in Montana are needed, especially surveys throughout the state in appropriate habitats and landscapes to determine the full extent of its distribution. The audible calls make a survey much easier to conduct (Pierson and Rainey 1998), as no special skill is needed, other than familiarity with the calls and knowledge of the habitats likely to support spotted bats. The most immediate management action that can benefit this species (and other bat species as well) is protection of water sources in arid

9760

9761

9762

9763

9764

9765

9766 regions where this bat is present and water sources are limited. Open waste sumps, and similar hazardous standing water bodies associated with oil and gas fields, could present a significant hazard to spotted bats and other bat species as these energy resources are exploited.

\section{Conservation Concerns}




\section{DRAFT WORKING DOCUMENT DO NOT DUPLICATE}

9767

9768

9769

9770

9771

9772

9773

9774

9775

9776

9777

9778

9779

9780

9781

9782

9783

9784

9785

9786

9787

9788

9789

9790

9791

9792

9793

9794

9795

9796

9797

9798

9799

9800

9801

9802

9803

9804

9805

9806

9807

9808

9809

9810

9811

- Riparian degredation that could affect sustainable prey (moths) populations

- Open waste sumps and similar hazardous standing water bodies associated with oil and gas fields

- Lack of information due to difficulty of surveying

- Recreational climbing disturbs roost sites

- Use of pesticides that bats may accumulate through their diet and that kill their prey

\section{Conservation Strategies}

- Complete the Montana Bat Management Plan (in progress)

- Protection of water sources in arid regions

- Increase monitoring and surveys

- Support and cooperate in studies to determine more about the impacts of humans

\section{Management Plans}

Altenbach, J. S., W. Amy, P. V. Bradley, P. E. Brown, K. Dewberry, D. B. Hall, J. Jeffers, B. Lund, J. E. Newmark, M. J. O'Farrell, M. Rahn, R. E. Sherwin, C. R. Tomlinson, J. A. Williams. 2002. Nevada Bat Conservation Plan. Nevada Bat Working Group. Austin, Nevada. 188 pp.

Ellison, L. E., M. B. Wunder, C. A. Jones, C. Mosch, K. W. Navo, K. Peckham, J. E. Burghardt, J. Annear, R. West, J. Siemers, R. A. Adams, and E. Brekke. 2003. Colorado bat conservation plan. Colorado Committee of the Western Bat Working Group. Available at http://www.wbwg.org/colorado/colorado.htm

Hinman, K.E. and T.K. Snow, eds. 2003. Arizona Bat Conservation Strategic Plan. Version 1.0. Nongame and Endangered Wildlife Program Technical Report xxx. Arizona Game and Fish Department, Phoenix, AZ. (In progress)

\section{Citations}

Dubois, K. 2005. Personal Communication. Native Species Coordinator, Montana Fish Wildlife and Parks. Missoula, Montana.

Fenton, M. B., D. C. Tennant, and J. Wyszecki. 1987. Using echolocation calls to measure distribution of bats: the case of EUDERMA MACULATUM. J. Mamm. 68:142-144.

Foresman, K.R. 2001. The wild mammals of Montana. Special Publication No. 12. American Society of Mammologists. 


\section{DRAFT WORKING DOCUMENT DO NOT DUPLICATE}

9812 Gitzen, R. A., S. D. West, and J. A. Baumgardt. 2001. A record of the Spotted 9813 Bat (Euderma maculatum) from Crescent Bar, Washington. Northwestern 9814 Naturalist 82:28-30.

9815

9816

9817

9818

9819

9820

9821

9822

9823

9824

9825

9826

9827

9828

9829

9830

9831

9832

9833

9834

9835

9836

9837

9838

9839

9840

9841

9842

9843

9844

9845

9846

9847

9848

9849

Handley, C. O., Jr. 1959. A revision of American bats of the genera Euderma and Plecotus. Proc. U.S. Natl. Mus. 110:95-246.

Hendricks, P. and J. C. Carlson. 2001. Bat use of abandoned mines in the Pryor Mountains. Report to the Montana Department of Environmental Quality, Mine Waste Cleanup Bureau. Montana Natural Heritage Program, Helena. 8pp.

Leonard, M. L., and M. B. Fenton. 1983. Habitat use by spotted bats (EUDERMA MACULATUM, Chiroptera: Vespertilionidae): roosting and foraging behavior.

Can. J. Zool. 61:1487-1491.

Nicholson, A. J. 1950. A record of the spotted bat (EUDERMA MACULATUM) for Montana. J. of Mammalogy 31:197.

Perry, T. W., P. M. Cryan, S. R. Davenport, and M. A. Bogan. 1997. New locality for Euderma maculatum (Chiroptera: Vespertilionidae) in New Mexico.

Southwestern Naturalist 42:99-101.

Pierson, E. D., and W. E. Rainey. 1998. Distribution of the spotted bat, EUDERMA MACULATUM, in California. Journal of Mammalogy 79:1296-1305.

Rabe, M. J., M. S. Siders, C. R. Miller, and T. K. Snow. 1998. Long foraging distance for a Spotted Bat (Euderma maculatum) in northern Arizona.

Southwestern Naturalist 43:266-269.

Snow, C. 1974. Habitat management series for endangered species Report No. 4. Spotted bat (EUDERMA MACULATUM). USDI BLM Tech. Note TN 170.

Storz, J. 1995. Local distribution and foraging behavior of the Spotted bat (EUDERMA MACULATUM) in northwestern Colorado and adjacent Utah. Great Basin Naturalist 55(1):78-83.

Van Zyll de Jong, C. G. 1985. Handbook of Canadian mammals, Volume 2, bats. National Museums of Canada, Ottawa.

9850

9851

9852

9853

9854

9855

Wai-Ping, V. and M. B. Fenton. 1989. Ecology of spotted bat (EUDERMA MACULATUM) roosting and foraging. J. Mamm. 70:617-622.

Worthington, D. J. 1991. Abundance, distribution, and sexual segregation of bats in the Pryor Mountains of south central Montana. M.A. Thesis, University of 9856 9857 Montana, Missoula, Montana. 41 pp. 


\section{DRAFT WORKING DOCUMENT DO NOT DUPLICATE}

9858 Worthington, D. J. 1991. Abundance and distribution of bats in the Pryor 9859 Mountains of south central Montana and northeastern Wyoming. Montana 9860 Natural Heritage Program. Helena. 23 pp.

9861

9862 


\section{Townsend's Big-eared Bat (Corynorhinus townsendii)}

9864 9865 9866 9867 9868 9869 9870 9871 9872 9873 9874 9875 9876 9877 9878 9879 9880 9881 9882 9883 9884 9885 9886 9887 9888 9889 9890 9891 9892 9893

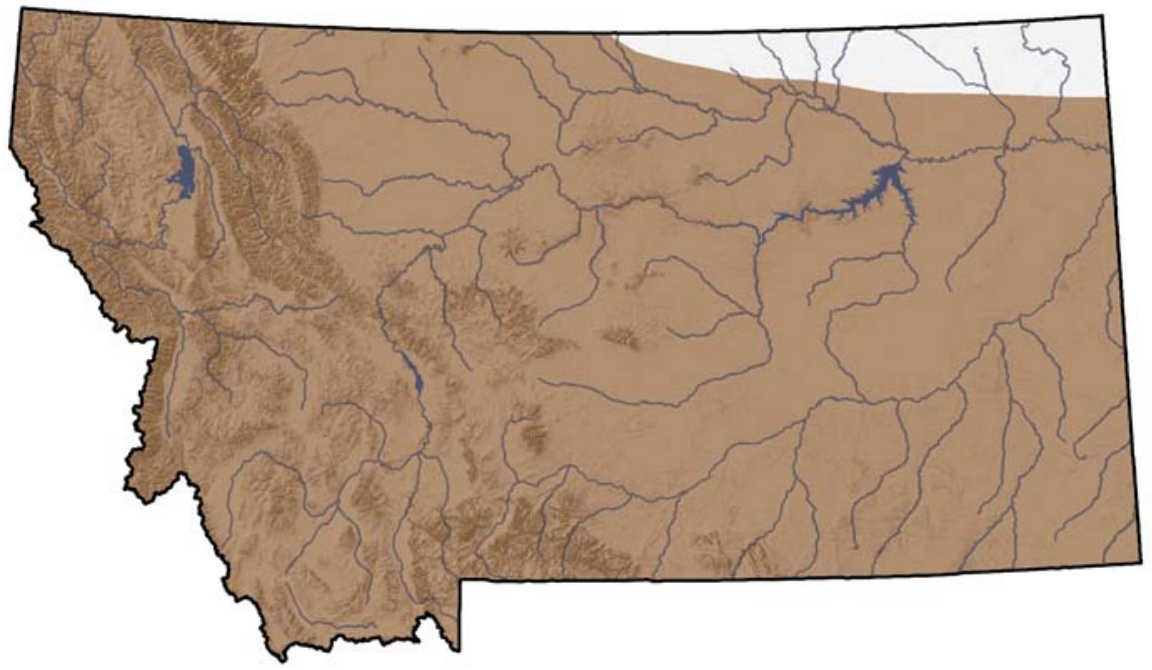

Figure 72. Distribution of the Townsend's Big-eared Bat

\section{Range}

The complete extent of the range of Townsend's big-eared bat in Montana is unknown, due to the limited survey effort across many areas. It has been documented in over 20 counties (voucher specimens from 14) and on both sides of the Continental Divide, from the Idaho state line in the west to the North Dakota and South Dakota state lines in the east, and from the Wyoming state line in the south to the Canadian border with Alberta in the northwest (Hoffmann et al. 1969, Swenson and Shanks 1979, Hendricks et al. 1996, Hendricks and Kampwerth 2001, Foresman 2001), at elevations of 1968 to 7820 feet (600 to 2384 meters). The only known location north of the Missouri River in northeastern Montana is in the Little Rocky Mountains (Hendricks et al. 2000); this species has not yet been reported in Alberta or Saskatchewan.

\section{Habitat}

Habitat use in Montana has not been evaluated in detail, but seems to be similar to other localities in the western United States. Caves and abandoned mines are used for maternity roosts and hibernacula (Worthington 1991, Hendricks et al. 1996, Hendricks 2000, Hendricks et al. 2000, Foresman 2001, Hendricks and Kampwerth 2001); use of buildings in late summer has also been reported (Swenson and Shanks 1979). Habitats in the vicinity of roosts include Douglas-fir and lodgepole pine forests, ponderosa pine woodlands, Utah juniper-sagebrush scrub, and cottonwood bottomland. In hibernacula, ambient temperatures ranged from -1.0 to 8.0 degrees ( 30 to 46 when torpid Townsend's big-eared bats were present) (Hendricks and Kampwerth 2001). Temperatures at maternity roosts are poorly documented; the temperature was 12 degrees (54 in mid-July near a 


\section{DRAFT WORKING DOCUMENT DO NOT DUPLICATE}

9894 colony in an abandoned mine in Lake County), and 18 degrees (66 in August 9895 near a colony in a large and relatively open cave chamber in Lewis and Clark 9896 County). Most caves and mines in Montana appear to be too cool in summer for 9897 9898 9899

9900 9901 9902 9903 9904 9905 9906 9907 9908 9909

9910

9911

9912

9913

9914

9915

9916

9917

9918

9919 use as maternity roosts. Townsend's big-eared bat feed on many different flying insects and may be a moth specialist.

\section{Management}

The response by Townsend's big-eared bats to human activities is largely undocumented in Montana. The maternity colony at Lewis and Clark Caverns has persisted for over a century, but has decreased in recent years, with no bats returning in 2005. In eastern Montana, numerous abandoned coal mines have been completely closed in recent decades, several of which were used as hibernacula; these mines are no longer accessible to bats. Abandoned mine reclamation has also been underway in western Montana during the same time. During the last decade, mine surveys prior to closure have been undertaken by land management agencies to determine the potential of abandoned mines as bat habitat. In some cases bat-friendly gates were installed at known Townsend's big-eared bat roosts, and the roosts have continued to be used after gate installation (Hendricks 1999, Hendricks and Kampwerth 2001). Some caves in the Pryor Mountains and Little Rocky Mountains with documented use by Townsend's big-eared bat are protected with bat-friendly gates (Worthington 1991, Hendricks et al. 2000). Abandoned mines should be surveyed for Townsend's big-eared bats or other bat species prior to any reclamation activity. Surveys should follow protocols in the conservation assessment and conservation strategy (Pierson et al. 1999). Installation of bat-friendly gates should be considered as a protective measure for all Townsend's big-eared bat roosts. Other land management activity (cave management, pesticide spraying, timber harvest, other vegetation conversion) at or near known roosts should also be conducted according to the best management practices outlined in the conservation assessment and strategy. Maternity roosts and hibernacula should be routinely monitored to establish population trends across the state. Undiscovered maternity colonies and hibernacula undoubtedly exist in Montana. All observations of Townsend's big-eared bat roosts should be reported to the appropriate land management agency, the Montana Natural Heritage Program,

9930

9931

9932

9933

9934

9935 or the Montana Department of Fish, Wildlife \& Parks.

9936

9937

9938

9939

\section{Conservation Concerns}

- Vandalism to maternity colonies and hibernacula

- Abandoned mine closures

- Toxic material impoundments

- Degradation and loss of native riparian vegetation 


\section{DRAFT WORKING DOCUMENT DO NOT DUPLICATE}

9940

9941

9942

9943

9944

9945

9946

9947

9948

9949

9950

9951

9952

9953

9954

9955

9956

9957

9958

9959

9960

9961

9962

9963

9964

9965

9966

9967

9968

9969

9970

9971

9972

9973

9974

9975

9976

9977

9978

9979

9980

9981

9982

9983

9984

\section{Conservation Strategies}

- Complete the Montana Bat Management Plan (in progress)

- Identification of maternity colonies and hibernacula and closures to recreationalists to these areas

- Install bat-friendly gates to coal mines instead of closure

- Ensure non-toxic materials utilized and non-toxic byproducts during mining activities

- Reduce levels of human activities around known bat roosts through road management, signs, and public education

- Maintain and improve the condition of riparian vegetation for bat foraging areas

- Recruit and educate recreational caving groups to assist with management of caves

\section{Management Plans}

Altenbach, J. S., W. Amy, P. V. Bradley, P. E. Brown, K. Dewberry, D. B. Hall, J. Jeffers, B. Lund, J. E. Newmark, M. J. O'Farrell, M. Rahn, R. E. Sherwin, C. R. Tomlinson, J. A. Williams. 2002. Nevada Bat Conservation Plan. Nevada Bat Working Group. Austin, Nevada. 188 pp.

Ellison, L. E., M. B. Wunder, C. A. Jones, C. Mosch, K. W. Navo, K. Peckham, J. E. Burghardt, J. Annear, R. West, J. Siemers, R. A. Adams, and E. Brekke. 2003. Colorado bat conservation plan. Colorado Committee of the Western Bat Working Group. Available at http://www.wbwg.org/colorado/colorado.htm

Hinman, K.E. and T.K. Snow, eds. 2003. Arizona Bat Conservation Strategic Plan. Version 1.0. Nongame and Endangered Wildlife Program Technical Report xxx. Arizona Game and Fish Department, Phoenix, AZ. (In progress)

Pierson, E.D., M.C. Wackenhut, J.S. Altenbach, P. Bradley, P. Call, D.L. Genter, C. E. Harris, B. L. Keller, B. Lengus, L. Lewis, B. Luce, K. W. Navo, J. M.

Perkins, S. Smith, and L. Welch. 1999. Species conservation assessment and strategy for Townsend's big-eared bat (Corynorhinus townsendii townsendii and Coynorhinus townsendii pallescens). Idaho Conservation Effort, Idaho Department of Fish and Game, Boise, Idaho.

\section{Citations}

Christy, R. E.; S. D. West. 1993. Biology of bats in Douglas-fir forests. General Technical Report. PNW-GTR-308. USDA Forest Service, Pacific Northwest Research Station, Portland, Oregon, USA 


\section{DRAFT WORKING DOCUMENT DO NOT DUPLICATE}

9985 Ecotype. T. W. Clark, A. H. Harvey, R. D. Dorn, D. L. Genter, and C. Groves,

9986

9987

9988

9989

9990

9991

9992

9993

9994

9995

9996

9997

9998

9999

10000

10001

10002

10003

10004

10005

10006

10007

10008

10009

10010

10011

10012

10013

10014

10015

10016

10017

10018

10019

10020

10021

10022

10023

10024

10025

10026

10027

10028

10029

10030 editors. Northern Rockies Conservation Cooperative, Montana Heritage

Program, The Nature Conservancy, and Mountain West Environmental Services, Helena, Montana, USA.

Engle, J. C. and C. E. Harris. 2001. Idaho species of special concern element state ranking reviews. Nongame and endangered wildlife program, Conservation Data Center, Idaho Department of Fish and Game, Boise, Idaho, USA.

Foresman, K. R. 2001. The wild mammals of Montana. American Society of Mammalogists, Special Publication No. 12. 278 pp.

Gillies, K. E. and R. Dixon. 2004. Draft Idaho Bat Conservation Plan. Nongame and Endangered Wildlife Program tech. Report. Idaho Conservation Data Center, Idaho Department of Fish and Game, Boise, Idaho, USA.

Hendricks, P., K. A. Jurist, D. L. Genter and J. D. Reichel. 1996. Bats of the Kootenai National Forest, Montana. [Unpublished report]. Montana Natural Heritage Program, Helena, MT. 99 pp.

Hendricks, P. 1999. Effect of gate installation on continued use by bats of four abandoned mine workings in western Montana. Unpublished report to Montana Department of Environmental Quality. Montana Natural Heritage Program, Helena, Montana. 13 pp.

Hendricks, P., D. L. Genter, and S. Martinez. 2000. Bats of Azure Cave and the Little Rocky Mountains, Montana. Canadian Field-Naturalist 114: 89-97.

Hendricks, P., and D. Kampwerth. 2001. Roost environments for bats using abandoned mines in southwestern Montana: a preliminary assessment. Report to the U.S. Bureau of Land Management. Montana Natural Heritage Program, Helena, Montana. 19 pp.

Hickman, G. R., B. G. Dixon, and J. Corn. 1999. Small mammals. Intermountain/foothill grassland 4.1-4.16 in The effects of recreation on Rocky Mountain wildlife: A review for Montana.

Hoffmann, R. S., D. L. Pattie and J. F. Bell. 1969. The distribution of some mammals in Montana. II. Bats. J. Mammal. 50(4): 737-741.

Joslin, G. and H. Youmans, coordinators. Committee on Effects of Recreation on Wildlife, Montana Chapter of The Wildlife Society, Helena, Montana, USA.

Montana Online Animal Field Guide. 2004. Montana Heritage Program and Montana Department of Fish, Wildlife \& Parks, Helena, Montana, USA (Accessed May 18, 2004: <http://www.fwp.state.mt.us/fieldguide/help.aspx\#overview>). 


\section{DRAFT WORKING DOCUMENT DO NOT DUPLICATE}

10031

10032 Swenson, J. E. and G. F. Shanks, Jr. 1979. Noteworthy records of bats from 10033 northeastern Montana. J. Mammal. 60:650-652.

10034

10035

10036

Worthington, D. J. 1991. Abundance, distribution, and sexual segregation of bats

10037

in the Pryor Mountains of south central Montana. M.A. Thesis, University of

10038

10039 


\section{DRAFT WORKING DOCUMENT DO NOT DUPLICATE}

10039 10040

10041

10042

10043

10044

10045

10046

10047

10048

10049

10050

10051

10052

10053

10054

10055

10056

10057

10058

10059

10060

10061

10062

10063

10064

10065

10066

10067

10068

10069

10070

\section{Pallid Bat (Antrozous pallidus)}

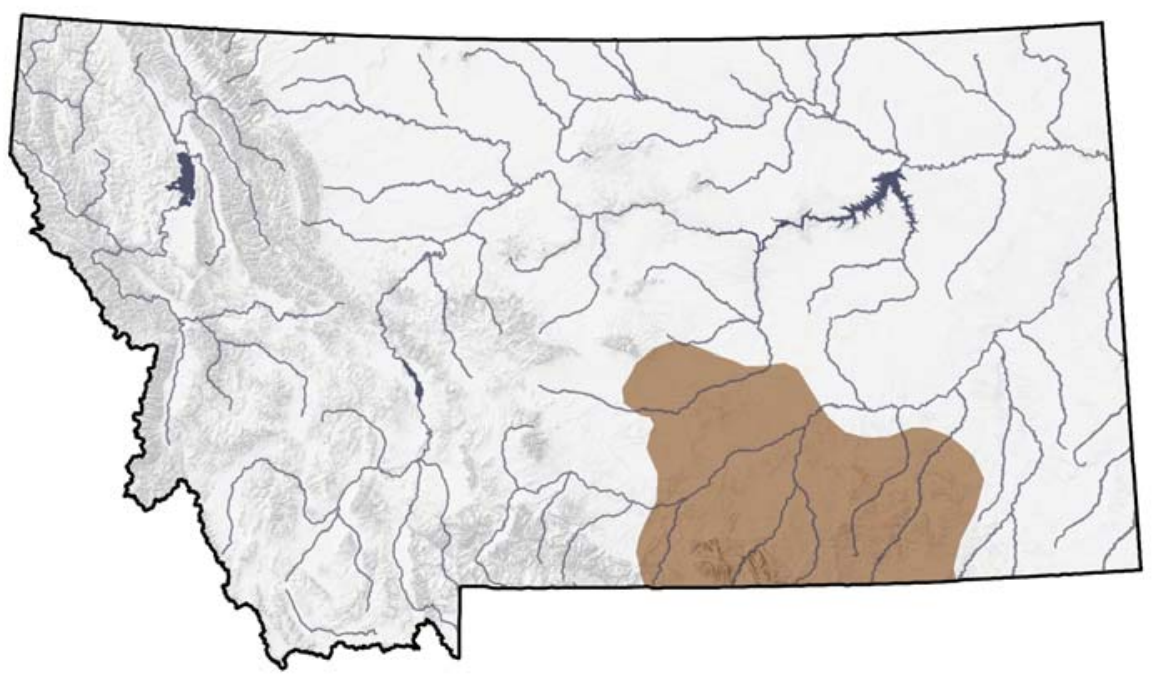

Figure 73. Distribution of the Pallid Bat

\section{Range}

The known distribution of the pallid bat in Montana is not yet well defined, but Montana is at the northeastern edge of the global range. Several have been captured east of the Continental Divide in south-central Montana, at Layout Creek and Gyp Spring in southern Carbon County (Shryer and Flath 1980, Worthington 1991, P Hendricks and J. Carlson personal observation), and west of Colestrip, Rosebud County. Montana records are from 1158 to 1402 meters (3800 to 4600 feet) elevation.

\section{Habitat}

Habitat at the Carbon County sites is Utah juniper-black sagebrush (Juniperus osteosperma-Artemisia nova). The Rosebud County site is in an area of ponderosa pine (Pinus ponderosa) savannah and big sagebrush (Artemisia tridentata). Both areas have rock outcrops (limestone or sandstone) in the immediate vicinity or within short flying distance. This species has not yet been detected at rock crevices, caves or abandoned mines in Montana; most observations have been at water sources (spring-fed streams or ponds; e.g. Carbon County) (Shryer 1980). However, habitat use in Montana by this species remains poorly known and unstudied.

At other locations, pallid bats have been found in arid deserts, juniper woodlands, sagebrush shrub-steppe, and grasslands, often with rocky outcrops and water nearby. They are less abundant in evergreen and mixed conifer woodlands, but in British Columbia are found in ponderosa pine forest near cliffs (Nagorsen and Brigham 1993). They typically roost in rock crevice or buildings, less often in 


\section{DRAFT WORKING DOCUMENT DO NOT DUPLICATE}

10071 caves, tree hollows, under bridges, and in abandoned mines (Hermanson and 10072 O'Shea 1983, Verts and Carraway 1998); night roosts often are in caves in 10073 Oklahoma (Caire et al. 1989). Four summer roosts in Wyoming were in rock 10074 10075 10076 shelters (1), caves (2), and mines (1) (Priday and Luce 1997). Day and night roosts are usually distinct. In Oregon, night roosts were in buildings, under rock overhangs, and under bridges; bats generally were faithful to particular night roosts both within and between years (Lewis 1994). Night roosts in British Columbia were often in cavities in ponderosa pine (Nagorsen and Brigham 1993). Day roosts include rock piles, tree hollows, and rock crevices. Pallid bats found in caves or mines usually use crevices within these places (Hermanson and O'Shea 1983, Caire et al. 1989). Maternity colonies are often located in horizontal crevices in rock outcrops and man-made structures, where temperatures are a fairly constant 30 degrees. Pallid bats forage on or near the ground and consume invertebrates such as scorpions, centipedes, crickets, grasshoppers and beetles.

\section{Management}

Pallid bats have persisted for over 20 years in the general area of the state where they were first discovered (Shryer and Flath 1980, Worthington 1991, P.

10091

10092

10093

10094

10095

Hendricks and J. Carlson personal observation). This is encouraging, given that essentially nothing is known of abundance, reproductive biology, habitat requirements, movements, and roost site selection in Montana, nor have the potential threats to this bat been identified. The lack of information on this species makes development and implementation of any effective management activity tenuous at best. Fortunately, the roosting habitat often favored by this bat (crevices in cliffs and rock outcrops) provides it protection from many kinds of disturbance. Nevertheless, any roosts that are discovered should be protected and monitored, as pallid bats also use abandoned buildings and bridges as roosts. Studies to fill the gaps in our knowledge of this bat in Montana are needed, especially surveys throughout the state in appropriate habitats and 10102 10103 10104 10105 landscapes to determine the full extent of its distribution. The most immediate management action that can benefit this species (and other bat species as well) is protection of water sources in arid regions where this bat is present and water sources are limited. Open waste sumps, and similar hazardous standing water bodies associated with oil and gas fields, could present a significant hazard to pallid bats and other bat species as these energy resources are exploited.

\section{Conservation Concerns}

- Little information of distribution, population and requirements

- Oil and gas fields disturbance of water sources

- Roost disturbance

- Recreational caving

10116

- Closure of mines for reclamation

- Overuse of pesticide spraying of rangelands 


\section{DRAFT WORKING DOCUMENT DO NOT DUPLICATE}

10117

10118

10119

10120

10121

10122

10123

10124

10125

10126

10127

10128

10129

10130

10131

10132

10133

10134

10135

10136

10137

10138

10139

10140

10141

10142

10143

10144

10145

10146

10147

10148

10149

10150

10151

10152

10153

10154

10155

10156

10157

10158

10159

10160

10161

10162

\section{Conservation Strategies}

- Complete the Montana Bat Management Plan (in progress)

- Protection of water sources in arid regions

- Protection of roost sites

- Increased survey and monitoring techniques

- Educate recreationalists on the threats to bats

\section{Management Plans}

Altenbach, J. S., W. Amy, P. V. Bradley, P. E. Brown, K. Dewberry, D. B. Hall, J. Jeffers, B. Lund, J. E. Newmark, M. J. O'Farrell, M. Rahn, R. E. Sherwin, C. R. Tomlinson, J. A. Williams. 2002. Nevada Bat Conservation Plan. Nevada Bat Working Group. Austin, Nevada. 188 pp.

Ellison, L. E., M. B. Wunder, C. A. Jones, C. Mosch, K. W. Navo, K. Peckham, J. E. Burghardt, J. Annear, R. West, J. Siemers, R. A. Adams, and E. Brekke. 2003. Colorado bat conservation plan. Colorado Committee of the Western Bat Working Group. Available at http://www.wbwg.org/colorado/colorado.htm.

Hinman, K.E. and T.K. Snow, eds. 2003. Arizona Bat Conservation Strategic Plan. Version 1.0. Nongame and Endangered Wildlife Program Technical Report xxx. Arizona Game and Fish Department, Phoenix, AZ. (In progress)

\section{Citations}

Caire, W., et al. 1989. Mammals of Oklahoma. Univ. Oklahoma Press, Norman. $567 \mathrm{pp}$.

Hermanson, J. W. and T. J. O'Shea 1983. ANTROZOUS PALLIDUS. Mammalian Species 213:1-8.

Lewis, S. E. 1994. Night roosting ecology of pallid bats (ANTROZOUS

PALLIDUS) in Oregon. Am. Midl. Nat. 132:219-226.

Nagorsen, D. and R. M. Bringham. 1993. Bats of British Columbia. University of British Columbia Press, Vancouver, B. C. 164 pp.

Priday, J., and B. Luce. 1997. Inventory of bats and bat habitat associated with caves and mines in Wyoming: completion report. Pp. 50-109 in Endangered and nongame bird and mammal investigations annual completion report. Nongame Program, Biological Science.

Shryer, J. S. and D. S. Flath. 1980. First record of the pallid bat (ANTROZOUS PALLIDUS) from Montana. Great Basin Nat. 40(2): 115. 


\section{DRAFT WORKING DOCUMENT DO NOT DUPLICATE}

10163

10164 Verts, B. J., and L. N. Carraway. 1998. Land mammals of Oregon. University of 10165 10166 10167 10168 10169 10170 10171
California Press, Berkeley. xvi + 668 pp.

Worthington, D. J. 1991. Abundance, distribution, and sexual segregation of bats in the Pryor Mountains of south central Montana. M.A. Thesis, University of Montana, Missoula, Montana. 41 pp. 


\section{DRAFT WORKING DOCUMENT DO NOT DUPLICATE}

10171 10172

10173

10174

10175

10176

10177

10178

10179

10180

10181

10182

10183

10184

10185

10186

10187

10188

10189

10190

10191

10192

10193

10194

10195

10196

10197

10198

10199

10200

10201

10202

\section{Pygmy Rabbit (Brachylagus idahoensis)}

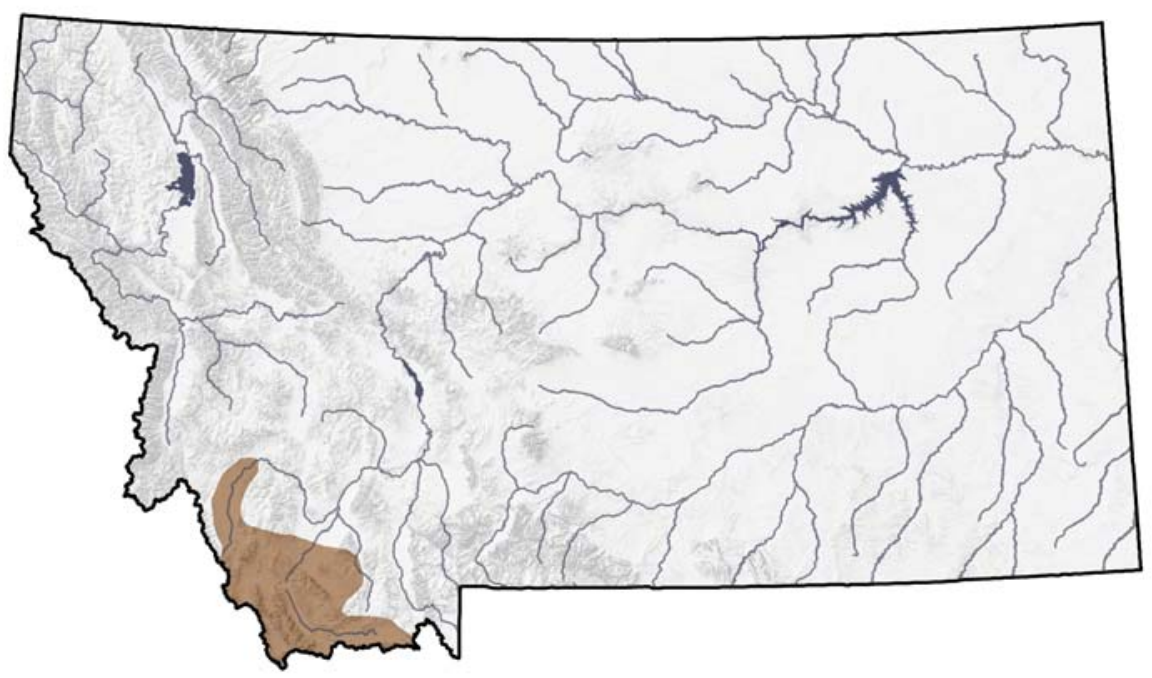

Figure 74. Distribution of the Pygmy Rabbit

\section{Range}

Montana lies on the northeastern edge of pygmy rabbit distribution. There are confirmed records dating back to 1918 from three southwestern counties (Beaverhead, Jefferson, Madison), with most of the Montana range in Beaverhead County (Davis 1937, Hoffmann et al. 1969, Rauscher 1997, Foresman 2001a); a 1937 specimen reported from near Lake Como in Ravalli County needs verification. Rauscher (1977) documented occupation in the southern portion of SilverBow County. Records are from elevations between 4500 to 6700 feet (1372 to 2042 meters).

\section{Habitat}

Occupied habitats in Montana include shrub-grasslands on alluvial fans, floodplains, plateaus, high mountain valleys, and mountain slopes, where suitable sagebrush cover and soils for burrowing are available. Some occupied sites may support a relatively sparse cover of sagebrush and shallow soils, but these usually support patches of dense sagebrush and deeper soils. Big sagebrush was the dominant shrub at all occupied sites, averaging 21.3 to $22.6 \%$ coverage; bare ground averaged $33 \%$ and forbs $5.8 \%$. Average height of sagebrush in occupied sites was 0.4 meter (Rauscher 1997). In southwestern Wyoming, pygmy rabbits selectively used dense and structurally diverse stands of sagebrush that accumulated a relatively large amount of snow; the subnivean environment provided access to a relatively constant supply of food and protection from predators and thermal extremes (Katzner and Parker 1997).

Pygmy rabbits dig burrows extending to a depth of 1 meter and they form 


\section{DRAFT WORKING DOCUMENT DO NOT DUPLICATE}

10203 chambers as part of the burrow system. Burrows have been excavated but no

10204

10205

10206

10207

10208

10209

10210

10211

10212

10213

10214

10215

10216

10217

10218

10219

10220

10221

10222

10223

10224

10225

10226

10227

10228

10229

10230

10231

10232

10233

10234

10235

10236

10237

10238

10239

10240

10241

10242

10243

10244

10245

10246

10247

10248

nests have been found and the location of nests is not known (Green and

Flinders 1980a).

\section{Management}

No special management activities have been developed or implemented in Montana specifically for pygmy rabbits. However, conservation habitat management to preserve sagebrush habitat for other species, e.g. sage grouse, will likely benefit pygmy rabbits. The loss of habitat from conversion to cropland and pasture is probably not great in southwestern Montana. Burning and other methods of sagebrush removal, however, have been used in past and recent years to improve rangeland for livestock. Removal of sagebrush will make the landscape unsuitable for pygmy rabbits. This species is found where grazing occurs, so long as sagebrush cover is maintained, but overgrazing could result in loss of forbs and grasses that are summer foods to pygmy rabbits, and livestock could damage sagebrush structure by trampling plants and thinning the shrub canopy. Dense stands of sagebrush along streams, fence lines, and borrow ditches are probably essential avenues for dispersal of pygmy rabbits. If sagebrush is removed, it may isolate or eliminate pygmy rabbits in some areas, unless it is done in such a way as to maintain a mosaic of patches of relatively large size isolated only by narrow expanses of unsuitable habitat. All areas within the range of the pygmy rabbit in Montana where sagebrush removal is planned should first be evaluated for impact to this species (Rauscher 1997).

\section{Conservation Concerns}

- Sagebrush destruction from clearing and livestock

- Fragmentation of available habitat

- Habitat specialist on all scales

\section{Conservation Strategies}

- Consider preparing management plan for pygmy rabbit or inclusion into other comprehensive taxonomic plan

- Sagebrush protection on a large scale

- Livestock rotation on lands

- Continue surveying for new populations and monitoring of existing ones

- Coordination efforts with federal agencies including BLM and USFS

\section{Management Plan}

None

\section{Citations}




\section{DRAFT WORKING DOCUMENT DO NOT DUPLICATE}

10249 Davis, W. B. 1937. Some mammals from western Montana and eastern Idaho. 10250 Murrelet 18:22-27.

10251 10252 10253 10254 10255 10256 10257 10258 10259 10260 10261 10262 10263 10264

Foresman, K.R. 2001. The wild mammals of Montana. Special Publication No. 12. American Society of Mammalogists.

Green, J. S. and J. T. Flinders. 1980. Habitat and dietary relationships of the pygmy rabbit. Jour. Range Mgmt. 33(2): 136-142.

Heady, L.T., Gabler, K.I. and Laundre, J. W. 2001. Habitat selection by pygmy rabbits in Southeast Idaho. Technical Bulletin No. 01-7. Idaho Bureau of Land Management.

Hoffmann, R. S., P. L. Wright and F. E. Newby. 1969. Distribution of some mammals in Montana. I. Mammals other than bats. J. Mammal. 50(3): 579-604.

Katzner, T.E. and K.L. Parker. 1997. Vegetative characteristics and size of home ranges used by pygmy rabbits (Brachylagus idahoensis) during winter. Journal of Mammalogy. 78:1063-1072,

Rauscher, Ryan. 1997. Status and distribution of the pygmy rabbit in Montana. Montana Department of Fish, Wildlife \& Parks, nongame program. Unpublished report, 19 pp plus appendices.

Roberts, Hadley B. 2001. Survey of pygmy rabbit distribution, numbers and habitat use in Lemhi and Custer counties, Idaho. Technical Bulletin No. 01-11. Idaho Bureau of Land Management. 


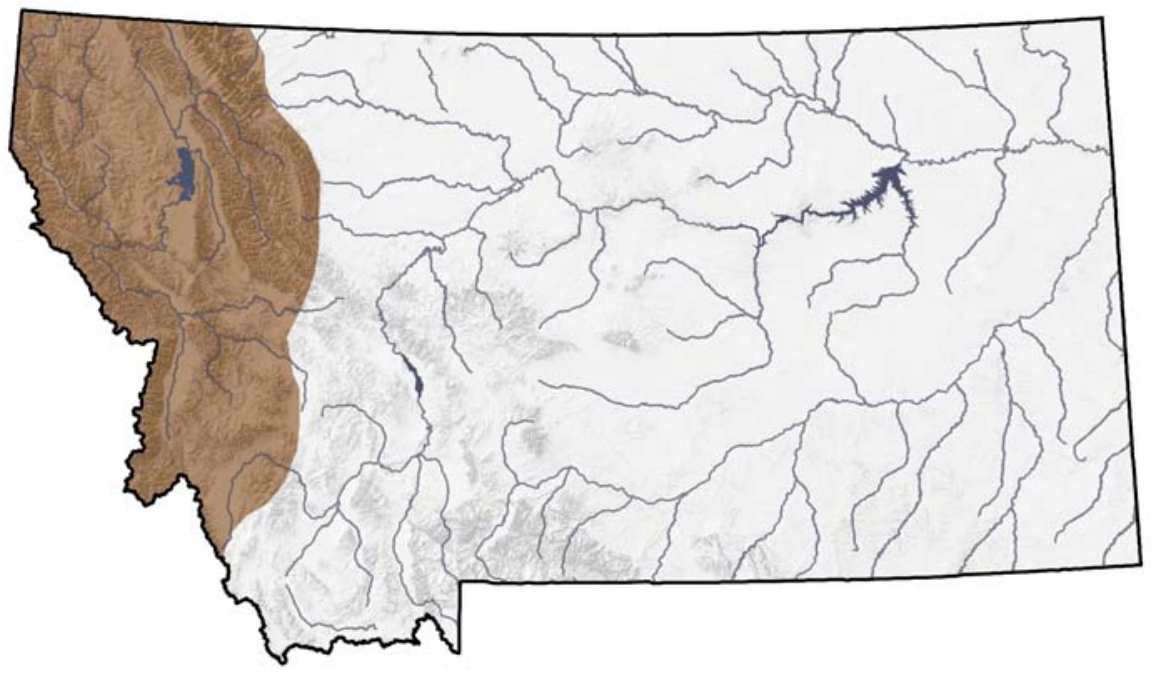

10279

10280

10281

10282

10283

10284

10285

10286

10287

10288

10289

10290

10291

10292

10293

10294

10295

10296

10297

10298

10299

10300

10301

10302

10303

10304

10305

10306

10307

10308

Figure 75. Distribution of the Hoary Marmot

\section{Range}

Although the distribution map provided above indicates that Haory Marmots occur throughout western Montana, they most likely only occupy 5 to $10 \%$ of the area depicted. They do not occur in the Salish Mountains and only in small pockets in the Whitfish range. They are generally confined to high subalpine and alpine habitats. May move through coniferous forest in NW MT. Small, scattered, isolated populations South of Mission Mountains (Foresman 2001). Emphasis should be placed on future field inventory to identify their range in Montana.

\section{Habitat}

Found primaryly in rocky outcroppings and large boulder fields high subalpine and alpine regions of Montana where they feed, burrow and raise young.

\section{Management}

Management of species includes collecting information on where Hoary marmots are distributed, population numbers, and about habits. In addition, conserve small populations found on the periphery of their distribution, including scattered populations in high mountains of the Mission and Swan Mountains.

\section{Conservation Concerns}

- Lack of data on status and size of Montana populations, mountain range by mountain range

- Little or no connectivity between populations in distinct mountain ranges 
10309

10310

10311

10312

10313

10314

10315

10316

10317

10318

10319

10320

10321

10322

10323

10324

10325

10326

10327

10328

10329

10330
- Change in climate due to global warming

\section{Conservation Strategies}

- Determine the effects of inbreeding in isolated populations and examine feasibility of transplanting individuals between populations in an effort to increase genetic diversity

- Prepare conservation plan, addressing conservation concerns and establishing a monitoring protocol

- Conduct inventory to obtain estimates of population status and size, and distribution

\section{Management Plan}

None

\section{Citations}

Foresman, K.R. 2001. The wild mammals of Montana. Special Publication No. 12. American Society of Mammalogists. 
10332

10333

10334

10335

10336

10337

10338

10339

10340

10341

10342

10343

10344

10345

10346

10347

10348

10349

10350

10351

10352

10353

10354

10355

10356

10357

10358

10359

10360

10361

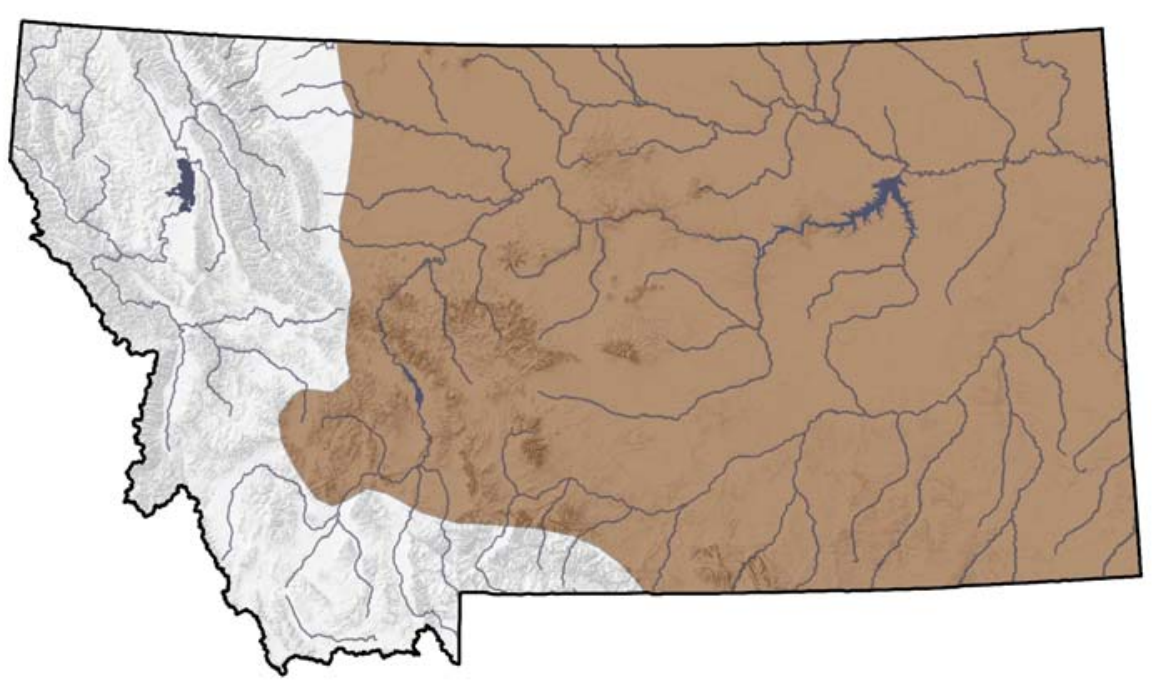

Figure 76. Distribution of the Black-tailed Prairie Dog

\section{Range}

Black-tailed prairie dogs are found across eastern Montana except in the northeastern corner and the Clarks Fork of the Yellowstone drainage (Campbell 1989).

\section{Habitat}

Prairie dog colonies are found on flat, open grasslands and shrub/grasslands with low, relatively sparse vegetation. The most frequently occupied habitat in Montana is dominated by western wheatgrass, blue grama and big sagebrush (Montana Fish, Wildlife \& Parks 2002). Colonies are associated with silty clay loams, sandy clay loams, and loams (Thorp 1949, Bonham and Lerwick 1976, Klatt and Hein 1978, Agnew et al. 1986) and fine to medium textured soils are preferred (Merriam 1902, Thorp 1949, Koford 1958), presumably because burrows and other structures tend to retain their shape and strength better than in coarse, loose soils. Encroachment into sandy soil (e.g., loamy fine sand) does occur if the habitat is needed for colony expansion (Osborn 1942).

Shallow slopes of less than $10 \%$ are preferred (Koford 1958, Hillman et al. 1979, Dalsted et al. 1981), presumably in part because such areas drain well and are only slightly prone to flooding. By colonizing areas with low vegetative stature, prairie dogs often select areas with past human (as well as animal) disturbance, including areas heavily used by cattle, such as water tanks and long-term supplemental feeding sites (Licht and Sanchez 1993, FaunaWest 1998).

\section{Management}




\section{DRAFT WORKING DOCUMENT DO NOT DUPLICATE}

10362

10363

10364

10365

10366

10367

10368

10369

10370

10371

10372

10373

10374

10375

10376

10377

10378

10379

10380

10381

10382

10383

10384

10385

10386

10387

10388

10389

10390

10391

10392

10393

10394

10395

10396

10397

10398

10399

10400

10401

10402

10403

10404

10405

10406

10407

In Montana, the black-tailed prairie dog has been designated a nongame wildlife species in need of management. Shooting of prairie dogs on public lands (excluding state school trust lands) has been regulated. Consult Montana Fish, Wildlife \& Parks for the latest regulations. Prairie dogs are managed under the Conservation Plan for Black-tailed and White-tailed Prairie Dogs in Montana (Montana Prairie Dog Working Group 2002). Please consult this plan for details concerning prairie dog management in Montana.

\section{Conservation Concerns}

- Conversion of native rangelands to agriculture and to a lesser degree, residential development

- Conflicts between the present abundance of prairie dogs, and other land uses

- Disease, particularly sylvatic plague (Yersinia pestis)

\section{Conservation Strategies}

- Develop regional prairie dog distribution and abundance goals

- Continue prairie dog inventory and monitoring efforts

- Institute a landowner incentive program and a prairie dog control program designed to contain prairie dog acreage, rather than eradicate prairie dogs

- Identify isolated prairie dog colonies and apply management measures necessary to maintain current distribution

- Develop and implement a prairie dog ecosystem education program

- Identify and support or conduct research projects designed to form solutions to short-term and long-term biological and social problems related to black-tailed prairie dog communities and their managment

\section{Management Plan}

Conservation Plan for Black-tailed and White-tailed Prairie Dogs in Montana (Montana Prairie Dog Working Group 2002).

\section{Citations}

Agnew, W., D. W. Uresk and R. M. Hansen. 1986. Flora and fauna associated with prairie dog colonies and adjacent ungrazed mixed-grass prairie in western South Dakota. Journal of Range Management 39:135-9.

Bonham, C. D. and A. Lerwick. 1976. Vegetation changes induced by prairie dogs on shortgrass range. Journal of Range Management 29:221-25.

Campbell, T. M., III. 1989. Prairie dog colony location surveys and black-footed ferret searches in Montana. Intermountain/foothill grassland 1-12 In The prairie 


\section{DRAFT WORKING DOCUMENT DO NOT DUPLICATE}

10408 dog ecotype: Managing for biological diversity. Montana BLM Wildlife Technical 10409 Bulletin No. 2. 55 pp.

10410

10411

10412

10413

10414

10415

10416

10417

10418

10419

10420

10421

10422

10423

10424

10425

10426

10427

10428

10429

10430

10431

10432

10433

10434

10435

10436

10437

10438

10439

10440

10441

10442

10443

10444

10445

10446

10447

Conservation Plan for Black-tailed and White-tailed Prairie Dogs in Montana

(Montana Prairie Dog Working Group 2002).

Dalsted, K. J., et. al. 1981. Application of remote sensing to prairie dog management. Journal of Range Management 34:218-23.

FaunaWest. 1998. Status of the black and white-tailed prairie dog in Montana. Montana Fish, Wildlife \& Parks, Helena. 34 pp.

Hillman, C. N., R. L. Linder, and R. B. Dahlgren. 1979. Prairie dog (CYNOMYS LUDOVICIANUS) distribution in areas inhabited by black-footed ferrets (MUSTELA NIGRIPES). Am. Midl. Nat. 102:185-7.

Klatt, L. E. and D. Hein. 1978. Vegetative differences among active and abandoned towns of black-tailed prairie dogs (CYNOMYS LUDOVICIANUS). Journal of Range Management 31:315-7.

Koford, C. B. 1958. Prairie dogs, whitefaces, and blue grama. Wildlife Monograph 3:1-78.

Licht, D. S. and K. D. Sanchez. 1993. Association of black-tailed prairie dog colonies with cattle point attractants in the northern Great Plains. Great Basin Nat. 53:385-389.

Merriam, C. H. 1902. The prairie dog of the Great Plains. Pp. 257-70 in USDA Yearbook Agriculture for 1901, U.S. Government Printing Office, Washington, DC.

Miller, B., G. Ceballos, and R. Reading. 1994. The prairie dog and biotic diversity. Conservation Biology 8(3):677-681.

Osborn, B. 1942. Prairie dogs in shinnery (oak scrub) savannah. Ecology 23:1105.

Thorp, J. 1949. Effects of certain animals that live in soils. Scientific Monthly 68:180-91.

10448 


\section{DRAFT WORKING DOCUMENT DO NOT DUPLICATE}

10448 10449

10450

10451

10452

10453

10454

10455

10456

10457

10458

10459

10460

10461

10462

10463

10464

10465

10466

10467

10468

10469

10470

10471

10472

10473

10474

10475

10476

10477

10478

10479

\section{White-tailed prairie Dog (Cynomys leucurus)}

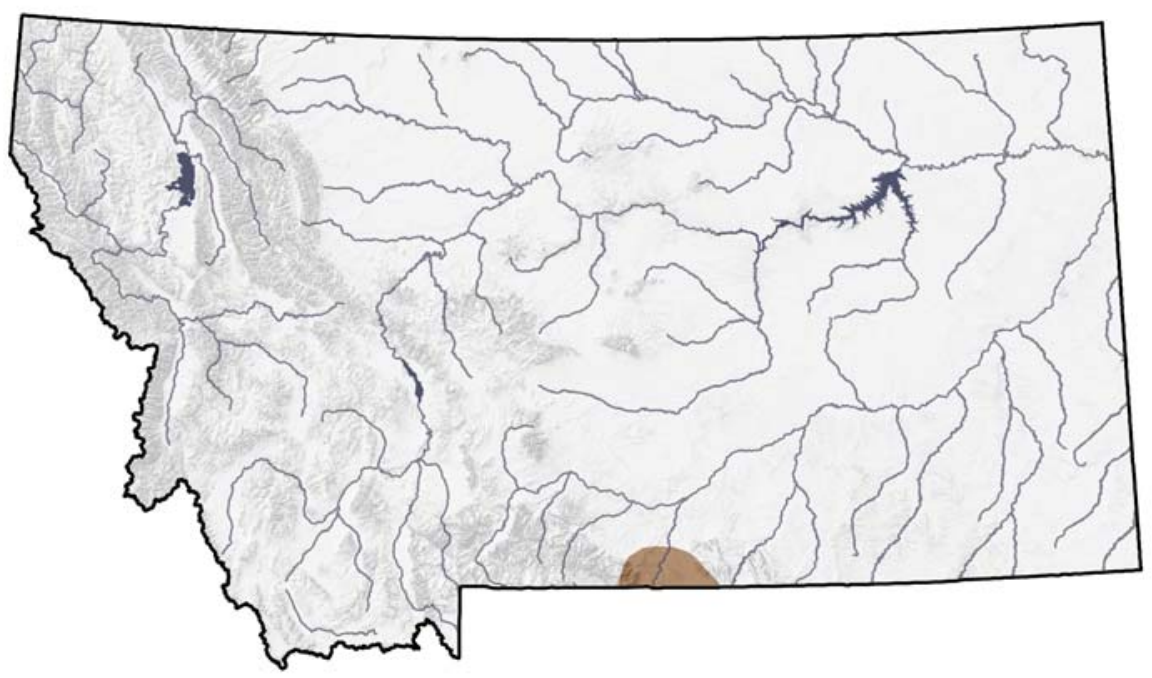

Figure 77. Distribution of the White-tailed Prairie Dog

\section{Range}

In Montana, white-tailed prairie dogs now only inhabit a small area in the Southcentral portion of state, near the Pryor Mountains.

\section{Habitat}

Throughout their range, white-tailed prairie dogs inhabit xeric sites with mixed stands of shrubs and grasses. In Montana they inhabit sites dominated by Nuttall saltbrush with lesser amounts of big sage, and areas with povery sumpweed (Flath 1979). They live at higher elevations and in meadows with more diverse grass and herb cover than do black-tailed prairie dogs (Hoffmann, in Wilson and Ruff 1999) and their range in Montana is at higher elevations than other sites within their distribution.

\section{Management}

White-tailed prairie dogs are desifnated as nongame wildlife species in need of management in Montana. Public lands (excluding state school trust lands) in the portion of Carbon County occupied by white-tailed prairie dogs has been closed to sport shooting on a year round basis. Please consult Montana Fish, Wildlife \& Parks for the most current regulations concerning prairie dogs. White-tailed prairie dogs are managed under the Conservation Plan for Black-tailed and White-tailed Prairie Dogs in Montana (Montana Prairie Dog Working Group 2002). Please consult this plan for details concerning prairie dog management in Montana. 


\section{DRAFT WORKING DOCUMENT DO NOT DUPLICATE}

10480

10481

10482

10483

10484

10485

10486

10487

10488

10489

10490

10491

10492

10493

10494

10495

10496

10497

10498

10499

10500

10501

10502

10503

10504

10505

10506

10507

10508

10509

10510

10511

10512

10513

10514

10515

10516

10517

\section{Conservation Concerns}

- Conversion of native rangelands to agriculture and, to a lesser degree, residential development

- Disease, particularly sylvatic plague (Yersima pestis)

- Vulnerability of remaining small and isolated colonies to extirpation, which could result in contraction in the current range of this species

\section{Conservation Strategies}

- Reintroduce white-tailed prairie dogs to sites that were formerly occupied until the early 1990s

- Translocate white-tailed prairie dogs from a colony in the path of a highway upgrade project, to a formerly occupied site on BLM land

\section{Management Plan}

Conservation Plan for Black-tailed and White-tailed Prairie Dogs in Montana; Montana Prairie Dog Working Group 2002.

\section{Citations}

An Inventory of Black-tailed and White-tailed Prairie Dog Colonies in the Billings and Powder River Areas. 2004.

Conservation Plan for Black-tailed and White-tailed Prairie Dogs in Montana; Montana Prairie Dog Working Group 2002.

Flath, D. L. 1979. Status of the white-tailed prairie dog in Montana. Proc. Mont. Acad. Sci. 38:63-67.

Knowles, C.J. 2002. Status of the white-tailed and Gunnison's prairie dog. Environmental Defense and National Wildlife Federation. FaunaWest Wildlife Consultants. Boulder, Montana.

Wilson, D. E., and S. Ruff. 1999. The Smithsonian book of North American mammals. Smithsonian Institution, Washington, DC. 750pp. 


\section{DRAFT WORKING DOCUMENT DO NOT DUPLICATE}

10517 10518
10519

10520

10521

10522

10523

10524

10525

10526

10527

10528

10529

10530

10531

10532

10533

10534

10535

10536

10537

10538

10539

10540

10541

10542

10543

10544

10545

10546

10547

10548

\section{Great Basin Pocket Mouse (Perognathus parvus)}

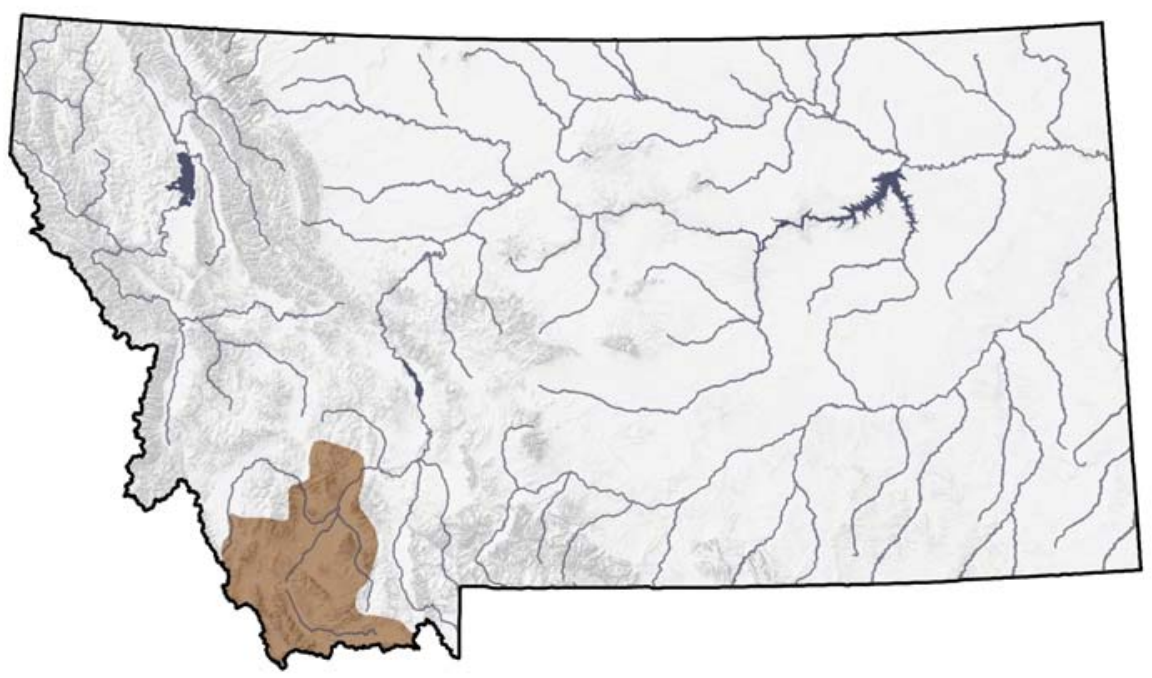

Figure 78. Distribution of the Great Basin Pocket Mouse

\section{Range}

The Great Basin pocket mouse is restricted in Montana to the extreme southwestern portion of the state, east of the Continental Divide. All records are from Beaverhead County except one from Jefferson County (Hoffmann et al. 1969, Foresman 2001a, Hendricks and Roedel 2002). They are suspected to occur in Madison County. Individuals have been captured at elevations up to 2030 meters (6660 feet). The Great Basin pocket mouse is found throughout the Great Basin and adjacent regions of the West, from south-central British Columbia southward through eastern Washington and Oregon to southern California, Nevada, northern Arizona, western Utah, southern Idaho, southwestern Montana, and southwestern Wyoming (Verts and Kirkland 1988). It usually occurs below elevations of 2500 meters (8200 feet).

\section{Habitat}

Occupied habitats in Montana are arid and sometimes sparsely vegetated. They include grassland-shrubland with less than $40 \%$ cover, stabilized sandhills, and landscapes with sandy soils, more than $28 \%$ sagebrush cover, and 0.3 to 2.0 meters shrub height (Hoffmann et al. 1969, Frissell 1978, Hendricks and Roedel 2001, 2002, P. Hendricks unpublished data).

Data from other portions of its range suggest a variety of western arid and semiarid habitats are occupied, including pine woodland, juniper-sagebrush scablands, sandy short-grass steppes, and shrubland covered with sagebrush, bitterbrush, greasewood, and rabbitbrush; heavily forested habitats are avoided. They are captured more often than expected (based on availability) at sites with 


\section{DRAFT WORKING DOCUMENT DO NOT DUPLICATE}

10549 more than $40 \%$ ground cover. On plots where fire killed the shrub cover, the 10550 species is one-third as abundant as on adjacent unburned plots. They usually are 10551 found in habitats with light-textured, deep soils, and sometimes in shrublands 10552 10553 among rocks. Presence is positively correlated with percent sand and negatively with percent clay. Adults sleep and rear young in underground burrows (Verts 10554 10555 10556 10557 10558 10559 10560 10561 10562 10563 10564 10565 10566 10567 10568 10569 10570 10571 10572 10573 10574 10575 10576 10577 10578 10579 10580 10581 10582 10583 10584 10585 10586 10587 10588 10589 10590 10591 10592 10593 and Kirkland 1988, Verts and Carraway 1998).

\section{Management}

No special management activities are currently recognized in order to maintain viable populations of this species in Montana. Land management designed to maintain a mosaic of sagebrush cover, size, and age classes would benefit this species, especially if it promotes the growth of grasses and forbs within sagebrush stands; large-scale sagebrush removal should be avoided. Livestock probably competes with pocket mice for grasses and reduce shrub and grass cover (Hendricks and Roedel 2001).

\section{Conservation Concerns}

- Habitat loss, large scale removal of sagebrush

- Competition for grasses, livestock probably compete with pocket mice for grasses and reduce shrub and grass cover

\section{Conservation Strategies}

- Consider preparing management plan for Great Basin Pocket Mouse or inclusion into other comprehensive taxonomic plan

- Land management designed to maintain a mosaic of sagebrush cover, size, and age classes will benefit this species, especially if it promotes the growth of grasses and forbs within sagebrush stands

- Rotation of livestock areas

- Evaluate the quality and quantity of occupied and potentially suitable areas

\section{Management Plan}

None

\section{Citations}

Foresman, K.R. 2001. The wild mammals of Montana. Special Publication No. 12. American Society of Mammologists.

Frissell, S. S. 1978. Nongame wildlife inventory. Prepared for: US Dept. of Interior, Bureau of Land Management, Dillon Resource Area, Dillon, Montana. $10594194 \mathrm{pp}$. 


\section{DRAFT WORKING DOCUMENT DO NOT DUPLICATE}

10595

10596 10597 10598

10599 10600 10601 10602 10603 10604 10605 10606 10607 10608 10609 10610 10611 10612 10613 10614 10615 10616 10617 10618 10619 10620 10621
Hall, E. R. 1981. The Mammals of North America, Vols. I \& II. John Wiley \& Sons, New York, New York, USA.

Hendricks, P. and M. Roedel. 2001. A faunal survey of the Centennial Valley Sandhills, Beaverhead County, Montana. Report to the U.S. Bureau of Land Management and US Fish and Wildlife Service. Montana Natural Heritage Program, Helena, Montana, USA.

Hendricks, P., and M. Roedel. 2002. Preble's Shrew and Great Basin Pocket Mouse from the Centennial Valley Sandhills of Montana. Northwestern Naturalist 83: 31-34.

Hoffmann, R. S., P. L. Wright and F. E. Newby. 1969. Distribution of some mammals in Montana. I. Mammals other than bats. J. Mammal. 50(3): 579-604.

J. Mammal. 50: 579-604. NatureServe Explorer: An online encyclopedia of life. 2002. Version 1.6. Arlington, Virginia, USA. (Accessed: March 20, 2003; http://www.natureserve.org/explorer.http://nhp.nris.state.mt.us/animalguide/).

Verts, B. J., and G. L. Kirkland, Jr. 1988. PEROGNATHUS PARVUS. Am. Soc. Mamm., Mammalian Species 318:1-8.

Verts, B. J., and L. N. Carraway. 1998. Land mammals of Oregon. University of California Press, Berkeley. 668 pp. 


\section{DRAFT WORKING DOCUMENT DO NOT DUPLICATE}

10621 10622

10623

10624

10625

10626

10627

10628

10629

10630

10631

10632

10633

10634

10635

10636

10637

10638

10639

10640

10641

10642

10643

10644

10645

10646

10647

10648

10649

10650

10651

10652

\section{Northern Bog Lemming (Synaptomys borealis)}

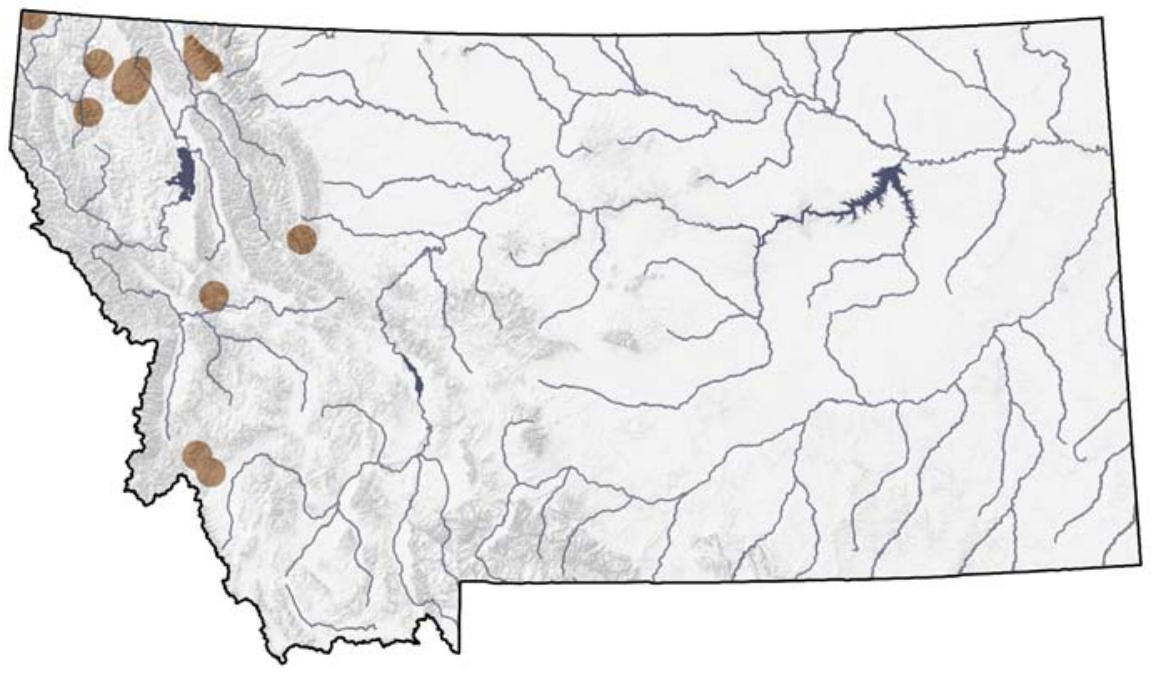

Figure 79. Distribution of the Northern Bog Lemming

\section{Range}

The Northern bog lemming has a widespread distribution extending from Alaska easterly to Labrador and south to portions of the northern U.S. In Montana, the northern bog lemming is at the southern margin of global distribution in the Rocky Mountains, and has been documented at 18 isolated sites. Records are available for six counties (Beaverhead, Flathead, Lewis and Clark, Lincoln, Missoula, Ravalli), with all but two sites (one in Beaverhead County - Lost Trail Pass, one in Lewis and Clark County) occurring west of the Continental Divide (Reichel and Corn 1997, Foresman 2001a). Elevation of these sites ranges from 3340 to 6520 feet (1018 to 1987 meters), but a 2003 record from a new site in Ravalli County extends the upper elevation limit to 7400 feet (2256 meters) (B. Maxell personal communication).

\section{Habitat}

Northern bog lemmings occupy a variety of habitats throughout their range, especially near the southern edge of the global distribution. Typically, these habitats have high moisture levels and include sphagnum bogs, wet meadows, moist mixed and coniferous forests, montane sedge meadows, krummholz spruce-fir forest with dense herbaceous and mossy understory, alpine tundra, mossy streamsides, and even sagebrush slopes in the case of $S$. b. artemisiae in British Columbia (Clough and Albright 1987, West 1999, Streubel 2000). Within these habitats, they occupy surface runways and burrow systems up to 12 inches deep and can be found in small colonies with population densities that may reach 36 individuals per acre. (Streubel 2000). They are active day and night throughout the year, feeding on grasses and other herbaceous vegetation. 


\section{DRAFT WORKING DOCUMENT DO NOT DUPLICATE}

10653

10654

10655

10656

10657

10658

10659

10660

10661

10662

10663

10664

10665

10666

10667

10668

10669

10670

10671

10672

10673

10674

10675

10676

10677

10678

10679

10680

10681

10682

10683

10684

10685

10686

10687

10688

10689

10690

10691

10692

10693

10694

10695

10696
Young are born in nests that may be underground or on the surface in concealing vegetation. Northern Bog Lemmings in Montana have been found in at least nine community types, including Engelmann spruce, subalpine fir, birch, willow, sedge (Carex), spike rush (Eleocharis), or combinations of the above, often occurring in wet meadows, fens, or bog-like environments. Wright (1950) captured lemmings in a swampy area containing spruce trees, timothy, alder and other moist-site plants (Wright 1950). The Upper Rattlesnake Creek specimen was captured in a wet-sedge/bluejoint meadow near subalpine fir (Adelman 1979). Areas with extensive moss mats, primarily sphagnum, are the most likely sites to find new populations (Wright 1950, Reichel and Beckstrom 1994, Reichel and Corn 1997, Pearson 1999, Foresman 2001a).

\section{Management}

No coordinated management activities have been developed or implemented for this species in Montana. Nevertheless, some populations on U.S. Forest Service lands are providing added protection through special management/conservation policy guidelines applied to peatlands, including the Research Natural Area (RNA) designation (Chadde et al. 1998). RNA designation typically prohibits manipulative management, such as timber harvest and livestock grazing. The Clean Water Act and state water quality standards protect water quality of these peatlands. Protection guidelines (Reichel and Corn 1997) should be applied to all sites where Northern bog lemmings are known to occur, as well as potential peatland sites not yet surveyed for them. Guidelines include 1) assumption that Northern bog lemmings are present at sphagnum or bog/fen habitat patches unless site-specific surveys indicate otherwise, 2) restriction of timber harvest to a zone beyond a 100 meter buffer surrounding sphagnum or other bog/fens, or associated riparian areas that could provide corridors for dispersal to adjacent patches of suitable habitat, 3) minimizing livestock grazing in drainages with unsurveyed mossy areas present, and maintaining range conditions there and in those with populations present at good to excellent, and 4) elimination of management activities that could destroy bogs/fens (road-building, pothole blasting, trail construction, dam construction, alteration of surface and subsurface water flow, recreational vehicle use in fen habitats). Additional surveys should be undertaken to better understand the distribution in Montana, and known sites should be monitored routinely to determine population persistence and trends.

\section{Conservation Concerns}

- Bogs/fens are threatened by unsustainable domestic stock grazing, invasion of heavily grazed fens by exotic plants, and potential changes in the water regimes feeding the bogs/fens.

- Timber harvest around bog/fen habitats

- Poorly understood distribution in Montana 


\section{DRAFT WORKING DOCUMENT DO NOT DUPLICATE}

10697

10698

10699

10700

10701

10702

10703

10704

10705

10706

10707

10708

10709

10710

10711

10712

10713

10714

10715

10716

10717

10718

10719

10720

10721

10722

10723

10724

10725

10726

10727

10728

10729

10730

10731

10732

10733

10734

10735

10736

10737

10738

10739

10740

10741

- Human disturbances (timber harvesting and roads) are directly related to the decreased diversity of vascular plants, a common food sources for Northern Bog Lemmings, in bogs/fens

\section{Conservation Strategies}

- Consider preparing management plan for Northern Bog Lemming or inclusion into other comprehensive taxonomic plans

- Restriction of timber harvest to a zone beyond a 100 meter buffer surrounding sphagnum or other fen moss mats, or associated riparian areas which could provide corridors for dispersal to adjacent patches of suitable habitat

- Additional surveys should be undertaken to better understand both the potential distribution in Montana and known sites of occupancy

- Known sites should be monitored routinely to determine population persistence and trends

- Minimizing livestock grazing in drainages with unsurveyed moss mats

- Elimination of management activities that could destroy bogs (roadbuilding, pothole blasting, trail construction, dam construction, alteration of surface and subsurface water flow, recreational vehicle use in fen habitats).

\section{Management Plan}

None

\section{Citations}

Adelman, E. B. 1979. A survey of the nongame mammals in the Upper

Rattlesnake Creek drainage of western Montana. M.S. thesis. University of Montana, Missoula. 129 pp.

Chadde, S. W., J. S. Shelly, R. J. Bursik, R. K. Moseley, A. G. Evenden, M. Mantas, F. Rabe and B. Heidel. 1998. Peatlands on National Forests of the Northern Rockies.

Clough, G. C., and J. J. Albright. 1987. Occurrence of the northern bog lemming, SYNAPTOMYS BOREALIS, in the northeastern United States. Can. FieldNaturalist 101:611-613.

Foresman, K. R. 2001. The wild mammals of Montana. American Society of Mammalogists, Special Publication No. 12. 278 pp.

Groves, C.R. 1994. Effects of Timber Harvest on Small Mammals and Amphibians in Old-Growth Coniferous Forests on the Priest Lane Ranger District, 


\section{DRAFT WORKING DOCUMENT DO NOT DUPLICATE}

10742 Unpublished report to the Priest Lake Ranger District, Idaho Panhandle National 10743 Forest. The Nature Conservancy, Boulder, Colorado, U.S.A.

10744

10745

Idaho Fish and Game. (Accessed April 26, 2004;

10746

10747

10748

10749

10750

10751

10752

10753

10754

10755

10756

10757

10758

10759

10760

10761

10762

10763

10764

10765

10766

10767

10768

10769

10770

<http://fishandgame.idaho.gov/tech/CDC/county_spp_lists>).

Jones, W. M. 2003. Kootenai National Forest Peatlands: Description and Effect of Forest Management. Report to the Kootenai National Forest, Montana. Montana Natural Heritage Program, Helena, Montana, U.S.A.

Pearson, Dean E. 1999. Small mammals of the Bitterroot National Forest: A literature review and annotated bibliography. Gen. Tech. Rep. RRS-GTR-25. Ogden, UT: U.S. Department of Agriculture, Forest Service, Rocky Mountain Research Station. 63. Pg.

Reichel, J. D. and S. G. Beckstrom. 1994. Northern bog lemming survey: 1993. Unpublished report. Montana Natural Heritage Program. Helena, MT. 87 pp.

Reichel, J. D. and J. G. Corn. 1997.Northern bog lemmings: survey, population parameters, and population analysis. Unpublished report to the Kootenai National Forest. Montana Natural Heritage Program, Helena, MT. 27 pp.

West, S. D. 1999. Northern bog lemming Synaptomys borealis. Pp. 655-656, In The Smithsonian book of North American mammals (D. E. Wilson and S. Ruff, eds.). Smithsonian Institution Press, Washington, D.C.

Wright, P. L. 1950. SYNAPTOMYS BOREALIS from Glacier National Park, Montana. J. Mammal. 31(4): 460.

10771 


\section{DRAFT WORKING DOCUMENT DO NOT DUPLICATE}

10771 10772

10773

10774

10775

10776

10777

10778

10779

10780

10781

10782

10783

10784

10785

10786

10787

10788

10789

10790

10791

10792

10793

10794

10795

10796

10797

10798

10799

10800

10801

10802

\section{Meadow Jumping Mouse (Zapus hudsonius)}

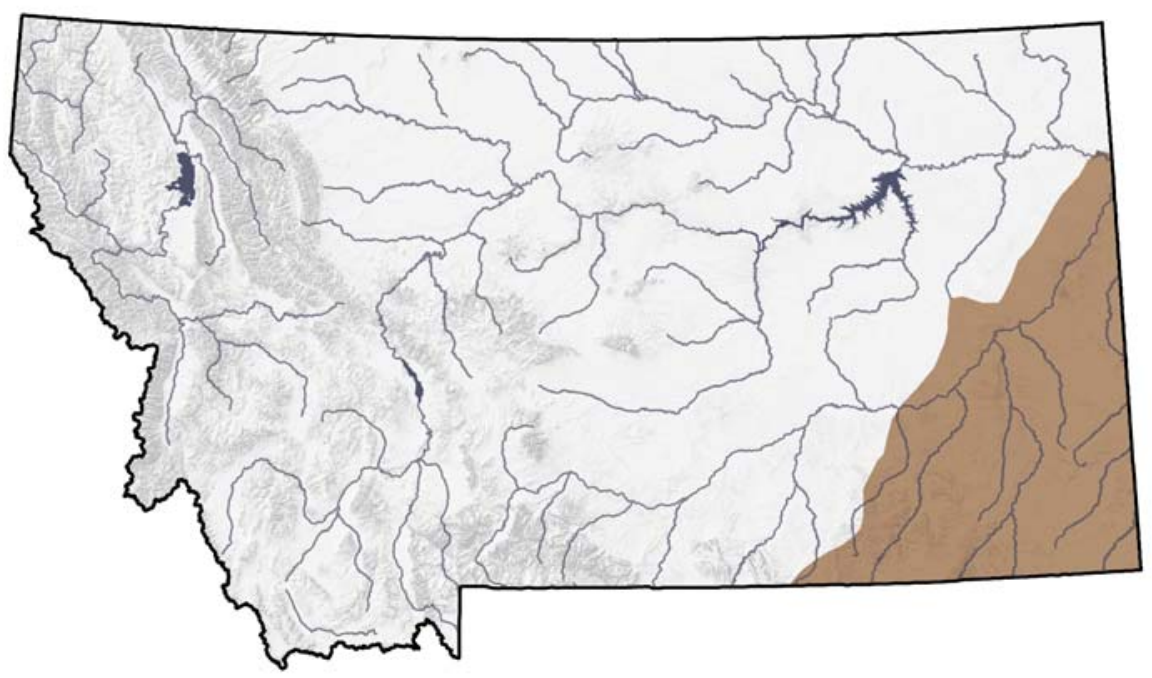

Figure 80. Distribution of the Meadow Jumping Mouse

\section{Range}

Montana is on the western edge of the global distribution in the Northern Great Plains. Meadow jumping mouse has been documented in six eastern and southeastern counties (Bighorn, Carter, Dawson, Powder River, Richland, Wibaux), at elevations to 4200 feet (1272 meters) (Foresman 2001a, Montana Natural Heritage Program database).

\section{Habitat}

In Montana, meadow jumping mice have been found in dense, tall and lush grass and forbs in marshy areas (sometimes with standing water), riparian areas, woody draws, and grassy upland slopes, sometimes within or near forested sites of ponderosa pine (Lampe et al. 1974, Matthews 1980, Matthews and Swenson 1982).

The meadow jumping mouse is generally described as a species which occupies moist lowland habitats rather than drier uplands, preferring relatively dense vegetation in open grassy and brushy areas of marshes, meadows, swamps, open conifer forest, and often favor sites bordered by small streams. On the Northern Great Plains this usually results in its restriction primarily to riparian habitats. When inactive, they occupy underground burrows, usually in banks or hills (winter), or under logs or grass clumps. Young are born in an underground nest or under other cover (Krutzsch 1954, Whitaker 1972, Jones et al. 1983).

\section{Management}


10803 No special management activities have been developed or implemented for this 10804 species in Montana. Alteration of natural surface water sources for livestock, 10805 especially free-flowing springs and seeps, could have negative impacts on 10806 10807 populations, given the preference of meadow jumping mice for grassland sites whose structure is influenced by the nearby presence of water (Lampe et al. 1974, Matthews 1980, Matthews and Swenson 1982). A thorough small mammal 10809 survey of appropriate mesic grassland, shrub-grassland, and meadow habitats in 10810 10811 10812 eastern and southeastern Montana is desirable to define the distribution and relative abundance of this species in the state.

\section{Conservation Concerns}

- Destruction of natural springs/seeps by and for livestock, and wetland conversion

- Lack of knowledge regarding immediate and long-term impacts of grazing

- Lack of data on status, distribution, habitat use, and abundance in Montana

\section{Conservation Strategies}

- Prepare conservation plan, addressing species-specific concerns and actions, or those pertaining to a suite of species with similar habitat use and needs

- Immediate protection of all springs and seeps within the potential range

- Standardized surveys to obtain estimates of population status, distribution, and habitat use, and to monitor known populations

\section{Management Plan}

None

\section{Citations}

Foresman, K. R. 2001. The wild mammals of Montana. American Society of Mammalogists, Special Publication No. 12. 278 pp.

Jones, J. K. Jr., D. M. Armstrong, R. S. Hoffmann and C Jones. 1983. Mammals of the northern Great Plains. Univ. Neb. Press, Linclon. 379 pp.

Krutzsch, P. H. 1954. North American jumping mice (genus Zapus). University of Kansas Publications, Museum of Natural History 7:349-472.

Lampe, R. P., J. K. Jones Jr., R. S. Hoffman, and E. C. Birney. 1974. The mammals of Carter County, southeastern Montana. Occa. Pap. Mus. Nat. Hist. 10848 Univ. Kan. 25:1-39. 


\section{DRAFT WORKING DOCUMENT DO NOT DUPLICATE}

10849 Matthews, W. L. 1980. The meadow jumping mouse in southeastern Montana. 10850 Prairie Nat. 12(2): 63-64.

10851

10852 Matthews, W. L., and J. E. Swenson. 1982. The Mammals of east-central

10853 Montana. Proc. Mont. Acad. Sci. 39:1-13.

10854

10855 Whitaker, J. O., Jr. 1972. ZAPUS HUDSONIUS. Am. Soc. Mamm., Mammalian 10856 Species No. 11. 7 pp.

10857

10858 


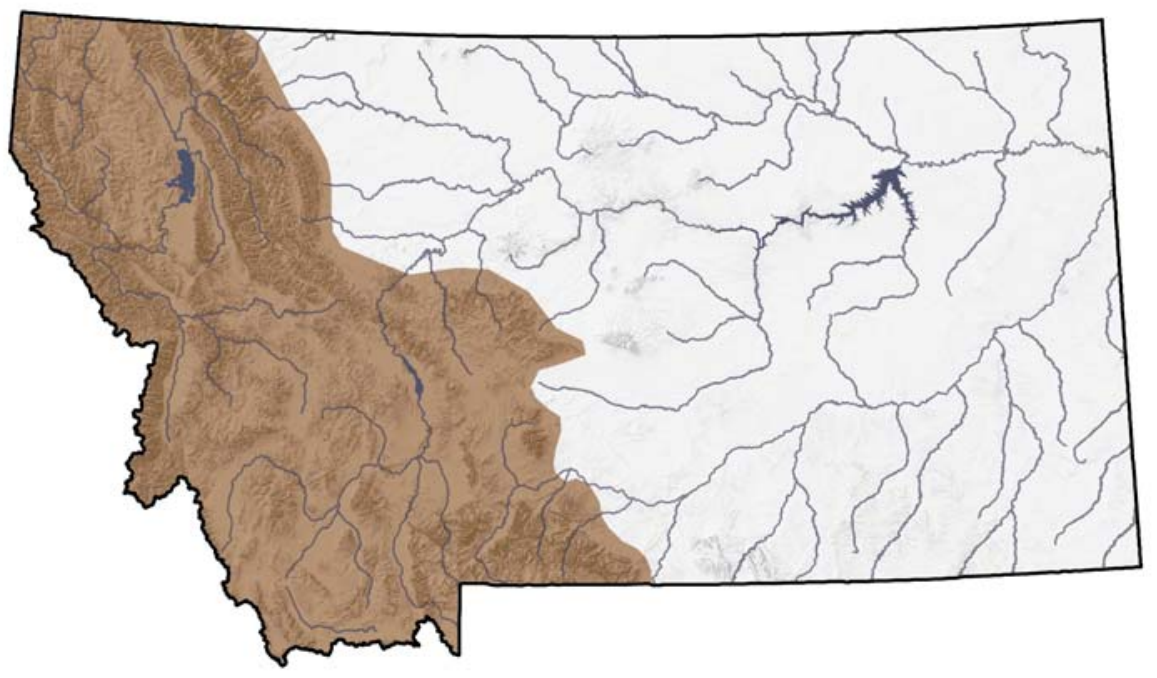

10860

10861

10862

10863

10864

10865

10866

10867

10868

10869

10870

10871

10872

10873

10874

10875

10876

10877

10878

10879

10880

10881

10882

10883

10884

10885

10886

10887

10888

10889
Figure 81. Distribution of the Gray Wolf

\section{Range}

There are three primary subpopulations in the Northern Rocky region. Natural dispersers have recolonated Northwest Montana. In 1995 and 1996, wolves were reintroduced in both Central Idaho and Yellowstone National Park. Wolves are expanding their range in Montana today. Yellowstone and Idaho wolves are expanding their range into new regions of Montana including the Bitterroot, Gravellys and Absaroka-Beartooths.

\section{Habitat}

The gray wolf exhibits no particular habitat preference. Wolves establishing new packs in Montana have demonstrated greater tolerance of human presence and disturbance than previously thought characteristic of this species (Thiel 1985, Mech et al. 1988, Mech 1989). They have established territories where prey is more abundant at lower elevations than expected, especially in winter (Montana Fish, Wildlife \& Parks 2003).

\section{Management}

Although wolves dispersing from Canada were occasionally observed, gray wolves were essentially extirpated from Montana and the rest of the western United States in the early 1900 s primarily due to conflicts with people. Wolves started recolonizing the area around Glacier National Park in 1979 and the first den documented in Montana in over 50 years was found in Glacier National Park in 1986. Wolves have since colonized much of northwestern Montana as a result of dispersal from Canada and Glacier National Park. In 1995 and 1996 wolves 


\section{DRAFT WORKING DOCUMENT DO NOT DUPLICATE}

10890 were reintroduced into Yellowstone National Park and central Idaho. Wolves

10891

10892

10893

10894

10895

10896

10897

10898

10899

10900

10901

10902

10903

10904

10905

10906

10907

10908

10909

10910

10911

10912

10913

10914

10915

10916

10917

10918

10919

10920

10921

10922

10923

10924

10925

10926

10927

10928

10929

10930

10931

10932

10933

10934

10935

resulting from these reintroductions have since expanded into areas in Montana near these reintroduction sites and continue to expand in numbers and distribution in Montana.

Gray wolves in Montana are classified under the Endangered Species Act as "threatened" in the northwest Montana recovery area and as "experimental nonessential" across the southern part of Montana. Gray wolves reached biological recovery goals for the Northern Rocky Mountains at the end of 2002. However, the process of delisting the species is currently on hold due to the lack of approved management plans from all three states. Early in 2004, the U.S. Fish and Wildlife Service approved the Montana Gray Wolf Conservation and Management Plan (Montana Fish, Wildlife \& Parks 2003). Since then, Montana Fish, Wildlife \& Parks has been increasing its role and the agency is now implementing the state's wolf conservation and management plan. Montana Fish, Wildlife \& Parks assumed that management responsibility through cooperative agreements between the two agencies. The agreements transfer legal authority to Montana Fish, Wildlife \& Parks to begin implementing as much of the state plan as allowed under federal regulations, even though wolves currently remain listed.

\section{Conservation Concerns}

- Chronic livestock-wolf interactions often result in lethal control to resolve conflicts

- Illegal human mortality

- Variable public tolerance throughout Montana landscape of ownership

\section{Conservation Strategies}

- Public outreach to increase awareness of wolf biology, conservation and management

- Monitoring to document primarytenance of a recovered population via different protocols

- Adaptive management that is dynamic with status of wolf population and distribution

- Technical assistance to private landowners to decrease potential for negative livestock-wolf interactions

\section{Management Plan}

Montana Fish, Wildlife \& Parks. 2003. Montana Gray Wolf Conservation and Management Plan.

\section{Citations}




\section{DRAFT WORKING DOCUMENT DO NOT DUPLICATE}

10936 Mech, L. D., et al. 1988. Wolf distribution and road density in Minnesota. Wildl. 10937 Soc. Bull. 16:85-87.

10938

10939

10940

10941

10942 Thiel, R. P. 1985. Relationship between road densities and wolf habitat suitability

10943 in Wisconsin. Am. Midl. Nat. 113:404-407.

10944

10945

Mech, L. D. 1989. Wolf population survival in an area of high road density. Am. Midl. Nat. 121:387-389. 


\section{Grizzly Bear (Ursus arctos horribilis)}

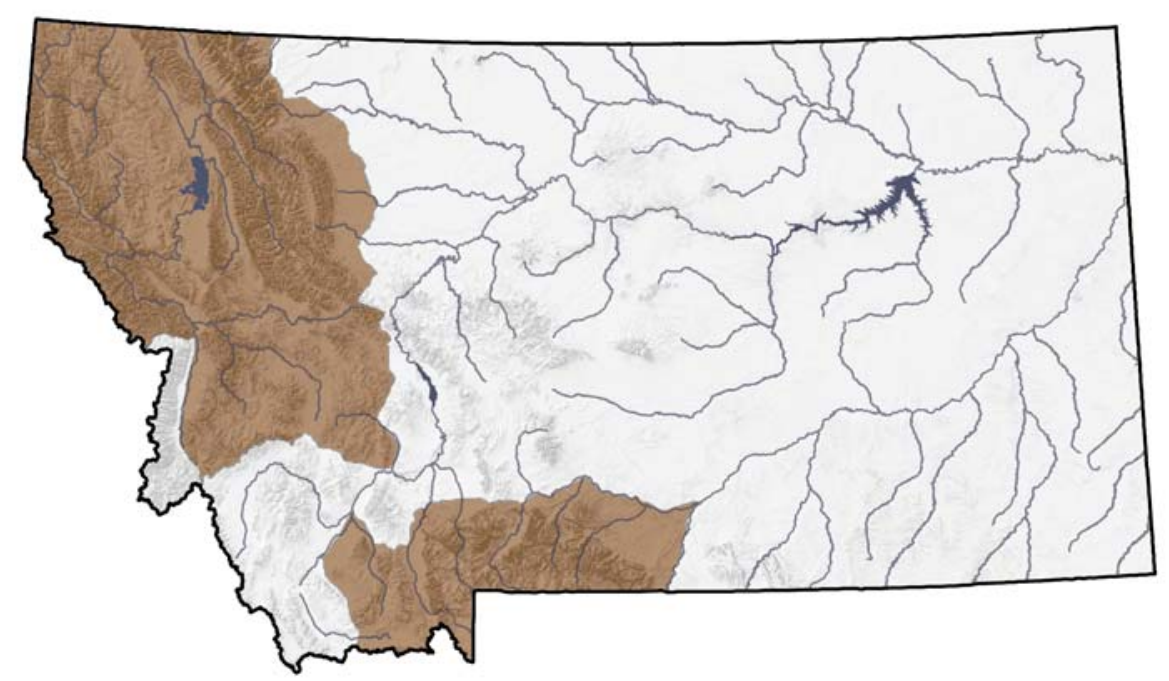

10947

10948

10949

10950

10951

10952

10953

10954

10955

10956

10957

10958

10959

10960

10961

10962

10963

10964

10965

10966

10967

10968

10969

10970

10971

10972

10973

10974

10975

10976
Figure 82. Distribution of the Grizzly Bear

\section{Range}

In Montana, grizzlies occur in Northwest Montana, extending through Glacier National Park, down the Bob Marshall Wilderness area, down to the Blackfoot River. Grizzlies are also found coming down east off the Rocky Mountain Front. Individuals may also be found in the Helena and Bitterroot National Forests. In addition, grizzlies are found in Yellowstone National Park and individuals are moving into the Absaroka-Beartooths Wilderness and in the Gallatin National Forests.

\section{Habitat}

In Montana, grizzlies primarily use meadows, seeps, riparian zones, mixed shrub fields, closed timber, open timber, side hill parks, snow chutes, and alpine slabrock habitats. Habitat use is highly variable between areas, seasons, local populations, and individuals (Servheen 1983, Craighead et al. 1982, Aune et al. 1984). Historically, the grizzly was also present on the plains occurring throughout most of eastern Montana.

\section{Management}

Current grizzly bear management throughout their range in Montana is dictated by their threatened listing under the Endangered Species Act (ESA). Under the ESA, no federal actions can cause further endangerment of grizzly bears. Federal land management agencies such as the U.S. Forest Service and the Bureau of Land Management must conduct management actions on their lands so that grizzly bears are not jeopardized. Interagency grizzly bear management 


\section{DRAFT WORKING DOCUMENT DO NOT DUPLICATE}

10977 guidelines have been developed for these managed lands. In addition, the state

10978

10979

10980

10981

10982

10983

10984

10985

10986

10987

10988

10989

10990

10991

10992

10993

10994

10995

10996

10997

10998

10999

11000

11001

11002

11003

11004

11005

11006

11007

11008

11009

11010

11011

11012

11013

11014

11015

11016

11017

11018

11019

11020

11021

11022

of Montana has a Grizzly Bear Policy (MCA 12.9.103) that outlines policy

guidelines for Montana Fish, Wildlife \& Parks to promote the conservation of

grizzly bears in Montana. Other regionally specific management plans include the Grizzly Bear Management Plan for Southwestern Montana 2002-2012 (Montana Fish, Wildlife \& Parks 2002), and various tribal, National Forest, and National Park plans and policies. Most of these management plans are centered on three major themes: management of habitat to ensure grizzly bears have large expanses of suitable interconnected lands in which to exist management of grizzly/human interactions that most often result in death for the bears (and sometimes humans) involved (this is a particularly important concern for female bears because their removal may have significant impacts on the demography of isolated populations), and research to determine the population size and trends to ensure that grizzly bear populations are not being jeopardized. Please consult any of the management plans listed above for grizzly bear management specifics.

\section{Conservation Concerns}

- Human-bear and bear-livestock interactions

- Habitat loss and fragmentation

- Genetic fragmentation among Montana populations

\section{Conservation Strategies}

- Proactive management utilizing Montana citizens

- Protection of critical habitats through easements and other methods

- Ongoing research projects, including genetic analysis projects

- Continued interagency management efforts

\section{Management Plans}

Dood, A.R., Brannon R.D., Mace, R.D. 1986. Final Programmatic Environmental Impact Statement, the Grizzly Bear in Northwestern Montana. Montana Department of Fish, Wildlife \& Parks.

Montana Fish, Wildlife \& Parks. 2002. Grizzly Bear Management Plan for Southwestern Montana 2002-2012.

Montana Fish, Wildlife \& Parks. 2001. Conservation Plan for Grizzly Bear in Montana. Pursuant to Section 6(C )(1) of the endangered species act and Montana Fish, Wildlife \& Parks Endangered Wildlife Program E-6. Montana Department of Fish, Wildlife \& Parks. 1420 East Sixth Avenue P.O. Box 200701 Helena, MT 59620

\section{Citations}




\section{DRAFT WORKING DOCUMENT DO NOT DUPLICATE}

11023

11024

11025

11026

11027

11028

11029

11030

11031

11032

11033

11034

11035
Aune, K., T. Stivers, and M. Madel. 1984. Rocky Mountain Front grizzly bear monitoring and investigation. Montana Dept. Fish, Wildl. And Parks, Helena. 239 pp.

Craighead, J.J., J. Sumner, and G. Scaggs. 1982. A definitive system for analysis of grizzly bear habitat and other wilderness resources. WildlifeWildlands Inst. Monogr. 1. Univ. Montana, Missoula, 279 pp.

Servheen, C. 1983. Grizzly bear food habits, movements and habitat selection in the Mission Mountains, Montana. J. Wildl. Manage. 47:1026-1035. 


\section{DRAFT WORKING DOCUMENT DO NOT DUPLICATE}

11035 11036

11037

11038

11039

11040

11041

11042

11043

11044

11045

11046

11047

11048

11049

11050

11051

11052

11053

11054

11055

11056

11057

11058

11059

11060

11061

11062

11063

11064

11065

11066

\section{Black-footed Ferret (Mustela nigripes)}

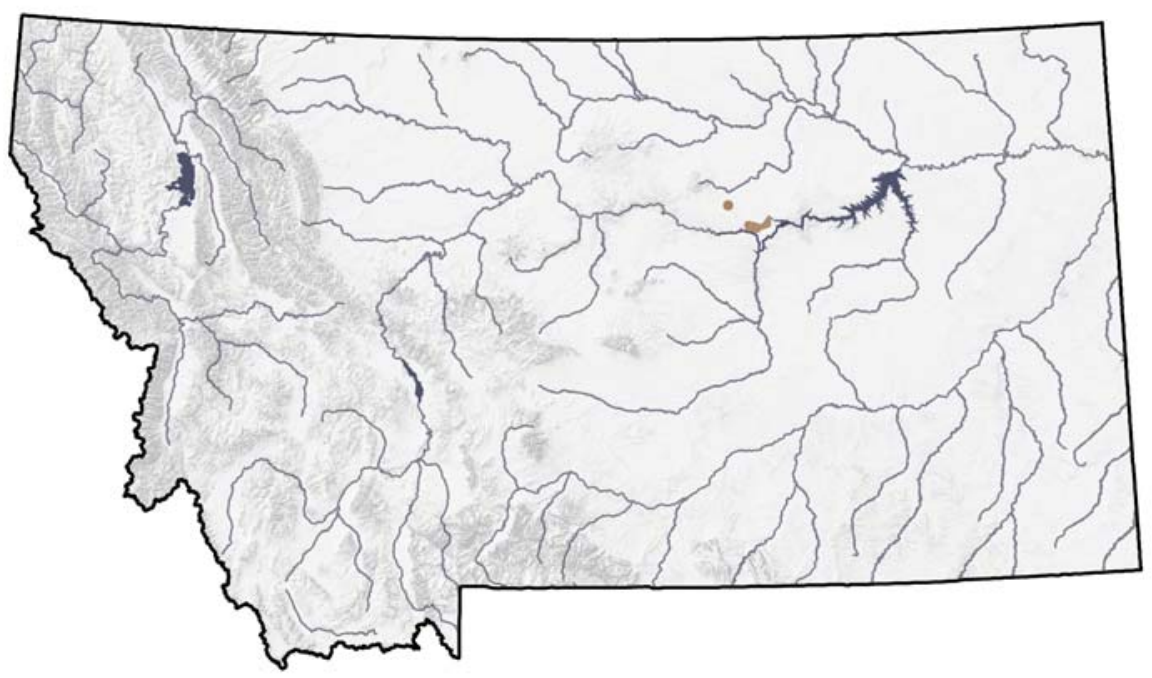

Figure 83. Distribution of the Black-footed Ferret

\section{Range}

Only a reintroduced population in southern Phillips is currently present. Historically, ferrets ranged throughout much of central and eastern Montana.

\section{Habitat}

Black-footed ferrets are intimately tied to prairie dogs (Cynomys spp.) throughout their range and have only been found in association with prairie dogs. They are therefore limited to the same open habitat used by prairie dogs: grasslands, steppe, and shrub steppe. Black-footed ferrets do not dig their own burrows and rely on abandoned prairie dog burrows for shelter. Only large complexes (several thousand acres of closely spaced colonies) can support and sustain a breeding population of black-footed ferrets. It has been estimated that about 40 to 60 hectares of prairie dog colony is needed to support one ferret, and females with litters have never been found on colonies less than 49 hectares (Miller et al. 1996). Ferrets scent-mark to maintain spatial separation (Richardson 1986).

\section{Management}

Black-footed ferrets have been extirpated from most of their former large range largely as a result of lost of habitat due to prairie dog control programs. Canine distemper, in conjunction with captures for captive breeding, resulted in extirpation of the last known wild population near Meeteetse, Wyoming by early 1987. See Miller et al. (1996) for more information on the discovery of the Meeteetse ferrets and subsequent distemper-caused decline and captive breeding decisions that occurred in 1985. All known populations are a result of 


\section{DRAFT WORKING DOCUMENT DO NOT DUPLICATE}

11067 the reintroduction of captive bred ferrets from animals taken into captivity from 11068 this population. Reintroductions have occurred annually in Montana on federal 11069 and/or tribal land since 1994 with varying success. It is unknown why 11070 11071 11072 reintroductions in Montana have not established a self-sustaining population. Predation by coyotes and badgers, and long distance dispersal may be the primary problems with the reintroduction efforts. Disease, such as sylvatic plague has also apparently resulted in deaths for released animals. Some wild reproduction has occurred but no self-sustaining populations have been established yet.

\section{Conservation Concerns}

- Loss of habitat

- Disease such as canine distemper

\section{Conservation Strategies}

- Management of prairie dogs

- Continue disease surveys

\section{Management Plans}

Anderson, M. E. et al. 1978. Black-footed ferret recovery plan. U.S. Fish and Wildlife Service Black-footed ferret Recovery Team. 150 pp.

Bureau of Land Management. 1979. Habitat management plan prairie dog ecotypes. USDI, BLM, Montana State Office. Wildlife Habitat Area MT-02-06-07S1. $61 \mathrm{pp}$.

Christopherson, D., Stoneberg, R., Matchett, R., Biggins, D., Grensten, J., Dood, A., Haglan, B. 1994. Black-footed ferret reintroduction in Montana: Project description and 1994 protocol. 31 pp + appendix.

Montana Fish, Wildlife \& Parks. 1992. North Central Montana Black-footed ferret reintroduction and management plan. Prepared by North Central Montana Working Group. 59 pp.

U.S. Fish and Wildlife Service (USFWS). 1988. Black-footed ferret recovery plan. Denver, CO. 154 pp.

U.S. Fish and Wildlife Service. 1994. Endangered and threatened wildlife and plants: Establishment of a nonessential experimental population of black-footed ferrets in north-central Montana; final rule. Federal Register 59:42696-42715.

\section{Citations}




\section{DRAFT WORKING DOCUMENT DO NOT DUPLICATE}

11113 Miller, B., R.P. Reading, and S. Forrest. 1996. Prairie Night. Smithsonian Institute 11114 Press. Washington D.C. 320 pp.

11115

11116

Richardson, L. 1986. On the track of the last black-footed ferrets. Nat. Hist. 95(2): 11117 69-77.

11118

11119 


\section{DRAFT WORKING DOCUMENT DO NOT DUPLICATE}

11119

11120

\section{Lynx (Felis lynx)}

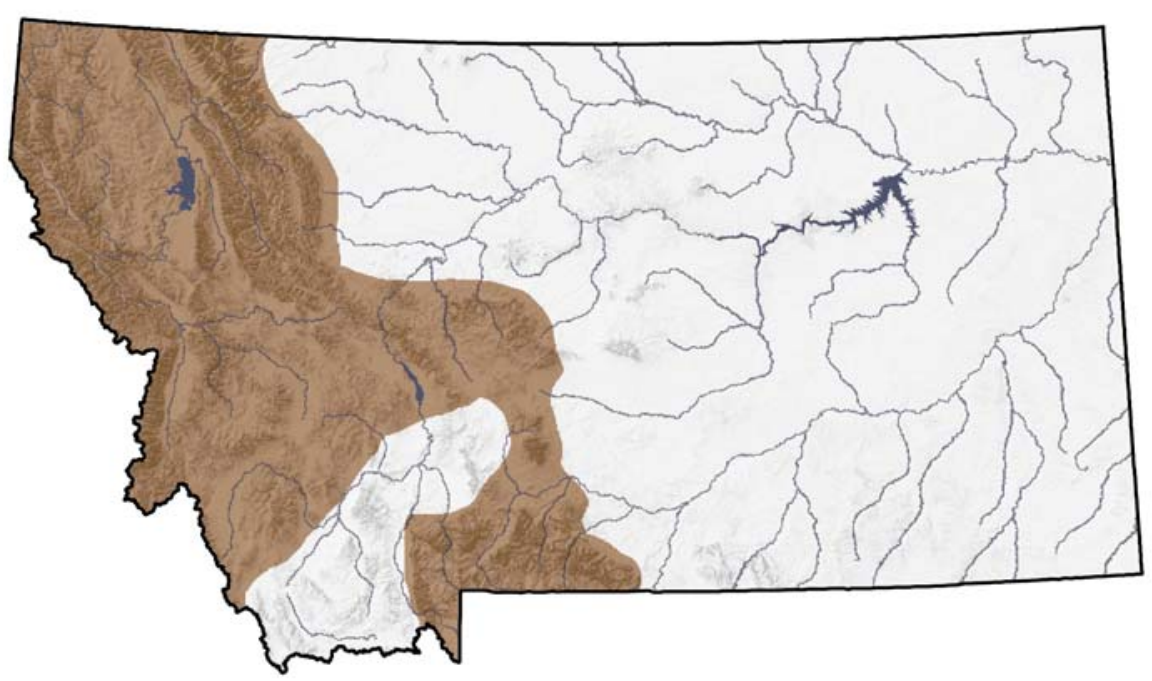

11121

11122

11123

11124

11125

11126

11127

11128

11129

11130

11131

11132

11133

11134

11135

11136

11137

11138

11139

11140

11141

11142

11143

11144

11145

11146

11147

11148

11149

11150
Figure 84. Distribution of the Lynx

\section{Range}

Canada lynx are limited to western mountains of Montana, however dispersers have been occasionally documented in eastern Montana.

\section{Habitat}

Canada lynx west of the Continental Divide generally occur in subalpine forests between 1,220 and 2,150 meters in stands composed of pure lodgepole pine but also mixed stands of subalpine fir, lodgepole pine, Douglas-fir, grand fir, western larch and hardwoods (J. Squires pers. comm. 1999 in Ruediger et al. 2000). In extreme northwestern Montana, primary vegetation may include cedar-hemlock habitat types (Ruediger et al. 2000). East of the Continental Divide the subalpine forests inhabited by lynx occur at higher elevations (1,650 to 2,400 meters) and are composed mostly of subalpine fir. Secondary habitat is intermixed Englemann spruce and Douglas-fir habitat types where lodgepole pine is a major seral species (Ruediger et al. 2000). Throughout their range, shrub-steppe habitats may provide important linkage habitat between the primary habitat types described above (Reudiger et al. 2000). Typical snow conditions are important factors for lynx, with lynx occurring primarily in habitats that also receive relatively uniform and moderately deep snowfall amounts (total annual snowfall of 100 to 127 centimeters) (Kelsall et al. 1977). Within these habitat types, disturbances that create early successional stages such as fire, insect infestations, and timber harvest, provide foraging habitat for lynx by creating forage and cover for snowshoe hares, although older forests also provide habitats for snowshoe hares and lynx for longer periods of time than disturbance-created habitats (Ruediger et al. 2000). 


\section{DRAFT WORKING DOCUMENT DO NOT DUPLICATE}

11151

11152

11153

11154

11155

11156

11157

11158

11159

11160

11161

11162

11163

11164

11165

11166

11167

11168

11169

11170

11171

11172

11173

11174

11175

11176

11177

11178

11179

11180

11181

11182

11183

11184

11185

11186

11187

11188

11189

11190

11191

11192

11193

11194

11195

11196
Canada lynx avoid large openings but often hunt along edges in areas of dense cover (Ruediger et al. 2000). When inactive or birthing, they occupy dens typically in hollow trees, under stumps, or in thick brush. Den sites tend to be in mature or old-growth stands with a high density of logs (Koehler 1990, Koehler and Brittell 1990). These habitats must be near or adjacent to foraging habitat because the hunting range of the female is reduced during this time (Ruediger et al. 2000).

In the South Fork Flathead, lynx were mostly located in fire-created, densely stocked young stands of lodgepole pine where snowshoe hares were most abundant. No locations in open or semi-open areas were observed (Koehler at al. 1979). In the Garnet Range, most were found in subalpine fir forest (Smith 1984). Denning sites are found in mature and old-growth lodgepole pine, spruce, and subalpine fir forests with a high density of logs (Koehler 1990, Koehler and Brittell 1990). Denning stands need not be large (1 to 3 hectares) but several stands should be interconnected (Koehler and Brittell 1990). Lynx require cover for stalking and security, and usually do not cross openings wider than 100 meters (Koehler and Brittell 1990).

\section{Management}

Canada lynx are classified as a furbearer in Montana but the trapping season is currently closed in Montana. Any lynx accidentally trapped must be released uninjured and reported to designated Fish, Wildlife \& Parks employees within the trapping district within five days. Any lynx trapped that cannot be released unharmed must be reported to Fish, Wildlife \& Parks for assistance to determine disposition and/or collection of the animal. The Canada Lynx was listed as a threatened species under the Endangered Species Act in the contiguous United States in 2000 because of the inadequacy of guidance for conservation of lynx in the National Forest Land and Resource Management Plans and Bureau of Land Management Land Use Plans (Reudiger et al. 2000). Subsequently, the Canada Lynx Conservation Assessment and Strategy (Reudiger et al. 2000) was produced to provide guidance for conservation measures on federally managed lands to ensure that lynx populations were not jeopardized by management of critical habitat. Please consult the plan for details of this strategy.

\section{Conservation Concerns}

- Habitat, specifically conifer loss and destruction

- Fragmented landscapes suppress principle prey (snowshoe hare) populations

- Road construction decreases connectivity and movement and increases potential for human disturbance

- Grazing increases competition for forage resources with lynx prey 


\section{DRAFT WORKING DOCUMENT DO NOT DUPLICATE}

11197

11198

11199

11200

11201

11202

11203

11204

11205

11206

11207

11208

11209

11210

11211

11212

11213

11214

11215

11216

11217

11218

11219

11220

11221

11222

11223

11224

11225

11226

11227

11228

11229

11230

\section{Conservation Strategies}

- Adequate management strategies between agencies to protect dense tree stands

- Conserve contiguous tracks of habitat

- Continue research on prey base such as snowshoe hare and red squirrel

- Maintain natural mosaic of forest by allowing low to medium level fires

- Manage forests for sustainable livestock grazing

\section{Management Plan}

Ruediger, Bill \& 14 others on Lynx Biology Team. 2000. Canada Lynx Conservation Assessment and Strategy. 120 pp.

\section{Citations}

Kelsall, J. P., E. S. Telfar, and T. D. Wright. 1977. The effects of fire on the ecology of the boreal forest, with particular reference to the Canadian north: a review and selected bibliography. Canadian Wildlife Service, Occasional Paper No. 32. Ottawa, Canada.

Koehler, G. M. and J. D. Brittell. 1990. Managing spruce-fir habitat for lynx and snowshoe hares. Journal of Forestry, October 1990.

Koehler, G. M., M. G. Hornocker, and H. S. Hash. 1979. Lynx movements and habitat use in Montana. Canadian Field-Naturalist 93(4): 441-442.

Paige, L.C. 2000. America's Wildlife: The Challenge Ahead. International Association of Fish and Wildlife Agencies. Washington, D.C.

Smith, D. S. 1984. Habitat use, home range, and movements of bobcats in western Montana. M.S. thesis. University of Montana, Missoula. 58 pp. 


\section{DRAFT WORKING DOCUMENT DO NOT DUPLICATE}

11230

11231

11232

11233

11234

11235

11236

11237

11238

11239

11240

11241

11242

11243

11244

11245

11246

11247

11248

11249

11250

11251

11252

11253

11254

11255

11256

11257

11258

11259

11260

11261

\section{American Bison (Bos bison)}

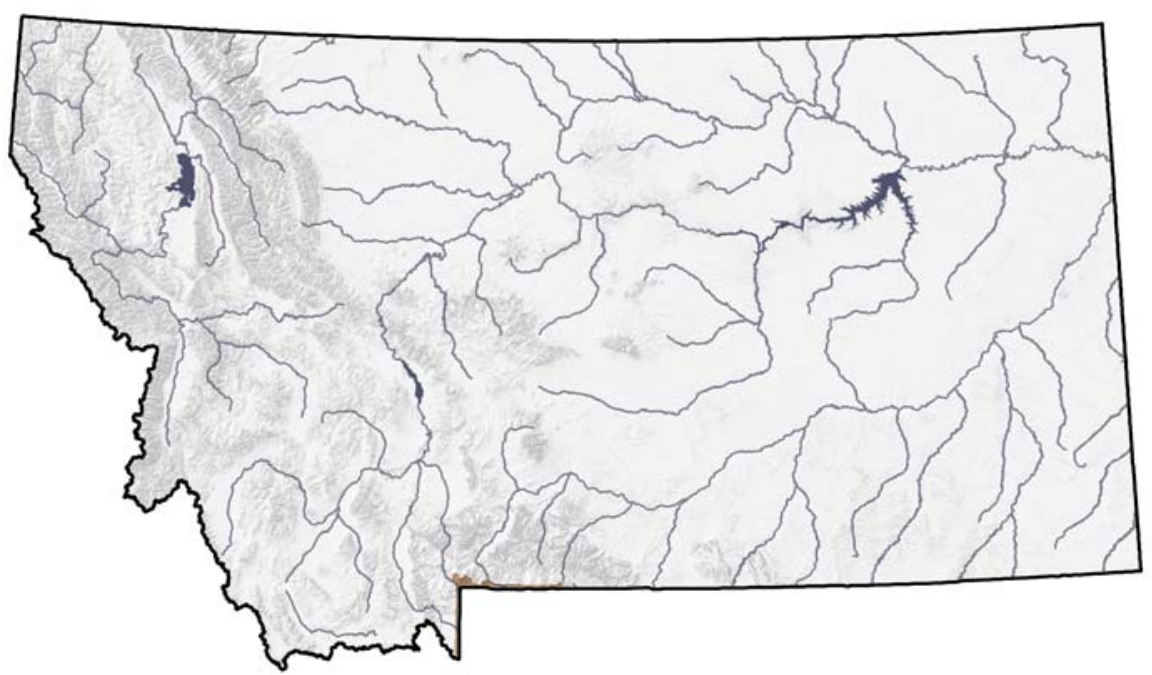

Figure 85. Distribution of the American Bison

\section{Range}

Free-ranging American bison in Montana are located only in areas surrounding Yellowstone National Park. Another semi-wild population occurs at the National Bison Range in northwestern Montana. American bison are also located on private ranches throughout Montana. The animals in Yellowstone National Park are partially descended from animals originally found in the park. Intervention has led to a genetically diverse a population with genetics derived from bison imported in the early 1900s mixed with remnant native bison following the great reduction in the 1800s. Other bison descended from 5 founder herds captured in various portions of the bison's former range, including Canada. Some were caught along the Milk River in Montana (Pattie and Hoffman 1992). American bison were formerly widespread in North America from Alaska and western Canada across the U.S. into northern Mexico.

Some American bison migrate out of Yellowstone National Park during the winter and these movements are more frequent and involve greater numbers of animals during years of heavy snow when populations are high, generally over 3000 individuals (National Academy of Sciences 1998). Recently, (1985-1986) harvest has resumed in response to Montana movements out of Yellowstone National Park. American bison at the National Bison Range are confined to the range and no migration is possible. This species previously made mass migrations across the prairie in spring and fall, with mountain populations moving to lower elevations in valleys.

Taxonomists recognize two subspecies of Bison, the plains and woodland bison that have distinct differences in habitat preference and historic range. 


\section{DRAFT WORKING DOCUMENT DO NOT DUPLICATE}

11262

11263

11264

11265

11266

11267

11268

11269

11270

11271

11272

11273

11274

11275

11276

11277

11278

11279

11280

11281

11282

11283

11284

11285

11286

11287

11288

11289

11290

11291

11292

11293

11294

11295

11296

11297

11298

11299

11300

11301

11302

11303

11304

11305

11306

\section{Habitat}

Because of restrictions, currently occupied habitat does not reflect the full natural range for American bison. Throughout their range, American bison inhabit woodlands and open plains and grasslands. Woodlands and openings in boreal forest, meadows, and river valleys are used in the northern parts of their range. Like other large grazers, they are attracted to burn areas the next growing season (Shaw and Carter 1990). During the growing season at the Konza Prairie in northeastern Kansas, they preferred areas that had been burned in spring. Summer grazing was concentrated in large watershed area (79 to 119 hectares) dominated by warm-season, perennial $\mathrm{C} 4$ grasses. In fall and winter, they grazed both burned and unburned watersheds more uniformly, but grazed most intensively in areas with large stands of cool-season, C3 grasses (Vinton et al. 1993).

\section{Management}

Management of free-ranging American bison in Montana has been controversial. The presence of brucellosis in these animals and their migration out of Yellowstone National Park into adjacent public and private lands has led to conflicts between private landowners, citizens, public administrative agencies and public land management agencies. Free-ranging herds in Montana are currently managed under the Interagency Bison Management Plan. The current distribution of Yellowstone National Park bison and the management potential of this herd is limited to several very small areas outside of Yellowstone National Park where they can be tolerated and will not pose a disease risk to cattle grazing on surrounding habitats. It is unlikely that the distribution of bison in the Greater Yellowstone Area will dramatically change until brucellosis is eliminated from the herd. Efforts are currently being explored to isolate a brucellosis free population with acceptable genetics in order to establish free ranging herds outside Yellowstone National Park. Establishing this type of herd would require extensive cooperation from various federal and state agencies and private partners. If successful, these herds could serve to help restore the ecology of many community types in greatest need of conservation such as grassland complexes, mixed shrub/grass associations, woody draws and mixed broadleaf forests. Along with the restoration of these community types many associated species in greatest need of conservation could benefit (ex. prairie dogs, blackfooted ferrets, and swift fox).

\section{Conservation Concerns}

- Decreased natural areas for free roaming herds

- Disease (Brucellosis)

- Control issues for bison moving in and out of Yellowstone National Park 


\section{DRAFT WORKING DOCUMENT DO NOT DUPLICATE}

11307

11308

11309

11310

11311

11312

11313

11314

11315

11316

11317

11318

11319

11320

11321

11322

11323

11324

11325

11326

11327

11328

11329

11330

11331

11332

11333

11334

11335

11336

11337

11338

11339

11340

11341

11342

11343

11344

11345

11346

11347

11348

11349

11350

11351
- Although suitable habitat exists, the Bison is ecologically extinct outside Yellowstone National Park

- Bison Genome has been eroded by unnatural management practices and introgression with domestic cattle genes

- Exclusion of Bison from management plans as part of the natural mammalian fauna in Montana eligible for regulated harvest

\section{Conservation Strategies}

- Establish a free ranging disease free Bison populations in suitable grassland habitats where they can function ecologically and operate as keystone species to restore grassland systems

- Preserve wild Bison genome through herd expansion and restoration projects in North America

- Continue development of working relationships with landowners

- Brucellosis control

- Create populations of wild bison that can be harvested and provide economic and social benefits to Montana

\section{Management Plan}

USDI National Park Service. 2000, Bison Management for the State of Montana and Yellowstone National Park. Final Environmental Impact Statement for the Interagency Bison Management Plan for the State of Montana and Yellowstone National Park. Vol. I. August 2000.

\section{Citations}

Keiter, R. B. 1997. Greater Yellowstone's Bison: unraveling of an early American Wildlife Conservation achievement. J. Wildlife Management 61:1-11.

National Academy of Sciences. 1998. Brucellosis in the Greater Yellowstone Area, by N.F. Cheville, D. R. McCullough, and L.R. Paulson. Washington, DC: National Academy Press.

Pattie, D. L. and R.S. Hoffmann. 1992. Mammals of the North American Parks and Prairies. Self published.

Shaw, J. A. and T. S. Carter. 1990. Bison movements in relation to fire and seasonality. Wildl. Soc. Bull. 18:426-430.

Vinton, M. A., D.C. Hartnett, E.J. Finck and J.M. Briggs. 1993. Interactive effects of fire, bison (Bison bison) grazing and plant community composition in tallgrass prairie. Am. Midl. Nat. 129:10-18. 


\section{DRAFT WORKING DOCUMENT DO NOT DUPLICATE}

\section{Fish}

11355

11356

11357

11358

11359

11360

11361

11362

11363

11364

11365

11366

11367

11368

11369

11370

11371

11372

11373

11374

11375

11376

11377

11378

11379

11380

11381

11382

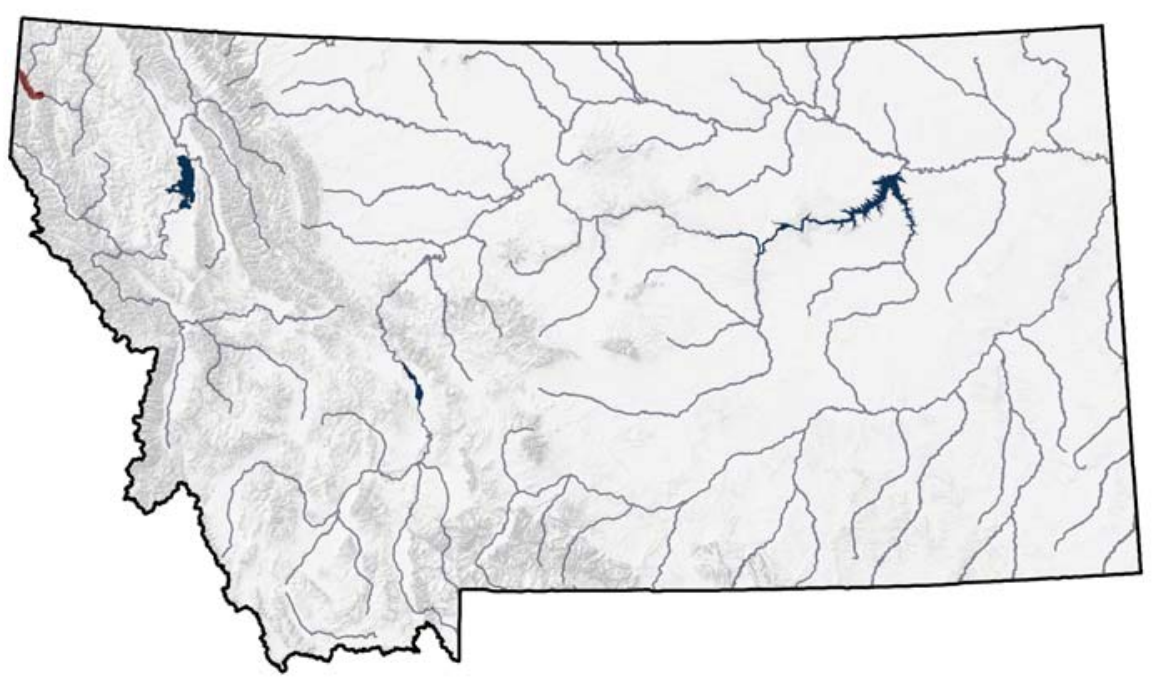

Figure 86. Distribution of the White Sturgeon

\section{Range}

The range extends from Kootenai Falls, Montana, located 50 river kilometers downstream of Libby Dam, to Corra Linn Dam at the outlet from Kootenay Lake, British Columbia. A natural barrier at Bonnington Falls downstream of Kootenay Lake isolated the white sturgeon in the Kootenai River from other populations in the Columbia River since the last ice age approximately 10,000 years ago (Alden 1953, Northcote 1973, Duke et al. 1999, USFWS 1999) (AFS website 2003).

\section{Habitat}

The white sturgeon is landlocked in Montana and live in large cool rivers (Kootenai).

\section{Management}

Recovery of the white sturgeon population in the Kootenai River is contingent upon re-establishing natural recruitment, minimizing additional loss of genetic variability, and successfully mitigating biological and habitat alterations that continue to harm the population. The White Sturgeon Recovery Plan (USFWS 1999) recommends simultaneous implementation of three high priority recovery approaches: 1) augment spring flows in the Kootenai River to enhance natural production; 2) implement a conservation aquaculture program to prevent extinction and preserve genetic variability; and 3) re-establish suitable habitat conditions to increase white sturgeon survival past the embryonic and larval 


\section{DRAFT WORKING DOCUMENT DO NOT DUPLICATE}

11383

11384

11385

11386

11387

11388

11389

11390

11391

11392

11393

11394

11395

11396

11397

11398

11399

11400

11401

11402

11403

11404

11405

11406

11407

11408

11409

11410

11411

11412

11413

11414

11415

11416

11417

11418

11419

11420

11421

11422

11423

11424

11425

11426

11427 stages (AFS website 2003). The Kootenai River White Sturgeon Study and Conservation Aquaculture Project was initiated to preserve the genetic variability of the population, begin rebuilding natural age class structure, and prevent extinction while measures are implemented to restore natural recruitment (Anders and Westerhof 1996, USFWS 1999, Ireland 2000, Ireland et al. 2001 in press). A breeding plan has been implemented to guide management in the systematic collection and spawning of wild adults before they are lost from the breeding population (Kincaid 1993). The implementation of the breeding plan includes measures to minimize potential detrimental effects of conventional stocking programs (AFS website 2003).

\section{Conservation Concerns}

- Reduced spring flows, unnatural flow fluctuations and altered thermal regime caused by Libby Dam operation, may have interrupted spawning behavior and recruitment

- A suite of post-fertilization early life mortality factors (embryo suffocation, predation on early life stages, resource limitation) and possible intermittent female stock limitation have been reported as possibly contributing to observed recruitment failure for Kootenai River white sturgeon

- Habitat conditions in the spawning areas may also affect spawning and rearing success. Cessation of periodic flushing flows has allowed fine sediments to build up in the Kootenai River bottom substrates. Fine sediments fill interstitial spaces in riverbed cobbles, reducing fish egg survival, larval and juvenile fish security, cover and insect production

\section{Conservation Strategies}

- Coordinate flow fluctuations in Libby Dam as more natural

- Habitat conservation of surrounding terrestrial habitat

- Decrease fine sediments found in lake area

- Management of non-native species which may prey on young white sturgeon

\section{Management Plan}

U.S. Department of Interior, Fish and Wildlife Service. 1999. White Sturgeon; Kootenai River Population Recovery Plan. Region 1, USFWS, Portland, Oregon.

\section{Citations}

Alden, W. C. 1953. Physiographic and glacial geology of Western Montana and adjacent areas. Geological Survey Professional Paper 231. U.S. Government Printing Office. 


\section{DRAFT WORKING DOCUMENT DO NOT DUPLICATE}

11428

11429

11430

11431

11432

11433

11434

11435

11436

11437

11438

11439

11440

11441

11442

11443

11444

11445

11446

11447

11448

11449

11450

11451

11452

11453

11454

11455

11456

11457

11458

11459

11460

11461

11462

11463

11464

11465

11466

11467

11468

11469

11470

11471

11472
American Fisheries Society Montana Chapter website.

http://www.fisheries.org/AFSmontana/SSCintermountain/foothill grassland/White\%20Sturgeon\%20Status.htm

Anders, P. J., and D. L. Richards. 1996. Implications of ecotype collapse on white sturgeon (Acipenser transmontanus) in the Kootenai River, Idaho, Montana, and British Columbia. Intermountain/foothill grassland 27-40 in Proceedings from the International Congress on the Biology of Fishes: Culture and Management of Sturgeon and Paddlefish Symposium Proceedings. San Francisco State University, July 14-18, 1996.

Anders, P. J., and R. E. Westerhof. 1996. Conservation aquaculture of endangered white sturgeon (Acipenser transmontanus) in the Kootenai River, Idaho. Intermountain/foothill grassland 51-62 in Proceedings from the International Congress on the Biology of Fishes: Culture and Management of Sturgeon and Paddlefish Symposium Proceedings. San Francisco State University, July 14-18, 1996.

Apperson, K.A. and P.J. Anders. 1990. Kootenai River white sturgeon investigations and experimental culture. Annual Progress Report FY 1989. Idaho Department of Fish and Game and the Bonneville Power Administration. Contract No. DE-AI79-88BP93497; Project No. 88-65. Portland, Oregon. 67 pp.

Apperson, K.A. and P. J. Anders. 1991. Kootenai River white sturgeon investigations and experimental culture. Annual Progress Report FY 1990. Bonneville Power Administration. 75 pp.

Duke, S., P. Anders, G. Ennis, R. Hallock, J. Hammond, S. Ireland, J. Laufle, L. Lockard, B. Marotz, V. Paragamian, and R. Westerhof. 1999. Recovery plan for Kootenai River white sturgeon (Acipenser transmontanus). Journal of Applied Ichthyology (15): 157-163.

Ireland, S.C. 2000. Kootenai River White Sturgeon Studies and Conservation Aquaculture. Annual Progress Report. Prepared for U.S. Department of Energy, Bonneville Power Administration. Contract No. 88 BI 93743; Project No. 88-64. Portland, Oregon.

Kincaid, M.L. 1993. A breeding plan to preserve the genetic variability of the Kootenai River white sturgeon. Contract No. DE-Al79-93BP02886. Bonneville Power Administration, Portland, Oregon.

Korman, J., and C. J. Walters. 1999. Summary of the Kootenai River Adaptive Environmental Assessment modeling exercise. Prepared for the Kootenai Tribe of Idaho. Ecometric Research Inc. Vancouver, British Columbia, Canada. 


\section{DRAFT WORKING DOCUMENT DO NOT DUPLICATE}

11473 Northcote, T. G. 1973. Some impacts of man on Kootenay Lake and its 11474 salmonids. Great Lakes Fisheries Commission Tech. Rep. 25

11475

11476 


\section{DRAFT WORKING DOCUMENT DO NOT DUPLICATE}

11476 11477

11478

11479

11480

11481

11482

11483

11484

11485

11486

11487

11488

11489

11490

11491

11492

11493

11494

11495

11496

11497

11498

11499

11500

11501

11502

11503

11504

11505

11506

11507

\section{Pallid Sturgeon (Scaphirhynchus albus)}

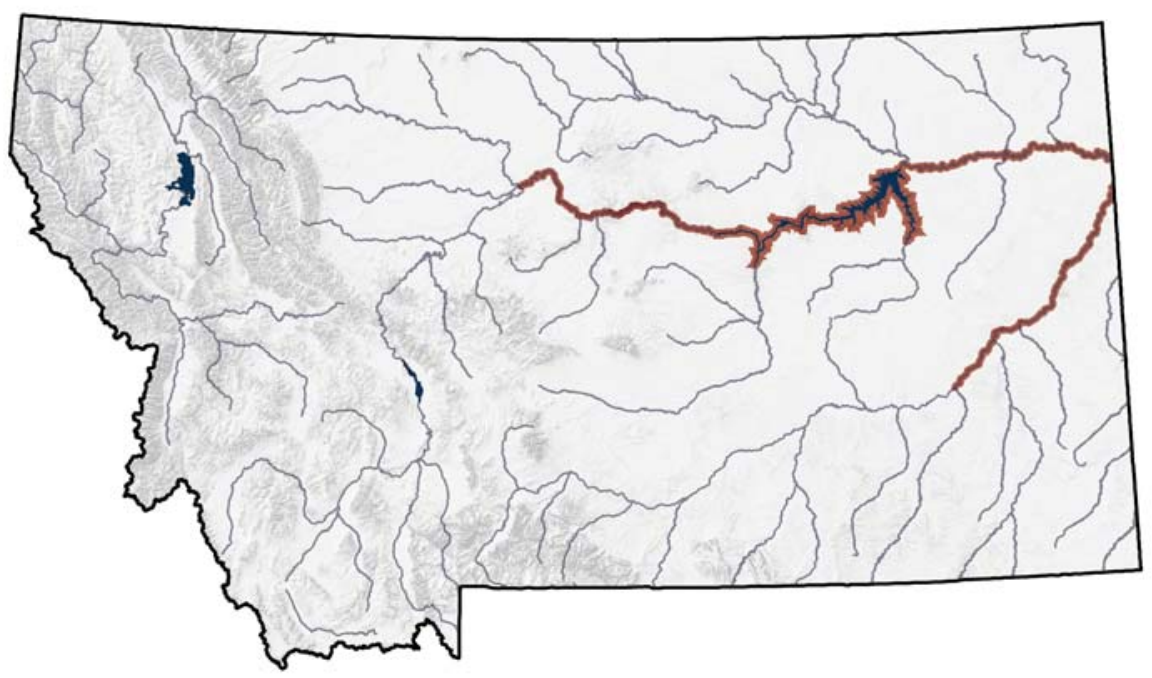

Figure 87. Distribution of the Pallid Sturgeon

\section{Range}

Pallid sturgeons are native in major rivers in eastern Montana including the Missouri River below Fort Benton and the Yellowstone River below the Carterville Diversion Dam near Forsyth.

\section{Habitat}

Pallid sturgeon use large, turbid rivers over sand and gravel bottoms, usually in strong current; also impoundments of these rivers (FWP). In Montana, pallid sturgeon use large turbid streams including the Missouri and Yellowstone rivers (Brown 1971, Flath 1981). They use all channel types, primarily straight reaches with islands (Bramblett 1996). They primarily use areas with substrates containing sand (especially bottom sand dune formations) and fines (93\% of observations) (Bramblett 1996). Stream bottom velocities ranged between 0.0 and 1.37 meters per second, with an average of 0.65 meter per second (Bramblett 1996). Depths used were 0.6 to 14.5 meters and averaged 3.30 meters, and they appeared to move deeper during the day (Bramblett 1996). Channel widths from 110 to 1100 meters are used and average 324 meters (Bramblett 1996). Water temperatures used ranged from 2.8 to 20 degrees C. (Tews 1994, Bramblett 1996). Water turbidity ranged from 12 to 6400 NTU (Turbidity Units) (Tews 1994).

\section{Management}

Beginning in 1996, research efforts focused on pallid sturgeon recovery and preserving the pallid sturgeon genetic pool through stocking. The primary 


\section{DRAFT WORKING DOCUMENT DO NOT DUPLICATE}

11508

11509

11510

11511

11512

11513

11514

11515

11516

11517

11518

11519

11520

11521

11522

11523

11524

11525

11526

11527

11528

11529

11530

11531

11532

11533

11534

11535

11536

11537

11538

11539

11540

11541

11542

11543

11544

11545

11546

11547

11548

11549

11550

11551

11552

11553 purpose of the stocking program is to preserve the genetic pool and reconstruct an optimal population size within the habitat's carrying capacity (Krentz 1997a) (AFS website 2003). One of the most obvious detrimental changes in the pallid sturgeon environment was the damming of the Missouri River and several other important tributaries. Efforts are now being directed at restoring the river to a more normal condition. In 2000, the U.S. Fish and Wildlife Service (USFWS) completed an Endangered Species Act consultation with the U.S. Army Corps of Engineers regarding operation of Missouri River dams. Through an informal agreement the U.S. Bureau of Reclamation (BOR) has agreed to provide a dominant discharge spring pulse out of Tiber Reservoir every 4 to 5 years for Missouri River fish migrations which could help the Upper Missouri River pallid sturgeon population. To address pallid sturgeon passage and entrainment on the Yellowstone River, the USFWS has begun consultation with BOR regarding problems at Intake Diversion Dam. The future for pallid sturgeon recovery may continue to be uncertain even after positive changes have been implemented because pallid sturgeon populations are so depleted and the newly stocked fish will take at least 15 years before the females first reach sexual maturity and begin to spawn. Therefore, it is important to realize that immediate evaluations are impractical and recovery will take a dedicated, long-term commitment (AFS website 2003). Implementing the pallid sturgeon recovery program in this area is a multi-state and agency task. To facilitate this, the Montana/Dakota Pallid Sturgeon workgroup was organized in 1993. The group is comprised of representatives from FWP, NDGF, USFWS, USBOR, WAPA and PPL-MT, and acts in an advisory role identifying research needs and funding sources, developing work plans and providing an opportunity for communication between biologists and agency personnel (AFS website 2003).

\section{Conservation Concerns}

- Habitat modifications such as dams prevent movement to spawning and feeding areas, alter flow regimes, turbidity, and temperature, and reduce food supply

- Upstream and nearby, land use practices may degrade water quality

- Heavy metals and organic compounds may affect reproduction

- Hybridization with shovelnose sturgeon, possibly caused by reductions in habitat diversity

\section{Conservation Strategies}

- Movement of pallid sturgeons between upstream and downstream sections of dam impoundments

- Increased regulations of land use practice near riparian zones

- Increased regulations on point source runoff into streams 


\section{DRAFT WORKING DOCUMENT DO NOT DUPLICATE}

\section{Management Plan}

11555

11556

11557

11558

11559

11560

11561

11562

11563

11564

11565

11566

11567

11568

11569

11570

11571

11572

11573

11574

11575

11576

11577

11578

11579

11580

11581

11582

11583

11584

11585

11586

11587

11588
Dryer, M.P. and A.J. Sandvol. 1993. Recovery plan for the pallid sturgeon (Scaphirhynchus albus). U.S. Fish and Wildlife Service. Bismarck, ND. 55 pp.

\section{Citations}

American Fisheries Society (AFS), Montana Chapter Website.

Bramblett, R.G. 1996. Habitats and movements of pallid and shovelnose sturgeon in the Yellowstone and Missouri rivers, Montana and North Dakota. Ph. D. dissertation. Montana State University, Bozeman. 210 pp.

Brown, C. J. D. 1971. Fishes of Montana. Big Sky Books. Montana State University-Bozeman.

Flath, D. L. 1981. Vertebrate species of special concern. Montana Department of Fish, Wildlife, and Parks. 74 pp.

Keenlyne, K.D. 1989. A report on the pallid sturgeon. U. S. Fish and Wildlife Service, Pierre, South Dakota. Unpublished report.

Krentz, Steven. 1997a. Stocking/augmentation plan for the pallid sturgeon (Scaphirhynchus albus) in Recovery Priority Management Areas 1 and 2 in Montana and North Dakota. U.S. Fish and Wildlife Service. Bismarck. 38 pp.

Ruelle, R., and K. D. Keenlyne. 1991. A contaminant evaluation of Missouri River pallid sturgeon. U.S. Fish and Wildlife Service. Pierre, South Dakota. 25 pp.

Tews, A. 1994. Pallid sturgeon and shovelnose sturgeon in the Missouri River from Fort Peck dam to Lake Sacagawea and in the Yellowstone River from Intake to its mouth. Fort Peck Pallid Sturgeon Study. Submitted to U.S. Army Corps of Engineers, Planning Branch, Omaha, NE. 


\section{DRAFT WORKING DOCUMENT DO NOT DUPLICATE}

11588 11589

11590

11591

11592

11593

11594

11595

11596

11597

11598

11599

11600

11601

11602

11603

11604

11605

11606

11607

11608

11609

11610

11611

11612

11613

11614

11615

11616

11617

11618

11619

\section{Paddlefish (Polyodon spathula)}

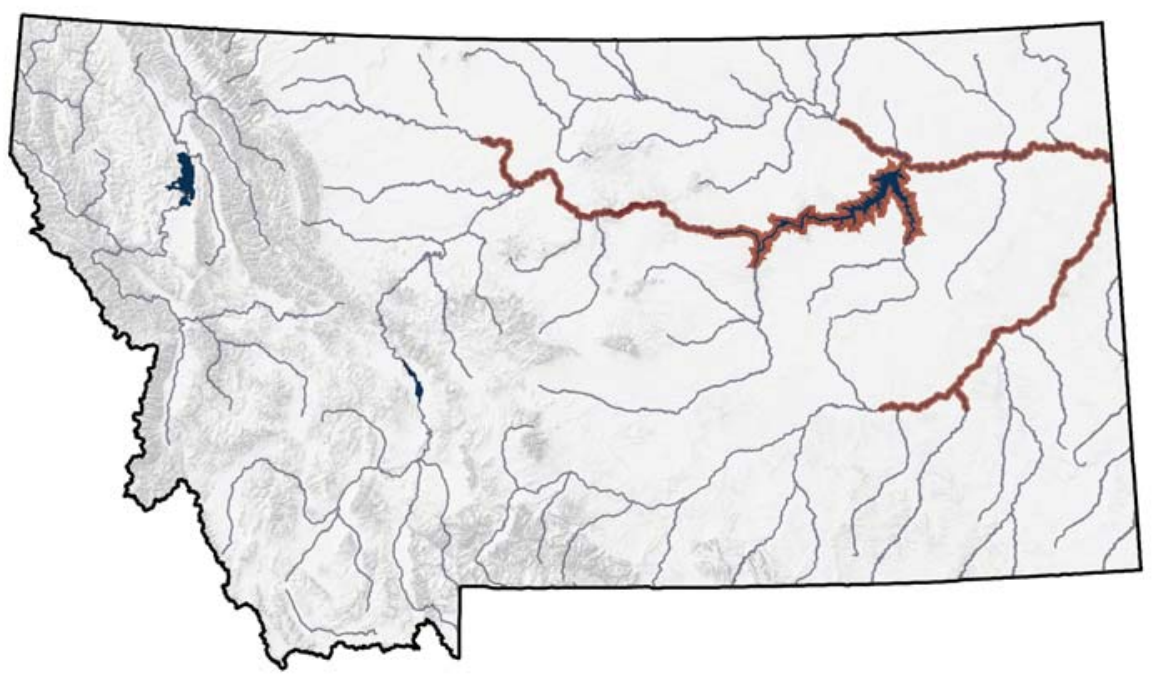

Figure 88. Distribution of the Paddlefish

\section{Range}

In Montana, two distinct paddlefish stocks are recognized. The YellowstoneSakakawea stock is distributed from the eastern boundary of the state up the Yellowstone River westward to the Cartersville Diversion Dam at Forsyth, as well as up the Missouri River westward to Fort Peck Dam (Scarnecchia et al. 1996b; Holton 2003). Most fish of this stock rear in Lake Sakakawea, a Missouri River mainstem reservoir in North Dakota (Fredericks and Scarnecchia 1997;

Scarnecchia et al. 1997), and ascend the two rivers (mainly the Yellowstone) into Montana in spring to spawn (Firehammer 2004). Upriver distribution is more westerly in years of higher discharge. A few fish reside year-round in the Dredge Cuts below Fort Peck Dam. An important recreational snag fishery exists for this stock at the Intake Diversion Dam, near Glendive (Montana-North Dakota Paddlefish Management Plan 1995). Other sites on the Yellowstone River (e.g., Sidney Bridge, Richland Park, State Line) and on Missouri River below Fort Peck Dam (e.g., Wolf Point, Frazer Rapids) also are fished. A modest bow-and-arrow fishery also exists in the Dredge Cuts.

The Fort Peck stock is distributed from Fort Peck Dam up the Missouri River westward at least as far as the mouth of the Marias River (Berg 1981). Most fish of this stock rear in Fort Peck Reservoir, and ascend the river in spring to spawn. Upriver distribution is more westerly in years of higher discharge. Since the closure of Fort Peck Dam, Fort Peck stock fish have been isolated from fish below the dam, although some upriver fish can pass downstream. An important recreational snag fishery exists for this stock at several sites near the Fred Robinson Bridge (Scarnecchia et al. 2000). 


\section{DRAFT WORKING DOCUMENT DO NOT DUPLICATE}

\section{Habitat}

11621

11622

11623

11624

11625

11626

11627

11628

11629

11630

11631

11632

11633

11634

11635

11636

11637

11638

11639

11640

11641

11642

11643

11644

11645

11646

11647

11648

11649

11650

11651

11652

11653

11654

11655

11656

11657

11658

11659

11660

11661

11662

11663

11664

11665
The paddlefish is a large river species that utilizes a wide variety of habitats seasonally and at different life stages. Optimal spawning habitat consists mainly of turbid, faster flowing main channel areas with gravel substrates, whereas feeding habitat is typically slower moving backwaters, side-channels and sloughs where their zooplanktonic food is more abundant. In the twentieth century, Montana's paddlefish have adapted successfully to feeding in Missouri River reservoir habitat, resulting in an increased population size over historical (prereservoir) levels (Scarnecchia et al. 1996b). Young-of-the-year paddlefish utilize turbid headwater reaches of Fort Peck Reservoir (Kozfkay and Scarnecchia 2002) and Lake Sakakawea (Fredericks and Scarnecchia 1997) for particulate feeding. Larger juveniles and adults large enough to more effectively avoid predation (Parken and Scarnecchia 2002) filter feed throughout the reservoirs.

\section{Management}

Historical information on the Yellowstone-Sakakawea stock and fisheries in the Yellowstone River is provided in Robinson (1966), Rehwinkel (1978), and a series of Federal Aid reports (e.g., Stewart 1984) as summarized in the MontanaNorth Dakota Paddlefish Management Plan (1995) and Scarnecchia and Stewart (1996). Socio-economic information on the anglers is provided in Scarnecchia et al. (1996), and Scarnecchia and Stewart (1997). Recent harvest data is summarized in a series of Federal Aid reports (e.g., Riggs 1999). Historical information on the Fort Peck stock and fisheries is provided by Berg (1981) and a series of Federal Aid reports (e.g., Needham 1984; Gilge and Liebelt 2001). Some of the latter reports also provide information on the YellowstoneSakakawea stock fish inhabiting the Dredge Cuts. Socio-economic information on the Fort Peck stock fishery is provided in Scarnecchia et al. (2000). Montana's goals, objectives, and approaches for paddlefish management are outlined in the Montana-North Dakota Paddlefish Management Plan (1995). This plan being revised and updated as of 2005. Management of the YellowstoneSakakawea stock is a cooperative, interstate effort involving coordinated and uniform management goals, objectives, data collection, and stock assessment by the Montana Department of Fish, Wildlife and Park and the North Dakota Game and Fish Department. For the Fort Peck stock, which is located entirely within Montana, management goals, objectives, data collection and stock assessment are designed where possible to be consistent with that of the YellowstoneSakakawea stock.

Harvest management for both stocks is designed to prevent over-harvest and insure sustainable wild fisheries. An extensive data collection program for the Yellowstone-Sakakawea stock has permitted a more rigorous scientific approach to harvest management. A harvest cap of 1,000 fish per state per year is intended to stabilize the population at its present level of about 30,000 adult fish. The harvest cap is considered a maximum acceptable harvest rather than a 


\section{DRAFT WORKING DOCUMENT DO NOT DUPLICATE}

11666 target catch to be met. The number of fish allowed to be harvested is based on a

11667

11668

11669

11670

11671

11672

11673

11674

11675

11676

11677

11678

11679

11680

11681

11682

11683

11684

11685

11686

11687

11688

11689

11690

11691

11692

11693

11694

11695

11696

11697

11698

11699

11700

11701

11702

11703

11704

11705

11706

11707

11708

11709

11710

straightforward harvest model involving determination of population size and age structure. Population size is estimated based on jaw-tag recoveries from adult fish. Biologists accurately estimate and validate the ages of the fish caught in the fishery (Scarnecchia et al. 2005) to insure that young adult fish are added, and old fish retained, in the stock. The harvest cap is set to not exceed the most recent 5-year estimated recruitment of young adults (ages 10-14 males and ages 17-21 females). Monitoring and stock assessment approaches for the Fort Peck stock (including population estimation and age determination) are being developed to permit the implementation of a similar approach to harvest management for that stock. No harvest cap for that stock currently exists. Harvest regulations differ for the two stocks. For the Yellowstone-Sakakawea stock, harvest regulations on the Yellowstone River include an open season from May 15 through June 30, or until the harvest cap is reached. In the Missouri River below Fort Peck Dam, harvest is open all year or until the harvest cap is reached. All snagged paddlefish must be retained and tagged with a locking individually-identifiable paddlefish tag purchased by the angler. The annual bag limit for this stock is one fish per person. Catch-and-release fishing (with mandatory release), which when monitored has been shown to not cause excessive mortality (Scarnecchia and Stewart 1997b), is also permitted for two six-hour periods per week at the Intake fishing site. For the Fort Peck stock, anglers may harvest up to 2 fish per year (but only one if the angler caught one from the Yellowstone-Sakakawea stock). The season is open all year, and highgrading (immediate release of captured fish) is permitted (Montana Department of Fish, Wildlife \& Parks 2005). No limit is set on the total number of tags sold for either stock.

For both stocks, extensive collection of harvest data as well as adult tagging and juvenile monitoring are conducted to obtain information on age composition, population size, reproductive success, and recruitment of young adult fish. Onsite and telephone creel surveys provide additional information on the fishery and harvest.

\section{Conservation Concerns}

- Loss of spawning habitat. Paddlefish spawn most effectively in turbid, free-flowing rivers with natural hydrographs and gravel, cobble and perhaps sand substrates.

- Water depletions. Excessive and increasing water depletions for irrigation during drought or low-flow years influence paddlefish migratory and spawning behavior. Adequate flows in spring and early summer are needed to initiate spawning migrations.

- Decreasing quality of rearing habitat in impoundments. Extensive sedimentation of Missouri mainstem reservoirs, including the headwater depositional areas, will reduce available habitat, especially for young fish. 


\section{DRAFT WORKING DOCUMENT DO NOT DUPLICATE}

11711

11712

11713

11714

11715

11716

11717

11718

11719

11720

11721

11722

11723

11724

11725

11726

11727

11728

11729

11730

11731

11732

11733

11734

11735

11736

11737

11738

11739

11740

11741

11742

11743

11744

11745

11746

11747

11748

11749

11750

11751

11752

11753

11754
Reservoir drawdowns for downriver water uses decreases available habitat and food, and exposes young fish to greater predation.

- Potential introduction of exotic competitors (e.g. bighead carp, Aristichthys nobilis)

- Over-fishing. Although much progress has been made to prevent legal over-fishing, vigilance is needed to prevent illegal harvest.

\section{Conservation Strategies}

- Maintenance of instream flows and spawning habitat in large rivers (especially the Yellowstone River and Missouri River above Fort Peck Reservoir)

- Improving harvest management

- Increased reservoir water retention during times of drought

- Improved public awareness of paddlefish conservation concerns

\section{Management Plan}

Montana-North Dakota Paddlefish Management Plan. 1995. North Dakota Game and Fish Department and Montana Department of Fish, Wildlife \& Parks.

Bismarck and Helena.

\section{Citations}

Berg, R. K. 1981. Fish populations of the wild and scenic River, Montana. Montana Department of Fish, Wildlife \& Parks, Federal Aid to Fish Restoration Project FW-3-R. Helena.

Firehammer, J. A. 2004. Spawning migration of adult paddlefish, Polyodon spathula, of the Yellowstone-Sakakawea stock in the Yellowstone and Missouri Rivers, Montana and North Dakota. Doctoral Dissertation, University of Idaho, Moscow.

Fredericks, J. F. and D. L. Scarnecchia. 1997. The use of surface visual counts for estimating the relative abundance of age-0 paddlefish in Lake Sakakawea. North American Journal of Fisheries Management 17:1014-1018.

Gilge, K., and J. Liebelt. 2001. Northeast Montana warmwater ecosystems investigations. Montana Department of Fish, Wildlife \& Parks, Federal Aid to fish Restoration Project F-113-R-1. Helena.

Holton, G. D. 2003. A field guide to Montana fishes. Montana Department of Fish, Wildlife and Parks, Helena. 


\section{DRAFT WORKING DOCUMENT DO NOT DUPLICATE}

11755

11756

11757

11758

11759

11760

11761

11762

11763

11764

11765

11766

11767

11768

11769

11770

11771

11772

11773

11774

11775

11776

11777

11778

11779

11780

11781

11782

11783

11784

11785

11786

11787

11788

11789

11790

11791

11792

11793

11794

11795

11796

11797

11798

11799
Kozfkay, J. R. and D. L. Scarnecchia. 2002. Year-class strength and feeding ecology of age-0 and age-1 paddlefish (Polyodon spathula) in Fort Peck Lake, Montana, USA. Journal of Applied Ichthyology 18:601-607.

Montana Department of Fish, Wildlife \& Parks. 2005. Montana fishing regulations. Helena.

Parken, C. and D. L. Scarnecchia. 2002. Predation on age-0 paddlefish by piscivorous fishes in a Great Plains reservoir. North American Journal of Fisheries Management 22:750-759.

Needham, R. G. 1984. Paddlefish investigations. Montana Department of Fish, Wildlife \& Parks, Federal Aid to fish Restoration Project F-11-R-32. Progress Report. Helena.

Rehwinkel, B. J. 1978. The fishery for paddlefish at Intake, Montana during 1973 and 1974. Transactions of the American Fisheries Society 107:263-268.

Riggs, V. 1999. Yellowstone River paddlefish investigations. Montana Department of Fish, Wildlife \& Parks, Federal Aid to Fish Restoration Project F78-R-5\&6. Helena.

Robinson, J. R. 1966. Observations on the life history, movement and harvest of paddlefish, Polyodon spathula, in Montana. Proceedings of the Montana Academy of Science 26:33-44.

Scarnecchia, D. and P. Stewart. 1996. Managing Montana's paddlefish: new approaches. Montana Outdoors 27(3):10-14.

Scarnecchia, D. L., P. A. Stewart, and Y. Lim. 1996a. Profile of recreational paddlefish snaggers on the lower Yellowstone River, Montana. North American Journal of Fisheries Management 16:872-879.

Scarnecchia, D. L., P. A. Stewart, and G. Power. 1996b. Age structure of the Yellowstone-Sakakawea paddlefish stock, 1963-1993, in relation to reservoir history. Transactions of the American Fisheries Society 125:291-299.

Scarnecchia, D. L. and P. A. Stewart. 1997a. Angler response to harvest regulations in Montana's Yellowstone River paddlefish (Polyodon spathula) fishery. Intermountain Journal of Sciences 3:94-100.

Scarnecchia, D. L., F. Ryckman, and J. Lee. 1997b. Capturing and tagging of wild age- 0 and age- 1 paddlefish in a Great Plains reservoir. North American Journal of Fisheries Management 17:800-802. 


\section{DRAFT WORKING DOCUMENT DO NOT DUPLICATE}

11800 Scarnecchia, D. L. and P. A. Stewart. 1997. Implementation and evaluation of a 11801 catch-and-release fishery for paddlefish. North American Journal of Fisheries 11802 Management 17:795-799.

11803

11804

11805

11806

11807

11808

11809

11810

11811

11812

11813

11814

11815

Scarnecchia, D. L., K. Gilge and P. A. Stewart. 2000. Profile of recreational paddlefish snaggers on the Upper Missouri River, Montana. Intermountain Journal of Sciences 6:68-77.

11816

Scarnecchia, D. L., L. F. Ryckman, Y. Lim, G. Power, B. Schmitz, and V. Riggs. 2005. A long-term program for validation and verification of dentaries for age estimation in the Yellowstone-Sakakawea paddlefish stock. Manuscript in review.

Stewart, P. A. 1984. Paddlefish investigations. Montana Department of Fish, Wildlife \& Parks, Federal Aid to Fish Restoration Project F-30-R-20. Helena. 


\section{DRAFT WORKING DOCUMENT DO NOT DUPLICATE}

11816 11817

11818

11819

11820

11821

11822

11823

11824

11825

11826

11827

11828

11829

11830

11831

11832

11833

11834

11835

11836

11837

11838

11839

11840

11841

11842

11843

11844

11845

11846

11847

\section{Shortnose Gar (Lepisosteus platostomus)}

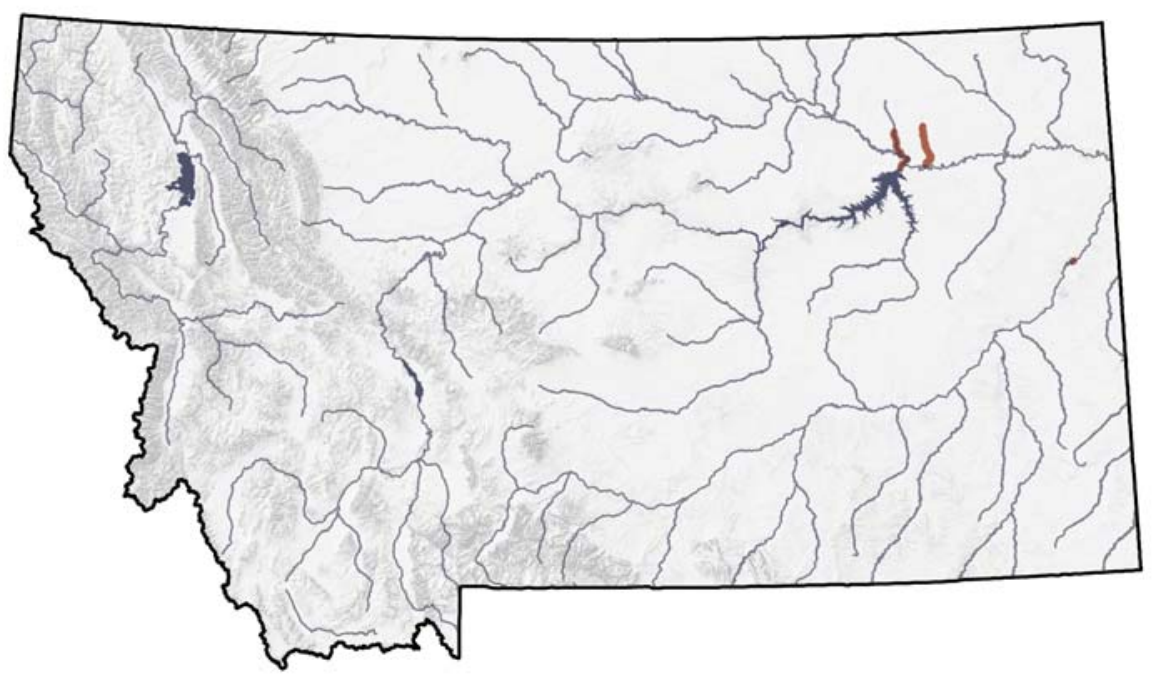

Figure 89. Distribution of Shortnose Gar

\section{Range}

The distribution of shortnose gar within Montana is very limited, with their presence being documented primarily in the Missouri River dredge cuts downstream of Fort Peck Dam (Brown 1971). The only other documented observation of shortnose gar in Montana is a single specimen collected on the Yellowstone River approximately 15 miles upstream of its confluence with the Missouri River in 1998 (K. Kapuscinski, FWP, personal communication, February 2003) (AFS website 2003).

\section{Habitat}

Due to their limited distribution little is know about shortnose gar within the State of Montana. Shortnose gar is typically found in large rivers, quiet pools, backwaters, and oxbow lakes. It has a higher tolerance to turbid water than the other four gar species found in North America. Gar also have the unique ability to supply a high vascularized swim bladder with supplemental oxygen by engaging in a behavior of "breaking" where air is gulped at the surface (Pflieger 1975). This allows gar to occupy waters with extremely low dissolved oxygen concentrations, which would not be suitable for most other fish inhabitation. They are found in dredge cuts below Fort Peck Dam (Holton 2003).

\section{Management}

Due to low numbers and poor quality flesh, the shortnose gar is not considered a sport fish in Montana (AFS website 2003). 
11848

11849

11850

11851

11852

11853

11854

11855

11856

11857

11858

11859

11860

11861

11862

11863

11864

11865

11866

11867

11868

11869

11870

11871

11872

11873

11874

11875

11876

11877

11878

11879

11880

11881

11882

11883

11884

\section{Conservation Concerns}

- Limited information in Montana

- Limited habitat used in Montana

- Backwater habitat filled in for agriculture \& modified by lack of channel primarytenance flows

- Cold water release, lack of turbidity and artificial hydrograph below Ft. Peck Dam may inhibit abundance in lower Missouri

\section{Conservation Strategies}

- Consider preparing management plan for Shortnose Gar or inclusion into other comprehensive taxonomic plan

- Increase survey and monitoring efforts

- Increase conservation initiatives for backwater sloughs and channels

- Regulate water regimes to be more closely tied to natural water regimes

\section{Management Plan}

None

\section{Citations}

American Fisheries Society Montana Chapter website:

http://www.fisheries.org/AFSmontana/SSCintermountain/foothill grassland/Shortnose\%20Gar\%20Status.htm

Brown, C. J. D. 1971. Fishes of Montana. Big Sky Books, The Endowment and Research Foundation, Montana State University, Bozeman.

Holton, G. D. 2003. A field guide to Montana fishes. Mont. Dept. Fish, Wildl. Parks, 95 pp.

Pflieger, W.L. 1975. The fishes of Missouri. Missouri Department of Conservation, Jefferson City. 


\section{DRAFT WORKING DOCUMENT DO NOT DUPLICATE}

11884 11885

11886

11887

11888

11889

11890

11891

11892

11893

11894

11895

11896

11897

11898

11899

11900

11901

11902

11903

11904

11905

11906

11907

11908

11909

11910

11911

11912

11913

11914

11915

\section{Yellowstone Cutthroat Trout (Oncorhynchus clarki bouvieri)}

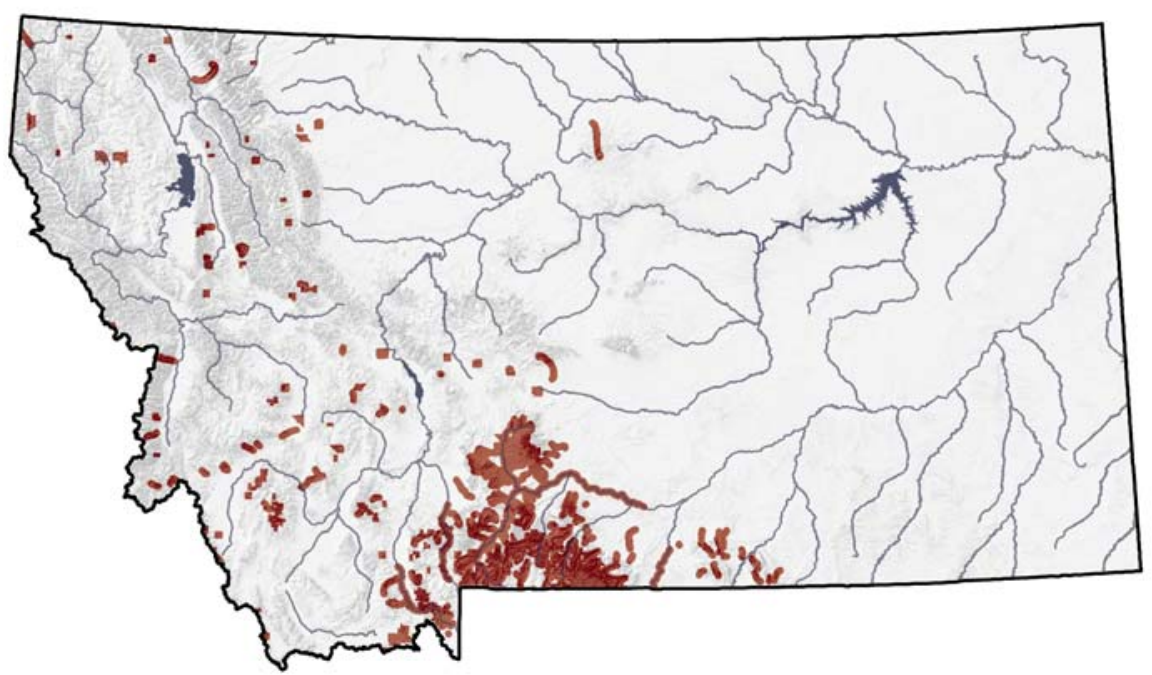

Figure 90. Distribution of the Yellowstone Cutthroat Trout

\section{Range}

Historically, Yellowstone cutthroat trout were believed to have occupied much of the Yellowstone River basin, including portions of the Clarks Fork of the Yellowstone River, Bighorn River, and Tongue River basins in Montana and Wyoming, and parts of the Snake River basin in Wyoming, Idaho, Utah, and Nevada (Behnke 1992). The lower portions of some primary-stem rivers e.g., the Tongue River may have been too warm to support populations. Range wide, Yellowstone cutthroat trout have undergone substantial declines in distribution and abundance. Populations in Utah and Nevada are limited to 1-2 basins (May 1996). Based on a survey of biologists, May (1996) concluded that in Idaho, Yellowstone cutthroat trout occupied $43 \%$ of their historical range, in Wyoming $42 \%$, and in Montana, $32 \%$. Most remaining indigenous populations in Montana inhabit headwater streams, though the Yellowstone River primary stem also supports large numbers of this subspecies. More recent estimates suggest that in Montana $10 \%$ of the historically occupied fluvial habitat still contains genetically pure populations (May 1998; Anonymous 1999). Yet all these estimates must be regarded as approximations because many waters in its historical range were probably barren of fish because of barriers to upstream migration (May 1996; Dufek et al. 1999). Also, stocking in previously barren waters in historically occupied basins has been commonplace. For example, in Montana only 2-6 lakes historically were occupied, whereas over 100 lakes now support genetically pure Yellowstone cutthroat trout (May 1996; May et al. 1998). Finally, recent comprehensive field surveys of Montana waters are lacking. Similar surveys in northwestern Wyoming outside Yellowstone National Park revealed that of $1,700 \mathrm{~km}$ of potential historical habitat, only $245 \mathrm{~km}$ contained reasonably genetically pure Yellowstone cutthroat trout distributed in four 
11916 populations, all of which had been exposed to introgression with Snake River

11917 fine-spotted cutthroat trout (Kruse et al. 2000).

11918

11919

11920

11921

11922

11923

11924

11925

11926

11927

11928

11929

11930

11931

11932

11933

11934

11935

11936

11937

11938

11939

11940

11941

11942

11943

11944

11945

11946

11947

11948

11949

11950

11951

11952

11953

11954

11955

11956

11957

11958

11959

11960

11961

\section{Habitat}

Yellowstone cutthroat trout inhabit relatively clear, cold streams, rivers, and lakes. Optimal temperatures have been reported to be from 4 to 15 degrees $\mathrm{C}$., with occupied waters ranging from 0 to 27 degrees C. (Gresswell 1995) (AFS website 2003).

\section{Management}

To maintain healthy populations of Yellowstone cutthroat trout and to ensure the wide-ranging persistence of this subspecies in Montana and elsewhere, a number of tactics have been proposed in recent status assessments (Yellowstone Cutthroat Trout Working Group 1994, Gresswell 1995, May 1996, May et al. 1998, Anonymous 1999, Dufek et al. 1999, Wyoming Game and Fish Department 2000). These include field surveys, harvest management, habitat protection and improvement, non-native species control, and broodstock management (AFS website 2003).

\section{Conservation Concerns}

- Persistence of non-native fish

- Widespread stocking of non-indigenous populations of Yellowstone cutthroat trout

- Susceptibility to infection by Myxobolus cerebralis, a European protozoan and the causative agent of whirling disease

- Tributary dewatering by unsustainable irrigation practices

- Culverts, dams, irrigation diversions or other instream barriers that fully or partially impede fish movement and reduce connectivity of habitat

- River channelization or rip rap

- Unsustainable grazing, mining, logging, and road building

\section{Conservation Strategies}

- Decrease stocking of non-native trout

- Decrease stocking of non-indigenous Yellowstone Cutthroat Trout to decrease genetically homogenization

- Increased funding for studying whirling disease

- Decreased channels and irrigation developments

\section{Management Plans}

Cooperative Conservation Agreement for Yellowstone Cutthroat Trout within Montana between Crow Tribe, Montana Department of Fish, Wildlife \& Parks 


\section{DRAFT WORKING DOCUMENT DO NOT DUPLICATE}

11962 (FWP), Montana Department of Environmental Quality (DEQ), Montana

11963

11964

11965

11966

11967

11968

11969

11970

11971

11972

11973

11974

11975

11976

11977

11978

11979

11980

11981

11982

11983

11984

11985

11986

11987

11988

11989

11990

11991

11992

11993

11994

11995

11996

11997

11998

11999

12000

12001

12002

12003

12004

12005

12006

12007
Department of Natural Resources and Conservation (DNRC), USDA-Forest

Service, Northern Region, Gallatin \& Custer National Forests, USDI-Bureau of Land Management - Montana (BLM), USDI-Fish and Wildlife Service (FWS), USDI-Bureau of Indian Affairs (BIA), Yellowstone National Park. 2000. Montana Department of Fish, Wildlife \& Parks.

May, B. E., Urie, W., Shepard, B.B., Montana Cooperative Fishery Research Unit. 2003. Range-wide status of Yellowstone Cutthroat Trout (Oncorhynchus clarki bouvieri): 2001.

May, B. E. 1998. Yellowstone cutthroat trout: current status and conservation recommendations with the state of Montana. U.S. Forest Service, Gallatin National Forest, Bozeman, Montana.

Yellowstone Cutthroat Trout Working Group. 1994. Yellowstone cutthroat trout (Oncorhynchus clarki bouvieri) management guide for the Yellowstone River drainage. Montana Department of Fish, Wildlife \& Parks, Helena, and Wyoming Game and Fish Department, Cheyenne.

\section{Citations}

American Fisheries Society Montana Chapter website.

http://www.fisheries.org/AFSmontana/SSCintermountain/foothill

grassland/yellowstone_cutthroat_trout.htm

Anonymous. 1999. Yellowstone cutthroat trout: current status and recommendations within the state of Montana. Gallatin and Custer National Forests, Regions 3 and 5, Montana Department of Fish, Wildlife \& Parks, and U.S. Fish and Wildlife Service Montana Technical Assistance Office.

Behnke, R. J. 1992. Native trout of western North America. American Fisheries Society Monograph 6, Bethesda, Maryland.

Bergersen, E. P., and D. E. Anderson. 1997. The distribution and spread of Myxobolus cerebralis in the United States. Fisheries 22(8): 6-7.

Chamberlin, T. W., R. D. Harr, and F. H. Everest. 1991. Timber harvesting, silviculture, and watershed processes. Intermountain/foothill grassland 181-206 in W. R. Meehan, editor. Influences of forest and rangeland management on salmonid fishes and their habitats. American Fisheries Society Special Publication 19, Bethesda, Maryland.

Clancy, C. G. 1988. Effects of dewatering on spawning by Yellowstone cutthroat trout in tributaries to the Yellowstone River, Montana. American Fisheries Society Symposium 4: 37-41. 


\section{DRAFT WORKING DOCUMENT DO NOT DUPLICATE}

12008

12009

12010

12011

12012

12013

12014

12015

12016

12017

12018

12019

12020

12021

12022

12023

12024

12025

12026

12027

12028

12029

12030

12031

12032

12033

12034

12035

12036

12037

12038

12039

12040

12041

12042

12043

12044

12045

12046

12047

12048

12049

12050

12051

12052

12053
Corsi, C. 1988. The life history and status of the Yellowstone cutthroat trout (Salmo clarki bouvieri) in the Willow Creek drainage, Idaho. Masters thesis, Idaho State University, Pocatello.

Dufek, D., K. Johnson, J. Kiefling, B. McDowell, R. McKnight, S. Roth, and S. Yekel. 1999. Status and management of Yellowstone cutthroat trout Oncorhynchus clarki bouvieri. Wyoming Game and Fish Department, Cheyenne.

Dunham J. B., G. L. Vinyard, and B. E. Rieman. 1997. Habitat fragmentation and extinction risk of Lahontan cutthroat trout. North American Journal of Fisheries Management 17: 1126-1133.

Furniss, M. J., T. D. Roelofs, and C. S. Yee. 1991. Road construction and primarytenance. Intermountain/foothill grassland 297-324 in W. R. Meehan, editor. Influences of forest and rangeland management on salmonid fishes and their habitats. American Fisheries Society Special Publication 19, Bethesda, Maryland.

Gresswell, R. E. 1995. Yellowstone cutthroat trout. Intermountain/foothill grassland 36-54 in M. K. Young, technical editor. Conservation assessment for inland cutthroat trout. U.S. Forest Service General Technical Report RM-GTR256.

Gresswell, R. E., W. J. Liss, and G. L. Larson. 1994. Life-history organization of Yellowstone cutthroat trout (Oncorhynchus clarki bouvieri) in Yellowstone Lake. Canadian Journal of Fisheries and Aquatic Sciences 51(Supplement 1): 298309.

Kruse, C. G., W. A. Hubert, and F. J. Rahel. 2000. Status of Yellowstone cutthroat trout in Wyoming waters. North American Journal of Fisheries Management 20: 693-705.

May, B. E. 1996. Yellowstone cutthroat trout. Intermountain/foothill grassland 11-34 in D. Duff, editor. Conservation assessment for inland cutthroat trout: distribution, status and habitat management implications. U.S. Forest Service, Northern, Rocky Mountain, Intermountain, and Southwestern Regions.

May, B. E., and twelve others. 1998. Yellowstone cutthroat trout conservation program within the state of Montana. Prepared for the Montana Department of Fish, Wildlife \& Parks, Helena.

Nelson, R. L., M. L. McHenry, and W. S. Platts. 1991. Mining. Intermountain/foothill grassland 425-458 in W. R. Meehan, editor. Influences of forest and rangeland management on salmonid fishes and their habitats. American Fisheries Society Special Publication 19, Bethesda, Maryland. 


\section{DRAFT WORKING DOCUMENT DO NOT DUPLICATE}

12054

12055 Thurow, R. F., C. E. Corsi, and V. K. Moore. 1988. Status, ecology, and

12056 management of Yellowstone cutthroat trout in Upper Snake River Drainage,

12057 Idaho. American Fisheries Society Symposium 4:25-36.

12058

12059

Varley, J. D., and R. E. Gresswell. 1988. Ecology, status, and management of

12060

12061

12062

12063

12064

the Yellowstone cutthroat trout. American Fisheries Society Symposium 4:13-24.

12065

12066

Wyoming Game and Fish Department. 2000. Yellowstone cutthroat trout management summary. Wyoming Game and Fish Department, Fish Division, Cheyenne. 
12068

12069

12070

12071

12072

12073

12074

12075

12076

12077

12078

12079

12080

12081

12082

12083

12084

12085

12086

12087

12088

12089

12090

12091

12092

12093

12094

12095

12096

12097

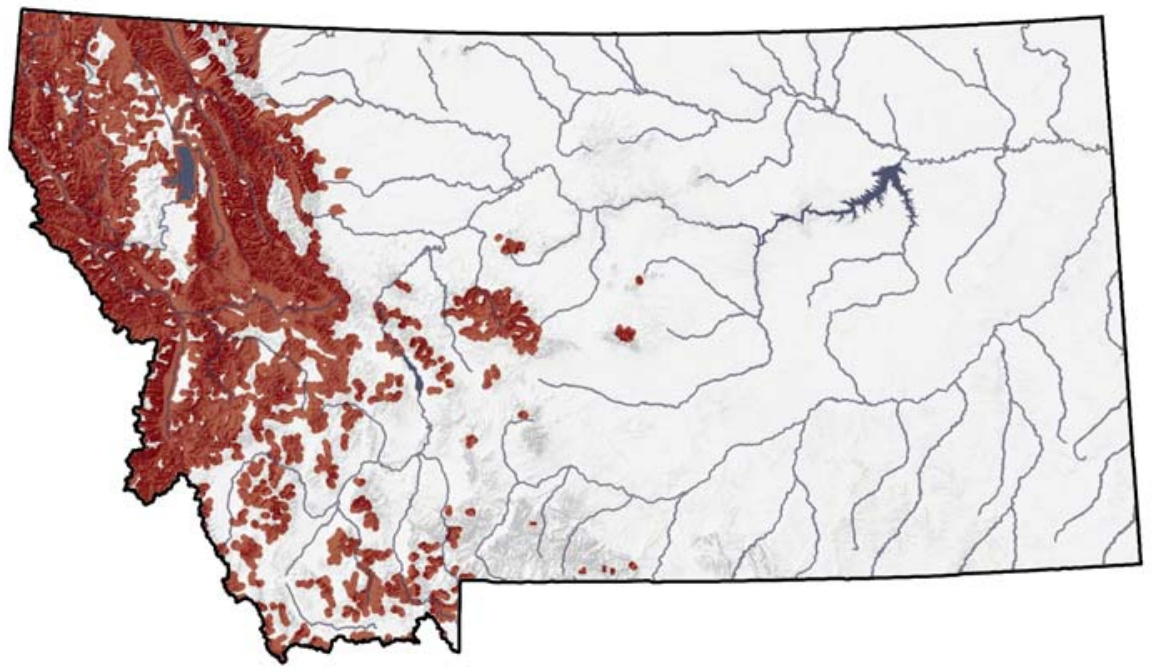

Figure 91. Distribution of the Westslope Cutthroat Trout

\section{Range}

The westslope cutthroat trout is found in the Kootenai watershed, the Clark Fork watershed, the headwaters of the Missouri River and the headwaters of the Saskatchewan River. Westslope cutthroat trout were first described by Lewis and Clark and were once extremely abundant. Unfortunately, the species has lost a lot of ground. Various studies have estimated that the westslope cutthroat trout now only occupies between 19 to $27 \%$ of its historic range in Montana and about $36 \%$ of its historical range in Idaho (Van Eimeren 1996). But westslope cutthroat trout can hybridize with other cutthroat trout subspecies and rainbow trout. Thus, genetically pure westslope cutthroat trout are estimated to exist in only 2 to $4 \%$ of their historic stream distribution (McIntyre and Rieman 1995). East of the Continental Divide, westslope cutthroat trout are confined to headwater reaches, and most of these small populations face an extremely high risk of extinction (AFS website 2003).

\section{Habitat}

Spawning and rearing streams tend to be cold and nutrient poor. Westslope cutthroat trout seek out gravel substrate in riffles and pool crests for spawning habitat. Cutthroat trout have long been regarded as sensitive to fine sediment (generally defined as 6.3 millimeters or less). Although studies have documented negative survival as fine sediment increases (Weaver and Fraley 1991), it is difficult to predict their response in the wild (Mclntyre and Rieman 1995). This is due to the complexity of stream environments and the ability of fish to adapt somewhat to changes in microhabitat (Everest et al. 1987) (AFS website 2003). 


\section{DRAFT WORKING DOCUMENT DO NOT DUPLICATE}

12098

12099

12100

12101

12102

12103

12104

12105

12106

12107

12108

12109

12110

12111

12112

12113

12114

12115

12116

12117

12118

12119

12120

12121

12122

12123

12124

12125

12126

12127

12128

12129

12130

12131

12132

12133

12134

12135

12136

12137

12138

12139

12140

12141

12142

12143

Westslope cutthroat trout also require cold water, although it has proven elusive to define exact temperature requirements or tolerances. Likewise, cutthroat trout tend to thrive in streams with more pool habitat and cover than uniform, simple habitat (Shepard, Pratt and Graham 1984). Juvenile cutthroat trout overwinter in the interstitial spaces of large stream substrate. Adult cutthroat trout need deep, slow moving pools that do not fill with anchor ice in order to survive the winter (Brown and Mackay 1995) (AFS website 2003).

\section{Management}

Management of this species involves protecting the population strongholds and making tough decisions on restoration priorities for the depressed populations.

The State of Montana has altered fishing regulations to reduce fishing mortality. Montana has also developed a Conservation Agreement signed by nine government agencies and conservation groups (Montana Department of Fish, Wildlife \& Parks 1999). This agreement prioritizes protecting genetically pure populations first, then slightly introgressed populations. Recovering depressed populations will involve habitat restoration and removing non-native species. To a large degree management activities are different between the west of the Continental Divide (focus on barriers and non-native trout) and east (focus on habitat restoration). Research suggests that it is not a good idea to bolster populations with stocked fish from other watersheds due to considerable genetic variation between watersheds (Leary, Allendorf and Kanda 1998). It will be especially challenging to recover migratory life forms. Governmental agencies will need to work together to share expertise, pool financial resources and monitor progress toward restoration of this species (AFS website 2003).

\section{Conservation Concerns}

- Habitat loss due to unsustainable grazing or logging practices, mining, agriculture, residential development and the impact of forest roads

- Fish spawning habitat loss due to dewatering of streams for irrigation and because of barriers created by dams and road culverts

- Over competition and predation by non-native species

- Increased hybridization with other species

- Isolated and small population sizes

- Overfishing

\section{Conservation Strategies}

- Reduce limits on westslope cutthroat trout

- Educate the public and outreach on need of westslope cutthroat trout

- Increase stock populations of genetically pure westslope cutthroat trout

- Continue to conserve genetically pure populations

- Increase limits of non-native fish

- Conservation of habitat, including better natural resource use practices 


\section{DRAFT WORKING DOCUMENT DO NOT DUPLICATE}

12144

12145

12146

12147

12148

12149

12150

12151

12152

12153

12154

12155

12156

12157

12158

12159

12160

12161

12162

12163

12164

12165

12166

12167

12168

12169

12170

12171

12172

12173

12174

12175

12176

12177

12178

12179

12180

12181

12182

12183

12184

12185

12186

12187
- Removal of nonnative fish where appropriate

- Creation of barriers to protect remaining populations

- Reintroduction of Westslope Cutthroat

\section{Management Plans}

Memorandum of Understanding and Conservation Agreement for Westslope Cutthroat Trout (Onchorhynchus clarki lewisi) in Montana. 1999. Montana Fish, Wildlife \& Parks.

Shepard, Brad B., May, B.E, Urie, W. 2003. Status of Westslope Cutthroat Trout (Onchorhyncus clarki lewisi) in the United States 2002. Westslope Cutthroat Conservation Team.

\section{Citations}

American Fisheries Society Montana Chapter website.

http://www.fisheries.org/AFSmontana/SSCintermountain/foothill

grassland/westslope_cutthroat_trout.htm

Behnke. R.J. 1992. Native trout of western North America. American Fisheries Society Monograph 6.

Brown, R.S. and W.C. Mackay. 1995. Fall and Winter Movements of and Habitat Use by Cutthroat Trout in the Ram River, Alberta. Transactions of the American Fisheries Society 124:873-885.

Everest, F.H., R.L. Beschta, J.C. Scrivener, K.V. Koski, J.R. Sedell and C.J. Cederholm. 1987. Fine Sediment and Salmonid Production: A Paradox. IN Streamside Management: Forestry and Fishery Interactions. University of Washington, Seattle, Washington. E.O. Salo and T.W. Cundy, tech Ed. Intermountain/foothill grassland 98-142.

Leary, R.F., F.W. Allendorf and N. Kanda. 1998. Lack of Genetic Divergence between Westslope Cutthroat Trout from the Columbia and Missouri River Drainages. Wild Trout and Salmon Genetics Laboratory Report 97/1. Missoula, Montana.

McIntyre, J.D. and B.E. Rieman. 1995. Westslope Cutthroat Trout IN Conservation Assessment for Inland Cutthroat Trout. General Technical Report RM-256. US Department of Agriculture, Forest Service, Rocky Mountain Forest and Range Experiment Station, Fort Collins, Colorado. M.K. Young, tech. Ed. Intermountain/foothill grassland 1-15. 


\section{DRAFT WORKING DOCUMENT DO NOT DUPLICATE}

12188 Montana Department of Fish, Wildlife \& Parks. 1999. Memorandum of 12189 Understanding and Conservation Agreement for Westslope Cutthroat Trout 12190 (Oncorhynchus clarki lewisi) in Montana. Helena, Montana.

12191

12192 Novinger, D.C. and F.J. Rahel. 1999. Exploring Competitive Mechanisms that 12193 Allow Nonnative Brook Trout to Displace Native Cutthroat Trout in a Rocky 12194 Mountain Stream. American Fisheries Society $129^{\text {th }}$ Annual Meeting Abstracts. 12195 Charlotte, North Carolina.

12196

12197

Shepard, B.B., K.L. Pratt, and P.J. Graham. 1984. Life Histories of Westslope Cutthroat Trout and Bull Trout in the upper Flathead River Basin, Montana. Montana Department of Fish, Wildlife \& Parks, Helena, Montana.

Tews, A., M. Enk, S. Leathe, W. Hill, S. Dalbey, and G. Liknes. 2000 Overview of Status and Restoration Strategies for Westslope Cutthroat Trout (Oncorhynchus clarki lewisi) in Northcentral Montana. Special Report by Montana Fish, Wildlife \& Parks in collaboration with the Lewis and Clark National Forest. Great Falls, Montana.

Van Eimeren, P. 1996. Westslope Cutthroat Trout Oncorhynchus clarki lewsi IN Conservation Assessment for Inland Cutthroat Trout. Distribution, Status and Habitat Management Implications. US Department of Agriculture, Forest Service, Intermountain Region, Ogden, Utah. D.A. Duff, tech. Ed. Intermountain/foothill grassland 1-10. 


\section{DRAFT WORKING DOCUMENT DO NOT DUPLICATE}

12213 12214

12215

12216

12217

12218

12219

12220

12221

12222

12223

12224

12225

12226

12227

12228

12229

12230

12231

12232

12233

12234

12235

12236

12237

12238

12239

12240

12241

12242

12243

\section{Columbia Basin Redband Trout (Oncorhynchus mykiss gairdneri)}

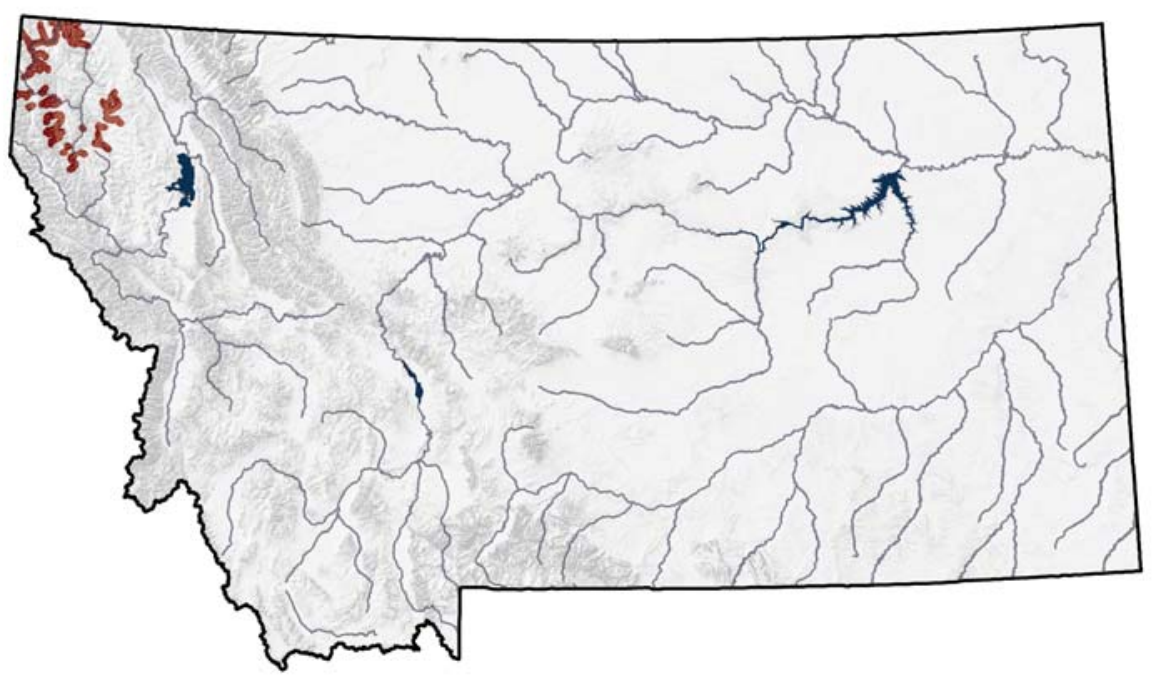

Figure 92. Distribution of the Columbia Basin Redband Trout

\section{Range}

The Kootenai River drainage population of redband trout is Montana's only native rainbow trout and represents the furthest inland penetration of redband trout in the Columbia River Basin. Until recently, the upper distribution of redband trout in the Columbia River Basin was believed to extend upstream to Kootenai Falls, which was considered a barrier falls located approximately $8 \mathrm{~km}$ east of Troy, Montana (Allendorf et al. 1980). Recent information suggests that the barrier was not Kootenai Falls, but existed in geologic time near the present day Libby Dam or Fisher River (Hensler et al. 1996).

Presently, populations of redband trout have been identified using starch gel electrophoresis in the following streams in the Kootenai River drainage in Montana: Callahan Creek, North Fork Yaak River and East Fork Yaak River, upper Libby Creek and several tributaries, and several tributaries to Fisher River including Wolf Creek (Allendorf et al. 1980; Leary et al. 1991; Huston 1995; Hensler et al. 1996; M. Hensler MFWP, personal communication).

Results of genetic surveys indicate that redband trout historically preferred lowgradient valley-bottom streams throughout the Kootenai River drainage but are presently restricted to headwater areas or streams with barriers. Allendorf et al. (1980) concluded that redband trout is a native rainbow trout to the Kootenai River, Montana, and that "planting of hatchery rainbow trout has created a situation of tremendous genetic divergence among local populations" (e.g. hybridization). 


\section{DRAFT WORKING DOCUMENT DO NOT DUPLICATE}

12244 The Kootenai redband trout are effectively separated into two primary regions,

12245

12246

12247

12248

12249

12250

12251

12252

12253

12254

12255

12256

12257

12258

12259

12260

12261

12262

12263

12264

12265

12266

12267

12268

12269

12270

12271

12272

12273

12274

12275

12276

12277

12278

12279

12280

12281

12282

12283

12284

12285

12286

12287

12288

12289 those below Kootenai Falls and those above. Fish of the size known to inhabit these streams may mix downstream but are unlikely to traverse up the falls (Chapman 1986). Below Kootenai Falls, redband trout inhabiting Callahan Creek and the upper Yaak River Drainage are isolated into two separate regions by Yaak River Falls, a falls-chute barrier located $4 \mathrm{~km}$ from the mouth of Callahan Creek and a barrier falls located in the lower East Fork of the Yaak River. These remnant populations, which are spatially fragmented and isolated from genetic exchange, represent the only known remaining sources of native redband trout capable of re-founding their historic distribution in Montana downstream of Kootenai Falls.

There are no barriers to protect redband trout from hybridization upstream of Kootenai Falls. Still, there are several tributaries to Fisher River drainage and Libby Creek drainage that maintain non- or nearly non-introgressed populations and could be used for re-founding if necessary (M. Hensler MFWP, personal communication).

Perkinson (1993) hypothesized that of $300 \mathrm{~km}$ of habitat originally used by redband trout in Montana, only $100 \mathrm{~km}(33 \%)$ of their historic range is presently occupied by a stock that is at least $95 \%$ pure. More recent genetic evaluation of the species showed the historic range was more on the order of $1200 \mathrm{~km}$ and current is $493 \mathrm{~km}$. The current distribution includes instances where redband trout are sympatric with westslope cutthroat trout. These populations show small first generation hybridization and almost no post-first generation hybridization. Approximately $152 \mathrm{~km}$ or 13 percent of the historic distribution is relatively invasion due to barriers in the Callahan Creek and Yaak River drainages.

\section{Habitat}

The seasonal habitat requirements of redband trout in the Kootenai River drainage in Montana were investigated in the Kootenai River drainage during 1997 and 1998 (Hensler and Muhlfeld 1999; Muhlfeld 1999; Muhlfeld et al. 2001 In-press). Summer results demonstrated that juvenile $(36-125 \mathrm{~mm})$ and adult $(\geq$ $126 \mathrm{~mm}$ ) redband trout prefer deep microhabitats $(\geq 0.4 \mathrm{~m})$ with low to moderate velocities $(\leq 0.5 \mathrm{~m} / \mathrm{s})$ adjacent to the thalweg. Conversely, age- $0(\leq 35 \mathrm{~mm})$ redband trout select slow water $(\leq 0.1 \mathrm{~m} / \mathrm{s})$ and shallow depths $(\leq 0.2 \mathrm{~m})$ located in lateral areas of the channel. Age- 0 , juvenile and adult redband trout strongly select pools and avoided riffles; runs were used generally as expected (based on availability) by juveniles and adults and more than expected by age-0 redband trout. At the macrohabitat scale, a multiple regression model indicated that lowgradient, mid-elevation reaches with an abundance of complex pools are critical areas for the production of redband trout. Mean reach densities ranged from $0.01-0.10 \mathrm{fish} / \mathrm{m}^{2}$. During the fall and winter period, adult redband trout occupied small home ranges and found suitable overwintering habitat in deep pools with extensive amounts of cover in headwater streams. In Basin Creek, adult 


\section{DRAFT WORKING DOCUMENT DO NOT DUPLICATE}

12290

12291

12292

12293

12294

12295

12296

12297

12298

12299

12300

12301

12302

12303

12304

12305

12306

12307

12308

12309

12310

12311

12312

12313

12314

12315

12316

12317

12318

12319

12320

12321

12322

12323

12324

12325

12326

12327

12328

12329

12330

12331

12332

12333

12334

12335

redband trout commenced spawning (e.g. redd construction) during June as spring flows subsided following peak runoff. Redband trout generally selected redd sites in shallow pool tail-out areas (mean depth $=0.27 \mathrm{~m}$; range: $0.20-0.46$ ) with moderate water velocities (mean velocity $=0.50 \mathrm{~m} / \mathrm{s}$; range: $0.23-0.69 \mathrm{~m} / \mathrm{s}$ ) dominated by gravel substrate.

\section{Management}

Long-term conservation and management of this subspecies will require state and federal agencies to develop a comprehensive plan to protect and restore redband trout throughout their native range in Montana. First and foremost, the populations that are non-introgressed must be protected and where necessary enhanced through habitat improvements. Maintaining channel complexity and quality pool habitat throughout their limited range is probably essential to the persistence of this subspecies in Montana. Montana Fish, Wildlife \& Parks and the U.S. Forest Service and local conservation groups have scheduled future habitat improvement and conservation efforts for the foreseeable future.

Another objective should be consideration reintroductions throughout the Kootenai River drainage in the historic range for redband trout. To that end, MFWP are in the process of assessing redband trout performance at the Libby Field Station and Murray Springs State Fish Hatchery and in two lakes (M. Hensler, personal communication). Results of microsatellite analyses based on allozyme electrophoresis of several populations of redband trout in Montana and British Columbia indicate significant differences between watersheds and relatively small differences between populations within watersheds (Knudsen et al. 2002). In order for potential reintroduction programs to be genetically rational, drainage-specific stocks are needed for successful recovery programs.

Habitat surveys should be conducted to identify streams suitable for reintroductions of redband trout. However, re-introduction efforts should be implemented with caution because introduction of a species to any aquatic habitat requires many considerations because species interactions are complex and difficult to predict (Li and Moyle 1981).

\section{Conservation Concerns}

- Land and water use practices, such as logging, grazing and use of pesticides

- Culverts, dams, irrigation diversions or other instream barriers that fully or partially impede movement and reduce connectivity of habitat

- Hybridization

- Geographical restricted range

\section{Conservation Strategies}




\section{DRAFT WORKING DOCUMENT DO NOT DUPLICATE}

12336

12337

12338

12339

12340

12341

12342

12343

12344

12345

12346

12347

12348

12349

12350

12351

12352

12353

12354

12355

12356

12357

12358

12359

12360

12361

12362

12363

12364

12365

12366

12367

12368

12369

12370

12371

12372

12373

12374

12375

12376

12377

12378

12379

12380

12381

- Consider preparing management plan for Columbia Basin Redband Trout or inclusion into other comprehensive taxonomic plan

- Reduce stocking of non-native trout in sensitive areas

- Protect genetic composition by raising hatchery Columbian Basin Redband Trout

- Management of riparian zones and waters where Redband Trout reside

- Reduce stream intake of pesticides and herbicides

\section{Management Plan}

None

\section{Citations}

Allendorf, F.W., D.M. Esperlund, and D.T. Scow. 1980. Coexistence of native and introduced rainbow trout in the Kootenai River Drainage. Proceedings of the Montana Academy of Sciences 39:28-36.

Behnke, R.J. 1992. Native trout of western North America. American Fisheries Society Monograph 6. Bethesda, Maryland.

Chapman, D.W. 1986. Downstream movement of Rainbow Trout Past Kootenai Falls, Montana. North American Journal of Fisheries Management 6:47-51.

Hensler, M.E., J.E. Huston and G. K. Sage. 1996. A Genetic Survey of Lakes in the Cabinet Wilderness Area and Proposed Inland Rainbow Trout Recovery. Montana Fish, Wildlife \& Parks, Kalispell, Montana.

Hensler, M.E., C.C. Muhlfeld. 1999. Spawning ecology of redband trout in Basin Creek, Montana. A Report to the Whirling Disease Foundation. Montana Fish, Wildlife \& Parks, Bozeman, MT.

Huston, J.E. 1995. A Report on the Kootenai River Drainage Native Species Search. A Report to the U.S. Fish and Wildlife Service. Montana Fish, Wildlife \& Parks, Kalispell, MT.

Knudsen, K.L., C.C. Muhlfeld, G.K. Sange, and R.F. Leary. 2002. Genetic structure of Columbia River redband trout populations in the Kootenai River drainage, Montana, revealed by microsatellite and allozyme loci. Transactions of the American Fisheries Society 131: 1093-1105.

Leary, R.F, F.W. Allendorf, and K. G. Sage. 1991. Genetic analysis of trout populations in the Yaak River Drainage, Montana. Wild trout and salmon genetics laboratory report 91/3. University of Montana, Missoula.

Li, H.W. and P.B. Moyle. 1981. Ecological analysis of species introductions into aquatic systems. Transactions of the American Fisheries Society 110:772-782. 


\section{DRAFT WORKING DOCUMENT DO NOT DUPLICATE}

12382

12383

12384

12385

12386

12387

12388

12389

12390

12391

12392

12393

12394

12395

12396

12397

12398

12399
Muhlfeld, C.C. 1999. Seasonal habitat use by redband trout (Oncorhynchus mykiss gairdneri) in the Kootenai River drainage, Montana. Masters thesis. University of Idaho, Moscow, Idaho.

Muhlfeld, C.C., D.H. Bennett, and B. Marotz. 2001-In press. Summer habitat use by redband trout in the Kootenai River drainage, Montana. North American Journal of Fisheries Management (February).

Perkinson, R.D. 1993. Presentation to the American Fisheries Society, Montana Chapter, 17 February 1993.

Williams, J.E., J.E Johnson, D.A. Hendrickson, S. Contreras-Balderas, J.D.

Williams, M Avarro-Mendoza, D.E. McAllister, and J.E. Deacon. 1989. Fishes of North America endangered, threatened, or of special concern: 1989. Fisheries 14(6): 2-20. 


\section{DRAFT WORKING DOCUMENT DO NOT DUPLICATE}

12399 12400

12401

12402

12403

12404

12405

12406

12407

12408

12409

12410

12411

12412

12413

12414

12415

12416

12417

12418

12419

12420

12421

12422

12423

12424

12425

12426

12427

12428

12429

12430

\section{Bull Trout (Salvelinus confluentus)}

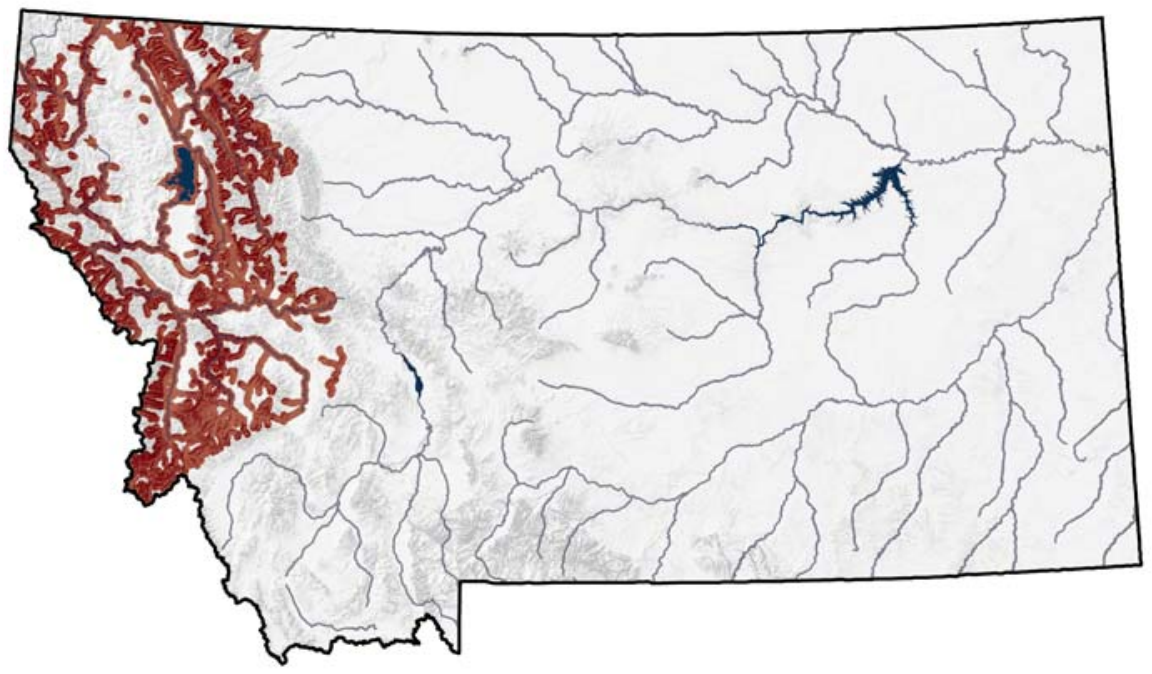

Figure 93. Distribution of the Bull Trout

\section{Range}

Montana populations are limited to the Columbia and Saskatchewan River basins. Major bull trout drainages are the Kootenai River, Clark Fork River (including Bitterroot, Flathead/Swan and Blackfoot River systems). Metaline Falls (Tom Weaver, FWP, personal communication) and Bonnington Falls have isolated Clark Fork and Kootenai River populations from downstream Columbia basin populations for approximately 10,000+ years (Montana Bull Trout Restoration Team (MBTRT) 2000). The St. Mary's River in the Saskatchewan basin, draining north into Canada, contains the only bull trout populations east of the continental divide in the United States.

\section{Habitat}

Sub-adult and adult fluvial bull trout reside in larger streams and rivers and spawn in smaller tributary streams, whereas adfluvial bull trout reside in lakes and spawn in tributaries. They spawn in cold headwater streams with clean gravel bottom (Brown 1971, Holton 1981).

\section{Management}

Several studies report bull trout local population genetic divergence down to the geographic scale of adjacent tributaries (Leary et al. 1993; Kanda et al. 1997; Spruell et al. 1999; Taylor et al. 1999). Based on similar patterns of population genetic structure in steelhead, Parkinson (1984) suggested that populations in geographically adjacent streams be managed as separate stocks. 


\section{DRAFT WORKING DOCUMENT DO NOT DUPLICATE}

12431 Because of their opportunistic feeding habits and late maturity, bull trout are

12432

12433

12434

12435

12436

12437

12438

12439

12440

12441

12442

12443

12444

12445

12446

12447

12448

12449

12450

12451

12452

12453

12454

12455

12456

12457

12458

12459

12460

12461

12462

12463

12464

12465

12466

12467

12468

12469

12470

12471

12472

12473

12474

12475

12476 vulnerable to overharvest and poaching/accidental harvest, especially during spawning migrations and when in tributaries (Leathe and Enk 1985, Long 1997, Schmetterling and Long 1999, Carnefix 2002). Some Montana bull trout populations (e.g. Swan, South Fork Flathead, Kootenai, and Blackfoot) have responded well to more restrictive angling regulations or closures (Tom Weaver, FWP, personal communication), and initial conservation efforts in Montana focused on such measures. The first minimum length limit was imposed in 1951 (Long 1997). From 1953 to 1972, 11 of 33 major North and Middle Fork Flathead River spawning tributaries were closed to fishing and an 18-inch minimum size limit was established in 1982 to protect pre-spawners in the rivers and Flathead Lake was in effect (Fraley et al. 1981; Deleray et al. 1999). Regulations closing all state waters except Swan Lake and Hungry Horse Reservoir to intentionally fishing for and/or harvesting bull trout became effective in 1993 (Deleray et al. 1999). Harvest is currently permitted in Swan Lake, Hungry Horse Reservoir (South Fork Flathead) and Koocanusa Reservoir (Kootenai). Some level of poaching (Swanberg 1996; Long 1997) and accidental harvest due to misidentification (Schmetterling and Long 1999) probably continues to impact bull trout populations, but is difficult to detect, quantify, prosecute or prevent. Recent efforts to reduce misidentification include a Bull Trout Identification and

Education webpage at the FWP website (http://fwp.state.mt.us/bulltroutid/default.htm).

The state of Montana began development of a bull trout restoration plan in 1993. The final plan, published in June 2000, identifies 115 bull trout core areas and connecting "nodal habitat" within twelve Restoration/Conservation Areas (RCAs); sets goals, objectives and criteria for restoration; outlines actions to meet those criteria; and establishes a structure to monitor implementation and evaluate effectiveness of the plan. The stated goal of the plan is "to ensure the long-term persistence of complex (all life histories represented), interacting groups of bull trout distributed across the species' range and manage for sufficient abundance within restored RCAs to allow for recreational utilization" (MBTRT 2000). Bull trout conservation is also a stated goal of the Plum Creek Timber Company's Native Fish Habitat Conservation Plan (HCP)

(http://www.plumcreek.com/environment/HCP-fish.cfm), for which agreement was reached with the USFWS in October 2000. Though approved, this $\mathrm{HCP} /$ take permit is currently in litigation.

With "threatened" listing (USFWS 1998), USFWS has separate responsibility under the Endangered Species Act for development of a federal recovery plan and designation of critical habitat. A draft Recovery Plan built on the foundation of state restoration plans (USFWS 2002a, Internet-accessible at http://pacific.fws.gov/bulltrout/recovery/Default.htm) and proposed critical habitat (USFWS 2002b, http://pacific.fws.gov/bulltrout/criticalhab.htm), were released. Although all bull trout within the U.S. are now listed as threatened, this draft Recovery Plan and proposed critical habitat are organized hierarchically by "local 


\section{DRAFT WORKING DOCUMENT DO NOT DUPLICATE}

12477

12478

12479

12480

12481

12482

12483

12484

12485

12486

12487

12488

12489

12490

12491

12492

12493

12494

12495

12496

12497

12498

12499

12500

12501

12502

12503

12504

12505

12506

12507

12508

12509

12510

12511

12512

12513

12514

12515

12516

12517

12518

12519

12520

12521

12522 populations" within "core areas" within "recovery subunits" within 24 "recovery units" within three (of five) designated "distinct population segments" (DPSs). The draft Recovery Plan covers the Klamath basin, Columbia River and St. MaryBelly River DPSs. Although extensive bull trout habitat was proposed for critical designation in Montana, including 5,341 stream km (3,319 miles) and 88,051 ha $(217,577 \mathrm{ac})$ of lake and reservoir, the final critical habitat designation di not include any habitat in Montana. Ten local populations within four core areas have been identified within the Kootenai River Recovery Unit in Montana. About 119 local populations distributed among 36 core areas within three Recovery Subunits (Flathead, Upper and Lower Clark Fork) are identified within Montana in the Clark Fork Recovery Unit. Nine local populations within six core areas are identified within Montana in the St. Mary-Belly River Recovery Unit.

\section{Conservation Concerns}

- Habitat degradation and loss due to land and water management practices

- Isolation and fragmentation of populations by both structural (e.g. dams) and environmental (e.g. thermal or pollution) barriers

- Introduction of non-native fishes resulting in competition, predation and hybridization threats

- Historical eradication efforts

- Historical overharvest

- Ongoing poaching and accidental harvest due to misidentification

- Loss of the migratory component of bull trout life history diversity

\section{Conservation Strategies}

- Restoration of degraded habitat and preservation of existing healthy habitat

- Reestablish connectivity between habitats isolated by constructed barriers

- Prevent illegal introductions of fish species

- Management of water bodies from overfishing

- Increased management of non-native fishes

- Education of what bull trout look like and where they are distributed

\section{Management Plans}

Flathead Lake and River Co-Management Plan, 2001-2010. (November 2000). Montana Fish, Wildlife \& Parks, Kalispel, Montana and Confederated Salish and Kootenai Tribes, Pablo, Montana.

MBTRT (Montana Bull Trout Restoration Team). 2000. Restoration plan for bull trout in the Clark Fork River basin and Kootenai River basin, Montana. Montana Department of Fish, Wildlife \& Parks, Helena. 116 intermountain/foothill grassland. 


\section{DRAFT WORKING DOCUMENT DO NOT DUPLICATE}

12523

12524

12525

12526

12527

12528

12529

12530

12531

12532

12533

12534

12535

12536

12537

12538

12539

12540

12541

12542

12543

12544

12545

12546

12547

12548

12549

12550

12551

12552

12553

12554

12555

12556

12557

12558

12559

12560

12561

12562

12563

12564

12565

12566

12567

12568
USFWS (United States Fish and Wildlife Service). 2002a. Endangered and Threatened Wildlife and Plants; Bull Trout (Salvelinus confluentus) Draft Recovery Plan. Available: http://pacific.fws.gov/bulltrout/recovery/Default.htm. (February 2003).

\section{Citations}

American Fisheries Society.

http://www.fisheries.org/AFSmontana/SSCintermountain/foothill grassland/Bull\%20Trout.htm

Bond, C. E. 1992. Notes on the nomenclature and distribution of the bull trout and the effects of human activity on the species. Intermountain/foothill grassland 1-4 in P. J. Howell and D. V. Buchanan, editors. Proceedings of the Gearhart Mountain bull trout workshop. Oregon Chapter of the American Fisheries Society, Corvallis.

Brown, C. J. D. 1971. Fishes of Montana. Big Sky Books, Montana State University, Bozeman, MT. 207 intermountain/foothill grassland.

Carnefix, G. 2002. Movement patterns of fluvial bull trout in relation to habitat parameters in the Rock Creek drainage, Missoula and Granite Counties, Montana. M.Sc. Thesis, University of Montana, Missoula. 185 pages.

Deleray, M.L., Knotek, S. Rumsey, and T. Weaver. 1999. Flathead Lake and River System Fisheries Status Report. Montana Fish, Wildlife \& Parks, Kalispel, Montana. 200 pages, appendices.

Donald, D. B. and J. D. Stelfox. 1997. Effects of fisheries enhancement and access on adfluvial bull trout populations in mountain lakes of southern Alberta. Intermountain/foothill grassland 227-234 in Mackay, W. C., M. K. Brewin and M. Monita, editors. Friends of the bull trout conference proceedings. Bull Trout Task Force (Alberta), c/o Trout Unlimited Canada, Calgary

Fraley, J. J. and B. B. Shepard. 1989. Life history, ecology, and population status of migratory bull trout (Salvelinus confluentus) in the Flathead Lake and River System, Montana. Northwest Science 63:133-143.

Fraley, J., D. Read and P. Graham. 1981. Flathead River fisheries study. Montana Department of Fish, Wildlife \& Parks.

Goetz, F. 1989. Biology of the bull trout Salvelinus confluentus: a literature review. Willamette National Forest. Eugene, Oregon. 53 intermountain/foothill grassland. 


\section{DRAFT WORKING DOCUMENT DO NOT DUPLICATE}

12569

12570

12571

12572

12573

12574

12575

12576

12577

12578

12579

12580

12581

12582

12583

12584

12585

12586

12587

12588

12589

12590

12591

12592

12593

12594

12595

12596

12597

12598

12599

12600

12601

12602

12603

12604

12605

12606

12607

12608

12609

12610

12611

12612

12613
Holton, G. D. 1981. Identification of Montana's most common game and sport fishes. Montana Outdoors reprint.

Kanda, N., R. F. Leary and F. W. Allendorf. 1997. Population genetic structure of bull trout in the upper Flathead River drainage. Intermountain/foothill grassland 299-308 in Mackay, W. C., M. K. Brewin and M. Monita, editors. Friends of the bull trout conference proceedings. Bull Trout Task Force (Alberta), c/o Trout Unlimited Canada, Calgary.

Kitano, S., K. Maekawa, S. Nakano and K. D. Fausch. 1994. Spawning behavior of bull trout in the upper Flathead drainage, Montana, with special reference to hybridization with brook trout. Transactions of the American Fisheries Society 123:988-992.

Leary, R. F., F. W. Allendorf, S. H. Forbes. 1993. Conservation genetics of bull trout in the Columbia and Klamath River Drainages. Conservation Biology 7:856865.

Leathe, S. A. and M. D. Enk. 1985. Cumulative effects of micro-hydro development on the fisheries of the Swan River drainage, Montana. Report prepared for Bonneville Power Administration, Division of Fish and Wildlife. 114 intermountain/foothill grassland, appendices.

Long, M. H. 1997. Sociological implications of bull trout management in Northwest Montana: illegal harvest and game warden efforts to deter poaching. Intermountain/foothill grassland 71-73 in Mackay, W. C., M. K. Brewin and M. Monita, editors. Friends of the bull trout conference proceedings. Bull Trout Task Force (Alberta), c/o Trout Unlimited Canada, Calgary.

Marnell, L. F. 1985. Bull trout investigations in Glacier National Park, Montana. Intermountain/foothill grassland 33-35 in D. D. MacDonald, editor, Proceedings of the Flathead River Basin bull trout biology and population dynamics modeling information exchange. Fisheries Branch, British Columbia Ministry of Environment, Cranbrook, British Columbia.

Meehan, W. R. and T. C. Bjornn. 1991. Salmonid distributions and life histories. Intermountain/foothill grassland 76-78 in Influences of Forest and Rangeland Management on Salmonid Fishes and Their Habitats, W. R. Meehan, Ed. American Fisheries Society Special Publication 19, Bethesda, MD.

Parkinson, E. A. 1984. Genetic variation in populations of steelhead trout (Salmo gairdneri) in British Columbia. Can. J. Fish. Aquat. Sci. 41:1412-1420.

Ratliff, D. E. 1992. Bull trout investigations in the Metolius River-Lake Billy Chinook system. Intermountain/foothill grassland 37-44 in P. J. Howell and D. V. 


\section{DRAFT WORKING DOCUMENT DO NOT DUPLICATE}

12614 Buchanan, editors. Proceedings of the Gearhart Mountain bull trout workshop.

12615 Oregon Chapter of the American Fisheries Society, Corvallis.

12616

12617

12618

Ratliff, D. E. and P. J. Howell. 1992. The status of bull trout populations in

12619

12620

12621

12622

12623

Oregon. Intermountain/foothill grassland 10-17 in P. J. Howell and D. V.

Buchanan, editors. Proceedings of the Gearhart Mountain bull trout workshop.

Oregon Chapter of the American Fisheries Society, Corvallis.

12624

Riehle, M., W. Weber, A. M. Stuart, S. L. Thiesfeld and D. E. Ratliff. 1997.

Progress report of the multi-agency study of bull trout in the Metolius River

12625

system, Oregon. Intermountain/foothill grassland 137-144 in Mackay, W. C., M.

12626

12627

12628

12629

12630

12631

12632

12633

12634

12635

12636

12637

12638

12639

12640

12641

12642

12643

12644

12645

12646

12647

12648

12649

$\mathrm{K}$. Brewin and M. Monita, editors. Friends of the bull trout conference

proceedings. Bull Trout Task Force (Alberta), c/o Trout Unlimited Canada,

Calgary.

Rieman, B. E. and J. D. McIntyre. 1993. Demographic and habitat requirements for conservation of bull trout. USDA Forest Service, General Technical Report INT-302. 40 intermountain/foothill grassland.

Schmetterling, D. A. and M. H. Long. 1999. Montana anglers' inability to identify bull trout and other salmonids. Fisheries 24:24-27.

Spruell, P., B. E. Rieman, K. L. Knudsen, F. M. Utter and F. W. Allendorf. 1999. Genetic population structure within streams: microsatellite analysis of bull trout populations. Ecol. Freshwater Fish. 8:114-121.

Swanberg, T. R. 1996. The movement and habitat use of fluvial bull trout in the upper Clark Fork River drainage. Masters Thesis, University of Montana, 61 intermountain/foothill grassland.

12650

12651

12652

12653

12654

12655

12656

12657

Taylor, E. B., S. Pollard, and D. Louie. 1999. Mitochondrial DNA variation in bull trout (Salvelinus confluentus) from northwestern North America: implications for zoogeography and conservation. Mol. Ecol. 8:1155-1170.

USFWS (United States Fish and Wildlife Service). 1998. Endangered and threatened wildlife and plants; determination of threatened status for the Klamath River and Columbia River distinct population segments of bull trout. Federal Register 63:31647-31674.

12658

USFWS (United States Fish and Wildlife Service) 2002b. Endangered and Threatened Wildlife and Plants; Proposed Designation of Critical Habitat for the Klamath River and Columbia River Distinct Population Segments of Bull Trout. Federal Register 67: 71235-71284. Available:

http://pacific.fws.gov/bulltrout/criticalhab.htm. (February 2003). 


\section{DRAFT WORKING DOCUMENT DO NOT DUPLICATE}

12659 USFWS (United States Fish and Wildlife Service). 2002. Bull Trout (Salvelinus 12660 confluentus) Recovery Plan. U.S. Fish and Wildlife Service, Portland Oregon. 12661137 pages.

12662

12663 


\section{DRAFT WORKING DOCUMENT DO NOT DUPLICATE}

12663 12664

12665 12666 12667 12668 12669

12670 12671 12672 12673 12674 12675 12676

12677 12678 12679 12680 12681 12682 12683 12684 12685 12686 12687 12688 12689 12690 12691 12692 12693 12694

\section{Lake Trout (native lakes) (Salvelinus namaycush)}

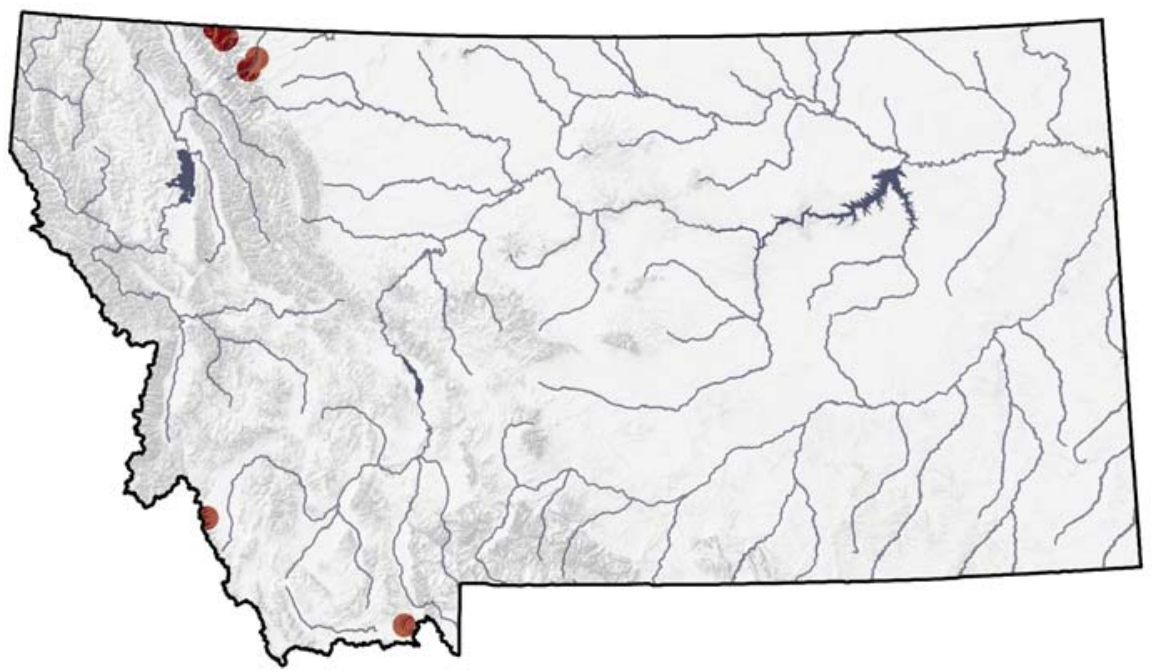

Figure 94. Distribution of Native Populations of lake Trout

\section{Range}

Montana's native lake trout populations remain in Waterton Lake, Glenns Lake, Cosley Lake, and St. Mary Lake in Glacier National Park and Lower St. Mary Lake in the Blackfeet Indian Reservation. All of these waters are in drainages that eventually reach Hudson Bay. Other native populations occur in Twin Lake in the Big Hole River drainage and Elk Lake in the Red Rock River drainage, both tributaries to the upper Missouri River drainage. Although there are records of some stocking of lake trout into Cosley, Glenn and Lower St. Mary lakes, mtDNA analysis by Wilson and Hebert (Wilson and Hebert 1998) gives evidence of the native status of the listed populations. Other lake trout populations in Montana are the result of legal and illegal introductions and are not remnant native populations.

\section{Habitat}

While lake trout can be found in cold rivers and shallow lakes in the northern portion of its range, (Scott and Crossman 1973) in Montana native lake trout inhabit a few deep, cold lakes remaining from the Pleistocene glaciations. Lake trout prefer water temperatures in the $50-57^{\circ} \mathrm{F}$ range and, therefore, spend most of their lives in the deeper, benthic habitats with these water temperatures. Lake trout can occasionally be found in shallow water habitats, usually immediately after ice-out when surface waters are within their preferred temperature range. They spawn in the fall on the rocky substrate of the shoreline. They scatter or broadcast their spawn, a rarity in the trout group. 


\section{DRAFT WORKING DOCUMENT DO NOT DUPLICATE}

12695

12696

12697

12698

12699

12700

12701

12702

12703

12704

12705

12706

12707

12708

12709

12710

12711

12712

12713

12714

12715

12716

12717

12718

12719

12720

12721

12722

12723

12724

12725

12726

12727

12728

12729

12730

12731

12732

12733

12734

12735

12736

12737

12738

12739

12740

\section{Management}

Management recommendations within this document pertain only to Elk Lake and Twin Lake populations. Little is known about the status of Montana's native lake trout populations. The populations in Waterton, Cosley, Glenns and St. Mary lakes are afforded the protection of their location within Glacier National Park. The Waterton population is believed to be abundant and stable. (Leo Marnell, NPS, personal communication).

St. Mary Lake is a 3500 acre lake at 4473 feet above mean sea level. The St. Mary Lake population is believed to be abundant and stable. Lake trout are the most dominant fish species after lake whitefish. There are records of stocking lake trout into St. Mary Lake so the genome of this population may contain exotic alleles. DNA analysis has been performed, but not reported, to identify the source stock for these introductions. (Leo Marnell, NPS, personal communication, Robbin Wagner, USFWS, personal communication).

Some question whether the Glenns and Cosley lakes populations are native due to the location of a downstream high barrier falls. (Leo Marnell, NPS, personal communication). Holton and Johnson 1996 did not list these as native populations; however, Wilson and Hebert 1998 found that there is genetic evidence that the Cosley Lake haplotype is consistent with the other populations that formed the Alberta/Montana refuge. The Cosley and Glenns lakes populations are believed to be stable. There are records of stocking lake trout of unknown origin into Cosley and Glenns lakes, so the genome of these populations may contain exotic alleles. DNA analysis has been performed, but not reported, to identify the source stock for these introductions. (Leo Marnell, NPS, personal communication, Robbin Wagner, USFWS, personal communication).

Lower St. Mary Lake is located within the Blackfeet Indian Reservation. This population is stable and abundant. Lake trout are the most dominant fish species after lake whitefish and comprise $10-30 \%$ of the commercial lake whitefish catch. Again, there are records of stocking lake trout of unknown origin into Lower St. Mary Lake. Water level fluctuations and dewatering due to lake management for irrigation impacts this population. (Robbin Wagner, USFWS, personal communication)

Elk Lake is a 283 surface acre lake at 6674 feet elevation with a maximum depth of 70 feet. (USFS, 2004). The population in Elk Lake is small (250-1000 fish) and declining. This population has a poor age structure due to limited recruitment. (Oswald, unpublished FWP data)

Twin Lake is a 75 surface acre lake at 7235 feet elevation with a maximum depth of 72 feet. (USFS, 2004). The Twin Lake population is also small (50-250 fish), declining, with little recruitment. (Oswald, unpublished FWP data) 


\section{DRAFT WORKING DOCUMENT DO NOT DUPLICATE}

12741

12742

12743

12744

12745

12746

12747

12748

12749

12750

12751

12752

12753

12754

12755

12756

12757

12758

12759

12760

12761

12762

12763

12764

12765

12766

12767

12768

12769

12770

12771

12772

12773

12774

12775

12776

12777

12778

12779

12780

12781

12782

12783

The genetic uniqueness and significance of Montana's lake trout populations to the post-glacial distribution of the species mandate that these remnant native populations be conserved.

\section{Conservation Concerns}

- Little information on native populations

- Irregular recruitment

- Genetic bottlenecks caused by small size of remainding populations

- Limiting factors unknown

\section{Conservation Strategies}

- Consider preparing management plan for Native lakes Lake Trout or inclusion into other comprehensive taxonomic plan

- Increased monitoring and surveying

- Reintroduce native genetically pure populations

- Identify and remedy limiting factors

\section{Management Plan}

None

\section{Citations}

Marnell, Leo. NPS, 2004, personal communication.

Scott, W.B. and E.J. Crossman. 1973. Freshwater Fishes of Canada. Bulletin 184. Fisheries Research Board of Canada, Ottawa. 966 pp.

Snyder, Bob \& Oswald, Richard. 2004. Status of Native Lake Trout in Montana. Montana Fish, Wildlife \& Parks. Helena, MT. Draft--in progress.

United States Forest Service. 2004. Beaverhead National Forest Lake Inventory. Available at http://www.fs.fed.us/r1/b-d/ (Accessed August 27, 2004).

Wagner, Robbin. USFWS, 2004, personal communication

Wilson, C.C. and P.D.N. Hebert. 1998. Phylogeography and postglacial dispersal of lake trout (Salvelinus namaycush) in North America. Can. J. Fish Aquat. Sci. 55: 1010-1024. 


\section{DRAFT WORKING DOCUMENT DO NOT DUPLICATE}

12783 12784

12785

12786

12787

12788

12789

12790

12791

12792

12793

12794

12795

12796

12797

12798

12799

12800

12801

12802

12803

12804

12805

12806

12807

12808

12809

12810

12811

12812

12813

12814

\section{Arctic Grayling (Thymallus arcticus)}

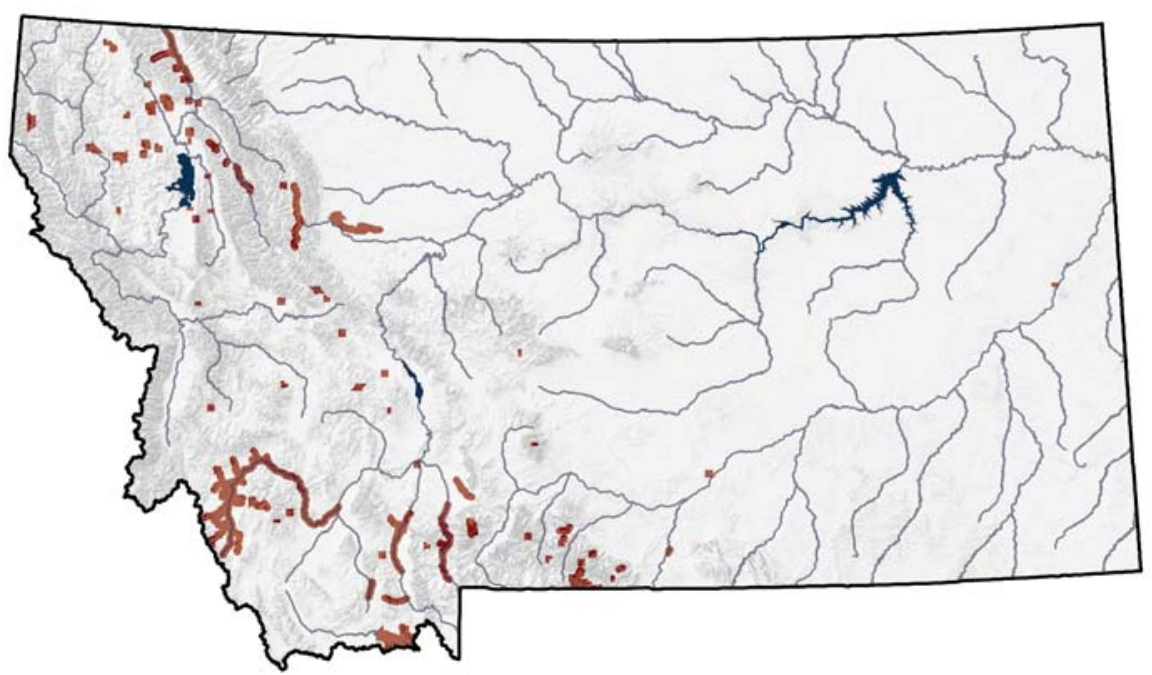

Figure 95. Distribution of the Arctic Grayling

\section{Range}

At the end of the 19th century, fluvial Arctic grayling were intermittently distributed throughout the upper Missouri drainage above Great Falls (Vincent 1962). During the 20th century, the range of fluvial Arctic grayling has been restricted to the Big Hole River of southwest Montana, about $4 \%$ of its native range (Kaya 1992a). Vincent (1962) attributed the decline of fluvial Arctic grayling throughout their native range to four factors: habitat degradation, introduction of non-native salmonids, climatic change, and exploitation by anglers.

\section{Habitat}

Occur in both ponds/lakes as well as riverine systems, however these differences make two distinct populations of either adfluvial or fluvial populations. Cool temperatures are needed to sustain populations as well as gravelly substrate needed for breeding purposes.

\section{Management}

The Fluvial Arctic Grayling Workgroup (FGW) developed a plan to research, protect, and restore fluvial Arctic grayling (FGW 1995). A primary objective was to develop a brood stock from wild Big Hole River Arctic grayling to preserve their genetic identity. Gametes were collected from spawning Arctic grayling in the Big Hole River between 1988 and 1992, until a sufficient founding population was represented (Leary 1991). Progeny of the brood stock with genetic diversity equivalent to the wild stock were available in 1995. Arctic grayling derived from 


\section{DRAFT WORKING DOCUMENT DO NOT DUPLICATE}

12815

12816

12817

12818

12819

12820

12821

12822

12823

12824

12825

12826

12827

12828

12829

12830

12831

12832

12833

12834

12835

12836

12837

12838

12839

12840

12841

12842

12843

12844

12845

12846

12847

12848

12849

12850

12851

12852

12853

12854

12855

12856

12857

12858

12859

12860

the brood may be used to augment the Big Hole River population, if necessary, and to reestablish other populations within their native range.

Another objective of FGW is to expand the range of fluvial grayling beyond the Big Hole River basin. Kaya (1992b) identified streams suitable for reintroductions of fluvial grayling. Experimental reintroductions have occurred in Cougar Creek, Yellowstone National Park, and in the West and East Gallatin rivers using progeny of the brood stock. Intensive reintroduction efforts are scheduled in 1997 for the Ruby River of southwestern Montana and the Firehole and Gibbons rivers in Yellowstone National Park in the near future.

Water quality and quantity problems are being addressed in the Big Hole basin. Efforts are underway to develop groundwater to supply livestock water while preserving minimum instream flows. Supplementation of instream flows through storage and water leasing has been investigated. Water conservation efforts in conjunction with water users were successful in preserving flows during severe drought in 1994.

A habitat inventory conducted in 1994 will provide baseline information necessary to identify degraded habitats and potential rehabilitation projects. Projects will be oriented toward riparian rehabilitation, decreasing peak water temperatures, and identifying and protecting critical habitats. While catch-andrelease-only regulations protect grayling from over-harvest, angling regulations will also be used to exert pressure on non-native trout. More liberal regulations may inhibit encroachment of rainbow and brown trout into key grayling habitat.

\section{Conservation Concerns}

- Low flows during severe drought decrease survival of older Arctic grayling due to high water temperatures, increased susceptibility to predation, and diminished habitat volume

- Displacement by non-native rainbow and brook trout

- Arctic grayling are easily caught by anglers and are susceptible to overharvest

- Degradation of riparian vegetation and stream banks by unsustainable grazing practices, mass willow removal, and dewatering the river for agricultural uses have negatively impacted fish habitat

- Blockage of fish passage by irrigation diversions

\section{Conservation Strategies}

- Support management of grazing to maintain riparian vegetation and streambank and channel stability in excellent condition

- Increased management of anglers

- Less stocking of non-native fish

- Decreased water runoff for irrigation purposes to increase stream volumes 


\section{DRAFT WORKING DOCUMENT DO NOT DUPLICATE}

12861

12862

12863

12864

12865

12866

12867

12868

12869

12870

12871

12872

12873

12874

12875

12876

12877

12878

12879

12880

12881

12882

12883

12884

12885

12886

12887

12888

12889

12890

12891

12892

12893

12894

12895

12896

12897

12898

12899

12900

12901

12902

12903

12904

12905

12906

\section{Management Plans}

Kaya, Calvin M. 1990. Status Report on Fluvial Arctic Grayling (Thymallus arcticus) in Montana. Biology Department, Montana State University. Bozeman, MT. Prepared for: FWP. Helena, MT

Montana Fluvial Arctic Grayling Workgroup. 1995. Montana Fluvial Arctic Grayling Restoration Plan. Montana Department of Fish, Wildlife, and Parks, Helena.

\section{Citations}

Byorth, P. A. 1993. Big Hole River Arctic grayling recovery project: Annual monitoring report 1992.Submitted to: Fluvial Arctic Grayling Workgroup. Montana Department of Fish, Wildlife, and Parks, Bozeman.

Clark, R. A. 1992. Influence of stream flows and stock size on recruitment of Arctic grayling (Thymallus arcticus) in the Chena River, Alaska. Canadian Journal of Fisheries and Aquatic Sciences 49(5): 1027-1034.

Kaya, C.M. 1992a. Review of the decline and status of fluvial Arctic grayling (Thymallus arcticus), in Montana. Proceedings of Montana Academy of Sciences 52:43-70.

Kaya, C.M. 1992b. Restoration of fluvial Arctic grayling to Montana streams: assessment of reintroduction potential of streams in the native range, the upper Missouri River drainage above Great Falls. Prepared for: Montana Chapter of the American Fisheries Society and Montana Department of Fish, Wildlife, and Parks, Bozeman.

Leary, R. F. 1991. Establishment, primarytenance, and use of a genetic reserve of Big Hole River Arctic grayling. Wild Trout and Salmon Genetics Laboratory Report 91/5. University of Montana, Missoula.

Lohr, S. C., P. A. Byorth, C. M. Kaya, and W. P. Dwyer. 1996. High temperature tolerances of fluvial Arctic grayling and comparisons with summer water temperatures of the Big Hole River, Montana. Transactions of the American Fisheries Society 125:933-939.

Magee, J. P. and P. A. Byorth. 1994. Competitive interactions of fluvial Arctic grayling (Thymallus arcticus) and brook trout (Salvelinus fontinalis) in the upper Big Hole River, Montana. Submitted to: Fluvial Arctic Grayling Workgroup. Montana Department, of Fish, Wildlife, and Parks, Bozeman. 


\section{DRAFT WORKING DOCUMENT DO NOT DUPLICATE}

12907 Magee, J.P. and P.A. Byorth. 1995. Competitive interactions of fluvial Arctic 12908 grayling and sympatric species in the Big Hole River drainage, Montana.

12909 Submitted to: Fluvial Arctic Grayling Workgroup. Montana Fish, Wildlife, and 12910 Parks, Bozeman.

12911

12912

12913

12914

12915

12916

12917

12918

12919

12920

12921

12922

12923

12924

12925

12926

Shepard, B. B., and R. A. Oswald. 1989. Timing, location, and population characteristics of spawning Montana Arctic grayling (Thymallus arcticus montanus [Milner]) in the Big Hole River drainage, 1988. Montana Department of Fish, Wildlife, and Parks, Bozeman.

Skaar, D. 1989. Distribution, relative abundance, and habitat utilization of Arctic grayling (Thymallus arcticus) in the upper Big Hole River drainage, Montana, July 5 to September 8, 1988. Report to: Montana Natural Heritage Program, Beaverhead National Forest, and Montana Department. of Fish, Wildlife, and Parks, Bozeman.

Vincent, R. E. 1962. Biogeographical and biologic factors contributing to the decline of Arctic grayling (Thymallus arcticus [Pallus]) in Michigan and Montana. Ph.D. Dissertation, University of Michigan, Ann Arbor. 


\section{DRAFT WORKING DOCUMENT DO NOT DUPLICATE}

12927

12928

12929

12930

12931

12932

12933

12934

12935

12936

12937

12938

12939

12940

12941

12942

12943

12944

12945

12946

12947

12948

12949

12950

12951

12952

12953

12954

12955

12956

12957

12958

\section{Sturgeon Chub (Hybopsis gelida)}

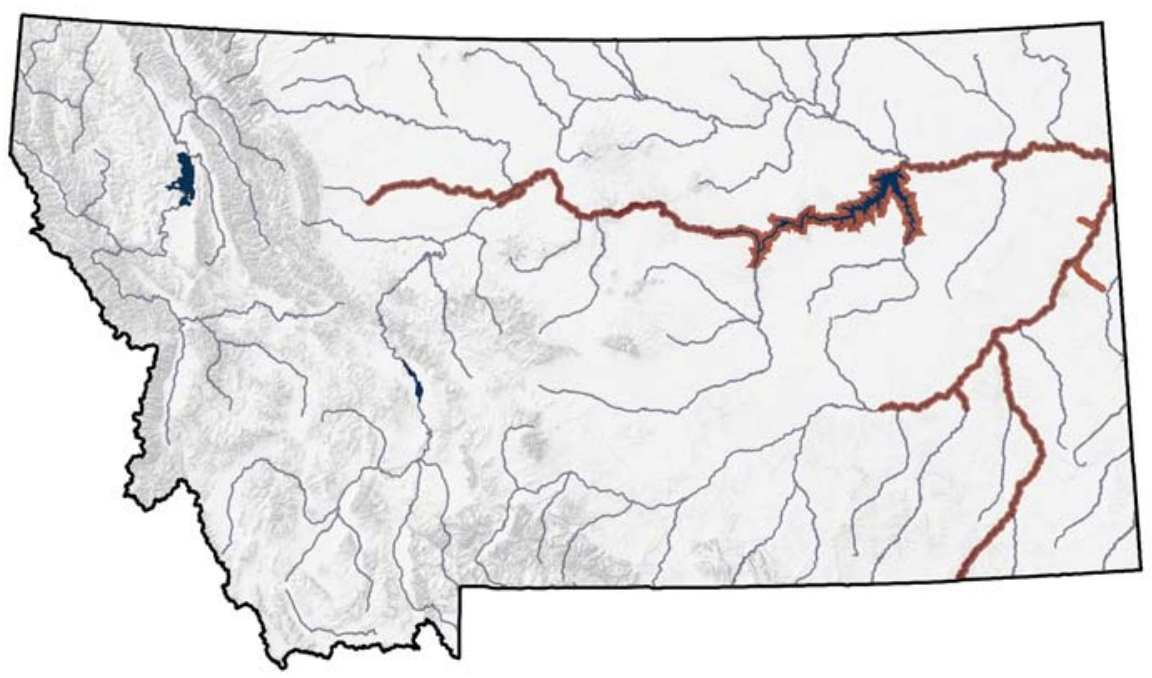

Figure 96. Distribution of the Sturgeon Chub

\section{Range}

The sturgeon chub is indigenous to the Missouri-Mississippi river basins from Montana to Louisiana (Lee et al. 1980; Werdon 1993). Historically, sturgeon chub have been collected in small numbers from only a few locations in Montana so the Montana Department of Fish, Wildlife \& Parks designated it a state species of special concern over two decades ago (Holton 1980). More recently, Werdon (1993) reported the sturgeon chub was in possible danger of extinction over much of its former range, including all relevant Montana waters except the Powder River. However, recent collections of this species show it is more widespread and abundant than previously understood. Prior to 1975 only four collections of sturgeon chub were known from Montana. The first collection was taken from an unknown site on the Milk River (Girard 1856) and three collections were reported over 100 years later from the Yellowstone River drainage (Bailey and Allum 1962; Brown 1971). Collections from 1975-1982 determined that chubs were also present throughout the Powder River (Rehwinkle 1978), in the lower Tongue River 1980), in the lower Teton and the middle Missouri rivers (Gardner and Berg 1982).

During the Period 1990-95, collections have verified the persistence of sturgeon chub in much of their previously known range and established major range extensions. Sturgeon chub are still present in the Powder River (Werdon 1993; Gould 1994), lower Yellowstone River (Werdon 1993; 1994 MSU collections by Bramblett et al.) and mid-Missouri River (1994 MSU collections by Gardner and Grisak). Furthermore, collections from 1993 - 1995 have yielded significant up and down-stream range extensions in the lower Yellowstone (MSU collections by Bramblett et al., Ruggles 1997 and Stewart 1994), mid-Missouri (MSU collections 


\section{DRAFT WORKING DOCUMENT DO NOT DUPLICATE}

12959 by Gardner and Grisak) and the lower Missouri rivers (Tews 1993 and Ruggles

12960

12961

12962

12963

12964

12965

12966

12967

12968

12969

12970

12971

12972

12973

12974

12975

12976

12977

12978

12979

12980

12981

12982

12983

12984

12985

12986

12987

12988

12989

12990

12991

12992

12993

12994

12995

12996

12997

12998

12999

13000

13001

13002

13003

13004

1997). In total, recent sturgeon chub have been found over some $650 \mathrm{~km}$ in three Montana rivers (Gould 1994). However, sampling has not been able to establish their continued existence in the lower Teton, Milk and Tongue rivers (Gould 1994).

\section{Habitat}

Sturgeon chub are highly adapted to life in turbid waters. They have small eyes and many external papillae on their bodies and fins, probably to aid in locating food (Cross 1967, Pflieger 1975). Chub are most closely associated with sites having moderate currents and depths and sand or rock substrates (Baxter and Simon 1970; Brown 1971; Lee et al. 1980). In the Powder River, sturgeon chub were taken most frequently at sites with depths less than $51 \mathrm{~cm}$ and depth velocities of less than $90 \mathrm{~cm} / \mathrm{s}$ at 0.6 depth (Stewart 1981; Werdon 1992; Gould unpublished data).

\section{Management}

The management of this species should involve routine monitoring (once every 2-3 years) of existing populations. The program should be designed to monitor population trends, range expansion or losses and collect additional information on life history and ecology. This could be conducted while sampling for other species. Recommendations for operating reservoir and irrigation projects should be developed for improving and maintaining sturgeon chub populations and habitats in Montana. Reintroduction of sturgeon chub should be considered for the lower Teton, Milk and Tongue rivers.

\section{Conservation Concerns}

- Habitat alteration by dam operations, reducing turbidities and/or altering temperature and flow regimes

- Channelization of the Missouri river due to irrigation operations and development

- Decreased range and abundance of prey aquatic insect larvae due to dam construction and snag removal

- Removal of wild individuals used for bait fish

- Predation by non-native fish

- Low stream flows probably have eliminated some peripheral sturgeon chub populations in smaller streams

\section{Conservation Strategies}

- Consider preparing management plan for Sturgeon Chub or inclusion into other comprehensive taxonomic plan

- Support sustainable irrigation projects 
13005 13006 13007 13008 13009 13010 13011 13012 13013 13014 13015 13016 13017 13018 13019 13020 13021 13022 13023 13024 13025 13026 13027 13028 13029 13030 13031 13032 13033 13034 13035 13036 13037 13038 13039 13040 13041 13042 13043 13044 13045 13046 13047 13048 13049

- Conservation practices on large rivers in Eastern Montana

- Increased monitoring and survey efforts in Eastern Montana

- Educate the public of necessity of native species

- Repopulate smaller tributaries such as Teton, Milk and Tongue to establish periphery populations

\section{Management Plan}

None

\section{Citations}

Bailey, R. and M. Allum. 1962. Fishes of South Dakota. Museum of Zoology, University of Michigan. Ann Arbor.

Baxter, G. and J. Simon. 1970. Wyoming fishers. Bulletin Number 4, Wyoming Game and Fish Department. Cheyenne.

Bicknell, William. 2001. USFWS Federal Registry. Notice of 12-month petition finding to list the Sicklefin Chub (Macrhybopsis meeki) and the Sturgeon Chub (Macrhybopsis gelida) as Endangered. 3425 Miriam Avenue, Bismarck, North Dakota, 58501.10 pgs.

Brown, C. 1976. Fishes of Montana. Big Sky Books, Montana State University. Bozeman.

Cross, F. 1967. Handbook of fishes of Kansas. Museum of Natural History, University of Kansas. Lawrence, Kansas.

Gardner, W. M. and R. Berg. 1982. An analysis of the instream flow requirements for selected fishes in the wild and scenic portion of the Missouri River. Montana Fish, Wildlife \& Parks. Helena. 111pp.

Girard, C. 1856. Researches upon the cyprinoid fishes inhabiting the fresh waters of the United States, west of the Mississippi Valley, from specimens in the museum of the Smithsonian Institution. Proceedings of the Academy of Natural Science of Philadelphia. 8: 165-213.

Gould, W. 1994. The recent distribution of sturgeon chub (Macrhybopsis gelida) in Montana. Report to the Montana Department of Fish, Wildlife \& Parks. Helena.

Hiebert, S. D., R. Wydoski and T.J. Parks. 1999. Fish entrainment at the lower Yellowstone Diversion Dam, Intake Canal, Montana - 1996-1998. Technical Service Center Data Report. Bureau of Reclamation. In press. 52 pp. 


\section{DRAFT WORKING DOCUMENT DO NOT DUPLICATE}

13050 Holton, G. 1980. The riddle of existence; fishes of special concern. Montana 13051 Outdoors 11: 2-6.

13052

13053

13054

13055

13056

13057

13058

13059

13060

13061

13062

13063

13064

13065

13066

13067

13068

13069

13070

13071

13072

13073

13074

13075

13076

13077

13078

13079

13080

13081

13082

13083

13084

13085

13086

13087

13088

Lee, S. et al. 1980. Atlas of North American freshwater fishes. North Carolina State Museum of Natural History. Raleigh.

Pflieger, W. 1975. The fishes of Missouri. Missouri Department of Conservation. Jefferson City, Missouri.

Rehwinkle, B. 1978. Powder River aquatic ecology project. Report to Utah International, Inc. Salt Lake City.

Ruggles, M.P. 1997. Sections 2 \& 3: Upper Inter-Reservoir I and Lower Yellowstone River, Montana. In D.J. Dieterman, M.P. Ruggles, M.L. Wildhaber, and D.L. Galat, editors. Population structure and habitat use of benthic fishes along the Missouri and Lower Yellowstone Rivers. 1997 Annual Report of Missouri River Benthic Fish Study PD-95-5832 to U.S. Army Corps of Engineers and U.S. Bureau of Reclamation.

Stewart, D. 1981. The biology of the sturgeon chub (Hybopsis gelida Girard) in Wyoming. Masters Thesis. University of Wyoming. Laramie.

Tews A. 1993. Pallid sturgeon and shovelnose sturgeon in the Missouri River from Fort Peck Dam to Lake Sacagawea and in the Yellowstone from Intake to its mouth. Report submitted to the U.S. Army Corps of Engineers. Planning Branch. Omaha.

Welker, T. L., Scarnecchia D. L. Habitat use and population structure of four native minnows (family Cyprinidae) in the upper Missouri and lower Yellowstone rivers, North Dakota (USA). Ecology of Freshwater Fish 2004: 13: 8-22.

Werdon, S. 1992. Population status and characteristics of Macrhybopsis gelida, Platygobio gracilis and Rhinichthyes cataractae in the Missouri river Basin. Masters Thesis. South Dakota State University. Brookings.

Werdon, S. 1993. Status report on sturgeon chub (Macrhybopsis gelida), a candidate endangered species. U.S. Fish and Wildlife Service, Ecological Services, North Dakota State Office. Bismarck.

13089 


\section{DRAFT WORKING DOCUMENT DO NOT DUPLICATE}

13089 13090

13091

13092

13093

13094

13095

13096

13097

13098

13099

13100

13101

13102

13103

13104

13105

13106

13107

13108

13109

13110

13111

13112

13113

13114

13115

13116

13117

13118

13119

13120

\section{Sicklefin Chub (Hybopsis meeki)}

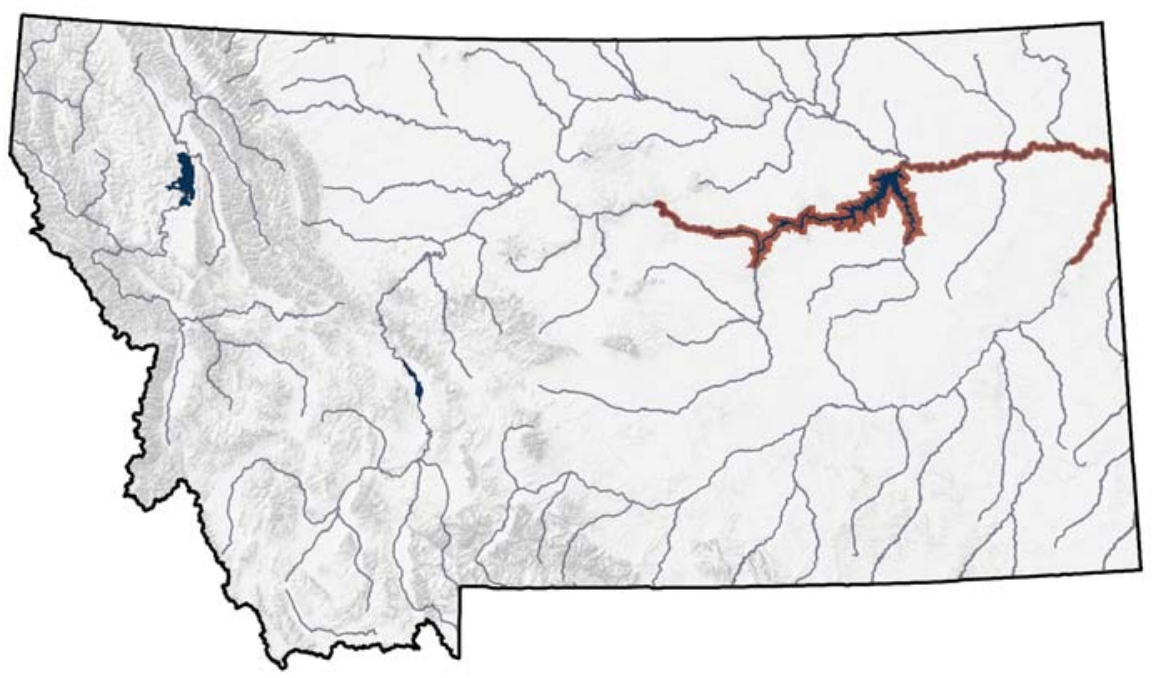

Figure 97. Distribution of the Sicklefin Chub

\section{Range}

The first observation of sicklefin chub in Montana was in 1979 in the middle Missouri River upstream of Fort Peck Reservoir (Gould 1981 and Gardner and Berg 1982). Until this time they were unknown to exist in the state most likely because of the lack of sampling effort in eastern Montana. At present, the distribution of sicklefin chub in Montana includes the middle Missouri River from Cow Island downstream to the headwaters of Fort Peck Reservoir (Grisak 1996), the lower Missouri River from the mouth of Redwater River to the Yellowstone River confluence (Liebelt 1996), and in the lower Yellowstone River, from Intake Diversion Dam to the confluence with the Missouri (Ruggles 1997). As of 1997, the known range of sicklefin chub encompasses nearly 280 kilometers of river in the Missouri and Yellowstone drainages.

\section{Habitat}

Spawning occurs in primary channel areas of large turbid rivers that they inhabit. The spawning period is in the summer months and probably occurs over a wide time span, similar to other big river species. Young of the year sicklefin chub have never been collected and early life history remains a mystery. Although the species has been sampled from shallow water and rocky substrate, there seems to be a general preference for deeper water and sandy substrate. Unlike the sturgeon chub, all of the Montana captures have been from only the Missouri and Yellowstone rivers, indicating a strong preference for large turbid rivers.

\section{Management}




\section{DRAFT WORKING DOCUMENT DO NOT DUPLICATE}

13121

13122

13123

13124

13125

13126

13127

13128

13129

13130

13131

13132

13133

13134

13135

13136

13137

13138

13139

13140

13141

13142

13143

13144

13145

13146

13147

13148

13149

13150

13151

13152

13153

13154

13155

13156

13157

13158

13159

13160

13161

13162

13163

13164

13165

13166

The management of this species should involve routine monitoring (once every 2-3 years) of existing populations. The program should be designed to monitor population trends, range expansion or losses and collect additional information on life history and ecology. This could be conducted while sampling for other species. The lack of proper monitoring of these populations could lead to their demise by virtue of not recognizing if and when they are in jeopardy of becoming extirpated by any artificial or natural entity. Recommendations for operating reservoir and irrigation projects should be developed for improving and maintaining sicklefin chub populations and habitats in Montana.

\section{Conservation Concerns}

- Habitat alteration by dam operations, reducing turbidities and/or altering temperature and flow regimes

- Channelization of the Missouri river due to irrigation operations and development

- Decreased range and abundance of prey aquatic insect larvae due to dam construction and snag removal

- Removal of wild individuals used for bait fish

- Predation by non-native fish

\section{Conservation Strategies}

- Consider preparing management plan for Sicklefin Chub or inclusion into other comprehensive taxonomic plan

- Support sustainable irrigation practices

- Conservation practices on large rivers in Eastern Montana

- Increased monitoring and survey efforts in Eastern Montana

- Educate the public of necessity of native species

\section{Management Plan}

None

\section{Citations}

Bicknell, William. 2001. USFWS Federal Registry. Notice of 12-month petition finding to list the Sicklefin Chub (Macrhybopsis meeki) and the Sturgeon Chub (Macrhybopsis gelida) as Endangered. 3425 Miriam Avenue, Bismarck, North Dakota, 58501. 10 pgs.

Dieterman, Douglas J. and Galat, David L. 2004. Large-Scale factors associated with Sicklefin Chub distribution in the Missouri and Lower Yellowstone Rivers. Transactions of the American Fisheries Society 133:577-587. 


\section{DRAFT WORKING DOCUMENT DO NOT DUPLICATE}

13167 Gardner, W. M. and R. Berg. 1982. An analysis of the instream flow 13168 requirements for selected fishes in the wild and scenic portion of the Missouri 13169 River. Montana Fish, Wildlife \& Parks. Helena. 111pp.

13170

13171

13172

13173

13174

13175

13176

13177

13178

13179

13180

13181

13182

13183

13184

13185

13186

13187

13188

13189

13190

13191

Grisak, G. G. 1996. The status and distribution of the sicklefin chub in the middle Missouri River, Montana. Masters thesis. Montana State University, Bozeman.

Gould, W.R. 1981. First records of the rainbow smelt (Osmeridae), sicklefin chub (Cyprinidae) and white bass (Percichthyidae) from Montana. Proc. Mont. Acad. Sci. 40: 9-10.

Liebelt, J.E. 1996. Lower Missouri River and Yellowstone River pallid sturgeon study, 1994-1995. Montana Department of Fish, Wildlife \& Parks. Helena.

Ruggles, M.P. 1997. Sections 2 \& 3: Upper Inter-Reservoir I and Lower Yellowstone River, Montana. In D.J. Dieterman, M.P. Ruggles, M.L. Wildhaber, and D.L. Galat, editors. Population structure and habitat use of benthic fishes along the Missouri and Lower Yellowstone Rivers. 1997 Annual Report of Missouri River Benthic Fish Study PD-95-5832 to U.S. Army Corps of Engineers and U.S. Bureau of Reclamation.

Welker, T. L., Scarnecchia D. L. Habitat use and population structure of four native minnows (family Cyprinidae) in the upper Missouri and lower Yellowstone rivers, North Dakota (USA). Ecology of Freshwater Fish 2004: 13: 8-22. 


\section{DRAFT WORKING DOCUMENT DO NOT DUPLICATE}

13192 13193

13194

13195

13196

13197

13198

13199

13200

13201

13202

13203

13204

13205

13206

13207

13208

13209

13210

13211

13212

13213

13214

13215

13216

13217

13218

13219

13220

13221

13222

13223

\section{Pearl Dace (Margariscus margarita)}

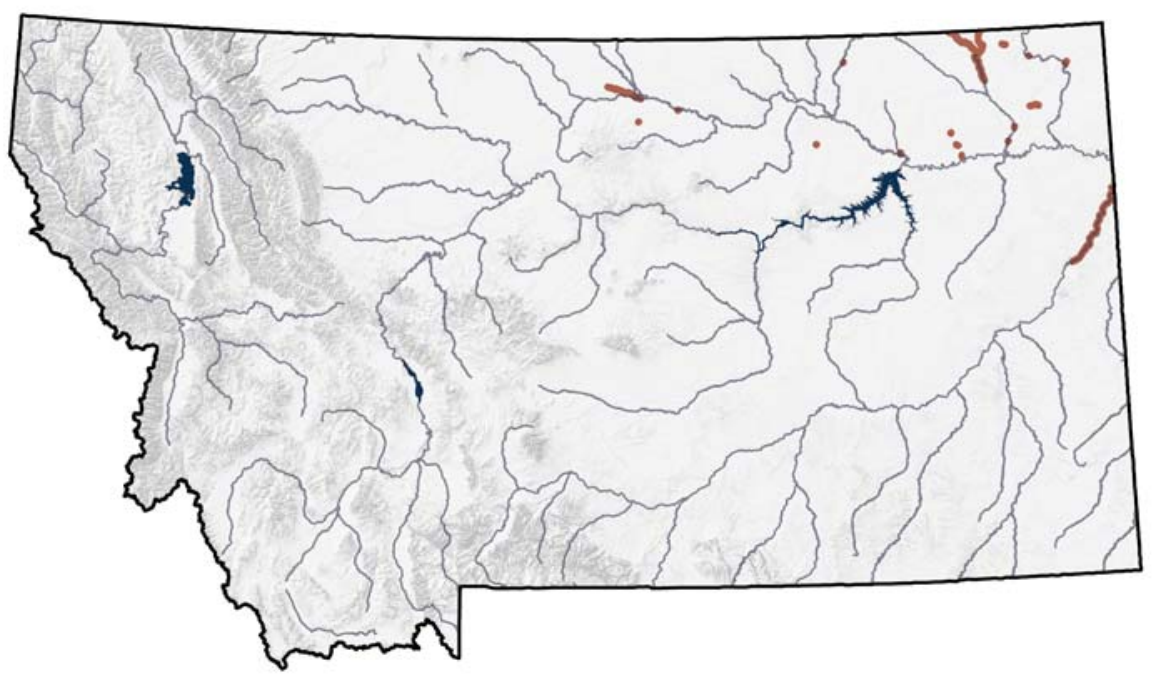

Figure 98. Distribution of the Pearl Dace

\section{Range}

Montana contains the southwestern periphery of the continental range of the pearl dace. In Montana, pearl dace occur only in the Missouri and

Saskatchewan River basins. Most known pearl dace localities are in southflowing tributaries to the Missouri River downstream of the confluence of the Milk River, in the Milk River drainage, or on the Blackfeet Indian Reservation in Glacier County and in Glacier National Park (Schultz 1941; Gould and Brown 1968; Brown 1971; Holton and Johnson 2003; Stash 2001; Bramblett, unpublished data; Robbin Wagner, U. S. Fish and Wildlife Service, personal communication, January 2004).

Two previously reported localities for pearl dace in the lower Yellowstone River (Gould and Brown 1968; Brown 1971; Holton and Johnson 2003) were probably attributable to misidentified creek chubs. The Gould and Brown (1968) collection was reexamined and the putative pearl dace was found to be a creek chub (William R. Gould, Montana State University, personal communication, January 2004). Other surveys have failed to find pearl dace in the Yellowstone River basin in Montana (Elser et al. 1980; Bramblett, unpublished data). Pearl dace appear to be a glacial relict in Montana as they are most commonly found in formerly glaciated portions of the plains regions.

\section{Habitat}

Pearl dace occur in lakes, cool bog ponds, creeks, and cool springs (Scott and Crossman 1973). Little habitat-related information exists for this species in Montana. At four stream locations where pearl dace were captured in 


\section{DRAFT WORKING DOCUMENT DO NOT DUPLICATE}

13224 northeastern Montana, average stream widths ranged from 5.4 to $11.8 \mathrm{~m}$,

13225

13226

13227

13228

13229

13230

13231

13232

13233

13234

13235

13236

13237

13238

13239

13240

13241

13242

13243

13244

13245

13246

13247

13248

13249

13250

13251

13252

13253

13254

13255

13256

13257

13258

13259

13260

13261

13262

13263

13264

13265

13266

13267

13268

average thalweg depths ranged from 0.4 to $1.4 \mathrm{~m}$, substrates ranged from 53 to $100 \%$ fine substrate $(<0.06 \mathrm{~mm})$, and aquatic macrophytes were sparse to very heavy ( $<10 \%$ to $>75 \%$ coverage; Bramblett, unpublished data). Eleven fish species were associated with pearl dace in seven collections from four sites on four Montana streams.

Pearl dace appear to prefer cool to coldwater temperatures. In Canada, pearl dace were more often found to co-occur with brook trout (Salvelinus fontinalis) and mottled sculpin (Cottus bairdi) at water temperatures of 15.8 to $16.6^{\circ} \mathrm{C}$, than with smallmouth bass (Micropterus dolomieu) and rock bass (Ambloplites rupestris) at 20.8 to $21.5^{\circ} \mathrm{C}$ (Becker 1983). The upper lethal temperature for pearl dace was found to be $31.1^{\circ} \mathrm{C}$ (Becker 1983). In the southernmost part of their range in Maryland and Virginia, pearl dace were found in streams that were cool in summer and warm in winter, with substantial spring-water input (Tsai and Fava 1982). In Montana, pearl dace were captured in streams with daytime water temperatures in July-September ranging from 9.6 to $23.1^{\circ} \mathrm{C}$ (Bramblett, unpublished data).

\section{Management}

Montana Fish, Wildlife \& Parks classify the pearl dace as a species of special concern. The primary management task is to monitor the status of the species in Montana. Fish surveys supported by voucher specimens should be conducted in streams across the range of the species to better determine its geographic range. Streams with historical collection records should be sampled to determine if the species is still extant there. Further introductions or expansions of the ranges of introduced piscivores, especially northern pike, should be discouraged.

\section{Conservation Concerns}

- Limited distribution in Montana renders it vulnerable to extirpation from the state

- Populations vulnerable to predation and competition

- Collected by anglers seeking bait minnows

- Anthropogenic stressors that increase water temperatures

\section{Conservation Strategies}

- Consider preparing management plan for Pearl Dace or inclusion into other comprehensive taxonomic plan

- Reduce introduction of non-native species into river systems

- Conservation of prairie streams to include less livestock use, increase riparian quality, decrease fertilizers and nutrients used

- Educate anglers of importance of native fish 
13269

13270

13271

13272

13273

13274

13275

13276

13277

13278

13279

13280

13281

13282

13283

13284

13285

13286

13287

13288

13289

13290

13291

13292

13293

13294

13295

13296

13297

13298

13299

13300

13301

13302

13303

13304

13305

13306

13307

13308

13309

13310

13311

13312
- Reduce stocking of non-native fish which may compete or prey on this species

\section{Management Plan}

None

\section{Citations}

Becker, G. C. 1983. Fishes of Wisconsin. The University of Wisconsin Press, Madison.

Brown, C. J. D. 1971. Fishes of Montana. Big Sky Books. Montana State University-Bozeman.

Elser, A. A., M. W. Gorges, and L. M. Morris. 1980. Distribution of fishes in southeastern Montana. Montana Department of Fish, Wildlife, and Parks, Helena.

Findlay, C. S., D. G. Bert, and L. Zheng. 2000. Effect of introduced piscivores on native minnow communities in Adirondack lakes. Canadian Journal of Fisheries and Aquatic Sciences 57:570-580.

Gould, W. R., and C. J. D. Brown. 1968. Fishes of the genus Semotilus (Cyprinidae) from Montana. Copeia 1968: 628-629.

Holton, G. D., and H. E. Johnson. 2003. A field guide to Montana fishes, 3rd edition. Montana Fish, Wildlife \& Parks, Helena.

MacRae, P. S. D., and D. A. Jackson. 2000. The influence of smallmouth bass (Micropterus dolomieui) predation and habitat complexity on the structure of littoral zone fish assemblages. Canadian Journal of Fisheries and Aquatic Sciences 58:342-351.

Schultz, L. P. 1941. Fishes of Glacier National Park Montana. U. S.

Department of the Interior Conservation Bulletin, Number 22, Washington, D. C.

Scott, W. B., and E. J. Crossman. 1973. Freshwater fishes of Canada. Bulletin 184 Fisheries Research Board of Canada, Ottawa.

Stash, S.W. 2001. Distribution, relative abundance, and habitat association of Milk River fishes related to irrigation diversion dams. Masters thesis. Montana State University, Bozeman. 


\section{DRAFT WORKING DOCUMENT DO NOT DUPLICATE}

13313 Tsai, C., and J. A. Fava. 1982. Habitats and distribution of the pearl dace, 13314 Semotilus margarita (Cope), in the Potomac River drainage. Virginia Journal of 13315 Science 33:201-205.

13316

13317

13318

Whittier, T. R., D. B. Halliwell, and S. G. Paulsen. 1997. Cyprinid distributions in

13319 Northeastern U.S.A. lakes: Evidence of regional-scale minnow biodiversity

13320 losses. Canadian Journal of Fisheries and Aquatic Sciences 54:1593-1607. 


\section{DRAFT WORKING DOCUMENT DO NOT DUPLICATE}

13321

13322

13323

13324

13325

13326

13327

13328

13329

13330

13331

13332

13333

13334

13335

13336

13337

13338

13339

13340

13341

13342

13343

13344

13345

13346

13347

13348

13349

13350

13351

13352

\section{Blue Sucker (Cycleptus elongates)}

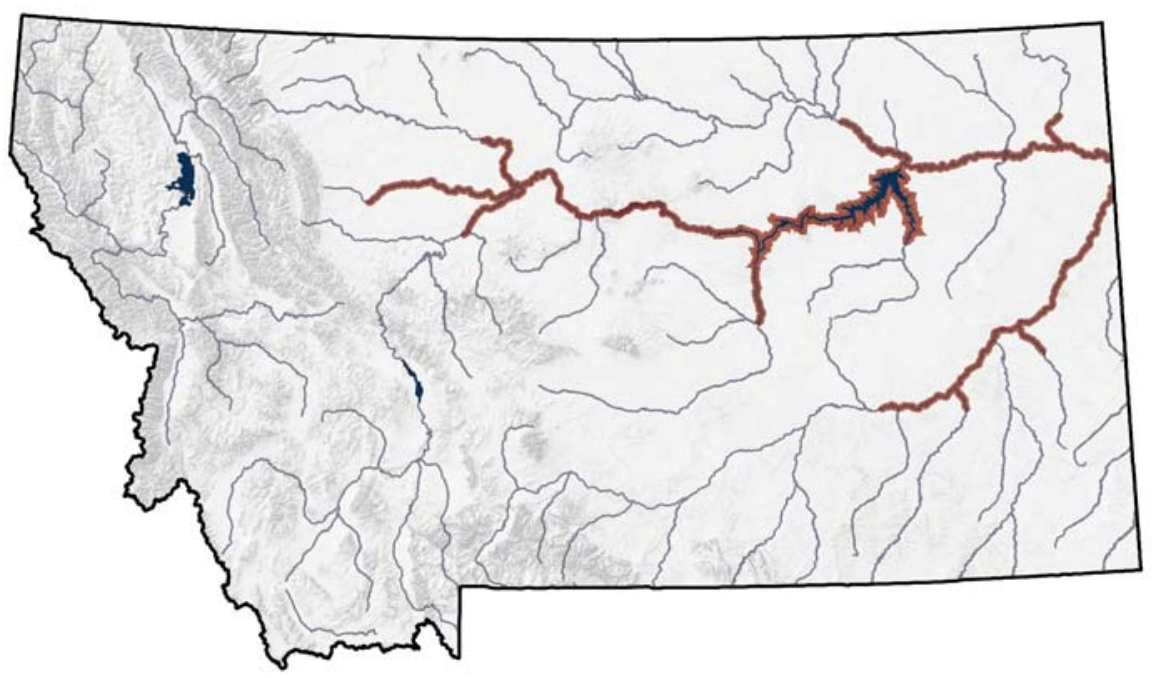

Figure 99. Distribution of the Blue Sucker

\section{Range}

In Montana, blue suckers are found in the Missouri River as far upriver as Morony Dam near Great Falls, and in the Yellowstone River upriver of Forsyth, Montana. Blue suckers have been found in many of the major tributary streams during their spawning season. There have been very few blue suckers sampled in Fort Peck Reservoir, indicating their avoidance of lake environments (AFS website 2003).

\section{Habitat}

The blue sucker is adapted for life in swift current areas with low turbidity. This fish prefers swift current areas of large rivers, feeding on insects in cobble areas (Moss et al. 1983). In the spring blue suckers migrate upriver and congregate in fast rocky areas to spawn. Large numbers have been observed migrating up tributary streams to spawn. The Tongue, Marias, Milk and Teton rivers are the tributary streams most heavily used.

\section{Management}

Management of the blue sucker consists primaryly of routine monitoring of population status and habitat protection. The blue sucker is considered an indicator species for ecotype health because of its habitat-specific requirements. Current monitoring information indicates the populations are in stable condition. Efforts towards locating spawning and rearing areas should be continued. Habitat protection includes protecting or promoting the natural springtime hydrograph. Establishment of more natural seasonal flow conditions is presently being 


\section{DRAFT WORKING DOCUMENT DO NOT DUPLICATE}

13353 discussed and initiated for three storage reservoirs in Montana (AFS website 13354 2003).

13355

13356

13357

13358

13359

13360

13361

13362

13363

13364

13365

13366

13367

13368

13369

13370

13371

13372

13373

13374

13375

13376

13377

13378

13379

13380

13381

13382

13383

13384

13385

13386

13387

\section{Conservation Concerns}

- Habitat changes caused by large dams that block passage to spawning grounds, alter streamflow, and eliminate peak flows that initiate spawning runs. Dams also discharge cold, clear water as opposed to the warm, turbid waters in which these species evolved

- Fragmentation of habitat due to impoundments

- Channelization of large lotic systems

- Changes in riparian habitat, less regeneration of woody trees and understory

\section{Conservation Strategies}

- Consider preparing management plan for Blue Sucker or inclusion into other comprehensive taxonomic plan

- Continue conservation of habitats by managing grazing in riparian areas

- Regulate water regimes to be more closely tied to natural water regimes

- Create "fish wheels" so suckers can move upstream of river impoundments

\section{Management Plan}

None

\section{Citations}

American Fisheries Society Montana

website.http://www.fisheries.org/AFSmontana/SSCintermountain/foothill grassland/Bluesuckstatus.htm

Moss, R. E., J. W. Scanlan, and C. S. Anderson. 1983. Observations on the natural history of the blue sucker (Cycleptus elongatus LeSueur) in the Neosho

13388

13389

River. The American Midland Naturalist 109(1): 15-22.

13390 


\section{DRAFT WORKING DOCUMENT DO NOT DUPLICATE}

13390

13391

13392

13393

13394

13395

13396

13397

13398

13399

13400

13401

13402

13403

13404

13405

13406

13407

13408

13409

13410

13411

13412

13413

13414

13415

13416

13417

13418

13419

13420

13421

\section{Trout-perch (Percopsis omiscomaycus)}

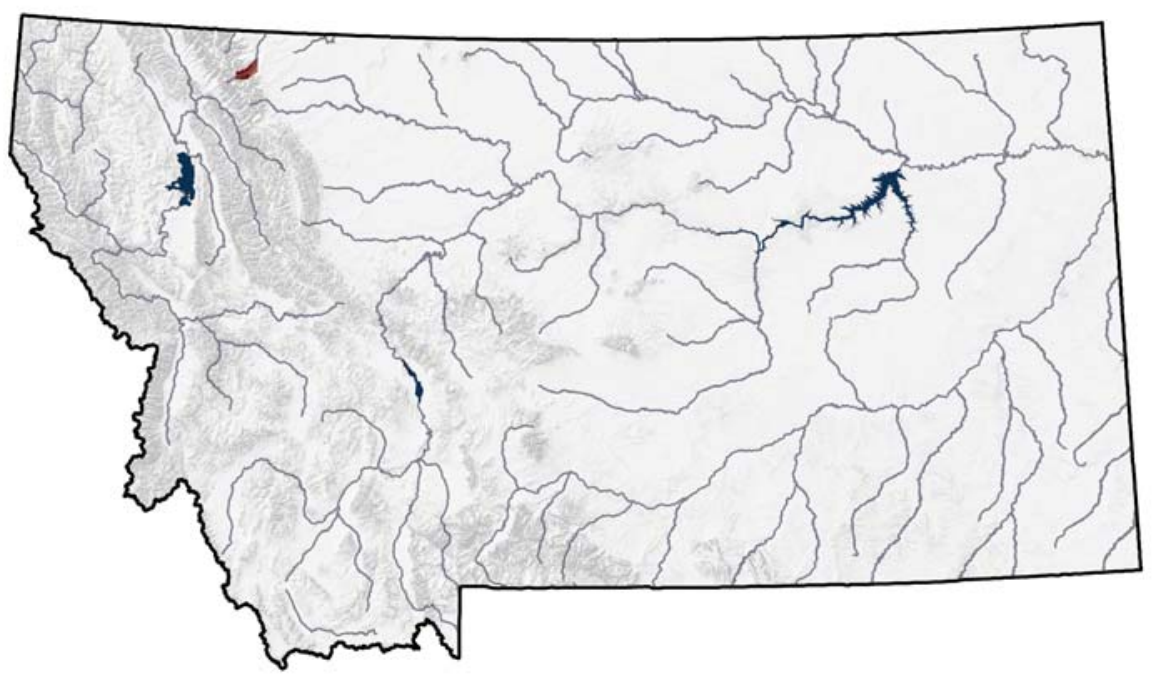

Figure 100. Distribution of the Trout-perch

\section{Range}

In Montana, the trout-perch occurs in the South Saskatchewan River basin, which drains northeastern Glacier National Park and the northwestern portion of the Blackfeet Indian Reservation. Trout-perch were not reported in Montana until 1968 (Gould 1969), and the only Montana collection records are from Lower St. Mary Lake (Gould 1969; Brown 1971) and the associated St. Mary canal (Holton and Johnson 1996). Trout-perch have not been reported in other areas of the South Saskatchewan River basin in Montana, such as the Belly River and Waterton Lake, but they may occur there, as this basin has not been surveyed extensively (Brown 1971; L. Marnell, National Park Service, personal communication, October 2000). Moreover, trout-perch are commonly collected in the Belly River and Waterton Lake systems in Alberta (T. Clayton, Alberta Environment, unpublished data, January 2001). Trout-perch have also been captured in the Milk River in Alberta (T. Clayton, Alberta Environment, unpublished data, January 2001). The Milk River basin is outside of the troutperch's native range. Trout-perch apparently gained access to the Milk River basin via the St. Mary Canal, which connects the St. Mary River system with the North Fork Milk River.

\section{Habitat}

In Montana, trout-perch are regularly captured in Lower Saint Mary Lake and the Saint Mary Canal using backpack and boat electrofishing (R. Wagner, U.S. Fish and Wildlife Service, personal communication, October 2000). In the lake, they are associated with large rocky cover, and are not captured over sandy or silty substrates. During daylight periods they appear to use rocks as hiding cover, 


\section{DRAFT WORKING DOCUMENT DO NOT DUPLICATE}

13422 while at night they are out of, but in close proximity, to rocky cover. In the Saint

13423 Mary Canal, trout-perch have been captured in winter after the canal head gate is 13424 closed. In the canal, trout-perch are found in residual pools associated with large, rocky cover or concrete riprap (R. Wagner, U.S. Fish and Wildlife Service, personal communication, October 2000). Scott and Crossman (1973) report that trout-perch are typically a lake species in eastern Canada, but that it also occurs in streams, including somewhat turbid streams, in western Canada. Trout-perch are reported to undergo diel migrations into shallower inshore waters of lakes at night (Brown 1971; Eddy and Underhill 1974; Becker 1983; Nelson and Paetz 1992).

\section{Management}

Montana Fish, Wildlife \& Parks classify trout-perch as a nongame wildlife species. They are too small to be sought by anglers. The entire known range of trout-perch in Montana is within Glacier National Park and the Blackfeet Indian Reservation. Neither entity has a specific management program for trout-perch.

\section{Conservation Concerns}

- Sensitive to pollution and sedimentation associated with row crop agriculture, as well as channelization

- Sensitive to warm water temperatures

- Impoundments restricting proper movement of populations

\section{Conservation Strategies}

- Consider preparing management plan for Trout-perch or inclusion into other comprehensive taxonomic plan

- Surveys in the Belly River and Waterton Lake in Montana are needed to establish the presence of trout-perch in these waters

- Conservation of riparian areas, including increased restrictions of fertilizers and nutrients seeped into waters

- Manage irrigation and development to improve connectivity of habitat

\section{Management Plan}

None

\section{Citations}

Becker, G. C. 1983. Fishes of Wisconsin. The University of Wisconsin Press, Madison. 


\section{DRAFT WORKING DOCUMENT DO NOT DUPLICATE}

13468

13469

13470

13471

13472

13473

13474

13475

13476

13477

13478

13479

13480

13481

13482

13483

13484

13485

13486

13487
Eddy, S., and J. C. Underhill. 1974. Northern fishes. University of Minnesota Press, Minneapolis.

Gould, W. R. 1969. First record of the trout-perch, Percopsis omiscomaycus, from Montana. Proceedings of the Montana Academy of Sciences 29:51.

Holton, G. D., and H. E. Johnson. 1996. A field guide to Montana fishes. Montana Fish, Wildlife \& Parks, Helena.

Nelson, J. S., and M. J. Paetz. 1992. The fishes of Alberta, second edition. The University of Alberta Press, Edmonton, and The University of Calgary Press.

Pflieger, W. L. 1997. The fishes of Missouri. Missouri Department of Conservation, Jefferson City.

Scott, W. B., and E. J. Crossman. 1973. Freshwater fishes of Canada. Bulletin 184 Fisheries Research Board of Canada, Ottawa. 


\section{DRAFT WORKING DOCUMENT DO NOT DUPLICATE}

13487

13488

13489

13490

13491

13492

13493

13494

13495

13496

13497

13498

13499

13500

13501

13502

13503

13504

13505

13506

13507

13508

13509

13510

13511

13512

13513

13514

13515

13516

13517

13518

\section{Burbot (Lota lota)}

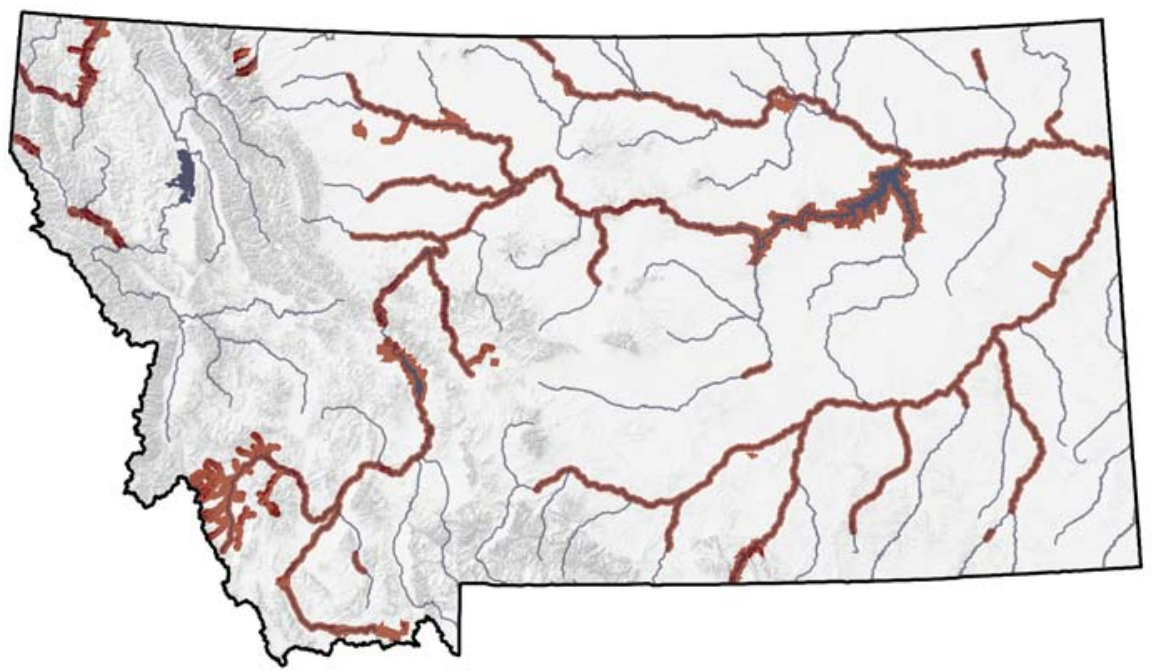

Figure 101. Distribution of the Burbot

\section{Range}

Burbot are found in all three major river drainages in Montana. Burbot, also known as ling, are usually found in larger streams and cold, deep lakes and reservoirs.

\section{Habitat}

Burbot habitat includes large rivers and cold, deep lakes and reservoirs. In lakes, they are mostly associated with bedrock and rubble substrates (Edsall et al. 1993). If soft substrates are present, burbot may construct burrows (Boyer et al. 1989). River requirements are less understood, but some believe they were originally restricted to backwater areas of cooler high-altitude systems (McPhail and Paragamian 2000). Their long cylindrical shape and poor swimming ability prevents them from inhabiting high current areas (Jones et al. 1974). Most spawning is believed to occur in lakes (Scott and Crossman 1973; McPhail and Paragamian 2000); however, reproduction may also occur in rivers and streams (Cahn 1936; Arndt and Hutchinson 2000; Paragamian 2000). They spawn in shallow water, usually in rocky areas.

\section{Management}

Presently, burbot management is poorly understood or non-existent (McPhail and Paragamian 2000). To implement any management strategies designed at maintaining or enhancing burbot populations in Montana, we must know more information regarding basic population characteristics (e.g., population sizes, age structure, and condition). Little effort has been made to sample specifically for 


\section{DRAFT WORKING DOCUMENT DO NOT DUPLICATE}

13519 burbot and assess their population status in Montana waters. Sampling has been impeded by the relative inactivity of burbot during common sampling periods.

13521

13522 Thus, basic population characteristic data (e.g., size structure, age structure, mortality, size at maturity) is lacking throughout the state. The burbot population in the Kootenai River below Kootenai Falls is declining and because of this, it has been petitioned for listing as a federally endangered species. The decline in this population has been attributed to the operation of Libby Dam for hydroelectric power flood control. Similar declines in burbot populations have been seen in other states following dam construction.

Conservation Concerns

- Overfishing

- Poorly understood life history traits and habitat requirements

- Reduced numbers in river systems due to impoundments

\section{Conservation Strategies}

- Evaluate angler exploitation rates and determine sustainability of wild populations

- Increased surveys to gain knowledge

- Work with managing authorities to encourage reservoir management to mimic natural hydrograph

\section{Management Plan}

Jones-Wuellner, Melissa R. and Guy, Christopher S. 2004. Status of Burbot in Montana. Prepared for Montana Fish, Wildlife \& Parks. Montana Cooperative Fisheries Research Unit, Montana State University-Bozeman.

\section{Citations}

13551

13552

13553

Arndt, S. K. A., and J. Hutchinson. 2000. Characteristics of a tributary-spawning population of burbot from Columbia Lake, British Columbia. Intermountain/foothill ecology and management. American Fisheries Society, Fisheries Management Section, publication Number 1, Bethesda. Research 15:174-185. 


\section{DRAFT WORKING DOCUMENT DO NOT DUPLICATE}

13564 Edsall, T.A., G.W. Kennedy and W.H. Horns. 1993. Distribution, abundance and 13565 resting microhabitat of burbot on Julian's Reef, southwestern Lake Michigan.

13566 Transactions of the American Fisheries Society 122:560-574.

13567

13568

McPhail, J.D. and V.L. Paragamian. 2000. Burbot biology and life history.

13569 Intermountain/foothill grassland 11-23 in V. L. Paragamian and D. W. Willis,

13570 editors. Burbot: biology, ecology and

13571 management. American Fisheries Society, Fisheries Management Section,

13572 Publication Number 1, Bethesda.

13573

13574 Paragamian, V. L. 2000. The effects of varying flows on burbot spawning

13575 migrations in the Kootenai River, Idaho and British Columbia, Canada, after 13576 construction of the Libby Dam. Intermountain/foothill grassland 111-123 in V. L.

13577 Paragamian and D. W. Willis, editors. Burbot: biology, ecology and management.

13578 American Fisheries Society, Fisheries Management Section, Publication Number

13579 1, Bethesda.

13580

13581 Scott, W. B., and E. J. Crossman. 1973. Freshwater fishes of Canada. Fisheries

13582 Research Board Canada, Bulletin 1973: Ottawa.

13583 


\section{Sauger (Sander canadensis)}

13585

13586

13587

13588

13589

13590

13591

13592

13593

13594

13595

13596

13597

13598

13599

13600

13601

13602

13603

13604

13605

13606

13607

13608

13609

13610

13611

13612

13613

13614

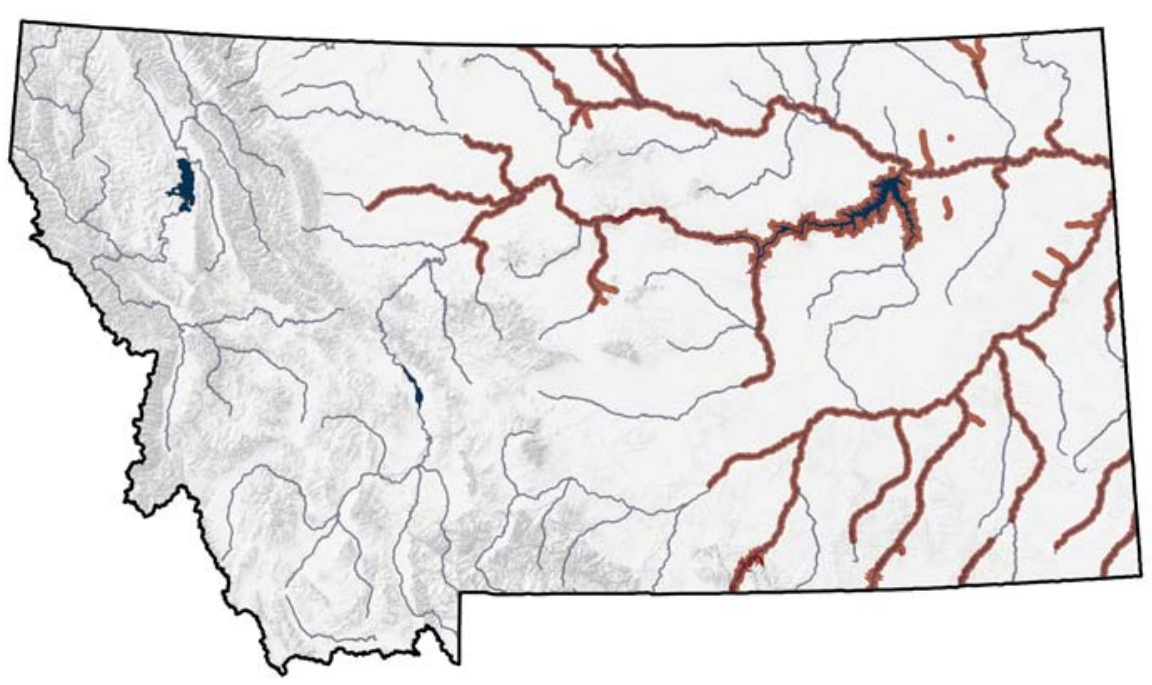

Figure 102. Distribution of the Sauger

\section{Range}

Sauger are one of the most widely distributed North American fishes with a historical range extending across most of central and eastern North America from the St. Lawrence-Champlain system south, west of the Appalachian Mountains, to the Tennessee River in Alabama, and northwestward to central Montana and Alberta (Scott and Crossman 1973).

In Montana, historical distribution included the Missouri River and its major tributaries downstream of Great Falls and the Yellowstone River and its major tributaries downstream of the Clark Fork (McMahon and Gardner 2001). Current distribution in Montana has declined by $53 \%$ from historical levels with the largest losses occurring in tributaries (McMahon and Gardner 2001). Current distribution in the Missouri River drainage is confined to the primarystem Missouri and small parts of the previously widely occupied Marias, Musselshell, and Milk rivers (McMahon and Gardner 2001). Sauger are considered rare or absent in other major tributaries such as the Teton, Judith, and Poplar rivers (McMahon and Gardner 2001). In the primarystem Yellowstone River, distribution is now considered limited to downstream of Rosebud Creek; sauger are considered rare or absent in major tributaries such as the Big Horn and Tongue Rivers although a small, partially isolated population may persist in the upper Powder River (McMahon and Gardner 2001; B. Stewart, Wyoming Department of Game and Fish, Sheridan, WY, personal communication). 


\section{DRAFT WORKING DOCUMENT DO NOT DUPLICATE}

\section{Habitat}

13616

13617

13618

13619

13620

13621

13622

13623

13624

13625

13626

13627

13628

13629

13630

13631

13632

13633

13634

13635

13636

13637

13638

13639

13640

13641

13642

13643

13644

13645

13646

13647

13648

13649

13650

13651

13652

13653

13654

13655

13656

13657

13658

13659

13660
Sauger typically occurs in large turbid rivers and shallow turbid lakes (Becker 1983). Turbidity is an important delineator of suitable habitat for sauger.

Physiological adaptations, such as a highly advanced light-gathering retina, allow sauger to thrive in low-light environments (Ali and Anctil 1977; Crance 1987). As cool water mesotherms, sauger have a fairly wide range of thermal tolerance with occupied temperatures ranging from 1 to $30 \mathrm{C}$ and a physiological optimum of 18 to 24 C (Crance 1987; Carlander 1997).

Sauger are heavily dependent throughout their life history on unimpeded access to the wide diversity of physical habitats that are present in large river systems. They are considered to be the most migratory percid (Collette 1977). Their migratory behavior, which is primarily related to spawning, is well documented throughout their range with annual movements of up to $600 \mathrm{~km}$ between spawning and rearing habitats (Nelson 1968; Collette et al. 1977; Penkal 1992; Pegg et al. 1997; M. E. Jaeger, Montana State University, unpublished data). Sauger are highly selective for spawning sites and commonly travel long distances to aggregate in a relatively few discrete areas to spawn (Nelson 1968; Nelson 1969; Gardner and Stewart 1987; Penkal 1992). Although primarystem spawning does occur (Jeager 2004), it has been suggested that sauger populations are strongly reliant on access to large tributaries for spawning (Nelson 1968; Gardner and Stewart 1987; Penkal 1992; Hesse 1994; McMahon 1999). Spawning locations are associated with unique geomorphic features, such as bluff pools and bedrock reefs, and rocky substrates over which sauger broadcast their eggs (Nelson 1968; Gardner and Stewart 1987; Hesse 1994; Jeager 2004). During a 10-12 day period following emergence, its thought that larval sauger drift long distances downstream--up to 300 kilometers--prior to gaining the ability to maneuver horizontally and begin feeding (Nelson 1968; Penkal 1992; McMahon 1999). Juveniles rear in side channels, backwaters, oxbows, and other off-channel habitats during spring and summer before shifting to primary channel habitats in autumn (Gardner and Berg 1980; Gardner and Stewart 1987; Hesse 1994). Adult sauger also use off-channel and channelmargin habitats during the spring and early summer periods of high flow and turbidity, and then move to deeper primary channel habitats in late summer and autumn as decreasing flows and turbidities cause suitable off-channel habitats to become unavailable (Hesse 1994; M. E. Jaeger 2004).

\section{Management}

Mitigation of habitat loss and fragmentation holds the most potential for recovery of this species. Removal of primarystem and tributary impoundments, which would restore natural flow and sediment regimes, natural channel and habitat formation processes, and population and habitat connectivity, would be the single most effective restorative action that could be taken and holds far and away the greatest potential for recovery of sauger and other imperiled large river fishes in 


\section{DRAFT WORKING DOCUMENT DO NOT DUPLICATE}

13661 Montana. Although such restorative measures are unlikely at this time, other

13662

13663

13664

13665

13666

13667

13668

13669

13670

13671

13672

13673

13674

13675

13676

13677

13678

13679

13680

13681

13682

13683

13684

13685

13686

13687

13688

13689

13690

13691

13692

13693

13694

13695

13696

13697

13698

13699

13700

13701

13702

13703

13704

13705

13706

restoration potential does exist and is being pursued. Improved passage at several irrigation-related migratory barriers is being planned and implemented. Similarly, fish screens and return structures have been installed and more are planned to minimize entrainment of fish in irrigation canals. Negotiations to restore instream flows in some tributaries, especially during critical spring spawning times, are ongoing. Flow releases from primarystem dams can also be regulated throughout the year to maximize spawning success and year-class strength of sauger (Nelson 1968; Walburg 1972). Angler harvest has been restricted to reduce fishing mortality in areas where declines in sauger abundances are most marked. Supplementation of sauger populations by artificial propagation is being attempted to bolster abundances and restore sauger to areas where they have been extirpated. Levels of introgression with walleye are being investigated to determine the threat to sauger as walleye populations expand. Additionally, extant sauger populations are being closely monitored and research is being conducted to fill information gaps to allow managers to determine how and where restoration and conservation efforts can be most effectively directed.

Conservation of what habitat remains should also be recognized as essential to the recovery and restoration of sauger in Montana. Montana boasts some of the most pristine large-river habitat in the United States. Preservation of natural hydrographs, natural processes of channel formation, and high degrees of connectivity where they currently exist should be considered among the highest priorities for sauger conservation and recovery. Preservation of existing habitat can best occur by minimizing the diversion of water from river channels and limiting processes such as channelization and stream-bank armoring that result in loss of important off-channel habitats. Additionally, it is important that further disruptions to the connectivity of tributary and primarystem habitats be prevented to avoid further declines in abundance and distribution of sauger in Montana.

\section{Conservation Concerns}

- Water withdraws resulting in low river flows

- Reservoir operation that alters the natural hydrograph

- Barriers that negatively influence spawning movement patterns and larval drift

- Channelization and loss of side channel habitat for larval and juvenile sauger

- Hybridization with walleye

- Negative interactions with other species such as walleye and smallmouth bass

- Overexploitation 


\section{DRAFT WORKING DOCUMENT DO NOT DUPLICATE}

13707

13708

13709

13710

13711

13712

13713

13714

13715

13716

13717

13718

13719

13720

13721

13722

13723

13724

13725

13726

13727

13728

13729

13730

13731

13732

13733

13734

13735

13736

13737

13738

13739

13740

13741

13742

13743

13744

13745

13746

13747

13748

13749

13750

13751

13752

\section{Conservation Strategies}

- Removal of primarystem and tributary impoundments

- Improved passage at several irrigation-related migratory barriers

- Flow releases from primarystem dams can also be regulated throughout the year to maximize spawning success and year-class strength of sauger

- Minimizing the diversion of water from river channels and limiting processes such as channelization and stream-bank armoring that result in loss of important off-channel habitats

\section{Management Plan}

Montana Department of Fish, Wildlife \& Parks. 2004. Memorandum of Understanding and Conservation Agreement for Sauger (Sander canadensis) in Montana. 23 pg. Draft-In progress.

\section{Citations}

Ali, M. A., and M. Anctil. 1977. Retinal structure and function in the walleye (Stizostedion vitreum vitreum) and sauger (S. canadense). Journal of the Fisheries Research Board of Canada 34:1467-1474.

Becker, G. C. 1983. Fishes of Wisconsin. The University of Wisconsin Press, Madison, WI.

Carlander, K. D. 1997. Handbook of freshwater fishery biology, volume three: life history data on ichthyopercid and percid fishes of the United States and Canada. lowa State University Press, Ames, IA.

Collette, B. B. and 7 co-authors. 1977. Biology of the percids. Journal of the Fisheries Research Board of Canada 34:1890-1899.

Crance, J. H. 1987. Preliminary habitat suitability curves for sauger.

Proceedings of the Annual Conference of Southeast Association Fish and Wildlife Agencies 41:159-167.

Gardner, W. M., and P. A. Stewart. 1997. The fishery of the lower Missouri River, Montana. Montana Department of Fish, Wildlife \& Parks report, FW-2-R.

Gardner, W. M., and R. K. Berg. 1980. An analysis of the instream flow requirements for selected fishes in the Wild and Scenic portion of the Missouri River. Montana Fish, Wildlife \& Parks report, Great Falls, MT.

Hesse, L. W. 1994. The status of Nebraska fishes in the Missouri River. 6. Sauger (Percidae: Stizostedion canadense). Transactions of the Nebraska Academy Sciences 21:109-121. 


\section{DRAFT WORKING DOCUMENT DO NOT DUPLICATE}

13753

13754

13755

13756

13757

13758

13759

13760

13761

13762

13763

13764

13765

13766

13767

13768

13769

13770

13771

13772

13773

13774

13775

13776

13777

13778

13779

13780

13781

13782

13783

13784

13785

13786

13787

13788

13789

13790

13791

13792

13793

13794

13795

13796

13797
Jaeger, M.E.. 2004. An empirical assessment of factors precluding recovery of sauger in the lower Yellowstone River: movement , habitat use, exploitation and entrainment. Masters Thesis. Montana State University, Bozeman, Montana.

Leach, J. H., and 5 co-authors. 1977. Responses of percids and their habitats to eutophication. Journal of the Fisheries Research Board of Canada 34:19641971.

McMahon, T. E., and W. M. Gardner. 2001. Status of sauger in Montana. Intermountain Journal of Sciences 7:1-21

McMahon, T. E. 1999. Status of sauger in Montana. Montana Fish, Wildlife \& Parks report, Helena, MT.

Nelson, W. R., and C. H. Walburg. 1977. Population dynamics of yellow perch (Perca flavescens), sauger (Stizostedion candense), and walleye (S. vitreum vitreum) in four primarystem Missouri River reservoirs. Journal of the Fisheries Research Board of Canada 34:1748-1763.

Nelson, W. R. 1968. Reproduction and early life history of sauger, Stizostedion canadense, in Lewis and Clark Lake. Transactions of the American Fisheries Society 97:159-166.

Pegg, M. A., P. W. Bettoli, and J. B. Layzer. 1997. Movement of saugers in the lower Tennessee River determined by radio telemetry, and implications for management. North American Journal of Fisheries Management 17:763-768.

Penkal, R. F. 1992. Assessment and requirements of sauger and walleye populations in the Lower Yellowstone River and its tributaries. Montana Department of Fish, Wildlife \& Parks report, Helena, MT.

Rawson, M. R., and R. L. Scholl. 1978. Reestablishment of sauger in western Lake Erie. Intermountain/foothill grassland 261-265 in R. L. Kendall, editor, Selected cool water fishes of North America. American Fisheries Society Special Publication 11. Bethesda, Maryland.

Scott W. B., and E. J. Crossman. 1973. Freshwater Fishes of Canada. Fisheries Research Board of Canada Bulletin 184.

Walburg C. H. 1972. Some factors associated with fluctuation in year-class strength of sauger, Lewis and Clark Lake, South Dakota. Transactions of the American Fisheries Society 101:311-316. 


\section{DRAFT WORKING DOCUMENT DO NOT DUPLICATE}

13797

13798

13799

13800

13801

13802

13803

13804

13805

13806

13807

13808

13809

13810

13811

13812

13813

13814

13815

13816

13817

13818

13819

13820

13821

13822

13823

13824

13825

13826

13827

13828

13829

13830

13831

13832

13833

13834

13835

13836

13837

13838

13839

13840

13841

13842

\section{Component IV: Greatest Inventory Needs}

"Over time, this strategy will allow us to collect data for 1) for species we do not have sufficient information to determine their level of conservation need, 2) species that are important or indicator species for health of certain communities, or 3) species we think can help us measure the success we are having at conserving our fish and wildlife using a comprehensive approach"

Prior to assessing inventory needs, we obtained and entered 130,000 additional observation points to the POD maintained by the Montana Natural Heritage Program. However, many species still have inadequate amounts of data, poor quality data, or the information is outdated. Without adequate occurrence data it is difficult to determine the abundance or distribution of the species, making it impossible to confidently classify the need for conservation of a species and the habitats that sustain them. Likewise, many species and groups of species that might have adequate observations offer unique opportunities to gauge the health of other fish and wildlife as well as habitats through ongoing monitoring. We define inventory as collecting data in order to establish the occurrence and distribution of species, but we also recognized that collecting data in order to establish population trends of species statewide over time is important and could occur coincidentally with inventory efforts. Future versions of this Strategy should consider developing separate species monitoring and species research components that assign species and species groups to Tiers based on specific need for trend monitoring or research.

The following species and groups of species were identified as Tier I (in greatest need of inventory). This Tier assignment is separate from the species component Tier assignments provided earlier in this Strategy. In other words the Species assigned Tier I for this inventory component were assessed regardless if the species has a population considered low or declining. Ongoing inventory for the following groups should continue and coordinated efforts should be made to inventory these groups and species. The following legend can be used to provide information about why a group or species has been classified as Tier I, and can also be used to frame experimental design. All species and group inventory Tier assignments can be found in Tables 8 and 9.

\section{Legend for Groups \& Species in Greatest Inventory Needs:}

\section{Inventory:}

$I^{1}:$ Observational data are lacking

$\mathrm{I}^{2}$ :Observational data are outdated

$\mathrm{I}^{3}$ :Observational data are of poor quality

$\mathrm{I}^{4}$ :Statewide inventory needed

$I^{5}$ :Localized inventory needed 
$13843 \quad \mathrm{I}^{6}:$ Group/Species require targeted survey efforts

$13844 \quad I^{7}$ :Information required to know is species a migratory or peripheral species

$13845 \quad \mathrm{I}^{\mathrm{M}}$ :Monitoring efforts required

13846

13847

13848

13849

13850

13851

13852

13853

13854

13855

13856

13857

13858

13859

13860

13861

13862

13863

13864

13865

13866

13867

13868

13869

13870

13871

13872

13873

13874

13875

13876

13877

13878

13879

13880

13881

13882

13883

13884

13885

13886

13887

Other:

$\mathrm{O}^{1}$ :Dependant on critical habitats

$\mathrm{O}^{2}$ :Opportunity exists for Law Enforcement to assist with inventory

\section{Groups with Greatest Inventory Needs}

Birds, owls group

Birds, shorebirds/waterbirds group

Fish-Prairie group

Mammals, bats group

Mammals, small group

Reptiles group

Crayfish Group

Mussels group

Invertebrate Group

$I^{1}, I^{4}, I^{6}, O^{1}$

$I^{1}, I^{4}, I^{6}, O^{1}$

$I^{1}, 1^{4}, I^{6}$

$1^{1}, I^{4}, 1^{6}$

$I^{1}, I^{4}, I^{6}$

$I^{1}, I^{4}, I^{6}$

$I^{1}, I^{4}, I^{6}$

$1^{1}, 1^{4}, I^{6}$

$I^{1}, I^{4}, I^{6}$

\section{Species with Greatest Inventory Needs}

American Bittern

Black-crowned Night-heron

White-faced Ibis

Northern Goshawk

Columbia Sharp-tailed Grouse

Yellow Rail

Greater Yellowlegs

Solitary Sandpiper

Semipalmated Sandpiper

Western Sandpiper

Least Sandpiper

Baird's Sandpiper

Pectoral Sandpiper

Dunlin

Long-billed Dowitcher

Arctic Tern

Black-billed Cuckoo

Yellow-billed Cuckoo

Barn Owl

Northern Hawk Owl

Common Nighthawk

Common Poorwill

Black Swift
$\mathrm{I}^{1}, \mathrm{I}^{4}, \mathrm{O}^{1}$

$\mathrm{I}^{1}, \mathrm{I}^{4}, \mathrm{O}^{1}$

$I^{1}, I^{4}, O^{1}$

$I^{1}, I^{6}, I^{\mathrm{M}}$

$I^{1}, I^{6}, I^{M}$

$I^{1}, I^{4}, I^{7}$

$I^{1}, I^{4}, I^{7}$

$I^{1}, I^{4}, I^{7}$

$I^{1}, I^{4}, I^{7}$

$I^{1}, I^{4}, I^{7}$

$I^{1}, I^{4}, I^{7}$

$I^{1}, I^{4}, I^{7}$

$I^{1}, I^{4}, I^{7}$

$I^{1}, I^{4}, I^{7}$

$I^{1}, I^{4}, I^{7}$

$I^{1}, I^{4}, I^{7}$

$\mathrm{I}^{1}, \mathrm{I}^{4}, \mathrm{O}^{1}$

$I^{1}, I^{4}, I^{7}, O^{1}$

$I^{1}, I^{4}, 1^{7}, O^{1}$

$I^{1}, I^{4}, I^{6}$

$I^{1}, I^{4}, I^{6}, I^{M}$

$I^{1}, I^{4}, I^{6}, I^{M}$

$\mathrm{I}^{1}, \mathrm{I}^{5}, \mathrm{I}^{6}, \mathrm{I}^{\mathrm{M}}, \mathrm{O}^{1}$ 


\begin{tabular}{|c|c|c|}
\hline 13889 & Chimney Swift & $I^{1}, I^{4}, I^{6}, O^{1}$ \\
\hline 13890 & White-throated Swift & $I^{1}, I^{4}, I^{6}, I^{7}, I^{M}$ \\
\hline 13891 & Black-chinned Hummingbird & \\
\hline 13892 & Alder Flycatcher & $1^{1}, 1^{4}, I^{6}$ \\
\hline 13893 & Purple Martin & \\
\hline 13894 & Canyon Wren & $\mathrm{I}^{1}$, \\
\hline 13895 & Sedge Wren & \\
\hline 13896 & American Dipper & $I^{6}, I^{M}$ \\
\hline 13897 & Blue-gray Gnatcatcher & \\
\hline 13898 & Eastern Bluebird & \\
\hline 13899 & Western Bluebird & $1^{1}$, \\
\hline 13900 & Black-and-white Warbler & $I^{\mathrm{M}}, \mathrm{O}^{1}$ \\
\hline 13901 & Indigo Bunting & $I^{\mathrm{M}}, \mathrm{O}^{1}$ \\
\hline 13902 & Green-tailed Towhee & $\mathrm{I}^{\mathrm{M}}, \mathrm{O}^{1}$ \\
\hline 13903 & Field Sparrow & $7, \mathrm{I}^{\mathrm{M}}$ \\
\hline 13904 & Le Conte's Sparrow & \\
\hline 13905 & Nelson's Sharp-tailed Sparrow & \\
\hline 13906 & Black Rosy-finch & \\
\hline 13907 & Torrent Sculpin & $1^{1}, I^{4}$ \\
\hline 13908 & Spoonhead Sculpin & $1^{1}, 1^{4}$ \\
\hline 13909 & Shortnose Gar & $1^{1}, 1^{5}$ \\
\hline 13910 & Lake Trout (native lakes) & $\mathrm{I}^{1}, \mathrm{I}^{6}, \mathrm{I}^{\mathrm{M}}, \mathrm{O}^{2}$ \\
\hline 13911 & Western Silvery Minnow & \\
\hline 13912 & Brassy Minnow & \\
\hline 13913 & Plains Minnow & ${ }^{6}, I^{\mathrm{M}}$ \\
\hline 13914 & Pearl Dace & $I^{1}, I^{4}$ \\
\hline 13915 & Trout-perch & $I^{1}, I^{4}$ \\
\hline 13916 & Iowa Darter & $I^{1}, I^{4}$ \\
\hline 13917 & Arctic Shrew & $1^{1}, 1^{5}, 1^{7}$ \\
\hline 13918 & Northern Myotis & $I^{1}, I^{4}, I^{7}$ \\
\hline 13919 & Eastern Red Bat & $I^{1}, I^{4}, I^{7}$ \\
\hline 13920 & Spotted Bat & \\
\hline 13921 & Townsend's Big-eared Bat & $, I^{\mathrm{M}}, \mathrm{O}^{1}$ \\
\hline 13922 & Pallid Bat & $I^{1}, I^{4}, I^{7}$ \\
\hline 13923 & American Pika & $I^{1}, I^{4}, I^{6}, I^{M}, O^{1}$ \\
\hline 13924 & Eastern Cottontail & \\
\hline 13925 & Black-tailed Jackrabbit & $I^{1}, I$ \\
\hline 13926 & Uinta Chipmunk & \\
\hline 13927 & Hoary Marmot & $I^{1}, I^{5}, I^{6}, I^{M}, O^{1}$ \\
\hline 13928 & Uinta Ground Squirrel & $1^{1}$, \\
\hline 13929 & Wyoming Ground Squirrel & \\
\hline 13930 & Northern Flying Squirrel & $I^{1}, I^{5}$ \\
\hline 13931 & Idaho Pocket Gopher & $I^{1}, I^{5}, I^{6}, I^{M}$ \\
\hline 13932 & Hispid Pocket Mouse & $I^{1}, I^{5}$ \\
\hline 13933 & Water Vole & ${ }^{6}, I^{\mathrm{M}}$ \\
\hline 3934 & Sagebrush Vole & $I^{1}, I^{4}, I^{6}, I^{M}$ \\
\hline
\end{tabular}


13935

13936

13937

13938

13939

13940

13941

13942

13943

13944

13945

13946

13947

13948

13949

13950

13951

13952

13953

13954

13955

13956

13957

13958

13959

13960

13961

13962

13963

13964

13965

13966

13967

13968

13969

13970

13971

13972

13973

13974

13975

13976

13977

13978

13979

13980
Northern Bog Lemming

Meadow Jumping Mouse

Common Porcupine

Western Spotted Skunk

Snapping Turtle

Spiny Softshell

Northern Alligator Lizard

Western Skink

Rubber Boa

Western Hognose Snake

Milk Snake

Smooth Green Snake

Calico Crayfish

Virile Crayfish

A Crayfish

Signal Crayfish

Black Sandshell

Western Pearlshell

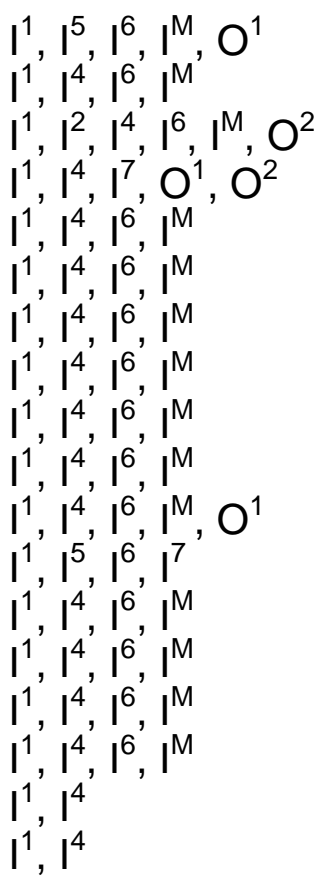

\section{Revision and Monitoring of the Strategy}

The scope of this Strategy exceeds the funding provided through the State Wildlife Grants (SWG) that would be necessary to fully implement the conservation strategies identified in each of the four components. As of 2005, SWG funding is authorized on an annual basis and the amount can vary from year to year. The unstable nature of this funding will continue to serve as a roadblock that could prevent FWP and its partners from committing to long-term conservation projects. Due to these factors, caution should be used when attempting to apply performance measures to any of the components of this plan. At current levels and time intervals of SWG funding, the Inventory and Monitoring component of the Strategy is the most likely to be more completely implemented and therefore, provide more adequate results that can be for monitored through performance measures.

The Montana Comprehensive Fish and Wildlife Conservation Strategy is intended to be dynamic and the potential exists to review and revise priorities and monitor success within two of the four components (species and inventory) at short term intervals. Although this would not always be necessary, it is mentioned to demonstrate the degree to which these two components are connected and automated. The remaining two components (focus areas and community types) are linked as well, however, performance measures of landscape or community level health and conservation success are more difficult to parameterize and measure. Adequate information does not exist to establish a statewide baseline of landcover types or habitat conditions that contain consistent estimates of precision. For example, classified sagebrush land cover types in the existing database have a relatively low confidence interval attached 


\section{DRAFT WORKING DOCUMENT DO NOT DUPLICATE}

13981 to them. Likewise, true community structures have not necessarily been

13982

13983

13984

13985

13986

13987

13988

13989

13990

13991

13992

13993

13994

13995

13996

13997

13998

13999

14000

14001

14002

14003

14004

14005

14006

14007

14008

14009

14010

14011

14012

14013

14014

14015

14016

14017

14018

14019 established and validated for Montana's fish and wildlife and their related habitats and geo-climatic factors. The necessary land covers and community type structures will need to be developed and refined between the beginning of Strategy implementation and the next review cycle.

Because the components range from broad to fine-scale, the time needed to detect the success of implementation may vary from years to decades. As such, we will revise and monitor conservation success for each of the four components at different intervals. Although components will be monitored separately, the overall Strategy will be revised every six years. The following is the general timetable for monitoring and revision.

\begin{tabular}{lcc}
\hline \multicolumn{1}{c}{ Component } & $\begin{array}{c}\text { Monitoring (FWP } \\
\text { Information Management } \\
\text { Unit) }\end{array}$ & $\begin{array}{c}\text { Revision (FWP Responsive } \\
\text { Management Unit) }\end{array}$ \\
\hline Focus Areas & Every 6 years & Every 6 Years \\
Community Types & Every 6 years & Every 6 Years \\
Species & Annually & Every 6 Years \\
Inventory & Annually & Every 6 Years \\
\hline
\end{tabular}

\section{Conservation Focus Areas}

Conservation Focus Areas were identified that provide some of the greatest opportunities to conserve the community types and species in greatest need of conservation. The long-term success at conserving these areas can be measured by measuring the health of the communities and species that are associated with these areas. In most cases these long-term successes will require decades to detect. In the absence of other means, progress toward implementing the conservation strategies described for each Focus Area will be used as the performance measure for this component. Implementation will be measured as not implemented, partially implemented, fully implemented, or ongoing indefinite implementation needed. In the future, if adequate land cover layers are developed, and communities are defined, methods for monitoring the health and status of the communities and species within focus areas could be refined. The FWP Responsive Management Unit will coordinate the revision of this component in coordination with the Information Management Unit and FWP fish and wildlife staff every six years in collaboration with our partners and with public review.

\section{Community Types}

Fish and wildlife communities have not been defined in Montana. Although much of the information contained in this Strategy is not new, the Strategy planning process provided an opportunity to begin developing general and essential associations for all fish and wildlife species with their habitats by building on 


\section{DRAFT WORKING DOCUMENT DO NOT DUPLICATE}

14020 many years research and work. We linked fish and wildlife with plants and

14021

14022

14023

14024

14025

14026

14027

14028

14029

14030

14031

14032

14033

14034

14035

14036

14037

14038

14039

14040

14041

14042

14043

14044

14045

14046

14047

14048

14049

14050

14051

14052

14053

14054

14055

14056

14057

14058

14059

14060

14061

14062

14063

14064

14065

14066

14067 geoclimatic characteristics to attempt and create community types. In the future, much research is needed to fully develop and validate true fish and wildlife communities in Montana. Success at conserving these communities could then be measured by using an index of overall community conditions. Success at conserving communities will require long term conservation efforts and success will most likely be detected on the scale of decades versus years.

In the absence of validated communities for Montana, progress toward implementing the conservation strategies described for each Community Type will be used as the performance measure for this component. Implementation will be measured as not implemented, partially implemented, fully implemented, or ongoing indefinite implementation needed. Once validated communities have been defined for Montana, monitoring the health and status of the communities will provide measures of success for implemented conservation strategies. The FWP Responsive Management Unit will coordinate the revision of this component in coordination with the Information Management Unit and FWP fish and wildlife staff every six years in collaboration with our partners and with public review.

\section{Species}

The FWP Information Management Unit will monitor success of implementing the species component of the Strategy annually. The Montana Animal Species of Concern List cooperatively maintained by FWP and NHP will be used as a performance measure for this component. Each year the NHP Senior Zoologist and the Chief of the FWP Information Unit will conduct a review of the list using a protocol developed by NaturServe and modified by Montana. The review combines the quantitative documentation approach from NaturServe with professional knowledge of staff from numerous agencies and organizations to determine species status. Subsequent to the annual review, the FWP Information Management Unit will use information from the updated Species of Concern list to re-calculate the assignment of level of conservation need to all Montana fish and wildlife species as described in the species methods section of this Strategy. Changes in Tier assignment will be used to help gauge if species are being successfully conserved in Montana. Overall, any species that moves from a higher Tier to a lower Tier (for example Tier I to Tier II), or off the list entirely, will be noted as a positive. Species that move from a being lower Tier to a higher Tier will be identified as a "matter of concern".*

\footnotetext{
*Note: Upward movement of species in Tier assignment should not be considered a conservation failure. If inventory needs are successfully addressed awareness will be raised of the imperiled status of some species that were previously not known due to inadequate observational or monitoring data. Likewise prudent judgment should be used when considering a downward movement of species in Tier assignment as a conservation success because addressing inventory needs will also raise awareness of the healthy status of some species that were previously not know due to inadequate observational or monitoring data. It is impossible in most cases to link specific
} 


\section{DRAFT WORKING DOCUMENT DO NOT DUPLICATE}

14068

14069

14070

14071

14072

14073

14074

14075

14076

14077

14078

14079

14080

14081

14082

14083

14084

14085

14086

14087

14088

14089

14090

14091

14092

14093

14094

14095

14096

14097

14098 conservation actions to the success or failure of a species and for this reason, the SOC list is used as a tool for helping to gauge success not quantify it.

Identifying if conservation strategies identified for each of the Tier I species are being implemented will also be used as a performance measure for this component. Implementation will be measured as not implemented, partially implemented, fully implemented, or ongoing indefinite implementation needed. The FWP Responsive Management Unit will coordinate the revision of this component in coordination with the Information Management Unit and FWP fish and wildlife staff every six years in collaboration with our partners and with public review.

\section{Inventory}

The FWP Information Management Unit will measure success in the inventory component of the Strategy annually. The performance measure for this component will be the FWP/NHP point observation database (POD). The database is the statewide clearinghouse for fish and wildlife species data from many agencies and organizations such as FWP, NHP, USFS, TNC and The Audubon Society for species not currently being monitored any other way. The POD will be queried to determine if gaps in occurence data for species and species groups identified in the Strategy as in greatest need of inventory have been met. The Tier assignments for species and species groups will be recalculated based on the updated POD and other information and revised priorities for Inventory will be updated in the web based Strategy and then transmitted to FWP's collaborators. The FWP Responsive Management Unit will coordinate the revision of this component in coordination with the Information Management Unit and FWP fish and wildlife staff every six years in collaboration with our partners and with public review. 


\section{DRAFT WORKING DOCUMENT DO NOT DUPLICATE}

14098

14099

14100

14101

14102

14103

14104

14105

14106

14107

14108

14109

14110

14111

14112

14113

14114

14115

14116

14117

14118

14119

14120

14121

14122

14123

14124

14125

14126

14127

14128

14129

14130

14131

14132

14133

14134

14135

14136

14137

14138

14139

14140

14141

14142

14143

\section{Law Enforcement, Con/Ed, and State Parks}

To date, Congressional wording of legislation has not allowed, or as limited, the direct allocation of SWG funds to projects pertaining to law enforcement, outreach or activities in state parks. This does not mean that opportunities do not exist for developing projects within these areas that would provide benefits to species and habitats in greatest need of conservation. In fact, activities of this type have already been and continue to be conducted within each of these areas without SWG funding. Law enforcement officers regularly use domestic livestock to assist fisheries biologists with the transport of arctic grayling and cutthroat trout for restoration projects occurring in wilderness and remote areas of the state. Montana Fish, Wildlife \& Parks Conservation Education staff have been instrumental in helping develop information strategies for the SWG planning efforts, and are actively involved in issues related to many species and habitats described in this Strategy such as loons, native fish, and invasive species that require intense education and information campaigns in order to address human related conservation concerns. Montana's State Parks have been involved with recent inventory of small mammals, bats and other wildlife species that have been identified as in greatest need and offer an unequaled venue for communicating the foundations of comprehensive conservation to Montana's public through interpretation and hands on experience. Montana Fish, Wildlife \& Parks firmly believes that the successful implementation of this Strategy will require that law enforcement, conservation education and state parks be engaged in activities and be eligible for funding.

The following list is intended to provide examples of how these areas of FWP could be integrated with the implementation of the FWP Comprehensive Fish and Wildlife Conservation Strategy. The list is not complete, but should provide an idea of the diversity of opportunity that exists and will be required.

\section{Law Enforcement}

- Investigation and prosecution of individuals who seek to profit through the commercial exploitation of sensitive species or species of special concern

- Regular patrols, presence and covert operations in areas where sensitive species projects (such as brood stock ponds or in-channel spawning and rearing areas for natives fish) and efforts are in process

- Investigate and prosecute illegal introductions of fish and wildlife. Provide an enforcement presence in areas where the transportation of live fish to other bodies of water is suspected to occur

- Through SWG, augment financial resources through overtime and other means, for special species related projects that merit an enhanced presence or protection by law enforcement officers 


\section{DRAFT WORKING DOCUMENT DO NOT DUPLICATE}

14144

14145

14146

14147

14148

14149

14150

14151

14152

14153

14154

14155

14156

14157

14158

14159

14160

14161

14162

14163

14164

14165

14166

14167

14168

14169

14170

14171

14172

14173

14174

14175

14176

14177

14178

14179

14180

14181

14182

14183

14184

14185

14186

14187

14188

14189
- Participate in the planning and management of sensitive species, offering social component information in season-setting, season-types or special regulations for certain areas that would serve to enhance certain game species of concern

- Utilize relationships built with other resource agency's law enforcement and wildlife control divisions in the protection and enhancement of sensitive species

- Focus attention on violations associated with snowmobiles, ATV's, and water-based recreation that directly affect fish and wildlife and their habitats during certain times of the year

- Expand investigations and prosecution of individuals involved in the introduction of non-native or exotic plants and animals

- Continue a leadership role in the on-the-ground efforts to resolve conflicts between wildlife and humans (bears, ungulates in urban environments, etc.) Develop new technologies, equipment and approaches to reduce the effects of wildlife damage to private property

- Provide the equipment and technical expertise in the logistics of transporting personnel, equipment and fish/wildlife species in restoration efforts

- Provide increased field assistance as well as informational support to biologists in the carrying-out of fish and wildlife inventories, tagging and marking operations, etc.

- Dovetail efforts with the Conservation Education Division in preparing sensitive species issues presentations in public forums such as Hunter Education classes, school programs, and in the media.Work with biologists to conduct inventory of fish and wildlife through tagging, investigation of illegal kills and harvest, and road kills. Special opportunities exist in wilderness and remote areas where officers can provide domestic livestock for transportation. Opportunities exist at check stations and especially with species such as wolfs, raptors, and furbearers.

- Work directly with biologists with species related to issues such as disease, and re-introduction

- Help conserve habitats by addressing issues related to snowmobiles and ATV's, no-wake zones,exotic introductions of plants and animals, human/bear and wolf conflicts, 310 permit violations 


\section{DRAFT WORKING DOCUMENT DO NOT DUPLICATE}

14190

14191

14192

14193

14194

14195

14196

14197

14198

14199

14200

14201

14202

14203

14204

14205

14206

14207

14208

14209

14210

14211

14212

14213

14214

14215

14216

14217

14218

14219

14220

14221

14222

14223

14224

14225

14226

14227

14228

14229

14230

14231

14232

14233

14234

\section{Conservation Education}

Montana Fish, Wildlife \& Parks' mission is to provide for the stewardship of the fish, wildlife, parks and recreational resources of Montana, while contributing to the quality of life for present and future generations. To carry out its mission, FWP's Conservation Education Division strives to provide and support fiscally responsible programs that help Montanans and other understand and appreciate the importance of the conservation and management of Montana's:

- Aquatic ecosystems, habitats, and species

- Terrestrial ecosystems, habitats, and species

- Important cultural and recreational resources

Under the CFWCS, FWP Conservation Education will focus on programs to:

- Provide aquatic education and information materials and programs to the public, to schools and teachers

- Develop, refine, and expand native fish species program

- Provide information about the problems caused by illegal introductions

- Conduct aquatic education and comprehensive fisheries management training for FWP staff

- Enhance the stewardship of public and private lands, and their wildlife inhabitants through education

- Increase knowledge of species identified as being in greatest conservation need

- Provide wildlife-oriented information and educational efforts to meet hunting and non-hunting public needs and to address changing social conditions

- Offer education and information programs to help people learn to live with all wildlife and reduce wildlife/human conflicts

\section{State Parks}

- Provide sites for the inventory of fish and wildlife species on State Park properties

- Work with Con/Ed to create interpretive programs that inform the public about comprehensive conservation 


\section{DRAFT WORKING DOCUMENT DO NOT DUPLICATE}

14235

14236

14237

14238

14239

- Provide programs that educate and inform the public about the species and habitats in greatest need of conservation and what conservation activities need to occur in order to conserve them 


\section{DRAFT WORKING DOCUMENT DO NOT DUPLICATE}

14239

14240

14241

14242

14243

14244

14245

14246

14247

14248

14249

14250

14251

14252

14253

14254

14255

14256

14257

14258

14259

14260

14261

14262

14263

14264

14265

14266

14267

14268

14269

14270

14271

14272

14273

14274

14275

14276

14277

14278

14279

14280

14281

14282

14283

14284

\section{Methods}

The Strategy is organized from broad-scale (ecotype/focus area) to fine-scale (species). However, the priorities were actually developed using methods that working from species to ecotype/focus areas. Our first step was to update our occurrence databases and assess updated databases to determine which native Montana species are in greatest need of conservation (Tier I). Please refer to Categorizing the Levels of Conservation Need in the Introduction of this Strategy for complete definitions of the Tiers used in this document. Using this information, community types were identified that offer some of the greatest opportunity to conserve these Tier I species. Finally, the community types in greatest need of conservation were used to locate the areas of the state where those communities are the richest and offer some of the best opportunities for comprehensive conservation of all associated species and their habitats.

\section{Species}

During the first year of planning, we collected as much observational data as possible from all agencies and organizations in Montana for incorporation into existing FWP and Natural Heritage Program (NHP) Point Observation Database (POD). More than 130,000 new observations were added during this period. The updated database was used by FWP and NHP to review the Montana Species of Concern List (except fish). A matrix was developed that included all species occurring in Montana with their corresponding score for each of the fields listed below.

$\mathrm{MP}=$ Management plan (0=no, 1=yes)

$\mathrm{CF}=$ Current funding ( $0=$ none, $1=$ partial, $3=$ full)

$\mathrm{CM}=$ Current management effort ( $0=$ none, $1=$ group level, $2=$ species specific)

$\mathrm{SC}=$ Species of Concern Rank (1=S1, $2=\mathrm{S} 2,3=\mathrm{S} 3,4=\mathrm{S} 4,5=\mathrm{S} 5)$

$\mathrm{LR}=$ Limited MT Range (0=yes, $1=$ no)

$\mathrm{LT}=$ Existing local threats $(0=\mathrm{yes}, 1=\mathrm{no})$

$\mathrm{I}=$ Incidental to Montana (default to Tier IV)

$\mathrm{N}=$ Non-native species (default to Tier IV)

Tiers for conservation need had previously been identified for birds by the Partners-in-Flight effort and for fish by a separate FWP effort. We used these existing Tier assignments to model the following equation and then calculated the original draft Tiers assignment for all species including land birds and fish using this equation.

$$
\text { Tier }=(\mathrm{CF}+\mathrm{CM}+2 * \mathrm{SC}) / 4+\mathrm{MP} / 4+\mathrm{LR}-\mathrm{LT}
$$

Staff from NHP and staff from each of FWP's 7 Regions reviewed the draft tiers and recommended if species should be reassigned to a different level Tier. The planning team was concerned about not including a species in Tier I that should 


\section{DRAFT WORKING DOCUMENT DO NOT DUPLICATE}

14285

14286

14287

14288

14289

14290

14291

14292

14293

14294

14295

14296

14297

14298

14299

14300

14301

14302

14303

14304

14305

14306

14307

14308

14309

14310

14311

14312

14313

14314

14315

14316

14317

14318

14319

14320

14321

14322

14323

14324

14325

14326

14327

14328

14329

14330

have been and adopted the following rules for adjusting Tier assignments. It required only one FWP Region indicated that any species should be assigned a greater conservation need status such as from Tier II or Tier III to a Tier I, for that species to be reassigned. However, it required at least 2 FWP administrative regions indicating a species should be reassigned from a Tier II to a Tier III and 3 Regions indicating a species should be reassigned from a Tier I to a Tier II before an adjustment was made.

The SWG Technical and Steering Committees then reviewed the species Tier assignments and made some final adjustments based on knowledge of future funding and management issues. All contacts from the agencies and nongovernmental organizations that were invited to the October 2003 exploratory group were emailed the draft list and comments were received and incorporated. The final draft of the species tier assignments was then reviewed and approved by the SWG Steering Committee (Table 3).

\section{Community Types}

Although fish and wildlife communities have never been formally established for Montana, associations were developed between species and their related habitats to the degree that we have described them in this Strategy as community types. Future efforts should be made to define and validate fish and wildlife communities for Montana. To begin developing communities and identify those in greatest need of conservation, the FWP Technical Committee, field staff and, Habitat Montana staff determined the scales and coverages best suited for assessing the levels of community type conservation need. Three mapable coverages were selected to allow for planning at three scales, 1) the FWP Habitat Montana ecotypes 2) USFS subsections (HUC for aquatic ${ }^{{ }^{*}}$ ), and 3 ) GAP 50 cover types ${ }^{{ }^{2}}$ (habitat descriptors for aquatic ${ }^{\star 3}$ ), (Montana Fish, Willdife and Parks 1991, Nesser et.al 1997, Fisher et. al 1998). All riparian and wetland covertypes from the GAP 50 were combined to create one covertype. The same was done for sagebrush and salt flats, shrub grassland associations, and grassland covertypes. Cover types with minor associations such as snow and rock were removed prior to any analysis. Fish and wildlife species addressed in the strategy were linked with the GAP covertypes to establish essential and general biological associations that are described in this strategy as community types. The newly created community types were then linked with the USFS subsections and HUC's and finally with the FWP Habitat Montana ecotypes.

GAP covertypes, such as for grasslands, one of Montana's most important habitats, are based on the amount of grass cover interpretable by remote sensing. They are not strongly associated with ecological site factors or a recognized vegetation classification like the National Vegetation Classification System. Future classifications and maps will have a stronger relationship to habitat if they are ecological and based on data that are more comprehensive. The scale of GAP coverage is often also not suitable for comprehensive mapping 


\section{DRAFT WORKING DOCUMENT DO NOT DUPLICATE}

14331 of wetlands and riparian areas, another significant habitat, which often occur as

14332

14333

14334

14335

14336

14337

14338

14339

14340

14341

14342

14343

14344

14345

14346

14347

14348

14349

14350

14351

14352

14353

14354

14355

14356

14357

14358

14359

14360

14361

14362

14363

14364

14365

14366

14367

14368

14369

14370

14371

14372

14373

14374

14375

14376 narrow or small areas. These habitats will be better known and managed if National Wetlands Inventory mapping or a similar product is completed for Montana.

*1 Note: We initially used USFS subsections for aquatic but later changed to HUC 4 to better represent aquatic communities

*2 Note: For clarity of description, GAP 50 cover types were used as a surrogate for habitat

*3 Note: Aquatic communities were described as prairie streams, mixed source rivers, intermountain valley rivers, intermountain valley streams, mountain streams, prairie rivers, lowland lakes, lowland reservoirs, mountain lakes, and mountain reservoirs.

A habitat matrix containing all community types along with the information listed below was developed and the following formula was used to calculate draft tiers for all community types within each subsection or HUC.

$$
((\mathrm{S}+\mathrm{AR}+\mathrm{SAR}+\mathrm{CR}+\mathrm{CCR}) / 5)
$$

$\mathrm{S}=$ Percentage of cover type in stewardship (1=private, $2=$ public, 3=wilderness/park)

$\mathrm{AR}=$ Animal richness $(1=(>100), 2=(11$ to 100$), 3=(0$ to 10$))$ SAR $=$ Average of SWG Tier ranks for animal richness ( $1=(0$ to 2.34$), 2=(2.34$ to 2.647), $3=(2.647$ to 3$)$ )

$\mathrm{CR}=$ NHP Community richness $(1=(47$ to 100$), 2=(16$ to 46$), 3=(0$ to 15$))$ $\mathrm{CCR}=$ NHP Community of concern richness (1=(10 to 17$), 2=(4$ to 9$), 3=(0$ to 3$)$ )

Staff from FWP administrative regions reviewed draft tiers that were assigned to each community type within the subsection or HUC under their authority and adjustments to Tier assignment were made. Reviewers also scored the level of threat (high, medium or low) associated with the community type within each subsection or HUC. An average statewide Tier was calculated for each community type using the staff's adjusted Tier assignments for each community type within subsections and HUC's (Tables 4 and 5).

\section{Focus Areas}

USFS Subsections and HUC's were inserted with the final statewide community type Tier assignments to determine what areas contained the greatest percentage of Tier I community types. These subsections and HUC's were assigned Tier I status. Staff from FWP administrative regions were provided opportunities to review and comment on the draft focus area tier assignments. Habitat Montana, Upland Game Bird Habitat Enhancement, and Future Fisheries Staff involved with administration of the programs then reviewed all adjusted draft tier assignments. Technical and Steering Committees reviewed and approved 


\section{DRAFT WORKING DOCUMENT DO NOT DUPLICATE}

14377 community and focus area Tier assignments. Tier I focus areas were then

14378 organized by Ecotype (Tables 6 and 7).

14379

14380

14381

14382

14383

14384

14385

14386

14387

14388

14389

14390

14391

14392

14393

14394

14395

14396

14397

Inventory

The inventory component addresses species in greatest need of collecting data in order to establish the occurrence and distribution of that species. The inventory component was designed to help direct survey efforts toward species and groups of species that have inadequate occurrence data.

A inventory matrix was developed using the following information and all groups of species and individual species were assighned a Tier I, II, or III (Tables 8 and 9).

14398

14399

14400

14401

IIS = Need for inventory of individual species

ISP $=$ Need for inventory of species group (ISP $1-2.3=$ Tier 1, ISP $2.4-2.6=$ Tier 2, ISP $2.7-3=$ Tier 3)

$\mathrm{IE}=$ inventory effort (observation points in point observation database): (0 to $100)=1,(101$ to 500$)=2,(>500)=3$

$\mathrm{I} / \mathrm{P}=$ incidental/peripheral species: $1=$ native incidental $/$ peripheral, $2=$ native not incidental/peripheral

ST= sum of Tier scores for all species in a given taxonomic group

$\mathrm{SP}=$ number of species in a taxonomic group

IIS $=(I E+1 / P) / 2$ and ISP $=S T / S P$ 


\section{Table 1. Conservation \& Management Plans of Montana}

Note: This is not a complete list of all management plans prepared for Montana. Please alert us to any additional plans for inclusion.

\begin{tabular}{|c|c|c|}
\hline Author & Year & Title \\
\hline Amphibians \& Reptiles & 2000 & $\begin{array}{l}\text { Management of Montana's amphibians: A Review of factors that may present a risk to } \\
\text { population viability and accounts on the identification, distribution, taxonomy, habitat } \\
\text { use, natural history and the status and conservation of individual species. Contract No. } \\
43-0343-0-0224 \text {. }\end{array}$ \\
\hline $\begin{array}{l}\text { Fisheries } \\
\text { Jones-Wuellner, Melissa R. and Guy, Christopher } \\
\text { S. }\end{array}$ & 2004 & $\begin{array}{l}\text { Status of Burbot in Montana. Prepared for Montana Fish, Wildlife \& Parks. Montana } \\
\text { Cooperative Fisheries Research Unit, Montana State University-Bozeman. }\end{array}$ \\
\hline $\begin{array}{l}\text { Montana Department of Fish, Wildlife \& Parks } \\
\text { May, B. E., Urie, W., Shepard, B.B., Montana }\end{array}$ & 2004 & $\begin{array}{l}\text { Memorandum of Understanding and Conservation Agreement for Sauger (Sander } \\
\text { canadensis) in Montana. } 23 \mathrm{pg} \text {. Draft In progress. }\end{array}$ \\
\hline $\begin{array}{l}\text { Cooperative Fishery Research Unit. } \\
\text { Shepard, Brad B., May, B.E, Urie, W. }\end{array}$ & 2003 & $\begin{array}{l}\text { Range-wide status of Yellowstone Cutthroat Trout (Oncorhynchus clarki bouvieri): } 2001 . \\
\text { Status of Westslope Cutthroat Trout (Onchorhyncus clarki lewisi) in the United States } \\
\text { 2002. Westslope Cutthroat Conservation Team. }\end{array}$ \\
\hline U. S. Fish and Wildlife Service & 2002 & $\begin{array}{l}\text { Endangered and Threatened Wildlife and Plants; Bull Trout (Salvelinus confluentus) } \\
\text { Draft Recovery Plan. Available: http://pacific.fws.gov/bulltrout/recovery/Default.htm. } \\
\text { (February 2003). }\end{array}$ \\
\hline Magee, James P. & 2000 & $\begin{array}{l}\text { Montana fluvial arctic grayling recovery project : annual monitoring report } \\
\text { Restoration plan for bull trout in the Clark Fork River basin and Kootenai River basin, } \\
\text { Montana. Montana Department of Fish, Wildlife \& Parks, Helena. } 116 \\
\text { intermountain/foothill grassland. }\end{array}$ \\
\hline
\end{tabular}




\section{DRAFT WORKING DOCUMENT DO NOT DUPLICATE}

Montana Department of Fish, Wildlife \& Parks.

Montana Fish, Wildlife \& Parks.

U.S. Department of Interior, Fish and Wildlife Service

May, B. E.

Montana Fluvial Arctic Grayling Workgroup

North Dakota Game \& Fish Department, Montana Department of Fish, Wildlife \& Parks \& University of Idaho

Yellowstone Cutthroat Trout Working Group Fluvial Arctic Grayling Workgroup.

U.S. Fish and Wildlife Service.

Kaya, Calvin M.

Montana Department of Fish, Wildlife, and Parks.

Schrader, William C.
Cooperative Conservation Agreement for Yellowstone Cutthroat Trout within Montana between Crow Tribe, Montana Department of Fish, Wildlife \& Parks (FWP), Montana Department of Environmental Quality (DEQ), Montana Department of Natural Resources and Conservation (DNRC), USDA-Forest Service, Northern Region, Gallatin \& Custer National Forests, USDI-Bureau of Land Management - Montana (BLM), USDI-Fish and 2000 Wildlife Service (FWS), USDI-Bureau of Indian Affairs (BIA), Yellowstone National Park. Memorandum of Understanding and Conservation Agreement for Westslope Cutthroat 1999 Trout (Onchorhynchus clarki lewisi) in Montana.

White Sturgeon; Kootenai River Population Recovery Plan. Region 1, USFWS,

1999 Portland, Oregon

Yellowstone cutthroat trout: current status and conservation recommendations with the state of Montana. U.S. Forest Service, Gallatin National Forest, Bozeman, Montana.

Montana Fluvial Arctic Grayling Restoration Plan. Montana Department of Fish, Wildlife, 1995 and Parks, Helena.

Montana-North Dakota Paddlefish Management Plan. A cooperative venture between: North Dakota Game \& Fish Department, Montana Department of Fish, Wildlife \& Parks \& University of Idaho. $45 \mathrm{pgs}$.

Yellowstone cutthroat trout (Oncorhynchus clarki bouvieri) management guide for the Yellowstone River drainage. Montana Department of Fish, Wildlife \& Parks, Helena, and 1994 Wyoming Game and Fish Department, Cheyenne.

1993 Fluvial arctic grayling conservation plan. [unpublished draft]. $44 \mathrm{pp}$.

1993 Pallid sturgeon recovery plan. U.S. Fish and Wildlife Serv., Bismarck, N.D. 55 pp.

Status Report on Fluvial Arctic Grayling (Thymallus arcticus) in Montana. Biology

1990 Department, Montana State University. Bozeman, MT. Prepared for: FWP. Helena, MT Hauser Reservoir: fisheries management plan: September 1989-September 1994. 16 $\mathrm{pp}$

Trout Mortality, Movements, and Habitat Selection During Winter in South Willow Creek, 


\section{DRAFT WORKING DOCUMENT DO NOT DUPLICATE}

\begin{tabular}{|l} 
Birds \\
Montana Sage-grouse Work Group \\
Rich, T.D., C.J. Beardmore, H. Berlanga, P.J. \\
Blancher, M. S. W. Bradstreet, G. S. Butcher, \\
D.W. Demarest, E. H. Dunn, W. C. Hunter, E. E. \\
Inigo-Elias, J. A. Kennedy, A. M. Martell, A. O. \\
Panjabi, D. N. Pashley, K. V. Rosenberg, C. M. \\
Rustay, J. S. Wendt, T. C. Will. \\
Klute, D. S., L.W. Ayers, M.T. Green, W.H. Howe, \\
S.L. Jones, J.A. Shaffer, S.R. Sheffield, and T.S. \\
Zimmerman \\
Montana Piping Plover Working Group \\
Pacific Flyway Council and USFWS \\
James A. Kushlan, Melanie J. Steinkamp, \\
Katherine C. Parsons, Jack Capp, Martin Acosta \\
Cruz, Malcolm Coulter, lan Davidson, Loney \\
Dickson, Naomi Edelson, Richard Elliot, R. \\
Michael Erwin, Scott Hatch, Stephen Kress, \\
Robert Milko, Steve Miller, Kyra Mills, Richard \\
Paul, Roberto Phillips, Jorge E. Saliva, Bill \\
Sydeman, John Trapp, Jennifer Wheeler, and \\
Kent Wohl. \\
Brown, S., C. Hickey, B. Harrington, and R. Gill, \\
eds. \\
Casey, D. \\
North America Waterfowl Planning Team \\
Mississippi and Central Flyway Councils \\
\end{tabular}

Management plan and covservation strategies for sage-grouse in Montana

\section{Partners in Flight North American Landbird Conservation Plan. Cornell Lab of} Ornithology. Ithaca, NY.

Status Assessment and Conservation Plan for the Western Burrowing Owl in the United States. U.S. Department of the Interior; Fish and Wildlife Service, Biological Technical

Montana Piping Plover Management Plan. Unpublished Report. 35 pp.

Pacific Flyway Implementation Plan for the Rocky Mountain Population of Trumpeter Swans 2003 Annual Report. 29 pp.

Waterbird Conservation for the Americas: The North American Waterbird Conservation Plan, Version 1. Waterbird Conservation for the Americas, Washington, D.C. U.S.A., 78 2002 pp.

The U.S. Shorebird Conservation Plan, 2nd ed. Manomet Center for Conservation 2001 Sciences, Manomet, MA.

Partners in Flight Bird Conservation Plan Montana Version 1.0. Montana Partners in 2000 Flight. Kalispell, Montana.

North American Waterfowl Management Plan. Expanding the Vision-Update. 32 pp.

Subcommittee on the Interior Population of Trumpeter Swans. Mississippi and Central flyway management plan for the Interior population of Trumpeter Swan. Mississippi and 


\section{DRAFT WORKING DOCUMENT DO NOT DUPLICATE}

Subcommittee on the Interior Population of Trumpeter Swans.

Cassirer, E. F., J. D. Reichel, R. L. Wallen, and E. C. Atkinson.

Montana Bald Eagle Working Group.

U.S. Fish and Wildlife Service.

Sidle, J. G. and W. F. Harrison.

Skaar, D.

Haig, S., et al.

Skaar, D.

U.S. Fish and Wildlife Service.

Zubik, R. J.

Bureau of Land Management.

Escano, R., D. Flath, R. Hazelwood and B. Klaver. (eds.).

Will, G. C.

Trumpeter Swan Recovery Group

U.S. Fish and Wildlife Service.

U.S. Fish and Wildlife Service, Division of Wildlife Management.
Mississippi and Central flyway management plan for the Interior population of Trumpeter Swan. Mississippi and Central Flyway Councils. c/o USFWS, Migratory Bird Coordinator 1997 Twin Cities, M

Harlequin Duck (Histrionicus histrionicus) conservation assessment and strategy for the U.S. Rocky Mountains. Unpublished Technical Report, Idaho Department of Fish and 1996 Game, Lewiston, Idaho, U.S.A.

1994 Montana Bald Eagle management plan. 2nd edition. Bureau of Reclamation. 104 pp. Revised recovery plan for piping plovers CHARADRIUS MELODUS breeding on the 1994 Great Lakes and Northern Great Plains. 121 pp.

Recovery plan for the interior population of the Least Tern (STERNA ANTILLARUM).

1990 U.S. Fish and Wildlife Service. 90 pp.

Montana common loon management plan. Unpublished report prepared for U.S. Forest 1990 Service, Region 1. $61 \mathrm{pp}$.

Recovery plan for piping plovers CHARADRIUS MELODUS of the Great Lakes and

northern great plains. U.S. Fish \& Wildlife Service, 160pp.

Creation of a management plan for the common loon in Montana. Intermountain/foothill 1988 grassland 101-102 in: North American Loon Fund conference report

1988 Great Lakes and northern Great Plains piping plover recovery plan. 160 pp.

A site specific management plan for the lower Stillwater bald eagle territory. Unpublished 1988 report. Montana Department of Fish, Wildife, and Parks, Kalispell. 43 PP.

1986 Montana Bald Eagle Management Plan. U.S.D.I., Billings, MT.

Montana eagle management plan. Montana Bald Eagle Working Group. BLM, MT State 1986 Office. 61pp.

1986 Waterfowl, Sandhill Crane and Snipe Management Plan

1984 The North American Management Plan for Trumpeter Swans

American peregrine falcon recovery plan (Rocky Mtn./southwest population). Prepared 1984 in cooperation with American pregrine falcon recovery team. USFWS, Denver, CO.

1981 Draft western golden eagle management plan. Washington, D.C. 


\section{DRAFT WORKING DOCUMENT DO NOT DUPLICATE}

Olsen, David L.

Whooping Crane Recovery Team: U.S. Fish \& Wildlife Service, Nebraska Game and Parks Commission, Texas Parks \& Wildlife Department, National The Audubon Society Society Molini, W. A.

\section{Mammals}

Montana Fish, Wildlife \& Parks Montana Prairie Dog Working Group Montana Fish, Wildlife \& Parks.

Montana Fish, Wildlife \& Parks

Ruediger, Bill \& 14 others on Lynx Biology Team

\section{USDI National Park Service.}

Pierson, E.D., M.C. Wackenhut, J.S. Altenbach, P. Bradley, P. Call, D.L. Genter, C. E. Harris, B. L. Keller, B. Lengus, L. Lewis, B. Luce, K. W. Navo, J. M. Perkins, S. Smith, and L. Welch Montana Department of Livestock and Montana Fish, Wildlife \& Parks.

Montana Fish, Wildlife \& Parks

Servheen, C.

Montana Fish, Wildlife \& Parks
Whooping Crane Recovery Plan. Whooping Crane Recovery Team (USFWS, Nebraska Game and Parks Commission, Texas Parks \& Wildlife Department, National The Audubon Society Society). 206 pp.

1980 Whooping Crane Recovery Plan

Chukar Partridge, Species Management Plan

Montana Gray Wolf Conservation and Management Plan

Conservation plan for black-tailed and white-tailed prairie dogs in Montana

Grizzly bear management plan for southwestern Montana : 2002-2012

Conservation plan for grizzly bear in Montana

Canada Lynx Conservation Assessment and Strategy. 120 pp.

Bison Management for the State of Montana and Yellowstone National Park. Final Environmental Impact Statement for the Interagency Bison Management Plan for the

State of Montana and Yellowstone National Park. Vol. I.

Species conservation assessment and strategy for Townsend's big-eared bat (Corynorhinus townsendii townsendii and Coynorhinus townsendii pallescens). Idaho Conservation Effort, Idaho Department of Fish and Game, Boise, Idaho.

1996 Interim bison management plan. $70 \mathrm{pp}$.

1996 Management of Mountain Lions in Montana: Final EIS

Grizzly bear recovery plan. Unpublished report to the U.S. FWS. University of Montana, 1993 Missoula. $181 \mathrm{pp}$.

North Central Montana Black-footed ferret reintroduction and management plan.

1992 Prepared by North Central Montana Working Group. 59 pp. 


\section{DRAFT WORKING DOCUMENT DO NOT DUPLICATE}

Shaffer, M.

Casey, D., and P. Malta

U.S. Fish and Wildlife Service.

U.S. Fish and Wildlife Service (USFWS).

U.S. Fish and Wildlife Service.

Dood, A.R., Brannon R.D., Mace, R.D.

Parker, T. and M. Scott

U.S. Fish and Wildlife Service.

Tsukamoto, G.K.

U.S. Fish and Wildlife Service.

Joslin, G.

Northern Rocky Mountain Wolf Recovery Team.

Bureau of Land Management.

Anderson, M. E. et al.

Greenwalt, L. A.

Phelps, D. E., B. Jamieson, and R. A. Demarchi McGowan, T. A.

U. S. Fish and Wildlife Service

Riley, Shawn J.
Keeping the grizzly bear in the American West: an alternative recovery plan. The 1992 Wilderness Society, Washington, D.C.

Long-term habitat management plan for elk and mule deer winter range enhancment 1990 firefighter mountain and spotted bear winter ranges

1990 Grizzly bear recovery plan (Draft). Unpubl. Rep., Missoula, MT. 117 pp.

1988 Black-footed ferret recovery plan. Denver, CO. 154 pp.

Northern Rocky Mountain wolf recovery plan. U.S. Fish and Wildlife Service, Denver CO.

$1987119 \mathrm{pp}$.

Final Programmatic Environmental Impact Statement, the Grizzly Bear in Northwestern

1986 Montana. Montana Department of Fish, Wildlife \& Parks.

1985 Bighorn Sheep Management Plan

Selkirk mountain caribou management/recovery plan. U.S. Fish Wildlife Service,

1984 Portland, Oregon. 121 pp.

1983 Pronghorn Antelope species management plan

Grizzly bear recovery plan. Unpublished report prepared in cooperation with the

1982 Recovery Team Leader, Don L. Brown of the MT DFWP. 195 pp.

Mountain goat habitat management plan for the Cabinet Mountains, Montana. MT. Dept.

1980 Fish, Wildl. and Parks and Kootenai National Forest.

1980 Northern Rocky Mountain wolf recovery plan interagency report. 67 pp.

Habitat management plan prairie dog ecotypes. USDI, BLM, Montana State Office.

1979 Wildlife Habitat Area MT-02-06-07-S1. 61 pp.

Black-footed ferret recovery plan. U.S. Fish and Wildlife Service Black-footed ferret

1978 Recovery Team. 150 pp.

1978 Black-footed ferret recovery plan

Mountain goat management in the Kootenays I. The history of goat management II. A 1975 goat management plan, 1975-1985

1970 Antelope management and BLM's wildlife habitat management planning system

1970 A summary of the Northern Rocky Mountain wolf recovery plan

Cougars in Montana: A review of biology and management and a plan for the future. 


\section{DRAFT WORKING DOCUMENT DO NOT DUPLICATE}

\section{Resource Areas, Communities, Habitats and} Landscape Level Conservation Plans

Stagliano, D.M

The Nature Conservancy

Kootenai Tribe of Idaho and Montana Fish, Wildlife \& Parks

The Nature Conservancy

\section{U. S. Fish \& Wildlife Service}

Confederated Salish and Kootenai Tribes and Montana Fish, Wildlife \& Parks

Frisina, Michael R., McCarthy, John, J.

National Wildlife Federation and the Natural Resources Defense Council.

R. Noss, G. Wuerthner, K. Vance-Borland, and C. Carroll

The Nature Conservancy

The Nature Conservancy

Ostlie, W.R, R. E. Schneider, J. M. Aldrich, T. M. Faust, R. L. B. McKim and S. J. Chaplin

The Nature Conservancy.

Aquatic Ecotype Diversity in Montana's Missouri River Drainages: A Community Classification Project. Montana Natural Heritage Program: A report to the BLM and The

2005

2005

2004

2004 Missouri, Yellowstone and Upper Columbia watersheds. Publisher: USFWS, Benton

2004

Nature Conservancy. 98pp.

Unpublishe Report

Public Review Draft Kootenai Subbasin Plan. Executive Summary. Report prepared for the Northwest Power and Conservation Council. Portland, OR.

Canadian Rocky Mountains Ecoregional Assessment. Four volumes, including Report, Appendices, Conservation Area Descriptions \& Maps.

Conservation Focus Areas of the Great Divide: A vast region encompassing the Uppe Lake Wildlife Refuge, Great Falls, MT. 77pgs.

Flathead Subbasin Plan Assessment: Executive Summary. NWPCC. Portland, OR.

Montana Sagebrush Bibliography. Montana Fish, Wildlife \& Parks. 69 pp.

Conservation Management of America's Public Lands: An Assessment and

Recommendations for Progress 25 Years after FLPMA.

A Biological Conservation Assessment for the Utah-Wyoming Rocky Mountain Ecoregion: Report to the Nature Conservancy. Conservation Science, Inc. 125 pp. + Executive Summary and Appendix D.

Middle Rockies-Blue Mountains Ecoregional Conservation Plan. Prepared by the Middle Rockies - Blue Mountains Planning Team. 58 pgs + appendices.

Ecoregional Conservation in the Northern Great Plains Steppe. Northern Great Plains Steppe Ecoregional Planning Team. 76 pgs.

The status of biodiversity in the Great Plains. The Nature Conservancy, Arlington, VA, USA. $326 \mathrm{pp}+$ XII.

Statewide conservation plan. Prepared by The Nature Conservancy of Montana,

Montana Natural Heritage Program. 48pp. 


\section{DRAFT WORKING DOCUMENT DO NOT DUPLICATE}

\section{Montana Fish, Wildlife \& Parks}

U.S. Fish and Wildlife Service.

Bureau of Land Management, Big Dry Resource Area.

Bureau of Reclamation, U.S. Department of Interior

Helena National Forest, Townsend Ranger District and Bureau of Land Management, Headwaters Resource Area.

Carlsen, Tom, and Rick Northrup

Bureau of Land Management.

Platts, W.S.

Vashro, J., et al.

Montana Dept. of State Lands. Flathead County Park Board.

Gibson, R. S.

Bissell, G. and C. A. Yde.

Bissell, G. and C. Yde.

U.S. Fish \& Wildlife Service.

Gorman, J. D.
Statewide Habitat Plan. Implementation of Fish, Wildlife \& Parks Commission. Habitat 1994 Montana Policy.

Endangered and threatened wildlife and plants: Establishment of a nonessential

1994 experimental population of black-footed ferrets in North-Central Montana.

Draft - Resource management plan and environmental impact statement for the Big Dry 1993 Resource Area, Miles City District. United States Department of the Interior.

1993 Canyon Ferry Reservoir noxious weed management plan

Environmental assessment of vegetation treatement and allotment management plan revisions for the Greater Crow Creek and Indian Creek watershed

1992 Canyon Ferry Wildlife Management Area Final Draft Management Plan. Rangeland program summary update: Missouri Breaks grazing EIS, Prairie Potholes grazing EIS, Headwaters resource management plan (Great Falls Resource Area

1991 portion). $102 \mathrm{pp}$.

Compatibility of livestock grazing strategies with fisheries. p. 103-110. In: R.E.

Gresswell, B.A. Barton, J.L. Kershner (eds.), Practical approaches to riparian resource management. U.S. Bureau of Land Management, P.O. Box 36800, Billings, Montana.

Upper Flathead system fisheries management plan: 1989-1994. Unpublished report. MT 1989 Dept. of Fish, Wildlife \& Parks and the Confederated Salish and Kootenai Tribes. 47 pp.

Proposed Master Plan for Owen Sowerwine State Natural Area.

Environmental impact statement for the Helena National Forest, land and resource management plan. USDA, Forest Service.

Wildlife and wildlife habitat mitigation plan for Hungry Horse hydroelectric project. Final 1985 report. Mont. Dept. Fish, Wildlife, \& Parks.

Wildlife and wildlife habitat mitigation plan for the Noxon Rapids and Cabinet Gorge 1985 hydroelectric. Mont. Dept. Fish, Wild., \& Parks.

Charles M. Russell National Wildlife Refuge, Montana: Final Environmental Impact 1985 Statement.

1984 Interagency Rocky Mountain Front Wildlife Monitoring/Evaluation Program. 


\section{DRAFT WORKING DOCUMENT DO NOT DUPLICATE}

Lehmkuhl, J. F.

Platts, W.S.

Molini, W. A., and G. K. Tsukamoto

Brown, D. L., T. Musshel, and J. Gaffney

Smith, C. A., and G. N. Boz

USDA, Forest Service.

Tennant, Donald

Ormiston, J. H.

Aldrich, D. F.

Wikstrom, J. H., and S. B. Hutchison

Yellowstone National Park

U. S. Fish \& Wildlife Service- Missouri River basin studies

Elis, Janet H., Richard, Jim
Determining size and dispersion of minimum viable populations for land management 1984 planning and species conservation. Environmental Management 8(2):167-176.

Influence of forest and rangeland management on anadromous fish habitat in western North America: 7. Effects of livestock grazing. USDA Forest Serv. Gen. Tech. Rep.

1981 PNW-124.

1979 Individual species management plans

A strategic plan for the protection, perpetuation and recreational use of the fish and

1977 wildlife resources in Montana

1977 Management plans for alternative uses of wildlife

1977 Western spruce budworm management plan.

Instream Flow Regimes for Fish, Wildlife, Recreation, and Related Environmental

1975 Resources (Billings, Mont.: U.S. Fish and Wildlife Service)

1973 Fleecer Mountain game range. Game management plan. MT Fish and Game.

1972 Wilderness fire management planning guidelines and inventory procedures Stratification of forest land for timber management planning on the Western National

1971 Forests

1963 1963-1964 Northern Yellowstone wildlife and range management plan

A preliminary report on fish and wildlife resources in relation to the water development

1955 plan for the Sun-Teto divison Missouri River basin project Montana

A planning guide for protecting Montana's wetlands riparian areas. Montana

Watercourse, Montana Department of Environmental Quality and Montana The Audubon Society. 


\begin{tabular}{l}
\hline \multicolumn{1}{c}{ Species } \\
\hline Long-toed Salamander \\
Tiger Salamander \\
Coeur D'Alene Salamander \\
Roughskin Newt \\
Idaho Giant Salamander \\
Rocky Mountain Tailed Frog \\
Boreal Toad \\
Great Plains Toad \\
Canadian Toad \\
Woodhouse's Toad \\
Boreal Chorus Frog \\
Pacific Treefrog \\
Plains Spadefoot \\
Great Basin Spadefoot \\
Bullfrog \\
Northern Leopard Frog \\
Wood Frog \\
Columbia Spotted Frog \\
Barn Owl \\
Flammulated Owl \\
Eastern Screech-owl \\
Western Screech-owl \\
Great Horned Owl \\
Snowy Owl \\
Northern Hawk Owl \\
Northern Pygmy-owl \\
Burrowing Owl \\
Barred Owl \\
Great Gray Owl \\
Long-eared Owl \\
Short-eared Owl \\
Boreal Owl \\
Northern Saw-whet Owl \\
Rock Dove \\
Band-tailed Pigeon \\
Eurasian Collared-dove \\
White-winged Dove \\
Black-billed Cuckoo \\
Yellow-billed Cuckoo \\
Common Nighthawk \\
Common Poorwill \\
Whip-poor-will \\
Black Swift \\
\hline
\end{tabular}




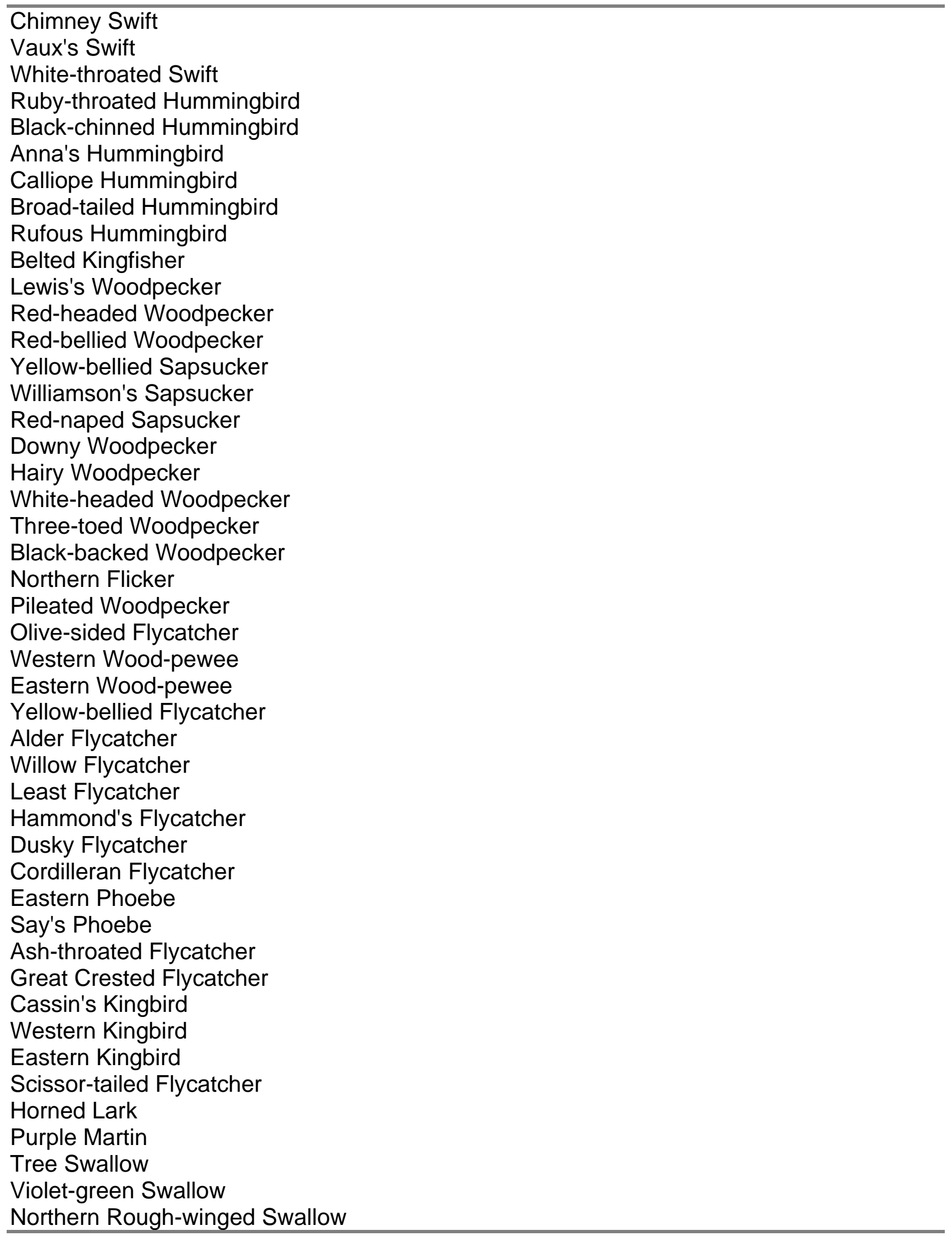









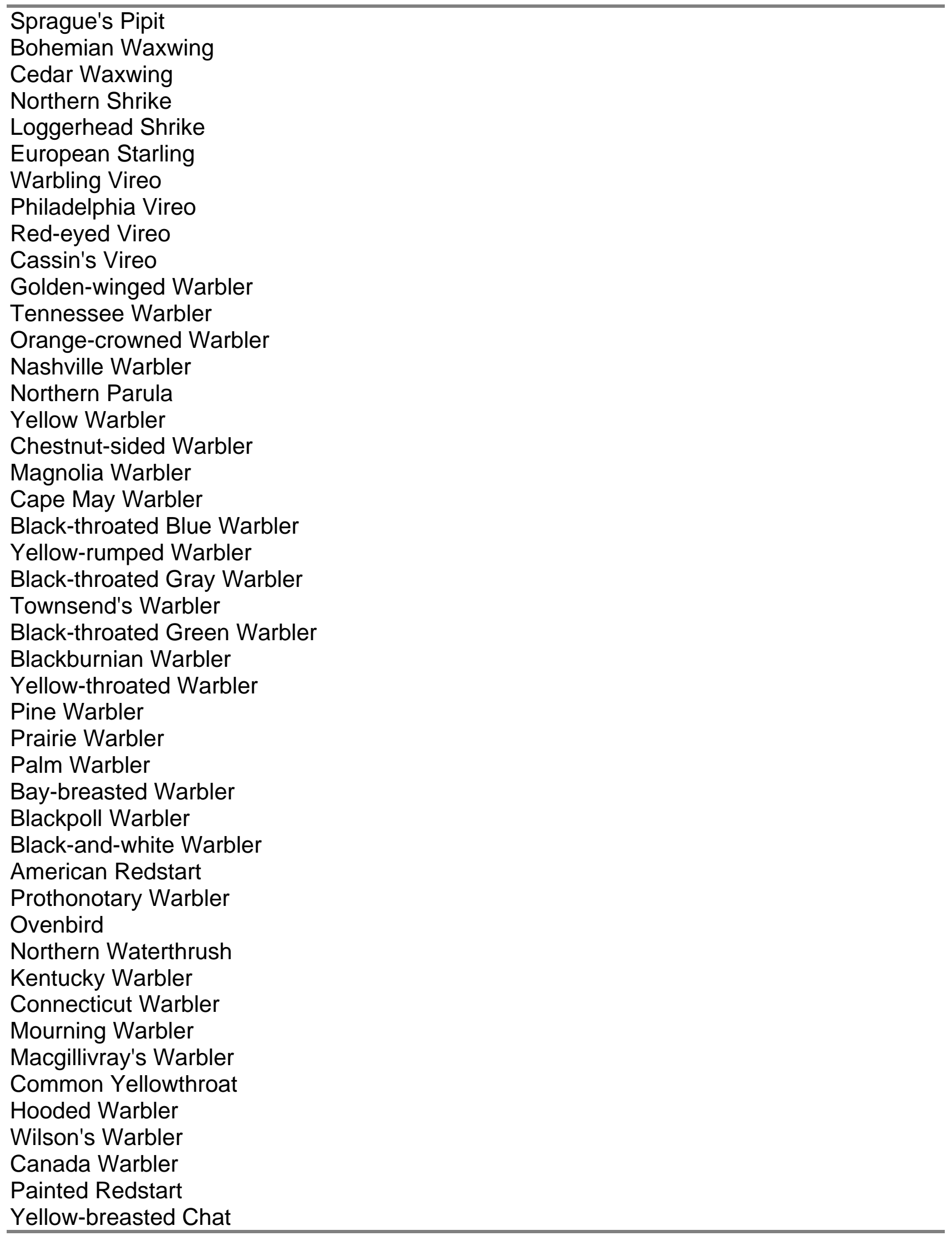




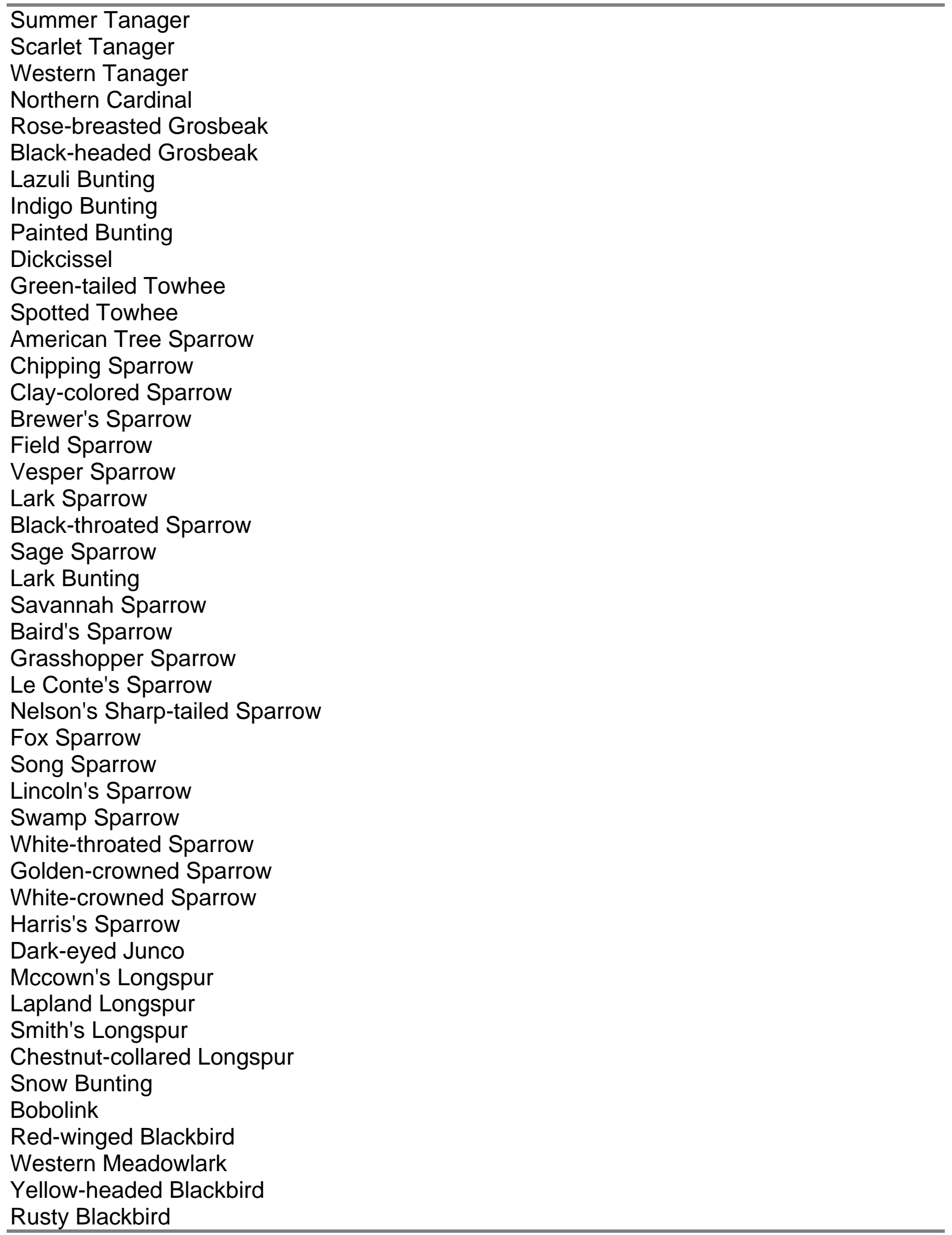




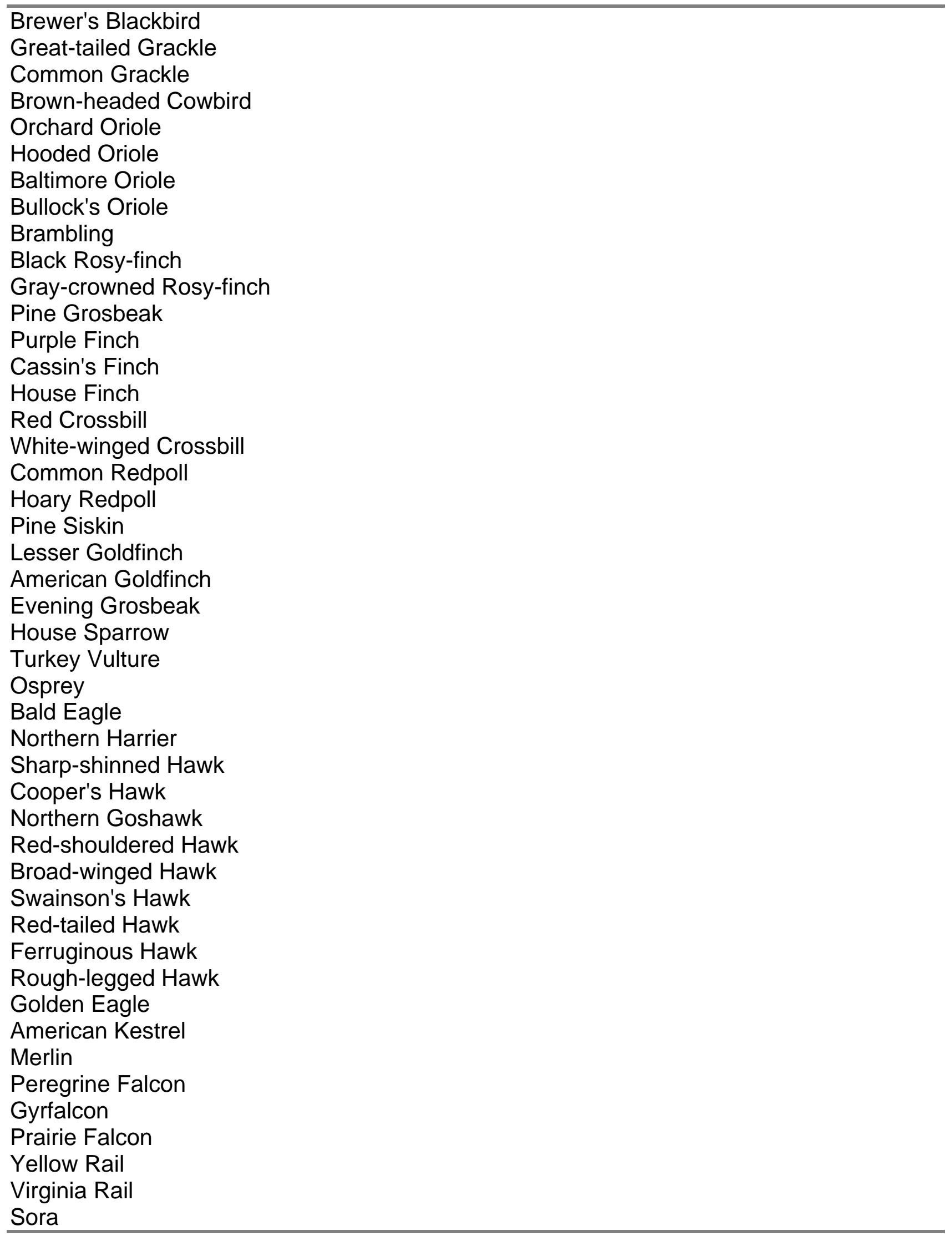




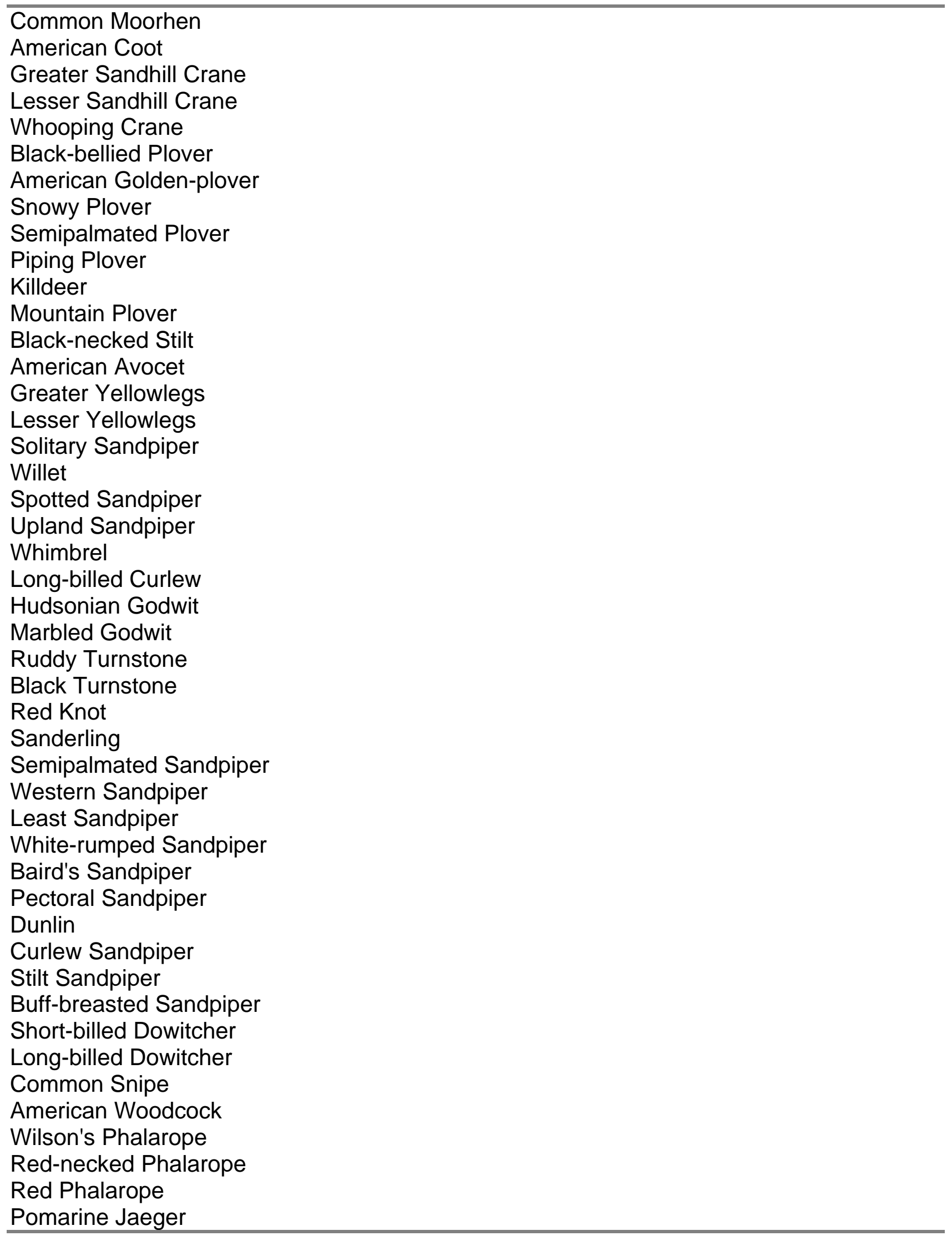




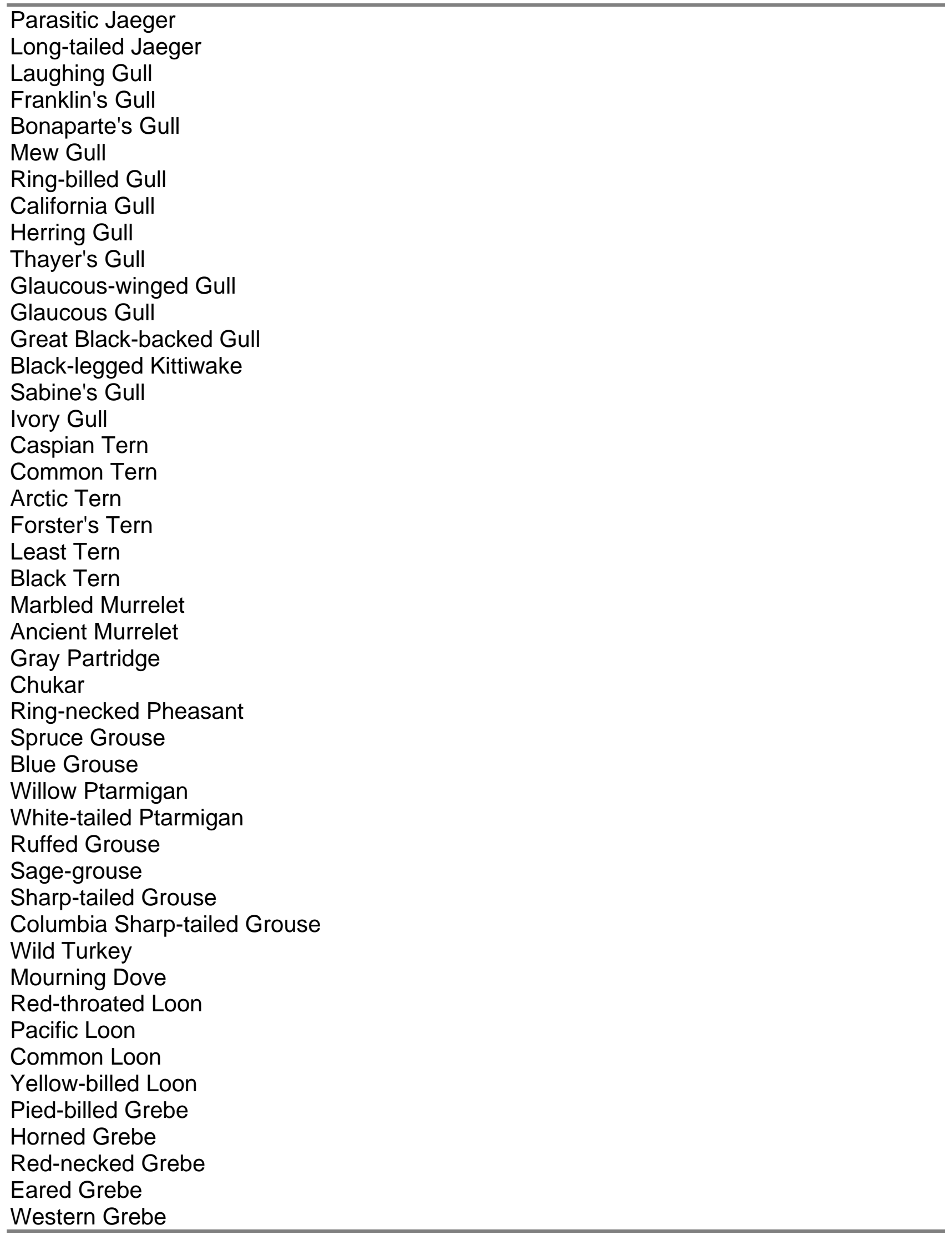




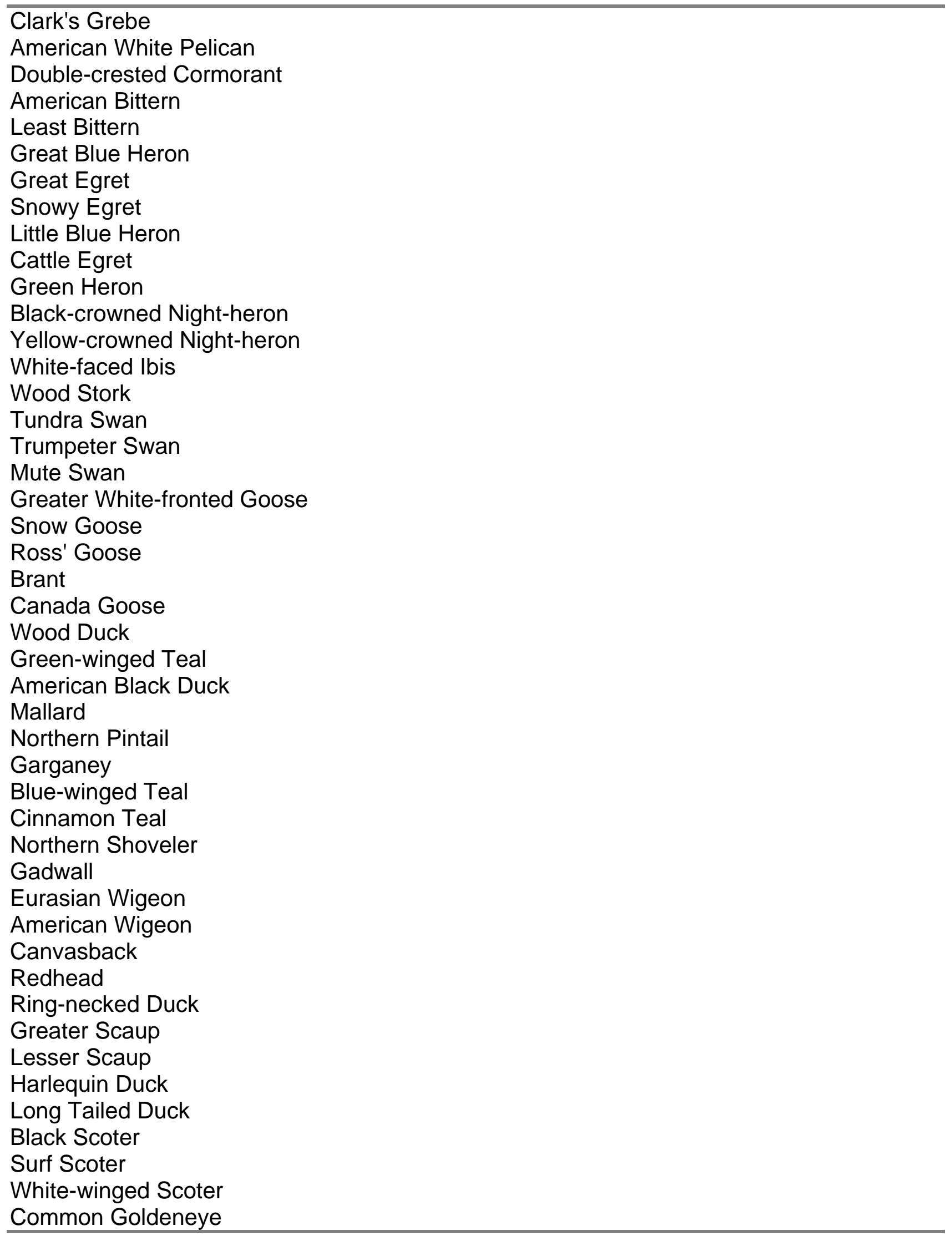




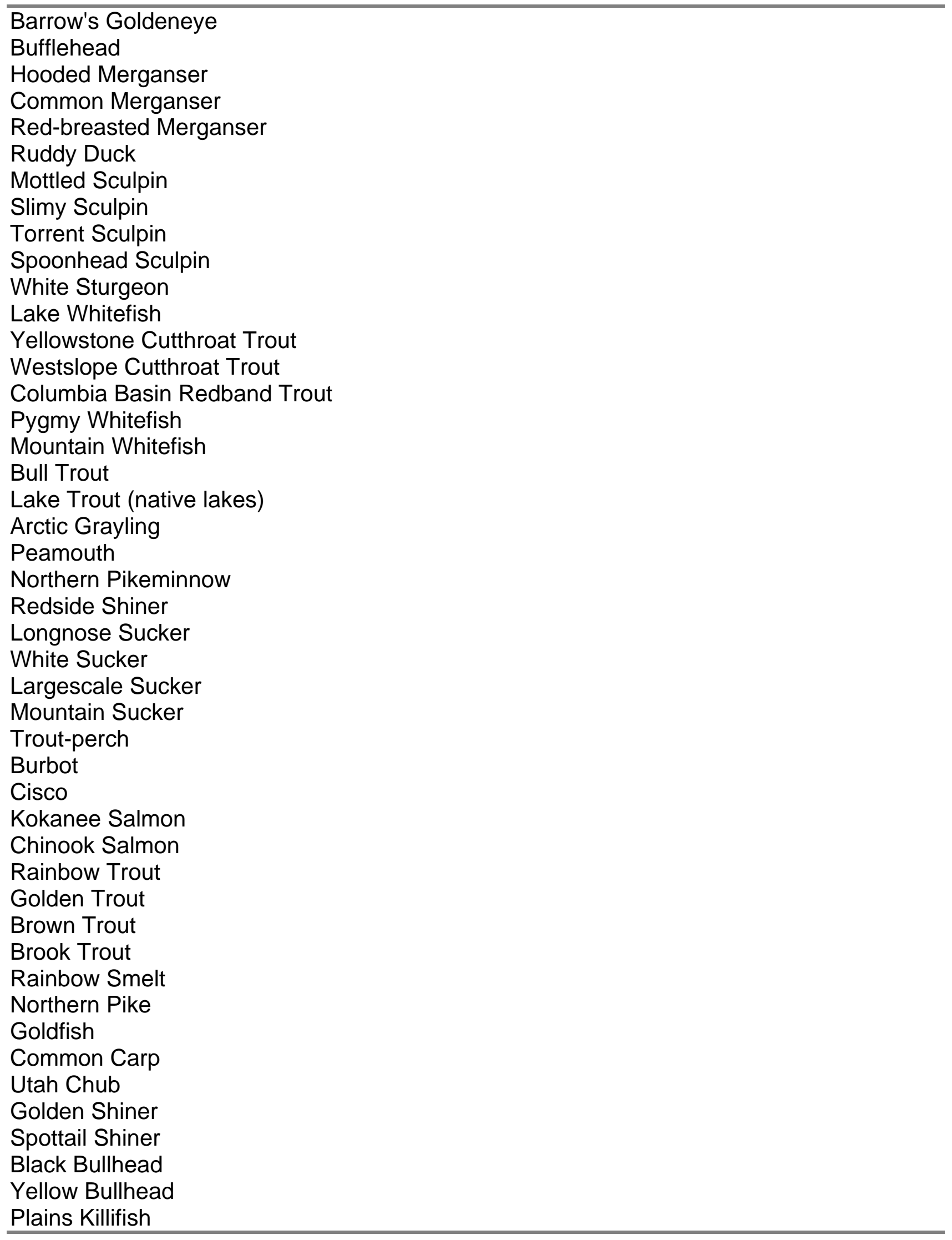




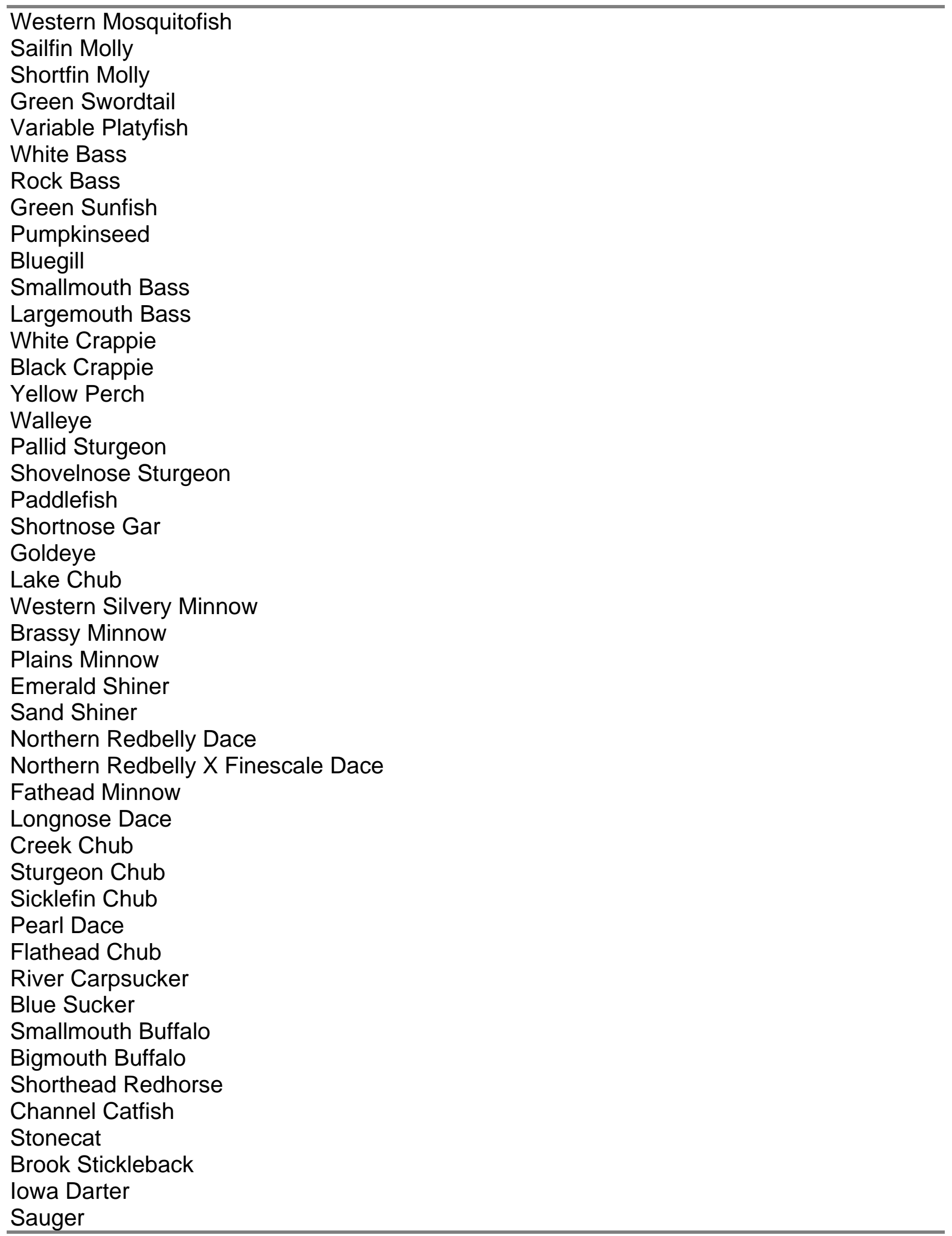


Freshwater Drum

Little Brown Myotis

Yuma Myotis

Long-eared Myotis

Fringed Myotis

Long-legged Myotis

California Myotis

Western Small-footed Myotis

Northern Myotis

Silver-haired Bat

Big Brown Bat

Eastern Red Bat

Hoary Bat

Spotted Bat

Townsend's Big-eared Bat

Pallid Bat

Black Bear

Grizzly Bear

Mountain Lion

Wapiti Or Elk

Mule Deer

White-tailed Deer

Moose

Caribou

Pronghorn

American Bison

Mountain Goat

Bighorn Sheep

Feral Horse

American Beaver

Gray Wolf

Swift Fox

American Marten

Fisher

Black-footed Ferret

Mink

Wolverine

American Badger

Western Spotted Skunk

Striped Skunk

Northern River Otter

Lynx

Bobcat

Coyote

Red Fox

Common Raccoon 


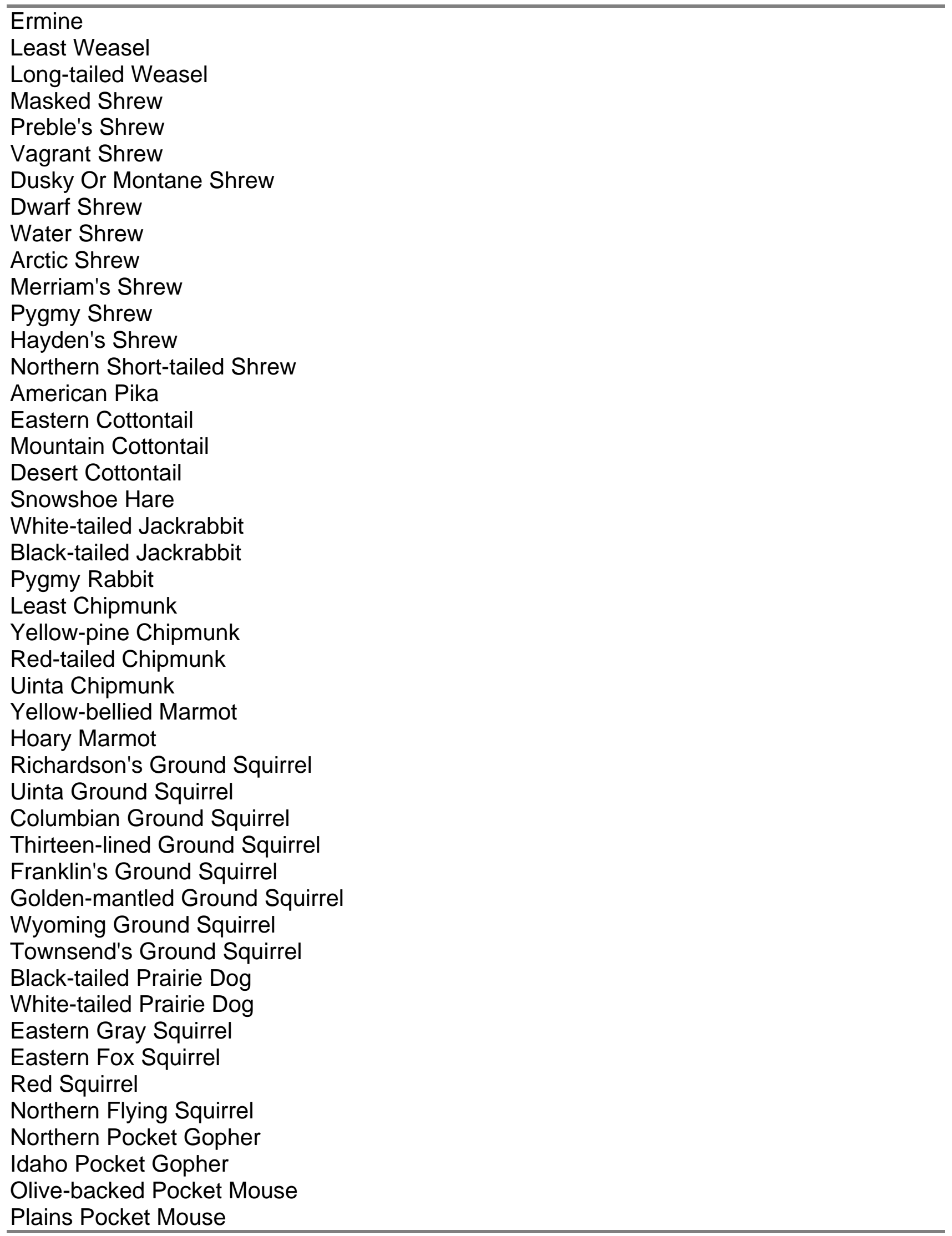




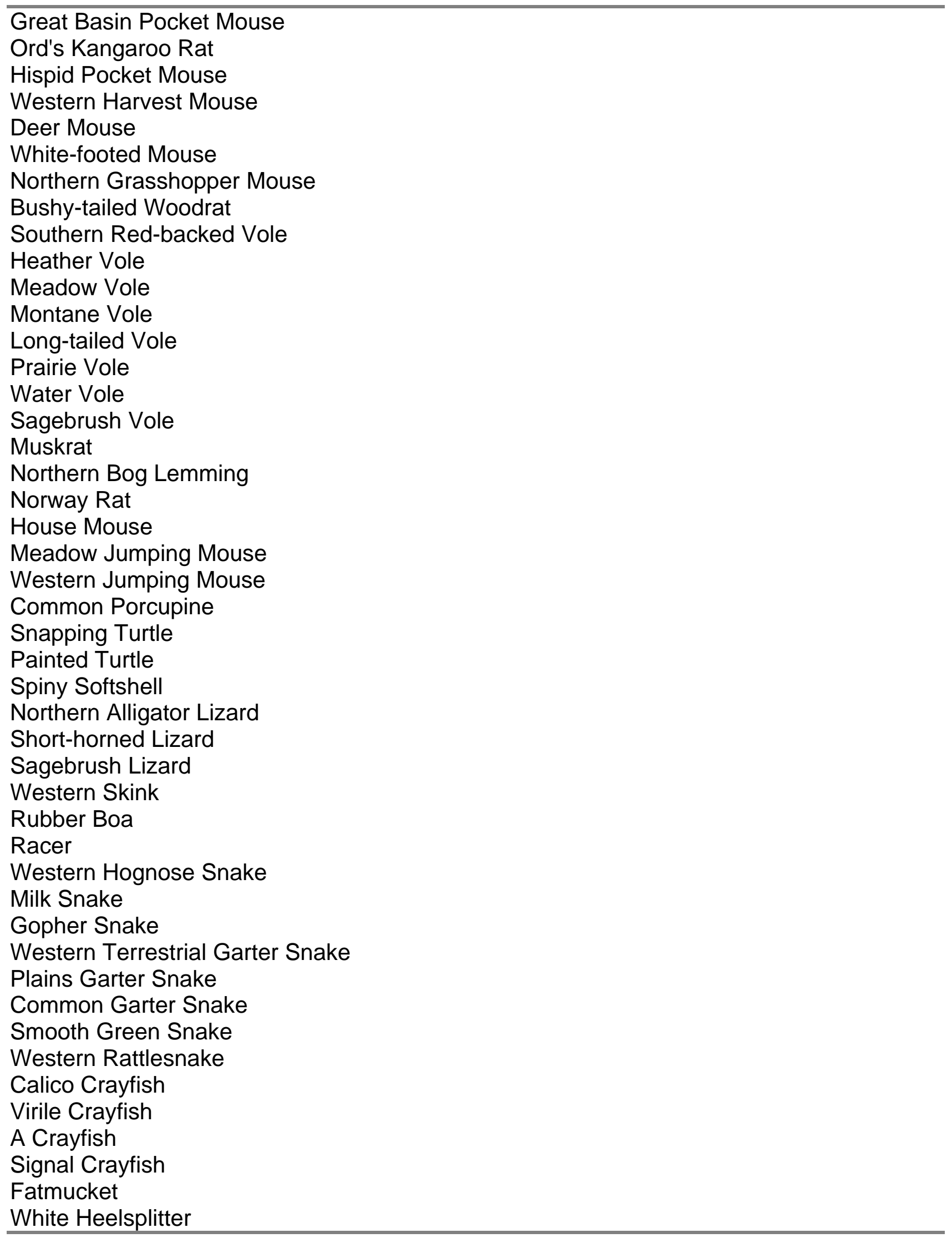




\section{Black Sandshell}

Western Pearlshell

Giant Floater

14409

14410

14411

14412

14413
Table 3. Species Tier Assignments

This list is subject to change as information and understanding increases for each species biological needs.
Species

\begin{tabular}{llllllll}
\hline Coeur D'Alene Salamander & 0 & 0 & 0 & 2 & & & 1 \\
Boreal Toad & 0 & 0 & 1 & 3 & & & 1 \\
Northern Leopard Frog & 0 & 0 & 1 & 3 & 1 & 1 & 1 \\
Common Loon & 1 & 1 & 2 & 2 & & 1 & 1 \\
Trumpeter Swan & 1 & 0 & 2 & 2 & & 1 & 1 \\
Harlequin Duck & 1 & 0 & 1 & 2 & & & 1 \\
Bald Eagle & 1 & 1 & 2 & 3 & & & 1 \\
Sage-grouse & 1 & 0 & 2 & 4 & & 1 & 1 \\
Columbian Sharp-tailed Grouse & 0 & 0 & 1 & 4 & & & 1 \\
Yellow Rail & 0 & 0 & 0 & 1 & & & 1 \\
Whooping Crane & 1 & 0 & 2 & 1 & 1 & & 1 \\
Piping Plover & 1 & 0 & 2 & 2 & & 1 & 1 \\
Mountain Plover & 0 & 0 & 2 & 2 & & & 1 \\
Long-billed Curlew & 0 & 0 & 0 & 4 & & 1 & 1 \\
Least Tern & 1 & 0 & 0 & 1 & & & 1 \\
Black Tern & 0 & 0 & 0 & 3 & & 1 & 1 \\
Flammulated Owl & 0 & 0 & 0 & 3 & & & 1 \\
Burrowing Owl & 0 & 0 & 1 & 3 & & 1 & 1 \\
Black-backed Woodpecker & 0 & 0 & 2 & 3 & & 1 & 1 \\
Olive-sided Flycatcher & 0 & 0 & 1 & 3 & & & 1 \\
Sedge Wren & 0 & 0 & 1 & 1 & & & 1 \\
Nelson's Sharp-tailed Sparrow & 0 & 0 & 1 & 1 & & & 1 \\
White Sturgeon & 0 & 0 & 1 & 1 & & 1 \\
Pallid Sturgeon & 1 & 1 & 2 & 1 & & \\
Paddlefish & 1 & 0 & 1 & 1 & & & 1 \\
Shortnose Gar & 0 & 0 & 1 & 1 & 1 & 1 & 1 \\
Yellowstone Cutthroat Trout & 1 & 1 & 2 & 2 & & 1 & 1 \\
Westslope Cutthroat Trout & 1 & 1 & 2 & 2 & 1 & 1 \\
Columbia Basin Redband Trout & 0 & 0 & 1 & 1 & & 1 \\
Bull Trout & 1 & 1 & 2 & 2 & & 1 & 1 \\
\hline
\end{tabular}


DRAFT WORKING DOCUMENT DO NOT DUPLICATE

\begin{tabular}{|c|c|c|c|c|c|c|c|}
\hline Lake Trout (native lakes) & 0 & 0 & 1 & 2 & & & 1 \\
\hline Arctic Grayling & 1 & 1 & 2 & 1 & & 1 & 1 \\
\hline Sturgeon Chub & 0 & 0 & 1 & 2 & & & 1 \\
\hline Sicklefin Chub & 0 & 0 & 1 & 1 & & & 1 \\
\hline Pearl Dace & 0 & 0 & 1 & 2 & & & 1 \\
\hline Blue Sucker & 0 & 0 & 1 & 2 & & & 1 \\
\hline Trout-perch & 0 & 0 & 1 & 2 & 1 & & 1 \\
\hline Burbot & 0 & 0 & 1 & 3 & & 1 & 1 \\
\hline Sauger & 0 & 0 & 1 & 2 & & & 1 \\
\hline Spotted Bat & 0 & 0 & 1 & 1 & & & 1 \\
\hline Townsend's Big-eared Bat & 1 & 0 & 1 & 2 & & & 1 \\
\hline Pallid Bat & 0 & 0 & 1 & 1 & & & 1 \\
\hline Pygmy Rabbit & 0 & 0 & 0 & 3 & 1 & 1 & 1 \\
\hline Hoary Marmot & 0 & 0 & 0 & 4 & & 1 & 1 \\
\hline Black-tailed Prairie Dog & 1 & 0 & 2 & 3 & & 1 & 1 \\
\hline White-tailed Prairie Dog & 1 & 0 & 2 & 1 & & & 1 \\
\hline Great Basin Pocket Mouse & 0 & 0 & 0 & 2 & 1 & & 1 \\
\hline Northern Bog Lemming & 0 & 0 & 0 & 2 & & & 1 \\
\hline Meadow Jumping Mouse & 0 & 0 & 1 & 2 & & & 1 \\
\hline Gray Wolf & 1 & 1 & 2 & 3 & & & 1 \\
\hline Grizzly Bear & 1 & 1 & 2 & 3 & & 1 & 1 \\
\hline Black-footed Ferret & 1 & 2 & 2 & 1 & & & 1 \\
\hline Lynx & 1 & 0 & 2 & 3 & & 1 & 1 \\
\hline American Bison & 1 & 0 & 2 & 2 & 1 & & 1 \\
\hline Snapping Turtle & 0 & 0 & 0 & 3 & & & 1 \\
\hline Spiny Softshell & 0 & 0 & 0 & 3 & & 1 & 1 \\
\hline Western Hognose Snake & 0 & 0 & 0 & 3 & & 1 & 1 \\
\hline Milk Snake & 0 & 0 & 0 & 2 & & & 1 \\
\hline Smooth Green Snake & 0 & 0 & 0 & 2 & & & 1 \\
\hline Western Pearlshell & 0 & 0 & 0 & 3 & & & 1 \\
\hline Long-toed Salamander & 0 & 0 & 0 & 5 & & & 2 \\
\hline Tiger Salamander & 0 & 0 & 0 & 5 & & 1 & 2 \\
\hline Tailed Frog & 0 & 0 & 1 & 4 & & & 2 \\
\hline Great Plains Toad & 0 & 0 & 1 & 3 & & & 2 \\
\hline Woodhouse's Toad & 0 & 0 & 1 & 4 & & & 2 \\
\hline Pacific Treefrog & 0 & 0 & 1 & 4 & & & 2 \\
\hline Plains Spadefoot & 0 & 0 & 1 & 3 & & & 2 \\
\hline Columbia Spotted Frog & 0 & 0 & 1 & 4 & & & 2 \\
\hline Horned Grebe & 0 & 0 & 0 & 4 & & & 2 \\
\hline Red-necked Grebe & 0 & 0 & 0 & 4 & & & 2 \\
\hline Western Grebe & 0 & 0 & 0 & 4 & & & 2 \\
\hline American Bittern & 0 & 0 & 0 & 4 & & & 2 \\
\hline Black-crowned Night-heron & 0 & 0 & 0 & 3 & & & 2 \\
\hline White-faced Ibis & 0 & 0 & 0 & 1 & & & 2 \\
\hline Canvasback & 1 & 0 & 1 & 5 & & & 2 \\
\hline Redhead & 1 & 0 & 1 & 5 & & & 2 \\
\hline
\end{tabular}


DRAFT WORKING DOCUMENT DO NOT DUPLICATE

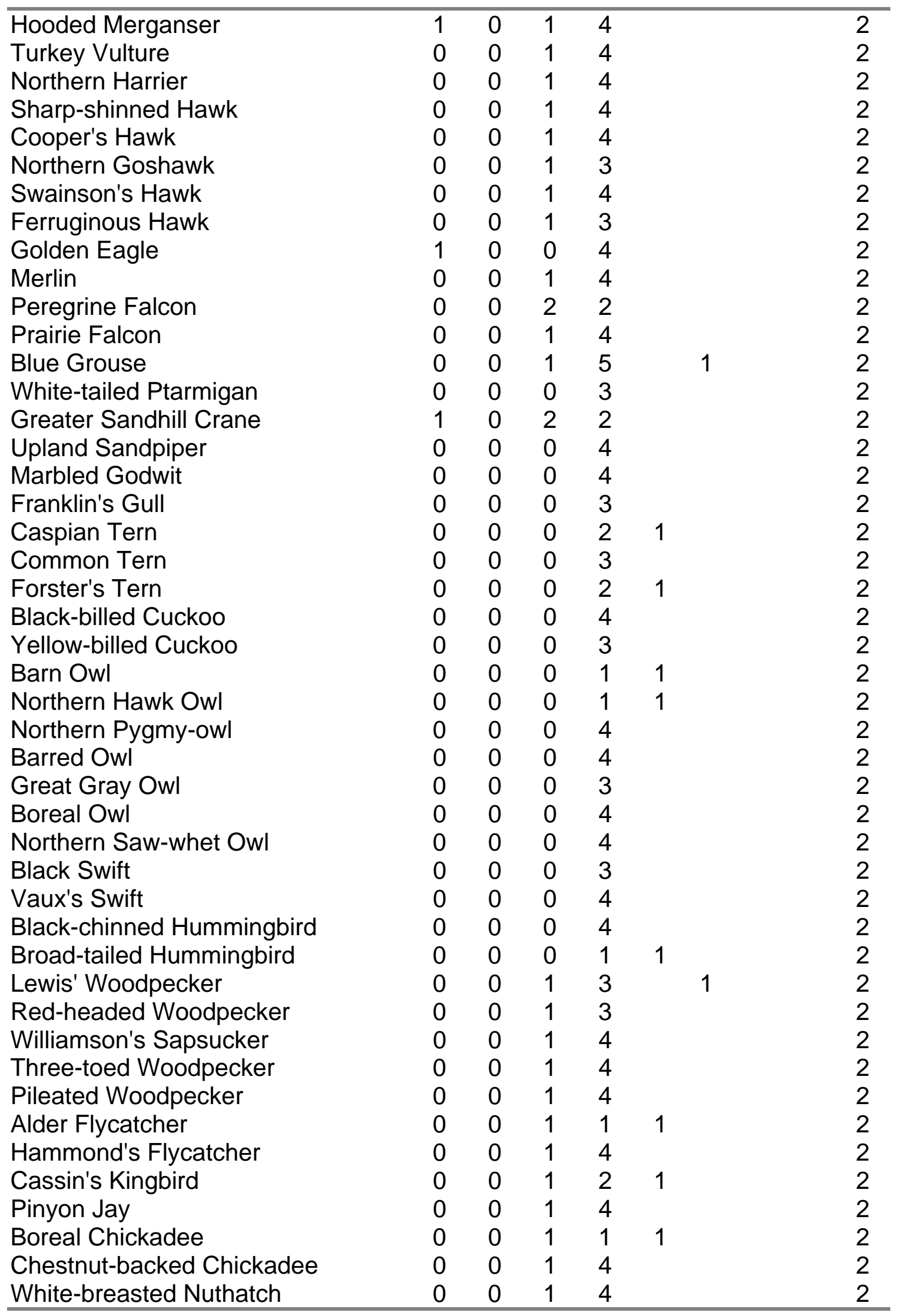


DRAFT WORKING DOCUMENT DO NOT DUPLICATE

\begin{tabular}{|c|c|c|c|c|c|c|}
\hline Pygmy Nuthatch & 0 & 0 & 1 & 4 & & 2 \\
\hline Brown Creeper & 0 & 0 & 1 & 4 & & 2 \\
\hline Canyon Wren & 0 & 0 & 1 & 4 & & 2 \\
\hline Winter Wren & 0 & 0 & 1 & 4 & & 2 \\
\hline Blue-gray Gnatcatcher & 0 & 0 & 1 & 1 & 1 & 2 \\
\hline Eastern Bluebird & 0 & 0 & 1 & 2 & 1 & 2 \\
\hline Western Bluebird & 0 & 0 & 1 & 4 & & 2 \\
\hline Veery & 0 & 0 & 1 & 4 & & 2 \\
\hline Sprague's Pipit & 0 & 0 & 1 & 3 & & 2 \\
\hline Loggerhead Shrike & 0 & 0 & 1 & 4 & & 2 \\
\hline Black-and-white Warbler & 0 & 0 & 1 & 2 & 1 & 2 \\
\hline American Redstart & 0 & 0 & 1 & 5 & 1 & 2 \\
\hline Yellow-breasted Chat & 0 & 0 & 1 & 5 & 1 & 2 \\
\hline Indigo Bunting & 0 & 0 & 1 & 2 & 1 & 2 \\
\hline Green-tailed Towhee & 0 & 0 & 1 & 4 & & 2 \\
\hline Clay-colored Sparrow & 0 & 0 & 1 & 4 & & 2 \\
\hline Brewer's Sparrow & 0 & 0 & 1 & 4 & & 2 \\
\hline Field Sparrow & 0 & 0 & 1 & 4 & & 2 \\
\hline Lark Bunting & 0 & 0 & 1 & 4 & & 2 \\
\hline Baird's Sparrow & 0 & 0 & 1 & 3 & & 2 \\
\hline Grasshopper Sparrow & 0 & 0 & 1 & 4 & & 2 \\
\hline Le Conte's Sparrow & 0 & 0 & 1 & 1 & 1 & 2 \\
\hline Mccown's Longspur & 0 & 0 & 1 & 4 & & 2 \\
\hline Dickcissel & 0 & 0 & 1 & 1 & 1 & 2 \\
\hline Baltimore Oriole & 0 & 0 & 1 & 3 & & 2 \\
\hline Bullock's Oriole & 0 & 0 & 1 & 5 & 1 & 2 \\
\hline Black Rosy-finch & 0 & 0 & 1 & 3 & & 2 \\
\hline Gray-crowned Rosy-finch & 0 & 0 & 1 & 3 & & 2 \\
\hline White-winged Crossbill & 0 & 0 & 1 & 4 & & 2 \\
\hline Torrent Sculpin & 0 & 0 & 1 & 3 & & 2 \\
\hline Spoonhead Sculpin & 0 & 0 & 1 & 3 & & 2 \\
\hline Northern Redbelly X Finescale Dace & 0 & 0 & 1 & 3 & & 2 \\
\hline Bigmouth Buffalo & 0 & 0 & 1 & 4 & 1 & 2 \\
\hline Freshwater Drum & 0 & 0 & 1 & 4 & & 2 \\
\hline Preble's Shrew & 0 & 0 & 0 & 3 & 1 & 2 \\
\hline Vagrant Shrew & 0 & 0 & 0 & 4 & & 2 \\
\hline Dwarf Shrew & 0 & 0 & 0 & 3 & & 2 \\
\hline Arctic Shrew & 0 & 0 & 0 & 1 & & 2 \\
\hline Merriam's Shrew & 0 & 0 & 0 & 3 & & 2 \\
\hline Pygmy Shrew & 0 & 0 & 0 & 3 & & 2 \\
\hline Hayden's Shrew & 0 & 0 & 0 & 4 & & 2 \\
\hline Yuma Myotis & 0 & 0 & 1 & 4 & & 2 \\
\hline Long-eared Myotis & 0 & 0 & 1 & 4 & & 2 \\
\hline Fringed Myotis & 0 & 0 & 1 & 3 & & 2 \\
\hline Long-legged Myotis & 0 & 0 & 1 & 4 & & 2 \\
\hline California Myotis & 0 & 0 & 1 & 4 & & 2 \\
\hline
\end{tabular}


DRAFT WORKING DOCUMENT DO NOT DUPLICATE

\begin{tabular}{|c|c|c|c|c|c|c|c|}
\hline Western Small-footed Myotis & 0 & 0 & 1 & 4 & & & 2 \\
\hline Northern Myotis & 0 & 0 & 1 & 4 & & & 2 \\
\hline Silver-haired Bat & 0 & 0 & 1 & 4 & & & 2 \\
\hline Big Brown Bat & 0 & 0 & 1 & 4 & & & 2 \\
\hline Eastern Red Bat & 0 & 0 & 1 & 4 & & & 2 \\
\hline Hoary Bat & 0 & 0 & 1 & 4 & & & 2 \\
\hline Eastern Cottontail & 0 & 0 & 0 & 4 & & & 2 \\
\hline Mountain Cottontail & 0 & 0 & 0 & 4 & & & 2 \\
\hline White-tailed Jackrabbit & 0 & 0 & 0 & 4 & & & 2 \\
\hline Black-tailed Jackrabbit & 0 & 0 & 0 & 2 & & & 2 \\
\hline Uinta Chipmunk & 0 & 0 & 0 & 3 & & & 2 \\
\hline Uinta Ground Squirrel & 0 & 0 & 0 & 4 & & & 2 \\
\hline Wyoming Ground Squirrel & 0 & 0 & 0 & 3 & & & 2 \\
\hline Northern Flying Squirrel & 0 & 0 & 0 & 4 & & & 2 \\
\hline Idaho Pocket Gopher & 0 & 0 & 0 & 3 & & & 2 \\
\hline Olive-backed Pocket Mouse & 0 & 0 & 0 & 4 & & & 2 \\
\hline Ord's Kangaroo Rat & 0 & 0 & 0 & 4 & & & 2 \\
\hline Hispid Pocket Mouse & 0 & 0 & 0 & 1 & 1 & 1 & 2 \\
\hline White-footed Mouse & 0 & 0 & 0 & 4 & & & 2 \\
\hline Water Vole & 0 & 0 & 0 & 4 & & & 2 \\
\hline Sagebrush Vole & 0 & 0 & 0 & 4 & & & 2 \\
\hline Swift Fox & 1 & 0 & 2 & 3 & & & 2 \\
\hline American Marten & 0 & 0 & 1 & 4 & 1 & & 2 \\
\hline Fisher & 0 & 0 & 1 & 3 & & & 2 \\
\hline Least Weasel & 0 & 0 & 1 & 4 & & & 2 \\
\hline Wolverine & 0 & 0 & 2 & 2 & 1 & & 2 \\
\hline American Badger & 0 & 0 & 1 & 4 & & & 2 \\
\hline Western Spotted Skunk & 0 & 0 & 1 & 1 & & & 2 \\
\hline Northern River Otter & 0 & 0 & 1 & 4 & & & 2 \\
\hline Northern Alligator Lizard & 0 & 0 & 0 & 3 & & & 2 \\
\hline Short-horned Lizard & 0 & 0 & 0 & 3 & & & 2 \\
\hline Sagebrush Lizard & 0 & 0 & 0 & 3 & & & 2 \\
\hline Western Skink & 0 & 0 & 0 & 3 & & & 2 \\
\hline Rubber Boa & 0 & 0 & 0 & 4 & & & 2 \\
\hline Common Garter Snake & 0 & 0 & 0 & 4 & & & 2 \\
\hline Western Rattlesnake & 0 & 0 & 0 & 4 & & & 2 \\
\hline Black Sandshell & 0 & 0 & 0 & 5 & & & 2 \\
\hline Boreal Chorus Frog & 0 & 0 & 1 & 5 & & & 3 \\
\hline Great Basin Spadefoot & 0 & 0 & 1 & 5 & & & 3 \\
\hline Pied-billed Grebe & 0 & 0 & 0 & 5 & & & 3 \\
\hline Eared Grebe & 0 & 0 & 0 & 5 & & & 3 \\
\hline Clark's Grebe & 0 & 0 & 0 & 5 & & & 3 \\
\hline American White Pelican & 0 & 0 & 1 & 3 & & & 3 \\
\hline Double-crested Cormorant & 0 & 0 & 0 & 5 & & & 3 \\
\hline Great Blue Heron & 0 & 0 & 0 & 5 & & & 3 \\
\hline Snowy Egret & 0 & 0 & 0 & 5 & & & 3 \\
\hline
\end{tabular}




\begin{tabular}{|c|c|c|c|c|c|}
\hline Cattle Egret & 0 & 0 & 0 & 5 & 3 \\
\hline Tundra Swan & 0 & 0 & 1 & 5 & 3 \\
\hline Greater White-fronted Goose & 0 & 0 & 1 & 5 & 3 \\
\hline Snow Goose & 1 & 0 & 1 & 4 & 3 \\
\hline Ross' Goose & 1 & 0 & 1 & 4 & 3 \\
\hline Canada Goose & 0 & 0 & 1 & 5 & 3 \\
\hline Wood Duck & 1 & 0 & 1 & 5 & 3 \\
\hline Green-winged Teal & 1 & 0 & 1 & 5 & 3 \\
\hline American Black Duck & 1 & 0 & 1 & 5 & 3 \\
\hline Mallard & 1 & 0 & 1 & 5 & 3 \\
\hline Northern Pintail & 1 & 0 & 1 & 5 & 3 \\
\hline Blue-winged Teal & 1 & 0 & 1 & 5 & 3 \\
\hline Cinnamon Teal & 1 & 0 & 1 & 5 & 3 \\
\hline Northern Shoveler & 1 & 0 & 1 & 5 & 3 \\
\hline Gadwall & 1 & 0 & 1 & 5 & 3 \\
\hline American Wigeon & 1 & 0 & 1 & 5 & 3 \\
\hline Ring-necked Duck & 1 & 0 & 1 & 5 & 3 \\
\hline Greater Scaup & 1 & 0 & 1 & 5 & 3 \\
\hline Lesser Scaup & 1 & 0 & 1 & 5 & 3 \\
\hline Long Tailed Duck & 1 & 0 & 1 & 5 & 3 \\
\hline White-winged Scoter & 1 & 0 & 1 & 5 & 3 \\
\hline Common Goldeneye & 1 & 0 & 1 & 5 & 3 \\
\hline Barrow's Goldeneye & 1 & 0 & 1 & 5 & 3 \\
\hline Bufflehead & 1 & 0 & 1 & 5 & 3 \\
\hline Common Merganser & 1 & 0 & 1 & 5 & 3 \\
\hline Red-breasted Merganser & 1 & 0 & 1 & 5 & 3 \\
\hline Ruddy Duck & 1 & 0 & 1 & 5 & 3 \\
\hline Osprey & 0 & 0 & 1 & 5 & 3 \\
\hline Red-tailed Hawk & 0 & 0 & 1 & 5 & 3 \\
\hline Rough-legged Hawk & 0 & 0 & 1 & 5 & 3 \\
\hline American Kestrel & 0 & 0 & 1 & 5 & 3 \\
\hline Gyrfalcon & 0 & 0 & 1 & 5 & 3 \\
\hline Spruce Grouse & 0 & 0 & 1 & 4 & 3 \\
\hline Ruffed Grouse & 0 & 0 & 1 & 5 & 3 \\
\hline Sharp-tailed Grouse & 0 & 0 & 1 & 4 & 3 \\
\hline Virginia Rail & 0 & 0 & 0 & 5 & 3 \\
\hline Sora & 0 & 0 & 0 & 5 & 3 \\
\hline American Coot & 0 & 0 & 0 & 5 & 3 \\
\hline Lesser Sandhill Crane & 1 & 0 & 2 & 2 & 3 \\
\hline Killdeer & 0 & 0 & 0 & 5 & 3 \\
\hline Black-necked Stilt & 0 & 0 & 0 & 5 & 3 \\
\hline American Avocet & 0 & 0 & 0 & 5 & 3 \\
\hline Greater Yellowlegs & 0 & 0 & 0 & 5 & 3 \\
\hline Lesser Yellowlegs & 0 & 0 & 0 & 5 & 3 \\
\hline Solitary Sandpiper & 0 & 0 & 0 & 5 & 3 \\
\hline Willet & 0 & 0 & 0 & 5 & 3 \\
\hline
\end{tabular}




\begin{tabular}{|c|c|c|c|c|c|c|}
\hline Spotted Sandpiper & 0 & 0 & 0 & 5 & & 3 \\
\hline Semipalmated Sandpiper & 0 & 0 & 0 & 5 & & 3 \\
\hline Western Sandpiper & 0 & 0 & 0 & 5 & & 3 \\
\hline Least Sandpiper & 0 & 0 & 0 & 5 & & 3 \\
\hline White-rumped Sandpiper & 0 & 0 & 0 & 5 & & 3 \\
\hline Baird's Sandpiper & 0 & 0 & 0 & 5 & & 3 \\
\hline Pectoral Sandpiper & 0 & 0 & 0 & 5 & & 3 \\
\hline Dunlin & 0 & 0 & 0 & 5 & & 3 \\
\hline Long-billed Dowitcher & 0 & 0 & 0 & 5 & & 3 \\
\hline Common Snipe & 0 & 0 & 0 & 5 & & 3 \\
\hline Wilson's Phalarope & 0 & 0 & 0 & 5 & & 3 \\
\hline Red-necked Phalarope & 0 & 0 & 0 & 5 & 1 & 3 \\
\hline Ring-billed Gull & 0 & 0 & 0 & 5 & & 3 \\
\hline California Gull & 0 & 0 & 0 & 5 & & 3 \\
\hline Herring Gull & 0 & 0 & 0 & 5 & & 3 \\
\hline Glaucous-winged Gull & 0 & 0 & 0 & 5 & & 3 \\
\hline Glaucous Gull & 0 & 0 & 0 & 5 & & 3 \\
\hline Arctic Tern & 0 & 0 & 0 & 5 & & 3 \\
\hline Mourning Dove & 0 & 0 & 0 & 5 & & 3 \\
\hline Eastern Screech-owl & 0 & 0 & 0 & 5 & & 3 \\
\hline Western Screech-owl & 0 & 0 & 0 & 5 & & 3 \\
\hline Great Horned Owl & 0 & 0 & 0 & 5 & & 3 \\
\hline Snowy Owl & 0 & 0 & 0 & 5 & & 3 \\
\hline Long-eared Owl & 0 & 0 & 0 & 5 & & 3 \\
\hline Short-eared Owl & 0 & 0 & 0 & 5 & & 3 \\
\hline Common Nighthawk & 0 & 0 & 0 & 5 & & 3 \\
\hline Common Poorwill & 0 & 0 & 0 & 5 & & 3 \\
\hline Chimney Swift & 0 & 0 & 0 & 5 & & 3 \\
\hline White-throated Swift & 0 & 0 & 0 & 5 & & 3 \\
\hline Calliope Hummingbird & 0 & 0 & 0 & 5 & & 3 \\
\hline Rufous Hummingbird & 0 & 0 & 0 & 5 & & 3 \\
\hline Belted Kingfisher & 0 & 0 & 0 & 5 & & 3 \\
\hline Red-naped Sapsucker & 0 & 0 & 1 & 5 & & 3 \\
\hline Downy Woodpecker & 0 & 0 & 1 & 5 & & 3 \\
\hline Hairy Woodpecker & 0 & 0 & 1 & 5 & & 3 \\
\hline Northern Flicker & 0 & 0 & 1 & 5 & & 3 \\
\hline Western Wood-pewee & 0 & 0 & 1 & 5 & & 3 \\
\hline Willow Flycatcher & 0 & 0 & 1 & 5 & & 3 \\
\hline Least Flycatcher & 0 & 0 & 1 & 5 & & 3 \\
\hline Dusky Flycatcher & 0 & 0 & 1 & 5 & & 3 \\
\hline Cordilleran Flycatcher & 0 & 0 & 1 & 5 & & 3 \\
\hline Say's Phoebe & 0 & 0 & 1 & 5 & & 3 \\
\hline Western Kingbird & 0 & 0 & 1 & 5 & & 3 \\
\hline Eastern Kingbird & 0 & 0 & 1 & 5 & & 3 \\
\hline Horned Lark & 0 & 0 & 1 & 5 & & 3 \\
\hline Purple Martin & 0 & 0 & 1 & 5 & & 3 \\
\hline
\end{tabular}




\begin{tabular}{|c|c|c|c|c|c|}
\hline Tree Swallow & 0 & 0 & 1 & 5 & 3 \\
\hline Violet-green Swallow & 0 & 0 & 1 & 5 & 3 \\
\hline Northern Rough-winged Swallow & 0 & 0 & 1 & 5 & 3 \\
\hline Bank Swallow & 0 & 0 & 1 & 5 & 3 \\
\hline Cliff Swallow & 0 & 0 & 1 & 5 & 3 \\
\hline Barn Swallow & 0 & 0 & 1 & 5 & 3 \\
\hline Gray Jay & 0 & 0 & 1 & 5 & 3 \\
\hline Steller's Jay & 0 & 0 & 1 & 5 & 3 \\
\hline Blue Jay & 0 & 0 & 1 & 5 & 3 \\
\hline Clark's Nutcracker & 0 & 0 & 1 & 5 & 3 \\
\hline Black-billed Magpie & 0 & 0 & 1 & 5 & 3 \\
\hline American Crow & 0 & 0 & 1 & 5 & 3 \\
\hline Common Raven & 0 & 0 & 1 & 5 & 3 \\
\hline Black-capped Chickadee & 0 & 0 & 1 & 5 & 3 \\
\hline Mountain Chickadee & 0 & 0 & 1 & 5 & 3 \\
\hline Red-breasted Nuthatch & 0 & 0 & 1 & 5 & 3 \\
\hline Rock Wren & 0 & 0 & 1 & 5 & 3 \\
\hline House Wren & 0 & 0 & 1 & 5 & 3 \\
\hline Marsh Wren & 0 & 0 & 1 & 5 & 3 \\
\hline American Dipper & 0 & 0 & 1 & 5 & 3 \\
\hline Golden-crowned Kinglet & 0 & 0 & 1 & 5 & 3 \\
\hline Ruby-crowned Kinglet & 0 & 0 & 1 & 5 & 3 \\
\hline Mountain Bluebird & 0 & 0 & 1 & 5 & 3 \\
\hline Townsend's Solitaire & 0 & 0 & 1 & 5 & 3 \\
\hline Swainson's Thrush & 0 & 0 & 1 & 5 & 3 \\
\hline Hermit Thrush & 0 & 0 & 1 & 5 & 3 \\
\hline American Robin & 0 & 0 & 1 & 5 & 3 \\
\hline Varied Thrush & 0 & 0 & 1 & 5 & 3 \\
\hline Gray Catbird & 0 & 0 & 1 & 5 & 3 \\
\hline Northern Mockingbird & 0 & 0 & 1 & 5 & 3 \\
\hline Sage Thrasher & 0 & 0 & 1 & 5 & 3 \\
\hline Brown Thrasher & 0 & 0 & 1 & 5 & 3 \\
\hline American Pipit & 0 & 0 & 1 & 5 & 3 \\
\hline Bohemian Waxwing & 0 & 0 & 1 & 5 & 3 \\
\hline Cedar Waxwing & 0 & 0 & 1 & 5 & 3 \\
\hline Northern Shrike & 0 & 0 & 1 & 5 & 3 \\
\hline Warbling Vireo & 0 & 0 & 1 & 5 & 3 \\
\hline Red-eyed Vireo & 0 & 0 & 1 & 5 & 3 \\
\hline Cassin's Vireo & 0 & 0 & 1 & 5 & 3 \\
\hline Tennessee Warbler & 0 & 0 & 1 & 5 & 3 \\
\hline Orange-crowned Warbler & 0 & 0 & 1 & 5 & 3 \\
\hline Nashville Warbler & 0 & 0 & 1 & 5 & 3 \\
\hline Yellow Warbler & 0 & 0 & 1 & 5 & 3 \\
\hline Black-throated Blue Warbler & 0 & 0 & 1 & 5 & 3 \\
\hline Yellow-rumped Warbler & 0 & 0 & 1 & 5 & 3 \\
\hline Black-throated Gray Warbler & 0 & 0 & 1 & 5 & 3 \\
\hline
\end{tabular}




\begin{tabular}{|c|c|c|c|c|c|}
\hline Townsend's Warbler & 0 & 0 & 1 & 5 & 3 \\
\hline Ovenbird & 0 & 0 & 1 & 5 & 3 \\
\hline Northern Waterthrush & 0 & 0 & 1 & 5 & 3 \\
\hline Macgillivray's Warbler & 0 & 0 & 1 & 5 & 3 \\
\hline Common Yellowthroat & 0 & 0 & 1 & 5 & 3 \\
\hline Wilson's Warbler & 0 & 0 & 1 & 5 & 3 \\
\hline Western Tanager & 0 & 0 & 1 & 5 & 3 \\
\hline Black-headed Grosbeak & 0 & 0 & 1 & 5 & 3 \\
\hline Lazuli Bunting & 0 & 0 & 1 & 5 & 3 \\
\hline Spotted Towhee & 0 & 0 & 1 & 5 & 3 \\
\hline American Tree Sparrow & 0 & 0 & 1 & 5 & 3 \\
\hline Chipping Sparrow & 0 & 0 & 1 & 5 & 3 \\
\hline Vesper Sparrow & 0 & 0 & 1 & 5 & 3 \\
\hline Lark Sparrow & 0 & 0 & 1 & 5 & 3 \\
\hline Sage Sparrow & 0 & 0 & 1 & 5 & 3 \\
\hline Savannah Sparrow & 0 & 0 & 1 & 5 & 3 \\
\hline Fox Sparrow & 0 & 0 & 1 & 5 & 3 \\
\hline Song Sparrow & 0 & 0 & 1 & 5 & 3 \\
\hline Lincoln's Sparrow & 0 & 0 & 1 & 5 & 3 \\
\hline Swamp Sparrow & 0 & 0 & 1 & 5 & 3 \\
\hline White-throated Sparrow & 0 & 0 & 1 & 5 & 3 \\
\hline White-crowned Sparrow & 0 & 0 & 1 & 5 & 3 \\
\hline Harris' Sparrow & 0 & 0 & 1 & 5 & 3 \\
\hline Dark-eyed Junco & 0 & 0 & 1 & 5 & 3 \\
\hline Lapland Longspur & 0 & 0 & 1 & 5 & 3 \\
\hline Chestnut-collared Longspur & 0 & 0 & 1 & 5 & 3 \\
\hline Snow Bunting & 0 & 0 & 1 & 5 & 3 \\
\hline Bobolink & 0 & 0 & 1 & 5 & 3 \\
\hline Red-winged Blackbird & 0 & 0 & 1 & 5 & 3 \\
\hline Western Meadowlark & 0 & 0 & 1 & 5 & 3 \\
\hline Yellow-headed Blackbird & 0 & 0 & 1 & 5 & 3 \\
\hline Rusty Blackbird & 0 & 0 & 1 & 5 & 3 \\
\hline Brewer's Blackbird & 0 & 0 & 1 & 5 & 3 \\
\hline Common Grackle & 0 & 0 & 1 & 5 & 3 \\
\hline Brown-headed Cowbird & 0 & 0 & 1 & 5 & 3 \\
\hline Orchard Oriole & 0 & 0 & 1 & 5 & 3 \\
\hline Pine Grosbeak & 0 & 0 & 1 & 5 & 3 \\
\hline Purple Finch & 0 & 0 & 1 & 5 & 3 \\
\hline Cassin's Finch & 0 & 0 & 1 & 5 & 3 \\
\hline House Finch & 0 & 0 & 1 & 5 & 3 \\
\hline Red Crossbill & 0 & 0 & 1 & 5 & 3 \\
\hline Common Redpoll & 0 & 0 & 1 & 5 & 3 \\
\hline Hoary Redpoll & 0 & 0 & 1 & 5 & 3 \\
\hline Pine Siskin & 0 & 0 & 1 & 5 & 3 \\
\hline American Goldfinch & 0 & 0 & 1 & 5 & 3 \\
\hline Evening Grosbeak & 0 & 0 & 1 & 5 & 3 \\
\hline
\end{tabular}




\begin{tabular}{|c|c|c|c|c|c|c|}
\hline Mottled Sculpin & 0 & 0 & 1 & 5 & & 3 \\
\hline Slimy Sculpin & 0 & 0 & 1 & 5 & & 3 \\
\hline Shovelnose Sturgeon & 0 & 0 & 1 & 4 & & 3 \\
\hline Goldeye & 0 & 0 & 1 & 5 & & 3 \\
\hline Lake Whitefish & 0 & 0 & 1 & 4 & & 3 \\
\hline Pygmy Whitefish & 0 & 0 & 1 & 5 & & 3 \\
\hline Mountain Whitefish & 0 & 0 & 1 & 5 & & 3 \\
\hline Lake Chub & 0 & 0 & 1 & 5 & & 3 \\
\hline Western Silvery Minnow & 0 & 0 & 1 & 4 & & 3 \\
\hline Brassy Minnow & 0 & 0 & 1 & 5 & & 3 \\
\hline Plains Minnow & 0 & 0 & 1 & 5 & 1 & 3 \\
\hline Peamouth & 0 & 0 & & 5 & & 3 \\
\hline Emerald Shiner & 0 & 0 & 1 & 5 & & 3 \\
\hline Sand Shiner & 0 & 0 & 1 & 4 & & 3 \\
\hline Northern Redbelly Dace & 0 & 0 & 1 & 5 & 1 & 3 \\
\hline Fathead Minnow & 0 & 0 & 1 & 4 & & 3 \\
\hline Northern Pikeminnow & 0 & 0 & 1 & 5 & & 3 \\
\hline Longnose Dace & 0 & 0 & 1 & 5 & & 3 \\
\hline Redside Shiner & 0 & 0 & 1 & 5 & & 3 \\
\hline Creek Chub & 0 & 0 & 1 & 5 & & 3 \\
\hline Flathead Chub & 0 & 0 & 1 & 5 & & 3 \\
\hline River Carpsucker & 0 & 0 & 1 & 5 & & 3 \\
\hline Longnose Sucker & 0 & 0 & 1 & 5 & & 3 \\
\hline White Sucker & 0 & 0 & 1 & 5 & & 3 \\
\hline Largescale Sucker & 0 & 0 & 1 & 5 & & 3 \\
\hline Mountain Sucker & 0 & 0 & 1 & 5 & 1 & 3 \\
\hline Smallmouth Buffalo & 0 & 0 & 1 & 5 & 1 & 3 \\
\hline Shorthead Redhorse & 0 & 0 & 1 & 5 & & 3 \\
\hline Channel Catfish & 0 & 0 & 1 & 5 & & 3 \\
\hline Stonecat & 0 & 0 & 1 & 5 & & 3 \\
\hline Brook Stickleback & 0 & 0 & 1 & 5 & & 3 \\
\hline lowa Darter & 0 & 0 & 1 & 5 & & 3 \\
\hline Masked Shrew & 0 & 0 & 0 & 5 & & 3 \\
\hline Dusky Or Montane Shrew & 0 & 0 & 0 & 5 & & 3 \\
\hline Water Shrew & 0 & 0 & 0 & 5 & & 3 \\
\hline Little Brown Myotis & 0 & 0 & 1 & 5 & & 3 \\
\hline American Pika & 0 & 0 & 0 & 5 & & 3 \\
\hline Desert Cottontail & 0 & 0 & 0 & 5 & & 3 \\
\hline Snowshoe Hare & 0 & 0 & 0 & 5 & & 3 \\
\hline Least Chipmunk & 0 & 0 & 0 & 5 & & 3 \\
\hline Yellow-pine Chipmunk & 0 & 0 & 0 & 5 & & 3 \\
\hline Red-tailed Chipmunk & 0 & 0 & 0 & 5 & & 3 \\
\hline Yellow-bellied Marmot & 0 & 0 & 0 & 5 & & 3 \\
\hline Richardson's Ground Squirrel & 0 & 0 & 0 & 5 & & 3 \\
\hline Columbian Ground Squirrel & 0 & 0 & 0 & 5 & & 3 \\
\hline Thirteen-lined Ground Squirrel & 0 & 0 & 0 & 5 & & 3 \\
\hline
\end{tabular}




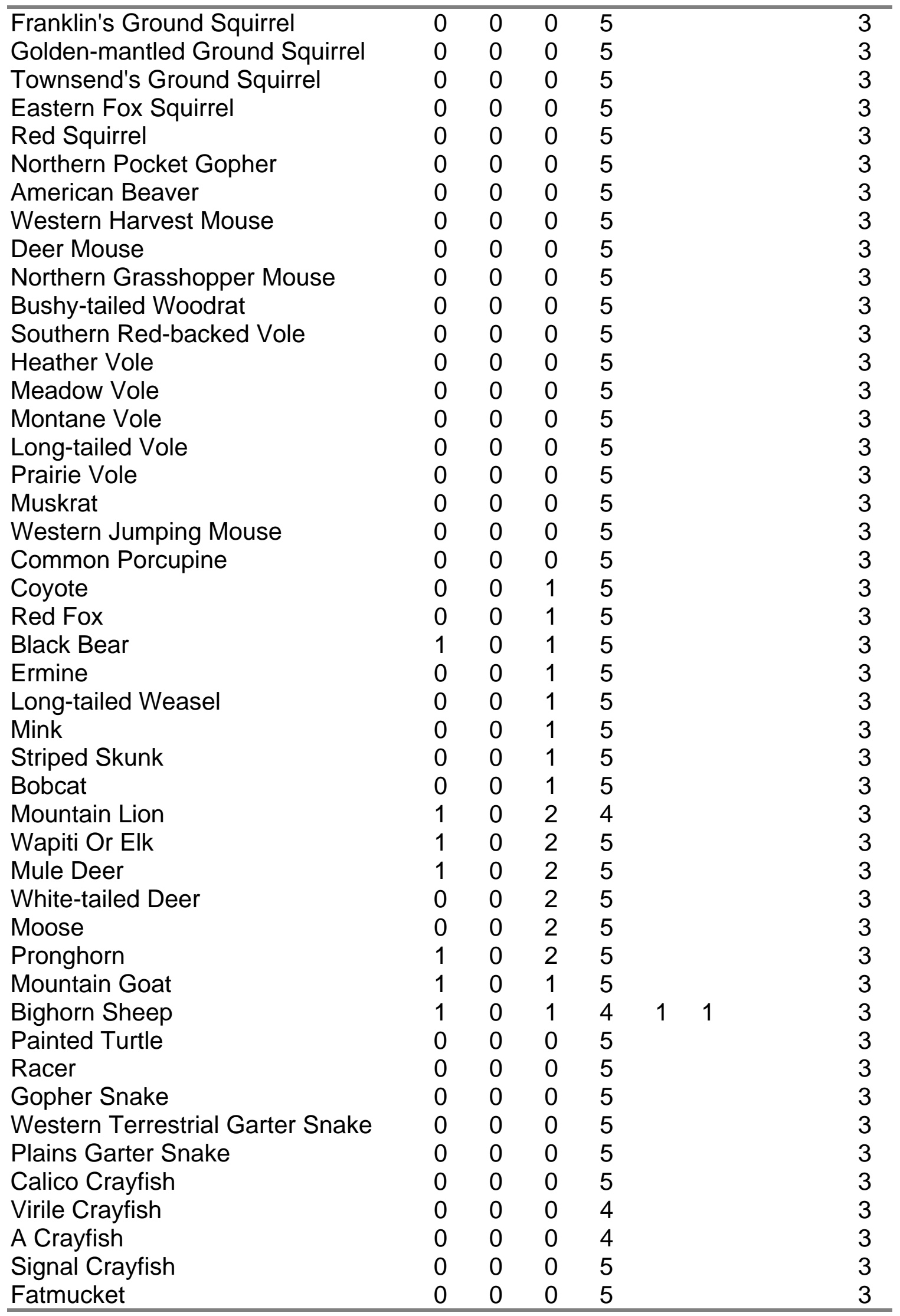




\begin{tabular}{llllllll}
\hline Giant Floater & 0 & 0 & 0 & 5 & & & 3 \\
Roughskin Newt & 0 & 0 & 0 & 5 & & 1 & 4 \\
Idaho Giant Salamander & 0 & 0 & 0 & 5 & 1 & & 4 \\
Canadian Toad & 0 & 0 & 1 & 5 & 1 & & 4 \\
Bullfrog & 0 & 0 & 1 & 5 & & 1 & 4 \\
Wood Frog & 0 & 0 & 1 & 5 & & & 4 \\
Red-throated Loon & 0 & 0 & 0 & 5 & 1 & & 4 \\
Pacific Loon & 0 & 0 & 0 & 5 & 1 & 4 \\
Yellow-billed Loon & 0 & 0 & 0 & 5 & 1 & 4 \\
Least Bittern & 0 & 0 & 0 & 5 & 1 & 4 \\
Great Egret & 0 & 0 & 0 & 5 & 1 & 4 \\
Little Blue Heron & 0 & 0 & 0 & 5 & 1 & 4 \\
Green Heron & 0 & 0 & 0 & 5 & 1 & & 4 \\
Yellow-crowned Night-heron & 0 & 0 & 0 & 5 & 1 & 4 \\
Wood Stork & 0 & 0 & 0 & 5 & 1 & & 4 \\
Mute Swan & 0 & 0 & 1 & 5 & & 1 & 4 \\
Brant & 0 & 0 & 1 & 5 & 1 & & 4 \\
Garganey & 0 & 0 & 1 & 5 & 1 & & 4 \\
Eurasian Wigeon & 0 & 0 & 1 & 5 & 1 & & 4 \\
Black Scoter & 0 & 0 & 1 & 5 & 1 & & 4 \\
Surf Scoter & 0 & 0 & 1 & 5 & 1 & & 4 \\
Red-shouldered Hawk & 0 & 0 & 1 & 5 & 1 & & 4 \\
Broad-winged Hawk & 0 & 0 & 1 & 5 & 1 & & 4 \\
Gray Partridge & 0 & 0 & 1 & 5 & & 1 & 4 \\
Chukar & 0 & 0 & 1 & 5 & & 1 & 4 \\
Ring-necked Pheasant & 0 & 0 & 1 & 5 & & 1 & 4 \\
Willow Ptarmigan & 0 & 0 & 0 & 5 & 1 & & 4 \\
Wild Turkey & 0 & 0 & 1 & 5 & & 1 & 4 \\
Common Moorhen & 0 & 0 & 0 & 5 & 1 & 4 \\
Black-bellied Plover & 0 & 0 & 0 & 5 & 1 & 4 \\
American Golden-plover & 0 & 0 & 0 & 5 & 1 & 4 \\
Snowy Plover & 0 & 0 & 0 & 5 & 1 & 4 \\
Semipalmated Plover & 0 & 0 & 0 & 5 & 1 & 4 \\
Whimbrel & 0 & 0 & 0 & 5 & 1 & 4 \\
Hudsonian Godwit & 0 & 0 & 0 & 5 & 1 & 4 \\
Ruddy Turnstone & 0 & 0 & 0 & 5 & 1 & 4 \\
Black Turnstone & 0 & 0 & 0 & 5 & 1 & 4 \\
Red Knot & 0 & 0 & 0 & 5 & 1 & 4 \\
Sanderling & 0 & 0 & 0 & 5 & 1 & 4 \\
Curlew Sandpiper & 0 & 0 & 0 & 5 & 1 & & 4 \\
Stilt Sandpiper & 0 & 0 & 0 & 5 & 1 & & 4 \\
Buff-breasted Sandpiper & 0 & 0 & 0 & 5 & 1 & 4 \\
Short-billed Dowitcher & 0 & 0 & 0 & 5 & 1 & 4 \\
American Woodcock & 0 & 0 & 0 & 5 & 1 & 4 \\
Red Phalarope & 0 & 0 & 0 & 5 & 5 & 1 & 4 \\
Pomarine Jaeger & & & & & & & 4 \\
\hline
\end{tabular}




\begin{tabular}{|c|c|c|c|c|c|c|c|}
\hline Parasitic Jaeger & 0 & 0 & 0 & 5 & 1 & & 4 \\
\hline Long-tailed Jaeger & 0 & 0 & 0 & 5 & 1 & & 4 \\
\hline Laughing Gull & 0 & 0 & 0 & 5 & 1 & & 4 \\
\hline Bonaparte's Gull & 0 & 0 & 0 & 5 & 1 & & 4 \\
\hline Mew Gull & 0 & 0 & 0 & 5 & 1 & & 4 \\
\hline Thayer's Gull & 0 & 0 & 0 & 5 & 1 & & 4 \\
\hline Great Black-backed Gull & 0 & 0 & 0 & 5 & 1 & & 4 \\
\hline Black-legged Kittiwake & 0 & 0 & 0 & 5 & 1 & & 4 \\
\hline Sabine's Gull & 0 & 0 & 0 & 5 & 1 & & 4 \\
\hline Ivory Gull & 0 & 0 & 0 & 5 & 1 & & 4 \\
\hline Marbled Murrelet & 0 & 0 & 0 & 5 & 1 & & 4 \\
\hline Ancient Murrelet & 0 & 0 & 0 & 5 & 1 & & 4 \\
\hline Rock Dove & 0 & 0 & 0 & 5 & & 1 & 4 \\
\hline Band-tailed Pigeon & 0 & 0 & 0 & 5 & 1 & & 4 \\
\hline Eurasian Collared-dove & 0 & 0 & 0 & 5 & 1 & & 4 \\
\hline White-winged Dove & 0 & 0 & 0 & 5 & 1 & & 4 \\
\hline Whip-poor-will & 0 & 0 & 0 & 5 & 1 & & 4 \\
\hline Anna's Hummingbird & 0 & 0 & 0 & 5 & 1 & & 4 \\
\hline Ruby-throated Hummingbird & 0 & 0 & 0 & 5 & 1 & & 4 \\
\hline Red-bellied Woodpecker & 0 & 0 & 1 & 5 & 1 & & 4 \\
\hline Yellow-bellied Sapsucker & 0 & 0 & 1 & 5 & 1 & & 4 \\
\hline White-headed Woodpecker & 0 & 0 & 1 & 5 & 1 & & 4 \\
\hline Eastern Wood-pewee & 0 & 0 & 1 & 5 & 1 & & 4 \\
\hline Yellow-bellied Flycatcher & 0 & 0 & 1 & 5 & 1 & & 4 \\
\hline Eastern Phoebe & 0 & 0 & 1 & 5 & 1 & & 4 \\
\hline Ash-throated Flycatcher & 0 & 0 & 1 & 5 & 1 & & 4 \\
\hline Great Crested Flycatcher & 0 & 0 & 1 & 5 & 1 & & 4 \\
\hline Scissor-tailed Flycatcher & 0 & 0 & 1 & 5 & 1 & & 4 \\
\hline Bewick's Wren & 0 & 0 & 1 & 5 & 1 & & 4 \\
\hline Gray-cheeked Thrush & 0 & 0 & 1 & 5 & 1 & & 4 \\
\hline Wood Thrush & 0 & 0 & 1 & 5 & 1 & & 4 \\
\hline European Starling & 0 & 0 & 1 & 5 & & 1 & 4 \\
\hline Philadelphia Vireo & 0 & 0 & 1 & 5 & 1 & & 4 \\
\hline Golden-winged Warbler & 0 & 0 & 1 & 5 & 1 & & 4 \\
\hline Northern Parula & 0 & 0 & 1 & 5 & 1 & & 4 \\
\hline Chestnut-sided Warbler & 0 & 0 & 1 & 5 & 1 & & 4 \\
\hline Magnolia Warbler & 0 & 0 & 1 & 5 & 1 & & 4 \\
\hline Cape May Warbler & 0 & 0 & 1 & 5 & 1 & & 4 \\
\hline Black-throated Green Warbler & 0 & 0 & 1 & 5 & 1 & & 4 \\
\hline Blackburnian Warbler & 0 & 0 & 1 & 5 & 1 & & 4 \\
\hline Yellow-throated Warbler & 0 & 0 & 1 & 5 & 1 & & 4 \\
\hline Pine Warbler & 0 & 0 & 1 & 5 & 1 & & 4 \\
\hline Prairie Warbler & 0 & 0 & 1 & 5 & 1 & & 4 \\
\hline Palm Warbler & 0 & 0 & 1 & 5 & 1 & & 4 \\
\hline Bay-breasted Warbler & 0 & 0 & 1 & 5 & 1 & & 4 \\
\hline Blackpoll Warbler & 0 & 0 & 1 & 5 & 1 & & 4 \\
\hline
\end{tabular}




\begin{tabular}{|c|c|c|c|c|c|c|c|}
\hline Prothonotary Warbler & 0 & 0 & 1 & 5 & 1 & & 4 \\
\hline Kentucky Warbler & 0 & 0 & 1 & 5 & 1 & & 4 \\
\hline Connecticut Warbler & 0 & 0 & 1 & 5 & 1 & & 4 \\
\hline Mourning Warbler & 0 & 0 & 1 & 5 & 1 & & 4 \\
\hline Hooded Warbler & 0 & 0 & 1 & 5 & 1 & & 4 \\
\hline Canada Warbler & 0 & 0 & 1 & 5 & 1 & & 4 \\
\hline Painted Redstart & 0 & 0 & 1 & 5 & 1 & & 4 \\
\hline Summer Tanager & 0 & 0 & 1 & 5 & 1 & & 4 \\
\hline Scarlet Tanager & 0 & 0 & 1 & 5 & 1 & & 4 \\
\hline Northern Cardinal & 0 & 0 & 1 & 5 & 1 & & 4 \\
\hline Brambling & 0 & 0 & 1 & 5 & & & 4 \\
\hline Rose-breasted Grosbeak & 0 & 0 & 1 & 5 & 1 & & 4 \\
\hline Painted Bunting & 0 & 0 & 1 & 5 & 1 & & 4 \\
\hline Black-throated Sparrow & 0 & 0 & 1 & 5 & 1 & & 4 \\
\hline Golden-crowned Sparrow & 0 & 0 & 1 & 5 & 1 & & 4 \\
\hline Smith's Longspur & 0 & 0 & 1 & 5 & 1 & & 4 \\
\hline Great-tailed Grackle & 0 & 0 & 1 & 5 & 1 & & 4 \\
\hline Hooded Oriole & 0 & 0 & 1 & 5 & 1 & & 4 \\
\hline Lesser Goldfinch & 0 & 0 & 1 & 5 & 1 & & 4 \\
\hline House Sparrow & 0 & 0 & 1 & 5 & & 1 & 4 \\
\hline Cisco & 0 & 0 & 1 & 5 & & 1 & 4 \\
\hline Kokanee Salmon & 0 & 0 & 1 & 5 & & 1 & 4 \\
\hline Chinook Salmon & 0 & 0 & 1 & 5 & & 1 & 4 \\
\hline Rainbow Trout & 0 & 0 & 1 & 5 & & 1 & 4 \\
\hline Golden Trout & 0 & 0 & 1 & 5 & & 1 & 4 \\
\hline Brown Trout & 0 & 0 & 1 & 5 & & 1 & 4 \\
\hline Brook Trout & 0 & 0 & 1 & 5 & & 1 & 4 \\
\hline Rainbow Smelt & 0 & 0 & 1 & 5 & & 1 & 4 \\
\hline Northern Pike & 0 & 0 & 1 & 5 & & 1 & 4 \\
\hline Goldfish & 0 & 0 & 1 & 5 & & 1 & 4 \\
\hline Common Carp & 0 & 0 & 1 & 5 & & 1 & 4 \\
\hline Utah Chub & 0 & 0 & 1 & 5 & & 1 & 4 \\
\hline Golden Shiner & 0 & 0 & 1 & 5 & & 1 & 4 \\
\hline Spottail Shiner & 0 & 0 & 1 & 5 & & 1 & 4 \\
\hline Black Bullhead & 0 & 0 & 1 & 5 & & 1 & 4 \\
\hline Yellow Bullhead & 0 & 0 & 1 & 5 & & 1 & 4 \\
\hline Plains Killifish & 0 & 0 & 1 & 4 & & 1 & 4 \\
\hline Western Mosquitofish & 0 & 0 & 1 & 5 & & 1 & 4 \\
\hline Sailfin Molly & 0 & 0 & 1 & 5 & & 1 & 4 \\
\hline Shortfin Molly & 0 & 0 & 1 & 5 & & 1 & 4 \\
\hline Green Swordtail & 0 & 0 & 1 & 5 & & 1 & 4 \\
\hline Variable Platyfish & 0 & 0 & 1 & 5 & & 1 & 4 \\
\hline White Bass & 0 & 0 & 1 & 5 & & 1 & 4 \\
\hline Rock Bass & 0 & 0 & 1 & 5 & & 1 & 4 \\
\hline Green Sunfish & 0 & 0 & 1 & 5 & & 1 & 4 \\
\hline Pumpkinseed & 0 & 0 & 1 & 5 & & 1 & 4 \\
\hline
\end{tabular}


DRAFT WORKING DOCUMENT DO NOT DUPLICATE

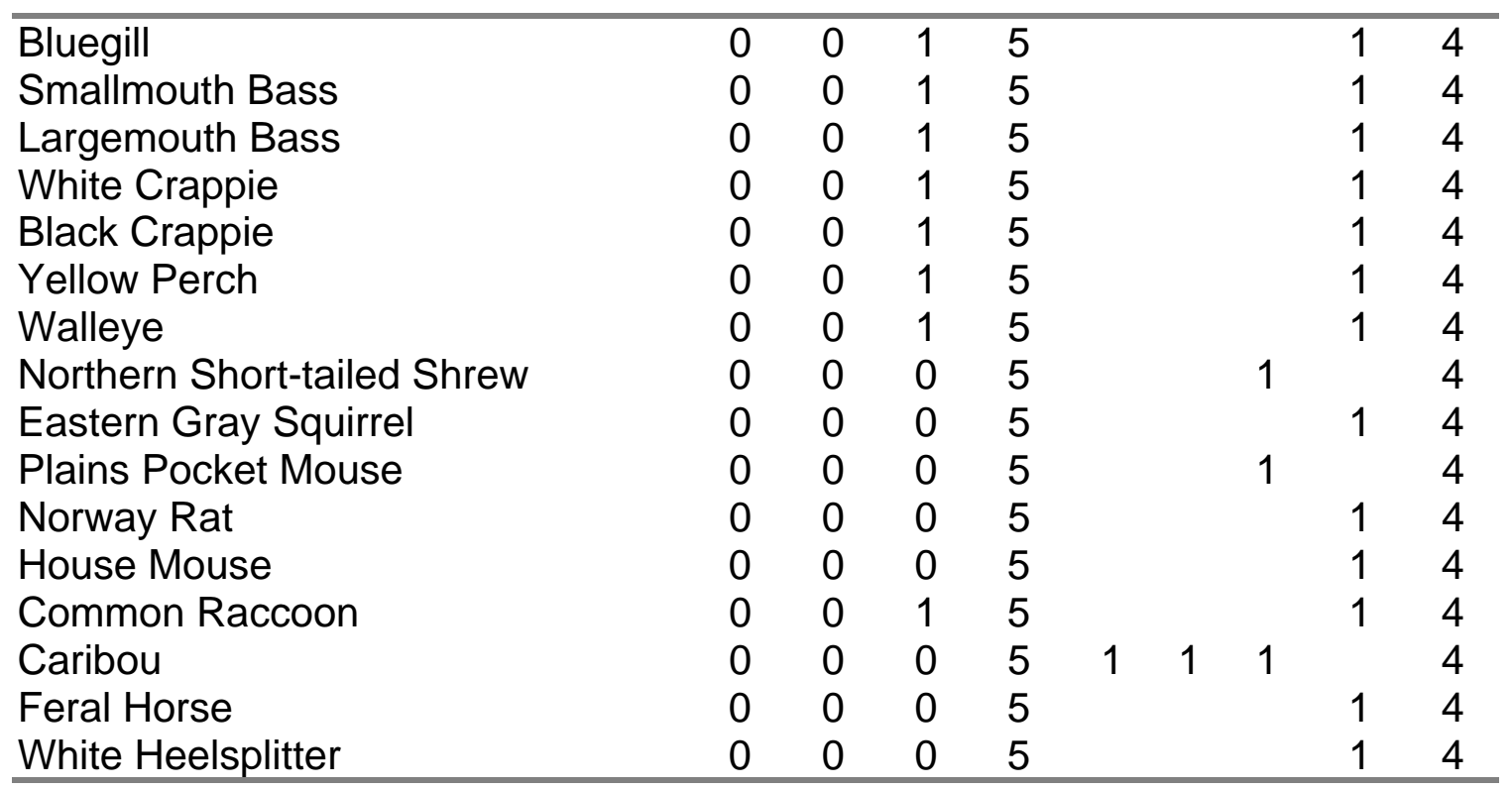

Table 4. Terrestrial Communities Tiers

\begin{tabular}{lc}
\hline \multicolumn{1}{c}{ Community / Habitat } & Tier \\
\hline Grassland Complexes & 1 \\
Mixed Broadleaf Forests & 1 \\
Mixed Shrub/Grass Associations & 1 \\
Riparian \& Wetlands & 1 \\
Sagebrush \& Salt Flats & 1 \\
Alpine Meadows & 2 \\
Altered Herbaceous & 2 \\
Badlands & 2 \\
Douglas Fir & 2 \\
Low Density Xeric Forest & 2 \\
Mixed Mesic Forest & 2 \\
Mixed Mesic Shrubs & 2 \\
Mixed Whitebark Pine Forests & 2 \\
Ponderosa Pine & 2 \\
Western Red Cedar & 2 \\
Western Larch & 2 \\
Standing Burnt Forest & 2 \\
Rocky Mountain Juniper & 2 \\
Snowfields Or Ice & 2 \\
Agricultural Lands - Dry & 3 \\
Agricultural Lands - Irrigated & 3 \\
Douglas-fir/ Lodgepole Pine & 3 \\
Grand Fir & 3 \\
\hline
\end{tabular}


Limber Pine 3

Lodgepole Pine 3

Mines, Quarries, Gravel Pits 3

Missouri Breaks 3

Mixed Barren Sites 3

Mixed Broadleaf and Conifer Forest 3

Mixed Subalpine Forest 3

Mixed Xeric Forest 3

Montane Parklands \& Subalpine Meadows 3

Rock 3

Utah Juniper 3

Western Hemlock 3

Cloud Shadows $\quad 4$

Clouds 4

Urban $\quad 4$

Water 4

Table 5. Aquatic Community Tiers

\begin{tabular}{lc}
\hline \multicolumn{1}{c}{ Community } & Tier \\
\hline Mountain Streams & 1 \\
Prairie Streams & 1 \\
Intermountain Valley Rivers & 2 \\
Intermountain Valley Streams & 2 \\
Mixed Source Rivers (Intermountain and Prairie Flow) & 2 \\
Prairie Rivers & 2 \\
Lowland Lakes & 3 \\
Lowland Reservoirs & 3 \\
Mountain Lakes & 3 \\
Mountain Reservoirs & 3 \\
\hline
\end{tabular}

14420

14421

14422

\section{Table 6. Terrestrial Focus Area Rankings based on USFS Subsections}

USFS Subsection

Bitterroot/Frenchtown Valleys

Central Montana Broad Valleys

Deerlodge Valley

Flathead River Valley

Little Belt Foothills

North Tobacco Root Mountains and
Ecotype

Intermountain/foothill grassland 1 Intermountain/foothill grassland 1 Intermountain/foothill grassland 1 Intermountain/foothill grassland 1 Intermountain/foothill grassland 1 Intermountain/foothill grassland 1 


\begin{tabular}{|c|c|c|}
\hline \multicolumn{3}{|l|}{ Foothills } \\
\hline Rocky Mountain Front Foothills & Intermountain/foothill grassland & 1 \\
\hline South Elkhorn Mountains & Intermountain/foothill grassland & 1 \\
\hline Southwest Montana Intermontane & & \\
\hline Basins and Valleys & Intermountain/foothill grassland & 1 \\
\hline Upper Yellowstone Valley & Intermountain/foothill grassland & 1 \\
\hline Mission/Swan Valley and Mountains & Montane Forest & 1 \\
\hline Missouri Coteau & Plains Grassland \& Plains Forest & 1 \\
\hline Montana Sedimentary Plains & Plains Grassland \& Plains Forest & 1 \\
\hline Bighorn Intermontane Basin & Shrub Grassland & 1 \\
\hline Montana Glaciated Plains & Shrub Grassland & 1 \\
\hline Montana Shale Plains & Shrub Grassland & 1 \\
\hline Powder River Basin/Breaks/Scoria Hills & Shrub Grassland & 1 \\
\hline Shale Scablands & Shrub Grassland & 1 \\
\hline Avon/Nevada Valleys & Intermountain/foothill grassland & 2 \\
\hline Belt Mountain Foothills & Intermountain/foothill grassland & 2 \\
\hline Bighorn Sedimentary Mountains & Intermountain/foothill grassland & 2 \\
\hline Flint Creek/Upper Willow Creek Basins & Intermountain/foothill grassland & 2 \\
\hline Snowy Foothills & Intermountain/foothill grassland & 2 \\
\hline Beartooth Front & Montane Forest & 2 \\
\hline Big Belt Foothills & Montane Forest & 2 \\
\hline East Pioneer Mountains & Montane Forest & 2 \\
\hline Gallatin Foothills/Spanish Peaks & Montane Forest & 2 \\
\hline Little Belt/Snowy/Judith/Mountains & Montane Forest & 2 \\
\hline Madison Mountains & Montane Forest & 2 \\
\hline Ruby/Tobacco Root Mountains & Montane Forest & 2 \\
\hline Missouri Plateau & Plains Grassland \& Plains Forest & 2 \\
\hline Missouri River Breaks & Plains Grassland \& Plains Forest & 2 \\
\hline Montana High Plains and Foothills & Plains Grassland \& Plains Forest & 2 \\
\hline Pierre Shale Plains & Plains Grassland \& Plains Forest & 2 \\
\hline Blacktail Mountains & Shrub Grassland & 2 \\
\hline Gravelly/Snowcrest Mountains & Shrub Grassland & 2 \\
\hline Montana Isolated Mountain Ranges & Intermountain/foothill grassland & 3 \\
\hline Absaroka/Gallatin Mountains & Montane Forest & 3 \\
\hline Anaconda Mountains & Montane Forest & 3 \\
\hline Anaconda/Flint Creek Mountains & Montane Forest & 3 \\
\hline Beartooth Mountains & Montane Forest & 3 \\
\hline Beaverhead Mountains & Montane Forest & 3 \\
\hline Big Belt Mountains & Montane Forest & 3 \\
\hline Bitterroot Glaciated Canyons & Montane Forest & 3 \\
\hline Boulder/Elkhorn Mountains & Montane Forest & 3 \\
\hline Bridger Mountains and Foothills & Montane Forest & 3 \\
\hline Cabinet Mountains & Montane Forest & 3 \\
\hline Clark Fork Valley and Mountains & Montane Forest & 3 \\
\hline
\end{tabular}




\begin{tabular}{lll}
\hline Coeur d'Alene Mountains & Montane Forest & 3 \\
Continental Divide Foothills & Montane Forest & 3 \\
Continental Divide Uplands & Montane Forest & 3 \\
Crazy Mountains & Montane Forest & 3 \\
Flathead Thrust Faulted Mountains & Montane Forest & 3 \\
Garnet/Sapphire Mountains & Montane Forest & 3 \\
Livingston Mountains & Montane Forest & 3 \\
Middle Rocky Mountain Front & Montane Forest & 3 \\
North Rocky Mountain Front & Montane Forest & 3 \\
Northern Absaroka Volcanic Mountains & Montane Forest & 3 \\
Purcell/North Cabinet Mountains & Montane Forest & 3 \\
Rattlesnake/Blackfoot/South Swan & & \\
Mountains & Montane Forest & 3 \\
Salish Mountains & Montane Forest & 3 \\
South Anaconda/Bitterroot Mountains & Montane Forest & 3 \\
South Rocky Mountain Front & Montane Forest & 3 \\
Southern Beaverhead Mountains & Montane Forest & 3 \\
St.Joe/Bitterroot Mountains & Montane Forest & 3 \\
West Pioneer Mountains & Montane Forest & 3 \\
West Yellowstone Valley & Montane Forest & 3 \\
Whitefish/Swan Mountains & Montane Forest & 3 \\
Yellowstone Volcanic Plateau & Montane Forest & 3 \\
Wolf Mountains & Plains Grassland \& Plains Forest & 3 \\
\hline
\end{tabular}

Table 7. Aquatic Focus Area Rankings based on Fourth Code HUC's

\begin{tabular}{llc}
\hline \multicolumn{1}{c}{ 4th Code HUC } & \multicolumn{1}{c}{ Ecotype } & Tier \\
\hline Big Hole & Intermountain/foothill grassland & 1 \\
Bitterroot & Intermountain/foothill grassland & 1 \\
Blackfoot & Intermountain/foothill grassland & 1 \\
Jefferson & Intermountain/foothill grassland & 1 \\
Upper Yellowstone \& Tributaries & Intermountain/foothill grassland & 1 \\
Lower Clark Fork & Montane Forest & 1 \\
Middle Clark Fork & Montane Forest & 1 \\
Lower Missouri & Plains Grassland \& Plains Forest & 1 \\
Lower Yellowstone & Plains Grassland \& Plains Forest & 1 \\
Powder & Plains Grassland \& Plains Forest & 1 \\
Tongue & Plains Grassland \& Plains Forest & 1 \\
Middle Missouri \& Tributaries & Shrub Grassland & 1 \\
Lower Musselshell & Intermountain/foothill grassland & 2 \\
Madison & Intermountain/foothill grassland & 2 \\
Middle Musselshell & Intermountain/foothill grassland & 2 \\
Teton & Intermountain/foothill grassland & 2 \\
Upper Musselshell & Intermountain/foothill grassland & 2 \\
\hline
\end{tabular}




\begin{tabular}{lll}
\hline Lower Milk & Shrub Grassland & 2 \\
Middle Milk & Shrub Grassland & 2 \\
Ruby & Shrub Grassland & 2 \\
Upper Milk & Shrub Grassland & 2 \\
Arrow & Intermountain/foothill grassland & 3 \\
Beaverhead & Intermountain/foothill grassland & 3 \\
Belt & Intermountain/foothill grassland & 3 \\
Boulder & Intermountain/foothill grassland & 3 \\
Box Elder & Intermountain/foothill grassland & 3 \\
Flathead Lake & Intermountain/foothill grassland & 3 \\
Flatwillow & Intermountain/foothill grassland & 3 \\
Gallatin & Intermountain/foothill grassland & 3 \\
Judith & Intermountain/foothill grassland & 3 \\
Lower Flathead & Intermountain/foothill grassland & 3 \\
Milk Headwaters & Intermountain/foothill grassland & 3 \\
Red Rock & Intermountain/foothill grassland & 3 \\
Upper Missouri & Intermountain/foothill grassland & 3 \\
Belly & Montane Forest & 3 \\
Clarks Fork Yellowstone & Montane Forest & 3 \\
Cut Bank & Montane Forest & 3 \\
Fisher & Montane Forest & 3 \\
Flint - Rock & Montane Forest & 3 \\
Lower Kootenai & Montane Forest & 3 \\
Middle Fork Flathead & Montane Forest & 3 \\
Moyie & Montane Forest & 3 \\
North Fork Flathead & Montane Forest & 3 \\
Shoshone & Montane Forest & 3 \\
Smith & Montane Forest & 3 \\
South Fork Flathead & Montane Forest & 3 \\
St. Mary & Montane Forest & 3 \\
Stillwater in Pend Oreille Catalog & Montane Forest & 3 \\
Stillwater in Upper Yellowstone & Montane Forest & 3 \\
Swan & Montane Forest & 3 \\
Two Medicine & Montane Forest & 3 \\
Upper Clark Fork & Montane Forest \\
Upper Kootenai & Montane Forest \\
Yaak & Montane Forest & 3 \\
Yellowstone Headwaters & Montane Forest \\
Big Dry & Plains Grassland \& Plains Forest & 3 \\
Big Muddy & Plains Grassland \& Plains Forest & 3 \\
Boxelder & Plains Grassland \& Plains Forest & 3 \\
Brush Lake Closed Basin & & 3 \\
Little Dry & Prassland \& Plains Forest & 3 \\
Lower Bighorn & Plains Forest & 3 \\
\hline & Plains Forest & 3 \\
\hline
\end{tabular}


DRAFT WORKING DOCUMENT DO NOT DUPLICATE

\begin{tabular}{llc}
\hline Mizpah & Plains Grassland \& Plains Forest & 3 \\
O'Fallon & Plains Grassland \& Plains Forest & 3 \\
Poplar & Plains Grassland \& Plains Forest & 3 \\
Pryor & Plains Grassland \& Plains Forest & 3 \\
Redwater & Plains Grassland \& Plains Forest & 3 \\
Rosebud & Plains Grassland \& Plains Forest & 3 \\
West Fork Poplar & Plains Grassland \& Plains Forest & 3 \\
Battle & Shrub Grassland & 3 \\
Beaver in Little Missouri Catalog & Shrub Grassland & 3 \\
Beaver in Milk River Catalog Unit & Shrub Grassland & 3 \\
Big Horn Lake & Shrub Grassland & 3 \\
Big Porcupine & Shrub Grassland & 3 \\
Big Sandy & Shrub Grassland & 3 \\
Cottonwood & Shrub Grassland & 3 \\
Frenchman & Shrub Grassland & 3 \\
Little Bighorn & Shrub Grassland & 3 \\
Little Powder & Shrub Grassland & 3 \\
Lodge & Shrub Grassland & 3 \\
Lower Belle Fourche & Shrub Grassland & 3 \\
Marias & Shrub Grassland & 3 \\
Middle Little Missouri & Shrub Grassland & 3 \\
Peoples & Shrub Grassland & 3 \\
Porcupine & Shrub Grassland & 3 \\
Rock & Shrub Grassland & 3 \\
Sage & Shrub Grassland & 3 \\
Upper Little Missouri & Shrub Grassland & 3 \\
Whitewater & Shrub Grassland & 3 \\
Wild Horse Lake & Shrub Grassland & 3 \\
Willow & Shrub Grassland & 3 \\
\hline & &
\end{tabular}

Table 8. Group Inventory Tier Assignments

Taxonomic Group

\begin{tabular}{llll}
\hline Invertebrate Group & 1.00 & 1 & $\mathrm{I}^{1}, \mathrm{I}^{4}, \mathrm{I}^{6}$ \\
Crayfish Group & 1.00 & 1 & $\mathrm{I}^{1}, \mathrm{I}^{4}, \mathrm{I}^{6}$ \\
Mammals, bats group & 1.67 & 1 & $\mathrm{I}^{1}, \mathrm{I}^{4}, \mathrm{I}^{6}$ \\
Reptiles group & 1.71 & 1 & $\mathrm{I}^{1}, \mathrm{I}^{4}, \mathrm{I}^{6}$ \\
Mussels group & 1.80 & 1 & $\mathrm{I}^{1}, \mathrm{I}^{4}, \mathrm{I}^{6}$ \\
\hline
\end{tabular}


DRAFT WORKING DOCUMENT DO NOT DUPLICATE

14429

14430

14431

\begin{tabular}{lllc}
\hline Mammals, small group & 1.92 & 1 & $\mathrm{I}^{1}, \mathrm{I}^{4}, \mathrm{I}^{6}$ \\
Birds, shorebird/waterbird group & 2.33 & 1 & $\mathrm{I}^{1}, \mathrm{I}^{4}, \mathrm{I}^{6}, \mathrm{O}^{1}$ \\
Birds, owls group & 2.33 & 1 & $\mathrm{I}^{1}, \mathrm{I}^{4}, \mathrm{I}^{6}, \mathrm{O}^{1}$ \\
Fish-Prairie group & 2.39 & 1 & $\mathrm{I}^{1}, \mathrm{I}^{4}, \mathrm{I}^{6}$ \\
Birds, raptors group & 2.42 & 2 & $\mathrm{I}^{1}, \mathrm{I}^{2}, \mathrm{I}^{3}, \mathrm{I}^{\mathrm{M}}, \mathrm{O}^{2}$ \\
Fish-Montane group & 2.57 & 2 & $\mathrm{I}^{5}, \mathrm{I}^{\mathrm{M}}, \mathrm{O}^{1}$ \\
Mammals, furbearers group & 2.57 & 2 & $\mathrm{I}^{1}, \mathrm{I}^{3}, \mathrm{I}^{4}, \mathrm{I}^{\mathrm{M}}, \mathrm{O}^{2}$ \\
Birds, passerine group & 2.68 & 2 & $\mathrm{I}^{5}, \mathrm{I}^{7}, \mathrm{I}^{\mathrm{M}}, \mathrm{O}^{1}$ \\
Birds, waterfowl group & 2.75 & 3 & $\mathrm{I}^{\mathrm{M}}, \mathrm{O}^{1}$ \\
Mammals, predators group & 2.83 & 3 & $\mathrm{I}^{1}, \mathrm{I}^{4}, \mathrm{I}^{\mathrm{M}}, \mathrm{O}^{2}$ \\
Amphibians group & 2.83 & 3 & $\mathrm{I}^{4}, \mathrm{I}^{7}, \mathrm{I}^{\mathrm{M}}, \mathrm{O}^{1}$ \\
Birds, upland game group & 2.86 & 3 & $\mathrm{I}^{\mathrm{M}}, \mathrm{O}^{1}$ \\
Fish-Non-native group & 3.00 & 3 & $\mathrm{I}^{\mathrm{M}}, \mathrm{O}^{2}$ \\
Mammals, big game group & 3.00 & 3 & $\mathrm{I}^{\mathrm{M}}, \mathrm{O}^{2}$ \\
\hline
\end{tabular}

Table 9. Species Inventory Tier Assignments

Species

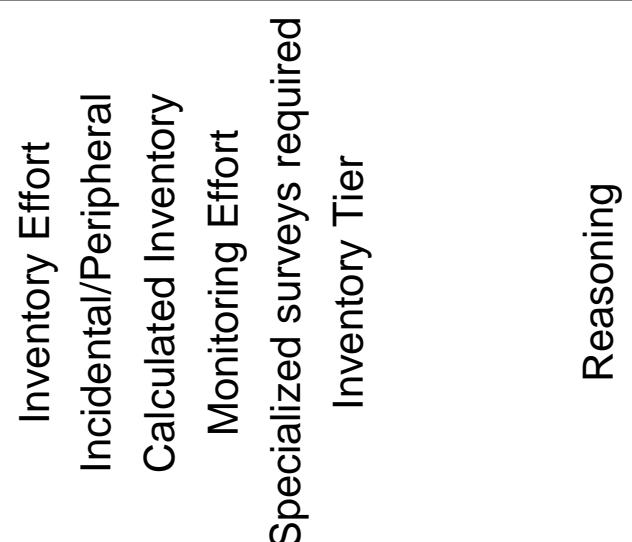

\begin{tabular}{llllllll}
\hline American Bittern & 1 & 1 & 1 & 1 & 2 & 1 & $\mathrm{I}^{1}, \mathrm{I}^{4}, \mathrm{O}^{1}$ \\
Black-crowned Night-heron & 1 & 1 & 1 & 1 & 2 & 1 & $\mathrm{I}^{1}, \mathrm{I}^{4}, \mathrm{O}^{1}$ \\
White-faced Ibis & 1 & 1 & 1 & 1 & 2 & 1 & $\mathrm{I}^{1}, \mathrm{I}^{4}, \mathrm{O}^{1}$ \\
Northern Goshawk & 2 & 2 & 2 & 1 & 1 & 1 & $\mathrm{I}^{1}, \mathrm{I}^{6}, \mathrm{I}^{\mathrm{M}}$ \\
Columbia Sharp-tailed Grouse & 1 & 2 & 2 & 1 & 1 & 1 & $\mathrm{I}^{1}, \mathrm{I}^{6}, \mathrm{I}^{\mathrm{M}}$ \\
Yellow Rail & 1 & 1 & 1 & 1 & 2 & 1 & $\mathrm{I}^{1}, \mathrm{I}^{4}, \mathrm{I}^{7}$ \\
Greater Yellowlegs & 1 & 1 & 1 & 1 & 3 & 1 & $\mathrm{I}^{1}, \mathrm{I}^{4}, \mathrm{I}^{7}$ \\
Solitary Sandpiper & 1 & 1 & 1 & 1 & 3 & 1 & $\mathrm{I}^{1}, \mathrm{I}^{4}, \mathrm{I}^{7}$ \\
Semipalmated Sandpiper & 1 & 1 & 1 & 1 & 3 & 1 & $\mathrm{I}^{1}, \mathrm{I}^{4}, \mathrm{I}^{7}$ \\
Western Sandpiper & 1 & 1 & 1 & 1 & 3 & 1 & $\mathrm{I}^{1}, \mathrm{I}^{4}, \mathrm{I}^{7}$ \\
Least Sandpiper & 1 & 1 & 1 & 1 & 3 & 1 & $\mathrm{I}^{1}, \mathrm{I}^{4}, \mathrm{I}^{7}$ \\
White-rumped Sandpiper & 1 & 1 & 1 & 1 & 3 & 1 & $\mathrm{I}^{1}, \mathrm{I}^{4}, \mathrm{I}^{7}$ \\
Baird's Sandpiper & 1 & 1 & 1 & 1 & 3 & 1 & $\mathrm{I}^{1}, \mathrm{I}^{4}, \mathrm{I}^{7}$ \\
\hline
\end{tabular}




\begin{tabular}{|c|c|c|c|c|c|c|c|}
\hline Pectoral Sandpiper & 1 & 1 & 1 & 1 & 3 & 1 & $I^{1}, I^{4}, I^{7}$ \\
\hline Dunlin & 1 & 1 & 1 & 1 & 3 & 1 & $I^{1}, I^{4}, I^{7}$ \\
\hline Long-billed Dowitcher & 1 & 1 & 1 & 1 & 3 & 1 & $I^{1}, I^{4}, I^{7}$ \\
\hline Glaucous-winged Gull & 1 & 1 & 1 & 1 & 3 & 1 & $I^{1}, I^{4}, I^{7}$ \\
\hline Glaucous Gull & 1 & 1 & 1 & 1 & 3 & 1 & $I^{1}, I^{4}, I^{7}$ \\
\hline Arctic Tern & 1 & 1 & 1 & 1 & 3 & 1 & $I^{1}, I^{4}, I^{7}$ \\
\hline Black-billed Cuckoo & 1 & 1 & 1 & 1 & 2 & 1 & $\mathrm{I}^{1}, \mathrm{I}^{4}, \mathrm{O}^{1}$ \\
\hline Yellow-billed Cuckoo & 1 & 1 & 1 & 1 & 2 & 1 & $I^{1}, I^{4}, I^{7}, O^{1}$ \\
\hline Barn Owl & 1 & 1 & 1 & 1 & 3 & 1 & $I^{1}, I^{4}, I^{7}, O^{1}$ \\
\hline Snowy Owl & 1 & 1 & 1 & 1 & 1 & 1 & $I^{1}, I^{4}, I^{6}, I^{7}$ \\
\hline Northern Hawk Owl & 1 & 1 & 1 & 1 & 1 & 1 & $I^{1}, I^{4}, I^{6}$ \\
\hline Common Nighthawk & 2 & 2 & 2 & 1 & 1 & 1 & $I^{1}, I^{4}, I^{6}, I^{M}$ \\
\hline Common Poorwill & 1 & 2 & 2 & 1 & 1 & 1 & $I^{1}, I^{4}, I^{6}, I^{M}$ \\
\hline Black Swift & 1 & 2 & 2 & 1 & 1 & 1 & $I^{1}, I^{5}, I^{6}, I^{M}, O^{1}$ \\
\hline Chimney Swift & 1 & 1 & 1 & 1 & 1 & 1 & $\mathrm{I}^{1}, \mathrm{I}^{4}, \mathrm{I}^{6}, \mathrm{O}^{1}$ \\
\hline White-throated Swift & 1 & 2 & 2 & 1 & 1 & 1 & $I^{1}, I^{4}, I^{6}, I^{7}, I^{M}$ \\
\hline Black-chinned Hummingbird & 1 & 1 & 1 & 1 & 2 & 1 & $\mathrm{I}^{1}, \mathrm{I}^{4}, \mathrm{O}^{1}$ \\
\hline Anna's Hummingbird & 1 & 1 & 1 & 1 & 3 & 1 & $I^{1}, I^{4}, I^{6}, I^{7}$ \\
\hline Alder Flycatcher & 1 & 2 & 2 & 1 & 1 & 1 & $I^{1}, I^{4}, I^{6}, I^{M}$ \\
\hline Purple Martin & 1 & 1 & 1 & 1 & 1 & 1 & $I^{1}, I^{4}, I^{6}, I^{7}$ \\
\hline Canyon Wren & 1 & 2 & 2 & 1 & 1 & 1 & $I^{1}, I^{4}, I^{6}, I^{M}, O^{1}$ \\
\hline Sedge Wren & 1 & 1 & 1 & 1 & 2 & 1 & $I^{1}, I^{4}, I^{7}$ \\
\hline American Dipper & 2 & 2 & 2 & 1 & 1 & 1 & $I^{1}, I^{2}, I^{4}, I^{6}, I^{M}$ \\
\hline Blue-gray Gnatcatcher & 1 & 1 & 1 & 1 & 1 & 1 & $I^{1}, I^{5}, I^{6}, I^{7}$ \\
\hline Eastern Bluebird & 1 & 1 & 1 & 1 & 2 & 1 & $I^{1}, I^{4}, I^{7}$ \\
\hline Western Bluebird & 1 & 2 & 2 & 1 & 1 & 1 & $I^{1}, I^{4}, I^{6}, I^{M}$ \\
\hline Black-and-white Warbler & 1 & 2 & 2 & 1 & 1 & 1 & $I^{1}, I^{4}, I^{6}, I^{M}, O^{1}$ \\
\hline Indigo Bunting & 1 & 2 & 2 & 1 & 1 & 1 & $I^{1}, I^{4}, I^{6}, I^{M}, O^{1}$ \\
\hline Green-tailed Towhee & 2 & 2 & 2 & 1 & 1 & 1 & $I^{1}, I^{4}, I^{6}, I^{M}, O^{1}$ \\
\hline Field Sparrow & 1 & 2 & 2 & 1 & 1 & 1 & $\mathrm{I}^{1}, \mathrm{I}^{5}, \mathrm{I}^{6}, \mathrm{I}^{7}, \mathrm{I}^{\mathrm{M}}$ \\
\hline Le Conte's Sparrow & 1 & 1 & 1 & 1 & 2 & 1 & $I^{1}, I^{4}, I^{7}$ \\
\hline Nelson's Sharp-tailed Sparrow & 1 & 1 & 1 & 1 & 2 & 1 & $I^{1}, I^{4}, I^{7}$ \\
\hline Black Rosy-finch & 1 & 1 & 1 & 1 & 2 & 1 & $1^{1}, 1^{4}, I^{7}$ \\
\hline Torrent Sculpin & 1 & 1 & 1 & 2 & 2 & 1 & $I^{1}, I^{4}$ \\
\hline Spoonhead Sculpin & 1 & 1 & 1 & 2 & 2 & 1 & $I^{1}, I^{4}$ \\
\hline Shortnose Gar & 1 & 1 & 1 & 2 & 2 & 1 & $1^{1}, 1^{5}$ \\
\hline Lake Trout (native lakes) & 1 & 2 & 2 & 1 & 1 & 1 & $I^{1}, I^{6}, I^{M}, O^{2}$ \\
\hline Western Silvery Minnow & 2 & 2 & 2 & 1 & 1 & 1 & $I^{1}, I^{4}, I^{6}, I^{M}$ \\
\hline Brassy Minnow & 1 & 2 & 2 & 1 & 1 & 1 & $I^{1}, I^{4}, I^{6}, I^{M}$ \\
\hline Plains Minnow & 2 & 2 & 2 & 1 & 1 & 1 & $I^{1}, I^{4}, I^{6}, I^{M}$ \\
\hline Pearl Dace & 1 & 1 & 1 & 1 & 3 & 1 & $I^{1}, I^{4}$ \\
\hline Trout-perch & 1 & 1 & 1 & 2 & 2 & 1 & $I^{1}, I^{4}$ \\
\hline Iowa Darter & 1 & 1 & 1 & 1 & 2 & 1 & $I^{1}, I^{4}$ \\
\hline
\end{tabular}




\begin{tabular}{|c|c|c|c|c|c|c|c|}
\hline Arctic Shrew & 1 & 1 & 1 & 1 & 2 & 1 & $I^{1}, I^{5}, I^{7}$ \\
\hline Northern Myotis & 1 & 1 & 1 & 1 & 2 & 1 & $I^{1}, I^{4}, I^{7}$ \\
\hline Eastern Red Bat & 1 & 1 & 1 & 1 & 2 & 1 & $1^{1}, 1^{4}, 1^{7}$ \\
\hline Spotted Bat & 1 & 2 & 2 & 1 & 1 & 1 & $I^{1}, I^{4}, I^{6}, I^{M}$ \\
\hline Townsend's Big-eared Bat & 2 & 2 & 2 & 1 & 1 & 1 & $\mathrm{I}^{1}, \mathrm{I}^{4}, \mathrm{I}^{6}, \mathrm{I}^{\mathrm{M}}, \mathrm{O}^{1}$ \\
\hline Pallid Bat & 1 & 1 & 1 & 1 & 2 & 1 & $1^{1}, 1^{4}, 1^{7}$ \\
\hline American Pika & 2 & 2 & 2 & 1 & 1 & 1 & $\mathrm{I}^{1}, \mathrm{I}^{4}, \mathrm{I}^{6}, \mathrm{I}^{\mathrm{M}}, \mathrm{O}^{1}$ \\
\hline Eastern Cottontail & 1 & 1 & 1 & 1 & 2 & 1 & $1^{1}, 1^{4}, I^{7}$ \\
\hline Black-tailed Jackrabbit & 1 & 2 & 2 & 1 & 1 & 1 & $I^{1}, I^{5}, I^{6}, I^{M}$ \\
\hline Uinta Chipmunk & 1 & 1 & 1 & 1 & 1 & 1 & $I^{1}, 1^{5}, I^{6}$ \\
\hline Hoary Marmot & 2 & 2 & 2 & 1 & 1 & 1 & $\mathrm{I}^{1}, \mathrm{I}^{5}, \mathrm{I}^{6}, \mathrm{I}^{\mathrm{M}}, \mathrm{O}^{1}$ \\
\hline Uinta Ground Squirrel & 1 & 2 & 2 & 1 & 1 & 1 & $I^{1}, I^{5}, I^{6}, I^{M}$ \\
\hline Wyoming Ground Squirrel & 1 & 2 & 2 & 1 & 1 & 1 & $I^{1}, I^{5}, I^{6}, I^{M}$ \\
\hline Northern Flying Squirrel & 1 & 2 & 2 & 1 & 1 & 1 & $I^{1}, I^{5}, I^{6}, I^{M}$ \\
\hline Idaho Pocket Gopher & 1 & 2 & 2 & 1 & 1 & 1 & $I^{1}, I^{5}, I^{6}, l^{M}$ \\
\hline Hispid Pocket Mouse & 1 & 1 & 1 & 1 & 2 & 1 & $I^{1}, I^{5}, I^{7}$ \\
\hline Water Vole & 1 & 2 & 2 & 1 & 1 & 1 & $\mathrm{I}^{1}, \mathrm{I}^{4}, \mathrm{I}^{6}, \mathrm{I}^{\mathrm{M}}$ \\
\hline Sagebrush Vole & 1 & 2 & 2 & 1 & 1 & 1 & $\mathrm{I}^{1}, \mathrm{I}^{4}, \mathrm{I}^{6}, \mathrm{I}^{\mathrm{M}}$ \\
\hline Northern Bog Lemming & 1 & 2 & 2 & 1 & 1 & 1 & $\mathrm{I}^{1}, \mathrm{I}^{5}, \mathrm{I}^{6}, \mathrm{I}^{\mathrm{M}}, \mathrm{O}^{1}$ \\
\hline Meadow Jumping Mouse & 1 & 2 & 2 & 1 & 1 & 1 & $I^{1}, I^{4}, I^{6}, I^{M}$ \\
\hline Common Porcupine & 2 & 2 & 2 & 1 & 1 & 1 & $I^{1}, I^{2}, I^{4}, I^{6}, I^{M}, O^{2}$ \\
\hline Western Spotted Skunk & 1 & 1 & 1 & 1 & 3 & 1 & $I^{1}, I^{4}, I^{7}, O^{1}, O^{2}$ \\
\hline Snapping Turtle & 1 & 2 & 2 & 1 & 1 & 1 & $I^{1}, I^{4}, I^{6}, I^{M}$ \\
\hline Spiny Softshell & 1 & 2 & 2 & 1 & 1 & 1 & $I^{1}, I^{4}, I^{6}, I^{M}$ \\
\hline Northern Alligator Lizard & 1 & 2 & 2 & 1 & 1 & 1 & $I^{1}, I^{4}, I^{6}, I^{M}$ \\
\hline Western Skink & 1 & 2 & 2 & 1 & 1 & 1 & $I^{1}, I^{4}, I^{6}, I^{M}$ \\
\hline Rubber Boa & 2 & 2 & 2 & 1 & 1 & 1 & $I^{1}, I^{4}, I^{6}, I^{M}$ \\
\hline Western Hognose Snake & 1 & 2 & 2 & 1 & 1 & 1 & $I^{1}, I^{4}, I^{6}, I^{M}$ \\
\hline Milk Snake & 1 & 2 & 2 & 1 & 1 & 1 & $\mathrm{I}^{1}, \mathrm{I}^{4}, \mathrm{I}^{6}, \mathrm{I}^{\mathrm{M}}, \mathrm{O}^{1}$ \\
\hline Smooth Green Snake & 1 & 1 & 1 & 1 & 1 & 1 & $I^{1}, I^{5}, I^{6}, I^{7}$ \\
\hline Calico Crayfish & 1 & 2 & 2 & 1 & 1 & 1 & $I^{1}, I^{4}, I^{6}, I^{M}$ \\
\hline Virile Crayfish & 1 & 2 & 2 & 1 & 1 & 1 & $I^{1}, I^{4}, I^{6}, I^{M}$ \\
\hline A Crayfish & 1 & 2 & 2 & 1 & 1 & 1 & $I^{1}, I^{4}, I^{6}, I^{M}$ \\
\hline Signal Crayfish & 1 & 2 & 2 & 1 & 1 & 1 & $I^{1}, I^{4}, I^{6}, I^{M}$ \\
\hline Black Sandshell & 0 & 2 & 1 & 1 & 3 & 1 & $I^{1}, I^{4}$ \\
\hline Western Pearlshell & 0 & 2 & 1 & 1 & 3 & 1 & $I^{1}, I^{4}$ \\
\hline Pacific Treefrog & 2 & 2 & 2 & 2 & 2 & 2 & $1^{4}$ \\
\hline Plains Spadefoot & 1 & 2 & 2 & 2 & 1 & 2 & $I^{1}, I^{4}$ \\
\hline Great Basin Spadefoot & 1 & 2 & 2 & 2 & 1 & 2 & $1^{1}, 1^{4}$ \\
\hline Pied-billed Grebe & 1 & 2 & 2 & 1 & 3 & 2 & $\mathrm{I}^{1}, \mathrm{I}^{4}, \mathrm{O}^{1}$ \\
\hline Horned Grebe & 2 & 2 & 2 & 1 & 2 & 2 & $I^{1}, I^{4}, I^{6}, O^{1}$ \\
\hline Red-necked Grebe & 2 & 2 & 2 & 1 & 2 & 2 & $\mathrm{I}^{1}, \mathrm{I}^{4}, \mathrm{I}^{6}, \mathrm{O}^{1}$ \\
\hline Eared Grebe & 2 & 2 & 2 & 1 & 2 & 2 & $I^{1}, I^{4}, O^{1}$ \\
\hline
\end{tabular}




\begin{tabular}{|c|c|c|c|c|c|c|c|}
\hline Western Grebe & 2 & 2 & 2 & 1 & 2 & 2 & $I^{1}, I^{4}, I^{6}, O^{1}$ \\
\hline Clark's Grebe & 1 & 2 & 2 & 1 & 2 & 2 & $1^{1}, 1^{4}, O^{1}$ \\
\hline Double-crested Cormorant & 2 & 2 & 2 & 1 & 3 & 2 & $1^{1}, I^{4}$ \\
\hline Snowy Egret & 1 & 2 & 2 & 1 & 3 & 2 & $1^{1}, 1^{4}$ \\
\hline Cattle Egret & 1 & 2 & 2 & 1 & 3 & 2 & $I^{1}, I^{4}$ \\
\hline Northern Harrier & 2 & 2 & 2 & 2 & 2 & 2 & $1^{2}$ \\
\hline Sharp-shinned Hawk & 2 & 2 & 2 & 1 & 2 & 2 & $1^{2}, 1^{6}$ \\
\hline Cooper's Hawk & 2 & 2 & 2 & 1 & 2 & 2 & $I^{2}, I^{6}$ \\
\hline Swainson's Hawk & 2 & 2 & 2 & 2 & 2 & 2 & $1^{2}$ \\
\hline Rough-legged Hawk & 2 & 2 & 2 & 1 & 3 & 2 & $1^{2}$ \\
\hline American Kestrel & 2 & 2 & 2 & 2 & 2 & 2 & $1^{2}$ \\
\hline Merlin & 1 & 2 & 2 & 1 & 2 & 2 & $1^{2}, 1^{6}$ \\
\hline Gyrfalcon & 1 & 2 & 2 & 1 & 2 & 2 & $1^{1}, 1^{5}$ \\
\hline Prairie Falcon & 2 & 2 & 2 & 1 & 2 & 2 & $I^{2}, I^{6}$ \\
\hline Virginia Rail & 1 & 2 & 2 & 1 & 3 & 2 & $1^{1}, 1^{4}$ \\
\hline Sora & 1 & 2 & 2 & 1 & 3 & 2 & $I^{1}, I^{4}$ \\
\hline American Coot & 2 & 2 & 2 & 1 & 3 & 2 & $I^{1}, I^{4}$ \\
\hline Black-necked Stilt & 1 & 2 & 2 & 1 & 3 & 2 & $I^{1}, I^{4}$ \\
\hline American Avocet & 2 & 2 & 2 & 1 & 3 & 2 & $I^{1}, I^{4}$ \\
\hline Lesser Yellowlegs & 2 & 2 & 2 & 1 & 3 & 2 & $I^{1}, I^{4}$ \\
\hline Willet & 2 & 2 & 2 & 1 & 3 & 2 & $I^{1}, I^{4}$ \\
\hline Spotted Sandpiper & 2 & 2 & 2 & 1 & 3 & 2 & $I^{1}, I^{4}$ \\
\hline Upland Sandpiper & 1 & 2 & 2 & 1 & 2 & 2 & $I^{1}, I^{4}, I^{6}$ \\
\hline Long-billed Curlew & 2 & 2 & 2 & 1 & 2 & 2 & $I^{1}, I^{4}, I^{6}$ \\
\hline Marbled Godwit & 2 & 2 & 2 & 1 & 2 & 2 & $I^{1}, I^{4}, I^{6}$ \\
\hline Common Snipe & 2 & 2 & 2 & 1 & 3 & 2 & $1^{1}, I^{4}$ \\
\hline Wilson's Phalarope & 2 & 2 & 2 & 1 & 3 & 2 & $1^{1}, 1^{4}$ \\
\hline Franklin's Gull & 1 & 2 & 2 & 1 & 2 & 2 & $I^{1}, I^{4}, I^{6}, O^{1}$ \\
\hline Ring-billed Gull & 1 & 2 & 2 & 1 & 3 & 2 & $I^{1}, I^{4}$ \\
\hline California Gull & 1 & 2 & 2 & 1 & 3 & 2 & $1^{1}, 1^{4}$ \\
\hline Herring Gull & 1 & 2 & 2 & 1 & 3 & 2 & $1^{1}, 1^{4}$ \\
\hline Caspian Tern & 1 & 2 & 2 & 1 & 2 & 2 & $I^{1}, I^{4}, I^{6}, O^{1}$ \\
\hline Common Tern & 1 & 2 & 2 & 1 & 2 & 2 & $I^{1}, I^{4}, I^{6}, O^{1}$ \\
\hline Forster's Tern & 1 & 2 & 2 & 1 & 2 & 2 & $I^{1}, I^{4}, I^{6}, O^{1}$ \\
\hline Black Tern & 1 & 2 & 2 & 1 & 2 & 2 & $I^{1}, I^{4}, I^{6}, O^{1}$ \\
\hline Eastern Screech-owl & 1 & 2 & 2 & 1 & 2 & 2 & $1^{1}, I^{4}$ \\
\hline Great Horned Owl & 2 & 2 & 2 & 1 & 2 & 2 & $1^{1}, I^{4}$ \\
\hline Northern Pygmy-owl & 1 & 2 & 2 & 2 & 2 & 2 & $1^{1}, 1^{4}$ \\
\hline Short-eared Owl & 1 & 2 & 2 & 1 & 2 & 2 & $1^{1}, 1^{4}$ \\
\hline Vaux's Swift & 1 & 2 & 2 & 1 & 2 & 2 & $I^{1}, I^{4}, I^{6}$ \\
\hline Calliope Hummingbird & 2 & 2 & 2 & 1 & 3 & 2 & $I^{1}, I^{4}$ \\
\hline Broad-tailed Hummingbird & 1 & 2 & 2 & 1 & 3 & 2 & $I^{1}, I^{4}, I^{6}, I^{7}$ \\
\hline Rufous Hummingbird & 2 & 2 & 2 & 1 & 3 & 2 & $I^{1}, I^{4}$ \\
\hline
\end{tabular}




\begin{tabular}{|c|c|c|c|c|c|c|c|}
\hline Belted Kingfisher & 2 & 2 & 2 & 1 & 3 & 2 & $1^{1}, 1^{4}$ \\
\hline Lewis's Woodpecker & 1 & 2 & 2 & 1 & 2 & 2 & $I^{1}, I^{4}, I^{6}$ \\
\hline Red-headed Woodpecker & 1 & 2 & 2 & 1 & 2 & 2 & $1^{1}, 1^{4}, I^{6}$ \\
\hline Cassin's Kingbird & 1 & 2 & 2 & 1 & 3 & 2 & $I^{1}, I^{4}, I^{6}$ \\
\hline Boreal Chickadee & 2 & 2 & 2 & 1 & 2 & 2 & $I^{1}, I^{4}, I^{6}$ \\
\hline Chestnut-backed Chickadee & 2 & 2 & 2 & 1 & 2 & 2 & $I^{1}, I^{4}, I^{6}$ \\
\hline Brown Creeper & 2 & 2 & 2 & 1 & 2 & 2 & $I^{1}, I^{4}, I^{6}$ \\
\hline Rock Wren & 2 & 2 & 2 & 1 & 3 & 2 & $I^{1}, I^{4}$ \\
\hline Marsh Wren & 1 & 2 & 2 & 1 & 2 & 2 & $1^{1}, 1^{4}, I^{6}$ \\
\hline American Pipit & 1 & 2 & 2 & 1 & 2 & 2 & $I^{1}, I^{4}, I^{6}$ \\
\hline Loggerhead Shrike & 2 & 2 & 2 & 2 & 1 & 2 & $I^{1}, I^{4}, I^{6}$ \\
\hline Yellow-breasted Chat & 2 & 2 & 2 & 1 & 2 & 2 & $I^{1}, I^{4}, I^{6}$ \\
\hline Snow Bunting & 1 & 2 & 2 & 2 & 1 & 2 & $I^{1}, I^{4}$ \\
\hline Orchard Oriole & 1 & 2 & 2 & 1 & 2 & 2 & $1^{1}, I^{4}, I^{6}$ \\
\hline Baltimore Oriole & 1 & 2 & 2 & 1 & 2 & 2 & $I^{1}, I^{4}, I^{6}$ \\
\hline Gray-crowned Rosy-finch & 1 & 2 & 2 & 1 & 2 & 2 & $1^{1}, 1^{4}, I^{6}$ \\
\hline White-winged Crossbill & 1 & 2 & 2 & 1 & 2 & 2 & $I^{1}, I^{4}, I^{6}$ \\
\hline Mottled Sculpin & 2 & 2 & 2 & 2 & 2 & 2 & $I^{1}, I^{4}$ \\
\hline Slimy Sculpin & 1 & 2 & 2 & 2 & 2 & 2 & $1^{1}, I^{4}$ \\
\hline Pallid Sturgeon & 2 & 2 & 2 & 3 & 1 & 2 & $I^{1}, I^{4}, O^{2}$ \\
\hline Northern Redbelly Dace & 1 & 2 & 2 & 1 & 3 & 2 & $1^{1}$ \\
\hline Northern Redbelly X Finescale Dace & 1 & 2 & 2 & 1 & 3 & 2 & $1^{1}$ \\
\hline Longnose Dace & 2 & 2 & 2 & 2 & 2 & 2 & $1^{1}$ \\
\hline Redside Shiner & 1 & 2 & 2 & 2 & 2 & 2 & $I^{1}$ \\
\hline Creek Chub & 1 & 2 & 2 & 2 & 2 & 2 & $I^{1}$ \\
\hline Sturgeon Chub & 1 & 2 & 2 & 2 & 2 & 2 & $\mathrm{I}^{\mathrm{M}}$ \\
\hline Sicklefin Chub & 2 & 1 & 2 & 2 & 2 & 2 & $\mathrm{I}^{\mathrm{M}}$ \\
\hline Burbot & 2 & 2 & 2 & 2 & 1 & 2 & $\mathrm{I}^{\mathrm{M}}$ \\
\hline Masked Shrew & 2 & 2 & 2 & 1 & 3 & 2 & $1^{1}, I^{4}$ \\
\hline Preble's Shrew & 1 & 2 & 2 & 1 & 2 & 2 & $1^{1}, 1^{4}$ \\
\hline Vagrant Shrew & 2 & 2 & 2 & 1 & 2 & 2 & $1^{1}, 1^{4}$ \\
\hline Dusky Or Montane Shrew & 1 & 2 & 2 & 1 & 3 & 2 & $1^{1}, 1^{4}$ \\
\hline Dwarf Shrew & 1 & 2 & 2 & 1 & 2 & 2 & $1^{1}, 1^{4}$ \\
\hline Water Shrew & 2 & 2 & 2 & 1 & 2 & 2 & $1^{1}, 1^{4}$ \\
\hline Merriam's Shrew & 1 & 2 & 2 & 1 & 2 & 2 & $1^{1}, 1^{4}$ \\
\hline Pygmy Shrew & 1 & 2 & 2 & 1 & 2 & 2 & $1^{1}, 1^{4}$ \\
\hline Hayden's Shrew & 1 & 2 & 2 & 1 & 2 & 2 & $1^{1}, I^{4}$ \\
\hline Little Brown Myotis & 2 & 2 & 2 & 1 & 2 & 2 & $1^{1}, 1^{4}$ \\
\hline Yuma Myotis & 1 & 2 & 2 & 1 & 2 & 2 & $1^{1}, 1^{4}$ \\
\hline Long-eared Myotis & 2 & 2 & 2 & 1 & 2 & 2 & $1^{1}, 1^{4}$ \\
\hline Fringed Myotis & 1 & 2 & 2 & 1 & 2 & 2 & $1^{1}, 1^{4}$ \\
\hline Long-legged Myotis & 1 & 2 & 2 & 1 & 2 & 2 & $1^{1}, 1^{4}$ \\
\hline California Myotis & 1 & 2 & 2 & 1 & 2 & 2 & $1^{1}, I^{4}$ \\
\hline
\end{tabular}




\begin{tabular}{|c|c|c|c|c|c|c|c|}
\hline Western Small-footed Myotis & 1 & 2 & 2 & 1 & 2 & 2 & $I^{1}, I^{4}$ \\
\hline Silver-haired Bat & 2 & 2 & 2 & 1 & 2 & 2 & $I^{1}, I^{4}$ \\
\hline Big Brown Bat & 2 & 2 & 2 & 1 & 2 & 2 & $I^{1}, I^{4}$ \\
\hline Hoary Bat & 1 & 2 & 2 & 1 & 2 & 2 & $I^{1}, I^{4}$ \\
\hline Mountain Cottontail & 2 & 2 & 2 & 1 & 2 & 2 & $I^{\mathrm{M}}$ \\
\hline Desert Cottontail & 1 & 2 & 2 & 1 & 3 & 2 & $\mathrm{I}^{\mathrm{M}}$ \\
\hline Snowshoe Hare & 2 & 2 & 2 & 1 & 3 & 2 & $\mathrm{I}^{\mathrm{M}}$ \\
\hline White-tailed Jackrabbit & 2 & 2 & 2 & 1 & 2 & 2 & $\mathrm{I}^{\mathrm{M}}$ \\
\hline Pygmy Rabbit & 2 & 2 & 2 & 3 & 1 & 2 & $\mathrm{I}^{\mathrm{M}}$ \\
\hline Least Chipmunk & 2 & 2 & 2 & 1 & 3 & 2 & $\mathrm{I}^{\mathrm{M}}$ \\
\hline Yellow-pine Chipmunk & 2 & 2 & 2 & 1 & 3 & 2 & $\mathrm{I}^{\mathrm{M}}$ \\
\hline Red-tailed Chipmunk & 2 & 2 & 2 & 1 & 3 & 2 & $\mathrm{I}^{\mathrm{M}}$ \\
\hline Yellow-bellied Marmot & 2 & 2 & 2 & 1 & 3 & 2 & $\mathrm{I}^{\mathrm{M}}$ \\
\hline Richardson's Ground Squirrel & 2 & 2 & 2 & 1 & 3 & 2 & $\mathrm{I}^{\mathrm{M}}$ \\
\hline Columbian Ground Squirrel & 2 & 2 & 2 & 1 & 3 & 2 & $\mathrm{I}^{\mathrm{M}}$ \\
\hline Thirteen-lined Ground Squirrel & 1 & 2 & 2 & 1 & 3 & 2 & $\mathrm{I}^{\mathrm{M}}$ \\
\hline Franklin's Ground Squirrel & 1 & 2 & 2 & 1 & 3 & 2 & $\mathrm{I}^{\mathrm{M}}$ \\
\hline Golden-mantled Ground Squirrel & 2 & 2 & 2 & 1 & 3 & 2 & $\mathrm{I}^{\mathrm{M}}$ \\
\hline Townsend's Ground Squirrel & 1 & 2 & 2 & 1 & 3 & 2 & $\mathrm{I}^{\mathrm{M}}$ \\
\hline Eastern Fox Squirrel & 1 & 2 & 2 & 1 & 3 & 2 & $\mathrm{I}^{\mathrm{M}}$ \\
\hline Northern Pocket Gopher & 2 & 2 & 2 & 1 & 3 & 2 & $I^{1}, I^{4}$ \\
\hline Olive-backed Pocket Mouse & 1 & 2 & 2 & 1 & 2 & 2 & $I^{1}, I^{4}$ \\
\hline Great Basin Pocket Mouse & 1 & 2 & 2 & 1 & 2 & 2 & $I^{1}, I^{4}$ \\
\hline Ord's Kangaroo Rat & 1 & 2 & 2 & 1 & 2 & 2 & $I^{1}, I^{4}$ \\
\hline American Beaver & 2 & 2 & 2 & 1 & 3 & 2 & $\mathrm{I}^{\mathrm{M}}$ \\
\hline Western Harvest Mouse & 1 & 2 & 2 & 1 & 3 & 2 & $I^{1}, I^{4}$ \\
\hline White-footed Mouse & 1 & 2 & 2 & 1 & 2 & 2 & $I^{1}, I^{4}$ \\
\hline Northern Grasshopper Mouse & 1 & 2 & 2 & 1 & 3 & 2 & $I^{1}, I^{4}$ \\
\hline Bushy-tailed Woodrat & 2 & 2 & 2 & 1 & 3 & 2 & $I^{1}, I^{4}$ \\
\hline Southern Red-backed Vole & 2 & 2 & 2 & 1 & 3 & 2 & $I^{1}, I^{4}$ \\
\hline Heather Vole & 1 & 2 & 2 & 1 & 3 & 2 & $I^{1}, I^{4}$ \\
\hline Montane Vole & 2 & 2 & 2 & 1 & 3 & 2 & $I^{1}, I^{4}$ \\
\hline Long-tailed Vole & 2 & 2 & 2 & 1 & 3 & 2 & $I^{1}, I^{4}$ \\
\hline Prairie Vole & 2 & 2 & 2 & 1 & 3 & 2 & $I^{1}, I^{4}$ \\
\hline Western Jumping Mouse & 2 & 2 & 2 & 1 & 3 & 2 & $I^{1}, I^{4}$ \\
\hline Swift Fox & 1 & 2 & 2 & 3 & 1 & 2 & $\mathrm{I}^{\mathrm{M}}$ \\
\hline Fisher & 2 & 2 & 2 & 2 & 2 & 2 & $\mathrm{I}^{\mathrm{M}}$ \\
\hline Least Weasel & 1 & 2 & 2 & 2 & 1 & 2 & $I^{1}, I^{4}$ \\
\hline American Badger & 2 & 2 & 2 & 2 & 2 & 2 & $1^{5}$ \\
\hline Short-horned Lizard & 2 & 2 & 2 & 1 & 2 & 2 & $I^{1}, I^{4}$ \\
\hline Sagebrush Lizard & 1 & 2 & 2 & 1 & 2 & 2 & $I^{1}, I^{4}$ \\
\hline Racer & 2 & 2 & 2 & 1 & 3 & 2 & $I^{1}, I^{4}$ \\
\hline Gopher Snake & 2 & 2 & 2 & 1 & 3 & 2 & $I^{1}, I^{4}$ \\
\hline
\end{tabular}




\begin{tabular}{|c|c|c|c|c|c|c|c|}
\hline Plains Garter Snake & 2 & 2 & 2 & 1 & 3 & 2 & $\mathrm{I}^{1}, \mathrm{I}^{4}$ \\
\hline Western Rattlesnake & 2 & 2 & 2 & 1 & 3 & 2 & $I^{1}, I^{4}$ \\
\hline Fatmucket & 1 & 2 & 2 & 1 & 3 & 2 & $\mathrm{I}^{1}, \mathrm{I}^{4}$ \\
\hline Giant Floater & 1 & 2 & 2 & 1 & 3 & 2 & $I^{1}, I^{4}$ \\
\hline Long-toed Salamander & 3 & 2 & 3 & 2 & 3 & 3 & $\mathrm{I}^{\mathrm{M}}$ \\
\hline Tiger Salamander & 2 & 2 & 2 & 2 & 3 & 3 & $\mathrm{I}^{\mathrm{M}}$ \\
\hline Coeur D'alene Salamander & 1 & 2 & 2 & 3 & 3 & 3 & $\mathrm{I}^{1}, \mathrm{I}^{7}$ \\
\hline Roughskin Newt & 1 & 4 & 3 & 1 & 3 & 3 & $\mathrm{I}^{1}, \mathrm{I}^{7}, \mathrm{I}^{\mathrm{M}}$ \\
\hline Idaho Giant Salamander & 1 & 1 & 1 & 1 & 1 & 3 & $\mathrm{I}^{1}, \mathrm{I}^{7}$ \\
\hline Rocky Mountain Tailed Frog & 3 & 2 & 3 & 2 & 1 & 3 & $I^{M}$ \\
\hline Boreal Toad & 3 & 2 & 3 & 2 & 3 & 3 & $\mathrm{I}^{\mathrm{M}}$ \\
\hline Great Plains Toad & 1 & 2 & 2 & 2 & 3 & 3 & $\mathrm{I}^{1}, \mathrm{I}^{7}$ \\
\hline Canadian Toad & 1 & 1 & 1 & 2 & 3 & 3 & $\mathrm{I}^{1}, \mathrm{I}^{7}$ \\
\hline Woodhouse's Toad & 2 & 2 & 2 & 2 & 3 & 3 & $I^{M}$ \\
\hline Boreal Chorus Frog & 3 & 2 & 3 & 2 & 3 & 3 & $\mathrm{I}^{\mathrm{M}}$ \\
\hline Bullfrog & 1 & 4 & 3 & 2 & 3 & 3 & $\mathrm{I}^{1}, \mathrm{I}^{7}$ \\
\hline Northern Leopard Frog & 3 & 2 & 3 & 2 & 2 & 3 & $\mathrm{I}^{\mathrm{M}}$ \\
\hline Wood Frog & 1 & 1 & 1 & 2 & 3 & 3 & $\mathrm{I}^{1}, \mathrm{I}^{7}$ \\
\hline Columbia Spotted Frog & 3 & 2 & 3 & 2 & 3 & 3 & $\mathrm{I}^{1}, \mathrm{I}^{7}$ \\
\hline Red-throated Loon & 1 & 1 & 1 & 1 & 3 & 3 & $I^{1}, I^{4}, I^{7}, O^{2}$ \\
\hline Pacific Loon & 1 & 1 & 1 & 1 & 3 & 3 & $\mathrm{I}^{1}, \mathrm{I}^{4}, \mathrm{I}^{7}, \mathrm{O}^{2}$ \\
\hline Common Loon & 3 & 2 & 3 & 3 & 3 & 3 & $\mathrm{O}^{2}$ \\
\hline Yellow-billed Loon & 1 & 1 & 1 & 1 & 3 & 3 & $\mathrm{I}^{1}, \mathrm{I}^{4}, \mathrm{I}^{7}, \mathrm{O}^{2}$ \\
\hline American White Pelican & 2 & 2 & 2 & 2 & 3 & 3 & $\mathrm{I}^{1}, \mathrm{I}^{4}, \mathrm{O}^{2}$ \\
\hline Least Bittern & 1 & 1 & 1 & 1 & 3 & 3 & $I^{1}, I^{4}, I^{7}$ \\
\hline Great Blue Heron & 3 & 2 & 3 & 1 & 3 & 3 & $\mathrm{I}^{\mathrm{M}}, \mathrm{O}^{2}$ \\
\hline Great Egret & 1 & 1 & 1 & 1 & 3 & 3 & $I^{1}, I^{4}, I^{7}$ \\
\hline Little Blue Heron & 1 & 1 & 1 & 1 & 3 & 3 & $I^{1}, I^{4}, I^{7}$ \\
\hline Green Heron & 1 & 1 & 1 & 1 & 3 & 3 & $I^{1}, I^{4}, I^{7}$ \\
\hline Yellow-crowned Night-heron & 1 & 1 & 1 & 1 & 3 & 3 & $I^{1}, I^{4}, I^{7}$ \\
\hline Wood Stork & 1 & 1 & 1 & 1 & 3 & 3 & $I^{1}, I^{4}, I^{7}$ \\
\hline Tundra Swan & 2 & 2 & 2 & 2 & 3 & 3 & $\mathrm{I}^{1}, \mathrm{I}^{4}, \mathrm{O}^{2}$ \\
\hline Trumpeter Swan & 1 & 2 & 2 & 3 & 3 & 3 & $\mathrm{I}^{1}, \mathrm{I}^{4}, \mathrm{O}^{2}$ \\
\hline Mute Swan & 1 & 2 & 2 & 2 & 3 & 3 & $\mathrm{I}^{1}, \mathrm{I}^{4}, \mathrm{I}^{7}, \mathrm{O}^{2}$ \\
\hline Greater White-fronted Goose & 1 & 1 & 1 & 2 & 3 & 3 & $I^{1}, I^{4}, I^{7}$ \\
\hline Snow Goose & 1 & 2 & 2 & 2 & 3 & 3 & $\mathrm{I}^{1}, \mathrm{O}^{1}, \mathrm{O}^{2}$ \\
\hline Ross' Goose & 1 & 2 & 2 & 2 & 3 & 3 & $\mathrm{I}^{1}, \mathrm{O}^{1}, \mathrm{O}^{2}$ \\
\hline Brant & 1 & 4 & 3 & 2 & 3 & 3 & $I^{1}, I^{4}, I^{7}$ \\
\hline Canada Goose & 3 & 2 & 3 & 2 & 3 & 3 & $\mathrm{O}^{1}, \mathrm{O}^{2}$ \\
\hline Wood Duck & 1 & 2 & 2 & 2 & 3 & 3 & $\mathrm{I}^{1}, \mathrm{O}^{1}, \mathrm{O}^{2}$ \\
\hline Green-winged Teal & 2 & 2 & 2 & 2 & 3 & 3 & $\mathrm{I}^{1}, \mathrm{O}^{1}, \mathrm{O}^{2}$ \\
\hline American Black Duck & 1 & 2 & 2 & 2 & 3 & 3 & $\mathrm{I}^{1}, \mathrm{O}^{1}, \mathrm{O}^{2}$ \\
\hline Mallard & 3 & 2 & 3 & 2 & 3 & 3 & $\mathrm{O}^{1}, \mathrm{O}^{2}$ \\
\hline
\end{tabular}




\begin{tabular}{|c|c|c|c|c|c|c|c|}
\hline Northern Pintail & 2 & 2 & 2 & 2 & 3 & 3 & $\mathrm{I}^{1}, \mathrm{O}^{1}, \mathrm{O}^{2}$ \\
\hline Garganey & 1 & 4 & 3 & 2 & 3 & 3 & $I^{1}, I^{4}, I^{7}$ \\
\hline Blue-winged Teal & 1 & 2 & 2 & 2 & 3 & 3 & $\mathrm{I}^{1}, \mathrm{O}^{1}, \mathrm{O}^{2}$ \\
\hline Cinnamon Teal & 1 & 2 & 2 & 2 & 3 & 3 & $\mathrm{I}^{1}, \mathrm{O}^{1}, \mathrm{O}^{2}$ \\
\hline Northern Shoveler & 2 & 2 & 2 & 2 & 3 & 3 & $\mathrm{I}^{1}, \mathrm{O}^{1}, \mathrm{O}^{2}$ \\
\hline Gadwall & 1 & 2 & 2 & 2 & 3 & 3 & $\mathrm{I}^{1}, \mathrm{O}^{1}, \mathrm{O}^{2}$ \\
\hline Eurasian Wigeon & 1 & 4 & 3 & 2 & 3 & 3 & $1^{1}, 1^{4}, I^{7}$ \\
\hline American Wigeon & 2 & 2 & 2 & 2 & 3 & 3 & $\mathrm{I}^{1}, \mathrm{O}^{1}, \mathrm{O}^{2}$ \\
\hline Canvasback & 1 & 2 & 2 & 2 & 3 & 3 & $\mathrm{I}^{1}, \mathrm{O}^{1}, \mathrm{O}^{2}$ \\
\hline Redhead & 1 & 2 & 2 & 2 & 3 & 3 & $\mathrm{I}^{1}, \mathrm{O}^{1}, \mathrm{O}^{2}$ \\
\hline Ring-necked Duck & 1 & 2 & 2 & 2 & 3 & 3 & $\mathrm{I}^{1}, \mathrm{O}^{1}, \mathrm{O}^{2}$ \\
\hline Greater Scaup & 1 & 2 & 2 & 2 & 3 & 3 & $\mathrm{I}^{1}, \mathrm{O}^{1}, \mathrm{O}^{2}$ \\
\hline Lesser Scaup & 1 & 2 & 2 & 2 & 3 & 3 & $\mathrm{I}^{1}, \mathrm{O}^{1}, \mathrm{O}^{2}$ \\
\hline Harlequin Duck & 3 & 2 & 3 & 1 & 1 & 3 & $\mathrm{I}^{\mathrm{M}}, \mathrm{O}^{1}, \mathrm{O}^{2}$ \\
\hline Long Tailed Duck & 1 & 2 & 2 & 2 & 3 & 3 & $\mathrm{I}^{1}, \mathrm{O}^{1}, \mathrm{O}^{2}$ \\
\hline Black Scoter & 1 & 4 & 3 & 2 & 3 & 3 & $I^{1}, I^{4}, I^{7}$ \\
\hline Surf Scoter & 1 & 4 & 3 & 2 & 3 & 3 & $I^{1}, I^{4}, I^{7}$ \\
\hline White-winged Scoter & 1 & 2 & 2 & 2 & 3 & 3 & $\mathrm{I}^{1}, \mathrm{O}^{1}, \mathrm{O}^{2}$ \\
\hline Common Goldeneye & 2 & 2 & 2 & 2 & 3 & 3 & $\mathrm{I}^{1}, \mathrm{O}^{1}, \mathrm{O}^{2}$ \\
\hline Barrow's Goldeneye & 2 & 2 & 2 & 2 & 3 & 3 & $\mathrm{I}^{1}, \mathrm{O}^{1}, \mathrm{O}^{2}$ \\
\hline Bufflehead & 2 & 2 & 2 & 2 & 3 & 3 & $\mathrm{I}^{1}, \mathrm{O}^{1}, \mathrm{O}^{2}$ \\
\hline Hooded Merganser & 1 & 2 & 2 & 2 & 3 & 3 & $\mathrm{I}^{1}, \mathrm{O}^{1}, \mathrm{O}^{2}$ \\
\hline Common Merganser & 3 & 2 & 3 & 2 & 3 & 3 & $\mathrm{O}^{1}, \mathrm{O}^{2}$ \\
\hline Red-breasted Merganser & 1 & 2 & 2 & 2 & 3 & 3 & $\mathrm{I}^{1}, \mathrm{O}^{1}, \mathrm{O}^{2}$ \\
\hline Ruddy Duck & 1 & 2 & 2 & 2 & 3 & 3 & $\mathrm{I}^{1}, \mathrm{O}^{1}, \mathrm{O}^{2}$ \\
\hline Turkey Vulture & 1 & 2 & 2 & 2 & 3 & 3 & $I^{1}, I^{4}$ \\
\hline Osprey & 3 & 2 & 3 & 2 & 3 & 3 & $\mathrm{I}^{\mathrm{M}}$ \\
\hline Bald Eagle & 3 & 2 & 3 & 3 & 3 & 3 & $\mathrm{I}^{\mathrm{M}}, \mathrm{O}^{2}$ \\
\hline Red-shouldered Hawk & 1 & 1 & 1 & 1 & 3 & 3 & $1^{1}, 1^{4}, I^{7}$ \\
\hline Broad-winged Hawk & 1 & 1 & 1 & 1 & 3 & 3 & $I^{1}, I^{4}, I^{7}$ \\
\hline Red-tailed Hawk & 3 & 2 & 3 & 2 & 2 & 3 & $\mathrm{I}^{\mathrm{M}}$ \\
\hline Ferruginous Hawk & 3 & 2 & 3 & 2 & 3 & 3 & $1^{\mathrm{M}}$ \\
\hline Golden Eagle & 3 & 2 & 3 & 1 & 2 & 3 & $\mathrm{I}^{\mathrm{M}}, \mathrm{O}^{2}$ \\
\hline Peregrine Falcon & 1 & 2 & 2 & 3 & 3 & 3 & $1^{1}$ \\
\hline Gray Partridge & 1 & 4 & 3 & 2 & 3 & 3 & $\mathrm{I}^{1}, \mathrm{O}^{2}$ \\
\hline Chukar & 1 & 4 & 3 & 2 & 3 & 3 & $1^{1}, O^{2}$ \\
\hline Ring-necked Pheasant & 1 & 4 & 3 & 2 & 3 & 3 & $\mathrm{I}^{1}, \mathrm{O}^{2}$ \\
\hline Spruce Grouse & 2 & 2 & 2 & 2 & 3 & 3 & $\mathrm{I}^{1}, \mathrm{O}^{2}$ \\
\hline Blue Grouse & 2 & 2 & 2 & 2 & 3 & 3 & $\mathrm{I}^{1}, \mathrm{O}^{2}$ \\
\hline Willow Ptarmigan & 1 & 1 & 1 & 1 & 2 & 3 & $I^{1}, I^{4}, I^{7}$ \\
\hline White-tailed Ptarmigan & 1 & 1 & 1 & 1 & 2 & 3 & $I^{1}, I^{4}, I^{7}$ \\
\hline Ruffed Grouse & 3 & 2 & 3 & 2 & 3 & 3 & $\mathrm{I}^{\mathrm{M}}$ \\
\hline Sage-grouse & 1 & 2 & 2 & 4 & 2 & 3 & $\mathrm{I}^{1}, \mathrm{O}^{2}$ \\
\hline
\end{tabular}




\begin{tabular}{|c|c|c|c|c|c|c|c|}
\hline Sharp-tailed Grouse & 1 & 2 & 2 & 3 & 3 & 3 & $\mathrm{I}^{1}, \mathrm{O}^{2}$ \\
\hline Wild Turkey & 1 & 4 & 3 & 2 & 3 & 3 & $1^{1}, O^{2}$ \\
\hline Common Moorhen & 1 & 1 & 1 & 1 & 3 & 3 & $I^{1}, I^{4}, I^{7}$ \\
\hline Greater Sandhill Crane & 1 & 2 & 2 & 3 & 3 & 3 & $\mathrm{I}^{1}, \mathrm{O}^{2}$ \\
\hline Lesser Sandhill Crane & 1 & 2 & 2 & 3 & 3 & 3 & $\mathrm{I}^{1}, \mathrm{O}^{2}$ \\
\hline Whooping Crane & 1 & 1 & 1 & 3 & 3 & 3 & $\mathrm{I}^{1}, \mathrm{O}^{2}$ \\
\hline Black-bellied Plover & 1 & 1 & 1 & 1 & 3 & 3 & $I^{1}, I^{4}, I^{7}$ \\
\hline American Golden-plover & 1 & 1 & 1 & 1 & 3 & 3 & $I^{1}, I^{4}, I^{7}$ \\
\hline Snowy Plover & 1 & 1 & 1 & 1 & 3 & 3 & $I^{1}, I^{4}, I^{7}$ \\
\hline Semipalmated Plover & 1 & 1 & 1 & 1 & 3 & 3 & $I^{1}, I^{4}, I^{7}$ \\
\hline Piping Plover & 2 & 2 & 2 & 3 & 3 & 3 & $\mathrm{I}^{1}, \mathrm{I}^{4}, \mathrm{O}^{1}$ \\
\hline Killdeer & 3 & 2 & 3 & 1 & 3 & 3 & $\mathrm{I}^{\mathrm{M}}$ \\
\hline Mountain Plover & 3 & 2 & 3 & 3 & 3 & 3 & $\mathrm{I}^{\mathrm{M}}$ \\
\hline Whimbrel & 1 & 1 & 1 & 1 & 3 & 3 & $I^{1}, I^{4}, I^{7}$ \\
\hline Hudsonian Godwit & 1 & 1 & 1 & 1 & 3 & 3 & $I^{1}, I^{4}, I^{7}$ \\
\hline Ruddy Turnstone & 1 & 1 & 1 & 1 & 3 & 3 & $I^{1}, I^{4}, I^{7}$ \\
\hline Black Turnstone & 1 & 1 & 1 & 1 & 3 & 3 & $I^{1}, I^{4}, I^{7}$ \\
\hline Red Knot & 1 & 1 & 1 & 1 & 3 & 3 & $I^{1}, I^{4}, I^{7}$ \\
\hline Sanderling & 1 & 1 & 1 & 1 & 3 & 3 & $I^{1}, I^{4}, I^{7}$ \\
\hline Curlew Sandpiper & 1 & 1 & 1 & 1 & 3 & 3 & $I^{1}, I^{4}, I^{7}$ \\
\hline Stilt Sandpiper & 1 & 1 & 1 & 1 & 3 & 3 & $I^{1}, I^{4}, I^{7}$ \\
\hline Buff-breasted Sandpiper & 1 & 1 & 1 & 1 & 3 & 3 & $I^{1}, I^{4}, I^{7}$ \\
\hline Short-billed Dowitcher & 1 & 1 & 1 & 1 & 3 & 3 & $I^{1}, I^{4}, I^{7}$ \\
\hline American Woodcock & 1 & 1 & 1 & 1 & 3 & 3 & $I^{1}, I^{4}, I^{7}$ \\
\hline Red-necked Phalarope & 2 & 4 & 3 & 1 & 3 & 3 & $I^{1}, I^{4}, I^{M}$ \\
\hline Red Phalarope & 1 & 1 & 1 & 1 & 3 & 3 & $I^{1}, I^{4}, I^{7}$ \\
\hline Pomarine Jaeger & 1 & 1 & 1 & 1 & 3 & 3 & $I^{1}, I^{4}, I^{7}$ \\
\hline Parasitic Jaeger & 1 & 1 & 1 & 1 & 3 & 3 & $I^{1}, I^{4}, I^{7}$ \\
\hline Long-tailed Jaeger & 1 & 1 & 1 & 1 & 3 & 3 & $I^{1}, I^{4}, I^{7}$ \\
\hline Laughing Gull & 1 & 1 & 1 & 1 & 3 & 3 & $I^{1}, I^{4}, I^{7}$ \\
\hline Bonaparte's Gull & 1 & 1 & 1 & 1 & 3 & 3 & $I^{1}, I^{4}, I^{7}$ \\
\hline Mew Gull & 1 & 1 & 1 & 1 & 3 & 3 & $I^{1}, I^{4}, I^{7}$ \\
\hline Thayer's Gull & 1 & 1 & 1 & 1 & 3 & 3 & $I^{1}, I^{4}, I^{7}$ \\
\hline Great Black-backed Gull & 1 & 1 & 1 & 1 & 3 & 3 & $I^{1}, I^{4}, I^{7}$ \\
\hline Black-legged Kittiwake & 1 & 1 & 1 & 1 & 3 & 3 & $I^{1}, I^{4}, I^{7}$ \\
\hline Sabine's Gull & 1 & 1 & 1 & 1 & 3 & 3 & $I^{1}, I^{4}, I^{7}$ \\
\hline Ivory Gull & 1 & 1 & 1 & 1 & 3 & 3 & $I^{1}, I^{4}, I^{7}$ \\
\hline Least Tern & 2 & 2 & 2 & 3 & 3 & 3 & $I^{1}, I^{4}, O^{1}$ \\
\hline Marbled Murrelet & 1 & 1 & 1 & 1 & 3 & 3 & $I^{1}, I^{4}, I^{7}$ \\
\hline Ancient Murrelet & 1 & 1 & 1 & 1 & 3 & 3 & $I^{1}, I^{4}, I^{7}$ \\
\hline Rock Dove & 1 & 4 & 3 & 1 & 3 & 3 & $I^{1}, I^{7}, I^{M}$ \\
\hline Band-tailed Pigeon & 1 & 4 & 3 & 1 & 3 & 3 & $I^{1}, I^{7}, I^{M}$ \\
\hline Eurasian Collared-dove & 1 & 4 & 3 & 1 & 3 & 3 & $I^{1}, I^{7}, I^{M}$ \\
\hline
\end{tabular}




\begin{tabular}{|c|c|c|c|c|c|c|c|}
\hline White-winged Dove & 1 & 4 & 3 & 1 & 3 & 3 & $I^{1}, I^{7}, I^{M}$ \\
\hline Mourning Dove & 3 & 2 & 3 & 3 & 3 & 3 & $\mathrm{I}^{\mathrm{M}}$ \\
\hline Flammulated Owl & 1 & 2 & 2 & 3 & 2 & 3 & $I^{1}, I^{4}, O^{1}$ \\
\hline Western Screech-owl & 1 & 2 & 2 & 2 & 3 & 3 & $I^{1}, I^{4}$ \\
\hline Burrowing Owl & 3 & 2 & 3 & 3 & 3 & 3 & $\mathrm{I}^{\mathrm{M}}$ \\
\hline Barred Owl & 1 & 2 & 2 & 2 & 3 & 3 & $I^{1}, I^{4}$ \\
\hline Great Gray Owl & 2 & 2 & 2 & 2 & 3 & 3 & $I^{1}, I^{4}$ \\
\hline Long-eared Owl & 1 & 2 & 2 & 2 & 3 & 3 & $I^{1}, I^{4}$ \\
\hline Boreal Owl & 2 & 2 & 2 & 2 & 3 & 3 & $I^{1}, I^{4}$ \\
\hline Northern Saw-whet Owl & 1 & 2 & 2 & 2 & 3 & 3 & $I^{1}, I^{4}$ \\
\hline Whip-poor-will & 1 & 1 & 1 & 1 & 3 & 3 & $I^{1}, I^{4}, I^{7}$ \\
\hline Ruby-throated Hummingbird & 1 & 1 & 1 & 1 & 3 & 3 & $I^{1}, I^{4}, I^{7}$ \\
\hline Red-bellied Woodpecker & 1 & 1 & 1 & 1 & 3 & 3 & $I^{1}, I^{4}, I^{7}$ \\
\hline Yellow-bellied Sapsucker & 1 & 1 & 1 & 1 & 3 & 3 & $I^{1}, I^{4}, I^{7}$ \\
\hline Williamson's Sapsucker & 2 & 2 & 2 & 2 & 3 & 3 & $I^{1}, I^{4}$ \\
\hline Red-naped Sapsucker & 3 & 2 & 3 & 2 & 3 & 3 & $\mathrm{I}^{\mathrm{M}}$ \\
\hline Downy Woodpecker & 2 & 2 & 2 & 2 & 3 & 3 & $I^{1}, I^{4}$ \\
\hline Hairy Woodpecker & 3 & 2 & 3 & 2 & 3 & 3 & $\mathrm{I}^{\mathrm{M}}$ \\
\hline White-headed Woodpecker & 1 & 1 & 1 & 1 & 3 & 3 & $I^{1}, I^{4}, I^{7}$ \\
\hline Three-toed Woodpecker & 2 & 2 & 2 & 2 & 3 & 3 & $\mathrm{I}^{1}, \mathrm{I}^{4}, \mathrm{O}^{1}$ \\
\hline Black-backed Woodpecker & 2 & 2 & 2 & 2 & 3 & 3 & $\mathrm{I}^{1}, \mathrm{I}^{4}, \mathrm{O}^{1}$ \\
\hline Northern Flicker & 3 & 2 & 3 & 2 & 3 & 3 & $\mathrm{I}^{\mathrm{M}}$ \\
\hline Pileated Woodpecker & 3 & 2 & 3 & 2 & 3 & 3 & $\mathrm{I}^{\mathrm{M}}$ \\
\hline Olive-sided Flycatcher & 3 & 2 & 3 & 2 & 3 & 3 & $\mathrm{I}^{\mathrm{M}}$ \\
\hline Western Wood-pewee & 2 & 2 & 2 & 2 & 3 & 3 & $I^{1}, I^{4}$ \\
\hline Eastern Wood-pewee & 1 & 4 & 3 & 2 & 3 & 3 & $1^{1}, 1^{4}$ \\
\hline Yellow-bellied Flycatcher & 1 & 1 & 1 & 1 & 3 & 3 & $1^{1}, I^{4}, I^{7}$ \\
\hline Willow Flycatcher & 2 & 2 & 2 & 2 & 3 & 3 & $\mathrm{I}^{1}, \mathrm{I}^{4}$ \\
\hline Least Flycatcher & 2 & 2 & 2 & 2 & 3 & 3 & $I^{1}, I^{4}$ \\
\hline Hammond's Flycatcher & 3 & 2 & 3 & 2 & 3 & 3 & $\mathrm{I}^{\mathrm{M}}$ \\
\hline Dusky Flycatcher & 3 & 2 & 3 & 2 & 3 & 3 & $\mathrm{I}^{\mathrm{M}}$ \\
\hline Cordilleran Flycatcher & 2 & 2 & 2 & 2 & 3 & 3 & $1^{1}, I^{4}$ \\
\hline Eastern Phoebe & 1 & 1 & 1 & 1 & 3 & 3 & $I^{1}, I^{4}, I^{7}$ \\
\hline Say's Phoebe & 1 & 2 & 2 & 2 & 3 & 3 & $\mathrm{I}^{1}, \mathrm{I}^{4}$ \\
\hline Ash-throated Flycatcher & 1 & 1 & 1 & 1 & 3 & 3 & $I^{1}, I^{4}, I^{7}$ \\
\hline Great Crested Flycatcher & 1 & 1 & 1 & 1 & 3 & 3 & $I^{1}, I^{4}, I^{7}$ \\
\hline Western Kingbird & 1 & 2 & 2 & 2 & 3 & 3 & $I^{1}, I^{4}$ \\
\hline Eastern Kingbird & 2 & 2 & 2 & 2 & 3 & 3 & $1^{1}, I^{4}$ \\
\hline Scissor-tailed Flycatcher & 1 & 1 & 1 & 1 & 3 & 3 & $I^{1}, I^{4}, I^{7}$ \\
\hline Horned Lark & 3 & 2 & 3 & 2 & 3 & 3 & $\mathrm{I}^{\mathrm{M}}$ \\
\hline Tree Swallow & 2 & 2 & 2 & 2 & 3 & 3 & $\mathrm{I}^{\mathrm{M}}$ \\
\hline Violet-green Swallow & 2 & 2 & 2 & 2 & 3 & 3 & $1^{1}, I^{4}$ \\
\hline Northern Rough-winged Swallow & 1 & 2 & 2 & 2 & 3 & 3 & $1^{1}, I^{4}$ \\
\hline
\end{tabular}




\begin{tabular}{|c|c|c|c|c|c|c|c|}
\hline Bank Swallow & 1 & 2 & 2 & 2 & 3 & 3 & $I^{1}, I^{4}$ \\
\hline Cliff Swallow & 2 & 2 & 2 & 2 & 3 & 3 & $I^{1}, I^{4}$ \\
\hline Barn Swallow & 2 & 2 & 2 & 2 & 3 & 3 & $1^{1}, 1^{4}$ \\
\hline Gray Jay & 3 & 2 & 3 & 2 & 3 & 3 & $\mathrm{I}^{\mathrm{M}}$ \\
\hline Steller's Jay & 2 & 2 & 2 & 2 & 3 & 3 & $\mathrm{I}^{\mathrm{M}}$ \\
\hline Blue Jay & 1 & 2 & 2 & 2 & 3 & 3 & $I^{1}, I^{4}$ \\
\hline Pinyon Jay & 1 & 2 & 2 & 2 & 3 & 3 & $I^{1}, I^{4}$ \\
\hline Clark's Nutcracker & 3 & 2 & 3 & 2 & 3 & 3 & $\mathrm{I}^{\mathrm{M}}$ \\
\hline Black-billed Magpie & 2 & 2 & 2 & 2 & 3 & 3 & $1^{1}, I^{4}$ \\
\hline American Crow & 2 & 2 & 2 & 2 & 3 & 3 & $\mathrm{I}^{\mathrm{M}}$ \\
\hline Common Raven & 3 & 2 & 3 & 2 & 3 & 3 & $\mathrm{I}^{\mathrm{M}}$ \\
\hline Black-capped Chickadee & 3 & 2 & 3 & 2 & 3 & 3 & $\mathrm{I}^{\mathrm{M}}$ \\
\hline Mountain Chickadee & 3 & 2 & 3 & 2 & 3 & 3 & $\mathrm{I}^{\mathrm{M}}$ \\
\hline Red-breasted Nuthatch & 3 & 2 & 3 & 2 & 3 & 3 & $\mathrm{I}^{\mathrm{M}}$ \\
\hline White-breasted Nuthatch & 2 & 2 & 2 & 2 & 3 & 3 & $I^{1}, I^{4}$ \\
\hline Pygmy Nuthatch & 1 & 2 & 2 & 2 & 3 & 3 & $I^{1}, I^{4}$ \\
\hline Bewick's Wren & 1 & 1 & 1 & 1 & 3 & 3 & $I^{1}, I^{4}, I^{7}$ \\
\hline House Wren & 3 & 2 & 3 & 2 & 3 & 3 & $\mathrm{I}^{\mathrm{M}}$ \\
\hline Winter Wren & 3 & 2 & 3 & 1 & 3 & 3 & $\mathrm{I}^{\mathrm{M}}$ \\
\hline Golden-crowned Kinglet & 3 & 2 & 3 & 2 & 3 & 3 & $\mathrm{I}^{\mathrm{M}}$ \\
\hline Ruby-crowned Kinglet & 3 & 2 & 3 & 2 & 3 & 3 & $\mathrm{I}^{\mathrm{M}}$ \\
\hline Mountain Bluebird & 3 & 2 & 3 & 2 & 3 & 3 & $\mathrm{I}^{\mathrm{M}}$ \\
\hline Townsend's Solitaire & 3 & 2 & 3 & 2 & 3 & 3 & $\mathrm{I}^{\mathrm{M}}$ \\
\hline Veery & 1 & 2 & 2 & 2 & 3 & 3 & $I^{1}, I^{4}$ \\
\hline Gray-cheeked Thrush & 1 & 4 & 3 & 2 & 3 & 3 & $1^{1}$ \\
\hline Swainson's Thrush & 3 & 2 & 3 & 2 & 3 & 3 & $\mathrm{I}^{\mathrm{M}}$ \\
\hline Hermit Thrush & 3 & 2 & 3 & 2 & 3 & 3 & $\mathrm{I}^{\mathrm{M}}$ \\
\hline Wood Thrush & 1 & 4 & 3 & 2 & 3 & 3 & $I^{1}$ \\
\hline American Robin & 3 & 2 & 3 & 2 & 3 & 3 & $\mathrm{I}^{\mathrm{M}}$ \\
\hline Varied Thrush & 3 & 2 & 3 & 2 & 3 & 3 & $\mathrm{I}^{\mathrm{M}}$ \\
\hline Gray Catbird & 2 & 2 & 2 & 2 & 3 & 3 & $I^{1}, I^{4}$ \\
\hline Northern Mockingbird & 1 & 2 & 2 & 2 & 3 & 3 & $I^{1}, I^{4}$ \\
\hline Sage Thrasher & 1 & 2 & 2 & 2 & 3 & 3 & $I^{1}, I^{4}$ \\
\hline Brown Thrasher & 1 & 2 & 2 & 2 & 3 & 3 & $I^{1}, I^{4}$ \\
\hline Sprague's Pipit & 2 & 2 & 2 & 2 & 3 & 3 & $\mathrm{I}^{\mathrm{M}}$ \\
\hline Bohemian Waxwing & 1 & 2 & 2 & 2 & 3 & 3 & $I^{1}, I^{4}$ \\
\hline Cedar Waxwing & 2 & 2 & 2 & 2 & 3 & 3 & $I^{1}, I^{4}$ \\
\hline Northern Shrike & 1 & 2 & 2 & 2 & 3 & 3 & $1^{1}, 1^{4}$ \\
\hline European Starling & 2 & 4 & 3 & 2 & 3 & 3 & $\mathrm{I}^{\mathrm{M}}$ \\
\hline Warbling Vireo & 3 & 2 & 3 & 2 & 3 & 3 & $\mathrm{I}^{\mathrm{M}}$ \\
\hline Philadelphia Vireo & 1 & 4 & 3 & 2 & 3 & 3 & $1^{1}$ \\
\hline Red-eyed Vireo & 2 & 2 & 2 & 2 & 3 & 3 & $I^{1}, I^{4}$ \\
\hline Cassin's Vireo & 1 & 2 & 2 & 2 & 3 & 3 & $I^{1}, I^{4}$ \\
\hline
\end{tabular}




\begin{tabular}{|c|c|c|c|c|c|c|c|}
\hline Golden-winged Warbler & 1 & 4 & 3 & 2 & 3 & 3 & $I^{1}$ \\
\hline Tennessee Warbler & 1 & 2 & 2 & 2 & 3 & 3 & $I^{1}, I^{4}$ \\
\hline Orange-crowned Warbler & 3 & 2 & 3 & 2 & 3 & 3 & $\mathrm{I}^{\mathrm{M}}$ \\
\hline Nashville Warbler & 2 & 2 & 2 & 2 & 3 & 3 & $I^{1}, I^{4}$ \\
\hline Northern Parula & 1 & 4 & 3 & 2 & 3 & 3 & $1^{1}$ \\
\hline Yellow Warbler & 3 & 2 & 3 & 2 & 3 & 3 & $\mathrm{I}^{\mathrm{M}}$ \\
\hline Chestnut-sided Warbler & 1 & 4 & 3 & 2 & 3 & 3 & $I^{1}$ \\
\hline Magnolia Warbler & 1 & 4 & 3 & 2 & 3 & 3 & $I^{1}$ \\
\hline Cape May Warbler & 1 & 4 & 3 & 2 & 3 & 3 & $I^{1}$ \\
\hline Black-throated Blue Warbler & 1 & 1 & 1 & 2 & 3 & 3 & $I^{1}, I^{4}$ \\
\hline Yellow-rumped Warbler & 3 & 2 & 3 & 2 & 3 & 3 & $\mathrm{I}^{\mathrm{M}}$ \\
\hline Black-throated Gray Warbler & 1 & 1 & 1 & 2 & 3 & 3 & $I^{1}, I^{4}$ \\
\hline Townsend's Warbler & 3 & 2 & 3 & 2 & 3 & 3 & $\mathrm{I}^{\mathrm{M}}$ \\
\hline Black-throated Green Warbler & 1 & 4 & 3 & 2 & 3 & 3 & $1^{1}$ \\
\hline Blackburnian Warbler & 1 & 4 & 3 & 2 & 3 & 3 & $1^{1}$ \\
\hline Yellow-throated Warbler & 1 & 4 & 3 & 2 & 3 & 3 & $I^{1}$ \\
\hline Pine Warbler & 1 & 4 & 3 & 2 & 3 & 3 & $I^{1}$ \\
\hline Prairie Warbler & 1 & 4 & 3 & 2 & 3 & 3 & $1^{1}$ \\
\hline Palm Warbler & 1 & 4 & 3 & 2 & 3 & 3 & $I^{1}$ \\
\hline Bay-breasted Warbler & 1 & 4 & 3 & 2 & 3 & 3 & $1^{1}$ \\
\hline Blackpoll Warbler & 1 & 4 & 3 & 2 & 3 & 3 & $I^{1}$ \\
\hline American Redstart & 2 & 2 & 2 & 2 & 3 & 3 & $I^{1}, I^{4}$ \\
\hline Prothonotary Warbler & 1 & 4 & 3 & 2 & 3 & 3 & $\mathrm{I}^{1}$ \\
\hline Ovenbird & 1 & 2 & 2 & 2 & 3 & 3 & $I^{1}, I^{4}$ \\
\hline Northern Waterthrush & 2 & 2 & 2 & 2 & 3 & 3 & $I^{1}, I^{4}$ \\
\hline Kentucky Warbler & 1 & 4 & 3 & 2 & 3 & 3 & $1^{1}$ \\
\hline Connecticut Warbler & 1 & 4 & 3 & 2 & 3 & 3 & $I^{1}$ \\
\hline Mourning Warbler & 1 & 4 & 3 & 2 & 3 & 3 & $I^{1}$ \\
\hline Macgillivray's Warbler & 3 & 2 & 3 & 2 & 3 & 3 & $\mathrm{I}^{\mathrm{M}}$ \\
\hline Common Yellowthroat & 2 & 2 & 2 & 2 & 3 & 3 & $\mathrm{I}^{\mathrm{M}}$ \\
\hline Hooded Warbler & 1 & 4 & 3 & 2 & 3 & 3 & $I^{1}$ \\
\hline Wilson's Warbler & 2 & 2 & 2 & 2 & 3 & 3 & $\mathrm{I}^{\mathrm{M}}$ \\
\hline Canada Warbler & 1 & 4 & 3 & 2 & 3 & 3 & $I^{1}$ \\
\hline Painted Redstart & 1 & 4 & 3 & 2 & 3 & 3 & $I^{1}$ \\
\hline Summer Tanager & 1 & 4 & 3 & 2 & 3 & 3 & $I^{1}$ \\
\hline Scarlet Tanager & 1 & 4 & 3 & 2 & 3 & 3 & $I^{1}$ \\
\hline Western Tanager & 3 & 2 & 3 & 2 & 3 & 3 & $\mathrm{I}^{\mathrm{M}}$ \\
\hline Northern Cardinal & 1 & 4 & 3 & 2 & 3 & 3 & $I^{1}$ \\
\hline Rose-breasted Grosbeak & 1 & 4 & 3 & 2 & 3 & 3 & $I^{1}$ \\
\hline Black-headed Grosbeak & 2 & 2 & 2 & 2 & 3 & 3 & $\mathrm{I}^{\mathrm{M}}$ \\
\hline Lazuli Bunting & 2 & 2 & 2 & 2 & 3 & 3 & $I^{1}, I^{4}$ \\
\hline Painted Bunting & 1 & 4 & 3 & 2 & 3 & 3 & $\mathrm{I}^{1}$ \\
\hline Dickcissel & 1 & 1 & 1 & 2 & 3 & 3 & $I^{1}, I^{4}$ \\
\hline
\end{tabular}




\begin{tabular}{|c|c|c|c|c|c|c|c|}
\hline Spotted Towhee & 2 & 2 & 2 & 2 & 3 & 3 & $I^{1}, I^{4}$ \\
\hline American Tree Sparrow & 1 & 2 & 2 & 2 & 3 & 3 & $\mathrm{I}^{1}, \mathrm{I}^{4}$ \\
\hline Chipping Sparrow & 3 & 2 & 3 & 2 & 3 & 3 & $\mathrm{I}^{\mathrm{M}}$ \\
\hline Clay-colored Sparrow & 1 & 2 & 2 & 2 & 3 & 3 & $I^{1}, I^{4}$ \\
\hline Brewer's Sparrow & 2 & 2 & 2 & 2 & 3 & 3 & $I^{1}, I^{4}$ \\
\hline Vesper Sparrow & 3 & 2 & 3 & 2 & 3 & 3 & $\mathrm{l}^{\mathrm{M}}$ \\
\hline Lark Sparrow & 2 & 2 & 2 & 2 & 3 & 3 & $I^{1}, I^{4}$ \\
\hline Black-throated Sparrow & 1 & 4 & 3 & 2 & 3 & 3 & $I^{1}$ \\
\hline Sage Sparrow & 1 & 2 & 2 & 2 & 3 & 3 & $I^{1}, I^{4}$ \\
\hline Lark Bunting & 2 & 2 & 2 & 2 & 3 & 3 & $I^{1}, I^{4}$ \\
\hline Savannah Sparrow & 2 & 2 & 2 & 2 & 3 & 3 & $\mathrm{I}^{\mathrm{M}}$ \\
\hline Baird's Sparrow & 3 & 2 & 3 & 2 & 3 & 3 & $\mathrm{I}^{\mathrm{M}}$ \\
\hline Grasshopper Sparrow & 2 & 2 & 2 & 2 & 3 & 3 & $\mathrm{I}^{1}, \mathrm{I}^{4}$ \\
\hline Fox Sparrow & 2 & 2 & 2 & 2 & 3 & 3 & $I^{1}, I^{4}$ \\
\hline Song Sparrow & 3 & 2 & 3 & 2 & 3 & 3 & $\mathrm{I}^{\mathrm{M}}$ \\
\hline Lincoln's Sparrow & 3 & 2 & 3 & 2 & 3 & 3 & $\mathrm{I}^{\mathrm{M}}$ \\
\hline Swamp Sparrow & 1 & 1 & 1 & 2 & 3 & 3 & $\mathrm{I}^{1}, \mathrm{I}^{4}$ \\
\hline White-throated Sparrow & 1 & 2 & 2 & 2 & 3 & 3 & $I^{1}, I^{4}$ \\
\hline Golden-crowned Sparrow & 1 & 4 & 3 & 2 & 3 & 3 & $I^{1}$ \\
\hline White-crowned Sparrow & 3 & 2 & 3 & 2 & 3 & 3 & $\mathrm{I}^{\mathrm{M}}$ \\
\hline Harris's Sparrow & 1 & 2 & 2 & 2 & 3 & 3 & $\mathrm{I}^{1}, \mathrm{I}^{4}$ \\
\hline Dark-eyed Junco & 3 & 2 & 3 & 2 & 3 & 3 & $\mathrm{I}^{\mathrm{M}}$ \\
\hline Mccown's Longspur & 1 & 2 & 2 & 2 & 3 & 3 & $\mathrm{I}^{1}, \mathrm{I}^{4}$ \\
\hline Lapland Longspur & 1 & 2 & 2 & 2 & 3 & 3 & $I^{1}, I^{4}$ \\
\hline Smith's Longspur & 1 & 4 & 3 & 2 & 3 & 3 & $I^{1}$ \\
\hline Chestnut-collared Longspur & 3 & 2 & 3 & 2 & 3 & 3 & $\mathrm{I}^{\mathrm{M}}$ \\
\hline Bobolink & 1 & 2 & 2 & 2 & 3 & 3 & $I^{1}, I^{4}$ \\
\hline Red-winged Blackbird & 2 & 2 & 2 & 2 & 3 & 3 & $\mathrm{I}^{\mathrm{M}}$ \\
\hline Western Meadowlark & 3 & 2 & 3 & 2 & 3 & 3 & $\mathrm{I}^{\mathrm{M}}$ \\
\hline Yellow-headed Blackbird & 1 & 2 & 2 & 2 & 3 & 3 & $I^{1}, I^{4}$ \\
\hline Rusty Blackbird & 1 & 2 & 2 & 2 & 3 & 3 & $I^{1}, I^{4}$ \\
\hline Brewer's Blackbird & 2 & 2 & 2 & 2 & 3 & 3 & $I^{1}, I^{4}$ \\
\hline Great-tailed Grackle & 1 & 4 & 3 & 2 & 3 & 3 & $I^{1}$ \\
\hline Common Grackle & 2 & 2 & 2 & 2 & 3 & 3 & $I^{1}, I^{4}$ \\
\hline Brown-headed Cowbird & 3 & 2 & 3 & 2 & 3 & 3 & $\mathrm{I}^{\mathrm{M}}$ \\
\hline Hooded Oriole & 1 & 4 & 3 & 2 & 3 & 3 & $1^{1}$ \\
\hline Bullock's Oriole & 1 & 2 & 2 & 2 & 3 & 3 & $I^{1}, I^{4}$ \\
\hline Brambling & 1 & 1 & 1 & 2 & 3 & 3 & $I^{1}, I^{4}$ \\
\hline Pine Grosbeak & 2 & 2 & 2 & 2 & 3 & 3 & $1^{1}, I^{4}$ \\
\hline Purple Finch & 1 & 1 & 1 & 2 & 3 & 3 & $I^{1}, I^{4}$ \\
\hline Cassin's Finch & 3 & 2 & 3 & 2 & 3 & 3 & $\mathrm{I}^{\mathrm{M}}$ \\
\hline House Finch & 1 & 2 & 2 & 2 & 3 & 3 & $I^{1}, I^{4}$ \\
\hline Red Crossbill & 3 & 2 & 3 & 2 & 3 & 3 & $\mathrm{I}^{\mathrm{M}}$ \\
\hline
\end{tabular}




\begin{tabular}{|c|c|c|c|c|c|c|c|}
\hline Common Redpoll & 1 & 2 & 2 & 2 & 3 & 3 & $1^{1}, I^{4}$ \\
\hline Hoary Redpoll & 1 & 1 & 1 & 2 & 3 & 3 & $1^{1}, 1^{4}$ \\
\hline Pine Siskin & 3 & 2 & 3 & 2 & 3 & 3 & $\mathrm{I}^{\mathrm{M}}$ \\
\hline Lesser Goldfinch & 1 & 4 & 3 & 2 & 3 & 3 & $1^{1}$ \\
\hline American Goldfinch & 2 & 2 & 2 & 2 & 3 & 3 & $1^{1}, I^{4}$ \\
\hline Evening Grosbeak & 3 & 2 & 3 & 2 & 3 & 3 & $\mathrm{I}^{\mathrm{M}}$ \\
\hline House Sparrow & 1 & 4 & 3 & 2 & 3 & 3 & $\mathrm{I}^{1}$ \\
\hline White Sturgeon & 1 & 1 & 1 & 2 & 3 & 3 & $1^{1}, 1^{4}$ \\
\hline Shovelnose Sturgeon & 2 & 2 & 2 & 2 & 3 & 3 & $\mathrm{I}^{\mathrm{M}}$ \\
\hline Paddlefish & 2 & 2 & 2 & 3 & 3 & 3 & $\mathrm{I}^{\mathrm{M}}, \mathrm{O}^{2}$ \\
\hline Goldeye & 3 & 2 & 3 & 2 & 3 & 3 & $\mathrm{I}^{\mathrm{M}}$ \\
\hline Cisco & 1 & 4 & 3 & 2 & 3 & 3 & $\mathrm{I}^{\mathrm{M}}$ \\
\hline Lake Whitefish & 1 & 2 & 2 & 2 & 3 & 3 & $\mathrm{I}^{\mathrm{M}}$ \\
\hline Kokanee Salmon & 2 & 4 & 3 & 2 & 3 & 3 & $\mathrm{I}^{\mathrm{M}}$ \\
\hline Chinook Salmon & 1 & 4 & 3 & 2 & 3 & 3 & $\mathrm{I}^{\mathrm{M}}$ \\
\hline Yellowstone Cutthroat Trout & 3 & 2 & 3 & 3 & 3 & 3 & $\mathrm{I}^{\mathrm{M}}$ \\
\hline Westslope Cutthroat Trout & 3 & 2 & 3 & 3 & 3 & 3 & $\mathrm{I}^{\mathrm{M}}, \mathrm{O}^{2}$ \\
\hline Rainbow Trout & 3 & 4 & 4 & 2 & 3 & 3 & $\mathrm{I}^{\mathrm{M}}$ \\
\hline Columbia Basin Redband Trout & 1 & 2 & 2 & 3 & 3 & 3 & $\mathrm{I}^{\mathrm{M}}$ \\
\hline Golden Trout & 1 & 4 & 3 & 2 & 3 & 3 & $\mathrm{I}^{\mathrm{M}}$ \\
\hline Pygmy Whitefish & 1 & 2 & 2 & 2 & 3 & 3 & $1^{1}, I^{4}$ \\
\hline Mountain Whitefish & 3 & 2 & 3 & 2 & 3 & 3 & $\mathrm{I}^{\mathrm{M}}$ \\
\hline Brown Trout & 3 & 4 & 4 & 2 & 3 & 3 & $\mathrm{I}^{\mathrm{M}}$ \\
\hline Bull Trout & 2 & 2 & 2 & 3 & 3 & 3 & $\mathrm{I}^{\mathrm{M}}, \mathrm{O}^{2}$ \\
\hline Brook Trout & 3 & 4 & 4 & 2 & 3 & 3 & $\mathrm{I}^{\mathrm{M}}$ \\
\hline Arctic Grayling & 2 & 2 & 2 & 3 & 3 & 3 & $\mathrm{I}^{\mathrm{M}}$ \\
\hline Rainbow Smelt & 1 & 4 & 3 & 2 & 3 & 3 & $\mathrm{I}^{\mathrm{M}}$ \\
\hline Northern Pike & 3 & 4 & 4 & 2 & 3 & 3 & $\mathrm{I}^{\mathrm{M}}$ \\
\hline Goldfish & 1 & 4 & 3 & 2 & 3 & 3 & $1^{1}, 1^{4}$ \\
\hline Lake Chub & 1 & 2 & 2 & 2 & 3 & 3 & $1^{1}, I^{4}$ \\
\hline Common Carp & 3 & 4 & 4 & 2 & 3 & 3 & $\mathrm{I}^{\mathrm{M}}$ \\
\hline Utah Chub & 1 & 4 & 3 & 2 & 3 & 3 & $1^{1}, 1^{4}$ \\
\hline Peamouth & 1 & 2 & 2 & 2 & 3 & 3 & $1^{1}, 1^{4}$ \\
\hline Golden Shiner & 1 & 4 & 3 & 2 & 3 & 3 & $1^{1}, I^{4}$ \\
\hline Emerald Shiner & 2 & 2 & 2 & 2 & 3 & 3 & $1^{1}, I^{4}$ \\
\hline Spottail Shiner & 1 & 4 & 3 & 2 & 3 & 3 & $1^{1}, I^{4}$ \\
\hline Sand Shiner & 1 & 2 & 2 & 2 & 3 & 3 & $1^{1}, 1^{4}$ \\
\hline Fathead Minnow & 2 & 2 & 2 & 2 & 3 & 3 & $1^{1}, 1^{4}$ \\
\hline Northern Pikeminnow & 1 & 2 & 2 & 2 & 3 & 3 & $1^{1}, 1^{4}$ \\
\hline Flathead Chub & 3 & 2 & 3 & 2 & 3 & 3 & $\mathrm{I}^{\mathrm{M}}$ \\
\hline River Carpsucker & 3 & 2 & 3 & 2 & 3 & 3 & $\mathrm{I}^{\mathrm{M}}$ \\
\hline Longnose Sucker & 3 & 2 & 3 & 2 & 3 & 3 & $\mathrm{I}^{\mathrm{M}}$ \\
\hline White Sucker & 3 & 2 & 3 & 2 & 3 & 3 & $\mathrm{I}^{\mathrm{M}}$ \\
\hline
\end{tabular}




\begin{tabular}{|c|c|c|c|c|c|c|c|}
\hline Largescale Sucker & 1 & 2 & 2 & 2 & 3 & 3 & $I^{1}, I^{4}$ \\
\hline Mountain Sucker & 1 & 2 & 2 & 2 & 3 & 3 & $\mathrm{I}^{\mathrm{M}}$ \\
\hline Blue Sucker & 2 & 2 & 2 & 3 & 3 & 3 & $\mathrm{I}^{\mathrm{M}}$ \\
\hline Smallmouth Buffalo & 2 & 2 & 2 & 2 & 3 & 3 & $\mathrm{I}^{\mathrm{M}}$ \\
\hline Bigmouth Buffalo & 2 & 2 & 2 & 2 & 3 & 3 & $\mathrm{I}^{\mathrm{M}}$ \\
\hline Shorthead Redhorse & 3 & 2 & 3 & 2 & 3 & 3 & $\mathrm{I}^{\mathrm{M}}$ \\
\hline Channel Catfish & 3 & 2 & 3 & 2 & 3 & 3 & $\mathrm{I}^{\mathrm{M}}$ \\
\hline Stonecat & 2 & 2 & 2 & 2 & 3 & 3 & $\mathrm{I}^{\mathrm{M}}$ \\
\hline Black Bullhead & 1 & 4 & 3 & 2 & 3 & 3 & $I^{1}, I^{4}$ \\
\hline Yellow Bullhead & 1 & 4 & 3 & 2 & 3 & 3 & $I^{1}, I^{4}$ \\
\hline Plains Killifish & 1 & 4 & 3 & 2 & 3 & 3 & $1^{1}, 1^{4}$ \\
\hline Western Mosquitofish & 1 & 4 & 3 & 2 & 3 & 3 & $1^{1}, 1^{4}$ \\
\hline Sailfin Molly & 1 & 4 & 3 & 2 & 3 & 3 & $I^{1}, I^{7}$ \\
\hline Shortfin Molly & 1 & 4 & 3 & 2 & 3 & 3 & $1^{1}, 1^{7}$ \\
\hline Green Swordtail & 1 & 4 & 3 & 2 & 3 & 3 & $1^{1}, 1^{7}$ \\
\hline Variable Platyfish & 1 & 4 & 3 & 2 & 3 & 3 & $1^{1}, 1^{7}$ \\
\hline Brook Stickleback & 1 & 2 & 2 & 2 & 3 & 3 & $I^{1}, I^{4}$ \\
\hline White Bass & 1 & 4 & 3 & 2 & 3 & 3 & $I^{1}, I^{4}$ \\
\hline Rock Bass & 1 & 4 & 3 & 2 & 3 & 3 & $I^{1}, I^{4}$ \\
\hline Green Sunfish & 1 & 4 & 3 & 2 & 3 & 3 & $I^{1}, I^{4}$ \\
\hline Pumpkinseed & 1 & 4 & 3 & 2 & 3 & 3 & $I^{1}, I^{4}$ \\
\hline Bluegill & 1 & 4 & 3 & 2 & 3 & 3 & $1^{1}, I^{4}$ \\
\hline Smallmouth Bass & 2 & 4 & 3 & 2 & 3 & 3 & $\mathrm{I}^{\mathrm{M}}$ \\
\hline Largemouth Bass & 1 & 4 & 3 & 2 & 3 & 3 & $\mathrm{I}^{\mathrm{M}}$ \\
\hline White Crappie & 1 & 4 & 3 & 2 & 3 & 3 & $\mathrm{I}^{\mathrm{M}}$ \\
\hline Black Crappie & 2 & 4 & 3 & 2 & 3 & 3 & $\mathrm{I}^{\mathrm{M}}$ \\
\hline Yellow Perch & 3 & 4 & 4 & 2 & 3 & 3 & $\mathrm{I}^{\mathrm{M}}$ \\
\hline Sauger & 3 & 2 & 3 & 2 & 2 & 3 & $\mathrm{I}^{\mathrm{M}}, \mathrm{O}^{2}$ \\
\hline Walleye & 3 & 4 & 4 & 2 & 3 & 3 & $\mathrm{I}^{\mathrm{M}}$ \\
\hline Freshwater Drum & 2 & 2 & 2 & 2 & 3 & 3 & $\mathrm{I}^{\mathrm{M}}$ \\
\hline Northern Short-tailed Shrew & 1 & 1 & 1 & 1 & 3 & 3 & $1^{1}, I^{7}$ \\
\hline Black-tailed Prairie Dog & 2 & 2 & 2 & 3 & 3 & 3 & $\mathrm{I}^{\mathrm{M}}, \mathrm{O}^{2}$ \\
\hline White-tailed Prairie Dog & 1 & 1 & 1 & 3 & 3 & 3 & $\mathrm{I}^{\mathrm{M}}, \mathrm{O}^{2}$ \\
\hline Eastern Gray Squirrel & 1 & 4 & 3 & 1 & 3 & 3 & $I^{1}, I^{4}, I^{M}$ \\
\hline Red Squirrel & 3 & 2 & 3 & 1 & 3 & 3 & $\mathrm{I}^{\mathrm{M}}$ \\
\hline Plains Pocket Mouse & 1 & 1 & 1 & 1 & 3 & 3 & $I^{1}, I^{4}$ \\
\hline Deer Mouse & 3 & 2 & 3 & 1 & 3 & 3 & $\mathrm{I}^{\mathrm{M}}$ \\
\hline Meadow Vole & 3 & 2 & 3 & 1 & 3 & 3 & $\mathrm{I}^{\mathrm{M}}$ \\
\hline Muskrat & 2 & 2 & 2 & 2 & 3 & 3 & $\mathrm{I}^{\mathrm{M}}$ \\
\hline Norway Rat & 1 & 4 & 3 & 1 & 3 & 3 & $I^{1}, I^{4}, I^{M}$ \\
\hline House Mouse & 1 & 4 & 3 & 1 & 3 & 3 & $I^{1}, I^{4}, I^{M}$ \\
\hline Coyote & 3 & 2 & 3 & 2 & 3 & 3 & $\mathrm{I}^{\mathrm{M}}$ \\
\hline Gray Wolf & 2 & 2 & 2 & 3 & 3 & 3 & $\mathrm{I}^{\mathrm{M}}, \mathrm{O}^{2}$ \\
\hline
\end{tabular}


DRAFT WORKING DOCUMENT DO NOT DUPLICATE

\begin{tabular}{llllllll}
\hline Red Fox & 2 & 2 & 2 & 2 & 3 & 3 & $\mathrm{I}^{\mathrm{M}}$ \\
Black Bear & 3 & 2 & 3 & 4 & 3 & 3 & $\mathrm{I}^{\mathrm{M}}$ \\
Grizzly Bear & 2 & 2 & 2 & 3 & 3 & 3 & $\mathrm{I}^{\mathrm{M}}, \mathrm{O}^{2}$ \\
Common Raccoon & 2 & 4 & 3 & 2 & 3 & 3 & $\mathrm{I}^{\mathrm{M}}$ \\
American Marten & 3 & 2 & 3 & 2 & 3 & 3 & $\mathrm{I}^{\mathrm{M}}$ \\
Ermine & 1 & 2 & 2 & 2 & 3 & 3 & $\mathrm{I}^{\mathrm{M}}$ \\
Long-tailed Weasel & 2 & 2 & 2 & 2 & 3 & 3 & $\mathrm{I}^{\mathrm{M}}$ \\
Black-footed Ferret & 1 & 1 & 1 & 3 & 3 & 3 & $\mathrm{I}^{\mathrm{M}}, \mathrm{O}^{2}$ \\
Mink & 2 & 2 & 2 & 2 & 3 & 3 & $\mathrm{I}^{\mathrm{M}}$ \\
Wolverine & 3 & 2 & 3 & 3 & 3 & 3 & $\mathrm{I}^{\mathrm{M}}$ \\
Striped Skunk & 2 & 2 & 2 & 2 & 3 & 3 & $\mathrm{I}^{\mathrm{M}}$ \\
Northern River Otter & 2 & 2 & 2 & 2 & 3 & 3 & $\mathrm{I}^{\mathrm{M}}$ \\
Lynx & 3 & 2 & 3 & 3 & 3 & 3 & $\mathrm{I}^{\mathrm{M}}{ }^{\mathrm{M}} \mathrm{O}^{2}$ \\
Bobcat & 2 & 2 & 2 & 2 & 3 & 3 & $\mathrm{I}^{\mathrm{M}}, \mathrm{O}^{2}$ \\
Mountain Lion & 3 & 2 & 3 & 4 & 3 & 3 & $\mathrm{I}^{\mathrm{M}}$ \\
Wapiti Or Elk & 3 & 2 & 3 & 4 & 3 & 3 & $\mathrm{I}^{\mathrm{M}}$ \\
Mule Deer & 3 & 2 & 3 & 4 & 3 & 3 & $\mathrm{I}^{\mathrm{M}}$ \\
White-tailed Deer & 3 & 2 & 3 & 4 & 3 & 3 & $\mathrm{I}^{\mathrm{M}}$ \\
Moose & 3 & 2 & 3 & 4 & 3 & 3 & $\mathrm{I}^{\mathrm{M}}$ \\
Caribou & 1 & 1 & 1 & 1 & 3 & 3 & $\mathrm{I}^{1}, \mathrm{I}^{7}$ \\
Pronghorn & 3 & 2 & 3 & 4 & 3 & 3 & $\mathrm{I}^{\mathrm{M}}$ \\
American Bison & 1 & 1 & 1 & 3 & 3 & 3 & $\mathrm{I}^{\mathrm{M}}, \mathrm{O}^{2}$ \\
Mountain Goat & 3 & 2 & 3 & 4 & 3 & 3 & $\mathrm{I}^{\mathrm{M}}$ \\
Bighorn Sheep & 3 & 2 & 3 & 4 & 3 & 3 & $\mathrm{I}^{\mathrm{M}}$ \\
Feral Horse & 1 & 4 & 3 & 3 & 3 & 3 & $\mathrm{I}^{\mathrm{M}}$ \\
Painted Turtle & 3 & 2 & 3 & 1 & 3 & 3 & $\mathrm{I}^{\mathrm{M}}$ \\
Western Terrestrial Garter Snake & 3 & 2 & 3 & 1 & 3 & 3 & $\mathrm{I}^{\mathrm{M}}$ \\
Common Garter Snake & 3 & 2 & 3 & 1 & 3 & 3 & $\mathrm{I}^{\mathrm{M}}$ \\
White Heelsplitter & 1 & 2 & 2 & 1 & 3 & 3 & $\mathrm{I}^{1}, \mathrm{I}^{4}$ \\
\hline
\end{tabular}



Table 10. Bitterroot/Frenchtown Valleys Focus Area-Species Associations

\begin{tabular}{|c|c|c|c|c|}
\hline TOTAL: 342 & TIER II: 96 & Marbled Godwit & /eery & Idaho Pocket Gopher \\
\hline $\begin{array}{c}\text { Group Breakdown } \\
\text { Amphibians: } 8 \\
\text { Birds: } 252 \\
\text { Mammals: } 73 \\
\text { Reptiles: } 9\end{array}$ & $\begin{array}{l}\text { Long-toed Salamander } \\
\text { Tailed Frog } \\
\text { Pacific Treefrog } \\
\text { Columbia Spotted Frog } \\
\text { Horned Grebe } \\
\text { Red-necked Grebe } \\
\text { Western Grebe }\end{array}$ & $\begin{array}{l}\text { Franklin's Gull } \\
\text { Caspian Tern } \\
\text { Common Tern } \\
\text { Forster's Tern } \\
\text { Northern Pygmy-owl } \\
\text { Barred Owl } \\
\text { Great Gray Owl }\end{array}$ & $\begin{array}{l}\text { Loggerhead Shrike } \\
\text { American Redstart } \\
\text { Yellow-breasted Chat } \\
\text { Green-tailed Towhee } \\
\text { Clay-colored Sparrow } \\
\text { Brewer's Sparrow } \\
\text { Baird's Sparrow }\end{array}$ & $\begin{array}{l}\text { Water Vole } \\
\text { American Marten } \\
\text { Fisher } \\
\text { Wolverine } \\
\text { American Badger } \\
\text { Western Spotted Skunk } \\
\text { Northern River Otter }\end{array}$ \\
\hline Harlequin Duck & Turkey Vulture & Broad-tailed Hummingbird & Vagrant Shrew & TIER III: 210 \\
\hline
\end{tabular}


DRAFT WORKING DOCUMENT DO NOT DUPLICATE

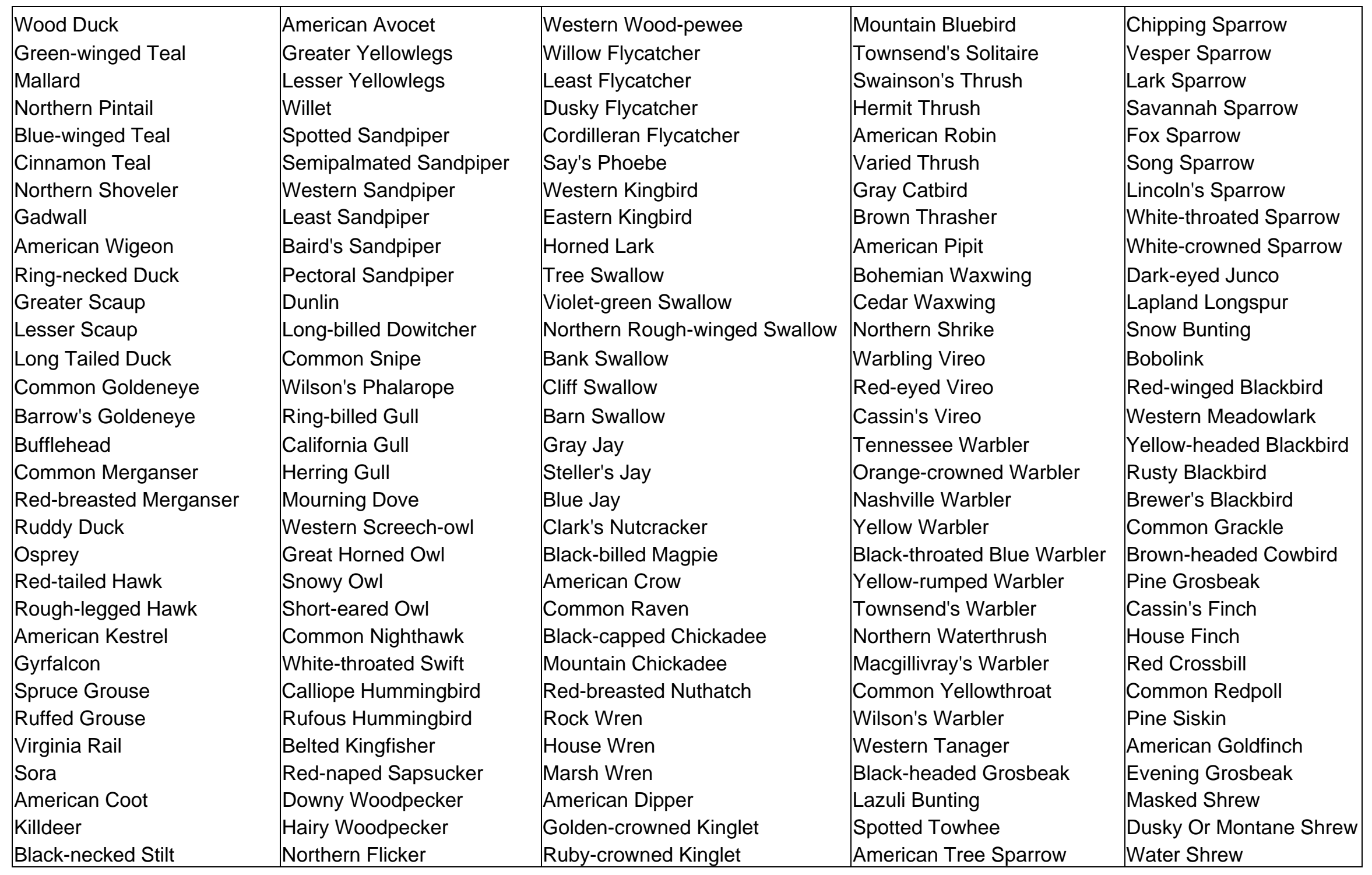




\begin{tabular}{|l|l|}
\hline Little Brown Myotis & Mountain Lion \\
American Pika & Wapiti Or Elk \\
Snowshoe Hare & Mule Deer \\
Least Chipmunk & White-tailed Deer \\
Yellow-pine Chipmunk & Moose \\
Red-tailed Chipmunk & Mountain Goat \\
Yellow-bellied Marmot & Bighorn Sheep \\
Columbian Ground Squirrel & Painted Turtle \\
Golden-mantled Ground Squirrel & Racer \\
Eastern Fox Squirrel & Gopher Snake \\
Red Squirrel & Western Terrestrial Garter Snake \\
Northern Pocket Gopher & \\
& \\
\cline { 2 - 2 } Deer Mouse & Bullfrog \\
Bushy-tailed Woodrat & Gray Partridge \\
Southern Red-backed Vole & Chukar \\
Heather Vole & Ring-necked Pheasant \\
Meadow Vole & Wild Turkey \\
Montane Vole & Bonaparte's Gull \\
Long-tailed Vole & Rock Dove \\
Muskrat & Yellow-bellied Sapsucker \\
Western Jumping Mouse & European Starling \\
Common Porcupine & Chestnut-sided Warbler \\
Coyote & Palm Warbler \\
Red Fox & Blackpoll Warbler \\
Black Bear & Rose-breasted Grosbeak \\
Ermine & House Sparrow \\
Long-tailed Weasel & Eastern Gray Squirrel \\
Mink & Norway Rat \\
Striped Skunk & House Mouse \\
Bobcat & Common Raccoon \\
\hline
\end{tabular}


Table 11. Central Montana Broad Valleys Focus Area-Species Associations

\begin{tabular}{|c|c|c|c|c|}
\hline TOTAL: 317 & Tiger Salamander & Alder Flycatcher & Silver-haired Bat & Cattle Egret \\
\hline $\begin{array}{l}\text { Group Breakdown } \\
\text { Amphibians: } 9 \\
\text { Birds: } 228 \\
\text { Mammals: } 73 \\
\text { Reptiles: } 7\end{array}$ & $\begin{array}{l}\text { Tailed Frog } \\
\text { Woodhouse's Toad } \\
\text { Plains Spadefoot } \\
\text { Columbia Spotted Frog } \\
\text { Horned Grebe } \\
\text { Western Grebe } \\
\text { American Bittern } \\
\text { Canvasback }\end{array}$ & $\begin{array}{l}\text { Hammond's Flycatcher } \\
\text { Pinyon Jay } \\
\text { White-breasted Nuthatch } \\
\text { Canyon Wren } \\
\text { Western Bluebird } \\
\text { Veery } \\
\text { Loggerhead Shrike } \\
\text { American Redstart }\end{array}$ & $\begin{array}{l}\text { Big Brown Bat } \\
\text { Hoary Bat } \\
\text { Mountain Cottontail } \\
\text { White-tailed Jackrabbit } \\
\text { Northern Flying Squirrel } \\
\text { Olive-backed Pocket Mouse } \\
\text { White-footed Mouse } \\
\text { Sagebrush Vole }\end{array}$ & $\begin{array}{l}\text { Tundra Swan } \\
\text { Greater White-fronted Goose } \\
\text { Snow Goose } \\
\text { Ross' Goose } \\
\text { Canada Goose } \\
\text { Wood Duck } \\
\text { Green-winged Teal } \\
\text { Mallard }\end{array}$ \\
\hline TIER I: 14 & Redhead & Clay-colored Sparrow & American Marten & Northern Pintail \\
\hline $\begin{array}{l}\text { Boreal Toad } \\
\text { Northern Leopard Frog } \\
\text { Common Loon } \\
\text { Bald Eagle } \\
\text { Sage-grouse } \\
\text { Mountain Plover } \\
\text { Long-billed Curlew } \\
\text { Black Tern }\end{array}$ & $\begin{array}{l}\text { Turkey Vulture } \\
\text { Northern Harrier } \\
\text { Sharp-shinned Hawk } \\
\text { Cooper's Hawk } \\
\text { Northern Goshawk } \\
\text { Swainson's Hawk } \\
\text { Ferruginous Hawk } \\
\text { Golden Eagle }\end{array}$ & $\begin{array}{l}\text { Brewer's Sparrow } \\
\text { Field Sparrow } \\
\text { Lark Bunting } \\
\text { Grasshopper Sparrow } \\
\text { Baltimore Oriole } \\
\text { Bullock's Oriole } \\
\text { Preble's Shrew } \\
\text { Vagrant Shrew }\end{array}$ & $\begin{array}{l}\text { Least Weasel } \\
\text { Wolverine } \\
\text { American Badger } \\
\text { Northern River Otter } \\
\text { Short-horned Lizard } \\
\text { Rubber Boa } \\
\text { Western Rattlesnake }\end{array}$ & $\begin{array}{l}\text { Blue-winged Teal } \\
\text { Cinnamon Teal } \\
\text { Northern Shoveler } \\
\text { Gadwall } \\
\text { Ring-necked Duck } \\
\text { Greater Scaup } \\
\text { Lesser Scaup } \\
\text { White-winged Scoter }\end{array}$ \\
\hline $\begin{array}{l}\text { Townsend's Big-eared Bat } \\
\text { Pallid Bat } \\
\text { Black-tailed Prairie Dog } \\
\text { Grizzly Bear } \\
\text { Lynx }\end{array}$ & $\begin{array}{l}\text { Prairie Falcon } \\
\text { Blue Grouse } \\
\text { Greater Sandhill Crane } \\
\text { Upland Sandpiper } \\
\text { Franklin's Gull } \\
\text { Common Tern }\end{array}$ & $\begin{array}{l}\text { Pygmy Shrew } \\
\text { Hayden's Shrew } \\
\text { Yuma Myotis } \\
\text { Long-eared Myotis } \\
\text { Fringed Myotis } \\
\text { Long-legged Myotis }\end{array}$ & $\begin{array}{l}\text { Boreal Chorus Frog } \\
\text { Pied-billed Grebe } \\
\text { Eared Grebe } \\
\text { Clark's Grebe } \\
\text { American White Pelican } \\
\text { Double-crested Cormorant }\end{array}$ & $\begin{array}{l}\text { Barrow's Goldeneye } \\
\text { Bufflehead } \\
\text { Common Merganser } \\
\text { Red-breasted Merganser } \\
\text { Ruddy Duck } \\
\text { Osprey }\end{array}$ \\
\hline TIER II: 72 & Forster's Tern & Western Small-footed & Great Blue Heron & Red-tailed Hawk \\
\hline Long-toed Salamander & Northern Saw-whet Owl & Northern Myotis & Snowy Egret & Rough-legged Hawk \\
\hline
\end{tabular}


DRAFT WORKING DOCUMENT DO NOT DUPLICATE

14438

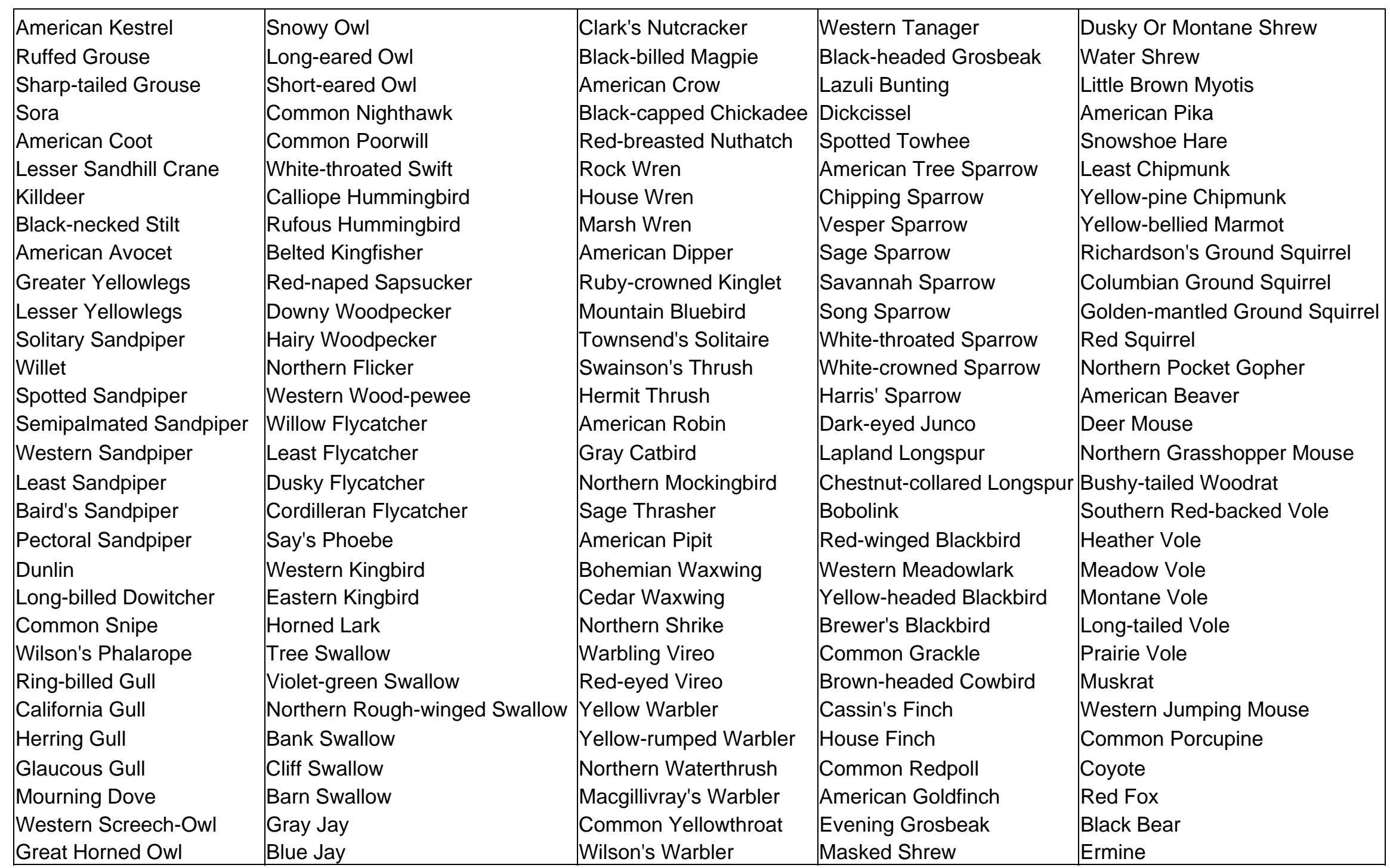




\begin{tabular}{|l|l|}
\hline Long-tailed Weasel & Ruddy Turnstone \\
Mink & Sanderling \\
Striped Skunk & Stilt Sandpiper \\
Bobcat & Buff-breasted Sandpiper \\
Wapiti Or Elk & Short-billed Dowitcher \\
Mule Deer & Red-necked Phalarope \\
White-tailed Deer & Pomarine Jaeger \\
Moose & Bonaparte's Gull \\
Pronghorn & Rock Dove \\
Mountain Goat & Band-tailed Pigeon \\
Painted Turtle & Scissor-tailed Flycatcher \\
Racer & Gray-cheeked Thrush \\
Gopher Snake & European Starling \\
Western Terrestrial Garter Snake & Scarlet Tanager \\
\hline \multicolumn{1}{|c}{ TIER IV: 32} & Rose-breasted Grosbeak \\
\hline \hline Great Egret & House Sparrow \\
Mute Swan & House Mouse \\
Eurasian Wigeon & Common Raccoon \\
Surf Scoter & \\
Broad-winged Hawk & \\
Gray Partridge & \\
Chukar & \\
Ring-necked Pheasant & \\
Wild Turkey & \\
Black-bellied Plover & \\
American Golden-plover & \\
Semipalmated Plover & \\
Whimbrel \\
Hudsonian Godwit & \\
\hline
\end{tabular}


Table 12. Deerlodge Valley Focus Area-Species Associations

\begin{tabular}{|c|c|c|c|c|}
\hline TOTAL: 260 & American Bittern & Brown Creeper & American Badger & Common Goldeneye \\
\hline \multirow{7}{*}{$\begin{array}{c}\text { Group Breakdown } \\
\text { Amphibians: } 4 \\
\text { Birds: } 189 \\
\text { Mammals: } 60 \\
\text { Reptiles: } 6\end{array}$} & \multirow{2}{*}{$\begin{array}{l}\text { Black-crowned Night-heron } \\
\text { White-faced lbis }\end{array}$} & \multirow{2}{*}{$\begin{array}{l}\text { Western Bluebird } \\
\text { Veery }\end{array}$} & \multirow{2}{*}{$\begin{array}{l}\text { Northern River Otter } \\
\text { Rubber Boa }\end{array}$} & \multirow{2}{*}{$\begin{array}{l}\text { Barrow's Goldeneye } \\
\text { Bufflehead }\end{array}$} \\
\hline & & & & \\
\hline & \multirow{3}{*}{ Canvasback } & \multirow{3}{*}{$\begin{array}{l}\text { Loggerhead Shrike } \\
\text { Indigo Bunting } \\
\text { Green-tailed Towhee }\end{array}$} & & Common Merganser \\
\hline & & & \multirow{2}{*}{ Western Rattlesnake } & Red-breasted Merganser \\
\hline & & & & Ruddy Duck \\
\hline & Northern Harrier & Clay-colored Sparrow & TIER III: 177 & Osprey \\
\hline & Sharp-shinned Hawk & Brewer's Sparrow & Pied-billed Grebe & Rough-legged Hawk \\
\hline TIER I: 10 & Northern Goshawk & Lark Bunting & Eared Grebe & American Kestrel \\
\hline Boreal Toad & Swainson's Hawk & Bullock's Oriole & American White Pelican & Ruffed Grouse \\
\hline Northern Leopard Frog & Ferruginous Hawk & Preble's Shrew & Double-crested Cormorant & Sharp-tailed Grouse \\
\hline Common Loon & Golden Eagle & Vagrant Shrew & Great Blue Heron & Virginia Rail \\
\hline Trumpeter Swan & Blue Grouse & Yuma Myotis & Cattle Egret & Sora \\
\hline Harlequin Duck & Greater Sandhill Crane & Long-eared Myotis & Tundra Swan & American Coot \\
\hline Bald Eagle & Franklin's Gull & Fringed Myotis & Greater White-fronted Goose & Lesser Sandhill Crane \\
\hline Long-billed Curlew & Caspian Tern & Long-legged Myotis & Snow Goose & Killdeer \\
\hline Black Tern & Common Tern & Western Small-footed Myotis & Canada Goose & Black-necked Stilt \\
\hline Townsend's Big-eared Bat & Northern Pygmy-owl & Silver-haired Bat & Wood Duck & American Avocet \\
\hline Lynx & Great Gray Owl & Big Brown Bat & Green-winged Teal & Greater Yellowlegs \\
\hline & Northern Saw-whet Owl & Hoary Bat & Mallard & Lesser Yellowlegs \\
\hline & Black-chinned Hummingbird & Mountain Cottontail & Northern Pintail & Solitary Sandpiper \\
\hline TIER II: 64 & Lewis' Woodpecker & White-tailed Jackrabbit & Blue-winged Teal & Willet \\
\hline Long-toed Salamander & Williamson's Sapsucker & Northern Flying Squirrel & Cinnamon Teal & Spotted Sandpiper \\
\hline Columbia Spotted Frog & Pileated Woodpecker & Water Vole & Northern Shoveler & Western Sandpiper \\
\hline Horned Grebe & Hammond's Flycatcher & Sagebrush Vole & Gadwall & Least Sandpiper \\
\hline Red-necked Grebe & White-breasted Nuthatch & American Marten & Greater Scaup & Baird's Sandpiper \\
\hline Western Grebe & Pygmy Nuthatch & Fisher & Lesser Scaup & Pectoral Sandpiper \\
\hline
\end{tabular}


DRAFT WORKING DOCUMENT DO NOT DUPLICATE

14443

\begin{tabular}{|c|c|c|c|c|}
\hline Long-billed Dowitcher & Cliff Swallow & Macgillivray's Warbler & Masked Shrew & Striped Skunk \\
\hline Common Snipe & Barn Swallow & Common Yellowthroat & Dusky Or Montane Shrew & Bobcat \\
\hline Wilson's Phalarope & Gray Jay & Wilson's Warbler & Water Shrew & Wapiti Or Elk \\
\hline Ring-billed Gull & Steller's Jay & Western Tanager & Little Brown Myotis & Mule Deer \\
\hline California Gull & Clark's Nutcracker & Black-headed Grosbeak & Snowshoe Hare & White-tailed Deer \\
\hline Herring Gull & Black-billed Magpie & Lazuli Bunting & Least Chipmunk & Moose \\
\hline Mourning Dove & American Crow & Spotted Towhee & Yellow-pine Chipmunk & Pronghorn \\
\hline Great Horned Owl & Black-capped Chickadee & American Tree Sparrow & Red-tailed Chipmunk & Racer \\
\hline Common Nighthawk & Rock Wren & Chipping Sparrow & Yellow-bellied Marmot & Gopher Snake \\
\hline White-throated Swift & House Wren & Vesper Sparrow & Columbian Ground Squirrel & Western Terrestrial Garter Snake \\
\hline Calliope Hummingbird & Marsh Wren & Lark Sparrow & Golden-mantled Ground Squirrel & \\
\hline Rufous Hummingbird & American Dipper & Savannah Sparrow & Red Squirrel & TIER IV: 8 \\
\hline Belted Kingfisher & Golden-crowned Kinglet & Song Sparrow & Northern Pocket Gopher & Gray Partridge \\
\hline Red-naped Sapsucker & Ruby-crowned Kinglet & White-throated Sparrow & American Beaver & Ring-necked Pheasant \\
\hline Downy Woodpecker & Mountain Bluebird & White-crowned Sparrow & Deer Mouse & Wild Turkey \\
\hline Hairy Woodpecker & Townsend's Solitaire & Dark-eyed Junco & Bushy-tailed Woodrat & Rock Dove \\
\hline Northern Flicker & Swainson's Thrush & Bobolink & Southern Red-backed Vole & European Starling \\
\hline Western Wood-pewee & Hermit Thrush & Red-winged Blackbird & Heather Vole & House Sparrow \\
\hline Willow Flycatcher & American Robin & Western Meadowlark & Meadow Vole & House Mouse \\
\hline Least Flycatcher & Gray Catbird & Yellow-headed Blackbird & Montane Vole & Common Raccoon \\
\hline Dusky Flycatcher & American Pipit & Brewer's Blackbird & Long-tailed Vole & \\
\hline Cordilleran Flycatcher & Bohemian Waxwing & Common Grackle & Muskrat & \\
\hline Say's Phoebe & Cedar Waxwing & Brown-headed Cowbird & Western Jumping Mouse & \\
\hline Western Kingbird & Northern Shrike & Pine Grosbeak & Common Porcupine & \\
\hline Eastern Kingbird & Warbling Vireo & Cassin's Finch & Coyote & \\
\hline Horned Lark & Red-eyed Vireo & House Finch & Red Fox & \\
\hline Tree Swallow & Yellow Warbler & Common Redpoll & Black Bear & \\
\hline Violet-green Swallow & Yellow-rumped Warbler & Hoary Redpoll & Ermine & \\
\hline Northern Rough-winged Swallow & Townsend's Warbler & American Goldfinch & Long-tailed Weasel & \\
\hline Bank Swallow & Northern Waterthrush & Evening Grosbeak & Mink & \\
\hline
\end{tabular}


Table 13. Flathead River Valley Focus Area-Species Associations

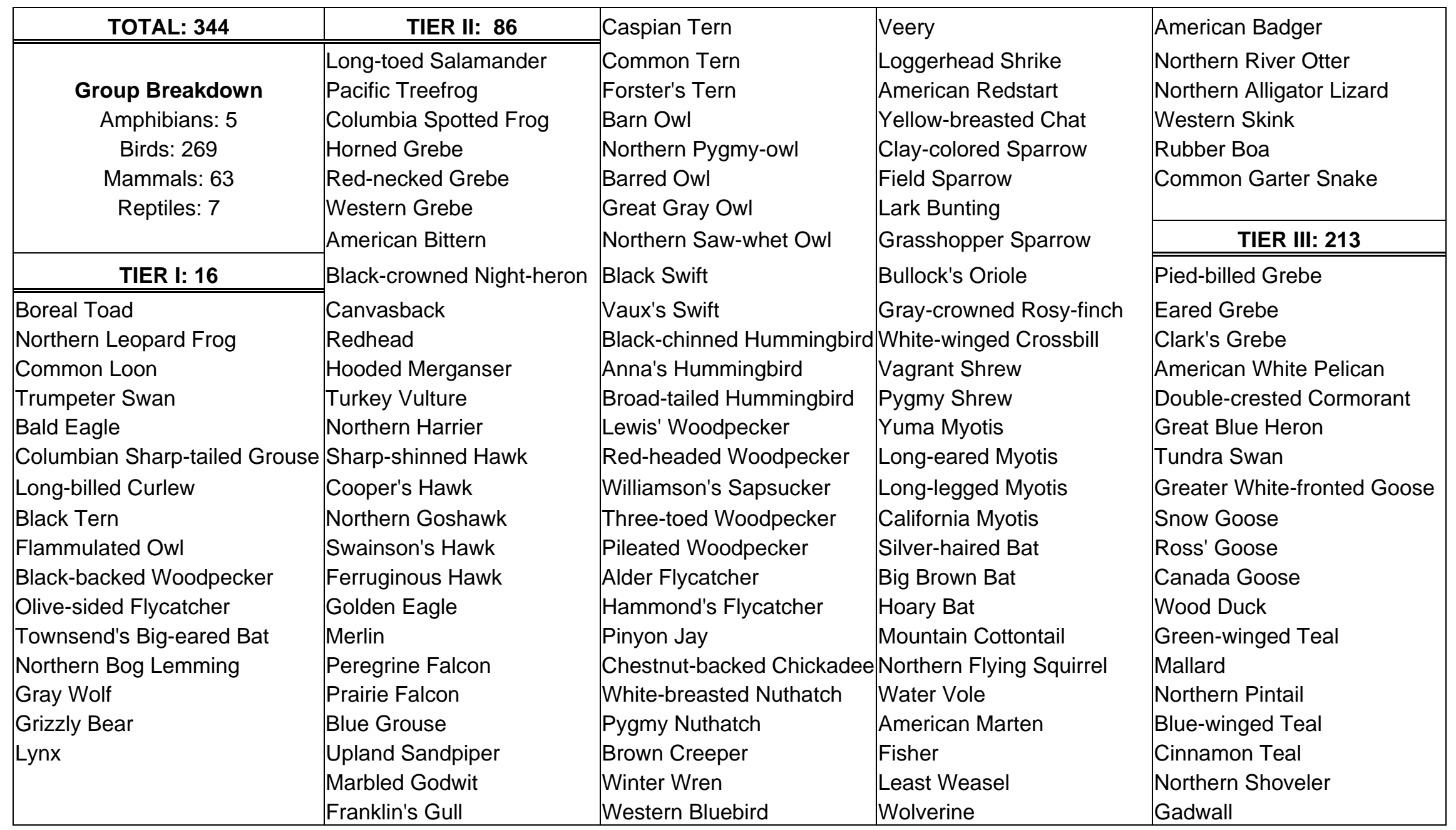


DRAFT WORKING DOCUMENT DO NOT DUPLICATE

14448

\begin{tabular}{|c|c|c|c|c|}
\hline American Wigeon & Semipalmated Sandpiper & Northern Flicker & Golden-crowned Kinglet & American Tree Sparrow \\
\hline ked Duck & per & d-pewee & Kinglet & rrow \\
\hline Greater Scaup & Ipiper & Willow Flycatcher & ird & Vesper Sparrow \\
\hline & Sandpiper & & taire & La! \\
\hline ailed Duck & andpiper & tcher & hrush & Sparrow \\
\hline White-winged Scoter & ndpiper & /catcher & $\mathrm{He}$ & Fox \\
\hline Common Goldeneye & & & & So \\
\hline Barrow's Goldeneye & Long-billed Dowitcher & Western K & ush & Lincoln's Sparrow \\
\hline & & & & \\
\hline rganser & W & & ingbird & Sparrow \\
\hline Red-breasted Merganser & Rin & $\operatorname{Tr}$ & $\mathrm{Ar}$ & Sparrow \\
\hline ck & & vallow & Bor & \\
\hline & & gh-winged Swallow & $\mathrm{Cec}$ & co \\
\hline wk & ged Gull & & & ared Longspur \\
\hline Rough-legged Hawk & Gla & & Wa & \\
\hline Kestrel & & & & \\
\hline Gyr & Mc & & & $\mathrm{R}$ \\
\hline Grouse & West & Jay & Narbler & We \\
\hline Virginia Rail & rned Owl & & & Yello \\
\hline Sora & Sn & utcracker & $Y e$ & Rus \\
\hline Coot & & & Ye & $\mathrm{Bre}$ \\
\hline Lesser Sandhill Crane & & & & Com \\
\hline Killdeer & & & & $\mathrm{Brc}$ \\
\hline k-necked Stilt & Swift & jed Chick & $\mathrm{Ma}$ & beak \\
\hline American Avocet & Calliope Hummingbird & n Chickadee & n Yellowthroat & Purple Finch \\
\hline Greater Yellowlegs & Rufous Hummingbird & Red-breasted Nuthatch & S lorblor & Cassin's Finch \\
\hline Lesser Yellowlegs & Bel & & W & $\mathrm{Hc}$ \\
\hline Solitary Sandpiper & Red-naped Sapsucke & House Wren & Black-headed Gros & Red Crossbill \\
\hline & & Marsh Wren & Lazuli Bunting & Common Redpol \\
\hline Spotted Sandpiper & Hairy Woodpecker & American Dipper & Spotted Towhee & Hoary Redpoll \\
\hline
\end{tabular}


DRAFT WORKING DOCUMENT DO NOT DUPLICATE

\begin{tabular}{|c|c|c|}
\hline Pine Siskin & Ermine & \multirow{29}{*}{\begin{tabular}{|l} 
Stilt Sandpiper \\
Short-billed Dowitcher \\
Red-necked Phalarope \\
Bonaparte's Gull \\
Thayer's Gull \\
Rock Dove \\
Scissor-tailed Flycatcher \\
European Starling \\
Magnolia Warbler \\
Mourning Warbler \\
Scarlet Tanager \\
Rose-breasted Grosbeak \\
House Sparrow \\
House Mouse \\
Common Raccoon
\end{tabular}} \\
\hline American Goldfinch & Long-tailed Weasel & \\
\hline Evening Grosbeak & Mink & \\
\hline Masked Shrew & Striped Skunk & \\
\hline Dusky Or Montane Shrew & Bobcat & \\
\hline Water Shrew & Mountain Lion & \\
\hline Little Brown Myotis & Wapiti Or Elk & \\
\hline Desert Cottontail & Mule Deer & \\
\hline Snowshoe Hare & White-tailed Deer & \\
\hline Least Chipmunk & Moose & \\
\hline Yellow-pine Chipmunk & Bighorn Sheep & \\
\hline Red-tailed Chipmunk & Painted Turtle & \\
\hline Yellow-bellied Marmot & Gopher Snake & \\
\hline $\begin{array}{l}\text { Richardson's Ground Squirrel } \\
\text { Columbian Ground Squirrel }\end{array}$ & Western Terrestrial Garter Snake & \\
\hline Golden-mantled Ground Squirrel & TIER IV: 29 & \\
\hline Red Squirrel & Green Heron & \\
\hline Northern Pocket Gopher & Brant & \\
\hline American Beaver & Eurasian Wigeon & \\
\hline Deer Mouse & Surf Scoter & \\
\hline Bushy-tailed Woodrat & Gray Partridge & \\
\hline Southern Red-backed Vole & Chukar & \\
\hline Heather Vole & Ring-necked Pheasant & \\
\hline Meadow Vole & Wild Turkey & \\
\hline Long-tailed Vole & Black-bellied Plover & \\
\hline Muskrat & American Golden-plover & \\
\hline Common Porcupine & Semipalmated Plover & \\
\hline Coyote & Whimbrel & \\
\hline Red Fox & Hudsonian Godwit & \\
\hline Black Bear & Sanderling & \\
\hline
\end{tabular}


Table 14. Little Belt Foothills Focus Area-Species Associations

\begin{tabular}{|c|c|c|c|c|}
\hline TOTAL: 293 & TIER II: 72 & Lewis' Woodpecker & Fringed Myotis & Great Blue Heron \\
\hline $\begin{array}{l}\text { Group Breakdown } \\
\text { Amphibians: } 9 \\
\text { Birds: } 204 \\
\text { Mammals: } 68 \\
\text { Reptiles: } 12\end{array}$ & $\begin{array}{l}\text { Tiger Salamander } \\
\text { Great Plains Toad } \\
\text { Woodhouse's Toad } \\
\text { Plains Spadefoot } \\
\text { Columbia Spotted Frog } \\
\text { Western Grebe } \\
\text { American Bittern }\end{array}$ & $\begin{array}{l}\text { Pinyon Jay } \\
\text { White-breasted Nuthatch } \\
\text { Brown Creeper } \\
\text { Canyon Wren } \\
\text { Eastern Bluebird } \\
\text { Western Bluebird } \\
\text { Veery }\end{array}$ & $\begin{array}{l}\text { Long-legged Myotis } \\
\text { Western Small-footed Myotis } \\
\text { Silver-haired Bat } \\
\text { Big Brown Bat } \\
\text { Hoary Bat } \\
\text { Mountain Cottontail } \\
\text { White-tailed Jackrabbit }\end{array}$ & $\begin{array}{l}\text { Tundra Swan } \\
\text { Snow Goose } \\
\text { Ross' Goose } \\
\text { Canada Goose } \\
\text { Green-winged Teal } \\
\text { Mallard } \\
\text { Northern Pintail }\end{array}$ \\
\hline TIER I: 13 & Turkey Vulture & Sprague's Pipit & Olive-backed Pocket Mouse & Blue-winged Teal \\
\hline $\begin{array}{l}\text { Boreal Toad } \\
\text { Northern Leopard Frog } \\
\text { Bald Eagle } \\
\text { Sage-grouse } \\
\text { Mountain Plover } \\
\text { Long-billed Curlew } \\
\text { Black Tern } \\
\text { Burrowing Owl } \\
\text { Townsend's Big-eared Bat } \\
\text { Black-tailed Prairie Dog } \\
\text { Black-footed Ferret }\end{array}$ & $\begin{array}{l}\text { Northern Harrier } \\
\text { Sharp-shinned Hawk } \\
\text { Cooper's Hawk } \\
\text { Northern Goshawk } \\
\text { Swainson's Hawk } \\
\text { Ferruginous Hawk } \\
\text { Golden Eagle } \\
\text { Merlin } \\
\text { Peregrine Falcon } \\
\text { Prairie Falcon } \\
\text { Blue Grouse }\end{array}$ & $\begin{array}{l}\text { Loggerhead Shrike } \\
\text { American Redstart } \\
\text { Yellow-breasted Chat } \\
\text { Clay-colored Sparrow } \\
\text { Brewer's Sparrow } \\
\text { Field Sparrow } \\
\text { Lark Bunting } \\
\text { Baird's Sparrow } \\
\text { Grasshopper Sparrow } \\
\text { Mccown's Longspur } \\
\text { Baltimore Oriole }\end{array}$ & $\begin{array}{l}\text { Ord's Kangaroo Rat } \\
\text { Sagebrush Vole } \\
\text { Swift Fox } \\
\text { Least Weasel } \\
\text { American Badger } \\
\text { Short-horned Lizard } \\
\text { Sagebrush Lizard } \\
\text { Rubber Boa } \\
\text { Common Garter Snake } \\
\text { Western Rattlesnake }\end{array}$ & $\begin{array}{l}\text { Cinnamon Teal } \\
\text { Northern Shoveler } \\
\text { Gadwall } \\
\text { American Wigeon } \\
\text { Ring-necked Duck } \\
\text { Lesser Scaup } \\
\text { Common Goldeneye } \\
\text { Bufflehead } \\
\text { Common Merganser } \\
\text { Ruddy Duck } \\
\text { Osprey }\end{array}$ \\
\hline Western Hognose Snake & Greater Sandhill Crane & Bullock's Oriole & TIER III: 195 & Red-tailed Hawk \\
\hline Milk Snake & $\begin{array}{l}\text { Upland Sandpiper } \\
\text { Marbled Godwit } \\
\text { Franklin's Gull } \\
\text { Northern Pygmy-owl } \\
\text { Great Gray Owl } \\
\text { Northern Saw-whet Owl }\end{array}$ & $\begin{array}{l}\text { Preble's Shrew } \\
\text { Vagrant Shrew } \\
\text { Dwarf Shrew } \\
\text { Hayden's Shrew } \\
\text { Yuma Myotis } \\
\text { Long-eared Myotis } \\
\end{array}$ & $\begin{array}{l}\text { Boreal Chorus Frog } \\
\text { Great Basin Spadefoot } \\
\text { Pied-billed Grebe } \\
\text { Eared Grebe } \\
\text { American White Pelican } \\
\text { Double-crested Cormorant }\end{array}$ & $\begin{array}{l}\text { Rough-legged Hawk } \\
\text { American Kestrel } \\
\text { Gyrfalcon } \\
\text { Ruffed Grouse } \\
\text { Sharp-tailed Grouse } \\
\text { Virginia Rail }\end{array}$ \\
\hline
\end{tabular}


DRAFT WORKING DOCUMENT DO NOT DUPLICATE

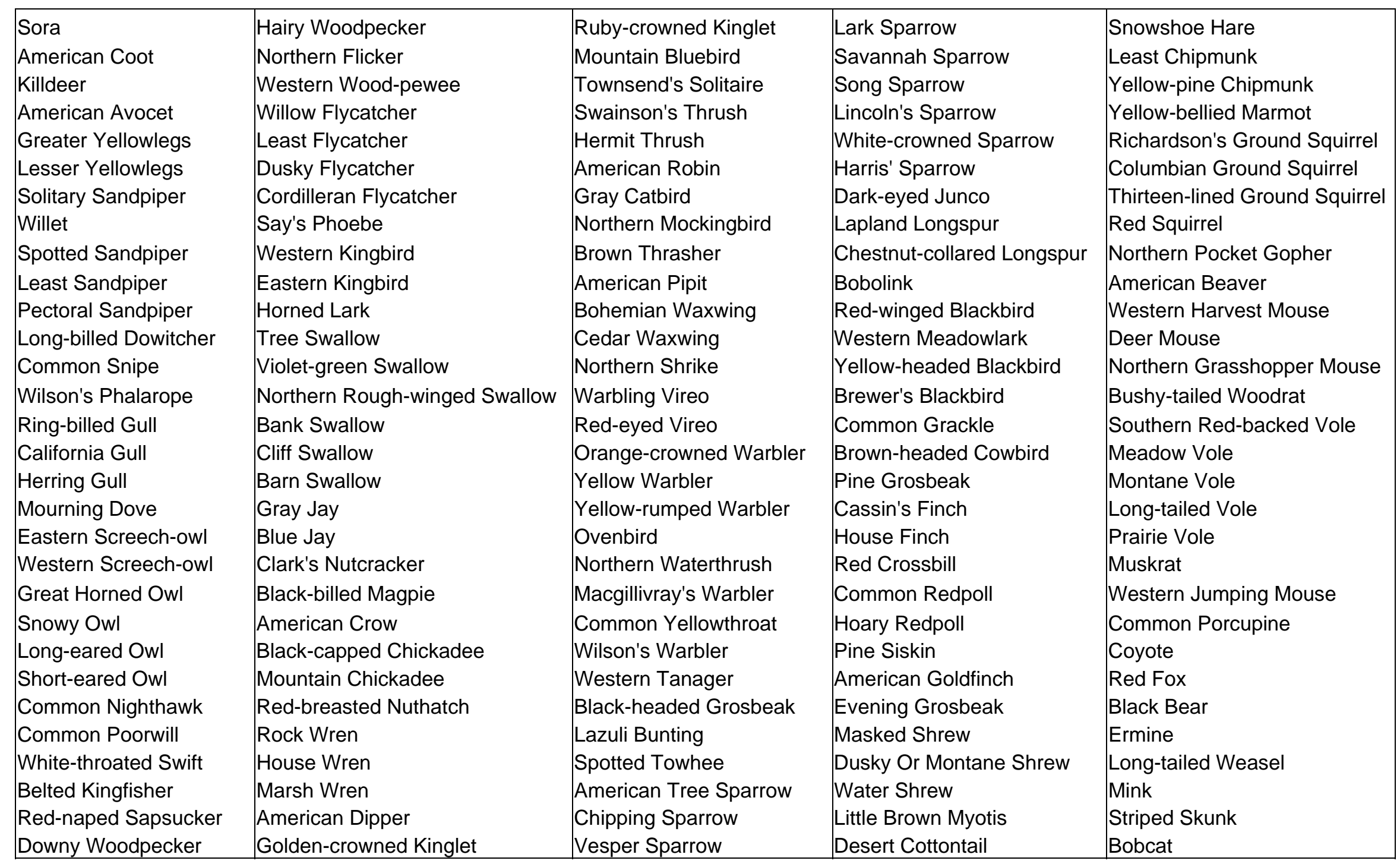


14454

Wapiti Or Elk

Mule Deer

White-tailed Deer

Moose

Pronghorn

Mountain Goat

Bighorn Sheep

Painted Turtle

Racer

Gopher Snake

Western Terrestrial Garter Snake

Plains Garter Snake

TIER IV: 10

Gray Partridge

Ring-necked Pheasant

Wild Turkey

Red-necked Phalarope

Bonaparte's Gull

Rock Dove

European Starling

House Sparrow

House Mouse

14455

14456

14457

14458

14459

14460 
Table 15. North Tobacco Root Mountains and Foothills Focus Area-Species Associations

\begin{tabular}{|c|c|c|c|c|}
\hline TOTAL: 244 & \multirow{8}{*}{$\begin{array}{l}\text { Ferruginous Hawk } \\
\text { Golden Eagle } \\
\text { Merlin } \\
\text { Prairie Falcon } \\
\text { Blue Grouse } \\
\text { Greater Sandhill Crane } \\
\text { Northern Saw-whet Owl } \\
\text { Alder Flycatcher } \\
\text { Hammond's Flycatcher }\end{array}$} & \multirow{3}{*}{$\begin{array}{l}\text { Western Small-footed Myotis } \\
\text { Silver-haired Bat } \\
\text { Big Brown Bat }\end{array}$} & \multirow{2}{*}{$\begin{array}{l}\text { Mallard } \\
\text { Northern Pintail }\end{array}$} & \multirow{2}{*}{$\begin{array}{l}\text { Spotted Sandpiper } \\
\text { Semipalmated Sandpiper }\end{array}$} \\
\hline & & & & \\
\hline Group Breakdown & & & Blue-winged Teal & Western Sandpiper \\
\hline Amphibians: 5 & & Hoary Bat & Cinnamon Teal & Least Sandpiper \\
\hline Birds: 170 & & Mountain Cottontail & Northern Shoveler & Baird's Sandpiper \\
\hline Mammals: 63 & & White-tailed Jackrabbit & Ring-necked Duck & Pectoral Sandpiper \\
\hline Reptiles: 6 & & $\begin{array}{l}\text { Northern Flying Squirrel } \\
\text { Olive-backed Pocket Mouse }\end{array}$ & $\begin{array}{l}\text { Lesser Scaup } \\
\text { Common Goldeneye }\end{array}$ & $\begin{array}{l}\text { Long-billed Dowitcher } \\
\text { Common Snipe }\end{array}$ \\
\hline TIER I: 6 & & White-footed Mouse & Barrow's Goldeneye & Wilson's Phalarope \\
\hline Boreal Toad & White-breasted Nuthatch & Sagebrush Vole & Bufflehead & Ring-billed Gull \\
\hline Bald Eagle & Canyon Wren & American I & on Merganser & Califo \\
\hline Flammulated Owl & Western Bluebird & American Badger & Red-breasted Merganser & Mourning Dove \\
\hline Townsend's Big-eared Bat & Veery & Northern River Otter & Ruddy Duck & Eastern Screech-owl \\
\hline Grizzly Bear & Loggerhead Shrike & Rubber Boa & Osprey & Great Horned Owl \\
\hline Lynx & Clay-colored Sparrow & Western Rattlesnake & Red-tailed Hawk & Short-eared Owl \\
\hline & Brewer's Sparrow & & Rough-legged Haw & White-throated Swift \\
\hline TIER II: 52 & Baltimore Oriole & TIER III: 168 & American Kestrel & Calliope Hummingbird \\
\hline Long-toed Salamander & Bullock's Oriole & Boreal Chorus Frog & Ruffed Grouse & Rufous Hummingbird \\
\hline Tiger Salamander & Preble's Shrew & Pied-billed Grebe & Virginia Rail & Belted Kingfisher \\
\hline Tailed Frog & Vagrant Shrew & Eared Grebe & Sora & Red-naped Sapsucker \\
\hline Western Grebe & Merriam's Shrew & Clark's Grebe & American Coot & Downy Woodpecker \\
\hline Turkey Vulture & Pygmy Shrew & American White Pelican & Lesser Sandhill Crane & Hairy Woodpecker \\
\hline Northern Harrier & Hayden's Shrew & Double-crested Cormorant & Killdeer & Northern Flicker \\
\hline Sharp-shinned Hawk & Yuma Myotis & Great Blue Heron & American Avocet & Western Wood-pewee \\
\hline Cooper's Hawk & Long-eared Myotis & Cattle Egret & Greater Yellowlegs & Willow Flycatcher \\
\hline Northern Goshawk & Fringed Myotis & Canada Goose & Lesser Yellowlegs & Least Flycatcher \\
\hline Swainson's Hawk & Long-legged Myotis & Green-winged Teal & Solitary Sandpiper & Dusky Flycatcher \\
\hline
\end{tabular}


DRAFT WORKING DOCUMENT DO NOT DUPLICATE

\begin{tabular}{|c|c|c|c|c|}
\hline $\begin{array}{l}\text { Cordilleran Flycatcher } \\
\text { Western Kingbird } \\
\text { Eastern Kingbird } \\
\text { Horned Lark } \\
\text { Tree Swallow } \\
\text { Violet-green Swallow } \\
\text { Northern Rough-winged Swallow } \\
\text { Bank Swallow } \\
\text { Cliff Swallow } \\
\text { Barn Swallow } \\
\text { Blue Jay } \\
\text { Clark's Nutcracker } \\
\text { Black-billed Magpie } \\
\text { American Crow } \\
\text { Black-capped Chickadee } \\
\text { Red-breasted Nuthatch } \\
\text { Rock Wren } \\
\text { House Wren } \\
\text { Marsh Wren } \\
\text { American Dipper } \\
\text { Ruby-crowned Kinglet } \\
\text { Mountain Bluebird } \\
\text { Townsend's Solitaire } \\
\text { Swainson's Thrush } \\
\text { Hermit Thrush } \\
\text { American Robin } \\
\text { Sage Thrasher } \\
\text { American Pipit } \\
\text { Bohemian Waxwing } \\
\text { Cedar Waxwing }\end{array}$ & $\begin{array}{l}\text { Northern Shrike } \\
\text { Warbling Vireo } \\
\text { Red-eyed Vireo } \\
\text { Yellow Warbler } \\
\text { Yellow-rumped Warbler } \\
\text { Ovenbird } \\
\text { Macgillivray's Warbler } \\
\text { Common Yellowthroat } \\
\text { Wilson's Warbler } \\
\text { Western Tanager } \\
\text { Black-headed Grosbeak } \\
\text { Lazuli Bunting } \\
\text { Spotted Towhee } \\
\text { American Tree Sparrow } \\
\text { Chipping Sparrow } \\
\text { Vesper Sparrow } \\
\text { Savannah Sparrow } \\
\text { Song Sparrow } \\
\text { White-crowned Sparrow } \\
\text { Harris' Sparrow } \\
\text { Dark-eyed Junco } \\
\text { Bobolink } \\
\text { Red-winged Blackbird } \\
\text { Western Meadowlark } \\
\text { Yellow-headed Blackbird } \\
\text { Brewer's Blackbird } \\
\text { Common Grackle } \\
\text { Brown-headed Cowbird } \\
\text { Cassin's Finch } \\
\text { House Finch } \\
\end{array}$ & $\begin{array}{l}\text { Common Redpoll } \\
\text { American Goldfinch } \\
\text { Evening Grosbeak } \\
\text { Masked Shrew } \\
\text { Dusky Or Montane Shrew } \\
\text { Water Shrew } \\
\text { Little Brown Myotis } \\
\text { Snowshoe Hare } \\
\text { Least Chipmunk } \\
\text { Yellow-pine Chipmunk } \\
\text { Yellow-bellied Marmot } \\
\text { Richardson's Ground Squirrel } \\
\text { Columbian Ground Squirrel } \\
\text { Golden-mantled Ground Squirrel } \\
\text { Red Squirrel } \\
\text { Northern Pocket Gopher } \\
\text { American Beaver } \\
\text { Deer Mouse } \\
\text { Bushy-tailed Woodrat } \\
\text { Southern Red-backed Vole } \\
\text { Heather Vole } \\
\text { Meadow Vole } \\
\text { Montane Vole } \\
\text { Long-tailed Vole } \\
\text { Muskrat } \\
\text { Western Jumping Mouse } \\
\text { Common Porcupine } \\
\text { Coyote } \\
\text { Red Fox } \\
\text { Black Bear }\end{array}$ & \begin{tabular}{l} 
Ermine \\
Long-tailed Weasel \\
Mink \\
Striped Skunk \\
Bobcat \\
Wapiti Or Elk \\
Mule Deer \\
White-tailed Deer \\
Moose \\
Pronghorn \\
Painted Turtle \\
Racer \\
Gopher Snake \\
Western Terrestrial Garter Snake \\
\multicolumn{1}{c}{ TIER IV: 18 } \\
Red-throated Loon \\
Great Egret \\
Broad-winged Hawk \\
Gray Partridge \\
Ring-necked Pheasant \\
Wild Turkey \\
American Golden-plover \\
Semipalmated Plover \\
Buff-breasted Sandpiper \\
Short-billed Dowitcher \\
Red-necked Phalarope \\
Rock Dove \\
Gray-cheeked Thrush \\
European Starling \\
\end{tabular} & $\begin{array}{l}\text { Scarlet Tanager } \\
\text { Rose-breasted Grosbeak } \\
\text { House Sparrow } \\
\text { Common Raccoon }\end{array}$ \\
\hline
\end{tabular}


Table 16. Rocky Mountain Front Foothills Focus Area-Species Associations

\begin{tabular}{|c|c|c|c|c|}
\hline TOTAL: 362 & Western Hognose Snake & Prairie Falcon & Veery & Silver-haired Bat \\
\hline \multirow{7}{*}{$\begin{array}{c}\text { Group Breakdown } \\
\text { Amphibians: } 9 \\
\text { Birds: } 270 \\
\text { Mammals: } 73 \\
\text { Reptiles: } 10\end{array}$} & TIER II: 95 & Blue Grouse & Sprague's Pipit & Big Brown Bat \\
\hline & Long-toed Salamander & Greater Sandhill Crane & Loggerhead Shrike & Hoa \\
\hline & Tiger Salamander & Upland Sandpiper & Black-and-white Warbler & Mountain Cottontail \\
\hline & Tailed Frog & Marbled Godwit & American Redstart & White-tailed Jackrabbit \\
\hline & Great Plains Toad & Franklin's Gull & Yellow-breasted Chat & Northern Flying Squirrel \\
\hline & defoot & rn & $\lg$ & Vole \\
\hline & Columbia Spotted Frog & Common Tern & Green-tailed Towhee & Swift \\
\hline TIER & Horned Grebe & Forster's Tern & Clay-colored Sparrow & American Marten \\
\hline Boreal Toad & Grebe & Iled Cuckoo & Brewer's Sparrow & Le \\
\hline Northern Leopard Frog & Wes & $y$-owl & ow & An \\
\hline Common Loon & American & wl & & Nor \\
\hline Trumpeter Swan & Black-crowned Night-heron & Northern Saw-whet Owl & Baird's Sparrow & Short-horned Lizard \\
\hline Harlequin Duck & White-faced Ibis & Black-chinned Hummingbird & Grasshopper Sparrow & Rubber Boa \\
\hline Bald Eagle & Canvasback & Broad-tailed Hummingbird & Le Conte's Sparrow & Common Garter Snake \\
\hline Piping Plover & Redhead & Lewis' Woodpecker & Mccown's Longspur & Western Rattlesnake \\
\hline Mountain Plover & Hooded Merganser & Pileated Woodpecker & Baltimore Oriole & TIER III: 219 \\
\hline Long-billed Curlew & Turkey Vulture & Alder Flycatcher & Bullock's Oriole & Boreal Chorus Frog \\
\hline Black Tern & Northern $\mathrm{H}$ & Hammond's Flycatcher & Preble's Shrew & lled Grebe \\
\hline Flammulated Owl & Sharp-shinned Hawk & Pinyon Jay & Vagrant Shrew & Eared Grebe \\
\hline Burrowing Owl & Cooper's Hawk & White-breasted Nuthatch & Dwarf Shrew & Clark's Grebe \\
\hline Townsend's Big-eared Bat & Northern Goshawk & Pygmy Nuthatch & Pygmy Shrew & American White Pelican \\
\hline Black-tailed Prairie Dog & Swainson's Hawk & Brown Creeper & Yuma Myotis & Double-crested Cormora \\
\hline Northern Bog Lemming & Ferruginous Hawk & Canyon Wren & Long-eared Myotis & Great Blue Heron \\
\hline Grizzly Bear & Golden Eagle & Winter Wren & Fringed Myotis & Snowy Egret \\
\hline Lynx & Merlin & Eastern Bluebird & Long-legged My & Cattle Egret \\
\hline American Bison & Peregrine Falcon & Western Bluebird & Western Small-footed Myotis & Tundra Swan \\
\hline
\end{tabular}


DRAFT WORKING DOCUMENT DO NOT DUPLICATE

14469

\begin{tabular}{|c|c|c|c|c|}
\hline Greater White-fronted Goose & Sharp-tailed Grouse & Long-eared Owl & Clark's Nutcracker & Ovenbird \\
\hline Snow Goose & Virginia Rail & hort-eared Owl & Black-billed Magpie & Northern Waterthrush \\
\hline Canada Goose & American Coot & Common Poorwill & Black-capped Chickadee & Common Yellowthroat \\
\hline Green-winged Teal & Black-necked Stilt & Calliope Hummingbird & Red-breasted Nuthatch & Western Tanager \\
\hline Mallard & American Avocet & Rufous Hummingbird & Rock Wren & Black-headed Grosbeak \\
\hline Northern Pintail & Greater Yellowlegs & Belted Kingfisher & House Wren & Lazuli Bunting \\
\hline Northern Shoveler & Willet & Hairy Woodpecker & Golden-crowned Kinglet & Chipping Sparrow \\
\hline $\mathrm{Ga}$ & ted Sandpiper & N & d Kinglet & row \\
\hline American Wigeon & Semipalmated Sandpiper & Western Wood-pewee & Mountain Bluebird & Lark Sparrow \\
\hline Ring-necked Duck & Western Sandpiper & Willow Flycatcher & Townsend's & Savannah Sparrow \\
\hline Greater Scaup & Least Sandpiper & catcher & Swainson's Thrush & Fox Sparrow \\
\hline Lesser Scaup & Baird's Sandpiper & Dusky Flycatcher & Thrush & rrow \\
\hline Bufflehead & Wilson's Phalarope & Horned Lark & American Pipit & Lapland Longspur \\
\hline Common Merganser & Ring-billed Gull & Tree Swallow & Bohemian Waxwing & Chestnut-collared Longspur \\
\hline Red-breasted Merganser & California Gull & Violet-green Swallow & Cedar Waxwing & Snow Bunting \\
\hline Ruddy Duck & Herring Gull & Northern Rough-winged Swallow & Northern Shrike & Bob \\
\hline Osprey & Glaucous Gull & Bank Swallow & Warbling Vireo & Red-winged Blackbird \\
\hline Red-tailed Hawk & Mourning Dove & Cliff Swallow & Red-eyed Vireo & Western Meadowlark \\
\hline Rough-legged Hawk & Eastern Screech-owl & Barn Swallow & Orange-crowned Warbler & Yellow-headed Blackbird \\
\hline American Kestrel & Western Screech-owl & Gray Jay & Yellow Warbler & Rusty Blackbird \\
\hline Gyrfalcon & Great Horned Owl & Steller's Ja & Yellow-rumped Warbl & Brewer's Blackbird \\
\hline Ruffed Grouse & Snowy Owl & Blue Jay & Townsend's Warbler & Common Grackle \\
\hline
\end{tabular}


DRAFT WORKING DOCUMENT DO NOT DUPLICATE

14470

\begin{tabular}{|c|c|c|}
\hline Brown-headed Cowbird & Bushy-tailed Woodrat & TIER IV: 29 \\
\hline Pine Grosbeak & Southern Red-backed Vole & Great Egret \\
\hline Cassin's Finch & Heather Vole & Green Heron \\
\hline House Finch & Meadow Vole & Brant \\
\hline Red Crossbill & Montane Vole & Eurasian Wigeon \\
\hline Common Redpoll & Long-tailed Vole & Black Scoter \\
\hline Hoary Redpoll & Muskrat & Surf Scoter \\
\hline Pine Siskin & Western Jumping Mouse & Gray Partridge \\
\hline American Goldfinch & Common Porcupine & Ring-necked Pheasant \\
\hline Evening Grosbeak & Coyote & Wild Turkey \\
\hline Masked Shrew & Red Fox & Black-bellied Plover \\
\hline Dusky Or Montane Shrew & Black Bear & American Golden-plover \\
\hline Water Shrew & Ermine & Semipalmated Plover \\
\hline Little Brown Myotis & Long-tailed Weasel & Whimbrel \\
\hline American Pika & Mink & Hudsonian Godwit \\
\hline Desert Cottontail & Striped Skunk & Ruddy Turnstone \\
\hline Snowshoe Hare & Bobcat & Red Knot \\
\hline Least Chipmunk & Wapiti Or Elk & Sanderling \\
\hline Yellow-pine Chipmunk & Mule Deer & Stilt Sandpiper \\
\hline Yellow-bellied Marmot & White-tailed Deer & Short-billed Dowitcher \\
\hline Richardson's Ground Squirrel & Moose & Red-necked Phalarope \\
\hline Columbian Ground Squirrel & Pronghorn & Red Phalarope \\
\hline Thirteen-lined Ground Squirrel & Mountain Goat & Bonaparte's Gull \\
\hline Golden-mantled Ground Squirrel & Bighorn Sheep & Rock Dove \\
\hline Red Squirrel & Painted Turtle & European Starling \\
\hline Northern Pocket Gopher & Racer & Palm Warbler \\
\hline American Beaver & Gopher Snake & Blackpoll Warbler \\
\hline Western Harvest Mouse & Western Terrestrial Garter Snake & House Sparrow \\
\hline Deer Mouse & Plains Garter Snake & House Mouse \\
\hline Northern Grasshopper Mouse & & Common Raccoon \\
\hline
\end{tabular}


Table 17. South Elkhorn Mountains Focus Area-Species Associations

\begin{tabular}{|c|c|c|c|c|}
\hline TO & \multirow{8}{*}{$\begin{array}{l}\text { Swainson's Hawk } \\
\text { Golden Eagle } \\
\text { Merlin } \\
\text { Prairie Falcon } \\
\text { Blue Grouse } \\
\text { Great Gray Owl } \\
\text { Boreal Owl } \\
\text { Northern Saw-whet Owl } \\
\text { Alder Flycatcher } \\
\text { Hammond's Flycatcher } \\
\text { White-breasted Nuthatch } \\
\text { Brown Creeper } \\
\text { Winter Wren } \\
\text { Western Bluebird } \\
\text { Veery } \\
\text { Loggerhead Shrike } \\
\text { Clay-colored Sparrow } \\
\text { Brewer's Sparrow } \\
\text { Baltimore Oriole } \\
\text { Bullock's Oriole } \\
\text { Black Rosy-finch } \\
\text { Gray-crowned Rosy-finch } \\
\text { White-winged Crossbill } \\
\text { Preble's Shrew } \\
\text { Vagrant Shrew } \\
\text { Merriam's Shrew } \\
\text { Hayden's Shrew } \\
\end{array}$} & \multirow{8}{*}{\begin{tabular}{l} 
Yuma Myotis \\
Long-eared Myotis \\
Long-legged Myotis \\
California Myotis \\
Western Small-footed Myotis \\
Silver-haired Bat \\
Big Brown Bat \\
Hoary Bat \\
Mountain Cottontail \\
White-tailed Jackrabbit \\
Northern Flying Squirrel \\
Olive-backed Pocket Mouse \\
White-footed Mouse \\
American Marten \\
Fisher \\
Least Weasel \\
Wolverine \\
American Badger \\
Northern River Otter \\
Western Rattlesnake \\
\multicolumn{1}{|c}{ TIER III: 168 } \\
Boreal Chorus Frog \\
Pied-billed Grebe \\
Eared Grebe \\
American White Pelican \\
Double-crested Cormorant \\
\end{tabular}} & \multirow{8}{*}{$\begin{array}{l}\text { Great Blue Heron } \\
\text { Canada Goose } \\
\text { Green-winged Teal } \\
\text { Mallard } \\
\text { Northern Pintail } \\
\text { Blue-winged Teal } \\
\text { Cinnamon Teal } \\
\text { Bufflehead } \\
\text { Common Merganser } \\
\text { Red-breasted Merganser } \\
\text { Ruddy Duck } \\
\text { Osprey } \\
\text { Red-tailed Hawk } \\
\text { Rough-legged Hawk } \\
\text { American Kestrel } \\
\text { Spruce Grouse } \\
\text { Ruffed Grouse } \\
\text { Sora } \\
\text { American Coot } \\
\text { Lesser Sandhill Crane } \\
\text { Killdeer } \\
\text { American Avocet } \\
\text { Greater Yellowlegs } \\
\text { Lesser Yellowlegs } \\
\text { Spotted Sandpiper } \\
\text { Semipalmated Sandpiper } \\
\text { Western Sandpiper } \\
\end{array}$} & \\
\hline $\begin{array}{l}\text { Group Breakdown } \\
\text { Amphibians: } 9 \\
\text { Birds: } 162 \\
\text { Mammals: } 69 \\
\text { Reptiles: } 5\end{array}$ & & & & \\
\hline $\mathbf{T}$ & & & & \\
\hline $\begin{array}{l}\text { Northern Leopard Frog } \\
\text { Bald Eagle } \\
\text { Black-backed Woodpecker } \\
\text { Townsend's Big-eared Bat }\end{array}$ & & & & \\
\hline TIER & & & & \\
\hline $\begin{array}{l}\text { Long-toed Salamander } \\
\text { Tiger Salamander } \\
\text { Tailed Frog }\end{array}$ & & & & \\
\hline Columbia Spotted Frog & & & & \\
\hline $\begin{array}{l}\text { Turkey Vulture } \\
\text { Northern Harrier } \\
\text { Sharp-shinned Hawk } \\
\text { Cooper's Hawk } \\
\text { Vorthern Goshawk }\end{array}$ & & & & \\
\hline
\end{tabular}


DRAFT WORKING DOCUMENT DO NOT DUPLICATE

\begin{tabular}{|c|c|c|c|c|}
\hline Northern Rough-winged Swallow & Yellow Warbler & House Finch & Coyote & House Sparrow \\
\hline Bank Swallow & Yellow-rumped Warbler & Common Redpoll & Red Fox & Common Raccoon \\
\hline Barn Swallow & Northern Waterthrush & Evening Grosbeak & Ermine & \\
\hline Steller's Jay & Common Yellowthroat & Dusky Or Montane Shrew & Mink & \\
\hline Blue Jay & Wilson's Warbler & Water Shrew & Striped Skunk & \\
\hline Clark's Nutcracker & Western Tanager & Little Brown Myotis & Bobcat & \\
\hline Common Raven & Spotted Towhee & Least Chipmunk & Mule Deer & \\
\hline Black-capped Chickadee & American Tree Sparrow & Yellow-pine Chipmunk & White-tailed Deer & \\
\hline Mountain Chickadee & Chipping Sparrow & Red-tailed Chipmunk & Moose & \\
\hline Red-breasted Nuthatch & Vesper Sparrow & Yellow-bellied Marmot & Pronghorn & \\
\hline Rock Wren & Savannah Sparrow & Richardson's Ground Squirrel & Mountain Goat & \\
\hline House Wren & Song Sparrow & Columbian Ground Squirrel & Painted Turtle & \\
\hline Townsend's Solitaire & Snow Bunting & Deer Mouse & TIER IV: 11 & \\
\hline Swainson's Thrush & Bobolink & Bushy-tailed Woodrat & Gray Partridge & \\
\hline Hermit Thrush & Red-winged Blackbird & Southern Red-backed Vole & Ring-necked Pheasant & \\
\hline American Robin & Western Meadowlark & Heather Vole & Wild Turkey & \\
\hline Gray Catbird & Yellow-headed Blackbird & Meadow Vole & Semipalmated Plover & \\
\hline Sage Thrasher & Brewer's Blackbird & Montane Vole & Stilt Sandpiper & \\
\hline American Pipit & Common Grackle & Long-tailed Vole & Rock Dove & \\
\hline Bohemian Waxwing & Brown-headed Cowbird & Muskrat & European Starling & \\
\hline Cedar Waxwing & Pine Grosbeak & Western Jumping Mouse & Scarlet Tanager & \\
\hline Red-eyed Vireo & Cassin's Finch & Common Porcupine & Rose-breasted Grosbeak & \\
\hline
\end{tabular}


Table 18. Southwest Montana Intermontane Basins \& Valleys Focus Area-Species Associations

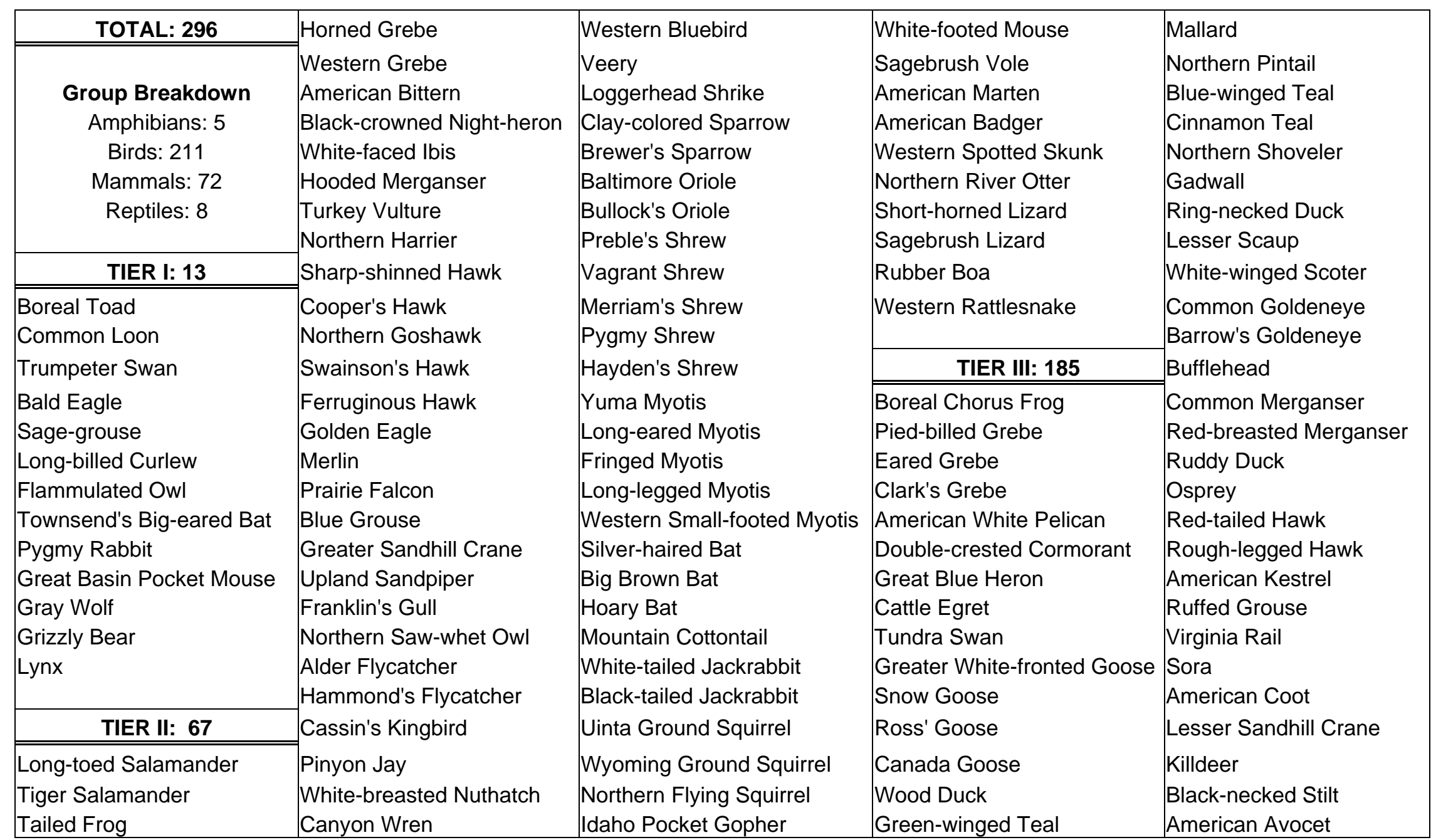


DRAFT WORKING DOCUMENT DO NOT DUPLICATE

\begin{tabular}{|c|c|c|c|c|}
\hline Greater Yellowlegs & Dusky Flycatcher & Northern Mockingbird & Red-winged Blackbird & Meadow Vole \\
\hline Lesser Yellowlegs & Cordilleran Flycatcher & Sage Thrasher & Western Meadowlark & ne Vole \\
\hline Solitary Sandpiper & Say's Phoebe & American Pipit & Yellow-headed Blackbird & Long-tailed Vole \\
\hline Willet & Weste & Bohemian Waxwing & Brewer's Blackbird & Mus \\
\hline Spotted Sandpiper & Eastern Kingbird & Cedar Waxwing & Common Grackle & Western Jumping Mouse \\
\hline Least Sandpiper & Horned Lark & Northern Shrike & Brown-headed Cowbird & Common Porcupine \\
\hline Baird's Sandpiper & Tree Swallow & Warbling Vireo & Cassin's Finch & Coyote \\
\hline Long-billed Dowitcher & Violet-green Swallow & Red-eyed Vireo & House Finch & Red Fox \\
\hline Common Snipe & Northern Rough-winged Swallow & Yellow Warbler & Common Redpoll & Black Bear \\
\hline Wilson's Phalarope & Bank Swallow & Yellow-rumped Warbler & Jldfinch & Erm \\
\hline Ring-billed Gull & Cliff Swallow & Ovenbird & Evening Grosbeak & Long-tailed Weasel \\
\hline California Gull & Barn Swallow & Northern Waterthrush & Masked Shrew & Mink \\
\hline Herring Gull & Gray Jay & Macgillivray's Warbler & Dusky Or Montane Shrew & Striped Skunk \\
\hline Mourning Dove & Blue Jay & Common Yellowthroat & Water Shrew & Bobcat \\
\hline Western Screech-owl & Clark's Nutcracker & Wilson's Warbler & own Myotis & Wapiti Or Elk \\
\hline Great Horned Owl & Black-billed Magpie & Wester & Snowshoe Hare & $\mathrm{Mul}$ \\
\hline Short-eared Owl & American Crow & Black-headed Grosbeak & Least Chipmunk & White-tailed Deer \\
\hline Common Nighthawk & Black-capped Chickadee & Lazuli E & Yellow-pine Chipmunk & Moose \\
\hline Common Poorwill & Red-breasted Nuthatch & Spotted Towhee & Red-tailed Chipmunk & Pronghorn \\
\hline White-throated Swift & Rock Wren & American Tree Sparrow & Yellow-bellied Marmot & Painted Turtle \\
\hline Calliope Hummingbird & House Wren & Chipping Sparrow & Richardson's Ground Squirrel & Racer \\
\hline Rufous Hummingbird & Marsh Wren & Vesper Sparrow & Columbian Ground Squirrel & Gopher Snake \\
\hline Belted Kingfisher & American Dipper & Sage Sparrow & Golden-mantled Ground Squirrel & Western Terrestrial Garter Snake \\
\hline Red-naped Sapsucker & Ruby-crowned Kinglet & Savannah Sparrow & Red Squirrel & \\
\hline Downy Woodpecker & Mountain Bluebird & Song Sparrow & Northern Pocket Gopher & TIER IV: $\mathbf{3 1}$ \\
\hline Hairy Woodpecker & Townsend's Solitaire & Lincoln's Sparrow & American Beaver & Red-throated Loon \\
\hline Northern Flicker & Swainson's Thrush & White-crowned Sparrow & Deer Mouse & Little Blue Heron \\
\hline Western Wood-pewee & Hermit Thrush & Harris' Sparrow & Bushy-tailed Woodrat & Wood Stork \\
\hline Willow Flycatcher & American Robin & Dark-eyed Junco & Southern Red-backed Vole & Eurasian Wige \\
\hline Least Flycatcher & Gray Catbird & Bobolink & Heather Vole & Black Scoter \\
\hline
\end{tabular}




\begin{tabular}{|l|}
\hline Surf Scoter \\
Gray Partridge \\
Chukar \\
Ring-necked Pheasant \\
American Golden-plover \\
Semipalmated Plover \\
Whimbrel \\
Ruddy Turnstone \\
Red Knot \\
Sanderling \\
Stilt Sandpiper \\
Short-billed Dowitcher \\
Red-necked Phalarope \\
Red Phalarope \\
Pomarine Jaeger \\
Bonaparte's Gull \\
Rock Dove \\
Scissor-tailed Flycatcher \\
European Starling \\
Pine Warbler \\
Blackpoll Warbler \\
Scarlet Tanager \\
Rose-breasted Grosbeak \\
House Sparrow \\
House Mouse \\
Common Raccoon \\
\hline
\end{tabular}


Table 19. Upper Yellowstone Valley Focus Area-Species Associations

\begin{tabular}{|c|c|c|c|c|}
\hline TOTAL: 265 & Turkey Vulture & Clay-colored Sparrow & Northern Flying Squirrel & Canada Goose \\
\hline & Northern Harrier & Brewer's Sparrow & Olive-backed Pocket Mouse & Wood Duck \\
\hline Group Breakdown & Sharp-shinned Hawk & Field Sparrow & White-footed Mouse & Green-winged Teal \\
\hline Amphibians: 7 & Cooper's Hawk & Baltimore Oriole & Sagebrush Vole & Mallard \\
\hline Birds: 179 & Northern Goshawk & Bullock's Oriole & American Marten & Northern Pintail \\
\hline Mammals: 74 & Swainson's Hawk & Black Rosy-finch & Fisher & Blue-winged Teal \\
\hline Reptiles: 5 & Ferruginous Hawk & Gray-crowned Rosy-finch & Least Weasel & Cinnamon Teal \\
\hline & Golden Eagle & White-winged Crossbill & Wolverine & Northern Shoveler \\
\hline TIER I: 9 & Merlin & Vagrant Shrew & American Badger & Gadwall \\
\hline Boreal Toad & Prairie Falcon & Merriam's Shrew & Western Spotted Skunk & Lesser Scaup \\
\hline Northern Leopard Frog & Blue Grouse & Pygmy Shrew & Northern River Otter & Common Goldeneye \\
\hline Trumpeter Swan & Greater Sandhill Crane & Hayden's Shrew & Sagebrush Lizard & Barrow's Goldeneye \\
\hline Bald Eagle & Franklin's Gull & Yuma Myotis & Rubber Boa & Bufflehead \\
\hline Long-billed Curlew & Barred Owl & Long-eared Myotis & Western Rattlesnake & Common Merganser \\
\hline Black-backed Woodpecker & Great Gray Owl & Fringed Myotis & & Red-breasted Merganser \\
\hline Gray Wolf & Boreal Owl & Long-legged Myotis & TIER III: 166 & Ruddy Duck \\
\hline Grizzly Bear & Northern Saw-whet Owl & California Myotis & Boreal Chorus Frog & Osprey \\
\hline Lynx & $\begin{array}{l}\text { Three-toed Woodpecker } \\
\text { Alder Flycatcher } \\
\text { Hammond's Flycatcher }\end{array}$ & $\begin{array}{l}\text { Western Small-footed Myotis } \\
\text { Northern Myotis } \\
\text { Silver-haired Bat }\end{array}$ & $\begin{array}{l}\text { Pied-billed Grebe } \\
\text { Eared Grebe } \\
\text { Clark's Grebe }\end{array}$ & $\begin{array}{l}\text { Red-tailed Hawk } \\
\text { Rough-legged Hawk } \\
\text { American Kestrel }\end{array}$ \\
\hline TIER II: 74 & White-breasted Nuthatch & Big Brown Bat & American White Pelican & Ruffed Grouse \\
\hline Long-toed Salamander & Brown Creeper & Hoary Bat & Double-crested Cormorant & Sora \\
\hline Tiger Salamander & Canyon Wren & Mountain Cottontail & Great Blue Heron & American Coot \\
\hline Tailed Frog & Winter Wren & White-tailed Jackrabbit & Cattle Egret & Lesser Sandhill Crane \\
\hline Columbia Spotted Frog & Western Bluebird & Uinta Chipmunk & Tundra Swan & Killdeer \\
\hline Horned Grebe & Veery & Uinta Ground Squirrel & Snow Goose & American Avocet \\
\hline Western Grebe & Loggerhead Shrike & Wyoming Ground Squirrel & Ross' Goose & Spotted Sandpiper \\
\hline
\end{tabular}


DRAFT WORKING DOCUMENT DO NOT DUPLICATE

\begin{tabular}{|c|c|c|c|c|}
\hline Common Snipe & Common Raven & Western Tanager & Little Brown Myotis & Wapiti Or Elk \\
\hline Wilson's Phalarope & Black-capped Chickadee & Black-headed Grosbeak & American Pika & Mule Deer \\
\hline Ring-billed Gull & Red-breasted Nuthatch & Lazuli Bunting & Snowshoe Hare & White-tailed Deer \\
\hline California Gull & Rock Wren & Spotted Towhee & Least Chipmunk & Moose \\
\hline Mourning Dove & House Wren & American Tree Sparrow & Yellow-pine Chipmunk & Mountain Goat \\
\hline Great Horned Owl & Marsh Wren & Chipping Sparrow & Yellow-bellied Marmot & Bighorn Sheep \\
\hline White-throated Swift & American Dipper & Vesper Sparrow & Richardson's Ground Squirrel & Racer \\
\hline Rufous Hummingbird & Golden-crowned Kinglet & Savannah Sparrow & Golden-mantled Ground Squirrel & Western Terrestrial Garter Snake \\
\hline Belted Kingfisher & Ruby-crowned Kinglet & Fox Sparrow & Red Squirrel & \\
\hline Downy Woodpecker & Mountain Bluebird & Song Sparrow & Northern Pocket Gopher & TIER IV: 15 \\
\hline Hairy Woodpecker & Townsend's Solitaire & Lincoln's Sparrow & American Beaver & Little Blue Heron \\
\hline Northern Flicker & Swainson's Thrush & White-crowned Sparrow & Deer Mouse & Wood Stork \\
\hline Western Wood-pewee & Hermit Thrush & Harris' Sparrow & Bushy-tailed Woodrat & Mute Swan \\
\hline Dusky Flycatcher & American Robin & Dark-eyed Junco & Southern Red-backed Vole & Surf Scoter \\
\hline Cordilleran Flycatcher & Varied Thrush & Bobolink & Heather Vole & Broad-winged Hawk \\
\hline Western Kingbird & Gray Catbird & Red-winged Blackbird & Meadow Vole & Gray Partridge \\
\hline Eastern Kingbird & Brown Thrasher & Western Meadowlark & Montane Vole & Chukar \\
\hline Horned Lark & American Pipit & Yellow-headed Blackbird & Long-tailed Vole & Ring-necked Pheasant \\
\hline Tree Swallow & Bohemian Waxwing & Brewer's Blackbird & Muskrat & Stilt Sandpiper \\
\hline Violet-green Swallow & Cedar Waxwing & Common Grackle & Western Jumping Mouse & Bonaparte's Gull \\
\hline Northern Rough-winged Swallow & Northern Shrike & Brown-headed Cowbird & Common Porcupine & Rock Dove \\
\hline Bank Swallow & Red-eyed Vireo & Pine Grosbeak & Coyote & European Starling \\
\hline Cliff Swallow & Yellow Warbler & Cassin's Finch & Red Fox & House Sparrow \\
\hline Barn Swallow & Yellow-rumped Warbler & House Finch & Black Bear & House Mouse \\
\hline Gray Jay & Townsend's Warbler & Common Redpoll & Ermine & Common Raccoon \\
\hline Steller's Jay & Ovenbird & American Goldfinch & Long-tailed Weasel & \\
\hline Blue Jay & Northern Waterthrush & Evening Grosbeak & Mink & \\
\hline Clark's Nutcracker & Macgillivray's Warbler & Masked Shrew & Striped Skunk & \\
\hline Black-billed Magpie & Common Yellowthroat & Dusky Or Montane Shrew & Bobcat & \\
\hline American Crow & Wilson's Warbler & Water Shrew & Mountain Lion & \\
\hline
\end{tabular}


Table 20. Big Hole River Focus Area-Species Associations

\begin{tabular}{|c|c|}
\hline TOTAL: 19 & TIER IV: 5 \\
\hline $\begin{array}{c}\text { Group Breakdown } \\
\text { Fish: } 16 \\
\text { Crayfish: } 2 \\
\text { Mussels: } 1\end{array}$ & $\begin{array}{l}\text { Rainbow Trout } \\
\text { Golden Trout } \\
\text { Brown Trout } \\
\text { Brook Trout } \\
\text { Common Carp }\end{array}$ \\
\hline TIER I: $\mathbf{5}$ & \\
\hline $\begin{array}{l}\text { Westslope Cutthroat Trout } \\
\text { Lake Trout (Native Lakes) } \\
\text { Arctic Grayling } \\
\text { Burbot } \\
\text { Western Pearlshell }\end{array}$ & \\
\hline TIER III: 9 & \\
\hline $\begin{array}{l}\text { Mottled Sculpin } \\
\text { Mountain Whitefish } \\
\text { Longnose Dace } \\
\text { Redside Shiner } \\
\text { Longnose Sucker } \\
\text { White Sucker } \\
\text { Mountain Sucker } \\
\text { Virile Crayfish } \\
\text { A Crayfish (Gambelii) }\end{array}$ & \\
\hline
\end{tabular}


Table 21. Bitterroot River Focus Area-Species Associations

14495

\begin{tabular}{|c|c|}
\hline TOTAL: 21 & TIER IV: 7 \\
\hline $\begin{array}{l}\text { Group Breakdown } \\
\text { Fish: } 19 \\
\text { Crayfish: } 1 \\
\text { Mussels: } 1\end{array}$ & $\begin{array}{l}\text { Rainbow Trout } \\
\text { Golden Trout } \\
\text { Brown Trout } \\
\text { Brook Trout } \\
\text { Northern Pike } \\
\text { Pumpkinseed }\end{array}$ \\
\hline TIER I: 3 & Largemouth Bass \\
\hline $\begin{array}{l}\text { Westslope Cutthroat Trout } \\
\text { Bull Trout } \\
\text { Western Pearlshell }\end{array}$ & \\
\hline TIER III: 11 & \\
\hline \begin{tabular}{|l} 
Mottled Sculpin \\
Slimy Sculpin \\
Mountain Whitefish \\
Peamouth \\
Northern Pike Minnow \\
Longnose Dace \\
Redside Shiner \\
Longnose Sucker \\
White Sucker \\
Largescale Sucker \\
Signal Crayfish
\end{tabular} & \\
\hline
\end{tabular}


Table 22. Blackfoot River Focus Area-Species Associations

14501

\begin{tabular}{|c|c|}
\hline TOTAL: 23 & TIER IV: 8 \\
\hline $\begin{array}{l}\text { Group Breakdown } \\
\text { Fish: } 21 \\
\text { Crayfish: } 1 \\
\text { Mussels: } 1\end{array}$ & $\begin{array}{l}\text { Kokanee Salmon } \\
\text { Rainbow Trout } \\
\text { Brown Trout } \\
\text { Brook Trout } \\
\text { Northern Pike } \\
\text { Pumpkinseed }\end{array}$ \\
\hline TIER I: $\mathbf{3}$ & Largemouth Bass \\
\hline $\begin{array}{l}\text { Westslope Cutthroat Trout } \\
\text { Bull Trout } \\
\text { Western Pearlshell }\end{array}$ & Yellow Perch \\
\hline TIER III: 12 & \\
\hline \begin{tabular}{|l} 
Mottled Sculpin \\
Slimy Sculpin \\
Mountain Whitefish \\
Peamouth \\
Fathead Minnow \\
Northern Pike Minnow \\
Longnose Dace \\
Redside Shiner \\
Longnose Sucker \\
White Sucker \\
Largescale Sucker \\
Signal Crayfish \\
\end{tabular} & \\
\hline
\end{tabular}


Table 23. Jefferson River Focus Area-Species Associations

\begin{tabular}{|c|c|}
\hline TOTAL: 20 & TIER IV: 7 \\
\hline $\begin{array}{l}\text { Group Breakdown } \\
\text { Fish: } 17 \\
\text { Crayfish: } 2 \\
\text { Mussels: } 1\end{array}$ & \multirow[t]{5}{*}{$\begin{array}{l}\text { Kokanee Salmon } \\
\text { Rainbow Trout } \\
\text { Brown Trout } \\
\text { Brook Trout } \\
\text { Lake Trout } \\
\text { Common Carp } \\
\text { Bluegill }\end{array}$} \\
\hline TIER I: $\mathbf{3}$ & \\
\hline $\begin{array}{l}\text { Westslope Cutthroat Trout } \\
\text { Burbot } \\
\text { Western Pearlshell }\end{array}$ & \\
\hline TIER III: 10 & \\
\hline \begin{tabular}{|l} 
Mottled Sculpin \\
Mountain Whitefish \\
Longnose Dace \\
Redside Shiner \\
Flathead Chub \\
Longnose Sucker \\
White Sucker \\
Mountain Sucker \\
Virile Crayfish \\
A Crayfish (Gambelii) \\
\end{tabular} & \\
\hline
\end{tabular}


14510

14511

\begin{tabular}{|c|c|c|}
\hline TOTAL: 46 & Flathead Chub & Largemouth Bass \\
\hline $\begin{array}{l}\text { Group Breakdown } \\
\text { Fish: } 45 \\
\text { Crayfish: } 1\end{array}$ & $\begin{array}{l}\text { River Carpsucker } \\
\text { Longnose Sucker } \\
\text { White Sucker } \\
\text { Mountain Sucker } \\
\text { Smallmouth Buffalo }\end{array}$ & $\begin{array}{l}\text { White Crappie } \\
\text { Black Crappie } \\
\text { Yellow Perch } \\
\text { Walleye }\end{array}$ \\
\hline TIER I: 3 & Shorthead Redhorse & \\
\hline \multirow[t]{2}{*}{$\begin{array}{l}\text { Yellowstone Cutthroat Trout } \\
\text { Burbot } \\
\text { Sauger }\end{array}$} & $\begin{array}{l}\text { Channel Catfish } \\
\text { Brook Stickleback } \\
\text { Stonecat } \\
\text { Virile Crayfish }\end{array}$ & \\
\hline & TIER IV: 19 & \\
\hline TIER II: 2 & Rainbow Trout & \\
\hline $\begin{array}{l}\text { Bigmouth Buffalo } \\
\text { Freshwater Drum }\end{array}$ & $\begin{array}{l}\text { Golden Trout } \\
\text { Brown Trout } \\
\text { Brook Trout }\end{array}$ & \\
\hline TIER III: 20 & Lake Trout & \\
\hline \begin{tabular}{|l} 
Mottled Sculpin \\
Goldeye \\
Mountain Whitefish \\
Lake Chub \\
Western Silvery Minnow \\
Emerald Shiner \\
Sand Shiner \\
Fathead Minnow \\
Longnose Dace \\
\end{tabular} & $\begin{array}{l}\text { Northern Pike } \\
\text { Common Carp } \\
\text { Black Bullhead } \\
\text { Yellow Bullhead } \\
\text { Plains Killifish } \\
\text { Green Sunfish } \\
\text { Pumpkinseed } \\
\text { Bluegill } \\
\text { Smallmouth Bass } \\
\end{array}$ & \\
\hline
\end{tabular}

\section{Table 24. Upper Yellowstone River Focus Area-Species Associations}


Table 25. Mission/Swan Valley and Mountains Focus Area-Species Associations

14514

\begin{tabular}{|c|c|c|c|c|}
\hline TOTAL: 246 & Pacific Treefrog & Pileated Woodpecker & White-tailed Jackrabbit & Spruce Grouse \\
\hline \multirow{7}{*}{$\begin{array}{c}\text { Group Breakdown } \\
\text { Amphibians: } 8 \\
\text { Birds: } 170 \\
\text { Mammals: } 63 \\
\text { Reptiles: } 5\end{array}$} & Columbia Spotted Frog & Hammond's Flycatcher & Northern Flying Squirrel & Ruffed Grouse \\
\hline & Horned Grebe & Boreal Chickadee & Water Vole & Sora \\
\hline & Red-necked Grebe & Chestnut-backed Chickadee & American Marten & Spotted Sandpiper \\
\hline & Hooded Merganser & White-breasted Nuthatch & Fisher & Common Snipe \\
\hline & Turkey Vulture & Pygmy Nuthatch & Wolverine & Western Screech-owl \\
\hline & Sharp-shinned Hawk & Brown Creeper & American Badger & Great Horned Owl \\
\hline & Cooper's Hawk & Canyon Wren & Northern River Otter & Common Nighthawk \\
\hline TIER I: 14 & Northern Goshawk & Winter Wren & Northern Alligator Lizard & Common Poorwill \\
\hline \multirow{4}{*}{$\begin{array}{l}\text { Boreal Toad } \\
\text { Common Loon } \\
\text { Trumpeter Swan } \\
\text { Harlequin Duck }\end{array}$} & Swainson's Hawk & Western Bluebird & Rubber Boa & \multirow{4}{*}{$\begin{array}{l}\text { White-throated Swift } \\
\text { Calliope Hummingbird } \\
\text { Rufous Hummingbird } \\
\text { Belted Kingfisher }\end{array}$} \\
\hline & Golden Eagle & Veery & Common Garter Snake & \\
\hline & Merlin & American Redstart & & \\
\hline & Peregrine Falcon & Clay-colored Sparrow & TIER III: 147 & \\
\hline Bald Eagle & Prairie Falcon & Brewer's Sparrow & Pied-billed Grebe & Red-naped Sapsucker \\
\hline Flammulated Owl & Blue Grouse & Gray-crowned Rosy-finch & Great Blue Heron & Downy Woodpecker \\
\hline Black-backed Woodpecker & White-tailed Ptarmigan & White-winged Crossbill & Tundra Swan & Hairy Woodpecker \\
\hline Olive-sided Flycatcher & Franklin's Gull & Preble's Shrew & Wood Duck & Northern Flicker \\
\hline Townsend's Big-eared Bat & Northern Pygmy-owl & Vagrant Shrew & Mallard & Western Wood-pewee \\
\hline Hoary Marmot & Barred Owl & Pygmy Shrew & Common Goldeneye & Willow Flycatcher \\
\hline Northern Bog Lemming & Great Gray Owl & Long-eared Myotis & Barrow's Goldeneye & Dusky Flycatcher \\
\hline Gray Wolf & Boreal Owl & Fringed Myotis & Bufflehead & Cordilleran Flycatcher \\
\hline Grizzly Bear & Northern Saw-whet Owl & Long-legged Myotis & Common Merganser & Tree Swallow \\
\hline Lynx & Black Swift & California Myotis & Ruddy Duck & Violet-green Swallow \\
\hline & Vaux's Swift & Western Small-footed Myotis & Osprey & Northern Rough-winged Swallow \\
\hline TIER II: 67 & Black-chinned Hummingbird & Silver-haired Bat & Red-tailed Hawk & Bank Swallow \\
\hline $\begin{array}{l}\text { Long-toed Salamander } \\
\text { Tailed Frog }\end{array}$ & $\begin{array}{l}\text { Williamson's Sapsucker } \\
\text { Three-toed Woodpecker }\end{array}$ & $\begin{array}{l}\text { Big Brown Bat } \\
\text { Hoary Bat }\end{array}$ & $\begin{array}{l}\text { Rough-legged Hawk } \\
\text { Gyrfalcon }\end{array}$ & $\begin{array}{l}\text { Cliff Swallow } \\
\text { Barn Swallow }\end{array}$ \\
\hline
\end{tabular}


DRAFT WORKING DOCUMENT DO NOT DUPLICATE

\begin{tabular}{|c|c|c|c|c|}
\hline Gray Jay & Orange-crowned Warbler & Cassin's Finch & Coyote & Magnolia Warbler \\
\hline Steller's Jay & Nashville Warbler & Red Crossbill & Red Fox & Connecticut Warbler \\
\hline Blue Jay & Yellow Warbler & Common Redpoll & Black Bear & Mourning Warbler \\
\hline Clark's Nutcracker & Yellow-rumped Warbler & Hoary Redpoll & Ermine & Scarlet Tanager \\
\hline American Crow & Townsend's Warbler & Pine Siskin & Mink & Rose-breasted Grosbeak \\
\hline Common Raven & Northern Waterthrush & American Goldfinch & Striped Skunk & Norway Rat \\
\hline Black-capped Chickadee & Macgillivray's Warbler & Evening Grosbeak & Bobcat & \\
\hline Mountain Chickadee & Common Yellowthroat & Masked Shrew & Mountain Lion & \\
\hline Red-breasted Nuthatch & Wilson's Warbler & Dusky Or Montane Shrew & Wapiti Or Elk & \\
\hline Rock Wren & Western Tanager & Water Shrew & Mule Deer & \\
\hline House Wren & Black-headed Grosbeak & Little Brown Myotis & White-tailed Deer & \\
\hline Marsh Wren & Lazuli Bunting & American Pika & Moose & \\
\hline American Dipper & Spotted Towhee & Snowshoe Hare & Mountain Goat & \\
\hline Golden-crowned Kinglet & American Tree Sparrow & Yellow-pine Chipmunk & Bighorn Sheep & \\
\hline Ruby-crowned Kinglet & Chipping Sparrow & Red-tailed Chipmunk & Painted Turtle & \\
\hline Mountain Bluebird & Vesper Sparrow & Yellow-bellied Marmot & Western Terrestrial Garter Snake & \\
\hline Townsend's Solitaire & Savannah Sparrow & Columbian Ground Squirrel & & \\
\hline Swainson's Thrush & Fox Sparrow & Golden-mantled Ground Squirrel & TIER IV: 18 & \\
\hline Hermit Thrush & Song Sparrow & Red Squirrel & Roughskin Newt & \\
\hline American Robin & Lincoln's Sparrow & Northern Pocket Gopher & Idaho Giant Salamander & \\
\hline Varied Thrush & White-crowned Sparrow & American Beaver & Bullfrog & \\
\hline Gray Catbird & Dark-eyed Junco & Deer Mouse & Red-throated Loon & \\
\hline American Pipit & Snow Bunting & Bushy-tailed Woodrat & Green Heron & \\
\hline Bohemian Waxwing & Bobolink & Southern Red-backed Vole & Broad-winged Hawk & \\
\hline Cedar Waxwing & Red-winged Blackbird & Heather Vole & Wild Turkey & \\
\hline Northern Shrike & Yellow-headed Blackbird & Meadow Vole & American Woodcock & \\
\hline Warbling Vireo & Brewer's Blackbird & Montane Vole & Rock Dove & \\
\hline Red-eyed Vireo & Brown-headed Cowbird & Long-tailed Vole & Yellow-bellied Sapsucker & \\
\hline Cassin's Vireo & Pine Grosbeak & Muskrat & Scissor-tailed Flycatcher & \\
\hline Tennessee Warbler & Purple Finch & Common Porcupine & Chestnut-sided Warbler & \\
\hline
\end{tabular}


14517

14518

\begin{tabular}{|c|c|}
\hline TOTAL: 30 & TIER IV: 13 \\
\hline $\begin{array}{c}\text { Group Breakdown } \\
\text { Fish } \\
\text { Crayfish } \\
\text { Mussels }\end{array}$ & \multirow{5}{*}{$\begin{array}{l}\text { Kokanee Salmon } \\
\text { Rainbow Trout } \\
\text { Golden Trout } \\
\text { Brown Trout } \\
\text { Brook Trout } \\
\text { Lake Trout } \\
\text { Northern Pike } \\
\text { Black Bullhead } \\
\text { Yellow Bullhead } \\
\text { Pumpkinseed } \\
\text { Smallmouth Bass } \\
\text { Largemouth Bass } \\
\text { Yellow Perch } \\
\text { Lake Whitefish }\end{array}$} \\
\hline TIER I: $\mathbf{3}$ & \\
\hline $\begin{array}{l}\text { Westslope Cutthroat Trout } \\
\text { Bull Trout } \\
\text { Western Pearlshell }\end{array}$ & \\
\hline TIER III: 10 & \\
\hline $\begin{array}{l}\text { Mottled Sculpin } \\
\text { Slimy Sculpin } \\
\text { Mountain Whitefish } \\
\text { Peamouth } \\
\text { Northern Pike Minnow } \\
\text { Longnose Dace } \\
\text { Redside Shiner } \\
\text { Longnose Sucker } \\
\text { Largescale Sucker } \\
\text { Signal Crayfish }\end{array}$ & \\
\hline
\end{tabular}


14521

14522

14523

14524

14525

14526
Table 27. Middle Clark Fork River Focus Area-Species Associations

\begin{tabular}{|c|c|}
\hline TOTAL: 22 & TIER IV: 7 \\
\hline $\begin{array}{l}\text { Group Breakdown } \\
\text { Fish: } 20 \\
\text { Crayfish: } 1 \\
\text { Mussels: } 1\end{array}$ & \multirow[t]{5}{*}{\begin{tabular}{|l} 
Rainbow Trout \\
Brown Trout \\
Brook Trout \\
Northern Pike \\
Pumpkinseed \\
Largemouth Bass \\
Yellow Perch
\end{tabular}} \\
\hline TIER I: $\mathbf{3}$ & \\
\hline $\begin{array}{l}\text { Westslope Cutthroat Trout } \\
\text { Bull Trout } \\
\text { Western Pearlshell }\end{array}$ & \\
\hline TIER III: 10 & \\
\hline \begin{tabular}{|l} 
Mottled Sculpin \\
Slimy Sculpin \\
Mountain Whitefish \\
Northern Pike Minnow \\
Longnose Dace \\
Redside Shiner \\
Longnose Sucker \\
White Sucker \\
Largescale Sucker \\
Signal Crayfish
\end{tabular} & \\
\hline
\end{tabular}


DRAFT WORKING DOCUMENT DO NOT DUPLICATE

Table 28. Missouri Coteau Focus Area-Species Associations

\begin{tabular}{|c|c|c|c|c|}
\hline TOTAL: 325 & \multirow{3}{*}{$\begin{array}{l}\text { Milk Snake } \\
\text { Smooth Green Snake }\end{array}$} & \multirow{3}{*}{$\begin{array}{l}\text { Swainson's Hawk } \\
\text { Ferruginous Hawk } \\
\text { Golden Eagle } \\
\text { Merlin } \\
\text { Peregrine Falcon } \\
\text { Prairie Falcon } \\
\text { Upland Sandpiper } \\
\text { Marbled Godwit } \\
\text { Franklin's Gull }\end{array}$} & \multirow{3}{*}{$\begin{array}{l}\text { Baird's Sparrow } \\
\text { Grasshopper Sparrow } \\
\text { Mccown's Longspur } \\
\text { Baltimore Oriole } \\
\text { Bullock's Oriole } \\
\text { Preble's Shrew } \\
\text { Vagrant Shrew } \\
\text { Arctic Shrew } \\
\text { Merriam's Shrew }\end{array}$} & \multirow[b]{2}{*}{$\begin{array}{l}\text { Least Weasel } \\
\text { American Badger } \\
\text { Northern River Otter } \\
\text { Short-horned Lizard } \\
\text { Rubber Boa } \\
\text { Common Garter Snake } \\
\text { Western Rattlesnake }\end{array}$} \\
\hline $\begin{array}{l}\text { Group Breakdown } \\
\text { Amphibians: } 6 \\
\text { Birds: } 239 \\
\text { Mammals: } 66 \\
\text { Reptiles: } 13\end{array}$ & & & & \\
\hline TIER I: $\mathbf{2 0}$ & & & & TIER III: 187 \\
\hline Northern Leopard Frog & TIER II: 78 & Caspian Tern & Hayden's Shrew & Boreal Chorus Frog \\
\hline Common Loon & Tiger Salamander & Common Tern & Yuma Myotis & Pied-billed Grebe \\
\hline Trumpeter Swan & Great Plains Toad & Forster's Tern & Long-eared Myotis & Eared Grebe \\
\hline Bald Eagle & Woodhouse's Toad & Black-billed Cuckoo & Long-legged Myotis & Clark's Grebe \\
\hline Yellow Rail & Plains Spadefoot & Red-headed Woodpecker & Western Small-footed Myotis & American White Pelican \\
\hline Whooping Crane & Horned Grebe & Alder Flycatcher & Northern Myotis & Double-crested Cormorant \\
\hline Piping Plover & Western Grebe & Cassin's Kingbird & Silver-haired Bat & Great Blue Heron \\
\hline Long-billed Curlew & American Bittern & White-breasted Nuthatch & Big Brown Bat & Snowy Egret \\
\hline Least Tern & Black-crowned Night-heron & Eastern Bluebird & Eastern Red Bat & Tundra Swan \\
\hline Black Tern & White-faced Ibis & Veery & Hoary Bat & Greater White-fronted Goose \\
\hline Burrowing Owl & Canvasback & Sprague's Pipit & Eastern Cottontail & Snow Goose \\
\hline Sedge Wren & Redhead & Loggerhead Shrike & Mountain Cottontail & Ross' Goose \\
\hline Nelson's Sharp-tailed Sparrow & Hooded Merganser & American Redstart & White-tailed Jackrabbit & Canada Goose \\
\hline Townsend's Big-eared Bat & Turkey Vulture & Yellow-breasted Chat & Olive-backed Pocket Mouse & Wood Duck \\
\hline Meadow Jumping Mouse & Northern Harrier & Clay-colored Sparrow & Ord's Kangaroo Rat & Green-winged Teal \\
\hline Snapping Turtle & Sharp-shinned Hawk & Brewer's Sparrow & White-footed Mouse & American Black Duck \\
\hline Spiny Softshell & Cooper's Hawk & Field Sparrow & Sagebrush Vole & Mallard \\
\hline Western Hognose Snake & Northern Goshawk & Lark Bunting & Swift Fox & Northern Pintail \\
\hline
\end{tabular}


DRAFT WORKING DOCUMENT DO NOT DUPLICATE

\begin{tabular}{|c|c|c|c|c|}
\hline $\begin{array}{l}\text { Blue-winged Teal } \\
\text { Cinnamon Teal } \\
\text { Northern Shoveler } \\
\text { Gadwall } \\
\text { American Wigeon } \\
\text { Ring-necked Duck } \\
\text { Greater Scaup } \\
\text { Lesser Scaup } \\
\text { Long Tailed Duck } \\
\text { White-winged Scoter } \\
\text { Common Goldeneye } \\
\text { Bufflehead } \\
\text { Common Merganser } \\
\text { Red-breasted Merganser } \\
\text { Ruddy Duck } \\
\text { Osprey } \\
\text { Red-tailed Hawk } \\
\text { Rough-legged Hawk } \\
\text { American Kestrel } \\
\text { Virginia Rail } \\
\text { Sora } \\
\text { American Coot } \\
\text { Lesser Sandhill Crane } \\
\text { Killdeer } \\
\text { Black-necked Stilt } \\
\text { American Avocet } \\
\text { Greater Yellowlegs } \\
\text { Lesser Yellowlegs } \\
\text { Solitary Sandpiper } \\
\text { Willet }\end{array}$ & $\begin{array}{l}\text { Spotted Sandpiper } \\
\text { Semipalmated Sandpiper } \\
\text { Western Sandpiper } \\
\text { Least Sandpiper } \\
\text { White-rumped Sandpiper } \\
\text { Baird's Sandpiper } \\
\text { Pectoral Sandpiper } \\
\text { Dunlin } \\
\text { Long-billed Dowitcher } \\
\text { Common Snipe } \\
\text { Wilson's Phalarope } \\
\text { Ring-billed Gull } \\
\text { California Gull } \\
\text { Herring Gull } \\
\text { Glaucous Gull } \\
\text { Mourning Dove } \\
\text { Eastern Screech-owl } \\
\text { Great Horned Owl } \\
\text { Snowy Owl } \\
\text { Short-eared Owl } \\
\text { Common Nighthawk } \\
\text { Belted Kingfisher } \\
\text { Downy Woodpecker } \\
\text { Hairy Woodpecker } \\
\text { Northern Flicker } \\
\text { Western Wood-pewee } \\
\text { Willow Flycatcher } \\
\text { Least Flycatcher } \\
\text { Say's Phoebe } \\
\text { Western Kingbird }\end{array}$ & \begin{tabular}{|l|} 
Eastern Kingbird \\
Horned Lark \\
Tree Swallow \\
Violet-green Swallow \\
Northern Rough-winged Swallow \\
Bank Swallow \\
Cliff Swallow \\
Barn Swallow \\
Blue Jay \\
Black-billed Magpie \\
American Crow \\
Black-capped Chickadee \\
Red-breasted Nuthatch \\
Rock Wren \\
House Wren \\
Marsh Wren \\
Ruby-crowned Kinglet \\
Mountain Bluebird \\
Townsend's Solitaire \\
Swainson's Thrush \\
American Robin \\
Gray Catbird \\
Brown Thrasher \\
American Pipit \\
Bohemian Waxwing \\
Cedar Waxwing \\
Northern Shrike \\
Red-eyed Vireo \\
Orange-crowned Warbler \\
Yellow Warbler
\end{tabular} & $\begin{array}{l}\text { Yellow-rumped Warbler } \\
\text { Ovenbird } \\
\text { Northern Waterthrush } \\
\text { Macgillivray's Warbler } \\
\text { Common Yellowthroat } \\
\text { Wilson's Warbler } \\
\text { Western Tanager } \\
\text { Black-headed Grosbeak } \\
\text { Lazuli Bunting } \\
\text { Dickcissel } \\
\text { Spotted Towhee } \\
\text { American Tree Sparrow } \\
\text { Chipping Sparrow } \\
\text { Vesper Sparrow } \\
\text { Lark Sparrow } \\
\text { Savannah Sparrow } \\
\text { Song Sparrow } \\
\text { Lincoln's Sparrow } \\
\text { Swamp Sparrow } \\
\text { White-throated Sparrow } \\
\text { White-crowned Sparrow } \\
\text { Harris' Sparrow } \\
\text { Dark-eyed Junco } \\
\text { Lapland Longspur } \\
\text { Chestnut-collared Longspur } \\
\text { Bobolink } \\
\text { Red-winged Blackbird } \\
\text { Western Meadowlark } \\
\text { Yellow-headed Blackbird } \\
\text { Rusty Blackbird }\end{array}$ & $\begin{array}{l}\text { Brewer's Blackbird } \\
\text { Common Grackle } \\
\text { Brown-headed Cowbird } \\
\text { Purple Finch } \\
\text { Cassin's Finch } \\
\text { House Finch } \\
\text { Red Crossbill } \\
\text { Common Redpoll } \\
\text { Pine Siskin } \\
\text { American Goldfinch } \\
\text { Evening Grosbeak } \\
\text { Masked Shrew } \\
\text { Dusky Or Montane Shrew } \\
\text { Little Brown Myotis } \\
\text { Desert Cottontail } \\
\text { Yellow-bellied Marmot } \\
\text { Richardson's Ground Squirrel } \\
\text { Thirteen-lined Ground Squirrel } \\
\text { Eastern Fox Squirrel } \\
\text { Northern Pocket Gopher } \\
\text { American Beaver } \\
\text { Western Harvest Mouse } \\
\text { Deer Mouse } \\
\text { Northern Grasshopper Mouse } \\
\text { Bushy-tailed Woodrat } \\
\text { Southern Red-backed Vole } \\
\text { Meadow Vole } \\
\text { Montane Vole } \\
\text { Long-tailed Vole } \\
\text { Prairie Vole }\end{array}$ \\
\hline
\end{tabular}




\begin{tabular}{|l|l|}
\hline Muskrat & Semipalmated Plover \\
Western Jumping Mouse & Whimbrel \\
Common Porcupine & Hudsonian Godwit \\
Coyote & Ruddy Turnstone \\
Red Fox & Red Knot \\
Black Bear & Sanderling \\
Long-tailed Weasel & Stilt Sandpiper \\
Mink & Short-billed Dowitcher \\
Striped Skunk & Red-necked Phalarope \\
Bobcat & Bonaparte's Gull \\
Wapiti Or Elk & Rock Dove \\
Mule Deer & Band-tailed Pigeon \\
White-tailed Deer & Ruby-throated Hummingbird \\
Moose & Gray-cheeked Thrush \\
Pronghorn & European Starling \\
Painted Turtle & Magnolia Warbler \\
Racer & Cape May Warbler \\
Gopher Snake & Palm Warbler \\
Plains Garter Snake & Blackpoll Warbler \\
\hline \multicolumn{1}{|c|}{ TIER IV: 34} & Mourning Warbler \\
\hline \hline Red-throated Loon & Canada Warbler \\
Pacific Loon & Rose-breasted Grosbeak \\
Least Bittern & House Sparrow \\
Eurasian Wigeon & House Mouse \\
Gray Partridge & Common Raccoon \\
Ring-necked Pheasant & \\
Wild Turkey & \\
Black-bellied Plover & \\
American Golden-plover & \\
\hline
\end{tabular}


Table 29. Montana Sedimentary Plains Focus Area-Species Associations

\begin{tabular}{|c|c|c|c|c|}
\hline TOTAL: 347 & Snapping Turtle & Peregrine Falcon & Indigo Bunting & White-footed Mouse \\
\hline $\begin{array}{l}\text { Group Breakdown } \\
\text { Amphibians: } 7 \\
\text { Birds: } 259\end{array}$ & $\begin{array}{l}\text { Spiny Softshell } \\
\text { Western Hognose Snake } \\
\text { Milk Snake }\end{array}$ & \begin{tabular}{|l} 
Prairie Falcon \\
Blue Grouse \\
Greater Sandhill Crane \\
Upland Sandpiper
\end{tabular} & $\begin{array}{l}\text { Clay-colored Sparrow } \\
\text { Brewer's Sparrow } \\
\text { Field Sparrow } \\
\text { Lark Bunting }\end{array}$ & $\begin{array}{l}\text { Sagebrush Vole } \\
\text { Swift Fox } \\
\text { Least Weasel } \\
\text { American Badger }\end{array}$ \\
\hline Mammals: 68 & TIER II: 85 & Marbled Godwit & Baird's Sparrow & Northern River Otter \\
\hline Reptiles: 13 & $\begin{array}{l}\text { Tiger Salamander } \\
\text { Great Plains Toad }\end{array}$ & $\begin{array}{l}\text { Franklin's Gull } \\
\text { Caspian Tern }\end{array}$ & $\begin{array}{l}\text { Grasshopper Sparrow } \\
\text { Mccown's Longspur }\end{array}$ & $\begin{array}{l}\text { Short-horned Lizard } \\
\text { Sagebrush Lizard }\end{array}$ \\
\hline TIER I: 22 & Woodhouse's Toad & Common Tern & Baltimore Oriole & Common Garter Snake \\
\hline $\begin{array}{l}\text { Northern Leopard Frog } \\
\text { Common Loon }\end{array}$ & $\begin{array}{l}\text { Plains Spadefoot } \\
\text { Horned Grebe }\end{array}$ & \begin{tabular}{|l} 
Forster's Tern \\
Black-billed Cuckoo
\end{tabular} & $\begin{array}{l}\text { Bullock's Oriole } \\
\text { Preble's Shrew }\end{array}$ & Western Rattlesnake \\
\hline Trumpeter Swan & Western Grebe & Northern Hawk Owl & Dwarf Shrew & TIER III: 206 \\
\hline Bald Eagle & American Bittern & Northern Pygmy-owl & Merriam's Shrew & Boreal Chorus Frog \\
\hline Sage-grouse & Black-crowned Night-heron & Northern Saw-whet Owl & Hayden's Shrew & Pied-billed Grebe \\
\hline Whooping Crane & White-faced Ibis & Red-headed Woodpecker & Yuma Myotis & Eared Grebe \\
\hline Mountain Plover & Canvasback & Cassin's Kingbird & Long-eared Myotis & Clark's Grebe \\
\hline Long-billed Curlew & Redhead & Pinyon Jay & Long-legged Myotis & American White Pelican \\
\hline Least Tern & Hooded Merganser & White-breasted Nuthatch & Western Small-footed Myotis & Double-crested Cormorant \\
\hline Black Tern & Turkey Vulture & Pygmy Nuthatch & Silver-haired Bat & Great Blue Heron \\
\hline Burrowing Owl & Northern Harrier & Canyon Wren & Big Brown Bat & Snowy Egret \\
\hline Spotted Bat & Sharp-shinned Hawk & Eastern Bluebird & Eastern Red Bat & Cattle Egret \\
\hline Townsend's Big-eared Bat & Cooper's Hawk & Veery & Hoary Bat & Tundra Swan \\
\hline Black-tailed Prairie Dog & Northern Goshawk & Sprague's Pipit & Eastern Cottontail & Greater White-fronted Goose \\
\hline Meadow Jumping Mouse & Swainson's Hawk & Loggerhead Shrike & Mountain Cottontail & Snow Goose \\
\hline Black-footed Ferret & Ferruginous Hawk & Black-and-white Warbler & White-tailed Jackrabbit & Ross' Goose \\
\hline Lynx & Golden Eagle & American Redstart & Ord's Kangaroo Rat & Canada Goose \\
\hline American Bison & Merlin & Yellow-breasted Chat & Hispid Pocket Mouse & Wood Duck \\
\hline
\end{tabular}


DRAFT WORKING DOCUMENT DO NOT DUPLICATE

\begin{tabular}{|c|c|c|c|c|}
\hline Green-winged Teal & Killdeer & White-throated Swift & Ruby-crowned Kinglet & Chipping Sparrow \\
\hline American Black Duck & Black-necked Stilt & Belted Kingfisher & Mountain Bluebird & Vesper Sparrow \\
\hline Mallard & American Avocet & Red-naped Sapsucker & Townsend's Solitaire & Lark Sparrow \\
\hline Northern Pintail & Greater Yellowlegs & Downy Woodpecker & Swainson's Thrush & Savannah Sparrow \\
\hline Blue-winged Teal & Lesser Yellowlegs & Hairy Woodpecker & American Robin & Song Sparrow \\
\hline Cinnamon Teal & Solitary Sandpiper & Northern Flicker & Gray Catbird & Lincoln's Sparrow \\
\hline Northern Shoveler & Willet & Western Wood-pewee & Northern Mockingbird & Swamp Sparrow \\
\hline Gadwall & Spotted Sandpiper & Willow Flycatcher & Sage Thrasher & White-throated Sparrow \\
\hline American Wigeon & Semipalmated Sandpiper & Least Flycatcher & Brown Thrasher & White-crowned Sparrow \\
\hline Ring-necked Duck & Western Sandpiper & Dusky Flycatcher & American Pipit & Harris' Sparrow \\
\hline Lesser Scaup & Least Sandpiper & Say's Phoebe & Bohemian Waxwing & Dark-eyed Junco \\
\hline Long Tailed Duck & White-rumped Sandpiper & Western Kingbird & Cedar Waxwing & Lapland Longspur \\
\hline White-winged Scoter & Baird's Sandpiper & Eastern Kingbird & Northern Shrike & Chestnut-collared Longspur \\
\hline Common Goldeneye & Pectoral Sandpiper & Horned Lark & Warbling Vireo & Bobolink \\
\hline Barrow's Goldeneye & Dunlin & Tree Swallow & Red-eyed Vireo & Red-winged Blackbird \\
\hline Bufflehead & Long-billed Dowitcher & Violet-green Swallow & Orange-crowned Warbler & Western Meadowlark \\
\hline Common Merganser & Common Snipe & Northern Rough-winged Swallow & Nashville Warbler & Yellow-headed Blackbird \\
\hline Red-breasted Merganser & Wilson's Phalarope & Bank Swallow & Yellow Warbler & Rusty Blackbird \\
\hline Ruddy Duck & Ring-billed Gull & Cliff Swallow & Yellow-rumped Warbler & Brewer's Blackbird \\
\hline Osprey & California Gull & Barn Swallow & Ovenbird & Common Grackle \\
\hline Red-tailed Hawk & Herring Gull & Blue Jay & Northern Waterthrush & Brown-headed Cowbird \\
\hline Rough-legged Hawk & Mourning Dove & Clark's Nutcracker & Macgillivray's Warbler & Orchard Oriole \\
\hline American Kestrel & Eastern Screech-owl & Black-billed Magpie & Common Yellowthroat & Purple Finch \\
\hline Gyrfalcon & Great Horned Owl & American Crow & Wilson's Warbler & Cassin's Finch \\
\hline Ruffed Grouse & Snowy Owl & Black-capped Chickadee & Western Tanager & House Finch \\
\hline Sharp-tailed Grouse & Long-eared Owl & Mountain Chickadee & Black-headed Grosbeak & Red Crossbill \\
\hline Virginia Rail & Short-eared Owl & Red-breasted Nuthatch & Lazuli Bunting & Common Redpoll \\
\hline Sora & Common Nighthawk & Rock Wren & Dickcissel & Pine Siskin \\
\hline American Coot & Common Poorwill & House Wren & Spotted Towhee & American Goldfinch \\
\hline Lesser Sandhill Crane & Chimney Swift & Marsh Wren & American Tree Sparrow & Evening Grosbeak \\
\hline
\end{tabular}


DRAFT WORKING DOCUMENT DO NOT DUPLICATE

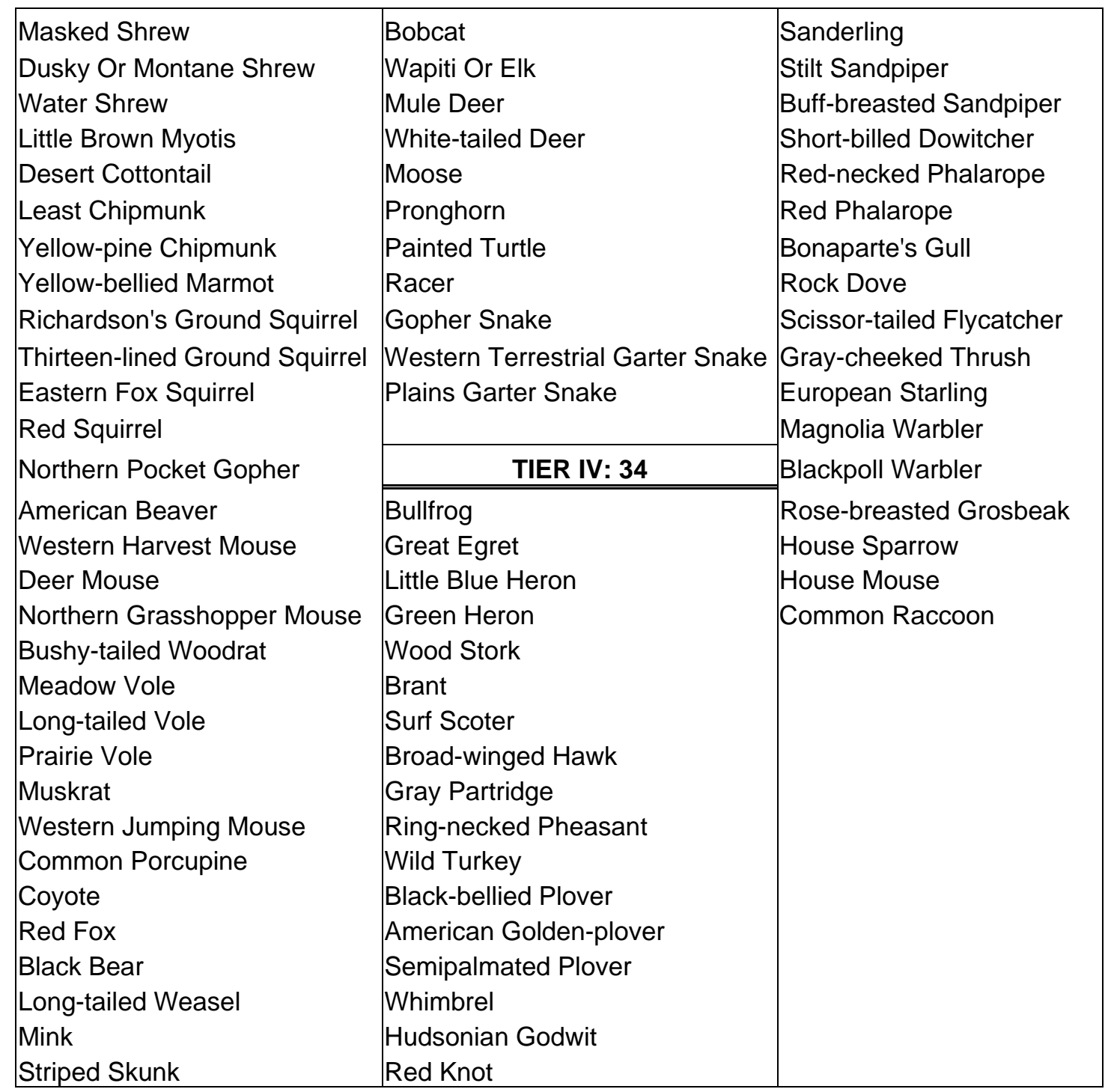


14538

14539

\begin{tabular}{|c|c|c|}
\hline TOTAL: 55 & \multirow{8}{*}{$\begin{array}{l}\text { Lake Whitefish } \\
\text { Mountain Whitefish } \\
\text { Lake Chub } \\
\text { Brassy Minnow } \\
\text { Plains Minnow } \\
\text { Emerald Shiner } \\
\text { Sand Shiner } \\
\text { Northern Redbelly Dace } \\
\text { Fathead Minnow } \\
\text { Longnose Dace } \\
\text { Creek Chub } \\
\text { Flathead Chub } \\
\text { River Carpsucker } \\
\text { Longnose Sucker } \\
\text { White Sucker } \\
\text { Smallmouth Buffalo } \\
\text { Shorthead Redhorse } \\
\text { Channel Catfish } \\
\text { Stonecat } \\
\text { Brook Stickleback } \\
\text { Iowa Darter } \\
\text { Calico Crayfish } \\
\text { Virile Crayfish } \\
\text { Fatmucket } \\
\text { Giant Floater } \\
=\end{array}$} & \multirow{8}{*}{\begin{tabular}{l}
\multicolumn{1}{c}{ TIER IV: 15 } \\
Cisco \\
Chinook Salmon \\
Rainbow Trout \\
Brown Trout \\
Lake Trout \\
Rainbow Smelt \\
Northern Pike \\
Common Carp \\
Spottail Shiner \\
Black Bullhead \\
Smallmouth Bass \\
Largemouth Bass \\
White Crappie \\
Yellow Perch \\
Walleye \\
\end{tabular}} \\
\hline $\begin{array}{l}\text { Group Breakdown } \\
\text { Fish: } 50 \\
\text { Crayfish: } 2 \\
\text { Mussels: } 3\end{array}$ & & \\
\hline TIER I: 9 & & \\
\hline $\begin{array}{l}\text { Pallid Sturgeon } \\
\text { Paddlefish } \\
\text { Shortnose Gar } \\
\text { Sturgeon Chub } \\
\text { Sicklefin Chub } \\
\text { Pearl Dace } \\
\text { Blue Sucker } \\
\text { Burbot } \\
\text { Sauger }\end{array}$ & & \\
\hline TIER II: 4 & & \\
\hline $\begin{array}{l}\text { Northern Redbelly X Finescale Dace } \\
\text { Bigmouth Buffalo } \\
\text { Freshwater Drum } \\
\text { Black Sandshell }\end{array}$ & & \\
\hline TIER: 27 & & \\
\hline $\begin{array}{l}\text { Shovelnose Sturgeon } \\
\text { Goldeye }\end{array}$ & & \\
\hline
\end{tabular}

\section{Table 30. Lower Missouri River Focus Area-Species Associations}


Table 31. Lower Yellowstone River Focus Area-Species Associations

14542

\begin{tabular}{|c|c|c|}
\hline TOTAL: 65 & Goldeye & TIER IV: 24 \\
\hline $\begin{array}{l}\text { Group Breakdown } \\
\text { Fish: } 60 \\
\text { Crayfish: } 1 \\
\text { Mussels: } 3\end{array}$ & $\begin{array}{l}\text { Mountain Whitefish } \\
\text { Lake Chub } \\
\text { Western Silvery Minnow } \\
\text { Brassy Minnow } \\
\text { Plains Minnow } \\
\text { Emerald Shiner }\end{array}$ & \begin{tabular}{|l} 
Cisco \\
Rainbow Trout \\
Brown Trout \\
Brook Trout \\
Rainbow Smelt \\
Northern Pike
\end{tabular} \\
\hline TIER I: 9 & Sand Shiner & Common Carp \\
\hline $\begin{array}{l}\text { Pallid Sturgeon } \\
\text { Paddlefish } \\
\text { Shortnose Gar } \\
\text { Sturgeon Chub } \\
\text { Sicklefin Chub } \\
\text { Pearl Dace } \\
\text { Blue Sucker } \\
\text { Burbot } \\
\text { Sauger }\end{array}$ & $\begin{array}{l}\text { Northern Redbelly Dace } \\
\text { Fathead Minnow } \\
\text { Longnose Dace } \\
\text { Creek Chub } \\
\text { Flathead Chub } \\
\text { River Carpsucker } \\
\text { Longnose Sucker } \\
\text { White Sucker } \\
\text { Mountain Sucker } \\
\text { Smallmouth Buffalo } \\
\text { Shorthead Redhorse }\end{array}$ & $\begin{array}{l}\text { Golden Shiner } \\
\text { Spottail Shiner } \\
\text { Black Bullhead } \\
\text { Yellow Bullhead } \\
\text { Rock Bass } \\
\text { Plains Killifish } \\
\text { Sailfin Molly } \\
\text { White Bass } \\
\text { Green Sunfish } \\
\text { Pumpkinseed } \\
\text { Bluegill }\end{array}$ \\
\hline TIER II: 4 & Channel Catfish & Smallmouth Bass \\
\hline $\begin{array}{l}\text { Northern Redbelly X Finescale Dace } \\
\text { Bigmouth Buffalo } \\
\text { Freshwater Drum } \\
\text { Black Sandshell }\end{array}$ & $\begin{array}{l}\text { Stonecat } \\
\text { Brook Stickleback } \\
\text { Iowa Darter } \\
\text { Virile Crayfish } \\
\text { Fatmucket }\end{array}$ & $\begin{array}{l}\text { Largemouth Bass } \\
\text { White Crappie } \\
\text { Black Crappie } \\
\text { Yellow Perch } \\
\text { Walleye }\end{array}$ \\
\hline TIER III: 27 & Giant Floater & \\
\hline Shovelnose Sturgeon & & \\
\hline
\end{tabular}


Table 32. Powder River Focus Area-Species Associations

14545

\begin{tabular}{|c|c|}
\hline TOTAL: 38 & Smallmouth Buffalo \\
\hline $\begin{array}{c}\text { Group Breakdown } \\
\text { Fish: } 36 \\
\text { Crayfish: } 1 \\
\text { Mussels: } 1\end{array}$ & $\begin{array}{l}\text { Shorthead Redhorse } \\
\text { Channel Catfish } \\
\text { Stonecat } \\
\text { Brook Stickleback } \\
\text { lowa Darter } \\
\text { Virile Crayfish }\end{array}$ \\
\hline TIER I: $\mathbf{3}$ & Fatmucket \\
\hline $\begin{array}{l}\text { Sturgeon Chub } \\
\text { Burbot }\end{array}$ & TIER IV: 13 \\
\hline Sauger & $\begin{array}{l}\text { Rainbow Trout } \\
\text { Brown Trout }\end{array}$ \\
\hline TIER III: 22 & Brook Trout \\
\hline $\begin{array}{l}\text { Shovelnose Sturgeon } \\
\text { Goldeye } \\
\text { Lake Chub } \\
\text { Western Silvery Minnow } \\
\text { Brassy Minnow } \\
\text { Plains Minnow } \\
\text { Sand Shiner } \\
\text { Fathead Minnow } \\
\text { Longnose Dace } \\
\text { Creek Chub } \\
\text { Flathead Chub } \\
\text { River Carpsucker } \\
\text { Longnose Sucker } \\
\text { White Sucker }\end{array}$ & $\begin{array}{l}\text { Northern Pike } \\
\text { Common Carp } \\
\text { Black Bullhead } \\
\text { Yellow Bullhead } \\
\text { Plains Killifish } \\
\text { Green Sunfish } \\
\text { Bluegill } \\
\text { Largemouth Bass } \\
\text { White Crappie } \\
\text { Walleye }\end{array}$ \\
\hline
\end{tabular}


Table 33. Tongue River Focus Area-Species Associations

14548

\begin{tabular}{|c|c|c|}
\hline TOTAL: 49 & \multirow{4}{*}{$\begin{array}{l}\text { Sand Shiner } \\
\text { Fathead Minnow } \\
\text { Longnose Dace } \\
\text { Creek Chub } \\
\text { Flathead Chub } \\
\text { River Carpsucker } \\
\text { Longnose Sucker } \\
\text { White Sucker } \\
\text { Mountain Sucker } \\
\text { Smallmouth Buffalo } \\
\text { Shorthead Redhorse } \\
\text { Channel Catfish } \\
\text { Stonecat } \\
\text { Virile Crayfish } \\
\text { Fatmucket }\end{array}$} & \multirow[b]{2}{*}{$\begin{array}{l}\text { Rock Bass } \\
\text { Green Sunfish } \\
\text { Pumpkinseed } \\
\text { Bluegill } \\
\text { Smallmouth Bass } \\
\text { Largemouth Bass } \\
\text { White Crappie }\end{array}$} \\
\hline $\begin{array}{c}\text { Group Breakdown } \\
\text { Fish: } 47 \\
\text { Crayfish: } 1 \\
\text { Mussels: } 1\end{array}$ & & \\
\hline TIER I: 5 & & Black Crappie \\
\hline $\begin{array}{l}\text { Paddlefish } \\
\text { Sturgeon Chub } \\
\text { Blue Sucker } \\
\text { Burbot } \\
\text { Sauger }\end{array}$ & & $\begin{array}{l}\text { Yellow Perch } \\
\text { Walleye }\end{array}$ \\
\hline TIER II: 1 & & \\
\hline Bigmouth Buffalo & TIER IV: 20 & \\
\hline & Rainbow Trout & \\
\hline TIER III: 23 & Brown Trout & \\
\hline $\begin{array}{l}\text { Shovelnose Sturgeon } \\
\text { Mountain Whitefish } \\
\text { Goldeye } \\
\text { Lake Chub } \\
\text { Western Silvery Minnow } \\
\text { Brassy Minnow } \\
\text { Plains Minnow } \\
\text { Emerald Shiner } \\
\end{array}$ & $\begin{array}{l}\text { Brook Trout } \\
\text { Northern Pike } \\
\text { Common Carp } \\
\text { Golden Shiner } \\
\text { Spottail Shiner } \\
\text { Black Bullhead } \\
\text { Yellow Bullhead } \\
\text { White Bass } \\
\end{array}$ & \\
\hline
\end{tabular}


Table 34. Bighorn Intermontane Basin Focus Area-Species Associations

14551

\begin{tabular}{|c|c|c|c|c|}
\hline TOTAL: 174 & Plains Spadefoot & Olive-backed Pocket Mouse & American Wigeon & Long-eared Owl \\
\hline $\begin{array}{l}\text { Group Breakdown } \\
\text { Amphibians: } 5 \\
\text { Birds: } 117 \\
\text { Mammals: } 43 \\
\text { Reptiles: } 9\end{array}$ & $\begin{array}{l}\text { Northern Harrier } \\
\text { Ferruginous Hawk } \\
\text { Rough-legged Hawk } \\
\text { Golden Eagle } \\
\text { Merlin } \\
\text { Peregrine Falcon } \\
\text { Gyrfalcon }\end{array}$ & $\begin{array}{l}\text { Ord's Kangaroo Rat } \\
\text { Sagebrush Vole } \\
\text { American Badger } \\
\text { Short-horned Lizard } \\
\text { Sagebrush Lizard } \\
\text { Western Rattlesnake }\end{array}$ & $\begin{array}{l}\text { Canvasback } \\
\text { Redhead } \\
\text { Ring-necked Duck } \\
\text { Lesser Scaup } \\
\text { Long Tailed Duck } \\
\text { Common Goldeneye } \\
\text { Barrow's Goldeneye }\end{array}$ & $\begin{array}{l}\text { Short-eared Owl } \\
\text { Common Nighthawk } \\
\text { Calliope Hummingbird } \\
\text { Belted Kingfisher } \\
\text { Northern Flicker } \\
\text { Say's Phoebe } \\
\text { Eastern Kingbird }\end{array}$ \\
\hline TIER I: 14 & Prairie Falcon & TIER III: 112 & Bufflehead & Horned Lark \\
\hline $\begin{array}{l}\text { Northern Leopard Frog } \\
\text { Bald Eagle } \\
\text { Sage-grouse } \\
\text { Mountain Plover } \\
\text { Long-billed Curlew } \\
\text { Burrowing Owl } \\
\text { Spotted Bat } \\
\text { Pallid Bat } \\
\text { Black-tailed Prairie Dog } \\
\text { White-tailed Prairie Dog } \\
\text { Gray Wolf } \\
\text { Black-footed Ferret } \\
\text { Western Hognose Snake } \\
\text { Milk Snake }\end{array}$ & $\begin{array}{l}\text { Canyon Wren } \\
\text { Blue-gray Gnatcatcher } \\
\text { Loggerhead Shrike } \\
\text { Black-and-white Warbler } \\
\text { Yellow-breasted Chat } \\
\text { Indigo Bunting } \\
\text { Green-tailed Towhee } \\
\text { Clay-colored Sparrow } \\
\text { Brewer's Sparrow } \\
\text { Bullock's Oriole } \\
\text { Preble's Shrew } \\
\text { Dwarf Shrew } \\
\text { Merriam's Shrew } \\
\text { Yuma Myotis } \\
\text { Long-eared Myotis }\end{array}$ & $\begin{array}{l}\text { Boreal Chorus Frog } \\
\text { Eared Grebe } \\
\text { Western Grebe } \\
\text { American White Pelican } \\
\text { Double-crested Cormorant } \\
\text { Great Blue Heron } \\
\text { Tundra Swan } \\
\text { Greater White-fronted Goose } \\
\text { Snow Goose } \\
\text { Canada Goose } \\
\text { Green-winged Teal } \\
\text { American Black Duck } \\
\text { Mallard } \\
\text { Northern Pintail } \\
\text { Blue-winged Teal }\end{array}$ & $\begin{array}{l}\text { Common Merganser } \\
\text { Ruddy Duck } \\
\text { Turkey Vulture } \\
\text { Red-tailed Hawk } \\
\text { American Kestrel } \\
\text { Sharp-tailed Grouse } \\
\text { American Coot } \\
\text { American Coot } \\
\text { Greater Sandhill Crane } \\
\text { Killdeer } \\
\text { American Avocet } \\
\text { Dunlin } \\
\text { Common Snipe } \\
\text { Wilson's Phalarope } \\
\text { California Gull }\end{array}$ & $\begin{array}{l}\text { Violet-green Swallow } \\
\text { Bank Swallow } \\
\text { Cliff Swallow } \\
\text { Barn Swallow } \\
\text { Pinyon Jay } \\
\text { Black-billed Magpie } \\
\text { American Crow } \\
\text { Common Raven } \\
\text { Mountain Chickadee } \\
\text { Rock Wren } \\
\text { House Wren } \\
\text { Mountain Bluebird } \\
\text { American Robin } \\
\text { Gray Catbird } \\
\text { Northern Mockingbird }\end{array}$ \\
\hline TIER II: 36 & Long-legged Myotis & Cinnamon Teal & Mourning Dove & Sage Thrasher \\
\hline $\begin{array}{l}\text { Tiger Salamander } \\
\text { Woodhouse's Toad }\end{array}$ & $\begin{array}{l}\text { Western Small-footed Myotis } \\
\text { Mountain Cottontail }\end{array}$ & $\begin{array}{l}\text { Northern Shoveler } \\
\text { Gadwall }\end{array}$ & $\begin{array}{l}\text { Great Horned Owl } \\
\text { Snowy Owl }\end{array}$ & $\begin{array}{l}\text { Bohemian Waxwing } \\
\text { Cedar Waxwing }\end{array}$ \\
\hline
\end{tabular}




\begin{tabular}{|l|l|}
\hline Northern Shrike & Bobcat \\
Spotted Towhee & Mountain Lion \\
Vesper Sparrow & Wapiti or Elk \\
Lark Sparrow & Mule Deer \\
Savannah Sparrow & White-tailed Deer \\
Lapland Longspur & Pronghorn \\
Bobolink & Painted Turtle \\
Red-winged Blackbird & Racer \\
Western Meadowlark & Gopher Snake \\
Yellow-headed Blackbird & Plains Garter Snake \\
Brewer's Blackbird & \\
\cline { 2 - 2 } Common Grackle & \multicolumn{1}{|c|}{ TIER IV: 12 } \\
\hline House Finch & Broad-winged Hawk \\
Common Redpoll & Chukar \\
Dusky Or Montane Shrew & Ring-necked Pheasant \\
Desert Cottontail & Wild Turkey \\
Least Chipmunk & Rock Dove \\
Thirteen-lined Ground Squirrel & European Starling \\
Northern Pocket Gopher & Pine Warbler \\
American Beaver & Palm Warbler \\
Western Harvest Mouse & House Sparrow \\
Deer Mouse & Eastern Fox Squirrel \\
Northern Grasshopper Mouse & House Mouse \\
Meadow Vole & Common Raccoon \\
Muskrat & \\
Common Porcupine & \\
Coyote & \\
Red Fox & \\
Black Bear & \\
Striped Skunk & \\
\hline
\end{tabular}


Table 35. Montana Glaciated Plains Focus Area-Species Associations

\begin{tabular}{|c|c|c|c|c|}
\hline TOTAL: 368 & Lynx & Swainson's Hawk & Black-and-white Warbler & Eastern Red Bat \\
\hline $\begin{array}{l}\text { Group Breakdown } \\
\text { Amphibians: } 6 \\
\text { Birds: } 280 \\
\text { Mammals: } 69 \\
\text { Reptiles: } 13\end{array}$ & $\begin{array}{l}\text { American Bison } \\
\text { Snapping Turtle } \\
\text { Spiny Softshell } \\
\text { Western Hognose Snake } \\
\text { Milk Snake }\end{array}$ & \begin{tabular}{|l} 
Ferruginous Hawk \\
Golden Eagle \\
Merlin \\
Peregrine Falcon \\
Prairie Falcon \\
Greater Sandhill Crane \\
Upland Sandpiper
\end{tabular} & $\begin{array}{l}\text { American Redstart } \\
\text { Yellow-breasted Chat } \\
\text { Indigo Bunting } \\
\text { Green-tailed Towhee } \\
\text { Clay-colored Sparrow } \\
\text { Brewer's Sparrow } \\
\text { Field Sparrow }\end{array}$ & $\begin{array}{l}\text { Hoary Bat } \\
\text { Mountain Cottontail } \\
\text { White-tailed Jackrabbit } \\
\text { Olive-backed Pocket Mouse } \\
\text { Ord's Kangaroo Rat } \\
\text { White-footed Mouse } \\
\text { Sagebrush Vole }\end{array}$ \\
\hline
\end{tabular}


DRAFT WORKING DOCUMENT DO NOT DUPLICATE

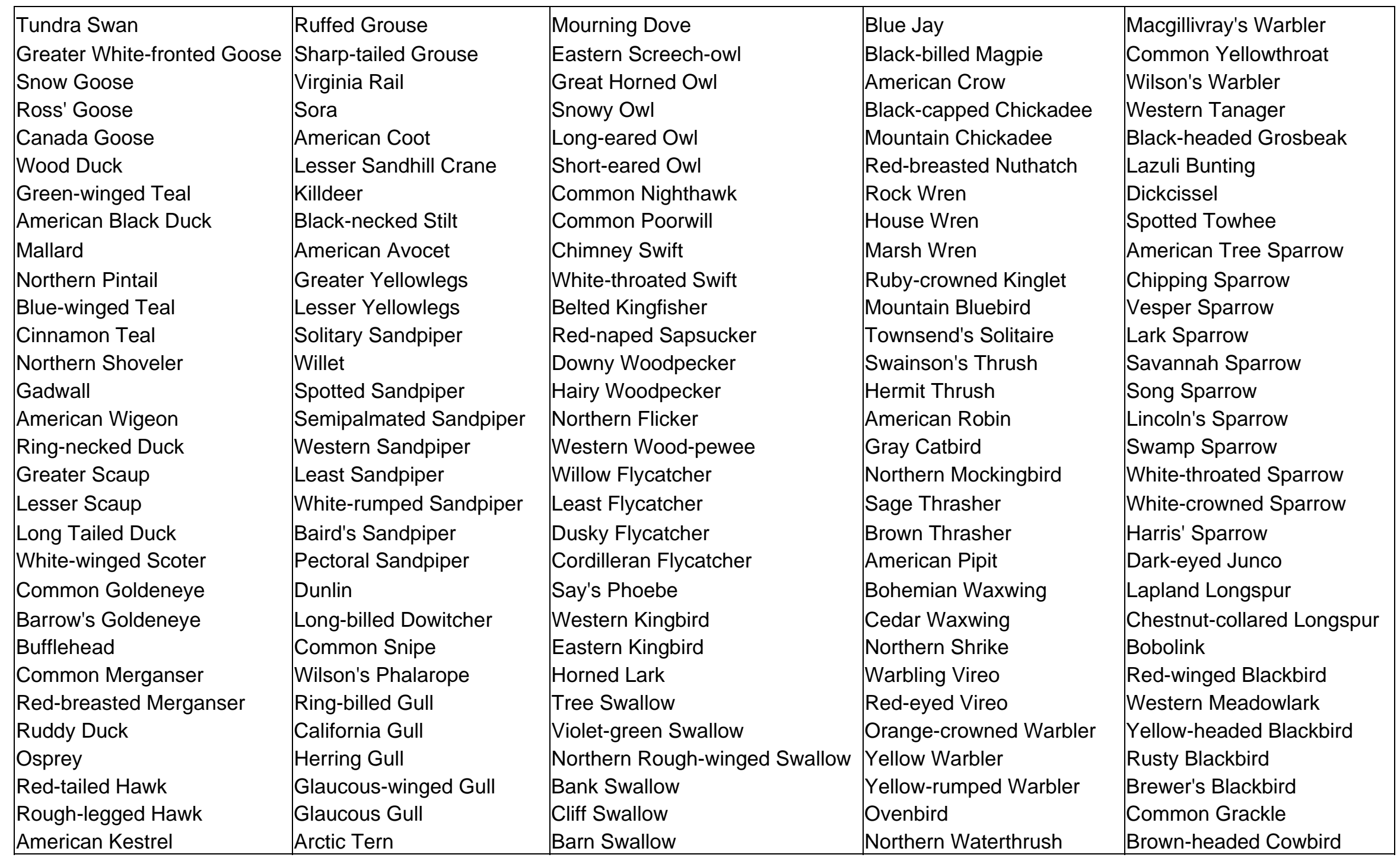


DRAFT WORKING DOCUMENT DO NOT DUPLICATE

\begin{tabular}{|c|c|c|c|}
\hline Purple Finch & Common Porcupine & Ring-necked Pheasant & Hooded Warbler \\
\hline Cassin's Finch & Coyote & Wild Turkey & Canada Warbler \\
\hline House Finch & Red Fox & Black-bellied Plover & Scarlet Tanager \\
\hline Red Crossbill & Black Bear & American Golden-plover & Rose-breasted Grosbeak \\
\hline Common Redpoll & Ermine & Semipalmated Plover & Golden-crowned Sparrow \\
\hline Pine Siskin & Long-tailed Weasel & Whimbrel & House Sparrow \\
\hline American Goldfinch & Mink & Hudsonian Godwit & House Mouse \\
\hline Evening Grosbeak & Striped Skunk & Ruddy Turnstone & Common Raccoon \\
\hline Masked Shrew & Bobcat & Red Knot & \\
\hline Dusky Or Montane Shrew & Wapiti Or Elk & Sanderling & \\
\hline Water Shrew & Mule Deer & Curlew Sandpiper & \\
\hline Little Brown Myotis & White-tailed Deer & Stilt Sandpiper & \\
\hline Desert Cottontail & Moose & Buff-breasted Sandpiper & \\
\hline Snowshoe Hare & Pronghorn & Short-billed Dowitcher & \\
\hline Least Chipmunk & Painted Turtle & Red-necked Phalarope & \\
\hline Yellow-bellied Marmot & Racer & Red Phalarope & \\
\hline Richardson's Ground Squirrel & Gopher Snake & Bonaparte's Gull & \\
\hline Thirteen-lined Ground Squirrel & Western Terrestrial Garter Snake & Mew Gull & \\
\hline $\begin{array}{l}\text { Red Squirrel } \\
\text { Northern Pocket Gopher }\end{array}$ & Plains Garter Snake & $\begin{array}{l}\text { Thayer's Gull } \\
\text { Rock Dove }\end{array}$ & \\
\hline American Beaver & TIER IV: 47 & Band-tailed Pigeon & \\
\hline Western Harvest Mouse & Least Bittern & Ruby-throated Hummingbird & \\
\hline Deer Mouse & Great Egret & Red-bellied Woodpecker & \\
\hline Northern Grasshopper Mouse & Green Heron & Eastern Wood-pewee & \\
\hline Bushy-tailed Woodrat & Yellow-crowned Night-heron & Gray-cheeked Thrush & \\
\hline Meadow Vole & Eurasian Wigeon & European Starling & \\
\hline Montane Vole & Black Scoter & Magnolia Warbler & \\
\hline Long-tailed Vole & Surf Scoter & Cape May Warbler & \\
\hline Prairie Vole & Broad-winged Hawk & Blackpoll Warbler & \\
\hline Muskrat & Gray Partridge & Mourning Warbler & \\
\hline
\end{tabular}


Table 36. Montana Shale Plains Focus Area-Species Associations

\begin{tabular}{|c|c|c|c|c|}
\hline TOTAL: 307 & TIER II: 75 & Caspian Tern & Hayden's Shrew & American White Pelican \\
\hline $\begin{array}{l}\text { Group Breakdown } \\
\text { Amphibians: } 6 \\
\text { Birds: } 230 \\
\text { Mammals: } 59 \\
\text { Reptiles: } 12\end{array}$ & \begin{tabular}{|l} 
Tiger Salamander \\
Great Plains Toad \\
Woodhouse's Toad \\
Plains Spadefoot \\
Western Grebe \\
American Bittern \\
Black-crowned Night-heron
\end{tabular} & $\begin{array}{l}\text { Common Tern } \\
\text { Forster's Tern } \\
\text { Black-billed Cuckoo } \\
\text { Northern Saw-whet Owl } \\
\text { Lewis' Woodpecker } \\
\text { Red-headed Woodpecker } \\
\text { Pinyon Jay }\end{array}$ & $\begin{array}{l}\text { Yuma Myotis } \\
\text { Long-eared Myotis } \\
\text { Long-legged Myotis } \\
\text { Western Small-footed Myotis } \\
\text { Silver-haired Bat } \\
\text { Big Brown Bat } \\
\text { Eastern Red Bat }\end{array}$ & $\begin{array}{l}\text { Double-crested Cormorant } \\
\text { Great Blue Heron } \\
\text { Snowy Egret } \\
\text { Tundra Swan } \\
\text { Greater White-fronted Goose } \\
\text { Snow Goose } \\
\text { Ross' Goose }\end{array}$ \\
\hline TIEF & White-faced Ibis & White-breasted Nuthatch & Hoars & Canada Goose \\
\hline Northern Leopa & Canvasback & Pygmy Nuthatch & Mountain Cottontail & Wood Duck \\
\hline Common Loon & Redh & Veery & White-tailed & Green-winged Teal \\
\hline Bald & Merganser & Spra & ket Mouse & \\
\hline Sage-grouse & Turke & Loggerhe & Ord's Kans & Northern Pintail \\
\hline Whooping Crane & North & American & Mouse & Blue-winged Teal \\
\hline Mour & Sharp-shinned Hawk & Yellow-breasted Chat & Sagebrush Vole & Cinnamc \\
\hline ed Curlew & Cooper's Hawk & Clay-colored Sparrow & Swift & Northe \\
\hline Black & Northern Goshawk & Brewer's Sparrow & American Badger & Gadwall \\
\hline Burrowing Owl & Swainson's Hawk & Field Sparrow & Northern River Otter & American Wigeon \\
\hline Townsend's Big-eare & Ferruginous Hawk & Lark Bunting & Short-horned Lizard & Ring-necked Duck \\
\hline Black-tailed Prairie Dog & Golden Eagle & Baird & ssh lizard & Lesser Scaup \\
\hline Meadow Jumping Mouse & Merlin & Grasshopper Sparrow & Common Garter Snake & Long Tailed Duck \\
\hline $\begin{array}{l}\text { Black-footed Ferret } \\
\text { Lynx }\end{array}$ & $\begin{array}{l}\text { Peregrine Falcon } \\
\text { Prairie Falcon }\end{array}$ & $\begin{array}{l}\text { Mccown's Longspur } \\
\text { Baltimore Oriole }\end{array}$ & Western Rattlesnake & White-winged Scoter \\
\hline American Bison & Greater Sandhill Crane & Bullock's Oriole & TIER III: 189 & Barrow's Goldeneye \\
\hline $\begin{array}{l}\text { Spiny Softshell } \\
\text { Western Hognose Snake } \\
\text { Milk Snake }\end{array}$ & $\begin{array}{l}\text { Upland Sandpiper } \\
\text { Marbled Godwit } \\
\text { Franklin's Gull }\end{array}$ & $\begin{array}{l}\text { Preble's Shrew } \\
\text { Dwarf Shrew } \\
\text { Merriam's Shrew }\end{array}$ & $\begin{array}{l}\text { Boreal Chorus Frog } \\
\text { Pied-billed Grebe } \\
\text { Eared Grebe }\end{array}$ & $\begin{array}{l}\text { Bufflehead } \\
\text { Common Merganser } \\
\text { Red-breasted Merganser }\end{array}$ \\
\hline
\end{tabular}


DRAFT WORKING DOCUMENT DO NOT DUPLICATE

\begin{tabular}{|c|c|c|c|c|}
\hline Ruddy Duck & California Gull & Clark's Nutcracker & Macgillivray's Warbler & Common Redpoll \\
\hline Osprey & Herring Gull & Black-billed Magpie & Common Yellowthroat & Pine Siskin \\
\hline Rough-legged Hawk & Eastern Screech-owl & Black-capped Chickadee & Western Tanager & Evening Grosbeak \\
\hline Gyrfalcon & Snowy Owl & Red-breasted Nuthatch & Lazuli Bunting & Little Brown Myotis \\
\hline Ruffed Grouse & Long-eared Owl & Rock Wren & Dickcissel & Desert Cottontail \\
\hline Sharp-tailed Grouse & Short-eared Owl & House Wren & Spotted Towhee & Least Chipmunk \\
\hline American Coot & White-throated Swift & Mountain Bluebird & Vesper Sparrow & Thirteen-lined Ground Squirrel \\
\hline Lesser Sandhill Crane & Belted Kingfisher & Townsend's Solitaire & Lark Sparrow & Eastern Fox Squirrel \\
\hline Killdeer & Downy Woodpecker & Swainson's Thrush & Savannah Sparrow & Red Squirrel \\
\hline Black-necked Stilt & Hairy Woodpecker & Hermit Thrush & Song Sparrow & Northern Pocket Gopher \\
\hline American Avocet & Northern Flicker & American Robin & Lincoln's Sparrow & American Beaver \\
\hline Greater Yellowlegs & Western Wood-pewee & Gray Catbird & White-throated Sparrow & Western Harvest Mouse \\
\hline Semipalmated Sandpiper & Western Kingbird & Bohemian Waxwing & Chestnut-collared Longspur & Long-tailed Vole \\
\hline Western Sandpiper & Eastern Kingbird & Cedar Waxwing & Bobolink & Prairie Vole \\
\hline Least Sandpiper & Horned Lark & Northern Shrike & Red-winged Blackbird & Muskrat \\
\hline Baird's Sandpiper & Tree Swallow & Warbling Vireo & Western Meadowlark & Common Porcupine \\
\hline Pectoral Sandpiper & Violet-green Swallow & Red-eyed Vireo & Yellow-headed Blackbird & Coyote \\
\hline Dunlin & Northern Rough-winged Swallow & Orange-crowned Warbler & Brewer's Blackbird & Red Fox \\
\hline Long-billed Dowitcher & Bank Swallow & Yellow Warbler & Common Grackle & Long-tailed Weasel \\
\hline Common Snipe & Cliff Swallow & Yellow-rumped Warbler & Brown-headed Cowbird & Mink \\
\hline Wilson's Phalarope & Barn Swallow & Ovenbird & House Finch & Striped Skunk \\
\hline Ring-billed Gull & Blue Jay & Northern Waterthrush & Red Crossbill & Bobcat \\
\hline
\end{tabular}




\begin{tabular}{|l|l|}
\hline Wapiti Or Elk & European Starling \\
Mule Deer & Blackpoll Warbler \\
White-tailed Deer & Rose-breasted Grosbeak \\
Pronghorn & House Sparrow \\
Painted Turtle & House Mouse \\
Racer & Common Raccoon \\
Gopher Snake & \\
Western Terrestrial Garter Snake & \\
Plains Garter Snake & \\
\hline \multicolumn{1}{|c}{ TIER IV: 25 } & \\
\hline \hline Great Egret & \\
Brant & \\
Eurasian Wigeon & \\
Broad-winged Hawk & \\
Gray Partridge & \\
Ring-necked Pheasant & \\
Wild Turkey & \\
Black-bellied Plover & \\
Semipalmated Plover & \\
Whimbrel & \\
Hudsonian Godwit & \\
Red Knot & \\
Sanderling & \\
Stilt Sandpiper & \\
Buff-breasted Sandpiper & \\
Red-necked Phalarope & \\
Bonaparte's Gull & \\
Rock Dove & \\
Gray-cheeked Thrush & \\
\hline
\end{tabular}


Table 37. Powder River Basin/Breaks/Scoria Hills Focus Area-Species Associations

\begin{tabular}{|c|c|c|c|c|}
\hline TOTAL: 299 & Milk Snake & Upland Sandpiper & Lark Bunting & Sagebrush Lizard \\
\hline \multirow[b]{2}{*}{ Group Breakdown } & & Franklin's Gull & Grasshopper Sparrow & Common Garter Snake \\
\hline & TIER II: 81 & Caspian Tern & Le Conte's Sparrow & Western Rattlesnake \\
\hline \multirow{2}{*}{$\begin{array}{c}\text { Amphibians: } 6 \\
\text { Birds: } 219\end{array}$} & Tiger Salamander & Common Tern & Mccown's Longspur & \\
\hline & Great Plains Toad & Forster's Tern & Bullock's Oriole & TIER III: 180 \\
\hline $\begin{array}{l}\text { Mammals: } 61 \\
\text { Reptiles: } 13\end{array}$ & $\begin{array}{l}\text { Woodhouse's Toad } \\
\text { Plains Spadefoot } \\
\text { Horned Grebe }\end{array}$ & $\begin{array}{l}\text { Black-billed Cuckoo } \\
\text { Yellow-billed Cuckoo } \\
\text { Barn Owl }\end{array}$ & $\begin{array}{l}\text { Preble's Shrew } \\
\text { Dwarf Shrew } \\
\text { Merriam's Shrew }\end{array}$ & $\begin{array}{l}\text { Boreal Chorus Frog } \\
\text { Pied-billed Grebe } \\
\text { Eared Grebe }\end{array}$ \\
\hline TIER I: 19 & Western Grebe & Northern Saw-whet Owl & Hayden's Shrew & American White Pelican \\
\hline Northern Leopard Frog & American Bittern & Lewis' Woodpecker & Yuma Myotis & Double-crested Cormorant \\
\hline Common Loon & Black-crowned Night-heron & Cassin's Kingbird & Long-eared Myotis & Great Blue Heron \\
\hline Trumpeter Swan & Canvasback & Pinyon Jay & Long-legged Myotis & Cattle Egret \\
\hline Bald Eagle & Redhead & White-breasted Nuthatch & Western Small-footed Myotis & Tundra Swan \\
\hline Sage-grouse & Hooded Merganser & Pygmy Nuthatch & Silver-haired Bat & Greater White-fronted Goose \\
\hline Whooping Crane & Turkey Vulture & Brown Creeper & Big Brown Bat & Snow Goose \\
\hline Long-billed Curlew & Northern Harrier & Canyon Wren & Eastern Red Bat & Canada Goose \\
\hline Black Tern & Sharp-shinned Hawk & Winter Wren & Hoary Bat & Wood Duck \\
\hline Burrowing Owl & Cooper's Hawk & Veery & Mountain Cottontail & Green-winged Teal \\
\hline Spotted Bat & Northern Goshawk & Sprague's Pipit & White-tailed Jackrabbit & American Black Duck \\
\hline Townsend's Big-eared Bat & Swainson's Hawk & Loggerhead Shrike & Olive-backed Pocket Mouse & Mallard \\
\hline Black-tailed Prairie Dog & Ferruginous Hawk & Black-and-white Warbler & Ord's Kangaroo Rat & Northern Pintail \\
\hline Meadow Jumping Mouse & Golden Eagle & American Redstart & White-footed Mouse & Blue-winged Teal \\
\hline Black-footed Ferret & Merlin & Yellow-breasted Chat & Sagebrush Vole & Cinnamon Teal \\
\hline American Bison & Peregrine Falcon & Indigo Bunting & Swift Fox & Northern Shoveler \\
\hline Snapping Turtle & Prairie Falcon & Green-tailed Towhee & American Badger & Gadwall \\
\hline Spiny Softshell & Blue Grouse & Brewer's Sparrow & Northern River Otter & American Wigeon \\
\hline Western Hognose Snake & Greater Sandhill Crane & Field Sparrow & Short-horned Lizard & Ring-necked Duck \\
\hline
\end{tabular}


DRAFT WORKING DOCUMENT DO NOT DUPLICATE

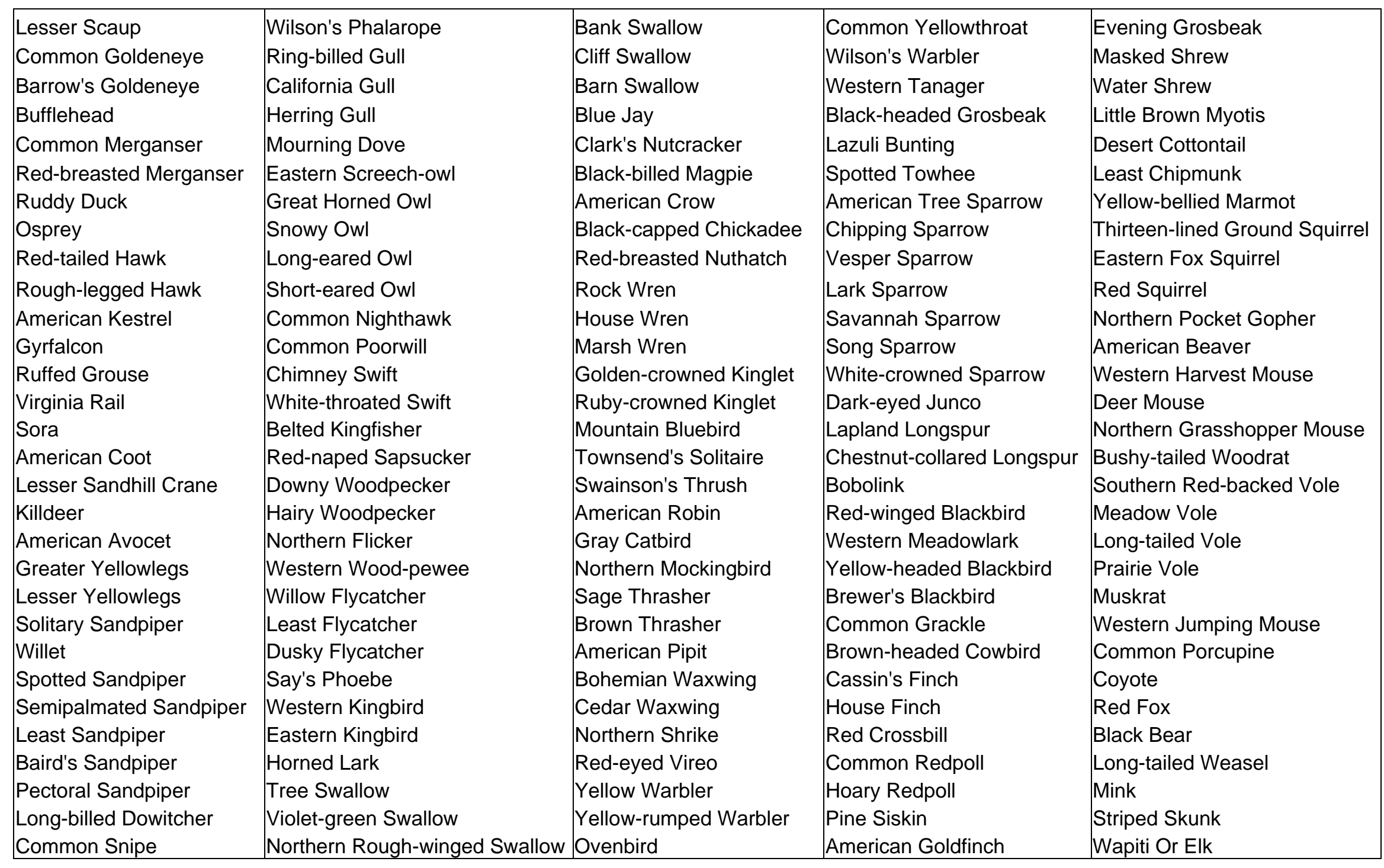


Mule Deer

White-tailed Deer

Pronghorn

Painted Turtle

Racer

Gopher Snake

Western Terrestrial Garter Snake

Plains Garter Snake

TIER IV: 19

Surf Scoter

Broad-winged Hawk

Gray Partridge

Chukar

Ring-necked Pheasant

Wild Turkey

Black-bellied Plover

American Golden-plover

Semipalmated Plover

Whimbrel

Stilt Sandpiper

Red-necked Phalarope

Rock Dove

Yellow-bellied Sapsucker

European Starling

Blackpoll Warbler

House Sparrow

House Mouse

Common Raccoon 
Table 38. Shale Scablands Focus Area-Species Associations

14571

\begin{tabular}{|c|c|c|c|c|}
\hline TOTAL: 245 & TIER II: 77 & Black-billed Cuckoo & Bullock's Oriole & Pied-billed Grebe \\
\hline $\begin{array}{l}\text { Group Breakdown } \\
\text { Amphibians: } 6 \\
\text { Birds: } 172 \\
\text { Mammals: } 55 \\
\text { Reptiles: } 12\end{array}$ & $\begin{array}{l}\text { Tiger Salamander } \\
\text { Great Plains Toad } \\
\text { Woodhouse's Toad } \\
\text { Plains Spadefoot } \\
\text { Horned Grebe } \\
\text { Western Grebe } \\
\text { American Bittern }\end{array}$ & $\begin{array}{l}\text { Yellow-billed Cuckoo } \\
\text { Barn Owl } \\
\text { Northern Saw-whet Owl } \\
\text { Lewis' Woodpecker } \\
\text { Red-headed Woodpecker } \\
\text { Cassin's Kingbird } \\
\text { Pinyon Jay }\end{array}$ & $\begin{array}{l}\text { Dwarf Shrew } \\
\text { Merriam's Shrew } \\
\text { Hayden's Shrew } \\
\text { Long-eared Myotis } \\
\text { Long-legged Myotis } \\
\text { Western Small-footed Myotis } \\
\text { Silver-haired Bat }\end{array}$ & $\begin{array}{l}\text { Eared Grebe } \\
\text { American White Pelican } \\
\text { Double-crested Cormorant } \\
\text { Great Blue Heron } \\
\text { Canada Goose } \\
\text { Green-winged Teal } \\
\text { Mallard }\end{array}$ \\
\hline TIER I: 17 & Black-crowned Night-heron & White-breasted Nuthatch & Big Brown Bat & Northern Pintail \\
\hline $\begin{array}{l}\text { Northern Leopard Frog } \\
\text { Common Loon } \\
\text { Bald Eagle } \\
\text { Sage-grouse } \\
\text { Whooping Crane } \\
\text { Mountain Plover } \\
\text { Long-billed Curlew } \\
\text { Black Tern } \\
\text { Burrowing Owl } \\
\text { Townsend's Big-eared Bat } \\
\text { Black-tailed Prairie Dog } \\
\text { Meadow Jumping Mouse } \\
\text { Black-footed Ferret } \\
\text { Snapping Turtle } \\
\text { Spiny Softshell } \\
\text { Western Hognose Snake }\end{array}$ & $\begin{array}{l}\text { Canvasback } \\
\text { Redhead } \\
\text { Hooded Merganser } \\
\text { Turkey Vulture } \\
\text { Northern Harrier } \\
\text { Sharp-shinned Hawk } \\
\text { Cooper's Hawk } \\
\text { Northern Goshawk } \\
\text { Swainson's Hawk } \\
\text { Ferruginous Hawk } \\
\text { Golden Eagle } \\
\text { Merlin } \\
\text { Peregrine Falcon } \\
\text { Prairie Falcon } \\
\text { Greater Sandhill Crane } \\
\text { Upland Sandpiper }\end{array}$ & $\begin{array}{l}\text { Pygmy Nuthatch } \\
\text { Brown Creeper } \\
\text { Canyon Wren } \\
\text { Winter Wren } \\
\text { Eastern Bluebird } \\
\text { Veery } \\
\text { Sprague's Pipit } \\
\text { Loggerhead Shrike } \\
\text { Black-and-white Warbler } \\
\text { American Redstart } \\
\text { Yellow-breasted Chat } \\
\text { Indigo Bunting } \\
\text { Clay-colored Sparrow } \\
\text { Brewer's Sparrow } \\
\text { Field Sparrow } \\
\text { Lark Bunting }\end{array}$ & $\begin{array}{l}\text { Eastern Red Bat } \\
\text { Hoary Bat } \\
\text { Eastern Cottontail } \\
\text { White-tailed Jackrabbit } \\
\text { Olive-backed Pocket Mouse } \\
\text { Hispid Pocket Mouse } \\
\text { White-footed Mouse } \\
\text { Sagebrush Vole } \\
\text { Swift Fox } \\
\text { American Badger } \\
\text { Northern River Otter } \\
\text { Short-horned Lizard } \\
\text { Sagebrush Lizard } \\
\text { Common Garter Snake } \\
\text { Western Rattlesnake }\end{array}$ & $\begin{array}{l}\text { Blue-winged Teal } \\
\text { Cinnamon Teal } \\
\text { Northern Shoveler } \\
\text { Gadwall } \\
\text { American Wigeon } \\
\text { Ring-necked Duck } \\
\text { Lesser Scaup } \\
\text { Bufflehead } \\
\text { Common Merganser } \\
\text { Ruddy Duck } \\
\text { Osprey } \\
\text { Red-tailed Hawk } \\
\text { Rough-legged Hawk } \\
\text { American Kestrel } \\
\text { Gyrfalcon } \\
\text { Sharp-tailed Grouse }\end{array}$ \\
\hline Milk Snake & $\begin{array}{l}\text { Franklin's Gull } \\
\text { Forster's Tern }\end{array}$ & $\begin{array}{l}\text { Baird's Sparrow } \\
\text { Grasshopper Sparrow }\end{array}$ & \begin{tabular}{|c|} 
TIER III: 138 \\
Boreal Chorus Frog \\
\end{tabular} & $\begin{array}{l}\text { Sora } \\
\text { American Coot }\end{array}$ \\
\hline
\end{tabular}


DRAFT WORKING DOCUMENT DO NOT DUPLICATE

\begin{tabular}{|c|c|c|c|c|}
\hline Lesser Sandhill Crane & Violet-green Swallow & Song Sparrow & Meadow Vole & European Starling \\
\hline Killdeer & Northern Rough-winged Swallow & Lincoln's Sparrow & Long-tailed Vole & Blackpoll Warbler \\
\hline Greater Yellowlegs & Cliff Swallow & White-throated Sparrow & Prairie Vole & House Sparrow \\
\hline Lesser Yellowlegs & Barn Swallow & White-crowned Sparrow & Muskrat & House Mouse \\
\hline Solitary Sandpiper & Clark's Nutcracker & Chestnut-collared Longspur & Common Porcupine & Common Raccoon \\
\hline Willet & Red-breasted Nuthatch & Snow Bunting & Coyote & \\
\hline Spotted Sandpiper & House Wren & Bobolink & Red Fox & \\
\hline Western Sandpiper & Golden-crowned Kinglet & Red-winged Blackbird & Long-tailed Weasel & \\
\hline Least Sandpiper & Mountain Bluebird & Western Meadowlark & Mink & \\
\hline Dunlin & American Robin & Yellow-headed Blackbird & Striped Skunk & \\
\hline Long-billed Dowitcher & Gray Catbird & Brewer's Blackbird & Bobcat & \\
\hline Common Snipe & Sage Thrasher & Common Grackle & Wapiti Or Elk & \\
\hline Wilson's Phalarope & Brown Thrasher & Brown-headed Cowbird & Mule Deer & \\
\hline Ring-billed Gull & American Pipit & Orchard Oriole & White-tailed Deer & \\
\hline California Gull & Bohemian Waxwing & Red Crossbill & Pronghorn & \\
\hline Mourning Dove & Cedar Waxwing & American Goldfinch & Bighorn Sheep & \\
\hline Snowy Owl & Northern Shrike & Masked Shrew & Painted Turtle & \\
\hline Short-eared Owl & Orange-crowned Warbler & Dusky Or Montane Shrew & Racer & \\
\hline Common Nighthawk & Yellow Warbler & Little Brown Myotis & Western Terrestrial Garter Snake & \\
\hline Belted Kingfisher & Northern Waterthrush & Desert Cottontail & Plains Garter Snake & \\
\hline Downy Woodpecker & Common Yellowthroat & Least Chipmunk & & \\
\hline Northern Flicker & Wilson's Warbler & Thirteen-lined Ground Squirrel & TIER IV: 13 & \\
\hline Western Wood-pewee & Black-headed Grosbeak & Eastern Fox Squirrel & Least Bittern & \\
\hline Willow Flycatcher & Dickcissel & Red Squirrel & Great Egret & \\
\hline Least Flycatcher & Spotted Towhee & Northern Pocket Gopher & Gray Partridge & \\
\hline Say's Phoebe & American Tree Sparrow & American Beaver & Ring-necked Pheasant & \\
\hline Western Kingbird & Chipping Sparrow & Western Harvest Mouse & Black-bellied Plover & \\
\hline Eastern Kingbird & Vesper Sparrow & Deer Mouse & Stilt Sandpiper & \\
\hline Horned Lark & Lark Sparrow & Northern Grasshopper Mouse & Rock Dove & \\
\hline Tree Swallow & Savannah Sparrow & Bushy-tailed Woodrat & Eastern Wood-pewee & \\
\hline
\end{tabular}


14574

14575

\begin{tabular}{|c|c|c|c|}
\hline TOTAL: 67 & TIER III: 31 & Iowa Darter & Walleye \\
\hline \multirow[t]{2}{*}{$\begin{array}{l}\text { Group Breakdown } \\
\text { Fish: } 62 \\
\text { Crayfish: } 2 \\
\text { Mussels: } 3\end{array}$} & \multirow{2}{*}{$\begin{array}{l}\text { Mottled Sculpin } \\
\text { Shovelnose Sturgeon } \\
\text { Goldeye } \\
\text { Lake Whitefish } \\
\text { Mountain Whitefish } \\
\text { Lake Chub }\end{array}$} & $\begin{array}{l}\text { Calico Crayfish } \\
\text { Virile Crayfish } \\
\text { Fatmucket } \\
\text { Giant Floater }\end{array}$ & \\
\hline & & TIER IV: 21 & \\
\hline TIER I: 9 & Western Silvery Minnow & Cisco & \\
\hline $\begin{array}{l}\text { Pallid Sturgeon } \\
\text { Paddlefish } \\
\text { Shortnose Gar } \\
\text { Sturgeon Chub } \\
\text { Sicklefin Chub } \\
\text { Blue Sucker } \\
\text { Burbot } \\
\text { Sauger }\end{array}$ & \begin{tabular}{|l} 
Brassy Minnow \\
Plains Minnow \\
Emerald Shiner \\
Sand Shiner \\
Northern Redbelly Dace \\
Fathead Minnow \\
Longnose Dace \\
Creek Chub \\
Flathead Chub \\
River Carpsucker \\
Longnose Sucker \\
White Sucker
\end{tabular} & $\begin{array}{l}\text { Chinook Salmon } \\
\text { Kokanee Salmon } \\
\text { Rainbow Trout } \\
\text { Brown Trout } \\
\text { Brook Trout } \\
\text { Lake Trout } \\
\text { Northern Pike } \\
\text { Common Carp } \\
\text { Spottail Shiner } \\
\text { Black Bullhead } \\
\text { Pumpkinseed } \\
\text { Plains Killifish }\end{array}$ & \\
\hline TIER II: 4 & Mountain Sucker & Green Sunfish & \\
\hline $\begin{array}{l}\text { Bigmouth Buffalo } \\
\text { Freshwater Drum } \\
\text { Northern Redbelly X Finescale Dace } \\
\text { Black Sandshell }\end{array}$ & $\begin{array}{l}\text { Smallmouth Buffalo } \\
\text { Shorthead Redhorse } \\
\text { Channel Catfish } \\
\text { Stonecat } \\
\text { Western Mosquitofish } \\
\text { Brook Stickleback }\end{array}$ & $\begin{array}{l}\text { Bluegill } \\
\text { Smallmouth Bass } \\
\text { Largemouth Bass } \\
\text { White Crappie } \\
\text { Black Crappie } \\
\text { Yellow Perch } \\
\end{array}$ & \\
\hline
\end{tabular}

Table 39. Middle Missouri River Focus Area-Species Associations 
Table 40. Grassland Complexes Communities-Species Associations

Note: Essentially associated species are bolded in table. Total number of species essentially associated with each community type can be found in parenthesis.

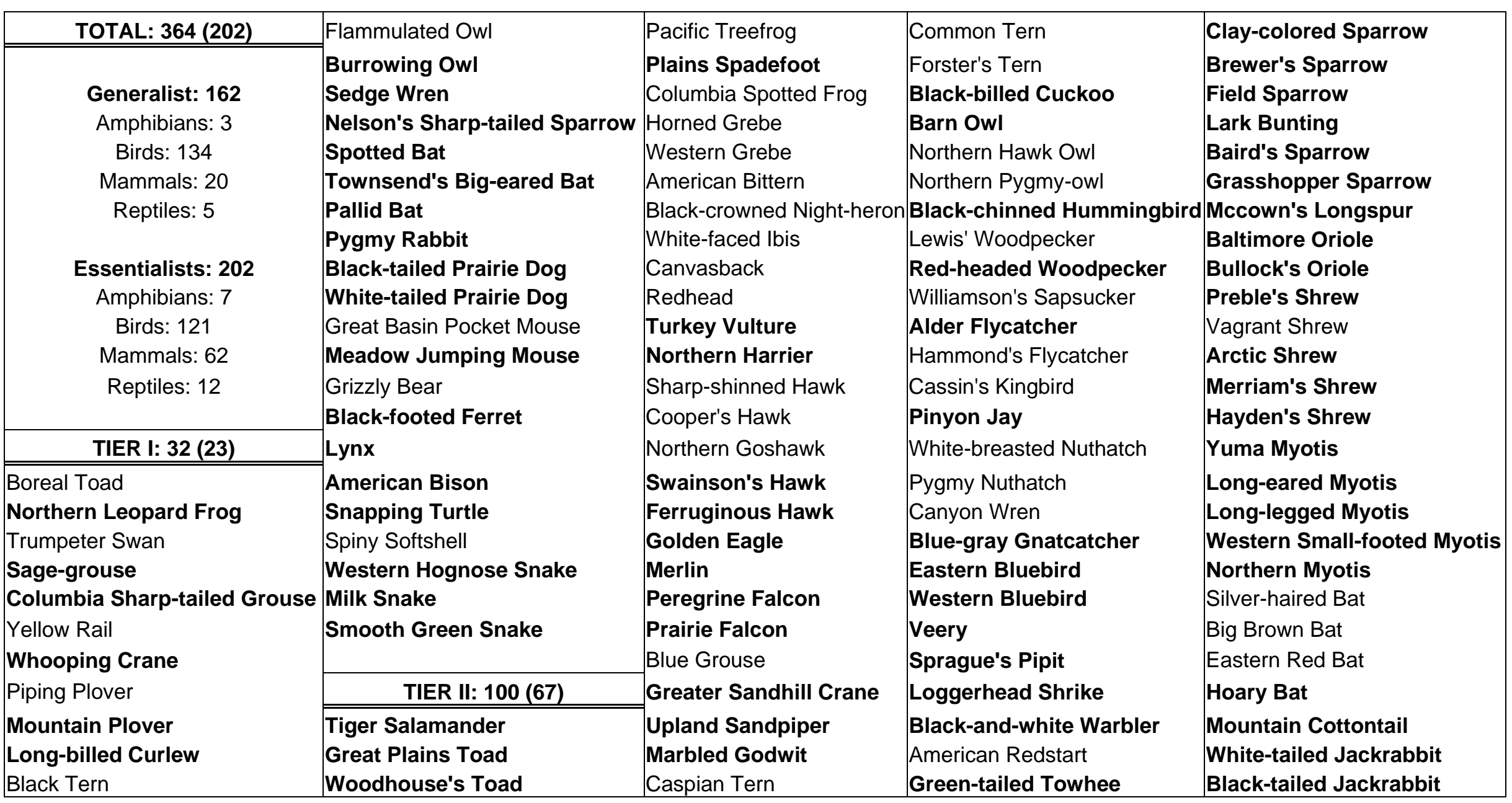




\begin{tabular}{|c|c|c|c|c|}
\hline Ord's Kangaroo Rat & Green-winged Teal & Solitary Sandpiper & Hairy Woodpecker & Hermit Thrush \\
\hline Hispid Pocket Mouse & American Black Duck & Willet & Northern Flicker & American Robin \\
\hline White-footed Mouse & Mallard & Spotted Sandpiper & Western Wood-pewee & Gray Catbird \\
\hline Uinta Ground Squirrel & Snow Goose & Black-necked Stilt & Rufous Hummingbird & Ruby-crowned Kinglet \\
\hline Wyoming Ground Squirrel & Ross' Goose & American Avocet & Belted Kingfisher & Mountain Bluebird \\
\hline Northern Flying Squirrel & Canada Goose & Greater Yellowlegs & Red-naped Sapsucker & Townsend's Solitaire \\
\hline Olive-backed Pocket Mouse & Wood Duck & Lesser Yellowlegs & Downy Woodpecker & Swainson's Thrush \\
\hline Sagebrush Vole & Northern Pintail & Semipalmated Sandpiper & Willow Flycatcher & Northern Mockingbird \\
\hline Swift Fox & Blue-winged Teal & Western Sandpiper & Dusky Flycatcher & Sage Thrasher \\
\hline Least Weasel & Cinnamon Teal & Least Sandpiper & Cordilleran Flycatcher & Brown Thrasher \\
\hline American Badger & Northern Shoveler & White-rumped Sandpiper & Say's Phoebe & American Pipit \\
\hline Western Spotted Skunk & Gadwall & Baird's Sandpiper & Western Kingbird & Bohemian Waxwing \\
\hline Northern Alligator Lizard & American Wigeon & Pectoral Sandpiper & Eastern Kingbird & Cedar Waxwing \\
\hline Short-horned Lizard & Greater Scaup & Dunlin & Horned Lark & Northern Shrike \\
\hline Sagebrush Lizard & Lesser Scaup & Long-billed Dowitcher & Tree Swallow & Warbling Vireo \\
\hline Western Skink & Long Tailed Duck & Common Snipe & Violet-green Swallow & Red-eyed Vireo \\
\hline Rubber Boa & White-winged Scoter & Wilson's Phalarope & Northern Rough-winged Swallow & Orange-crowned Warbler \\
\hline Common Garter Snake & Common Merganser & Ring-billed Gull & Cliff Swallow & Yellow Warbler \\
\hline Western Rattlesnake & $\begin{array}{l}\text { Red-breasted Merganser } \\
\text { Ruddy Duck }\end{array}$ & $\begin{array}{l}\text { California Gull } \\
\text { Mourning Dove }\end{array}$ & $\begin{array}{l}\text { Barn Swallow } \\
\text { Gray Jay }\end{array}$ & $\begin{array}{l}\text { Yellow-rumped Warbler } \\
\text { Ovenbird }\end{array}$ \\
\hline TIER III: 200 (96) & Red-tailed Hawk & Western Screech-owl & Blue Jay & Northern Waterthrush \\
\hline Boreal Chorus Frog & Rough-legged Hawk & Great Horned Owl & Clark's Nutcracker & Macgillivray's Warbler \\
\hline Pied-billed Grebe & American Kestrel & Snowy Owl & Black-billed Magpie & Common Yellowthroat \\
\hline Eared Grebe & Ruffed Grouse & Long-eared Owl & American Crow & Wilson's Warbler \\
\hline American White Pelican & Sharp-tailed Grouse & Short-eared Owl & Black-capped Chickadee & Western Tanager \\
\hline Double-crested Cormorant & Virginia Rail & Common Nighthawk & Mountain Chickadee & Black-headed Grosbeak \\
\hline Great Blue Heron & Sora & Common Poorwill & Red-breasted Nuthatch & Lazuli Bunting \\
\hline Snowy Egret & American Coot & Chimney Swift & Rock Wren & Dickcissel \\
\hline Tundra Swan & Lesser Sandhill Crane & White-throated Swift & House Wren & Spotted Towhee \\
\hline Greater White-fronted Goose & Killdeer & Calliope Hummingbird & Marsh Wren & American Tree Sparrow \\
\hline
\end{tabular}




\begin{tabular}{|c|c|c|c|}
\hline $\begin{array}{l}\text { Song Sparrow } \\
\text { Lincoln's Sparrow } \\
\text { White-throated Sparrow } \\
\text { Chipping Sparrow } \\
\text { Vesper Sparrow } \\
\text { Lark Sparrow } \\
\text { Savannah Sparrow } \\
\text { White-crowned Sparrow } \\
\text { Harris' Sparrow } \\
\text { Dark-eyed Junco } \\
\text { Lapland Longspur } \\
\text { Chestnut-collared Longspur } \\
\text { Bobolink } \\
\text { Red-winged Blackbird } \\
\text { Western Meadowlark } \\
\text { Yellow-headed Blackbird } \\
\text { Brewer's Blackbird } \\
\text { Common Grackle } \\
\text { Brown-headed Cowbird } \\
\text { Brambling } \\
\text { Purple Finch } \\
\text { Cassin's Finch } \\
\text { House Finch } \\
\text { Red Crossbill } \\
\text { Common Redpoll } \\
\text { Pine Siskin } \\
\text { American Goldfinch } \\
\text { Evening Grosbeak } \\
\text { Masked Shrew } \\
\text { Dusky Or Montane Shrew }\end{array}$ & $\begin{array}{l}\text { Red-tailed Chipmunk } \\
\text { Yellow-bellied Marmot } \\
\text { Richardson's Ground Squirrel } \\
\text { Little Brown Myotis } \\
\text { Desert Cottontail } \\
\text { Least Chipmunk } \\
\text { Yellow-pine Chipmunk } \\
\text { Columbian Ground Squirrel } \\
\text { Thirteen-lined Ground Squirrel } \\
\text { Golden-mantled Ground Squirrel } \\
\text { Red Squirrel } \\
\text { Northern Pocket Gopher } \\
\text { American Beaver } \\
\text { Western Harvest Mouse } \\
\text { Deer Mouse } \\
\text { Northern Grasshopper Mouse } \\
\text { Bushy-tailed Woodrat } \\
\text { Meadow Vole } \\
\text { Montane Vole } \\
\text { Long-tailed Vole } \\
\text { Prairie Vole } \\
\text { Muskrat } \\
\text { Western Jumping Mouse } \\
\text { Common Porcupine } \\
\text { Coyote } \\
\text { Red Fox } \\
\text { Black Bear } \\
\text { Ermine } \\
\text { Long-tailed Weasel } \\
\text { Mink }\end{array}$ & \begin{tabular}{|l}
\multicolumn{1}{|c}{ TIER IV: 32 (16) } \\
Canadian Toad \\
Great Egret \\
Little Blue Heron \\
Green Heron \\
Eurasian Wigeon \\
Surf Scoter \\
Broad-winged Hawk \\
Gray Partridge \\
Ring-necked Pheasant \\
Wild Turkey \\
Black-bellied Plover \\
Semipalmated Plover \\
Whimbrel \\
Red Knot \\
Sanderling \\
Stilt Sandpiper \\
Rock Dove
\end{tabular} & $\begin{array}{l}\text { Pine Warbler } \\
\text { Palm Warbler } \\
\text { Blackpoll Warbler } \\
\text { Band-tailed Pigeon } \\
\text { Ruby-throated Hummingbird } \\
\text { Scissor-tailed Flycatcher } \\
\text { European Starling } \\
\text { Hooded Warbler } \\
\text { Scarlet Tanager } \\
\text { Rose-breasted Grosbeak } \\
\text { Golden-crowned Sparrow } \\
\text { House Sparrow } \\
\text { House Mouse } \\
\text { Common Raccoon } \\
\text { Feral Horse }\end{array}$ \\
\hline
\end{tabular}


14584 14585 14586 14587
Table 41. Mixed Broadleaf Forest Communities-Species Associations

Note: Essentially associated species are bolded in table. Total number of species essentially associated with each community type can be found in parenthesis.

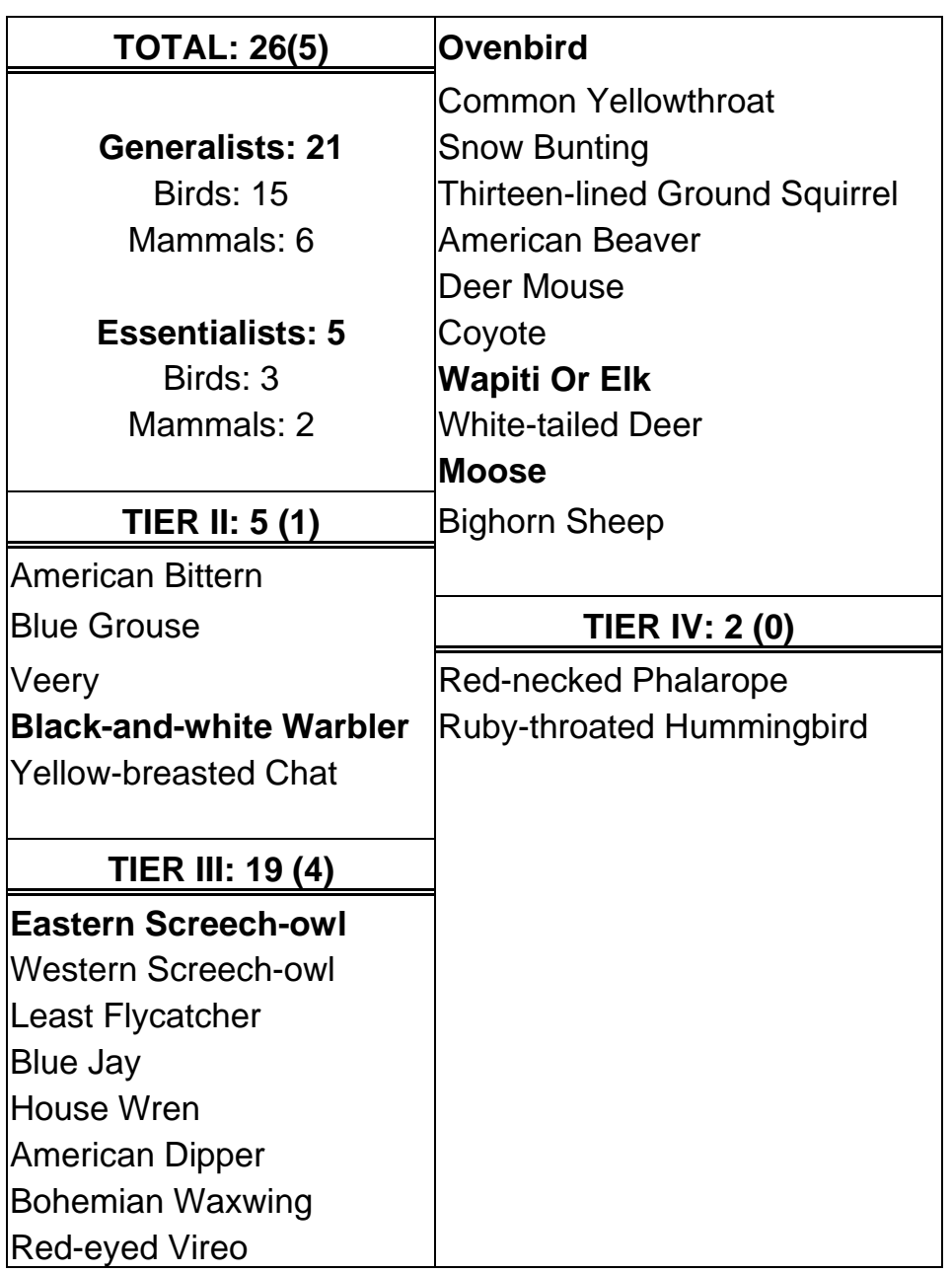


Table 42. Mixed Shrub/Grass Associations Communities-Species Associations

Note: Essentially associated species are bolded in table. Total number of species essentially associated with each community type can be found in parenthesis.

\begin{tabular}{|c|c|c|}
\hline TOTAL: $39(10)$ & \multirow{3}{*}{$\begin{array}{l}\text { Ferruginous Hawk } \\
\text { Upland Sandpiper } \\
\text { Yellow-billed Cuckoo } \\
\text { Barn Owl }\end{array}$} & \multirow{2}{*}{$\begin{array}{l}\text { Northern Grasshopper Mouse } \\
\text { Prairie Vole } \\
\text { Gopher Snake }\end{array}$} \\
\hline $\begin{array}{l}\text { Generalists: } 29 \\
\text { Amphibians: } 4\end{array}$ & & \\
\hline Birds: 17 & & TIER IV: 2 (0) \\
\hline $\begin{array}{l}\text { Mammals: } 6 \\
\text { Reptiles: } 2\end{array}$ & \multirow{6}{*}{$\begin{array}{l}\text { Red-headed Woodpecker } \\
\text { Pinyon Jay } \\
\text { Blue-gray Gnatcatcher } \\
\text { Veery } \\
\text { Mccown's Longspur } \\
\text { Bullock's Oriole } \\
\text { Dwarf Shrew } \\
\text { Eastern Cottontail } \\
\text { Ord's Kangaroo Rat } \\
\text { Sagebrush Lizard }\end{array}$} & $\begin{array}{l}\text { Broad-winged Hawk } \\
\text { Ring-necked Pheasant }\end{array}$ \\
\hline $\begin{array}{c}\text { Essentialists: } 10 \\
\text { Birds } 3\end{array}$ & & \\
\hline Mammals: 5 & & \\
\hline Reptiles: 2 & & \\
\hline TIER 1: 7 (3) & & \\
\hline \multirow{7}{*}{\begin{tabular}{|l} 
Sage-grouse \\
Mountain Plover \\
Burrowing Owl \\
Spotted Bat \\
Black-tailed Prairie Dog \\
Western Hognose Snake \\
Milk Snake
\end{tabular}} & & \\
\hline & TIER III: 13 (2) & \\
\hline & \multirow{7}{*}{$\begin{array}{l}\text { Boreal Chorus Frog } \\
\text { Gyrfalcon } \\
\text { Chimney Swift } \\
\text { Western Kingbird } \\
\text { Bank Swallow } \\
\text { Spotted Towhee } \\
\text { Desert Cottontail } \\
\text { Least Chipmunk } \\
\text { Western Harvest Mouse } \\
\text { Deer Mouse }\end{array}$} & \\
\hline & & \\
\hline & & \\
\hline & & \\
\hline & & \\
\hline TIER II: 17 (5) & & \\
\hline \begin{tabular}{|l} 
Woodhouse's Toad \\
Pacific Treefrog \\
Plains Spadefoot
\end{tabular} & & \\
\hline
\end{tabular}


Table 43. Riparian \& Wetland Communities-Species Associations

Note: Essentially associated species are bolded in table. Total number of species essentially associated with each community type can be found in parenthesis.

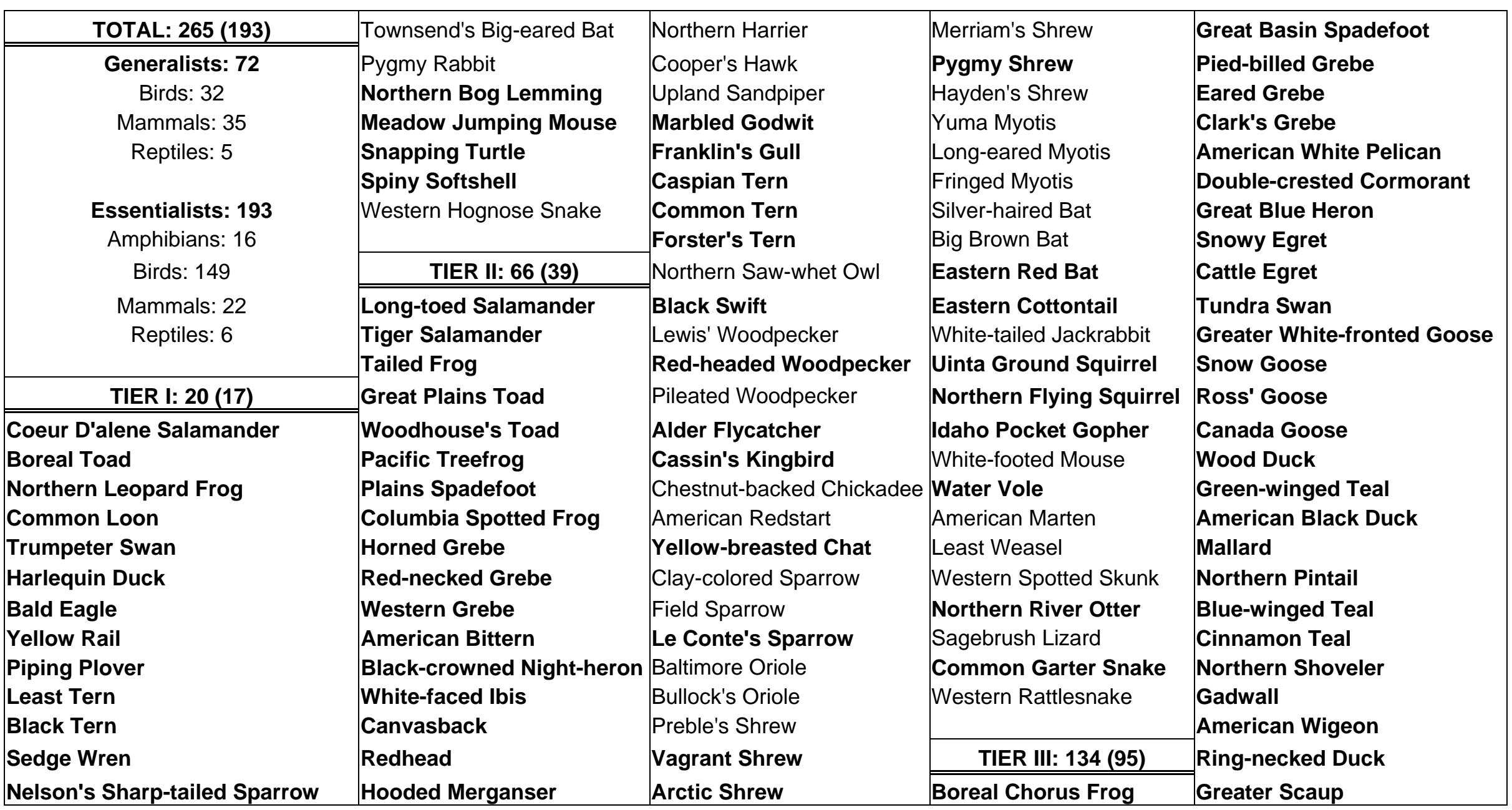




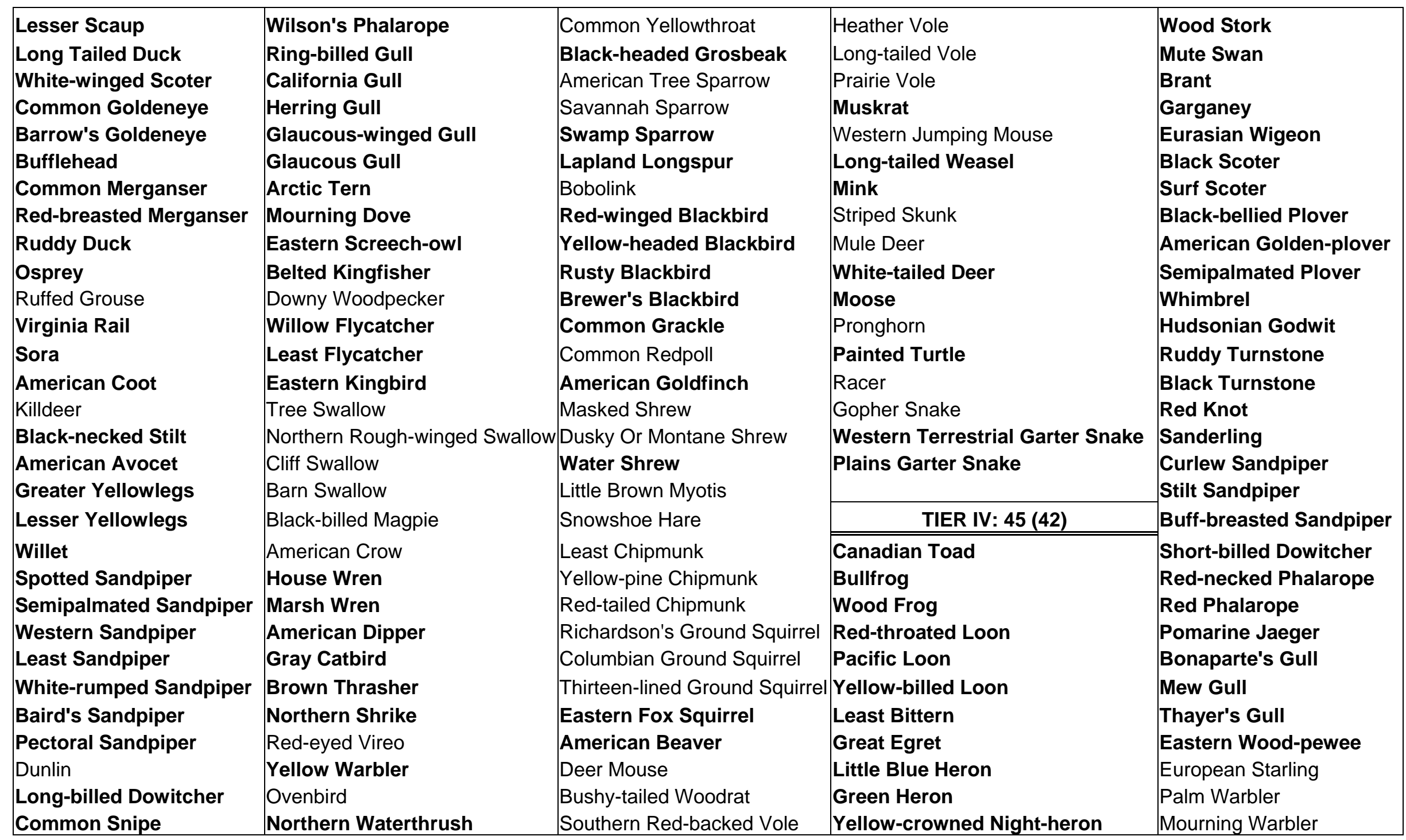


DRAFT WORKING DOCUMENT DO NOT DUPLICATE

Hooded Warbler

Canada Warbler

Northern Short-tailed Shrew

Common Raccoon

14600

14601

14602

14603

14604

14605

14606

14607

14608

14609

14610

14611

14612

14613

14614

14615

14616

14617

14618

14619

14620

14621

14622

14623

14624

14625

14626 
Table 44. Sagebrush \& Salt Flat Communities Species-Associations

Note: Essentially associated species are bolded in table. Total number of species essentially associated with each community type can be found in parenthesis.

\begin{tabular}{|c|c|c|c|}
\hline TOTAL: 81 (23) & Milk Snake & Ord's Kangaroo Rat & Vesper Sparrow \\
\hline Generalists: 58 & TIER II: 31 (9) & Sagebrush Vole & Lark Sparrow \\
\hline $\begin{array}{l}\text { Amphibians: } 3 \\
\text { Birds: } 32 \\
\text { Mammals: } 16 \\
\text { Reptiles: } 7 \\
\text { Essentialists: } 23\end{array}$ & $\begin{array}{l}\text { Tiger Salamander } \\
\text { Plains Spadefoot } \\
\text { Northern Harrier } \\
\text { Swainson's Hawk } \\
\text { Ferruginous Hawk } \\
\text { Golden Eagle }\end{array}$ & $\begin{array}{l}\text { American Badger } \\
\text { Western Spotted Skunk } \\
\text { Short-horned Lizard } \\
\text { Sagebrush Lizard } \\
\text { Western Rattlesnake }\end{array}$ & $\begin{array}{l}\text { Sage Sparrow } \\
\text { Savannah Sparrow } \\
\text { Western Meadowlark } \\
\text { Brewer's Blackbird } \\
\text { Desert Cottontail } \\
\text { Least Chipmunk }\end{array}$ \\
\hline Amphibians: 1 & Prairie Falcon & TIER III: 35 (7) & Northern Pocket Gopher \\
\hline $\begin{array}{l}\text { Birds: } 8 \\
\text { Mammals: } 13 \\
\text { Reptiles: } 1\end{array}$ & $\begin{array}{l}\text { Upland Sandpiper } \\
\text { Blue-gray Gnatcatcher } \\
\text { Loggerhead Shrike } \\
\text { Indigo Bunting }\end{array}$ & $\begin{array}{l}\text { Boreal Chorus Frog } \\
\text { Great Basin Spadefoot } \\
\text { American Kestrel } \\
\text { Short-eared Owl }\end{array}$ & $\begin{array}{l}\text { Deer Mouse } \\
\text { Northern Grasshopper Mouse } \\
\text { Montane Vole } \\
\text { Common Porcupine }\end{array}$ \\
\hline TIER I: 13 (7) & Green-tailed Towhee & Say's Phoebe & Red Fox \\
\hline $\begin{array}{l}\text { Sage-grouse } \\
\text { Mountain Plover } \\
\text { Long-billed Curlew } \\
\text { Burrowing Owl } \\
\text { Spotted Bat }\end{array}$ & $\begin{array}{l}\text { Brewer's Sparrow } \\
\text { Grasshopper Sparrow } \\
\text { Baltimore Oriole } \\
\text { Preble's Shrew } \\
\text { Merriam's Shrew }\end{array}$ & $\begin{array}{l}\text { Western Kingbird } \\
\text { Eastern Kingbird } \\
\text { Horned Lark } \\
\text { Violet-green Swallow } \\
\text { Cliff Swallow }\end{array}$ & $\begin{array}{l}\text { Mule Deer } \\
\text { Pronghorn } \\
\text { Racer } \\
\text { Gopher Snake }\end{array}$ \\
\hline Pallid Bat & Long-eared Myotis & Barn Swallow & TIER IV: 2 (0) \\
\hline $\begin{array}{l}\text { Pygmy Rabbit } \\
\text { Black-tailed Prairie Dog } \\
\text { White-tailed Prairie Dog } \\
\text { Great Basin Pocket Mouse } \\
\text { Snapping Turtle } \\
\text { Western Hognose Snake } \\
\end{array}$ & $\begin{array}{l}\text { Western Small-footed Myotis } \\
\text { Mountain Cottontail } \\
\text { Black-tailed Jackrabbit } \\
\text { Wyoming Ground Squirrel } \\
\text { Idaho Pocket Gopher } \\
\text { Olive-backed Pocket Mouse }\end{array}$ & $\begin{array}{l}\text { Black-billed Magpie } \\
\text { Rock Wren } \\
\text { Mountain Bluebird } \\
\text { Sage Thrasher } \\
\text { Bohemian Waxwing } \\
\text { American Tree Sparrow } \\
\end{array}$ & $\begin{array}{l}\text { Gray Partridge } \\
\text { Chukar }\end{array}$ \\
\hline
\end{tabular}


14632

14633

14634

14635

Table 45. Mountain Stream Communities-Species Associations

Note: Essentially associated species are bolded in table. Total number of species essentially associated with each community type can be found in parenthesis

\begin{tabular}{|c|c|}
\hline TOTAL: 18 (17) & Longnose Dace \\
\hline $\begin{array}{l}\text { Generalists: } 1 \\
\text { Fish: } 1\end{array}$ & $\begin{array}{l}\text { Redside Shiner } \\
\text { Longnose Sucker } \\
\text { Mountain Sucker } \\
\text { Signal Crayfish }\end{array}$ \\
\hline Fish: 15 & TIER IV: 2 (2) \\
\hline $\begin{array}{l}\text { Mussels: } 1 \\
\text { Crayfish: } 1\end{array}$ & $\begin{array}{l}\text { Rainbow Trout } \\
\text { Brook Trout }\end{array}$ \\
\hline TIER 1: $6(6)$ & \\
\hline $\begin{array}{l}\text { Yellowstone Cutthroat Trout } \\
\text { Westslope Cutthroat Trout } \\
\text { Columbia Basin Redband Trout } \\
\text { Bull Trout } \\
\text { Arctic Grayling } \\
\text { Western Pearlshell }\end{array}$ & \\
\hline TIER II: 2 (2) & \\
\hline $\begin{array}{l}\text { Torrent Sculpin } \\
\text { Spoonhead Sculpin }\end{array}$ & \\
\hline TIER III: 8 (7) & \\
\hline $\begin{array}{l}\text { Mottled Sculpin } \\
\text { Slimy Sculpin } \\
\text { Pygmy Whitefish }\end{array}$ & \\
\hline
\end{tabular}


14637 14638

14639 14640
Table 46. Prairie Stream Communities-Species Associations

Note: Essentially associated species are bolded in table. Total number of species essentially associated with each community type can be found in parenthesis

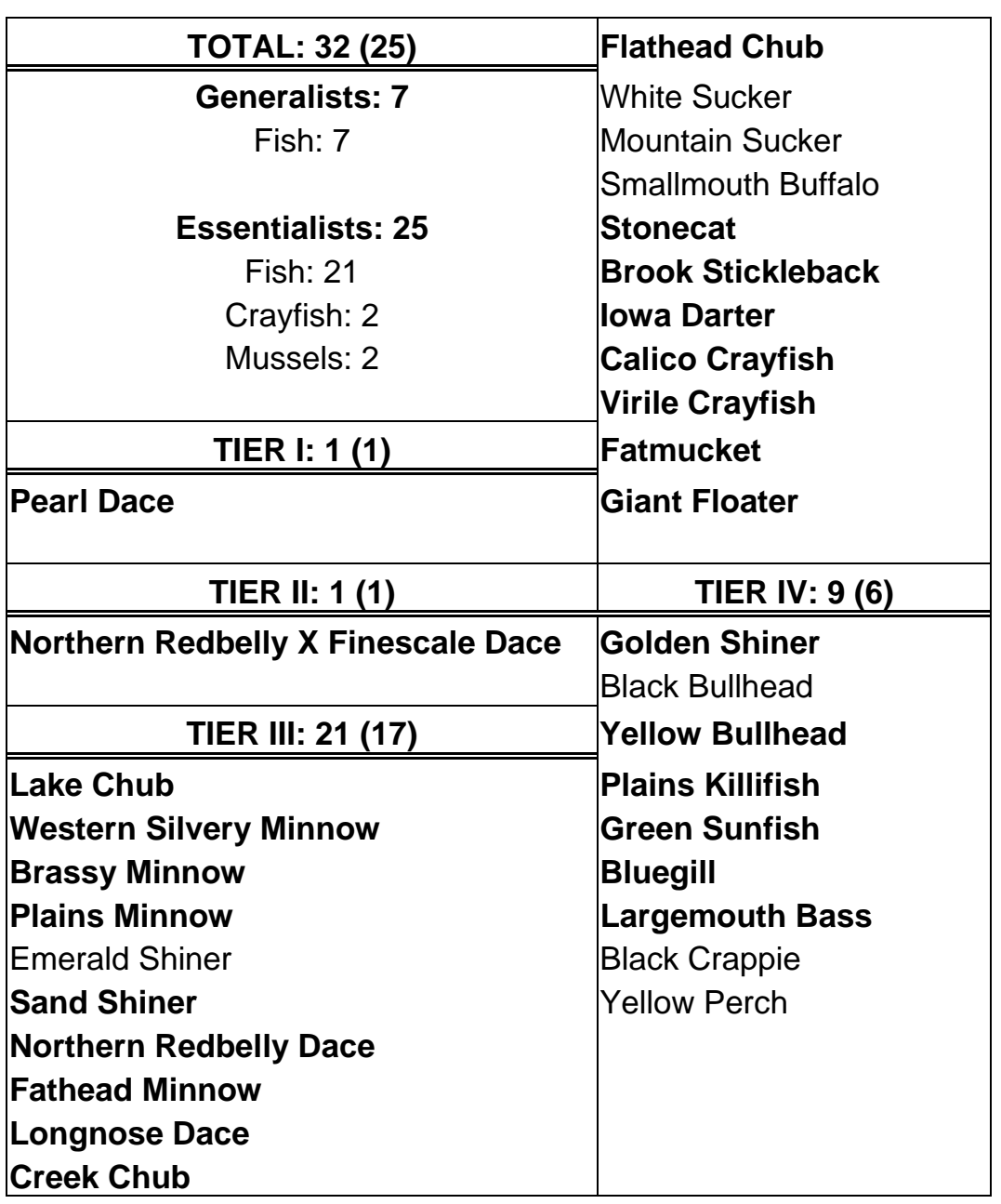




\section{DRAFT WORKING DOCUMENT DO NOT DUPLICATE}

\section{Bibliography}

14643

14644

14645

14646

14647

14648

14649

14650

14651

14652

14653

14654

14655

14656

14657

14658

14659

14660

14661

14662

14663

14664

14665

14666

14667

14668

14669

14670

14671

14672

14673

14674

14675

14676

14677

14678

14679

14680

14681

14682

14683

14684

14685

14686
A Biological Conservation Assessment for the Utah-Wyoming Rocky Mountain Ecoregion: Report to the Nature Conservancy. 2001. R. Noss, G. Wuerthner, K. Vance-Borland, and C. Carroll. Conservation Science, Inc. 125 pp. + Executive Summary and Appendix D.

A Landowner's Guide to Montana Wetlands. Montana Watercourse.

Adelman, E. B. 1979. A survey of the nongame mammals in the Upper

Rattlesnake Creek drainage of western Montana. M.S. thesis. University of Montana, Missoula. 129 pp.

Agnew, W., D. W. Uresk and R. M. Hansen. 1986. Flora and fauna associated with prairie dog colonies and adjacent ungrazed mixed-grass prairie in western South Dakota. Journal of Range Management 39:135-9.

Alden, W. C. 1953. Physiographic and glacial geology of Western Montana and adjacent areas. Geological Survey Professional Paper 231. U.S. Government Printing Office.

Aldrich, J. W. 1963. Geographic orientation of American Tetraonidae. Journal of Wildlife Management 27: 529-545.

Ali, M. A., and M. Anctil. 1977. Retinal structure and function in the walleye (Stizostedion vitreum vitreum) and sauger (S. canadense). Journal of the Fisheries Research Board of Canada 34:1467-1474.

Allendorf, F.W., D.M. Esperlund, and D.T. Scow. 1980. Coexistence of native and introduced rainbow trout in the Kootenai River Drainage. Proceedings of the Montana Academy of Sciences 39:28-36.

Altenbach, J. S., W. Amy, P. V. Bradley, P. E. Brown, K. Dewberry, D. B. Hall, J. Jeffers, B. Lund, J. E. Newmark, M. J. O'Farrell, M. Rahn, R. E. Sherwin, C. R. Tomlinson, J. A. Williams. 2002. Nevada Bat Conservation Plan. Nevada Bat Working Group. Austin, Nevada. 188 pp.

Altman, B., and R. Sallabanks. 2000. Olive-sided Flycatcher (CONTOPUS COOPERI). No. 502 IN A. Poole and F. Gill (eds.), The birds of North America. The Birds of North America, Inc., Philadelphia, PA. 28pp.

American Fisheries Society Montana Chapter website. http://www.fisheries.org/AFSmontana/SSCintermountain/foothill grassland/White\%20Sturgeon\%20Status.htm 


\section{DRAFT WORKING DOCUMENT DO NOT DUPLICATE}

14687 Anders, P. J., and D. L. Richards. 1996. Implications of ecotype collapse on

14688

14689

14690

14691

14692

14693

14694

14695

14696

14697

14698

14699

14700

14701

14702

14703

14704

14705

14706

14707

14708

14709

14710

14711

14712

14713

14714

14715

14716

14717

14718

14719

14720

14721

14722

14723

14724

14725

14726

14727

14728

14729

14730

14731

14732 white sturgeon (Acipenser transmontanus) in the Kootenai River, Idaho,

Montana, and British Columbia. Intermountain/foothill grassland 27-40 in

Proceedings from the International Congress on the Biology of Fishes: Culture

and Management of Sturgeon and Paddlefish Symposium Proceedings. San

Francisco State University, July 14-18, 1996.

Anderson, M. E. et al. 1978. Black-footed ferret recovery plan. U.S. Fish and

Wildlife Service Black-footed ferret Recovery Team. 150 pp.

Anonymous. 1999. Yellowstone cutthroat trout: current status and recommendations within the state of Montana. Gallatin and Custer National Forests, Regions 3 and 5, Montana Department of Fish, Wildlife \& Parks, and U.S. Fish and Wildlife Service Montana Technical Assistance Office.

AOU. 1957. American Ornithological Union Check-list of North American Birds. The Lord Baltimore Press, Inc., Baltimore, Maryland. pp 137-139.

Apperson, K.A. and P. J. Anders. 1991. Kootenai River white sturgeon investigations and experimental culture. Annual Progress Report FY 1990. Bonneville Power Administration. 75 pp.

Arndt, S. K. A., and J. Hutchinson. 2000. Characteristics of a tributary-spawning population of burbot from Columbia Lake, British Columbia. Intermountain/foothill grassland 48-60 in V. L. Paragamian and D. W. Willis, editors. Burbot: biology, ecology and management.

American Fisheries Society, Fisheries Management Section, publication Number 1, Bethesda, Maryland.

Arno, Stephen F. 1979. Forest regions of Montana. Res. Pap INT-218. U.S. Department of Agriculture, Forest Service, Intermountain Forest and Range Experiement Station, Odgen, UT. 39 p.

Ashley, J. 1994. Progress report: harlequin duck inventory and monitoring in Glacier National Park, Montana. Unpublished report. Division of Research Management, Glacier Natl. Park, Montana. 14 pp.

Atkinson, E. C. and M. L. Atkinson. 1990. Distribution and status of Flammulated Owls (OTUS FLAMMEOLUS) on the Salmon National Forest. Idaho Nat. Heritage Prog., Idaho Dept. Fish Game, Salmon Natl. Forest Unpublished report. 25 pp. plus appendices.

Aune, K., T. Stivers, and M. Madel. 1984. Rocky Mountain Front grizzly bear monitoring and investigation. Montana Dept. Fish, Wildl. And Parks, Helena. 239 pp. 


\section{DRAFT WORKING DOCUMENT DO NOT DUPLICATE}

14733

14734

14735

14736

14737

14738

14739

14740

14741

14742

14743

14744

14745

14746

14747

14748

14749

14750

14751

14752

14753

14754

14755

14756

14757

14758

14759

14760

14761

14762

14763

14764

14765

14766

14767

14768

14769

14770

14771

14772

14773

14774

14775

14776

14777

14778

Bailey, R. and M. Allum. 1962. Fishes of South Dakota. Museum of Zoology, University of Michigan. Ann Arbor.

Bartelt, P. E. 1998. Bufo boreas (Western Toad). Mortality. Herpetological Review 29:96.

Bartos, Dale L. and Campbell, Robert B. February, 1998. Decline of Quaking Aspen in the Interior West-Examples from Utah. Rangelands. Vol. 20, No. 1

Baskins, Y. 1993. Trumpeter swans relearn migration. BioSci. 43(2): 76-79.

Baxter, G. and J. Simon. 1970. Wyoming fishers. Bulletin Number 4, Wyoming Game and Fish Department. Cheyenne.

Baydack, R. K. and D. A. Hein. 1987. Tolerance of sharp-tailed grouse to lek disturbance. Wildlife Society Bulletin 15: 535-539.

Becker, G. C. 1983. Fishes of Wisconsin. The University of Wisconsin Press, Madison.

Behnke, R. J. 1992. Native trout of western North America. American Fisheries Society Monograph 6, Bethesda, Maryland.

Bent, A. C. 1939. Life histories of North American Woodpeckers. U. S. National Museum Bulletin 174, Washington DC, USA.

Bergersen, E. P., and D. E. Anderson. 1997. The distribution and spread of Myxobolus cerebralis in the United States. Fisheries 22(8): 6-7.

Berkey, G., R. Crawford, S. Galipeau, D. Johnson, D. Lambeth, and R. Kreil. 1993. A review of wildlife management practices in North Dakota: effects on nongame bird populations and habitats. Report submitted to Region 6 . U. S. Fish and Wildlife Service, Denver. 51 p.

Bicknell, William. 2001. USFWS Federal Registry. Notice of 12-month petition finding to list the Sicklefin Chub (Macrhybopsis meeki) and the Sturgeon Chub (Macrhybopsis gelida) as Endangered. 3425 Miriam Avenue, Bismarck, North Dakota, 58501. 10 pgs.

Bissell, Gael N. 2005. Third Annual Common Loon Report (Draft). Unpublished report. March 2005. Region One, Montana Fish, Wildlife \& Parks, 490 N. Meridian Rd, Kalispell, MT 59901.

Bissell, Gael N. 2005. Personal communication. 


\section{DRAFT WORKING DOCUMENT DO NOT DUPLICATE}

14779

14780

14781

14782

14783

14784

14785

14786

14787

14788

14789

14790

14791

14792

14793

14794

14795

14796

14797

14798

14799

14800

14801

14802

14803

14804

14805

14806

14807

14808

14809

14810

14811

14812

14813

14814

14815

14816

14817

14818

14819

14820

14821

14822

14823

14824
Black, J. H. 1969. The frog genus RANA in Montana. Northwest Sci. 43:191-195.

Bock, C. E. and J. H. Bock. 1974. On the geographical ecology and evolution of the three-toed woodpeckers, Picoides tridactylus and P. arcticus. Amer. Midl. Nat., 92(2): 397-405.

Bond, C. E. 1992. Notes on the nomenclature and distribution of the bull trout and the effects of human activity on the species. Intermountain/foothill grassland 1-4 in P. J. Howell and D. V. Buchanan, editors. Proceedings of the Gearhart Mountain bull trout workshop. Oregon Chapter of the American Fisheries Society, Corvallis.

Bonham, C. D. and A. Lerwick. 1976. Vegetation changes induced by prairie dogs on shortgrass range. Journal of Range Management 29:221-25.

Boundy, J. 2001. Herpetofaunal surveys in the Clark Fork Valley region, Montana. Herpetological Natural History 8:15-26.

Bownan, C.W. 1904. Nelson's Sharp-tailed Sparrow in North Dakota. Auk 21:385-386.

Boyer, L. F., R. A. Cooper, D. T. Long, and T. M. Askew. 1989. Burbot (Lota lota)biogenic sedimentary structure in Lake Superior. Journal of Great Lakes Research 15:174-185.

Bramblett, R.G. 1996. Habitats and movements of pallid and shovelnose sturgeon in the Yellowstone and Missouri rivers, Montana and North Dakota. Ph. D. dissertation. Montana State University, Bozeman. 210 pp.

Braun, C.E. 1999b. Conservation plans. Presentation given to the Western Sagegrouse Status Conference, Jan. 14-15, 1999, Boise, ID. Online. Available:

http://www.rangenet.org/projects/grouse.html

Brodie, E. D., Jr. and R. M. Storm. 1970. PLETHODON VANDYKEI. Cat. Am. Amph. Rep. 91.1-91.2.

Brown, C. 1976. Fishes of Montana. Big Sky Books, Montana State University. Bozeman.

Brown, G. P., and R. J. Brooks. 1994. Characteristics of and fidelity to hibernacula in a northern population of snapping turtles, CHELYDRA SERPENTINA. Copeia 1994:222-226.

Brown, R.S. and W.C. Mackay. 1995. Fall and Winter Movements of and Habitat Use by Cutthroat Trout in the Ram River, Alberta. Transactions of the American Fisheries Society 124:873-885. 


\section{DRAFT WORKING DOCUMENT DO NOT DUPLICATE}

14825

14826

14827

14828

14829

14830

14831

14832

14833

14834

14835

14836

14837

14838

14839

14840

14841

14842

14843

14844

14845

14846

14847

14848

14849

14850

14851

14852

14853

14854

14855

14856

14857

14858

14859

14860

14861

14862

14863

14864

14865

14866

14867

14868

14869

14870
Brown, S., C. Hickey, B. Harrington, and R. Gill, eds. 2001. The U.S. Shorebird Conservation Plan, 2nd ed. Manomet Center for Conservation Sciences, Manomet, MA.

Brunson, R. B. 1952. Recent collections of BUFO BOREAS from western Montana. Proc. Montana Acad. Sci. 11:17-19.

Brunson, R. B. and H. A. Demaree. 1951. The herpetology of the Mission Mountains, Montana. Copeia 1951:306-308.

Bull, E. L., A. L. Wright and M. G. Henjum. 1990. Nesting habitat of flammulated owls in Oregon. J. Raptor Res. 24:52-55.

Bull, E. L. and R. G. Anderson. 1978. Notes on flammulated owls in northeastern Oregon. Murrelet 59:26-28.

Bureau of Land Management. 1979. Habitat management plan prairie dog ecotypes. USDI, BLM, Montana State Office. Wildlife Habitat Area MT-02-06-07S1. $61 \mathrm{pp}$.

Burger, J. and M. Gochfeld. 1990. Nest site selection in least terns (Sterna Antillarum) in New Jersey and New York. Colonial Waterbirds 13:31-40.

Byorth, P. A. 1993. Big Hole River Arctic grayling recovery project: Annual monitoring report 1992.Submitted to: Fluvial Arctic Grayling Workgroup.

Montana Department of Fish, Wildlife, and Parks, Bozeman.

Cahn, A. R. 1936. Observations on the breeding of the lawyer, Lota lota maculosa. Copeia 1936:163-165.

Caire, W., et al. 1989. Mammals of Oklahoma. Univ. Oklahoma Press, Norman. 567 pp.

Campbell, R. W., N. K. Dawe, I. McTaggart-Cowan, J. M. Cooper, G. W. Kaiser and M. C. McNall. 1990. The birds of British Columbia, Vols. 1 and 2: Nonpasserines. Royal British Columbia Museum, Victoria, B. C. 518 and 636 pp.

Campbell, T. M., III. 1989. Prairie dog colony location surveys and black-footed ferret searches in Montana. Intermountain/foothill grassland 1-12 In The prairie dog ecotype: Managing for biological diversity. Montana BLM Wildlife Technical Bulletin No. 2. 55 pp.

Cannon, R. W., and F. L. Knopf. 1981. Lek numbers as a trend index to prairie grouse populations. Journal of Wildlife Management 45: 776-778.

Caprio and Nielsen 1992 


\section{DRAFT WORKING DOCUMENT DO NOT DUPLICATE}

14871

14872

14873

14874

14875

14876

14877

14878

14879

14880

14881

14882

14883

14884

14885

14886

14887

14888

14889

14890

14891

14892

14893

14894

14895

14896

14897

14898

14899

14900

14901

14902

14903

14904

14905

14906

14907

14908

14909

14910

14911

14912

14913

14914
Carlander, K. D. 1997. Handbook of freshwater fishery biology, volume three: life history data on ichthyopercid and percid fishes of the United States and Canada. Iowa State University Press, Ames, IA.

Carnefix, G. 2002. Movement patterns of fluvial bull trout in relation to habitat parameters in the Rock Creek drainage, Missoula and Granite Counties, Montana. M.Sc. Thesis, University of Montana, Missoula. 185 pp.

Carter, M. F., and K. Barker. 1993. An interactive database for setting conservation priorities for western neotropical migrants. U.S. Forest Service General Technical Report RM-229: 120-144.

Casey, D. 2000. Partners in Flight Bird Conservation Plan Montana Version 1.0. Montana Partners in Flight. Kalispell, Montana.

Cassirer, E. F., J. D. Reichel, R. L. Wallen, and E. C. Atkinson. 1996. Harlequin Duck (Histrionicus histrionicus) conservation assessment and strategy for the U.S. Rocky Mountains. Unpublished Technical Report, Idaho Department of Fish and Game, Lewiston, Idaho, U.S.A.

Cassirer, E. F., C. R. Groves, and D. L. Genter. 1994. Coeur d'Alene salamander conservation assessment. U.S.D.A. Forest Service, Region 1, Missoula, MT. 55 $\mathrm{pp}$.

Cassirer, E. F, A. Breault, P. Clarkson, D. L. Genter, R. I. Goudie, B. Hunt, S. C. Latta, G. H. Mittelhauser, M. M. Schirato, R. L. Wallen. 1993. Status of harlequin ducks in North America. Report on harlequin duck working group.

Cassirer, E. F., C. R. Groves, and D. L. Genter. 1993. Sensitive species management guide for the Coeur d'Alene salamander. Idaho Department of Fish and Game, Boise, Idaho and the Montana Natural Heritage Program, Helena, Montana, U.S.A.

Cassirer, E. F., G. Schirato, F. Sharpe, C. R. Groves, and R. N. Anderson. 1993. Cavity nesting by harlequin ducks in the Pacific Northwest. Wilson Bull. 105:691694.

Cassirer, E.F. and C.R. Groves. 1991. Harlequin duck ecology in Idaho. 19871990. Idaho Fish and Game and US Fish and Wildlife Service.

Caton, E. M. 1996. Cavity nesting birds in a post-fire habitat in northwestern Montana. Ph.D. dissertation, University of Montana, Missoula, MT. 


\section{DRAFT WORKING DOCUMENT DO NOT DUPLICATE}

14915 Chadde, S. W., J. S. Shelly, R. J. Bursik, R. K. Moseley, A. G. Evenden, M. 14916 Mantas, F. Rabe and B. Heidel. 1998. Peatlands on National Forests of the 14917 Northern Rockies.

14918

14919

Chamberlin, T. W., R. D. Harr, and F. H. Everest. 1991. Timber harvesting, 14920 silviculture, and watershed processes. Intermountain/foothill grassland 181-206

14921 14922 14923 14924 14925 in W. R. Meehan, editor. Influences of forest and rangeland management on salmonid fishes and their habitats. American Fisheries Society Special Publication 19, Bethesda, Maryland.

Christie, D. A. and A. M. van Woudenberg. 1997. Modeling critical habitat for flammulated owls (OTUS FLAMMEOLUS). Intermountain/foothill grassland 97106 in J. R Duncan, D. H. Johnson, and T. H. Nicholls, editors. Biology and conservation of owls in the Northern Hemisphere. USDA Forest Service.

Christopherson, D., Stoneberg, R., Matchett, R., Biggins, D., Grensten, J., Dood, 14931 14932 14933 14934 14935 14936 14937 14938 14939 14940 14941 14942 14943 14944 A., Haglan, B. 1994. Black-footed ferret reintroduction in Montana: Project description and 1994 protocol. 31 pp + appendix.

Christopherson, D.M., Prellwitz, D. M., and M.J. Rabenberg. 1992. Status of Piping Plovers and Least Tern in Montana.

Christy, R. E.; S. D. West. 1993. Biology of bats in Douglas-fir forests. General Technical Report. PNW-GTR-308. USDA Forest Service, Pacific Northwest Research Station, Portland, Oregon, USA

Clancy, C. G. 1988. Effects of dewatering on spawning by Yellowstone cutthroat trout in tributaries to the Yellowstone River, Montana. American Fisheries Society Symposium 4: 37-41.

14951 14952 14953 14954 14955 14956 14957 14958 Clark, R. A. 1992. Influence of stream flows and stock size on recruitment of Arctic grayling (Thymallus arcticus) in the Chena River, Alaska. Canadian Journal of Fisheries and Aquatic Sciences 49(5): 1027-1034.

Clough, G. C., and J. J. Albright. 1987. Occurrence of the northern bog lemming, SYNAPTOMYS BOREALIS, in the northeastern United States. Can. FieldNaturalist 101:611-613.

Collette, B. B. and 7 co-authors. 1977. Biology of the percids. Journal of the Fisheries Research Board of Canada 34:1890-1899.

Confederated Salish and Kootenai Tribes and Montana Fish, Wildlife \& Parks. 2003. Flathead Subbasin Plan Assessment: Executive Summary. NWPCC. 14959 Portland, OR. 


\section{DRAFT WORKING DOCUMENT DO NOT DUPLICATE}

14960 Congdon, J. D., et al. 1987. Reproduction and nesting ecology of snapping

14961

14962

14963

14964

14965

14966

14967

14968

14969

14970

14971

14972

14973

14974

14975

14976

14977

14978

14979

14980

14981

14982

14983

14984

14985

14986

14987

14988

14989

14990

14991

14992

14993

14994

14995

14996

14997

14998

14999

15000

15001

15002

15003

15004

15005 turtles (CHELYDRA SERPENTINA) in southeastern Michigan. Herpetologica 43:39-54.

Connelly, J. 2001. Field Assessment. Sage-grouse Habitats and PopulationsBig Sheep Creek Basin, Montana. Unpublished report on file, BeaverheadDeerlodge National Forest, Dillon, Montana, USA.

Connelly, J.W., M. A. Schroeder, A. R. Sands, and C. E. Braun. 2000b. Guidelines to manage Sage-grouse populations and their habitats. Wildlife Society Bulletin 28:967-985.

Conservation Management of America's Public Lands: An Assessment and Recommendations for Progress 25 Years after FLPMA. 2001. National Wildlife Federation and the Natural Resources Defense Council.

Conservation Plan for Black-tailed and White-tailed Prairie Dogs in Montana (Montana Prairie Dog Working Group 2002).

Cooperative Conservation Agreement for Yellowstone Cutthroat Trout within Montana between Crow Tribe, Montana Department of Fish, Wildlife \& Parks (FWP), Montana Department of Environmental Quality (DEQ), Montana Department of Natural Resources and Conservation (DNRC), USDA-Forest Service, Northern Region, Gallatin \& Custer National Forests, USDI-Bureau of Land Management - Montana (BLM), USDI-Fish and Wildlife Service (FWS), USDI-Bureau of Indian Affairs (BIA), Yellowstone National Park. 2000. Montana Department of Fish, Wildlife \& Parks.

Cope, E. D. 1879. A contribution to and zoology of Montana. American Naturalist 13(7): 432-441.

Corsi, C. 1988. The life history and status of the Yellowstone cutthroat trout (Salmo clarki bouvieri) in the Willow Creek drainage, Idaho. Master's thesis, Idaho State University, Pocatello.

Craighead, J.J., J. Sumner, and G. Scaggs. 1982. A definitive system for analysis of grizzly bear habitat and other wilderness resources. WildlifeWildlands Inst. Monogr. 1. Univ. Montana, Missoula, 279 pp.

Crance, J. H. 1987. Preliminary habitat suitability curves for sauger. Proceedings of the Annual Conference of Southeast Association Fish and Wildlife Agencies 41:159-167.

Cross, F. 1967. Handbook of fishes of Kansas. Museum of Natural History, University of Kansas. Lawrence, Kansas. 


\section{DRAFT WORKING DOCUMENT DO NOT DUPLICATE}

15006 Cummins, K.S., A.C. Buchanan, and L.M. Koch (eds.). The conservation and

15007

15008

15009

15010

15011

15012

15013

15014

15015

15016

15017

15018

15019

15020

15021

15022

15023

15024

15025

15026

15027

15028

15029

15030

15031

15032

15033

15034

15035

15036

15037

15038

15039

15040

15041

15042

15043

15044

15045

15046

15047

15048

15049

15050

15051 management of freshwater mussels II: initiatives for the future. Upper Mississippi

River Conservation Committee, Rock Island Illinois.

Dalsted, K. J., et. al. 1981. Application of remote sensing to prairie dog management. Journal of Range Management 34:218-23.

Davis, W. B. 1937. Some mammals from western Montana and eastern Idaho. Murrelet 18:22-27.

Dechant, J. A., M. L. Sondreal, D. H. Johnson, L. D. Igl, C. M. Goldade, P. A. Rabie, and B. R. Euliss. 2000. Effects of management practices on grassland birds: Long-billed Curlew. Northern Prairie Wildlife Research Center, Jamestown, ND. Jamestown, ND: Northern Prairie Wildlife Research Center Home Page. http://www.npwrc.usgs.gov/resource/literatr/grasbird/fplbcu/fplbcu.htm (Version 29FEB2000).

Deeble, B.D. 1996. Conservation of Columbian sharp-tailed grouse, with special emphasis on the upper Blackfoot Valley, Montana. Unpublished MS Thesis, University of Montana, Missoula, Montana. U.S.A..

Diamond, S. and P. Finnegan. 1993. Harlequin duck ecology on Montana's Rocky Mountain Front. [Unpublished report]. Rocky Mountain District, Lewis and Clark National Forest, Choteau, MT. 45 pp.

Dickerman, R.W. and J. P. Hubbard. 1994. An extinct subspecies of sharp-tailed grouse from New Mexico. Western Birds 25: 128-136.

Dieterman, Douglas J. and Galat, David L. 2004. Large-Scale factors associated with Sicklefin Chub distribution in the Missouri and Lower Yellowstone Rivers. Transactions of the American Fisheries Society 133:577-587.

Digital Atlas of Idaho. (Accessed June 5, 2004;<http://imnh.isu.edu/digitalatlas>).

Dixon, R. D., and V. A. Saab. 2000. Black-backed woodpecker (Picoides arcticus). In Birds of North America, No. 509. A. Poole, and F. Gill, editors. The Academy of Natural Sciences, Philadelphia, Pennsylvania, and The American Ornithologists' Union, Washington, DC. A. Poole and F. Gill, editors. The birds of North America Inc., Philadelphia, PA.

Dolan, P. M. 1994. The Common loon (GAVIA IMMER) in the northern region: biology and management recommendations. Unpublished report. U.S.D.A. Forest Service Region 1. 76 pp.

Donald, D. B. and J. D. Stelfox. 1997. Effects of fisheries enhancement and access on adfluvial bull trout populations in mountain lakes of southern Alberta. 


\section{DRAFT WORKING DOCUMENT DO NOT DUPLICATE}

15052 Intermountain/foothill grassland 227-234 in Mackay, W. C., M. K. Brewin and M. 15053 Monita, editors. Friends of the bull trout conference proceedings. Bull Trout

15054 Task Force (Alberta), c/o Trout Unlimited Canada, Calgary

15055

15056

Dood, A.R., Brannon R.D., Mace, R.D. 1986. Final Programmatic Environmental 15057 Impact Statement, the Grizzly Bear in Northwestern Montana. Montana

15058

15059

15060

15061

15062

15063

15064

15065

15066

15067

15068

15069

15070

15071

Department of Fish, Wildlife \& Parks.

Dood, A. R. 1980. Terry Badlands nongame survey and inventory: final report.

[BLM Contract \#YA-512-CT8-217]. Montana Dept. of Fish, Wildlife, and Parks. 70 pp.

Dryer, M.P. and A.J. Sandvol. 1993. Recovery plan for the pallid sturgeon (Scaphirhynchus albus). U.S. Fish and Wildlife Service. Bismarck, ND. 55 pp.

15072

15073

Dufek, D., K. Johnson, J. Kiefling, B. McDowell, R. McKnight, S. Roth, and S.

Yekel. 1999. Status and management of Yellowstone cutthroat trout

Oncorhynchus clarki bouvieri. Wyoming Game and Fish Department, Cheyenne.

15074

15075

15076

15077

Duke, S., P. Anders, G. Ennis, R. Hallock, J. Hammond, S. Ireland, J. Laufle, L.

Lockard, B. Marotz, V. Paragamian, and R. Westerhof. 1999. Recovery plan for

Kootenai River white sturgeon (Acipenser transmontanus). Journal of Applied

Ichthyology (15): 157-163.

15078

15079

15080

Dunham J. B., G. L. Vinyard, and B. E. Rieman. 1997. Habitat fragmentation

and extinction risk of Lahontan cutthroat trout. North American Journal of

Fisheries Management 17: 1126-1133.

15081

Dunn, E. H. and D. J. Agro. 1995. Black Tern (CHLIDONIAS NIGER). In: A.

15082

Poole and F. Gill, (eds.), The Birds of North America, No. 147. Philadelphia: The

15083

15084

15085

Academy of Natural Sciences; Washington D.C.: The American Ornithologists

Union. 24 pp.

15086

Eddy, S., and J. C. Underhill. 1974. Northern fishes. University of Minnesota

15087

15088

15089

15090 Press, Minneapolis.

15091

15092

15093

15094

15095

15096

Edsall, T.A., G.W. Kennedy and W.H. Horns. 1993. Distribution, abundance and resting microhabitat of burbot on Julian's Reef, southwestern Lake Michigan.

Transactions of the American Fisheries Society 122:560-574.

15097

Elis, Janet $\mathrm{H}$., Richard, Jim. A planning guide for protecting Montana's wetlands riparian areas. Montana Watercourse, Montana Department of Environmental Quality and Montana The Audubon Society.

Ellison, L. E., M. B. Wunder, C. A. Jones, C. Mosch, K. W. Navo, K. Peckham, J. E. Burghardt, J. Annear, R. West, J. Siemers, R. A. Adams, and E. Brekke. 2003. 


\section{DRAFT WORKING DOCUMENT DO NOT DUPLICATE}

15098 Colorado bat conservation plan. Colorado Committee of the Western Bat

15099

15100

15101

15102

15103

15104

15105

15106

15107

15108

15109

15110

15111

15112

15113

15114

15115

15116

15117

15118

15119

15120

15121

15122

15123

15124

15125

15126

15127

15128

15129

15130

15131

15132

15133

15134

15135

15136

15137

15138

15139

15140

15141
Working Group. Available at http://www.wbwg.org/colorado/colorado.htm

Elser, A. A., M. W. Gorges, and L. M. Morris. 1980. Distribution of fishes in southeastern Montana. Montana Department of Fish, Wildlife, and Parks, Helena.

Engle, J. C. and C. E. Harris. 2001. Idaho species of special concern element state ranking reviews. Nongame and endangered wildlife program, Conservation Data Center, Idaho Department of Fish and Game, Boise, Idaho, USA.

Environment Canada. 1997. Sustaining Canada's Forests: Timber Harvesting. National Environmental Indicator Series, SOE Bulletin No. 95-4. Online. Available: http://199.212.18.79/ind/English/Forest/Bulletin.

Erickson, K. And Prellwitz, D.M. 1999. Piping plover surveys for Nelson Reservoir, Bowdoin NWR and Hewitt Lake NWR.

Ernst, C. H., J. E. Lovich, and R. W. Barbour. 1994. Turtles of the United States and Canada. Smithsonian Institution Press, Washington, D.C. 578 pp.

Everest, F.H., R.L. Beschta, J.C. Scrivener, K.V. Koski, J.R. Sedell and C.J. Cederholm. 1987. Fine Sediment and Salmonid Production: A Paradox. IN Streamside Management: Forestry and Fishery Interactions. University of Washington, Seattle, Washington. E.O. Salo and T.W. Cundy, tech Ed. Intermountain/foothill grassland 98-142.

Evers, David C. 2004. Status Assessment and Conservation Plan for the Common Loon (Gavia Immer) in North America, David C. Evers, BioDiversity Research Institute, April 12, 2004) available at http://alaska.fws.gov/mbsp/mbm/loons/pdf/Common_Loon_Status_Assessment.p df

Fairman, L. M. and V. E. Miller. 1990. Results of 1990 surveys for harlequin ducks on the Kootenai and Lolo National Forests, Montana. Unpublished report. Montana Natural Heritage Program, Helena.

Fargione, Joseph, Brown, Cynthia S., Tilman, David. 2003. Community assembly and invasion: An experimental test of neutral versus niche processes. PNAS. Vol. 100 (15): 8916-8920.

FaunaWest Wildlife Consultants. 1998. Status of the black and white-tailed prairie dog in Montana. Montana Fish, Wildlife \& Parks, Helena. 34 pp. 


\section{DRAFT WORKING DOCUMENT DO NOT DUPLICATE}

15142 FaunaWest Wildlife Consultants. 1991. Status and breeding distribution of the 15143 mountain plover in Montana. Report to USDI Bureau of Land Management.

15144 FaunaWest Wildlife Consultants, Boulder, MT, 44pp.

15145

15146

Fenton, M. B., D. C. Tennant, and J. Wyszecki. 1987. Using echolocation calls to measure distribution of bats: the case of EUDERMA MACULATUM. J. Mamm. 68:142-144.

15149

15150

15151

15152

15153

15154

15155

15156

15157

15158

15159

15160

15161

15162

15163

15164

15165

15166

15167

15168

15169

15170

Figg, D. E. 1993. Missouri Department of Conservation wildlife diversity report, July 1992-June 1993. 75 pp.

Findlay, C. S., D. G. Bert, and L. Zheng. 2000. Effect of introduced piscivores on native minnow communities in Adirondack lakes. Canadian Journal of Fisheries and Aquatic Sciences 57:570-580.

Fisher, F.B, J.C. Winne, M.M. Thornton, T.P. Tady, Z. M.M. Hart, and R.L. Redmond. 1998. Montana Land Cover Atlas. Unpublished report. Montana Cooperative Willdife Research Unit, The University of Montana, Missoula viii +50 p.

Flath, D. L. 1979. Status of the white-tailed prairie dog in Montana. Proc. Mont. Acad. Sci. 38:63-67.

Flathead River Subbasin Executive Summary. 2004. A summary of Flathead River Subbasin Assessment, Inventory, and Management Plan. Northwest Power and Conservation council.

Flores, R., Stricker, G., Meyer, J., Doll, T., Norton, P., Livingston, R., Jennings, M. 2001. A Field Conference on Impacts of Coal Bed Methane Development in the Powder River Basin, Wyoming, USGS Open-File Report 01-126.

Foresman, K. R. 2001. The wild mammals of Montana. American Society of Mammalogists, Special Publication No. 12. 278 pp.

Fraley, J. J. and B. B. Shepard. 1989. Life history, ecology, and population status of migratory bull trout (Salvelinus confluentus) in the Flathead Lake and 15178 15179 River System, Montana. Northwest Science 63:133-143.

Fraley, J., D. Read and P. Graham. 1981. Flathead River fisheries study. Montana Department of Fish, Wildlife \& Parks.

Frisina, Michael R., McCarthy, John, J. 2001. Montana Sagebrush Bibliography. Montana Fish, Wildlife \& Parks. 69 pp.

15185 


\section{DRAFT WORKING DOCUMENT DO NOT DUPLICATE}

15186

15187

15188

15189

15190

15191

15192

15193

15194

15195

15196

15197

15198

15199

15200

15201

15202

15203

15204

15205

15206

15207

15208

15209

15210

15211

15212

15213

15214

15215

15216

15217

15218

15219

15220

15221

15222

15223

15224

15225

15226

15227

15228

15229

15230

15231
Frissell, S. S. 1978. Nongame wildlife inventory. Prepared for: US Dept. of Interior, Bureau of Land Management, Dillon Resource Area, Dillon, Montana. $194 \mathrm{pp}$.

Fuller, P. L., G. Nico, and J. D. Williams. 1999. Nonindigenous fishes introduced into inland waters of the United States. American Fisheries Society, Bethesda, MD.

Furniss, M. J., T. D. Roelofs, and C. S. Yee. 1991. Road construction and primarytenance. Intermountain/foothill grassland 297-324 in W. R. Meehan, editor. Influences of forest and rangeland management on salmonid fishes and their habitats. American Fisheries Society Special Publication 19, Bethesda, Maryland.

Gardner, W. M., and P. A. Stewart. 1997. The fishery of the lower Missouri River, Montana. Montana Department of Fish, Wildlife \& Parks report, FW-2-R.

Gardner, W. M. and R. Berg. 1982. An analysis of the instream flow requirements for selected fishes in the wild and scenic portion of the Missouri River. Montana Fish, Wildlife \& Parks. Helena. 111pp.

Gardner, W. M., and R. K. Berg. 1980. An analysis of the instream flow requirements for selected fishes in the Wild and Scenic portion of the Missouri River. Montana Fish, Wildlife \& Parks report, Great Falls, MT.

Genter, D.L. 1993. Harlequin duck status report 1992: Montana.

Intermountain/foothill grassland 31-34 in Cassirer, E.F., A. Breault, P. Clarkson, D. L. Genter, R. I. Goudie, B. Hunt, S. C. Latta, G. H. Mittelhauser, M. M. Schirato, and R. L. Wallen, editors. Harlequin ducks in North America. Harlequin Duck Working Group.

Genter, D. L., Wilson, A. G. and E. M. Simon. 1988. Supplementary report on the status of the Coeur d'Alene salamander (Plethodon vandykei idahoensis) in Montana. Unpublished report to USDA Forest Service. Montana Natural Heritage Program, Helena, Montana, U.S.A. including maps.

Gervais, J. A., and R. G. Anthony. 2003. Chronic organochlorine contaminants, environmental variability, and demographics of a burrowing owl population. Ecological Applications 13: 1250-1262.

Giesen, K. M. and J. W. Connelly. 1993. Guidelines for management of sharptailed grouse habitats. Wildlife Society Bulletin 21: 325-333.

Gillies, K. E. and R. Dixon. 2004. Draft Idaho Bat Conservation Plan. Nongame and Endangered Wildlife Program tech. Report. Idaho Conservation Data Center, Idaho Department of Fish and Game, Boise, Idaho, USA. 


\section{DRAFT WORKING DOCUMENT DO NOT DUPLICATE}

15232

15233

15234

15235

15236

15237

15238

15239

15240

15241

15242

15243

15244

15245

15246

15247

15248

15249

15250

15251

15252

15253

15254

15255

15256

15257

15258

15259

15260

15261

15262

15263

15264

15265

15266

15267

15268

15269

15270

15271

15272

15273

15274

15275

15276

15277
Girard, C. 1856. Researches upon the cyprinoid fishes inhabiting the fresh waters of the United States, west of the Mississippi Valley, from specimens in the museum of the Smithsonian Institution. Proceedings of the Academy of Natural Science of Philadelphia. 8: 165-213.

Gitzen, R. A., S. D. West, and J. A. Baumgardt. 2001. A record of the Spotted Bat (Euderma maculatum) from Crescent Bar, Washington. Northwestern Naturalist 82:28-30.

Goetz, F. 1989. Biology of the bull trout Salvelinus confluentus: a literature review. Willamette National Forest. Eugene, Oregon. 53 intermountain/foothill grassland.

Goggans, R. 1989. Black-backed woodpecker. Pp. 88-89 in Clark, T. W., A. H. Harvey, R. D. Dorn, D. L. Genter, and C. Groves, editors. Rare, Sensitive and threatened species of the Greater Yellowstone Ecotype. Northern Rockies Conservation Cooperative.

Goggans, R. 1986. Habitat use by flammulated owls in northeastern Oregon. Master's thesis, Oregon State University, Corvallis, OR.

Gould, W. 1994. The recent distribution of sturgeon chub (Macrhybopsis gelida) in Montana. Report to the Montana Department of Fish, Wildlife \& Parks.

Helena.

Gould, W.R. 1981. First records of the rainbow smelt (Osmeridae), sicklefin chub (Cyprinidae) and white bass (Percichthyidae) from Montana. Proc. Mont. Acad. Sci. 40: 9-10.

Gould, W. R. 1969. First record of the trout-perch, Percopsis omiscomaycus, from Montana. Proceedings of the Montana Academy of Sciences 29:51.

Gould, W. R., and C. J. D. Brown. 1968. Fishes of the genus Semotilus (Cyprinidae) from Montana. Copeia 1968: 628-629.

Green, J. S. and J. T. Flinders. 1980. Habitat and dietary relationships of the pygmy rabbit. Jour. Range Mgmt. 33(2): 136-142.

Greenlaw, J. S. 1993. Behavioral and morphological diversification in sharp-tailed sparrows (AMMODRAMUS CAUDACUTUS) of the Atlantic coast. Auk 110:286303.

Gresswell, R. E. 1995. Yellowstone cutthroat trout. Intermountain/foothill grassland 36-54 in M. K. Young, technical editor. Conservation assessment for 


\section{DRAFT WORKING DOCUMENT DO NOT DUPLICATE}

15278 inland cutthroat trout. U.S. Forest Service General Technical Report RM-GTR15279256.

15280

15281

15282

15283

15284

15285

15286

15287

15288

15289

15290

15291

15292

15293

15294

15295

15296

15297

15298

15299

Gresswell, R. E., W. J. Liss, and G. L. Larson. 1994. Life-history organization of Yellowstone cutthroat trout (Oncorhynchus clarki bouvieri) in Yellowstone Lake. Canadian Journal of Fisheries and Aquatic Sciences 51(Supplement 1): 298309.

Grisak, G. G. 1996. The status and distribution of the sicklefin chub in the middle Missouri River, Montana. Masters thesis. Montana State University, Bozeman.

Grover, P. B. and F. L. Knopf. 1982. Habitat requirements and breeding success of charadriiform birds nesting at Salt Plains National Wildlife Refuge, Oklahoma. J. Field Ornithol. 53:139-148.

15300

15301

Groves, C., T. Frederick, G. Frederick, E. Atkinson, M. Atkinson, J. Shepard and G. Servheen. 1997. Density, distribution, and habitat of flammulated owls in Oregon. Great Basin Naturalist 57:116-123.

Groves, C. R., E. F. Cassirer, D. L. Genter, and J. D. Reichel. 1996. Coeur d'Alene Salamander (PLETHODON IDAHOENSIS). Natural Areas Journal 16(3): 238-247.

Groves, C.R. 1994. Effects of Timber Harvest on Small Mammals and

15302

Amphibians in Old-Growth Coniferous Forests on the Priest Lane Ranger District, 15303 15304 15305

15306 Unpublished report to the Priest Lake Ranger District, Idaho Panhandle National Forest. The Nature Conservancy, Boulder, Colorado, U.S.A.

Groves, C. R. and C. Peterson. 1992. Distribution and population trends of Idaho amphibians as determined by mail questionnaire. Conservation Data center, Idaho Department of Fish and Game, Boise, Idaho, U.S.A.

15309

15310

Groves, C. 1988, 1989. Status and distribution of the Coeur d'Alene salamander

15311 (Plethodon vandykei idahoensis) in Idaho - part II. Unpublished report. Idaho Department of Fish and Game, Boise, Idaho, U.S.A.

15321

Gurevitch, J., P. S. Curtis, and M. H. Jones. 2001. Meta-analysis in Ecology. Advances in Ecological Research 32: 200-241.

Gustafson, D.L. 1996. http://www.esg.montana.edu/dlg/aim/mollusca/marfal.html

Haig, S., et al. 1994. Revised recovery plan for piping plovers CHARADRIUS MELODUS breeding on the Great Lakes and Northern Great Plains. [Technical/Agency review draft]. Great Lakes/Northern Great Plains Piping Plover Recovery Team. 121 pp.

15323 


\section{DRAFT WORKING DOCUMENT DO NOT DUPLICATE}

15324 Haig, S. M. 1992. Distribution and status of piping plovers in winter. Abstract, 6th

15325

15326

15327

15328

15329

15330

15331

15332

15333

15334

15335

15336

15337

15338

15339

15340

15341

15342

15343

15344

15345

15346

15347

15348

15349

15350

15351

15352

15353

15354

15355

15356

15357

15358

15359

15360

15361

15362

15363

15364

15365

15366

15367
Annual Meeting of the Society for Conservation Biology, p. 69.

Haig, S., et al. 1988. Recovery plan for piping plovers CHARADRIUS MELODUS of the Great Lakes and northern great plains. U.S. Fish \& Wildlife Service, 160pp.

Hall, E. R. 1981. The Mammals of North America, Vols. I \& II. John Wiley \& Sons, New York, New York, USA.

Hammerson, G. A. 1999. Amphibians and reptiles in Colorado. Second edition. University Press of Colorado, Boulder, Colorado. xxvi + 484 pp.

Handley, C. O., Jr. 1959. A revision of American bats of the genera Euderma and Plecotus. Proc. U.S. Natl. Mus. 110:95-246.

Hansen, Paul L., and S.W. Chadde, and R.D. Pfister. 1988. Riparian Dominance Types of Montana. Miscellaneous Publication No. 49. Montana Forest and Conservation Experiment Station. School of Forestry, University of Montana, Missoula, Montana.

Hansen, A., Rotella, J., Klass, L., Gyskiewicz, D. 2003. Riparian habitat Dynamics and wildlife along the Upper Yellowstone River. Technical Report \#1. Landscape Biodiversity Lab, Montana State University, Bozeman, MT. In cooperation with The Governor's Upper Yellowstone River Task Force.

Harlequin duck working group. 1993. Status of harlequin ducks (Histrionicus histrionicus) in North America. Report of the Harlequin Duck Working Group.

Harris, M. A. 1982. Habitat use among woodpeckers in forest burns. M.S. thesis. University of Montana, Missoula. 62 pp.

Hart, M. M., W. A. Williams, P. C. Thornton, K. P. McLaughlin, C. M. Tobalske, B. A. Maxell, D. P. Hendricks, C. R. Peterson, and R. L. Redmond. 1998. Longbilled curlew (Numernius americanus) in Montana atlas of terrestrial vertebrates. Unpublished report. Montana Cooperative Wildlife Research Unit, The University of Montana, Missoula. Pp. 269-271.

Haug, E. A., B. A. Millsap, and M. S. Martell. 1993. In Birds of North America, No. 61, A. Poole and F. Gill, editors. Academy of Natural Science, Philadelphia, The American Ornithologist's Union, Washington, DC, USA.

Hawk Watch International. 2003. An online search for migration watch results, 1999-2002 data. http://www.hawkwatch.org/. Accessed 11 September 2003. 


\section{DRAFT WORKING DOCUMENT DO NOT DUPLICATE}

15368

15369

15370

15371

15372

15373

15374

15375

15376

15377

15378

15379

15380

15381

15382

15383

15384

15385

15386

15387

15388

15389

15390

15391

15392

15393

15394

15395

15396

15397

15398

15399

15400

15401

15402

15403

15404

15405

15406

15407

15408

15409

15410

15411

15412

15413
Hayward, G. D., and J. Verner. 1994. Flammulated, boreal, and great gray owls in the United States. General Technical Report RM-253, USDA Forest Service, Rocky Mountain Research Station, Fort Collins, Colorado, USA.

Heady, L.T., Gabler, K.I. and Laundre, J. W. 2001. Habitat selection by pygmy rabbits in Southeast Idaho. Technical Bulletin No. 01-7. Idaho Bureau of Land Management.

Hejl, S.J., R.L. Hutto, C.R. Preston, and D.M. Finch. 1995. Effects of silvicultural treatments in the Rocky Mountains. Intermountain/foothill grassland 220-244 in T.E. Martin and D.M. Finch, editors. Ecology and management of neotropical migratory birds. Oxford University Press.

Hendricks, P., and M. Roedel. 2002. Preble's Shrew and Great Basin Pocket Mouse from the Centennial Valley Sandhills of Montana. Northwestern Naturalist 83: 31-34.

Hendricks, P. and J. C. Carlson. 2001. Bat use of abandoned mines in the Pryor Mountains. Report to the Montana Department of Environmental Quality, Mine Waste Cleanup Bureau. Montana Natural Heritage Program, Helena. 8pp.

Hendricks, P., and D. Kampwerth. 2001. Roost environments for bats using abandoned mines in southwestern Montana: a preliminary assessment. Report to the U.S. Bureau of Land Management. Montana Natural Heritage Program, Helena, Montana. 19 pp.

Hendricks, P. and M. Roedel. 2001. A faunal survey of the Centennial Valley Sandhills, Beaverhead County, Montana. Report to the U.S. Bureau of Land Management and US Fish and Wildlife Service. Montana Natural Heritage Program, Helena, Montana, USA.

Hendricks, P., D. L. Genter, and S. Martinez. 2000. Bats of Azure Cave and the Little Rocky Mountains, Montana. Canadian Field-Naturalist 114: 89-97.

Hendricks, P. 1999. Amphibian and reptile survey of the Bureau of Land Management Miles City District, Montana. Montana Natural Heritage Program, Helena, Montana. 80 pp.

Hendricks, Paul. 1999, Amphibian and reptile surveys on Montana refuges: 1998-1999. December 1999.

Hendricks, P. 1999. Effect of gate installation on continued use by bats of four abandoned mine workings in western Montana. Unpublished report to Montana Department of Environmental Quality. Montana Natural Heritage Program, Helena, Montana. 13 pp. 


\section{DRAFT WORKING DOCUMENT DO NOT DUPLICATE}

15414 Hendricks, P., K. A. Jurist, D. L. Genter and J. D. Reichel. 1996. Bats of the 15415 Kootenai National Forest, Montana. [Unpublished report]. Montana Natural 15416 Heritage Program, Helena, MT. 99 pp.

15417

15418

Hendricks, P. and J. D. Reichel. 1996. Preliminary amphibian and reptile survey 15419

15420

15421

15422

15423

15424

15425

15426

15427

15428

15429

15430

15431

15432

15433 of the Ashland District, Custer National Forest: 1995. Montana Natural Heritage Program. Helena, MT. 79 pp.

Hensler, M.E., C.C. Muhlfeld. 1999. Spawning ecology of redband trout in Basin Creek, Montana. A Report to the Whirling Disease Foundation. Montana Fish, Wildlife \& Parks, Bozeman, MT.

Hensler, M.E., J.E. Huston and G. K. Sage. 1996. A Genetic Survey of Lakes in the Cabinet Wilderness Area and Proposed Inland Rainbow Trout Recovery. Montana Fish, Wildlife \& Parks, Kalispell, Montana.

15434

15435

15436

15437

15438

15439

Hermanson, J. W. and T. J. O'Shea 1983. ANTROZOUS PALLIDUS. Mammalian Species 213:1-8.

Hesse, L. W. 1994. The status of Nebraska fishes in the Missouri River. 6. Sauger (Percidae: Stizostedion canadense). Transactions of the Nebraska Academy Sciences 21:109-121.

Hickman, G. R., B. G. Dixon, and J. Corn. 1999. Small mammals. Intermountain/foothill grassland 4.1-4.16 in The effects of recreation on Rocky Mountain wildlife: A review for Montana.

15440

15441

15442

15443

15444

15445

15446

15447

15448

15449

15450

15451

15452

15453

15454

15455

15456

15457

Hiebert, S. D., R. Wydoski and T.J. Parks. 1999. Fish entrainment at the lower Yellowstone Diversion Dam, Intake Canal, Montana - 1996-1998. Technical Service Center Data Report. Bureau of Reclamation. In press. 52 pp.

Hill, N.P. 1968. Nelson's Sharp-tailed Sparrow. Intermountain/foothill grassland 815-819 in O.L. Austin, Jr., editor. Life histories of North American cardinals, grosbeaks, buntings, towhees, finches, sparrows, and allies. Dover Publications Inc., New York, NY.

Hillman, C. N., R. L. Linder, and R. B. Dahlgren. 1979. Prairie dog (CYNOMYS LUDOVICIANUS) distribution in areas inhabited by black-footed ferrets (MUSTELA NIGRIPES). Am. Midl. Nat. 102:185-7.

Hinman, K.E. and T.K. Snow, eds. 2003. Arizona Bat Conservation Strategic Plan. Version 1.0. Nongame and Endangered Wildlife Program Technical Report xxx. Arizona Game and Fish Department, Phoenix, AZ. (In progress) 


\section{DRAFT WORKING DOCUMENT DO NOT DUPLICATE}

15458

15459

15460

15461

15462

15463

15464

15465

15466

15467

15468

15469

15470

15471

15472

15473

15474

15475

15476

15477

15478

15479

15480

15481

15482

15483

15484

15485

15486

15487

15488

15489

15490

15491

15492

15493

15494

15495

15496

15497

15498

15499

15500

15501

15502

15503
Hoffman, N.J. 1997. Distribution of Picoides woodpeckers in relation to habitat disturbance within the Yellowstone area. M.S. Thesis. Montana State University. Bozeman, MT. 74 pg.

Hoffmann, R. S., D. L. Pattie and J. F. Bell. 1969. The distribution of some mammals in Montana. II. Bats. J. Mammal. 50(4): 737-741.

Holt, D. W. and J. M. Hillis. 1987. Current status and habitat associations of forest owls in western Montana. Pp 281-288 in: Biology and conservation of northern forest owls: symposium proceedings, Feb. 3-7, Winnepeg, Manitoba. Gen. Tech. Rep. RM-142. Fo

Holton, G. D., and H. E. Johnson. 2003. A field guide to Montana fishes, 3rd edition. Montana Fish, Wildlife \& Parks, Helena.

Holton, G. D., and H. E. Johnson. 1996. A field guide to Montana fishes. Montana Fish, Wildlife \& Parks, Helena.

Holton, G. D. 1981. Identification of Montana's most common game and sport fishes. Montana Outdoors reprint.

Holton, G. 1980. The riddle of existence; fishes of special concern. Montana Outdoors 11: 2-6.

Hornaday, William T. 1913. Our vanishing wildlife: its extermination and preservation. New York Zoological Society, New York.

Howard, J. 1993. Genetic variation and population diverg4ence in the Plethodon Vandykei species group. Herpetologica 49: 238-247.

Howie, R.R. and R. Ritcey. 1987. Distribution, habitat selection, and densities of flammulated owls in British Columbia. Intermountain/foothill grassland 249-254 in: B87NER01.

Hoyt, J. S, and S. J. Hannon. 2002. Habitat associations of black-backed and three toed woodpeckers in the boreal forest of Alberta. Canadian Journal of Forest Research. 32: 1881-1888.

Huston, J.E. 1995. A Report on the Kootenai River Drainage Native Species Search. A Report to the U.S. Fish and Wildlife Service. Montana Fish, Wildlife \& Parks, Kalispell, MT.

Hutto, R. L., and J. S. Young. 1999. Habitat relationships of land birds in the Northern Region, USDA Forest Service. General Technical Report RMRS-GTR32. USDA Forest Service, Rocky Mountain Research Station, Ogden, UT. 


\section{DRAFT WORKING DOCUMENT DO NOT DUPLICATE}

15504 Hutto, R.L. 1995a. USFS Northern Region Songbird Monitoring Program:

15505 Distribution and habitat relationships. USDA Forest Service Northern Region

15506 internal report, Missoula, MT.

15507

15508

Hutto, R.L. 1995b. Composition of bird communities following stand-replacement

15509

15510

15511

15512

15513

15514

15515

15516

15517

15518

15519

15520

15521

15522

15523

15524

15525

15526

15527

15528

15529

15530

15531

15532

15533

15534

15535

15536

15537 fires in northern Rocky Mountain (U.S.A.) conifer forests. Conservation Biology 9:1041-1058.

Idaho Fish and Game. (Accessed April 26, 2004;

<http://fishandgame.idaho.gov/tech/CDC/county_spp_lists>).

Ireland, S.C. 2000. Kootenai River White Sturgeon Studies and Conservation Aquaculture. Annual Progress Report. Prepared for U.S. Department of Energy, Bonneville Power Administration. Contract No. 88 BI 93743; Project No. 88-64. Portland, Oregon.

J. Mammal. 50: 579-604. NatureServe Explorer: An online encyclopedia of life. 2002. Version 1.6. Arlington, Virginia, USA. (Accessed: March 20, 2003; http://www.natureserve.org/explorer.http://nhp.nris.state.mt.us/animalguide/).

Jean, C., P. Hendricks, M. Jones, S. Cooper, and J. Carlson. 2002. Ecological communities on the Red Rock Lakes National Wildlife Refuge: inventory and review of aspen and wetland systems. Report to the Red Rock Lakes National Wildlife Refuge. Montana

Jaeger, M.E.. 2004. An empirical assessment of factors precluding recovery of sauger in the lower Yellowstone River: movement, habitat use, exploitation and entrainment. Masters Thesis.

Jewett, S. G. 1931. Nesting of the Pacific harlequin duck in Oregon. Condor 33:255.

Johnsgard, P. A. 1986. Birds of the Rocky Mountains with particular reference to national parks in the Northern Rocky Mountain region. Colorado Associated

15538

15539

15540 University Press, Boulder. xi +504 pp.

15541

15542

15543

15544

15545

15546

15547

Jones, J. K. Jr., D. M. Armstrong, R. S. Hoffmann and C Jones. 1983. Mammals of the northern Great Plains. Univ. Neb. Press, Linclon. 379 pp.

15548

Jones, M. S., J. P. Goettl, and L. J. Livo. 1999. Bufo boreas (Boreal Toad).

Predation. Herpetological Review 30:91

Jones, W. M. 2003. Kootenai National Forest Peatlands: Description and Effect of Forest Management. Report to the Kootenai National Forest, Montana.

15549 Montana Natural Heritage Program, Helena, Montana, U.S.A. 


\section{DRAFT WORKING DOCUMENT DO NOT DUPLICATE}

15550 Jones, Z. F., and C. E. Bock. 2002. Conservation of grassland birds in an

15551

15552

15553

15554

15555

15556

15557

15558

15559

15560

15561

15562

15563

15564

15565

15566

15567

15568

15569

15570

15571

15572

15573

15574

15575

15576

15577

15578

15579

15580

15581

15582

15583

15584

15585

15586

15587

15588

15589

15590

15591

15592

15593

15594 urbanizing landscape: a historical perspective. Condor 104: 643-651.

Jones-Wuellner, Melissa R. and Guy, Christopher S. 2004. Status of Burbot in Montana. Prepared for Montana Fish, Wildlife \& Parks. Montana Cooperative Fisheries Research Unit, Montana State University-Bozeman.

Joslin, G. and H. Youmans, coordinators. 1999. Committee on Effects of Recreation on Wildlife, Montana Chapter of The Wildlife Society, Helena, Montana, USA.

Kanda, N., R. F. Leary and F. W. Allendorf. 1997. Population genetic structure of bull trout in the upper Flathead River drainage. Intermountain/foothill grassland 299-308 in Mackay, W. C., M. K. Brewin and M. Monita, editors. Friends of the bull trout conference proceedings. Bull Trout Task Force (Alberta), c/o Trout Unlimited Canada, Calgary.

Karl, J. 2000. Columbian sharp-tailed grouse (Tympanuchus phasianellus columbianus). Digital atlas of Idaho. (Accessed May 25, 2004;

$<$ http://imnh.isu.edu/digitalatlas >).

Katzner, T.E. and K.L. Parker. 1997. Vegetative characteristics and size of home ranges used by pygmy rabbits (Brachylagus idahoensis) during winter. Journal of Mammalogy. 78:1063-1072,

Kaya, C.M. 1992a. Review of the decline and status of fluvial Arctic grayling (Thymallus arcticus), in Montana. Proceedings of Montana Academy of Sciences 52:43-70.

Kaya, C.M. 1992b. Restoration of fluvial Arctic grayling to Montana streams: assessment of reintroduction potential of streams in the native range, the upper Missouri River drainage above Great Falls. Prepared for: Montana Chapter of the American Fisheries Society and Montana Department of Fish, Wildlife, and Parks, Bozeman.

Kaya, Calvin M. 1990. Status Report on Fluvial Arctic Grayling (Thymallus arcticus) in Montana. Biology Department, Montana State University. Bozeman, MT. Prepared for: FWP. Helena, MT

Keenlyne, K.D. 1989. A report on the pallid sturgeon. U. S. Fish and Wildlife Service, Pierre, South Dakota. Unpublished report.

Keiter, R. B. 1997. Greater Yellowstone's Bison: unraveling of an early American Wildlife Conservation achievement. J. Wildlife Management 61:1-11. 


\section{DRAFT WORKING DOCUMENT DO NOT DUPLICATE}

15595

15596

15597

15598

15599

15600

15601

15602

15603

15604

15605

15606

15607

15608

15609

15610

15611

15612

15613

15614

15615

15616

15617

15618

15619

15620

15621

15622

15623

15624

15625

15626

15627

15628

15629

15630

15631

15632

15633

15634

15635

15636

15637

15638

15639

15640
Kelly, L. M. 1992. The effects of human disturbance on common loon productivity in northwestern Montana. M.S. Thesis, University of Montana, Missoula. 65 p.

Kelsall, J. P., E. S. Telfar, and T. D. Wright. 1977. The effects of fire on the ecology of the boreal forest, with particular reference to the Canadian north: a review and selected bibliography. Canadian Wildlife Service, Occasional Paper No. 32. Ottawa, Canada.

Kessler, W.B. and R.P. Bosch. 1982. Sharp-tailed grouse and range management practices in western rangelands. 1982. Intermountain/foothill grassland 133-136 in Proceedings of wildlife-livestock relationships symposium. J.M. Peek and P. Dallce, editors. University of Idaho, Moscow, Idaho, USA.

Kincaid, M.L. 1993. A breeding plan to preserve the genetic variability of the Kootenai River white sturgeon. Contract No. DE-AI79-93BP02886. Bonneville Power Administration, Portland, Oregon.

Kirby, V. C. 1980. An adaptive modification in the ribs of woodpeckers and piculets (Picidae). Auk 97: 521-532.

Kitano, S., K. Maekawa, S. Nakano and K. D. Fausch. 1994. Spawning behavior of bull trout in the upper Flathead drainage, Montana, with special reference to hybridization with brook trout. Transactions of the American Fisheries Society 123:988-992.

Klatt, L. E. and D. Hein. 1978. Vegetative differences among active and abandoned towns of black-tailed prairie dogs (CYNOMYS LUDOVICIANUS). Journal of Range Management 31:315-7.

Klott, James H.; Lindzey, Frederick G. 1990. Brood habitats of sympatric sage grouse and Columbian sharp-tailed grouse in Wyoming. Journal of Wildlife Management. 54(1): 84-88.

Klute, D. S., L.W. Ayers, M.T. Green, W.H. Howe, S.L. Jones, J.A. Shaffer, S.R. Sheffield, and T.S. Zimmerman. 2003. Status Assessment and Conservation Plan for the Western Burrowing Owl in the United States. U.S. Department of the Interior; Fish and Wildlife Service, Biological Technical Publication FWS/BTPR6001-2003, Washington, D.C.

Knapton, R.W. 1979. Birds of the Gainsborough-Lyleton region. Saskatchewan Natural History Society Special Publication 10. 72 pp.

Knopf, F. L. 1991. Status and conservation of mountain plovers: the evolving regional effort. Report of research activities, USFWS National Ecology Research Center, Ft. Collins, CO, 9pp. 


\section{DRAFT WORKING DOCUMENT DO NOT DUPLICATE}

15641 Knowles, C. and P. Knowles. 1997. Mountain Plover Numbers, Reproduction, 15642 and Habitat Use in Montana: A Summary of Six Survey Years. FaunaWest 15643 Wildlife Consultants. Prepared for the Montana Department of Fish, Wildlife, \& 15644 Parks, Great Falls, Montana, and the Bureau of Land Management, Billings, 15645 Montana. 22 April 1997.

15646

Knowles, C., P. Knowles, M. Maj, and D. Hinckley. 1995. Mountain Plover Montana.

Knowles, C. J. and P. R. Knowles. 1993. Mountain plover numbers, reproduction, and habitat use in three areas of Montana. Unpublished report for the Bureau of Land Management, Billings. 50pp.

15661

15662

15663

15664

15665

15666

15667

15668

15669

15670

15671

15672

15673

15674

15675

15676

15677

15678

15679

15680

15681

15682

15683

15684

15685

15686
Knowles, C. J. and P. R. Knowles. 1984. Additional records of mountain plovers using prairie dog towns in Montana. Prairie Nat. 16:183-186.

Knowles, C. J., C. J. Stoner and S. P. Gieb. 1982. Selective use of black-tailed prairie dog towns by mountain plovers. Condor 84:71-74.

Knowles, C.J. 2002. Status of the white-tailed and Gunnison's prairie dog. Environmental Defense and National Wildlife Federation. FaunaWest Wildlife Consultants. Boulder, Montana.

Knudsen, K. C. Muhlfeld, K. Sage, and R. Leary. In-prep. Genetic differences among populations of redband trout in the Kootenai River drainage, Montana. Transactions of the American Fisheries Society.

Koch, E. D., and C. R. Peterson. 1995. Amphibians \& reptiles of Yellowstone and Grand Teton national parks. University of Utah Press, Salt Lake City. xviii +188 pp.

Koehler, G. M. and J. D. Brittell. 1990. Managing spruce-fir habitat for lynx and snowshoe hares. Journal of Forestry, October 1990.

Koehler, G. M., M. G. Hornocker, and H. S. Hash. 1979. Lynx movements and habitat use in Montana. Canadian Field-Naturalist 93(4): 441-442.

Koford, C. B. 1958. Prairie dogs, whitefaces, and blue grama. Wildlife Monograph 3:1-78.

Kootenai Tribe of Idaho and Montana Fish, Wildlife \& Parks. 2004. Public Review Draft Kootenai Subbasin Plan. Executive Summary. Report prepared for the Northwest Power and Conservation Council. Portland, OR. 


\section{DRAFT WORKING DOCUMENT DO NOT DUPLICATE}

15687

15688

15689

15690

15691

15692

15693

15694

15695

15696

15697

15698

15699

15700

15701

15702

15703

15704

15705

15706

15707

15708

15709

15710

15711

15712

15713

15714

15715

15716

15717

15718

15719

15720

15721

15722

15723

15724

15725

15726

15727

15728

15729

15730

15731

15732
Korman, J., and C. J. Walters. 1999. Summary of the Kootenai River Adaptive Environmental Assessment modeling exercise. Prepared for the Kootenai Tribe of Idaho. Ecometric Research Inc. Vancouver, British Columbia, Canada.

Kotliar, N. B., S. Heil, R. L. Hutto, V. A. Saab, C. P. Melcher, M. E. McFadzen. 2002. Effects of fire and post-fire salvage logging on avian communities in conifer-dominated forests of the western United States. Studies in Avian Biology 25:49-64.

Kovalak, W.P., S.D. Dennis and J.M. Bates. 1986. Sampling effort required finding rare species of freshwater mussels. Intermountain/foothill grassland 34-45 in B.G. Isom, ed. Rationale for sampling and interpretation of ecological data in the assessment of freshwater ecotypes. American Society for Testing and Material, Special Technical Publication No. 894.

Krapu, G.L., and R.K. Green. 1978. Breeding bird populations of selected semipermanent wetlands in south-central North Dakota. American Birds 32:110-112.

Krentz, Steven. 1997a. Stocking/augmentation plan for the pallid sturgeon (Scaphirhynchus albus) in Recovery Priority Management Areas 1 and 2 in Montana and North Dakota. U.S. Fish and Wildlife Service. Bismarck. 38 pp.

Kruse, C. G., W. A. Hubert, and F. J. Rahel. 2000. Status of Yellowstone cutthroat trout in Wyoming waters. North American Journal of Fisheries Management 20: 693-705.

Krutzsch, P. H. 1954. North American jumping mice (genus Zapus). University of Kansas Publications, Museum of Natural History 7:349-472.

Kuchel, C. R. 1977. Some aspects of the behavior and ecology of harlequin ducks breeding in Glacier National Park, Montana. M.S. thesis. Univ. of Montana, Missoula. $160 \mathrm{pp}$.

Kushlan, James A., Melanie J. Steinkamp, Katherine C. Parsons, Jack Capp, Martin Acosta Cruz, Malcolm Coulter, Ian Davidson, Loney Dickson, Naomi Edelson, Richard Elliot, R. Michael Erwin, Scott Hatch, Stephen Kress, Robert Milko, Steve Miller, Kyra Mills, Richard Paul, Roberto Phillips, Jorge E. Saliva, Bill Sydeman, John Trapp, Jennifer Wheeler, and Kent Wohl. 2002. Waterbird Conservation for the Americas: The North American Waterbird Conservation Plan, Version 1. Waterbird Conservation for the Americas, Washington, D.C. U.S.A., 78 pp.

Lampe, R. P., J. K. Jones Jr., R. S. Hoffman, and E. C. Birney. 1974. The mammals of Carter County, southeastern Montana. Occa. Pap. Mus. Nat. Hist. Univ. Kan. 25:1-39. 


\section{DRAFT WORKING DOCUMENT DO NOT DUPLICATE}

15733

15734

15735

15736

15737

15738

15739

15740

15741

15742

15743

15744

15745

15746

15747

15748

15749

15750

15751

15752

15753

15754

15755

15756

15757

15758

15759

15760

15761

15762

15763

15764

15765

15766

15767

15768

15769

15770

15771

15772

15773

15774

15775

15776

15777
Leach, J. H., and 5 co-authors. 1977. Responses of percids and their habitats to eutophication. Journal of the Fisheries Research Board of Canada 34:19641971.

Leary, R.F., F.W. Allendorf and N. Kanda. 1998. Lack of Genetic Divergence between Westslope Cutthroat Trout from the Columbia and Missouri River Drainages. Wild Trout and Salmon Genetics Laboratory Report 97/1. Missoula, Montana.

Leary, R. F., F. W. Allendorf, S. H. Forbes. 1993. Conservation genetics of bull trout in the Columbia and Klamath River Drainages. Conservation Biology 7:856865.

Leary, R. F. 1991. Establishment, primarytenance, and use of a genetic reserve of Big Hole River Arctic grayling. Wild Trout and Salmon Genetics Laboratory Report 91/5. University of Montana, Missoula.

Leary, R.F, F.W. Allendorf, and K. G. Sage. 1991. Genetic analysis of trout populations in the Yaak River Drainage, Montana. Wild trout and salmon genetics laboratory report 91/3. University of Montana, Missoula.

Leathe, S. A. and M. D. Enk. 1985. Cumulative effects of micro-hydro development on the fisheries of the Swan River drainage, Montana. Report prepared for Bonneville Power Administration, Division of Fish and Wildlife. 114 intermountain/foothill grassland, appendices.

Lee, S. et al. 1980. Atlas of North American freshwater fishes. North Carolina State Museum of Natural History. Raleigh.

Lenard, S., J. Carlson, J. Ellis, C. Jones, and C. Tilly. 2003. P. D. Skaar's Montana Bird Distribution, 6th Edition. Montana The Audubon Society, Helena, Montana. vi + $144 \mathrm{pp}$.

Leonard, M. L., and M. B. Fenton. 1983. Habitat use by spotted bats (EUDERMA MACULATUM, Chiroptera: Vespertilionidae): roosting and foraging behavior.

Can. J. Zool. 61:1487-1491.

Lesica. 2005. Restoring Green Ash Regeneration from seed in declining hardwood draws. Unpublished.

Lewis, S. E. 1994. Night roosting ecology of pallid bats (ANTROZOUS PALLIDUS) in Oregon. Am. Midl. Nat. 132:219-226.

Li, H.W. and P.B. Moyle. 1981. Ecological analysis of species introductions into aquatic systems. Transactions of the American Fisheries Society 110:772-782. 


\section{DRAFT WORKING DOCUMENT DO NOT DUPLICATE}

15778 Licht, D. S. and K. D. Sanchez. 1993. Association of black-tailed prairie dog

15779

15780

15781

15782

15783

15784

15785

15786

15787

15788

15789

15790

15791

15792

15793

15794

15795

15796

15797

15798

15799

15800

15801

15802

15803

15804

15805

15806

15807

15808

15809

15810

15811

15812

15813

15814

15815

15816

15817

15818

15819

15820

15821

15822 colonies with cattle point attractants in the northern Great Plains. Great Basin Nat. 53:385-389.

Liebelt, J.E. 1996. Lower Missouri River and Yellowstone River pallid sturgeon study, 1994-1995. Montana Department of Fish, Wildlife \& Parks. Helena.

Linkhart, B. D. and R. T. Reynolds. 1997. Territories of flammulated owls (OTUS FLAMMEOLUS): is occupancy a measure of habitat quality?

Intermountain/foothill grassland 150-154 in J.R. Duncan, D.H. Johnson, and T.H. Nicholls, editors. Biology and conservation of owls in the Northern.

Linkhart, B. D. 1984. Range, activity, and habitat use by nesting flammulated owls in a Colorado ponderosa pine forest. Masters thesis, Colorado State University, Fort Collins, CO.

Lohr, S. C., P. A. Byorth, C. M. Kaya, and W. P. Dwyer. 1996. High temperature tolerances of fluvial Arctic grayling and comparisons with summer water temperatures of the Big Hole River, Montana. Transactions of the American Fisheries Society 125:933-939.

Long, M. H. 1997. Sociological implications of bull trout management in Northwest Montana: illegal harvest and game warden efforts to deter poaching. Intermountain/foothill grassland 71-73 in Mackay, W. C., M. K. Brewin and M. Monita, editors. Friends of the bull trout conference proceedings. Bull Trout Task Force (Alberta), c/o Trout Unlimited Canada, Calgary.

Lowe, C. H. Jr. 1950. The systematic status of the salamander Plethodon hardii with a discussion of problems in Aneides. Copeia 1950: 92-99.

MacRae, P. S. D., and D. A. Jackson. 2000. The influence of smallmouth bass (Micropterus dolomieui) predation and habitat complexity on the structure of littoral zone fish assemblages. Canadian Journal of Fisheries and Aquatic Sciences 58:342-351.

Magee, J.P. and P.A. Byorth. 1995. Competitive interactions of fluvial Arctic grayling and sympatric species in the Big Hole River drainage, Montana.

Submitted to: Fluvial Arctic Grayling Workgroup. Montana Fish, Wildlife, and Parks, Bozeman.

Magee, J. P. and P. A. Byorth. 1994. Competitive interactions of fluvial Arctic grayling (Thymallus arcticus) and brook trout (Salvelinus fontinalis) in the upper Big Hole River, Montana. Submitted to: Fluvial Arctic Grayling Workgroup. Montana Department, of Fish, Wildlife, and Parks, Bozeman. 


\section{DRAFT WORKING DOCUMENT DO NOT DUPLICATE}

15823 Marcuson, P.E. 1977. Overgrazed streambanks depress fishery production in 15824 Rock Creek, Montana. p. 143-156. In: Proc. of the workshop on livestock and 15825 wildlife-fisheries relationships in the Great Basin. Univ. California, Agric. Station, 15826 Sci. Spec. Publ. 3301, Berkeley, CA.

15827

15828

15829

Marks, Jeffrey S.; Marks, Victoria Saab. 1988. Winter habitat use by Columbian

15830

15831

15832

15833

15834

15835

15836

15837 sharp-tailed grouse in western Idaho. Journal of Wildlife Management. 52(4):743746.

Marnell, Leo. NPS, 2004, personal communication.

Marnell, L.F. 1997. Herpetofauna of Glacier National Park. Northwest Naturalist, 78:17-33.

Marnell, L. F. 1985. Bull trout investigations in Glacier National Park, Montana. Intermountain/foothill grassland 33-35 in D. D. MacDonald, editor, Proceedings of the Flathead River Basin bull trout biology and population dynamics modeling information exchange. Fisheries Branch, British Columbia Ministry of Environment, Cranbrook, British Columbia.

Marti, C. 1997. Flammulated owls (OTUS FLAMMEOLUS) breeding in deciduous 15844 15845 15846 15847 forests. Intermountain/foothill grassland 262-266 in J.R. Duncan, D.H. Johnson, and T.H. Nicholls, editors. Biology and conservation of owls in the Northern Hemisphere. USDA Forest Service General Technical Report. Montana. Proc. Mont. Acad. Sci. 39:1-13.

Matthews, W. L. 1980. The meadow jumping mouse in southeastern Montana. Prairie Nat. 12(2): 63-64.

Maxell, B. A., G. Hokit, J. Miller, and K. Werner. 2004 (unpublished). Detection of Batrachochytrium dendrobatidis, the Chytrid fungus associated with global Montana, Missoula, Montana, U.S.A.

Maxell, B., Werner K.J., Hendricks, and P., Flath, D., 2003. Herpetology in Montana. Society for Northwestern Vertebrate Biology

15866

Maxell, B. A., J. K. Werner, P. Hendricks, and D. L. Flath. 2003. Herpetology in Montana: a history, status summary, checklists, dichotomous keys, accounts for native, potentially native, and exotic species, and indexed bibliography. Northwest Fauna 


\section{DRAFT WORKING DOCUMENT DO NOT DUPLICATE}

15867 Maxell, B. A., K. J. Nelson, and S. Browder. 2002. Record clutch size and 15868 observations on breeding and development of the Western Toad (Bufo boreas) in 15869 Montana. Northwestern Naturalist 83:27-30.

15870

15871

15872

15873

15874

15875

15876

15877

15878

15879

15880

15881

15882

15883

15884

15885

15886

15887

15888

15889

15890

15891

15892

15893

15894

15895

15896

15897

15898

15899

15900

15901

15902

15903

15904

15905

15906

Maxell, B. 2002. [Database file of herp. observations from 2001.]

Maxell, Bryce A., 2000, Management of Montana's amphibians: A Review of factors that may present a risk to population viability and accounts on the identification, distribution, taxonomy, habitat use, natural history and the status and conservation of individual species. Contract No. 43-0343-0-0224. September 20,2000

May, B. E., Urie, W., Shepard, B.B., Montana Cooperative Fishery Research Unit. 2003. Range-wide status of Yellowstone Cutthroat Trout (Oncorhynchus clarki bouvieri): 2001.

May, B. E. 1998. Yellowstone cutthroat trout: current status and conservation recommendations with the state of Montana. U.S. Forest Service, Gallatin National Forest, Bozeman, Montana.

May, B. E. 1996. Yellowstone cutthroat trout. Intermountain/foothill grassland 11-34 in D. Duff, editor. Conservation assessment for inland cutthroat trout: distribution, status and habitat management implications. U.S. Forest Service, Northern, Rocky Mountain, Intermountain, and Southwestern Regions.

MBTRT (Montana Bull Trout Restoration Team). 2000. Restoration plan for bull trout in the Clark Fork River basin and Kootenai River basin, Montana. Montana Department of Fish, Wildlife \& Parks, Helena. 116 intermountain/foothill grassland.

McCallum, D. A. 1994a. Flammulated Owl (Otus flammeolus). In The Birds of North America, No. 93, (A. Poole and F. Gill, eds.). Philadelphia: The Academy of Natural Sciences; Washington D.C.: The American Ornithologists' Union. 24 p.

McCallum, D. A. 1994b. Review of technical knowledge: flammulated owls. Intermountain/foothill grassland 14-46 in G. D. Hayward and J. Verner, editors. Flammulated, boreal and great gray owls in the United States: a technical conservation assessment. USFS General Technical Report,

15907 15908 15909 15910 McClelland, B. R., S. S. Frissell, W. C. Fischer, and C. H. Halvorson. 1979. Habitat management for hole-nesting birds in forests of western larch and Douglas-fir. Journal of Forestry 77:480-483.

15912

McIntyre, J.D. and B.E. Rieman. 1995. Westslope Cutthroat Trout IN Conservation Assessment for Inland Cutthroat Trout. General Technical Report RM-256. US Department of Agriculture, Forest Service, Rocky Mountain Forest 


\section{DRAFT WORKING DOCUMENT DO NOT DUPLICATE}

15913 and Range Experiment Station, Fort Collins, Colorado. M.K. Young, tech. Ed.

15914

15915

15916

15917

15918

15919

15920

15921

15922

15923

15924

15925

15926

15927

15928

15929

15930

15931

15932

15933

15934

15935

15936

15937

15938

15939

15940

15941

15942

15943

15944

15945

15946

15947

15948

15949

15950

15951

15952

15953

15954

15955

15956

15957

15958
Intermountain/foothill grassland 1-15.

McIntyre, J.W., and J. F. Barr. 1997. Common Loon (Gavia immer). In The Birds of North America. No. 313. A. Poole, and F.Gills, editors. The Academy of Natural Sciences, Philadelphia, PA, and the American Ornithologists' Union, Washington, DC, U.S.A.

Mclver, J. D, and L. Starr, L. 2001. A literature review on the environmental effects of post fire. Western Journal of Applied Forestry 16: 159-168.

McMahon, T. E. 1999. Status of sauger in Montana. Montana Fish, Wildlife \& Parks report, Helena, MT.

McMahon, T. E., and W. M. Gardner. 2001. Status of sauger in Montana. Intermountain Journal of Sciences 7:1-21

McPhail, J.D. and V.L. Paragamian. 2000. Burbot biology and life history. Intermountain/foothill grassland 11-23 in V. L. Paragamian and D. W. Willis, editors. Burbot: biology, ecology and management. American Fisheries Society, Fisheries Management Section, Publication Number 1, Bethesda.

Mech, L. D. 1989. Wolf population survival in an area of high road density. Am. Midl. Nat. 121:387-389.

Mech, L. D., et al. 1988. Wolf distribution and road density in Minnesota. Wildl. Soc. Bull. 16:85-87.

Meehan, W. R. and T. C. Bjornn. 1991. Salmonid distributions and life histories. Intermountain/foothill grassland 76-78 in Influences of Forest and Rangeland Management on Salmonid Fishes and Their Habitats, W. R. Meehan, Ed. American Fisheries Society Special Publication 19, Bethesda, MD.

Memorandum of Understanding and Conservation Agreement for Westslope Cutthroat Trout (Onchorhynchus clarki lewisi) in Montana. 1999. Montana Fish, Wildlife \& Parks.

Merriam, C. H. 1902. The prairie dog of the Great Plains. Pp. 257-70 in USDA Yearbook Agriculture for 1901, U.S. Government Printing Office, Washington, DC.

Miller, B., R. P. Reading, and S. Forrest. 1996. Prairie Night. Smithsonian Institute Press. Washington D.C. 320 pp.

Miller, B., G. Ceballos, and R. Reading. 1994. The prairie dog and biotic diversity. Conservation Biology 8(3):677-681. 


\section{DRAFT WORKING DOCUMENT DO NOT DUPLICATE}

15959 Miller, J. D. 1978. Observations on the diet of RANA PRETIOSA, RANA 15960 PIPIENS, and BUFO BOREAS from western Montana. Northwestern Sci.

15961 52:243-249.

15962

15963

Mitchell, C.D. 1994. Trumpeter Swan (Cygnus buccinator). In The Birds of North

15964

America, No. 105 (A. Poole and F. Gill, Eds.). Philadelphia: The Academy of

15965

15966

15967

Natural Sciences; Washington, D.C.: The American Ornithologist Union.

15968

Montagne, C., Munn, L.C., Nielsen, G.A., Rogers, J. W., Hunter, H. E. 1982.

Soils of Montana (including 1:1,000,000 General Soils Map). Bulletin 744.

15969

Montana Agricultural Experiment Station and U.S. Department of Agriculture, Soil

15970

15971

15972

15973

15974

15975

Conservation Service, Bozeman, MT.

15976

15977

15978

15979

15980

15981

15982

15983

15984

15985

15986

15987

15988

15989

15990

Montana Bald Eagle Working Group. 1994. Montana Bald Eagle management plan. 2nd edition. Bureau of Reclamation. 104 pp.

Montana Bald Eagle Working Group. 1991. Habitat management guide for bald eagles in northwestern Montana. 29pp.

Montana Bird Distribution Online Database. 2003. Helena, Montana, USA. AprilSeptember 2003. http://nhp.nris.state.mt.us/mbd/.

Montana Bird Distribution: An Online Database [web application]. 2002. Helena, Montana USA: Montana The Audubon Society Society. Available at http://nhp.nris.state.mt.us/mbd/. (Accessed October 7, 2002)

Montana Bird Distribution Online Database. 2001. Helena, Montana, USA. AprilSeptember 2003. http://nhp.nris.state.mt.us/mbd/.

15991

15992

15993

Montana Bird Distribution Committee. 1996. Skaar's Montana Bird Distribution, Fifth Edition. Special Publication No. 3. Montana Natural Heritage Program, Helena. $130 \mathrm{pp}$.

Montana Department of Fish, Wildlife \& Parks. 1991. Statewide Habitat Plan. Implementation of Fish, Wildlife \& Parks Commission Habitat Montana Policy. 44 15994 pp.

15995

15996

15997

15998

15999

16000

16001

16002

16003

Montana Department of Fish, Wildlife \& Parks. 2004. Memorandum of Understanding and Conservation Agreement for Sauger (Sander canadensis) in Montana. 23 pg. Draft-In progress.

Montana Fish, Wildlife \& Parks. 2003. Montana Gray Wolf Conservation and Management Plan.

16004

Montana Department of Fish, Wildlife \& Parks. 2003. Online information search on Least Tern in Montana. 


\section{DRAFT WORKING DOCUMENT DO NOT DUPLICATE}

16005 http//www.fwp.state.mt.us/wildthings/t\&e/threatened.asp (Accessed: May 19, 16006 2003)

16007

16008

16009

16010

16011

16012

16013

16014

16015

16016

16017

16018

16019

16020

16021

16022

16023

16024

16025

16026

16027

16028

16029

16030

16031

16032

16033

16034

16035

16036

16037

16038

16039

16040

16041

16042

16043

16044

16045

16046

16047

16048

16049

16050
Montana Department of Fish, Wildlife, and Parks. 2003. Online informational search on Piping Plovers in Montana.

http://www.fwp.state.mt.us/wildthings/t\&e/threatened.asp.

Montana Fish, Wildlife \& Parks. 2002. Grizzly Bear Management Plan for Southwestern Montana 2002-2012.

Montana Fish, Wildlife \& Parks. 2001. Conservation Plan for Grizzly Bear in Montana. Pursuant to Section 6(C )(1) of the endangered species act and Montana Fish, Wildlife \& Parks Endangered Wildlife Program E-6. Montana Department of Fish, Wildlife \& Parks. 1420 East Sixth Avenue P.O. Box 200701 Helena, MT 59620

Montana Department of Fish, Wildlife \& Parks. 1999. Memorandum of Understanding and Conservation Agreement for Westslope Cutthroat Trout (Oncorhynchus clarki lewisi) in Montana. Helena, Montana.

Montana Fish, Wildlife \& Parks. 1992. North Central Montana Black-footed ferret reintroduction and management plan. Prepared by North Central Montana Working Group. 59 pp.

Montana Fluvial Arctic Grayling Workgroup. 1995. Montana Fluvial Arctic Grayling Restoration Plan. Montana Department of Fish, Wildlife, and Parks, Helena.

Montana Natural Heritage Program Online database. (Accessed April 26, 2004; $<$ <ttp://nhp.nris.state.mt.us/animalguide>).

Montana Natural Heritage Program. Montana field guide. Northern leopard frog. Online database. (Accessed November 19, 2003;

<http://fwp.state.mt.us/fieldguide>).

Montana Natural Heritage Program (MTNHP): Biological and Conservation Database. 2002. Helena, MT (Accessed: October 7, 2002)

Montana Natural Heritage Program. 1987. Status report on the Coeur d'Alene salamander (Plethodon idahoensis) in Montana. Unpublished mimeo. USDA Forest Service Kootenai National Forest and Lolo Forest, Libby, Montana, U.S.A.

Montana Online Animal Field Guide. 2004. (Accessed May 27, 2004; $<$ http://www.fwp.state.mt.us/fieldguide/help.aspx\#overview>). Montana Heritage Program and Montana Department of Fish, Wildlife \& Parks. Helena, Montana. 
16051 Montana Online Animal Field Guide. 2004. Montana Heritage Program and 16052 16053 16054 16055 16056 16057 16058 16059 16060 16061 16062 16063 16064 16065 16066 16067 16068 16069 16070 16071 16072 16073 16074 16075 16076 16077 16078 16079 16080 16081 16082 16083 16084 16085 16086 16087 16088 16089 16090 16091 16092 16093 16094 Montana Department of Fish, Wildlife \& Parks, Helena, Montana, USA (Accessed May 18, 2004: <http://www.fwp.state.mt.us/fieldguide/help.aspx\#overview>).

Montana Partners for Fish \& Wildlife. 2000. Big Hole River Watershed. 4 pgs. More information at http://www.r6.fws/gpv/pfw/montana/mt3c.htm

Montana Partners in Flight Online Database. (Accessed April 26, 2004; $<$ http://biology.dbs.umt.edu/landbird/mbcp/mtpif>).

Montana Piping Plover Recovery Committee. 1995. 1994 Surveys for Piping Plover (CHARADRIUS MELODUS) and Least Tern (STERNA ANTILLARUM) in Montana. 117 pp. plus appendices.

Montana Piping Plover Recovery Committee. 1994. 1993 Surveys for Piping Plover (CHARADRIUS MELODUS) and Least Tern (STERNA ANTILLARUM) in Montana. Unpublished report. 116 pp. plus appendices.

Montana Piping Plover Working Group. 2003. Montana Piping Plover Management Plan. Unpublished Report. 35 pp.

Montana Sage-grouse Work Group. 2004. Management plan and conservation strategies for sage-grouse in Montana.

Montana-North Dakota Paddlefish Management Plan. 1995. A cooperative venture between: North Dakota Game \& Fish Department, Montana Department of Fish, Wildlife \& Parks \& University of Idaho. 45 pgs.

Mosimann, J. E. and G. B. Rabb. 1952. The herpetology of Tiber Reservoir Area, Montana. Copeia 1952: 23-27.

Moss and Campbell 1947

Moss, R. E., J. W. Scanlan, and C. S. Anderson. 1983. Observations on the natural history of the blue sucker (Cycleptus elongatus LeSueur) in the Neosho River. The American Midland Naturalist 109(1): 15-22.

Mueggler, W.F., and W. L. Stewart. 1980. Grassland and Shrubland Habitat Types of Wester Montana. USDA.

Muhlfeld, C.C., D.H. Bennett, and B. Marotz. 2001-In press. Summer habitat use by redband trout in the Kootenai River drainage, Montana. North American Journal of Fisheries Management (February). 


\section{DRAFT WORKING DOCUMENT DO NOT DUPLICATE}

16095 Muhlfeld, C.C. 1999. Seasonal habitat use by redband trout (Oncorhynchus 16096 mykiss gairdneri) in the Kootenai River drainage, Montana. Master's thesis. 16097 University of Idaho, Moscow, Idaho.

16098

16099

Murray, B.G., Jr. 1969. A comparative study of Le Conte's and Sharp-tailed 16100

16101

16102

16103

16104

16105

16106

16107

16108

16109

16110

16111

16112

16113

16114

16115

16116

16117

16118

16119

16120

16121

16122

16123

16124

16125

16126

16127

16128

16129

16130

16131

16132

16133

16134

16135

16136

16137

16138 sparrows. Auk 86:199-231.

Mussehl, T., P. Schladweiler, and R. Weckwerth. 1971. Forest grouse. Intermountain/foothill grassland 143-151 in T. W. Mussehl and F. W. Howell, eds. Game management in Montana. Montana Fish and Game Dept., Game Manage. Div., Helena, MT.

Nagorsen, D. and R. M. Bringham. 1993. Bats of British Columbia. University of British Columbia Press, Vancouver, B. C. 164 pp.

National Academy of Sciences. 1998. Brucellosis in the Greater Yellowstone Area, by N.F. Cheville, D. R. McCullough, and L.R. Paulson. Washington, DC: National Academy Press.

NatureServe Explorer. (Accessed June 5, 2004;

http://www.natureserve.org/explorer/>). Montana Animal Field Guide. (Accessed June 5, 2004,<http://nhp.nris.state.mt.us/animalguide/>).

NatureServe. 2004. NatureServe explorer. An online encyclopedia of life. Version 3.0. (Accessed April 22, 2004: http://www.natureserve.org/explorer)

Nelson, J. S., and M. J. Paetz. 1992. The fishes of Alberta, second edition. The University of Alberta Press, Edmonton, and The University of Calgary Press.

Nelson, R. L., M. L. McHenry, and W. S. Platts. 1991. Mining.

Intermountain/foothill grassland 425-458 in W. R. Meehan, editor. Influences of forest and rangeland management on salmonid fishes and their habitats. American Fisheries Society Special Publication 19, Bethesda, Maryland.

Nelson, W. R., and C. H. Walburg. 1977. Population dynamics of yellow perch (Perca flavescens), sauger (Stizostedion candense), and walleye (S. vitreum vitreum) in four primarystem Missouri River reservoirs. Journal of the Fisheries Research Board of Canada 34:1748-1763.

Nelson, W. R. 1968. Reproduction and early life history of sauger, Stizostedion canadense, in Lewis and Clark Lake. Transactions of the American Fisheries Society 97:159-166.

16139

Nesser, J. A., Ford, G. L., Maynard, C. L., Page-Dumroese, D. S. 1997. Ecological Units of the Northern Region Subsection. General Technical Report 


\section{DRAFT WORKING DOCUMENT DO NOT DUPLICATE}

16140 INT-GTR-369. Ogden, UT: U.S. Department of Agriculture, Forest Service,

16141

16142

16143

16144

16145

16146

16147

16148

16149

16150

16151

16152

16153

16154

16155

16156

16157

16158

16159

16160

16161

16162

16163

16164

16165

16166

16167

16168

16169

16170

16171

16172

16173

16174

16175

16176

16177

16178

16179

16180

16181

16182

16183

16184

Intermountain Research Station. 88 p.

Nicholson, A. J. 1950. A record of the spotted bat (EUDERMA MACULATUM) for Montana. J. of Mammalogy 31:197.

North American Waterfowl Management Plan. 1998. Expanding the VisionUpdate. $32 \mathrm{pp}$.

Northcote, T. G. 1973. Some impacts of man on Kootenay Lake and its salmonids. Great Lakes Fisheries Commission Tech. Rep. 25

Northern Prairie Wildlife Research Center: Biological Resources - Eastern Bluebird. United States Geological Survey: http://www.npwrc.usgs.gov. (Last updated February 21, 2003).

Novinger, D.C. and F.J. Rahel. 1999. Exploring Competitive Mechanisms that Allow Nonnative Brook Trout to Displace Native Cutthroat Trout in a Rocky Mountain Stream. American Fisheries Society 129th Annual Meeting Abstracts. Charlotte, North Carolina.

Nussbaum, R. A., E. D. Brodie, Jr. and R. M. Storm. 1983. Amphibians and reptiles of the Pacific Northwest. Univ. Press of Idaho. 332 pp.

Olsen, David L. 1980. Whooping Crane Recovery Plan. Whooping Crane Recovery Team (USFWS, Nebraska Game and Parks Commission, Texas Parks \& Wildlife Department, National The Audubon Society Society). 206 pp.

Olson, S. L. 1985. Mountain plover food items on and adjacent to a prairie dog town. Prairie Naturalist 17(2):83-90.

Olson, S. L. and D. Edge. 1985. Nest site selection by mountain plovers in northcentral Montana. Journal of Range Management 38(3):280-282.

Olson-Edge, S. L. and W. D. Edge. 1987. Density and distribution of the mountain plover on the Charles M. Russell National Wildlife Refuge. The Prairie Naturalist. 19(4):233-238.

Orth, P. B., and P. L. Kennedy. 2001. Do land-use patterns influence nest-site selection by burrowing owls (Athene cuncularia hypugaea) in northeastern Colorado. Canadian Journal of Zoology 79:1038-1045.

Osborn, B. 1942. Prairie dogs in shinnery (oak scrub) savannah. Ecology 23:1105. 


\section{DRAFT WORKING DOCUMENT DO NOT DUPLICATE}

16185 Ostlie, W.R, R. E. Schneider, J. M. Aldrich, T. M. Faust, R. L. B. McKim and S. J.

16186

16187

16188

16189

16190

16191

16192

16193

16194

16195

16196

16197

16198

16199

16200

16201

16202

16203

16204

16205

16206

16207

16208

16209

16210

16211

16212

16213

16214

16215

16216

16217

16218

16219

16220

16221

16222

16223

16224

16225

16226

16227

16228

16229
Chaplin. 1997. The status of biodiversity in the Great Plains. The Nature

Conservancy, Arlington, VA, USA. 326 pp + XII.

Pacific Flyway Council and USFWS. 2003. Pacific Flyway Implementation Plan for the Rocky Mountain Population of Trumpeter Swans 2003 Annual Report. 29 pp.

Paige, L.C. 2000. America's Wildlife: The Challenge Ahead. International Association of Fish and Wildlife Agencies. Washington, D.C.

Paragamian, V. L. 2000. The effects of varying flows on burbot spawning migrations in the Kootenai River, Idaho and British Columbia, Canada, after construction of the Libby Dam. Intermountain/foothill grassland 111-123 in V. L. Paragamian and D. W. Willis, editors. Burbot: biology, ecology and management. American Fisheries Society, Fisheries Management Section, Publication Number 1, Bethesda.

Parkinson, E. A. 1984. Genetic variation in populations of steelhead trout (Salmo gairdneri) in British Columbia. Can. J. Fish. Aquat. Sci. 41:1412-1420.

Partners in Amphibian and Reptile Conservation. 1999. Conference, Conserving Amphibians and Reptiles in the New Millennium, 2-4 June 1999; Atlanta, Georgia. (Accessed May 20, 2004; <http://www.parcplace.org>).

Pattie, D. L. and R.S. Hoffmann. 1992. Mammals of the North American Parks and Prairies. Self published.

Paulson, D. D. 1988. CHAETODIPUS HISPIDUS. Am. Soc. Mamm., Mammalian Species 320:1-4.

Pavelka, Greg. 2003. Threatened and Endangered Species Specialist. U.S. Army Corps of Engineers, Operations Division, Omaha District, Gavings Pt. Project Office. Personal communication regarding recent river censuses of Least Terns in Montana. 12 August 2003.

Payne, B.S., A.C. Miller and R. Whiting. 1997. Designing a riverine mussel survey. Intermountain/foothill grassland 150-156 in K.S. Cummings, A.C. Buchanan, C.A. Mayer and T.J. Naimo, eds. Conservation and management of freshwater mussels II: initiatives for the future. Proceedings of a UMRCC symposium, 16-18 October 1995, St. Louis, Missouri. Upper Mississippi River Conservation Committee, Rock Island, Illinois.

Pearson, Dean E. 1999. Small mammals of the Bitterroot National Forest: A literature review and annotated bibliography. Gen. Tech. Rep. RRS-GTR-25. 


\section{DRAFT WORKING DOCUMENT DO NOT DUPLICATE}

16230 Ogden, UT: U.S. Department of Agriculture, Forest Service, Rocky Mountain

16231 Research Station. 63. Pg.

16232

16233

16234

16235

16236

16237

16238

16239

16240

16241

16242

16243

16244

16245

16246

16247

16248

16249

16250

16251

16252

16253

16254

16255

16256

16257

16258

16259

16260

16261

16262

16263

16264

16265

16266

16267

16268

16269

16270

16271

16272

Pefaur, J. E. and R. S. Hoffman. 1971. Merriam's shrew and hispid pocket mouse in Montana. American Midland Naturalist 86:247-248.

Pegg, M. A., P. W. Bettoli, and J. B. Layzer. 1997. Movement of saugers in the lower Tennessee River determined by radio telemetry, and implications for management. North American Journal of Fisheries Management 17:763-768.

Penkal, R. F. 1992. Assessment and requirements of sauger and walleye populations in the Lower Yellowstone River and its tributaries. Montana Department of Fish, Wildlife \& Parks report, Helena, MT.

Perkinson, R.D. 1993. Presentation to the American Fisheries Society, Montana Chapter, 17 February 1993.

Perry, T. W., P. M. Cryan, S. R. Davenport, and M. A. Bogan. 1997. New locality for Euderma maculatum (Chiroptera: Vespertilionidae) in New Mexico.

Southwestern Naturalist 42:99-101.

Petranka, J. W., Eldridge, M. E. and K. E. Haley. 1993. Effects of timber harvesting on southern Appalachian salamanders. Conservation Biology 7: 363370.

Pfister. R.D., B.L. Kovalchik, S. F. Arno, and R. C. Presby. 1977. Forest Habitat types of Montana. USDA Forest Service.

Pflieger, W. 1975. The fishes of Missouri. Missouri Department of Conservation. Jefferson City, Missouri.

Pflieger, W. L. 1997. The fishes of Missouri. Missouri Department of Conservation, Jefferson City.

Pierson, E.D., M.C. Wackenhut, J.S. Altenbach, P. Bradley, P. Call, D.L. Genter, C. E. Harris, B. L. Keller, B. Lengus, L. Lewis, B. Luce, K. W. Navo, J. M.

Perkins, S. Smith, and L. Welch. 1999. Species conservation assessment and strategy for Townsend's big-eared bat (Corynorhinus townsendii townsendii and Coynorhinus townsendii pallescens). Idaho Conservation Effort, Idaho Department of Fish and Game, Boise, Idaho.

Pierson, E. D., and W. E. Rainey. 1998. Distribution of the spotted bat, EUDERMA MACULATUM, in California. Journal of Mammalogy 79:1296-1305.

16273 


\section{DRAFT WORKING DOCUMENT DO NOT DUPLICATE}

16274 Platts, W.S. 1991. Livestock grazing. p. 389-424. In: W.R. Meehan (ed.), 16275 Influences of forest and rangeland management on salmonid fishes and their

16276 16277

16278 16279 16280 16281 16282 16283 16284 16285 16286 16287 16288 16289 16290 16291 16292 16293 16294 16295 16296 16297 16298 16299 16300 16301 16302 16303 16304 16305 16306 16307 16308 16309 16310 16311 16312 16313 16314 16315 16316 16317 16318 habitats. Amer. Fisheries Soc. Sp. Publ 19:389-423.

Platts, W.S. 1989. Compatibility of livestock grazing strategies with fisheries. p. 103-110. In: R.E. Gresswell, B.A. Barton, J.L. Kershner (eds.), Practical approaches to riparian resource management. U.S. Bureau of Land Management, P.O. Box 36800, Billings, Montana.

Platts, W.S. 1981b. Influence of forest and rangeland management on anadromous fish habitat in western North America: 7. Effects of livestock grazing. USDA Forest Serv. Gen. Tech. Rep. PNW-124.

Priday, J., and B. Luce. 1997. Inventory of bats and bat habitat associated with caves and mines in Wyoming: completion report. Pp. 50-109 in Endangered and nongame bird and mammal investigations annual completion report. Nongame Program, Biological Science.

Rabe, M. J., M. S. Siders, C. R. Miller, and T. K. Snow. 1998. Long foraging distance for a Spotted Bat (Euderma maculatum) in northern Arizona.

Southwestern Naturalist 43:266-269.

Rahel, F. J. 2002. Homogenization of freshwater faunas. Annual Review of Ecology and Systematics 33:291-315.

Rahel, F. J. 2000. Homogenization of fish faunas across the United States. Science 288:854-856.

Rahel, F. J. 1990. The hierarchical nature of community persistence: a problem of scale. American Naturalist 136:328-334.

Ratliff, D. E. 1992. Bull trout investigations in the Metolius River-Lake Billy Chinook system. Intermountain/foothill grassland 37-44 in P. J. Howell and D. V. Buchanan, editors. Proceedings of the Gearhart Mountain bull trout workshop. Oregon Chapter of the American Fisheries Society, Corvallis.

Ratliff, D. E. and P. J. Howell. 1992. The status of bull trout populations in Oregon. Intermountain/foothill grassland 10-17 in P. J. Howell and D. V. Buchanan, editors. Proceedings of the Gearhart Mountain bull trout workshop. Oregon Chapter of the American Fisheries Society, Corvallis.

Rauscher, Ryan. 1997. Status and distribution of the pygmy rabbit in Montana. Montana Department of Fish, Wildlife \& Parks, nongame program. Unpublished report, 19 pp plus appendices. 


\section{DRAFT WORKING DOCUMENT DO NOT DUPLICATE}

16319 Rawson, M. R., and R. L. Scholl. 1978. Reestablishment of sauger in western 16320 Lake Erie. Intermountain/foothill grassland 261-265 in R. L. Kendall, editor, 16321 Selected cool water fishes of North America. American Fisheries Society Special 16322 Publication 11. Bethesda, Maryland.

16323

Redmond, R. L., M. M. Hart, J. C. Winne, W. A. Williams, P. C. Thornton, Z. Ma, 16325 16326 16327

16328 16329 C. M. Tobalske, M. M. Thornton, K. P. McLaughlin, T. P. Tady, F. B. Fisher, and S. W. Running. 1998. The Montana Gap Analysis Project: Final Report. Unpublished report. Montana Cooperative Wildlife Research Unit, University of Montana, Missoula, Montana, USA.

Redmond, R. L., and D. A. Jenni. 1986. Population ecology of the long-billed curlew (Numernius americanus) in western Idaho. Auk 103: 755-767.

Reed, J. M. 1995. Relative vulnerability to extirpation of montane breeding birds in the Great Basin. Great Basin Naturalist 55:342-351.

Rehwinkle, B. 1978. Powder River aquatic ecology project. Report to Utah International, Inc. Salt Lake City.

Reichel, J. D. and J. G. Corn. 1997. Northern bog lemmings: survey, population parameters, and population analysis. Unpublished report to the Kootenai National Forest. Montana Natural Heritage Program, Helena, MT. 27 pp.

Reichel, J. D. 1995. Montana Species of Special Concern. Montana Natural Heritage Program, Helena, Montana. 10 pp.

Reichel, J. D. and D. Flath. 1995. Identification of Montana's amphibians and reptiles. Mont. Outdoors 26: 15-34.

Reichel, James D., 1995, Preliminary amphibian and reptile survey of the Lewis and Clark National Forest: 1994. March 1995.

Reichel, J. D. and D. L. Genter. 1995. Harlequin duck surveys in western 16354 16355 16356 16357

Reichel, J. D. and S. G. Beckstrom. 1994. Northern bog lemming survey: 1993. Unpublished report. Montana Natural Heritage Program. Helena, MT. 87 pp.

Reynolds, R. T. and B. D. Linkhart. 1992. Flammulated owls in Ponderosa pine: evidence of preference for old growth. IN: Kaufmann, M. R., W. H. Moir, and R. L. Bassett (tech. coord.), Old-growth forests in the Southwest and Rocky Mountain regions. USDA For. Serv. Gen. Tech. Rep. RM-213. 201 pp.

Reynolds, R. T., R. A. Ryder, and B. D. Linkhart. 1989. Small forest owls. Intermountain/foothill grassland 131-143 in National Wildlife Federation. 


\section{DRAFT WORKING DOCUMENT DO NOT DUPLICATE}

16365 Proceedings of the western raptor management symposium and workshop.

16366

16367

16368

16369

16370

16371

16372

16373

16374

16375

16376

16377

16378

16379

16380

16381

16382

16383

16384

16385

16386

16387

16388

16389

16390

16391

16392

16393

16394

16395

16396

16397

16398

16399

16400

16401

16402

16403

16404

16405

16406

16407

16408

16409

16410
National Wildlife Federation Scientific and Technical Series No.

Reynolds, R. T. and B. D. Linkhart. 1987. The nesting biology of flammulated owls in Colorado. Pp. 239-248 in: Nero, R.W., et al., (eds). Biology and conservation of northern forest owls. USDA For. Serv., Gen. Tech. Rep. RM-142.

Rich, T.D., C.J. Beardmore, H. Berlanga, P.J. Blancher, M. S. W. Bradstreet, G. S. Butcher, D.W. Demarest, E. H. Dunn, W. C. Hunter, E. E. Inigo-Elias, J. A. Kennedy, A. M. Martell, A. O. Panjabi, D. N. Pashley, K. V. Rosenberg, C. M. Rustay, J. S. Wendt, T. C. Will. 2004. Partners in Flight North American Landbird Conservation Plan. Cornell Lab of Ornithology. Ithaca, NY.

Richardson, L. 1986. On the track of the last black-footed ferrets. Nat. Hist. 95(2): 69-77.

Riehle, M., W. Weber, A. M. Stuart, S. L. Thiesfeld and D. E. Ratliff. 1997. Progress report of the multi-agency study of bull trout in the Metolius River system, Oregon. Intermountain/foothill grassland 137-144 in Mackay, W. C., M. $\mathrm{K}$. Brewin and M. Monita, editors. Friends of the bull trout conference proceedings. Bull Trout Task Force (Alberta), c/o Trout Unlimited Canada, Calgary.

Rieman, B. E. and J. D. Mclntyre. 1993. Demographic and habitat requirements for conservation of bull trout. USDA Forest Service, General Technical Report INT-302. 40 intermountain/foothill grassland.

Roberts, Hadley B. 2001. Survey of pygmy rabbit distribution, numbers and habitat use in Lemhi and Custer counties, Idaho. Technical Bulletin No. 01-11. Idaho Bureau of Land Management.

Rodgers, T. L., and W. L. Jellison. 1942. A collection of amphibians and reptiles from western Montana. Copeia 1942:10-13.

Rolfe, E.S. 1899. Nesting of Nelson's Sparrow (AMMODRAMUS NELSONI) in North Dakota. Auk 16:356-357.

Ross, R. L., Hunter, H. E. 1976. Climax vegetation of Montana based on soils and climate (includes 1:1,000,000 map). U.S. Department of Agriculture, Soil Conservation Service, Bozeman, MT.

Ross, C. P., Andrews, D. A., Witkind, I. J. 1955. Geologic Map of Montana, 1:500,000, U. S. Geological Survey.

Ruediger, Bill \& 14 others on Lynx Biology Team. 2000. Canada Lynx Conservation Assessment and Strategy. 120 pp. 


\section{DRAFT WORKING DOCUMENT DO NOT DUPLICATE}

16411

16412

16413

16414

16415

16416

16417

16418

16419

16420

16421

16422

16423

16424

16425

16426

16427

16428

16429

16430

16431

16432

16433

16434

16435

16436

16437

16438

16439

16440

16441

16442

16443

16444

16445

16446

16447

16448

16449

16450

16451

16452

16453

16454

16455

16456
Ruelle, R., and K. D. Keenlyne. 1991. A contaminant evaluation of Missouri River pallid sturgeon. U.S. Fish and Wildlife Service. Pierre, South Dakota. 25 pp.

Ruggles, M.P. 1997. Sections 2 \& 3: Upper Inter-Reservoir I and Lower Yellowstone River, Montana. In D.J. Dieterman, M.P. Ruggles, M.L. Wildhaber, and D.L. Galat, editors. Population structure and habitat use of benthic fishes along the Missouri and Lower Yellowstone Rivers. 1997 Annual Report of Missouri River Benthic Fish Study PD-95-5832 to U.S. Army Corps of Engineers and U.S. Bureau of Reclamation.

Russell, A. P., and A. M. Bauer. 1993. The amphibians and reptiles of Alberta. University of Calgary Press, Calgary, Alberta, and University of Alberta Press, Edmonton, Alberta. 264 pp.

Saab, V.A. and J.S. Marks. 1992. Summer habitat use by Columbian sharp-tailed grouse in western Idaho. Great Basin Naturalist. 52: 166-173.

Schmetterling, D. A. and M. H. Long. 1999. Montana anglers' inability to identify bull trout and other salmonids. Fisheries 24:24-27.

Schroeder, Michael A., Cameron L. Aldridge, Anthony D. Apa, Joseph R. Bohne, Clait E. Braun, S. Dwight Bunnell, John W. Connelly, Pat A. Deibert, Scott C. Gardner, Mark A. Hilliard, Gerald D. Kobriger, Susan M. McAdam, Clinton W. McCarthy, John J. McCarthy, Dean L. Mitchell, Eric V. Rickerson, and San J. Stiver. 2004. Distribution of Sage-grouse in North America. Condor 106: 363376.

Schulenberg, J. and M. Ptacek. 1984. Status of the interior least tern in Kansas. Am. Birds 38:975-981.

Schultz, L. P. 1941. Fishes of Glacier National Park Montana. U. S.

Department of the Interior Conservation Bulletin, Number 22, Washington, D. C.

Schulz, T.T., and W.C. Leininger. 1990. Differences in riparian vegetation structure between grazed areas and exclosures. J. Range Manage. 43:295-299.

Scott W. B., and E. J. Crossman. 1973. Freshwater Fishes of Canada. Fisheries Research Board of Canada Bulletin 184.

Seabloom, R. W. 2002. Additional records of the Hispid Pocket Mouse in North Dakota. Prairie Naturalist 34:61-62.

Sergio, I., and I. Newton 2003. Occupancy as a measure of territory quality. Journal of Animal Ecology 72: 857-865. 


\section{DRAFT WORKING DOCUMENT DO NOT DUPLICATE}

16457

16458

16459

16460

16461

16462

16463

16464

16465

16466

16467

16468

16469

16470

16471

16472

16473

16474

16475

16476

16477

16478

16479

16480

16481

16482

16483

16484

16485

16486

16487

16488

16489

16490

16491

16492

16493

16494

16495

16496

16497

16498

16499

16500

16501
Servheen, C. 1983. Grizzly bear food habits, movements and habitat selection in the Mission Mountains, Montana. J. Wildl. Manage. 47:1026-1035.

Shaw, J. A. and T. S. Carter. 1990. Bison movements in relation to fire and seasonality. Wildl. Soc. Bull. 18:426-430.

Shepard, Brad B., May, B.E, Urie, W. 2003. Status of Westslope Cutthroat Trout (Onchorhyncus clarki lewisi) in the United States 2002. Westslope Cutthroat Conservation Team.

Shepard, B. B., and R. A. Oswald. 1989. Timing, location, and population characteristics of spawning Montana Arctic grayling (Thymallus arcticus montanus [Milner]) in the Big Hole River drainage, 1988. Montana Department of Fish, Wildlife, and Parks, Bozeman.

Shepard, B.B., K.L. Pratt, and P.J. Graham. 1984. Life Histories of Westslope Cutthroat Trout and Bull Trout in the upper Flathead River Basin, Montana. Montana Department of Fish, Wildlife \& Parks, Helena, Montana.

Shryer, J. S. and D. S. Flath. 1980. First record of the pallid bat (ANTROZOUS PALLIDUS) from Montana. Great Basin Nat. 40(2): 115.

Skaar, D. 1989. Distribution, relative abundance, and habitat utilization of Arctic grayling (Thymallus arcticus) in the upper Big Hole River drainage, Montana, July 5 to September 8, 1988. Report to: Montana Natural Heritage Program, Beaverhead National Forest, and Montana Department. of Fish, Wildlife, and Parks, Bozeman.

Skaar, D. 1990. Montana common loon management plan. Unpublished report prepared for U.S. Forest Service, Region 1. 61 pp.

Skaar, P. D. 1969. Birds of the Bozeman lat-long. P. D. Skaar, Pub., Bozeman, MT. 132 pp.

Slater, J. R. and J. W. Slipp. 1940. A new species of Plethodon from northern Idaho. Occasional Papers of Smith, D. S. 1984. Habitat use, home range, and movements of bobcats in western Montana. M.S. thesis. University of Montana, Missoula. $58 \mathrm{pp}$.

Snow, C. 1974. Habitat management series for endangered species Report No. 4. Spotted bat (EUDERMA MACULATUM). USDI BLM Tech. Note TN 170.

Snyder, Bob \& Oswald, Richard. 2004. Status of Native Lake Trout in Montana. Montana Fish, Wildlife \& Parks. Helena, MT. Draft--in progress. 


\section{DRAFT WORKING DOCUMENT DO NOT DUPLICATE}

16502 Spahr, R., L. Armstrong, D. Atwood, and M. Rath. 1991. Threatened, 16503 endangered, and sensitive species of the Intermountain Region. U.S. Forest 16504 Service, Ogden, Utah, U.S.A.

16505

16506

Spruell, P., B. E. Rieman, K. L. Knudsen, F. M. Utter and F. W. Allendorf. 1999. 16507 Genetic population structure within streams: microsatellite analysis of bull trout 16508 16509 16510 16511 16512 16513 16514 16515 16516 populations. Ecol. Freshwater Fish. 8:114-121.

Stagliano, D.M. 2005. Aquatic Ecotype Diversity in Montana's Missouri River Drainages: A Community Classification Project. Montana Natural Heritage Program: A report to the BLM and The Nature Conservancy. 98pp.

Stagliano, D. 2004. Systematic Survey Plan for the Freshwater Mussels in Montana. Montana Natural Heritage Program, Helena MT. 10 pgs.

Stash, S.W. 2001. Distribution, relative abundance, and habitat association of Milk River fishes related to irrigation diversion dams. Master's thesis. Montana State University, Bozeman.

16522

16523

16524

16525

16526

16527

16528

16529

16530

16531

16532

16533

16534

16535

16536

Statewide Habitat Plan. 1994. Implementation of Fish, Wildlife \& Parks

Commission. Habitat Montana Policy.

Stebbins, R. C. 2003. A Field guide to western reptiles and amphibians. Third edition. Houghton Mifflin Company, Boston, Massachusetts. 533 pp.

Stebbins, R. C. 1985. Peterson Field Guides: Western Reptiles and Amphibians. Houghton Mifflin Company, Boston, Massachusetts, U.S.A.

Stewart, D. 1981. The biology of the sturgeon chub (Hybopsis gelida Girard) in Wyoming. Masters Thesis. University of Wyoming. Laramie.

Stewart, R. E. 1975. Breeding birds of North Dakota. Tri-College Cent. for Env. Stud., Fargo. 295 pp.

Stohlgren, T. J. 1998. Rocky Mountains. Pp. 473-504 in M. J. Mac, P. A. Opler, 16538 16539 16540 16541 16542 16543 16544 16545 C. E. Puckett Haecker, and P. D. Doran. Status and Trends of the Nation's Biological Resources. USDI U.S. Geological Survey, Washington, D.C.

Storz, J. 1995. Local distribution and foraging behavior of the Spotted bat (EUDERMA MACULATUM) in northwestern Colorado and adjacent Utah. Great Basin Naturalist 55(1):78-83.

Street, R. 1999. Histrionicus histrionicus. Animal Diversity Web. (Accessed May 13, 2004;

$16546<$ http://animaldiversity.ummz.umich.edu/accounts/information/Histrionicus

16547 histrionicus.html>). 


\section{DRAFT WORKING DOCUMENT DO NOT DUPLICATE}

16548

16549

16550

16551

16552

16553

16554

16555

16556

16557

16558

16559

16560

16561

16562

16563

16564

16565

16566

16567

16568

16569

16570

16571

16572

16573

16574

16575

16576

16577

16578

16579

16580

16581

16582

16583

16584

16585

16586

16587

16588

16589

16590

16591

16592

16593
Subcommittee on the Interior Population of Trumpeter Swans. 1997. Mississippi and Central flyway management plan for the Interior population of Trumpeter Swan. Mississippi and Central Flyway Councils. [C/o USFWS, Migratory Bird Coordinator] Twin Cities, MN

Swanberg, T. R. 1996. The movement and habitat use of fluvial bull trout in the upper Clark Fork River drainage. Master's Thesis, University of Montana, 61 intermountain/foothill grassland.

Swenson, J. E. and G. F. Shanks, Jr. 1979. Noteworthy records of bats from northeastern Montana. J. Mammal. 60:650-652.

Taylor, A. R., and R. L. Knight. 2003. Wildlife responses to recreation and associated visitor perceptions. Ecological Applications 13: 951-963.

Taylor, E. B., S. Pollard, and D. Louie. 1999. Mitochondrial DNA variation in bull trout (Salvelinus confluentus) from northwestern North America: implications for zoogeography and conservation. Mol. Ecol. 8:1155-1170.

Teberg, E. K. 1965. Range extensions of the salamander Plethedon vandykei idahoensis. Copeia 1965:244.

Teberg, E. K. 1963. An extension into Montana of the known range of the salamander Plethodon vandykei idahoensis. Herpetologica 19:287.

Tennant, Donald. Instream Flow Regimes for Fish, Wildlife, Recreation, and Related Environmental Resources (Billings, Mont.: U.S. Fish and Wildlife Service, 1975).

Tews, A., M. Enk, S. Leathe, W. Hill, S. Dalbey, and G. Liknes. 2000. Overview of Status and Restoration Strategies for Westslope Cutthroat Trout (Oncorhynchus clarki lewisi) in Northcentral Montana. Special Report by Montana Fish, Wildlife \& Parks in collaboration with the Lewis and Clark National Forest. Great Falls, Montana.

Tews A. 1993. Pallid sturgeon and shovelnose sturgeon in the Missouri River from Fort Peck Dam to Lake Sacagawea and in the Yellowstone from Intake to its mouth. Report submitted to the U.S. Army Corps of Engineers. Planning Branch. Omaha.

The Nature Conservancy. 2005. Unpublished Report.

The Nature Conservancy. 2004. Canadian Rocky Mountains Ecoregional Assessment. Four volumes, including Report, Appendices, Conservation Area Descriptions \& Maps. 


\section{DRAFT WORKING DOCUMENT DO NOT DUPLICATE}

16594

16595

16596

16597

16598

16599

16600

16601

16602

16603

16604

16605

16606

16607

16608

16609

16610

16611

16612

16613

16614

16615

16616

16617

16618

16619

16620

16621

16622

16623

16624

16625

16626

16627

16628

16629

16630

16631

16632

16633

16634

16635

16636

16637

16638
The Nature Conservancy. 2000. Middle Rockies-Blue Mountains Ecoregional Conservation Plan. Prepared by the Middle Rockies - Blue Mountains Planning Team. 58 pgs + appendices.

The Nature Conservancy. 1999. Ecoregional Conservation in the Northern Great Plains Steppe. Northern Great Plains Steppe Ecoregional Planning Team. 76 pgs.

The North American Management Plan for Trumpeter Swans. 1984.

Thiel, R. P. 1985. Relationship between road densities and wolf habitat suitability in Wisconsin. Am. Midl. Nat. 113:404-407.

Thompson, I. D., H. A. Hogan, and W. A. Montevecchi. 1999. Avian communities of mature balsam forests in Newfoundland: age-dependence and implications for timber harvest. Condor 99: 311-323.

Thompson, L. 1985. A harlequin romance. Montana Outdoors 16:21-25. Thorp, J. 1949. Effects of certain animals that live in soils. Scientific Monthly 68:180-91.

Thurow, R. F., C. E. Corsi, and V. K. Moore. 1988. Status, ecology, and management of Yellowstone cutthroat trout in Upper Snake River Drainage, Idaho. American Fisheries Society Symposium 4:25-36.

Todd, L. D., R. G. Poulin, T. I. Wellicome, and R. M. Brigham 2003. Post fledging survival of burrowing owls in Saskatchewan. Journal of Wildlife Management 67: 512-519.

Tsai, C., and J. A. Fava. 1982. Habitats and distribution of the pearl dace, Semotilus margarita (Cope), in the Potomac River drainage. Virginia Journal of Science 33:201-205.

United States Fish \& Wildlife Service. 2004. Conservation Focus Areas of the Great Divide: A vast region encompassing the Upper Missouri, Yellowstone and Upper Columbia watersheds. Publisher: USFWS, Benton Lake Wildlife Refuge, Great Falls, MT. 77pgs.

U.S. Fish and Wildlife Service. 2003. Online informational search on Piping Plover in Montana. http://mountainprairie.fws.gov/pipingplover/Piping_Plover_Q\&A_Sept5.htm.

USFWS (United States Fish and Wildlife Service). 2002a. Endangered and Threatened Wildlife and Plants; Bull Trout (Salvelinus confluentus) Draft 


\section{DRAFT WORKING DOCUMENT DO NOT DUPLICATE}

16639 Recovery Plan. Available: http://pacific.fws.gov/bulltrout/recovery/Default.htm.

16640 (February 2003).

16641

16642

16643

16644

16645

16646

16647

16648

16649

16650

16651

16652

16653

16654

16655

16656

16657

16658

16659

16660

16661

16662

16663

16664

16665

16666

16667

16668

16669

16670

16671

16672

16673

16674

16675

16676

16677

16678

16679

16680

16681

16682

16683

USFWS (United States Fish and Wildlife Service) 2002b. Endangered and Threatened Wildlife and Plants; Proposed Designation of Critical Habitat for the Klamath River and Columbia River Distinct Population Segments of Bull Trout. Federal Register 67: 71235-71284. Available:

http://pacific.fws.gov/bulltrout/criticalhab.htm. (February 2003).

U.S. Fish and Wildlife Service. 1999. White Sturgeon; Kootenai River Population Recovery Plan. Region 1, USFWS, Portland, Oregon.

U.S. Fish and Wildlife Service (USFWS). 1999. Endangered and threatened wildlife and plants: 90 day finding on a petition to list the Columbian sharp-tailed grouse as threatened. Federal Register: October 26, 1999. V.64. No. 206. pp 57620-57623.

USFWS (United States Fish and Wildlife Service). 1998. Endangered and threatened wildlife and plants; determination of threatened status for the Klamath River and Columbia River distinct population segments of bull trout. Federal Register 63:31647-31674.

U.S. Fish and Wildlife Service, Office of Migratory Bird Management. 1995.

Migratory nongame birds of management concern in the United States: the 1995 list. U.S. Government Printing Office:1996-404-911/44014. 22 pp.

U.S. Fish and Wildlife Service. 1994. Endangered and threatened wildlife and plants: Establishment of a nonessential experimental population of black-footed ferrets in north-central Montana; final rule. Federal Register 59:42696-42715.

U.S. Fish and Wildlife Service. 1990. Recovery plan for the interior population of the least tern (Sterna Antillarum). Twin Cities, Minnesota. 90 pp.

U.S. Fish and Wildlife Service (USFWS). 1988. Black-footed ferret recovery plan. Denver, CO. 154 pp.

USDA Forest Service. 2004. Draft Multiple Species Inventory and Monitoring Technical Guide. Ecotype Management Coordination. USDA Forest Service, Washington DC, USA.

United States Forest Service. 2004. Beaverhead National Forest Lake Inventory. Available at http://www.fs.fed.us/r1/b-d/ (Accessed August 27, 2004).

USDA Forest Service (USFS). 1994. Neotropical Migratory Bird Reference Book. USDA Forest Service, Pacific Southwest Region. 832 pp.

16684 


\section{DRAFT WORKING DOCUMENT DO NOT DUPLICATE}

16685 United States Geological Survey. Nov 2001. Fact Sheet FS-110-01, online:

16686 http://pubs.usgs.gov/fs/fs-0110-01/.

16687

16688

16689

16690

16691

16692

16693

16694

16695

16696

16697

16698

16699

16700

16701

16702

16703

16704

16705

16706

16707

16708

16709

16710

16711

16712

16713

16714

16715

16716

16717

16718

16719

16720

16721

16722

16723

16724

16725

16726

16727

Ulliman, M.J., A. Sands, and T. Hemker. 1998. Conservation Plan for Columbian Sharp-tailed Grouse and its Habitat in Idaho - Draft. Draft document on file at the Forest Supervisors Office, Idaho Falls, Idaho, U.S.A.

United States Geological Survey. 1988. Cumulative Potential Hydrologic Impacts of Surface Coal Mining in the Eastern Powder River Structural Basin, Northeastern Wyoming. USGS Water-Resources Investigations Report 88-4046. Prepared by L.J. Martin, D.L. Naftz, H.W. Lowham, and J.G. Rankl in Cooperation with the Wyoming Department of Environmental Quality and the U. S. Office of Surface Mining, Cheyenne, WY.

USDI National Park Service. 2000, Bison Management for the State of Montana and Yellowstone National Park. Final Environmental Impact Statement for the Interagency Bison Management Plan for the State of Montana and Yellowstone National Park. Vol. I. August 2000.

Van Eimeren, P. 1996. Westslope Cutthroat Trout Oncorhynchus clarki lewsi IN Conservation Assessment for Inland Cutthroat Trout. Distribution, Status and Habitat Management Implications. US Department of Agriculture, Forest Service, Intermountain Region, Ogden, Utah. D.A. Duff, tech. Ed. Intermountain/foothill grassland 1-10.

Van Woudenberg, A. M. 1999. Status of the Flammulated Owl (OTUS FLAMMEOLUS) in British Columbia. Working Report No. 96, British Columbia Ministry of Environment, Lands, and Parks, Victoria, B.C. 45pp.

Van Zyll de Jong, C. G. 1985. Handbook of Canadian mammals, Volume 2, bats. National Museums of Canada, Ottawa.

Varley, J. D., and R. E. Gresswell. 1988. Ecology, status, and management of the Yellowstone cutthroat trout. American Fisheries Society Symposium 4:13-24.

Vaughn, C.C., C.M. Taylor and K.J. Eberhard. 1996. A Comparison of the Effectiveness of Timed Searches vs. Quadrate Sampling in Mussel Surveys. In

Verts, B. J., and L. N. Carraway. 1998. Land mammals of Oregon. University of California Press, Berkeley. 668 pp.

Verts, B. J., and G. L. Kirkland, Jr. 1988. PEROGNATHUS PARVUS. Am. Soc. Mamm., Mammalian Species 318:1-8.

16728 


\section{DRAFT WORKING DOCUMENT DO NOT DUPLICATE}

16729 Vincent, R. E. 1962. Biogeographical and biologic factors contributing to the 16730 decline of Arctic grayling (Thymallus arcticus [Pallus]) in Michigan and Montana.

16731 16732

16733 Ph.D. Dissertation, University of Michigan, Ann Arbor.

16734

16735

16736

16737

16738

16739

16740

16741

16742

16743

Vinton, M. A., D.C. Hartnett, E.J. Finck and J.M. Briggs. 1993. Interactive effects of fire, bison (Bison bison) grazing and plant community composition in tallgrass prairie. Am. Midl. Nat. 129:10-18.

Wagner, Robbin. USFWS, 2004, personal communication

Wai-Ping, V. and M. B. Fenton. 1989. Ecology of spotted bat (EUDERMA MACULATUM) roosting and foraging. J. Mamm. 70:617-622.

Walburg C. H. 1972. Some factors associated with fluctuation in year-class strength of sauger, Lewis and Clark Lake, South Dakota. Transactions of the American Fisheries Society 101:311-316.

16745

16746

16747

16748

16749

16750

16751

16752

16753

16754

16755

16756

16757

16758

16759

16760

16761

16762

16763

16764

16765

16766

16767

16768

16769

16770

16771

16772

Wallen, R.L. and C.R. Groves, 1989. Distribution, breeding biology and nesting habitat of harlequin ducks (Histrionicus histrionicus) in Northern Idaho. Natural Heritage Section. Nongame wildlife/Endangered Species Program, Bureau of wildlife.

Wallen, R.L. 1987. Habitat utilization by harlequin ducks in Grand Teton National Park. Unpublished MS Thesis. Montana State University, Bozeman, Montana, U.S.A.

Warheit, K. I. and M. A. Schroeder. 2001. Genetic analysis of Columbian sharptailed grouse: A preliminary study. Submitted to US Department of Interior Bureau of Land Management Spokane, Washington. WDFW Contract No. 39001257. 16 pp.

Welker, T. L., Scarnecchia D. L. Habitat use and population structure of four native minnows (family Cyprinidae) in the upper Missouri and lower Yellowstone rivers, North Dakota (USA). Ecology of Freshwater Fish 2004: 13: 8-22.

Werdon, S. 1993. Status report on sturgeon chub (Macrhybopsis gelida), a candidate endangered species. U.S. Fish and Wildlife Service, Ecological Services, North Dakota State Office. Bismarck.

Werdon, S. 1992. Population status and characteristics of Macrhybopsis gelida, Platygobio gracilis and Rhinichthyes cataractae in the Missouri river Basin. Masters Thesis. South Dakota State University. Brookings. the Flathead Indian Reservation. Intermountain Journal of Science 4:33-49. 


\section{DRAFT WORKING DOCUMENT DO NOT DUPLICATE}

16775 Werner, J. Kirwin and J. D. Reichel. 1996. Amphibian and reptile

16776

16777

16778

16779

16780

16781

16782

16783

16784

16785

16786

16787

16788

16789

16790

16791

16792

16793

16794

16795

16796

16797

16798

16799

16800

16801

16802

16803

16804

16805

16806

16807

16808

16809

16810

16811

16812

16813

16814

16815

16816

16817

16818 monitoring/survey of the Kootenai National Forest: 1995. Montana Natural Heritage Program, Helena, Montana, U.S.A.

Werner, J. K. and J. D. Reichel. 1994. Amphibian and reptile monitoring/survey of the Kootenai National Forest: 1995. Montana Natural Heritage Program, Helena, Montana, U.S.A.

Wershler, C. R. 1989. A management strategy for mountain plovers in Alberta. Proc. Prairie Cons. Endangered Sp. Workshop, Sask. Nat. Hist. Soc. and Can. Plains Res. Center. 5 pp.

West, S. D. 1999. Northern bog lemming Synaptomys borealis. Pp. 655-656, In The Smithsonian book of North American mammals (D. E. Wilson and S. Ruff, eds.). Smithsonian Institution Press, Washington, D.C.

Whitaker, J. O., Jr. 1972. ZAPUS HUDSONIUS. Am. Soc. Mamm., Mammalian Species No. 11. 7 pp.

Wheaton, J., Metesh, J.J., 2002, Potential ground-water drawdown and recovery for coal bed methane development in the Powder River Basin, Montana, Montana Bureau of Mines and Geology Open File Report 458, 59 page(s).

Whitewater Wetlands Conservation Area Plan. 2004. B. Martin \& J. Stutzman, 16 $\mathrm{pp}+$ appendices.

Whittier, T. R., D. B. Halliwell, and S. G. Paulsen. 1997. Cyprinid distributions in Northeastern U.S.A. lakes: Evidence of regional-scale minnow biodiversity losses. Canadian Journal of Fisheries and Aquatic Sciences 54:1593-1607.

Will, G. C., January 1986, Waterfowl, Sandhill Crane and Snipe Management Plan.

Williams, J.D., and M. Zimmer. 1992. First Sharp-tailed Sparrow South Dakota nesting record. South Dakota Bird Notes 44:84-85.

Williams, J.E., J. E. Johnson, D.A. Hendrickson, S. Contreras-Balderas, J.D. Williams, M Avarro-Mendoza, D.E. McAllister, and J.E. Deacon. 1989. Fishes of North America endangered, threatened, or of special concern: 1989. Fisheries. 14(6): 2-20.

Wilson, A. G., E. Simon, and J. H. Larsen, Jr. 1989. Range extension for the Coeur d'Alene salamander, PLETHODON VANDYKEI IDAHOENSIS, to the Canada-United States border. Canadian Field-Nat. 103:93-94. 


\section{DRAFT WORKING DOCUMENT DO NOT DUPLICATE}

16819 Wilson, C.C. and P.D.N. Hebert. 1998. Phylogeography and postglacial dispersal 16820 of lake trout (Salvelinus namaycush) in North America. Can. J. Fish Aquat. Sci.

16821 55: 1010-1024.

16822

16823

Wilson, D. E., and S. Ruff. 1999. The Smithsonian book of North American

16824

16825

16826

16827

16828

16829 mammals. Smithsonian Institution, Washington, DC. 750pp.

Wisdom, M. J., R. S. Holthausen, B. C. Wales, C. D. Hargis, V. A. Saab, D. C. Lee, W. J. Hann, T. D. Rich, M. M. Rowland, W. J. Murphy and M. R. Eames. 2000. Source habitats for terrestrial vertebrates of focus in the Interior Columbia 16830 16831 16832 Basin: broad-scale trends and management implications. Vols. 1-3. General Technical Report PNW-GTR-485. USDA Forest Service Pacific Northwest Research Station, Portland Oregon, USA.

Worthington, D. J. 1991. Abundance and distribution of bats in the Pryor 16834 16835 16836 16837 16838 16839

Mountains of south central Montana and northeastern Wyoming. Montana Natural Heritage Program. Helena. 23 pp.

Wright, J.C., and E. A. Wright. 1948. Grassland types of South Central Montana. Ecology 29(4):449-460.

Wright, P.L. 1997. Status of Rare Birds in Montana, With Comments on Known Hybrids. Northwestern Naturalist 77:57-85.

Wright, P. L. 1950. SYNAPTOMYS BOREALIS from Glacier National Park, Montana. J. Mammal. 31(4): 460.

Wright, V. 2000. The Aldo Leopold Wilderness Research Institute: A National Wilderness Research Program in Support of Wilderness Management. In: McCool, Stephen F.; Cole, David N.; Borrie, William T.; O'Loughlin, Jennifer, comps. Wilderness Science in a Time of Change Conference Vol 3: Wilderness 16850 16851 16852 16853 16854 16855 16856 16857 16858 16859 16860 16861 as a place for scientific inquiry; 1999 May 23-27; Missoula, MT. Proc. RMRS-P15-VOL-3. Ogden, UT: Department of Agriculture, Forest Service, Rocky Mountain Research Station: 260-268.

Wright, V., S. Hejl, and R.L. Hutto. 1997. Conservation implications of a multiscale study of flammulated owl (OTUS FLAMMEOLUS) habitat use in the northern Rocky Mountains, USA. Intermountain/foothill grassland 506-516 in J. R. Duncan, D. H. Johnson, and T. H. Nicholls, editors. B

Wright, V. 1996. Multi-scale analysis of flammulated owl habitat use: owl distribution, habitat management, and conservation. Unpublished M. S. Thesis, University of Montana, Missoula, USA.

16862 
16863 Wyoming Game and Fish Department. 2000. Yellowstone cutthroat trout

16864

16865

16866

16867

16868

16869

16870

16871

16872

16873

16874

16875

16876

16877

16878

16879

16880

16881

16882

16883

16884

16885

16886

16887

16888

16889

16890

16891

16892

16893

16894

16895

16896

16897

16898

16899

16900

16901

16902

16903

16904

16905

16906

16907 management summary. Wyoming Game and Fish Department, Fish Division, Cheyenne.

Yellowstone Cutthroat Trout Working Group. 1994. Yellowstone cutthroat trout (Oncorhynchus clarki bouvieri) management guide for the Yellowstone River drainage. Montana Department of Fish, Wildlife \& Parks, Helena, and Wyoming Game and Fish Department, Cheyenne.

Young, Lewis. 1995 (unpublished). Range Permit Re-issuance: Columbian Sharp-tailed grouse. Kootenai National Forest, Eureka, Montana, U.S.A.

Yunick, R. P. 1985. A review of recent irruptions of the black-backed woodpecker and three-toed woodpecker in eastern North America. Journal of Field Ornithology 56: 138-152.

Zickefoose, J. 1985. Least tern/piping plover recovery program. Final report to The Nature Conservancy, Connecticut Chapter. 22 pp.

\section{Appendices}

\section{Appendix A}

Guiding Principles for States to Consider in Developing Comprehensive Wildlife Conservation Plans and Wildlife Conservation Strategies (PlansStrategies) for the State Wildlife Grant and Wildlife Conservation and Restoration Programs

Final: September 27, 2002

The International Association of Fish and Wildlife Agencies recommends the following guiding principles for the States, the U.S. Fish and Wildlife Service, and their conservation partners to consider and apply while developing Comprehensive Wildlife Conservation Plans to meet their obligations under the State Wildlife Grant (SWG) and the Wildlife Conservation Strategies under the Wildlife Conservation and Restoration (WCRP) programs.

These Guiding Principles identify goals, objectives, and actions to strive for over time. Few if any will be fully realized in any State under what is hopefully just the first round of conservation program development under SWG and WCRP. Some things must occur from the outset, because they are legally required and/or because they are essential to success. Clearly, broad-scale public participation is an example of one such area. Among the diverse stakeholders in this effort are: private, local, State, and Federal agencies and governments, NGOs, etc. 


\section{DRAFT WORKING DOCUMENT DO NOT DUPLICATE}

16908

16909

16910

16911

16912

16913

16914

16915

16916

16917

16918

16919

16920

16921

16922

16923

16924

16925

16926

16927

16928

16929

16930

16931

16932

16933

16934

16935

16936

16937

16938

16939

16940

16941

16942

16943

16944

16945

16946

16947

16948

16949

16950

The Plan-Strategy provides an opportunity for the State wildlife agency to provide effective and visionary leadership in conservation. The Plan-Strategy can identify the measures that will be used, the results achieved, and the threats and needs that remain with regard to wildlife and wildlife habitat. It is also an opportunity to address broader issues and programs, including environmental and wildliferelated education, outdoor recreation, and wildlife-related law enforcement. These other areas can constrain, or enhance, wildlife conservation efforts, and funding and public support for wildlife conservation can be increased, or at least stretched, by involving partners that share those interests.

\section{A: Planning Process and Partnerships}

1. Involve multiple staff levels within each agency, and broad public-private partnerships, to develop and implement the Plan-Strategy.

2. Involve partners that have the authorities necessary to ensure that the Plan-Strategy addresses the full range of issues at hand.

3. Build capacity for cooperative engagement among all partners in the effort, and make sure that it is productive, so trust and confidence grow, and organizational and interpersonal relationships become strengths of the Plan-Strategy.

4. Share responsibility and credit for planning and implementation among all partners, who collectively share responsibility for success of the PlanStrategy.

5. Focus on efficiency and effectiveness, so the value added in planning and implementation is commensurate to the funds invested.

6. Ensure that the planning processes and the resultant Plans-Strategies are dynamic - so they can be improved and updated efficiently as new information is gained.

7. Communicate effectively with stakeholders, other partners, and the public, early and often.

8. The planning processes, and the decisions made during planning, should be obvious to those who read and use the Plan-Strategy, and repeatable document the processes and the decisions so the next planning cycle can build on this one.

\section{B. Focus and Scope}

1. Base the Plan-Strategy in the principles of "best science," "best management practices," and "adaptive management," with measurable goals, objectives, strategies, approaches, and activities that are complete, realistic, feasible, logical, and achievable. Describe these processes and practices sufficiently that partners understand what they entail and how they should function. 
16951 16952 16953 16954

16955 16956 16957

16958 16959 16960

16961 16962 16963 16964 16965 16966 16967 16968 16969 16970 16971 16972 16973 16974 16975 16976 16977 16978

16979

16980 16981 16982

16983 16984 16985 16986 16987 16988 16989 16990 16991

2. Address the broad range of wildlife and associated habitats, with appropriate priority placed on those species of greatest conservation need and taking into account the relative level of funding available for conservation of those species.

3. Integrate and address wildlife-related issues statewide, across jurisdictions and interests, and coordinate with parallel efforts in other States and countries.

4. Combine landscape/ecotype/habitat-based approaches and smaller-scale approaches (e.g. focal, keystone, and/or indicator species; guilds; species of special concern) for planning and implementation.

5. Make the Plan-Strategy an effective, long-lasting blueprint for conservation that provides a broad vision and priorities, so a broad array of organizations, including other government agencies and NGOs, can help realize the vision. The Plan-Strategy should have sufficient flexibility to respond to the full spectrum of conditions and circumstances likely to be encountered within the planning area.

\section{Format and Content}

1. Make the Plan-Strategy readable, understandable, and useful, with welldefined issues, short and long-term goals and objectives, strategies, and realistic measures of performance that enable State agencies and their partners to demonstrate accountability.

2. Make full and effective use of relevant existing information; in particular, integrate appropriate elements of other plans and initiatives (such as Partners-in-Flight and the many regional and other plans), databases, GIS layers, records, reports, other information sources, and management information systems that overlap or complement these Plans-Strategies.

3. Identify knowledge gaps, as well as areas of knowledge, to help focus future efforts to improve understanding and planning, but do not allow a lack of information to inappropriately limit necessary short-term application of the best available science and good judgment in decision-making.

4. Make the Plan-Strategy spatially explicit, to the extent feasible and appropriate, with a full complement of GIS and other maps, figures, and other graphics, as well as appropriate text to provide sufficient detail and consistency in describing species and habitat conditions, conservation needs, conservation recommendations, and other issues/actions, so it can be used effectively by all partners.

5. Use "threats analyses," "risk and stressor assessments," and other techniques to help set priorities for goals, objectives, strategies, and activities.

6. In addition to wildlife, address factors that can have substantial impact on wildlife conservation, such as management of invasive species, wildlife- 


\section{DRAFT WORKING DOCUMENT DO NOT DUPLICATE}

16994

16995

16996 16997

16998

16999

17000

17001

17002

17003

17004

17005

17006

17007

17008

17009

17010

17011

17012

17013

17014

17015

17016

17017

17018

17019

17020

17021

17022

17023

17024

17025

17026

17027

17028

17029

17030

17031

17032

17033

17034 related and conservation-related education, law enforcement, and outdoor recreation.

7. Include a comprehensive glossary, so partners and the public have a shared and common understanding of key terms used in the PlanStrategy.

8. Develop an updatable information system to monitor Plan-Strategy implementation and the status and trends of wildlife and habitat.

9. Consider wildlife conservation-related education and wildlife-associated recreation as tools that can help accomplishing conservation goals.

\section{Completion, Outcomes, and Availability}

1. Provide annual written progress updates on the planning effort and progress to IAFWA's CARA Implementation Committee each September, in addition to annual performance reports that must be submitted to the U.S. Fish and Wildlife Service pursuant to Federal Aid guidelines.

2. Ensure that the Plan-Strategy clearly and definitively meets State obligations to Congress under the WCRP and SWG legislation, and to the U.S. Fish and Wildlife Service with regard to Federal Aid administration.

3. Provide sufficient documentation in or with the Plan-Strategy to facilitate public understanding of the decisions that are made, how and why they were made.

4. Make the Plan-Strategy a driving force in guiding activities under diverse wildlife and habitat conservation initiatives, and usable for helping to inform land-use decision-making.

5. Make the Plan-Strategy readily available to the public in variety of media

6. Provide a mechanism for reporting accomplishments and tracking progress so local partners are aware of both.

7. Ensure that the Plan-Strategy can be implemented, i.e. that it is administratively and politically feasible, and that there are sufficient resources (funding and staff) among the partners to accomplish significant gains at a large scale, and within an appropriate time frame, to preserve our Nation's wildlife heritage.

\section{Appendix B}

\section{Process for Allocating Annual State Wildlife Grant Funds}

This framework applies to the allocation of Montana's State Wildlife Grant funds only until the approval of the Comprehensive Fish and Wildlife Plan. Following that approval, project selection and fund allocation will be based on the plan. 


\section{DRAFT WORKING DOCUMENT DO NOT DUPLICATE}

17035

17036

17037

17038

17039

17040

17041

17042

17043

17044

17045

17046

17047

17048

17049

17050

17051

17052

17053

17054

17055

17056

17057

17058

17059

17060

17061

17062

17063

17064

17065

17066

17067

17068

17069

17070

17071

17072

17073

17074

17075

17076

17077

17078

17079
1. Appropriation passes Congress and apportionment to Montana is determined.

2. Chief of Staff determines if spending authority is available for fiscal year and alerts Technical Committee if paperwork needed. Overhead portion is determined and total amount available is provided to Technical Committee

3. Within 1 month after apportionment is determined: Steering Committee establishes program-level allocation of funds, if necessary. (Program level allocations could include a percentage to Conservation and Education, if appropriate, or tribal subgrants.)

4. Development of Recommended Projects (Completed within 3 months after program-level allocations are set). - Technical Committee Recommended projects will be generated by:

- Review of proposals provided in previous year that were not funded.

- Review of projects that were "multi-year" from previous allocations

- Generate list of conservation needs

- Solicit new projects

o Internal Solicitation- List of Conservation Needs and Request for Proposals (Appendix A) sent to FWP staff; Division Leads contact the appropriate staff in their divisions for proposals and help fleshing out ideas. Fleshing out needs to include a general discussion of match opportunities for the project.

o External Solicitation - Project leads will contact partners to solicit projects that will align with conservation needs;

- Determines feasibility through follow-up contacts to identify match, personnel needs, etc. and enter into Table 1.

- Develops recommendations based on selection criteria (Appendix B)

5. 3 months after program-level allocations are set: Steering Committee reviews and acts on Technical Committee recommendations on projects; revises program-level allocations of uncommitted funds.

\section{Appendix C}

\section{Fish, Wildlife \& Parks State Wildlife Grant Program Request for Proposals}

FWP has receiving their 3rd allocation of funds from Congress for State Wildlife Grants (SWG) in the amount of $\$ 840,000$ (after overhead has been removed). The Director's office has allocated $\$ 250,000$ each to the Fisheries and Wildlife divisions. An additional $\$ 300,000$ is available for projects that may have been solicited internally/externally, can be multi-disciplinary in nature and will be ranked on a competitive basis. Projects will also be solicited outside the 


\section{DRAFT WORKING DOCUMENT DO NOT DUPLICATE}

17080 agency and projects will be based on merit; this is just a request for

17081

17082

17083

17084

17085

17086

17087

17088

17089

17090

17091

17092

17093

17094

17095

17096

17097

17098

17099

17100

17101

17102

17103

17104

17105

17106

17107

17108

17109

17110

17111

17112

17113

17114

17115

17116

17117

17118

17119

17120

17121

17122

17123

17124 proposals, not a guarantee that you will receive the funding.

Congress has directed that the funds be used to address the state's greatest conservation needs that are currently unmet. Typically, projects to be funded with SWG dollars will involve Montana's Species of Concern and/or other nongame species for which funding is very limited or unavailable. Wildlife projects that have been funded with previous allocations include: sage-grouse surveys (identification of leks and wintering areas); evaluation of recreational shooting on prairie dogs; surveys of small animals associated with sagebrush and grassland habitats; bird monitoring efforts; planning processes; loon monitoring and research; expansion of Montana's coordinated land bird monitoring program and prairie- riparian habitat surveys of eastern Montana. Fisheries projects have included: prairie fish surveys in Regions 4-7, sauger telemetry study in the Powder and Tongue rivers, native species creel, cutthroat restoration in Region 4, and burbot status assessment

Please provide the following information by (date):

- A brief project proposal including the location, the objectives, and deliverables (one page);

- An estimated budget;

- Staffing needs (additional FTE would have to be "modified FTE," and while getting modified FTE is not a sure thing, the Fisheries Division has been successful in the past for SWG projects); and

- Projects can be for more than one year; please reflect that in your proposal.

- Submit Fisheries Projects to Ken McDonald or Wildlife Projects to Heidi Youmans by (insert date)

As you think of potential projects, be mindful of the following information:

- "Interdivisional" projects such as amphibian work or riparian-associated work will be especially welcomed but not mandatory.

- A non-federal match (between 33\% and 100\% depending on the type of project) is required for all projects. At this time, we are not requiring you to have the match in hand, but do ask that you think about sources of nonfederal match. Sources of funds that we cannot use include DJ or PR-funded projects, BPA, USFS and other federal funds. We also can't use the same non-federal funds to match more than one source of federal money. We will work with you on lining out the match if your proposal is selected.

- SWG is administered through the Federal Aid Program, so a project needs to meet all federal aid requirements. We can assist with the necessary paperwork but you will have to ensure enough time so that it can be completed, approved, and the project set up prior to initiation of the project (i.e., plan well ahead of your field season for the project).

- Projects that are eligible for other funding sources will not be scored as high as those without any other potential sources of funding. 
17125

17126

17127

17128

17129

17130

17131

17132

17133

17134

17135

17136

17137

17138

17139

17140

17141

17142

17143

17144

17145

17146

17147

17148

17149

17150

17151

17152

17153

17154

17155

17156

17157

17158

17159

17160

17161

17162

17163

17164

17165

17166

After ranking projects based on a set of criteria, the SWG Technical Committee will make recommendations to the SWG Steering Committee who will give final approval to projects.

\section{Appendix D}

\section{SWG Project Selection Ranking Criteria}

Project (Number or Title):

Ranking Criteria - Each proposal is to be scored according to the following criteria. This calculation will be done in an excel spreadsheet. apply.

Indicate with a "1" for each that apply. Leave blank for those that don't

1. Project results will reduce the immediacy and/or severity of threats to one or more of Montana's native species.

2. Is it a Species of Concern or a USFWS Threatened or Endangered Species.

3. Conservation needs identified in project currently are not being addressed by any existing programs or other funding sources (excluding SWG funding).

4. __ Project benefits the public.

5. The project will yield occurrence/distribution data and/or can be used for comprehensive planning efforts.

6. Budget total is appropriate for the scope of the project.

7.

Partnerships outside the agency are being used in the project.

8. Degree to which project results can benefit multiple native species (species assemblages or wildlife communities)

From the average of the Technical Committee scoring, projects will be prioritized and funding recommendations will be provided to the Steering Committee based on available funding. 


\section{Appendix E}

\section{DRAFT WORKING COPY \\ Do Not Duplicate}

17168

17169

17170

17171

17172

17173

17174

17175

17176

17177

17178

17179

17180

17181

17182

17183

17184

17185

17186

17187

17188

17189

17190

17191

17192

17193

17194

17195

17196

17197

17198

17199

17200

17201

17202

17203

17204

17205

17206

17207

17208

17209

17210

17211

17212

Montana Fish, Wildlife \& Parks Staff Exploratory Group

The following FWP Staff participated:

Thomas Baumeister

Conservation Education

Dianne Tipton

T.O. Smith

Conservation Education

Andrew Jakes

CFWCS Coordinator

Chris Smith

CFWCS Planning Team

Marc Scow

Directors Office

Mark Deleray

Facilitation

Mark Sweeney

Fisheries

Ken McDonald

Fisheries

Tom Flowers

Fisheries

Pat Flowers

Carolyn Sime

Law Enforcement

Bill Semmons

Regional Management

Wildlife

Kristi Dubois

Wildlife

Allison Puchniak

Wildlife

Pat Gunderson

Wildlife

Howard Burt

Wildlife

Wildlife

\section{Working Statement 1}

"What are some of the strategies, processes and actions that would foster the best possible outcome of broadening FWP's focus to try and more completely achieve its vision and mission statement?"

Participation

- Develop a strategy that includes FWP employees, commission, legislators and community groups

- Do a public survey to measure the state of the publics knowledge and familiarity with funding and management needs and opinion of what we should be doing

- Must have intra agency participation

- Create partnership with other agencies

- Collaboration with other agencies and within FWP

- We must bring the public along with us as we plan and move our paradigm

- Continue the regional and cross regional discussions

- Involvement of the public early and often

Outreach/Education and Marketing 


\section{DRAFT WORKING COPY \\ Do Not Duplicate}

17214

17215

17216

17217

17218

17219

17220

17221

17222

17223

17224

17225

17226

17227

17228

17229

17230

17231

17232

17233

17234

17235

17236

17237

17238

17239

17240

17241

17242

17243

17244

17245

17246

17247

17248

17249

17250

17251

17252

17253

17254

17255

17256
- Use focus groups

- Work with Con/Ed to develop a message and delivery method

- Use bottom up approach for internal buy in

- Find ways to sell the program to landowners through positive example

- Tailor outreach messages to specific audiences

- We need to plan to meet MEPA and NEPA (a plan that doesn't require these isn't worth having)

- Meet with traditional hunters and anglers's groups to get their feedback and ideas MWF, TU etc...

- Legislative Outreach

- Prepare a public involvement strategy

- As much public involvement as feasible

- Get buy in through marketing

- Revise the roadmap as needed

- Keep hunters and anglers and legislator informed through web site and email

- Use facilitated meetings to include all biologists and public

- Use lots of education and outreach

- Develop a way to "sell" the program to traditional constituents

- In-Reach and Outreach efforts will be important

- Have outreach for private landowners

- Use internet, radio, TV, papers to get the word out to the public

- Need to let the public know that we are not using license dollars for broadening focus, but need additional funding

- Identify the financial risks and reward and inform the public upfront about those

- Need education to get everyone on the same page

- Prepare a historical account of where we have come from and where we need to go

- Try and eliminate misconceptions from the beginning

- Answer the question why? We need to do this and then tell the public

- Identify the goals and priorities of the plan and then gauge the public to see if theirs are the same

- Develop a statement that is 50 words or less that explains why we need comprehensive management and it makes sense then educate the public

- Provide information to the public about FWP funding really works and why we need additional funding

- Identify the "hook" to get people to buy in

- Seek buy in internally and outside FWP

- Sell the program internally

- Discuss how SWG funds would be allocated internally and upfront

- Use landowner incentives

- Public Outreach 
17257

17258

17259

17260

17261

17262

17263

17264

17265

17266

17267

17268

17269

17270

17271

17272

17273

17274

17275

17276

17277

17278

17279

17280

17281

17282

17283

17284

17285

17286

17287

17288

17289

17290

17291

17292

17293

17294

17295

17296

17297

17298

17299

17300

17301

\section{DRAFT WORKING COPY \\ Do Not Duplicate}

Planning

- Use leadership to keep process moving

- Set a modest agenda

- Use caution as plan develops

- Be flexible during the planning process in order to amend the roadmap as needed

- Develop a clear statement with other partners of intent for what the plan will be

- Use innovative methods

- Develop a planning goal alongside our partners and with FWP employees

- Identify alternative funding sources that we can use as match

- Write the plan by habitat type not by species

- Through [...planning...], identify specific projects at regional level for funding

- Use existing plans

- Identify knowledge gaps

- A plan that is measurable, quantifiable, and has real objectives

- A plan that includes the needed resources of funding and staffing to meet objectives

- Need to incorporate all the plans we currently have (elk, wolf, prairie dog etc.)

- Plan should focus on Federal threatened or endangered species and special concern then expand to include communities and systems not a single species approach

- Use habitats as the foundation for all planning

- Develop a timeline

- Create a statement of Intent

- Develop a Roadmap

- Find ways to broaden our management protocol to including monitoring of all species

- Provide future SWG funding at the regional level

- Plan should be the framework for decision making not the decision itself

- Plan must provide enough direction to be meaningful but not obligate FWP to focusing future funding on specific things

- Identify Goals and objectives for plan within a time frame

\section{Working Statement 2}

"What would be the best possible outcomes of broadening FWP's focus to try and more completely achieve its vision and mission statement?"

\section{Constituents or Other Agencies}




\section{DRAFT WORKING COPY \\ Do Not Duplicate}

17302 Primary Finding: FWP employees thought that one of the best outcomes could

17303 be acceptance by and support from the public, private landowners and other

17304 agencies for FWP comprehensive programs

17305

17306

- Hunters and anglers would have a broader ownership commitment

17307

17308

17309

17310

17311

17312

17313

17314

17315

17316

17317

17318

17319

17320

17321

17322

17323

17324

17325

17326

17327

17328

17329

17330

17331

17332

17333

17334

17335

17336

17337

17338

17339

17340

17341

17342

17343

17344

17345

17346

- Engagement of the non-hunting public with FWP that results in their support for our programs

- A truly comprehensive plan for all wildlife that is accepted by the public

- Forges strong partnership with interest groups and public

- All agencies cooperate so that we can manage comprehensively

- Increased support for FWP from diverse constituencies

- Landowners participate in habitat incentives that come from the plan

- Hunter and anglers that realize the benefits that comes from comprehensive management

- A better land ethic where people respect the biological community

- Improved public perception of all FWP programs

- Everyone accepts overall plan

- There are no political ramifications to broadening the focus

\section{Funding and Staff}

Primary Finding: Participants were clear in pointing out that increased funding to FWP could be a best possible outcome, but that increased funding must be accompanied by increased staffing.

- Needed funding and staff for (...increased management, monitoring ... of all species

- We have increased long term permanent funding

- Funding and personnel become available for management of all species

- Increased staff

- More staff to accomplish goals

- Have additional funding to manage all species

- SWG is a funded federal mandate

- Increased funding

- Secure funding and FWP spends it responsibly toward conservation of all species

- FWP gains support and ability to protect resources

- We have sufficient funds to implement the plan so it becomes permanent

- More FTE's to accomplish comprehensive management

\section{Management Paradigm}

Primary Finding: Participants expressed that a shift in the way FWP and its constituents view wildlife and wildlife management to a more comprehensive approach could be a best possible outcome. Note: this outcome indicates that 


\section{DRAFT WORKING COPY \\ Do Not Duplicate}

17347 there is a perception that FWP and our constituents currently do not view wildlife

17348

17349

17350

17351

17352

17353

17354

17355

17356

17357

17358

17359

17360

17361

17362

17363

17364

17365

17366

17367

17368

17369

17370

17371

17372

17373

17374

17375

17376

17377

17378

17379

17380

17381

17382

17383

17384

17385

17386

17387

17388

17389

17390

17391

and wildlife management in a comprehensive enough manner.

- Sportsmen and FWP acceptance of multi species approach

- Constituents shift the way they think from species specific to comprehensive

- Public would accept new way of managing

- Everyone sees the big picture of management

- A greater appreciation of regional ecotypes

- Hunter and anglers that realize the benefits that comes from comprehensive management

- Move our paradigm of management to all species management

- Shift our approach to management and view all fish and wildlife in an integrated way

- Move our paradigm of management to all species management

- FWP would manage for all species regardless of game classification

\section{Multi-Species}

Primary Finding: Comments were made that being able to focus on more of Montana's species could be a best outcome of broadening FWP's focus.

- More efficient use of dollars to manage all not just single species

- FWP would have a true ecotype approach

- Integration of all species management

- Game and nongame species benefit

- Increased management, monitoring and management of all species

- Recover all T\&E species and stabilize sensitive species

- All outdoor activities are perceived as important

- Better information about species and habitat relationships

- Better comprehensive management of all species

- Fewer listings under ESA

Montana Fish, Wildlife \& Parks

Primary Finding: Broadening FWP's focus could lead to achieving its mission.

- Gap between Helena office and the field is bridged

- All FWP's vision and mission statements are met

- FWP advances the conservation agenda

- Fulfill our FWP mission

- Move away from crisis management and species of special concern

Environment or habitat 


\section{DRAFT WORKING COPY \\ Do Not Duplicate}

17392 Primary finding: Healthier habitats and environment could be a best possible 17393 outcome.

17394

17395

17396

17397

17398

17399

17400

17401

17402

17403

17404

17405

17406

17407

17408

17409

17410

17411

17412

17413

17414

17415

17416

17417

17418

17419

17420

17421

17422

17423

17424

17425

17426

17427

17428

17429

17430

17431

17432

17433

17434

17435

17436

- We have healthier natural environment for all species

- Healthy ecotypes across Montana that support Fish and Wildlife that live in all habitats

- (Plan...) creates better habitat resulting in increased hunting opportunities

\section{Working Statement 3}

"What are the worst possible outcomes of broadening FWP's focus to try and more completely achieve its vision and mission statement?"

Constituents

Primary finding: More comments were received concerning constituent relations than any other category. By far the largest concern was that by broadening our focus FWP would loose its traditional hunters and anglers community support

- Outside stakeholder groups might not participate

- We alienate one or more groups of constituents

- We actually cause less support for any of our programs

- We loose traditional support from sportsmen

- Constituent groups become divided

- We promise the public something we can't deliver

- Public will not understand plan

- Game and nongame constituents are divided

- Alienate our sportsmen

- Loose our traditional constituents

- Alienate our traditional supporters

- If we use habitat approach, we might be accused of taking authority from land managers and private landowners

- Backlash from the public about species of concern

- Private landowners will oppose the agency

- Loss of traditional constituent support

- Drives a wedge between game and non game supporters and managers

- Sportsmen perceive we are moving game dollars to nongame issues

\section{Biology}

Primary finding: FWP employees were concerned that moving from an individual species approach to a comprehensive approach could create conflicts in management needs. This problem was somewhat addressed by comments that the plan should focus on quality habitat management for communities 


\section{DRAFT WORKING COPY \\ Do Not Duplicate}

17437

17438

17439

17440

17441

17442

17443

17444

17445

17446

17447

17448

17449

17450

17451

17452

17453

17454

17455

17456

17457

17458

17459

17460

17461

17462

17463

17464

17465

17466

17467

17468

17469

17470

17471

17472

17473

17474

17475

17476

17477

17478

17479

17480

17481

- Potential for ecological conflict between species and between native and non-native would be realized

- Plan does not result in biological actions and further degrades support for planning efforts

- Plan is not habitat based enough

- Conflicting management mandates for different species

- Loose our focus on community habitat

- Plan will not be habitat based and will continue promoting species management

- There is no change in how we manage habitats and species

- Data collected will be misused

Money

Primary finding: FWP employees were concerned that either permanent funding would not materialize, or that additional work would be created without the funding to acquire additional FTE resulting in additional workload

- Other states do not participate fully and derail the opportunity for long term permanent funding

- Waste time and money

- Legislators divert funding

- Develop plan in anticipation of funding and it doesn't come

- Creates more work with no additional FTE or money

- We can't match federal funds and loose funding

- Adds more work with no additional FTE or funding

- Creates work with no meaningful outcome

Politics

Primary finding: FWP employees were concerned that legislators would not approve of our actions and would create difficulties for FWP

- FWP embraces a comprehensive management approach, but the public and legislators do not

- SWG becomes an un-funded federal mandate

- Legislators attempt to punish us because they do not support it

- Our actions create political fallout

Montana Fish, Wildlife \& Parks

Primary findings: FWP employees were concerned that FWP would be divided among by management interest or by field versus the staff

- Division within FWP 
17482

17483

17484

17485

17486

17487

17488

17489

17490

17491

17492

17493

17494

17495

17496

17497

17498

17499

17500

17501

17502

17503

17504

17505

17506

17507

17508

17509

17510

17511

17512

17513

17514

17515

17516

17517

17518

17519

17520

17521

17522

17523

17524

17525

17526
- Department becomes divided

DRAFT WORKING COPY

Do Not Duplicate

- Increases the division between field and HQ

- Division within FWP

General

Primary finding: FWP employees commented that by further addressing the needs of all species, recreational opportunities and thus quality of life could actually be lost while enhancing our wildlife communities

- Loss of recreational opportunities

- Quality of life is lost

\section{Working Statement 4}

Participants were informed that even if SWG became a long term permanent funding source FWP would need alternative funding sources to fulfill its mission. They were asked to brainstorm all possible ways that FWP could gather additional new funds.

- .01\% sales tax

- License plates

- Coal bed methane tax

- Property tax surcharge

- Tax on RV's

- Federal land use tax

- Soda pop tax like Arkansas

- Non-resident entry tax

- University cooperation

- Lottery

- Interest from a one-time investment of hunters and anglers's dollars

- Auction Grizzly/Wolf and other unique animal tags

- Nongame stamp

- Wild trout stamp

- Real estate transaction tax

- Gambling or other sin tax

- NGO donations

- Outfitters and guides tax

- Private donations

- Develop a line of nongame products (maps/etc.) for sale

- Old CARA type tax (bird seed etc.)

- An endowed foundation

- Oil/Gas taxation

- Coal tax trust fund

- Sell state lands to create an endowment 


\section{DRAFT WORKING COPY \\ Do Not Duplicate}

17527

17528

17529

17530

17531

17532

17533

17534

17535

17536

17537

17538

17539

17540

17541

17542

17543

17544

17545

17546

17547

17548

17549

17550

17551

17552

17553

17554

17555

17556

17557

17558

17559

17560

17561

17562

17563

17564

17565

17566

17567

17568

17569

17570

17571
- Remove SWG and or DJ and PR match requirements

- Nongame activities license or stamps (bird watching/mountain biking stamps)

- FWP foundation dollars

- Solicit contributions through NGO type org.

- Canoe and Kayak fees

- Off road vehicle tax

- Bed tax

- Public lands fee

- Local options tax

- Birdathon and other non-sporting competitions

- State highway funds mitigation

- Travel Montana

- Surcharge on all new construction permits

\section{Federal Requirement \#1}

"Information on the distribution and abundance of species of wildlife (including low and declining populations as the State fish and wildlife agency deems appropriate) that are indicative of the diversity and health of the State's wildlife"

Participants were asked about what data, resources or methods should be considered or used to meet this requirement.

- Gather info from all databases into one spot

- State databases

- Use information from NHP species of concern list

- Include professional judgment at the regional level in concert with NHP and USFWS list

- MFISH database

- Game database

- Furbearer database (harvest/tracking surveys)

- Wildlife collection permits

- Migratory bird permits (bird banding lab)

- Other agencies and tribal data

- (Caution that much of this data will be observational not abundance data that could provide historical trends/ data we have is not population trend data and will ultimately be subjective)

- GAP analysis data

- Baseline data from conservation easements

- Use observations taken during game surveys

- Raptor routes

- Incidental observations by biologists

- Incidental observations by public

- Make use of NGO lists of low and declining populations (birds espc.) 
17572

17573

17574

17575

17576

17577

17578

17579

17580

17581

17582

17583

17584

17585

17586

17587

17588

17589

17590

17591

17592

17593

17594

17595

17596

17597

17598

17599

17600

17601

17602

17603

17604

17605

17606

17607

17608

17609

17610

17611

17612

17613

17614

17615

17616

17617

\section{DRAFT WORKING COPY \\ Do Not Duplicate}

\section{Federal Requirement \#2}

"Descriptions of locations and relative condition of key habitats and community types essential to conservation of species identified in (1)."

Participants were asked about what data, resources or methods should be considered or used to meet this requirement.

- Agricultural statistics service data could be used to determine $\%$ habitat not currently providing habitat

- Use GIS layers and maps of species ID'd in \#1, expand those locations and access that total habitat

- Use species richness to determine what habitat types are most essential

- Use GAP type analysis to ID habitat types with greatest richness of species that we determine to be of concern in \#1 (this will be dependant on past surveys)

- Look for communities that are still compromised of native species containing a species we ID as of concern in \#1 and give priority to that related habitat

- Need to review life history and habitat needs of species we ID in \#1

- Intersect Species information with all related habitat layers in a matrix (eg wolf grassland yes, Mountain yes etc....)

- Use current distribution layers of species we ID in \#1 overlaid on different scales of habitat

- Develop a list of specialist versus generalists species and use their related habitats to ID those essential for conservation

- Use different habitat scales depending on species range size and number of habitats used

- Have a broad-scale habitat map, then have all less pronounced habitat type within each of the broad categories (1 montane forest/ 2 meadow complex/ montane riparian etc...)

- Rely heavily on professional judgment

- Make sure to relate small-scale habitat types to the public

- Scale will be dependant on species

- *Group concluded to use three scales of habitat type 1) broad habitat types, 2) smaller scale within each habitat type, GAP type fine detail (if necessary for species)

\section{Federal Requirement \#3}

"Descriptions of problems, which may adversely affect species identified in (1) or their habitats, and priority research and survey efforts needed to identify factors, which may assist in restoration and improved conservation of these species and habitats" 


\section{DRAFT WORKING COPY \\ Do Not Duplicate}

17618 Participants were asked about what data, resources or methods should be

17619

17620

17621

17622

17623

17624

17625

17626

17627

17628

17629

17630

17631

17632

17633

17634

17635

17636

17637

17638

17639

17640

17641

17642

17643

17644

17645

17646

17647

17648

17649

17650

17651

17652

17653

17654

17655

17656

17657

17658

17659

17660

17661

17662

considered or used to meet this requirement.

- Use local biologists expertise

- Use existing management and recovery efforts

- Wholesale damage to habitat

- Describe habitat related problems

- Describe invasive or exotic species

- Describe harvest/poaching/collecting problems

- Identify contaminants issues

- Disease and climate change issues

- Describe the FTE and funding needed to address problems

- Include genetic information about hybridization

- Use GIS to target habitats

- Allow biologists to help identify problems

\section{Federal Requirement \#4}

"Descriptions of conservation actions determined to be necessary to conserve the identified species and habitats and priorities for implementing such actions"

Participants were asked about what data, resources or methods should be considered or used to meet this requirement.

- Ask local biologists expertise

- Cost share with private groups on purchases of habitat

- Develop a good ownership boundary on habitats we are concerned with

- Pull people together on each specific species to determine

- Prioritize habitats versus critical value that is intact and those that are in jeopardy

- Develop lists of species/groups of species and habitats

- Protect what is left/stop the bleeding/recover the degraded

\section{Federal Requirement \#5}

"Proposed plans for monitoring species identified in (1) and their habitats, for monitoring the effectiveness of the conservation actions proposed in (4), and for adapting these conservation actions to respond appropriately to new information or changing conditions"

Participants were asked about what data, resources or methods should be considered or used to meet this requirement.

- Continue ongoing monitoring efforts

- Identify monitoring gaps 


\section{DRAFT WORKING COPY \\ Do Not Duplicate}

17663

17664

17665

17666

17667

17668

17669

17670

17671

17672

17673

17674

17675

17676

17677

17678

17679

17680

17681

17682

17683

17684

17685

17686

17687

17688

17689

17690

17691

17692

17693

17694

17695

17696

17697

17698

17699

17700

17701

17702

17703

17704

17705

17706

17707

- Question if we are monitoring the right things

- Look at assemblages of species

- Don't duplicate efforts of other agencies

- Do more habitat and vegetation monitoring

- Use aerial photography

- We need to develop new monitoring methods for species not being monitored

- FTE's will be a huge issue determining if this is even feasible

- Asses current monitoring plans that aren't being implemented

- Include monitoring protocols for groups of target species

- Peer review should be used

- Set a follow up for monitoring to determine if it is having effect

- ID desired outcomes and monitor to see if they are met

- Set a number of places and species to survey and measure over the long term

- Get commitment of staff to actually do it

- Plan must be flexible to change monitoring plan if it isn't meeting objectives

- Use adaptive management

- Define trigger points (at what point do you start doing something)

\section{Federal Requirement \#6}

"Descriptions of procedures to review the Plan-Strategy at intervals not to exceed ten years"

Participants were asked about what data, resources or methods should be considered or used to meet this requirement.

- Revise actions and priorities every five years

- Compare accomplishments with objectives annually

- Internal committee review of progress

- Special projects bureau Chief conducts review

- Provide summary of annual accomplishments to public

- Newsletter

- How much \$ spent annually and on what

- ID key interest groups and methods to communicate progress

\section{Federal Requirement \#7}

"Plans for coordinating, to the extent feasible, the development, implementation, review, and revision of the Plan-Strategy with Federal, State, and local agencies and Indian Tribes that manage significant land and water areas within the State or administer programs that significantly affect the conservation of identified species and habitat plans for coordinating, to the extent feasible, the 


\section{DRAFT WORKING COPY \\ Do Not Duplicate}

17708 development, implementation, review, and revision of the Plan-Strategy with

17709 Federal, State, and local agencies and Indian Tribes that manage significant land 17710 and water areas within the State or administer programs that significantly affect

17711 the conservation of identified species and habitats"

17712

17713

17714

Participants were asked about what data, resources or methods should be

17715

17716

17717

17718

17719

17720

17721

17722

17723

17724

17725

17726

17727

17728

17729

17730

17731

17732

17733

17734

17735

17736

17737

17738

17739

17740

17741

17742

17743

17744

17745

17746

17747

17748

17749

17750

17751

17752

- Create working groups oriented towards species /habitats

- Have management attendance at technical meetings and have them report back to administrative level meeting group and vice versa

- Establish oversight committee for each region (multi-agency) at the administrative level

- Base the technical committee on habitats

- Make sure to invite all experts in habitat or species from each region

- Private landowners should be considered at the oversight level

- Use MOU to finalize the coordination between agencies

- Coordinate monitoring with other agencies

- Make sure other agencies know what we are responsible for and have sideboards

- Use an email list to communicate a newsletter

\section{Appendix F}

\section{Law Enforcement Exploratory Group}

The following staff participated.

Jim Kropp

Chief of Law Enforcement

T.O. Smith

CFWCS Coordinator

Mark Anderson

Tom Flowers

Warden Sergeant

John Lesofski

Warden

Jim Conner

Warden

Warden

Law Enforcement Officers were asked what activities they currently perform that benefit conservation of the species and habitats identified through the Strategy as in greatest need.

\section{Survey/Inventory/Monitoring}

- Furbearer and game animal tagging

- Predator tagging

- Investigation of illegal kills

- Road kills 


\section{DRAFT WORKING COPY}

Do Not Duplicate

17753

17754

17755

17756

17757

17758

17759

17760

17761

17762

17763

17764

17765

17766

17767

17768

17769

17770

17771

17772

17773

17774

17775

17776

17777

17778

17779

17780

17781

17782

17783

17784

17785

17786

17787

17788

17789

17790

17791

17792

17793

17794

17795

17796
- Wolf sightings, kills and enforcement

- Public request for identification of nongame species

- Falcon/Hawk (falconer enforcement)

- Incidental encounters with species during checks/stations etc.

- CWD and west Nile monitoring

- Transfer of DNA samples

Species Specific Involvement (including Con/Ed, survey, disease issues, re-introduction and management and enforcement activities)

- Waterfowl

- West Slope Cutthroat

- Bull Trout

- Sauger

- Native Lake Trout

- Paddlefish

- Sage-grouse

- Pallid Sturgeon

- Grizzly Bear

- Wolf

- Lynx

- Bald Eagle

- Prairie Dog

- Bison

- Numerous Nongame

- Loons

- Bobcats

- Swans

- Pelicans

- Harlequin Ducks

- Great Blue Herrons

- Black Footed Ferret

Habitat

- Snowmobile and ATV Issues with Habitat

- Animal Feeding (bears, deer, turkey pheasant)

- No-Wake Zone enforcement

- Fish Ponds

- Exotic Introductions

- Human/Bear and Wolf Habitat Conflicts

- Aquatic Habitat Restoration for West Slope Cutthroat

- Public Point of Contact for Most Current FWP Habitat Programs

- Fire Season Restriction Enforcement in Critical and all Habitat 
17797

17798

17799

17800

17801

17802

17803

17804

17805

17806

17807

17808

17809

17810

17811

17812

17813

17814

17815

17816

17817

17818

17819

17820

17821

17822

17823

17824

\section{DRAFT WORKING COPY}

Do Not Duplicate

- 310 Violations/Motorhomes/Fuel Storage

- Enforcement of Habitat Easements

- Drought Restriction Enforcement for Aquatic Habitat

- Weed Issues/Weed Free Hay

- Focus already existing Con/Ed activities to better meet SWG priorities

\section{Ideas For the Future}

- Fund current FTE for Survey/Inventory work on SWG Tier Species

- Additional Funding could be used for saturation patrols to focus staff support here needed on SWG projects

- Integrate current patrols and habitat assessments (example whitebark pine, water conditions in critical areas. Wardens cover large amounts of habitat)

- Determine which wardens in the state have a greater proportions of their duties that are SWG related and consider funding and match benefits to agency.

- Increase overtime to allow for flexibility to support more SWG activities

- Serve on SWG Committees so Enforcement can collaborate with future projects from the beginning

- Seek compensation from SWG projects for work performed

- Emphasize the importance of Law Enforcement being included in future SWG legislative appropriation language

\section{Appendix G}

Invitees to Advisory Group Meeting October 1, 2003

\begin{tabular}{|c|c|c|c|c|c|}
\hline $\begin{array}{l}\text { Agency or } \\
\text { Organization }\end{array}$ & Contact & Title & Address & City & Zip \\
\hline BLM & Roxanne Falise & Wildlife Biologist & P.O. Box 36800 & Billings & 59107 \\
\hline & & $\begin{array}{l}\text { Director, Watershed } \\
\text { Wildlife, Fisheries anc }\end{array}$ & Federal Building, & & \\
\hline USFS & Cindy Swanson & Rare Plants & P.O. Box 7669 & Missoula & 59807 \\
\hline USFWS & Lori Nordstrom & Biologist & $\begin{array}{l}100 \text { N. Park Suite } \\
320\end{array}$ & Helena & 59601 \\
\hline USFWS & Mark Wilson & & & & \\
\hline NHP & Sue Crispin & Director & $\begin{array}{l}\text { Montana State } \\
\text { Library }\end{array}$ & Helena & 59620 \\
\hline
\end{tabular}




\section{DRAFT WORKING COPY \\ Do Not Duplicate}

\begin{tabular}{|c|c|c|c|c|c|}
\hline $\begin{array}{l}\text { Montana and } \\
\text { Wyoming Tribal Fish } \\
\text { and Wildlife }\end{array}$ & & & & & \\
\hline Commission & Gayle Skunk Cap & Vice Chairman & Blackfeet Nation & Browning & 59417 \\
\hline NRCS & Dave White & State Conservationist & $\begin{array}{l}10 \text { East Babcock } \\
\text { Street Room } 443\end{array}$ & Bozeman & 59715 \\
\hline DNRC & Tom Schultz & Administrator & 1625 11th Avenue & Helena & 59620 \\
\hline & & Forest Management & 2705 Spurgeon & & \\
\hline DNRRC & Pete van sickie & Bureau Chief & & Missoula & 59804 \\
\hline MSU & Dr. Scott Creel & $\begin{array}{l}\text { Department of } \\
\text { Ecology }\end{array}$ & 310 Lewis Hall & Bozeman & 59717 \\
\hline UM & Dr. Dan Pletcher & $\begin{array}{l}\text { Director, Wildlife } \\
\text { Biology }\end{array}$ & School of Forestry & Missoula & 59812 \\
\hline $\begin{array}{l}\text { Turner Endangered } \\
\text { Species Fund }\end{array}$ & Mike Phillips & Executive Director & $\begin{array}{l}1123 \text { Research } \\
\text { Drive }\end{array}$ & Bozeman & 59718 \\
\hline $\begin{array}{l}\text { The Nature } \\
\text { Conservancy }\end{array}$ & & Ctato Director & 32 S. Ewing, Suite & مإO & 59601 \\
\hline $\begin{array}{l}\text { The National Wildlife } \\
\text { Federation }\end{array}$ & & & 240 N. Higgins & & \\
\hline Trout Unlimited & Bruce Farling & Executive Director & PO Box 7186 & Missoula & 59807 \\
\hline $\begin{array}{l}\text { Montana Wildlife } \\
\text { Federation }\end{array}$ & Craig Sharpe & Executive Director & PO Box 1175 & Helena & 59624 \\
\hline Walleye Unlimited & Bob Gilbert & Executive Director & PO Box 1228 & Sidney & 59270 \\
\hline $\begin{array}{l}\text { Montana Stock } \\
\text { Growers }\end{array}$ & Steve Pilcher & $\begin{array}{l}\text { Executive Vice } \\
\text { President }\end{array}$ & $\begin{array}{l}420 \text { North } \\
\text { California }\end{array}$ & Helena & 59601 \\
\hline $\begin{array}{l}\text { Montana } \\
\text { Association of } \\
\text { Counties }\end{array}$ & Harold Blattie & Assistant Director & 2715 Skyway Drive & Helena & 59620 \\
\hline $\begin{array}{l}\text { Montana Petroleum } \\
\text { Association }\end{array}$ & Gail Abercrombie & Executive Director & 601 Euclid Avenue & Helena & 59624 \\
\hline
\end{tabular}




\section{DRAFT WORKING COPY \\ Do Not Duplicate}

Montana Wood

Products

Association

Honorable Walter

MT State Gov.

McNutt

Chairman EQC

Sidney

59270

MT State Gov. Todd O'Hair

Natural Resources

Policy Advisor

Montana State

Capitol

Helena 59620

MT State Gov.

Todd Everts

Legislative Analysist

PO Box 201704

Helena

59620

Rocky Mountain Elk

Foundation

J. Dart

President

2291 West

Broadway

Missoula 59807

Montana Farm

Bureau

John Youngberg

Vice President of

Gov. Affairs

502 South 19th

Avenue Suite 104

Bozeman 59718

Western

Environmental

Trade Association

Don Allen

Executive Director

33 S. Last Chance

Gulch

Helena 59601

Room 211, AJM

Johnson Hall,

Montana State

USGS

Dick Jackowski

Center Director

Bozeman 59717

Private Land Owner Barbara Cowen

Havre

59501

Defenders of Wildlife Minette Johnson

114 West Pine

Street

Missoula 59802

Boone and Crockett

Club George Bettas

Executive Officer

250 Station Drive

Missoula 59801

17825

17826

17827

17828

17829

17830

17831

17832

17833

17834

17835

17836

Questions and Input of Participants of October 1, 2003 Advisory Group

17837

Attendance

Montana State University

Montana Natural Heritage Program

Stockgrowers Association

WETA

Walleyes Unlimited

Farm Bureau

17838

Boone and Crockett

USGS

\author{
Scott Creel \\ Sue Crispin \\ Steve Pilcher \\ Don Allen \\ Mike Sedlock \\ Greg Heil \\ John Youngberg \\ George Bettas \\ Dick Jackowski
}


Do Not Duplicate

17839 University Of Montana

17840 DNRC

17841

17842

17843

17844

17845

17846

17847

17848

17849

17850

17851

17852

17853

17854

17855

17856

17857

17858

17859

17860

17861

17862

17863

17864

17865

17866

17867

17868

17869

17870

17871

17872

17873

17874

17875

17876

17877

17878

17879

17880

17881

17882

BLM

USFS

MACO

For Barbara Cowan if possible)

\section{Participant Input}

Involve Indian Tribes. input into the plan.
The Nature Conservancy

NRCS

National Wildlife Federation

\section{Questions for Discussion}

- What role does your agency or organization want to play in the development of the Comprehensive Fish and Wildlife Plan?

- Is there a representative from your organization other than you who should be the contact for becoming involved with planning or receiving information about planning activities? (Please provide contact information,

- Are there any other agencies and organizations you think should be involved in the planning process?

Collaboration with agencies, organizations and the public

May be difficult to get enough conservationists in some parts of the state (e.g. north central and eastern portions).

It would help the NPS to be informed of where they fit and be a part of collaborative efforts, instead of only looking inward - as an island.

Involve more people with economic interest, e.g. outfitters and guides.

Make efforts to be sure large private landowners, especially ranchers and farmers, feel included and have opportunities to be involved.

Farmers and ranchers feed $75 \%$ of Montana's wildlife and therefore will want 


\section{DRAFT WORKING COPY \\ Do Not Duplicate}

17883 We need to include private landowners in the process. The recommendations

17884

17885

17886

17887

17888

17889

17890

17891

17892

17893

17894

17895

17896

17897

17898

17899

17900

17901

17902

17903

17904

17905

17906

17907

17908

17909

17910

17911

17912

17913

17914

17915

17916

17917

17918

17919

17920

17921

17922

17923

17924

17925

17926

17927

17928 coming out of the plan could have implications for them. We need to have

meetings in small eastern communities to be sure we get their input.

Most of the land use impacts are not going to come from agriculture but from other groups.

Most of wildlife issues will be land use/growth related. Consequently we need to incorporate land use planning efforts.

Groups that should be included in the process include real estate, oil and gas, city/county planning and others involved in land use planning issues.

Should think about how this fit into the growth policy debate and development that is going on statewide.

Need to get legislators involved.

We need to be able to develop trust in us and in the process if it is going to succeed.

\section{Information and Education}

Can involve more people if organizations are used as an information conduit. The Farm Bureau could get the word out via its newsletter, which goes out to all 11,000 members.

Needs to be taken (by FWP) out to the people. Open houses/listening sessions are best and will result in participation by more people including those who do not want to speak in front of large groups.

We are experiencing dramatic changes in user groups (e.g., growing interest in birds and birding) and we need to be thinking how to tie this in with traditional hunting and fishing. We have an upcoming segment of the population with no connection with hunting and fishing but they are interested in wildlife. In addition, as ethnicity changes, we should look at them see how user trends are changing which could put us in a position to better address the needs of Montanans. We need to be looking at nature trails as well as shooting ranges and giving maps to floaters, etc.

Need to be sensitive to landowners feeling things may be shoved down their throats, and expensive (e.g. if species get listed)

Place more emphasis on why the SWG plan must be done (especially if we want to engage landowners or others not as familiar with this process) 


\section{DRAFT WORKING COPY \\ Do Not Duplicate}

17929 There are wildlife recreation/tourism/economic diversification aspects to

17930 Montana's wildlife that should be incorporated. Look at how we're capitalizing on

17931 Lewis and Clark.

17932

17933

Conduct a series of open house like we did with wolf plan. In the first round of

17934 open houses have a dog and pony show to explain what we are doing, benefits

17935

17936

17937

17938

17939

17940

17941

17942

17943

17944

17945

17946

17947

17948

17949

17950

17951

17952

17953

17954

17955

17956

17957

17958

17959

17960

17961

17962

17963

17964

17965

17966

17967

etc. Treat these as a kind of scoping session. When we have a draft plan

completed, go back out to those same places to present the draft and get local input.

There are a lot of organizations with newsletters and other publications that would be willing to print information on the plan and process if we provide it to them, for example, in a press release format. Some of these include:

Stockgrowers, Farm Bureau, Grain growers.

Produce maps showing land ownership and species present so landowners could see the distribution and better understand the implications for them.

Many people will feel that frogs and snakes are not important and that we are wasting our time and theirs. We need to overcome this mindset somehow.

Use phone inquiries, advertise in newspapers, or other means; don't just have meetings as a means to make participation easier for more people

Once the plan is completed and the information is available to the public there will be great expectations of the agency. People will expect us to do something about the issues we identify. Need to address their expectation in the plan. Especially the question of what we will do if we don't get any more SWG funding.

There was some concern expressed that FWS approval of the plan somehow constitutes an expansion of FWS authority. Due to negativity toward ESA by landowners, this could be a difficult problem to overcome.

The whole deal comes down to the public trusting FWP and what we will do with the data.

\section{Planning}

No participants desired to be actively involved in the technical aspects of the plan 17968

17969

17970

17971

17972

17973 but preferred to be informed of progress and have future opportunities to support planning efforts and review drafts.

The Strength of the plan in setting up monitoring programs.

17974

Advantages of organizing the plan by 3 or 4 regions of the state are it is easier for people to participate and take advantage of information from existing plans; 


\section{DRAFT WORKING COPY \\ Do Not Duplicate}

17975 disadvantage is combining them into one plan, and ensuring statewide view and

17976

17977

17978

17979

17980

17981

17982

17983

17984

17985

17986

17987

17988

17989

17990

17991

17992

17993

17994

17995

17996

17997

17998

17999

18000

18001

18002

18003

18004

18005

18006

18007

18008

18009

18010

18011

18012

18013

18014

18015

18016

18017

18018

18019

18020 interest from groups with statewide not regional perspective.

USGS has a heritage of data collection from the time of the 1885 Biological Survey to mapping by Merriam. Those functions live on within USGS today. The plan could help us prioritize/plan research that will have the strength of a partnership with the state. It would also help USGS align our priorities with state priorities.

FWP should make a concerted effort to spend time with NRCS staff, learn about their programs, see what NCRS spends money on and how; identify opportunities and build synergies, avoid duplications; 5-10 year funding is available from Farm Bill programs gets spent

SWG plan needs to compliment the work the National Wildlife Federation and others are doing, and not duplicate efforts of other agencies; SWG plan will be a failure if we don't accomplish this

Be sure to keep the process open

We should consider including incentives for private landowners in the plan.

We need to think about how will habitat be addressed and how we can develop a comprehensive plan for animals when the habitat is owned by others?

The shorter and tighter the planning process the better (get it done in a matter of months, not years like Canyon Ferry; bull trout was endless and unrewarding, grizzly planning had good facilitation)

FWP is already oriented toward a successful model in garnering public comment, the difficultly will be in defining "comprehensive" and setting priorities and from groups/individuals focused on specific conservation issues and feeling like their focus is not garnering the prioritization that it deserves.

The plan is an opportunity to establish comprehensive surveys - including coordinated statewide surveys and inventories. To get information more quickly, there could be a coordinated statewide survey every year to address a particular issue.

DNRC would find the comp plan helpful in layout and design of our forest management activities. And it would establish communication links between DNRC and FWP biologists. It would help reduce conflicts and help us with our conservation plans.

It might be difficult to please everyone. 


\section{DRAFT WORKING COPY \\ Do Not Duplicate}

18021 We have a varied knowledge base where we know a lot about one species and

18022

18023

18024

18025

18026

18027

18028

18029

18030

18031

18032

18033

18034

18035

18036

18037

18038

18039

18040

18041

18042

18043

18044

18045

18046

18047

18048

18049

18050

18051

18052

18053

18054

18055

18056

18057

18058

18059

18060

18061

18062

18063

18064

18065 not much about another and how that will impact the prioritization process.

There is a planning conflict with managing species that live in the same areas but have different habitat needs. E.g. mountain plover and sage-grouse both living in eastern MT with one liking grazed over lands and the other preferring 'old growth' sagebrush.

Need to asses whether we've "restored" something and determine how will that be done even for more localized efforts like the Milltown Dam project.

The explicit differences between species are important to recognize up front.

Organize review groups taxonomically rather than geographically; or by method or approach (by type of data needed for all groups - first determine species, the associated habitat, then associated threats).

Perhaps a quid pro quo approach would be helpful. We are asking landowners and others for their help with this process. In exchange, perhaps we can provide some help with other wildlife issues.

FWP should make tentative decisions on things like lists of species, habitat types (e.g. say here's what we think is an endangered habitat and what species are viable); then have an advisory committee test the reality.

The plan is a great opportunity to join with partners.

The plan should stay away from using this money for habitat acquisition. We should tell the public right up front that the funding would not be used for that purpose.

Limit the scope of the plan either geographically or by species. It might be too big.

Limit the range of activities that we would undertake as part of the plan and make this clear to the public. For example, if we are going to seek additional regulatory authority to implement the plan the public should know that-if we aren't they should know that as well.

Given the number of species, the plan has to focus on habitat

Plan should be adaptive and flexible including flexibility in scale meaning that one can "zoom in" if you need to, or remain "zoomed out" the rest of the time.

Plan should be used for setting priorities and address suites of species. 


\section{DRAFT WORKING COPY \\ Do Not Duplicate}

18066 The plan should be geographically based because MT is diverse in terms of

18067

18068

18069

18070

18071

18072

18073

18074

18075

18076

18077

18078

18079

18080

18081

18082

18083

18084

18085

18086

18087

18088

18089

18090

18091

18092

18093

18094

18095

18096

18097

18098

18099

18100

18101

18102

18103

18104

18105

18106

18107

18108

18109

18110

18111 habitat and people (local areas have different customs, etc.)

The planning process is a good opportunity to learn more about our fish and wildlife resources and prioritize conservation needs.

We need to look at dimensions of the plan: 1) figure out what is out there; 2) gather presence/absence info; 3 ) monitor trend; 4) identify what is driving trends;

5 ) adaptive management; 6 ) work from the level of individuals to populations then communities the to ecotypes.

Another, more rapid way for the plan to take us where we need to go would be to: 1 ) find out what is out there; 2 ) identify habitat relationships (including land uses) - which provides insight into issues for the species, and then 3) move directly into adaptive management including incentives. (The model for this approach is the land bird-monitoring program at University of Montana)

During planning sit down with leadership and get them on board then identify potentially affected parties and who will be most impacted. Then solicit their involvement and determine where you are going to concentrate efforts. Develop creative solutions to get consent and focus on collaboration.

Look at PIF Plan. All bird - good process-habitat driven-coarse scale; also look at PPJV and BBS plans.

Must be careful of getting into a popularity contest rather than prioritizing based on biological resource; good planning effort that she has been involved with is the "YES" committee- structure is blend of science and agency working group. GB Management Plan; different groups but concepts blended together.

Look at systems and how to manage and conserve them.

Geographic means of organizing the plan would include "ecotypes," "biomes," and/or "hot spots."

To be successful, the FWS needs to give up some control to landowners. Landowners have management objectives for their lands and the plan has to be compatible with those landowner goals in meeting species needs. Most landowners want to support critters out there to some degree. FWP needs to be seen as a partner instead of an enforcer.

Plan needs to have the full range of tools including public education.

Plan needs to take into consideration what FWP has authority for and what it doesn't. It needs to recognize parties who do have the authority to take actions (that FWP does not have authority to take). 
18112

18113

18114

18115

18116

18117

18118

18119

18120

18121

18122

18123

18124

18125

18126

18127

18128

18129

18130

18131

18132

18133

18134

18135

18136

18137

18138

18139

18140

18141

18142

18143

18144

18145

18146

18147

18148

18149

18150

18151

18152

18153

18154

18155

18156

18157

\section{DRAFT WORKING COPY \\ Do Not Duplicate}

FWP should develop the strategy (plan for the plan) then later, organizations can decide how much involvement they want, at what points

Utilize existing plans and fit them into the SWG plan (e.g. prairie dog, or sagegrouse/sage-steppe); don't reinvent them and use indicator species where possible

Funding options, and implementing existing plans should be integral to the SWG plan because people will be more energetic about how they can influence spending of money from various sources, not just be involved in a planning effort.

\section{Match and Alternative Funding}

Identify focus areas and use FWP programs like Habitat Montana as match

The Boone and Crockett Club is interested in funding for good research and in partnering with FWP in any areas that would lend themselves to Conservation Education and working with teachers and schools.

University will be able to help describe low and declining populations and threats; already a strong emphasis at MSU on T and E, species assemblages and landscape projects; nationwide trend with conservation planning; universities just part of that trend. Providing match beyond deferring overhead is difficult because most is federal dollars.

The plan needs to consider if SWG money dries up, how much game money will FWP have to support the new efforts.

Align project priorities with various sources of funds; integrate opportunities from all applicable (federal and state) funding sources available to FWP (e.g. SWG, LIP, Section 6 competitive funds are some of the federal opportunities) as well as other agencies.

Groups like Walleyes Unlimited have grant programs and may be able to help with matching funds.

DNRC has T\&E species as well as species of special concern on their lands. If we are match limited they could provide match and use the SWG funds. DNRC is working on a Habitat Conservation Plan for $T$ and $E$ species and other species for a total of 30 (wolverine, woodpecker, goshawk, westslope cutthroat) on their forested land; developing strategies to conserve species and identify data gaps.

There could be value of SWG plan in filling in data gaps; suggested that if the plan identified species that were of concern to DNRC they could possibly match SWG funds for survey, inventory and research. DNRC is a major landowner in 


\section{DRAFT WORKING COPY \\ Do Not Duplicate}

18158 the state; CFWP plan could fit into DNRC plan depending on project suitability. 18159 Their plan will be very prescriptive in solutions; tiered down to activities that are 18160 being conducted on the ground but will not just be metrics but also ID information 18161 needs.

18162

18163

18164

18165

18166

18167

18168

18169

18170

18171

18172

18173

18174

18175

18176

18177

18178

18179

18180

18181

18182

18183

18184

18185

18186

18187

18188

18189

18190

18191

18192

18193

18194

18195

18196

18197

18198

18199

18200

18201

18202

18203

\section{General}

Emphasis on wildlife in addition to elk, rainbow trout (e.g. sauger, eastern Montana surveys) is good.

Congress and others are tired of train wrecks with T\&E listings; being able to avoid listings to begin with would be helpful.

Comment was made that the expectation is that FWP will do more of what we are doing now (efforts like collection of sage-grouse information and cutthroat trout restoration) which will help MT get ahead of the curve.

This plan would help federal land management agencies deal with land management issues in concert with surrounding lands (in context with those lands and on an ecological basis with them). DNRC could use some of the SWG money to do things like the HCP they are preparing for state lands and a culvert survey they are doing. 


\section{DRAFT WORKING COPY \\ Do Not Duplicate}

18204

18205

18206

\section{Appendix H: Terrestrial Focus Area Priorities}

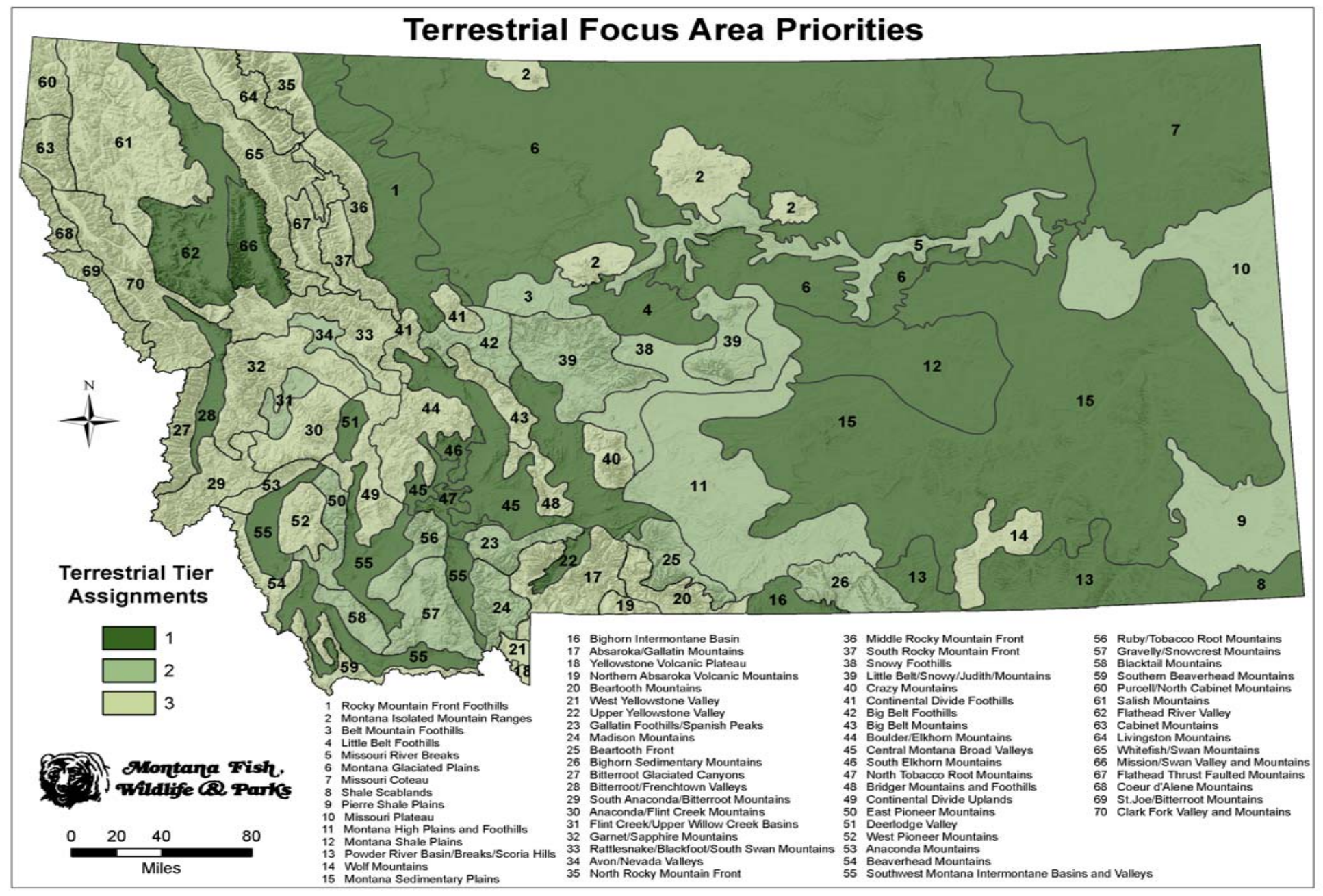




\section{DRAFT WORKING COPY}

Do Not Duplicate

\section{Appendix I: Aquatic Focus Area Priorities}

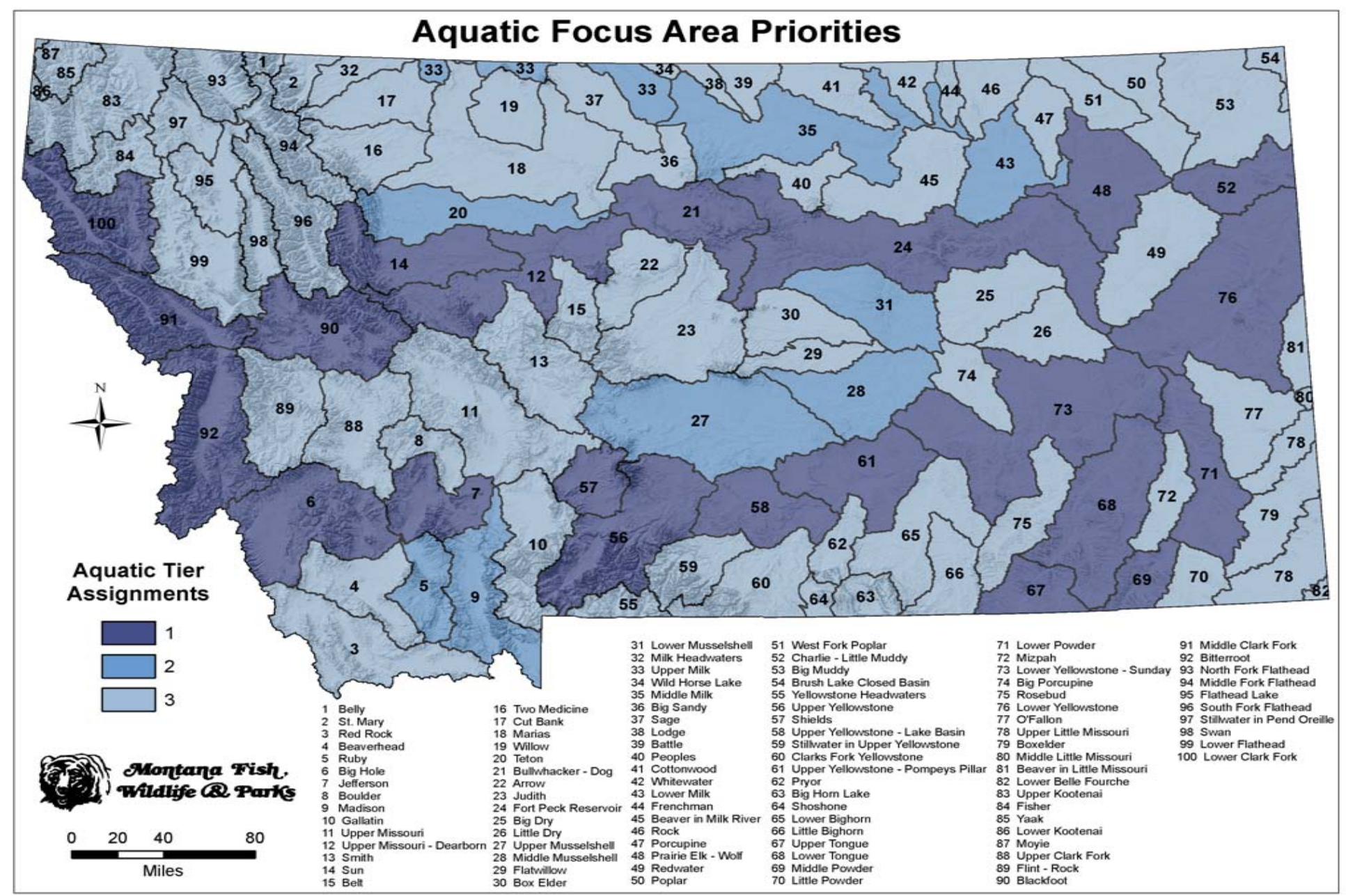




\section{DRAFT WORKING COPY \\ Do Not Duplicate}

\section{Glossary}

18211

18212

18213

18214

18215

18216

18217

18218

18219

18220

18221

18222

18223

18224

18225

18226

18227

18228

18229

18230

18231

18232

18233

18234

18235

18236

18237

18238

18239

18240

18241

18242

18243

18244

18245

18246

18247

18248

18249

18250

18251

18252

18253

18254

18255
Tier: Three levels of Conservation need assigned to focus areas, community types, species, and Inventory Needs. (a fourth Tier was used for just the species component that identifies non-native or peripheral species)

Ecotype: Georgaphic reference to broad-scale areas of Montana that have similar landscape, geoclimatic and vegetation characteristics.

Essentially Associated: An association between geographic area, vegetation, or fish and wildlife species that is critical to the existence of a population of fish or wildlife.

Focus Area: A terrestrial or aquatic area based on geographic features or the drainage of water that are used to frame locations where comprehensive conservation will occur.

Community Type: A group of associated plantsa, animals and the related geoclimatic characteristics.

Greatest Conservation Need: Focus Areas, Community Types and Species that are low or declining, federally listed species as either "threatened" or "endangered" or individual/groups of species that lack distribution and occurance information to asses their status or trends

Comprehensive Conservation: A term used to describe how fish and wildlife and their related habitats are interconnected and how concervation concerns common to all of these can be addressed on a broad-scale giving equal importance to all components.

Conservation Concern: Description of the critical threats that have, are or could adversely affect the populations of fish and wildife and their related habitats.

Conservation Strategies: Strategic guidance that address conservation concerns.

Ustic: A soil moisture regime that occurs with a limited amount of water available for plants but occurs at times when the soil temperature is optimum for plant growth.

Mesic: Shrubs, grasslands or combination of both that are adapted to a moderately moist habitat

Xeric: Shrubs, grasslands or combination of both that are adapted to an extremely dry habitat 